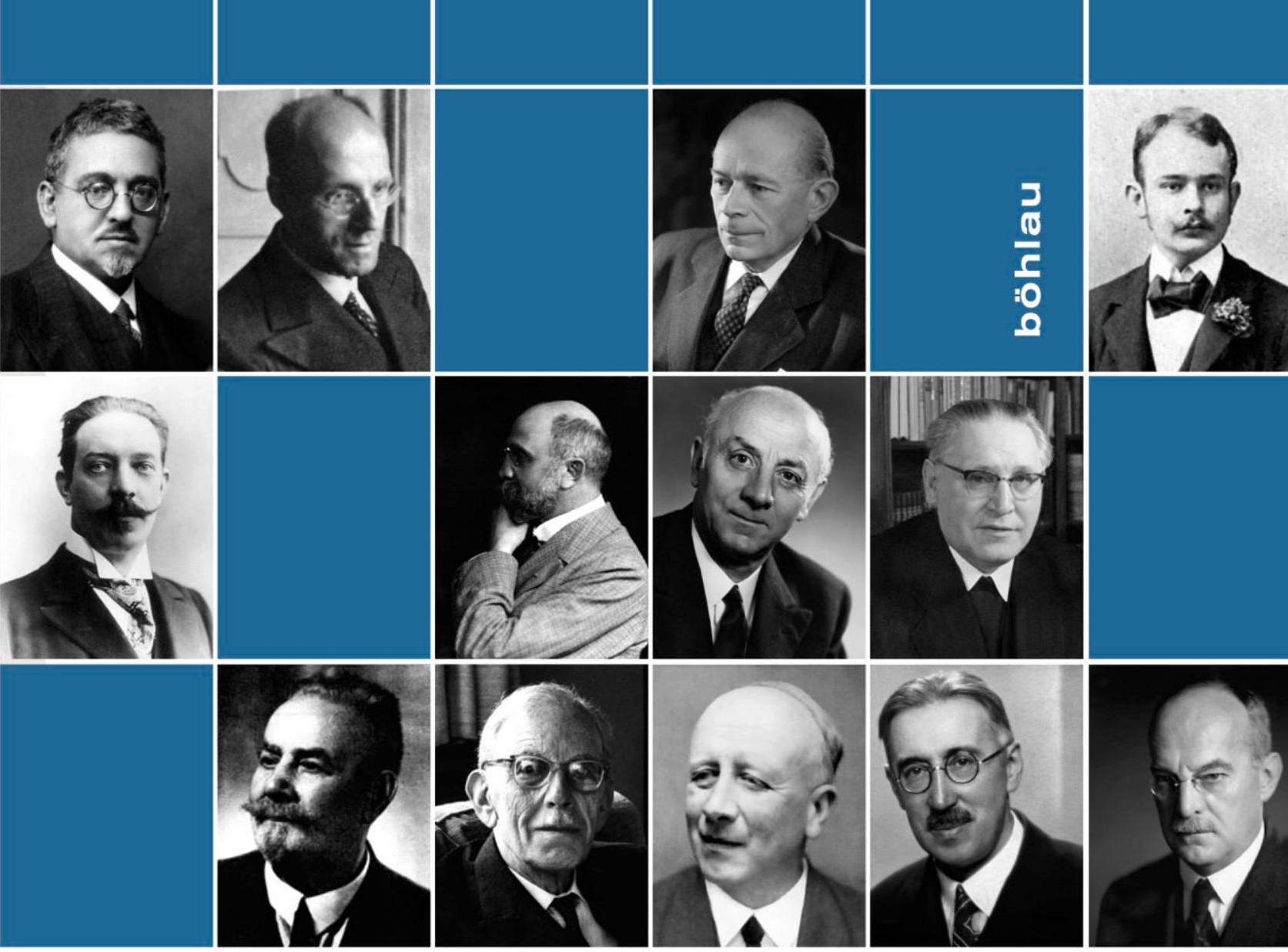

\title{
ÖSTERREICHISCHE HISTORIKER
}

Lebensläufe und Karrieren 1900-1945 Band 2

KAREL HRUZA (HG.) 
böhlau 

Karel Hruza (Hg.)

\section{Österreichische Historiker}

Lebensläufe und Karrieren 1900-1945

Band 2

Böhlau Verlag Wien · Köln · Weimar 


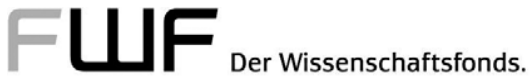

Gedruckt mit der Unterstützung durch den Fonds zu Förderung der wissenschaftlichen Forschung

Bibliografische Information der Deutschen Nationalbibliothek:

Die Deutsche Nationalbibliothek verzeichnet diese Publikation in der Deutschen Nationalbibliografie; detaillierte bibliografische Daten sind im Internet über http://dnb.d-nb.de abrufbar.

ISBN 978-3-205-78764-8

Das Werk ist urheberrechtlich geschützt. Die dadurch begründeten Rechte, insbesondere die der Übersetzung, des Nachdruckes, der Entnahme von Abbildungen, der Funksendung, der Wiedergabe auf fotomechanischem oder ähnlichem Wege, der Wiedergabe im Internet und der Speicherung in Datenverarbeitungsanlagen, bleiben, auch bei nur auszugsweiser Verwertung, vorbehalten.

(C) 2012 by Böhlau Verlag Ges. m. b. H und Co. KG, Wien · Köln · Weimar http://www.boehlau-verlag.com

Gedruckt auf umweltfreundlichem, chlor- und säurefrei gebleichtem Papier

Umschlaggestaltung: Michael Haderer

Umschlagabbildungen: v.l.n.r.: Martin Wutte, Konrad Josef Heilig, Karl Maria Swoboda, Max Dvořák, Michael Tangl, Anton Chroust, Franz Huter, Hugo Hantsch, Arthur Stein, Adolf Grohmann, Ernst Klebel, Gustav Pirchan und Heinrich Srbik

Druck: Wissenschaftlicher Bücherdienst, 50668 Köln 


\section{Inhalt}

Vorwort des Herausgebers $\ldots \ldots \ldots \ldots \ldots \ldots \ldots \ldots$

Karel Hruza

Österreichische Historiker I900-I945. Eine Einleitung . . . . . . . . . . 9

Andrea Rzihacek und Christoph Egger

Michael Tangl (I86I-I92I). Ein Österreicher in Berlin . . . . . . . . . . 23

Peter Herde

Anton Chroust (1864-1945). Ein streitbarer Historiker aus Österreich in Franken . . . . . . . . . . . . . . . . . . . . . 85

Klaus Wachtel

Arthur Stein (I87I-1950) und Edmund Groag (1873-1945).

Zwei jüdische Gelehrtenschicksale in Wien und Prag . . . . . . . . . . . . . . . . 129

Hans Aurenhammer

Max Dvořák (I 874-I92I). Von der historischen Quellenkritik

zur Kunstgeschichte als Geistesgeschichte . . . . . . . . . . . . . . . . . . . 169

Ulfried Burz

Martin Wutte (1876-1948). Ein Kärntner Historiker und die

Iānusköpfigkeit in der nationalen Frage . . . . . . . . . . . . . . . . . . 201

Martina Pesditschek

Heinrich (Ritter von) Srbik (I878-I95I). „Meine Liebe gehört

bis zu meinem Tod meiner Familie, dem deutschen Volk, meiner

österreichischen Heimat und meinen Schülern" . . . . . . . . . . . . . . . . . . 263

Stefan Lehr mit einem Exkurs von Tomáš Borovský

Gustav Pirchan (I88I-I945). Ein Prager Historiker zwischen

Deutschen und Tschechen . . . . . . . . . . . . . . . . . . . . . . 329 
Sibylle Wentker

Adolf Grohmann (I887-I977). Orientalist und Historiker ........ 379

Alena Janatková

Karl Maria Swoboda (I889-1977). „Von einem kulturgeschichtlich-biologischen

Perspektivismus her" .................... 411

Johannes Holeschofsky

Hugo Hantsch (I 895-I972). Ein großösterreichischer Verfechter der Reichsidee . 451

Wolfram Ziegler

Ernst Klebel (I 896-I96I). Facetten einer österreichischen Historikerkarriere . . . 489

Stefan Eminger und Ralph Andraschek-Holzer

Karl Lechner (I 897-I975). Landeshistoriker zwischen Katholizismus

und Nationalsozialismus . . . . . . . . . . . . . . . . . . . 523

Michael Wedekind

Franz Huter (I 899-I997). „Verfügen Sie über mich, wann immer Sie

im Kampfe um die Heimat im Gedränge sind“ . . . . . . . . . . . . . . . . . . . 591

Helmut Maurer

Konrad Josef Heilig (I907-I945). Mediävist und politischer Publizist . . . . . . . 615

Abkürzungsverzeichnis . . . . . . . . . . . . . . . . . . . 649

Abbildungsnachweis . . . . . . . . . . . . . . . . 653

Autorinnen und Autoren . . . . . . . . . . . . . . . . . . . 655

Personenregister . . . . . . . . . . . . . . . . . 659 


\section{Vorwort des Herausgebers}

Im Sommer des Jahres 2008 konnte der erste Band der „Österreichischen Historiker I 900I945" ausgeliefert werden, in dem I 8 österreichische Historiker und eine Historikerin porträtiert wurden. Monika Glettler schloss ihre das Buch positiv würdigende Rezension (siehe die nachfolgende Einleitung) mit dem von mir als angenehmen Imperativ aufgefassten Satz: „Ein zweiter Band sollte folgen.“ Ermuntert über die auch andernorts fast durchgehend gute oder sogar sehr gute Aufnahme des Buches, begann ich alsbald mit der Konzeption und Organisation eines zweiten Bandes. Das Team der Autorinnen und Autoren und die Liste der zu porträtierenden Historikerinnen und Historiker waren am Ende des Jahres 2008 bis auf wenige Ausnahmen zusammengestellt. Im Vorwort des ersten Bandes verwies ich darauf, dass damals einige Autoren ihre Beiträge aufgrund von Arbeitsüberlastung nicht fertig gestellt oder zurückgezogen hatten, sodass unter anderem die Biografien Otto Brunners, Adolf Helboks, Oswald Redlichs, Heinrich von Srbiks und Hermann Wopfners nicht aufgenommen werden konnten. Umso mehr freut es mich, dass wenigstens Srbik im vorliegenden Band in einer ausführlichen Studie gewürdigt wird. Dass zum zweiten Mal wegen erneut später bzw. nicht kommunizierter Absagen die wichtigen Biografien Brunners und Redlichs fehlen, ist zu bedauern. Über weitere ausgesprochene oder durch Schweigen vermittelte Absagen informiert die Einleitung.

Wie beim ersten Band erhielten die Autorinnen und Autoren ein Konzept zur Erstellung der Beiträge, gemäß dem weit über gewöhnliche Lexikonartikel hinausgehende wissenschaftsgeschichtliche Porträts eingefordert wurden. So haben im vorliegenden Buch wieder I 6 ,individuelle“ Historikerinnen und Historiker I 5 ihrer Fachkollegen biografisch aufgearbeitet und dabei viel - oftmals noch unbeachtetes - Quellenmaterial zugrunde gelegt und auch zitiert. Gerne betone ich, dass sich die Arbeitsstätten der auch dieses Mal aus Österreich, Deutschland und Tschechien stammenden Autorinnen und Autoren auf Klagenfurt, St. Pölten, Wien, Brünn, Berlin, Frankfurt am Main, Konstanz, Münster in Westfalen und Alzenau verteilen. Dank der Bereitschaft der Autorinnen und Autoren, bei der Fahnenkorrektur die für ein Personenregister relevanten Namen zu markieren, konnte dieses schnell erstellt werden. Dafür spreche ich allen Beteiligten meinen herzlichen Dank aus. Für trotzdem vorkommende Unzulänglichkeiten des Buches trägt der Herausgeber die Verantwortung.

Auch zu diesem Buch muss angemerkt werden, dass die vorliegende Historikerauswahl subjektiv ist und auch ein bestimmtes Element des Zufälligen enthält: Für diese oder jene 
Person konnte kein Bearbeiter gefunden werden, während mancher Autor sein „Sujet“ bereits mitbrachte. Trotzdem hoffe ich, dass wie im ersten Band individuelle, aber auch durch gemeinsame Wege in Forschung und Lehre zusammenhängende Lebensläufe und Schicksale präsentiert werden.

Etliche Personen und Institutionen waren in das Buchprojekt eingebunden: Alle involvierten Archivare und Bibliothekare im In- und Ausland standen mit Rat und Tat helfend zur Seite, wenn es um die Suche nach und die Einsicht in Akten ging. Die Autorinnen und Autoren haben trotz des anscheinend obligatorischen Zeitmangels in der Historikerzunft aus purem Interesse ihre Beiträge doch so zeitig ausgearbeitet, dass das Buchmanuskript nach knappen zweieinhalb Jahren Projektlaufzeit abgeschlossen werden konnte. Frau Eva Reinhold-Weiß und die Herren Peter Rauch und Johannes van Ooyen vom Böhlau-Verlag in Wien haben das Buch ohne Zögern in ihren Katalog aufgenommen. Die Fa. G\&L (USA) und meine Eltern Eva und Karel Hruza haben mir auf vielfältige Weise geholfen. Unterstützung erfuhr ich auch durch die Österreichische Akademie der Wissenschaften in Wien und den FWF - Fonds zur Förderung der wissenschaftlichen Forschung in Österreich. Andreas Froese (Konstanz), Franz Fuchs (Würzburg), Stefan Sienell (Wien) und Brigitte Slepička (Wien) aber haben mich in Gesprächen und mit Taten nicht nur unterstützt, sondern vor allem auch ermuntert, die Idee dieses Buches zu verwirklichen. Ihnen allen danke ich gerne aufs Herzlichste.

Karel Hruza

Wien, im Dezember 20I I 


\section{Österreichische Historiker 1900-1945}

EINE EINLEITUNG

In diesem Buch werden I 5 österreichische Historiker in ausführlichen wissenschaftsgeschichtlichen Porträts vorgestellt. Als Aufnahmekriterium unter die Porträtierten galt wie bereits im ersten Band -, dass die Person als Historiker ausgebildet worden sein sollte, in Österreich, das heißt in der Habsburgermonarchie geboren wurde, und/oder nach I 9 I 8 die österreichische Staatsbürgerschaft besaß und ihre entscheidende Wirkungsphase zwischen 1900 und 1945 durchlebt oder danach nicht wesentlich übertroffen hat. Zudem sollte der Porträtierte solche bleibenden Spuren in der Wissenschaft oder in anderen Bereichen hinterlassen haben, dass die Auseinandersetzung mit Werk und Person lohnende wissenschaftsgeschichtliche Ergebnisse erwarten lässt, seine Biografie also historisch zu denken geben sollte. Wie beim ersten Band wurde dieses Kriterienbündel jedoch nicht strikt eingeklagt. Waren im ersten Band dann auch einige als Archivare, Bibliothekare oder Geografen tätige Personen enthalten, so finden sich im vorliegenden zwei - freilich in ihrem Fach zumindest zeitweise sehr einflussreiche und nachwirkende - Kunsthistoriker, wie auch zwei Althistoriker und ein Orientalist ihren Platz gefunden haben. Dass in vorliegendem Buch keine Historikerin biografisch behandelt wird, ist der Tatsache geschuldet, dass zugesagte Manuskripte auch nach mehrmaliger Fristenverlängerung nicht geliefert wurden. Der „Ausfall“ von Manuskripten mit Porträts von Historikern war freilich zahlenmäßig weit gravierender. Insgesamt waren für das vorliegende Buch zusätzlich die Porträts Otto Brunners, Adolf Helboks, Erna Patzelts, Alfred Francis Přibrams, Oswald Redlichs, Balduin Sarias, Samuel Steinherz, Lucie Vargas und Hermann Wopfners vorgesehen. Einige dieser Personen hätten bereits im ersten Band porträtiert werden sollen ${ }^{1}$. Alexander Pinwinkler, selbst Autor eines Beitrags im ersten Band, äußerte 2005 die Meinung, dass für eine kritische Auseinandersetzung mit Paradigmen und Tendenzen in der österreichischen Geschichtswissenschaft während des 20. Jahrhunderts bis ca. I950 die ausführli-

1 Ein ebenfalls für den ersten Band erarbeiteter Beitrag wurde an anderer Stelle publiziert, siehe Michael НоснEDLINGER, Lothar Groß 1887-1944. Zur Geschichte des österreichischen Archivwesens in der ersten Hälfte des 20. Jahrhunderts, in: Archivalische Zeitschrift 89 (2007) 45-118. Hingewiesen sei zudem auf die Porträts Hans Uebersbergers, Alois Hajeks und Carl Patschs sowie anderer Historiker in: Osteuropäische Geschichte in Wien. 100 Jahre Forschung und Lehre an der Universität, hg. v. Arnold Suppan, Marija Wakounig, Georg Kastner (Innsbruck 2007), und auf Martina Pesditsche к, Barbar, Kreter, Arier. Leben und Werk des Althistorikers Fritz Schachermeyr 1-2 (Saarbrücken 2009). 
che Beschäftigung mit Werk und Leben der Historiker Wilhelm Bauer, Otto Brunner, Adolf Helbok, Hans Hirsch, Wilfried Krallert, Hans Pirchegger, Leo Santifaller, Heinrich von Srbik, Harold Steinacker, Hans Uebersberger, Hermann Wopfner und Martin Wutte unabdingbar sei ${ }^{2}$. Da die beiden Bände der „österreichischen Historiker“ immerhin acht Personen von Pinwinklers Liste mit zwölf Namen enthalten, bleibt zu hoffen, dass sie der künftigen Forschung eine wertvolle Grundlage liefern mögen, zumal sich ein dritter Band bereits in der Planungsphase befindet. Auf das Problem einer „Auswahl“ der zu proträtierenden Historikerinnen und Historiker komme ich unten nochmals zurück.

Wie wurde aber der erste Band der „Österreichischen Historiker I900-I945“ von den Rezensenten aufgenommen? Bis jetzt - mehr als zweieinhalb Jahre nach seiner Auslieferung im Sommer 2008 - sind I7 Rezensionen und Anzeigen zum Buch erschienen. Davon sind I4 Rezensionen oder Anzeigen in historischen oder politischen Zeitschriften ${ }^{3}$, zwei in bibliotheksgeschichtlichen Zeitschriften ${ }^{4}$ und eine in einer großen deutschen Tageszeitung ${ }^{5}$ zu finden. Dazu tritt eine Vorstellung des Buches im Rundfunk ${ }^{6}$. Obwohl das Buch allein von seinem Titel her auf ein österreichisches Thema hinweist, sind nur vier dieser Rezensionen in österreichischen Organen publiziert worden, die restliche Mehrheit in bundesdeutschen. Der Tenor der Besprechungen ist bis auf eine Ausnahme grundsätzlich positiv, wenn nicht sogar sehr positiv und rechtfertigt auch die Herausgabe des vorliegenden zweiten Bandes. Welche Aspekte wurden am ersten Band aber getadelt, welche gelobt? Diesen Fragen wird im Folgenden nachgegangen, wobei allgemeine Aspekte des Buches und nur marginal einzelne Beiträge diskutiert werden ${ }^{7}$. Zuvor sei noch angemerkt, dass ich aus der

2 Siehe Alexander Pinwinkler, Österreichische Historiker im Nationalsozialismus und in der frühen Zweiten Republik - eine ausgebliebene Debatte? Kritische Überlegungen zu Fritz Fellners Essay „Der Beitrag Österreichs zu Theorie, Methodik und Themen der Geschichte der Neuzeit“, in: Zeitgeschichte 1/32 (2005) 35-46, hier 39f.

3 In chronologischer und dann alphabetischer Reihung: Peter Autengruber in: Bücherschau des ÖGB 181 (4/2008); Doris A. Corradini in: Historicum. Zs. für Geschichte (Sommer/Herbst 2008) 76-78; Hans-Christof Kraus in: Das Historisch-Politische Buch Heft 5 (2008) 457f.; Gerhard Oвеr коfler in: Mitteilungen der Alfred Klahr Gesellschaft (4/2008) 20; Pavel Kolá ̌̌ in: HSK vom 14.03.2009; Ota Konrád in: Bohemia. Zs. für Geschichte und Kultur der böhmischen Länder 49 (2009) 258-263; Hiram Kümper in: ZRG GA 126 (2009) 773f.; Francesco Roberg in: Sehepunkte. Rezensionsjournal für die Geschichtswissenschaften 9 (2009, Nr. 10) vom 15.10.2009; Rudolf Schieffer in: DA 65 (2009) 183; Fritz Fellner in: MIÖG 118 (2010) 274-276; Monika Glettler in: Stifter Jb. NF 24 (2010) 208-210; Stefan Jordan in: ZfG 58/5 (2010) 467f.; Tomáš Borovskŕ in: Časopis Matice moravské 130/1 (2011) 137-140; Karsten JedLitschka in: HZ 293/1 (2011) 243-245.

4 Peter Vodosek in: Bibliothek. Forschung und Praxis 33/3 (2009) 403-405; Frank-Rutger HausmanN in: Informationsmittel (IFB). Digitales Rezensionsorgan für Bibliothek und Wissenschaft Jg. 18 (2010) CCB.

5 Christian Jostmann in: Süddeutsche Zeitung Nr. 262 vom 13.11.2009 13.

6 Präsentiert von Christina Höfferer im Magazin „Dimensionen“ des Senders Ö1 am 05.02.2010.

7 Die Nennung der einzelnen Beiträge erfolgt nach Absprache mit deren Autoren. 
Lektüre der meisten Rezensionen mit Dank wertvolle Anregungen empfangen habe und auch einsehe, dass bestimmte Kritikpunkte ihre Berechtigung haben.

Doris A. Corradini hob in „Historicum. Zeitschrift für Geschichte“ als „einen der primären Vorzüge des Buches“ hervor, dass die „wissenschaftliche Leistung [der porträtierten Historiker] von Vertretern der entsprechenden historischen Fachrichtung und damit kompetenter Seite dargestellt und auf ihre Geltung und Gültigkeit im gegenwärtigen Forschungsstand hin untersucht“ wurde ${ }^{8}$. „Bemerkenswert“ sei zudem „die unglaubliche Fülle an herangezogener Sekundärliteratur und die Gründlichkeit der Recherchen und der Quellenanalysen. Ebenso positiv ist die Illustration der Beiträge durch Photographien der Protagonisten.“ Als Kritik merkt Corradini an, dass die „Auswahlkriterien - und damit auch die Fragestellung des Buches - etwas weniger klar“ als die „Aufnahmekriterien“ sind. „Denn sollte die Sammlung darstellen, welche Personen die Geschichtswissenschaft dieser Zeit prägten, so fehlen eine Reihe wichtiger Persönlichkeiten, wie Alfred Francis Přibram, Samuel Steinherz, Wilhelm Erben, Hans Uebersberger, Ignaz Philipp Dengel oder Hugo Hantsch. Sollte Sie aber, wie die Aufnahme von Paul Heigl [...] und Wilfried Krallert [...] nahelegt, den Einfluß des Nationalsozialismus auf die Wissenschaft sowie die persönliche Verstrickung der ausgewählten Wissenschaftler zeigen, so wäre ein expliziter Hinweis, zum Beispiel im Titel oder Untertitel des Werkes, hilfreich.“ Dazu meint die Rezensentin aber auch, dass die „Beschäftigung mit vordergründig unbedeutenden Wissenschaftlern wie Krallert und Heigl lohnt, [...] insofern, als sie einen Teil der Realität des Wissenschaftsbetriebes darstellten“.

Für Hans-Christof Kraus ist in „Das Historisch-Politische Buch“ „bedauerlich, ja etwas ärgerlich [...] die Tatsache, daß mehrere gerade der wichtigsten österreichischen Historiker dieser Zeitspanne fehlen, allerdings aus Gründen, die dem Herausgeber nicht anzulasten sind“9. „So fehlen [...] beispielsweise die drei bedeutendsten Wiener Historiker dieses Zeitraums: Heinrich Ritter von Srbik, Oswald Redlich und Otto Brenner [sic]." Er bemängelt die Berücksichtigung der „eher unbedeutenden Persönlichkeiten“ [!] wie Heigl und Krallert. Mit den Historikern, bei denen eine „Verstrickung“ in das NS-Regime vorliegt, gingen „die Autoren des Bandes zumeist scharf ins Gericht“, wogegen „die ostentativ positive Herausstellung von Eduard Winter“ den Rezensenten „umso mehr verwundert“.

Gerhard Oberkofler schreibt in „Mitteilungen der Alfred Klahr Gesellschaft“, das Buch „ist eine Fundgrube und verdient eingehend studiert zu werden “. ${ }^{10}$ Er merkt aber auch an, „dass die Neuorientierung nach der Befreiung vom deutschen Faschismus in den Artikeln über Eduard Winter [...] und Leo Santifaller [...] zu wenig herausgearbeitet worden ist.

\footnotetext{
8 Siehe wie auch im Folgenden Corradini (wie Anm. 2).

9 Siehe wie auch im Folgenden Kraus (wie Anm. 2).

10 Siehe wie auch im Folgenden Овеr коfler (wie Anm. 2).
} 
Der international denkende Urkundenforscher Santifaller fand diese im patriotischen Interesse Österreichs, der Bolzano-Forscher Winter [...] im Dienste für ein besseres Deutschland. Das unterscheidet beide, die einander in Respekt begegnet sind, erheblich von so prominenten Akademiemitgliedern und Nazihistorikern wie Harold Steinacker [...] oder Wilhelm Bauer [...], die nach I 945 mit den ,Auswüchsen' des nach innen und außen barbarischen Deutschen Reiches nichts zu tun gehabt haben wollten und dessen Niederlage bedauerten."

Pavel Kolář meint in „H-Soz-u-Kult“, das Buch kann „als eine Krönung der bisherigen Forschungsarbeit" innerhalb der österreichischen Historiografiegeschichte bezeichnet werden; „es enthält nur scheinbar Biographisches: Vielmehr behandelt es Zentralfragen der Wissenschafts- und Politikgeschichte, wie das Verhältnis zwischen Wissenschaft und Ideologie, zwischen Institution und wissenschaftlichem Einzelwerk oder zwischen kontinuierlicher akademischer Karriere und einer brüchigen politischen Gegenwart“. Er betont des Weiteren, dass neben der „unverhüllten Politisierung der Geschichtswissenschaft und ihrer Indienstnahme für politische Zwecke [...] gerade die Zone der subtilen Politisierung der ,eigentlichen Forschung' von Interesse [ist], bzw. politische Aspekte der Tätigkeit jener Historiker, die sich grundsätzlich als ,reine Wissenschaftler verstanden haben“. ${ }^{11}$ Er kritisiert aber, dass „die vom Herausgeber betonte Einbettung der österreichischen Historiographie in den internationalen Rahmen, sowohl in Hinsicht auf die Rezeption ausländischer Ansätze und Methoden als auch bezüglich der ,Ausstrahlung' [...] nach außen“ hätte „stärker zum Vorschein kommen können“. Zudem „wäre generell die Bedeutung des Instituts für österreichische Geschichtsforschung für die moderne Mittelalterforschung stärker auszuarbeiten“ gewesen.

Ota Konrád, der in „Bohemia. Zeitschrift für Geschichte und Kultur der böhmischen Länder“ das Buch als „insgesamt einen wichtigen Forschungsbeitrag“ ansieht, meint, dass die Beiträge, die „von einer breiteren Quellengrundlage ausgehen“, die in der Einleitung genannte „Zielsetzung einer Interpretation von Leben und Werk der Historiker im Kontext ihrer Zeit einlösen“, die „methodologische Vielfalt der einzelnen Beiträge [...] jedoch zur Folge [hat], dass der Gesamtzusammenhang des Werkes mitunter nur schwer zu erkennen ist“. ${ }^{12}$ Und: „Zu Recht wird daher der Sozialisation der Historiker große Aufmerksamkeit gewidmet. Mehrere Beiträge zeigen, wie deren persönliche Erfahrungen mit dem kulturell, sprachlich und ethnisch gemischten Milieu der österreichischen Monarchie ihre wissenschaftliche Tätigkeit, das Verständnis für die gesellschaftlichen, kulturellen und politischen Aufgaben der Geschichtsschreibung beeinflusst haben." Schließlich regt der Rezensent an, den Kreis der aufzunehmenden Historiker zu erweitern: „Dieses ,deutschösterreichische Kriterium hat zwar seine Berechtigung, doch führt die Konzentration auf sudetendeutsche

11 Siehe wie auch im Folgenden Kolá ̌̌ (wie Anm. 2).

12 Siehe wie auch im Folgenden Konr Ád (wie Anm. 2). 
Historiker, ohne deren tschechische Partner und Gegenspieler in den Blick zu nehmen, zu einer gravierenden Verengung der Interpretation. Sollten deshalb nicht die Antworten auf die in dem Band gestellten Fragen eher in einem weiteren, wenigstens ,cisleithanischen Rahmen gesucht werden? Eine solche Perspektive würde es ermöglichen, die [...] Genese der einzelnen ,Nationalhistoriographien“ in der Monarchie [...], ihre wechselseitigen Beziehungen, die Herausbildung oder Einschränkung wissenschaftlicher und sozialer Kontakte und schließlich auch die Instrumentalisierung der deutschsprachigen Geschichtsschreibung in der Zeit des Dritten Reiches zu verfolgen."

Hiram Kümper zieht in „Zeitschrift der Savigny-Stiftung für Rechtsgeschichte“ das Fazit: „Dieser Band ist auch ein (wissenschafts-)politisches Statement. Zum einen setzt er sich konzeptionell gegen die bereits vorliegenden, älteren Arbeiten und das noch 2006 erschienene ,biographisch-bibliographische Lexikon` österreichischer Historikerinnen und Historiker (hg. von Doris A. Corradini und Fritz Fellner) ab, die ,sich jeder Wertung der Personen oder ihrer Arbeiten' (S. I 5 [des ersten Bandes]) enthalten. Statt lexikalischer Verzeichnung geht es bei diesem Projekt also um wissenschafts- und zeithistorisch analytische Portraits.“ "13 Und weiter: „[...] jedenfalls leisten die Beiträger [...] einen sehr elaborierten Beitrag zur eingeforderten Auseinandersetzung mit dem Erbe der ersten Hälfte des 20. Jahrhunderts. Und das sollte doch wohl das Entscheidende sein. [...] Ein solides Stück Historiographie- und in mancher Hinsicht ein aufschlussreiches Stück Zeitgeschichtsschreibung.“ Francesco Roberg schreibt in „Sehepunkte. Rezensionsjournal für die Geschichtswissenschaften“, dass die Beiträge „allesamt grundständig erarbeitet und quellengesättigt“ sind und verdeutlichen, „wie reizvoll und ergiebig die Beschäftigung mit der jüngeren Wissenschaftsgeschichte sein kann“. ${ }^{14}$ Monika Glettler, als Herausgeberin der für die „Österreichischen Historiker“ vorbildhaften „Prager Professoren“ 15 mit der Problematik großer Sammelbände vertraut, stellt in „Stifter-Jahrbuch“ fest, dass in allen Beiträgen bei den Porträtierten ihre „Verbindungen zum politischen, gesellschaftlichen und privaten ,Netzwerk ““ aufgezeigt wurden ${ }^{16}$. Und weiter: „Betreffend Forschungsstand, Fragen, Analysen, vor allem dank akribisch ausgewerteter Quellenfunde, ,Ego-Dokumenten' [...] und in Fußnoten versteckter Befragung von Zeitgenossen [...] liegt hier ein Pionierwerk vor, das Vergleichbares vermissen läßt. [...] Angesichts eines sehr weiten Feldes zwischen Anerkennung und Polemik unserer derzeitigen Historiker ist die unterschiedliche Länge der Beiträge [...] nicht zu bemängeln, auch nicht die unterschiedliche Qualität einzelner Beiträge.“

13 Siehe wie auch im Folgenden Kü MPer (wie Anm. 2).

14 Siehe wie auch im Folgenden Roberg (wie Anm. 2).

15 Prager Professoren 1938-1948. Zwischen Wissenschaft und Politik, hg. v. Monika Glettler, Alena MíšKová (Veröff. zur Kultur und Geschichte im östlichen Europa 17, Essen 2001).

16 Siehe wie auch im Folgenden Glettrer (wie Anm. 2). 
Stefan Jordan schreibt in „Zeitschrift für Geschichtswissenschaft“, die Beiträge „sind Grundlagenstudien mit einer durchschnittlichen Länge von vierzig Seiten. [...] Der Band ist damit nicht als ,schnelles Informationsmittel' geeignet. Dafür erreicht er eine Untersuchungstiefe zu Personen wie Alfons Dopsch, Harold Steinacker, Wilhelm Bauer, Otto Stolz, Theodor Mayer, Leo Santifaller oder Eduard Winter, die man so nirgendwo findet. Denn um ihr Ziel zu erreichen, Mitgliedschaften und Netzwerke sowie persönliche und ideologische Einstellungen der Porträtierten zu ergründen, haben alle Autoren intensive Quellenrecherchen betrieben und in enormem Umfang ungedrucktes Material ausgewertet. "17 Der „Band überzeugt sowohl durch seine Ausgangsfragen als auch durch die Gründlichkeit seiner Beiträge. Bemängeln lässt sich lediglich das, was nicht im Band enthalten ist. So wurden etwa Emigranten wie Franz Borkenau oder Friedrich Engel-Jánosi nicht aufgenommen“ sowie „führende Historiker Österreichs“ wie „Otto Brunner, Adolf Helbok, Oswald Redlich oder Heinrich Ritter von Srbik“. Tomáš Borovský bemerkt in seiner tschechischen und bisher einzigen fremdsprachigen Rezension in „Časopis Matice moravské", dass das Buch „viele neue Erkenntnisse“ bringt und die Beiträge bis zu einem gewissen Grad einen „einheitlichen Charakter" aufweisen. Insgesamt reiht er das Buch in den auf den Werken Pierre Bourdieus basierenden „habituellen Zugang zur Vergangenheit“ ein ${ }^{18}$. Zu dem Aspekt der politischen Tätigkeit der behandelten Historiker stellt Borovský fest, dass eine „große Variabilität der möglichen Situationen " erkennbar ist und dass für das Verständnis damaliger Zustände die Auseinandersetzung mit „individuellen menschlichen Schicksalen“ den besten Weg darstellt.

Karsten Jedlitschka schreibt in „Historische Zeitschrift“, die Beiträge im „stattlichen Werk“, das „kein übliches biographisches Nachschlagewerk“ ist, sind „erfrischend unterschiedlich, meist sehr quellengesättigt und gut recherchiert, einige zeigen inspirierende Interpretationen, manche [...] sind von geradezu monographischer Länge“"19. Alle Artikel „fühlen sich einem breit gefächerten methodischen Ansatz verpflichtet, der den klassischen biographischen Ansatz mit kultur-, sozial-, institutionen-, disziplin- und generationengeschichtlichen Aspekten verbindet und damit die lebensweltlichen Bezüge von Karriere und wissenschaftlicher Produktion reflektiert [...]“. Insgesamt stellt das Buch „einen bedeutenden, oft aus bislang unbekannten Quellen erarbeiteten Beitrag zur Wissenschaftsgeschichte dar und bietet [...] eine verlässliche Basis für weitere Studien. Die in den Beiträgen [...] so differenziert gebotene Analyse von Methoden, Werken und Verhaltensweisen unterstreicht im Ergebnis auch für den österreichischen Raum den ,Omnibuscharakter' (Thomas Nipperdey) des Nationalsozialismus, dessen polykratische Struktur die Flexibilität im Detail - bei grundsätzlicher ideologischer Übereinstimmung - erlaubte.“

17 Siehe wie auch im Folgenden Jordan (wie Anm. 2).

18 Siehe wie auch im Folgenden Borovský (wie Anm. 2).

19 Siehe wie auch im Folgenden Jedlitschка (wie Anm. 2). 
Peter Vodosek bemerkt in „Bibliothek. Forschung und Praxis“, dass „den Herausgeber

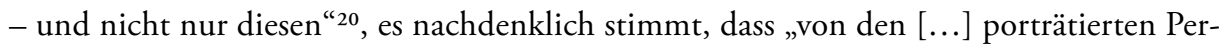
sonen vielleicht nur eine, die das Dritte Reich bis 1945 durchlebt hat, dieses - und das nur an dessen Ende - als menschenverachtende Diktatur empfunden oder sich wesentlicher Freiheiten beraubt gefühlt hat ${ }^{\text {“21 }}$ „ „Zugleich ist die Wahl des Zeitabschnitts I 900-1945 ein substanzieller Beitrag zur österreichischen Zeitgeschichtsforschung, die sich gegenüber der deutschen zwar verspätet, jetzt aber nicht weniger ,rücksichtslos und umfassend ' der düsteren Vergangenheit stellt. " 22 Trotz des Fehlens wichtiger Historiker (etwa Brunner, Redlich, Srbik) repräsentieren die 19 behandelten „Wissenschaftler [...] nichtsdestoweniger einen breiten Querschnitt unter verschiedenen Gesichtspunkten“, wobei auch die Porträts Heigls und Krallerts ihre Berechtigung haben. Und weiter: „Es ist beeindruckend, in welchem Umfang es gelungen ist, neues Archivmaterial aufzuspüren und die Porträtierten authentisch darzustellen. Die Beiträger verfügen über den erforderlichen unbestechlichen (nicht nur quellen-)kritischen Blick und kommen zu begründeten Urteilen, nicht aber Verurteilungen. Thomas Bernhard hätte wohl auch hier gesagt, ,es ist nichts zu loben, nichts zu verdammen, nichts anzuklagen`. Dieses bleibt dem Leser überlassen, dem es nicht schwerfallen wird, sich seine Meinung über Verstrickungen und Verfehlungen der Protagonisten zu bilden."

Frank-Rutger Hausmann meint in „Informationsmittel (IFB). Digitales Rezensionsorgan für Bibliothek und Wissenschaft“, die Autoren des Buches, das „vorzüglich und sorgfältig gemacht“ ist, hätten „sich nicht mit der Sichtung vorliegender Studien und der Auswertung des Primärschrifttums der in Frage kommenden Historiker begnügt, sondern mehrheitlich umfassende Archivstudien angestellt, die den Porträts eine eindrucksvolle Tiefenschärfe verleihen und viel wenig oder Unbekanntes zu Tage fördern“".23 Er bemerkt aber auch: „Über die Unterschiede zwischen österreichischen und deutschen Historikern hätte man gerne mehr gewußt, insbesondere über das Wechselspiel von großdeutscher und prononciert ,österreichischer ' Denkhaltung bei den Österreichern, wobei diese zwischen monarchistisch und republikanisch schwankt. Auch die spannungsreichen Beziehungen zu Deutschland allgemein oder Fragen der Konfessionalisierung hätten systematischer betrachtet werden können. [...] Ein interessanter Unterschied zwischen österreichischen und deutschen Historikern besteht sicherlich darin, daß die ersten im seit I 854 bestehenden Institut für Österreichische Geschichtsforschung eine Art Kaderschmiede besaßen und noch besitzen, die für die Qualität derer garantiert, die sie durchlaufen haben. [...] Insge-

20 Siehe wie auch im Folgenden Vodose k (wie Anm. 3).

21 Zitat aus dem ersten Band 34.

22 Siehe wie auch im Folgenden Vodose k (wie Anm. 3).

23 Siehe wie auch im Folgenden Hausmann (wie Anm. 4). 
samt ist der Band angenehm ,kosmopolitisch', da man nicht nur über die österreichischen Universitäten Wien, Graz und Innsbruck, sondern auch über Czernowitz [...] und besonders Prag [...], zumal in der NS-Zeit, viel Neues erfährt.“

Christian Jostmann schreibt in der „Süddeutschen Zeitung“: „Die Beiträge sind aufschlussreich nicht nur deshalb, weil sie deutliche Parallelen zu reichsdeutschen HistorikerBiographien aufzeigen, sondern auch die vielfältigen Vernetzungen in der ,großdeutschen akademischen Szene bis I 945 erhellen." 24

Außerhalb des wissenschaftlichen Diskurses positioniert - da den seit den I 99oer Jahren erreichten Forschungsstand ignorierend und mit persönlichen Angriffen untersetzt ist die vornehmlich auf pauschalen Urteilen und Apologien basierende „Rezension“ in „Mitteilungen des Instituts für Österreichische Geschichtsforschung “25. Eine direkt an

24 Siehe Jostmann (wie Anm. 4).

25 Zumindest folgende aufschlussreiche Passage, die auf einer selektiven Geschichtskenntnis zu basieren scheint, sei zitiert: „Es wird bei fast allen Beiträgen [des ersten Bandes, K.H.] besonderes Gewicht auf die Frage gelegt, wieweit der betreffende Historiker, völkisch` oder ,großdeutsch' gesinnt war und wie eng er institutionell oder in seiner politischen Einstellung dem Nationalsozialismus verbunden war. Es wird durch diese Betrachtungsweise nicht nur der Eindruck erweckt, als sei die österreichische Geschichtswissenschaft ideologisch besonders eng mit dem Nationalsozialismus verbunden gewesen, sondern es wird einigen der Historiker direkt moralische Verantwortung für die Verbrechen des NS-Regimes zugeschrieben, es wird ihnen unterstellt, dass sie in voller Kenntnis der Verbrechen dem Regime gedient haben. [Konkrete Beispiele werden vom Rezensenten nicht angeführt, K.H.] Es wird aus dem Wissen des Jahres 2000 ein wissenschaftliches Verhalten be- und verurteilt, das in einer völlig anderen Konstellation eingebettet war. Man hätte - so urteilt der Herausgeber - in den ,fünf Jahren zwischen 1933 und 1938 Zeit gehabt, die Errichtung und Etablierung des NS-Regimes in Deutschland 'von außen`zu beobachten' und hätte doch , anscheinend keine Angst oder Abscheu vor dieser Diktatur' gehabt. Was der Historiker Hruza heute weiß, konnten die Historiker der 1930er Jahre nicht wissen, nicht nur die Anschlussfreunde, sondern auch die Gegner des Regimes waren damals geblendet von den propagandistisch so erfolgreich präsentierten Leistungen im Dritten Reich, und die Meldungen über Entrechtung der Juden und die Verfolgung von Regimegegnern nahmen sich bis in die ersten Kriegsjahre weit weniger gefährlich aus als die Meldungen und das Wissen, das man in jenen fünf Jahren über das Geschehen in der Sowjetunion zu hören bekam. Die historische Situation der Jahre von 1933 bis 1945 ist viel zu komplex, um mit Schuldvorwürfen an jene abgetan zu werden, die das Unglück hatten damals zu leben. Das Bekenntnis zu einem nationalen Sozialismus und die Überzeugung von einer Verpflichtung zu einer kulturellen Führungsrolle der Deutschen ist nicht verschieden von dem idealistischen Anspruch des amerikanischen manifest destiny. Damals so wie heute wird weltanschaulicher Idealismus zu machtpolitischer Vernichtungspolitik missbraucht. Niemand wird Schostakowitsch vorwerfen, dass er durch sein künstlerisches Mitwirken mitschuldig wurde an den Untaten des Stalinismus, [...]. Erklären und verstehen, urteilen und nicht verurteilen sollte die Grundhaltung des Historikers sein : in einigen der Beiträge [...] wird gegen diese wissenschaftliche Grundhaltung verstoßen." Siehe Fellner (wie Anm. 2) 275. In Fritz Fellner, Geschichtsschreibung und nationale Identität. Probleme und Leistungen der österreichischen Geschichtswissenschaft (Wien/Köln/Weimar 2002) 12, postulierte der Rezensent, er hätte gelernt, „Verständnis für die Haltung von Andersdenkenden zu haben und ihnen gegenüber nicht nur Toleranz zu üben, sondern im wissenschaftlichen Leben ihnen die Chance zur Vertretung ihrer Auffassungen zu sichern“. Die ebd. 277-384 versammelten sieben „Biografischen Skiz- 
mich gerichtete Belehrung des Rezensenten, der Deutungshoheit beansprucht, trägt geradezu ahistorische Züge ${ }^{26}$. Dass diese den ersten Band bisher am negativsten qualifizierende Meinung in der Zeitschrift jenes Instituts erschien, das sowohl im ersten als auch im vorliegenden Band als Ausbildungsstätte und oftmals weiterer, auch zentraler Wirkungsort vieler Historiker thematisiert wird und über das bisher keine fundierte wissenschaftsgeschichtliche Studie für die Zeit vor 1945 erschien, sei an dieser Stelle lediglich festgestellt. Erfreulich für die Mitwirkenden am ersten Band der „Österreichischen Historiker“ ist neben den positiven Rezensionen, dass die Rezeption in der Fachliteratur schon bald nach dem Erscheinen eingesetzt hat und die Beiträge stellenweise die Grundlage für weitere Forschungen bilden ${ }^{27}$.

$\mathrm{Zu}$ einigen der oben angeführten Kritikpunkte aus Rezensionen sei angemerkt: Die von vielen Rezensenten sachlich formulierte Kritik an der Auswahl hat ihre Berechtigung; diese wird jedoch durch die Genese des Buches und nunmehr auch durch den vorliegenden zweiten Band relativiert. Die Auswahl der Historiker im ersten Band hat freilich bei einem Rezensenten richtiggehend zu „Unbehagen“ geführt, das ihn zu vehementer Kritik veranlasst hat ${ }^{28}$, und ich erlaube mir folgende Erwiderung: Das Buch basiert auf meiner Privatinitiative und wurde bis zur Druckvorlage ohne organisatorische Mithilfe des Verlags und ohne finanzielle Unterstützung staatlicher oder anderer Stellen erstellt. Nach der

zen“ kommen im Übrigen mit sehr knappen Verweisen auf Archivquellen und Literatur aus. Zu Fellners mit Apologien durchsetzter Sichtweise und Negierung des Forschungsstands siehe PIn w In KLER, Österreichische Historiker (wie Anm. 2).

26 „Den Herausgeber [Karel Hruza] ,stimmt es nachdenklich“, dass die [...] porträtierten Historiker das Dritte Reich nicht als ,menschenverachtende Diktatur empfunden haben ‘ - vielleicht könnte dieses Nachdenken dazu führen, dass er die Zeit zwischen 1918 und 1945 als weltweit beherrscht von menschenverachtenden Diktaturen erkennt und sich die Frage stellt, inwieweit nicht die Kriminalisierung der beruflichen Tätigkeit im Dritten Reich und die daraus abgeleitete Entlassung der meisten in jenen Jahren wissenschaftlich engagierten Historiker aus ihren Berufen und der Ausschluss von wissenschaftlicher Forschung die betroffenen Historiker daran gehindert hat, sich offen mit dem Problem ihrer Verstrickung in das menschenverachtende System auseinanderzusetzen." Siehe Fellner (wie Anm. 2) 276.

27 Siehe beispielsweise in einzelnen Beiträgen in: Österreichs Archive unter dem Hakenkreuz (MÖSTA 54, 2010), und ausgiebig bei Gernot Heiss, Die „Wiener Schule der Geschichtswissenschaft“ im Nationalsozialismus : „Harmonie kämpfender und Rankescher erkennender Wissenschaft“?, in: Geisteswissenschaft im Nationalsozialismus. Das Beispiel der Universität Wien, hg. v. Mitchell G. Ash, Wolfram Niess, Ramon Pils (Wien 2010) 397-426, sowie bei Ota Kon RÁD, Dějepisectví, germanistika a slavistika na německé univerzitě v Praze 1918-1945 (Praha 2011); DERs., Německé bylo srdce monarchie ... Rakušanství, němectví a střední Evropa v rakouském meziválečném dějepisectví [Deutsch war das Herz der Monarchie ... Österreichtum, Deutschtum und Mitteleuropa in der österreichischen Geschichtsschreibung der Zwischenkriegszeit] (im Druck).

28 Fellner (wie Anm. 2) 274f. Ich bitte den Rezensenten, der als Alleinherausgeber von Sammelbänden mit vielen Autorinnen und Autoren nicht in Erscheinung getreten ist (siehe das Werkverzeichnis in: FeLLNER, Geschichtsschreibung [wie Anm. 20] 385f.), um nochmalige, vorurteilsfreie Lektüre der Seiten 9f. des ersten Bandes der „Österreichischen Historiker“. 
Ausarbeitung einer recht langen Liste von infrage kommenden österreichischen Historikerinnen und Historikern habe ich via Telefonat, E-Mail und Brief bei möglichen Autoren angefragt, dabei $\mathrm{Zu}$ - und Absagen und wertvolle Hinweise auf weitere mögliche Autoren erhalten. Der so abgesteckte Autorenkreis brachte es natürlich mit sich, dass für bestimmte Historiker einfach kein Autor gefunden wurde, das heißt, die Verfügbarkeit von Autoren hat bei der Auswahl eine nicht unwesentliche Rolle gespielt, was ebenso für den vorliegenden zweiten Band Geltung besitzt. Der ursprüngliche Autorenkreis hat sich dann im Laufe der gesetzten Abgabefrist und darüber hinaus mittels Absagen verringert, wie erfreulicherweise auch neue Autoren hinzu kamen. Dass Absagen auch mal kurz vor Redaktionsschluss oder durch beharrliches Schweigen auf mehrfache Anfragen vollzogen wurden, habe ich versucht, mit Gleichmut hinzunehmen, es gelang nicht immer. Für mitgeteilte Absagen und ihre Gründe, die meistens in Krankheit oder Überbelastung liegen, habe ich hoffentlich genügend Verständnis gezeigt. Die soeben geschilderte Problematik ist vermutlich allen Herausgebern, die mit einem etwas größeren Autorenkreis arbeiten, bestens bekannt. Erinnert sei hier aber an Werner Conze, der sich 1978 in seiner Funktion als Herausgeber der „Geschichtlichen Grundbegriffe“ einem Kollegen anvertraute: „Wenn ich indiskret oder bösartig sein würde, so könnte ich einen zusätzlichen Artikel schreiben, der auf dem Hintergrundwissen der arcana editiones aufbauen könnte. Doch darf ich dies selbstverständlich nicht tun. [...] So erfreulich die Arbeit mit der Mehrzahl der Autoren ist, so fürchterlich ist die Last mit einer sehr ärgerlichen Minderheit." ${ }^{29}$

Absicht des ersten wie des zweiten Bandes war nicht primär (!) Historikerinnen und Historiker vorzustellen, deren Porträts in Summe ein repräsentatives Bild von der Bandbreite der österreichischen Geschichtsforschung 1900-1945 ergeben, dazu fehlen die Porträts „wichtiger" Personen wie auch Historiker aufgenommen wurden, deren Einfluss auf Methoden und Ausrichtung der Geschichtswissenschaft verhältnismäßig gering blieb, deren Lebens- und Karrierewege als Historiker dennoch von Interesse sind. Zudem muss betont werden, dass die von einzelnen Individuen vollzogene Einordnung unter „repräsentativ“ stark von subjektiven Momenten bestimmt wird. Die nunmehr 33 Porträts der beiden Bände transportieren freilich eine breite Palette an Lebensläufen und Karrierewegen, sicherlich auch von Personen, die „die Geschichtswissenschaft dieser Zeit prägten“ (Corradini). Dass damit eine brauchbare Grundlage für die Ausarbeitung eines „repräsentativen“ Bildes vorliegt, ist vermutlich kaum zu bestreiten ${ }^{30}$. In beiden Bänden haben sich die Autorinnen und Autoren „mit vordergründig unbedeutenden Wissenschaftlern“ auseinandergesetzt, die „Teil der Realität des Wissenschaftsbetriebes darstellten“ (Corradini) und deren Lebens-

29 Zitiert nach Jan Eike Dunkhase, Werner Conze. Ein deutscher Historiker im 20. Jahrhundert (Kritische Studien zur Geschichtswissenschaft 194, Göttingen 2010) 152.

30 Siehe auch unter Anm. 22. 
und Karrierewege aufschlussreich für damalige Einbindungen (tragend und nicht tragend) in Netzwerke und für die damalige Bandbreite an Möglichkeiten sind, als Berufshistoriker „sein Brot“ zu verdienen. Die Berücksichtigung der „eher unbedeutenden Persönlichkeiten“ zu kritisieren (Kraus), erscheint mir allein wegen des Wertes der erzielten Forschungsresultate als nicht zielführend.

Die beiden Bände primär an der Frage nach dem wissenschaftlichen und politischen Wirken österreichischer Historiker während des NS-Regimes (oder besser : für das NSRegime) auszurichten, war ebenso nicht das Hauptmoment bei der Konzipierung, denn sonst wäre doch die Aufnahme Johann Loserths, Emil von Ottenthals und Antons Mells im ersten Band und Michael Tangls, Anton Chrousts, Max Dvoráks, Hugo Hantschs und Konrad Josef Heiligs im zweiten Band nicht erfolgt. Dass unter den Porträtierten freilich einige geschichtspolitische Akteure anzutreffen und zu behandeln waren, brachte das Thema ebenso von selbst mit wie die Feststellung eines zeitspezifischen Vorhandenseins von Antisemitismus als geradezu „kulturellem Code“. Die Autorinnen und Autoren haben auch nicht „Verkünder der Größe der österreichischen Geschichte“ gesucht ${ }^{31}$, denn sonst würde die Reihe der Porträtierten andere Züge tragen. Dagegen wurde in den Beiträgen der Versuch unternommen, die behandelten Historikerinnen und Historiker in ihren historischen, so vor allem gesellschaftlichen und politischen Kontexten darzustellen. Der Gefahr, dabei aus gewonnenem „Verständnis“ für Ansichten und Handlungen der historischen Personen in Apologien zu verfallen, sind die Verfasser im Ganzen genauso gut entgangen wie harschen „Verurteilungen“. Das mag beispielsweise der neue Beitrag Martina Pesditscheks über Heinrich von Srbik verdeutlichen, in dem ein überaus differenziertes Bild eines der umstrittensten und problematischsten Historiker Österreichs gezeichnet wird. Dass die bis vor Kurzem vorgetragenen Apologien ${ }^{32}$ in einer aus gegenwärtiger wissenschaftsgeschichtlicher Perspektive verfassten Arbeit unterbleiben, wird nicht verwundern. Und nur nebenbei sei daran erinnert, dass Begriffen wie „Verständnis“ oder „Verurteilung“ im Vokabular der Geschichtswissenschaft immer eine Problematik beiwohnt.

31 So Fellner, Geschichtsschreibung (wie Anm. 20) 384, über Adam Wandruszka.

32 Siehe ebd. 340 die 2002 wiederholte Ansicht: „Srbik hat seine Verstrickung in das Machtgefüge des Nationalsozialismus nach 1945 [...] auch durch die politische Verfemung im Nachkriegsösterreich büßen müssen." Und 344: Nach 1945 „wurde seine Geschichtsauffassung, sein Lebenswerk verfemt, verurteilt [...]“. Srbik „ist nicht nur politisch nach 1945 Unrecht geschehen, sondern wird von einer jüngeren Generation bis heute Verständnislosigkeit entgegengebracht, weil man aus der Selbstgerechtigkeit der eigenen ideologischen Position heraus sich den Blick auf die historische Situation, in der Srbik gewirkt hat, wirken mußte, verstellt“. Auf den stark apologetisch ausgerichteten und mit deutlichen Resentiments gegen deutsche Historiker unterlegten Beitrag von Maximilian Weltin, Otto Brunner. Ein Niederösterreicher als Bahnbrecher der Mittelalterforschung, in: Mitteilungen aus dem Niederösterreichischen Landesarchiv 12 (2005) 154-170, sei nur mit der Bemerkung hingewiesen, dass der Text der interessanten Problematik der Person und des Werkes Brunners nicht gerecht wird. 
Die Anregung, den Kreis der aufzunehmenden Historiker grundlegend zu erweitern und etwa „das ,deutschösterreichische“ Kriterium“ zugunsten eines „wenigstens ,cisleithanischen“ Rahmen(s)“ aufzugeben, um so „tschechische Partner und Gegenspieler“ der sudetendeutschen Historiker zu porträtieren (Konrád), würde die konzeptionelle Basis des Vorhabens „Österreichische Historiker I900-1945“ wohl in ein internationales, mit noch größerer Arbeitsbelastung verbundenes Großprojekt verschieben. Vielleicht mögen sich aber tschechische Historiker ermuntert fühlen, das sicher höchst verdienstvolle Vorhaben einer zusammenhängenden wissenschaftsgeschichtlichen Galerie tschechischer und deutschböhmischer Historiker anzugehen.

Die Idee, „generell die Bedeutung des Instituts für österreichische Geschichtsforschung für die moderne Mittelalterforschung stärker auszuarbeiten“ (Kolář), ist sehr zu begrüßen, doch kann das eine Sammlung einzelner, auf die Zeitspanne von I 900 bis 1945 begrenzter Historikerporträts nicht leisten, sondern hierzu nur fallweise wertvolle Bausteine bieten ${ }^{33}$. Das Gleiche gilt auch für den Vorschlag, „das Wechselspiel von großdeutscher und prononciert ,österreichischer ' Denkhaltung bei den Österreichern“ und „die spannungsreichen Beziehungen zu Deutschland allgemein“ zu untersuchen (Hausmann).

Zuletzt bin ich als Herausgeber selbstverständlich verpflichtet, auf eine Aussage HansChristof Kraus' einzugehen, dessen Rezension wie folgt schließt: „Zu kritisieren ist ebenfalls, daß in anderen Beiträgen [...] z. T. schwerwiegende Vorwürfe [bezüglich der „Verstrickung" porträtierter Historiker in das NS-Regime] erhoben, aber nicht belegt werden. Man mag es einem einschlägig bekannten ,Volkshistoriker' wie Harold Steinacker vielleicht zutrauen, daß er bis ins hohe Alter den Holocaust, verleugnete' (S. 223) - aber für derart gravierende Behauptungen sollte der Nachweis dann auch nicht fehlen." ${ }^{34}$ Bei der entsprechenden Stelle im Beitrag Renate Spreitzers hat Kraus richtig gesehen, dass eine Anmerkung fehlt, was sowohl der Autorin als auch mir bei der Redaktion bedauerlicherweise entgangen ist. Der Verweis sei an dieser Stelle nachgetragen ${ }^{35}$. Da Kraus aber den Plural verwendet, nämlich von „anderen Beiträgen“ spricht, in denen nicht belegte „schwerwiegende Vorwürfe" gegen die Porträtierten erhoben würden, habe ich, um jene vermeintlichen Vorwürfe zusammen mit den Autorinnen und Autoren berichtigen oder nachweisen

33 Mehr Material zur Beantwortung der Frage liefert immer noch Alphons Lнотsкy, Geschichte des Instituts für österreichische Geschichtsforschung 1854-1954 (MIÖG Erg.-Bd. 17, Graz/Köln 1954), als Manfred Sтоу, Das Österreichische Institut für Geschichtsforschung 1929-1945 (MIÖG Erg.-Bd. 50, Wien 2007). Siehe zuletzt auch die relevanten Stellen bei Pavel Kolá ř, Geschichtswissenschaft in Zentraleuropa. Die Universitäten Prag, Wien und Berlin um 1900 1-2 (Geschichtswissenschaft und Geschichtskultur im 20. Jahrhundert 9, Berlin 2008).

34 Kraus (wie Anm. 2).

35 Anna Schader, Harold Steinacker (1875-1965) - Sein Weg in den Nationalsozialismus (ungedr. Diss. Klagenfurt 1997) $86 f$. 
zu können, nachgefragt, um welche „schwerwiegenden Vorwürfe“ es sich konkret handelt. Der Rezensent konnte erfreulicherweise außer der Steinacker-Stelle keine weiteren Stellen anführen ${ }^{36}$. Es ist aber nach 33 Historikerporträts der Befund erkennbar, dass generell eine reflexive Auseinandersetzung mit dem Holocaust nicht stattfand und in den einzelnen Biografien diese „Leerstelle“ (Jan Eike Dunkhase) bleibt. Abschließend gebe ich noch einige korrigierende Hinweise zum ersten Band ${ }^{37}$.

Hans Ulrich Wehler hat I97 I am Ende seines Vorworts zum ersten Band der von ihm herausgegebenen „Deutschen Historiker“ den englischen Philosophen und Mathematiker Alfred North Whitehead zitiert. 40 Jahre später darf dessen Diktum hier erneut angeführt werden. Es besagt, dass die Wissenschaft, „die zögert, ihre Begründer zu vergessen, verloren ist“. Für die Geschichtswissenschaft heißt dieses „vergessen“, den wirkmächtigen Historikerinnen und Historikern vergangener Jahrzehnte und ihren Werken einen wissenschaftsgeschichtlich fundierten Ort der Ruhe zuzuweisen, ohne sie immer wieder als Mahnmale und Wegweiser für das eigene wissenschaftliche Tun anzurufen.

36 Anfrage an Hans-Christof Kraus via E-Mail am 22.06.2009 und Antwort vom 23.06.2009: „[...] meine Formulierung bezog sich in diesem Fall ausschließlich auf die Bemerkung über Steinacker."

37 Der auf S. 357, Abb. 20, mit Hans Hirsch beim Spaziergang fotografierte Herr dürfte nicht, wie von mir im Beitrag von Andreas H. Zajic angegeben, mit Karl Maria Swoboda zu identifizieren sein. Meine S. 759 geäuBerte Vermutung, dass sich eine Briefstelle auf Konrad Josef Heilig bezieht, dürfte höchstwahrscheinlich nicht zutreffen, wie sich aus dem Beitrag zu Heilig im vorliegenden Band ergibt. 



\title{
Michael Tangl (I86I-I92I)
}

\author{
EIN ÖSTERREICHER IN BERLIN
}

\section{WOLFSBERG - WIEN - MARBURG - BERLIN : LEBENSLAUF UND WISSENSCHAFTLICHE KARRIERE}

Im Hinblick darauf, dass eine umfassende moderne und wissenschaftlichen Ansprüchen gerecht werdende Biografie Michael Tangls bereits existiert ${ }^{1}$, mag es hier genügen, die wesentlichen Stationen seines Lebens nur kurz zu umreißen. Geboren am 26. Mai I86I in Wolfsberg in Kärnten, entstammte Tangl einer durchaus kleinbürgerlichen - sowohl Vater als auch beide Großväter waren Bäcker katholischen Familie. Wieweit das Vorbild seines bereits I 866 verstorbenen Großonkels Karlmann Tangl, den er freilich kaum gekannt haben kann, Einfluss auf die spätere Berufswahl ausgeübt haben mag, ist nicht bekannt. Karlmann Tangl, Philologe und Historiker, hatte Lehrstühle in Lemberg (Lwów, Lwiw) und Graz bekleidet und sich in

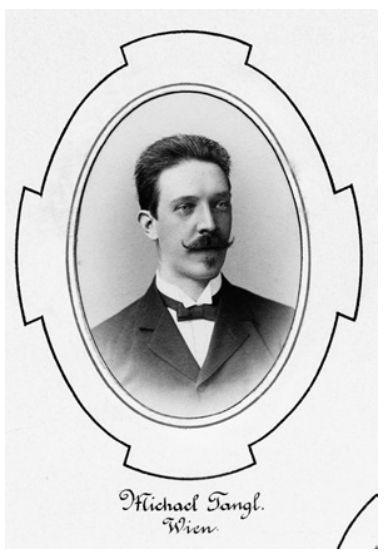

Abb. I: Michael Tangl I893 seinen historischen Arbeiten vor allem mit der Geschichte Kärntens und Innerösterreichs beschäftigt. Mit der Berufung nach Graz war ihm, wie er selbst sagte, ein Herzenswunsch erfüllt worden, da er Kärnthner durch Geburt, Steiermärker durch Neigung und vor allem Deutscher durch Gesinnung sei². Wie sein Großonkel

1 Annekatrin Schaller, Michael Tangl (1861-1921) und seine Schule. Forschung und Lehre in den Historischen Hilfswissenschaften (Pallas Athene. Beiträge zur Universitäts- und Wissenschaftsgeschichte 7, Stuttgart 2002). Die Biografie Tangls ist in dieser detaillierten Studie eingebettet in das Umfeld der wichtigsten wissenschaftlichen Institutionen, mit denen er in Verbindung stand, und berücksichtigt so gut wie lückenlos alle gedruckten und ungedruckten Quellen zu seinem Leben, wobei seine Lehrtätigkeit und seine zahlreichen Schüler besondere Berücksichtigung finden. - Für vielfältige Unterstützung danken wir dem Bibliothekar des IÖG Dr. Paul Herold, der stellvertretenden Leiterin der Handschriftenabteilung der Staatsbibliothek Preußischer Kulturbesitz in Berlin Dr. Jutta Weber, dem Bibliothekar der MGH in München, Dr. Arno Mentzel-Reuters, dem Archivar der ÖAW Dr. Stefan Sienell, dem Herausgeber Dr. Karel Hruza, dem Kärntner Landesarchiv in Klagenfurt sowie den Universitätsbibliotheken in Hamburg, Köln und München.

2 Zu Karlmann Tangl vgl. Constant v. Wurzbach, Art. „Tangl, Karlmann“, in: Biographisches Lexikon des 
besuchte Michael Tangl zunächst die Volksschule in Wolfsberg, um danach in das Gymnasium des Benediktinerklosters St. Paul im Lavant zu wechseln. Nach eigener Aussage waren es die in St. Paul im Lavanttal aufbewahrten Handschriften- und Urkundenschätze der Abtei St. Blasien im Schwarzwald, die sein Interesse weckten und seine Studienwahl beeinflussten ${ }^{3}$.

Nach Abschluss der gymnasialen Ausbildung am elitären Schottengymnasium in Wien ${ }^{4}$ begann Tangl zunächst - wohl auf Wunsch seiner Eltern - in Wien ein Studium der Rechtswissenschaften, das er indessen schon nach kurzer Zeit abbrach, um Geschichte zu studieren. Schon bald konzentrierte er sich auf das Gebiet der historischen Hilfswissenschaften und durchlief in den Jahren I 885 -1 887 den I6. Ausbildungskurs am IÖG5 Seine wesentliche Prägung erfuhr er durch Lehrer wie Theodor von Sickel und Engelbert Mühlbacher, sie förderten ihn im Hinblick auf eine streng hilfswissenschaftliche Ausrichtung, die seine gesamte spätere berufliche und wissenschaftliche Laufbahn bestimmen sollte ${ }^{6}$. Aufenthalte als Stipendiat am Österreichischen Historischen Institut in Rom in den Jahren I 888-I889 und I891 weckten sein Interesse für die Geschichte der päpstlichen Kanzlei, mit der er sich zeitlebens intensiv beschäftigen und aus deren Bereich er auch das Thema seiner Dissertation wählen sollte, die er Ende I 889 vorlegte und die in erweiterter Form eine seiner drei Habilitationsschriften ${ }^{7}$ bildete. Neben einer ersten be-

Kaiserthums Österreich 43 (1881) 50-54, die zitierte Stelle ebd. 51, und [Franz] von Krones, Art. „Tangl, Karlmann“, in: ADB 37 (1894) 370-371.

3 Michael TAngl, Antrittsrede, in: SB der Preußischen Akademie der Wissenschaften 1918, 2. Halbbd. (Berlin 1918) 702-704, hier $702 \mathrm{f}$.

4 Seine Tochter Georgine formulierte: „Die Vollendung seiner Gymnasialbildung am Wiener Schottengymnasium [...] brachte ihn früh zu den besten geistigen Kreisen der Hauptstadt in Beziehung." Siehe Georgine TANGL, Michael Tangl. Zur Lebensgeschichte, in: Michael TAngL, Das Mittelalter in Quellenkunde und Diplomatik. Ausgewählte Schriften 1-2 (Forschungen zur mittelalterlichen Geschichte 12, Berlin 1966) (= TANGL, Mittelalter 1-2) 19-12, hier 9.

5 Zu seinen Kurskollegen zählten Berthold Bretholz, Wilhelm Erben, Wladimir Milkowicz, Alfred Schnerich, sowie Anton Chroust, Julius Schönherr und Fritz Stöber als außerordentliche Mitglieder, vgl. Leo SAn T IfaLLER, Das Institut für österreichische Geschichtsforschung. Festgabe zur Feier des zweihundertjährigen Bestandes des Wiener Haus-, Hof- und Staatsarchivs (Veröff. des IÖG 11, Wien 1950) 112f.; Alphons Lнотsку, Geschichte des Instituts für Österreichische Geschichtsforschung 1854-1954 (MIÖG Erg.-Bd. 17, Graz/Köln 1954) 187-192.

6 Das Verhältnis Tangls zu seinen zwei großen Lehrern charakterisiert Paul Ke hr, Michael Tangl. Ein Nachruf, in: NA 44 (1922) 139-150, hier 139f.: „Tangl ist beider Schüler, Sickels und Mühlbachers; von jenem empfing er die stärkeren wissenschaftlichen Anregungen; diesem schloß er sich persönlich näher an, denn Mühlbacher war ihm im Alter und in der Gemeinsamkeit der Heimat vertrauter als der alte Meister, dessen Strenge das Alter nicht gemildert hatte [...] die Worte, die er [Tangl] Mühlbacher [in dessen Nachruf] widmete, zeugten von den herzlichen Gefühlen, die er für den geschiedenen Freund und Berater hegte.“

7 Michael TAngl, Das Taxwesen der päpstlichen Kanzlei vom 13. bis zur Mitte des 15. Jahrhunderts, in: MIÖG 13 (1892) 1-106. 
ruflichen Tätigkeit in den Archiven zunächst des Innen-, dann des Finanzministeriums und der Lehrtätigkeit an der Wiener Universität verfasste er seine bis heute als Standardwerk geltende Arbeit über die päpstlichen Kanzleiordnungen ${ }^{8}$ und begann, an der von Mühlbacher geleiteten Edition der Diplomata Karolinorum für die MGH mitzuarbeiten, als er I 895 als Extraordinarius an die Philipps-Universität in Marburg an der Lahn berufen wurde. Wegen der ein Jahr zuvor auf Initiative Heinrich von Sybels und Paul Fridolin Kehrs in Marburg eingerichteten „Archivschule“, einer Ausbildungsstätte in den historischen Hilfswissenschaften nach Wiener Vorbild, die einen besonderen Platz im universitären Studienablauf einnahm, kam die Berufung nach Marburg Tangl sehr entgegen ${ }^{9}$. In Marburg arbeitete Tangl weiterhin an den Karolingerdiplomen und widmete sich besonders den Urkundengruppen von Bremen und Verden sowie von Hersfeld und Fulda, wobei ihn seine Forschungen über die Fuldaer Urkunden ${ }^{10} \mathrm{zu}$ einer intensiven Beschäftigung mit dem Leben des heiligen Bonifatius ${ }^{11}$ und dessen Briefen führten.

Von Marburg wurde Tangl im Juni I 897 als außerordentlicher Professor an die Berliner Friedrich-Wilhelms-Universität berufen. Nach dem überraschenden Tod Wilhelm Wattenbachs sah er sich als alleiniger Vertreter der historischen Hilfswissenschaften mit sinkenden Hörerzahlen im Bereich der mittelalterlichen Geschichte konfrontiert; dementsprechend schwierig gestalteten sich die ersten Jahre - gerade für den Österreicher und Katholiken Tangl - in Berlin ${ }^{12}$. Auch nachdem er im Jahr I900 zum ordentlichen Professor ernannt worden war, empfand er sich im Wissenschaftsbetrieb und privat als isoliert, freundschaftliche Beziehungen pflegte er lediglich zu dem MGH-Mitarbeiter Oswald Holder-Egger und dem Rechtshistoriker Karl Zeumer ${ }^{13}$. Äußerliche Anhaltspunkte

8 Die päpstlichen Kanzleiordnungen von 1200 bis 1500, hg. v. Michael TANGL (Innsbruck 1894).

9 Gerhard Овевкоғцев, Über den Einfluß der österreichischen Schule der historischen Hilfswissenschaften in Berlin. Die Berufung von Michael Tangl (1861-1921) nach Berlin (1897) und seine Wahl zum ordentlichen Mitglied der Preußischen Akademie der Wissenschaften (1918), in: Tiroler Heimat. Jb. für Geschichte und Volkskunde $51 / 52$ (1987/1988) 233-241, spricht die Vermutung aus, dass Kehr Tangl, den er in Wien am IÖG kennen gelernt hatte, als seinen Nachfolger ins Spiel gebracht haben könnte (hier 234). Tangl selbst hätte allerdings eine akademische Laufbahn in Österreich vorgezogen: Ich wäre 1895 dem Ruf als Extraordinarius nach Marburg, der für mich, der bereits mit Weib und Kind belastet war, in mancher Hinsicht einen Sprung ins Ungewisse bedeutete, nicht so unbedenklich gefolgt, wenn nicht meine Aussichten für die akademische Carrière in Österreich dermaßen schlecht gestanden hätten [...]. Brief Tangls an Albert von Werminghoff, 08.05.1906, München, Archiv der MGH, B 425.

10 Vgl. etwa Michael TAngl, Die Fuldaer Privilegienfrage, in: MIÖG 20 (1899) 193-252.

11 Vgl. hier etwa Michael TAngL, Das Todesjahr des Bonifatius, in: Zs. des Vereins für hessische Geschichte und Landeskunde NF 27 (1903) 223-250.

12 Schaller, Tangl (wie Anm. 1) 103-117, hier besonders 114-117.

13 Kenr, Tangl (wie Anm. 6) 141, sah den Grund für Tangls bleibende Distanz zu seiner neuen Heimat Berlin vor allem in dessen zu unterschiedlichen Wesensart begründet: „Er war eine weiche und konziliante Natur; hier aber stießen die Menschen scharf aufeinander [...]. Vor den berühmteren Kollegen trat er bescheiden in 
scheint es für dieses Gefühl kaum gegeben zu haben, auch die Teilnehmerzahlen seiner Vorlesungen und Übungen nahmen in den folgenden Jahren in kontinuierlicher Weise $\mathrm{zu}^{14}$. Neben der Weiterarbeit an den Karolingerurkunden war Tangl zudem I 898 von den MGH mit der Bearbeitung der älteren fränkischen und italienischen Gerichtsurkunden der Placita - beauftragt worden. Trotz einer Reihe von Archivreisen, die schließlich eine nach seinen Angaben so gut wie vollständige Materialsammlung hinsichtlich der fränkischen Placita zur Folge hatten, wurde die Fertigstellung immer wieder aufgeschoben. Dem Urteil Kehrs zufolge war nach Tangls Tod weder die Materialsammlung vollständig, noch das Vorhandene in einem druckfertigen Zustand ${ }^{15}$. Ohne Zweifel hatte es sich um ein Projekt gehandelt, das Tangl pflichtgetreu übernommen, dem er sich aber wohl nie mit großer Begeisterung gewidmet hat.

Hingegen hatte Tangl im Zuge der Bearbeitung der Karolingerurkunden ein neues Gebiet entdeckt, dem er sich mit Hingabe zuwandte, die tironischen Noten. Die Entzifferung dieser im antiken Rom entwickelten Kurzschrift, die noch in merowingischen und karolingischen Urkunden für Kanzleivermerke verwendet wurde, war damals erst wenigen Gelehrten, unter ihnen Theodor von Sickel und französischen Forschern wie Pierre Carpentier, Jules Tardif und Maurice Jusselin, ansatzweise gelungen. Nach einer sehr mühsamen Phase der Einarbeitung entwickelte sich Tangl bald zum anerkannt besten Kenner der Tachygrafie und verfasste dazu nicht nur mehrere grundlegende wissen-

den Hintergrund; auch die Regierung tat nichts, seine Lage zu verbessern [...] in dieser schneidenden Luft, wo gemütliches Behagen nicht gedeihen will und wo die Verhältnisse der rechten Entfaltung seiner Eigenart nicht günstig waren, ist er nie recht heimisch geworden und trotz aller Erfolge als Lehrer und Gelehrter wohl auch nie glücklich gewesen. "Hermann Krabbo bemerkt in seinem vor dem Verein für Geschichte der Mark Brandenburgs gehaltenen Nachruf auf Tangl: „Bei alledem ist er aber - mochte er auch gelernt haben, gut preußisch zu empfinden - im Grunde doch stets ein echter Österreicher geblieben; nach den Bergen seines Vaterlandes hat es ihn immer wieder hingezogen [...]. “Vgl. den Abdruck dieser Rede in den SB des Vereins für Geschichte der Mark Brandenburg. Sitzung vom 12.10.1921, in: Forschungen zur Brandenburgischen und Preußischen Geschichte 35 (1923) 1-6. Heinrich Ficht enau, Diplomatiker und Urkundenforscher, in: MIÖG 100 (1992) 9-49, hier 39, spricht sogar wenig beschönigend von einer „Fehlentscheidung“ Tangls, den Ruf nach Berlin angenommen zu haben, denn dieser sei von seinen Berliner Kollegen „eher von der folkloristischen Seite betrachtet und [...] nicht als gleichranging angenommen "worden.

14 Schaller, Tangl (wie Anm. 1) 116f. Durchwegs positiv wird Tangls Wirken in Berlin auch heute noch beurteilt, vgl. etwa Eckart Henning, Die Historischen Hilfswissenschaften in Berlin, in: Geschichtswissenschaft in Berlin im 19. und 20. Jahrhundert. Persönlichkeiten und Institutionen, hg. v. Reimer Hansen, Wolfgang Rıвве (Veröff. der Historischen Kommission zu Berlin 82, Berlin/New York 1992) 365-408, hier 373-375, 392 und 397.

15 Paul Keнr, Bericht über die Herausgabe der Monumenta Germaniae Historica 1921, in: NA 45 (1924) 1-13, hier 8 . 
schaftliche Studien ${ }^{16}$, sondern gab sein Wissen auch in mehreren Lehrveranstaltungen ${ }^{17}$ an seine Studenten weiter.

Im Jahr 1902 wurde Tangl schließlich einstimmig in die Zentraldirektion der MGH gewählt und zum provisorischen Leiter der Epistolae-Abteilung bestellt. Die Ende 1903 nach dem Tod Engelbert Mühlbachers erfolgte Berufung Emil von Ottenthals als Nachfolger auf dessen Wiener Lehrstuhl, ließ Tangl die bis dahin gehegte Hoffnung, nach Wien zurückkehren zu können, wohl endgültig begraben. Jedoch übertrug ihm die Zentraldirektion der MGH Anfang 1904 die Leitung der Diplomata Karolinorum. In Wien wurde, um am dortigen Standort die weitere Mitwirkung an den MGH zu gewährleisten, eine Diplomata-Abteilung, die sich der Edition der Stauferurkunden bis Friedrich II. widmen sollte, eingerichtet, als deren Leiter Ottenthal bestellt wurde ${ }^{18}$. Durch die Übersiedlung

16 Vgl. unten S. $53 \mathrm{f}$.

17 So in den WS 1900/01, 1906/07, 1910/11 und im SS 1914; vgl. das Verzeichnis der akademischen Lehrveranstaltungen Tangls an der Friedrich-Wilhelm-Universität zu Berlin bei SCh a lle R, Tangl (wie Anm. 1) 376-380. Eine neuerliche Beschäftigung mit den tironischen Noten, diesmal in Form eines Privatissimums im Rahmen der „Übungen für Archivaspiranten“, plante Tangl für das Wintersemester 1921/1922, wie er am 06.08.1921 in einem seiner letzten Briefe an Kehr schrieb: Mir läge vor allem daran, die Tradition im Betrieb dieses abgelegenen und doch wichtigen Sondergebiets nicht abreißen zu lassen. Und soweit ich sie vermitteln kann, ists vielleicht letztes oder vorletztes Läuten. München, Archiv der MGH, 338/200 (Personalakten Michael Tangl), fol. 30v-31r.

18 Noch vor seiner Bestellung zum Ordentlichen Professor in Berlin im Jahr 1900 hatte Tangl ernsthafte Verhandlungen bezüglich der Stellung des Direktors des Finanzarchivs in Wien geführt, die jedoch letztlich wohl daran scheiterten, dass er mit der Übernahme des Direktorsposten ein Ordinariat an der Universität Wien gefordert hatte, vgl. Schalle R, Tangl (wie Anm. 1) 112f. Bereits Kenr, Tangl (wie Anm. 6) 142, beurteilte die damals getroffenen Entscheidungen sehr kritisch: „Tangl selbst hat unter diesen Verhältnissen schwer gelitten und am meisten unter den Vorgängen nach Mühlbachers Tod. Kein Zweifel, er wäre dessen berufener Nachfolger in Wien gewesen, wohin ihn sein Herz zog, und der geborene Leiter der dortigen Diplomataabteilung. “ Weiter bemerkt Kehr, ebd. 143, dazu: „[...] wie hätten diese Karolingerdiplome unter seiner Leitung in Wien, am Sitze der Sickelschen Tradition, unbeeinträchtigt durch die vielen Pflichten und Geschäfte, wie Berlin sie unserm geplagten Freunde aufbürdete, gefördert werden können! So ließ er schweren Herzens die Dinge bei den Diplomata gehen, so gut sie wollten [...].“ Lнотsку, Geschichte des Instituts (wie Anm. 5) 191 und 292 Anm. 17, resümierte nach einer kurzen Darstellung des wissenschaftlichen Wirkens Tangls: „Man muß sehr bedauern, daß die Rückgewinnung dieses Mannes für Wien nach Mühlbachers Tod nicht möglich war“, und deutete an, dass Tangl schon zu einem frühen Zeitpunkt aus persönlichen Gründen nicht mehr in Erwägung gezogen wurde. Seine Einschätzung teilte auch Fichtenau, Diplomatiker (wie Anm. 13) 38f.: Für die Weiterführung der Karolingerdiplome hätte „sich als weitaus beste Lösung eine Rückberufung Michael Tangls von Berlin nach Wien auf die freie Lehrkanzel Mühlbachers“ angeboten. Zur Annahme der Beauftragung mit den Karolingerdiplomen seitens der Monumenta habe sich Tangl auch nur deshalb entschlossen, „weil er hoffte, damit seine Rückkehr in die Heimat vorzubereiten“. Die Vorgänge rund um die Nachbesetzung der Lehrkanzel Mühlbachers hatten letztlich nicht nur für Tangl bittere persönliche Konsequenzen, sondern: „Das sachliche Ergebnis war auch für das Institut nicht günstig und trug mit dazu bei, bestehende Abneigungen gegen die Wiener Schule zu vertiefen." Von diesem Blickpunkt aus sei es zu „bedauern, daß dabei sehr menschliche 
der Karolingerabteilung nach Berlin, dadurch bedingte Mitarbeiterwechsel und Tangls Entschluss, den eigentlich druckfertigen ersten Band noch einmal einer Revision zu unterziehen, verzögerte sich dessen Erscheinen (nach I4-jähriger Bearbeitungszeit) bis ins Frühjahr I906. Seit Mitte I905 arbeitete die Berliner Karolingerabteilung unter Tangls Leitung an der Vorbereitung des zweiten Bandes, den Urkunden Ludwigs des Frommen, für die einige der im ersten Band befolgten Richtlinien abgeändert wurden. Daneben war das Seminar für Historische Hilfswissenschaften durch die I904 erfolgte Verlegung der Archivarsausbildung von Marburg nach Berlin, wo die Lehrveranstaltungen zum Teil an der Universität, zum Teil am Geheimen Staatsarchiv stattfanden, nun auch unmittelbar mit der Heranbildung zukünftiger preußischer Archivbeamter befasst, für die Tangl seit dieser Zeit eigens konzipierte Übungen abhielt ${ }^{19}$.

Nur zögernd stellten sich äußerliche Zeichen der Anerkennung seiner wissenschaftlichen Leistungen ein. 1909 wurde Michael Tangl zum Korrespondierenden Mitglied der Königlich böhmischen Gesellschaft der Wissenschaften in Prag und I9I 3 zum Korrespondierenden Mitglied der Bayerischen Akademie der Wissenschaften gewählt, im Januar I 9 I 8 erfolgte schließlich seine - im Hinblick auf seine Berufung auf den Berliner Lehrstuhl - späte Wahl zum Ordentlichen Mitglied der Preußischen Akademie der Wissenschaften in Berlin. Die Antrittsrede, die er zu diesem Anlass hielt, stellt eines der wichtigsten Selbstzeugnisse Tangls dar ${ }^{20}$.

Die Enttäuschung über die Nachfolge Mühlbacher zugunsten Ottenthals hatte zu einer dauerhaften und endgültigen Entfremdung zwischen Tangl und dem IÖG geführt. Anstatt wie bisher immer wieder Arbeiten in den MIÖG zu veröffentlichen, fasste Tangl I 905 gemeinsam mit Harry Bresslau und Karl Brandi den Plan, eine neue hilfswissenschaftlich orientierte Zeitschrift zu begründen. Als Titel des neuen Publikationsorganes, in dem nicht nur Aufsätze, sondern vor allem auch umfangreichere Einzeluntersuchungen, etwa Dissertationen, veröffentlicht werden sollten, einigte man sich schließlich nach einer Idee des Verlags, in dem die Zeitschrift erscheinen sollte, Veit \& Comp. in Leipzig, - auf den Namen „Archiv für Urkundenforschung“21. Tangl nützte die neue

Beweggründe eine große Rolle spielten“ (ebd. 41). - Zu den Vorgängen um die Nachfolge Mühlbachers vgl. auch Bettina Pferschy-Malecze K, Die Diplomata-Edition der Monumenta Germaniae Historica am Institut für Österreichische Geschichtsforschung (1875-1990), in: MIÖG 112 (2004) 412-467, hier $415 f$.

19 „Paläographisch-diplomatische Übungen für Archivaspiranten“ wurden von Tangl seit dem Wintersemester 1904/05 bis zu seinem Tod in jedem Semester angeboten, wenn diese auch in den Jahren 1914-1918 kriegsbedingt zum Großteil nicht zustande kamen, vgl. das Verzeichnis der akademischen Lehrveranstaltungen Tangls bei Schaller, Tangl (wie Anm. 1) 377-380.

20 TAngl, Antrittsrede (wie Anm. 3) 703f.

21 Über die kritischen Reaktionen - vor allem von Vertretern des IÖG - auf die in der programmatischen Einleitung des „Archivs für Urkundenforschung“ sehr akzentuiert vorgetragene Abgrenzung zur Sickel'schen diplomatischen Schule, die die Spannungen zu dem Wiener Institut weiter verschärften, vgl. weiter unten $66 \mathrm{f}$. 
Zeitschrift weniger für eigene Arbeiten als vor allem als Plattform für die Veröffentlichung von Arbeiten seiner Schüler ${ }^{22}$. In die folgenden Jahre fällt auch die Mitarbeit Tangls an einem weiteren großen editorischen Unternehmen des deutschen Sprachraums, der - wie die MGH auf Anregung des Freiherrn vom Stein gemeinsam mit Georg Heinrich Pertz begründeten - Reihe der „Geschichtsschreiber der deutschen Vorzeit“, in der seit I 846 bis I9I I 90 Bände mit deutschen Übersetzungen mittelalterlicher lateinischer Geschichtsquellen erschienen waren. Nach dem Tod Oswald Holder-Eggers i9 I , der zuletzt das Unternehmen geleitet hatte, trat Tangl dessen Nachfolge an und bearbeitete selbst vier Bände ${ }^{23}$. Mit der zunächst provisorischen Leitung der Epistolae-Abteilung ( 902 bis I 906 und neuerlich I 908 bis April I909) und der daran anschließenden Bestellung zum definitven Leiter erfolgte in den darauffolgenden Jahren eine verstärkte Beschäftigung mit der Quellengruppe der Briefe, für die Tangl einen detaillierten Editionsplan erstellte, an dessen Verwirklichung er und seine Mitarbeiter Ernst Perels und Erich Caspar arbeiteten.

Durch den Ausbruch des Ersten Weltkrieges, der mit der Einberufung der wehrfähigen Mitarbeiter sowie finanziellen Engpässen die wissenschaftliche Arbeit allerorts wenn nicht ganz zum Erliegen brachte so doch zumindest in hohem Maße einschränkte, kam es auch zu Beeinträchigungen in den von Tangl geleiteten Projekten. Nach dem Tod Reinhold Kosers im August I9I4 wurde Tangl einstimmig zum stellvertretenden Vorsitzenden der MGH gewählt, da sich die Regierung nicht in der Lage sah, frei gewordene Stellen vor Ende des Krieges definitiv wiederzubesetzen. Für Tangl bedeutete die De-facto-Leitung der MGH neben seiner Lehrtätigkeit und der Leitung von drei MGH-Projekten, die er damals innehatte - Placita, Diplomata Karolinorum und Epistolae -, sowie seit i9i I der Redaktion des „Neuen Archivs“ und darüber hinaus seinen persönlichen wissenschaftlichen Vorhaben eine erhebliche Arbeitsbelastung und übergroße Verantwortung, der er letztlich nicht gewachsen war. Wenn es auch nicht zu der bereits Anfang August I 9 I 4 vom Reichsamt des Inneren aus Spargründen geforderten Einstellung der Arbeiten an allen Projekten der MGH kam, wurden doch allenthalben - zum Teil auch freiwillige - Einsparungsmaßnahmen als Folge des Krieges spürbar. Zudem war die personelle Situation durch Einberufungen von Mitarbeitern zum Militärdienst sowie alters- und nicht wenige kriegsbedingte Todesfälle so angespannt, dass sowohl das Erscheinen des „Neuen Archivs“ als auch die Editionsarbeiten darunter litten. Auf Letztere wirkte sich zusätzlich noch besonders die weitgehende Unmöglichkeit von Archivreisen, besonders in Länder, mit denen man sich im Kriegszustand befand, aber auch im eigenen Land, ungünstig aus. Stagnierten die Arbeiten an den

22 Von seinen eigenen Arbeiten veröffentlichte er lediglich zwei in der neu gegründeten Zeitschrift: Michael TANGL, Die Tironischen Noten in den Urkunden der Karolinger, in: Archiv für Urkundenforschung (= AUF) 1 (1908) 87-166, und DERs., Forschungen zu Karolinger-Diplomen, in: ebd. 2 (1909) 167-326.

23 Vgl. unten 57 (mit Anm. 153-155). 
Diplomata Karolinorum und den Placita während des Krieges, so intensivierte Tangl in dieser Zeit seine Arbeit an den Epistolae, besonders der von ihm begründeten Reihe der Epistolae selectae. Obwohl die Hörerzahlen während des Krieges drastisch zurückgingen - Das Semester [Sommersemester I9 I 5] begann, wie zu erwarten stand: in Urk[undenlehre] II I Buckliger, I Lahmer, s Herzkranke, I Nierenkranker und 4 Damen $^{24}$-, bot Tangl auch während der Kriegsjahre immer mindestens vier Lehrveranstaltungen pro Semester an. Um in seinen Berliner Studenten das Bewusstsein der geschichtlichen Entwicklung und der Rolle der österreichisch-ungarischen Monarchie innerhalb Europas zu schärfen, wandte er sich gerade in der Zeit, als sich ihr Zusammenbruch abzuzeichnen begann, in seinen Vorlesungen, aber auch in seinen Seminaren an der Berliner Universität vermehrt Themen aus der österreichischen Geschichte, sogar aus dem Bereich der Neuzeit, $\mathbf{z u}^{25}$.

Die sowohl beruflich als auch in menschlicher Hinsicht schwierigen Kriegsjahre und der sich ankündigende Zerfall der Donaumonarchie, deren Bestand für Tangl aus historischer Sicht, wohl aber auch aus emotionalen Gründen eine Notwendigkeit darstellte, forderten von Tangl in physischer (durch die Mangelernährung) ${ }^{26}$ und psychischer (durch die zahlreichen Todesfälle im Bekanntenkreis und durch die unsichere politische Zukunft seiner Heimat) Hinsicht ihren Tribut. Seine Überforderung machte sich in verschiedener Hinsicht bemerkbar. Zum einen war es ihm nicht mehr möglich, seine Kräfte gleichermaßen auf die verschiedenen ihm anvertrauten Projekte zu konzentrieren, was zu einer Verzögerung oder, wie ihm mehrfach vorgeworfen wurde, Verschleppung anstehender Arbeitsschritte führte. Zum anderen zeigte sich nun vor allem, dass große Organisationsaufgaben nicht seiner Natur entsprachen und ihn besonders in dieser Zeit überforderten. Diesen von seinen Zeitgenossen als „Kriegsnervosität“ oder auch „Kriegspassivität“ apostrophierten Zustand, der als Folge des Krieges während dieser Jahre gar nicht selten zu beobachten war $^{27}$, bezeichnete Tangl selbst als geistige Abnormität, die er in den letzten zwei Jahren selbst mit Bangen und Schrecken wachsen sah ${ }^{28}$. Andere wiederum konstatierten,

24 Tangl in einem Brief an Bresslau vom 08.05.1915, zitiert nach Schaller, Tangl (wie Anm. 1) 262. Mit der befremdlichen Nennung von weiblichen Studenten in einem Atemzug mit Behinderten und Kranken wollte Tangl vermutlich ausdrücken, dass durch den Ausfall der nahezu gesamten wehrhaften Bevölkerung auch Exoten, zu denen Frauen damals zweifellos noch an den Universitäten zählten, plötzlich einen im Vergleich zu vorher unverhältnismäßig großen Anteil der Hörerschaft ausmachten.

$25 \mathrm{Zu}$ ähnlichen Haltungen österreichischer Historiker in Österreich vgl. Günther Ramh a R d ter, Geschichtswissenschaft und Patriotismus. Österreichische Historiker im Weltkrieg 1914-1918 (Österreich Archiv 22, Wien 1973) 57-62 und 180-183.

26 Karl Hampe vermerkte am 26.04.1917 in seinem Tagebuch: Tangl hatte 40 Pfund abgenommen; das ist so ziemlich die Regel. Siehe Karl Hampe, Kriegstagebuch 1914-1919, hg. v. Folker Reichert, Eike Wolgast (Deutsche Geschichtsquellen des 19. und 20. Jahrhunderts 63, München $\left.{ }^{2} 2007\right) 539$.

27 Vgl. dazu mit den entsprechenden Nachweisen Schalle r, Tangl (wie Anm. 1) 270f. mit Anm. 1134.

28 Ebd. 271, nach einem Schreiben Tangls vom 16.01.1919 an Bresslau. München, Archiv der MGH, B 40. 
einen nahezu an Geistesstörung befindlichen Zustand der Überarbeitung an Tangl beobachtet zu haben ${ }^{29}$. Die körperliche und seelische Verfassung Tangls verursachte eine Passivität und wohl auch zeitweilig gleichsam eine Lähmung, die sich nachteilig auf die Geschäftsführung der MGH auswirkte. Von verschiedenen Seiten wurden Klagen und Vorwürfe geäußert, Tangl vernachlässige vor allem die Erledigung seiner Korrespondenz und sei auch für die Verzögerung des seit dem Tod Karl Zeumers I9I4 ihm allein anvertrauten „Neuen Archivs" verantwortlich zu machen ${ }^{30}$. Wie anhaltend schwierig die Lage jedoch allgemein war, zeigt sich auch daran, dass es durch die Nachwirkungen des Krieges und wegen der unsicheren politischen Situation der Nachkriegszeit nicht möglich war, die geplanten Feierlichkeiten zum ıoo-jährigen Bestehen der MGH, am Jahrestag, der am 20. Januar I9 9 begangen werden sollte, abzuhalten. Auch hatte das Reichsamt des Inneren eine Entscheidung über den zu bestellenden Vorsitzenden der MGH hinausgezögert, obwohl die Zentraldirektion bereits I9I 6 in einem ersten Wahlgang Tangl selbst, in einem zweiten und dritten dann Bresslau gewählt und dementsprechende Vorschläge dem RMI übermittelt hatte. Der vom RMI favorisierte Kandidat, Kehr, war seitens der Zentraldirektion wegen bestehender Animositäten nicht in Betracht gezogen worden ${ }^{31}$. Erst I 9 I 9 widmete sich das RMI erneut der Bestellung eines Vorsitzenden der MGH und konnte nach der endgültigen Ablehnung Bresslaus die Zentraldirektion zur Wahl Kehrs bewegen - ein von den Mitgliedern der Zentraldirektion mit Empörung aufgenommener Akt der Einmischung in die internen Angelegenheiten der MGH, dem sie aber nichts entgegenzusetzen vermochten. Für Tangl jedoch, der Bresslau zwar bis zuletzt unterstützt hatte, bedeutete die Wahl des energisch-tatkräftigen Kehr letztlich die Befreiung von einer zu schwer gewordenen Last, und er beeilte sich, den neuen Vorsitzenden seiner Kooperationsbereitschaft zu versichern. Auch eine für Tangl unangenehme finanzielle Angelegenheit - unter seiner Verwaltung der Gelder der MGH war eine nicht unbeträchtliche Summe an Ersparnissen der MGH

29 Schaller, Tangl (wie Anm. 1) 271 mit Anm. 1138. Vgl. dazu auch den Brief Emil Seckels an Bresslau vom 16.01.1919. München, Archiv der MGH, B 40: So vollkommen rätselhaft ist mir das Verhalten Tangls nicht. Er ist durch seine zwei großen Bonifatius-Aufsätze überarbeitet, und jedenfalls ist er kriegsnervös. Sein Sohn steht seit Mitte Dezember an einem sehr gefährlichen Posten bei Verdun [...]. Ich bitte Sie also, Tangl nicht sehr böse zu sein, wenn er Ihnen demnächst die Papiere schickt.

30 Schaller, Tangl (wie Anm. 1) 269-271 und 250-252.

31 Tangl versicherte in einem Brief vom 16.01.1919 Bresslau seiner ausdrücklichen Unterstützung. München, Archiv der MGH, B 40 (zitiert unten Anm. 200). Allerdings gab es durchaus auch innerhalb der Zentraldirektion Stimmen, die eine Wahl Kehrs wegen dessen energischer Durchsetzungskraft und Zielstrebigkeit als die beste Lösung für die angeschlagenen Monumenta befürworteten, vgl. Hampe, Kriegstagebuch (wie Anm. 26) 539: Hampe schrieb am Donnerstag, dem 26.04.1917, anlässlich seiner Wahl in die Zentraldirektion der MGH: Aber andererseits ist der gegenwärtige Zustand sehr traurig, und selbst der körperlich und geistig etwas reduziert scheinende Tangl, den ich besuchte, meinte, das Ende vom Liede würde wohl ein aufoktroyiertes Regime Kehrs sein. Ich persönlich würde das für einen Weg der Rettung halten, der freilich zu heftigen persönlichen Reibereien führen müßte. 
verschwunden - konnte schließlich durch die Rettungsaktion einer anonym handelnden, mit Tangl befreundeten Persönlichkeit beigelegt werden ${ }^{32}$.

Die letzten Lebensjahre Tangls nach dem Krieg waren gekennzeichnet einerseits von der Beendigung seiner Mitarbeit an den Diplomata Karolinorum, denen er im April I 920 - ob freiwillig oder auf Druck Kehrs, ist nicht sicher - den Rücken zuwandte, andererseits von der Wiederaufnahme der Arbeiten für die Epistolae-Abteilung, wobei er sich besonders der Vorbereitung seiner Edition des Registrum super negotio imperii aus der Kanzlei Papst Innocenz' III. widmete. Sein plötzlicher Tod am 7. September I92 I nach einer Ruhrinfektion, die er sich im Sommer I92 I zugezogen hatte, als er erstmals nach dem Krieg wieder in seiner Heimat Kärnten den Urlaub verbrachte, entriss ihn, 6o-jährig, einer weiteren wissenschaftlichen Tätigkeit, der er sich nach Jahren der Entbehrungen, psychischer Strapazen und Überforderung durch organisatorische Verpflichtungen wieder mit Enthusiasmus zuzuwenden begonnen hatte ${ }^{33}$. Tangls Tochter Georgine, die ebenfalls Historikerin war und neben ihrer Tätigkeit als Gymnasiallehrerin freiberuflich für die MGH arbeitete - sie widmete sich besonders Fragen aus dem Gebiet der Diplomatik und den Registern Innocenz' III. - machte sich die Bewahrung des wissenschaftlichen Vermächtnisses ihres Vaters zur Lebensaufgabe. Die Krönung ihrer Bemühungen war das Erscheinen einer zweibändigen Aufsatzsammlung „Mittelalter in Quellenkunde und Diplomatik“, der sie eine kurze Lebensbeschreibung ihres Vaters voranstellte ${ }^{34}$.

\section{II. ... dieser wahrhaft gute Mensch: FAMILIE UND PERSÖNLICHKEIT}

Der geschwisterlos aufwachsende Tangl muss eine „recht sorglose“ und „behütete“ Kindheit in seiner Kärntner Heimat verbracht haben ${ }^{35}$, da seine lebenslange Verbundenheit

32 Vgl. dazu Schaller, Tangl (wie Anm. 1) 275f. Selbst Kehr, der Tangls Leitung der MGH aus verschiedenen Gründen skeptisch gegenüberstand, urteilte abschließend folgendermaßen über dessen Amtszeit: „Bereits vor dem 1. Weltkrieg war die Aufgabenfülle, die Tangl zu bewältigen hatte, zu groß geworden: Aber so groß seine Arbeitskraft war, alle diese Aufgaben nebeneinander und gleichmäßig zu fördern, war menschenunmöglich; im großen Stile zu organisieren lag nicht in seiner Art [...]. Tangl selbst hat unter diesen Verhältnissen schwer gelitten [...]. Um so mehr ist anzuerkennen, was Tangl unter so schwierigen und ungünstigen Verhältnissen [seit 1914] für unser Unternehmen [die MGH] geleistet hat. "KeHr, Tangl (wie Anm. 6) 142f.

33 Tangl wurde in Klagenfurt auf dem Städtischen Friedhof Annabichl begraben. Ende der 1920er-Jahre wurde sein Grab, dessen Grabstein nach einem Aufruf des Geschichtsvereins für Kärnten von zahlreichen Mitgliedern der Preußischen Akademie der Wissenschaften und den MGH finanziert wurde, von der Stadt Klagenfurt zum Ehrengrab erhoben; vgl. dazu Schaller, Tangl (wie Anm. 1) 286, und Ines Oberling, Ernst Perels (1882-1945). Lehrer und Forscher an der Berliner Universität (Bielefeld 2005) 132f.

34 TAngl, Mittelalter 1-2. Zur Lebensbeschreibung vgl. oben Anm. 4.

35 So zumindest Schaller, Tangl (wie Anm. 1) 18. 
mit ihr von nahezu allen, die ihn persönlich kannten und sich - meist in Form von Nachrufen - zu seiner Biografie äußerten, besonders hervorgehoben wurde ${ }^{36}$ und auch in seinen regelmäßigen sommerlichen Besuchen zum Ausdruck kommt.

Besonders während seiner Studienzeit in Wien ${ }^{37}$ nahm Tangl am reichen kulturellen Leben der Hauptstadt regen Anteil, er war Mitglied des Wiener Männergesang-Vereines und regelmäßiger Besucher in den Wiener Theatern. Die Frau, die er schließlich heiratete, Georgine Nüchtern, hatte nach ihrer Gesangsausbildung eine Karriere als Opernsängerin angestrebt. Dazu kam es jedoch nicht, da sie sich I 890 entschloss, den Heiratsantrag Michael Tangls anzunehmen. Die Hochzeit fand Ende Juli I 892 in der Karlskirche in Wien statt, im Mai des folgenden Jahres wurde als erstes Kind des Paares die Tochter Georgine geboren. I 897 - bereits in Marburg - folgte die Geburt eines Sohnes, der auf den Namen Eberhard getauft wurde. Gemeinsame Musikabende, an denen Tangl seine Frau am Klavier begleitete, bildeten einen regelmäßigen Fixpunkt im Privatleben der Familie und bezogen auch Freunde und Schüler Tangls mit ein ${ }^{38}$. Bereits in Marburg, besonders aber in Berlin konnte sich das Ehepaar nur schwer in seine neue Umgebung einleben. Tangl selbst blieb zeitlebens in Berlin ein Fremder, als der er offenbar besonders an seiner sprachlichen Färbung erkennbar blieb: „Er gehörte nicht zu denen, die jeder kannte; aber den Kopf mit dem scharfen Profil des Alpendeutschen, der hohen Stirn, dem straffen Haar vergißt nicht, wer ihn sah. Man spürte auch am ganzen Wesen, nicht nur am Dialekt, dass er von fernher gekommen war. "39 Nicht nur die österreichische Herkunft, auch die katholische Glaubenszugehörigkeit und deren bewusste Pflege ${ }^{40}$ dürften dazu beigetragen haben, dass die Familie in Berlin und Tangl innerhalb der protestantisch geprägten Berliner Universität doch bis zu einem gewissen Grad Fremdkörper blieben. Wie in politischen Dingen

36 So sprechen Kenr, Tangl (wie Anm. 6) 145, und Karl Brandi, Michael Tangl. 21.5.1861-7.9.1921, in: AUF 8 (1923) 1-5, hier 1, vom Tod und der Beisetzung Tangls nahe den „geliebten Bergen“, Ernst Perels, Michael Tangl, in: Historische Vierteljahresschrift 21 (1922/1923) 123-127, hier 127, erwähnt im Zusammenhang mit dem Ende der Donaumonarchie Tangls „heimatstreues [!] Herz“, und August von Ja KsCH, Universitätsprofessor Dr. Michael Tangl $\dagger$, in: Carinthia I 113 (1923) 80f., hier 81, bezeichnet ihn als „dieses Heimatskind“. Auch beruflich wandte sich Tangl immer wieder Themen der österreichischen Geschichte zu; vgl. Edmund E. Stengel, Michael Tangl, in: HZ 125 (1922) 372-375, der 373 festhält, dass Tangl „bis zu seinem Ende ein österreichischer Historiker gewesen“ sei.

37 Zum Privat- und Familienleben Tangls vgl. Schaller, Tangl (wie Anm. 1) 44-46, 92-94 und 114-117.

38 Heinrich Sproemberg, Zum Geleit, in: Tangl, Mittelalter 18: „Die Atmosphäre seines Hauses, die durch seine verständnisvolle Gattin, Georgine Tangl, eine künstlerische Note und große Warmherzigkeit erhalten hat, ist für seine Schüler eine Stätte der Anregung und freundlicher Betreuung geworden. “ Kr a в в o, SB (wie Anm. 13) 6, berichtet, dass Tangl „mit seiner Gattin und seinen beiden Kindern [...] das glücklichste Familienleben verband".

39 Vgl. Stengel, Tangl (wie Anm. 36) 372.

40 Vgl. Schaller, Tangl (wie Anm. 1) 103. 
übte Tangl aber auch in Äußerungen zu religiösen Fragen große Zurückhaltung und bemühte sich als Historiker in der Behandlung kirchengeschichtlicher Ereignisse um Objektivität ${ }^{41}$. Die fortwährende starke Verbundenheit der Familie mit Österreich kommt nicht zuletzt dadurch zum Ausdruck, dass Frau Tangl und ihre Kinder mehrmals im Jahr die lange Reise nach Wien auf sich nahmen, um dort Zeit mit ihren Verwandten zu verbringen, und auch Michael Tangl selbst in den vorlesungsfreien Sommermonaten regelmäßig die Gelegenheit ergriff, zu einem Urlaub nach Wien oder Kärnten zurückzukehren.

Während des Ersten Weltkrieges wurde die Sorge um seinen erst I9-jährig einberufenen Sohn Eberhard, der bald an der Westfront eingesetzt wurde, mit verantwortlich für Tangls drohenden körperlichen und seelischen Zusammenbruch ${ }^{42}$. Der plötzliche Tod Tangls brachte seine Familie in beträchtliche materielle Nöte, die Kehr durch erfolgreiche Interventionen beim damaligen Kultusminister zu lindern versuchte ${ }^{43}$. Georgine Tangl, die neben ihrem Beruf als Lehrerin den Spuren ihres Vaters folgte ${ }^{44}$, starb 1972 ledig und kinderlos in München ${ }^{45}$. Tangls Sohn Eberhard, der noch studierte, als sein Vater starb, konnte sein Studium der Slawistik 1928 abschließen und wurde schließlich von Richard Salomon, einem Schüler seines Vaters, als dessen Assistent an das Osteuropäische Seminar der Universität Hamburg geholt. Als Salomon, der jüdischer Herkunft war, nach der Machtergreifung der Nationalsozialisten die Universität verlassen musste, ging Eberhard Tangl, der einen Beitritt zur NSDAP verweigerte, nach Belgrad, habilitierte sich dort und kehrte erst 1953 nach längerer Kriegsgefangenschaft nach Hamburg zurück, wo er I 979 starb und seine zweite Frau, Claudia, als Witwe hinterließ ${ }^{46}$.

Eine sehr wertvolle, da nicht unkritische Beurteilung der Persönlichkeit und des Lebenswerks Tangls verdanken wir Kehr, der sich in seinem Nachruf auf Tangl merklich bemühte, den Leistungen und der Persönlichkeit des Verstorbenen gerecht zu werden, ohne dessen Schwächen - die Kehr, wie aus anderweitigen Äußerungen hervorgeht, mit der ihm eigenen selbstbewußten, scharfsinnigen, aber auch schonungslosen Kritik kommentierte ${ }^{47}$ - zuzudecken. Kehr erinnert sich an seine erste Begegnung mit Tangl am IÖG

41 Vgl. unten Anm. 218.

42 Dazu Schaller, Tangl (wie Anm. 1) 270, sowie oben 30f. mit Anm. 29 und 33.

43 Ebd. 286-289, über das weitere Schicksal der Familie.

$44 \mathrm{Zu}$ nennen sind vor allem die Arbeiten: Georgine TAngl, Das Register Innocenz' III. über die Reichsfrage 1198-1209. Nach der Ausgabe von Baluze, Epistolarum Innocentii III. Tomus I, in Auswahl übers. und erl. (Geschichtsschreiber der deutschen Vorzeit 2/95, Leipzig 1923), und DiEs., Studien zum Register Innocenz' III. (Weimar 1929). Vgl. den Nachruf von Gottfried OpItz in: DA 29 (1973) 667f.

$45 \mathrm{Zu}$ Georgine Tangl vgl. Schalle r, Tangl (wie Anm. 1) $287 \mathrm{f}$.

$46 \mathrm{Zu}$ Eberhad Tangl vgl. Werner Lenfendt, Zum Lebensweg und zu den lituanistischen Arbeiten von Eberhard Tangl (1897-1979), in: Res Balticae 5 (1999) 237-246.

47 Vgl. etwa Schaller, Tangl (wie Anm. 1) 291, nach Berlin, Geheimes Staatsarchiv, Rep. 92 Brackmann, Nr. 16, zitierten Stellen aus Briefen Kehrs an Brackmann aus den ersten Monaten nach Tangls Tod: [...] der selige Michael 
in den I 88oer Jahren: „[...] den schlanken und sangesfrohen Jüngling, dessen innerstes Wesen Frohsinn und Treuherzigkeit, Offenheit und Enthusiasmus waren, eine echte österreichische Natur, aber von dem kräftigeren und solideren Kärntner Schlag.“ ${ }^{48}$ „Der liebenswürdige und heitere Österreicher“, wie Kehr den bereits zum Universitätsprofessor avancierten Tangl bezeichnet, der „,vor den berühmteren Kollegen [...] bescheiden in den Hintergrund" 49 trat, war sich seiner wissenschaftlichen Leistungen aber durchaus bewusst, wie seine Antrittsrede vor der Preußischen Akademie der Wissenschaften anläßlich der Wahl zum Ordentlichen Mitglied I9 8 zeigt $^{50}$.

Menschliche Wärme, Geradlinigkeit, Ehrlichkeit, Bescheidenheit, auch Heiterkeit, Kunstsinn und vor allem große Hingabe an seinen Beruf als Wissenschaftler und Lehrer sind jene Eigenschaften, die von Zeitgenossen Tangls, die ihn persönlich gekannt haben, am häufigsten zur Charakterisierung des Menschen Michael Tangl hervorgehoben werden $^{51}$. Dem gegenüber stand offenbar eine gewisse Unfähigkeit, in Zeiten der Überfor-

[...], [...] der alles übernahm, nichts fertig machte und viel Geld kostete [...], der gute Michael wird so schließlich gar ein großer Mann $[\ldots]$ und andere herabwürdigende Bemerkungen in einem Brief an Werner Richter vom 20.02.01923 (München, Archiv der MGH 338/15 fol. 48r-50r); ed. Horst Fuhr mann, „Sind eben alles Menschen gewesen". Gelehrtenleben im 19. und 20. Jahrhundert. Dargestellt am Beispiel der Monumenta Germaniae Historica und ihrer Mitarbeiter (München 1996) 157-160, hier 158: [...] Tangl, der kein großes Licht war [...]. Dem gegenüber steht die bei Pferschy-Maleczek, Diplomata-Edition (wie Anm. 18) 419 Anm. 46, zitierte Stelle aus einem Brief Tangls an Ottenthal (20.01.1905, Wien, IÖG, Diplomata, Ordner 2) im Zusammenhang mit der von Kehr - nicht auf ganz geradem Weg - erwirkten Beauftragung mit der Edition der Diplome Friedrichs II.: Kehr hat sich auch bei dieser Gelegenheit wieder in wahrem Lichte gezeigt, als der Mann, der nichts ohne Brutalität und nichts ohne Schwindel unternehmen kann. In der Auseinandersetzung, ob die Diplome Friedrichs II. durch die Wiener Diplomataabteilung oder, wie von Kehr angestrebt, durch das seiner Leitung unterstehende Preußische Historische Institut in Rom durchgeführt werden sollte, hatte Tangl Ottenthal in mehreren Briefen (Wien, IÖG, Diplomata, Ordner 2: 18.12. und 28.12.1904; 20.01., 22.01., 15.03. und 30.03.1905) über seinen Standpunkt und die neuesten Entwicklungen in Berlin informiert.

48 Kenr, Tangl (wie Anm. 6) 139.

49 Ebd. 141.

50 „Ich habe“, so schildert er, „[...] das Treiben eines modernen Fälschers, des Lilienfelder Zisterziensers Chrysostomos Hanthaler, als erster im ganzen Zusammenhang aufgedeckt, für die angefochtene Echtheit des österreichischen Privilegium Minus eine Lanze gebrochen [...] Ich darf bekennen, zur Kenntnis des päpstlichen Urkunden- und Verwaltungswesens des späteren Mittelalters durch grundlegende Arbeiten beigetragen [...] zu haben." Und im Zusammenhang mit seiner Arbeit an den Karolingerurkunden stellt er fest: „Es gelang mir, die zur guten Hälfte noch nicht entzifferten tachygraphischen Vermerke der Urkunden zu lesen und die Bedeutung dieser Eintragungen für die Kenntnis des Zustandekommens der Urkunden und der Kanzleiorganisation festzulegen." Etwas zurückhaltender fällt sein Urteil über seine Leistungen auf dem Gebiet der Urkundenkritik aus: „Bei der Bearbeitung wichtiger und schwieriger Urkundenreihen wie der Fuldaer und Osnabrücker glaube ich an der Ausfeilung der Methode der Urkundenkritik, zumal der Kritik der Urkundenfälschungen, nicht unbeteiligt geblieben zu sein."Vgl. TANGL, Antrittsrede (wie Anm. 3) 703-704.

51 „Große innere Wärme“, „unbestechliche Urteilskraft“ und „hingebende Lehrtätigkeit“ bescheinigt etwa Brandi, gemeinsam mit Bresslau Tangls Weggefährte bei der Gründung des Archivs für Urkundenforschung, 
derung oder bei Projekten, die er zwar aus Pflichtbewusstsein übernommen hatte, aber nicht mit der ihm sonst eigenen wissenschaftlichen Begeisterung bearbeitete, die Energie aufzubringen, Begonnenes zum Abschluss zu bringen oder unangenehme Aufgaben zu erledigen oder auch delegieren zu können ${ }^{52}$. Die ihm so häufig attestierte menschliche Wärme und Güte ging einher mit einer offenbar sehr großen Sensibilität, die sich in Krisensituationen, etwa während des Ersten Weltkrieges, an dessen Widrigkeiten und Schicksalsschlägen Tangl nahezu zu zerbrechen drohte, in beinahe selbstzerstörerischer Weise äußerte. Neben der Sorge um seinen an der Front dienenden Sohn, der Trauer um gefallene Schüler und Freunde, den Entbehrungen der Kriegsjahre war es vor allem auch der drohende Zusammenbruch der österreichisch-ungarischen Monarchie, der Michael Tangl sowohl physisch als auch psychisch an den Rand des Zusammenbruchs führte. Der besorgniserregende Zustand Tangls blieb seiner Umgebung nicht verborgen, er wird regelmäßig auch in den Nachrufen auf den Verstorbenen thematisiert: „Wer damals in dies abgezehrte und tiefbekümmerte Antlitz schaute, sah darin mit Schrecken das Werk unerhörter Leiden und quälender Sorgen“, formulierte - offensichtlich mit Betroffenheit - Kehr ${ }^{53}$, als gewissermaßen „ein Opfer des Krieges“ bezeichnete ihn Perels ${ }^{54}$.

dem Verstorbenen: Brandi, Tangl (wie Anm. 36) 5. Perels, einer der engsten Mitarbeiter Tangls, betont in seinem Nachruf: „Tangl war ein wirklich wissenschaftlicher Kopf, eine Gelehrtennatur, die nicht nach äußeren Erfolgen haschte [...], unabhängig und von unbestechlicher Wahrheitsliebe [...] eine durchaus heitere, optimistische Natur [...] Gerade und ehrlich, wohlwollend und warmherzig, ja weich, im äußeren Auftreten, zumal in früherer Zeit, fast allzu bescheiden, dabei innerlich des eigenen Wertes stets sich bewußt, zuweilen eifrig und scharf in der Kritik, aber im Grunde doch friedfertig und ein Feind aller Gehässigkeit und Intrigue, humorvoll, freundlich, gemütstief, auch kunstfreudig [...]“ Perels, Tangl (wie Anm. 36) 126f., und selbst Kehr zollt Tangls Charakter mit den schlichten Worten „diesem wahrhaft guten Menschen“ Respekt: Kenr, Tangl (wie Anm. 6) 146. Kraвво, SB (wie Anm. 13) 5, bezeichnet Tangl in seinem Nachruf als „der schlichte, treue, liebenswerte Mensch [...] in seiner harmlosen Fröhlichkeit“. Dagegen deutet Rudolf v. Heckel in seinem Nachruf, Michael Tangl $\dagger$, in: HJb 41 (1921) 403, mit seiner Charakteristik von Tangls „lauterer, streng wahrheitsliebenden und jeder Konvention abholden, dabei im Grunde kindlich gutmütigen Gemütsart“ an, dass Tangls Güte und Gutmütigkeit auch ins Negative verkehrt als Naivität und gewissermaßen sogar Beschränktheit aufgefasst werden konnte; vgl. dazu auch die in Anm. 47 zitierten Äußerungen Kehrs Brackmann gegenüber, die in dieselbe Richtung gehen.

52 Vgl. etwa Perels, Tangl (wie Anm. 36) 126: „eine gewisse Schwerfälligkeit in der Erledigung geschäftlicher Angelegenheiten und vor allem in der Korrespondenzführung, deren große Unregelmäßigkeit ihm ungewollt manche Verstimmung eintrug [...]“, oder etwa KEHR, Tangl (wie Anm. 6) 142: „eine gewisse lässige Art, die Dinge gehen zu lassen."

53 KeHr, Tangl (wie Anm. 6) 144f.: „Bald bangte auch er um das Leben des einzigen Sohnes, bald ergriff ihn die Angst um das Schicksal des großen Vaterlandes und seiner geliebten Heimat. Der Krieg mit seinen Entbehrungen lastete auf ihm, dessen materielle Mittel sehr bescheiden waren, mit furchtbarer Härte. “

54 Perels, Tangl (wie Anm. 36) 127: „Im großen Kriege [...] sind ihm Heiterkeit und Freudigkeit nicht voll erhalten geblieben. Schwer hat er unter dem Dunkel der vergangenen Jahre gelitten, und namentlich Österreichs Schicksal hat sein heimattreues Herz wohl viel schwerer getroffen, als er es sich anmerken ließ. Ja, es ist kein 


\section{EINE, "TANGL-SCHULE“? DAS VERHÄLTNIS MICHAEL TANGLS ZU SEINEN SCHÜLERN UND MITARBEITERN}

Einer der wenigen Kritikpunkte, die über die Biografie Tangls von Annekatrin Schaller geäußert wurden ${ }^{55}$, betrifft das Postulat einer von Tangl begründeten „Schule“, die bereits im Titel des Buches angesprochen wird und der Schaller einen beträchtlichen Teil ihrer Biografie widmet ${ }^{56}$. Dabei handelt es sich, wie so oft, um eine Frage der Definition - im konkreten Fall des Begriffs der wissenschaftlichen „Schule“. Wenn das innovative Element, sei es in inhaltlichem oder in methodischem Sinn, als unerlässliches Merkmal einer Schule - wovon die Rezensenten augenscheinlich ausgehen - gesehen wird, ist die Kritik berechtigt. Denn Tangl stand nach seinem eigenen Selbstverständnis in erster Linie und vor allem in der hilfswissenschaftlichen Tradition Sickels und des IÖG, ohne diese selbst maßgeblich weiterentwickelt zu haben. Freilich finden sich in seinen Arbeiten auch gewisse Neuansätze, deren Verbreitung mit der Gründung des „Archivs für Urkundenforschung" beabsichtigt war. Hier ist besonders die Forderung nach Ausweitung der Urkundenforschung in chronologischer und quellengattungsmäßiger Hinsicht zu nennen. Eine Weiterentwicklung der Methode stellt auch der von Tangl mehrfach geforderte - freilich seltener tatsächlich vollzogene - Dialog mit Nachbarwissenschaften, die „Interdisziplinarität“, dar. Insgesamt gesehen kommt diesen Ansätzen jedoch eher der Stellenwert einer fast natürlichen Weiterentwicklung und Erweiterung der Historischen Hilfswissenschaften als der einer grundlegenden Neubegründung zu. Innovativen Charakter hat jedoch die Tatsache, dass Tangl als einer der Ersten die in Wien begründeten und damals vorrangig auch nur dort institutionell verankerten Historischen Hilfswissenschaften nach Deutschland brachte, und es ihm gelang, sie dort sowohl im Universitätsbetrieb als auch etwa durch die Ausbildung künftiger Archivare und Mitarbeiter bei den MGH fest zu verankern.

leeres Wort, wenn man ihn selbst ein Opfer des Krieges nennt. Nicht ohne Erschütterung beobachteten die ihm Näherstehenden [...] die Folgen der Unterernährung [...]. Nicht nur ihm Nahestehende oder Personen, die - wie Kehr - Tangl schon seit Langem kannten, waren Zeugen des körperlichen und geistigen Verfalls, auch Karl Hampe beschrieb anlässlich seiner Wahl in die Zentraldirektion der MGH in einer Tagebucheintragung vom 28.04.1917 Tangl als körperlich und geistig etwas reduziert scheinend [...]. Hampe, Kriegstagebuch, hg. v. Reichert, Wolgast (wie Anm. 26) 539.

55 Vgl. etwa die Rezensionen von Schaller, Tangl (wie Anm. 1): Georg Vogeler in: sehepunkte 3 (2003) Nr. 2 (15.02.2003); http://www.sehepunkte.de/2003/02/1709.html (letzter Zugriff 12.11.2009): ,[...] schält sich nur eine sehr undeutliche inhaltliche Kontur heraus“, und Mark MersiowsKy in: DA 59 (2003) 616: „Die ,Kenntnis der exakten kritischen Methode im Umgang mit den Quellen als Fundament historischer Forschung' (S. 304) ist allerdings zu wenig, um wirklich von einer Schule Tangls sprechen zu können."

56 So Kapitel 10 des ersten Teils (Biografie): „Die Tangl-Schule - Verbindung von Forschung und Lehre“ 188214, und den gesamten zweiten Teil: „Die Schüler von Michael Tangl - Wissenschaftliche Entwicklungswege und Prosopographien“302-350. 
Wenn man aber, wie Schaller, den Begriff „Schule“ so versteht, dass es um die Ausbildung einer außergewöhnlich großen Zahl von Nachwuchswissenschaftlern in einer bestimmten Disziplin oder Methode geht, kann mit Recht von einer Schule Tangls gesprochen werden, dessen Schüler von seiner Persönlichkeit geprägt wurden und zwischen denen auch untereinander ein gewisses Verbundenheitsgefühl bestand. Zweifellos gehörte Tangl zu jenen Professoren in Berlin und wohl sogar in ganz Deutschland, die hinsichtlich ihrer Lehrtätigkeit, der Betreuung von Dissertationen und Begutachtung von Habilitationen zu ihrer Zeit am meisten geleistet haben ${ }^{57}$. Von den Zeitgenossen jedenfalls wird explizit und fast ausnahmslos - in ebendiesem Sinne - von einer „Tangl-Schule“ gesprochen. So hält etwa Kehr in seinem Nachruf fest: „So ist er in seinem kleinen Kreise das Haupt einer Schule geworden, um die ihn die Inhaber der großen Lehrstühle beneiden mochten. Fast alle unsere jüngeren Mitarbeiter sind durch seine Schule hindurchgegangen." 58 Rudolf von Heckel, ab I9I3 erst außerordentlicher, ab I93 I ordentlicher Professor für Geschichte und Historische Hilfswissenschaften an der Universität München, schrieb am 28. Oktober 1922 in einer Postkarte an Perels als Reaktion auf dessen Tangl-Nachruf: Auch die Betonung der Tangl-Schule hat mich sehr gefreut: es sind nicht allzu viele, die eine wirkliche Schule in der letzten Generation gegründet haben, wie Tangl59. Und in jüngster Zeit verwendete noch Pavel Kolár den Begriff „Schule“ im Zusammenhang mit Michael Tangl: „Eine weitere ,Schule‘ formierte sich um den Diplomatiker Michael Tangl auf dem Gebiet der Mittleren Geschichte und der Hilfswissenschaften (Erich Caspar, Ernst Perels, Hermann Krabbo, Adolf Hofmeister), deren Mitglieder sich während der Weimarer Republik als Hochschullehrer deutschlandweit behaupteten. “60

57 Vgl. dazu die tabellarischen Übersichten und deren Erläuterungen bei Pavel Kolá ̌̌, Geschichtswissenschaft in Zentraleuropa. Die Universitäten Prag, Wien und Berlin um 1900 1-2 (Geschichtswissenschaft und Geschichtskultur im 20. Jahrhundert 9, Berlin 2008) 2407-410 mit Tabelle III.

58 KeHr, Tangl (wie Anm. 6) 145. Auch Stengel spricht im Zusammenhang mit Tangls Lehrtätigkeit von einer Schule, die noch nach Tangls Tod Fortbestand haben werde: „er war [...] ein begnadeter Lehrer von starker Wirkung, nicht so sehr auf die Masse - die hat er sich nie gewünscht - als auf die vielen einzelnen, die ihm näher kamen und den Hauch seiner wissenschaftlichen Persönlichkeit in sich aufnahmen. Die Schule, die er gemacht, wird sein Andenken ehren und bewahren, indem sie in seiner Bahn weiter arbeitet." STENGEL, Tangl (wie Anm. 36) 375.

59 NL Perels, Berlin, Staatsbibliothek Preußischer Kulturbesitz. Oве Rling, Perels (wie Anm. 33) 132 etwas irreführend mit Bezug auf den Namen von Tangls Schüler Max Hein, dessen Reaktion auf die Zusendung des Nachrufs eher gegenteilige Empfindungen ausdrückt: Die vielen Vorzüge Tangls werde ich nie vergessen, ja ich kann sagen, seit mit meiner Herversetzung [nach Königsberg] ein ganz neuer Lebensabschnitt für mich begonnen hat, wird mir der alte Tangl meiner Studentenzeit wieder etwas lebendiger. Was ich aber stets bedauern werde, ist, daß ich mich nicht [Otto] Hintze, den ich eigentlich als meinen Lehrer verehre, näher angeschlossen habe, sondern T. Wieviel Bitterkeit und Hemmung wäre mir erspart geblieben (Postkarte an Perels 20.11.1922, ebd.).

60 Kola r., Geschichtswissenschaft (wie Anm. 57) 406. 
Tangl war den Zeugnissen seiner Zeitgenossen und Schüler zufolge ein hervorragender Lehrer, der es verstand, die Studenten für seine Disziplin zu begeistern und sie nachhaltig zu beeinflussen. Kehr konnte sich das Phänomen nicht so recht erklären, musste aber dennoch anerkennen: „[...] er war ein ungewöhnlich erfolgreicher Lehrer. Obwohl kein Mann der Rede und aller rhetorischen Künste bar, übte er eine merkwürdig starke Wirkung auf seine Schüler aus, die sich ihm hingaben. "61 Perels, einer der wichtigsten Schüler Tangls, würdigte die Leistung seines Lehrers dagegen ohne Vorbehalte: „[...] sein höchstes Verdienst wird unstreitig seine Lehrtätigkeit bleiben [...], seine Vorlesungen waren ausgezeichnet [...], seine Hauptstärke aber war das Seminar."62 Und er erklärte auch, worin wohl die eigentliche Anziehungskraft Tangls für seine Schüler bestand: „Das Verhältnis Tangls war nicht nur von wissenschaftlicher Teilnahme, sondern von einem persönlichen Wohlwollen getragen, das aus ehrlichstem Herzen kam [...]."63 Dieses menschliche Naheverhältnis Tangls zu seinen Schülern, denen er „ein wahrhaft väterlicher Freund“ war, „der immer für sie Zeit hatte und an ihren Arbeiten ein rührendes Interesse nahm, “war auch Kehr nicht entgangen ${ }^{64}$. Bei abendlichen geselligen Zusammenkünften mit Kollegen und Schülern zeigte er sich als unterhaltsamer Erzähler von Anekdoten: „Gesellig und mitteilsam wie er war, saß er, namentlich in den entschwundenen Vorkriegszeiten, nach getaner Arbeit gern einmal mit Fachgenossen oder Schülern bei einem fröhlichen Trunk zusammen. Hier konnter er, der schier unendlich viele Anekdoten auf Lager hatte und solche gern und gut erzählte, namentlich den, der ihn von dieser Seite noch nicht kannte, und über den nun an einem Abend ein ganzes Füllhorn solcher Geschichten ausgeschüttet wurde, einfach verblüffen. "65 Tatsächlich förderte Tangl viele seiner Schüler nach Kräften und verfolgte ihre Laufbahn auch noch über ihre Studienzeit hinaus. Einige von ihnen, wie vor allem Perels und Caspar, wurden schließlich zu engen Mitarbeitern Tangls, die auch privaten Umgang mit ihrem Lehrer pflegten. Salomon, I9I9 bis 1933 ordentlicher Professor für Osteuropäische Geschichte an der Universität Hamburg, wurde seinerseits zum Förderer von Tangls Sohn Eberhard, mit dem er auch nach seiner Emigration in die USA persönlich verbunden blieb.

61 KeHr, Tangl (wie Anm. 6) 145. Sogar in vertraulicheren und weniger respektvollen Äußerungen konnte Kehr Tangl die Anerkennung seiner Leistungen als Lehrer nicht versagen, vgl. einen Brief Kehrs an Werner Richter vom 20.02.1923, bei Fuhrmann, „Sind eben alles Menschen gewesen“ (wie Anm. 47), 157-160, hier 158 (München, Archiv der MGH 338/15 fol. 48r-50): Mit dem Ausfall Tangls, der kein großes Licht, aber ein vorzüglicher Lehrer war, und unseren Ersatz ausbildete, ist ein irreparables Vacuum entstanden.

62 Perels, Tangl (wie Anm. 36) 125.

63 Ebd. 125.

64 KeHr, Tangl (wie Anm. 6) 145.

65 So erinnert sich Kraвво, SB (wie Anm. 13) 5, und ähnlich Stengel, Tangl (wie Anm. 36) 374: „nie ward er müde, im geselligen Kreise aus dieser glücklichen Zeit [d.i. den Jahren, die er am Österreichischen Historischen Institut in Rom verbrachte] mit drastischem Humor und anekdotischer Begabung zu erzählen.“ 
Aus verschiedenen Gutachten Tangls geht hervor, dass er selbst wie seine anderen Berliner Kollegen bei Habilitanden Wert auf allgemeine historische Kenntnisse, die Erfassung politischer Zusammenhänge und großer zusammenhängender Entwicklungen legte. Gegen enges Spezialistentum sprach er sich mehrfach dezidiert aus. Er forderte zudem - und lobte ausdrücklich - Klarheit, leichte Lesbarkeit, Anschaulichkeit und Lebendigkeit der Darstellung66. Trotzdem war die Tatsache, der „Schule“ Tangls angehört zu haben, für manche zeitgenössischen Fachkollegen nicht immer eine unbedingte Empfehlung. Wie gegen Tangl wurden auch gegen viele seine Schüler - dokumentiert etwa in den Habilitationsgutachten über Otto Cartellieri und Walter Norden, oder auch in jenem Dietrich Schäfers über Perels ${ }^{67}$ - immer wieder, meist doch teilweise auch berechtigte, Vorwürfe des Spezialistentums erhoben.

\section{TAXEN, KANZLEIORDNUNGEN, PAPSTURKUNDEN : \\ TANGLS BEITRÄGE ZUR PÄPSTLICHEN DIPLOMATIK}

Unter Tangls wissenschaftlichen Arbeitsgebieten ist die Beschäftigung mit der Diplomatik der Papsturkunden vielleicht am meisten der Gunst der Stunde verdankt. Als er im Januar I 888 nach Rom kam, lag die Öffnung des Archivio Segreto Vaticano für die historische Forschung erst wenige Jahre zurück und die - wie es die Zeitgenossen nannten - „Ausbeutung“ der Schätze des Archivs durch die sich nach und nach konstituierenden ausländischen historischen Institute und Akademien kam langsam in Fahrt. Tangls akademischer Lehrer Sickel hatte frühzeitig die Bedeutung der vatikanischen Archivbestände betont und konnte durch hartnäckiges und zielstrebiges Werben die zuständigen Stellen von Kaiser Franz Joseph I. abwärts von der Sinnhaftigkeit der Errichtung einer ständigen österreichischen historischen Forschungseinrichtung in Rom überzeugen ${ }^{68}$. I 883 erhielt

66 Vgl. dazu Kola ř, Geschichtswissenschaft (wie Anm. 57) 421-430. Es fehlt nicht an Aussagen von Schülern und Kollegen Tangls, die dessen weiten Horizont hervorheben, vgl. etwa Kraвво, SB (wie Anm. 13) 4: „wie er die Hilfswissenschaften nie um ihrer selbst willen betrieben hatte, sondern stets als Mittel zum Zweck historischer Erkenntnis, so traten allgemeingeschichtliche Interessen je länger je mehr bei ihm in den Vordergrund; namentlich für kulturgeschichtliche Zusammenhänge besaß er Verständnis. “

67 Vgl. Kola ř, Geschichtswissenschaft (wie Anm. 57) 429.

68 Vgl. Theodor von Sickel, Römische Erinnerungen. Nebst ergänzenden Briefen und Aktenstücken hg. v. Leo SAntifaller (Veröff. des IÖG 3, Wien 1947); Walter Goldinger, Österreich und die Eröffnung des Vatikanischen Archivs, in: Archivalische Zs. 47 (1951) 23-52; Karl Rudolf, Geschichte des Österreichischen Historischen Instituts in Rom von 1881-1938, in: Römische Historische Mitteilungen 23 (1981) 1-137, zur Vorgeschichte der Gründung hier 8-19. Vgl. auch Christine M. Grafinger, Anfänge der österreichischen Forschung im Archivio Segreto Vaticano und in der Biblioteca Apostolica Vaticana, in: Römische Historische Mitteilungen 49 (2007) 429-455. Zum wissenschaftsgeschichtlich-zeithistorischen Kontext: Il libro del Cen- 
dieses „Istituto Austriaco di Studii storici“ ein provisorisches Statut, das die Arbeitsgebiete festlegte und - um die Befähigung der Stipendiaten zur Ausführung anspruchsvoller Forschungsvorhaben zu gewährleisten - Sickel, der das römische Institut in Personalunion mit dem Wiener IÖG leiten sollte, deren Auswahl auftrug. Daher hatte der überwiegende Teil der Stipendiaten der frühen Jahre den Wiener Institutskurs absolviert und verfügte somit über eine gründliche paläografische und diplomatische Ausbildung. Als ursprüngliche Arbeitsaufgabe des römischen Institutes war die Erschließung der Quellen zur Geschichte des Hauses Habsburg und der habsburgischen Monarchie vorgesehen gewesen; da sich die Ausbeute in diesem Bereich aber bald als geringer erwies als zunächst erhofft, fanden Fragestellungen insbesondere hilfswissenschaftlich-diplomatischer Art bald zunehmende Berücksichtigung: Es war naheliegend, die Methoden, die Sickel vor allem an Urkunden aus dem Bereich des mittelalterlichen Kaiser- und Königtums entwickelt hatte, nun auch auf die Erzeugnisse der päpstlichen Kanzlei und auf deren Arbeitsweise anzuwenden. Nicht zuletzt hatte Sickel selbst durch seine grundlegende Beschäftigung mit dem „Liber diurnus“, die schließlich in die erste kritischen Ansprüchen genügende Ausgabe dieser Formularsammlung aus dem Umkreis der frühmittelalterlichen päpstlichen Kanzlei mündete, den Weg in diese Richtung gewiesen ${ }^{69}$. Bereits bei den ersten durch Sickel nach Rom gesandten Stipendiaten ist der doppelte Arbeitsschwerpunkt erkennbar ${ }^{70}$. So erarbeiteten Ferdinand Kaltenbrunner ${ }^{71}$ und Adolf Fanta ${ }^{72}$ einerseits eine umfangreiche Quellenedition zur Geschichte der deutschen Könige Rudolf I. und Albrecht I. ${ }^{73}$, leisteten aber andererseits bedeutende Beiträge zur Diplomatik, insbesondere des päpstlichen Urkundenwesens, die sich zunächst gewissermaßen von selbst als Nebenprodukte bei der Durchsicht vor allem der päpstlichen Register ergaben ${ }^{74}$. Bei Ottenthal, der sich

tenario. L'Archivio Segreto Vaticano a un secolo dalla sua apertura (1880/81-1980/81) (Città del Vaticano 1982); Leone XIII e gli studi storici. Atti del convegno internazionale commemorativo, Città del Vaticano, 30-31 ottobre 2003, hg. v. Cosimo Semera ro (Pontificio comitato di scienze storiche, Atti e documenti 21, Città del Vaticano 2004).

69 Liber diurnus Romanorum pontificum ex unico codice Vaticano denuo edidit Th. E. A в Sickel (Wien 1889).

$70 \mathrm{Vgl}$. Theodor von Sickel, Bericht über die bisherigen Arbeiten des Istituto Austriaco di studii storici in Rom, in: MIÖG 6 (1885) 203-223. Es handelt sich um die gekürzte Fassung eines von Sickel 1884 dem Unterrichtsministerium vorgelegten Berichtes.

$71 \mathrm{Zu}$ ihm vgl. Sickel, Römische Erinnerungen, passim; Lнотsкy, Geschichte des Instituts (wie Anm. 5) 166; ÖBL III, 203.

72 Zu ihm vgl. den Nachruf auf ihn in MIÖG 9 (1888) 175f.; Sickel, Römische Erinnerungen (wie Anm. 68) passim; Lноткку, Geschichte des Instituts (wie Anm. 5) 177; Funrmann, „Sind eben alles Menschen gewesen“ (wie Anm. 47) 89.

73 Adolf Fanta, Ferdinand Kalten brunner, Actenstücke zur Geschichte des deutschen Reiches unter den Königen Rudolf I. und Albrecht I. (Mittheilungen aus dem Vaticanischen Archive 1, Wien 1889).

74 Dies trifft vor allem auf Kaltenbrunner zu, der bereits durch die Mitarbeit an der Neubearbeitung von Jaffés 
im Herbst I 882 erstmals in Rom aufhielt, überwog schon die Beschäftigung mit papstdiplomatischen Themen ${ }^{75}$, die I 888 mit seiner Ausgabe der päpstlichen Kanzleiregeln ihren Höhepunkt fand ${ }^{76}$. Auch andere Stipendiaten der I 88 oer-Jahre veröffentlichten, vor allem in den MIÖG, einschlägige Arbeiten ${ }^{77}$.

Diese papstdiplomatisch angeregte Atmosphäre fand nun Tangl vor, als er am 5. Januar I 888 als Stipendiat in Rom eintraf. Schon am ıo. Januar führte ihn Ottenthal in die Benützung des Vatikanischen Archivs ein und stellte auch allerhand nützliche Kontakte her $^{78}$. Wie alle Stipendiaten hatte Tangl Aufträge Sickels auszuführen, die sich vor allem auf die vatikanische Handschrift des Liber Diurnus bezogen, mit dessen Edition Sickel damals beschäftigt war. Als Ottenthal, der von Sickel als sein römischer Stellvertreter in der Leitung des Istituto Austriaco bestimmt worden war, im März I 888 die Stadt verließ,

Regesta Pontificum Romanorum und einen einschlägigen Artikel (Die äußeren Merkmale der Papsturkunden des 12. Jahrhunderts, in: MIÖG 1 [1880] 373-410) papstdiplomatische Interessen gezeigt hatte. Eine Bibliografie der Veröffentlichungen, die als Frucht seiner römischen Jahre gelten können, findet sich in: Hans Kramer, Das Österreichische Historische Institut in Rom 1881-1931. Denkschrift zu seinem fünfzigjährigen Bestande (Rom 1932) 49, hier 47 auch zu Fanta.

75 Susanne Lichtmannegger, Emil von Ottenthal (1855-1931). Diplomatiker in der Tradition Theodor von Sickels und Julius von Fickers, in: Österreichische Historiker 1900-1945. Lebensläufe und Karrieren in Österreich, Deutschland und der Tschechoslowakei in wissenschaftsgeschichtlichen Porträts, hg. v. Karel Hruza (Wien/Köln/Weimar 2008) 73-95, bes. 82f.; Elena TAddeI, Emil von Ottenthal (1885-1931). Eine Nachlese anhand der Privatkorrespondenz mit seinen Eltern, in : MIÖG 118 (2010) 201-213. Zu seinen papstdiplomatischen Veröffentlichungen Kramer, Institut (wie Anm. 74) 50.

76 Emil von Otтеnthal, Regulae cancellariae apostolicae. Die päpstlichen Kanzleiregeln von Johannes XXII. bis Nicolaus V. (Innsbruck 1888, ND Aalen 1968).

77 Z.B. Emil Werunsky (Stipendiat 1883/84), Josef Donabaum (Stipendiat 1886/87) oder Josef Teige (Stipendiat 1893/94). Vgl. Kramer, Institut (wie Anm 74) 46, 54f. Kein Stipendiat, aber unter der Leitung von Sickel mit der Ausgabe des Liber Diurnus beschäftigt, war der Westfale Wilhelm Diekamp, der 1881-1883 am Institutskurs teilgenommen hatte und 1885 in Rom verstarb: Zum päpstlichen Urkundenwesen des XI., XII. und der ersten Hälfte des XIII. Jahrhunderts, in: MIÖG 3 (1882) 565-627; Zum päpstlichen Urkundenwesen von Alexander IV. bis Johann XXII. (1254-1334), in: ebd. 4 (1883) 497-540.

78 Brief Tangls an Sickel 12.01.1888, IÖG NL Sickel: Ihrem durch Dr. Donabaum mir übermittelten Wunsche entsprechend, ist es mir eine angenehme Pflicht, über die gestellten Anfragen, wie überhaupt über die erste Woche meines Aufenthaltes in Rom zu berichten. Am 5. d. M. angekommen, benützte ich die noch bis zum 9. währenden Archivferien dazu, eine Wohnung zu suchen und mich überhaupt in die doch ziemlich fremden Verhältnisse einzugewöhnen, wobei mir Dr. Donabaum in der liebenswürdigsten Weise an die Hand ging. Dies war mir umso willkommener, als angesichts des ganz gewaltigen Pilgerrummels die Frage der provisorischen und definitiven Unterkunft nicht geringe Schwierigkeiten bot. Am 10. wurde ich sodann durch Hr. Dr. v. Ottenthal nach Abwicklung der erforderlichen Formalitäten in das vaticanische Archiv eingeführt und machte mich zunächst an den liber diurnus, worüber ich in Beantwortung der gewünschten Auskünfte folgendes mittheilen kann [...]. Es folgen mehr als eine Seite Lesarten und Detailangaben aus dem Liber diurnus. Zu Tangls Romaufenthalten vgl. Schaller, Tangl (wie Anm. 1) 33-37. 
erhielt Tangl auch diese administrative Aufgabe übertragen ${ }^{79}$. In den fünf Briefen, die sich von Tangls erstem Rom-Aufenthalt in Sickels Nachlass erhalten haben ${ }^{80}$, nehmen daher Antworten auf Anfragen zum Liber Diurnus viel Raum ein. Außerdem finden sich Berichte über verschiedene Institutsangelegenheiten und Erledigungen, die Sickel seinem römischen „Statthalter“ übertragen hatte, vor allem aber ausführliche Berichte über die Durchsicht von Archivbeständen, die Tangl im Rahmen der „gemeinsamen Arbeiten“ ${ }^{81}$ der Stipendiaten zugewiesen bekommen hatte. Tangl befasste sich vor allem mit dem Archiv der Engelsburg und gab Sickel detailliert Auskunft über die dabei gemachten Funde. So erwähnt ein Brief vom I 9. Mai I $888^{82}-$ Für die Zeit Eugen III drei Stücke in A. I C. XI $N^{o}$ I-3 [...] und $N^{o} 3$ (IISI Sept 5) Sofia, Witwe eines gewissen Miccinus, schenkt dem Papste ein Haus in der Leostadt, gegenüber der Kirche des S. Vincentius und dem novum palatium des Papstes - ein Stück, das Tangl in seiner ersten wissenschaftlichen Veröffentlichung überhaupt, einer Miscelle mit Dokumenten zur Baugeschichte des vatikanischen Palastes, abdruckte ${ }^{83}$. Die Durchforschung des Engelsburg-Archivs beschäftigte Tangl auch noch bei seinem zweiten, von Ende Dezember I 888 bis Ende Juni I 889 dauernden Rom-Aufenthalt; zusätzlich hatte er sich nun auch mit dem Archiv der Konsistorialkongregation zu befassen, für dessen Benützung Sickel, der Anfang I 889 selbst in Rom weilte, die Erlaubnis erwirkt hatte ${ }^{84}$. Vor allem aber hatte Tangl, wie aus Briefen besonders an seinen Lehrer Mühlbacher, mit dem ihn ein offenkundig weit persönlicheres Verhältnis verband als mit Sickel, erkennbar ist, nun „sein“ Thema gefunden, dessen Erkundung und Durchforschung ihm die Abfassung einer Dissertation ermöglichen und später auch für seine Habilitation eine bedeutende Rolle spielen sollte. Die im März I 889 brieflich gegenüber

79 Eine Regelung, die Ottenthal gewisse Bedenken verursachte, da er befürchtete, dass Tangl den Erfordernissen der Aufgabe nicht gewachsen sein würde, vgl. Rudolf, Geschichte (wie Anm. 68) 30; Schaller, Tangl (wie Anm. 1) 34.

80 IÖG, NL Sickel: 12.01.1888, 05.05.1888, 19.05.1888, 23.05.1888, 20.07.1888 (dieser Brief bereits aus Wolfsberg, wo Tangl seine Ferien verbrachte).

81 So die Bezeichnung in einem Brief an Mühlbacher (Rom 09.03.1889, IÖG, NL Mühlbacher, siehe unten Anm. 84).

82 IÖG, NL Sickel.

83 Michael TANGL, Zur Baugeschichte des Vatikan, in: MIÖG 10 (1889) 428-442, hier 433 Nr. 1.

84 Brief Tangls an Mühlbacher, 09.03.1889, IÖG, NL Mühlbacher: Wie Herr Professor daraus ersehen, liege ich so tief in päpstlicher Diplomatik begraben, als mir das die Betheiligung an den gemeinsamen Arbeiten gestattet, bei welchletzteren mir das Consistorial-Archiv und die Einzelakten des Engelsburg-Archivs obliegen, während Engelmann über den Brevenbüchern brütet. Vgl. auch die Erwähnung Tangls in einem Bericht Sickels an das Unterrichtsministerium: zu einem ersten Besuch im Consistorial-Archiv nahm ich Tangl mit. Außerdem unterstützte Tangl Sickel bei der Durchsicht der Lateranregister: Kardinal Joseph Hergenröther hatte Sickel gestattet, diese von ihm selbst zu privaten Studien benützten Bände in seiner Wohnung einzusehen, um sie für die Geschichte Maximilians auszubeuten [...] zuerst mir und jetzt Tangl, welcher mit dieser Arbeit die Nachmittagsstunden ausfüllt (gedruckt in Goldinger, Österreich [wie Anm. 68] 49-52, hier 49 und 51). 
Mühlbacher geäußerte Feststellung liege ich so tief in päpstlicher Diplomatik begraben ${ }^{85}$ war das Resümee eines ausführlichen Berichtes über die Entdeckung einer bisher unbekannten Überlieferung des Liber cancellariae apostolicae in der Redaktion des Dietrich von Nieheim im Fondo Ottoboni der Vatikanischen Bibliothek ${ }^{86}$, die ihn nicht nur in die Lage versetzte, wesentliche Korrekturen zu einer gerade erschienenen Ausgabe dieses Werkes durch Georg Erler zu liefern ${ }^{87}$, sondern auch Ottenthals Edition der Kanzleiregeln ${ }^{88}$ zu ergänzen. Ein weiterer bedeutsamer Fund glückte Tangl nur wenige Wochen später in der damals noch nicht zur Vatikanischen Bibliothek gehörigen Bibliotheca Barberiniana. Am I9. März und am 5. April s 889 berichtet er Mühlbacher ausführlich von seiner Entdeckung des zweiten Teils der Redaktion des Kanzleibuches durch Dietrich von Nieheim. Vor dem Hintergrund dieses Neufundes erwies sich nun Erlers Ausgabe noch klarer als nicht nur in der Ausführung, sondern auch schon der Anlage nach verfehlt: Sickel sowohl als auch Ottenthal sind jetzt dafür, dass ich auch die Untersuchung über den L. I. C. wieder aufnehme und ausser dem hier erreichbaren Material vor allem auf der Rückfahrt den Codex des spanischen Collegs in Bologna nochmals vergleiche, dem seinerzeit Merkel seine Bruchstücke über Kanzleiordnungen entnommen hatte; der C. Vat. 3984 bietet die Taxverordnung Johanns XXII. in ungleich vollständigerer und klarerer Weise als die bei Erler gedruckte Bulle ,Pater familias: Bei Übersicht des ganzen Materials [...] wird sich dann ja über die Frage der Verwertung wohl entscheiden lassen, wobei ich persönlich schon jetzt Ihrer Meinung beipflichte, dass eine einheitliche Ausgabe des ganzen Kanzleibuches das allervernünftigste wäre ${ }^{89}$. Offenkundig hatte Mühlbacher, der damals auch für die Redaktion der MIÖG zuständig war, Tangl sofort um eine kurze Anzeige seines Fundes gebeten, denn im Brief vom

85 So Tangls Formulierung im oben (Anm. 84) zitierten Brief an Mühlbacher.

86 Ebd.: Ich habe nämlich in Cod. Ottob. 911 ein Erler vollständig entgangenes Exemplar des Liber cancellariae gefunden; die Schrift deckt sich vollständig mit der unter Urban VI. und Bonifaz IX. ̈̈blichen Registerschrift; dies sowie Zusätze im Context führen mich zu dem sicheren Ergebnis, dass dies Exemplar unter Bonifaz IX. in der päpstlichen Kanzlei angelegt wurde; Codex authenticus ist es also wohl so wenig wie die einzige Hs., nach welcher Erler seine Ausgabe veranstaltete. In wieweit aber wenigstens eine Einflussnahme des damals in der päpstlichen Kanzlei ja wohl noch thätigen Autors angenommen werden kann, muss ich noch untersuchen. An den l. cancellariae schliesst sich eine Ottenthal entgangene recht gute und vollständige Hs. der Regulae cancellariae, die ich c. 1410 setzen möchte, weil bis zum 4. Pontificatsjahr Gregors XII. alles von einer Hand herrührt, während die Verordnungen aus den späteren Jahren dieses Papstes in wechselnder Schrift folgen. Zugleich will ich auch dem Verhältnis des l. canc. zum Cod. Vat. 3984, auf den bereits Ottenthal Regulae canc. XLI hingewiesen, näher nachgehen.

87 Der Liber cancellariae apostolicae vom Jahre 1380 und der Stilus palatii abbreviatus Dietrichs von Nieheim, hg. v. Georg Er LER (Leipzig 1888).

88 Vgl. oben Anm. 76.

89 Tangl an Mühlbacher, 05.04.1889, IÖG NL Mühlbacher. Es folgt eine scharfe Kritik von Details der Erler'schen Ausgabe - ich habe offen gesagt die wohlwollende Recension Ottenthals mit ihren ganz versteckten Hieben nie begriffen. Ottenthals Besprechung findet sich in: MIÖG 9 (1888) 679-682. 
5. April wird auch die Beilage eines entsprechenden Manuskriptes erwähnt ${ }^{90}$. Der Bericht erschien noch in den MIÖG I 88991. Er lässt auch die Vielseitigkeit von Tangls Arbeitsweise erkennen: zur Klärung der letztlich papstdiplomatischen Fragestellung nach der Entstehungsgeschichte des Liber cancellariae werden sehr gekonnt paläografische und kodikologische Beobachtungen angestellt und interpretiert. Zugleich verweist die Miscelle auf Tangls weitere Arbeitspläne, indem festgestellt wird, dass der Autor sich eingehendere kritische Erörterungen für die vollständige oder theilweise Ausgabe vorbehalte ${ }^{92}$.

Tangls paläografische und kodikologische Kompetenz zeigt sich auch in einer dritten kurzen Veröffentlichung, die inhaltlich ebenfalls zum Komplex der päpstlichen Kanzleiordnungen gehört und ein weiteres Ergebnis von systematischen Handschriftenforschungen in diesem Zusammenhang ist. Seinem gegenüber Mühlbacher geäußerten Plan entsprechend, besuchte er auf der Rückreise von Rom neben Archiven in Florenz und Siena auch die Bibliothek des Collegio di Spagna in Bologna. In einem Brief an Sickel lobt er nicht nur die hervorragenden Arbeitsbedingungen, die man ihm dort gewährte, sondern berichtet auch ausführlich über eine Handschrift, die eine Reihe von die Verfahrensweisen der päpstlichen Kanzlei betreffenden Texten überliefert ${ }^{93}$. Aus der eingehenden Untersuchung dieses Codex entstand eine kurze Mitteilung, in der Tangl durch gründlichen Textvergleich den Nachweis erbringt, dass der Autor der sogenannten Brevis nota, eines Berichts über die Absetzung Kaiser Friedrichs II. auf dem ersten Konzil von Lyon, tatsächlich ein Augenzeuge der Ereignisse war, der dem Umfeld der päpstlichen Kanzlei angehörte, was wiederum Rückschlüsse auf den Charakter seines Berichtes erlaubt ${ }^{94}$. Außerdem bestärkte ihn die Beschäftigung mit der Handschrift neuerlich in der Auffassung, dass eine Neuausgabe des päpstlichen Kanzleibuches erforderlich sei ${ }^{95}$.

90 Wie Anm. 89: Zugleich erlaube ich mir beiliegend die gewünschte Fundnotiz für die ,Kleinen Mitteilungen' einzusenden; hoffentlich wird das darin Gesagte als vorläufige Anzeige genügen.

91 Michael TANGL, Der vollständige Liber cancellariae des Dietrich von Nieheim, in: MIÖG 10 (1889) 464466.

92 Ebd. 464.

93 IÖG, NL Sickel, 04.07.1889: Seit gestern weile ich hier in Bologna, wo ich mich der vollsten Gunst des Rettore del Collegio Spagnolo erfreue, der mir den von Merkel einst benützten Codex sofort ausfolgte, ein eigenes Zimmer anwies, und den Schlüssel hiezu übergab und unbeschränkte Arbeitszeit gestattete, die ich denn auch redlich ausnütze, so dass ich in höchstens noch 3-4 Arbeitstagen den Cod. ganz vollständig durchzuarbeiten hoffe; und das lohnt er denn auch reichlich. Die Zeitbestimmung Merkels (14. Jh.) erwies sich auf den ersten Blick als falsch; ebenso seine Vermuthung, dass er in Bologna zu Studienzwecken entstanden sei; er gehört sicher noch dem 13. Jahrh. an und ist ebenso sicher in der päpstlichen Kanzlei entstanden. Eine Neubearbeitung auch des Erler'schen Liber Cancellariae ergibt <sich> daraus schon jetzt als nothwendiges Erfordernis. Vgl. Johannes MER KEL, Documenta aliquot quae ad romani pontificis notarios et curiales pertinent, in: Archivio Storico Italiano 5 [App.] (1847) 129-153.

94 Michael TANGL, Die sogenannte Brevis nota über das Lyoner Concil von 1245, in: MIÖG 12 (1891) 246253.

95 Wie Anm. 93. 
In der Beschäftigung mit den Verfahrensregeln der päpstlichen Kanzlei folgte Tangl einer Fragestellung, der sich neben Ottenthal auch schon Kaltenbrunner, Fanta und besonders Diekamp gewidmet hatten ${ }^{96}$, die ihre jeweiligen Vorhaben aber aus verschiedenen Gründen nicht zum Abschluss bringen konnten. Tangl gelang es durch seine profunden hilfswissenschaftlichen Fähigkeiten und getragen von Begeisterung und Ausdauer, die Erforschung dieser zum Teil etwas spröden Materie wesentlich voranzubringen. Im Juli I 889 legte er brieflich Sickel seine weiteren Arbeitspläne dar. Mit der Rückkehr aus Italien war die Materialsammlung vorerst abgeschlossen und es ging an die Durcharbeitung und Musterung meines ganz gewaltig angewachsenen Manuscripts ${ }^{97}$; dies hatte Tangl im Herbst so weit abgeschlossen, dass er das Ergebnis seiner Arbeit an der Universität Wien unter dem Titel „Das Taxwesen der päpstlichen Kanzlei vom I 3. bis zur Mitte des I 5 . Jahrhunderts“ als Dissertation einreichen konnte. Seine Promotion erfolgte am 23. Dezember $1889^{98}$, I 892 wurde die Arbeit in Aufsatzform in den MIÖG veröffentlicht ${ }^{99}$. Mit den von den Parteien zu leistenden Zahlungen für die Dienste der päpstlichen Kanzlei untersucht sie einen, allerdings zentralen, Teilaspekt der Tätigkeit und Verfahrensregeln dieser Institution. Tangl verbindet hier die überaus gründliche Darstellung der Sachverhalte, die sich nicht nur auf die gleichsam normativen Texte der Verfahrensvorschriften der Kanzlei, sondern auch auf deren praktische Umsetzung, wie sie aus den Taxvermerken auf den Urkundenausfertigungen erkennbar ist, stützt, mit dem Abdruck einiger für seinen Gegenstand zentraler Texte aus den Kanzleiordnungen.

Nicht nur diese Veröffentlichung zeigt Tangls Spezialisierung im Gebiet der Papstdiplomatik, sondern auch eine Reihe von zum Teil umfangreichen Rezensionen einschlägiger Werke, die er neben seiner im Herbst I 889 aufgenommenen beruflichen Tätigkeit als Archivar vor allem in den MIÖG veröffentlichte. So erschien I 890 eine ausführliche und sehr lobende Besprechung von Ottenthals Ausgabe der Kanzleiregeln mit wertvollen Ergänzungen aus Tangls eigener Arbeit ${ }^{100}$, während er I 89I eingehend eine Arbeit Henry Simonsfelds ${ }^{101}$

96 Wilhelm Diекамp, Die neuere Literatur zur päpstlichen Diplomatik, in: HJb 4 (1883) 210-261, 361-394, hier 380: Handschriften der Kanzleiregeln und der Formeln sind viele erhalten; auch hier steht eine Publikation von Kaltenbrunner und Fanta in Aussicht; die Handschrift Dietrichs [von Nieheim] hoffe ich demnächst veröffentlichen zu können.

97 IÖG, NL Sickel, 04.07.1889; vgl. auch den Brief vom 15.05.1889 an Mühlbacher, IÖG, NL Mühlbacher. 98 Schaller, Tangl (wie Anm. 1) 37.

99 Michael TANgL, Das Taxwesen der päpstlichen Kanzlei vom 13. bis zur Mitte des 15. Jahrhunderts, in: MIÖG 13 (1892) 1-106, und in: DERs., Mittelalter 2 734-838. Tangl berichtete am 12.04.1891 Mühlbacher über gewisse Erweiterungen der Arbeit gegenüber der Dissertationsfassung, IÖG, NL Mühlbacher.

100 MIÖG 11 (1890) 337-342. Am Schluss druckt Tangl aus dem von ihm entdeckten Barberinicodex eine Kanzleiangelegenheiten betreffende Anordnung Bonifaz' IX.

101 Henry Simonsfeld, Beiträge zum päpstlichen Kanzleiwesen im Mittelalter und zur deutschen Geschichte im 14. Jahrhundert, in: SB München 2 (1890) 218-284. 
kritisierte, der ebenfalls den Codex des Collegio di Spagna in Bologna sowie eine auch Tangl aus eigenem Studium bekannte Handschrift der Bibliotheca Marciana in Venedig für eine Untersuchung des päpstlichen Kanzleiwesens genützt hatte. Er wies dem Autor zahlreiche Flüchtigkeiten und verfehlte Interpretationen nach ${ }^{102}$, was Simonsfeld zu einer Replik veranlasste, die von Tangl beantwortet wurde, worauf wiederum Simonsfeld entgegnete ${ }^{103}$. Ebenso beginnt in diesen Jahren die lange Reihe der unzähligen in verschiedenen Zeitschriften veröffentlichen Anzeigen und Notizen, in denen Tangl meist knapp, aber gehaltvoll Bücher und Aufsätze anderer Autoren bekannt machte und mitunter wichtige sachliche Anmerkungen und Stellungnahmen gab ${ }^{104}$.

Hauptbeschäftigung neben seiner beruflichen Tätigkeit blieb aber die Arbeit an den päpstlichen Kanzleiordnungen. In Anknüpfung an das - allerdings umfassender angelegte - Vorhaben von Diekamp ${ }^{105}$ und in Ausführung seiner wiederholt geäußerten Pläne erarbeitete er eine Sammlung von Texten, die er unter dem Begriff „Kanzleiordnungen“ zusammenfasste. Dieses Vorhaben konnte er bei zwei weiteren Rom-Aufenthalten i 89 I wesentlich fördern, so dass er Sickel brieflich seine Hoffnung mitteilen konnte, das Manuskript bis Ostern I 892 im Wesentlichen abschließen zu können ${ }^{106}$. Im Zuge der Arbeit

102 MIÖG 12 (1891) 187-191, dort 190 das harte Resümee: Denifle wies einst in einer Abhandlung über die Registerfrage [...] auf die Höhe hin, die die Kaiserdiplomatik durch Genauigkeit und Sorgfalt der Einzelforschung erklommen und schloß mit den Worten: ,Aufkeinem anderen Wege kann die päpstliche Diplomatik dieselbe erreichen: Mit flüchtig hingeworfenen Bemerkungen und dem eiligen Abklatschen einiger Codexblätter ist ihr kaum ein Dienst geleistet.

103 Mit sehr kritisch-ironischen Anmerkungen erwähnt in zwei Briefen Tangls an Mühlbacher (Rom, 12.04.1891 und Wien, 08.08.1891, IÖG, NL Mühlbacher). Die Formulierung der Briefe läßt vermuten, dass die Kontroverse in den MIÖG gedruckt werden sollte, doch ist dort nichts davon zu finden. Da weder Simonsfeld selbst in einem weiteren einschlägigen Aufsatz (Neue Beiträge zum päpstlichen Urkundenwesen im Mittelalter und zur Geschichte des 14. Jahrhunderts, in: Abh. München 21 [1898] 333-425) noch Tangl in seiner Besprechung dieser Arbeit (Deutsche Zs. für Geschichtswissenschaft 8 N.F. 2 Monatshefte [1897/98] 158-162) etwas davon erwähnt, scheinen die Kontrahenten doch von einer Veröffentlichung abgesehen zu haben.

104 Bedauerlicherweise bleiben die kleinen Anzeigen und Notizen in der Tangl-Biografie Schallers unberücksichtigt. Gerade durch sie ließe sich unsere Kenntnis seiner Stellung in der zeitgenössischen geschichtswissenschaftlichen Diskussion, die sich doch gerade auch in solchen Kleintexten abspielte, wesentlich bereichern, vgl. das Verzeichnis der Rezensionen in Schaller, Tangl (wie Anm. 1) 368-375 und die Vorbemerkung dazu.

105 Vgl. neben der oben (Anm. 96) zitierten Äußerung Diekamps seine Briefe an Sickel vom 30.12.1883, 27.12.1884 und 08.05.1885 (gedruckt in SiCKEL, Römische Erinnerungen [wie Anm. 68] 270f. Nr. 7, 273-276 Nr. 10f.), den von Mühlbacher verfassten Nachruf in MIÖG 7 (1886) 206f., die ausführliche Widmung an Diekamp in Er LER, Liber cancellariae (wie Anm. 87) III-IV, und Sickel in seinem Bericht über das Istituto Austriaco di studii storici in Rom in MIÖG 13 (1892) 367-376, hier 369.

106 Tangl an den in Rom weilenden Sickel, 30.11.1891: Die grössere Edition hoffe ich bis Ostern druckfertig zu haben [...]. IÖG, NL Sickel. Der Brief enthält unter anderem Antworten auf Anfragen Sickels, die dieser be- 
kam es kurz sogar zu einer Art Rollentausch zwischen Sickel und Tangl: Hatte ersterer bisher von Wien aus dem in Rom befindlichen Schüler Anweisungen zu Nachforschungen erteilt, so bat Tangl nun im eben genannten Brief seinen Lehrer um Erkundigungen über von Diekamp während seiner kurzen Tätigkeit in Rom in der Vatikanischen Bibliothek eingesehene Handschriften ${ }^{107}$. Der Hintergrund der Angelegenheit war Tangls Bemühen, ein falsches Zitat zweier Vatikanischer Codices im Abdruck der Kanzleiordnung Nikolaus III. in Kardinal Pitras Analecta Novissima Spicilegii Solesmensis zu verifizieren. Tatsächlich stellte Sickel Nachforschungen an, die allerdings nur ergaben, dass Diekamp den fraglichen Text nicht aus den Handschriften selbst, sondern nur nach Pitra zitiert hatte. Tangls in einem Dankbrief geäußerte Vermutung Gegen Pitra hege ich den Verdacht, dass er absichtlich falsch citierte, um irrezuführen und das Nacharbeiten zu erschweren beziehungsweise unmöglich zu machen ${ }^{108}$ sollte erst viele Jahre später widerlegt werden ${ }^{109}$. In einer seiner letzten Publikationen, die erst nach seinem Tod erschien, kehrte Tangl noch einmal zu der Problematik zurück ${ }^{110}$.

In seinen Briefen an Sickel berichtete Tangl regelmäßig über den Fortgang der Arbeit an den Kanzleiordnungen. Mit meinen Kanzleiordnungen geht es wenn auch langsam so doch stetig vorwärts, schreibt er am 9. Februar I 892, berichtet von ersten Kontakten zu einem Verleger und schickt einen Teil der Einleitung mit Bitte um Meinungsäußerung ${ }^{111}$. Im April des Jahres kann er bereits die Übereinkunft mit dem Verlag Wagner in Innsbruck melden - selbstverständlich ohne Honorar; ich bin froh, es überhaupt angebracht zu haben ${ }^{112}$. Doch der Verlag ließ sich Zeit; im Dezember I 892 klagt Tangl jetzt hat der Mann meine

nötigte, um für die MIÖG einen Bericht über die Aktivitäten des Istituto Austriaco zu verfassen. Der Bericht erschien in MIÖG 13 (1892) 367-376 und nimmt in den Tangl betreffenden Passagen erkennbar von diesem in dem Brief geäußerte inhaltliche Anregungen auf, allerdings zum Teil in möglicherweise bezeichnender Umformulierung: Binnen einigen Monaten glaubt er ein grösseres Werk folgen lassen zu können [auf den Artikel über das Taxwesen], eine vollständige und übersichtliche geordnete Sammlung der Urkunden zur Geschichte der Kanzlei von Johann XXII. bis Alexander VI. (ebd. 369).

107 Wie Anm. 106.

108 Tangl an Sickel, 30.12.1891; verklausuliert auch in TANGL, Kanzleiordnungen (wie unten Anm. 114) 429: [...] dann reichte die Annahme eines Schreib-oder Druckfehlers zur Erklärung der arg verschiedenen Zablen [...] wohl nicht aus und man müsste Schlimmeres argwöhnen.

109 Karl Rieder, Die von Pitra zu der Kanzleiordnung Nicolaus' III. benützten Handschriften Cod. Vat. 3039 und 3040, in: Quellen und Forschungen aus Italienischen Archiven und Bibliotheken 9 (1906) 193-196; vgl. die etwas knurrige Anzeige dieses Artikels durch Tangl in: NA 31 (1906) 770.

110 Michael TANGL, Neue Forschungen über den Liber Cancellariae Apostolicae, in: NA 42 (1921) 551-578, dort 562: Ueber die Lösung eines Zitaten-Rätsels zu berichten, das Kardinal Pitra verschuldet und mit dem er uns durch Jahrzehnte gepeinigt hat, ist nämlich der eigentliche Zweck dieser Zeilen. Unangenehm berührt, dass in diesem Aufsatz die Arbeit Rieders (wie Anm. 109) nicht erwähnt wird.

111 Tangl an Sickel, 09.02.1892, IÖG, NL Sickel.

112 Tangl an Sickel, 26.04.1892, ebd. 
Edition seit Anfang Mai fertig in Innsbruck liegen, und es ist trotz der Intervention von Mühlbacher, Ottenthal und Redlich kein Correcturbogen zu bekommen. Ich bedauere längst tief und lebhaft, mich mit ihm eingelassen zu haben ${ }^{113}$. Es dauerte schließlich noch bis I 894, bis das Buch tatsächlich erscheinen ${ }^{114}$ und von Sickel in einer Audienz Papst Leo XIII. als eine der Leistungen des Istituto Austriaco präsentiert werden konnte ${ }^{115}$.

Eine „Neubearbeitung des Erler'schen Liber Cancellariae“116 im strengen Sinne ist das Werk aber nicht. Erler hatte den Liber Cancellariae in der Fassung des Dietrich von Nieheim aus den ihm bekannten Handschriften als fortlaufenden Text abgedruckt. Tangls Ausgabe versucht hingegen, das Werden der Verfahrensvorschriften und Hilfsmittel der Kanzlei in seinem chronologischen Verlauf seit dem späten I 2. Jahrhundert darzustellen und so ein „brauchbares Hilfsbuch“ für die Lehre von den Papsturkunden des späten Mittelalters, „sozusagen einen ,Codex diplomaticus cancellariae apostolicae', zu schaffen“"117. $\mathrm{Zu}$ diesem Zweck ordnet er die Texte in fünf große Sachabschnitte: Provinciale, Juramenta, Constitutiones, Formulae, Reformationes; die „Einheit“ der Texte wird durch eine umfangreiche, mehr als 6o Seiten lange Einleitung erschlossen, auf die noch die zum Teil sehr ausführliche Beschreibung der verwendeten Handschriften folgt. Trotz ihres mittlerweile hohen Alters ist Tangls Ausgabe bis heute ein wesentliches Hilfsmittel. Als solches erkannten es auch die Zeitgenossen, auch wenn die einzige ausführliche Rezension durch Johannes Haller ${ }^{118}$ eine eher zweideutige Mischung von Lob, Detailkritik und durchaus weitgehender allgemeiner Kritik enthielt. Manches ist nicht nur durch das Auffinden neuer Handschriften, sondern auch durch eine Neubewertung der Überlieferungsverhältnisse überholt - dies trifft etwa auf die Konstitution Nikolaus' III. zu, für deren Texterstellung Tangl sich so verzweifelt um die Aufklärung des Pitra’schen Zitierirrtums bemüht hatte. Sie wurde 1933 durch Geoffrey Barraclough neu herausgegeben, wobei der Editor Tangls Texterstellung als im Grundsätzlichen verfehlt beurteilte ${ }^{119}$. Den großen Bereich der Verfahrensvorschriften und Formularsammlungen der Audientia litterarum contradictarum, den Tangl völlig ausgespart hatte, behandelte aufbauend auf Vorarbeiten des durch diesen angeregten Tangl-Schülers Heckel in erschöpfender Weise erst Peter Herde ${ }^{120}$. Eine

113 Tangl an Sickel, 13.12.1892, ebd.

114 Die päpstlichen Kanzleiordnungen von 1200-1500, hg. v. Michael TANGL (Innsbruck 1894, ND Aalen 1959). Zum Neudruck vgl. Sch alle R, Tangl (wie Anm. 1) 46-48.

115 Sickel, Römische Erinnerungen (wie Anm.68) 192.

116 So Tangl an Sickel, 04.07.1889, wie oben Anm. 93.

117 TANGL, Kanzleiordnungen (wie Anm. 114) VII. Dementsprechend weist Tangl selbst auf die fortbestehende Aktualität der Erler'schen Ausgabe hin (ebd. VI).

118 HZ 77 (1896) 115-119.

119 Geoffrey Barraclough, The Chancery Ordinance of Nicholas III. A Study of the Sources, in: Quellen und Forschungen aus Italienischen Archiven und Bibliotheken 25 (1933/34) 192-250.

120 Peter Herde, Audientia litterarum contradictarum. Untersuchungen über die päpstlichen Justizbriefe und 
Neubearbeitung der im Umkreis der päpstlichen Kanzlei entstandenen Verfahrensregeln, Formularsammlungen und Hilfsmittel, die eine in Anbetracht der Komplexität der Überlieferungslage gewaltige Aufgabe darstellt, zumal sie unter Berücksichtigung moderner editionstechnischer Paradigmen eigentlich jede einzelne Überlieferung als Repräsentant eines wesenhaft lebendigen Textes aufzufassen hätte ${ }^{121}$, hat jüngst mit Blick auf Ottenthals Ausgabe der Kanzleiregeln Andreas Meyer in Angriff genommen ${ }^{122}$.

Tangl selbst blieb zwar in seiner weiteren wissenschaftlichen Tätigkeit stark an Problemen der päpstlichen Diplomatik und der Papstgeschichte interessiert, in seinen Publikationen traten aber zunehmend andere Themen und Interessen in den Vordergrund. Bis um die Jahrhundertwende veröffentlichte er noch einige kleinere Arbeiten, die wohl Nachlesen aus dem während der Rom-Aufenthalte in den Jahren I 888 bis I89I gesammelten Material sind ${ }^{123}$. In späteren Jahren erschienen neben den bereits erwähnten neuen Forschungen zum Liber cancellariae ${ }^{124}$ noch eine von einer Rezension zum Aufsatz gewachsene Abhandlung zur spätantik-frühmittelaterlichen Papstdiplomatik ${ }^{125}$ und eine Untersuchung der Deliberatio super tribus electis Innocenz' III. ${ }^{126}$ Mit diesem Thema

die päpstliche Delegationsgerichtsbarkeit vom 13. bis zum Beginn des 16. Jahrhunderts 1-2 (Bibliothek des deutschen historischen Instituts in Rom 31-32, Tübingen 1970).

121 In dieser Hinsicht stimmt etwa Tangls in Zusammenhang mit dem Pitra-Problem brieflich gegenüber Sickel (30.11.1891, wie oben Anm. 106) geäußerte Bemerkung [...] an den Lesarten der von Pitra wirklich benützten Handschrift ist mir, wenn nur die eine Frage klar gelegt ist, eigentlich wenig gelegen, da die drei mir bekannten Quellen zur Herstellung eines correkten Textes vollkommen ausreichen durchaus bedenklich.

122 Andreas Meyer, Emil von Ottenthal revisited. Unterwegs zu einer erweiterten Neuedition der spätmittelalterlichen Regulae cancellariae apostolicae, in: ZRG KA 91 (2005) 218-236; DERs., Die geplante neue Edition spätmittelalterlicher päpstlicher Kanzleiregeln, in: Stagnation oder Fortbildung? Aspekte des Kirchenrechts im 14. und 15. Jahrhundert, hg. v. Martin Bertram (Bibliothek des Deutschen Historischen Instituts 108, Tübingen 2005) 103-117; DERs., Spätmittelalterliche päpstliche Kanzleiregeln, in: Von der Ordnung zur Norm: Statuten in Mittelalter und Früher Neuzeit, hg. v. Gisela Dross B ACH (Paderborn/ München/Wien/Zürich 2010) 95-108. Vgl. zu den Editionsarbeiten Peter Her dE, On Editing Formularies for Papal Letters of Justice and Letter Collections (Thirteenth - Fifteenth Centuries), in: Proceedings of the Twelfth International Congress of Medieval Canon Law, Washington D.C. 1-7 August 2004, hg. v. UtaRenate Blumenthal, Kenneth Pennington, Atria A. Larson (Monumenta Iuris Canonici C 13, Città del Vaticano 2008) 581-594.

123 Rückdatierung in Papsturkunden, in: MIÖG 15 (1894) 128-130; Die päpstlichen Register von Benedikt XII. bis Gregor XI., in: Festgaben zu Ehren Max Büdingers von seinen Freunden und Schülern (Innsbruck 1898) 287-309, und in: Mittelalter 2 839-856. Tangls Kommentare zu dieser Arbeit bei Schalle R, Tangl (wie Anm. 1) 48; Der Jahresanfang in den Papsturkunden des 13. Jh., in: Historische Vierteljahrschrift 3 (1900) 86-89; Eine Rota-Verhandlung vom Jahre 1323, in: MIÖG Erg.-Bd. 6 (Innsbruck 1901) 320-332.

124 Siehe oben Anm. 110.

125 Gregor-Register und Liber Diurnus. Eine Kritik, in: NA 41 (1917-1919) 741-752, und in Ders., Mittelalter 2 709-718. Kritisiert wurden zwei Veröffentlichungen von Wilhelm Peitz.

126 Die Deliberatio Innocenz' III., in: SB Berlin 1919, 1012-1028, und in: DERs., Mittelalter 2 719-733. 
hatte sich Tangl bereits 1898 in seinem Beitrag zur Festschrift für Max Büdinger befassen wollen, jedoch dann aus persönlichen Gründen davon abgesehen. Vielleicht findet sich ein erster Anhaltspunkt für sein einschlägiges Interesse schon in einem am 27. März I 893 verfassten Brief an Sickel, in dem Tangl über seine seit I 889 betriebene Materialsammlung zur Geschichte des Konsistoriums berichtet, mit der er jetzt schon am Anfang des I3. Jahrhunderts angelangt sei ${ }^{127}$. Auch eine Beschäftigung mit dem Thronstreitregister Innocenz' III. ist frühzeitig fassbar ${ }^{128}$, der Plan einer Edition gelangte allerdings nicht zur Verwirklichung ${ }^{129}$. Zwei Pläne für größere Arbeiten, die sicher in engem Zusammenhang mit Tangls Lehrtätigkeit in Marburg und Berlin zu sehen sind, betrafen die Erstellung einer Faksimilesammlung zur päpstlichen Diplomatik, wohl gedacht in Entsprechung zu Sickels „Kaiserurkunden in Abbildungen“"130, und die Abfassung einer umfassenden Darstellung der Papstdiplomatik ${ }^{131}$; beide Vorhaben blieben jedoch unausgeführt.

Welche Bedeutung Tangl der Arbeit an Originalen für den Unterricht der Diplomatik beimaß, geht aus seinen Bemühungen um den Ausbau des diplomatischen Apparats des Historischen Seminars der Universität Berlin hervor. Zu diesem Zweck beteiligte er sich sogar an Auktionen und erwarb dort Urkunden, wie aus einem I 9 I 6 an Ottenthal gerichteten Schreiben hervorgeht: Ihre Brondolo-Abhandlung interessierte mich umso mehr, als ich selbst eine ähnliche, aber aus späterer Zeit auf Lager habe: I3. Jh.: Appellationen Brondolos an den Papst und daraufhin erlassene päpstliche Schutzurkunden (nach Formularen des Liber Cancellariae). Die Originale kommen natürlich auch von einer Auktion (Meyer-Cohn Igo6), auf der ich sie durch ganz mäßiges Überbieten dem Russen Likatschoff abjagte, der sie nach Petersburg mitführen wollte ${ }^{132}$. Tangls geplante Abhandlung ist nie erschienen, die Stücke

127 Bezüglich des Consistoriums fällt es mir gar nicht ein, Mayr in die Quere zu kommen; seine Arbeit dürfte sich jedenfalls über die Zeit des 15.-16. Jahrhunderts erstrecken; auch ich habe seinerzeit in Rom durch die Arbeiten im Consistorialarchiv die Anregung zu meiner geplanten Arbeit erhalten, habe mich aber nicht so sehr für das Consistorium jener Zeit, als um die Frage nach Entstehung, Ausbildung und Wirkungskreis des Consistoriums überhaupt gekümmert: und dabei bin ich nun (ich sammle wie gesagt seit 1889) Schritt für Schritt weiter zurückgerathen, so dass ich nun für den Anfang des 13. Jahrhunderts schon ziemlich klar zu sehen glaube (27.03.1893, IÖG, NL Sickel).

128 Tangl an Sickel 30.11.1891, IÖG, NL Sickel.

129 Erwähnt in der von Georgine Tangl verfassten Einleitung zu TANGL, Mittelalter 116.

130 Schaller, Tangl (wie Anm. 1) 79f.

131 Erwähnt in: Stengel (wie Anm. 36) 375; Oswald Redlich in: MIÖG 39 (1923) 321-325, hier 325.

132 Tangl an Ottenthal, 24.01.1916, IÖG, NL Ottenthal. Tangl bezieht sich auf Emil von Oтtentнац, Das Brondolo-Privileg Leo's IX., in: MIÖG 36 (1915) 288-311. Die genannte Auktion betraf den Verkauf der Sammlung des Berliner Bankiers Alexander Meyer-Cohn durch das Auktionshaus Stargardt: Die Autographen-Sammlung Alexander Meyer Cohn's 1-2. Mit einem Vorwort von Erich Sch mid (Berlin 1905-1906), Brondolo betreffende Urkunden hier 149 Nr. 446 (heute im Diplomatischen Apparat der Universität Göttingen, vgl. Dieter Girgensohn, Die Zisterzienser von Brondolo wehren sich gegen Besteuerung. Über die procurationes päpstlicher Legaten im 13. Jahrhundert, in: Vielfalt und Aktualität des 
fanden jedoch Aufnahme in die Urkundensammlung des Historischen Seminars; ob sie allerdings die Wirren nach dem Zweiten Weltkrieg überstanden haben, ist derzeit nicht eindeutig feststellbar ${ }^{133}$. Dass die Papstdiplomatik in seiner Lehrtätigkeit eine wichtige Stellung einnahm, ist auch aus der Liste der von ihm abgehaltenen Lehrveranstaltungen ${ }^{134}$ und vor allem der von ihm angeregten und betreuten Dissertationen ${ }^{135}$ erkennbar. Vor allem Caspar, Heckel und Perels führten Tangls hilfswissenschaftlich-diplomatischen Zugang zur Geschichte des Papsttums weiter und fühlten sich ihm zeitlebens als seine Schüler verpflichtet ${ }^{136}$.

\section{DiplomatA, LEgES, EPISTOLAE : TANGLS MITWIRKUNG AN DEN EDITIONSUNTERNEHMEN DER MGH}

Bereits I 892, als Michael Tangl noch im Archivdienst stand, konnte ihn Mühlbacher für die Mitarbeit an den von ihm im Auftrag der MGH bearbeiteten Diplomata Karolino-

Mittelalters. FS für Wolfgang Petke zum 65. Geburtstag, hg. v. Sabine Arend [Veröff. des Instituts für Historische Landesforschung der Universität Göttingen 48, Bielefeld 2006] 95-127, ebd. 119-122 ein Überblick über die tragische Geschichte des Archivs der Zisterzienserabtei Brondolo). Der „Russe Likatschoff“ ist der Sammler Nikolai Petrovich Likachev (1862-1936), der mit fast unbegrenzten Geldmitteln europaweit Handschriften und Urkunden für sein „Museum des geschriebenen und gedruckten Wortes“ kaufte. Vgl. den biografischen Abriss in: Likhachev's Watermarks. An English-Language Version 1, hg. v. J. S. G. Simmons, Bé Ginneken-Van de Kasteele (Monumenta Chartae Papyraceae Historiam Illustrantia 15, Amsterdam 1994) XLI-XLVIII.

133 Vgl. Michael TAngl, Das historische Seminar, in: Max Lenz, Geschichte der königlichen Friedrich-Wilhelms-Universität zu Berlin 3: Wissenschaftliche Anstalten, Spruchkollegium, Statistik (Halle a. d. Saale 1910) 247-263, hier 262; Johanna A berle - Ina Prescher, Die Urkundensammlung des Historischen Seminars der Friedrich-Wilhelms-Universität zu Berlin. Rückblick und Bestandsaufnahme, in: Archivistica docet. Beiträge zur Archivwissenschaft und ihres interdisziplinären Umfelds, hg. v. Friedrich BEck, Wolfgang Hempel, Eckart Henning (Potsdamer Studien 9, Potsdam 1999) 525-557; dies., Die Urkundensammlung des Historischen Seminars der Friedrich-Wilhelms-Universität zu Berlin, heute in der Universitätsbibliothek der Humboldt-Universität, Zweigbibliothek Geschichte. Inventar: Sammlungsgeschichte, -beschreibung und Regesten der Urkunden nordalpiner Provenienz (Schriftenreihe der Universitätsbibliothek der Humboldt-Universität zu Berlin 60, Berlin 1997); Die Urkundensammlung des Historischen Seminars der Friedrich-Wilhelms-Universität zu Berlin 2: Regesten der Urkunden nichtdeutscher Provenienz, bearb. v. Harald Mülle r u.a. Mit einem Beitrag zu Handschriften aus dem paläographisch-diplomatischen Apparat des Historischen Seminars der Friedrich-Wilhelms-Universität an anderen Aufbewahrungsorten von Wolfgang Eric WAGner (Schriftenreihe der Universitätsbibliothek der Humboldt-Universität zu Berlin 62, Berlin 2007).

134 Schaller, Tangl (wie Anm. 1) 376-380.

135 Ebd. 305-350.

136 Ebd. 311f. zu Caspar, 317 zu Heckel, 333f. zu Perels. 
rum gewinnen. Gemeinsam mit Alfons Dopsch, dem die Hauptlast der für dieses Projekt notwendigen Archivreisen zufiel, wurde die Arbeit an den etwa 2000 zu bearbeitenden Urkunden aufgenommen ${ }^{137}$. Auch als Tangl I 895 nach Marburg berufen wurde, blieb seine Mitarbeit an dem Projekt auf seinen ausdrücklichen Wunsch aufrecht, gestaltete sich jedoch der räumlichen Entfernung wegen als schwierig. Sinnvollerweise konzentrierte sich Tangl auf die im Marburger Staatsarchiv lagernden Materialien zu den Urkundengruppen Fulda und Hersfeld, sowie Bremen und Verden. Besonders die Forschungen über die Reichsabtei Fulda führten ihn dabei weit über die karolingischen Herrscherurkunden hinaus ${ }^{138}$, unter anderem zu seiner ihn nahezu zeitlebens begleitenden Beschäftigung mit dem Leben und den Briefen des heiligen Bonifatius ${ }^{139}$. Seit dem Sommer I 897 unternahm er - bereits von Berlin aus - ausgedehnte Archivreisen in die Schweiz sowie nach Italien und beschäftigte sich eingehend mit den Osnabrücker Fälschungen ${ }^{140}$. I 898 begann er, sich mit der mühevollen Entzifferung der tironischen Noten, die in den Diplomen der karolingischen Herrscher noch für Kanzleivermerke verwendet wurden, auseinanderzu-

137 Vgl. zu den Anfängen der Arbeiten an den Diplomata Karolinorum zusammenfassend Sch ALle R, Tangl (wie Anm. 1) 48-54.

138 So leistete er wesentliche Vorarbeiten für den letztlich erst 1958 von Stengel vollendeten ersten Band des Urkundenbuches von Fulda: Urkundenbuch des Klosters Fulda 1: Die Zeit der Äbte Sturmi und Baugulf, bearb. v. Edmund E. Stengel (Veröff. der Historischen Kommission für Hessen und Waldeck 10/1, Marburg 1958). Aufsätze zu diesem Themenkreis: Michael TAngl, Die Fuldaer Privilegienfrage, in: MIÖG 20 (1899) 193-252, und in: Ders., Mittelalter 1 489-539; DERs., Die Urkunde Ludwigs d. Fr. für Fulda vom 4. August 817, in: NA 27 (1902) 9-34. Vgl. zu dieser Phase seiner Mitarbeit an den Diplomata Karolinorum Schaller, Tangl (wie Anm. 1) 77-88.

139 Michael Tangl, Das Todesjahr des Bonifatius, in: Zs. des Vereins für Hessische Geschichte und Landeskunde NF 27 (1903) 223-250, und in : DERs., Mittelalter 1 25-46; DERs., Studien zur Neuausgabe der Bonifatiusbriefe 1-2, in: NA 40 (1916), 639-790, und ebd. 41 (1917) 23-101, und in: DERs., Mittelalter 1 60-240, sowie Ders., Bonifatiusfragen, in: Abh. der Preußischen Akademie der Wissenschaften 19192 1-41, und in: DERs., Mittelalter 1 241-272. In die Marburger Jahre fällt auch der Beginn der Überarbeitung und Ergänzung der von Wilhelm Arndt herausgegebenen zwei Hefte der „Schrifttafeln zur Erlernung der lateinischen Paläographie“, die Tangl vor allem auch im Hinblick auf die Urkundenschriften zu erweitern trachtete und die ihn dann besonders in seiner Berliner Zeit in Anspruch nahmen: mit dem sogenannen „Arndt - Tangl“ wird wohl heute noch jeder Student der historischen Hilfswissenschaften zuerst mit dem Namen Tangls bekannt: Schrifttafeln zur Erlernung der lateinischen Paläographie, hg. v. Wilhelm ArNDT, Heft 1-2, 3. erw. Aufl. besorgt v. Michael TANGL (Berlin 1897-1898), Heft 3 hg. v. Dems. (Berlin 1903).

140 Die Ergebnisse seiner Arbeiten legte er, nachdem ihm Brandi mit einem inhaltlich verwandten Aufsatz (Karl Brandi, Die Osnabrücker Fälschungen, in: Westdeutsche Zs. 19 [1900] 120-170) zuvorgekommen war, erst 1909 im Rahmen einer umfangreicheren Arbeit vor: Michael TAngL, Forschungen zu Karolinger Diplomen, in: AUF 2 (1909) 167-326, hier 186-326 unter den Titel: Die Osnabrücker Fälschungen, und in: DERs., Mittelalter 1 356-474, hier 372-474; DERs., Zum Osnabrücker Zehntstreit, in: Historische Aufsätze. Karl Zeumer zum sechzigsten Geburtstag (Weimar 1909) 637-650. 
setzen $^{141}$. Mithilfe von Fotografien, Handpausen und Nachzeichnungen bemühte man sich, diese aus der Antike stammende Kurzschrift zu entziffern, doch, wie Tangl betonte, mussten die Ergebnisse immer wieder nach Einsicht in die Originale revidiert werden ${ }^{142}$. Hinzu kam noch die schwierige Untersuchung nicht selten nachgeahmter oder gefälschter tironischer Noten; doch lohnten die wichtigen Erkenntnisse, die die Noten über Kapelle und Kanzlei der karolingischen Herrscher lieferten, die Mühe und die aufgewendete Zeit. Im Winter I 899/ 900 konnte mit dem Druck der ersten Bogen des ersten Bandes, der die Urkunden Pippins, Karlmanns und Karls des Großen enthalten sollte, begonnen werden und Tangl sich der Erstellung der Verzeichnisse widmen. Nachdem Mühlbacher im Juli I 903 verstorben war, wurde Tangl die Leitung der Abteilung übertragen. Er ließ einige Urkundengruppen einer neuerlichen Revision unterziehen, sodass der erste Band der Diplomata Karolinorum, auch wegen der Verzögerungen, die die Verlegung der Abteilung nach Berlin mit sich brachten, schließlich erst 1906 erschien ${ }^{143}$. Maßgeblich nach den Grundsätzen Mühlbachers bearbeitet, die nicht in jeder Hinsicht von Tangl mitvertreten wurden, fand der Band in der Fachwelt geteilte Aufnahme, wobei die Kritik im Einzelnen mitunter auch durch persönliche Animositäten beeinflusst war ${ }^{144}$. Immerhin konnte Tangl nach dem endgültigen Abschluss des ersten Bandes auch zwei die Edition flankierende grundlegende Arbeiten vorlegen ${ }^{145}$.

141 Michael TANGL, Die Tironischen Noten in den Urkunden der Karolinger, in: AUF 1 (1908) 87-166, und in: Ders., Mittelalter 1 285-355; Ders., Forschungen (wie Anm. 140), hier 167-186 unter dem Titel: Tironiana und Konzeptfrage, und in: DERs., Mittelalter $1356-372$; DERs., Das Testament Fulrads von Saint-Denis, in: NA 32 (1907) 167-217, und in: Ders., Mittelalter 1 540-581, hier 546f.; Ders., Zum Judenschutzrecht unter den Karolingern, in: NA 33 (1908) 197-200, und in: DERs., Mittelalter 1 598-600; Ders., Die Tironischen Noten des Cod. Vat. Regin. Lat. 612, in: NA 39 (1914) 507-509, und in: Ders., Mittelalter 2 706-708. Auch eine von Bonifatius und Lullus verwendete Geheimschrift, deren Dekodierung wesentlich einfacher war, entsprach offenbar Tangls gewissermaßen detektivischen Neigungen, vgl. Michael TANGL, Studien zur Neuausgabe der Briefe des heiligen Bonifatius und Lullus, in: NA 40 (1916) 639-790, und NA 41 (1917) 23-101, und in: DERs., Mittelalter 1 60-240, hier 125-131.

142 Vgl. dazu Tangl, Die Tironischen Noten in den Urkunden der Karolinger (wie Anm. 141) 87f., sowie DERs., Forschungen zu Karolinger Diplomen (wie Anm. 140) $167 \mathrm{f}$.

143 Die Urkunden der Karolinger 1: Die Urkunden Pippins, Karlmanns und Karls des Großen. Unter Mitwirkung von Alfons Dopsch, Johannes Lechner, Michael Tangl bearb. v. Engelbert Mühlbacher (MGH DD. Karol. I, Hannover 1906). Zur Arbeit Tangls an den Diplomata Karolinorum in den Jahren 1898 bis 1906 siehe SCH A Ller, Tangl (wie Anm. 1) 128-143 sowie 166-173.

144 Vgl. dazu Schaller, Tangl (wie Anm. 1) 168-172. Die berechtigten Kritikpunkte, die von den Rezensenten aufgezeigt wurden, waren genau jene von Tangl abgelehnten Editionsprinzipien Mühlbachers, wie etwa die - sonst in den MGH-Editionen nie vorgenommenen - Verbesserungen von Schreibfehlern in den Originalen sowie die wegen der weitgehenden Verwendung von Formularsammlungen nicht erfolgte Diktatuntersuchung.

145 Michael TAngl, Die Tironischen Noten (wie Anm. 141) 87-166; Ders., Forschungen zu Karolinger Diplomen (wie Anm. 140) 167-326. 
Bereits seit Ende I905 widmete er sich mit seinen Mitarbeitern der Vorbereitung des zweiten Bandes, der die Urkunden Ludwigs des Frommen enthalten sollte. Für ihn ließ Tangl von Beginn an Diktatuntersuchungen vornehmen, breiten Raum nahm auch die Beschäftigung mit den zahlreichen Fälschungen in Anspruch. Zu Beginn des Ersten Weltkrieges zeigte sich Tangl noch optimistisch, bald mit dem Druck der Urkunden Ludwigs des Frommen beginnen zu können ${ }^{146}$. Wegen der Einberufung der wichtigsten Mitarbeiter kam das Projekt jedoch ins Stocken und konnte erst nach Kriegsende wieder aufgenommen werden. Hinderlich war allerdings auch dann noch die Unmöglichkeit, ausländische, vor allem französische Archive zu besuchen. Tangl hatte sich schon seit Beginn des Krieges nicht mehr selbst an der Bearbeitung der Urkunden Ludwigs des Frommen beteiligt und überließ I92 I die Edition zur Gänze seinem Mitarbeiter Ernst Müller. Bereits im Frühjahr I920 hatte er bei der Zentraldirektion der MGH beantragt, die Leitung der Abteilung niederlegen zu dürfen und diese Kehr zu übertragen, zu einer entsprechenden Regelung kam es jedoch zu Lebzeiten Tangls nicht mehr ${ }^{147}$.

Im Dezember I 897 wurde Michael Tangl vom Leiter der Leges-Abteilung, Heinrich Brunner, angeboten, die Herausgabe der unter dem Begriff Placita zusammengefassten älteren fränkischen und italienischen Gerichtsurkunden zu übernehmen. Obwohl Tangl wegen der mangelhaften Vorarbeiten zögerte, die Aufgabe zu übernehmen, konnte ihn Brunner schließlich überreden, bestimmte Untersuchungen an Handschriften durchzuführen und die editionstechnische Vorbereitung der Ausgabe zu betreuen. Noch von Marburg, später von Berlin aus unternahm Tangl zu diesem Zweck mehrere Reisen nach Frankreich, vor allem nach Paris, dann auch nach Süddeutschland und in die Schweiz. Nachdem I 902 die Materialsammlung in Deutschland als abgeschlossen betrachtet werden konnte, konzentrierte sich Tangl von 1904 bis 1906 gemeinsam mit seinem Schüler Mario Krammer auf die Vervollständigung des französischen Materials. In der Folge wandte sich Tangl gemeinsam mit dem Historiker und Juristen Karl Rauch der Texterstellung zu, anschließend der Einleitung und den Kommentaren zu den einzelnen Stücken. Nach I 908 dürfte Tangl sich kaum mehr mit den Placita beschäftigt haben: andere Editionsvorhaben, besonders die Epistolae rückten in den Mittelpunkt seines Interesses. Obwohl er den Druckbeginn mehrfach angekündigt, wieder verschoben und schließlich für die Zeit nach dem Ende des Krieges in Aussicht genommen hatte, konnte er offenbar unter den widrigen Umständen der schwierigen Nachkriegsjahre die Energie für den endgültigen Abschluss der Arbeiten nicht mehr aufbringen. Kehr resümierte nach dem Tod Tangls: „Das Manuskript ist heute noch nicht druckfertig. Schuld daran war weniger eine gewisse lässige Art, die Dinge gehen zu lassen, als die damals häufig wechselnde Lage der

146 Vgl. Schaller, Tangl (wie Anm. 1) $263 f$.

147 Ebd. 278-281. 
Monumenta, [...] welche nicht nur eine stetige Personalpolitik, sondern auch die Durchführung eines rationellen Editionsplanes, wenn nicht verhinderten, so doch immer wieder störten: das Opfer ist in gewissem Sinne Tangl selbst geworden. Schließlich wurde, daß er die Placita liegenlassen mußte, [...] unvermeidlich."148

Der jüngste von Tangl für die MGH übernommene Aufgabenbereich war zugleich jener, in welchem er am erfolgreichsten arbeitete ${ }^{149}$. Nach dem Tod Ernst Dümmlers im September 1902 war nicht nur die Position des Vorsitzenden der Zentraldirektion, sondern auch jene des Leiters der Scriptores- sowie der Epistolae-Abteilung nachzubesetzen. Bis die endgültigen Personalentscheidungen getroffen waren, wurde Tangl zum provisorischen Leiter der Epistolae-Abteilung ernannt ${ }^{150}$. Da dieser zunächst noch durch seine Arbeiten an den beiden anderen MGH-Projekten gebunden war, überließ er die bereits laufenden Briefeditionen, die Briefe der Päpste Nikolaus' I. (858-867) und Hadrians II. (867-872), Fedor Schneider, dem damals einzigen Mitarbeiter der Epistolae-Abteilung, der 1904 nach seinem Wechsel an das Preußische Historische Institut in Rom durch Perels ersetzt wurde. Nach der kurzfristigen Leitung der Epistolae-Abteilung durch Albert Werminghoff vom Sommer 1906 bis Herbst 1907 wurde Tangl I908 erneut provisorisch, im April I909 schließlich endgültig zum Leiter der Abteilung bestellt. In der Folgezeit gelang es Tangl unter Mitarbeit seiner Schüler Perels und Caspar, die Editionen der Briefe Nikolaus' I. und des Briefregisters Johannes' VIII. vorzulegen ${ }^{151}$. Durch die Einberufung beider Mitarbeiter zum Militärdienst kam es auch hier während des Ersten Weltkrieges zu einer Unterbrechung der Arbeiten. Tangl selbst wandte sich immer stärker den „Epistolae selectae in usum scholarum ex Monumentis Germaniae Historicis separatim editae“, einer als Schulausgabe konzipierten Nebenreihe der Epistolae, zu. Für diese Reihe, die nicht dem chrono-

148 Kenr, Tangl (wie Anm. 6) 142f. - Zur Beschäftigung Tangls mit den Placita vgl. Schaller, Tangl (wie Anm. 1) 124-128.

149 Kehr, Tangl (wie Anm. 6) 143-144: „[...] die Epistolae, deren Bearbeitung auch mehr [als jene der Karolingerurkunden] seinen wissenschaftlichen Neigungen entsprach [...] Hier sind nun in der Tat unter seiner Leitung und dank seiner eigenen Mitarbeit große Fortschritte gemacht worden. Er zeigte sich hier als ein ebenso gewissenhafter Abteilungsleiter wie als eifriger Herausgeber." Zur Edition der Briefe des Bonifatius und Lullus: „Diese vorzügliche Arbeit wird ihm immer einen ehrenvollen Platz in der Reihe der Editoren der Monumenta sichern."

$150 \mathrm{Zu}$ den Vorgängen innerhalb der MGH nach dem Tod Dümmlers vgl. Schaller, Tangl (wie Anm. 1) 150-153, zum Wirken Tangls im Rahmen der Epistolae-Abteilung ebd. 233-250.

151 Nicolai I. papae epistolae, hg. v. Ernst Perels (MGH Epistolae in Quart 6 = Epistolae Karolini aevi 4, Berlin 1902-1925, ND 1995) 257-690; Registrum Iohannis VIII. papae, ed. Erich Caspar (MGH Epistolae in Quart 7 = Epistolae Karolini aevi 5, Berlin 1912-1928, ND 1993) 1-333. Vgl. Dietrich Lohrmann, Das Register Papst Johannes' VIII. (872-882). Neue Studien zur Abschrift Reg. Vat. 1, zum verlorenen Originalregister und zum Diktat der Briefe (Bibliothek des Deutschen Historischen Instituts in Rom 30, Tübingen 1968). 
logischen Prinzip der Hauptreihe zu folgen hatte, plante Tangl unter anderem sowohl eine Neuausgabe der Bonifatius-Briefe als auch des Thronstreitregisters Innocenz' III. - beides Projekte, die ihm persönlich sehr wichtig waren ${ }^{152}$. Hier entwickelte er wieder einen in anderen Bereichen lange nicht mehr spürbar gewesenen Elan, der sich positiv auf den Fortgang der Arbeiten auswirkte. I9 I I übernahm er nach dem Tod Oswald Holder-Eggers zusätzlich noch die Leitung der Reihe „Die Geschichtsschreiber der deutschen Vorzeit“" ${ }^{153}$. Schon von der Idee her, mittelalterliche erzählende Quellen auf breiterer Basis Interessierten, die nicht des Lateinischen mächtig waren, zugänglich zu machen, entsprach das Ziel des Unternehmens Tangls eigenen Anliegen. Dass er zudem die Freiheit genoss, sich hier Texten zu widmen, mit denen er sich in anderem Zusammenhang bereits beschäftigt hatte, kam ihm ebenfalls entgegen. So war eines seiner ersten Projekte die Übersetzung der Briefe des heiligen Bonifatius, die bereits I9I 2 erscheinen konnte ${ }^{154}$, ihr folgte, erst nach dem Ersten Weltkrieg im Jahr I920, eine Übersetzung der Vita des Heiligen ${ }^{155}$. Bereits bei der Übersetzung der Bonifatiusbriefe waren Tangl die Mängel der bisherigen MGH-Edition Dümmlers ${ }^{156}$ aufgefallen, und er sah sich veranlasst, eine Neuausgabe in Angriff zu nehmen. Bereits I9I 2 wurden die Arbeiten aufgenommen und kriegsbedingt etwas verzögert konnte diese I9I6 als erster Band der „Epistolae selectae“ erscheinen ${ }^{157}$. Sie ist bis heute die maßgeblich zu benützende Edition der Briefe geblieben, die sich vor allem durch die eingehende Untersuchung der Überlieferungslage und die erstmals gelungene chronologische Einordnung der I 50 Briefe auszeichnet. Wie bei den Karolingerdiplomen begleite-

152 Eine Übersetzung des Registrum Innocencii III. super negotio Romani imperii für die „Die Geschichtsschreiber der deutschen Vorzeit“ konnte Tangl ebenfalls nicht mehr verwirklichen. Dieses Vorhaben setzte Georgine Tangl nach seinem Tod in die Tat um: TANGL, Register Innocenz’ III. (wie Anm. 44).

153 Zu Tangls Tätigkeit für die „Geschichtsschreiber der deutschen Vorzeit“vgl. Schaller, Tangl (wie Anm. 1) 229-233. Neben den genannten Bänden zu Bonifatius publizierte Tangl zwei weitere Übersetzungen in dieser Reihe: Das Leben des Bischofs Benno II. von Osnabrück von Norbert Abt von Iburg. Nach der neuen Ausgabe der Monumenta Germaniae in den Scriptores rerum Germanicarum übersetzt von Michael TANGL (Die Geschichtsschreiber der deutschen Vorzeit, 2. Gesamtausgabe 91, Leipzig 1911) und Kaiser Karls Leben von Einhard, übersetzt von Otto AвеL, bearb. und erweitert v. Michael TAngl (ebd. 2. Gesamtausgabe 16, Leipzig ${ }^{4} 1920$ ). Seine Übersetzungen, vor allem die nach dem Urteil Kehrs „vortrefflichen Einleitungen“, stießen allgemein auf Anerkennung und Wertschätzung; vgl. Ken R, Tangl (wie Anm. 6) 146.

154 Die Briefe des heiligen Bonifatius. Nach der Ausgabe in den MGH in Auswahl übersetzt und erläutert von Michael TANGL (Die Geschichtsschreiber der deutschen Vorzeit, 2. Gesamtausgabe 92, Leipzig 1912).

155 Das Leben des heiligen Bonifatius von Willibald bis Otloh, der heiligen Leoba von Rudolf von Fulda, des Abtes Sturmi von Eigil, neubearb. v. Michael TANGL (Die Geschichtsschreiber der deutschen Vorzeit, 2. Gesamtausgabe 13, ${ }^{3}$ Leipzig 1920).

156 S. Bonifatii et Lulli Epistolae, hg. v. Ernst Dümmler (MGH Epistolae in Quart 3 = Epistolae Merowingici et Karolini aevi 1, Berlin 1892, ND 1994) 215-433.

157 Die Briefe des Heiligen Bonifatius und Lullus, hg. v. Michael TAngL (MGH. Epistolae selectae 1, Berlin 1916). 
ten auch diese Edition eingehende, über einen Zeitraum von mehreren Jahren hindurch veröffentlichte Studien zu Detailfragen ${ }^{158}$. Tangls intensive Beschäftigung mit Leben und Schriften des heiligen Bonifatius veranlasste ihn offenbar, sich mit dem Gedanken an eine Biografie des Heiligen zu tragen, zu der es jedoch nicht mehr kam ${ }^{159}$.

\section{KLEINERE ARBEITEN ZUR ÖSTERREICHISCHEN GESCHICHTE}

So geschlossen sich Tangls Werk in seiner Konzentration auf wenige Themenkreise präsentiert, so finden sich darin doch auch Arbeiten, die außerhalb dieser Forschungsbereiche liegen. Zeitlebens beschäftig sich Tangl immer wieder mit Fragestellungen aus der österreichischen Geschichte. Diese Gruppe von Arbeiten bildet einen kleinen weiteren Schwerpunkt im Euvre Tangls, vor allem wenn man auch seine Vorlesungen über österreichische Geschichte in Berlin während der Weltkriegsjahre mit in Betracht zieht. Naturgemäß gehören etliche seiner Publikationen auf diesem Gebiet in die Anfangsjahre seiner wissenschaftlichen Karriere, die thematisch noch besonders stark von seiner Ausbildung am IÖG geprägt war ${ }^{160}$. Bereits in seine Berliner Zeit fällt eine Studie, in der er die Echtheit des Privilegium minus verteidigte, das kurz zuvor von Wilhelm Erben in einer eingehenden Untersuchung für interpoliert erklärt worden war ${ }^{161}$. Noch kurz vor seinem

158 Michael TANgl, Das Todesjahr des Bonifatius, in: Zs. des Vereins für Hessische Geschichte und Landeskunde NF 27 (1903) 223-250; DERs., Studien zur Neuausgabe der Bonifatiusbriefe 1-2, in: NA 40 (1916) 639-790 und NA 41 (1917) 23-101; DE Rs., Bonifatiusfragen, in: Abh. der Preußischen Akademie der Wissenschaften 1919, phil.-hist. Kl. Nr. 2, 1-41. Tangl verfasste daneben auch einen populärwissenschaftliche Artikel: DERs., Das Bonifatius-Jubiläum, in: Beilage der Germania vom 01.06.1919.

159 Eigene Aussagen Tangls über einen solchen Plan sind nicht bekannt, er fand jedoch Erwähnung in: KEHR, Tangl (wie Anm. 6) 3; Kr A в во, SB (wie Anm. 13) 4.

160 Michael TAngL, Studien über das Stiftungsbuch des Klosters Zwettl, in: AÖG 76 (1890) 261-348; DERs., Die Fälschungen Chrysostomus Hanthalers, in: MIÖG 19 (1898) 1-54, und DE Rs., Das Itinerar Herzog Leopolds VI. im Jahre 1217, in: Blätter des Vereins für Landeskunde von Niederösterreich NF 32 (1898) 85-102.

161 Michael TAngl, Die Echtheit des österreichischen Privilegium minus, in: ZRG GA 25 (1904) 258-286. Vgl. auch Wilhelm Er в en, Das Privilegium Friedrich I. für das Herzogtum Österreich (Wien 1902). Einen guten Überblick über die wissenschaftliche Auseinandersetzung mit dem Privilegium minus findet man bei Heinrich Appelt, Privilegium minus. Das staufische Kaisertum und die Babenberger in Österreich (Böhlau Quellenbücher, ${ }^{2}$ Wien/Köln/Graz 1976) 11-18, mit einer kurzen Erwähnung der quellenkritischen Untersuchung Tangls 15; vgl. neuerdings auch Werner Maleczen, Das Privilegium minus. Diplomatische Gesichtspunkte, in: Die Geburt Österreichs. 850 Jahre Privilegium minus, hg. v. Peter SCHMID und Heinrich WANDERWITZ (Regensburger Kulturleben 4, Regensburg 2007) 103-141. Im Zusammenhang mit der Untersuchung des Privilegium minus ist folgende Arbeit Tangls zu sehen: Michael TAngL, Der Bericht Otto's von Freising über die Erhebung Österreichs zum Herzogtum, in: NA 30 (1905) 477-484. 
Tod beschäftigte sich Tangl mit einer Arbeit über die Herzogseinsetzung in Kärnten und nützte den Aufenthalt in seinem Heimatland, um dafür Archive zu besuchen und die Inschriften auf dem Herzogsstuhl zu entziffern ${ }^{162}$.

Gänzlich isoliert steht eine Arbeit Tangls, die er während seiner Tätigkeit als Archivar im Ministerium des Inneren unter Heranziehung der dortigen Archivbestände über die Haft des italienischen Dichters Silvio Pellico ${ }^{163}$ verfasste. Pellico war von I 822 bis I 830 wegen seines Engagements für die lombardische Freiheitsbewegung, die die Ablösung vom Kaiserreich Österreich anstrebte, in der Festung Spielberg bei Brünn (Brno) gefangen gehalten worden und hatte über diese Zeit seiner Inhaftierung seine eine Welle der Anteilnahme in ganz Europa hervorrufenden Erinnerungen „I mei prigioni“ veröffentlicht. Tangl prüfte und ergänzte die Aufzeichnungen Pellicos anhand der Polizeiakten im Ministerium des Inneren und lieferte mit seiner Studie eine hervorragend formulierte, gut lesbare und einfühlsam verfasste Darstellung des Geschehens. Schon in dieser frühen Arbeit zeigen sich deutlich Tangls Stärken: der souveräne Umgang mit den Quellen in Kombination mit der Gabe zur sprachlichen Formulierung und lebhaften Darstellung - in diesem Fall noch gepaart mit einer sehr menschlichen, nahezu humanitären Sichtweise der geschilderten Schicksale - die auch an manchen Stellen eines gewissen Humors nicht entbehrt. Auch in dieser Arbeit war ihm die Einbettung des dargestellten Gegenstandes in größere Zusammenhänge ein Anliegen und, obwohl zeitlebens ein leidenschaftlicher Anhänger der habsburgischen Donaumonarchie, sparte er nicht mit Kritik am Erwerb und der Regierung der I 8 I 5 auf dem Wiener Kongress Österreich zuerkannten italienischen Gebiete.

\section{KONTROVERSEN UND NEUANSÄTZE: TANGLS STELLUNG IN DEN WISSENSCHAFTLICHEN DISKURSEN SEINER ZEIT}

Im Februar 1903 erschien der Artikel „Die Monumenta Germaniae Historica, ihre bisherige Leitung und Leistung “164, der polemisch formulierte Äußerungen zu Programm,

162 Vgl. die im Anhang II abgedruckten Briefe Tangls an Jaksch vom 17.07. und 15.08.1921 und an Perels vom 12.08.1921, sowie Eberhard Tangls an Jaksch vom 24.11.1921. Im NA 43 (1922) 440 erschien eine Rezension Tangls des darin genannten Werks von Georg Gra Ber, Der Einritt des Herzogs von Kärnten am Fürstenstein zu Karnburg (SB Wien 190 5, 1919), in der er bedauerte, den Versuch des Autors, die Kärntner Herzogserhebung „entgegen der bisher herrschenden Annahme starker slavischer Grundlage ,aus rein deutschem Rechtsempfinden heraus' zu erklären [...] in Grundlage und Methode und daher auch in den Ergebnissen vollkommen verfehlt ablehnen zu müssen“.

163 Michael Tangl, Die Haft Silvio Pellicos, in: Deutsche Rundschau 110 (1892) 58-75, und in: Ders., Mittelalter 2 871-888.

164 Wilhelm Gundeach, Die Monumenta Germaniae historica, ihre bisherige Leitung und Leistung, in: Die Grenzboten 9, 26.02.1903, 1-8; vgl. zur Angelegenheit SCH a Ller, Tangl (wie Anm. 1) 153-158. 
Tätigkeit und Organisation der MGH enthielt. Sein Verfasser, Wilhelm Gundlach, war als ehemaliger Mitarbeiter der MGH mit den internen Strukturen des Unternehmens vertraut. Er hatte unter der Leitung von Dümmler in der Abteilung Epistolae am ersten Band der Edition der „Epistolae Merowingici et Karolini aevi“ mitgearbeitet ${ }^{165}$, war jedoch I 892 von diesem - offiziell aus Einsparungsgründen - entlassen worden ${ }^{166}$. Persönliche Verbitterung über diesen Schritt veranlassten Gundlach in der Folge mehrfach - zunächst im Rahmen seiner Edition von „Heldenliedern“ - die MGH, Dümmler und insbesondere Holder-Egger aufs Schärfste anzugreifen ${ }^{167}$. In den „Grenzboten“ nahm er erneut die Gelegenheit wahr, seine Kritik, nun vor breiterem Publikum, zum Ausdruck zu bringen. Neben der Einsparung des Amtes des Vorsitzenden der Zentraldirektion ${ }^{168}$, die

165 Epistolae Merowingici et Karolini aevi 1, hg. v. Wilhelm Gundlach, Ernst Dümmler u.a. (MGH. Epistolae [in Quart] 3, Berlin 1892, ND 1994).

166 Michael TAngl, Wilhelm Gundlach und sein Angriff auf die Monumenta Germaniae historica, in : Allgemeine Zeitung Nr. 76 vom 4. April 1903, 1-3, geht auf die Umstände der Entlassung Gundlachs nicht näher ein. Aus seiner Bemerkung, „[...] daß es an Gründen in seiner Person nicht mangelte“ (ebd. 1), geht aber hervor, dass es sich nicht um eine reine Sparmaßnahme gehandelt hat. Vgl. dazu auch die Stellungnahme Dümmlers gegenüber dem Staatssekretär von Bötticher im Reichsministerium des Inneren: Obgleich im Ganzen fleißig und gewissenhaft arbeitete er doch ungemein langsam [...] er zeigte sich außerdem im Verkehr so dünkelhaft, eigensinnig und verschroben, daß überhaupt Niemand etwas mit ihm zu thun haben mochte und er sich allen Belehrungen stets fast unzugänglich erwies. Anträge Gundlachs auf weitere Mitarbeit bei den MGH habe er daher mit Rücksicht auf die Notwendigkeit weiteren Sparens, aber keineswegs bloß aus diesem Grunde, sogleich abgelehnt [...]. Brief Dümmlers an Bötticher vom 20.04.1892, München, Archiv der MGH, 338/195 (PA Wilhelm Gundlach).

167 Heldenlieder der deutschen Kaiserzeit 1-3, hg. v. Wilhelm Gundlach (Innsbruck 1894-1899). Hier hatte Gundlach bereits 1896 im Vorwort zum 2. Band wesentliche Punkte seiner Angriffsschrift - die Vernachlässigung der Scriptores rerum germanicarum in usum scholarum durch die Leitung der MGH und die Verwendung der lateinischen Sprache in den Einleitungen und Erläuterungen zu den Editionen, zum Großteil in wortwörtlicher Übereinstimmung, unter Anführung derselben Beispiele und Zitate sowie der gleichen polemisierenden Ausdrucksweise - vorgebracht, vgl. Heldenlieder 2 V-XIII. In einem Excurs „Über Stilvergleichung als Mittel des historischen Beweisverfahrens“ 757-780 im selben Band sowie in den „Verbesserungen und Nächträgen“ zum dritten Band der „deutschen Heldenlieder“, Heldenlieder 3 1052-1061, nahm er in ausführlichster Form zur Kritik Holder-Eggers an seiner wissenschaftlichen Argumentation, die ebenfalls in den wesentlichen Punkten im Artikel in den „Grenzboten“ wiederholt wird, vorweg. In diesem Zusammenhang findet sich auch bereits die Kritik an der Position des Vorsitzenden der Zentraldirektion gegenüber seinen Abteilungsleitern, die Gundlach letztlich dazu bewogen haben dürfte, für die Abschaffung dieses Amtes zu plädieren.

168 Zum Beweis der „Machtlosigkeit“ des Vorsitzenden gegenüber den Abteilungsleitern führte er die - in seinen Augen - verbalen Entgleisungen Holder-Eggers in seinen Rezensionen an, in denen dieser abwertende Ausdrücke wie „ridiculus/lächerlich“, ,,ineptus/läppisch“, „puerilia/kindisch/Kindereien“ und ,ineptia/Albernheit" verwendete, denen der Vorsitzende, selbst wenn er gewollt hätte, nicht Einhalt gebieten konnte, vgl. Gundlach, Monumenta (wie Anm. 164) 2, nur mit den ins Deutsche übersetzten Begriffen; davor bereits in Heldenlieder 2 (wie Anm. 167) 779f. - hier gibt er die tatsächlich in den lateinischen Vorreden verwendeten lateinischen Ausdrücke wieder. 
eine Aufbesserung der Gehälter der Mitarbeiter ermöglichen würde, forderte er die konsequente Verwendung der deutschen Sprache für Vorbemerkungen und Erläuterungen zu allen MGH-Editionen sowie hinsichtlich des Editionsprogrammes den Verzicht auf die Herausgabe von Quellen zur Papstgeschichte, italienischen Geschichtsquellen über das Ende des I 2. Jahrhunderts hinaus und Auszügen aus ausländischen Geschichtswerken ${ }^{169}$. Gundlach hatte mit seiner Kritik durchaus Punkte angesprochen, die auch in der Vergangenheit schon diskutiert worden waren, jedoch war die Form, in der sie vorgebracht wurde, polemisch, besonders was die persönlichen Angriffe betraf.

Holder-Egger hatte, abgesehen von in äußerst pointierter Form bereits I 889 und I 894 vorgebrachter Kritik an der Arbeitsweise und den Ergebnissen Gundlachs ${ }^{170}$, in seiner Besprechung des 2. Bandes der „Heldenlieder"171 die Angriffe Gundlachs nicht nur aufs Schärfste zurückgewiesen, sondern sparte darin seinerseits nun nicht mit beleidigenden Formulierungen und herabsetzenden Ausdrücken ${ }^{172}$. Auf die Entgegnungen und in derselben Tonart weitergeführte neuerliche heftige Angriffe Gundlachs in den „Verbesserungen und Berichtigungen“ zum 3. Band der „Heldenlieder“173 reagierte man seitens der MGH in einer Rezension dieses Bandes ${ }^{174}$ nur mehr mit dem Nachsatz: „Sehr bedauerlich ist, dass G. dem Bande Nachträge und Berichtigungen beigegeben hat mit persönlichen Angriffen gegen hochgeachtete Gelehrte, die sehr nachdrücklich als durchaus unangemessen bezeichnet werden müssen, und durch die der Vf. [...] nur sich selbst schadet." Und auch nach dem Erscheinen des Artikels in den „Grenzboten“ hatte man im Neuen Archiv die „hämischen und tückischen Angriffe“ gegen Dümmler und seine eigene

169, „...] wenn nicht beizeiten dem Eifer Holder-Eggers [...] ein Zügel angelegt wird, so werden [...] die Monumenta auch im zwanzigsten Jahrhundert noch nicht zum Abschluß gelangen [...]“, GundeaCH, Monumenta (wie Anm. 164) 8.

170 Carmen de bello saxonico, hg. v. Oswald Holder-Egger (MGH Scriptores rerum germanicarum in usum scholarum [17], Hannover 1889, etwa in der Vorrede VIII Anm. 4 und in einigen Anmerkungen, z.B. 24 Anm. b, 26 Anm. b und d), sowie DERs., Studien zu Lambert von Hersfeld II, in: NA 19 (1894) 369-430, hier bes. $404 \mathrm{f}$.

171 NA 21 (1896) 774-777.

172 „Ich würde mich zu tief erniedrigen, wenn ich auf die groben Beleidigungen meiner Person, auf die Verdrehungen und falschen Unterstellungen antwortete, von denen dieses Pasquill strotzt. Ich kann das Urtheil über einen Mann, der den Versuch macht, meine wissenschaftliche Gewissenhaftigkeit anzuzweifeln, den Fachgenossen überlassen und kann darauf verzichten, den Strafrichter gegen ihn anzurufen“, NA 21 (1896) $775 f$. „Sieht man von der unwiderstehlichen Komik der Selbstüberhebung des Schreibers dieser Äußerungen ab [...]“ (ebd. 776), oder „Nach dieser Bemerkung wird man es begreiflich finden, dass ich es unterlasse, mich mit Auslassungen dieser Persönlichkeit weiter zu beschäftigen, deren weitere Verdrehungen aufzudecken oder gar solche jämmerlichen Insinuationen zurückzuweisen, wie [...]“ (ebd. 777).

173 Heldenlieder 3 (wie Anm. 167) 1052-1061. Auch hier finden sich Ausführungen, von denen ganze Passagen mehr oder minder unverändert in den „Grenzboten“-Artikel übernommen wurden.

174 NA 25 (1900) 222f., hier 223. 
Person nicht wert befunden, „von neuem darauf einzugehen, um so weniger, als auch ein mit diesen Verhältnissen gar nicht vertrauter Leser den Ausfällen anmerken muss, dass sie durch Rachsucht eingegeben sind“"175.

Die im Grunde leicht zu durchschauenden und zum Großteil auf Nebensächlichkeiten beruhenden Angriffe Gundlachs kamen für die MGH jedoch zu einem überaus ungünstigen Zeitpunkt. Nach mehreren kurz aufeinanderfolgenden Todesfällen in ihren Reihen - zunächst Wattenbach, etwas später Scheffer-Boichorst und Dümmler - und wegen des immer wieder stockenden Fortschreitens der Arbeiten und der ständigen Erweiterungen der Editionsvorhaben wurden seitens des RMI prinzipielle Überlegungen zum Fortbestand der MGH angestellt ${ }^{176}$, wobei die unverhohlenen und ohne Bedacht- und Rücksichtnahme vorgebrachten Angriffe Gundlachs, der dem Anschein nach bereit war, bis zum Äußersten zu gehen, sehr gelegen kamen. Wohl aus diesem Grund entschloss man sich bei den MGH zu einer ausführlicheren Stellungnahme zum Artikel in den „Grenzboten“, ebenfalls in einem breitenwirksamen Medium, die die wahren Motive Gundlachs und die Haltlosigkeit und Unsinnigkeit seiner Kritik offenbaren sollte.

Die Beantwortung der Frage, warum gerade der sonst so zurückhaltende Tangl es auf sich nahm, diese Replik zu verfassen, dürfte wohl in seiner persönlichen Verbundenheit mit Holder-Egger zu suchen sein. Seine Entgegnung erschien am 4. April I 903 in der Münchener „Allgemeinen Zeitung“ unter dem Titel „Wilhelm Gundlach und sein Angriff auf die Monumenta Germaniae historica"177. Mit Verve vertrat er die Aufnahme von Quellen zur Papstgeschichte: „die universale Stellung des alten Kaisertums, seine engen Wechselbeziehungen zum Papsttum, der Kampf der beiden höchsten Gewalten der mittelalterlichen Welt“ hätten zur Folge, „daß Papstgeschichte von Reichsgeschichte nicht zu trennen ist“. Im Gegenteil beklagte Tangl dabei die noch immer nicht erfolgte Herausgabe des „Registrum super negotio Romani imperii“: „Nicht bereits zu viel, sondern noch viel zu wenig ist auf diesem Gebiete bisher geschehen." Ebenso verteidigte er sachlich überzeugend die Berücksichtigung italienischer Quellenwerke zumindest bis zum Ende der Staufer ${ }^{178}$. Besonders scharf wandte sich Tangl dabei gegen die Angriffe Gundlachs auf

175 NA 28 (1903) 563f.

176 Vgl. dazu Schaller, Tangl (wie Anm. 1) 146-173, die das entsprechende Kapitel ihrer Arbeit mit dem Titel „Die Krise der Monumenta“versieht.

177 TANGL, Gundlach (wie Anm. 166).

178 Interessant ist in diesem Zusammenhang die betont deutsch-nationale Haltung Gundlachs, die in dessen Argumentation zum Ausdruck kommt, die er auf seine Auffassung des mittelalterlichen römisch-deutschen Reiches übertrug: „[...] daß es in jener Zeit eine zwar äußerlich lateinische, aber innerlich echt deutsche Geschichtsschreibung gibt, so reich und glänzend, wie sie kein andres Volk für diese Zeit aufweisen kann“, Gundlach, Monumenta (wie Anm. 164) 6, oder: „[...] sollte man nur die verrotteten Zustände der römischen Republik einer solchen Betrachtung für wert halten, nicht aber die Verhältnisse einer glänzenden Periode unsrer eignen Geschichte, ,in der der Wille, das Wort und das Schwert der dem deutschen Volk 
Holder-Egger, und stellte fest, dass sich der Artikel Gundlachs in diesem Zusammenhang als „unehrenhafte Schmähschrift“ selbst entlarvt habe.

Obwohl Tangl Gundlach in der Frage der Berücksichtigung mittelalterlicher Geschichtsschreiber im Unterricht beipflichtete, so verteidigte er doch die bisher in dieser Hinsicht geleistete Arbeit der MGH. Über die Frage der lateinischen Vorbemerkungen, die „für Wert und Verbreitung der Ausgaben höchst nebensächlich" seien, mit wenigen Worten hinweggehend, widmete er auch der sozialen Stellung der MGHMitarbeiter unter Hinweis auf deren stark angestiegene Zahl und die doch immerhin kontinuierlich steigenden Gehälter nur wenig Raum und Worte ${ }^{179}$. Dagegen

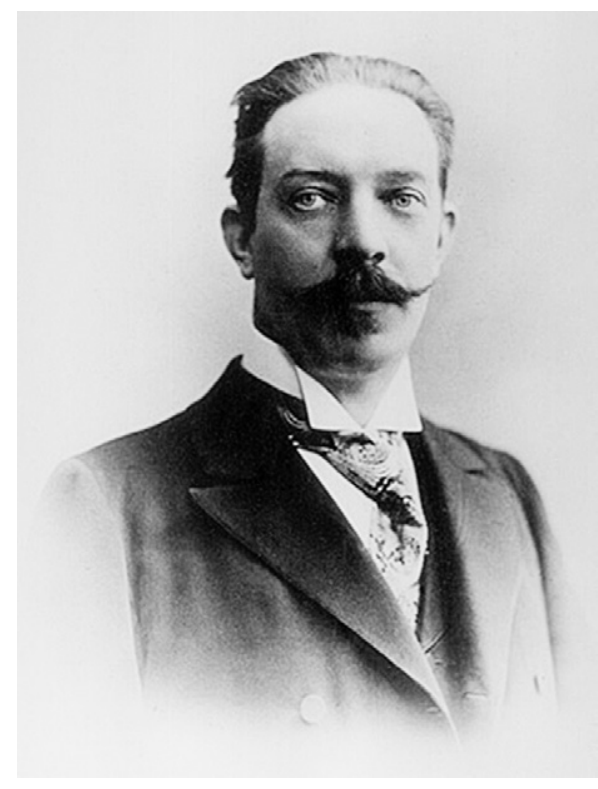
Abb. 2: Michael Tangl lehnte er etwas weiter ausholend den ,verblüffenden“ und „unzutreffenden“ Vorschlag Gundlachs, den Vorsitz der MGH unter den Mitgliedern der Zentraldirektion rotieren zu lassen, wegen der heterogenen Zusammensetzung der Zentraldirektion aus Delegierten der Akademien, Reichsbeamten und kooptierten Mitgliedern als undurchführbar ab. Er schloss mit den Worten: „Damit nehme ich von Gundlach Abschied. Sein Angriff ist ein in den Beweggründen unlauterer, in der Beweisführung vom Anfang bis zum Ende mißlungener Rachakt wider den toten Dümmler und den lebenden Holder-Egger."

Es fällt auf, dass Tangl, anstatt in der „Krise der Monumenta“ die Gelegenheit zur Veröffentlichung einer fundierten programmatischen Verteidigungsschrift des Unternehmens zu ergreifen, offenbar die Widerlegung der einzelnen - auch in seinen Augen ganz

entstammenden Kaiser die Geschichte des Abendlandes entschieden“?“ (ebd.), sowie wenn er von der „[...] schon in Friedrich dem Zweiten vollendeten Entdeutschung“ des staufischen Hauses (ebd. 8) spricht. Die Argumentation Tangls scheint eher einer moderneren, nicht engen nationalen Kategorien verhafteten Geschichtsauffassung zu entsprechen.

179 Dass die Gehälter der MGH-Mitarbeiter aber entgegen dieser Beschwichtigungen Tangls äußerst niedrig waren und eine Mitarbeit bei den MGH nur jenen möglich war, die auf privates Vermögen zurückgreifen konnten, zeigt die Tatsache, dass im selben Jahr, 1903, sechs MGH-Mitarbeiter in schriftlicher Form eine dringende Bitte an die Zentraldirektion richteten, die Gehälter zu erhöhen; vgl. dazu Funrmann, „Sind eben alles Menschen gewesen“ (wie Anm. 47) 79 und $156 f$. 
nebensächlichen - Kritikpunkte Gundlachs als beste Strategie erachtete. Allerdings hatte er sich selbst mit seiner Entgegnung, die es durchaus nicht an Schärfe fehlen ließ, nun zur Zielscheibe Gundlachs gemacht, der wegen „öffentlicher Beleidigung“ Klage gegen ihn erhob. Nachdem die Gerichtsverhandlung zunächst verzögert und schließlich nicht mehr weiter verfolgt wurde, verfasste Gundlach einen neuerlichen, nun hauptsächlich gegen die Person Tangls, aber auch gegen den zuständigen Referenten im RMI Friedrich Althoff, gerichteten Artikel in der „Frankfurter Zeitung“ vom 25. Oktober 1906 ${ }^{180}$. Über die darin geäußerten persönlichen Angriffe auf Tangl ging der permanente Ausschuss der Zentraldirektion der MGH im Neuen Archiv ${ }^{181}$ nur mehr kurz hinweg. Aber auch das RMI und Althoff ${ }^{182}$, der noch im Juni 1903 den von Gundlach geschilderten Vorwurf der „aus dem Mangel einer strafferen Organisation unter einheitlicher Leitung folgenden Übelstände"183 auch nach Tangls Entgegnung nicht widerlegt sah, maßen der Kritik Gundlachs nun keine Bedeutung mehr bei. I903/04 holte es von zehn nahmhaften Historikern, darunter Paul Kehr, Georg von Below, Hermann Grauert, Max Lehmann, Ottokar Lorenz und Dietrich Schäfer, Gutachten über die Zukunft der MGH ein, zu denen Reinhold Koser seitens der MGH eine Stellungnahme verfasste ${ }^{184}$. Das Ergebnis der gesamten, sich über mehrere Jahre ziehenden Angelegenheit dürfte ganz im Sinne der MGH gewesen sein: Die Neuorganisation der MGH wurde vertagt und mit der Bestellung Reinhold Kosers, der als Generaldirektor der Preußischen Staatsarchive die MGH in Personalunion ab I905 kommissarisch und ab April I 906 endgültig als neuer Vorsitzender leitete, eine „Übernahme“ der MGH durch Paul Kehr zunächst erfolgreich verhindert ${ }^{185}$.

180 Wilhelm Gundlach, Das preussische Kultusministerium Althoff und die Monumenta Germaniae historica, in: Frankfurter Zeitung Nr. 295 (25.10.1906) 1-3.

181 NA 32 (1907) 507f.: „Die neuen Expektorationen [...] wiederholen fast nur schon früher von ihm gesagtes und aus unserem Kreise bereits mehrfach abgewiesenes." Ein Dementi erfolgte lediglich zu den Anschuldigungen der wissenschaftlichen Voraussetzungslosigkeit der Berufung Tangls nach Berlin sowie zur Behauptung Gundlachs, seine Kritik habe die 1905 neu geregelte Geschäftsführung innerhalb der Zentraldirektion beeinflusst.

$182 \mathrm{Zu}$ Althoff vgl. Wissenschaftsgeschichte und Wissenschaftspolitik im Industriezeitalter. Das „System Althoff“ in historischer Perspektive, hg. v. Bernhard vom Brocke (Geschichte von Bildung und Wissenschaft Reihe B/5, Hildesheim 1991).

183 BAB, R 1501, Nr. 1599, Althoff an den Reichskanzler, 25.06.1903, zitiert nach Schaller, Tangl (wie Anm. 1) 157 Anm. 657.

184 In den meisten wesentlichen Punkten waren sich alle Gutachter einig. So sprachen sie sich etwa (nur mit Ausnahme Kehrs) für die Beibehaltung der Gliederung in weitgehend autonome Abteilungen innerhalb der MGH, für eine stärkere Förderung der Ausbildung des wissenschaftlichen Nachwuchses in den historischen Hilfswissenschaften sowie (mit Ausnahme Belows) prinzipiell für eine zeitliche Befristung des Unternehmens aus, wenn auch die Meinungen im Detail mitunter erheblich divergierten.

185 Noch in seinen „Forschungen zu Karolinger Diplomen“ (wie Anm.141) kritisierte Tangl wissenschaftliche 
Persönliche Beziehungen bestimmten auch in anderen Bereichen Tangls Stellung in der wissenschaftlichen Welt seiner Zeit. Sein Hervorgehen aus dem von Sickel geleiteten IÖG stellte ihn in wissenschaftliche und persönliche Zusammenhänge, von denen sich Tangl erst nach und nach emanzipieren konnte. Sein Verhältnis zu Sickel, soweit es aus Briefen ablesbar ist, ist stets von verehrungsvoller Hochachtung gekennzeichnet, lässt aber trotzdem eine gewisse persönliche Distanz erkennen. Besonders deutlich wird dies, wenn man Tangls Briefe an seinen Lehrer Engelbert Mühlbacher zum Vergleich heranzieht. Eine Passage wie die folgende wäre in einem Brief an Sickel undenkbar: Sonst zählt zu den gemeinsamen Arbeiten auch das Erscheinen bei den allfreitäglichen Empfangsabenden des Herrn Hofraths, die an Buntscheckigkeit des Publikums schon gar nichts zu wünschen übrig lassen, oft aber recht belebt und jedenfalls ungleich hübscher sind als die bei Petersen auf dem Capitol, wo die öde Art der gewissen ästhetischen deutschen Jungfrauen noch viel zahlreicher vertreten ist; ein geradezu abschreckendes Beispiel letzterer Sorte ist Frl. Schottmüller ${ }^{186}$. Tangls größere persönliche Nähe zu Mühlbacher wird auch in seinen Äußerungen über den Konflikt zwischen Mühlbacher und Sickel sichtbar ${ }^{187}$. In einem Brief an Emil von Ottenthal über Sickels kürzlich erfolgtes Ableben erwähnt er ausdrücklich Sickels Hass auf Mühlbacher und geht näher auf die Schwierigkeiten ein, die ihm dieser Sachverhalt bei der Abfassung des Nachrufes bereitete ${ }^{188}$. Möglicherweise hatten sich diese Spannungen auch hemmend auf Tangls Karriere ausgewirkt, indem ihm für die Nachfolge Mühlbachers in Wien auf

Äußerungen Gundlachs zu Datierung und Echtheit einiger Urkunden Heinrichs IV. (hier besonders 233250), jedoch nicht ohne auch dessen zutreffenden Beobachtungen zuzustimmen.

186 Wien, IÖG, NL Mühlbacher, 09.03.1889, Brief an Mühlbacher. Die genannten Personen sind Adolf Hermann Eugen Petersen (1836-1919), 1887-1905 Leiter des Deutschen Archäologischen Instituts in Rom (NDB 20, 254f.), und Conrad Schottmüller (1841-1894), als „Dirigierender Sekretär der Historischen Station in Rom “ 1888-1890 erster Leiter des Preußischen Historischen Instituts, siehe Reinhard Elze, Das Deutsche Historische Institut in Rom 1888-1988, in: Das Deutsche Historische Institut in Rom 18881988, hg. v. Reinhard Edems., Arnold Esch (Bibliothek des Deutschen Historischen Instituts in Rom 70, Tübingen 1990) 1-31, hier 5f. Vgl. auch IÖG, NL Mühlbacher, Brief vom 05.04.1889: Um aber doch auch was Heiteres zu bringen: das Frl. Schottmüller erzählte mir unlängst: „Der Papa steht morgens um 6 Uhr auf, dann frühstückt er, und dann diktiert er durch zwei Stunden der Mama. “- „da kommt aber auch was heraus", fügte sie stolz hinzu!

187 Zum schwierigen Verhältnis Mühlbacher-Sickel vgl. Walther Holtzmann, La corrispondenza fra Theodor von Sickel ed Oreste Tommasini, in: Archivio della Società romana di Storia patria 79 ser. III 10 (1956) 89143, hier 109 Nr. 25 (Tommasini an Sickel, 17.08.1892); Leo Santifaller, Briefe von Wilhelm Fraknói an Theodor von Sickel aus den Jahren 1877 bis 1906, in: Römische Historische Mitteilungen 6/7 (1964) 191-351, hier 226 Nr. 34 (21.06.1892) und 287 Nr. 102 (02.05.1903); Lнотsку, Geschichte des Instituts (wie Anm. 5) 202f.; Sickel, Römische Erinnerungen (wie Anm. 68) 50 (Mühlbacher wird von Sickel als „Gegner" bezeichnet); Fichtenau (wie Anm.13) 19 und 33.

188 Wien, IÖG, NL Ottenthal, 04.07.1908, Brief an Ottenthal; siehe Anhang. Vgl. auch die Andeutungen in: Theodor von Sickel. Ein Nachruf von M. TANGL, in: NA 33 (1908) 773-781, besonders 778 und 780. 
Betreiben Sickels Ottenthal vorgezogen wurde. Dies mag Tangls innere Distanz zu seinem Lehrer vergrößert haben.

Das von Tangl gemeinsam mit Harry Bresslau und Karl Brandi gegründete „Archiv für Urkundenforschung“, dessen erster Band I908 erschien, sollte „eine Vereinigungsstelle sein für solche gelehrten Untersuchungen, die den Umfang von Zeitschriftenaufsätzen überschreiten, insbesondere für alle allgemeinen und systematischen Arbeiten auf dem Gebiet der Urkundenwissenschaft im weiteren Sinne“189. Ziel war es, einer gegenüber der Sickel'schen diplomatischen Schule erweiterten „neuen Diplomatik“ Stimme zu verleihen. Diese sollte nicht auf die Untersuchung streng diplomatischer Fragen wie Fälschungskritik, Schrift- und Diktatvergleich sowie kanzleigeschichtliche Gesichtspunkte beschränkt bleiben, sondern als erweiterte - vergleichende und angewandte - Diplomatik auch behördenorganisatorische, verfassungs-, wirtschafts- und sozialgeschichtliche Aspekte einbeziehen und zudem die „Bedingtheiten“ und damit die „historische Verwendbarkeit der urkundlichen Quellen“190 untersuchen - Gesichtspunkte, deren Berücksichtigung auch heute noch den großen Reiz, aber auch die große Herausforderung für Urkundeneditoren darstellt. Außerdem wurde die programmatische Ausdehnung der diplomatischen Studien nicht nur hinsichtlich der zu berücksichtigenden Quellengattungen auf andere nicht erzählende Quellen - wie etwa Konzepte und Briefe, ja sogar Urbare, Stadtbücher und Stilübungen -, sondern sowohl auf die antiken Voraussetzungen des europäischen Urkundenwesens als auch auf dessen Weiterentwicklung zum neuzeitlichen Aktenwesen gefordert. Obwohl das Archiv für Urkundenforschung auch Editionen offenstand, war von den Herausgebern ausdrücklich beabsichtigt, dass „die Untersuchung und Verarbeitung stets den Vortritt haben soll vor der Edition“191. Die Förderung der „allgemeine[n] Geschichte als Wissenschaft“ war den Herausgebern wichtiger, wie betont wurde, als die Schaffung „neuer Spezialitäten“" ${ }^{192}$.

Auf die Motive, die Bresslau, Brandi und Tangl zur Gründung der neuen Zeitschrift veranlassten ${ }^{193}$ und die Missverständnisse und Kritik hervorrufenden - wohl zumindest

189 Vgl. das programmatische Geleitwort der Herausgeber: Einführung, in: AUF 1 (1908) 1-4, die hier zitierte Stelle ebd. 1.

190 Ebd. 2.

191 Ebd. 3.

192 Ebd. 4.

193 Bresslau war bei der Bestellung des Vorsitzenden der Zentraldirektion der MGH 1903 nach dem Tod Dümmlers kalt übergangen worden. Bei Brandi dürften die gescheiterten Bemühungen Kehrs, zunächst in Göttingen und dann in Berlin ein großes hilfswissenschaftliches Institut, an dem Projekte der MGH, eine Archivschule sowie eine Fortbildungsstätte von Nachwuchshistorikern verankert sein sollten, zu schaffen, Enttäuschung bewirkt haben; vgl. dazu Schaller, Tangl (wie Anm. 1) 215-223, und Fichtenau, Diplomatiker (wie Anm. 13) 44: Die Gründung des Archivs für Urkundenforschung „war, vom Persönlichen her gesehen, ein Abgesang auf große Pläne Kehrs und diejenigen zweier der Herausgeber, Tangl und Bresslau“. Sie hatte, wie Fichtenau feststellte, „mehrere Väter: jene, die auf dem Titelblatt stammen, und dazu Paul 
unterschwellig von diesen Motiven mitbestimmten - Formulierungen im Programm des „Archivs“, die zu einem erbitterten Schlagabtausch zwischen den Vertretern der „Wiener Schule“ und den Herausgebern führte, soll hier nicht näher eingegangen werden. Im Fall Tangls war die Verstimmung über seine verhinderte Rückkehr nach Wien und die darauffolgende wachsende Distanz zwischen ihm und dem Wiener IÖG mit hoher Wahrscheinlichkeit mit ausschlaggebend für die Gründung der neuen Zeitschrift. Doch auch die empfindliche Kritik an den Intentionen der Herausgeber seitens Vertretern des Wiener Instituts, allen voran Karl Uhlirzs, scheint heute - wenn man die ihr zugrunde liegenden persönlichen Differenzen, die zwar als Erklärung, nicht aber als Rechtfertigung dienen, beiseite lässt - überzogen ${ }^{194}$. Die zentralen Angelpunkte der Auseinandersetzung, Brandi, Bresslau und Tangl hätten Sickel und seiner Schule vorgeworfen, beim Discrimen veri ac falsi stehen geblieben zu sein, und würden nun einen künstlichen Gegensatz zwischen der „alten“ Diplomatik der Sickel'schen Schule und einer mit dem „Archiv für Urkundenforschung“ zu begründenden „neuen“ Diplomatik zu konstruieren beabsichtigen, sind in der unterstellten polemischen Pointiertheit im Geleitwort zum ersten Band nicht formuliert worden ${ }^{195}$. Brandi, der gleich im zweiten Band die Kritik mit dem Bedauern, dass die kurzgefassten Ausführungen im programmatischen Geleitwort offensichtlich zu Missverständnissen geführt hätten, aufgriff, verwahrte sich daher auch dezidiert in seiner Entgegnung gegen eine entsprechende Interpretation des Programms der neuen Zeitschrift ${ }^{196}$. Er betonte dabei - nun unmissverständlicher - dass es Ziel des „Archivs“ sei, einer - im übrigen bereits von Sickel selbst geforderten - Erweiterung der Diplomatik eine Plattform zu bieten ${ }^{197}$.

Kehr“, der mit seinen eben erwähnten Plänen große Proteste ausgelöst hatte, denen er sich entzog, indem er 1902 als Direktor des Preußischen Historischen Instituts nach Rom ging.

194 Vgl. die entsprechende Notiz von Oswald Redlich, in: MIÖG 28 (1907) 711f., Karl Uhlirz, Ein „Archiv für Urkundenforschung“, in: Deutsche Literaturzeitung 29 (1908) 1349-1353; eine eingehendere Auseinandersetzung mit den Vorwürfen der Kritiker bei Schalle r, Tangl (wie Anm. 1) 221-223. Lнотsкy, Geschichte des Instituts (wie Anm. 5) 315, weist darauf hin, dass, obwohl die „Wiener Schule unter dem Einfluß Innsbrucks“ für die Weiterentwicklung der Sickel'schen Diplomatik Großes geleistet habe, der seit 1903 als Direktor des IÖG amtierende Ottenthal „Abweichungen von der geheiligten Sickel-Tradition“, an der er glaubte, starr festhalten zu müssen, strikt ablehnte. Somit war die mit der Gründung des „Archivs für Urkundenforschung “ beabsichtigte Erneuerung und Erweiterung der Urkundenforschung nicht als Provokation, sondern als zum damaligen Zeitpunkt durchaus berechtigte Forderung zu verstehen.

195 Die entsprechende Formulierung, die wohl in erster Linie zum Stein des Anstoßes wurde, lautet im Geleitwort folgendermaßen : „Aber indem wir an die Arbeiten Sickels und seiner Generation überall anknüpfen, wollen wir über die Frage des Discrimen veri ac falsi in vetustis membranis vordringen zu einer möglichst genauen Erkenntnis der Bedingtheiten und damit der historischen Verwendbarkeit unserer urkundlichen Quellen“, Einführung, in: AUF 1 (wie Anm. 189) 2.

196 Karl Brandi, Urkundenforschung, in: AUF 2 (1909) 155-166.

197 So resümiert auch Fichtenau, Diplomatiker (wie Anm. 13) 45, der sich zwar im Wesentlichen der Kri- 
In Fragen des politischen Tagesgeschehens und der Weltanschauung übte Tangl Zurückhaltung ${ }^{198}$ und schätzte solche auch bei anderen ${ }^{199}$. Allerdings war er keineswegs unpolitisch. Teils lassen sich gewisse Tendenzen durch das persönliche Umfeld und die Vorgangsweise Tangls in bestimmten Situationen erkennen, teils bezog er, wohl unter dem Eindruck der innenpolitischen Situation seiner Heimat, vor allem in der Nationalitätenfrage eindeutig und engagiert Stellung.

In einer Zeit, in der antisemitische Strömungen in allen Bereichen Fuß fassten und jemand, der seine antisemitische Gesinnung offen zum Ausdruck brachte, zunehmend mit breiter Zustimmung rechnen durfte, scheint Tangl an den auch an den Universitäten immer häufiger zu beobachtenden Versuchen, Juden auszugrenzen, nicht beteiligt gewesen zu sein. Mit jüdischen Kollegen, allen voran Bresslau, mit dem gemeinsam er das „Archiv für Urkundenforschung“ begründete und dem er als Gelehrten und Menschen große

tik der Vertreter der Wiener Schule anschließt: „Die neue Zeitschrift hat frischen Wind in die Gefilde der Diplomatik gebracht, ohne diese völlig zu verändern." Bereits vorher hatte er selbst festgestellt, dass mit der Nachfolge Ottenthals sowohl auf die Lehrkanzel Mühlbachers als auch in der Direktion des IÖG eine 22 Jahre andauernde „Zeit innerer und äußerer Stagnation“ (ebd. 41) angebrochen war. In Anbetracht dieser im Übrigen auf persönliche Erfahrungen Lhotskys - beruhenden Einschätzung wird man den Herausgebern des „Archivs“ konzedieren können, dass doch - abgesehen von den persönlichen Motiven - auch eine gewisse äußere Veranlassung bestand, den Hilfswissenschaften neue Impulse zu verleihen.

198 Georgine Tangl beschrieb die Haltung des Vaters wie folgt: „Überdies hat er sich auch in mancher Hinsicht mit vollem Bewußtsein Zurückhaltung auferlegt, so vor allem in der Politik. Von Haus aus in den öffentlichen Verhältnissen Österreichs vorzüglich beschlagen und für die Fehler des deutschen politischen Lebens sehr scharfsichtig, trat er dennoch politisch in keiner Weise hervor und vermied es, zu Tagesfragen öffentlich Stellung zu nehmen." (Vgl. Tangl, Tangl [wie Anm. 4] 11). Auch bei Oвer kofler, Einfluß (wie Anm. 9) 235, steht die politische Zurückhaltung Tangls im Vordergrund: „[...] Tangl, der sich im Berliner Kreis von politischen Erörterungen zurückhielt [...] wollte, das ist ganz deutlich, in Berlin Verständnis für das untergegangene alte Österreich wecken. Er hat deshalb den Nationalismus, der unter den bürgerlichen Historikern seiner Zeit verbreitet war, nicht unterstützt. “ Ähnlich auch Tangls Schüler Heinrich Sproemberg, Zum Geleit, in: TANGL, Mittelalter 1 7f., hier 8: „Die Jung-Rankianer und auch die Nationalisten hatten eine beherrschende Stellung eingenommen; die Folgen haben sich in schmerzlicher Weise beim Ausbruch des ersten Weltkrieges gezeigt. Kein geringerer als Gerhard Ritter hat durch seinen Schüler und auch selbst den Nachweis des völligen Versagens der Berliner Historiker und ihrer politischen Blindheit geführt. Michael Tangl hat sich, wie auch seine Tochter betont, von derartigen Bestrebungen ferngehalten - und man hat ihn das auch fühlen lassen."

199 So irritierte Tangl im Rahmen des Berufungsverfahrens für die Nachfolge Scheffer-Boichorst an der Persönlichkeit Dietrich Schäfers dessen politischer Aktivismus: Jens P. AскеR mann, Die Geburt des modernen Propagandakrieges im Ersten Weltkrieg. Dietrich Schäfer, Gelehrter und Politiker (Europäische Hochschulschriften III/987, Frankfurt/Main/Berlin/Bern u.a. 2004) 132f. 
Hochachtung entgegenbrachte ${ }^{200}$, pflegte er genauso Kontakt wie mit nichtjüdischen. Auch mit Bertold Bretholz, der mit ihm den Ausbildungslehrgang am IÖG absolviert hatte, verband ihn ein, wenn auch lockeres, so doch offenbar recht freundschaftliches Verhältnis. Umso mehr verwundert es, dass Bretholz I9 9 einen angeblichen Hinweis Tangls auf seine jüdische Herkunft für das Scheitern seiner Berufung auf den außerordentlichen Lehrstuhl für Osteuropäische Geschichte an der Berliner Friedrich-Wilhelms-Universität verantwortlich machte ${ }^{201}$. Bretholz, der I 889 zum evangelischen Glauben übergetreten war und seit 1900 als mährischer Landesarchivar tätig war, hatte mit seiner „Kontinuitätstheorie“, nach der ein großer Teil der deutschsprachigen Bevölkerung Böhmens und Mährens nicht erst im Zuge der mittelalterlichen Ostkolonisation, sondern bereits vor der slawischen Einwanderung dort angesiedelt war, geteilte Reaktionen hervorgerufen ${ }^{202}$. Für die Nachbesetzung des Osteuropa-Lehrstuhles nach Theodor Schiemann hatte sich die auch Tangl angehörende Kommission gegen den Wunschkandidaten des Kultusministeriums, den hauptsächlich publizistisch tätigen Otto Hoetzsch, ausgesprochen und eine von Tangl angeführte Gruppe von Kommissionsmitgliedern mehrere Anträge zuguns-

200 Im Zusammenhang mit den Versäumnissen Tangls bei der Leitung der MGH während des Ersten Weltkrieges, durch die Bresslau beunruhigt war und hinter den für ihn nachteiligen Folgen er möglicherweise sogar eine Absicht Tangls erwog, versicherteTangl ihn seiner Unterstützung: Ich habe Sie im Gegenteil stets warm verehrt und bin bei jeder Gelegenheit für Sie eingetreten. Ich halte es auch jetzt für eine Ehrenpflicht, daß man Sie nach all den furchtbaren Heimsuchungen, die Sie mitmachen mußten, durch den Vorsitz in der Zentraldirektion entschädigt. Tangl an Bresslau vom 16.01.1919 (München, Archiv der MGH, B 40); zu den Vorgängen, die dazu führten, dass später trotzdem Kehr anstelle Bresslaus der neue Vorsitzenden der Zentraldirektion wurde, vgl. Schalle R, Tangl (wie Anm. 1) 271-274.

201 Vgl. Brünn, MZA, G 37, Karton 1, Nr. 14, Folio 9: Dass meine fast schon feststehende Ernennung an der Berliner Universität durch den Rückenstoss meines besten Freundes, Tangl, der das Professorenkolleg vor mir warnte, weil ich jüdischer Abstammung sei, und mir dadurch meine beste Stütze bei meiner Bewerbung, Prof. Dietrich Schäfer abspenstig machte, war ein furchtbarer Schlag für mich. Zitiert nach Zdeňka Sток LÁs коvÁ, „Stets ein guter und zuverlässiger Deutschmährer.“ Zur Laufbahn von Bertold Bretholz (1862-1936), in: Die „sudetendeutsche Geschichtsschreibung“ 1918-1960. Zur Vorgeschichte und Gründung der Historischen Kommission der Sudetenländer, hg. v. Stefan Al brecht, Jiři Malíř, Ralph Melville (Veröff. des Collegium Carolinum 114, München 2008) 25-41, hier 33. Dieser Annahme widerspricht jedoch, dass nicht nur die Berufungskommission, der Tangl angehörte, am 07.07.1919 eine einstimmige Empfehlung für Bretholz beschloss, und auch die Fakultät sich einstimmig für die Berufung Bretholz' aussprach, sondern auch dass das Protokoll der Kommissionssitzung sowie das Schreiben an das Ministerium von Tangl selbst konzipiert worden ist (Berlin, Archiv der Humboldt-Universität, phil. Fak. Nr. 1468, fol. 124r-127v). Offenbar ging die Ablehnung auf das Ministerium für Wissenschaft, Kunst und Volksbildung zurück, während sich Tangl gerade besonders für Bretholz eingesetzt zu haben scheint. Auch die weitere Entwicklung der Dinge gibt keinen Hinweis auf ein Agieren Tangls, wie es Bretholz vermutete. Noch im Juni 1920 empfahl Ludo Moritz Hartmann Bretholz sich nochmals an Tangl zu wenden, damit dieser neuerlich einen Antrag zu seinen Gunsten einbringe, vgl. STокLÁs KovÁ 31-35.

202 Dazu Stoklás ková, Bretholz (wie Anm. 201) 26-30. 
ten Bretholz' eingebracht. Als nach einem durch die Nachkriegsereignisse in Ost- und Südosteuropa bedingten Stillstand in der Angelegenheit die Nachbesetzungsfrage wieder aufgenommen wurde, gehörte Bretholz - wohl wegen Widerstands gegen ihn aus dem Ministerium - nicht mehr zum Kreis der möglichen Kandidaten. Tangl befürwortete nun eine Berufung seines Schülers Richard Salomon - ebenfalls jüdischer Herkunft -, dem jedoch letztlich Karl Stählin vorgezogen wurde ${ }^{203}$.

Neben Salomon, der bis zu seiner Berufung nach Hamburg für Tangl im Rahmen der Redaktion des „Neuen Archivs“ tätig war, gehörten zwei weitere Juden, Erich Caspar und Tangls wichtigster Schüler Ernst Perels, zu Tangls engstem Mitarbeiterkreis. Auf Veranlassung von Herrn Professor Tangl ${ }^{204}$ wurde Perels bereits unmittelbar nach Abschluss seines Studiums I 904 als Mitarbeiter der Epistolae-Abteilung der MGH beschäftigt. 1923 als außerordentlicher, I93 I als ordentlicher Professor auf Tangls Lehrstuhl berufen, nahm Perels' Leben im nationalsozialistischen Terrorregime einen tragischen Verlauf. I935 zwangsemeritiert, jedoch bis 1944 noch für die MGH nebenamtlich tätig, wurde er wegen der Beteiligung seines Sohnes Friedrich Justus am Hitlerattentat vom 20. Juli I 944 ins Konzentrationslager Buchenwald gebracht und starb noch im Mai 1945 nach dessen Befreiung an Entkräftung ${ }^{205}$. Zu Perels, dem er nicht nur wissenschaftliche, sondern auch wichtige organisatorische Aufgaben übertrug, pflegte Tangl auch private Beziehungen. So gehörten beide einem Kreis von Wissenschaftlern an, die regelmäßig ,in dichten Zigarrendampf gehüllt zu gedeihlichem Gedankenaustausch“ zusammenkamen ${ }^{206}$. Nach Aussage seines Sohnes Otto hatte Perels in besonders engem Verhältnis zu Tangl gestanden, diesen sehr verehrt und war von Tangls plötzlichem Tod tief erschüttert ${ }^{207}$.

Ebensowenig wie antisemitische Stellungnahmen ${ }^{208}$ lassen sich bei Tangl extreme nationalistische Haltungen feststellen. Vermutlich vor dem Hintergrund des zunehmenden

203 Vgl. dazu die Darstellung bei Kolá ̌̌, Geschichtswissenschaft (wie Anm. 57) 492-499. Zu Salomons Schicksal während der nationalsozialistischen Zeit vgl. oben 39.

204 Oberling, Perels (wie Anm. 33) 82, zitiert nach einem Lebenslauf Perels' von 1911 in: Berlin, Geheimes Staatsarchiv, Preußischer Kulturbesitz, K, I, HA Rep. 76 Va, Sekt. 2 Titl IV, Nr. 51 Bd. XVIII, fol. 454 .

205 Zur Berufung Perels' als Nachfolger Tangls vgl. neben Ове ring, Perels (wie Anm. 33) 131-144, auch Gerhard Овек коғler, Die österreichische Schule der historischen Hilfswissenschaften im Urteil des deutschen Historikers Albert Brackmann, in: Tiroler Heimat 48/49 (1984/85) 207-215. Zu Perels vgl. auch SCHALLer, Tangl (wie Anm. 1) 333f., Fuhrmann, „Sind eben alles Menschen gewesen“ (wie Anm. 47) 102 mit Fotografie.

206 Vgl. Oberling, Perels (wie Anm. 33) 99.

207 Ebd. 131.

208 Unter den Arbeiten Tangls finden sich nur zwei kurze Aufsätze, die sich mit Fragen des Judentums befassen: TANGL, Judenschutzrecht (wie Anm. 141), und DERs., Gregor VII. jüdischer Herkunft? ebd. 31 (1906) 159-179, und in: Ders., Mittelalter 2 637-651. Während es sich bei der erstgenannten Arbeit um eine kurze Studie handelt, die ein aufgrund einer fehlerhaften Lesung tironischer Noten in den Formulae imperia- 
Nationalitätenstreites in der österreichisch-ungarischen Monarchie engagierte sich Tangl im Deutschen Schulverein ${ }^{209}$. Er war, wie viele seiner Kollegen, Mitglied des I 880 gegründeten Vereines, der sich zum Ziel gesetzt hatte, deutschsprachige Minderheiten im cisleithanischen Teil der österreich-ungarischen Monarchie vor allem durch den Bau von Schulen und die Unterstützung deutscher Bildungseinrichtungen zu schützen ${ }^{210}$. Die betont unpolitische Grundhaltung des Vereines, der als Mitglieder Personen aller politischen Lager, wie die Sozialdemokraten Engelbert Pernerstorfer und Viktor Adler, der Christlichsoziale Karl Lueger, aber zunächst auch Georg Ritter von Schönerer angehörten, kam Tangls eigener Haltung entgegen. Der Verein entwickelte sich bis zum Jahr I9I4 mit einem Mitgliederstand von etwa 200.000 Personen, darunter vor allem Angehörige des Bildungsbürgertums und viele Juden ${ }^{211}$, zu einem der größten Vereine in der österreichungarischen Monarchie. Nachdem Tangl nach Berlin gegangen war, schloss er sich dort

\footnotetext{
les bis dahin angenommenes spezielles Judenschutzrecht in der Karolingerzeit verneint, widerlegt Tangl in der zweitgenannten Arbeit die These Pietro Fedeles, der behauptet hatte, Gregor VII. sei mit der Familie der Pierleonis verwandt und daher jüdischer Abstammung gewesen (vgl. Pietro Fedele, Le famiglie di Anacleto II. e di Gelasio II., in: Archivio della R. Società Romana di storia patria 1904, XXVII, 399-344). Diese These, deren politische und historische Tragweite Fedele möglicherweise gar nicht bewusst war, wird von Tangl nüchtern-sachlich widerlegt („Die ganze Papstgeschichte der Zeit müsste umgeschrieben, die herrschende Meinung, dass das Eingreifen Heinrichs III. in Rom vom Jahre 1046 einen einschneidenden Personen- und Systemwechsel mit sich brachte, gänzlich aufgegeben werden [...] Jüdisches Convertitentum hätte es dann nicht bis zu einem Gegenpapst - Anaklet II. - gebracht, sondern der Kirche einen der größten Päpste aller Jahrhunderte - Gregor VII. - geschenkt" (vgl. hier 162f.). Mit deutlichen Worten spricht Tangl in diesem Zusammenhang über die antisemitische Haltung Bernhards von Clairvaux: „Mit voller Schärfe vertrat Bernhard von Clairvaux den Rassen-Antisemitismus; von dem gleichen Gedanken nahm die Schmähschrift Arnulfs gegen Anaklet ihren Ausgang; und diesen Verhetzungen gegenüber soll [...] Anaklet II. auf die schärfste Waffe verzichtet haben, auf den Hinweis, dass sein Geschlecht der Kirche bereits einen Papst geschenkt habe [...]."Vgl. ebd. 178.
}

209 Zur Geschichte des 1908 in Verein für das Deutschtum im Ausland (VDA) umbenannten Deutschen Schulvereins vgl. Gerhard Weidenfeller, VDA. Verein für das Deutschtum im Ausland. Allgemeiner Deutscher Schulverein (1881-1918). Ein Beitrag zur Geschichte des deutschen Nationalismus und Imperialismus im Kaiserreich (Europäische Hochschulschriften III, 66, Bern/Frankfurt/M. 1976) 108-126.

210 Wohl schon vorher war Tangl, wie zahlreiche andere Vertreter deutscher und österreichischer wissenschaftlicher Institutionen, etwa der Präsident der MGH Georg Waitz und der Direktor des IÖG Sickel sowie in besonders aktiver Rolle Wattenbach, Mitglied des Vereins für siebenbürgische Landeskunde; vgl. WeIDENFELLER, VDA (wie Anm. 209) 89.

211 Mehrere Versuche antisemitischer Gruppen, Juden von der Mitgliedschaft auszuschließen und Schulen israelitischer Kultusgemeinden nicht mehr durch den Deutschen Schulverein zu unterstützen, schlugen fehl und führten 1886 zum demonstrativen Austritt Schönerers aus dem nach seiner Ansicht „verjudeten Verein“, vgl. Weidenfeller, VDA (wie Anm. 209) 115-123. Aus Furcht vor zu großen Mitgliederverlusten entschloss sich allerdings der Deutsche Schulverein zu einem Kompromiss und gestattete den Ortsgruppen, autonom über die Zulassung von Juden zu entscheiden. Viktor Adler und Engelbert Pernerstorfer zogen sich in der Folge aus dem Vorstand des Vereins zurück. 
dem Allgemeinen Deutschen Schulverein an, der I88 I nach dem Vorbild des österreichischen Deutschen Schulvereines gegründet worden war. Auch diesem Verein gehörten führende Wissenschaftler und Künstler aller politischer Couleurs an, auch er stand einer Mitgliedschaft jüdischer Personen positiv gegenüber. Unter dem Vorsitz des aus Innsbruck stammenden Anglisten Alois Brandl ${ }^{212}$ wurde im Jahr I 900 eine neue Reihe, die „Schriften des Allgemeinen Deutschen Schulvereins“ begründet, die von Michael Tangl betreut wurde ${ }^{213}$. Für das publizistische Organ des Vereines für das Deutschtum im Ausland verfasste er selbst mehrere Artikel ${ }^{214}$.

In den Anfangstagen des Ersten Weltkrieges scheint Tangl gegenüber der radikalen Kriegsbegeisterung gerade in akademischen Kreisen Zurückhaltung geübt zu haben. Den am 4. Oktober I9I4 veröffentlichten, leidenschaftlich-nationalistischen Aufruf „An die Kulturwelt!“, der von bekannten Personen des Wissenschafts- und Kulturlebens wie Max Liebermann, Gerhard Hauptmann, Max Reinhardt und Max Planck, aber auch aus dem Umfeld Tangls wie Alois Brandl unterstützt wurde, unterzeichnete er nicht ${ }^{215}$. Hingegen findet sich sein Name in der Liste der zahlreichen Unterfertiger der in weitaus gemäßigterem Ton abgefassten, am 23. Oktober I 9 I 4 veröffentlichten „Erklärung der Hochschullehrer des Deutschen Reiches“216.

212 Vgl. Weidenfeller, VDA (wie Anm. 209) 271-293. Brandl widmete seiner Tätigkeit für den Verein ein Kapitel seiner Autobiografie: Alois BrandL, Zwischen Inn und Themse. Lebensbeobachtungen eines Anglisten. Alt-Tirol/England/Berlin (Berlin 1936) 271-279.

213 Vgl. Weidenfeller, VDA (wie Anm. 209) 274.

214 Michael TANGL, Ein bedrohtes deutsches Städtchen Kärntens. Bilder aus den nationalen Grenzkriegen in Österreich, in: Das Deutschtum im Ausland 19 (1900) 19f.; Die Vorgänge an der Innsbrucker Universität, ebd. 20 (1901) 100; Die Suppenvereine an den Alpenschulen Deutschösterreichs, ebd. 23 (1904) Sp. 33f.; Vom Deutschtum in Kärnten, ebd. 26 (1907) 146f. In diesen Arbeiten tritt Tangl als national gesinnter und leidenschaftlicher Verfechter der Interessen deutschsprachiger Volksgruppen hervor, der, wenn auch parteipolitisch betont neutral, deren vermeintlichen und von ihm als Bedrohung empfundenen Zurückdrängung durch anderssprachige (in den konkreten in seinen Artikeln behandelten Fällen besonders der slowenischen und der italienischen) Volksgruppen entgegentritt. Im Vereinsorgan veröffentlichte er auch Nachrufe auf die beiden ebenfalls dem Verein angehörenden Historiker Wattenbach (Das Deutschtum im Ausland 20 [1901] 49) und Scheffer-Boichorst (ebd. 21 [1902] 43), den er als politisch neutral, aber „von guter und zuverlässiger nationaler Gesinnung" beschreibt.

215 Jürgen Ungern-Sternberg, Wolfgang Ungern-Sternberg, Der Aufruf „An die Kulturwelt!“. Das Manifest der 93 und die Anfänge der Kriegspropaganda im Ersten Weltkrieg (Stuttgart 1996).

216 Erklärung der Hochschullehrer des Deutschen Reiches/Déclaration des professeurs des universités et des écoles supérieures de l'Empire Allemand: Berlin, den 23. Oktober 1914 (Berlin 1914). Auch, allerdings ohne Unterschriften und mit Datum 16.10.1914, gedruckt in: Aufrufe und Reden deutscher Professoren im Ersten Weltkrieg, hg. v. Klaus Böнme (Reclams Universal-Bibliothek 9787, Stuttgart 1975) 49 f. 


\section{DIE WISSENSCHAFTLICHEN LEISTUNGEN TANGLS IM BLICK SEINER ZEIT UND AUS HEUTIGER SICHT}

Angesichts des fast völligen Fehlens einschlägiger eigener Äußerungen ist es kaum möglich, Tangl eindeutig einer der an der Universität Berlin zu seiner Zeit bestehenden Gruppierungen zuzuordnen ${ }^{217}$. Als Österreicher und Katholik ${ }^{218}$ blieb er wohl bis zu einem gewissen Grad tatsächlich - wie dies von ihm besonders in den Anfangsjahren stark empfunden wurde - ein Außenseiter. Von seiner Weltanschauung her ist er am ehesten zu jener Gruppe von Professoren zu zählen, der etwa auch Dietrich Schäfer und Eduard Meyer angehörten und die, meist gemäßigt-national, den konservativen Historismus vertraten $^{219}$. Innerhalb seiner Disziplin gehörte er, was die Übernahme und Ausübung organisatorischer und wissenschaftlicher Schlüsselfunktionen betrifft, zur Gruppe der einflussreichsten Berliner Professoren seiner Zeit. So rangiert er sowohl hinsichtlich seiner Mitgliedschaften in Habilitations- und Berufungskommissionen, bei der Zahl von Habilitationen, die er als Erst- und Zweitgutachter betreute, sowie als Institutsleiter jeweils im Spitzenfeld unter den 25 zwischen I 890 und 1933 als ordentliche Lehrstuhlinhaber an der Berliner Universität wirkenden Historikern ${ }^{220}$. Im Gegensatz dazu war sein wissenschaftliches Prestige nach außen hin jedoch bemerkenswert gering. Dies zeigt sich in der vergleichsweise geringfügigen Übernahme wichtiger Universitätsämter (nur einmal, nämlich I 9 I2/I3, fungierte Tangl als Dekan), seiner erst ungewöhnlich spät - nämlich erst I 8 Jahre nach seiner Berufung nach Berlin - erfolgten Wahl in die Preußische Akademie der Wissenschaften ${ }^{21}$ sowie in seiner erst nach seinem Tod erfolgten Berücksichtigung in den

217 Vgl. oben 68 mit Anm. 198-199.

218 Nach Stengel, Tangl (wie Anm. 36) 374, hatte Tangl „oft betont [...] daß er, der österreichische Katholik, kein eifernder Sohn seiner Kirche war."

219 Vgl. Kolá ̌̌, Geschichtswissenschaft (wie Anm. 57) 405. Ob allerdings etwa die ablehnende Haltung Tangls im Habilitationsverfahren des sozialistischen Publizisten Gustav Mayer, nachdem sich dieser nach seiner eigenen Schilderung in der Befragung nach seinem Habilitationskolloquium bemerkenswerte fachliche Blößen gegeben hatte, mit „politischem Konservativismus“ begründet werden kann (vgl. ebd. 461-465) darf bezweifelt werden.

220 Kolár untersuchte, was er die „Distribution des wissenschaftlichen Machtkapitals 1890-1933“ bzw. die „Distribution der disziplinären Macht“ nennt, an der Berliner Universität; vgl. Kolá ̌̌, Geschichtswissenschaft (wie Anm. 57) 407 (Tabelle III). „[...] Hans Delbrück, Dietrich Schäfer, Friedrich Meinecke, Otto Hintze, Michael Tangl, Eduard Meyer und Max Lenz [...] hielten die Kontrolle über die ganze Disziplin zwischen den Jahren 1890 und 1933 in ihren Händen“, ebd. 409.

221 Der Wahlvorschlag wurde von Schäfer eingebracht. Dazu Oве R коғLer, Einfluß (wie Anm. 9) 236: „Eigentlich ist es erstaunlich, daß ein so politisch auftretender Historiker wie Schäfer, der zum rechten Flügel unter den imperialistischen Historikern zählt, diese Initiative für Tangl ergriffen hat." Oberkofler sieht die Erklärung dafür in der auch im Antrag (ediert ebd. 240f.) formulierten Wertschätzung der methodischen und hohen wissenschaftlichen Ansprüchen genügenden Arbeiten Tangls. 
wichtigsten Konversationslexika des deutschen Sprachraumes ${ }^{222}$. Hand in Hand mit diesem Befund geht die Tatsache, dass Tangl zu den weitaus am niedrigsten dotierten ordentlichen Professoren der Berliner Universität gehörte. Mit einem Anfangsgehalt von 4.800 Goldmark und einem Gehalt von 6.00o Goldmark im Jahr I9I 4 fiel er deutlich hinter andere Kollegen, wie etwa Eduard Meyer, der zur gleichen Zeit mit I 2.00o Goldmark doppelt so viel verdiente, zurück. Dabei ist allerdings festzuhalten, dass diese Diskrepanz bei den Gehältern nicht nur mit dem Verhandlungsgeschick oder dem persönlichen Ansehen des einzelnen zu tun hatte, sondern auch mit dem, im Falle Tangls vergleichsweise geringen Prestige seines hilfswissenschaftlichen Lehrstuhls ${ }^{223}$.

Mit drei großen Editionen - den päpstlichen Kanzleiordnungen, den Karolingerurkunden, den Bonifatius-Briefen - vier Übersetzungen von Briefeditionen, einem Tafelwerk (Arndt-Tangl) und so Aufsätzen, die Tangl neben einer langen Reihe von fachlich sehr anspruchsvollen Rezensionen im Laufe seines etwa 30 Jahre umspannenden Gelehrtenlebens vorlegen konnte, gehört sein Werk sicher nicht zu den großen, den wirkungskräftigsten Cuvres der Geschichtswissenschaft ${ }^{224}$. Mehrere Vorhaben, zu denen bereits in jahrelanger Beschäftigung wertvolles Material erarbeitet worden war und die wohl auch schon in konkreter Form geplant waren, wie etwa weitere Editionen von Papstbriefen in der MGH-Reihe der Epistolae, ein Tafelwerk zu den mittelalterlichen Urkundenfälschungen, Überblicksdarstellungen zur Chronologie und Paläografie, eine Papsturkundenlehre oder eine Biografie des heiligen Bonifatius, konnten - sicher zunächst durch die Über-

222 Vgl. die Untersuchung der „Distribution des wissenschaftlichen Prestiges 1890-1933“ an der Berliner Universität durch Kolá ̌̌, Geschichtswissenschaft (wie Anm. 57) 408 (Tabelle IV). Im „Brockhaus“ erhielt Tangl erst 1934 einen eigenen Eintrag, in „Meyers Konversationslexikon“ immerhin bereits fünf Jahre früher, 1929 - jedoch immer noch erst acht Jahre nach seinem Tod. In „Degener's Wer ist's“ (erschienen seit 1905) fand er als einer der wenigen seiner Professorenkollegen in Berlin nie Aufnahme (dies könnte allerdings, sofern die Aufnahme in einschlägige Lexika auf Eigeninitiative der betreffenden Person erfolgte, im Gegenteil auch als Ausdruck von Tangls persönlicher Bescheidenheit interpretiert werden). Nach Kolářs Resümee zählte Tangl aber doch wohl zu jenen „Professoren, die zwar im Fach mächtig waren, dagegen aber niedrigere Werte wissenschaftlichen Prestiges aufzeigen“ (ebd. 410). Dieser Befund lässt sich bis heute in den wichtigsten Gelehrtenlexika nachverfolgen: Zu Tangl gibt es kurze Artikel in Wolfgang WEBER, Biographisches Lexikon zur Geschichtswissenschaft in Deutschland, Österreich und der Schweiz (Frankfurt a. M./Bern/New York u.a. 1984) 599f., der Deutschen biographischen Enzyklopädie 9 (1998) 654, und in Fritz Fellner, Doris CorRADINI, Österreichische Geschichtswissenschaft im 20. Jahrhundert. Ein biographisch-bibliographisches Lexikon (Wien/Köln/Weimar 2006) 408.

223 Vgl. dazu Kolá ̌̌, Geschichtswissenschaft (wie Anm. 57) 411 (Tabelle V: Distribution des ökonomischen Kapitals). Allerdings verdiente Scheffer-Boichorst 1900 auf demselben Lehrstuhl 9.200 Goldmark.

224 Vgl. dazu die Zusammenfassung bei Schaller, Tangl (wie Anm. 1) 296-298. Ове r коf ler, Einfluß (wie Anm. 9) 233, leitet seine Arbeit wie folgt ein: „Michael Tangl ist wohl nur noch wenigen Spezialisten der Historischen Hilfswissenschaften bekannt. Aber innerhalb dieses engen Kreises ist sein Name ein weit herausragender." 
lastung während der Kriegsjahre, später jedoch durch den unerwartet frühen Tod Tangls - letztendlich nicht realisiert werden.

Das gesamte Werk Tangls ist dem Studium, der Analyse, Interpretation und Auswertung der schriftlichen Quellen gewidmet ${ }^{225}$. Den Absolventen des so stark von Sickel geprägten IÖG stand in den späten I $880 e r-J a h r e n$ nicht nur eine damals neue und bahnbrechende Methode zu Gebote, sie fanden auch ein in vielerlei Hinsicht kaum ausgewertetes, beinahe unerschöpflich scheinendes Reservoir an schriftlichen Quellen vor - es mag hier genügen, nur an das damals erst seit Kurzem der Forschung zugängliche Vatikanische Geheimarchiv, aber auch viele andere vor allem kirchliche und private Archive zu erinnern -, die es galt, zu sammeln, zu sichten und mit der nun zur Verfügung stehenden wissenschaftlichen Methode zu bearbeiten. In den Werken Tangls wird die Entdeckerlust und die Begeisterung für die damit verbundene Pionierarbeit spürbar. Aus umfassender und eingehender Kenntnis der mittelalterlichen Quellentexte entspringt seine nähere Beschäftigung mit einzelnen Themenbereichen, wobei die Anwendung der hilfswissenschaftlichen Methoden immer den roten Faden der wissenschaftlichen Eröterung bildet. Gleich welchem Thema Tangl sich zuwandte, immer war die Konsolidierung einer soliden Quellenbasis der Ausgangspunkt, von dem aus allein erst weiterführende Überlegungen anzustellen waren. Die schriftlichen Zeugnisse mussten zuerst eingehend geprüft, ihre Glaubwürdigkeit, wenn es um Fakten ging, nachgewiesen, ihre Tendenz, wenn es um subjektive Darstellung ging, erkannt und ihre möglichst exakte chronologische Einordnung festgestellt werden.

So widmete sich Tangls interne Quellenkritik Datierungsfragen, dem Schrift- und Stilvergleich, Verfasserfragen, der handschriftlichen Überlieferung und ihren gegenseitigen Abhängigkeiten, der Entstehung der Quellen, der Untersuchung von Textstufen, Fassungen und Redaktionen sowie bei Urkunden besonders auch der Frage nach Formularbehelfen, Konzepten und Textentwürfen ${ }^{226}$, der Registerführung, aber auch der späteren Verwendung der Texte, ihrem Nachwirken und „Nachleben“. Großen Wert legte Tangl dabei auf die Nachvollziehbarkeit seiner Argumentation und bediente sich daher häufig des damals noch neuen Mediums der Fotografie und der Beigabe von Nachzeichnungen. Fälschungsfragen nehmen in diesem Rahmen einen nicht unwesentlichen Platz ein, wobei nicht nur rein diplomatische Kriterien zur Anwendung gelangten, sondern die Frage nach den Motiven für Fälschungen und Interpolationen im

225 Schaller, Tangl (wie Anm. 1) 300, bezeichnet ihn nicht unzutreffend als „gewissenhaften Arbeiter im unerschöpflichen Steinbruch der Quellenerschließung“.

226 Vgl. etwa Michael TANGL, Der Entwurf einer Königsurkunde aus Karolingerzeit, in: NA 25 (1900) 345 359, und in: Ders., Mittelalter 1 582-591, sowie Ders., Der Entwurf einer unbekannten Urkunde Karls d. Gr. in Tironischen Noten, in: MIÖG 21 (1900) 344-350, und in: DE Rs., Mittelalter 1 592-597. 
Vordergrund stand ${ }^{227}$. Aber so wie die noch vorhandenen Quellen Interpretation und Auswertung erfuhren, beschäftigte Tangl auch die Frage nach Lücken in der Überlieferung und nach verlorenen Schriftzeugnissen. Immer wieder betonte er die Relativität aller historischen Forschung, deren Ergebnisse sich mit der Entdeckung neuer Quellen, aber auch mit der Neuinterpretation bereits bekannter Quellen, oft völlig ins Gegenteil verkehren konnten, und hielt fest: „[...] daß wir bei allen unseren Forschungen Sklaven der Überlieferung sind, von deren Reichhaltigkeit und Zuverlässigkeit, von deren richtiger Deutung und Lesung wir ganz und gar abhängen“228. Neben der Berücksichtigung der größeren geschichtlichen Zusammenhänge, in denen seine Quellen standen, war ihm darüber hinausgehend die Einbeziehung der Nachbardisziplinen ein großes Anliegen. Interdisziplinäre Forschung, die er durch die Pflege persönlicher Kontakte zu Kollegen anderer Forschungsrichtungen zu institutionalisieren suchte, war für ihn Notwendigkeit und Selbstverständlichkeit ${ }^{229}$ zugleich.

Dass Michael Tangl, wie von Zeitgenossen und Biografen mehrfach bedauert, mitunter auch kritisiert wurde, keine überblicksmäßige und zusammenfassende große Monografie hinterlassen hat, mag der Grund dafür sein, dass sein Name heute weitgehend in Vergessenheit geraten ist. Am Unvermögen, in größeren Zusammenhängen zu denken, und an mangelnder Gabe zu fesselnder Darstellung liegt dies, wie mehrere gerade seiner oft ganz kurzen Schriften zeigen ${ }^{230}$, mit Sicherheit nicht. Vielleicht ist der wahre Grund aber in

227 Vgl. etwa Michael TAngL, Die Urkunden Karls d. Gr. für Bremen und Verden, in: MIÖG 18 (1897) 53-68; DERs., Die Fälschungen Chrysostomos Hanthalers, in: MIÖG 19 (1898) 1-54.

228 TANGL, Judenschutzrecht (wie Anm. 141) 198. Die zu vermutende Lückenhaftigkeit der Überlieferung schmerzte ihn besonders im Zusammenhang mit dem Fehlen von Konzepten für Herrscherurkunden : „Es sei mir gestattet, in diesem Zusammenhang die Conceptfrage im allgemeinen in wenigen Sätzen zur Sprache zu bringen. In unserer nach möglichster Exactheit ringenden Disciplin bedeutet sie den wunden Punkt. Während uns bei allen anderen Ueberlieferungsformen reichliche Grundlagen zur allein richtigen inductiven Forschung gegeben sind, fehlen sie bei den Concepten besonders aus älterer Zeit fast ganz, und nirgends vollständiger als auf dem Gebiet der deutschen Königsurkunden [...]. Wir sind hier auf Vermuthungen und Erwägungen von recht wankender Sicherheit angewiesen. “TANGL, Entwurf einer Königsurkunde (wie Anm. 226) $355 f$.

229 In seiner Antrittsrede als Ordentliches Mitglied vor der Preußischen Akademie der Wissenschaften 1918 hob er als einen Schwerpunkt seiner Beschäftigung mit den historischen Hilfswissenschaften die interdisziplinäre Forschung hervor: Die historischen Hilfswissenschaften stünden „in steter Wechselbeziehung zu den verwandten Wissenschaften der Philologie und Rechtsgeschichte, der Kirchen und Kunstgeschichte [...]. Die Bebauung der Grenzgebiete legen sie ihrem Vertreter als ernste Pflicht auf. In diesem Sinne habe ich in meinen Arbeiten die Beziehungen zur klassischen und germanischen Philologie, zum deutschen und Kirchenrecht zu gewinnen und festzuhalten gesucht, am nächsten wohl den Anschluß an die kirchengeschichtliche Forschung erreicht." TANGL, Antrittsrede (wie Anm. 3) 704. In wortwörtlicher Anlehnung an diese Ausführungen würdigte KEHR, Tangl (wie Anm. 6) 145f., die diesbezüglichen Bemühungen Tangls und bezeichnete sie als „dominierenden Zug in seiner wissenschaftlichen Spezialität“:

230 Als ein Beispiel sei nur sein im Jahr 1895 in Marburg gehaltener, glänzend formulierter Vortrag über Kon- 
einer für Tangl wohl sogar typischen - bei aller Hingabe und allem Enthusiasmus gegenüber seinem Fach - gewissen Distanziertheit gegenüber vergröbertem Urteil und seiner Ablehnung jeglicher Ideologisierung geschichtlicher Ereignisse und Entwicklungen zu suchen, die es ihm schwer machten, den alle Einzelheiten berücksichtigenden und möglichst objektiven Standpunkt des Quellenforschers zu verlassen. So überließ er das Feld der breiten zusammenfassenden Darstellung wohl nicht ungern großzügigeren Geistern, die sich auf die gut abgesicherten Ergebnisse akribischer Quellenforschung stützen und mit ihren Arbeiten einen bleibenden Platz in der Geschichtsforschung erringen konnten ${ }^{231}$. Im Urteil der Zeitgenossen, besonders derer, die ihn persönlich kannten und mit ihm, sei es als Kollegen oder als Schüler, zusammengearbeitet hatten, stieß diese vermutlich doch bewusst gewählte Beschränkung - oder Konzentration - auf die Detailstudie mit Blick auf den größeren Zusammenhang durchaus auf Verständnis ${ }^{232}$. Was aus heutiger Sicht bleibt, ist vor allem Tangls ungeheurer Einfluss auf seine Schüler, den er sowohl in wissenschaftlicher als auch in menschlicher Hinsicht auszuüben in der Lage war ${ }^{233}$.

radin, den glücklosen Sohn Kaiser Friedrichs II., genannt, in dem es ihm gelang, vor dem Hörer eine ganze Epoche in starken Bildern lebendig zu machen: Michael TANGL, Konradin von Hohenstaufen. Ein Vortrag, in: DERS., Mittelalter 2 859-870.

231 So kritisierte Tangl im Zusammenhang mit einer Studie von Georg Hü frer, Korveier Studien. Quellenkritische Untersuchungen zur Karolinger-Geschichte (Münster i. W. 1898) dessen durch übergroße Heimatliebe getrübte Urteilskraft, die den wissenschaftlichen Wert seiner Arbeit erheblich mindere: Michael TANGL, Die Urkunden Ottos I. für Brandenburg und Havelberg, die Vorbilder für die gefälschten Gründungsurkunden der sächsischen Bistümer, in: FS zu Gustav Schmollers 70. Geburtstag (Leipzig 1908) 369-401, und in: DERs., Mittelalter 1 601-627, hier 604: „Ich will nicht leugnen, daß Hüffers Ausführungen $[\ldots]$ noch durch etwas anderes zunächst für sich einnehmen: durch die sichere Heimatkenntnis und durch die mächtig hervortretende Heimatliebe, die ihn für seine Darstellung lebhafte Farben und warme Töne finden lassen. Die Lebhaftigkeit dieser Gefühle hat aber bei Hüffer über die Besonnenheit des Forschers Oberhand gewonnen, und er hat dadurch den Vorsprung, den ihm Orts- und Landeskenntnis gaben, wieder vollständig eingebüßt.“

232 In diesem Sinne urteilte Brandi, Tangl (wie Anm. 36) 5: „Aus Tangls wissenschaftlichem Werk ergibt sich ein gedrängtes Bild von großer Geschlossenheit [...] Die vielseitigen Naturen verbrauchen sich in ihren Wirkungen, die einseitigen dünken uns unersetzlich.“ Perels, Tangl (wie Anm. 36) 124 formulierte: „Alles was er schrieb zeichnet sich aus durch Gediegenheit und Klarheit, durch Ernst und Besonnenheit der Forschung, vieles durch Scharfsinn und hervorragende Kombinationsgabe - wobei er aber allem hypothetischen Blendertum stets abhold blieb. Einige seiner Arbeiten [...] dürfen wohl geradezu abschließend genannt werden [...] Einzelabhandlungen - sie lagen seiner Natur zweifellos am meisten: die methodische und exakte Untersuchung, die zu gesichertem Ergebnis führte und eine feste Grundlage für weitere Forschung bilden konnte, war ihm offenbar mehr wert als die abgerundete zusammenfassende Darstellung."

233 Schaller, Tangl (wie Anm. 1) 300, bezeichnet ihn folgerichtig als „Multiplikator der quellenkritischen Methode“, dessen „Langzeitwirkung“ nicht in „epochemachenden historischen Darstellungen oder geschichtsphilosophischen Modellen“, sondern in seiner Wirkung auf seine Schüler besteht. 
IX. ANHANG

I. Tangl zwischen Theodor von Sickel und Engelbert Mühlbacher

I908 Juli 4, Brief an Emil von Ottenthal.

IÖG, NL Ottenthal.

Berlin W.50, Nürnbergerplatz 6

d. 4. Juli 1908

Verehrter Herr Kollege!

Ihnen und Ihrer verehrten Frau Gemahlin wünschen meine Frau und ich zur Geburt Ihres Töchterchens ${ }^{234}$ von Herzen Glück. Möge die liebe Kleine aufs beste gedeihen und zu Ihrer Freude heranwachsen! Herzlich freue ich mich, Sie beim Historiker-Kongress ${ }^{235}$ wiederzusehen. Ihr Vortrag ist für den Tag eingesetzt, an dem wir den besten Raum (Beethovensaal) ${ }^{236}$ zur Verfügung haben, und hier an bester Stelle; (der erste Vortrag gilt noch mehr als Sammelblasen). Wenn Sie irgend etwas als Demonstrations-Material vorlegen wollen, steht Ihnen mein Apparat unbeschränkt zur Verfügung; Sie brauchen mir nur Ihre Wünsche bekannt zu geben. Ich schrieb jetzt für das 3. Heft des NA., das in 8-1o Tagen ausgegeben werden dürfte, den Nachruf auf Sickel ${ }^{237}$. Die Arbeit wurde mir, wie ich offen gestehen will, nach den verschiedenen Anrempelungen durch die Herren von der engsten Gefolgschaft ${ }^{238}$ und durch den wilden Hass, mit dem Sickel das Andenken des armen Mühlbacher verlästerte ${ }^{239}$, recht sauer. Erich Schmidt ${ }^{240}$, der Sickel ganz

234 Ottenthal war mit Hedda Primavesi verheiratet. 1908 wurde die Tochter Hroswitha geboren. Hans Hirsch, Emil von Ottenthal. Ein Nachruf, in: MÖIG 45 (1931) 271-277, hier 277.

235 Karl Dietrich Erdmann, Die Ökumene der Historiker. Geschichte der Internationalen Historikerkongresse und des Comité International des Sciences Historiques (Abh. Göttingen 3, 158, Göttingen 1987) 64-85.

236 Berlin, Köthener Straße 32, nahe dem Potsdamer Platz, errichtet 1898 als zusätzliches Veranstaltungslokal der Philharmonie, im 2. Weltkrieg zerstört.

237 Sickel. Ein Nachruf von M. TAngl (wie Anm. 188) 778: „... Und das möchte ich auch gegenüber der Gereiztheit von Herren aus der engsten Gefolgschaft, die in jüngster Zeit in recht unerquicklicher Weise sich kundgibt, mit allem Nachdruck wiederholen.“ 780 : „Daneben brachte ihm aber gerade dieses letzte Jahrzehnt seines öffentlichen Wirkens auch manche Enttäuschung und Verbitterung. Reibungen und Verstimmungen in Rom, mehr aber noch mit den Wiener Kreisen zehrten an seiner Kraft; und wer ihn 1901 unmittelbar vor seinem Abschied von Rom sah, der gewahrte mit tiefer Bewegung einen vergrämten, innerlich unbefriedigten Mann. Aus dem Bann dieser Stimmung vermochte er sich auch in den folgenden stillen Jahren in Meran nicht völlig frei zu machen."

238 Besonders Erben und Uhlirz fühlte sich Sickel sehr eng verbunden; das galt aber auch für Kehr. Vgl. Michèle Schu bert, Meister - Schüler. Theodor von Sickel und Paul Fridolin Kehr (nach ihrem Briefwechsel), in : MIÖG 106 (1998) 149-166, hier 151.

239 Engelbert Mühlbacher. Ein Nachruf von M. TANGL, in: NA 29 (1904) 266-274.

240 Vgl. zu ihm NDB 23, $182 \mathrm{f}$. 
wenige Tage vor seinem Tod in Meran aufsuchte, brachte mir seine letzten Grüße, aber begleitet von Flüchen auf Mühlbacher und seiner Misbilligung [!], daß ich von Beinflußung durch ihn nicht freigeblieben sei. Ich habe mich möglich [!] vorsichtig gefaßt und manches verschwiegen; aber daß das letzte Jahrzehnt in Rom I 89I-I90 I den Abstieg von der Höhe bedeutete, mußte ich doch, für den Wissenden kennbar, zwischen den Zeilen andeuten. Wirklich interessant sind die Aktenstücke, die uns Sickel über die MonumentaFrage geschenkt hat, und die Angaben Jungs in seiner Ficker-Biographie ${ }^{241}$ scheinen das Verdienst, das Sickel in seinem „Kommentar“ für sich in Anspruch nimmt, in der Tat zu bestätigen. In der heutigen „Sonnabend-Beilage“ der Vossischen Zeitung (Besprechung von Simonsfelds Jahrbüchern ${ }^{242}$ ) steht eine ebenso unwahre wie ungezogene Bemerkung von Helmolt ${ }^{243}$ gegen Sie. (der Band sei so spät erschienen, weil Simonsfeld auf Ihre Ausgabe der DD. Friedrichs I. hätte warten wollen!!).

Mit den besten Grüßen und Empfehlungen von Haus zu Haus, Ihr M. Tangl.

I908 August 20, Brief an Emil von Ottenthal IÖG, MGH Diplomata, Ordner 2. Doppelblatt, Briefkopf MGH. Mit Stift auf der ersten Seite: b(eantwortet) $4 / 9$.

Wien d. 20.VIII. I908

Sehr verehrter Herr Kollege!

Ihre Absage wurde nicht nur von mir, sondern von allen Kongreßteilnehmern, mit denen zu sprechen ich Gelegenheit hatte, lebhaft beklagt. Da auch Chroust ${ }^{244}$ im letzten Augenblick absagte, war gerade die Vortragsordnung für Freitag d. 7. arg gestört, während sich sonst in meiner Sektion alles programmmäßig abwickelte. Der Verlauf im ganzen war viel günstiger und vor allem viel ernsthafter, als ich erwartet hatte. Auch der Besuch meiner Sektion gestaltete sich überraschend gut. Nur der Gesamtbesuch blieb weit hinter den Erwartungen der Sanguiniker zurück, besonders Eduard Meyers ${ }^{245}$, den allein oder doch hauptsächlich die Schuld trifft für die Wahl des nicht nur ungünstigen, sondern fast unmöglichen Zeitpunkts. Ich hatte Ihnen alles Gruppenmaterial, das irgend für Sie in Betracht kommt, zurecht gelegt, in der Hoffnung, daß Sie es in einer freien Stunde bei mir

241 J[ulius] Jung, Julius Ficker. Ein Beitrag zur deutschen Gelehrtengeschichte (Innsbruck 1907).

242 Henry Simonsfeld, Jahrbücher des Deutschen Reiches: Friedrich I. (Leipzig 1908). Die Besprechung erschien unter dem Titel „Die Anfänge Kaiser Friedrich Rotbarts“ in der Sonntagsbeilage Nr. 27 zur Vossischen Zeitung Nr. 311 (5.7.1908) 209f.

243 Vgl. zu ihm NDB 8, $502 \mathrm{f}$.

$244 \mathrm{Vgl}$. zu ihm den Beitrag von Peter Herde in diesem Band.

245 Vgl. zu ihm NDB 17, 309-311. 
einsehen und erledigen könnten. Nun muß ich es Ihnen natürlich schicken und tue dies von meinem einzigen Rasttag in Wien aus, da ich das Zeug auf meiner Briefwage abwog und fand, daß die Sendung als eingeschriebener Brief bereits Schwierigkeiten begegnen könnte; und wegen Io-I 5 Gram [!] Ihnen und mir die Scherereien eines Zoll-Packets zu machen, steht wahrlich nicht dafür. Um Rücksendung bitte ich nicht vor Anfang Oktober, da ich selbst nicht vor diesem Zeitpunkt zurückkehre. Ich gehe nach kurzer Rast in Kärnten über Venedig, Verona, Modena, Arezzo, Parma nach Frankreich zu den letzten Nachträgen für Ludwig d. Fr. Die Stationen sind alle nur ganz kurz bis auf Paris, wo ich etwa um den Io. Sept. anzukommen und mich 8-ı o Tage aufzuhalten hoffe. Über Sickels letztes Decennium in Rom unterhalten wir uns vielleicht noch einmal mündlich. Ich kann über dieses Walten nicht anders als hart urteilen und zur Begründung dieses Urteils außer der allgemein bekannten Tatsachen auch noch ein paar aus eigenster Erfahrung beisteuern. Aus diesen und auch noch anderen Gründen ist es mir auch nicht möglich, bei dem übertriebenen Sickel-Kult mitzutun, der seit Mühlbachers Tod von neuem eingesetzt hat.

Mit besten Grüßen und Empfehlungen von Haus zu Haus

Ihr M. Tangl.

\section{Tangls letzter Aufsatz}

I92 I Juli I7, Brief an August von Jaksch ${ }^{246}$

Klagenfurt, Kärntner Landesarchiv, NL August von Jaksch. Teilabdruck in: August von

JAKSCH, Universitätsprofessor Dr. Michael Tangl †, in: Carinthia I II3 (I923) 8of., hier 80. Unterstreichungen werden wie im Original wiedergegeben.

Berlin W. Nürnbergerplatz 6

d. I7.VII.I92 I

Lieber Freund!

In zwei Wochen schnüre ich mein Ränzel, um nach 8 Jahren mein liebes Heimatland wieder aufzusuchen. Über die äußeren Umstände, unter denen es geschieht, will ich nicht viel schreiben, weil ich darüber kaum ruhig denken kann. Der Io. Oktober ${ }^{247}$ macht es mir überhaupt möglich, meinen Entschluß auszuführen. Diesen Ehrentag Kärntens werde ich nie vergessen. Die zwingende Einheit des Landschaftsbildes von Klagenfurt

246 Vgl. zu ihm ÖBL 3, 66; NDB 10, $324 f$.

247 Am 10.10.1920 fand in Kärnten eine Volksabstimmung statt, in der für einen Verbleib des Gebietes um Klagenfurt und Völkermarkt bei Österreich entschieden wurde. Vgl. Claudia Fräss-Ehrfeld, Kärnten 19181920. Abwehrkampf, Volksabstimmung, Identitätssuche (Geschichte Kärntens 3, 2, Klagenfurt 2000). 
und Völkermarkt entzweigerissen zu sehen, hätte ich nicht ertragen, am allerwenigsten mit eigenen Augen schauen können. Koll. Uebersberger ${ }^{248}$ hat für mich, meine Frau und meinen Sohn, der hoffentlich auch mitkann, obwohl er den Urlaub vom auswärtigen Amt, wo er nebenamtlich beschäftigt ist, noch nicht erhalten hat, eine Unterkunft in Maria Rain besorgt. Von dort hoffe ich des öftern zu dir nach Klagenfurt zu kommen und habe dabei noch das besondere Anliegen, die pseudorömischen Inschriften auf dem Herzogstuhl, deren eine du ja endgültig erledigt hast, doch auch selbst sehen zu können. Der „Eintritt“ (!!) Eures Prof. Dr. Graber ${ }^{249}$ ist mir nämlich furchtbar in meine alten Glieder gefahren, und ich habe mich hingesetzt und selbst diese Frage einmal vorgenommen, um nun endlich auch langjährige Schuld abzutragen und auch für die Heimatgeschichte zu schaffen, was ich bislang immer nur für Rom, Fulda und Osnabrück getan hatte. Zunächst habe ich meine vollständige und unbedingte Ablehnung Grabers in der beifolgenden kurzen Anzeige niedergelegt ${ }^{250}$, im übernächsten Heft des N.A. (44.I) folgt der Aufsatz, in dem ich einfach ausführe, was du längst erlangt hattest, was durch Schneiders Neuausgabe des Joh. von Viktring ${ }^{251}$ auch äußerlich spruchreif geworden war und was der junge Mann nun in kaum begreiflicher Verblendung ganz außer Acht gelassen hat, die philologisch-kritische Untersuchung. Deine Puntschart-Anzeige ${ }^{252}$ kommt dabei zu hohen Ehren, und nur in einem, allerdings wesentlichen Punkt weiche ich von dir ab, indem ich auch die Einsetzung von I I6 I als echte beim Fürstenstein, nicht als bevollmächtigte Lehenübertragung in Villach nachweise. Doch über diesen einen Punkt werden wir alten Knaben uns schon vertragen. Es kommen bei der Untersuchung aber auch noch andere Dinge ganz neu heraus, die deinen Beifall sicher finden werden. Mein Sohn Eberhard, der Sprachvergleichung und slavische Philologie studiert, möchte den Monat in Kärnten auch benützen, um etwas Beziehungen zum „Windischen“ zu gewinnen. Ich schrieb schon an Uebersberger, ob zu solchem Zweck etwa ein Lehrer, Landpfarrerl [!] oder Kaplanle [!] zu gewinnen wäre. Von hier reise ich am I. August Abends ab (mein Sohn kann erst am 6. nachfolgen) und könnte, wenn die Anschlüsse klappen, am 2. Abends in Villach sein. $\mathrm{Ob}$ es dann noch Anschluß nach Klagenfurt oder gar nach Maria Rain gibt, kann ich hier al-

248 Vgl. zu ihm Arnold Suppan, Marija Wakounig, Hans Uebersberger (1877-1962), in: Osteuropäische Geschichte in Wien. 100 Jahre Forschung und Lehre an der Universität, hg. v. DEns., Georg Kast NeR (Innsbruck 2007) 91-166.

249 Georg Graber, Der Einritt des Herzogs von Kärnten am Fürstenstein zu Karnburg (SB Wien 190 [1919], 5. Abh.). Vgl. zu ihm den Nachruf in: Carinthia I 148 (1958) 737-740.

250 NA 43 (1922) 440.

251 Iohannis abbatis Victoriensis liber certarum historiarum, hrg. v. Fedor SCHneider (MGH Scriptores rerum Germanicarum in usum scholarum [36], Hannover/Leipzig 1909).

252 Paul Puntschart, Herzogseinsetzung und Huldigung in Kärnten. Ein verfassungs- und culturgeschichtlicher Beitrag (Leipzig 1899), von Jaksch ausführlich rezensiert in: MIÖG 23 (1902) 311-329. 
lerdings nicht feststellen. Hoffentlich gibt es in Klagenfurt im Notfall bei „Moser“253 oder im „Kaiser von Österreich“254 ( - heißt der Gasthof aber auch noch so??) Unterkunft. Also hoffentlich in etwas über 2 Wochen auf Wiedersehen.

Mit herzlichen Grüßen

Dein alter M. Tangl

\section{I92I August I2, Postkarte an Ernst Perels}

Berlin, Staatsbibliothek Preußischer Kulturbesitz, NL Perels. Postkarte, Adresse: Herrn Professor Dr. Ernst Perels, Berlin-Friedenau, Stubenrauchstr. 3 (ist mit Bleistift korrigiert zur Nachsendung wohl an Perels Urlaubsort ...berg Riesengebirge). Absender: Geh.-Rat Prof. Dr. M. Tangl, Maria-Rain bei Klagenfurt, Gasthof Kirschner ${ }^{255}$.

Lieber Herr Kollege! Nun habe ich das Ms. meiner Abhandlung doch noch nicht ganz fertig stellen können, da ich wider Erwarten noch ein Gutachten für das Reichsamt d. I[nnern] (Antiqua oder Fraktur!) aufgehalst erhielt ${ }^{256}$, das ich vor meiner Abreise eilig noch fertig stellte. Übrigens erwies sich die Verzögerung als sehr günstig; denn ich habe hier im Arch. des Gesch. Vereins in Klagenfurt vor einigen Tagen eine noch ungedruckte Urk. Hzg. Rudolfs IV. gefunden, die sich für die Einsetzung dieses Herzogs im Okt. I 36I als sehr wichtig erweist. Nächste Woche will ich auch die Inschriften auf dem Herzogsstuhl persönlich in Augenschein nehmen. Das Ms wird dann binnen 3 Tagen nach meiner Rückkehr, also bis Mitte September, versandfertig sein und zu diesem Zeitpunkt hoffentlich noch zurecht kommen. Die Lage von Maria Rain unmittelbar gegenüber dem Zug der Karawanken ist prächtig, die Verpflegung vorzüglich und reichlich und dank dem günstigen (!) Markkurs fast billig (25 Mark pro Tag und Person einschließlich alle Getränke). Wenn nur die Reise nicht so umständlich wäre! Da ich durch die Schuld der Sachsen (Riesenverspätung in Reichenbach i[m] V[ogtland]) den Anschluß in München versäumte, brauchte ich von Montag Abend bis Donnerstag Vormittag, um von Berlin hierher zu gelangen ${ }^{257}$.

Mit herzlichen Grüßen Ihr M. Tangl

253 Möglicherweise Domgasse 2, zumindest besteht dort heute ein Hotel Moser.

254 Heuplatz 1, das Gebäude wurde 1904/05 errichtet.

255 Ausflugslokal nahe Klagenfurt.

256 In Silvia Hartmann, Fraktur oder Antiqua. Der Schriftstreit von 1881 bis 1941 (Theorie und Vermittlung der Sprache 28, Frankfurt/M./Wien [u.a.] 1998, ${ }^{2}$ 1999), und in Peter Rüск, Paläographie und Ideologie. Die deutsche Schriftwissenschaft im Fraktur-Antiqua-Streit von 1871-1945, in: Signo 1 (1994) 15-33, ist davon nichts erwähnt.

257 Auch in einem Brief an Kehr aus Maria Rain, 06.08.1921, erwähnt Tangl die lange - zweieinhalb Tage Reise, siehe Sch aller, Tangl (wie Anm. 1) 285 mit Anm. 1192. 
I92I August IS, Postkarte an August von Jaksch

Klagenfurt, Kärntner Landesarchiv, NL August von Jaksch.

Lieber Freund! Mittwoch d. I7. d. M. möchte ich meine Besichtigung des Herzogsstuhls ausführen und zwar in der Weise, daß ich wegen des elenden Bahnanschlusses nach St. Veit bei meiner Ankunft in Klagenfurt $1 / 28 \mathrm{~h}$ Vormittag die Straßenbahn bis zum Theater und von dort weiter nach Annabichl benütze und das kurze weitere Stück gehe. Ich hoffe auf diese Weise bereits etwa um 9 h beim Herzogstuhl sein zu können, um dann für den 2. Teil des Vormittags noch Maria-Saal mitzunehmen. Deine freundliche Beihilfe erbitte ich mir nur für den Fall, wenn ich deiner Vermittlung bedürfte, um durch das Eisengitter zum Stein selbst und seinen beiden Inschriften zu gelangen.

Mit besten Grüßen dein M. Tangl.

Maria-Rain I 5.VIII. I92 I

I92I November 24, Berlin: Eberhard Tangl an August von Jaksch

Klagenfurt, Kärntner Landesarchiv, NL August von Jaksch. Unterstreichungen im Brief.

Hochverehrter Herr Archivdirektor!

Es freut uns herzlich, dass die Photographie meines lieben Vaters ${ }^{258}$ in so hohem Masse Ihren Beifall gefunden hat. Meine Mutter wird Ihnen mit grossem Vergnügen, sobald die Vervielfältigungen fertig geworden sind, ein weiteres Exemplar der selben Aufnahme für Ihr eigenes Arbeitszimmer übersenden. Die im Brief erwähnten Bilder aus der jüngeren Zeit konnten wir leider nicht beifügen, weil die hohe Behörde Schwierigkeiten machte, wollen aber versuchen, ob wir bei der nächsten Gelegenheit mehr Glück haben. Beiliegend $^{259}$ lege ich die angefangene Arbeit über „die Einsetzung des Kärntner Herzogs“ samt allen Vorarbeiten und Notizen vertrauensvoll in Ihre Hände. Mein Vater hoffte den Aufsatz, wie er an Prof. Perels schrieb, „binnen 3 Tagen“ nach seiner Rückkehr zu vollenden. Leider muss ich nach allerdings flüchtiger Durchsicht der Aufzeichnungen gewisse Zweifel hegen, ob es Ihnen möglich sein wird, die Arbeit so rasch zum Abschluss zu bringen, weil sie doch nicht so weit vorgeschritten ist, wie man nach der Mitteilung an Perels annehmen sollte; das Schwergewicht der Untersuchung lag wohl auf der wirklich druckfertigen, kritischen Zergliederung von Johann v. Viktring's Bericht und dieser Teil allein wäre

258 Laut freundlicher Auskunft von Mag. Martin Stermitz (Kärntner Landesmuseum) ist die Fotografie Tangls, die seine Witwe Jaksch übersandt hatte, nicht im Museum vorhanden. Sie wurde möglicherweise im Zweiten Weltkrieg vernichtet.

259 Die Arbeit, die Tangl angekündigt hatte (vgl. oben Anm. 162), ist nie erschienen; das Manuskript dürfte verschollen sein. 
wohl der Veröffentlichung wert, sollte die Ergänzung sich als undurchführbar erweisen. Zum zweiten (kürzeren?) Abschnitt, dem Vergleich dieser Darstellung mit Reimchronik und Schwabenspiegel, sind die Vorarbeiten vorhanden, die wohl manchen Anhalt geben. Zwei Bemerkungen möchte ich mir noch zu den Notizen erlauben:

I) Zur Karte [Alexander] Brückners (Slavist an der Berliner Universität) ${ }^{260}$ : Mein Vater wollte einer Anrregung Brückners folgend, die Inschrift auf dem Herzogsstuhl, die er trotz der späteren Übermeisselung für echt slavisch hielt, auslegen als wörtliche Übersetzung der formelhaften Wendung "habet sanctae fidei fidem = (i)ma sveti veri vero (verschrieben zu i). Ob er aber die üble Frage überhaupt wieder anschneiden wollte, ist mir nicht bekannt.

2) In einem Brief aus Maria Rain an Perels schreibt mein Vater, er habe im Archiv des Kärntner Geschichtsvereins gefunden „eine ungedruckte Urkunde Herzog Rudolfs IV., die sich für die Einsetzung dieses Herzogs im Oktober I 36I als sehr wichtig erweist." Die mit Bleistift geschriebene Notiz über die Urkunde liegt im Manuskript. Ich neige zu der Vermutung, dass mein Vater auf das Verzeichnis der Zeugen Gewicht legte, da er damit das „rediens ad ecclesiam Soliensem“ des Johann v. Viktring aus der Verwendung von Maria Saal als Absteigequartier der Gäste erklären wollte.

Sonntag, den 28. August, war mein Vater noch einmal nach Maria Saal gefahren, um eine schwache Spur, die auf Erhaltung des kirchlichen Rituals zu deuten schien, zu verfolgen. Dieser Streifzug, der letzte Spaziergang seines Lebens, denn schon bei der Heimkehr am Mittag vermochte er sich nicht mehr auf den Beinen zu erhalten, führte zu keinem Ergebnis; wünschen wir seiner letzten Arbeit einen umso besseren Erfolg! Einen rein geschäftlichen Punkt gestatte ich mir noch zu berühren: Mein Vater war, soviel ich weiss, korrespondierendes Mitglied der Bayrischen Akademie; ich glaube, dass die Bayern sich auch gerne an der Errichtung eines würdigen Grabmals beteiligen würden. Hier in Berlin würde die Sammlung wahrscheinlich Privatdozent Dr. Höpke, der Bibliothekar des Historischen Seminars, übernehmen; die älteren Schüler meines Vaters (Stengel, v. Heckel u.s.w.) könnte vielleicht Prof. Perels oder Archivrat Krabbo, wohl der älteste Berliner Schüler u. Duzfreund meines Vaters (Geheimes Staatsarchiv) von dem Unternehmen verständigen. Gerade diese älteren Schüler legten bisher eine so warme Anhänglichkeit an den Tag, dass wir wohl sicher auf Ihre Unterstützung rechnen können.

In der Hoffnung, dass Ihnen die Vollendung der Arbeit nicht allzuviele Mühe bereitet, verbleibe ich mit herzlichstem Dank, für die treue Freundeshilfe, die Sie uns immer wieder leisten, Ihr aufrichtig ergebener Eberhard Tangl.

260 Vgl. zu ihm ÖBL 1, $119 f$. 


\section{Anton Chroust (I864-I945)

\author{
EIN STREITBARER HISTORIKER AUS ÖSTERREICH IN FRANKEN
}

I.

Nach Würdigung der wissenschaftlichen Werke des am ı o. März I 864 in Graz geborenen Anton Chroust bemerkte Alphons Lhotsky in seiner eindrücklichen Geschichte des Wiener IÖG von 1954: „Es ist unverantwortlich, daß bis heute keine der großen Fachzeitschriften Österreichs und Deutschlands des 1945 im 82. Lebensjahre Verstorbenen nach Gebühr gedacht hat." Es sollte bis 1998 dauern, dass eine ausführliche Studie über Chroust erschien, und das freilich nicht in Chrousts Heimatland Österreich, sondern am Ort seiner wirkungsvollsten Tätigkeit, im fränkischen Würzburg*. Auch heute noch gehört Chroust in Österreich wie im deutschsprachigen Raum trotz seiner

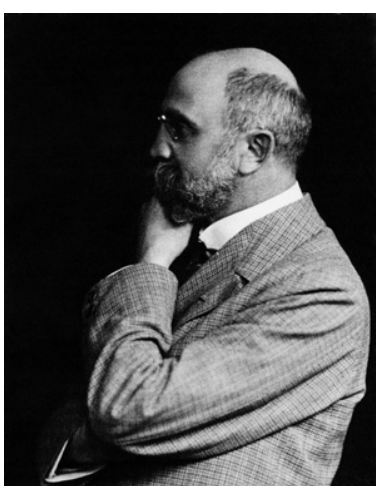

Abb. 3: Anton Chroust beachtenswerten wissenschaftlichen und wissenschaftsorganisatorischen Leistungen zu den weniger bekannten Historikern, so dass es angebracht erscheint, ihm in der Galerie „österreichischer Historiker“ mit einem kritischen Porträt zu gedenken.

\footnotetext{
* Alphons Lнотsкy, Geschichte des Instituts für österreichische Geschichtsforschung 1854-1954 (MIÖG Erg.-Bd. 17, Graz/Köln 1954) 192. - Der vorliegende Beitrag ist eine Überarbeitung meiner Studien: Peter Herde, Die Äbtissin Cuthsuuith, Anton Chroust und der Sturz des bayerischen Kultusministers Robert von Landmann (1901/02), in: Universität Würzburg und Wissenschaft in der Neuzeit. Beiträge zur Bildungsgeschichte. Gewidmet Peter Baumgart anläßlich seines 65. Geburtstages, hg. v. Dems., Anton Schinding (Quellen und Forschungen zur Geschichte des Bistums und Hochstifts Würzburg 53, Würzburg 1998) 231ff.; Peter Herde, Anton Chroust. Mitbegründer der Gesellschaft für fränkische Geschichte. Ein österreichischer Historiker im deutschen akademischen Umfeld von der Wilhelminischen Zeit bis zum Nationalsozialismus, in: Nachdenken über fränkische Geschichte. Vorträge aus Anlass des 100. Gründungsjubiläums der Gesellschaft für fränkische Geschichte vom 16.-19. September 2004 (Veröff. der Gesellschaft für fränkische Geschichte IX, 50, 2005) 39ff. - Franz Fuchs (Würzburg) und Karel Hruza (Wien) danke ich für eine redaktionelle Bearbeitung und wertvolle Hinweise. Im Gegensatz zu den Richtlinien des vorliegenden Bandes wurden im Apparat mit Zustimmung des Herausgebers die Seitenangaben mit „ff." belassen.
} 
II.

Im Jahr I 900 arbeitete Anton Chroust, der zwei Jahre zuvor auf Empfehlung von Felix Stieve als Extraordinarius für Neuere Geschichte und Historische Hilfswissenschaften an die Universität Würzburg berufen worden war, an seinem berühmten, aber wegen des exorbitanten Preises nicht weit verbreiteten Werk Monumenta Palaeographica ${ }^{1}$ in der Handschriftenabteilung der Würzburger Universitätsbibliothek. Dabei sah er insbesondere jene Handschriften der alten Dombibliothek durch, die I7I7 vom Domdekan Christoph Franz von Hutten auf dem Dachboden des Würzburger Doms entdeckt worden waren, wo man sie I63 I vor den Schweden versteckt hatte. Zuvor waren 45 oder 46 Handschriften, vermutlich von englischen Offizieren in schwedischen Diensten, gestohlen, nach England gebracht und dem Erzbischof von Canterbury und Kanzler der Universität Oxford, William Laud (I 573-I645), verkauft worden, der sie ab I635 der Bodleian Library schenkte, wo sie zusammen mit vielen weiteren, teilweise ebenfalls in Deutschland gestohlenen Handschriften den Bestand der Codices Laudiani bilden ${ }^{2}$. Es ist ein einmaliger, geschlossener Handschriftenbestand, vergleichbar mit dem der Kapitelsbibliothek Verona, Zeugnis der eminenten kulturellen Bedeutung Würzburgs zur Zeit des ersten angelsächsischen Bischofs Burkhard (742-53) und seiner Nachfolger. Irisches findet sich trotz der mittelalterlichen Bezeichnung Libri sancti Kyliani unter diesen Manuskripten nicht, dafür sind viele von ihnen in angelsächsischer Schrift geschrieben, die in Würzburg im 9. Jahrhundert noch Jahrzehnte hindurch von einheimischen Geistlichen geschrieben wurde, als überall sonst bereits die karolingische Minuskel herrschte ${ }^{3}$.

Als Chroust eine der wertvollsten Handschriften aus diesem Bestand studierte, den Kodex M.p.th.q.2, in italienischer Unziale des 5. Jh.s, mit dem Kommentar des hl. Hieronymus zum Ecclesiasten, fiel ihm auf fol. Iv ein Vermerk in angelsächsischer Halbunziale auf:

Cuthsunithae. boec. thaerae abbatissan. (Ein Buch der Cuthsuuith, der Äbtissin.)

1 Monumenta Palaeographica. Denkmäler der Schreibkunst im Mittelalter. In Verbindung mit Dr. Hans Schnorr von Carolsfeld (später: In Verbindung mit Fachgenossen) hg. v. Anton Ch roust, Abt. 1, Ser. 1, 1-3 (München 1902-1905); Abt. 1, Ser. 2, 1-3 (München 1911-1917); Abt. 1, Ser. 3, 1-2 (Leipzig 1931-1935). Im Folgenden sind bei Zitaten von Archivalien folgende Abkürzungen benutzt: UAWb, ARS (= Akten des Rektors und Senats der Universität Würzburg); BHStAM (= Bayerisches Hauptsstaatsarchiv München).

2 Ludwig Traube, Geschichte der Paläographie, in: Ders., Vorlesungen und Abhandlungen 1, hg. v. Franz Boll (München 1909) 48f.; Bernhard Bischoff, Josef Hofmann, Libri sancti Kyliani. Die Würzburger Schreibschule und die Dombibliothek im VIII. und IX. Jahrhundert (Quellen und Forschungen zur Geschichte des Bistums und Hochstifts Würzburg 4, Würzburg 1952) 63ff. (Hofmann); Hermann Knaus, in: Mittelalterliche Bibliothekskataloge Deutschlands und der Schweiz IV/2 (München 1979) 970f. Zu Erzbischof Laud vgl. Hugh Trevor-Roper, Archbischop Laud 1573-1645 (London ${ }^{3} 1988$ ) bes. $271 \mathrm{ff}$. 
Als Paläograph erkannte Chroust natürlich die angelsächsische Hand; zur genauen Datierung bedurfte es jedoch des Rats eines Spezialisten für Altenglisch, und Würzburg besaß in der Zeit des Aufblühens der historischen Sprachwissenschaft in Deutschland einen guten Fachmann: den Extraordinarius für Anglistik Max Förster. An diesen wandte er sich im Juni und November I 900 und dann mehrfach im Jahr I 90 I um Rat. Im Schreiben Chrousts an das Kultusministerium vom 9. Dezember I90 I und im Bericht des Senats der Universität vom 23. Juli $1902^{4}$ heißt es, Chroust habe Förster gefragt, ob Cuthsuuith ein angelsächsischer Name sei, was Förster bejahte und durch Mitteilungen über diese Person ergänzte. Förster machte auch darauf aufmerksam, dass die Eintragung als eine der ältesten datierbaren Aufzeichnungen in altenglischer Sprache für die englische Philologie von großem Interesse sei, und richtete daher an Chroust die Anfrage, ob er mit Nennung von Chroust als Finder eine diesbezügliche Notiz in Brandls „Archiv“ bringen dürfe, was Chroust auch zusagte, dann aber vorläufig zurückzog, bis das betreffende Heft seiner Monumenta Palaeographica erschienen sei. Als Grund gab er Schwierigkeiten an, die er andernfalls mit seinem Verlag haben würde ${ }^{5}$. Chroust seinerseits behauptete, Förster habe ihm nur Literatur zu Cuthsuuith genannt. Wie dem auch sei, jedenfalls identifizierte Chroust, was noch heute Bestand hat und von Bernhard Bischoff und Elias Avery Lowe akzeptiert wurde ${ }^{6}$, die Cuthsuuith mit einer in zwei Urkunden von ca. 700 genannten Äbtissin aus der Diözese Worcester; der genaue Ort ihres Klosters, Inkberrow, wurde von der Forschung erst später gefunden ${ }^{7}$. Somit wird deutlich, dass der berühmte italienische Unzialkodex zunächst

4 BHStA, MK 11364; UAWb, ARS Nr. 1623. Ausführlich Chroust ans Ministerium vom 09.12.1901, ebd. Nr. 1622.

5 Archiv für das Studium der neueren Sprachen und Literaturen, begründet von Ludwig He R IG, hg. (ab Bd. 94, 1895) v. Alois Brandl, Anton Tobler. In Bd. 107 (= N. F. 7) (1901) 103ff., erschien mit der Sigle A(lois) B(randl) unter: „Kleine Mitteilungen“ eine Miszelle mit dem Titel: „Chrousts Fund einer der ältesten a(n)g(el) s(ächsichen) Aufzeichnungen“, mit der Beschreibung der Handschrift durch Chroust in Bd. V der ,Monumenta Palaeographica', der am 01.08.1901 erschien und Abbildung des Eintrags, die Chroust ermöglichte. Förster wird 105 erwähnt; er habe „sich für die Aufhellung der Stelle [...] sachkundig interessiert [...]“ Über Cuthsuuith hatte Felix Liebermann Auskunft erteilt, für die Datierung (8. Jh.) war zusätzlich Michael Tangl befragt worden. Über Förster, der später ein führender anglistischer Sprachwissenschaftler wurde, dessen besondere Verdienste in der Erforschung der Einflüsse des Keltischen auf das Altenglische und in der Verbindung von Sprachwissenschaft, Siedlungsgeschichte und Volkskunde lagen, vgl. Wolfgang ClemeN, in: NDB 5 (Berlin 1961) 279f; Frank Rutger Hausman N, Anglistik und Amerikanistik im „Dritten Reich“ (Frankfurt/M. 2003) 247-262.

6 Bischof F, Libri sancti Kyliani (wie Anm. 2) 88 und 159; Ders., Mittelalterliche Studien 2 (Stuttgart 1967) 324 und 333; Elias Avery Low E, Codices latini antiquiores 9 (Oxford 1959) 1430; DE Rs., Palaeographical Papers 1907-1965 1, hg. v. Ludwig Bieler (Oxford 1972) 243.

7 Monumenta Palaeographica Abt. 1, Ser. 1 (wie Anm. 1) Lieferung 5, Tafel 2. Vgl. dazu Patrick Sims-WilLiams, Cuthswith, seventh-century abbess of Inkberrow, near Worcester, and the Würzburg manuscript of Jerome on Ecclesiastes, Anglo-Saxon England 5, hg. v. Peter Clemoes (Cambridge 1976) 1ff. (mit reichen Literaturangaben). 
vor 700 von Angelsachsen, die bei ihren engen Kontakten mit Rom Handschriften unter anderem aus der berühmten, von Vivarium in Kalabrien in den Lateran verbrachten Bibliothek Cassiodors erhielten und in England kopierten ${ }^{8}$, nach England und von dort aus zu einem unbestimmten späteren Zeitpunkt, vielleicht unter Bischof Burkhard, nach Würzburg gebracht wurde9 . Die Vorgänge vom Sommer I90 I führten jedoch an der Universität Würzburg ein Jahr später zu einem politischen Eklat und leiteten den Sturz des bayerischen Kultusministers Robert von Landmann und letztlich auch den des Kabinetts Crailsheim (I 890-1903) ein. Der Hauptakteur war der Historiker Anton Chroust.

III.

Anton Julius Chroust entstammte einer kleinbürgerlichen Handwerkerfamilie ${ }^{10}$. Sein Vater, Sohn eines Gastwirts, arbeitete als Buchbinder, seine Mutter war die Tochter eines k. u. k. Börsenagenten. Der Name „Chroust“ bedeutet in der tschechischen Sprache „Maikäfer“, doch bevorzugte Anton Chroust offensichtlich die heute weitgehend gebrauchte französisierende Aussprache gegenüber der tschechischen mit deutlich ausgesprochenen ch und ou. In Kollegenkreisen in Würzburg war - das sei nicht verschwiegen - eine auch schriftlich niedergelegte (absichtliche?) Fehldeutung als „Mistkäfer“ verbreitet. Nach dem Besuch des Gymnasiums, „stets von der Gefahr bedroht, aus Mangel an Mitteln das Studium abbrechen zu müssen"11, studierte er ab I 882 Geschichte und Germanistik in Graz, ging dann im Oktober I 884 nach Berlin, wo er Schüler von Julius Weizsäcker, aber auch von Harry Bresslau und Wilhelm Wattenbach wurde; Weizsäcker regte seine Dissertation

8 Vgl. Wilhelm Levison, England and the Continent in the Eighth Century (Oxford 1947) 132ff.; Elias Avery Lowe, English Uncial (Oxford 1960) 18 und passim.

9 Vgl. Sims-Williams, Cuthswith (wie Anm. 7) 16: „[... [ reached Germany during the last three quarters of the eighth century“. Die Handschrift ist die Grundlage der kritischen Edition von Marc Adriaen, in: Corpus christianorum. Series latina 72 (Turnholti 1959) $247 \mathrm{ff}$.

10 Bis heute erschien über Chroust: Carl Erdmann, Einleitung in: Anton Chroust, Aufsätze und Vorträge zur fränkischen, deutschen und allgemeinen Geschichte (Leipzig 1939); Anton Bigelmair, Anton Chroust, in: ZBLG 15 (1949) 185ff.; DERs., Chroust, Anton, Universitätsprofessor 1864-1945, in: Lebensläufe aus Franken 6, hg. v. Sigmund Freiherr von Pölnitz (Würzburg 1960) 98ff.; Wilhelm Engel, Anton Chroust, in: NDB 3 (Berlin 1957) 251; Walter Höflechner, Alois Kernbauer, Vom Historischen Seminar der Karl-Franzens-Universität Graz. Eine Dokumentation im Rückblick auf 125 Jahre (Publikationen aus dem Archiv der Universität Graz 26, Graz 1991) 268ff.; Fritz Fellner, Doris A. Cor Radini, Österreichische Geschichtswissenschaft im 20. Jahrhundert. Ein biographisch-bibliographisches Lexikon (VKGÖ 99, Wien 2006) 79f.; Ausführlich würdigte Chroust Herde, Äbtissin (wie Anm. *); ders., Chroust. (wie Anm. *).

11 Erdmann, Einleitung (wie Anm. 10) V. Während seiner Gymnasialzeit half er im kleinen Laden seines Vaters aus. Für das Folgende bes. Höflechner, Kernbauer, Historisches Seminar (wie Anm. 10) $268 f f$. 
„Die Romfahrt Ludwigs des Bayern I 327-I 329“ an, mit der er am 20. Januar I 886 in Graz mit Auszeichnung promoviert wurde. Seine wirtschaftlichen Verhältnisse waren ärmlich, und nur eine kleine Erbschaft bewahrte ihn vor dem Abbruch des Studiums. I 88 5-I 887 besuchte er als außerordentliches Mitglied den I6. Kurs des IÖG in Wien und erhielt eine gründliche hilfswissenschaftliche Ausbildung. Zu seinen Kurskollegen zählten Bertold Bretholz, Wilhelm Erben und Michael Tangl. Am IÖG setzte ihn Theodor Sickel für die Arbeiten am Liber diurnus ein, doch wandte sich Chroust der Erforschung der Urkunden der Langobarden zu. Im Sommer i 887 wurde er - das war damals nichts Außergewöhnliches - mit seiner Dissertation an der Universität Graz für mittelalterliche Geschichte habilitiert; anfängliche Bedenken der Fakultät wegen seines jugendlichen Alters von 23 Jahren konnte er durch gute Leistungen zerstreuen. Das ist das Profil eines jungen, begabten und fleißigen Gelehrten, dessen Venia I 888 aufgrund seiner „Untersuchungen über die langobardischen Königs- und Herzogsurkunden“ um die historischen Hilfswissenschaften erweitert wurde $^{12}$. Aber in Graz gab es für ihn kein Fortkommen. Sein Schüler Carl Erdmann und sein Freund, der Theologe Anton Bigelmair, behaupteten später, sicher aufgrund von Informationen von Chroust selbst, dass dieser in Graz wegen seiner deutschnationalen Haltung (er war Mitglied im Nationalverein Südmark) am Widerstand der liberalen Regierung gescheitert sei ${ }^{13}$. Aus den Akten lässt sich diese Behauptung nicht erhärten, doch sind Universitäten und Ministerien in solchen Dingen bekanntlich sehr vorsichtig. Entscheidender dürfte jedoch gewesen sein, dass die Universität Graz um I 890 mit Unterstützung des als Berater des Ministeriums sehr einflussreichen Wiener klassischen Archäologen Otto Benndorf die klassischen Altertumswissenschaften stark ausbaute und zudem I89 I eine Lehrkanzel für Kunstgeschichte eingerichtet wurde, so dass für den sehr jungen Chroust in Graz kaum Aussichten auf ein Extraordinariat oder Ordinariat bestanden. ${ }^{14}$ An seiner nationalistischen Gesinnung, die durch den Besuch der Vorlesungen von Heinrich von Treitschke in Berlin verstärkt worden sein könnte, bestand freilich kein Zweifel. Seine aus Triest stammende Frau Johanna (I884-I958), eine Deutsch-Österreicherin, die er am 28. Dezember 1904 in Innsbruck nach Genehmigung durch das Ministerium heiratete ${ }^{15}$, war

12 Vgl. Leo Santifaller, Das Institut für österreichische Geschichtsforschung. Festgabe zur Feier des zweihundertjährigen Bestandes des Wiener Haus-, Hof- und Staatsarchivs (Veröff. des IÖG 11, Wien 1950) 112f.; Lнотsкy, Geschichte des Instituts (wie Anm. *) 187-192; Walter Höflechner, Die Vertretung der historisch-mediävistischen Hilfswissenschaften an der Universität Graz, ZHVSt 70 (1979) 34ff. Die Angaben bei Erdmann, Einleitung (wie Anm. 10) V sind zu berichtigen.

13 Erdmann, Einleitung (wie Anm. 10) VI; Bigelmair, Lebensläufe (wie Anm. 10) 100; Bigelmair, Chroust (wie Anm. 10) 186.

14 So nach freundlicher brieflicher Auskunft von Walter Höflechner (Graz) vom 24.10.1991.

15 Die entsprechenden Akten im Personalakt Chroust UAWb, ARS. Am 25.12.1905 wurde die Tochter Karoline Anna, am 28.01.1907 der Sohn Anton Hermann Karl geboren (ebd.). 
eine vorzügliche Italianistin; sie verfasste u.a. eine Monografie über die sardische Dichterin und Nobelpreisträgerin von I926 Grazia Deledda; außerdem versuchte sie, die wegen der Südtirolfrage mit Benito Mussolini zerfallene deutsche Rechte mit dem italienischen Faschismus zu versöhnen und soll dabei mit Mussolini selbst Gespräche geführt haben ${ }^{16}$.

Aber auch ein anderes, für Chroust fast noch wichtigeres Charakteristikum wurde bereits in Graz offenkundig: sein iraszibles Temperament und seine Streitsucht. Seine schwierige wirtschaftliche Lage und seine Chancenlosigkeit in Graz veranlassten ihn, mithilfe von Stieve I89I als Mitarbeiter der Historischen Kommission bei der Bayerischen Akademie der Wissenschaft nach München überzuwechseln. Nach anfänglich eingeschränkter Lehrtätigkeit in Graz gab er dort im Dezember I 893 seine Venia auf, nachdem er sich in München für das Gesamtgebiet der Geschichte erneut habilitiert hatte. In den endenden achtziger und den beginnenden neunziger Jahren hat er nach seinen Arbeiten über Ludwig den Bayern und die langobardischen Urkunden wichtige Aufsätze zu mittelalterlichen Quellen publiziert, u. a. über den Kreuzzug Barbarossas, die ihn in Kontakt mit den MGH in Berlin brachten; 1928 publizierte er die vorzügliche Edition „Quellen zur Geschichte des Kreuzzuges Kaiser Friedrichs I“ bei den $\mathrm{MGH}^{17}$. Auch in den folgenden Jahrzehnten

16 Sie ist Verfasserin u.a. von: Saggi di letteratura italiana. Da G. Carducci al futurismo 1-3 (Würzburg 1921-22); Grazia Deledda e la Sardegna (Rom/Mailand 1932); mit Hermann Willers, Einführung in die italienische Sprache (Leipzig 1940). Dazu viele Zeitungsaufsätze zum Lob des faschistischen Italiens. Vgl. die Würzburger Gestapoakte Chroust, Hermann Anton (StA Würzburg). Hier heißt es über seine Mutter Johanna, geb. Sander, geb. 14.04.1884 in Triest, Ehefrau von Prof. Anton Chroust, Tochter des Oberbezirksarztes Friedrich Sander und seiner Ehefrau Josefine, geb. Erlacher, sie sei „eine eifrige Anhängerin der italienischen faschistischen Bewegung und wurde im Jahre 1933 oder 1934 von Mussolini in Rom auch in Privataudienz empfangen. Sie befasste sich im Jahre 1934 ernstlich mit dem Plan, in Würzburg eine Ortsgruppe des Vereins, Societa Nazionale Dante Alleghiere (sic) ins Leben zu rufen, stieß hier aber auf Schwierigkeiten, die ihr bis jetzt die Bildung des Vereins nicht ermöglichten“. Eine Würzburger Dante-Gesellschaft, die mit der Società Dante Alighieri in Verbindung steht, wurde erst nach dem Zweiten Weltkrieg gegründet. Wegen ihrer zahlreichen Auslandskontakte und Italienreisen wurden Frau Chroust und ihr Sohn, Priv.-Doz. Hermann Anton, sowie ihre Tochter Karoline von der Gestapo überwacht (über Anton Chroust dagegen gab es offensichtlich keine Gestapoakte) und 1934 sogar der Spionage verdächtigt, was sich jedoch nicht erhärten ließ. Die Postüberwachung führte zu dem Ergebnis: „Der Schriftwechsel ließ zum Teil zwar eine reaktionäre Einstellung erkennen, Verfehlungen im strafrechtlichen Sinne waren jedoch nicht festzustellen." In der Frühzeit des Nationalsozialismus galten Kontakte zum Faschismus oder der (im Gegensatz zur wissenschaftlichen Società Dantesca Italiana) stark faschistisch geprägten Società Dante Alighieri noch als verdächtig. Erst am 29.06.1939 änderte sich das Bild (StA Würzburg, Gestapoakte Schmitt, Alois). Hier wird Johanna Chrousts guter Ruf und Leumund bestätigt. Über sie sei nichts Nachteiliges bekannt. Sie habe sich in den letzten Jahren wiederholt in Italien aufgehalten. „Sie war schon vor der nationalen Erhebung eine eifrigste Anhängerin der italienischen faschistischen Bewegung. Dem Nationalsozialismus steht sie gleichfalls bejahend gegenüber. Seit 1.5.37 ist sie Mitglied der NSDAP. Sie hat die Mitgliedsnummer 4642711. "Dass sie Gespräche mit Mussolini führte, habe ich in dessen Akten im Archivio Centrale dello Stato in Rom bislang nicht verifizieren können.

17 Quellen zur Geschichte des Kreuzzuges Kaiser Friedrichs I., hg. v. Anton Chroust (MGH SS rer. Germ. n. s. 5, Berlin 1928). 
ist er ein ausgezeichneter Mediävist geblieben. Bei der Historischen Kommission erwarteten ihn freilich andere Aufgaben: die Mitarbeit an der Edition der Wittelsbacher Korrespondenz in den „Briefen und Akten zur Geschichte des Dreißigjährigen Krieges“; I 903 publizierte er den neunten Band in dieser Reihe: „Vom Einfall des Passauer Kriegsvolks bis zum Nürnberger Kurfürstentag“"18; 1906 erschien sein Band „Der Ausgang der Regierung Rudolfs II. und die Anfänge des Kaisers Mathias“19, I 909 der Band: „Der Reichstag von I6I “"20, umrahmt von zahlreichen Aufsätzen. Später kamen grundlegende Aktenausgaben und Darstellungen zur Geschichte des I9. Jahrhunderts hinzu, so vor allem über das Großherzogtum Würzburg ${ }^{21}$ und die vielbändige Ausgabe der Gesandtschaftsberichte aus München I 8I4-I848 22 , nicht zu vergessen die Geschichte des fränkischen Kreises ${ }^{23}$. Chroust wurde also ein echter Professor für Mittlere und Neuere Geschichte und gehört zweifellos zu den bedeutenderen deutschen bzw. österreichischen Historikern der ersten Jahrhunderthälfte.

Die Münchner Atmosphäre, die Ballung junger Nachwuchstalente und die sich daraus ergebenden Eifersüchteleien, Rivalitäten und Intrigen waren seit jeher kein günstiger Nährboden für aufstrebende Historiker. Chroust wurde bereits I 894 in die schweren Auseinandersetzungen zwischen Felix Stieve, dem er seine Stelle zu verdanken hatte, und Moritz Ritter hineingezogen ${ }^{24}$. Die fast täglichen Treffen der Mitarbeiter der Kommission, neben Chroust Walter Goetz, Karl Brandi, Albert Stauffer und Karl Mayr, im Café Heck und die historischen und politischen Diskussionen konnten über Rivalitäten nicht hinwegtäuschen, über die im Nachlass von Goetz viele Details berichtet werden ${ }^{25}$. Als

18 Anton Chroust, Der Einfall des Passauer Kriegsvolks bis zum Nürnberger Kurfürstentag (Briefe und Akten zur Geschichte des Dreißigjährigen Krieges 9, München 1903).

19 Anton Chroust, Der Ausgang der Regierung Rudolfs II. und die Anfänge des Kaisers Mathias (Briefe und Akten zur Geschichte des Dreißigjährigen Krieges 10, München 1906).

20 Anton Chroust, Der Reichstag von 1613 (Briefe und Akten zur Geschichte des Dreißigjährigen Krieges 11, München 1909).

21 Anton Сн roust, Geschichte des Großherzogtums Würzburg (1806-1814). Die äußere Politik des Großherzogtums (Veröff. der Gesellschaft für fränkische Geschichte 9/1, Würzburg 1932).

22 Anton Chroust, Gesandtschaftsberichte aus München 1814-1848, I 1-6. Die Berichte der französischen Gesandten (München 1935-37); II 1-4. Die Berichte der österreichischen Gesandten (München 1939-42); III 1-5. Die Berichte der preußischen Gesandten (München 1949-51).

23 Anton Chroust, Geschichte des fränkischen Kreises, Darstellung und Akten 1 (Leipzig 1910).

24 Die betreffenden Korrespondenzen aus dem Archiv der Historischen Kommission hat mir Herr Kollege Eberhard Weis (München) zur Verfügung gestellt. Felix Stieve widmete Chroust sein erstes in München entstandenes Werk: Felix Stieve, Abraham von Dohna. Sein Leben und sein Gedicht auf den Reichstag von 1613 (München 1896).

25 Ausgewertet von Wolf Volker Weigand, Walter Wilhelm Goetz 1867-1958. Eine biographische Studie über den Historiker, Politiker und Publizisten (Schriften des Bundesarchivs 40, Boppard a. Rhein 1992). Ich bin Helmuth Goetz zum Dank für die Genehmigung zur Benutzung des Nachlasses verpflichtet. 
Österreicher relativ niedriger, nichtakademischer und ärmlicher Herkunft musste er es in der Gesellschaft meist akademisch-großbürgerlicher oder aus der höheren Beamtenschaft stammender Söhne schwer haben. Und hinzukam, dass er getaufter Katholik, wenn auch der Kirche längst entfremdet war. Die Nachwehen des „Kulturkampfes“ waren noch stark. Da half ihm auch sein Nationalismus nichts. Als Ludwig Quidde I 894 seine berühmte Parodie auf Wilhelm II. publizierte, stieß diese bei Chroust und seinen Kollegen auf scharfe Ablehnung ${ }^{26}$. Als Erich Marcks I9I3 nach München berufen wurde, wollte er den Neuhistoriker Goetz auf dem mittelalterlichen Lehrstuhl neben sich haben, auf alle Fälle jedoch eine Berufung des österreichischen „Katholiken“ Chroust von Würzburg nach München verhindern, um nicht als Protestant drei katholischen Kollegen gegenüberstehen zu müssen; eventuell wollte er Brandi tolerieren, der katholisch getauft, aber evangelisch verheiratet war ${ }^{27}$. In Leipzig nützte das freilich Brandi, den mit Goetz nicht spannungsfreie freundschaftliche Beziehungen verbanden, I9 I 5 nichts. Dorthin wurde Goetz berufen, und er musste annehmen, obschon er Leipzig nicht mochte und gern nach München gegangen wäre. Eberhard Gothein, der wie Goetz anerkannte, infrage gekommen wäre ${ }^{28}$, wurde nicht berücksichtigt, weil er Jude war. Schon in Leipzig sagte mir der Dekan vertraulich, dass ich annehmen müsste, denn Deine [Brandis] Berufung sei nicht möglich. Das bestätigte man mir im Dresdener Kultusministerium. Trotz meiner Einwände: es sei unmöglich, im Lande der Reformation einen Katholiken als Historiker einzustellen ${ }^{29}$. Natürlich wurde nach außen ein „objektives“ Argument verbreitet: Brandis Interessen deckten sich zu sehr mit denen Seeligers. Diesen Hintergrund wird man berücksichtigen müssen, will man die Auseinandersetzungen in Würzburg verstehen. Sehr vielsagend ist die Bemerkung von Goetz über seine Beziehungen zu Chroust: Chroust [...], dessen Verhältnis zu mir in einem Wechsel stärksten Abgestoßenseins und dann wieder langsam sich Zuneigens besteht. Er ahnt drum wohl kaum etwas, wie ferne ich ihm stehe, selbst wenn ich mich dazu zwinge, seine Freundlichkeiten zu erwidern ${ }^{30}$. Chroust versuchte also, ein gutes Verhältnis zu Kollegen herzustellen, war aber dabei offensichtlich wenig erfolgreich. Immerhin hat ihm die Münchner Universität die Neuhabilitation und damit I 898 die Berufung auf das Würzburger Extraordinariat ermöglicht.

Kurz zuvor, gegen Ende I897, hatte er jedoch sein großes mediävistisches Unternehmen, das ihn auch international bekannt machte, die Monumenta Palaeographica initi-

26 Goetz an Brandi: 12.06.1894; Weigand, Goetz (wie Anm. 25) 42, 43 Anm. 58. Über Quidde vgl. Utz-Friedebert Taube, Ludwig Quidde. Ein Beitrag zur Geschichte des demokratischen Gedankens in Deutschland (Kallmünz 1963), über den, Caligula' ebd. 57ff.

27 Marcks an Goetz: 28.04.1913; Weigand, Goetz (wie Anm. 25)144f. mit Anm. 29.

28 Weigand, Goetz (wie Anm. 25) 151.

29 Goetz an Brandi: 27.08.1915; Weigand, Goetz (wie Anm. 25) 153.

30 Goetz an Brandi: 15.08.1894; Weigand, Goertz (wie Anm. 25) 43 Anm. 59. 
iert, das er mit dem Münchner Bibliothekar Hans Schnorr von Carolsfeld ab Ostern I 898 beim Münchner Verlag Bruckmann herauszugeben beabsichtigte. Am 2 I. Dezember I 897 wandte er sich in dieser Sache an das bayerische Kultusministerium und bat um umfangreiche Ausnahmegenehmigungen bei der Benutzung bayerischer Bibliotheken ${ }^{31}$. Seine Forderungen wurden vom Direktor der kgl. Hof- und Staatsbibliothek mit Schreiben vom 30. Januar I 898 an das Kultusministerium als maßlos in scharfer Form zurückgewiesen $^{32}$. Chroust, so heißt es darin, wünsche, ich möchte fast sagen, Befugnisse eines Diktators, gegen welche die betroffenen Biblibotheksvorstände [...] wenig mehr zu sagen hätten. Der Direktor der Münchner Staatsbibliothek stieß sich an Chrousts Bitte, ihm im weitest zulässigen Maße entgegenzukommen. [...] Als ob das nicht jede der genannten Bibliotheken von selbst thun würde [...]. Denn alle meine Kollegen in Bayern sind hierin so liberal wie ich und werden gewiß auch diesem schönen Unternehmen gegenüber so entgegenkommend sein als sie können und mit ihren Pflichten und ihrem Gewissen für vereinbar halten. Chroust aber würde Unbilliges und Unerfüllbares verlangen und sich selbst als Richter aufwerfen, was er verlangen kann und was man ihm zu gewähren hat.

Chroust hatte sich offensichtlich, seinem, wie der Brief zeigt, bereits damals fest etablierten Ruf als Streithahn entsprechend, wie ein Elefant im Porzellanladen benommen und ohne diplomatisches Geschick zu hohe Forderungen gestellt, die gewiss zur Erleichterung und Beschleunigung seiner Arbeiten geeignet waren, bei den hohen Herren der Staatsbibliothek, die ohnehin in einem von Eifersüchteleien nicht freien Verhältnis zum Lehrkörper der Universität standen, auf Ablehnung stoßen mussten, zumal der Antragsteller ein machtloser Privatdozent war und er erst im Laufe der ersten Runde dieser Auseinandersetzungen als Extraordinarius nach Würzburg berufen wurde. Das Kultusministerium behandelte den Fall emotionslos und wies am io. Februar I 898 die Senate der Universitäten München, Würzburg und Erlangen an ${ }^{33}$, dass gemäß dem Antrag Chrousts die Benützung der Handschriften zu diesem Zweck insoweit zu gestatten sein wird, als dies mit den bestehenden Grundsätzen und Vorschriften über die Benützung und Versendung von Handschriften sich vereinbaren läßt.

Chroust hat als Zweck des Werkes hervorgehoben, es solle der theoretischen Erforschung der Geschichte der Schrift sowie dem praktischen Unterricht in der Paläographie dienen ${ }^{34}$. Freilich war die Ausstattung der im Lichtdruckverfahren ausgeführten Lieferungen - die erste erschien bereits I 899 - viel zu aufwendig und viel zu teuer, als dass der zweite Teil

31 Die folgenden Ausführungen beruhen auf dem Akt BHStAM, MK 14244: Denkmäler der Schreibkunst des Mittelalters, Monumenta palaeographica, von Prof. Dr. Chroust.

32 Ebd.

33 Ebd.

34 So in seinem Schreiben an das Kultusministerium vom 21.12.1897, ebd. 
dieses Programms hätte erfüllt werden können. Man wird dem Verlag Bruckmann durchaus zugutehalten müssen, dass die Publikation eines solchen Werkes „nicht der kaufmännischen Erwägung des Verlages, sondern dem Wunsch, einem Bedürfnis der Wissenschaft entgegenzukommen", entsprungen sei und daß an einen Gewinn [...] von Haus aus dabei nicht zu denken war ${ }^{35}$. Offensichtlich waren Chroust und der Verlag bei der Abschätzung des finanziellen Risikos und der zu erwartenden Subskriptionen doch zu optimistisch gewesen. Bereits im April I 899 versuchte daher der Verlag, mithilfe des bayerischen Kultusministeriums den Absatz zu steigern. Am 28. dieses Monats ${ }^{36}$ teilte Bruckmann dem Ministerium mit, dass die Monumenta Palaeographica aus Kostengründen nur publiziert werden könnten, wenn alle infrage kommenden Institute es anschafften; der Verlag bat Entsprechendes zu veranlassen und wies darauf hin, es sei das erste große, in Deutschland von einem deutschen Gelehrten edierte Werk, welches die gesamte Entwicklung der lateinischen und deutschen Schrift von ihren Anfängen an mit besonderer Berücksichtigung der Entwicklung der Schrift in Deutschland, besonders in Bayern darzustellen unternimmt. Bisher sei die Forschung auf diesem Gebiet so gut wie ausschließlich auf französische und englische Werke angewiesen ${ }^{37}$, die wegen ihrer außergewöhnlichen Kostspieligkeit im ganzen Königreich Bayern nur in je einem Exemplar vertreten sind. Der Verlag übersah dabei, dass ebendies auch das wesentliche Hindernis für eine weitere Verbreitung seines Produkts war und dass sein Wunsch, es solle als Lehrmittel nicht nur für Universitäten, sondern auch Lyzeen, Gymnasien, Kunstschulen u.a. dienen, deshalb einigermaßen illusorisch war. Das Ministerium antwortete am 5. Mai I 899 sachlich $^{38}$, dass die höheren Lehranstalten und öffentlichen Bibliotheken Bayerns generell ermächtigt sind, die ihnen passend erscheinenden Werke anzuschaffen, sofern die etatmäßigen Mittel hierzu ausreichen. Zwei Jahre später wandte sich der Verlag Bruckmann noch einmal unter Berufung auf die Korrespondenz von I 899 an das Ministerium ${ }^{39}$, teilte mit, dass die dritte Lieferung erschienen sei und die vierte in Kürze erscheinen werde, und wies darauf hin, dass das preußische Unterrichtsministerium I 2 Exemplare abgenommen habe, während aus Bayern bislang nur drei Subskriptionen vorlägen. Noch nicht einmal das Historische Seminar der Universität München habe das Werk subskribiert. Dem Brief wurden positive Rezensionen beigefügt, das Ministerium wurde erneut gebeten, bei den betreffenden staatlichen Institutionen die Subskription zu

35 Bruckmann an das bayerische Kultusministerium 06.02.1903, ebd.

36 Ebd.

37 Gemeint sind wohl vornehmlich: Recueil des fac-similés à l'usage de l'École des Chartes, Fasz. I-IV (Paris 1880/87), Album paléographique [...] reproduits par la Société de l'École des Chartes (Paris 1887); Palaeographical Society, Facsimiles of Manuscripts and Inscriptions, Ser. I-II, hg. v. Edward Augustus Bond u.a. (London 1873/94).

38 Wie Anm. 31.

39 Schreiben vom 03.04.1901, ebd. 
fördern. Bereits am Io. März I90 I ${ }^{40}$ hatte es jedoch die Senate der bayerischen Universitäten, die Lyzeen und Bibliotheken auf das Werk aufmerksam gemacht und auf den Preis von 20 Mark pro Lieferung hingewiesen mit dem Zusatz, Mittel zur Subskription stünden dem Ministerium nicht zur Verfügung.

Es waren jene Monate, in denen Chroust an der fünften Lieferung arbeitete, in der dann der Vermerk der Cuthsuuith erschien ${ }^{41}$. Offensichtlich war der Fortgang des Werkes damals durch einen mit einem Vergleich beendeten Prozess zwischen Chroust und dem Verleger gefährdet. Aber es dauerte noch einmal zwei Jahre, bevor Herausgeber und Verlag sich entschlossen, Zuschüsse beim Kultusministerium zu beantragen. Das geschah mit Schreiben Bruckmanns vom 6. Februar $1903^{42}$. Man hatte damals immerhin I I9 Subskriptionen aufzuweisen, dennoch wurde das materielle Opfer des Verlags als sehr groß bezeichnet, und er bat um eine entsprechende Subvention. Damit musste das Kultusministerium ein Gutachterverfahren in Gang setzen; nach Aktenlage geschah das jedoch erst am I4. März I906: mit Schreiben von diesem Tage bat es die Bayerische Akademie der Wissenschaften um Gutachten zu Chrousts Unternehmen ${ }^{43}$. Bereits am 24. April sandte der Akademiepräsident entsprechende Gutachten an das Ministerium ${ }^{44}$ : ein kürzeres von Henry Simonsfeld (3 I. März I906) und ein ausführlicheres von Hermann Grauert, der sich zum Nutzen der Sache eine Woche länger Zeit gelassen hatte (8. April I906). In die vielen positiven Stimmen zu Chrousts Magnum Opus hatte die kritische Stimme von Johannes Haller, zeitlebens ein ebenso scharfsinniger wie übertreibender Kritiker und als Polemiker Chroust durchaus ebenbürtig, einigen Missklang gebracht ${ }^{45}$. Die beiden Münchner Gutachter berücksichtigten Hallers Einwände zwar, urteilten aber ausgewogen. Das Gutachten Simonsfelds ist insgesamt positiv, würdigt ein wundervoll ausgeführtes, paläographisches Prachtwerk ersten Ranges und die gute Auswahl, kritisiert aber in Anlehnung an Haller, dass die Darstellung der Schriftenentwicklung außerhalb Deutschlands nur beabsichtigt, aber nicht verwirklicht worden sei. Die Erforschung der Schreibschulen wird von ihm zwar bejaht, aber im gleichen Atemzug bezweifelt, ob der von Chroust eingeschlagene Weg der richtige sei; denn die angestrebten Ergebnisse wären durch Einzelmonografien besser erreicht worden. Die gebotenen Tafeln belegten nicht den ganzen Umfang der Schreibtätigkeit der Skriptorien. Chroust liefere sehr wichtige Beiträge zur Geschichte der Schrift in den betreffenden Schreibschulen, aber keine abgeschlossenen

\footnotetext{
40 Ebd.

41 Monumenta Palaeographica I ser. 5 (wie Anm. 1) Tafeln 2-3.

42 Wie Anm. 35.

43 Ebd. Es ist möglich, dass der Akt hier unvollständig und Korrespondenzen zwischen 1903 und 1906 verloren sind.

44 Ebd.

45 Vgl. seine Rezension in: Centralblatt für das Bibliothekswesen 20 (1903) 359ff.
} 
Monographien. Bemängelt wird auch das große Format und mit Haller die allzu luxuriöse Ausstattung; es sei ein Prachtwerk für Liebhaber und Bibliotheken, wegen des hohen Preises aber kein Lehrmittel für Universitäten, dafür auch zu unhandlich; für Privatgelehrte sei es unerschwinglich. Insgesamt jedoch befürwortet Simonsfeld einen Zuschuss aus Reichsmitteln, fordert aber einen genauen, detaillierten Plan für die Weiterführung. Das Gutachten Grauerts ist ausführlicher und gründlicher. Grauert findet den Plan für das Werk an sich gut, bezweifelt aber, ob ein einzelner ihn verwirklichen könne. Deshalb habe Chroust auch zu Recht für das spätere Mittelalter Mitarbeiter herangezogen. Die bisherigen 2 I Lieferungen seien ein Prachtwerk der Wissenschaft; es gebe aber auch Mängel in der Ausführung. Unter Verweis auf die Kritik Hallers betont auch Grauert, dass der Plan des Unternehmens nur zum Teil verwirklicht worden sei, dass in der Zusammenstellung der Lieferungen Willkür und Zufall herrschten, dass die abgebildeten Beispiele oft ohne innere Beziehung zueinander stünden; er verweist aber auch darauf, dass eine gewisse Ordnung durch Tabellen im Schlussheft hergestellt werde. Er geht sodann auf Fehler Chrousts in Einzelheiten ein, bemängelt, dass das von den Schreibschulen gegebene Bild unvollständig sei; das Spätmittelalter sei zu spärlich vertreten. Dennoch ist Grauert ohne Bedenken für die Gewährung einer Reichssubvention. Die Monumenta Palaeographica seien ein rühmliches Unternehmen, dessen Fortführung, volle Ausgestaltung und Vollendung der deutschen Wissenschaft zu hoher Ehre gereichen wird, sofern nur geeignete Vorkehrungen getroffen werden, um die bisher hervorgetretenen Missstände in der Publikation zu beseitigen. $\mathrm{Zu}$ den Missständen gehörten auch die luxuriöse Ausstattung und der hohe Preis von 20 Mark pro Lieferung von zehn Tafeln. Wegen dieses Preises seien Einzelkäufer in sehr großer Zahl nicht zu gewinnen. Für Professoren und Studenten sei das Werk ohnehin viel $\mathrm{zu}$ teuer, und so blieben als potenzielle Abnehmer nur Bibliotheken und Universitäts-Seminare, daneben auch solche in Frankreich, England und Amerika. Bezüglich der Verwendbarkeit im akademischen Studienbetrieb ist Grauert etwas optimistischer als Simonsfeld: ein leicht zugängliches Hilfsmittel für den paläografischen Unterricht werden die Monumente Palaeopraphica nur werden, wenn jede deutsche, deutsch-österreichische, belgische, holländische, englische und französische Universität mindestens zwei Exemplare erwerben könnte. Grauert verweist auf die Bedeutung des Werkes für das Ansehen der deutschen Wissenschaft; es könne den großen paläographischen Publikationen der anderen modernen Kulturvölker ebenbürtig zur Seite gestellt werden. Die technische Ausführung sei vorzüglich, die Erläuterungen Chrousts, von einzelnen Missgriffen abgesehen, sehr gut. Er empfiehlt jedoch, Chroust als Leiter des Unternehmens einen Kreis von beratenden Fachleuten zur Seite zu stellen, Spezialisten für einzelne Gebiete; er schlägt dafür eine Reihe von Personen vor, die damals Rang und (oder) Namen hatten: Reinhold Koser, Oswald Holder-Egger, Michael Tangl, Konrad Burdach, Johannes Haller, Karl Hampe, Harry Bresslau, Ludwig Traube, Emil von Ottenthal, Oswald Redlich u.a. Relativ spät 
verweist Grauert auf den entscheidenden methodischen Mangel des Werkes: genaue Forschungen, wie sie Traube über die Schriftenentwicklung vom Altertum zum Mittelalter geboten habe, lassen sich in dem Werk, das ein ganzes Jahrtausend umfasst, nicht durchführen. Die Schreibschulen könnten hier nicht bis in alle Verästelungen untersucht werden. In der Tat beruht das Konzept Chrousts angesichts der von Traube begonnenen, später vor allem von Elias Avery Lowe und Bernhard Bischoff fortgesetzten verfeinerten Skriptorien-Forschung, die bis heute freilich kaum wesentlich über das 9. Jahrhundert hinausreicht, auf einer viel zu groben und undifferenzierten Vorstellung von Schreibschulen. Resümierend hält Grauert die Monumenta Palaeographica dennoch für bedeutend und förderungswürdig. Da sie bereits von der Kaiserlichen Akademie in Wien bezuschusst worden seien, empfiehlt er einen Zuschuss von I 8.000 Mark, eventuell höher, weist aber noch einmal darauf hin, dass das Werk für Süddeutschland ergänzt, für Nord-, West- und Ostdeutschland fortgeführt werden solle.

Das Akademiegutachten schließt sich dem Gutachten Grauerts an, befürwortet sogar einen viel höheren Reichszuschuss von 30.000 Mark. Es empfiehlt die Berufung eines Beirats von höchstens zehn Mitgliedern, der aber nicht, wie Grauert vorschlägt, ausschließlich aus Universitätslehrern, sondern auch aus Archivaren bestehen solle. Chroust solle mehr wissenschaftliche Hilfskräfte erhalten und der Preis solle so gestaltet werden, dass das Werk auch für breite Kreise erschwinglich würde. Das Letztere war nicht mehr als ein frommer Wunsch. Immerhin wird man den Gutachtern und der Akademie zugestehen müssen, trotz aller berechtigten Bedenken den Antrag Chrousts und des Verlags fair behandelt und die Fortführung des Unternehmens damit gesichert zu haben. Am 3. Mai $1906^{46}$ schrieb das Kultusministerium an das Staatsministerium des kgl. Hauses und des Äußeren und befürwortete auf der Basis der von der Akademie eingereichten Gutachten einen entsprechenden Reichszuschuss. Das Schreiben enthält eine kurze Schilderung des Werdegangs Chrousts und hebt dabei besonders hervor, dass er sich um das Zustandekommen der im vorigen Jahre gegründeten Gesellschaft für fränkische Geschichte sehr verdient gemacht habe, deren geschäftsführender Sekretär er sei ${ }^{47}$. Es dauerte einige Zeit, bis sich mit Schreiben vom 4. Februar 1907 das Reichsamt des Inneren bereit erklärte, einen auf acht Rechnungsjahre zu verteilenden Reichszuschuss von 10.000 Mark zu gewähren ${ }^{48}$. Die

46 Wie Anm. 31.

47 Die Gesellschaft für fränkische Geschichte wurde am 17.12.1904 in Nürnberg auf einer von Chroust und Sebastian Göbel, Reichsarchivrat und Vorstand des Kreisarchivs Würzburg, zusammengerufenen Versammlung gegründet; vgl. Erster Jahresbericht der Gesellschaft für fränkische Geschichte für das Jahr 1905 (Würzburg 1906). Vgl. dazu: Dokumente zur Geschichte der Gesellschaft für fränkische Geschichte und ihres Umfeldes 1905-1961, hg. v. Alfred Wendehorst (Veröff. der Gesellschaft für fränkische Geschichte XIII/48, Stegaurach $\left.{ }^{2} 2010\right) 13 \mathrm{ff} .$, Nr. $1 \mathrm{ff} .$.

48 Wie Anm. 31. 
gemäß Finanzierungsplan des Verlags Bruckmann erforderlichen weiteren 6.00o Mark sollte jedoch das bayerische Kultusministerium zuschießen. Dieses wandte sich daraufhin am 22. Februar $1907^{49}$ an die Münchner Akademie, die die Summe aufbringen sollte, da dem Ministerium dafür Mittel fehlten. Das Reichsamt habe auch, so heißt es in dem Schreiben, vorgeschlagen, dass die Akademie Chroust beratende Fachleute und Mitarbeiter zur Verfügung stellen und die Aufsicht über das Unternehmen übernehmen solle. Am 7. März $1907^{50}$ teilte die Akademie dem Ministerium mit, dass sie sich außerstande sehe, den Zuschuss von 6.00o Mark zu übernehmen. Sie empfahl dem Ministerium, einen Antrag auf Bewilligung der Mittel an den Landtag zu stellen; beratende Fachleute wolle sie Chroust dagegen zur Verfügung stellen. Chroust sperrte sich anfangs gegen die Unterstellung der Monumenta Palaeographica unter eine Akademische Kommission, da er sie als unzweckmäßig ansah ${ }^{51}$, erklärte sich dann jedoch bereit, die Zentraldirektion der Monumenta Germaniae Historica als Aufsichtsgremium zu akzeptieren, wollte jedoch dieser nur Bericht erstatten und bat, davon abzusehen, ihr die Aufnahme jedes einzelnen Stücks zur Genehmigung vorzulegen, was die Zentraldirektion auch akzeptierte, aber die Vorlage des allgemeinen Editionsplans zur Prüfung verlangte ${ }^{52}$, wobei sich Chroust bereit erklärte, die Anregungen der Kommission zur Aufnahme einzelner noch fehlender Gruppen zu berücksichtigen. Mit der Angelegenheit wurde I 908 schließlich die Reichskanzlei befasst; Mitglieder des Beirats wurden der Vorsitzende der Zentraldirektion der MGH und Generaldirektor der preußischen Staatsarchive Koser, die Professoren Bresslau (Straßburg), Ottenthal (Wien), Tangl (Berlin) und Elias von Steinmeyer (Erlangen). Im Übrigen ging es um die Auszahlung des Reichszuschusses von ı.00o Mark, die das Reichsamt des Inneren von der Gewährung des Zuschusses von weiteren 6.00o Mark durch Bayern abhängig gemacht hatte, die erst im Haushaltsjahr I9 Io/ I I zur Verfügung standen ${ }^{53}$. Die Reichskanzlei genehmigte am 4. Juli I 908 die Zahlung von je 4.000 Mark für I 908 und I 909 direkt an Bruckmann und machte nur noch die Restzahlung von 2.000 Mark von der Bewilligung des bayerischen Anteils abhängig54. Als Dank widmete Chroust I9I7

49 Ebd.

50 Ebd.

51 Schreiben des Kultusministeriums an die Akademie vom 18.04.1907, ebd.

52 Schreiben der Akademie an das Kultusministerium vom 12.06.1907, des Kultusministeriums an das Ministerium des königlichen Hauses und des Äußeren vom 24.09.1907 und 05.03.1908, Schreiben dieses Ministeriums an das Reichsamt des Inneren vom 28.09.1907 und 09.03.1908, des Kultusministeriums an die Akademie vom 17.02.1908 und des Reichskanzlers (gez. v. Bethmann-Hollweg) an das bayerische Staatsministerium des königlichen Hauses und des Äußeren vom 04.07.1908, ebd.

53 Vgl. Schreiben des Kultusministeriums an das Ministerium des kgl. Hauses und des Äußeren vom 15.08.1910 und Einlaufprotokoll des Kultusministeriums vom 25.05.1910, ebd.

54 Schreiben wie Anm. 52. 
die zweite Serie der Monumenta Palaeographica König Ludwig III. von Bayern ${ }^{55}$. Der Erste Weltkrieg blieb dann nicht ohne Auswirkungen auf das Unternehmen. Am ıo. Mai I9I9 sandte Chroust ein ausführliches Schreiben an das Bayerische Staatsministerium für Unterricht und Kultus, das damals wie die gesamte Regierung vor der Revolution in München in Bamberg Schutz gesucht hatte ${ }^{56}$. Hier erfahren wir Einzelheiten über die Abwicklung des Projekts. Es seien, so berichtet Chroust, von den Monumenta Palaeographica bislang zwei Serien mit zusammen sechs Bänden im Doppelfolio-Format erschienen. Die Herstellungskosten seien sehr hoch gewesen; bei der ersten Serie habe der Verlag Bruckmann sehr hohe Verluste gehabt. Für die zweite Serie habe die Akademie der Wissenschaften in Wien, das Reichsamt des Inneren aufgrund eines Gutachtens der Preußischen Akademie der Wissenschaften in Berlin und die bayerische Staatsregierung aufgrund eines Gutachtens der Bayerischen Akademie der Wissenschaften einen Zuschuss von insgesamt I 8.000 Mark gewährt, wovon der Bayerische Landtag zwei Drittel (also I 2.000 Mark) bewilligt habe ${ }^{57}$. Die große wissenschaftliche Aufgabe, die sich der unterzeichnete Herausgeber gestellt, ließ sich aber in den bisher erschienenen sechs Bänden noch nicht lösen. Deshalb seien weitere vier Bände mit zusammen 320 Tafeln nötig. Die beigegebene Aufstellung sei bereits von den Akademien in Wien und Berlin gebilligt; sie enthält Material über Schreibschulen in Süddeutschland, Österreich, Ostdeutschland, BöhmenMähren, Nord- und Nordwestdeutschland und Mitteldeutschland (darunter Würzburg). Chroust berichtet weiter, dass die vier Bände nach Bruckmanns Berechnungen von I9I7 (unter verhältnismäßig noch günstigen Umständen) einen Zuschuss von 8.000 Mark pro Band, insgesamt also 32.00o Mark erfordern. Die Wiener Akademie habe einen Zuschuss von 4.000 Kronen zugesichert. Danach habe sich Chroust an das Reichsamt des Inneren gewandt, wo seit zwei Jahren über einen Zuschuss verhandelt werde. Die Gutachten der Preußischen Akademie der Wissenschaften und der Zentraldirektion der MGH hätten die Fortsetzung des Werkes sehr befürwortet. Laut beigegebenem Schreiben des Reichsministers des Inneren vom I 5. April I9 I9 habe sich die Reichsfinanzverwaltung bereit erklärt, die Herausgabe einer dritten und letzten Reihe der Monumenta Palaeographica finanziell zu fördern, falls die bayerische Regierung eine Beihilfe von mindestens 6.000 bis 8.000 Mark zusage. Chroust beantragt daher einen Zuschuss von 8.000 Mark. Nach Abschluss des Werkes werde dieses wenigstens dem äußeren Umfang nach den ersten Platz in der paläografischen Literatur einnehmen; es habe aber auch inhaltlich die Billigung

55 Vgl. Schreiben des Kultusministeriums an den Kabinettschef vom 30.12.1916, ebd. (Chroust's Monumenta Palaeographica sind ein Werk, mit dem Bayern sich sehen lassen kann.)

56 Wie Anm. 31.

57 Diese Zahlen lassen sich schwer mit dem obigen (bis 1911) in Einklang bringen. Doch fehlen im Akt Unterlagen für Zahlungen zwischen 1911 und 1919. 
aller wissenschaftlichen Institutionen erfahren. Die Fortsetzung werde auch ein Beweis dafür sein, dass in Bayern die wissenschaftliche Arbeit unerschüttert weiter geht und dass die große Verlagsindustrie in München auf der Höhe ihrer früheren Leistungsfähigkeit geblieben ist. Auch dem Ausland, besonders Frankreich gegenüber, sei das Werk ein positiver Beitrag. Der beantragte Betrag von 8.00o Mark könne in Raten von je 2.00o Mark gezahlt werden und solle voll Bruckmann zugutekommen. Am 5. Juni I9I9 antwortete das bayerische Kultusministerium Chroust ${ }^{58}$, die beantragte Summe von 8.00o Mark müsse vom Landtag genehmigt werden, da das Ministerium keine Mittel dafür besitze; es werde sich jedoch für eine Bewilligung im Staatshaushalt 1920 einsetzen. Doch kann unter den gegebenen Verhältnissen die [Be]willigung des Landtages noch nicht zugesichert werden, so heißt es abschließend. Damit enden die bayerischen Akten über die Monumenta Palaeographica. Die dritte Serie war bei Bruckmann nicht mehr zu verwirklichen. Chroust musste den Verlag wechseln; ihre 2 I Lieferungen erschienen bei Harrassowitz in Leipzig59.

\section{IV.}

Nach diesem Exkurs über die Geschichte der Monumenta Palaeographica zurück in den Sommer I90 I und nach Würzburg. Der von Chroust konsultierte Anglist Förster witterte natürlich in einer Zeit, da Handschriftenforschung und Neuentdeckungen in seinem Fach etwas galten, eine Chance, durch Publikation des, wie er glaubte, ältesten angelsächsischen Vermerks (heute spricht man vorsichtiger von einem „sehr frühen altenglischen Eintrag “60) seine wissenschaftliche Reputation zu erhöhen, während Chroust wohl fürchtete, um seine Meriten als Entdecker gebracht zu werden. Wie dem auch sei, jedenfalls war dieser Vorfall nur der Funke, der Sprengstoff zur Explosion brachte, der sich aus ganz anderen Gründen angesammelt hatte. Da der Bericht des Senats sich auf die Vordergründe beschränkt und die Hintergründe verschweigt, muss hier auf den sachlichen Bericht, den Kultusminister Landmann in der Angelegenheit Chroust am 8. Oktober I90 I an den Senat der Universität und am 2. Juli 1902 an den Prinzregenten Luitpold sandte ${ }^{61}$, und auf eine 25 Bögen umfassende Promemoria des Kultusministers an den Minister des kgl. Hauses und des Äu-

58 Ebd.

59 Siehe oben Anm. 1.

60 Simes-Williams, Cuthswith (wie Anm. 7) 1 : „a very early Old English inscription“. Förster glaubte nach dem Bericht des Senats vom 23.07.1902 (BHStAM, MK 11364), dass die Eintragung als älteste datierbare Aufzeichnung in angelsächsischer Sprache für die englische Philologie von großem Interesse sei [...].

61 BHStAM, MK 11364. Schreiben an den Senat vgl. Anm. 74. Danach das Folgende. Die unten zitierte Stellungnahme der Fakultät vom 04.07.1901 UAWb, ARS Nr. 1621. 
ßeren (Ministerpräsidenten) Freiherr von Crailsheim vom 29. Juli $1902^{62}$ zurückgegriffen werden. Hier offenbaren sich, über den Einzelfall hinaus, akademische Verhaltensmuster. Nach dem Tode Franz Xaver von Wegeles, des verdienstvollen Gründers des Würzburger Historischen Seminars, am I7. Oktober I 897 wurde der außerordentliche Professor für Bayerische Geschichte Theodor Henner zum ordentlichen, Anton Chroust zum außerordentlichen Professor in der ersten Sektion der Philosophischen Fakultät berufen, da das Geld für zwei Ordinariate damals fehlte ${ }^{63}$. Henner war ein durchschnittlicher Historiker, ${ }^{64}$ dessen Bevorzugung aus Gründen der Anciennität erfolgte. An Qualität war ihm Chroust zweifellos weit überlegen, doch war dessen Stern I 898 noch nicht aufgestiegen, und er konnte froh sein, damals den unangenehmen Münchner Verhältnissen nach Würzburg zu entrinnen. Immerhin beantragte die Fakultät I 899 mit sieben Stimmen Chrousts Ernennung zum Ordinarius, was etatmäßig vorgesehen war. In ihrem Schreiben an den Senat vom 4. Juli I90 I behauptete die Mehrheit der Fakultät später in nicht sehr überzeugender Weise, dieser Beschluss sei nur vorläufig und im Umlaufverfahren gefällt worden. Da der Antrag für die Aufstellung des Haushalts auf jeden Fall zu spät kam, erneuerten ihn für das Budget der 26. Periode im Frühjahr I9o I die Professoren Henner, der Chroust loyal unterstützte, Remigius Stölzle (Geschichte der Philosophie) und Georg Friedrich Unger (Alte Geschichte), fanden aber in der Fakultät keine Mehrheit mehr, die, nach dem Wortlaut des Ministerialschreibens an den Prinzregenten, inzwischen verschiedene neue Mitglieder erhalten hatte. Als erste Begründung wurde angegeben, Chroust habe keine die Beförderung rechtfertigenden wissenschaftlichen Leistungen aufzuweisen. Nun trifft es zwar zu, dass Chrousts große Publikationen erst seit 1902 zu erscheinen begannen, doch genügten seine bis dahin veröffentlichten Schriften durchaus den Anforderungen für eine Beförderung zum Ordinarius, und 1897 und 1899 hatte die damals noch nicht um verschiedene neue Mitglieder erweiterte Fakultät dem Antrag auf Ernennung Chrousts zum ordentlichen

62 BHStAM, MK 11364.

63 Vgl. Jürgen Petersohn, Franz Xaver Wegele und die Gründung des Würzburger Historischen Seminars (1857). Mit Quellenbeilagen, in: Vierhundert Jahre Universität Würzburg. Eine Festschrift, hg. v. Peter Baumgart (Neustadt a. d. Aisch 1982) 483ff. Chroust stand auf der Vorschlagsliste der Fakultät vom 26.01.1898 (UAWb, ARS, PA Chroust) hinter Felix Rachfahl (Privatdozent in Kiel) nur an zweiter Stelle (im Schreiben der Philosophischen Fakultät an den Senat vom 04.07.1901, UAWb, ARS Nr. 1621, „in weitem Abstand“, doch geht das aus den Laudationes nicht hervor); der Senat gab diese Liste am 07.02.1898 an das Ministerium. Die Ernennung Henners und Chrousts durch den Prinzregenten erfolgte am 03.04.1898 (ebd.). Warum Rachfahl nicht berufen wurde, geht aus den Akten nicht hervor. Am 23.04.1898 schied Chroust aus dem österreichischen Staatsverband aus (Urkunde der k.k. Statthalterei in Graz, ebd.).

$64 \mathrm{Zu}$ ihm vgl. Helmut Flachenecker, Theodor Henner, Geheimer Regierungsrat und ordentlicher Professor für Geschichte (1851-1928), in: Anfänge der geschichtlichen Forschung an der Universität Würzburg, 150 Jahre Historisches Institut/100 Jahre Kunstgeschichtliches Institut, hg. v. DEms., Franz Fuchs (Historische Studien der Universität Würzburg I, 9, Regensburg 2011) 108ff. 
Professor ja zugestimmt. Ein wesentlicher Grund für diese Ablehnung wird in der Korrespondenz mit dem Ministerium nicht berührt. Nach dem Rücktritt des Althistorikers Unger aus gesundheitlichen Gründen hatte die Mehrheit der Philosophischen Fakultät zur Neubesetzung des Lehrstuhls für Alte Geschichte am 24. Januar I 900 folgende Gelehrte vorgeschlagen: I. Ulrich Wilcken (Ordinarius in Breslau); 2. Alfred von Domaszewski (Ordinarius in Heidelberg); 3. Walter Judeich (Extraordinarius in Marburg) und 4. Cichorius Konrad (Extraordinarius in Leipzig). Man hatte sich für Wilcken, einen Schüler Alfred von Gutschmids und Theodor Mommsens, wegen dessen großer Vielseitigkeit und Kenntnis der orientalischen Sprachen entschieden; in der Tat war die Wahl auf einen der künftig bedeutendsten Althistoriker gefallen. Am 26. Januar I 900 reichten jedoch Henner und Stölzle ein Sondervotum ein, das die Absicht verfolgte, die finanziellen Mittel für eine Beförderung Chrousts zum Ordinarius zu schaffen. Sie schlugen vor, die Alte Geschichte vorerst nur durch einen Extraordinarius vertreten zu lassen und schlugen dafür die Privatdozenten Julius Kaerst (Leipzig) und Engelbert Drerup (München) vor. Dafür sollte Chroust in den Lehrstuhl eingewiesen werden. Obschon derartige Verschiebungen damals nicht unüblich waren, lehnte die Mehrheit der Fakultät den Vorschlag ab, und der Senat schloss sich am 3. Februar I 900 dem Listenvorschlag der Fakultät an; am 22. Juni ernannte der Prinzregent Wilcken zum Ordinarius für Alte Geschichte. Damit kam Wilcken als entschiedener Feind Chrousts und Henners nach Würzburg, und sein Eifer war nicht zu bremsen: Kaum in Würzburg angekommen, wurde er Dekan und Senator und verstärkte die Fakultätsmehrheit, die nach Chrousts Worten aus Katholikenfurcht ihn auf die andere Seite gewaltsam dräng $[\mathrm{t}] e^{65}$. Der eigentliche Grund für seine Ablehnung Chrousts war der zweite von der Fakultät genannte: da Henner die katholische Richtung vertrete, käme Chroust, der auch der katholischen Richtung zuneige, für die zweite ordentliche Professur nicht infrage; auf diese dürfe nur ein Ordinarius berufen werden, der ein überzengter Anhänger der liberalen Geschichtsauffassung sei. Angesichts der liberalen, der katholischen Kirche gegenüber distanzierten Einstellung Chrousts klingt es sehr merkwürdig, wenn die Fakultätsmehrheit betont, daß eine eventuelle zweite liberale Professur für Neuere Geschichte von einem Katholiken ebenso bekleidet werden könne, wenn nur sein Liberalismus außer Frage stehe. Als Beweis dafür, dass Chroust nicht geeignet sei, eine solche ausgesprochen liberale Geschichtsprofessur zu bekleiden, wurde angeführt, dass er I 894 in Tübingen und I 899 in Münster als geeignet für die Übernahme ausgesprochen katholischer Lehrstühle befunden

65 Die Akten über die Berufung Wilckens UAWb, ARS Nr. 897. Über den Papyrologen Wilcken vgl. Matthias Gelzer, in: Ders., Kleine Schriften 3 (Wiesbaden 1964) 336ff.; Friedrich Oertel, Ulrich Wilcken $1862-$ 1944, in: Bonner Gelehrte. Geschichtswissenschaften (Bonn 1968) 33ff.; Karlheinz Dietz, Die Entwicklung der Teildisziplin „Alte Geschichte“ in Würzburg (1877-1963), in: Anfänge der geschichtlichen Forschung (wie Anm. 64) 144ff. - Das Zitat aus dem Brief Chrousts an das Ministerium vom 09.12.1901, UAWb, ARS Nr. 1622. 
worden sei; zudem wurde auf einen Brief des Grazer Professors Eduard Richter verwiesen, der Chroust wissenschaftlich und menschlich lobt und seine Zugehörigkeit zu den Deutschnationalen, aber nicht zu den Radikalen Schönerers positiv hervorhebt; inwieweit das ein Beweis für seine „Katholizität“ darstellt, bleibt rätselhaft ${ }^{66}$.

In Philosophie und Neuerer Geschichte waren nach Ansicht der Fakultät ParallelLehrstühle mit Männern entgegengesetzter Weltanschauung zu besetzen. Nun wäre es völlig verfehlt zu glauben, ein solches Argument hätte beim damaligen bayerischen Kultusministerium Unmut hervorrufen können. Denn die bayerische Politik zwischen der Reichsgründung und dem Ersten Weltkrieg ist gekennzeichnet durch die Gegensätze zwischen liberalen Kabinetten und einer liberalen Ministerialbürokratie auf der einen und katholischen, „ultramontanen“ Parlamentsmehrheiten auf der anderen Seite. So war der damalige evangelische leitende Minister von Crailsheim ein „großer Bewunderer Bismarcks“, „Vertreter des bayerischen Beamtenliberalismus“ und „in seinem Denken [...] ganz der kulturkämpferischen Ära Lutz verhaftet" ${ }^{\text {"67 }}$, und auch der Mittelfranke Robert von Landmann, Minister des Inneren für Kirchen- und Schulangelegenheiten (Kultusminister), war ein Repräsentant der liberalen bayerischen Ministerialbürokratie ${ }^{68}$, gehörte aber als Katholik der eher liberal-konservativen, nicht der nationalliberalen Richtung an und war um Ausgleich mit der katholischen Parlamentsmehrheit bemüht. Bekanntlich hatte der I90 I noch nicht überwundene so genannte „Kulturkampf“ in Bayern nie die verbissenen ideologischen Formen angenommen wie andernorts, sondern war im Wesentlichen eine Auseinandersetzung um staatskirchenrechtliche Fragen geblieben, auch wenn die Sondergesetzgebung des Reiches auf Bayern übertragen worden war. Auf jeden Fall wünschte sich die bayerische Kultusbürokratie auch noch um I 900 sicher keine „Ultramontanen“ auf historischen Lehrstühlen, aber das war Chroust nun weiß Gott nicht. Und so hat das Ministerium, als ihm die Angelegenheit auf dem Wege der Beschwerde durch den Senat vorgelegt werden musste, auch das zweite, konfessionelle Argument der Fakultätsmehrheit keineswegs von vornherein abgelehnt, vielmehr zunächst betont, dass es sich vorbehalte, die von der Mehrheit der Fakultät bestrittene wissenschaftliche Qualifikation einer weiteren Würdigung zu unterziehen; den anderen Grund der Majorität, dass Chroust keine genügend liberale Geschichtsauffassung vertrete, konnte das Ministerium in dem gegebenen Falle nicht als berechtigt anerkennen, da es sich nicht um eine erst zu besetzende Stelle handelte, sondern die Stelle auf den eigenen Antrag der Fakultät hin mit Chroust besetzt und nur

66 Schreiben der Fakultät an den Senat vom 04.07.1901, UAWb, ARS Nr. 1621. Dort auch der Brief Ritters vom 06.03.1901. Des Weiteren wird bemängelt, Chroust habe in Czernowitz und Münster nur an letzter Stelle von Listen gestanden. Positiv über Chroust äußerte sich Dietrich Schäfer (ebd.).

67 Karl Otmar von Aretin, Krafft von Crailsheim, in: NDB 3 (Berlin 1957) 387f.

68 Walter SснӓвL, Die Zusammensetzung der bayerischen Beamtenschaft von 1806 bis 1918 (Kallmünz 1955) 98 Nr. 31. Vgl. auch 39, 46. 
die Frage zu würdigen ist, ob Chroust zu befördern sei oder nicht. Entsprechende Mittel seien beantragt worden, doch dann sei es zum Streit zwischen Chroust und Förster gekommen. Sowohl die Universität als auch das Ministerium hatten guten Grund, neben der durch das Ordinariat von Henner vertretenen Landesgeschichte auch die Neuere Geschichte durch ein Ordinariat vertreten sehen zu wollen.

Um Chroust das Wasser abzugraben und „Argumente“ gegen seine Beförderung zu finden, war es nach dem ersten Antrag auf Ernennung zur Ordinarius von I 899 zu einem Possenspiel gekommen; von den unmittelbarsten Kollegen Chrousts war hierbei, wie bemerkt, der Althistoriker Wilcken führend, der als Dekan und Mitglied des Senats noch eine unrühmliche Rolle spielen sollte. Da bei Beförderungen die Anciennität von Bedeutung war und Chroust hier in der Reihe der dazu anstehenden Extraordinarien an erster Stelle stand, musste das geändert werden ${ }^{69}$. Bis dahin galt das Datum der Ernennung als außerordentlicher Professor in Würzburg als Kriterium für die Reihenfolge. Hierbei gebührte Chroust (I. April I 898) vor Förster (I. Oktober I 898) und dem Geografen Regel (I. April I 899) der Vorzug. Und hier schlugen seine Gegner auch zuerst zu. Am I. Dezember 1900 beschloss der Senat, dass Dienstzeiten als Extraordinarius vor der Berufung nach Würzburg bei der Reihenfolge der Aufführung im Vorlesungsverzeichnis anzurechnen seien, und plötzlich stand Chroust unter den drei Anwärtern an letzter Stelle. Förster war bereits am I. März I 897 in Bonn zum außerordentlichen Professor ernannt worden ${ }^{70}$ und damit mehr als ein Jahr dienstälter als Chroust. Das war nach Ansicht der Juristen des Kultusministeriums nicht rechtens, da es dem damaligen Usus nicht entsprach und das Ministerium darüber nicht informiert wurde ${ }^{71}$. Aber das war auch erst der Anfang. Als im Februar I90 I Stölzle, Henner und Unger den Antrag auf Beförderung Chrousts erneut in der Fakultät einbrachten, wurde zunächst eine Kommission eingesetzt, die darüber beraten sollte; ihr gehörten neben Henner die beiden Intimfeinde Chrousts Wilcken und der Germanist Oskar Brenner an. Die beiden Letzteren waren entschieden gegen seine Ernennung zum Ordinarius, und ihnen schloss sich am 20. Mai I90 I die neue Mehrheit in der Fakultät an; es wurde auch abgelehnt, den Antrag an den Senat weiterzuleiten. In diesem Beratungsstadium war jedoch etwas geschehen, was die Mehrheit der Fakultät und des Senats später herunterzuspielen versuchte, was vom Ministerium jedoch aufs

69 Die folgenden Angaben nach der Promemoria des bayerischen Kultusministeriums vom 29.07.1902 an von Crailsheim (wie Anm. 62). Nach Chroust (Schreiben an das Ministerium vom 09.12.1901, UAWb, ARS Nr. 1622) hatte Förster seine Höherstufung bereits eigenmächtig bei der Korrektur des Vorlesungsverzeichnisses des WS 1901/02 im Sommer 1901 vorgenommen, was er zunächst als „harmlose Eitelkeit“ nicht beanstandet habe.

70 Mitteilung des Senats an das Kultusministerium vom 13.12.1902, MK 11364. Vielfach finden sich dieselben Schreiben (jeweils als Original, Abschrift oder Entwurf) auch in UAWb, ARS Nr. 1621, 1623.

71 So in der Promemoria wie Anm. 66. 
Entschiedenste missbilligt wurde: um gegen Chroust „Material zu sammeln“, hat Brenner am 24. Februar I90 I, noch bevor er offiziell Mitglied der Kommission geworden war (I. März), einen Erkundigungsbrief an den Dekan der Philosophischen Fakultät der Universität Graz, den bekannten Anglisten Karl Luick, gerichtet, offensichtlich weil er hoffte, hier „fündig“ zu werden. Darin hieß es u. a. über Chroust: Unser Extraordinarius Chroust will um jeden Preis Ordinarius werden und hat einen Fürsprecher in der Fakultät gefunden. Die Mehrheit hat nun gar keine Sympathie für den Mann. [...] Hier traut man ihm, offen gestanden, nicht viel Gutes zu, vor allem kein recht aufrichtiges Wesen (über seine politische Stellung z. B. weiß niemand Bestimmtes). Brenner bat Luick, besonders bezüglich Chrousts Grazer Zeit, über die widersprüchliche Informationen vorlagen, unser Urteil zu korrigieren oder zu bestätigen ${ }^{72}$. Dass hier Gesinnungsschnüffelei betrieben wurde, ist offenkundig, und man kann sich nur über die (wohlwollend ausgedrückt) Naivität wundern, mit der derartige beleidigende Äußerungen nicht etwa in einem vertraulichen Privatschreiben, sondern in einem an den Dekan einer Universität gerichteten, zumindest offiziösen Schreiben gemacht wurden; über die juristischen Konsequenzen ihrer Handlungsweise waren sich viele Mitglieder der Philosophischen Fakultät offensichtlich nicht im Klaren. Luick befragte daraufhin Grazer Professoren, die Chroust aus seiner Tätigkeit dort kannten, was natürlich dazu führte, dass Chroust Mitteilung vom Brief und seinem Inhalt erhielt; er erzwang von Luick die Herausgabe einer Abschrift ${ }^{73}$. Die Philosophische Fakultät, bei der Chroust Beschwerde gegen das Schreiben erhob, beanstandete den Brief Brenners nicht, da er keine Beleidigung oder ehrenrührige Beschuldigung enthalte. Dabei verstieg man sich zu so grotesken Ausführungen, dass der von Brenner gegenüber Chroust erhobene Vorwurf des Mangels an Aufrichtigkeit mit den Worten heruntergespielt wird: [...] Aufrichtigkeit [ist] zwar eine gepriesene, allerdings oft mehr theoretisch als praktisch geschätzte Eigenschaft, aber durchaus nicht Pflicht eines Jeden gegen Jeden; daher könne hierin bei ruhiger Erwägung nur ein Tadel, keine Beleidigung gefunden werden ${ }^{74}$. Die Fakultät beging damit eine weitere Unkorrektheit. Es war bereits die zweite: schon die Verweigerung der Weitergabe des Antrags auf Beförderung Chrousts an den Senat war nicht korrekt; einer entsprechenden

72 Zitat nach der Abschrift des Briefes durch Luick; auch im Schreiben Landmanns an den Senat der Universität Würzburg vom 08.10.1901, UAWb, ARS Nr. 1621, und nach dem Berichterstatter, dem Abgeordneten Dr. Schädler, in der Landtagsdebatte vom 26.06.1902; Stenographischer Bericht der Verhandlungen der bayerischen Kammer der Abgeordneten, 337. öffentliche Sitzung, Nr. 337, Bd. 9, 947. Nach Chrousts Brief an das Kultusministerium vom 03.07.1901 (UAWb, ARS Nr. 1621) hatte auch Wilcken nach Graz geschrieben und den Althistoriker Adolf Bauer um eine Stellungnahme gebeten, doch findet sich der Text des Schreibens und einer möglichen Antwort nicht in den Akten. Die Fakultät bestritt am 17.07.1901 (wie Anm. 74) die Existenz eines solchen Briefes Wilckens.

73 So die Promemoria (wie Anm. 66); auch das Folgende, und das Schreiben Landmanns und die Abschrift Luicks (wie Anm. 72).

74 Schreiben der Fakultät an den Senat vom 17.07.1901, UAWb, ARS Nr. 1621. 
Beschwerde Henners und Stölzles gaben Senat und Ministerium statt und erklärten, der von der Fakultät abgelehnte Antrag hätte dem Senat vorgelegt werden müssen.

Auch im Falle des für Chroust beleidigenden Schreibens Brenners verhielt sich der Senat zunächst korrekt: er schloss sich dem Missbilligungsbeschluss der Fakultät gegenüber Chroust nicht an, teilte die Ansichten Brenners über Chroust nicht und forderte ihn auf, Chroust eine beruhigende und befriedigende Erklärung abzugeben, was Brenner am 23. Juni I 90 I brieflich an Chroust und am 3. Juli I90 I vor zwei Zeugen tat ${ }^{75}$, womit sich Chroust zwar, soweit die Person des Professors Dr. Brenner in Frage kommt, zufriedengab, aber am gleichen Tag dennoch aus anderen Gründen Beschwerde direkt beim Kultusministerium einlegte, was von der Fakultät kritisiert wurde, und dabei den Vorwurf erhob, Brenner habe den Brief, den dieser als halboffiziell bezeichnete, mit Wissen und Zustimmung der Fakultät geschrieben. Er forderte, dass der Fakultätsbeschluss aufgehoben werde und dass bei seiner Beförderung seine politische Haltung nicht Gegenstand einer Untersuchung oder gar von ausschlaggebender Bedeutung sein dürfe. Mit aller Entschiedenheit betonte Chroust, dass ich meine Stellung als Geschichtslehrer und liberaler Katholik nicht dahin auffasse, für bestimmte Richtungen im politischen oder kirchlichen Leben vom Katheder Partei zu ergreifen, [...] vielmehr halte ich es für meine Pflicht, alle Lebensäußerungen in Staat und Kirche leidenschaftslos und gewissenhaft zu prüfen und das Ergebnis dieser Prüfung, nach welcher Seite es auch fallen mag, in einer Form und in einem Ton vorzutragen, der bei allen Hörern die Vermutung ausschließen soll, als wollte ich ihr kirchliches oder politisches Empfinden beeinflussen oder gar stören. [...] Wahrer Liberalismus, zu dem ich mich freudig bekenne, besteht niemals darin, andere in ihren religiösen oder politischen Anschauungen zu kränken, nur Schattenseiten hervorzuheben, die Lichtseiten aber zu verhüllen [...]. Chroust beanstandete auch, dass im Falle seiner beantragten Beförderung eine Kommission eingesetzt wurde, was für solche Fälle in Würzburg früher nicht üblich war, und dass man einen Nichtfachmann (Brenner) berief, dagegen einen verfügbaren Fachmann überging und nach allen Himmelsrichtungen Erkundigungsbriefe wegen eines Mannes aussandte, der keineswegs zurückgezogen und seit drei Jahrzehnten unter den Augen der Fakultät lebt und wirkt - ein im akademischen Leben geradezu unerhörter Vorgang, der obendrein geeignet ist, mich nach außen zu diskreditieren [...]. Die fast ausnahmslos günstigen Auskünfte auf jene Anfragen, von denen die Befragten mir zum Teil selbst Nachricht gaben, hätten dann jedoch auf die Entscheidung der Kommissions- und Fakultätsmehrheit keinerlei Einfluss geübt [...]. In der Fakultät erklärten Henner, Stölzle und Unger die Beschwerde Chrousts für berechtigt, die Mehrheit lehnte sie jedoch ab und erklärte, dass die zweite Geschichtsprofessur an einen Liberalen vergeben werden müsse, wofür Chroust keine ausreichende Gewähr böte. Der

75 Abschriften in UAWb, ARS Nr. 1621. Auch hier und später versuchte Brenner, seine beleidigenden Auslassungen herunterzuspielen. 
Brief Brenners sei ein Privatschreiben gewesen - dieser selbst hatte ihn freilich, wie wir sahen, als halboffiziell bezeichnet -, von dem die Fakultät erst durch Chrousts Beschwerde vom I 2. Mai erfahren habe ${ }^{76}$. Auch die diskriminierenden Erkundigungen Brenners nach Chrousts politischer Haltung wurden spitzfindig heruntergespielt. Der Minister missbilligte am 8. Oktober I90 I das Verhalten der Fakultät, weil sie gegen den Brenner'schen Brief, den er zu Recht als kränkend und verletzend und ehrenrührig bezeichnete, nicht von Anfang an entschieden protestiert habe, akzeptierte aber trotz der Widersprüche die nachträgliche Behauptung der Mehrheit der Fakultät, es habe sich um ein ohne ihre Billigung abgesandtes Privatschreiben gehandelt. Im Falle Chrousts handle es sich, so das uns schon bekannte Argument, nicht um eine Neubesetzung, sondern um eine Beförderung, für die nur die Leistungen in Wissenschaft und Lehre, nicht die vom Professor vertretene Richtung maßgebend sei. Bei Neubesetzungen in Philosophie und Neuerer Geschichte sei im Übrigen gegen das Prinzip, die Stellen mit Professoren verschiedener wissenschaftlicher Richtung zu besetzen, im Allgemeinen nichts einzuwenden. In diesem Punkt wird Chrousts Beschwerde als berechtigt bezeichnet ${ }^{77}$. Diese Vorgänge haben den ohnehin leicht erregbaren Chroust schwer verletzt. Wenn Chroust durch diese sich lange hinziehenden Streitereien nicht gereizt worden wäre, müßte er kein Mensch sein [...], so formulierte es der unbestechliche Theologe Sebastian Merkle ${ }^{78}$, obschon er an sich kein Freund Chrousts war. Dieser reagierte am I9. Oktober I90 I mit einem beleidigenden Schreiben an Förster, in dem er ihm Unkollegialität und Intrigen in der Fakultät aus Neid wegen seiner beantragten früheren Beförderung zum Ordinarius vorwarf.

Nach dem Scheitern des Versuchs einer gütlichen Einigung unter Vermittlung eines Professors der Rechte erhob Förster am 22. November I90 I Beschwerde beim Kultusministerium und legte die Wiederherstellung [s]einer beschimpften Ehre in die Hand des hohen Staatsministeriums. Am 4. Januar 1902 erhob er zudem Privatklage gegen Chroust. Die Juristen des Kultusministeriums bemühten sich sachlich um eine Bereinigung der Angelegenheit. Der beleidigende Charakter des Briefes Chrousts vom I9. Oktober I90 I

76 Die unterschiedlichen Voten der Mehrheit vom 17.07.1901 und der Minderheit vom 20.07.1901 UAWb, ARS Nr. 1621. Die Fakultät tadelte u.a., dass Chroust bei seiner Beschwerde nicht den Dienstweg eingehalten habe, und berief sich auf eine durch Senatsbeschluss vom 14.06.1901 eingeschärfte Verfügung des Kultusministeriums vom 16.07.1885 Nr. 7462. Doch wird man Chroust zugutehalten müssen, dass er bereits schlechte Erfahrungen gemacht hatte, da die Fakultät seinen Antrag auf Ernennung zum Ordinarius nicht an den Senat weitergereicht hatte. Am 20.07.1901 machte Brenner seinen „Fehler“ wieder gut und erklärte dem Senat gegenüber, der Brief an Luick sei vollkommen privater Natur gewesen [!].

77 UAWb, ARS Nr. 1621.

78 Sondervotum Merkle vom 04.07.1902 im Bericht des Akademischen Senats an das Kultusministerium vom 04.07.1902, BHStAM, MK 11364. Auch in UAWb, ARS Nr. 1623. Bericht des Senats vom 23.07.1902, wie Anm. 4, Auch für das Folgende. 
stand für das Ministerium aber außer Frage ${ }^{79}$. In seinem Schreiben vom 22. November I 90 I an das Ministerium zieh freilich der juristisch unbedarfte Förster Chroust der Lüge und machte sich damit ebenfalls der Beleidigung schuldig. Das Ministerium suchte die Sache aus der Welt zu schaffen, indem es beiden Kontrahenten am I 2. Januar I 902 den Entwurf gleich lautender Genugtuungserklärungen vorlegte und den Senat zur Beendigung dieser leidigen Angelegenheit mit dem Vollzug betraute. Chroust unterzeichnete am 20. Januar 1902 die Erklärung, worauf Förster am 25. Januar seine Privatklage zurückzog, am gleichen Tage dem Kultusministerium jedoch mitteilte, die gleich lautenden Erklärungen seien für ihn keine ausreichende persönliche Genugtuung, da sie die Vorstellung erwecken, daß hier ganz gleichartige Vergehen gegeneinander ausgeglichen würden, was er nicht akzeptieren könne. Er forderte das Ministerium auf, von gleich lautenden Erklärungen abzusehen und neue zu entwerfen, in denen die verschiedene Schwere des Vergehens in einer verschieden abgestuften Form der Entschuldigung zum Ausdruck gelangen. Von jetzt an begann die „leidige Angelegenheit“ weitere Kreise zu schlagen. Die Presse hatte sich ihrer schon seit Juni I90 I bemächtigt ${ }^{80}$. Denn Brenner und Wilcken hatten mittlerweile Stimmung gegen Chroust gemacht und eine Mehrheit für die Ansicht zustande gebracht, dass Chroust der alleinige Schuldige sei; die Entgleisung Försters spielte diese Mehrheit herunter, indem sie behauptete, er habe sich nur in der Wortwahl vergriffen, ein Verteidigungsexce $\beta .{ }^{81}$ Das Ministerium gab am I 5 . Februar 1902 insofern nach, als es von Förster vorgeschlagene und vom Senat befürwortete unterschiedliche Erklärungsentwürfe akzeptierte. Jetzt aber weigerte sich Chroust, seine „Abbitteformel“ zu unterschreiben. Daraufhin erging am 27. März 1902 eine dritte Ministerialentscheidung in der Sache, in der es heißt, es bestehe zu aufsichtlichem Zwang vom dienstlichen Standpunkt aus keine ausreichende Veranlassung, Chroust zum Unterschreiben der von Förster entworfenen und vom Senat unterstützten Erklärung zu zwingen; das Ministerium erklärte, es müsse daher bei der Ministerialentschließung vom I2. Januar sein Verbleiben haben. Das brachte den Senat endgültig gegen das Ministerium auf. Die Semesterferien bedeuteten zunächst eine Verschnaufpause. Erst am 20. Mai 1902 sandte der Senat einen von seiner Mehrheit gebilligten, völlig einseitig gegen Chroust gerichteten Bericht an das Ministerium, in dem diesem unter unzutreffender Auslegung des früheren Ministerialschreibens vom I 2. Januar 1902 der Vorwurf gemacht wurde, er habe die Interessen der Korporation schwer geschädigt und ein gedeihliches Zusammenwirken mit ihm sei für die Zukunft ausgeschlossen ${ }^{82}$,

79 So mit Schreiben vom 12.01.1902, wie Anm. 61f. Vgl. auch den Sonderakt Chroust contra Förster wegen Beleidigung UAWb, ARS Nr. 1622.

80 Presseausschnitte (auch Leserzuschriften) in UAWb, ARS Nr. 1621.

81 Wie Anm. 61, 62.

82 Ebd. Entwurf in UAWb, ARS Nr. 1623. Dass der diffamierende Schlusssatz von Wilcken stammt, sagt Abert in seinem Sondervotum ebd. 
so der vom Scharfmacher Wilcken eingebrachte Schluss. Landmann rügte diesen Bericht als nicht absolut objektiv und Beweis dafür, dass der Senat in dieser Sache etwas befangen sei. Unter Würdigung der ehrenrührigen Gesinnungsschnüffelei Brenners war der Minister zur Überzeugung gekommen, daß Chroust nicht der eigentliche und nicht der einzige Schuldige in dieser Sache ist, denn der Streit wurde nicht von ihm, sondern von der anderen Seite angefangen; zudem konnte der Senat deshalb nicht als ganz unbefangen gelten, da ihm Mitglieder angehörten (von Schanz, Wilcken und Brenner), die in der philosophischen Fakultät entschieden gegen Chroust Stellung genommen haben, aber im gegentheiligen Interesse Betheiligte sind ${ }^{83}$. In der Tat wollte der Senat damit die Beförderung des ungeliebten Österreichers zum Ordinarius für alle Zukunft verhindern. Gegen dieses Verfahren und die dabei begangenen Unkorrektheiten wandten sich die Mitglieder des Senats Friedrich Abert, Sebastian Merkle, beide Mitglieder der Theologischen Fakultät, und der Geologe Jakob Beckenkamp ${ }^{84}$, der, wie er betonte, als Sohn eines preußischen Beamten während seiner dreiundzwanzigjährigen Dienstzeit als Staatsbeamter an dem Grundsatze festgehalten, von allen politischen Kundgebungen mich fernzuhalten; er wollte den politisch-konfessionellen Kampf seiner Kollegen gegen Chroust nicht mitmachen ${ }^{85}$. Abert und Merkle distanzierten sich dann auch, bei aller Kritik an Chroust, entschieden von der einseitigen Stellungnahme der Senatsmehrheit.

Mittlerweile hatte die Angelegenheit jedoch jenen Punkt erreicht, der es den liberalen Professoren der Universität Würzburg, denen die ganze Richtung nicht passte, opportun erscheinen ließ, zusammen mit liberalen Abgeordneten der Deputiertenkammer dem Professorengezänk die höheren Weihen eines prinzipiellen Kampfes gegen Kultusminister Landmann zu verleihen, es mit der Absicht seines Sturzes zu „instrumentalisieren“.

\section{Ebd.}

84 Schreiben Aberts, Beckenkamps und Merkles an das Kultusministerium vom 02.07.1902, wie Anm. 61. Wir erfahren darin, dass in der Senatssitzung vom 14.05.1902 Aberts Einspruch, den Fall Chroust-Förster mit der Beförderungsangelegenheit Chroust in Verbindung zu bringen, nicht zu Ende behandelt wurde, sondern im Umlaufverfahren erledigt wurde. Das darauf folgende Schreiben vom 20.05. sei schärfer gefasst worden, insbesondere habe das Senatsmitglied Wilcken den letzten Satz hineingebracht mit der Absicht, die Beförderung Chrousts unmöglich zu machen. Abert, Beckenkamp und Merkle hätten dagegen protestiert; hätten sie geahnt, dass der Bericht des Senats der Presse zugespielt würde, hätten sie ein Sondervotum eingelegt. Vgl. unten.

85 Schreiben Beckenkamp vom 04.07.1902 im Bericht des Senats an das Kultusministerium vom 04.07.1902, wie Anm. 61. Indirekt verwahrt er sich darin gegen den Verdacht, er habe Zentrumsabgeordnete über Vorgänge in der Fakultät und im Senat informiert, und bittet Abert und Merkle zu versichern, sie hätte keine solchen Informationen an das Zentrum weitergegeben. - Weiteren Streit gab es wegen der von Chroust erhobenen Forderung, das Original seiner Erklärung vom 20.01.1902 und eine Abschrift von Försters Rücknahme seiner Klage gegen Chroust als Beweismittel im Prozess zu erhalten; auch hier musste sich das Ministerium einschalten (vgl. UAWb, ARS Nr. 1623). 
Denn liberale Partei und liberale Professoren waren entschlossen, den „Fall Chroust“ zu benutzen, um dem verhassten Kultusminister den Gnadenstoß zu versetzen. Landmann entstammte zwar selbst der liberalen Bürokratie, die Regierung und Verwaltung des Königreichs Bayern prägte, hatte aber deutlich zu erkennen gegeben, dass er den weltanschaulichen Konflikt und die konfessionelle Diskriminierung als schädlich für Staat und Gesellschaft ansah, und sich bemüht, in seinem Wirkungsbereich eine Politik des Ausgleichs zu betreiben. Das brachte ihm die immer schärfere Kritik der Nationalliberalen und ihrer Presse ein, die sich vor allem an dem seit dem Frühjahr des Jahres I90o einsetzenden Konflikt um das Schulbedarfsgesetz entzündete ${ }^{86}$. Es würde hier zu weit führen, die verwickelten Pfade der bayerischen Schulpolitik zu verfolgen ${ }^{87}$ - sie betrifft im Wesentlichen das Volksschulwesen. Seit dem Scheitern durchgreifender Veränderungen in einem bayerischen Vorgeplänkel des „Kulturkampfes“ in den späteren I 86oer-Jahren infolge der parlamentarischen Mehrheiten der Patriotenpartei ${ }^{88}$ hatten die liberalen Kabinette in einer Art „Salamitaktik“ auf dem Verordnungswege versucht, das Grundschulwesen stärker zu modernisieren, zu entkonfessionalisieren und zu säkularisieren, was jedoch nach Ansicht der Liberalen nur unzureichend gelang, so dass das Schulwesen, vor allem die der ministeriellen Weisungskompetenz unterliegende eingeschränkte Schulaufsicht durch Geistliche, ständiges Objekt liberaler Polemik war. Nun hat das Schulbedarfsgesetz zahlreiche Besoldungs-, Organisations- und Kapazitätsverbesserungen gebracht, die das bayerische Schulwesen zu einem der modernsten im damaligen Reich machten, und es war auch von der Kammer der Reichsräte gebilligt worden ${ }^{89}$; den Liberalen in der Deputiertenkammer ging es jedoch längst nicht weit genug, wofür sie Landmann verantwortlich machten. So arbeiteten sie auf den Sturz des Kultusministers hin und wussten sich dabei der geheimen oder offenen Sympathie des leitenden Ministers von Crailsheim, zweier nationalliberaler Minister, des Chefs der Geheimkanzlei sowie des preußischen Gesandten sicher; die Kabale reichte bis nach Berlin, wo man plante, Landmann bei der 50-jährigen Jubiläumsfeier des Germanischen Nationalmuseums am 25. Juni 1902 in Anwesenheit des Kaisers durch Nichtberücksichtigung bei der Ordensverleihung zu

86 Vgl. Gustav Seiler, Schulbedarfsgesetz (München 1903); Karl Möck L, Die Prinzregentenzeit. Gesellschaft und Politik während der Ära des Prinzregenten Luitpold in Bayern (München/Wien 1972) 521ff.

87 Guter Überblick (mit Lit.) von Albert Reble, Das Schulwesen, in: Handbuch der bayerischen Geschichte 4/2, hg. v. Max Spindle R (München 1975) $950 \mathrm{ff}$.

88 Vgl. Peter Herde, Der Heilige Stuhl und Bayern zwischen Zollparlament und Reichsgründung, in : ZBLG 45 (1982) 599ff., ND in: DERs., Abhandlungen zur fränkischen und bayerischen Kirchengeschichte und zu den christlich-jüdischen Beziehungen (Quellen und Forschungen zur Geschichte des Bistums und Hochstifts Würzburg 46, Würzburg 1996) $203 \mathrm{ff}$.

89 MöскL, Prinzregentenzeit (wie Anm. 86), 522. 
demütigen, was Crailsheim dann aber doch zu weit ging90. Bei den Verhandlungen des Gesetzes in den Ausschüssen und im Plenum der Deputiertenkammer hatte Landmann, wie ihm u.a Crailsheims vorwarf, die liberalen Interessen zu wenig gewahrt, hatte dann aber nach Intervention der Krone über den Staatsrat am Io. März 1902 in umstrittenen Punkten vor dem Landtag nachgegeben, was zunächst seinen Sturz verhinderte ${ }^{91}$. Da bot sich nun den enttäuschten Liberalen der Würzburger Professorenstreit als willkommene Gelegenheit an, den Kampf gegen den missliebigen Kultusminister wieder aufzunehmen, und sie fanden dabei willige Bundesgenossen unter den dortigen Professoren, die nun plötzlich in die Lage versetzt wurden, in einer, wie sie glaubten, ihr Image fördernden Weise in die hohe Politik eingreifen zu können. Sie bedienten sich dabei der liberalen Politiker und der Presse; vertrauliche Schreiben wurden heimlich den Zeitungen zugespielt, die Verantwortlichen in der zweiten Jahreshälfte nach wochenlangen Untersuchungen natürlich nie ermittelt, denn was konnte nicht alles im Umlaufverfahren geschehen. Diese „Instrumentalisierung“ des Streits führte nun dazu, dass sich am 26. Juni I 902 das Plenum der Kammer der Abgeordneten in seiner 337. öffentlichen Sitzung ausführlich mit dem Streit Chroust gegen Förster befasste ${ }^{92}$. Das Zentrum hatte allen Grund zur Euphorie, eignete sich der „Fall Chroust“ doch eigentlich gar nicht zur Verteidigung hehrer liberale Ideen, sondern er setzte das Zentrum vielmehr in die Lage, sich seinerseits zum Verteidiger der Wissenschaftsfreiheit aufzuschwingen. Bei der Debatte des Etatansatzes zur Umwandlung einer außerordentlichen Professur in der Philosophischen Fakultät Würzburg in eine ordentliche ( $1380 \mathrm{M}$ ), die vom Finanzausschuss gebilligt worden war, schilderte der Berichterstatter Schädler vom Zentrum unter ausführlichen Zitaten aus dem Brief Brenners an Luick den Verlauf des Streits und die, wie er es nennt, Konfessionsschnüffelei. Professor Chroust erklärte rund und nett, er sei liberal. Wir haben keinen Grund [...] vom politischen Standpunkt aus für ihn einzutreten; denn er gehört ja politisch nicht zu uns. Schädler glaubte, dass die großen Worte von der Freiheit der Wissenschaft und der Voraussetzungslosigkeit gefährdet sind durch die Art und Weise, wie hier vorgegangen wurde. Chroust habe sich suspekt gemacht, als er in einem Vortrag über Ignatius von Loyola nicht blos lauter Worte der Verdammung gefunden hat, und dieß genügte, um ihn in den Augen der voraussetzungslosen Professoren der Fakultät Würzburg als nicht geeignet für einen Lehrstuhl der Geschichte hinzustellen. Schädler betonte weiter, dass in Würzburg gerade in diesen Kreisen (der Professoren) eine krasse Intoleranz herrsche. Man habe den liberalen Chroust nicht vorgeschlagen, weil an der Würzburger philosophischen Fakultät nur dieje-

90 Ebd.

91 Ebd. 521.

92 Gedruckt in: Stenographischer Bericht über die Verhandlungen der bayerischen Kammer der Abgeordneten 9 935ff. Nr. 337 (337. öffentliche Sitzung). 
nigen Aussicht auf Vorschlag hätten, die kirchenfeindliche Tendenzen verfolgen. Er verwies auch auf die Versuche der Mehrheit der Fakultät, Chrousts wissenschaftliche Leistungen zu relativieren, was angesichts seiner Publikationen, der Monumenta Palaeographica und der Arbeiten über den Dreißigjährigen Krieg, die ihm Listenplätze in Tübingen, Czernowitz und Münster eingebracht hätten, nur als Vertuschung der eigentlichen Absichten angesehen werden müsse. In Wirklichkeit wolle man die Verhältnisse in der Fakultät nicht gestört wissen, daß nämlich sieben Evangelische gegen drei Katholische stehen ${ }^{93}$. Der Abgeordnete wies dann auf das Possenspiel mit der Änderung der Anciennität und auf einen Ruf, den Förster an die Handelshochschule Frankfurt (d.h. die Akademie für Sozial- und Handelswissenschaften) erhalten habe ${ }^{94}$, über die auch der Würzburger Rektor negative Äußerungen gemacht habe. Schädler verwies weiter auf die Notwendigkeit der Errichtung eines Ordinariats für Neuere Geschichte, auf das Chroust berufen werden sollte; wie das Ministerium argumentierte er, in diesem Falle handle es sich nicht um die Berufung auf ein freies Ordinariat, sondern um eine Beförderung, für die allein die wissenschaftlichen und lehramtlichen Leistungen, nicht aber die wissenschaftliche Richtung, der der Professor angehört, maßgeblich seien.

Der Sprecher der liberalen Fraktion, Leopold Casselmann ${ }^{95}$, offensichtlich der wichtigste Kontaktmann der Würzburger Chroust-Gegner, konterte mit persönlichen Angriffen auf Chroust, griff dabei, um ihn als Querulanten zu charakterisieren, auf seine Tätigkeit bei der Historischen Kommission in München zurück, stellte die Qualität seiner wissenschaftlichen Leistungen infrage und spielte die Gesinnungsschnüffelei Brenners herunter: Dessen Brief sei nicht im Auftrage der Fakultät geschrieben worden und nicht für Dritte bestimmt gewesen; er sei nur durch die verantwortungslose Indiskretion des Grazer Rektors Luick bekannt geworden. Die Fakultät habe Chroust keineswegs abgelehnt, weil er Katholik sei, denn sie sei darin sehr großzügig: Sie habe immerhin (so

93 Auf Antrag des Untersuchungsrichters am Landgericht Augsburg im Rahmen eines gegen die Augsburger Postzeitung eingeleiteten Ermittlungsverfahrens (vgl. Schreiben vom 08.09.1902) stellte die Universität am 10.09.1902 eine statistische Übersicht über die Konfession der Würzburger Universitätsprofessoren, also nicht nur der Ordinarien zusammen (UAWb, ARS Nr. 1623). Danach waren in der Philosophischen Fakultät 18 Protestanten, 10 Katholiken und ein Dissident (Theologische Fakultät: 8 Katholiken; Juristische Fakultät: 4 Protestanten, 3 Katholiken; Medizinische Fakultät: 13 Protestanten, 7 Katholiken, ein Altkatholik).

94 Kurz zuvor hatte Förster einen solchen Ruf erhalten; einen weiteren erhielt er an die Handelshochschule Köln. Um ihn zu halten, schlug die Fakultät seine Ernennung zum ordentlichen Professor vor, womit das Ministerium unter der Bedingung einverstanden war, dass die Universität die Mittel dafür aufbringe, was diese tat. Freilich zögerte das Ministerium zunächst nach Ablehnung der Rufe durch Förster, die Ernennung vorzunehmen, da sich die Presse des Falls bemächtigt und ihn mit der Sache Chroust in Verbindung gebracht hatte; es wollte die Erledigung der Angelegenheit Chroust abwarten (so die Promemoria des Ministeriums vom 29.07.1902), wie Anm. 61.

95 Wie Anm. 92, $944 f f$. 
seine Statistik) drei Katholiken in ihren Reihen, und der Lektor für französische Sprache sei sogar katholischer Geistlicher. Auf den Lehrstuhl für Neuere Geschichte gehöre nun einmal ein Liberaler, und das sei Chroust nicht, schon weil er in Münster auf eine spezifisch katholische Geschichtsprofessur berufen werden sollte. Der Zentrumsabgeordnete Gerstenberger ${ }^{96}$ betonte nochmals ausdrücklich, dass Chroust nach Auskunft von Hörern seines Kollegs und anderen Informanten keine Kontakte zur katholischen Kirche mehr habe und in seinen Kollegs Auffassungen vertrete, die nicht denen der Kirche entsprächen. Er gelte als Liberaler. Wenn wir [das Zentrum] dennoch für ihn eintreten, so thun wir es um der Gerechtigkeit halber, um der Cliquenwirtschaft, die an einzelnen Universitäten herrscht, entgegenzutreten, nicht um des Dr. Chroust wegen, der uns völlig fernsteht. Und bei der Deutung der Abneigung, die Chroust in Würzburg entgegenschlug, sieht er neben dem religiös-weltanschaulichen Moment wohl zu Recht andere, tiefer greifende Faktoren im Spiel: Chroust entspreche gesellschaftlich nicht ganz dem Würzburger Professorenambiente, und vielleicht auch deswegen nicht, weil er nicht aus Preußen stamme. Aus dieser wohl nicht ganz falschen Sicht wird die soziale Inakzeptanz des österreichischen Handwerkersohnes im bürgerlichen Professorenumfeld - ebenso wie vorher in München - deutlich; aus dieser Sicht wird das konfessionelle Moment fast schon zum „Überbau“ sozialer Verhältnisse. Gerstenberger beendete seine Rede mit den wenig schmeichelhaften Bemerkungen: [...] es ist ein trauriges Schauspiel, wenn Professoren, die sich sonst als Götter unter den armen, niederen Menschen aufspielen [...] ob ihrer Weisheit, wenn Männer der Wissenschaft, um einen weniger angenehmen Kollegen zu verdrängen, sich betragen wie Frauen in einem kleinstädtischen Kaffeeklatsch. Kultusminister Landmann ${ }^{97}$ versuchte, die Diskussion zu versachlichen, verwies auf die rechtliche Lage, kritisierte aber die Fakultät wegen ihrer rechtswidrigen Nichtweiterleitung des Minderheitsvotums für Chroust an den Senat und weil sie die ehrenrührigen Auslassungen Brenners in seinem Brief an Luick zu verharmlosen versucht habe, und den Senat wegen des ,ab irato' abgegebenen und das Ministerialschreiben vom I2. Januar I 902 einseitig zu Ungunsten von Chroust auslegenden Berichts vom 20. Mai I 902 an das Ministerium. Damit hatte er jedoch, wie schon die Replik Casselmanns vermuten lässt ${ }^{98}$, die Lunte angezündet, die das Pulverfass zwei Tage später zur Explosion bringen sollte, auch wenn er seinem Wunsch Ausdruck verlieh, dass über diese Angelegenheit bald Gras wüchse. Der Zentrumsvorsitzende Balthasar von Daller mahnte in gemäßigtem Ton ${ }^{99}$, die Debatte, eine unerhörte Zeitverschwendung auf Kosten des Landes, und den für das Ansehen der Universität Würzburg höchst abträglichen

96 Ebd. 951ff.

97 Ebd. 953ff., 958f.

98 Ebd. $955 f$.

99 Ebd. $956 f$. 
Professorenstreit zu beenden; der Referent Dr. Schädler ergriff aber nochmals das Wort ${ }^{100}$, beklagte erneut die konfessionelle Einseitigkeit, die an der Universität Würzburg herrsche, und kommentierte die Behauptung, Chrousts wissenschaftliche Leistungen seien nicht außergewöhnlich, eine heikle Frage, wie er meinte, so: [...] und wenn man vielleicht bei verschiedenen anderen Universitätsgrößen nachfragen würde, was sie an außerordentlichen wissenschaftlichen Leistungen aufzuweisen haben, glaube ich, daß man da viel auch pro nibilo fragen würde. Schädler rügte auch, dass in der Philosophischen Fakultät der Universität Würzburg ein gläubiger Gelehrter bei der Wahl zum Dekan stets übergangen werde; dafür habe man einen Professor (Wilcken!), der erst seit einem Jahr in Bayern ist, zum Dekan und Senator gewählt. In den letzten Vorschlägen der Fakultät für Professorenstellen seien nur Nichtkatholiken genannt worden, bei der Besetzung des Lehrstuhls für Alte Geschichte deren gleich vier. Es sei doch merkwürdig, dass man nie einen katholischen Gelehrten finde, der den Ansprüchen der Philosophischen Fakultät entspräche, zumal diese, wenn es sich um die Wahl eines Rektors handelt, keine sehr großen Anforderungen stellt. Die Emotionalität der Debatte beleuchten die Schlussbemerkungen Schädlers: es sei gut, wenn man manchmal in diese Circel hineinleuchtet, damit dieselben nicht in den Wahn verfallen, als könnten sie so ganz ungestört ihrer Wissenschaft leben, will ich einmal sagen (Große Heiterkeit rechts).

Das Pulverfass explodierte am 28. Juni I 902. An diesem Tag baten der Rektor der Universität und die Mehrheit der Senatoren wegen des in der Landtagsdebatte von Landmann erhobenen Vorwurfs der Befangenheit und des Mangels an Objektivität, über die sie offensichtlich durch zugespitzte Berichte in liberalen Zeitungen informiert waren ${ }^{101}$, den Kultusminister um Enthebung von ihrem $\mathrm{Amt}^{102}$. Dabei wurde ihr Schreiben wiederum der Presse zugespielt: Am I. Juli I902, als es dem Ministerium vorgelegt wurde, wurde es in den Münchner Neuesten Nachrichten veröffentlicht ${ }^{103}$. Am 3. Juli telegrafierten die Senatoren Abert, Beckenkamp und Merkle an das Ministerium, dass sie sich dem Beschluss der Mehrheit nicht anschlössen, die unter Verletzung der Vertraulichkeit Casselmann mitgeteilt worden war, und kündigten Sondervoten ein, die sie bereits früher abgegeben

100 Ebd. $964 \mathrm{ff}$.

101 Vgl. etwa den Bericht in der Augsburger Abendzeitung vom 27.06.1902 1-6, wo auch das Protokoll der Landtagsdebatte, in der es daneben um die von Landmann befürwortete Errichtung einer Professur für Kunstgeschichte in Würzburg ging, abgedruckt wurde.

102 BHStAM, MK 11364, auch UAWb, ARS Nr. 1623.

103 Ebd. Das Zitat aus dem Sondervotum vom 02.07.1902 (wie Anm. 104). Der Vorwurf, dass Mitglieder des Senats den liberalen Abgeordneten Casselmann unter Verletzung der Vertraulichkeit über den Senatsbeschluss unterrichtet hätten, im Schreiben des Kultusministeriums an den Senat der Universität Würzburg vom 28.06.1902 (BHStAM, MK 11364). Darin wird nochmals betont, dass Chroust und Förster gleich schuldig seien, Chroust nicht der eigentlich Schuldige sei. 
hätten, hätten sie vorausgesehen, daß von dem Inhalte dieses einzig für die vorgesetzte Behörde bestimmten Berichts (vom 20. Mai) die Presse Kenntnis erhalten und in der Abgeordnetenkammer hiervon Gebrauch gemacht würde. Die drei Senatoren gaben daher nachträglich ein auf den 2. Juli 1902 datiertes Sondervotum zum Senatsbericht vom 20. Mai ab ${ }^{104}$, in dem sie betonten, bei der Behandlung der Beförderung Chrousts durch Fakultät und Senat hätten persönliche, nicht sachliche Gründe den Ausschlag gegeben. Die Sache sei in der Sitzung vom I 4. Mai nicht zu Ende gebracht, sondern erst durch Zirkular erledigt worden, wobei von einem Senatsmitglied (Wilcken) der letzte, verschärfende Satz hineingebracht worden sei, um eine Beförderung Chrousts unmöglich zu machen. Sie hätten von Anfang an gegen den Missbrauch protestiert, den Fall Chroust-Förster mit der Beförderungsangelegenheit von Prof. Chroust in Verbindung zu bringen. Merkle hatte in der Senatsabstimmung einen Kompromissvorschlag für die Formulierung eingebracht. Mit Datum des 4. Juli 1902 gaben dann Abert, Merkle und Beckenkamp nochmals ausführlichere Sondervoten ab, die der Senat am gleichen Tag an das Ministerium sandte. ${ }^{105}$ Darin betonen Abert und Merkle, Chroust sei an den Vorgängen zwar mitschuldig, aber keineswegs der einzige Schuldige gewesen; die einseitige Stellungnahme des Senats habe nur das Ziel verfolgt, seine Beförderung zu einem Ding der Unmöglichkeit zu machen, so Abert; das alles mußte ihn [Chroust] in eine höchst gereizte Stimmung versetzen, wie dies bei anderen in völlig gleicher Lage wohl auch der Fall gewesen wäre, wenn vielleicht auch ihre Stimmung in weniger impulsiver Weise zum Ausdruck gekommen wäre. Ganz ähnlich äußerte sich Landmann. Nachdem er dem Prinzregenten die Verschärfung des Senatsberichts auf Antrag Wilckens geschickt hatte, fuhr er fort: Es wurde also die ganze Sache mit größter Eile und mit einer gewissen Überstürzung behandelt, während doch in einer so wichtigen Angelegenheit, bei der es sich um nichts weniger als die Existenz eines Mannes handelt, ein rubiges Abwägen [...] am Platz gewesen wäre. Wilcken, so heißt es weiter, habe die Beförderung Chrousts unmöglich machen, ihm aber auch bei einer möglichen Berufung an eine andere Universität schaden wollen. Der Minister bemängelte auch, dass Wilcken und Brenner in dieser Sache im Senat großen Einfluss ausübten, obschon sie bereits in der Fakultät und in der Kommission über die Beförderung Chrousts gegen diesen Stellung bezogen hatten; zudem war Brenner Verfasser des Chroust beleidigenden Briefs an Luick gewesen. Deshalb seien sie befangen und der Bericht des Senats sei nicht absolut objektiv gewesen; auch der Vorwurf der Aktenwidrigkeit des Senats an das Ministerium sei unzutreffend gewesen ${ }^{106}$. Während der Senat auf seinem Standpunkt beharrte und die Presse-Indiskretion damit begründete, er

104 BHStAM, MK 11364; UAWb, ARS Nr. 1623.

105 BHStAM, MK 11364.

106 So Landmann in der Promemoria vom 29.07.1902, ebd. Auch Wilcken als Dekan an den Senat 26.07.1902, UAWb, ARS Nr. 1621. 
habe den Protest aus Gründen der Rechtfertigung vor den Wählern den Dekanen und Professoren mitgeteilt, wodurch er der Natur der Sache nach nicht geheim zu halten gewesen sei $^{107}$, missbilligte Landmann in seinen Berichten vom 2., 4. und 29. Juli I 902 an den Prinzregenten ${ }^{108}$ entschieden das Verhalten des Senats. Landmann wäre an sich gezwungen gewesen, gegen den Rektor und die Mehrheit des Senats dienstrechtliche Maßnahmen wegen Verletzung der Vertraulichkeit einzuleiten. Wegen des großen Aufsehens, das die liberalen Politiker und die liberale Presse entfachten, zögerte er jedoch; er glaubte, dazu die Zustimmung des Prinzregenten zu benötigen ${ }^{109}$. Damit wurde die Sache endgültig zum Politikum. Nach der Verfassungspraxis war jeder Minister für sein Ressort allein der Krone verantwortlich, seine Entscheidungen bedurften nicht der Zustimmung des Ministerrats, der überhaupt kein Beschlussgremium war. Hier trat nun in das Intrigenspiel der Chef der Geheimkanzlei und Freund Luitpolds, der Sohn eines Münchner Schneidermeisters, Peter Wiedenmann, in Aktion ${ }^{110}$. Er machte in der Affäre Chroust gemeinsame Sache mit den Liberalen, denen er wegen seiner protestantischen Konfession nahestand, und den Würzburger Professoren; er soll sich zu dieser Zeit in Würzburg aufgehalten haben ${ }^{111}$. Um Landmann aus dem Amte zu entfernen, legte er dessen Antrag an Luitpold auf Disziplinierung des Senats dem Ministerrat vor, wo vor allem die Nationalliberalen, Innenminister Max Freiherr von Feilitzsch und Finanzminister Emil von Riedel, sowie der leitende Minister von Crailsheim selbst - obschon er sich taktisch bedeckt hielt - die große Chance sahen, den banalen Würzburger Professorenstreit zum Sturz von Landmann zu nutzen, nachdem das im Zusammenhang mit dem Schulgesetz wenige Monate früher misslungen war $^{112}$. Am 7. Juli 1902 berichtete Crailsheim dem Prinzregenten über das Ergebnis ${ }^{113}$. Die Feinde Landmanns im Kabinett waren natürlich geschickt vorgegangen. Die Rechtswidrigkeit des Vorgehens des Senats war nicht zu bestreiten. Deshalb galt es, Landmann in eine Situation zu manövrieren, die ihn zum Rücktritt zwingen musste. Der Ministerrat empfahl dem Prinzregenten, die Entscheidung über die Annahme der Rücktrittsgesuche von Rektor und Senatsmehrheit zu verschieben, und Luitpold stimmte zu. Wohl zu Recht sieht man in dieser Handlungsweise des Prinzregenten, der damals wegen

107 So im langen Bericht von Rektor und Senat an den Kultusminister vom 23.07.1902, BHStAM MK 11364.; Entwurf mit vielen Verbesserungen UAWb, ARS Nr. 1623.

108 BHStAM, MK 11364.

109 Möckl, Prinzregentenzeit (wie Anm. 86) $523 f$.

110 Ebd. 186f. mit Anm. 54, der Wiedenmann, der als enger Duzfreund des Prinzen bis zum General der Artillerie aufstieg, als „mächtigsten Mann im Staate“, aber auch als einen „der meistgehaßten Männer“ bezeichnet.

111 Ebd. 523 mit Anm. 146.

112 Ebd. 523; auch Ders., Gesellschaft und Politik während der Ära des Prinzregenten Luitpold. Ein Beitrag zur Vorgeschichte der Revolution in Bayern, in: Bayern im Umbruch. Die Revolution von 1918, ihre Voraussetzungen, ihr Verlauf und ihre Folge, hg. v. Karl Boss (München 1969) $16 f f$.

113 BHStAM, MK 11364. 
Verwicklungen in Finanzmanipulationen durch die Liberalen erpressbar war, eine Politisierung und damit Schwächung des monarchischen Prinzips von weit reichenden Konsequenzen, weil der Regent bei der Entlassung Landmanns auf seine verfassungsmäßigen Rechte der alleinigen Richtlinienkompetenz verzichtete und sich einer Entscheidung der Mehrheit des Ministerrats unterwarf, an die er nicht gebunden war ${ }^{114}$. Damit blieb dem gedemütigten Landmann nichts anderes übrig, als zurückzutreten; am Io. August I902 wurde sein Rücktrittsgesuch vom Prinzregenten angenommen ${ }^{115}$. Sein Nachfolger wurde der „Liebling des Regenten“ und Freund Wiedenmanns Clemens Freiherr von PodewilsDürnitz ${ }^{116}$.

Die Angelegenheit Chroust wurde elegant aus der Welt geschafft. Das Kultusministerium hatte noch am 9. August 1902 entsprechend dem Wunsch des Ministerrats die Rücktrittsgesuche von Rektor und Senatoren der Universität Würzburg abgelehnt, da deren Ämter eine dienstliche Pflicht seien, von der nur aus zwingenden Gründen entbunden werden kann, und diese lägen hier nicht vor ${ }^{117}$. Chroust und Förster, der Rufe an die Handelshochschule Köln und die Akademie für Sozial- und Handelswissenschaften Frankfurt erhalten hatte, wurden vom neuen Minister überredet, ihre Klagen zurückzuziehen und beide (!) wurden am 20. November 1902 zu Ordinarien befördert ${ }^{118}$. Die Maßregelung des Senats verlief im Sande, da die Quelle der Indiskretionen natürlich nicht zu ermitteln war. Von Landmann bemängelte in seiner langen Promemoria für den Prinzregenten vom 29. Juli I920, dass der Senat über die Frage, wie sein Rücktrittsbeschluss an die Münchner Neuesten Nachrichten gekommen sei, einer hinreichenden Antwort ausweiche, aber indirekt zu erkennen gebe, dass das mit Wissen und Willen des Senats geschehen sei: Das sei umso mehr zu beanstanden, als der Beschluss auch schwere Vorwürfe und Beleidigungen gegen den Minister enthalte, deren Veröffentlichung durch Erwägungen dieser Art nicht

114 Möckl, Prinzregentenzeit (wie Anm. 86) 524; dort Anm. 151 über die Verwicklung Luitpolds in Finanzmanipulationen und Geländespekulationen.

115 Ebd. 520.

116 Über ihn Sснӓrl, Zusammensetzung (wie Anm. 68) 108; МӧскL, Prinzregentenzeit (wie Anm. 86) 527f.

117 BHStAM, MK $11364 f$.

118 Beförderung Chrousts und Försters durch KMS Nr. 22973 vom 20.11.1902, in UAWb, ARS, PA Chroust, auch zitiert im Bericht des Senats vom 22.11.1902, UAWb, ARS Nr. 1623. Der Senat nutzte die Sache zu einer erneuten Stichelei gegen Chroust. Statt bei gleichen Ernennungsdaten beide Professoren in der Liste der Ordinarien in alphabetischer Reihenfolge anzuführen, wurde Förster vorangestellt, weil er nach der gegen ihn gerichteten Änderung in der Reihenfolge der Liste der Extraordinarien, die der Senat durch das KMS vom 12.11.1902 als „gutgeheißen“ ansah (was freilich nicht zutrifft, denn dort steht nur, dass das Ministerium die neue Reihenfolge genehmigt hätte, falls ein Antrag gestellt worden wäre, was jedoch nicht der Fall war), als dienstälterer Extraordinarius angesehen wurde. Immerhin bat diesmal der Rektor mit zitiertem Schreiben vom 22.11. das Ministerium um Bestätigung, die diese am 11.12.1902 erteilte (UAWb, ARS, PA Chroust). 
gedeckt oder entschuldigt werden können ${ }^{119}$. Noch kurz vor der Abdankung Landmanns begründete das Ministerium in seinem Schreiben an den Senat nochmals, dass sich der Minister korrekt verhalten habe, dass der Vorwurf der Aktenwidrigkeit vom Senat zu Unrecht erhoben worden sei und dass der Vorwurf des Ministers, der Bericht des Senats sei nicht ganz objektiv gewesen, berechtigt war, weil er ohne eingehende thatsächliche Begründung ein so abfälliges Urteil über Chroust enthält. Auch die Gründe, mit denen der Senat die Veröffentlichung des Berichts zu rechtfertigen suche, seien unzutreffend; die Veröffentlichung sei unzulässig und ungehörig ${ }^{120}$.

Die Auseinandersetzungen waren damit freilich nicht beendet. Am 8. Oktober 1902 erhob der Senat nach vorausgehender Erörterung in einem Schreiben an das Ministerium $^{121}$ erneut den Vorwurf der Aktenwidrigkeit und behauptete jetzt in spitzfindiger Weise, er habe Chroust nicht die alleinige, sondern die eigentliche Schuld zugeschrieben. Der zurückgetretene Minister wurde beschuldigt, den Vorwurf mangelnder Objektivität im Landtag, also in der Öffentlichkeit, ohne vorherige dienstliche Untersuchung erhoben zu haben. Nach Verhandlungen, in die sich Podewils-Dürnitz selbst einschaltete, erklärten sich Chroust und Förster Anfang November 1902 schließlich bereit, ihre Klagen zurückzuziehen. Durch ein Schreiben vom I2. November 1902 zog der Kultusminister dann einen Schlussstrich unter die für das Ansehen der Universität Würzburg höchst abträgliche Angelegenheit ${ }^{122}$. Darin wird die alte Auffassung des Ministeriums zwar bekräftigt, dass in der Streitsache Chroust-Förster beide Theile gefehlt haben, dafür jedoch in der Sache der Änderung der Reihenfolge der Anciennität der Liste der außerordentlichen Professoren die Konzession gemacht, dass, sofern in dieser vom Senat gebilligten Maßnahme die Entscheidung des Kultusministeriums angerufen worden wäre, dieses im gleichen Sinne hätte entscheiden müssen. Das Ministerium bestätigte, dass Förster die Änderung nicht eigenmächtig vorgenommen habe. Auch in anderen nebensächlichen Fragen ist dieses Ministerialschreiben ein wenig ungünstiger für Chroust als frühere, der dennoch am I 3 . November 1902 seine Klage zurückzog, worin ihm Förster zwei Tage später folgte. Die Chroust gegenüber kritischen Formulierungen waren offensichtlich der Grund dafür, dass das Schreiben erneut unter Verletzung der Vertraulichkeit der Presse zugespielt und ver-

119 BHStAM, MK $11364 f$.

120 Schreiben des Kultusministeriums an den Senat der Universität Würzburg vom 09.08.1902, ebd. und UAWb, ARS Nr. 1623.

121 BHStAM, MK 11364f.; UAWb, ARS Nr. 1623. Die Akten der Verhandlungen, die im September, also in den Semesterferien, darüber stattfanden (Wilcken hielt sich in Stettin auf), UAWb, ARS Nr. 1623. Über den ebenfalls aus kleinen Verhältnissen stammenden neuen Rektor Christian Meurer vgl. Dieter BLumenwitz, in: Lebensbilder bedeutender Würzburger Professoren, hg. v. Peter Baumgart (Quellen und Beiträge zur Geschichte der Universität Würzburg 8, Neustadt a. d. Aisch 1995) 217ff.

122 BHStAM, MK 11364f.; UAWb, ARS Nr. 1622, 1623. 
öffentlicht wurde. Gegen diese seiner Ansicht nach grobe Indiskretion legte Chroust am 8. Dezember 1902 Beschwerde beim Ministerium ein ${ }^{123}$. Dem Rektor war dieser erneute Bruch der Verpflichtung zur Vertraulichkeit durch einen oder mehrere Unbekannte natürlich sehr unangenehm. In einem Schreiben vom I3. Dezember I902 missbilligte er nach Beratungen im Senat auch aufs Schärfste die Weitergabe der Ministerialentschließung an die Presse, glaubte aber, Grund für die Annahme zu haben, die undichte Stelle sei nicht in der Universität zu suchen. Weder der Syndikus noch die Kanzlisten oder der Pedell hätten das im Umlaufverfahren in geschlossenen Kuverts den Mitgliedern des Senats bekannt gemachte Schreiben an die Presse weitergeleitet, und die Senatoren beteuerten, sie hätten keine Abschrift davon genommen und den Text auch nicht an die Presse gegeben ${ }^{124}$. Der Altphilologe Martin von Schanz begnügte sich jedoch mit einer wenig aussagekräftigen Bleistiftnotiz, was vom Ministerium am I6. Dezember 1902 gerügt wurde, das eine ausführliche Darstellung anforderte, die der Rektor am 20. Dezember nach München sandte. Darin bekräftigte Schanz erwartungsgemäß seine Unschuld, und Wilcken sowei zwei weitere Lehrende schlossen sich in weiteren Erklärungen $a^{125}$; der Letztere hatte freilich schriftlich erklärt: Im Interesse der Wahrheit ist die unerlaubte Publikation jedenfalls nicht zu bedauern, und mit Unterstützung anderer Senatsmitglieder durchgesetzt, dass ein entsprechender Passus im Entwurf einer Antwort des Rektors vom 3. Dezember auf die Beanstandung der Veröffentlichung durch das Ministerium gestrichen wurde ${ }^{126}$. Außerdem hatte Förster erklärt, er setze es als selbstverständlich voraus, die ihn reinigenden Erklärungen des hohen Staatsministeriums auch zur Kenntnis weiterer Kreise zu bringen, dass er jedoch mit seiner Erklärung keine Mitteilung an die Presse im Auge habe ${ }^{127}$. Immerhin wurde, da er Leutnant der Reserve war, zu seiner Exkulpation das Ministerialschreiben vom I 2. November auf dem Dienstwege an das Bezirkskommando Hanau gesandt. Damit wurde zu guter Letzt auch das bayerische Kriegsministerium mit dem Würzburger Professorenstreit befasst. Mit Schreiben vom 26. Januar I903 an das Kultusministerium teilte es mit, dass in Hanau sicher keine Abschrift gemacht und an die Presse weitergegeben worden sei ${ }^{128}$. Damit verliefen wie zuvor im August und September alle Untersuchungen im Sande, und auch ein staatsanwaltschaftliches Ermittlungsverfahren in dieser Sache wurde Ende Dezember I 902 eingestellt ${ }^{129}$. Am I 5 . Dezember I 902 berichtete Chroust dem Kultusminis-

123 Ebd.

124 Ebd.

125 Ebd.

126 UAWb, ARS Nr. 1623. Dort auch betreffende KMS vom 08.12.1902 und weitere Schreiben zur Frage der Anciennität.

127 Schreiben des Senats an das Ministerium vom 15.11.1902, UAWb, ARS Nr. 1623.

128 BHStAM, MK $11364 f$.

129 Ebd. 
terium das Ergebnis seines Gesprächs mit dem Rektor ${ }^{130}$ : Wir beide sind der Meinung, dass nichts dabei [d.h. aus der Untersuchung darüber, wer den Text des Ministerialschreibens an die Presse weitergeleitet habe] herauskommen wird; alle Beteiligten leugnen, also muss einer davon die Unwahrheit sagen. Für den Kenner der hiesigen Verhältnisse besteht kein Zweifel daran, dass Prof. Külpe ${ }^{131}$ an der Veröffentlichung beteiligt ist und wahrscheinlich die Einsendung an den "Fränkischen Kurier" veranlasst hat; von Personen, die ihm die Entschließung vermittelten, kommen allein in Betracht Wilcken, Förster und von Schanz, wovon ersterer am meisten verdächtig ist. Chroust betonte, die Veröffentlichung habe ihm sehr geschadet; Leute, die ihn bisher unterstützten, besonders aus militärischen Kreisen, wendeten sich nun von ihm ab, und Kollegen intrigierten gegen ihn. So glaubte er, dass seine Stellung in Würzburg unhaltbar geworden sei. Doch versuchte er, aus der Situation das Beste zu machen. Um in Würzburg einen wirklichen Frieden herbeizuführen, empfahl er sich dem Ministerium als neuen Vorstand des Münchner Reichsarchivs. Wenn möglich, werde er sich um die Stelle bewerben, da das ein Ausweg sei, der mir einen ehrenvollen Rückzug erlaubt und die hiesigen Verhältnisse dauernd beruhigt. Daraus wurde jedoch nichts.

Der Sturz Landmanns erwies sich jedoch für Crailsheim als Bumerang. Die Spiegelfechterei hinterließ in der Öffentlichkeit, nicht nur beim Zentrum, einen schlechten Eindruck. ${ }^{132}$ Als am Tage der Abdankung Landmanns, am ı. August I902, Kaiser Wilhelm II. noch die große Taktlosigkeit beging, in der sogenannten „Swinemünder Depesche“ dem Regenten I00.000 Mark zur Anschaffung von Kunstwerken anzubieten, die von der Deputiertenkammer am I 5. Juli 1902 als Maßnahme gegen die Haltung des Ministeriums im Budget gestrichen worden waren, ${ }^{133}$ und dabei seine „Empörung“ über die „schnöde Undankbarkeit“ der ihm ohnehin suspekten Parlamentarier ausdrückte, waren die Tage Crailsheims gezählt. Es war der neue Kultusminister Podewils-Dürnitz, der ihm die gleiche Falle stellte, die Crailsheim einst Landmann gelegt hatte: Eigenmächtigkeit ohne Konsultierung des Ministerrats. Am I7. Februar I 903 nahm Luitpold, anders als Crailsheim erwartet hatte, dessen Rücktrittsgesuch an; der neue Minister des kgl. Hauses und des Äußeren Podewils-Dürnitz verfolgte eine geschickte Politik des Ausgleichs zwischen Zentrum und Liberalen. ${ }^{134}$

130 Ebd.

131 Über Külpe ließ Chroust immerhin in dem von ihm herausgegebenen Werk: Lebensläufe aus Franken 2 (Würzburg 1922) 244ff., einen lobenden Beitrag von Karl Bü Hler, Külpe, Oswald, Professor der Philosophie 18921915, schreiben, der ihn so charakterisiert: „Eine fast frauenhafte Zartheit des Gemüts harmonisierte in ihm ohne erkennbaren Kampf oder Sieg mit der nordisch-herben Pflichtauffassung der Kantischen Ethik“ (ebd. 253).

132 Möckl, Prinzregentenzeit (wie Anm. 86) 525.

133 Ebd. 25. Die Kammer der Reichsräte setzte den Betrag wieder in das Budget ein, was die Zentrumsmehrheit in der Deputiertenkammer erneut ablehnte.

134 Ebd. 527ff. Vgl. (mit weiterer Lit.) Dieter Alв вснт, Von der Reichsgründung bis zum Ende des Ersten 
Nach den turbulenten Ereignissen des Jahres I 902 blieben Anton Chroust noch 43 Jahre bedeutender wissenschaftlicher Tätigkeit: als Mitbegründer und Leiter der Gesellschaft für fränkische Geschichte, als erfolgreicher akademischer Lehrer und fruchtbarer Forscher, Jahre freilich auch, die begleitet waren von Streitigkeiten und Prozessen. Im Grunde war die Atmosphäre in der Philosophischen Fakultät seit I902, was seine Person betraf, für lange Zeit vergiftet. Auch die Folgezeit war angefüllt mit Auseinandersetzungen, in die teilweise wiederum das Kultusministerium eingeschaltet wurde, so 1903 erneut mit Brenner, I907/08 mit dem Althistoriker Julius Kaerst, dem Nachfolger Wilckens, wobei Chroust die Trennung der beiden Abteilungen des Historischen Seminars, der für Alte Geschichte von der für Mittlere und Neuere Geschichte, anstrebte ${ }^{135}$.

Gleich darauf begann der jahrzehntelange Streit mit dem österreichischen Geistlichen Franz Joseph Bendel, den Chroust 1907 als Bearbeiter des Urkundenbuchs von St. Stephan in Würzburg für die Gesellschaft für fränkische Geschichte gewonnen hatte, dem er dann jedoch die Habilitation verweigerte und den er I9 Io fristlos entließ, was zu langen Prozessen führte ${ }^{136}$. In den späten I930er-Jahren folgte eine schwere Auseinandersetzung mit dem Generaldirektor der staatlichen Archive Bayerns Otto Riedner, der 1938 zum Austritt von sieben Archivbeamten aus der Gesellschaft führte und möglicherweise die von Chroust entschieden geforderte Rückführung der zu Anfang des I9. Jahrhunderts nach München verbrachten Würzburger Urkunden vor I 400 verhinderte (sie erfolgte erst 1993) ${ }^{137}$. Aber das waren im Grunde Nebensächlichkeiten, die nicht

Weltkrieges (1871-1918), in: Handbuch der bayerischen Geschichte 4/1, beg. v. Max SpindLER, hg. v. Alois ScHMID (22003) 404.

135 1903: UAWb, ARS Nr. 1624 (wieder ging die Sache vor das Ministerium). - 1907/08: Die Korrespondenz mit dem Ministerium darüber in BHStAM, MK 11364f. Weitere Akten über die Auseinandersetzung Chrousts mit den Kollegen, wobei er teilweise entlastet wurde, im PA Chroust UAWb, ARS. In einem Bericht vom 28.02.1907 an den Rektor der Universität versuchten seine Gegner, darunter Brenner, Külpe und Förster, die alten Streitigkeiten von 1901/02 wieder aufzugreifen. Auseinandersetzungen mit Fritz Regel wegen einer Dissertation in historischer Geografie, die Chroust (zu Recht) kritisierte, im Jahre 1908: UAWb, ARS Nr. 1625.

136 Die Akten des Prozesses Bendel gegen die Gesellschaft für fränkische Geschichte im NL Bendel im Archiv des bischöflichen Ordinariats Würzburg, Kasten 10.

137 Am 02.03.1938 traten die sieben Wahlmitglieder, die Beamte der staatlichen Archive Bayerns waren, aus Protest gegen eine angebliche Beleidigung des Generaldirektors Riedner durch Chroust aus der Gesellschaft für fränkische Geschichte aus, siehe Dokumente (wie Anm. 47) $231 \mathrm{ff}$., Nr. 97ff. Ein juristisches Gutachten vom 19.05.1938 entlastet jedoch Chroust von dem Vorwurf der Beleidigung. Betreffende Akten im Staatsarchiv Würzburg, Schönbornsches Archiv Wiesentheid, Repon. Akten, Allgemeine Betreffe Nr. 181. An Chrousts Auseinandersetzungen mit Riedner könnte auch eine frühere Rückgabe der Würzburger Urkunden vor 1400 an das Staatsarchiv Würzburg, die 1933 erfolgte, gescheitert sein; vgl. Hermann Hoff mann, Die Ge- 
davon ablenken können, dass die Erforschung der fränkischen Geschichte, die bisher vielfach den lokalen historischen Vereinen zugefallen war, durch Chroust eine übergreifende Organisation erhalten hatte, die sich gegen das Übergewicht Münchens zu behaupten versuchte. Aber auch sonst war Chroust bestrebt, in die breite Öffentlichkeit zu wirken. Im Jahre I9I 8 war er Mitgründer der Volkshochschule Würzburg, deren Vorsitzender er I92 I wurde ${ }^{138}$.

Von großer Bedeutung für die Universität Würzburg ist bis zum heutigen Tage, dass Chroust, der bereits I9I9 angesichts der wirtschaftlichen Notlage zur Unterstützung von Angehörigen der Universität eine „Wirtschaftliche Vereinigung an der Universität Würzburg “ ins Leben gerufen hatte ${ }^{139}$, im Jahre I92 I die Initiative zur Gründung einer Gesellschaft zur Förderung der Wissenschaften bei der Universität Würzburg ergriff, deren Geschichte Dieter Schäfer eine historisch-kritische Darstellung gewidmet hat ${ }^{140}$. Chroust gewann dafür den ihm aus der Gesellschaft für fränkische Geschichte nahestehenden Erwein Graf von Schönborn-Wiesentheid als ersten Vorsitzenden. In Zusammenarbeit mit der Universität, wo Chroust I920/2 I zum ersten Male Dekan der Philosophischen Fakultät geworden war, konstituierte sich die Gesellschaft, in der Chroust als erster Schriftführer eine führende Position einnahm, am 3. Dezember I92 I und gewann zahlreiche potente Förderer aus Adel, Industrie, Handel und Bankgewerbe, darunter den Großkaufmann Josef Neckermann. Ziel war es nach den Worten Chrousts, zu verhindern, „daß unser Land im Wettlauf um die geistige Geltung noch weiter zurückbleibt"141.

Die folgenden Jahre brachten den Höhepunkt des Ansehens, das Chroust in der Universität genoss. Neben Lehrer und Forscher war er in höherem Maße als damals üblich ein ausgezeichneter Wissenschaftsorganisator; für das Studienjahr 1924/25 wurde er, wenn auch erst im dritten Wahlgang, zum Rektor gewählt ${ }^{142}$. Aber seine Gegner warteten nach den Worten von Dieter Schäfer nur auf eine günstige Gelegenheit, ihn erneut in Schwierigkeiten zu bringen ${ }^{143}$. Diese bot sich im Jahre I927, als der vom Kellner zum Berliner Großhotelier aufgestiegene Curt Elschner, Mitglied der Fördergesellschaft, der Universi-

schichte der „Würzburger Urkunden“ in den letzten 150 Jahren, in: Würzburger Diözesangeschichtsblätter 16/17 (1954/55) 388ff.; Walter Ja roscнка, Franken in Geschichte und Gegenwart der staatlichen Archive Bayerns, in: Jb. für fränkische Landesforschung 40 (1980) $1 \mathrm{ff}$.

138 Walter Ziegler, Die Universität Würzburg im Umbruch (1918-20), in: Vierhundert Jahre Universität Würzburg (wie Anm. 63) 217.

139 Grundlegend auch für das Folgende ist Dieter SсH ̈̈ғER, Freunde und Förderer der Universität Würzburg. 80 Jahre Gesellschaft zur Förderung der Wissenschaften bei der Universität Würzburg (Stuttgart 2001) 19ff. 140 Ebd.

141 Erster Jahresbericht der Gesellschaft zur Förderung der Wissenschaften bei der Universität Würzburg für das Jahr 1921/22 (Würzburg 1922); vgl. SCḦ̈FER, Freunde (wie Anm. 139) 50.

142 SсHёFer, Freunde (wie Anm. 139) 19, 73.

143 Ebd. 85. 
tät 80.000 Mark, davon 50.000 Mark zur Errichtung der neuen Sternwarte, 30.000 Mark für das kunstgeschichtliche Institut der Universität spendete und dafür mit der Ehrendoktorwürde der Philosophischen Fakultät belohnt wurde ${ }^{144}$. Durch die sozialdemokratische Presse wurde der Fall in der Öffentlichkeit hochgespielt; die Dinge eskalierten, als 1927 und 1928 die Universität versuchte, durch eine Änderung der Statuten größeren Einfluss auf die Gesellschaft zu erhalten, und durch scharfe Attacken Chrousts in einer eigenen Schrift ${ }^{145}$, die ihm ein Dienststrafverfahren eintrugen ${ }^{146}$. Als Folge stellten sich Graf Schönborn, der Chroust bislang loyal unterstützt hatte, als erster Vorsitzender und dieser als erster Schriftführer 1928 nicht mehr zur Wiederwahl ${ }^{147}$. Die Leitung der Gesellschaft ging an den Regierungspräsidenten als ersten Vorsitzenden über, was nicht zu ihrem Vorteil gereichte. ${ }^{148}$ Die Disziplinarkammer beim Oberlandesgericht Bamberg urteilte am 3. April I930, dass Chroust sich verschiedener Dienstvergehen schuldig gemacht habe, worauf der der Bayerischen Volkspartei (BVP) angehörende Kultusminister Goldenberger ihm am I9. April mit der Versetzung in den dauernden Ruhestand drohte, falls er nicht um seine Emeritierung einging ${ }^{149}$. Chroust nahm damals Kontakte zu allen Parteien außer der KPD auf und fand diesmal Unterstützung bei den mit der BVP koalierenden Liberalen, die ihn I901/o2 noch bekämpft hatten. Für die Abgeordneten der bayerischen Deutschnationalen Volkspartei im Landtag war das Vorgehen des Kultusministers eine ungeheure Verletzung der Disziplinarrechte ${ }^{150}$, und deren Vorsitzender Hans Hilpert zeigte seinem Parteifreund Max Buchner, Nachfolger Henners auf dem Würzburger Lehrstuhl, die kalte Schulter, als dieser gegen Chroust in München intrigierte. Da der Antrag einiger Mitglieder des Senats der Universität, diesen zwangsweise in den Ruhestand zu versetzen, auch in der Fakultät keine Mehrheit fand ${ }^{151}$ - ein weiterer Beweis dafür, dass er an der Universität auch Freunde hatte -, musste Goldenberger nachgeben: von einer Dienstenthebung oder einer Zwangsemeritierung wurde wegen der Verdienste Chrousts, unter denen auch die Gründung der Gesellschaft für fränkische Geschichte vom Ministerium aufgeführt wurde, Abstand genommen ${ }^{152}$.

144 Ebd. 82ff., 318ff.

145 Anton Chroust, Die Gesellschaft zur Förderung der Wissenschaften bei der Universität Würzburg und ihr erster Schriftführer. Eine Feststellung (Würzburg 1928).

146 Sснӓ FER, Freunde (wie Anm. 139) 93ff.

147 Ebd. $93 \mathrm{ff}$. Akten dazu in UAWb, ARS, PA Chroust.

148 Ebd. 107.

149 Abschrift des Urteils und des KMS im NL Max Buchner, Bd. 101, im BAK.

150 Traub an Buchner 17.05.1930, ebd. Vgl. Peter Herde, Max Buchner (1881-1941) und die politische Stellung der Geschichtswissenschaft an der Universität Würzburg 1925-1945, in : Die Universität Würzburg in den Krisen der ersten Hälfte des 20. Jahrhunderts, hg. v. Peter Baumgart (Quellen und Forschungen zur Geschichte des Bistums und Hochstifts Würzburg 58, Würzburg 2002) $214 f$.

151 SCH ̈̈FER, Freunde (wie Anm. 139) $95 f$.

152 Ministerialschreiben vom 15.07.1930; Sснӓ FER, Freunde (wie Anm. 139) 96. Siehe oben Anm. 47. 
Wie sehr der gebürtige Österreicher Chroust mittlerweile Vertreter einer eigenständigen fränkischen Landesgeschichtsforschung geworden war, zeigte sich I 925 bei der Neubesetzung des Lehrstuhls für Mittelalterliche Geschichte und Bayerische Geschichte nach der Emeritierung Henners. Fakultät und Senat setzten den Würzburger Archivar und Erforscher der fränkischen Landesgeschichte Joseph Friedrich Abert auf die erste Stelle der Vorschlagsliste, und die Begründung stammt mit Sicherheit von Chroust: Man müsse einen Historiker gewinnen, der imstande sei, endlich im Rahmen der bayerischen Geschichte die überaus wichtige und seit einem Jahrhundert vernachlässigte fränkische Geschichte zu betreiben. Es geht nicht an, die fränkische Geschichte etwa nur als eine Nebensache neben der altbayerischen Geschichte zu behandeln; eine Vernachlässigung der fränkischen Belange durch die Universität könne bewirken, daß die schon sehr lebendig gewordene Frankenbewegung in ungeeignete Hände kommt und sich dadurch sogar recht unerwünschte politische Folgen ergeben könnten ${ }^{153}$. Berufen wurde jedoch durch politische Intervention der Zweitplazierte, der, obschon bald Mitglied der Kommission für bayerische Landesgeschichte bei der Bayerischen Akademie der Wissenschaften, keine eigentlichen landesgeschichtlichen Publikationen und schon gar nicht solche zur fränkischen Geschichte aufzuweisen hatte, der Münchner Max Buchner ${ }^{154}$.

Chroust, der in seinen Vorlesungen entsprechend der Ausrichtung seines Lehrstuhls die Neuere Geschichte, in Seminaren aber auch die Geschichte des Mittelalters und die Historischen Hilfswissenschaften behandelte, wurde am I. April I934, wie damals noch üblich mit 70 Jahren, emeritiert. Dadurch wurde er nicht mehr in die schweren Auseinandersetzungen hineingezogen, die auch die Universität Würzburg in den zwölf Jahren der Herrschaft des Nationalsozialismus heimsuchten. Auch sonst taucht sein Name in den Darstellungen über die deutsche Geschichtswissenschaft in der NS-Zeit kaum auf ${ }^{155}$. Er trat lediglich dem NS-Dozentenbund bei. Seine Frau Johanna aber, die sich, wie wir sahen, zur Aufgabe gesetzt hatte, die Deutschnationalen mit Mussolini zu versöhnen, trat I 937 der NSDAP bei; Chrousts Sohn Hermann Anton sollte in den USA als Hochschullehrer Karriere machen ${ }^{156}$.

Chrousts deutschnationale Haltung bedingte gewiss eine Teilidentifikation mit dem Regime, der er auch gelegentlich verbal Ausdruck verlieh. Eine besondere Affinität mit

153 Akademischer Senat der Universität Würzburg an das Bayerische Staatsministerium für Unterricht und Kultus, 08.03.1926, UAWb, ARS, PA Max Buchner.

154 Ausführlich Herde, Buchner (wie Anm. 150) $201 \mathrm{ff}$.

155 Vgl. die PA UAWb, ARS. Chroust wird nicht erwähnt in der ausführlichen Darstellung der Verhältnisse an der Universität Würzburg nach 1933 im materialreichen Werk von Helmut Heıв e R, Universität unterm Hakenkreuz 2: Die Kapitulation der Hohen Schulen 1: Das Jahr 1933 und seine Themen (München u.a. 1992) 175ff.; vgl. auch Schäfer, Freunde (wie Anm. 139) $316 f f$.

156 Siehe oben Anm. 16, und Sснӓ fE R, Freunde (wie Anm. 139) 317. 
dessen Ideologie geht aus seinen Schriften jedoch nicht hervor; sein Alter machte ihn für die radikaleren Nationalsozialisten uninteressant. Nach seiner Emeritierung versicherte er sich in Streitigkeiten um seine Vorlesungstätigkeit der Unterstützung des NS-Studentenbundes, indem er versprach, seine Vorlesungen in den Dienst des Regimes zu stellen. Vor allem aber genoss er das Wohlwollen des NS-Rektors Ernst Seifert, der ihm bis I94I zu Auslandsreisen zu Forschungszwecken und zu Kuren verhalf ${ }^{157}$. Die gleichgeschaltete Presse feierte seinen 70. und 75. Geburtstag. Aus Anlass seines 80. Geburtstags erhielt er am 27. März I944 mit Unterstützung des Rektors und des NS-Dozentenbundes die „Vom Führer“verliehene Goethe-Medaille für Kunst und Wissenschaft durch den Reichserziehungsminister Bernhard Rust aufgrund von Gutachten seiner Kollegen Eugen Franz (Würzburg) und Walter Kienast (Graz) ${ }^{158}$.

VI.

Am 22. Mai 1945 verstarb Anton Chroust, in Würzburg ausgebombt, als gebrochener Mann in Theilheim. Er hat sich, obwohl persönlich religiös, bis zu seinem Lebensende als „nicht kirchlich“ bezeichnet ${ }^{159}$. Sein Schicksal ist das eines Sohnes aus kleinen Verhältnissen, und noch dazu eines Österreichers, in einer vorwiegend aus dem protestantischen Bürgertum und der höheren Beamtenschaft stammenden und von deren Mentalität geprägten deutschen Professorenschaft ${ }^{160}$. Man könnte geneigt sein, bei tiefer greifender Analyse der hier geschilderten Vorgänge, die Erkenntnisse moderner gruppenpsychologischer Forschung über den sozialkognitiven Konsens bei Gruppenbildungen, hier von Professoren, anzuwenden, bei denen soziale, politische und ökonomische Verhältnisse, emotionale und rationale Kriterien interagieren und die häufig evaluative Komponenten einschließen: eine hohe Wertkonnotation der eigenen Gruppe („fortschrittlich“, „innovativ“, „liberal“) und abfällige Vorstellungen über die Fremdgruppe („konservativ“, „methodisch rückständig“, „ultramontan“) und mutatis mutandis um-

157 Vgl. das Obige nach dem Personalakt UAWb, ARS. Über die Vorgänge an der Universität Würzburg nach 1933 vgl. Heiber, Universität (wie Anm. 155) $175 f f$.

158 Ebd. Zu Kienast vgl. Peter Herde, Walther Kienast (31. Dezember 1896-17. Mai 1985), in: Walther Kienast, Die fränkische Vasallität. Von den Hausmeiern bis zu Ludwig dem Kind und Karl dem Einfältigen, hg. v. Peter Herde (Frankfurt/M. 1990) XIff. Zu Eugen Franz ausführlich ders., Buchner (wie Anm. 150) $238 \mathrm{ff}$.

159 Bigelmair, Lebensläufe (wie Anm. 10) 107. Dort 98f. über Chrousts schweres Schicksal und Tod 1945.

160 Vgl. Wolfgang Weber, Priester der Klio. Historisch-sozialwissenschaftliche Studien zur Herkunft und Karriere deutscher Historiker und zur Geschichte der Geschichtswissenschaft 1800-1970 (Frankfurt/M. u.a. 1984) $71 \mathrm{ff}$. Das gilt, soweit feststellbar, von der Mehrheit der Kollegen Chrousts in München und Würzburg. 
gekehrt $^{161}$. „Ultramontan“ war Chroust ganz sicher nicht, und sein Deutschnationalismus war zu österreichisch, um ihm zu helfen. Obschon in polemischer Absicht vorgebracht, sah der Zentrumsabgeordnete Gerstenberger die tiefer liegenden Gründe der schweren Auseinandersetzungen wohl richtig, wenn er "gesellschaftliche“ Divergenzen anführte $^{162}$, bei denen die katholische Konfession Chrousts für seine Gegner nur eine von mehreren negativen Kriterien bildete. Und hinzu kam: er hatte nicht „gedient“, war nicht Reserveoffizier und auch daher nicht salonfähig ${ }^{163}$. Die gefühlsmäßige Ablehnung, mit der man ihm bereits in München vielfach begegnete, war neben seiner Veranlagung verantwortlich für „die Härte seines Charakters“, wie es sein Freund Anton Bigelmair ausdrückte ${ }^{164}$, die „durch die schwere Jugendzeit und durch die Widerstände der späteren Zeit verstärkt“ wurde. So konnte es geschehen, dass er „bei der Verfolgung seiner Ziele zuweilen die gebotenen Rücksichten auf Menschen und Verhältnisse vermissen“ ließ ${ }^{165}$. In dem geschilderten schweren Streit haben sich der Kultusminister und die Juristen des Ministeriums korrekt verhalten, die Schuld an den Vorgängen gleichmäßig verteilt, die Machenschaften der Mehrheit von Fakultät und Senat durchschaut und Chroust auch wissenschaftlich Gerechtigkeit zuteil werden lassen, indem sie ihn - wie auch seinen Kontrahenten Förster - zum Ordinarius beförderten; beide haben das in sie gesetzte Vertrauen später voll gerechtfertigt. Mit großem Respekt nimmt man daneben das eigenständige und gerechte Urteil in dieser Sache zur Kenntnis, das Sebastian Merkle, der selbst in seinen ersten Jahren in Würzburg zahlreichen unfairen Angriffen ausgesetzt war ${ }^{166}$, und andere Professoren der Minderheit mutig vertraten. Umso betroffener machen muss hingegen der Mangel an Gerechtigkeitssinn und Augenmaß der Mehrheit von Fakultät und Senat, darunter eines so vorzüglichen Historikers wie

161 Aus der umfangreichen psychologischen Forschung verweise ich nur auf Henri TAJfel, Gruppenkonflikt und Vorurteil. Entstehung und Funktion sozialer Stereotypen (Bern/Stuttgart/Wien 1982) 70ff., $96 f$.

162 Wie oben bei Anm. 96.

163 In einem vielfach militaristisch geprägten Umfeld (vgl. oben Anm. 128) hatte es Chroust daher schwer. Vgl. das Protokoll der Verhandlungen des Ausschusses der Gesellschaft für fränkische Geschichte vom 28.05.1938 in: Dokumente (wie Anm. 47) 241, Nr. 103. Wörtlich sagte Chroust: „Er sei zwar nie Offizier gewesen, habe aber aus deren Kodex gelernt, nie das zu tun, was der Gegner wünscht, und einen angegriffenen Posten nicht zu räumen."

164 Bigelmair, Lebensläufe (wie Anm. 10) 107.

165 Ebd.

166 Theodbald Freudenberger, in: Sebastian Merkle, Ausgewählte Reden und Aufsätze, hg. v. Theobald Freudenberger (Quellen und Forschungen zur Geschichte des Bistums und Hochstifts Würzburg 17, Würzburg 1965) 12ff.; Klaus Ganzer, Sebastian Merkle (1862-1945), Theologe, in: Lebensbilder bedeutender Würzburger Professoren, hg. v. Peter Baumgart (Quellen und Beiträge zur Geschichte der Universität Würzburg 8, Neustadt a. d. Aisch 1995) 233ff. 
Ulrich Wilcken ${ }^{167}$, die den Streit zweier Kollegen, an dem beide ein etwa gleiches Maß an Schuld traf, dazu nutzen wollten, den sozial und weltanschaulich Ungeliebten der beiden wissenschaftlich schwer zu schädigen und die darüber hinaus die Angelegenheit durch Vertrauensbruch, also in rechtswidriger Weise, mit ihren politischen Freunden dazu nutzten, einen ihnen politisch und ideologisch nicht genehmen Kultusminister zu stürzen. Chroust hat auch später erbitterte Gegner gefunden, sich aber als Gelehrter und Wissenschaftsorganisator hohe Verdienste erworben, die auch bald anerkannt wurden, wenn ihm auch zur Erreichung der höchsten akademischen Ehren die Protektion der Lobby fehlte. Und schwer wiegt das Urteil eines der bedeutendsten deutschen Mediävisten der I93oer-Jahre, der erst später zu Chroust gestoßen war und von ihm in Würzburg promoviert wurde, obschon er ihm weder politisch noch konfessionell nahestand, und der später noch nicht einmal die Würde eines Professors erreichte: Carl Erdmann, der entschiedene und dadurch auf jede Karriere verzichtende Gegner des Nationalsozialismus ${ }^{168}$. In der Einleitung der von ihm herausgegebenen Sammlung von Aufsätzen Chrousts $^{169}$ schreibt er über seinen Lehrer: „Er vermag wie wenige Menschen das Bewusstsein zu haben, dass er nichts durch fremde Protektion, sondern alles durch eigene Leistung erreicht hat. Seine Kämpfernatur hat im Laufe der Jahre eine lange Reihe von Widerständen siegreich zu überwinden vermocht. Der Unterzeichnete als sein Schüler und einstiger Assistent, der in I 5 Jahren von ihm nichts als Gutes erfahren hat, kann bezeugen, wie Chroust das Sachliche über das Persönliche zu stellen wusste.“

167 Siehe oben Anm. 65.

168 Friedrich BAETHGEN, in: DA 8 (1950) 251ff.; ausführlicher Ders., in: Carl Erdmann, Forschungen zur politischen Ideenwelt des Frühmittelalters. Aus dem Nachlass des Verfassers hg. v. Friedrich BaEthgeN (Berlin 1951) VIIIff.; Nachdruck DE Rs., Mediaevalia. Aufsätze, Nachrufe und Besprechungen 2 (Schriften der MGH 17/2, Stuttgart 1960) 505ff. Erdmann, geb. 27.11.1898 in Dorat, war übrigens Professorensohn, hatte evangelische Theologie in Berlin, dann Geschichte in München und Würzburg studiert. Seit 1920 Mitarbeiter Paul Kehrs am Preußischen Historischen Institut in Rom, seit 1932 in Berlin, wo er sich habilitierte, musste er wegen seiner politischen Haltung seine Dozentur aufgeben und wurde Mitarbeiter bei den MGH. Am 07.05.1945 starb er in Agram als Soldat an Fleckfieber. Baethgen schilderte ihn als Menschen „von seltener Reinheit der Gesinnung und von einer Festigkeit des Charakters, wie man ihr nicht gerade häufig begegnet" (DA 8, 252).

169 Erdmann, Einleitung (wie Anm. 10) VIII. 



\section{Arthur Stein (I87I-1950) und Edmund Groag (1873-1945)}

\section{ZWEI JÜDISCHE GELEHRTENSCHICKSALE IN WIEN UND PRAG}

\section{Leivae Petersen}

clarissimae et doctissimae feminae

quae opus Prosopographiae Imperii Romani iteratis curis pertractandae a Groag et Stein inchoatum suscepit persequi autem non potuit ante XX annos mortuae LXXX annos natae

\section{E I N LE I T U N G ${ }^{1}$}

Unter dem Porträt Arthur Steins, das der Maler Max Plaček Anfang Juli I943 im Konzentrationslager Theresienstadt (Terezín) angefertigt hat ${ }^{2}$, stehen Verse des römi-

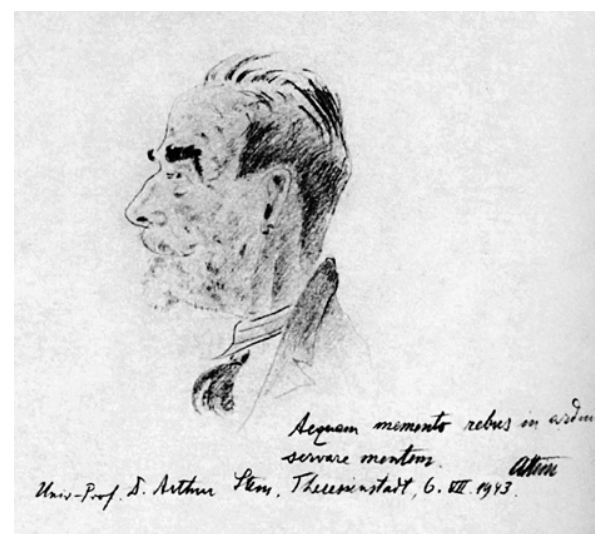

Abb. 4: Max Plaček: Porträt Arthur Steins (Theresienstadt I943) schen Dichters Horaz, die von der Hand des Porträtierten stammen: Aequam memento rebus in arduis servare mentem (Bewahre den Gleichmut im Unglück). Es ist der Beginn der Ode

1 Viele der hier dargestellten Tatsachen und Ereignisse wurden im Internet und per E-Mail-Korrespondenz recherchiert. Wesentliche Bedeutung hatten aber mehrere Archivreisen (nach Prag 17.-24.04.2001 und 05.-11.10.2003, nach Wien 15.-25.10.2001 und 13.-23.10.2003). Die Reisen 2001 fanden als Arbeitsstellenleiter der Prosopographia Imperii Romani an der Berlin-Brandenburgischen Akademie der Wissenschaften statt; nach der Emeritierung im Jahre 2002 ermöglichte das Deutsche Archäologische Institut (= DAI) die Reisen 2003. Schließlich konnten mit Mitteln des Forschungsclusters 5 am DAI abschließende Reisen 2010 (14.-26.03. nach Wien, vom 06.-16.04. nach Prag) durchgeführt werden. - Von vielen Seiten ist dem Autor Hilfe zuteilgeworden. Einzelne Institutionen und Personen sind an entsprechenden Stellen des Beitrags namentlich erwähnt. Einen ganz besonderen Dank schulde ich Karel Hruza für eine ausgiebige redaktionelle Überarbeitung, Ergänzung der Literaturangaben, Hinweise auf Literatur und thematische Aspekte sowie eine Überarbeitung der Stellen zu Steins Deportation und Aufenthalt in Theresienstadt, so auch zum unten zitierten NS-Propagandafilm über Theresienstadt.

2 Insgesamt hat Plaček (gestorben 1944 in Sachsenhausen) etwa 550 Porträts gezeichnet, deren Originale sich in Yad Vashem befinden. Das Porträt Steins wurde unter 70 im Jahre 1994 publizierte Stücke aufgenommen, siehe Max Plače K, Double Signature (Jerusalem 1994). Die Reproduktion der Zeichnung in diesem Beitrag stammt aus dieser Veröffentlichung. 
2,3, die der Dichter an Dellius gerichtet hat, einen Römer senatorischen Standes, der am Ende der Republik und unter Kaiser Augustus gelebt hat. Man kann sich gut vorstellen, dass Stein diese Worte des römischen Dichters an seinen Freund Edmund Groag gerichtet haben könnte, seinen wissenschaftlichen Weggefährten, den ein ähnlich hartes Schicksal wie ihn selbst getroffen hat. Beide verband eine gleiche Herkunft, gleiche wissenschaftliche Interessen und das gemeinsame wissenschaftliche Hauptwerk. Der Herausgeber dieses Bandes hat deshalb dankenswerterweise dem Vorschlag des Autors zugestimmt, diese Darstellung als ein Doppelporträt der beiden altösterreichisch-jüdischen Althistoriker abzufassen ${ }^{3}$.

\section{VORFAHREN UND VERWANDTSCHAFT}

Arthur Stein wurde am Io. Juni I87 I in Wien geboren ${ }^{4}$. Seine Eltern stammen aus Böhmen: Leopold Stein, der Vater, kam am I2. Februar I830 in Schönhof (Krásný Dvůr) auf die Welt, während die Mutter Karoline Pfau am ıo. Dezember I 838 in Zbraslawitz (Zbraslavice) südlich von Kuttenberg (Kutná Hora) geboren wurde 5 . Sie wurden I860 in der Pinkas-Synagoge in Prag getraut ${ }^{6}$, haben sich also vermutlich in Prag kennengelernt. Zwischen der Heirat und dem Jahr I 865, als die Mutter ein Dienstleistungsvermittlungsoder Gouvernanten-Institut in Wien gründete, sind Steins Eltern dorthin verzogen ${ }^{7}$. In den Jahren vor seinem Tod war Leopold Stein als „Lederagent“, also als Vertreter für Lederwaren tätig8. Er starb am 23. August I 892, seine Frau am 26. November 1907, und

3 Leben und Werk der beiden Gelehrten sind bisher kaum gewürdigt worden: veröffentlichte Nachrufe für Groag fehlen ganz, zu ihm siehe zuletzt Fritz Fellner, Doris A. Cor Radini, Österreichische Geschichtswissenschaft im 20. Jahrhundert. Ein biographisch-bibliographisches Lexikon (VKGÖ 99, Wien 2006) 152, und mit ausführlichem Stemma Klaus Wach tel, Prof. Dr. Edmund Groag (1873-1945). Zu den Vorfahren dieses jüdisch-österreichischen Althistorikers, in: Tyche 25 (2010) 173-183. Zu Stein existieren nur kurze Würdigungen von Karel Beranek (Eunomia 1 = Listy filologické 5 [1957] Suppl. 81-83), Victor EHrENBERG (Historia 1 [1950] 513f.) und Artur Betz (Anzeiger für die Altertumswissenschaft 4 [1951] 193f.).

4 Laut Geburtsurkunde (Abschrift im Archiv des Jüdischen Museums Prag).

5 Diese Geburtsorte und -daten nach Auskunft der Magistratsabteilung 61 Wien. Nach dem Grabstein (siehe Anm. 9) ist der Vater allerdings am 5. Februar 1830 geboren, während die Mutter am 26. November 1907 im 72. Lebensjahr starb, demnach also 1835 geboren wurde.

6 Trauungsmatrikel Bd. 1857-1864/5 im NA.

7 Im Wiener Adressbuch 1925,2 681, steht: „Gouvernanten-Institut Stein, Wollzeile 24. Erstrangiges größtes Placierungsinstitut im Lehr- und Erziehungsfach. Gegründet 1865. “ Die Jahrgänge 1871 bis 1879 von „Lehmann's Allgemeiner Wohnungs-Anzeiger nebst Handels- und Gewerbe-Adreßbuch für die k.k. ReichsHaupt- und Residenzstadt Wien“ geben als Adresse die Singerstraße 3 an. Gemäß der Jahrgänge 1872 bis 1875 war Leopold Stein als Baumwollhändler tätig.

8 Siehe Lehmanns Wohnungsanzeiger für 1887 bis 1892 und das Beerdigungsregister der Israelitischen Kultusgemeinde (= IKG) Wien. 
beide fanden ihre letzte Ruhe auf dem jüdischen Teil des Wiener Zentralfriedhofs ${ }^{9}$. Arthur Stein hatte zwei ältere Schwestern: Olga, geboren I 867, verheiratete Politzer, starb am 25. November I94I in Wien und scheint nach dem Tod der Mutter das Vermittlungsinstitut weitergeführt zu haben; Ida, geboren I 870, verheiratete Fischl, starb ebenfalls in Wien, wo sie im Oktober 1909 beerdigt wurde ${ }^{10}$.

Edmund Groags Vorfahren stammen aus Mähren: die Eltern Berthold ${ }^{11}$ und Charlotte, geborene Karpeles ${ }^{12}$, hatten 1870 in Loschitz (Loštice) geheiratet ${ }^{13}$ und verlegten zwischen I 873, als Edmund am 2. Februar in der mährischen Kleinstadt Prerau (Přerov), dem Familienwohnsitz, zur Welt kam, und s 876, dem Jahr der Geburt seiner Schwester Paula in Wien ${ }^{14}$, ihren Wohnsitz in die Metropole an der Donau. Groags Vorfahren mütterlicherseits weisen eine Reihe beeindruckender Persönlichkeiten auf: sie beginnt mit den Ururgroßvätern Moses Präger-Karpeles ${ }^{15}$ und Gerson Buchheim ${ }^{16}$, die um die Wende vom I 8. zum I9. Jahrhundert bedeutende Rabbiner in Mähren waren. Ihre Söhne, Groags Urgroßväter Eleazar Karpeles ${ }^{17}$ und David Buchheim ${ }^{18}$, waren ebenfalls mährische Rabbiner wie auch Groags Großvater Elias Karpeles, der schließlich seit I 88I in Wiens 4. und 5. Gemeindebezirk amtierte $^{19}$. Zu den erwähnenswerten Vorfahren Groags sind auch sein Onkel Gustav Karpeles, ein bekannter Berliner Germanist und Heine-Forscher ${ }^{20}$, und Groags Großonkel, der Germanist und Prinzenerzieher im London der Fontane-Zeit Karl Adolph Buchheim²1, zu zählen.

9 Grabstelle Abt.19, Reihe 8, Grab 42.

10 Angaben nach den Unterlagen (Geburtsregister, Friedhof) in der IKG Wien (freundliche Auskunft von Frau Weiß) und Lehmanns Wohnungsanzeiger und Wiener Adressbuch.

11 Eisenbahningenieur, geboren 1842 in Prerau (Auskünfte NA, und WStLA).

12 Groags Mutter ist mit der Schriftstellerin Belmonte-Groag alias Charlotte Karpeles-Buchheim gleichzusetzen.

13 Trauungsmatrikel von Loschitz und Prerau (freundliche Auskunft von Lenka Matušiková, NA).

14 Pauline Groag wurde am 19.06.1876 in Wien geboren (Auskunft Frau Weiß, IKG Wien). Auch die jüngeren Brüder der Mutter übersiedelten schließlich nach Wien. Vom älteren Bruder, dem Germanisten Gustav Karpeles (1848-1909), abgesehen, sind die jüngeren Brüder Rudolf Kars (1854-1919) und Ludwig Karell (1858-1930), die ebenfalls als Schriftsteller hervorgetreten sind, und der Ingenieur Emil Karell (geboren 1867, 1942 nach Theresienstadt deportiert) in Wien ansässig gewesen.

15 Biographisches Handbuch der Rabbiner 1,2. Die Rabbiner der Emanzipationszeit in den deutschen, böhmischen und großpolnischen Ländern 1781-1871, bearb. v. Carsten WiLKE (München 2004) Nr. 880.

16 Ebd. Nr. 216.

17 Ebd. Nr. 877.

18 Ebd. Nr. 215.

19 Ebd. Nr. 875.

$20 \mathrm{Zu}$ ihm Internationales Germanistenlexikon 1850-1950 2 H-Q, hg. v. Christoph KöNIG (Berlin 2003) 893-895; Lexikon deutsch-jüdischer Autoren 13 (München 2005) 267-281; NDB 11, 295f. (Gerhard WINKLER).

$21 \mathrm{Zu}$ ihm Derek Glass in: Exilanten und andere Deutsche in Fontanes London. Charlotte Jolles zum 85. Geburtstag, hg. v. Peter Alter, Rudolf Muns (Stuttgarter Arbeiten zur Germanistik 331, Stuttgart 1996) $41-76$. 
Zu den ersten Schuljahren Arthur Steins und Edmund Groags in der sogenannten Volksschule gibt es keine Nachrichten. Diese beginnen erst mit dem Besuch der Mittelschule in Form einer Oberrealschule oder eines Gymnasiums: 1883 wurde Stein in die I. Klasse der Communal-Oberrealschule im I. Wiener Gemeindebezirk (heute Bundesrealgymnasium Lise Meitner, Schottenbastei 7-9) aufgenommen. Nach Beendigung der 7. Klasse bestand er I 890 die Maturitätsprüfung mit Auszeichnung. Im Einzelnen erhielt er folgende Noten: in Deutsch, Französisch, Englisch, Geschichte, Mathematik und auch Sport vorzüglich, in Naturgeschichte, Geografie und Chemie lobenswert, in Physik, Geometrie und Zeichnen reichte es nur für befriedigend ${ }^{22}$. Offenbar vermisste Stein aber einen Abschluss in den klassischen Sprachen und besuchte daher im Schuljahr I 890/9I als Externer die 8. Klasse des k.k. Staatsgymnasiums im 3. Gemeindebezirk (heute Landstraßer Gymnasium, Kundmanngasse 20-22). Nach den Schulakten ${ }^{23}$ folgte er dem Unterricht in den Fächern Religionslehre, Latein, Griechisch, Deutsch, Geografie und Philosophische Propädeutik mit nicht ganz so gutem Erfolg wie in der Oberrealschule, bestand aber I 89 I die Reifeprüfung wieder mit Auszeichnung ${ }^{24}$. Er muss also schon in den Jahren seines Besuchs der Oberrealschule wohl zusätzlich privaten Unterricht in den klassischen Sprachen erhalten haben. Seine Lehrer am Gymnasium waren für Latein Anton Filipský, in Griechisch Anton Kunz, in Deutsch und Geografie Jacob Zeidler ${ }^{25}$. Am selben Gymnasium war zu dieser Zeit auch Karl Wessely ${ }^{26}$, der bekannte Papyrologe, als Lehrer angestellt, dem Stein zehn Jahre später als Supplent am selben Gymnasium wieder begegnen sollte.

$\mathrm{Zu}$ Groags Schulzeit lässt sich dagegen lediglich feststellen, dass er I 892 am Staatsgymnasium im 4. Wiener Gemeindebezirk maturiert hat: im 7. Jahresbericht dieses Gymnasiums wird er in der Liste der approbierten Abiturienten genannt. Folglich hat er - den Besuch von gewöhnlich 8 Klassen vorausgesetzt, vermutlich I 884, also mit elf Jahren, das Gymnasium zum ersten Mal betreten ${ }^{27}$.

22 Angaben aus dem Hauptkatalog der Oberrealschule; Prof. Kröter vom Bundesrealgymnasium Lise Meitner hat mir freundlicherweise die betreffenden Kataloge kopieren lassen.

23 Direktor Wolf Peschl hat mir freundlicherweise die entsprechenden Unterlagen kopieren lassen.

24 Siehe 22. Jahresbericht des Gymnasiums (1891) 50.

25 Bekannt durch eine zweibändige Deutsch-österreichische Literaturgeschichte.

26 Zu ihm Fellner, Corradini, Geschichtswissenschaft (wie Anm. 3) 450. Von diesem Kontakt könnte Steins späteres wissenschaftliches Interesse an Ägypten ausgegangen sein (vgl. unten).

27 Im Zweiten Weltkrieg wurden sämtliche Schulakten vernichtet, die über den Schüler Groag Näheres berichtet hätten. 


\section{ST UDIENZEIT}

Unmittelbar im Anschluss an sein zweites Abitur leistete Stein I891/92 seinen Militärdienst als Einjähriger ab, während von Groag kein Militärdienst bekannt ist ${ }^{28}$. Zu Weihnachten 1892 erhielt Stein das Patent als Leutnant der Reserve, das im Archiv des Jüdischen Museums in Prag aufbewahrt wird. Hier befindet sich auch ein eigenhändig geschriebener Lebenslauf Steins, in dem es heiß $\mathrm{t}^{29}$ : Vom Herbst I892 bis I896 war ich ordentlicher Student der Philosophischen Fakultät an der Wiener Universität; ich studierte hauptsächlich Geschichte bei [Max] Büdinger, Altertumskunde u. Epigraphik bei [Eugen] Bormann, [Otto] Benndorf u. [Emil] Szanto und Geographie bei [Albrecht] Penck u. [Wilhelm] Tomaschek ${ }^{30}$. Ende Okt. I897 legte ich in Wien die Lehramtsprüfung aus Geographie u. Geschichte als Hauptfach für Mittelschulen ab, am I6. Febr. I898 wurde ich zum Dr. phil. promoviert auf Grund einer Dissertation über die Quellen von Tacitus' ersten sechs Büchern der Annalen.

Zentrum der altertumswissenschaftlichen Forschung und Lehre an der Wiener Universität war das Archäologisch-epigrafische Seminar, das I 876 von dem Archäologen Alexander Conze und dem Althistoriker Otto Hirschfeld gegründet worden war ${ }^{31}$. Seit I 877 waren Benndorf als Nachfolger Conzes, seit I 885 Bormann als Nachfolger Hirschfelds Direktoren des Seminars, zu denen als 3. Direktor Szanto kam, der I 893 zum a.o. Prof. für Griechische Geschichte und Altertumskunde, I 90 I zum Ordinarius ernannt wurde.

$\mathrm{Zu}$ den Studenten dieser Jahre bei Büdinger und Bormann zählten auch Harold Steinacker $^{32}$ und Edmund Groag, die beide - in unterschiedlicher Weise und Intensität - im

$28 \mathrm{Zu}$ seiner Entbindung vom aktiven Landsturmdienst siehe unten.

29 Mit Anmerkungen wiedergegeben von Klaus Waсн tel, Curriculum vitae, in: Jahresbericht des GRG 3 für das Schuljahr 2005/2006 (Wien 2006) 29-32.

$30 \mathrm{Zu}$ Bormann, Büdinger und Szanto siehe Fellner, Corradini, Geschichtswissenschaft (wie Anm. 3) 63, 71f. und 408; Ingomar Weile R, Alte Geschichte, Klassische Archäologie und Altertumskunde, in: Geschichte der österreichischen Humanwissenschaften 4. Geschichte und fremde Kulturen, hg. v. Karl Aснам (Wien 2002) 83-126, hier 86, 94 und 98f.; zu Benndorf ebd. S. 90f. und Hedwig Kenner in: Archäologenbildnisse. Porträts und Kurzbiographien von klassischen Archäologen deutscher Sprache, hg. v. Reinhard Lullies, Wolfgang Schiering ('Mainz 1991) 67f;; vgl. außerdem ÖBL 1, 70; zu Penck vgl. Karl Albert Авве in: NDB 20, 172f.; zu Tomaschek vgl. Albrecht PenCк in: Almanach der Kaiserlichen Akademie der Wissenschaften Wien 52 (1902) 291-295.

$31 \mathrm{Zu}$ Conze siehe Adolf Bor bein in: Archäologenbildnisse (wie Anm. 30) 59f.; zu Hirschfeld Ernst KorNEMANN in: Bursians Biographisches Jb. für Altertumskunde (Nekrologe) 44 (1924) 104-116; ÖBL 2, $332 f$. Zum Fach Alte Geschichte in Wien siehe jetzt Pavel Kolá ř, Geschichtswissenschaft in Zentraleuropa. Die Universitäten Prag, Wien und Berlin um 1900 1-2 (Geschichtswissenschaft und Geschichtskultur im 20. Jahrhundert 9, Berlin 2008), hier 2, 293-297.

32 Zu ihm Renate Spreitzer, Harold Steinacker (1875-1965). Ein Leben für „Volk und Geschichte“, in : Österreichische Historiker 1900-1945. Lebensläufe und Karrieren in Österreich, Deutschland und der 
späteren Leben Steins eine Rolle spielten: als Steinacker I9I7 an die Deutsche Universität Prag berufen wurde und dort ein Jahr die historischen Hilfswissenschaften lehrte, traf er den einstigen Kommilitonen Stein wieder, der dort seit I9 I 5 als Privatdozent für Griechische und Römische Geschichte und Altertumskunde wirkte. Stein widmete ihm einige Jahre später seine Arbeit über die Reichsbeamten der Provinz Thracia ${ }^{33}$. I94I sollte Steinacker - Mitglied der NSDAP und Rektor der Universität Innsbruck - vergeblich versuchen, eine Deportation Steins aus Prag zu verhindern ${ }^{34}$. Mit Groag pflegte Stein zeitlebens eine enge freundschaftliche Beziehung, deren Hauptcharakteristikum in einem intensiv geführten wissenschaftlichen Gedankenaustausch bestand ${ }^{35}$ und seine Krönung in der gemeinsamen Erarbeitung und Herausgabe der zweiten Auflage der Prosopographia Imperii Romani finden sollte.

\section{DIE ERSTEN BERUFSJAHRE}

Stein begann seine Laufbahn als Lehrer im November I 897 als Probekandidat am Maximilians-Gymnasium in Wien und setzte sie seit April I 898 als Supplent an verschiedenen Wiener Gymnasien bis zum Januar 1902 fort $^{36}$. Eine Unterbrechung fand diese Lehrtätigkeit durch eine wissenschaftliche Reise nach Bulgarien, die er im Auftrag der Wiener Akademie der Wissenschaften als Begleiter Heinrich Hartls ${ }^{37}$ unternahm. Dabei hatte er den Bestand an antiken Inschriften im Museum von Sofia aufzunehmen und dann in Devnya (bei Varna), dem antiken Markianopolis, wo Hartl Ausgrabungen leitete, die epigrafischen und archäologischen Funde zu bearbeiten. Das Ergebnis dieser Arbeiten ist in dem von Ernst Kalinka herausgegebenen Sammelband „Antike Denkmäler in Bulgarien“ (Wien I906) niedergelegt. Eine weitere Studienreise führte Stein nach Italien und Sizi-

Tschechoslowakei in wissenschaftsgeschichtlichen Porträts, hg. v. Karel Hruza (Wien/Köln/Weimar 2008) 191-223.

33 Römische Reichsbeamte der Provinz Thracia (Sarajevo 1920) VI.

34 Siehe unten und den Brief Steinackers im Anhang.

35 Vgl. die Vorworte zu Steins Ritterstand, zu dessen Legaten von Mösien, den Reichsbeamten von Dazien und schließlich den Präfekten von Ägypten. Letztere sind dem Andenken Groags mit folgenden Worten gewidmet: "gewidmet ist dieses Buch dem Andenken des teuren Freundes, mit dem mich eine mehr als halbjahrhundertlange engste Arbeitsgemeinschaft verbunden hat und dessen unschätzbare Beiträge und Ratschläge ich nun zum erstenmal in meinen Publikationen schmerzlich vermissen mußte.“

36 Laut Personalbogen 13.143/39 des Unterrichtsministeriums (NA) war Stein Supplent am Franz-Joseph-Gymnasium 1898, am Maximilians-Gymnasium 1899, am Akademischen Gymnasium 1899 und 1901/02 und schließlich am k.k. Staatsgymnasium im 3. Wiener Gemeindebezirk; vgl. dazu auch den 32. Jahresbericht dieses Gymnasiums 1900/1901 (Wien 1901) 17 und 19.

$37 \mathrm{Zu}$ ihm ÖBL 2, 194. 
lien, Griechenland, Kreta und Kleinasien, die er mit Unterstützung durch ein staatliches Reisestipendium vom September I 899 bis August I 900 unternahm.

Im Januar 1902 wurde Stein provisorischer Lehrer an der Staatsrealschule im 2. Wiener Gemeindebezirk, verzog jedoch 1903 nach Prag, um als wirklicher Lehrer, später k.k. Professor, an der I. Deutschen Staatsrealschule in $\operatorname{Prag}^{38}$ zu arbeiten. Am I6. Juni 1905 wählte man Stein wie schon Groag drei Jahre zuvor zum korrespondierenden Mitglied des Österreichischen Archäologischen Instituts. Dass die beiden Freunde unterschiedliche berufliche Wege einschlagen würden, hatte sich bereits früh gezeigt: während Stein offenbar eine Karriere als Gymnasiallehrer im Auge hatte, trieb es Groag, der bereits I 895 promoviert hatte, wohl eher nicht an die Schule. Bereits von I 894 bis I 898 arbeitete er auf Vermittlung Adolf Beers ${ }^{39}$ an der Indizierung der „Historia gestorum generalis synodi Basiliensis“ des Johannes von Segovia ${ }^{40}$. Nach den Fasti des Archäologisch-epigrafischen Seminars arbeitete Groag daneben von I 896 bis I 898 als Stipendiat am Seminar, erhielt I 898/99 das Reisestipendium nach Italien und war nach seiner Rückkehr von I 899 bis I 90 I Bibliothekar am Seminar. Im Anschluss daran begann er noch I 90 I als unbesoldeter Volontär an der Hofbibliothek (der späteren Nationalbibliothek) zu arbeiten ${ }^{41}$. Am 7. Januar I90 I, also wohl nicht von ungefähr unmittelbar vor Beginn dieser Tätigkeit, ließ sich Groag, damals wohnhaft in der Heumühlgasse $6^{42}$, in der Paulanerkirche in Wieden, der Pfarrkirche zu den heiligen Schutzengeln, taufen und trat damit aus der israelitischen Kultusgemeinde aus ${ }^{43}$. Als Grund wird im Konvertitenverzeichnis der Kirche angegeben: das lautere Verlangen, der kathol. Kirche anzugehören, damals wohl eine stereotyp gebrauchte Formel ${ }^{44}$.

Bereits 1902 wurde Groag zum korrespondierenden Mitglied des Österreichischen Archäologischen Instituts gewählt. Seine weiteren Stationen an der Hofbibliothek waren I 903 unbesoldeter wissenschaftlicher Hilfsarbeiter, I905 besoldeter Hilfsarbeiter, nachdem er sich I904 offenbar erfolglos um eine Stelle als a manuensis an der Technischen Universität bemüht hatte ${ }^{45}$; I 906 wurde er Assistent, I 909 Kustosassistent ${ }^{46}$, I 9 I 3 Kustos

38 Vgl. den 43. Jahresbericht der 1. Deutschen Staats-Realschule 1903/04 (Prag 1904) 34-36.

$39 \mathrm{Zu}$ ihm ÖBL 1, 63.

40 Freundlicher Hinweis von Stefan Sienell auf die zugehörigen Akten im Archiv der ÖAW.

41 Entscheidung des Oberhofkämmerers vom 25.05.1901: Hausakten HB 302/1901; Dienstantritt am 18. Juni: HB 591/1901, ÖNB Archiv.

42 Adresse in der Taufmatrikel 1900 fol. 1 Taufeintrag vom 07.01.1901.

43 Auskunft von Frau Weiß (IKG Wien).

44 Die Hinweise auf die Taufe Groags und Kopien aus dem Taufregister und dem Konvertitenbuch verdanke ich Anna L. Staudacher, der dafür herzlichst gedankt sei.

45 HB 150/1904, ÖNB Archiv.

46 Ebd. Brief des Oberstkämmerers an die Direktion vom 20.07.1909: HB 1095/1909. 
2. Klasse ${ }^{47}$, als der er seit I9I7 auch in der Münz- und Medaillensammlung des Kaiserhauses tätig war ${ }^{48}$. Vom aktiven Landsturmdienst war er auf Antrag der Hofbibliothek bereits I9I 5 auf unbestimmte Zeit entbunden worden ${ }^{49}$. Trotz seiner bibliothekarischen Tätigkeit und seiner wissenschaftlichen Interessen, die ihren Ausdruck in zahlreichen Aufsätzen und Artikeln in Pauly's Realencyclopaedie der classischen Altertumswissenschaft (= RE) fanden, verschmähte Groag die Lehrtätigkeit nicht ganz. Wohl in Anbetracht seiner allzu kärglichen Löhnung an der Bibliothek sah er sich nach einer weiteren bezahlten Beschäftigung um und fand diese bei den bildungshungrigen, vorzugsweise jüdischen höheren Töchtern Wiens. Von I 904 bis I 909 unterrichtet er sie, wie aus seinem Curriculum vitae in der Personalakte der Universität hervorgeht, in Geschichte, Geografie, Latein und Griechisch in den Schwarzwaldischen Gymnasialkursen ${ }^{50}$, von I909 bis I9I 3 in denselben Fächern in den Gymnasialkursen des Cottage-Lyzeums.

An diesen Stationen von Groags Lebensweg werden zumindest teilweise die Konturen der geistig-kulturellen Umgebung sichtbar, in der er sich zu dieser Zeit bewegt hat, nicht zuletzt sicher auch dank seiner Mutter, mit der er offenbar zusammengewohnt hat, und der Brüder seiner Mutter, Groags Onkel. In diese Zeit dürfte auch der sogenannte Arnoldkreis $^{51}$ gehören, in dem sich der später bedeutende Prager Germanist Josef Körner ${ }^{52}$ und Groag begegnet sind: Jahrzehnte später schrieb Körner an Groag ${ }^{53}$ : An die Abende im Arnoldkreis freilich, wo ich Sie kennenlernte, und unsere damaligen Gespräche erinnere ich mich noch so lebhaft - ich könnte das Lokal beschreiben, und Nase, Gaumen spüren noch Duft und Schmack des Eierpunsches in jenem Ring-Cafe [...]. In diesen Zusammenhang könnte auch die Spaß-Karte im Nachlass Arnolds gehören, auf der steht ${ }^{54}$ : Ich verpflichte mich, an meinem 70. Geburtstag, also im Jahre 1942, Herrn Dr. Karl Ausserer ${ }^{55}$ eine schöne Hose nach

47 Ebd. Brief des Oberstkämmerers vom 25.04.1913; HB 250/1913.

48 Ebd. Antrag Rudolf Münsterbergs (zu ihm ÖBL 6, 436), Direktors der Sammlung, vom 27.04.1917: HB $188 / 1917$.

49 Ebd. Brief vom 28.12.1915: HB 441/1915.

50 Eugenie Schwarzwald hatte 1901 die Mädchenschule in Wien 1, Franziskanerplatz 5 (später Wallnerstr. 9), übernommen und daraus die nach ihr benannten Schulanstalten mit einem besonderen pädagogischen Profil gegründet. Das Niveau muß dank der beschäftigten Lehrkräfte sehr hoch gewesen sein, vor allem auch in künstlerischer Hinsicht.

51 Robert F. Arnold (1872-1938) war 1895-1913 wiss. Hilfsarbeiter und dann Kustos an der Hofbibliothek, seit 1913 wirklicher ordentlicher Professor an der Wiener Universität; vgl. zu ihm Internationales Germanistenlexikon (wie Anm. 20) 47-49.

52 Zu ihm ebd. 974-976.

53 Josef Körner, Philologische Schriften und Briefe, hg. v. Ralf Klausnitzer (Göttingen 2001) 391, vgl. 455-457 (ebd. „Grooz“ verlesen für Groag).

54 ÖNB 361/20-6.

55 Oberstaatsbibliothekar an der ÖNB, vgl. Kürschners Gelehrtenkalender 1940/41; ÖBL 1, 38. 
der dann geltenden Mode zu stiften. Dr. Robert Arnold, Freischwimmer, Steuerzahler, Landsturmoffiziers-Designierter usw. Dr. Edmund Groag (als Zeuge). Auch Karl Gladt scheint diesen Kreis zu meinen, wenn er anlässlich des Ioo. Geburtstages von Arnold schreibt: Schon vor dem ersten Weltkrieg hatte Arnold einen Kreis von, Jüngern' um sich geschart, die an Freitag-Abenden in der Art eines Geselligkeitsvereins erst im Hotel Klomser in der Bankgasse, später im Café Magistrat in der Universitätsgasse zusammenzukommen pflegten. Von diesem zweiten Lokal hatte die Vereinigung dann auch den Namen ,Magistrat' angenommen ${ }^{56}$.

Im Jahr I 896 wurden schließlich die Weichen für das wissenschaftliche Tätigkeitsfeld beider Freunde gestellt ${ }^{57}$ : im dritten Band der RE, der I 897 erschien, sind ab dem Anfangsbuchstaben C die Artikel zu Personen der römischen Kaiserzeit von Groag und Stein bearbeitet, die damit das Erbe von Elimar Klebs und Paul von Rohden angetreten hatten ${ }^{58}$. Dass die jungen Absolventen der Wiener Universität, von denen der eine im selben Jahr, der andere erst im nächsten Jahr promovierte, als Mitarbeiter dieses renommierten und ambitionierten Nachschlagewerkes genommen wurden, zeigt einerseits, dass ihr wissenschaftliches Talent bereits deutlich hervorgetreten sein musste, zum anderen, dass sie auf die Fürsprache und Förderung ihrer Lehrer - vor allem wohl Bormanns - zählen konnten. Ihre spätere wissenschaftliche Produktion hat jedenfalls die Richtigkeit dieser frühen Entscheidung vollauf bestätigt. Und sogar die systematische Aufteilung der zu bearbeitenden Personen in Senatoren (Groag) bzw. Ritter und Kaiser (Stein) war hier bereits mit einer Ausnahme (Kaiser Claudius wurde von Groag bearbeitet) vorgenommen worden.

\section{DIE PRAGER JAHRE ARTHUR STEINS BIS ZUR EMERITIERUNG I939}

Während der ersten Jahre in Prag lernte Stein seine spätere Frau Flora Utitz ${ }^{59}$ kennen, eine Schwester des bekannten Charakterologen und Philosophen Emil Utitz ${ }^{60}$. Die Trauung

56 Karl Gladt, Robert Franz Arnold zu seinem 100. Geburtstag, in: Österreich in Geschichte und Literatur 16 (1972) 482. Die wöchentlichen Zusammenkünfte in der Gastwirtschaft „Zum Magistrat“ erwähnt bereits der Literaturwissenschaftler Eduard Castle in „Worte des Gedenkens“ bei der Trauerfeier am 24.02.1938, siehe Gedenkblatt für Robert Franz Arnold (Privatdruck, Horn [1938]) 8. Auf beide Zeugnisse hat mich freundlicherweise Elisabeth Grabenweger (Universität Wien) aufmerksam gemacht.

57 In seinem Antrag auf Wahl Groags zum korrespondierenden Mitglied der Deutschen Gesellschaft der Wissenschaften und Künste in Prag schrieb Stein: Seit 1896 ist er (Groag) ständiger Mitarbeiter an der Real-Encyclopädie der classischen Altertumswissenschaft [...]. Dasselbe Jahr für Steins Beginn der Mitarbeit an der RE wird in den Dokumenten zu Steins Zulassung zur Habilitation genannt.

58 Klebs und Rohden waren auch - neben Hermann Dessau - Herausgeber der ersten Auflage der Prosopographia Imperii Romani (Berlin 1897/1898), mit deren Fertigstellung Groag und Stein 1915 betraut werden.

59 Geboren 22.05.1884 in Prag (polizeiliche Meldekartei).

60 Professor für Philosophie an der Deutschen Universität in Prag; zu ihm zuletzt Josef Zumr, Emil Utitz (1883- 
durch den Rabbiner an der Meiselsynagoge, Dr. Alexander Kisch, einen Verwandten Egon Erwin Kischs ${ }^{61}$, fand am I4. Juli 1908 im repräsentativen Hause der Schwiegereltern statt $^{62}$. Stein wirkte von I 903 bis I9I 8 an der I. Deutschen Staatsrealschule und wohnte mit seiner Frau in unmittelbarer Nähe seiner Arbeitsstätte. Diese Nähe der Wohnung zum Arbeitsplatz erscheint als charakteristischer Gegensatz zu Groag, den es eher ins Grüne zog. Etwa ein ganzes Jahrzehnt bis in die Mitte der I920er-Jahre wohnte Groag in Mauer bei Wien. Stein dagegen verzog später - nach seinem Wechsel an die Universität - wieder in die Nähe seiner Arbeitsstätte im Prager Klementinum.

Als k. k. Professor unterrichtete Stein Deutsch, Geschichte und Geografie, und wie es damals guter alter Brauch bei den Gymnasiallehrern war, vernachlässigte er die wissenschaftliche Arbeit nicht: I9I 5 konnte er sich an der Deutschen Universität in Prag mit der Arbeit „Untersuchungen zur Geschichte und Verwaltung Ägyptens in römischer Zeit“ habilitieren, die im selben Jahr in Stuttgart gedruckt wurde. Im von Heinrich Swoboda ${ }^{63}$, Anton von Premerstein ${ }^{64}$ und Alois Rzach ${ }^{65}$ unterzeichneten Protokoll des Habilitationskolloquiums vom 4. Februar I9I5 heißt es: Dem Herrn Habilitanden wurden folgende Fragen vorgelegt: I. Angliederung Ägyptens an das römische Reich 2. rechtliche und politische Stellung der Staatsordnung des Augustus 3. ist die Bezeichnung des Verhältnisses Ägyptens zum römischen Reich als "Realunion“ zutreffend? 4. die hypomnematismoi und ihre allgemeine Bedeutung 5. Gliederung des ptolemäischen Ägyptens 6. römische Auxiliardiplome; Interpretation eines solchen Diploms (Dessau I99I). Sämtliche Fragen wurden vom Herrn Habilitanden in durchaus anerkennenswerter Weise, mit großer Sachkenntnis und in gefälliger und fießender Form beantwortet. Seit dem SS I9 I 5 war Stein gleichzeitig Gymnasialprofessor und Privatdozent für Griechische und Römische Geschichte und Altertumskunde an der Deutschen Universität, die Venia docendi hatte das zuständige Ministerium am 30. März I 9 I 5 bestätigt. Im gleichen Jahr wurde er zum korrespondierenden, I 9 I 7 zum ordentlichen Mitglied der Numismatischen Gesellschaft Wien gewählt.

In das Jahr I9I 5 fiel aber auch der Beginn von Steins und Groags Arbeit an der Prosopographia Imperii Romani (= PIR), die wohl zu Recht als die wissenschaftliche Hauptleistung beider Gelehrter bezeichnet werden darf und von ihnen selbst auch als solche

1956) Ästhetiker. Für den humanistischen Sinn der Kultur, in: Prager Professoren 1938-1948. Zwischen Wissenschaft und Politik, hg. v. Alena MíšKová, Monika Glett le r (Veröff. zur Kultur und Geschichte im östlichen Europa 17, Essen 2001) 237-248.

$61 \mathrm{Zu}$ ihm Guido Kisch, Alexander Kisch (Halle 1934).

62 Israelitische Trauungsmatrikel Sign. HBMa 2704, Seite 76 Nr. 186 (freundlicher Hinweis von K. Beránek).

$63 \mathrm{Zu}$ ihm Arthur St E IN in: Bursians Biographisches Jb. für Altertumskunde (Nekrologe) 55 (1929) 34-57.

$64 \mathrm{Zu}$ ihm ÖBL 8, $262 \mathrm{f}$.

$65 \mathrm{Zu}$ ihm ÖBL 9, 353. 
gesehen wurde. Auf Initiative Hermann Dessaus ${ }^{66}$ wurden die zwei Gelehrten Groag und Stein - der eine in Wien, der andere in Prag - mit der Fertigstellung der PIR betraut ${ }^{67}$ : Die drei bereits I 897 und I 898 erschienenen Bände sollte ein vierter Band mit addenda et corrigenda sowie Fasten ${ }^{68}$ der wichtigsten Reichsämter komplettieren. Die Wahl Dessaus war, wie er in seinem Vorschlag an Otto Hirschfeld ${ }^{69}$ und Heinrich Dressel ${ }^{70}$ am 29. Mai I 9 I 5 schrieb $^{71}$, auf die beiden Althistoriker gefallen, weil diese bereits seit I 897 als Mitarbeiter an der RE die entsprechenden Personenlemmata bearbeiteten und sich damit sowie durch zahlreiche Veröffentlichungen vor allem in den Jahresheften des Österreichischen Archäologischen Institutes in Wien bereits als exzellente Kenner der Materie ausgewiesen hatten. Außerdem war Dessau über Hirschfeld mit Bormann, dem wichtigsten Lehrer Steins und Groags, befreundet und hatte dadurch gute Beziehungen zur sogenannten Wiener Schule ${ }^{72}$. Hirschfeld und Dressel, als akademische Kommission für die PIR zuständig, brachten den Antrag in der epigrafisch-numismatischen Kommission vor, der unter Vorsitz Hirschfelds neben Dressel noch Hermann Diels ${ }^{73}$, Ulrich von WilamowitzMoellendorff ${ }^{44}$ und Georg Loeschke ${ }^{75}$ angehörten. Bereits am Io. Juni I 9 I 5 genehmigte die Klasse den Antrag für die Mitarbeit Groags und Steins.

Der ursprüngliche Plan eines vierten Bandes der PIR erwies sich jedoch angesichts des stetig und beträchtlich anwachsenden Materials zunehmend als undurchführbar, so dass 1926 beschlossen wurde, stattdessen eine zweite, völlig neu bearbeitete Auflage unter Federführung Steins vorzubereiten. ${ }^{76}$ Wieder überrascht die unkomplizierte Schnelligkeit der Prozedur: Am 8. Juni schrieb Dessau an Ulrich Wilcken, der seit I92 I als Vorsitzender der nach dem Rücktritt Hirschfelds vom Vorsitz mehrerer Kommissionen gegründeten Kommission für griechisch-römische Altertumskunde amtierte. Am I7. Juni stimmte

66 Zu ihm Hermann Dessau (1856-1931). Zum 150. Geburtstag des Berliner Althistorikers und Epigrafikers. Beiträge eines Kolloquiums und wissenschaftliche Korrespondenz des Jubilars (Berlin/New York 2009), hg. v. Manfred G. SснміDт.

67 SB Berlin 10.06.1915.

68 Mit dem bereits in der römischen Republik verwandten Begriff „fasti“ werden in der modernen Forschung meist chronologisch geordnete Verzeichnisse von Amtsträgern vor allem hoher Staats- und Priesterämter bezeichnet.

$69 \mathrm{Zu}$ ihm ÖBL 2, 332f.

$70 \mathrm{Zu}$ ihm NDB 4, $111 \mathrm{f}$.

71 Brief im ABBAW, II-VIII, 140.

72 Siehe Salomon Fr AN k furter in: Bursians Biographisches Jb. für Altertumskunde (Nekrologe) 59 (1933) 102.

$73 \mathrm{Zu}$ ihm NDB 3, 646f.

$74 \mathrm{Zu}$ ihm DBE 10, $494 \mathrm{f}$

$75 \mathrm{Zu}$ ihm NDB 15, 61f.

76 SB Berlin vom 08. und 22.07.1926. Dass Stein die Endredaktion hatte, ergibt sich aus dem Briefwechsel zwischen ihm und Wilcken (im ABBAW). 
die Kommission Dessaus Antrag auf Neuauflage der PIR zu, und im Juli genehmigte die Klasse den Antrag.

Die ersten beiden Bände - die Personen mit den Anfangsbuchstaben A bis C enthaltend - wurden von Groag und Stein 1933 und I 936 herausgegeben. Doch I 938 zeichnete sich ab, dass die Arbeit Groags und Steins an der PIR im Auftrag der Berliner Akademie immer mehr auf Schwierigkeiten stoßen sollte. Nachdem die Akademie im Januar I 939 die Zusammenarbeit mit beiden aufgekündigt hatte, erschien noch der dritte Band I943, ohne dass jedoch die Namen Steins und Groags im Titelblatt genannt werden durften; immerhin wurden sie in der Praefatio erwähnt, und ihre Namenskürzel bezeugten die Autorenschaft bei jedem Artikel; das hatten Stein und Wilcken sowie Stroux, der im August I939 die akademische Leitung der PIR übernommen hatte, offenbar noch arrangieren können ${ }^{77}$.

I9I 8 war Stein zum außerordentlichen Professor für römische Altertumskunde und Epigrafik ernannt worden: Seine k.k. Apostolische Majestät haben mit Allerhöchster Entschließung vom I6. Sept. d.J. den Privatdozenten, Realschulprofessor Dr. Arthur Stein zum außerordentlichen Professor für römische Altertumskunde und Epigraphik an der Deutschen Universität in Prag [...] allergnädigst zu ernennen geruht, heißt es in dem Schreiben aus dem Wiener Ministerium für Kultus und Unterricht an das Dekanat vom 30. September $^{78}$. Gleichzeitig wurde Stein - neben dem Archäologen Wilhelm Klein und dem Althistoriker Heinrich Swoboda - 3. Direktor des I 895 nach Wiener Vorbild gegründeten Archäologisch-epigrafischen Seminars, das sich im altehrwürdigen Klementinum befand ${ }^{79}$. Stein trat damit an die Stelle von Premersteins, der nach Marburg gewechselt war. I9I9 scheiterte Stein mit einer Bewerbung in Rostock: nach eigenen Angaben im Lebenslauf ${ }^{80}$ war er in diesem Jahr in Rostock i. M. im Vorschlag für die durch den Abgang [Walter] $K_{o l b e s^{81}}$ erledigte ordentliche Professur für alte Geschichte, an 2. Stelle, hinter Oscar Leuze ${ }^{82}$.

77 Zu den Vorgängen 1938/1939 um die Kündigung der Mitarbeit Groags und Steins an der Berliner Akademie siehe unten.

78 Im UAP, siehe dazu auch Pavel Kolá ř, Die Geschichtswissenschaft an der Deutschen Universität Prag 1882-1938: Entwicklung der Lehrkanzeln und Institutionalisierung unter zwei Regimen, in: Universitäten in nationaler Konkurrenz. Zur Geschichte der Prager Universitäten im 19. und 20. Jahrhundert, hg. v. Hans Lem berg (Veröff. des Collegium Carolinum 86, München 2003) 85-114, hier 93f. Über Steins Wirken an der Deutschen Universität in Prag unterrichtet zudem KolÁ Ř, Geschichtswissenschaft in Zentraleuropa 1 (wie Anm. 31), siehe die Registereinträge.

79 Das Seminar befand sich im so genannten Neuen Kolleg des Klementinums.

80 Vgl. oben Anm. 29.

$81 \mathrm{Zu}$ ihm NDB 12, $452 \mathrm{f}$.

82 Nachfolger Kolbes in Rostock wurde aber Ernst Hohl (zu ihm Lexikon der DDR-Historiker [München 2006] 663), während Leuze 1914 einen Ruf nach Czernowitz annahm und nach dem Krieg zunächst in Halle a.d.S., schließlich 1921 Ordinarius in Königsberg war, vgl. Gnomon. Kritische Zs. für die gesamte klassische Altertumswissenschaft 10 (1934) 510-512. 
(In Czernowitz I9I4 im Besetzungsvorschlag nach [Johannes] Kromayer ${ }^{83}$ bloß ehrenvoll erwähnt.)

I92 I empfahl eine Kommission der Prager Deutschen Universität, bestehend aus den Professoren Heinrich Swoboda, Samuel Steinherz, Alois Rzach und Hans Hirsch, der Fakultät, die Beförderung Steins zum ordentlichen Professor beim Ministerium zu beantragen. Im zugehörigen Schreiben heißt es: Stein ist ein guter und gewandter Redner, dem die Gabe klarer Darlegung in hohem Maße eignet; es ist daher begreiflich, dass seine Vorlesungen lebhaften Zuspruch seitens der Studenten finden und es ihm auch gelungen ist, im Seminar einen Stamm von Leuten heranzuziehen, die tieferes Interesse für wissenschaftliche Arbeit zeigen. Nachfolgend wurde Stein schließlich im Dezember 1922 zum ordentlichen Professor ernannt.

Neben seiner Lehrtätigkeit entstand in den folgenden Jahren parallel zur Vorbereitung des ersten Bandes der PIR Steins nächstes größeres Werk „Der römische Ritterstand. Ein Beitrag zur Sozial- und Personengeschichte des römischen Reiches" ${ }^{\text {"84. }}$. Dieses Standardwerk, zu seiner Zeit mit Hochachtung begrüßt ${ }^{85}$, hat bei aller Abhängigkeit vom damaligen Quellenstand bis heute kaum an Bedeutung eingebüßt, zumal es durch kein anderes Werk bisher richtig ersetzt worden ist. Die Angehörigen dieses, des sogenannten Zweiten Standes bildeten ja bereits in den allerersten Veröffentlichungen Steins den Gegenstand seines Interesses ${ }^{86}$. Auch seine bereits genannte Habilitationsschrift hatte die ritterlichen Beamten im kaiserzeitlichen Ägypten im Visier, und nicht zuletzt war auch der in der PIR zu bearbeitende Personenkreis im Wesentlichen so aufgeteilt worden, dass Stein unter anderem die Ritter, Groag die Personen des Senatorenstandes bearbeitete ${ }^{87}$.

I 927 wurde Stein zum ordentlichen Mitglied der Deutschen Gesellschaft der Wissenschaften und Künste in der Tschechoslowakischen Republik gewählt ${ }^{88}$. Im selben Jahr schenkte der Kunstsammler und -händler Ludwig Pollak der Gesellschaft 35 stadtrömi-

$83 \mathrm{Zu}$ ihm NDB 13, 75.

84 (Münchener Beiträge zur Papyrusforschung und antiken Rechtsgeschichte X, München 1927.)

$85 \mathrm{Vgl}$. die Rezensionen u. a. von Matthias Gelzer in: Gnomon. Kritische Zs. für die gesamte klassische Altertumswissenschaft 4 (1928) 47-51; Wilhelm Enssis in: Philologische Wochenschrift 48 (1928) 1037-1044; Friedrich MünZER in: HZ 138 (1928) 97-100; Bernhard Kü BLER in: ZRG 61 RA 48 (1928) 651-658); Friedrich Cauer, in: Mitteilungen aus der historischen Literatur (1928) 125-129.

86 „Aegypten und der Aufstand des Avidius Cassius“ (1896), „Praefecti Aegypti“ (1897), „Das Todesjahr des Gardepräfekten Perennis“ (1900), „Nachlese zur Liste der Präfekten von Ägypten“ (1900), „Die Iuridici Alexandreae" (1901) usw.

87 Vgl. Steins Vorwort zu PIR A² IX.

88 Personalakte im AAVČR; vgl. Alena Míš́novÁ, Michael Neumüler, Die Gesellschaft zur Förderung deutscher Wissenschaft, Kunst und Literatur in Böhmen (Deutsche Akademie der Wissenschaften in Prag). Materialien zu ihrer Geschichte (Praha 1994) 365. 
sche Inschriften, die in Steins Seminar im Klementinum als Studienobjekte aufgestellt ${ }^{89}$ und im Folgejahr von Stein in einer Publikation vorgestellt wurden ${ }^{90}$. 1928 setzte er sich als Mitglied einer Kommission, der außerdem die Klassischen Philologen Carl Ritter von Holzinger und Alois Rzach angehörten, für die Gewährung eines Druckkostenzuschusses durch die Deutsche Gesellschaft der Wissenschaften und Künste für das Hannibalbuch Groags ein, das mit dieser Unterstützung 1929 erscheinen konnte; drei Jahre später empfahl Stein zusammen mit [?] ${ }^{91}$ und Rzach die Wahl Groags zum korrespondierenden Mitglied der Gesellschaft, und die Wahl erfolgte in der Vollversammlung am I7. Mai I 933 mit 3 I von 35 Stimmen ${ }^{92}$. Im Studienjahr I928/9 amtierte Stein als Dekan der Philosophischen Fakultät. In dieser Eigenschaft verfügte er im Sommer 1929 die Wiederaufnahme des Habilitationsverfahrens des Germanisten Josef Körner ${ }^{93}$. Mit Erlass vom 24. September 1929 wurde die Lehrverpflichtung Steins auf Römische Geschichte und Epigrafik erweitert. Für das Sommersemester I930 war er anstelle des nach Jena berufenen Archäologen Camillo Praschniker erneut mit der Führung des Dekanats betraut.

I932 stand Stein als „Rangältester“ an der Spitze einer Kommission, die über das von Käthe Spiegel, der Tochter des renommierten Juristen Ludwig Spiegel ${ }^{94}$, eingereichte Habilitations-Gesuch entscheiden sollte. Der Kommission gehörten ferner die Historiker Wilhelm Wostry95, Victor Ehrenberg96, Josef Pfitzner ${ }^{97}$ und Heinz Zat-

89 Ludwig Pollak, Römische Memoiren (Roma 1994) 176; Margarete Merkel Guldan, Die Tagebücher von Ludwig Pollak. Kennerschaft und Kunsthandel in Rom 1893-1934 (Wien 1988) 67f.

90 Bullettino della Commissione Archeologica Comunale di Roma (1928) 285-306; vgl. auch Václav MAR E K, Greek and Latin Inscriptions on Stone in the Collections of the Charles University (Praha 1977).

91 Name unleserlich.

92 Akten der Gesellschaft im AAVČR, K. 13.

931924 hatte Körner seine Habilitationsschrift „Romantiker und Klassiker“ eingereicht. Sie war zunächst von August Sauer abgelehnt worden. Nach Protesten von verschiedenen Seiten erfolgte dann die Wiederaufnahme des Verfahrens 1929: Körner, Schriften (wie Anm. 53) 423-445, der 445 Anm. 158 genannte Dekan war Stein.

$94 \mathrm{Zu}$ beiden Gerhard Ове к коғце R, Käthe Spiegel. Aus dem Leben einer altösterreichischen Historikerin und Frauenrechtlerin in Prag (Innsbruck 2005).

95 Zu ihm Karel HruzA, „Wissenschaftliches Rüstzeug für aktuelle politische Fragen. “ Kritische Anmerkungen zu Werk und Wirken der Historiker Wilhelm Weizsäcker und Wilhelm Wostry, in: ZfO 54 (2005) 475-526; Nina Lohmann, in: Wilhelm Wostry und die „sudetendeutsche“ Geschichtsschreibung bis 1938, in: Acta Universitatis Carolinae - Historia Universitatis Carolinae Pragensis XLIV 2004 (Praha 2006) 45-145; Dies., „Heimat und Volk“. Der Historiker Wilhelm Wostry zwischen deutschböhmischer und sudetendeutscher Geschichtsschreibung, in: Die „sudetendeutsche Geschichtsschreibung“ 1918-1960. Zur Vorgeschichte und Gründung der Historischen Kommission der Sudetenländer, hg. v. Stefan ALBrecht, Jiří Malí Ř, Ralph Melville (Veröff. des Collegium Carolinum 114, München 2008) 127-149.

96 Zu ihm Kürschners Deutscher Gelehrten-Kalender 1976, 604f.

97 Zu ihm Frank Hadler, Vojtěch Šustek, Josef Pfitzner (1901-1945) Historiker. Geschichtsprofessor und Geschichtspolitiker, in: Prager Professoren (wie Anm. 60) 105-125. 
schek $^{98}$ an. Trotz des positiven Gutachtens lehnte die Fakultät das Gesuch ab ${ }^{99}$. Der Vorgang wirft ein bezeichnendes Licht auf die Kräfte, die zu diesem Zeitpunkt an der Philosophischen Fakultät (wohl exemplarisch für die gesamte Deutsche Universität) mit wechselndem Erfolg einander widersprachen. Am ıo. November I 933 wurde Stein zum Tätigen Mitglied des Orientalischen Instituts in Prag gewählt.

Im September 1938 wurde Stein mit der Leitung des Dekanats der Philosophischen Fakultät betraut, da sowohl der scheidende Dekan Heinz Zatschek ${ }^{100}$ als auch der antretende Dekan Karl Maria Swoboda ${ }^{101}$ nicht in Prag anwesend waren. Beide gehörten zu jenen 47 (von I05) Prager deutschen Universitätsprofessoren, die als überzeugte „Sudetendeutsche“ und teilweise auch schon als Nationalsozialisten - wohl aus Furcht vor Repressalien - während der Hochphase der „Sudetenkrise“ die tschechoslowakische Hauptstadt Prag verlassen hatten, um ins „Großdeutsche Reich“ zu „flüchten“102. Dass sich Stein als Professor jüdischer Herkunft nicht den „Flüchtlingen“ anschloss, ist völlig verständlich. Überraschend ist aber, dass er die Fakultätsleitung übernahm und damit in gewisser Weise seinen abwesenden Kollegen den Rücken frei hielt. Man kann nur vermuten, dass er seinem Pflichtbewusstsein als Beamter und seiner deutschnationalen Einstellung folgte. Wenige Monate später, am I7. Dezember, teilte eben Swoboda als Dekan brieflich dem Professorenkollegium der Philosophischen Fakultät mit, dass sich die Herren Prof. Dr. Arthur Stein und Prof. Dr. Victor Ehrenberg entschlossen haben, in diesem Semester ihre Vorlesungstätigkeit nicht mehr auszuüben. In einer Abstimmung folgten die Professoren dem Antrag Swobodas, den Archäologen Alois Gotsmich ${ }^{103}$ mit der alleinigen Direktion des Archäologisch-althistorischen Seminars zu betrauen ${ }^{104}$. Die Vorgänge sind innerhalb der nach dem Münchener Diktat vom Herbst 1938 intensiv und freiwillig von den („arischen“) Universitätsmitgliedern betriebenen „Gleichschaltung“ bzw. „Arisierung “ der Deutschen Universität in Prag zu platzieren ${ }^{105}$. Die jüdischen Professoren

98 Zu ihm Karel Hruza, Heinz Zatschek (1901-1965) - „Radikales Ordnungsdenken“ und „gründliche, zielgesteuerte Forschungsarbeit“, in: Österreichische Historiker (wie Anm. 32) 677-792.

99 Siehe Oве r коғ Ler, Käthe Spiegel (wie Anm. 94) 68-70 und 114-119 (Gutachten).

100 Siehe Hruza, Zatschek (wie Anm. 98) 708.

101 Zu ihm Sigrid Canz, Karl Maria Swoboda (1889-1977) Kunsthistoriker. Wissenschaftler zwischen Wien und Prag, in: Prager Professoren (wie Anm. 60) 175-190, und der Beitrag von Alena Janatková in diesem Band.

102 Zu diesen Ereignissen Alena Mıšková, Deutsche Professoren aus den böhmischen Ländern. „Flüchtlinge“ in der Zeit vor und nach den Münchner Verhandlungen, in: Prager Professoren (wie Anm. 60) 27-43.

103 Zu ihm Wolfgang Schie Ring in: Archäologenbildnisse (wie Anm. 30) $266 f$.

104 AUP.

105 Dazu siehe Alena Míš́ová, Die „Arisierung“ an der Deutschen Universität Prag, in: Wissenschaft in den böhmischen Ländern 1939-1945, hg. v. Antonín Kostlán (Praha 2004) 97-106, hier 104-106, sowie Dies., Die Deutsche (Karls-) Universität vom Münchener Abkommen bis zum Ende des Zweiten Weltkrieges (Universitätsleitung und Wandel des Professorenkollegiums) (Prag 2007) 58-76, 285-291, bes. 290. 
Stein und Ehrenberg kamen mit ihrem formal freiwilligen Rückzug den zu erwartenden und dann auch verwirklichten Repressionsmaßnahmen nur wenige Wochen zuvor. Als Stein zum I. März I 939 nach Erreichung der Altersgrenze in den dauernden Ruhestand versetzt wurde, unterlag er mit dieser Zwangspensionierung einer antijüdischen Bestimmung der tschecho-slowakischen Regierung vom Dezember I93 ${ }^{106}$. Ehrenberg konnte Stein nicht überzeugen, so wie er Prag und das deutsche Herrschaftsgebiet zu verlassen, und zwangsläufig hielten die Jahre im Protektorat Böhmen und Mähren für Stein viele Demütigungen bereit, die er mit erstaunlicher Kraft überwand.

Ein Zeitzeuge schrieb über den bei Kollegen hoch geachteten und bei Studenten beliebten, wenn auch hohe Ansprüche stellenden Hochschullehrer: Stein [...] war nicht nur ein sehr gelehrter Mann, sondern auch ein ausgezeichneter Lehrer. Er verlangte allerdings von den sieben bis zehn Teilnehmern seiner Seminarübungen auch viel und bemerkte zu Studenten, die auf eine Frage nicht sofort antworteten, stets: ich hätte denn doch gedacht, dass Sie das wissen werden $^{107}$. Dazu passt eine Anekdote, die sich die Prager Studenten Steins erzählten: Stein habe als junger Assistent an der Wiener Universität einmal Kaiser Franz Joseph I. über die Ausgrabungen von Carnuntum geführt, und als der Kaiser nach einer Einzelheit fragte, tadelnd geantwortet: Ich hätte denn doch gedacht, dass Majestät das wissen ${ }^{108}$. Nach Auskunft tschechischer Kollegen war das Verhältnis des demokratisch und liberal denkenden Ehrenberg wesentlich besser zu den Kollegen des tschechischen historisch-epigrafischen Seminars als es der national-konservativ-monarchistische Stein zu den tschechischen Kollegen ${ }^{109}$ pflegte. Zur Illustration seiner Einstellung sei aus dem „Gedenkblatt“ zitiert, das Stein anlässlich des I9I 6 erfolgten Todes Kaiser Franz Josephs I. verfasst hat ${ }^{110}$ :

Kaiser Franz Joseph I. ist nicht mehr! Fast wie ein Wunder der Natur schien es, daß der erhabene Herrscher bis nahe an die äußerste Grenze menschlichen Hochalters in ungebrochener Arbeits- und Schaffenskraft gelangen konnte, nachdem er, der Nestor unter den europäischen Fürsten, drei Menschengeschlechter an sich vorbeirauschen gesehen, und doch - es war uns allen, die wir von Jugend auf seine hochragende Erscheinung immer wieder vor uns zu sehen das Glück

106 Siehe Ota Konrád, Dějepisectví, germanistika a slavistika na Německé univerzitě v Praze 1918-1945 [Geschichtsschreibung, Germanistik und Slavistik an der Deutschen Universität in Prag 1918-1945] (Praha 2011) 201. Ein Exemplar der Emeritierungs-Urkunde befindet sich in den Akten des Unterrichts-Ministeriums im NA.

107 So Erich Fusse K, Sie lehrten in Prag (München 1975) 83.

108 Ebd. Dieselbe Anekdote wird auch über Eugen Bormann berichtet, siehe etwa Elise Richter, Summe des Lebens (Wien 1997) $144 \mathrm{f}$.

109 Jan Burian und Pawel Oliva im Gesprächen mit mir; vgl. dazu auch Josef Petré š, Nástin dějin filozofické fakulty Univerzity Karlovy v Praze (do roku 1948) (Praha 1983) 298.

110 Jahresbericht der 1. Deutschen Staatsrealschule 1916/17 3-7; vgl. auch Steins Reden als Lehrer zum 60. Regierungsjubiläum des Kaisers ebd. 1908/09, 54 oder seine Festrede zum Namenstag und Geburtstag des Kaisers ebd. 1910/11 7-10. 
hatten, der Gedanke unfaßbar, daß derjenige, dessen Persönlichkeit wir untrennbar mit dem Begriff unseres Staates zu verbinden pflegten, nicht mehr unter den Lebenden weilen sollte. Ja, noch heute zittert in uns die schmerzbewegte Ergriffenheit nach, die alle Gemüter durchzuckte, als die Trauerkunde von dem Hinscheiden des geliebten Monarchen blitzschnell durch alle Gaue unseres weiten Vaterlandes drang und die bewegliche Totenklage allüberall erscholl. [...] Drei Hauptprobleme kann man in der auswärtigen Politik Österreichs unter der Regierung des verewigten Kaisers erkennen: die deutsche, die italienische und die Balkanfrage. Der Rufnach einer Vorherrschaft Österreichs in Deutschland ist im Donner der Geschütze vor Königsgrätz verhallt. Aber aus den Rauchwolken und dem Schlachtennebel taucht in immer deutlicheren Umrissen das erhebende Schauspiel von der treuen Waffenbrüderschaft der nunmehr so innig verbündeten Staaten empor. Einen deutschen Fürsten hat sich Franz Joseph I. mit Stolz genannt.

Deutlicher als in diesen Gedenkworten können die Gesinnung, die geistige Haltung Steins wohl nicht ausgedrückt werden. Man kann sich vorstellen, dass sich Stein - in Anlehnung an die letzten zitierten Worte - mit Stolz einen deutschen Professor genannt hat. Dem kann die Einschätzung Steins zur Seite gestellt werden, die der tschechische Historiker Václav Vojtíšek postulierte, als er 1966 (unter antideutschen und antijüdischen Vorzeichen) über ehemalige deutsche und deutschjüdische Kollegen referierte: „[...] die jüdischen Professoren stellten sich ihren deutsch-nationalen Kollegen niemals entgegen, wie auch immer diese handelten. [...] Dr. Stein, getaufter Jude, stand den Deutschen, nicht den Tschechen nahe, obgleich er sah und selbst wusste, was die Juden ertragen mussten und wie seine Stammesgenossen vernichtet wurden. Er wurde zum Ehrenjuden ernannt, womit er selbst die Bestätigung erhielt, dass er für die Faschisten als Deutscher akzeptabel war, wenn auch nicht als ,reiner ' Deutscher." ${ }^{\text {‘11 }}$

Im Vorwort von Steins I9I5 in Stuttgart erschienenen „Untersuchungen zur Geschichte und Verwaltung Ägyptens unter römischer Herrschaft" heißt es im August I 9 I 4: „[...] dieses bescheidene Büchlein, vollendet in den Tagen, da sich Millionen von deutschen und österreichischen Streitern in treuem Waffenbunde ihrer Feinde im Osten, im Süden und im Westen zu erwehren im Begriffe sind, [ist] von den schicksalsschweren Kriegsereignissen nicht ganz unberührt geblieben.“ Im November i 91 5: „Nach mehr als 5/4jähriger Dauer tobt der Weltkrieg mit unverminderter Heftigkeit weiter, wenngleich unser unerschütterliches Vertrauen auf ein baldiges ruhmreiches Ende gegenwärtig besser begründet ist als jemals zuvor."

Von der Wirkung der Niederlage im Krieg, des Zerfalls der Habsburgermonarchie und der mit der Gründung der Tschechoslowakei zusammenhängenden zeitwei-

111 Siehe Karel Hruza, „Einige Deutsche habe ich auch wirklich gern empfangen“ - Ein Bericht des tschechischen Historikers Václav Vojtíšek aus dem Jahr 1966 über Deutsche Fachkollegen in Prag, in: Bohemia. Zs. für Geschichte und Kultur der böhmischen Länder 49 (2009) 96-163, hier 127 und 158. 
lig schwierigen Situation der betroffenen deutschen Bevölkerung auf Stein kann man sich angesichts fehlender Hinweise kaum eine Vorstellung machen. Doch scheinen ihn weder diese Ereignisse noch die immer stärker hervortretende antisemitische Atmosphäre ${ }^{112}$ in seiner Tätigkeit als akademischer Lehrer und Forscher über Gebühr beeinträchtigt zu haben, im Gegenteil: „Arthur Stein blieb [im Gegensatz zu Ehrenberg] im Land und arbeitete bis zur letzten Stunde (er soll im Lager Theresienstadt gestorben sein) [hier irrt der Autor]. Bis 1938 und wahrscheinlich bis zum letzten Hauch fühlte er sich mit Leib und Seele der deutschen Nation zugehörig. Für nationale Rechte der Universität und jedes Studierenden stand er in jeder Kommission, vor jedem Forum unbeugsam ein. Es war weit mehr als nationalliberale Gesinnung, was ihn an deutschen Geist und deutsche Sprache, deutsche Kulturgemeinschaft und -überlieferung band. Er hat, er hätte durch dick und dünn zu seiner Fakultät gehalten, er hätte niemals wider sie streiten können - so beschwört das Gedächtnis der Fakultät allzeit die Erinnerung an Arthur Stein als einen ihrer Unverlierbaren. “ So schrieb ein Kollege, der I 928-1938 mit ihm in der Fakultät gesessen hatte, voll anerkennender Hochachtung zwei Dezennien danach ${ }^{113}$; nur dass dieser Kollege, Herbert Cysarz, selbst zu den überzeugten Nationalsozialisten unter den Prager Lehrenden zählte, gibt dessen späten Lob einen bitteren Beigeschmack ${ }^{114}$.

Viktor Bassler, der Anfang der I93oer Jahre zu Steins Studenten zählte, erinnerte sich : „Als Examinator stellte Prof. Stein hohe Anforderungen. Er wußte jedoch in seinen Vorlesungen, in denen er seine Hörer durch Zwischenfragen zur Mitarbeit anzuregen pflegte, und in seinen stets gut besuchten Seminarübungen manch jungen Studenten zur wissenschaftlichen Arbeit auf dem Gebiete der Altertumskunde zu gewinnen, und wer einmal ernstes Interesse dafür gezeigt hatte, konnte mit unermüdlicher Förderung rechnen. [...] Seine ungeheuere Vitalität, begleitet von einer eisernen Gesundheit, die ihm trotz der schweren KZ-Jahre bis ins hohe Alter erhalten blieb, kam uns jungen Studenten besonders auf einer mehrwöchigen Studienreise nach Rom, Neapel und Pompeji (I93 I) zu Bewußtsein, auf der er als Sechzigjähriger den Teilnehmern die Antike an Ort und Stelle so temperamentvoll und nachdrücklich vor Augen führte, daß ich bei meinem nächsten

112 Vgl. beispielsweise die Proteste deutschnationaler bzw. völkischer Studenten gegen den zum Rektor für das Studienjahr 1922/23 gewählten Historiker Samuel Steinherz, siehe Peter ArLt, Samuel Steinherz (18571942) Historiker. Ein Rektor zwischen den Fronten, in: Prager Professoren (wie Anm. 60) 71-104, hier 73-97, und Gerhard Ове к коғ Lе R, Samuel Steinherz (1857-1942). Biographische Skizze über einen altösterreichischen Juden in Prag (Innsbruck 2008) 73-100.

113 Herbert Cysarz, Zehn Jahre Prag, in: Grenzfall der Wissenschaft: Herbert Cysarz, hg. v. Rudolf JaHN (Frankfurt/M. 1957) 107.

114 Siehe Peter Becher, Herbert Cysarz (1896-1985) Germanist. Seine Prager Universitätsjahre, in: Prager Professoren (wie Anm. 60) 277-297, hier 286-297. 
Besuch in Rom - 22 Jahre später ! - nun selbst als Leiter einer Schulklasse vor ähnlichen Aufgaben stehend, noch davon zehrte."115

Von Steins Wirken in der Fakultät und an der Universität abgesehen, darf man in ihm aber wohl eher einen typischen Vertreter der apolitischen Professoren vermuten. Auch für einen intensiveren Kontakt zur kulturell damals in der Stadt an der Moldau so reichen Szene fehlen konkrete Hinweise. Gleiches scheint auch cum grano salis (auf den kulturellen Hintergrund im Leben Groags, den die Familie seiner Mutter gebildet haben dürfte, ist bereits hingewiesen worden) für Groag zu gelten. Dieser habilitierte sich I9I 8 mit der in Linz gedruckten Schrift „Studien zur römischen Kaisergeschichte“. Am 5. März I9I9 hielt er seinen Probevortrag über „Die Zusammensetzung des Senats in der Zeit des Prinzipats" und wurde wenige Wochen später vom Ministerium als Privatdozent bestätigt. Seit dem 9. April 192 I war Groag Leiter der Katalogisierungsabteilung der Druckschriftensammlung ${ }^{116}$. I 923 wurde aus der Hof- die Nationalbibliothek in Wien, deren neuer Direktor Josef Bick an die Stelle des pensionierten Othmar Doublier ${ }^{117}$ Groag zum provisorischen Leiter der Druckschriftensammlung machte ${ }^{118}$. Bei den gegensätzlichen Charakteren beider war es eigentlich nur eine Frage der Zeit, bis es zum offenen Konflikt zwischen dem 1925 zum Oberstaatsbibliothekar ernannten Groag und Bick - seit 1926 Generaldirektor der Bibliothek - kam. Der Konflikt brach 1930 offen aus und endete mit der Absetzung Groags als Leiter der Druckschriftensammlung am 3. Juli 193 I $^{119}$. Er sollte stattdessen einen Katalog der Rara, Unica und Luxusdrucke der Sammlung herstel$\operatorname{len}^{120}$. Gegen diese völlige Kaltstellung waren die Einsprüche Groags beim Ministerium

115 Zitiert aus einem von Bassler verfassten Gedenkblatt anlässlich des 100. Geburtstages von Stein, dessen Kenntnis ich Martin Sicherl, einem weiteren Schüler Steins aus dieser Zeit, verdanke: Sicherl (1914-2009) hatte nach einer Dissertation zu den griechischen Zauberpapyri (Prag 1937) auf Empfehlung Steins das italienische Reisestipendium erhalten (briefliche Mitteilung).

116 Dazu und zu dem Folgenden vgl. Geschichte der Österreichischen Nationalbibliothek 1: Die Hofbibliothek (1368-1922), hg. v. Josef St um mvoll (Wien 1968), 2: Die Nationalbibliothek 1923-1967, hg. v. Josef Stummvoll, Rudolf Fiedle (Wien 1973). Zu Groag als Leiter der Katalogisierung ebd. 1589.

117 Er nahm hochbetagt 1945 an der Beerdigung Groags teil, siehe unten.

118 Siehe dazu Geschichte der Österreichischen Nationalbibliothek 2 (wie Anm. 116) 32: „Obwohl Groag [...] zumindest seit den Promemoria von 1919 zu Bick in Opposition stand, ernannte ihn dieser dennoch [...] zum provis. Leiter (NB 50 u. 1145/1923). Groag, u.a. Professor für Alte Geschichte an der Universität, der nur seinen Studien über römische Epigraphik lebte, war ein stiller, weltfremder Gelehrter, der sich bei den Beamten der Sammlung nicht durchsetzen konnte und Wachs in den Händen härterer Charaktere war. Er lehnte alle Reformen, die die Zeit erforderlich machte, grundsätzlich ab. Bicks vitale Durchschlagskraft und Energie waren ihm verhasst, und er trat allen Plänen einer Neugestaltung der Palatina zu einer modernen Gebrauchsbibliothek mit offener und versteckter Ablehnung entgegen."

119 Dementsprechend fehlt Groag auf dem Geburtstagsfoto zu Bicks 50. Geburtstag, siehe Geschichte der Österreichischen Nationalbibliothek 2 (wie Anm. 116) Abb. 3.

120 Diese Anordnung Bicks (NB 1336/1931) ist abgedruckt ebd. 84. 
erfolglos; am Ende wurde er im September 1932 im Rahmen des wegen Sparmaßnahmen vorgenommenen Stellenabbaus in den zeitlichen, 1936 in den endgültigen Ruhestand versetzt $^{121}$. Den Titel eines Hofrats hatte Groag bereits 1924 erhalten ${ }^{122}$, war 1925 mit dem Titel eines a.o. Professors ausgezeichnet und 1933 zum korrespondierenden Mitglied der Deutschen Gesellschaft der Wissenschaften und Künste in Prag gewählt worden ${ }^{123}$.

Im privaten Leben Groags hatte es bereits einige Jahre zuvor einschneidende Veränderungen gegeben: Am I7. Januar I 928 war seine Mutter gestorben, mit der er anscheinend innig verbunden gewesen war. Kurz zuvor, am 8. Januar, hatte er Alberta Schaschek geheiratet $^{124}$. Es war eine späte Heirat, denn Groag war bereits 55 Jahre alt, während Berta 52 Jahre zählte ${ }^{125}$. Ein mit Groags Frau verbundenes Rätsel gibt ein Testament auf, das Groag sechs Jahre nach der Heirat verfasst hat und in dem seine Frau mit keinem Wort erwähnt wird ${ }^{126}$. Erklärungen für diese auffallende Tatsache müssen mangels konkreter Anhaltspunkte ins Reich der Spekulation gehören. Das Testament enthält auch einen sehr beachtenswerten Hinweis auf die Persönlichkeit Groags. Es werden darin nämlich Schriften Groags zum Tierschutz genannt. Im Katalog der ÖNB finden sich nun interessanterweise unter Groag, Edmund II (also dort nicht als identisch mit Nr. I angesehen) zwei Arbeiten von 1929 mit den Titeln „Die Barbarei des Hundefanges“ und „Das Elend der Kettenhunde“. Es handelt sich dabei um zwei Vorträge, die Groag auf dem Internationalen Tierschutzkongress hielt, der vom I 2. bis I7. Mai 1929 in Wien stattfand. Aus den Kongressakten ergibt sich auch, dass Groag Vizepräsident des Wiener Tierschutzvereins war; I93 I bis 1933 ist er als Mitglied des Vereinsvorstands in der Zeitschrift „Tierfreund“ genannt. Groag schrieb auch den Beitrag „Ein Tierfreund im klassischen Altertum“, mit dem er den griechischen Schriftsteller, Popularphilosophen und Verfasser von Biografien Plutarch meinte ${ }^{127}$.

Der kämpferische Ton, mit dem Groag gegen die staatlichen Hundefänger und das Anketten von Hunden Partei ergriff, fällt ebenso auf wie das starke Mitgefühl für die Tierwelt. So wundert es nicht, dass Groag bei Plutarch vegetarische Tendenzen entdeckte, und

$121 \mathrm{Vgl}$. zu diesen Vorgängen ebd. $34 \mathrm{f}$.

122 Beantragt am 11.07.1924: NB 1073/1924, ÖNB Archiv.

123 Der Vorschlag zur Professorenernennung findet sich im UAW, PA Edmund Groag. Dass die Ernennung auch tatsächlich erfolgt ist, geht aus einem Schreiben des Unterrichtsministeriums an das Rektorat der Universität Wien vom 22.04.1938 hervor, in dem unter den beurlaubten Professoren auch der tit.a.o. Prof. Edmund Groag verzeichnet ist. Zur Mitgliedschaft von 1933 siehe oben.

124 Trauungsbuch des Pfarramtes Ober-St. Veit in Wien, Tom XIII-N, fol. 53.

125 Alberta, Tochter von Jan Šašek und Katharina Obrovná (?), wurde am 15.04.1876 in Prag geboren und verzog 1907 nach Wien (Auskunft des Kreisarchivs in Deutschbrod).

126 Das Testament befindet sich in der ÖNB, Handschriftenabteilung; Kat.-Nr. Cod. Ser. 23698.

127 Österreichischer Tierschutzkalender 3 (1930) 62-64. Zu Plutarch siehe PIR P² 526; RE 21 (1949) 636-962 $=$ Konrad Ziegler, Plutarch von Chaeronea (Stuttgart $\left.{ }^{2} 1964\right)$. 
man ist versucht, auch bei Groag diese zu vermuten. Auf jeden Fall waren der Tierfreund Groag und der Althistoriker und Bibliothekar Groag ein und dieselbe Person ${ }^{128}$.

\section{UNTER DEN NATIONALSOZIALISTEN}

I938 zeichnete sich ab, dass die weitere Arbeit Groags und Steins an der PIR im Auftrag der Berliner Akademie auf Schwierigkeiten stoßen würde. Am 2 I. November schrieb Ulrich Wilcken ${ }^{129}$ an Ernst Heymann, den Sekretar der Philosophisch-historischen Klasse unter anderem ${ }^{130}: Z u$ meinem großen Bedauern muß ich Ihnen mitteilen, daß ich wegen der Zukunft unserer Prosopographia imperii Romani in größter Sorge bin. Die beiden Herren, die sie bearbeiten, Prof. Arthur Stein (Prag) und Prof. Edmund Groag (Wien) sind Nichtarier. Vom Ersteren wußte ich es schon immer, vom Zweiten erfuhr ich es erst in diesen Tagen. Es wurde mir bestätigt durch ein Telephongespräch mit unserem neuen Beamten, Herrn Prof. [Helmuth] Scheel ${ }^{131}$, der u.a. erwähnte, daß es ihm aus diesem Grunde nicht möglich sei, die beiden Herren zum Bericht über ihre Jahresarbeit aufzufordern. Damit steht die Akademie vor schweren Entscheidungen. Dementsprechend durften Groag und Stein ihre Arbeitsberichte nicht mehr direkt an die Akademieleitung schicken, sondern mussten dem Kommissionsvorsitzenden Wilcken Bericht erstatten, der Stein diesbezüglich am 2. Dezember 1938 geschrieben hatte $^{132}$ : Ich möchte Sie bitten, den Bericht über die diesjährige Tätigkeit an der Prosopographie als Unterlage für meinen Bericht für die nächste Friedrichsitzung dieses Mal an mich direkt zu schicken. Zugleich muß ich Ihnen nach Rücksprache mit unserem Sekretar, Prof. Heymann, zu meinem großen Bedauern mitteilen, dass nach der Lage der jetzigen Gesetzgebung Ihre und Herrn Groags Mitarbeit an der Prosopographia Imperii Romani voraussichtlich nicht fortgesetzt werden kann.

Stein reagierte tief betroffen und schrieb in seiner Antwort ${ }^{133}$ : Nicht ohne tiefe innere Bewegung habe ich Ihre Mitteilung empfangen, daß unsere Mitarbeit an der Prosopographie voraussichtlich nicht fortgesetzt werden kann. Denn mit dieser Aufgabe, die ich wohl ohne Übertreibung als mein Lebenswerk bezeichnen darf, war ich und war Groag durch jahr-

128 Bereits in Wer ist Wer? Lexikon der österreichischen Zeitgenossen, hg. v. Paul Emödi, Robert Teichl (Wien 1937) 124, ist zu Groag angegeben: „Arbeiten auf dem Gebiete der Geschichte und Kultur des Altertums und des Tierschutzes“.

$129 \mathrm{Zu}$ ihm Wilhelm Sснu ва т in: Gnomon. Kritische Zs. für die gesamte klassische Altertumswissenschaft 21 (1949) 88-90; Matthias Gelzer in: Jb. DAW Berlin 1946-1949 (1950) 244-251.

130 ABBAW, II-VIII, 141. Über die Angelegenheit gibt es einen Gedankenaustausch zwischen Wilcken und Heymann.

131 Seit 1939 Direktor der Preußischen Akademie der Wissenschaften.

132 ABBAW, II-VIII, 141.

133 Ebd. Brief vom 14.12.1938. 
zehntelange, in liebevoller Hingabe geleistete Arbeit innerlich so innig verbunden, wie dies nicht alltäglich vorkommt. Und die Urteile in den Fachzeitschriften aller Nationen haben so ziemlich einmütig gezeigt, daß unsere Leistungen der Akademie nicht zur Unehre gereichten. Besonders nahe geht mir auch, daß ich mit dem Aufhören unserer Mitarbeit den Vorzug und die Freude nicht mehr genießen soll, mit Ihnen, hochgeschätzter Herr Geheimrat, in regelmäßiger und sozusagen amtlicher Verbindung zu stehen [...].

Im Januar 1939 erfolgte die offizielle Kündigung des Vertragsverhältnisses ${ }^{134}$. Die Reaktionen der Betroffenen in Prag und Wien unterschieden sich voreinander: Stein erklärte, dass er die Beendigung des Vertragsverhältnisses [...] mit schmerzlichem Bedauern zur Kenntnis nimmt und bereit sei, seine Materialsammlung zu den restlichen Personen der Prosopografie der Akademie gegen ein angemessenes Honorar zur Verfügung zu stellen; außerdem wünschte er der von der Akademie betreuten Prosopographia imperii Romani, die uns beiden, Groag und mir, als eine Lebensarbeit ans Herz gewachsen ist, auch nach unserem Ausscheiden einen gedeiblichen Fortgang und besten Erfolg ${ }^{135}$. Groag dagegen antwortete kurz und kühl und lehnte eine Übergabe seiner Materialsammlung ab ${ }^{136}$. An dieser ablehnenden Haltung konnte auch der Freund aus Prag, den die Akademie um Vermittlung gebeten hatte, nichts ändern: Ich habe Groag von Ihrem bzw. der Akademie Verlangen, das gesamte Material abzuliefern, Mitteilung gemacht und ihn zu bestimmen gesucht, diesem Verlangen zu entsprechen, so wie ich selbst dazu bereit bin. Leider ist es mir nicht gelungen, meinen Freund umzustimmen: Er beharrt auf seiner Weigerung und so trennen sich in unserer seit Jahrzehnten gemeinsamen Arbeit unsere Wege ${ }^{137}$. Man spürt Resignation und Enttäuschung hinter diesen Worten; auf der anderen Seite beeindruckt die loyale Haltung tief, die Stein der Akademie gegenüber einnahm, wenn er vor allem das Wohl des an der Akademie herausgegebenen Werkes im Auge hatte.

Trotzdem wurde von Prag aus weiter gegen ihn intrigiert. Der kommissarische Gaudozentenbundsführer Konrad Bernhauer ${ }^{138}$ schrieb am 6. Juni 1939 an die Preußische Akademie der Wissenschaften ${ }^{139}$ : Laut uns vorgelegtem Schreiben vom I5. Mai d.J. des einstigen Professors der Universität Prag Dr. Arthur Stein an Herrn Dozenten [Willy Johann] Hüttl soll der Erstgenannte, obzwar er Jude ist, von der Preußischen Akademie der Wissenschaften beauftragt worden sein, den dritten Band der Prosopographie herauszugeben. Wir erachten es für vollkommen untragbar, dass heute noch der Jude Stein im Auftrag der Preußischen Akademie der Wissenschaften mit einer wissenschaftlichen Arbeit betraut wird. Da wir nicht annehmen

134 Ebd. gleichlautende Briefe Heymanns an Groag und Stein vom 09.01.1939.

135 Ebd. Brief Steins an Heymann vom 18.01.1939.

136 Ebd. Brief Groags an die Akademie vom 16.01.1939.

137 Ebd. Brief Steins an Heymann vom 15.02.1939.

138 Zu ihm Kürschners Deutscher Gelehrtenkalender 1940/41; 1950; 1961.

139 ABBAW, II-VIII, 141 ; eine Abschrift befindet sich im UAP. 
können, dass Stein einen solchen Auftrag bekommen hat, bitten wir um Mitteilung des Sachverhaltes. Im Antwortschreibens an den Reichsminister für Wissenschaft, Erziehung und Bildung wird auf die schon im Januar erfolgte Auflösung des Vertragsverhältnisses und die bereits im Druck befindliche I. Hälfte des 3. Bandes (D-F) sowie die Vorbereitung der Materialsammlung zur Übergabe durch Stein an die Akademie verwiesen ${ }^{140}$. Der gesamte Vorgang war wohl, wie aus dem Schreiben Bernhauers hervorgeht, dem intriganten Betreiben Hüttls ${ }^{141}$ geschuldet, der schließlich auch die Nachfolge Steins antreten konnte ${ }^{142}$.

Am Fortgang der PIR-Arbeiten ist, vom Erscheinen des 3. Bandes abgesehen, in den Jahren des Krieges nichts Substanzielles zu verzeichnen. Bevor Johannes Stroux die akademische Leitung der PIR übernahm, war zunächst Josef Keil in Wien und nach dessen Absage und auf dessen Vorschlag Ernst Hohl in Rostock die Fortsetzung der PIR angetragen worden. Keil hatte in einem Brief an Wilcken vom ıo. März 1939 unter Hinweis auf andere Verpflichtungen (Tituli Asiae Minoris), Hohl in einem Brief vom 23. März unter Hinweis auf fehlende Literatur in Rostock abgelehnt ${ }^{143}$. Nachdem die Akademie im Januar I939 die Zusammenarbeit mit den beiden jüdischen Gelehrten aufgekündigt hatte ${ }^{144}$, arbeitete Stein trotzdem unermüdlich weiter, obwohl ihm der Zugang zu Universität und Bibliotheken untersagt war, wie einer seiner Schüler sich erinnert, der ihn wöchentlich in der Wohnung besuchte und mit der gewünschten Literatur versorgte ${ }^{145}$. So konnte Stein zwei bedeutende prosopografische Arbeiten zu den Statthaltern der mösischen und dakischen Provinzen abschließen und mithilfe seines Freundes Andreas Alföldi in den von diesem herausgegebenen Dissertationes Pannonicae in Ungarn veröffentlichen ${ }^{146}$.

Steins Lage wurde - wie die aller Juden im Herrschaftsbereich der Deutschen - immer unerträglicher und gefährlicher. Als im Oktober I94I die Registrierung der Prager

140 Ebd.

141 Ungenau ist Alena MíšKová, Die Deutsche Universität im Zweiten Weltkrieg, in: Universitäten in nationaler Konkurrenz (wie Anm. 78) 177-193, hier 181: „Als er [Konrad Bernhauer] entdeckte, daß der ehemalige Professor an der Deutschen Universität Prag Arthur Stein im Auftrag der Preußischen Akademie der Wissenschaften in Prager Archiven forschte, meldete er an die Akademie und an den Reichsprotektor [...]. “ Ähnlich Dies., „Arisierung“ (wie Anm. 105) 100; Dies., Deutsche (Karls-)Universität (wie Anm. 105) 68.

142 Zu ihm ebd. 280 und 303; vgl. auch Kürschners Deutschen Gelehrtenkalender 1940/41. Wie mir Jan Burian (Prag) berichtete, soll Hüttl bei der Flucht vor der Verhaftung oder bei dem Versuch, die Münzsammlung beiseitezuschaffen, 1945 erschossen worden sein; die Angaben bei Deutsche Geschichtswissenschaft nach dem Zweiten Weltkrieg (1945-1965), hg. v. Ernst Schulin (Schriften des Historischen Kollegs 14, München 1989) 65 mit Anm. 3 sind also zu korrigieren.

143 Beide Briefe im ABBAW, II-VIII, 141.

144 Offizielle Lösung des Vertrages durch Brief des Vizepräsidenten Heymann vom 09.01.39; ebd.

145 So der damalige Student Herbert Bujnoch in seiner Abschiedsrede als Studiendirektor 1977 in Krefeld. Dr. Bujnoch danke ich herzlich für eine Kopie.

146 Die Legaten von Moesien (Budapest 1940); Die Reichsbeamten von Dazien (Budapest 1944). 
Juden begann, drohte auch ihm, seiner Frau und auch Schwager und Schwägerin die Deportation. Auf irgendeine Weise musste die Kunde von der existenziellen Bedrohung Steins an dessen Freund Harold Steinacker ${ }^{147}$, Rektor der Universität in Innsbruck und überzeugten Nationalsozialisten, gelangt sein, der sich in einem Brief vom 21. Oktober I94I an seinen Amtskollegen in Prag, Wilhelm Saure, Rektor der Deutschen Universität, wandte. Steinacker bat Saure aus persönlichen und wissenschaftspolitischen Gründen und unter Hinweis auf bestimmte Arbeiten Steins ${ }^{148}$, sich für diesen einzusetzen und eine Deportation zu verhindern ${ }^{149}$. Das Ehepaar Stein entging den im Oktober und November 194I vollzogenen Deportationen von Prager Juden nach Łódź und damit einem fast sicheren Todesurteil ${ }^{150}$. Im Sommer 1942 wurde das Paar jedoch deportiert und kam am 6. Juli mit einem Transport von ungefähr ıooo Personen aus Prag im Konzentrationslager Theresienstadt an ${ }^{151}$. Ob bei diesen Vorgängen der Brief Steinackers von Bedeutung war, ob also Saure, Jurist und SS-Oberführer, für Stein tätig geworden ist, kann derzeit nicht schlüssig beantwortet werden; ein ähnliches Bittgesuch, das er zu derselben Zeit erhalten hat, ließ er höchstwahrscheinlich ohne weitere Reaktion zu den Akten legen; die Bittstellerin wurde nach Łódź deportiert und ermordet ${ }^{152}$. Allerdings dürfte das Gesuch Steinackers wegen der Stellung seines Verfassers von nicht zu unterschätzendem Gewicht gewesen sein. Zumindest kann festgehalten werden, dass Steinacker aus ehrlichen

147 Stein und Steinacker, der 1893-1897 in Wien Geschichte studiert hatte, kannten sich seit dem Studium und waren miteinander befreundet. Steins „Römische Reichsbeamte der Provinz Thracia“ (1920) sind Steinacker gewidmet, vgl. das Vorwort, S. VI.

148 Siehe Anm. 146.

149 Der Brief ist im Anhang wiedergegeben.

150 Siehe Alfred Gottwaldt, Diana Schulle: Die „Judendeportationen“ aus dem Deutschen Reich 19411945 (Wiesbaden 2005) 52-83 und 444f.

151 Laut Deportationskarten in der Jüdischen Gemeinde Prag. Siehe auch Käthe STarke, Der Führer schenkt den Juden eine Stadt. Bilder - Impressionen - Reportagen - Dokumente (Berlin 1975) 249. Zu den antijüdischen Maßnahmen siehe Hans G. Adler, Theresienstadt 1941-1945. Das Antlitz einer Zwangsgemeinschaft (Reprint Göttingen 2005) 3-15, 37-41, 60-71; Wolf Gruner, Das Protektorat Böhmen und Mähren und die antijüdische Politik 1939-1941. Lokale Initiativen, regionale Maßnahmen, zentrale Entscheidungen im „Großdeutschen Reich“, in: Theresienstädter Studien und Dokumente 2005, hg. v. Jaroslava Milotová (Prag 2005) 27-62; Gottwaldt, Schulle, „Judendeportationen“ (wie Anm. 150) 260-265. Mit demselben Transport wie Stein dürfte auch sein Universitätskollege Samuel Steinherz nach Theresienstadt gebracht worden sein, der dort im Dezember starb, vgl. Ar Lt, Steinherz (wie Anm. 112) 101; Oв в RKOFLER, Steinherz (wie Anm. 112) 128.

152 Zu Saure siehe Michael Grütt ner, Biographisches Lexikon zur nationalsozialistischen Wissenschaftspolitik (Studien zur Wissenschafts- und Universitätsgeschichte 6, Heidelberg 2004) 145f., zum anderen Bittgesuch Karel Hruza, Ein vergeblicher Hilferuf: Der Brief Käthe Spiegels an den Rektor der Deutschen Karls-Universität in Prag vom 11. Oktober 1941, in: Bohemia. Zeitschrift für Geschichte und Kultur der böhmischen Länder 48 (2008) 203-210. 
Motiven für Stein gehandelt hat ${ }^{153}$, denn Zynismus als Motiv hätte ihn wohl kaum angetrieben, seinen Brief zu verfassen. Möglich, wenn nicht sogar wahrscheinlich ist zudem auch, dass sich Stein um Hilfe bittend an seinen alten Freund gewandt hat ${ }^{154}$.

In Theresienstadt wurde das Ehepaar Stein wie im Übrigen auch das Ehepaar Utitz von der SS registriert und später den bevorzugten „Prominenten A“ zugeteilt ${ }^{155}$, von denen sich das "Prominentenalbum“ ( $1943 / 44$ ) mit biografischen Skizzen und Fotografien, so auch von Arthur Stein und Emil Utitz, erhalten hat ${ }^{156}$. Die Zuweisung

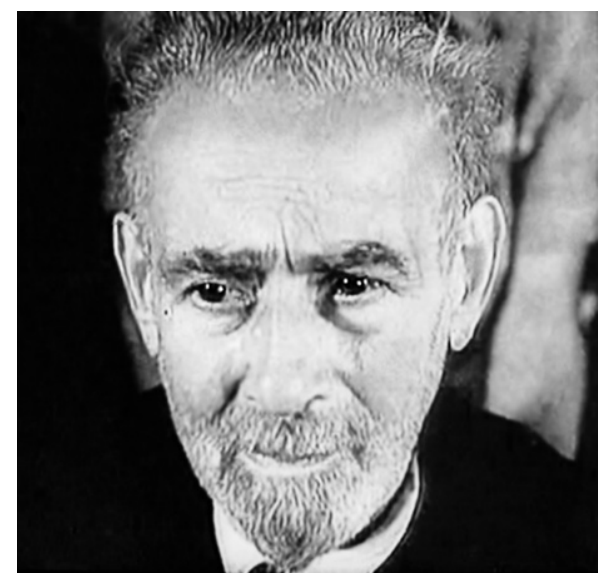

Abb. 5: Arthur Stein im NS-Propagandafilm "Theresienstadt-Ein Dokumentarfilm aus dem jüdischen Siedlungsgebiet" von 1944.

153 Einer Interpretation seines Briefes bietet MíškovÁ, Deutsche (Karls-) Universität (wie Anm. 105) 68: „Es ist schwer zu sagen, ob man einen derartigen Brief als zynisch oder als Hilfsbemühung für einen bedrohten Kollegen verstehen soll. Welcher Art jedoch die Beweggründe des Schreibers gewesen sein mögen; es scheint, dass sie Arthur Stein wenigstens zur Stellung eines ,Theresienstädter Prominenten 'verhalfen und ihm vielleicht auch das Überleben ermöglichten.“ Ähnlich DIEs., „Arisierung“ (wie Anm. 105) 100.

154 Ebd. 100 und bei Ders., Deutsche (Karls-) Universität (wie Anm. 105) 69, wird angeführt, dass sich Stein im Frühjahr 1941 - also bereits vor dem Einsetzen der Deportationsmaßnahmen, bei den tschechischen Protektoratsbehörden erfolglos bemüht hat, von antijüdischen Maßnahmen ausgenommen zu werden.

155 Dazu Adler, Theresienstadt (wie Anm. 151) 310f.: „Eine eigenartige Gruppe waren die ,Prominenten“, ein Begriff, den die SS im Herbst 1942 eingeführt hatte. Man unterschied zwei Untergruppen, A und B. ,A prominent' waren Personen, die dem Judenältesten von der SS bezeichnet wurden. Teils waren es Menschen von internationalem Namen oder deutsche und österreichische Offiziere [...]. Der Ältestenrat konnte von sich aus ,Prominente vorschlagen, die, falls bestätigt, ,B prominent' hießen. [...] Die ,Prominenz' bezog sich auch auf die Familienmitglieder. Im Jahre 1944 lebten 114 ,Prominente` mit 85 Angehörigen im Lager. [...] Die Vorrechte bestanden in besseren Unterkünften (möglichst familienweise in einem Zimmer), Schutz vor Deportation (den die SS in einigen Fällen entzog) und Befreiung von der Arbeitspflicht, worauf manche verzichteten. ,A-Prominente‘ genossen außerdem häufigeres Schreibrecht. [...] Durch manche menschlich hochstehende ,Prominente', an die sich bald ein Kreis anschloß, bildete sich eine gesellschaftliche Elite, die zwar deplaciert und anachronistisch in ihrem Elend wirkte und materiell schlechter gestellt war als der letzte Küchenjunge, aber trotzdem ein Gegengewicht zu der bisher allein tonangebenden Gesellschaft rund um die jüdische Leitung darstellte." Siehe auch die Quellenedition Anna Hyndrá Ková, Helena Krejčová, Jana Svoвоdová, Prominenti v ghettu Terezín (1942-1945). Edice dokumentů (Praha 1996).

156 Eine Liste der „Prominenten A“ vom Herbst 1943 ist gedruckt bei Ralph Oppenhejm, An der Grenze des Lebens. Theresienstädter Tagebuch (Hamburg 1961) 183-207, 205 der Eintrag zu Stein. Zum „Prominentenalbum" siehe mit kommentierter Wiedergabe der Personendaten und Fotografien Axel Feuss, Das Theresienstadt-Konvolut (Hamburg/Berlin 2002) 71 (die Stein betreffenden Angaben nicht in allem 
unter die „Prominenten“ geschah (auch oder nur?) mittels eines Antrags der betroffenen Person und der Intervention von Fürsprechern, als solche könnten im Fall Stein Steinacker und möglicherweise Saure genannt werden. Von der Deutschen Universität haben nur vier Professoren mit Erfolg den Versuch unternommen, unter die „Prominenten“ zu gelangen, und zurecht bemerkt Alena Míšková, dass mit dem Wissen, wie viele Insassen das Theresienstädter Lager nicht überlebt haben oder in Vernichtungslager abtransportiert wurden, „die Briefe der Fürsprecher vielleicht noch höher“ einzuschätzen sind ${ }^{157}$. Die Situation der „A-Prominenten“ gestaltete sich gegenüber der der übrigen Lagerinsassen in Theresienstadt wesentlich besser, denn: „Die Prominenten galten als transportgeschützt. Das war ihr vornehmliches Privileg. "158 Diese Personengruppe war also nicht der ständigen Gefahr ausgesetzt, in ein Vernichtungslager gebracht zu werden. Und die „Prominenten“ mussten nicht arbeiten, „aber die meisten tun es doch“159. Schließlich wurden die Wohnungen und Häuser der „Prominenten“ besonders gereinigt ${ }^{160}$, so auch das „Prominentenhaus“ L I 26 (= später Seestraße 20/I I I), in dem Stein und Utitz wohnten. ${ }^{161}$ Das Wohngebäude an der Lagerperipherie war ein „schöne[s] Haus mit seinen breiten, blitzblanken Korridoren, an jeder Tür der schön geschriebene Name des Bewohners" ${ }^{162}$. Es „atmete die großzügige Lebensweise, die seinen Einwohnern zu eigen gewesen war, die leichtlebige Nonchalance widrigen Lebensumständen gegenüber"163.

korrekt), und 74 Emil Utitz. Dieser als Vortragender und Stein als Zuhörer sitzend im Publikum und in einer Frontalaufnahme sind in einer Sequenz des im Spätsommer 1944 gedrehten NS-Propagandafilms „Theresienstadt - Ein Dokumentarfilm aus dem jüdischen Siedlungsgebiet“ (oder auch fälschlich „Der Führer schenkt den Juden eine Stadt") zu sehen, vgl. ebd. und auch Sta R Ke, Führer (wie Anm. 151) 132 und 212. Der Film ist einsehbar im Internet bei Google videos, die relevante Sequenz 33, Minute 9:30 bis 10:10 (letzter Zugriff 25.05.2010), die relevanten Stellen auch bei in der DVD-Dokumentation „Holocaust. Theresienstadt Camp. Deception \& Reality 1941-1945“ (Oracle Home Entertainment 2005).

157 Siehe Míšková, „Arisierung“ (wie Anm. 105) 103.

158 Starke, Führer (wie Anm. 151) 47f.

159 Ebd. Des Weiteren: „Mag sein, daß sie eine etwas höhere Verpflegungskategorie hatten, das konnte aber kaum eine Rolle spielen, sie hungerten wie alle anderen."

160 Siehe ebd. 47-49 den Bericht einer der „Putzfrauen“ über ihre Arbeit im Haus L 126 und mit weiteren eindrucksvollen Schilderungen vom Leben im Lager. Auf den bisweilen auch zweifelhaften Vorteil, zu den „Prominenten“ zu gehören, verweist Gerty SPIEs, Drei Jahre Theresienstadt (München 1984) 171.

161 Nach einer Karteikarte im Collegium Carolinum München; vgl. auch Hyndrá коvá, KrejČová, SvoвoDová, Prominenti (wie Anm. 155) 282 und 192-194 fehlerhaft zu Stein.

162 So beschreibt es Philipp Manes, Als ob’s ein Leben wär. Tatsachenbericht Theresienstadt 1942-1944, hg. v. Ben BAR Kow, Klaus Leist (Berlin 2005) 388, dazu auch 263f.: „Die Doppelreihe junger Linden säumt die Seestraße, in der die Prominentenhäuser stehen - Häuser mit weiten, hellen Korridoren, hohen Zimmern, die nur wenige Bewohner aufweisen, eiserne Betten, Tische, Stühle und ein wenig Komfort haben. Diese Prominentenhäuser sind ungewöhnlich gut instand gehalten, es blitzt vor Sauberkeit.“

163 So Star Ke, Führer (wie Anm. 151) 48. 
Abb. 6 und 7: Arthur Stein und Emil Utitz, beide den "Judenstern" tragend, im "Prominentenalbum" aus Theresienstadt.
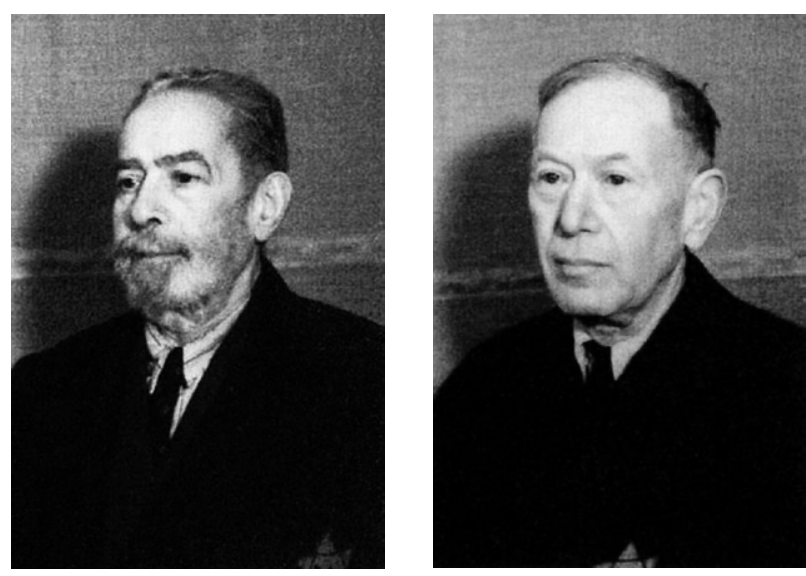

Stein hält im Rahmen einer von Utitz, der die "Ghettozentralbücherei“ und das Vortragswesen der „wissenschaftlichen Gesellschaft“ leitete, mitorganisierten Veranstaltungsreihe als Mitglied der so genannten Manes-Gruppe - eines von Philipp Manes ${ }^{164}$ im Herbst 1942 gegründeten kulturellen Zirkels ${ }^{165}$ - Vorträge zu Themen aus der Römischen Geschichte: so unter anderem am 2. Dezember I942 "Juden in der Diaspora“, am 6. Januar I943 "Judäa in der Diaspora“, am 25. Juni 1943 „Untergang der Antike“, am 30. Dezember I 943 „Die letzten Judenkriege der Römer“ und am 25. Juni I 944 „Aus der Welt der Papyri“" ${ }^{166}$. Utitz, der seinen Theresienstädter Aufenthalt in einem I 948 erschienen Buch verarbeitet hat, schrieb ${ }^{167}$ : Das „wissenschaftlich-künstlerische Vortragswesen [...] war zwar als Aushängeschild willkommen, aber unaufhörlich durch Verbote bedroht, sodaß zahlreiche Veranstaltungen unter falschem Titel starten mußten, und die Redner sich bereit zu halten hatten, mit einem anderen Thema fortzusetzen, falls plötzlich eine

164 Geboren 1875, 1942 nach Theresienstadt, 1944 nach Auschwitz deportiert, siehe das Vorwort bei Manes, Leben (wie Anm. 162) 10-12.

165 Viele Einzelheiten schildert der Gründer selbst sehr anschaulich in seinen Tagebuchaufzeichnungen, vgl. Manes, Leben (wie Anm. 162) etwa 253-258; zu den Vorträgen vgl. bereits Adler, Theresienstadt (wie Anm. 151) 597-603, sowie etwa Míš́ KovÁ, Deutsche (Karls-)Universität (wie Anm. 105) 66f.

166 Das Vortragsprogramm befindet sich im Archiv des Jüdischen Museums Prag; vgl. auch Elena MaKa Rová, Sergei Makarov, Victor Kuperman, University over the Abyss (Jerusalem 2000) 448f. mit einigen Fehlern in der Bibliografie und falschem Todesdatum Steins. Illustrationen (unter anderem Vortragsankündigungen) aus der Sammlung Hermann in Theresienstadt zum geistig-kulturellen Leben in Theresienstadt in: Kunst und Kultur in Theresienstadt, hg. v. Rudolf M. WLascheк (Gerlingen 2002). Das Blatt aus der Sammlung Hermann (unten Abb. 8) hat mir freundlicherweise Frau Iva Gaudesová (Theresienstadt) herausgesucht und als Kopie zugänglich gemacht.

167 Emil Utitz, Psychologie des Lebens im Konzentrationslager Theresienstadt (Wien 1948) 8 und 63. 
Inspektion erscheinen sollte.“ Und: „Der Geschmack des Publikums war überraschend: es vertrug auch schwere Kost.“ Die Vorträge Steins gehörten angesichts des „attraktiven“ Angebots an anderen Vortragsthemen vermutlich nicht zu den gefragtesten - Stein wird daher auch nicht in den Tagebüchern von Manes erwähnt -, zeigen aber doch seine aktive Teilnahme am geistigen Leben in Theresienstadt, das gewiss nicht unwesentlich zum Überleben seiner Bewohner beigetragen hat, wie viele dankbare Erinnerungen an das Vortragsprogramm und seinen Organisator beweisen.

Auch für den Freund in Wien brachte die Naziherrschaft ein bitteres, wenn auch nicht ganz so grausames Schicksal. Bereits einen Monat nach dem „Anschluss“ wurde Groag mit vielen anderen Professoren jüdischer Herkunft die Lehrbefugnis durch das Unterrichtsministerium entzogen ${ }^{168}$. Wenig später wird er aus der Mitgliederliste des Deutschen Archäologischen Instituts gestrichen, in das er auf der Gesamtsitzung der Zentraldirektion am I 4. und I 5. Juli I 933 unter Hinweis auf seine Verdienste bei der Herausgabe von Emil Ritterlings „Fasti des römischen Deutschland“ (Wien I932) als ordentliches Mitglied gewählt worden war ${ }^{169}$. Auch das Wohnen in der Feldmühlgasse I 5 wurde zum Problem. In einem Brief an den Altorientalisten Friedrich Wilhelm König ${ }^{170}$ schrieb Groag am I 5. August 1940: [...] wir sind jetzt in einer schwierigen Situation in Bezug auf unsere Wohnung: wir müssen diese spätestens im September räumen, haben aber noch keine neue gefunden. Sollte Ihnen zufälligerweise bekannt sein, dass in einem nichtarischen Haus eine kleinere Wohnung frei wäre oder auch eine größere, die man dann mit anderen Parteien teilen müsste, so wäre ich Ihnen für freundliche Mitteilung sehr dankbar. Obwohl (sic!) meine Frau den ,Ariernachweis' hat, sind uns, arische' Häuser anscheinend verschlossen ${ }^{171}$.

Bereits am 17. April I940 hatte sich Groag an die Wiener Akademie mit der Bitte gewandt ${ }^{172}$, sich dafür einzusetzen, dass er seine Wohnung behalten kann, und zwei Tage später schrieb der Akademiepräsident Heinrich von Srbik ${ }^{173}$ an den Leiter des Wohnungsamtes ein entsprechendes Gesuch. Groag wandte sich aber noch zweimal, am I 5 .

168 Brief des Unterrichtsministers an das Rektorat der Universität Wien vom 22.04.1938 im UA.

169 Auskunft von A. Krug, Archiv des DAI am 14.03.2002. Auffallend ist die Tatsache, dass Stein nicht und Groag erst 1933 zur Mitgliedschaft im DAI gelangt sind, hatte doch bereits am 20.03.1918 Dessau in einem Brief an Hirschfeld eine Ernennung der beiden Gelehrten zu korrespondierenden Mitgliedern für gerechtfertigt bezeichnet, siehe Hermann Dessau (wie Anm. 66) $346 f$.

170 Zu ihm Kürschners Deutscher Gelehrten-Kalender 1970, 1523; er wurde als Halbjude nach dem „Anschluss" aus seinem Dienst in der Nationalbibliothek entlassen, siehe Geschichte der Österreichischen Nationalbibliothek 2 (wie Anm. 116) 102, 168, 170.

171 Der Brief befindet sich - offenbar aus dem Nachlass König - in der Handschriftenabteilung der ÖNB (inv. 796/36-1 und 2).

172 Der Hofrat, an den der Brief gerichtet ist, ist wohl Carl Patsch (1865-1945), Obmann der Balkan-Kommission, zu ihm NDB 20, 101f.; ÖBL 7, 343f.

$173 \mathrm{Zu}$ ihm siehe den Beitrag von Martina Pesditschek in diesem Band. 
Mai und 24. August, an Patsch (?), bis die Intervention der Akademie Erfolg hatte. Am I 2. September I 940 bedankte er sich schließlich bei Patsch und Srbik für deren Unterstützung ${ }^{174}$. Offensichtlich war den Bemühungen der Akademie ein dauerhafter Erfolg beschieden, denn das Ehepaar Groag konnte bis zur Befreiung Wiens in seiner Wohnung in der Feldmühlgasse - wenn auch unter stark beengten Bedingungen und unter ständiger Angst und Bedrohung, die Wohnung doch aufgeben zu müssen - verbleiben ${ }^{175}$.

$\mathrm{Zu}$ Beginn des Jahres I942 musste Groag die Nachricht von der Deportation seiner Schwester Paula und ihres Mannes von Berlin nach Riga verkraften, im selben Jahr dazu noch die Deportation seines Onkels Emil Karell aus Wien nach Theresienstadt. Sicher hat er auch von der Deporta-

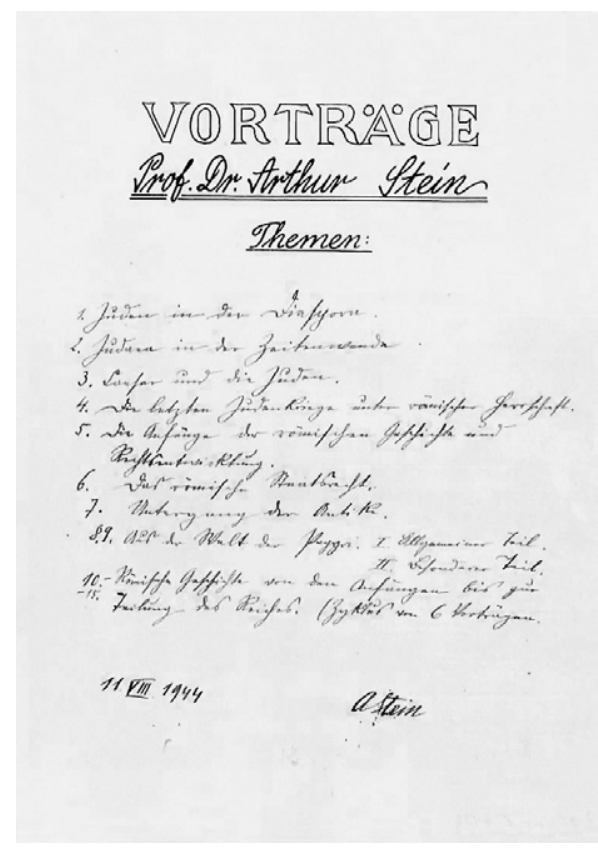

Abb. 8: Programm der Vorträge Arthur Steins in Theresienstadt tion des Prager Freundes und dessen Frau erfahren, was ihn tief getroffen haben muss ${ }^{176}$. In dieser Situation waren sicherlich die von Robert Adam Pollak in seinen Tagebüchern' ${ }^{177}$ erwähnten Zusammenkünfte mit Gleichgesinnten, die seit März 1942 allsonntäglich in Groags Wohnung stattfanden ${ }^{178}$ und an

174 Der Briefwechsel befindet sich im Archiv der ÖAW unter Balkan-Kommission H 14; ich danke herzlich dem Leiter des Archivs, Stefan Sienell, für die Übersendung von Kopien.

175 Dazu siehe unten.

176 Pollak, Tagebucheintrag 14.02.1943, berichtet, dass Groags den vierten Brief von Stein aus Theresienstadt erhalten haben.

177 Pollak (1877-1960) war Vizepräsident des Handelsgerichts in Wien, Schriftsteller und Privatgelehrter. Der Teil der Tagebücher, aus dem hier zitiert wird und dessen Kenntnis ich Monika Rauer, einer Großnichte Pollaks, verdanke, befindet sich in der ÖNB. Prof. Patzner und der ÖNB sei für die Erlaubnis herzlich gedankt, aus den Tagebüchern zitieren zu dürfen.

178 Die erste am 22.03., laut Pollak, Tagebucheintrag 22.10.1945: Forsche im Tagebuch nach, wie lange die Sonntagszusammenkünfte in der Feldmühlgasse gedauert haben, deren Aufhören wir alle ungemein bedauern: ich finde den 22. März 1942 als Anfangsdatum: das wären also mehr als drei Jahre. Wie bedauerlich, daß ich über die Gespräche, die allerdings manchmal dieselben Kriegsthemata in wenig nuancierter Weise behandelten, wegen der Gestapo-Gefahr kein Protokoll führen durfte. Geistreich waren sie nur selten, aber das Protokoll hätte ein äußerst lebendiges Bild der Zeit gegeben. 
denen neben Groag und Pollak noch der Orientalist und Geograf Hans von Mzik ${ }^{179}$ und der Philosoph Karl Roretz ${ }^{180}$ teilnahmen, von besonderer Bedeutung. Gelegentlich waren unter den Teilnehmern auch die Ehepaare Klein ${ }^{181}$ und Weichselgärtner anzutreffen ${ }^{182}$. I946 erinnerte sich Pollak an die vielen schönen Sonntagnachmittage, die wir in immer bestem Einvernehmen dort verbrachten und die fast der einzige Lichtblick in dieser grausigen Zeit waren ${ }^{183}$. Außer Pollaks und Kleins waren es ehemalige Kollegen aus Hofbibliothekszeiten, die sich bei Groags trafen.

Die Bekanntschaft zwischen Pollak und Groag ging auf eine erste Begegnung beider im August 1939 zurück: Zur Jause bei Frau Kappelmacher ${ }^{184}$, die mich gemeinsam mit Hofrat Dr. [Groag] eingeladen hatte, um zwei Zurückbleibende einander näher zu bringen. Er ist auch mit einer Arierin verheiratet und mit Dr. [...] befreundet. Er arbeitet noch immer an historischen Themen, Spezialgebiet die römische Kaiserzeit ${ }^{185}$. Groag traf sechs Tage später am selben Ort auf eine nun größere Gesellschaft: Nachmittags bei Frau Kappelmacher zur Jause, Hofrat Dr. Gr[oag], Prof. Dr. Braslof mit Frau ${ }^{186}$, Hofrat Dr. Seppeschi ${ }^{187}$, Dr. S. Frankfur${ }_{\text {ter }}{ }^{188}$ und Frau Dr. Herzog-Hauser, die in den nächsten Tagen nach Australien auswandert ${ }^{189}$.

179 Seit 1921 Leiter der Kartensammlung an der Nationalbibliothek.

180 Bibliothekar an der Nationalbibliothek.

181 Sicher der Professor für Zahnheilkunde Dr. Bruno Klein, geboren in Rajza bei Bielitz (daher der Hinweis auf die Bielitzer in Pollak, Tagebucheintrag 30.05.1943), dem im April 1938 die Lehrbefugnis entzogen wurde, siehe Pollak, Tagebucheintrag 12.08.1945. Als Groags Vetter bezeichnet ebd. 30.05.1943.

182 Mit großer Wahrscheinlichkeit Arpad Weixelgärtner und Frau, zu ihnen Deutsche Biographische Enzyklopädie 10 (1999) 419.

183 Pollak, Tagebucheintrag 20.05.1946.

184 Vermutlich ist Frau Kappelmacher mit der in Pollak, Tagebucheintrag 03.07.1939, genannten Frau Kappelmann identisch: Frau Kappelmann wird dort „Witwe nach Dr. Adolf Kappelmann“ genannt, doch findet sich in den Telefonbüchern Wiens der fraglichen Zeit keine Person dieses Namens, wohl aber ein Jurist Dr. Adolf Kappelmacher (nach den Telefonbüchern 1930-1939, ab 1940 kein Eintrag mehr), bekannt ist zudem der 1932 verstorbene Philologe Alfred Kappelmacher, siehe NDB 11, $139 \mathrm{f}$.

185 Pollak, Tagebucheintrag 17.08.1939.

186 Sicher der Rechtshistoriker Stephan Brassloff, 1943 in Theresienstadt gestorben (vgl. Pollak, Tagebucheintrag 05.04.1943).

187 Nicht identifizierbar, ebenso wie der gelegentlich zur Jause bei Groags ebenfalls anwesende Prof. Dr. Becz oder Becs (Pollak, Tagebucheintrag 11.07.1943; 24.7.1944). Möglicherweise sind die Namen durch Pollak nicht richtig wiedergegeben. Bei Becs könnte es sich angesichts des Bekanntenkreises Groags um Wilhelm Beetz, Kunsthistoriker und Oberstaatsbibliothekar an der Nationalbibliothek handeln (doch ist dessen NSVergangenheit bekannt), vgl. Geschichte der Österreichischen Nationalbibliothek 2 (wie Anm. 116) gemäß Register. Hinter Seppeschi könnte sich der ungarische Name Szepesi verbergen.

188 Wohl Salomon Frankfurter, zu ihm ÖBL 1, 346.

189 Gertrud Herzog-Hauser, Klassische Philologin, Universitäts-Dozentin und Direktorin des Mädchengymnasiums Rahlgasse. Wurde 1939 aller Posten enthoben und wanderte in die Niederlande (nicht nach Australien) aus; 1947 zurückgekehrt. 
Leider sind die Tagebücher Pollaks für die Jahre I940 bis I 942 gegenwärtig nicht verfügbar ${ }^{190}$, sodass im Unklaren bleibt, wie es zur Konstituierung der Gesellschaft kam, die sich dann seit dem März I 942 jeden Sonntag bei Groags versammelte. Ab I 943 konnten die Tagebücher wieder herangezogen werden. Aus ihnen ist zu ersehen, dass sich die Wohnungssituation seit Anfang 1944 wieder verschlechterte. Gerüchte kreisten immer wieder, dass auch die so genannten Mischehen von dramatischen Umsiedlungen betroffen sein sollten. Am r6. Februar notierte Pollak: Frau Groag ruft an, sie hätten polizeil. Aufforderung erhalten, binnen 8 Tagen auszuziehen. „Aus zwingenden Gründen ist eine Zusammensiedlung von Mischehen notwendig. Ich fordere Sie auf, mir binnen 8 Tagen gerechnet vom Tage der Zustellung an eine Mischehe bekannt zu geben, die bereit ist, Sie als zweite Hauptmieter aufzunehmen. "Eintrag am 30. April: Dr. Groag war am Freitag bei der Gestapo vorgeladen und mußte, um die angedrohte Abgabe in ein Konzentrationslager zu vermeiden, eine Erklärung unterschreiben, daß er die Wohnung binnen 8 Tagen räumen werde. Eine Ersatzwohnung zu suchen und aufzufinden sei seine Sache. Die Frau von einer bewundernswerten Ruhe. So ging das weiter: Aufforderungen zum Auszug, Drohung mit dem Konzentrationslager, Einreichung von Beschwerden durch die Groags. Im November werden zwei Zimmer der Wohnung beschlagnahmt, so dass Groags am Jahresende nur noch I Zimmer bewohnen (26. November). Doch das Ehepaar Groag überstand auch die letzten Monate des Krieges. Nachdem Wien von der Roten Armee eingenommen worden war, schaut Pollak am 29. April in der Feldmühlgasse vorbei: [...] er sieht gut aus und denkt nur an seine Arbeit, sie hingegen ist ganz fürchterlich eingegangen [...].

Leider war es Groag nicht vergönnt, seine prosopografischen Studien, wie er es gewollt hatte, wiederaufzunehmen. Am I2. August I945 lag er offensichtlich schwer krank auf dem Sofa, als Pollak ihn besuchte: Ich fand den Hofrat auf dem Sofa zugedeckt und mit einem Umschlag um die Stirne liegend: es sei ein völliger Kräfteverfall eingetreten, außerdem Fieber, Bronchialkatarrh, Blasenkatarrh. Ein zugezogener junger Arzt habe drei Mittel verschrieben, die in der Apotheke nicht erhältlich seien. Morgen will die Frau zu Professor Klein fahren, der aber sehr in Anspruch genommen sei: die Frau herzleidend, er richte sich wieder aufden Tuchlauben ein, habe zweimal in der Woche das Jüdische Spital. Bis zur Jause habe der Hofrat aber noch gearbeitet. Am nächsten Tag nachmittags bei sehr großer Hitze nach Ober-St. Veit; auf dem Wege viele Ackermelde, eine Aktentasche voll für uns und einen großen Buschen für die Groags abgeschnitten. Als ich zu Groags kam, traf ich Frau Frömel, die gerade auch hingekommen war und kostbare Nahrungsmittel, darunter zwei Eier und einen Krautkopf, mitbrachte. Frau Groag nicht daheim; sie war zu Prof. Klein gefahren. Der Hofrat lag sehr rot im Gesicht da, hatte hohes Fieber, wußte anscheinend nichts von sich; ich bekam den aller-

190 Sie befinden sich im Besitz von Christa Kupferblum, die auf Nachfrage mitgeteilt hat, dass keine Einträge über Groag enthalten sind (auch nicht am 22.03.1942). 
übelsten Eindruck. Am I6. August wurde Groag mit hohem Fieber in das jüdische Spital Malzgasse I 6 eingeliefert; zwei Tage später besuchte Pollak ihn im Spital: Der Hofrat liegt in einem hübschen Zimmer ganz allein, wird herrlich verpflegt, von Prof. Dr. Donath behandelt. Er hatte $40^{\circ}$ Fieber, als er vorgestern nachmittag eingeliefert wurde, hat das Fieber jetzt aber verloren. Doch bereitet ihm das Atemholen anscheinend Schwierigkeiten, ebenso das Hinunterschlucken von Pillen. Er bekommt Eleutheron; die Frau flüstert mir zu, daß Lunge und Herz affiziert seien. Sein Gesicht ist ungeheuer abgemagert, sodaß er kaum zu erkennen ist. ${ }^{191}$

Gestorben ist Groag nach der Todesfallaufnahme, ausgestellt vom Amtsgericht Hietzing, am I9. August 1945. Drei Tage später erhielt Pollak brieflich die Todesnachricht: Unter der Post finde ich einen kurzen Brief des Prof. Dr. Roretz, in dem er mich vom Ableben des Hofrats Groag verständigt. Die Nachricht trifft uns beide sehr schwer: hatten wir uns doch fast drei Jahre lang allwöchentlich gesehen und gesprochen. Als Todesursache wird laut Sterbeeintrag im Standesamt Brigittenau Arterienverkalkung und beiderseitige Lungenentzündung angegeben. Beigesetzt wurde Edmund Groag am 25. August I 945 auf dem Südwestfriedhof im I 2. Wiener Gemeindebezirk im Familiengrab 47, Reihe 4, Nummer ${ }^{192}$. An der Beisetzung nahmen teil ${ }^{193}$ : neben Frau Groag und dem Ehepaar Pollak noch Prof. Dr. Klein, Dr. Hrdlička ${ }^{194}$, Dr. Doublier ${ }^{195}$, Frau Weichselgärtner ${ }^{196}$, Prof. Mzik ${ }^{197}$, Frau Frömel ${ }^{198}$ und Prof. Dr. Keil, der die Leichenrede hielt, sehr schlicht, sehr herzlich ${ }^{199}$. Am 7. Juni 1950 wurde der Leichnam Groags auf Initiative seiner Frau, die im Mai 1946 in die Tschechoslowakei zurückgekehrt war und erst in Prag und dann in Deutschbrod (Havličkův Brod) lebte ${ }^{200}$, exhumiert, eingeäschert und die Urne nach Deutschbrod versendet $^{201}$. Frau Groag verstarb I959, ihre Urne ist gemeinsam mit der ihres Mannes im Urnenhain des Neuen Friedhofs beigesetzt ${ }^{202}$.

191 Pollak, Tagebucheintrag 18.08.1945.

192 Brief der städtischen Friedhofsverwaltung MA 43-3745/01.

193 Pollak, Tagebucheintrag.

194 Wohl Heinrich Hrdlička, zu ihm Geschichte der Österreichischen Nationalbibliothek 2 (wie Anm. 116) 172.

195 Wohl Othmar Doublier, siehe oben.

$196 \mathrm{Zu}$ ihr siehe oben.

$197 \mathrm{Zu}$ ihm siehe oben.

198 Wohl Hermine Frömmel, zu ihr Geschichte der Österreichischen Nationalbibliothek 2 (wie Anm. 116) 171.

199 Pollak, Tagebucheintrag 25.08.1945; zu Josef Keil siehe NDB 11, 404f.; vgl auch den Nachruf Keils im Anhang.

200 Nach Auskunft des staatlichen Kreisarchivs in Deutschbrod (Brief SOkA-601/01-0.82.9 vom 27.09.2001). Ein anderes Datum überliefert Pollak, Tagebucheintrag 20.05.1946: Nachmittags zum Abschiedsbesuch bei Frau Groag, die schon alles gepackt hat und übermorgen [also am 22.05.] früh mittels Lastauto zu ibren Stiefschwestern nach Deutschbrod übersiedelt.

201 Brief der städtischen Friedhofsverwaltung MA 43-3745/01.

202 Grab U 38. Brief des staatlichen Kreisarchivs in Deutschbrod (wie Anm. 200). 


\section{NACH DER BEFREIUNG}

Am 9. Mai 1945 wurden die Insassen des Lagers Theresienstadt von der Roten Armee befreit; wegen einer Flecktyphusseuche wurde am I4. Mai eine strenge Quarantäne verhängt, die mehrere Wochen dauerte ${ }^{203}$. Die Ehepaare Stein und Utitz befanden sich unter den Überlebenden, doch mussten sie noch bis Anfang August ausharren, ehe sie nach Prag zurückkehren konnte ${ }^{204}$. Man fragt sich, wie das Ehepaar Stein diese drei Jahre Zwangsaufenthalt überstehen konnte. Hat vielleicht die stoische Lebenseinstellung, wie sie das Motto auf Steins Theresienstädter Porträt andeutet, mit dazu beigetragen? In seine alte Wohnung konnte das Ehepaar Stein nicht wieder einziehen und fand Unterkunft an der Peripherie im Norden Prags. Die Steins konnten noch fünf gemeinsame Jahre in Prag genießen, in denen Arthur Stein seine wissenschaftliche Arbeit wieder aufnahm. Inwieweit er dabei seine ehemalige Privatbibliothek zur Verfügung hatte, ist unbekannt. Sicher ist allerdings, dass er seine beiden Handexemplare der PIR hatte retten können; diese sind nach seinem Tod von seiner Frau der Berliner Akademie übereignet worden und bilden bis heute eine der wertvollsten Grundlagen bei der Fertigstellung des Handbuchs. Das Leben in Prag war für die Rückkehrer aus Theresienstadt nicht einfach ${ }^{205}$, doch fanden die Steins materielle Unterstützung aus Übersee: Ein Neffe Steins, Theodore H. Loewy, sandte ihm aus New York monatlich I 50 Dollar aus einem privaten Stein-Fonds, den Alvin S. Johnson gegründet hatte ${ }^{206}$.

Am I 5 . November I 950 starb Stein an einem Schlaganfall. Ein halbes Jahr später, am I0. Mai I95 I, beging seine Frau Selbstmord; sie sprang aus dem Fenster ihrer Wohnung. Beide sind im Krematorium Vinohrady in Prag eingeäschert worden.

Stein, der 1947 zum Ehrenmitglied der Society for the Promotion of Roman Studies gewählt wurde ${ }^{207}$, konnte noch bis zu seinem Tod an der PIR weiterarbeiten. Dass die

203 Siehe Adler, Theresienstadt (wie Anm. 151) $217 \mathrm{f}$.

204 Nach Steins eigenen Worten in seinem Curriculum vitae (siehe oben Anm. 29) dauerte der Aufenthalt in Theresienstadt bis zum 2. August; die polizeiliche Anmeldung in Prag (im NA Prag) trägt das Datum 03.08.1945.

205 Zur Illustration kann ein Brief Körners dienen, den dieser am 05.021946 an Käte Hamburger schrieb (KöRNER, Schriften [wie Anm. 53] 191): Als ich im Mai v.J. aus der Deportation heimkehrte, schlug das Glücksgefühl der Befreiung schon nach wenigen Tagen in helle Verzweiflung um, denn es zeigte sich, daß die radikale Lösung der Deutschenfrage hierzulande rücksichtslos auch die (sei's noch so antinazistisch gesinnten und tätigen) Juden deutscher Kulturzugehörigkeit einbegreifen wolle. In dieser Verzweiflung, die tiefer war denn alle in den Jahren der Hitlerherrschaft erlittene und zum ersten Mal mich und die (nichtjüdische, tschechische) Gattin ernstlich an Selbstmord denken ließ, [...].

206 So ein Brief Steins an Johnson, der im Jüdischen Museum Prag aufbewahrt wird. Bei Johnson handelt es sich um den bekannten Wirtschaftswissenschaftler und Förderer von Exilwissenschaftlern.

207 Vgl. Journal of Roman Studies 37 (1947) 225. 
neue Kontaktaufnahme mit der Berliner Akademie über eine dritte Person erfolgte, lag vermutlich daran, dass der Postverkehr zwischen der Tschechoslowakei und den Besatzungszonen Deutschlands lange Zeit unterbrochen war oder schlecht funktionierte ${ }^{208}$. Karl Wagner ${ }^{209}$ schrieb am 23. August 1946 aus Gauting bei München an Stroux ${ }^{210}:$ Herr Prof. Dr. Arthur Stein in Prag VII-I334, u Smaltovny 22/B fragt durch mich bei Ihnen an, ob die Preußische Akademie der Wissenschaften wieder in Tätigkeit ist und die Prosopographia Imperii Romani fortgesetzt wird, ferner, wer die neuen Bearbeiter als Nachf. von Groag † und Arthur Stein sind. [...] Es dauerte dann noch bis zum I6. März I948, bis Stein - offenbar als Antwort auf ein Angebot von Stroux, die Arbeit an der PIR für die Berliner Akademie wieder aufzunehmen - an diesen schrieb ${ }^{211}$ : Ich bin gern bereit, die Arbeit an der Prosopographia Imperii Romani wieder aufzunehmen, und darf meiner Freude Ausdruck geben, daß die Akademie [...] zu der bisherigen Form der Ausarbeitung zurückzukehren geneigt ist. Dass Stein die Zusammenarbeit mit der Akademie trotz der hinter ihm liegenden Verfolgung fortzusetzen bereit war, wirft ein bezeichnendes Licht auf seine Persönlichkeit und verdient wohl größte Hochachtung. Den ersten Faszikel des vierten Bandes der PIR hat er noch imprimiert, seinen Druck aber nicht mehr erlebt, da dieser ein Jahr nach seinem Tod erschien. I950 hat er sich dagegen noch über das Erscheinen seiner „Präfekten von Ägypten in der römischen Kaiserzeit" erfreuen dürfen ${ }^{212}$. Mit dieser Publikation hat Stein einem Forschungsgegenstand, der ihn seit seinen ersten wissenschaftlichen Schritten mehr als 50 Jahre beschäftigt hatte, einen hervorragenden Schlusspunkt gesetzt, wie in den folgenden Jahren das Echo der Rezensenten in eindeutiger Weise bestätigt hat ${ }^{213}$.

\section{ZUSAMMENFASSUNG}

Sowohl Steins wie auch Groags Eltern sind typische Beispiele von Migration und Mobilität im Österreich-Ungarn des I9. Jahrhunderts, als es zahlreiche Menschen verschiedener

208 Aus dem in Anm. 205 bereits zitierten Briefen Körners geht hervor, dass im August 1946 noch kein direkter Briefverkehr von und nach Deutschland möglich war.

209 Er ist identisch mit dem Professor für Physikalische Chemie an der Deutschen Universität Prag Karl Ludwig Wagner (Auskunft des Archivs der Gemeinde Gauting). Zu ihm Kürschners Deutscher Gelehrten-Kalender 1950.

210 Zu ihm Kürschners Deutscher Gelehrten-Kalender 1954, 2341 ; ABBAW, II-VIII, 142.

211 ABBAW, II-VIII, 142.

212 Bern 1950.

213 Essenzielle Besprechungen des Werkes stammen unter anderem von Hans-Georg Pflaum in: Latomus 10 1951) 471-477, Eric Birley in: Gnomon. Kritische Zs. für die gesamte klassische Altertumswissenschaft 23 (1951) 440- 443, Jacques Schwartz in: Chronique d'Égypte 26 (1951) 439; Otto Reinmuth in: American Journal of Philology 73 (1952) 418-427, Sir Ronald Syme in: Journal of Roman Studies 44 (1954) 116-119, Eefje Prankje Wegener in: Museum 60 (1955) 36. 
sozialer und ethnischer Gruppen aus unterschiedlichen Ursachen und Gründen und mit unterschiedlichen Zielen nach Wien zog. Charakteristisch für einen Teil dieser "Zuwanderer" war es auch, vor allem ihren Söhnen, in geringem und zunehmendem Maße aber auch den Töchtern eine gute Schulbildung und damit den Weg zu einer universitären Ausbildung zu ermöglichen. Bei Groag und Stein waren es die Geistes-, speziell die historischen Wissenschaften, denen das Interesse beider galt und die sie an der Wiener Universität, im Archäologisch-epigrafischen Seminar Bormanns und im Historischen Seminar Büdingers zusammenführten, wo sie zu typischen Ver-

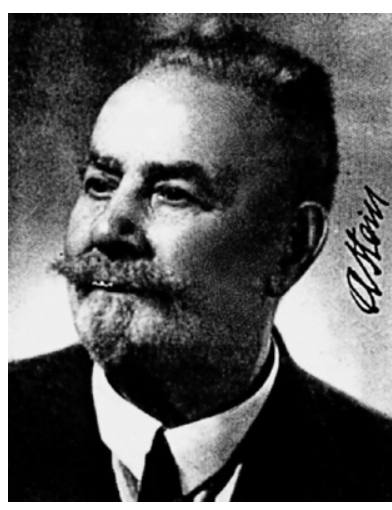

Abb. 9: Arthur Stein 1947 tretern der „Wiener Schule“214 ausgebildet wurden. Gepflegt wurde die handwerkliche Vollkommenheit bei der Bearbeitung und Auswertung des literarischen, epigrafischen, numismatischen, papyrologischen, im Bedarfsfall auch des archäologischen Quellenmaterials ${ }^{215}$. Dabei spielte die Epigrafik die Hauptrolle: in Bormann hatten die angehenden Althistoriker einen hervorragenden Lehrer auf dem Feld der lateinischen Inschriftenkunde, der - ein Schüler Mommsens - unter anderem am Berliner Inschriftenkorpus mitgewirkt hatte, bevor er I 885 die Wiener Lehrkanzel bestieg. ${ }^{216}$ Benndorf, zuvor Inhaber des archäologischen Lehrstuhls in Prag, übernahm I 877 die Lehrkanzel für Klassische Archäologie in Wien. Nachdem er mehrere Forschungsreisen nach Kleinasien organisiert und die Grabung Ephesos begonnen hatte, gründete er I 898 das Österreichische Archäologische Institut. Viele der auf den Forschungsreisen und Grabungen zutage gekommenen (vor allem griechischen) Inschriften wurden von Groag und Stein veröffentlicht.

Bormann war es vermutlich auch, der seine beiden Schüler mit der kaiserzeitlichen römischen Prosopografie vertraut machte und ihnen die Bearbeitung der entsprechenden Personenartikel in der RE vermittelte. Diese Forschungen zur Personenkunde, verbunden mit Untersuchungen zur Verwaltungsgeschichte der römischen Kaiserzeit, wurden ihr Spezialgebiet, auf dem sie eine nachhaltige Wirkung erzielt haben. Vor allem die genealogischen Studien und die Erkenntnisse zum ritterlichen und senatorischen Ämterwesen waren die wesentlichen Grundlagen für ihre Bearbeitungen der Personenartikel in der

214 Vgl. dazu Weiler, Geschichte (wie Anm. 30) 94-96.

215 Eine Bibliografie der Arbeiten Steins stammt von Ladislaus Vidman, Eunomia 2,1, in: Listy filologické 6 (1958) 40-49. Für Groag bildet eine solche Zusammenstellung ein Desiderat.

216 Im UAP befindet sich ein Teil der Korrespondenz Bormanns mit Mommsen und Hirschfeld, den Jana Kepartová bearbeitet und der sich unter anderem auch auf Bormanns Mitarbeit am CIL bezieht. 
RE und in der von ihnen herausgegebenen zweiten Auflage der PIR. Die Gültigkeit der dort niedergelegten Ergebnisse ist seither wesentlich nur durch neue Quellen verändert worden.

Detaillierte Erfassung des Quellenmaterials und seine Verarbeitung zu Einzelviten bildeten die Grundlage für sogenannte Fasten; die vorhandene Quantität bekannter Amtsträger in Kombination mit der Qualität des Kenntnisstandes der einzelnen Individuen erlaubte auch verallgemeinernde Aussagen etwa zu den Laufbahnen und der Herkunft der Inhaber eines bestimmten Amtes. Das hat Stein bereits in seinen Statthaltern von Thrakien (I920) gezeigt, Groag für die römischen Beamten von Achaia (I939 und I946) fortgesetzt, bis es Stein nach seinen Legaten von Mösien (I940) und Dakien (I944) schließlich für die Präfekten von Ägypten (1950) meisterlich demonstriert hat.

Natürlich ist das Werk Groags und Steins auch nach ihnen fortgesetzt worden, sind Methoden und auf ihnen basierend Erkenntnisse weiterentwickelt und verfeinert worden. Auf die Arbeiten von Ronald Syme, Hans-Georg Pflaum, Géza Alföldy und Werner Eck sei hier vor allem verwiesen. Auch für das Haupt- und Gemeinschaftswerk Groags und Steins, das beide nur beginnen, der Verfolgung während des Nationalsozialismus wegen aber nicht vollenden konnten, die PIR, zeichnet sich nun doch der glückliche Abschluss in naher Zukunft ab. Nach mühevoller Wiederaufnahme der Arbeit nach dem Zweiten Weltkrieg ${ }^{217}$ ist das Werk trotz zahlreicher Hindernisse ${ }^{218}$ bis zum Buchstaben T erschienen; die Personenartikel des letzten Bandes sind in Arbeit ${ }^{219}$.

217 Dass die Arbeit an der PIR nach 1945 fortgesetzt wurde, ist vor allem dem unermüdlichen Einsatz von Leiva Petersen zu verdanken; vgl. zu ihr Werner Ecк in: Gedenken an Leiva Petersen 1912-1992 (Köln/Weimar/ Wien 1993) 25-31.

218 Die PIR teilte hier das Schicksal mit vielen anderen altertumswissenschaftlichen Traditionsunternehmen der Berliner Akademie, deren detaillierte Geschichte noch der Aufarbeitung bedarf.

219 Vgl. das Vorwort zu PIR ${ }^{2}$ VIII 1 (2009). 


\title{
A N H A NG
}

I. Brief Harold Steinackers an Wilhelm Saure ${ }^{220}$

Persönlich, zu eigenen Handen.

Innsbruck Innstrasse III den 2 I. Oktober I94I

\author{
Sr. Magnifizenz \\ Herrn Professor Saure \\ Rektor der Universität Prag \\ Prag
}

Ew. Magnifizenz!

Sehr geehrter Herr Kollege!

Sie kennen mich und wissen, dass ich die harten Notwendigkeiten unseres Kampfes wider das Judentum voll verstehe und nicht leicht für Ausnahmen eintrete. Es liegt mir auch fern, Ihnen etwas zuzumuten, was Sie nach Lage der Dinge nicht tun können oder wollen. Aber ich kenne die Lage der Dinge eben nicht näher. Ich weiss über Anlass und Absicht der gegenwärtigen Evakuierung der Prager Juden nichts Näheres. So kann ich nicht beurteilen, auf welche Zeit sich die Maßnahmen verteilen und ob die Möglichkeit besteht, politisch harmlose oder sonst irgendwie berücksichtigungswerte Fälle vor anderen zurückzustellen. Falls davon die Rede sein kann, möchte ich meine Hemmungen überwinden und Sie darauf aufmerksam machen, dass dafür ein früherer Professor der Prager Universität, der heute 70 Jahre alte Althistoriker Arthur Stein besonders in Betracht käme. Ich kenne ihn aus Studienzeiten und als Prager Kollege genauer und bitte Sie, gegebenenfalls mein Urteil durch Befragung von Kollegen Wostry ${ }^{221}$ nachzuprüfen.

Es sind nicht nur persönliche Gründe, sondern auch eine politische Erwägung, die mich den Gedanken aussprechen lassen, ob sich die Verschickung Steins aus Prag, wenn nicht aufheben, so doch verschieben liesse. Stein, der international als Kenner der römischen Verwaltungsgeschichte bekannt ist, hat ein Werk über die Provinz Dazien so gut wie abgeschlossen, das vom Budapester Archäologischen Institut zur Herausgabe angenommen ist, wie schon vor einigen Jahren ein Buch über Moesien. Das bereits angekündigte Werk wird von der ungarischen, rumänischen und bulgarischen Wissenschaft mit Interesse erwartet. Der Herausgeber weiss sicherlich, dass es ziem-

220 UAP, Rektorat der Deutschen Universität in Prag, Amtskorrespondenz des Rektors Wilhelm Friedrich Saure, Sign. A6, K. 102. Zitiert auch von Míšková, Deutsche (Karls-)Universität (wie Anm. 105) 68; Alena Mísková hat mir freundlicherweise eine Kopie zugesandt. Jana Ratajová (UAP) danke ich herzlich für die Publikationserlaubnis und die Mitteilung der Archivsignatur.

$221 \mathrm{Zu}$ ihm siehe oben Anm. 95. 
lich fertig ist, und wird schon zu seiner Deckung dem Schicksal des Manuskripts nachgehen. Die Umstände, die das Erscheinen unmöglich gemacht haben, werden also in den Fachkreisen jener Länder ohne Zweifel bekannt werden. Ist es nun unser deutsches Interesse, dass hier ein Fall gesetzt werde, der für die Propaganda mit all der Wirksamkeit ausgenützt werden kann, die nun einmal an den konkreten Fällen und den bekannten Persönlichkeiten hängt? Dem Sieg der Waffen wird ja der Kampf der Propaganda folgen, gerade in diesen uns wenig geneigten und unter westlichem Einflußstehenden Ländern. Es scheint daher immerhin erwägenswert, ob man Stein nicht die wenigen Wochen oder Monate belassen könnte, die zum Abschluß der nahezu fertigen Arbeit unter Benützung seiner Prager Bücher und Materialien nötig wären. (Wenn man schon davon absieht, dass Stein 70 Jahre ist und dass solche Fälle sich in absehbarer Zeit auf natürlichem Weg regulieren.)

In der Hoffnung, dass Sie mein Einschreiten nicht falsch deuten und dass die Lage der Dinge es nicht gegenstandslos erscheinen lässt, habe ich geglaubt, mich persönlich an Sie wenden zu dürfen.

\section{Heil Hitler!}

Ihr ergebener

Steinacker

\section{Josef Keil: Nachruf für Hofrat Prof. Dr. Edmund Groag 222}

Edmund Groag, 1873 als Sohn des Eisenbahningenieurs Berthold Groag in Prerau geboren, hat seine wissenschaftliche Ausbildung an der Universität im historischen Seminar durch Max Büdinger und im Archäologisch-epigraphischen Seminar erhalten, wo der Mommsenschüler Eugen Bormann die grosse Tradition der römischen Altertumswissenschaft vertrat. Nach einem Staatsstipendiumsjahr in Rom als Bibliothekar am archäologisch-epigraphischen Seminar tätig, kam Groag dann in den Dienst der Nationalbibliothek, in dem er bis zu seiner vorzeitigen Pensionierung als einer ihrer hervorragendsten Beamten verblieb. An der Universität hat sich Groag im Jahre I9I9 als Privatdozent für Römische Geschichte habilitiert und ist im Jahre I925 mit dem Titel eines außerordentlichen Universitätsprofessors ausgezeichnet worden. Als gebürtiger, aber schon in seiner Jugend ${ }^{223}$ getaufter Jude im Jahre I93 8 aus dem Lehrkörper gestrichen, konnte er seine Lehrtätigkeit im neuen Österreich wegen Erreichung der Altersgrenze nicht mehr aufnehmen; das eben verfaßte Dankschreiben des Dekans für seine Leistung als akademischer Lehrer hat ihn nicht mehr erreicht und konnte nur der Witwe zugestellt werden.

222 Unveröffentlicht; aufbewahrt im AUW, Nekrologsammlung. Dr. Kurt Mühlberger danke ich für die Erlaubnis zur Veröffentlichung.

223 Als er sich 1901 taufen ließ (siehe oben), stand er allerdings bereits im 29. Lebensjahr. 
Groag hat sein ganzes Leben wie nur wenige völlig in den Dienst der Wissenschaft gestellt. Der ihm durch Bormann übermittelten Mommsenschen Tradition entsprechend hat er das Gesamtgebiet der Römischen Geschichte und ihrer Hilfsdisziplinen in den Bereich seiner Forschungsarbeit gezogen und auch dem grössten Gegner des republikanischen Rom Hannibal in einem besonderen Buche gerecht zu werden versucht. Vor allem waren es die Persönlichkeiten, die das tragende Gerüst jedes Staates und jeder Gesellschaft bilden, denen Groag sein Interesse immer mehr zuwandte, und so ist die Prosopographie der ausgehenden Republik und der Kaiserzeit sein Spezialgebiet geworden. Durch mühevolle Sammelarbeit und gründlichste Kenntnis der Zeitverhältnisse waren ihm die Kaiser und die Angehörigen des römischen Senatorenstandes so vertraut, als stünde er mit ihnen in persönlichem Verkehr. In einer Fülle wertvollster Aufsätze in Zeitschriften und einer fast unübersehbaren Zahl von Artikeln in der Realenzyklopädie der Klassischen Altertumswissenschaft und schließlich in den erschienenen drei Bänden der 2. Auflage der Prosopographia imperii Romani sowie dem Buche über die „Römischen Reichsbeamten der Provinz Achaia bis auf Diokletian" hat er sein Wissen um diese Persönlichkeiten der Altertumswissenschaft zur Verfügung gestellt und auch noch eine Reihe ganz oder fast fertiger Publikationen als Ergebnis seiner Lebensarbeit hinterlassen. So konnte Professor Keil in seiner Ansprache am Grabe Groags mit Recht sagen, daß dieser stille und bescheidene österreichische Gelehrte, der die ihm durch die nationalsozialistische Regierung zugefügte Diffamierung mitsamt ihren drückenden Folgen mit stoischer Ruhe und ohne je Rachegefüble zu äussern ertragen hat, der überall anerkannte erste Vertreter seines Spezialgebietes gewesen ist.

Auch unsere Fakultät wird ihn allezeit in dankbarer Erinnerung behalten. 



\section{Max Dvořák (I874-I92I)}

VON DER HISTORISCHEN QUELLENKRITIK ZUR KUNSTGESCHICHTE

ALS GEISTESGESCHICHTE

Der ursprünglich als Historiker ausgebildete Max Dvořák wurde als Kunsthistoriker zu einem der bekanntesten Vertreter der sogenannten „Wiener Schule der Kunstgeschichte“. Er bezeugt damit die seit der Reorganisation durch Theodor von Sickel I 874 ja auch institutionell enge Verbindung des Instituts für Österreichische Geschichtsforschung (= IÖG), dessen Absolvent er war, und der durch Rudolf von Eitelberger und Moritz Thausing begründeten und dann von Franz Wickhoff und Alois Riegl - beide waren Dvořáks Lehrer im Institutskurs - fortgeführten Tradition der Kunstgeschichte an der Wiener Uni-

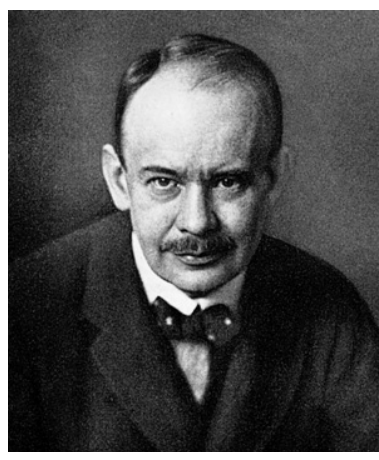

Abb. Io: Max Dvoŕák versitä $t^{1}$. Diese Tradition wurde von Dvořák allerdings auf entscheidende Weise revidiert, wobei er sowohl Erfahrungen der zeitgenössischen modernen Kunst als auch die geisteswissenschaftliche Kritik am Historismus rezipierte. Bekannt ist Dvořák bis heute vor allem als „Entdecker“ des Manierismus als eigenständiger Stilepoche und wegen seiner letzten Schriften, in denen „Kunstgeschichte als Geistesgeschichte" - so lautet der von den Herausgebern gewählte programmatische Titel eines I 923 postum erschienenen Sammelbands - verstanden wird ${ }^{2}$. Dvořáks Nachruhm, der

1 Vgl.: Julius von Schlosser, Die Wiener Schule der Kunstgeschichte. Rückblick auf ein Säkulum deutscher Gelehrtenarbeit in Österreich. Nebst einem Verzeichnis der Mitglieder, bearb. v. Hans Ha Hn Loser, in: MIÖG Erg.-Bd. 13, H. 2 (Innsbruck 1934); Alphons Lнотsкy, Geschichte des Instituts für österreichische Geschichtsforschung 1854-1954 (MIÖG Erg.-Bd. 17, Graz/Köln 1954) 271f. und 326-331; Walter Höflechner (unter Mitarbeit von Christian Brugger), Zur Etablierung der Kunstgeschichte an den Universitäten in Wien, Prag und Innsbruck. Samt einem Ausblick auf ihre Geschichte bis 1938, in: 100 Jahre Kunstgeschichte an der Universität Graz. Mit einem Ausblick auf die Geschichte des Faches an den deutschsprachigen österreichischen Universitäten bis in das Jahr 1938, hg. von Walter Höflechner, Götz Pochat (Graz 1992) 6-71; Hans AuRENhammer, 150 Jahre Kunstgeschichte an der Universität Wien (1852-2002). Eine wissenschaftshistorische Chronik, in: Mitteilungen der Gesellschaft für vergleichende Kunstforschung in Wien 54 (2002) 1-15.

2 Max Dvoř́́к, Kunstgeschichte als Geistesgeschichte. Studien zur abendländischen Kunstentwicklung (München 1928; Neuausgabe Berlin 1995). 
nicht zuletzt durch die unmittelbar nach seinem frühzeitigen Tod erschienenen, ebenso ausführlichen wie inhaltsreichen Gesamtwürdigungen durch seine Schüler Dagobert Frey und Otto Benesch befördert wurde ${ }^{3}$, verband sich vor allem mit diesen Texten der Spätzeit („Kunstgeschichte als Geistesgeschichte“ war schon nach einem Jahr ausverkauft). Deren idealistische Emphase erschien jedoch im Zeitalter der Neuen Sachlichkeit schon nach wenigen Jahren überholt.

Dvořáks wissenschaftliche Leistung ist allerdings weitaus komplexer, als seine Spätschriften vermuten lassen. Dass diese als das Ergebnis eines lebenslangen Prozesses der Selbstprüfung und Selbstkorrektur verstanden werden müssen, zeigen vor allem die Manuskripte seiner Vorlesungen und Vorträge, die sich in dem durch Karl Maria Swoboda und Johannes Wilde gleich nach I92 I geordneten Nachlass vollständig erhalten haben ${ }^{4}$. Auf dieses umfangreiche, zum überwiegenden Teil unpublizierte Material nimmt der folgende Beitrag immer wieder Bezug. Dieser kann bei dem derzeitigen Stand der Forschung dennoch nur einen vorläufigen Überblick über Dvořáks intellektuelle Biografie geben. Der Beitrag gliedert sich in zwei Teile. Vergleichsweise ausführlich behandelt werden im ersten Abschnitt die in bisherigen Studien nur kursorisch angedeuteten äußeren Daten der Biografie, soweit diese bisher erfasst werden können. Hier wird auch ansatzweise versucht, die in Dvořáks Schriften manifest werdende (kultur-)politische Haltung vor ihrem lebensweltlichen Horizont zu interpretieren. Der zweite Teil skizziert dann, gestützt auch auf frühere Arbeiten des Autors 5 , die wesentlichen Phasen der Entwicklung Dvořáks als Kunsthistoriker ${ }^{6}$. Auch hier können offene Fragen oft nur angeschnitten werden. Aus

3 Dagobert Frey, Max Dvořáks Stellung in der Kunstgeschichte, in: Jb. für Kunstgeschichte 1 (15) (1921/22) 1-21; Otto Benesch, Max Dvořák. Ein Versuch zur Geschichte der historischen Geisteswissenschaften, in: Repertorium für Kunstwissenschaft 44 (1924) 159-197.

4 Der Nachlass befindet sich im Archiv des Instituts für Kunstgeschichte der Universität Wien (= IKWA).

5 Folgende Arbeiten des Autors liegen vor: Dall’ „Impressionismo“ al „Manierismo espressionistico“: Tintoretto nel pensiero della Scuola Viennese di storia dell'arte (Max Dvořák), in: Jacopo Tintoretto nel quarto centenario della morte, hg. v. Paola Rossi, Lionello Puppi (Venezia 1996) 47-54; Max Dvořák, Tintoretto und die Moderne. Kunstgeschichte „vom Standpunkt unserer Kunstentwicklung“ betrachtet, in: Wiener Jb. für Kunstgeschichte 49 (1996) 9-39; Max Dvořák und die moderne Architektur. Bemerkungen zum Vortrag, Die letzte Renaissance' (1912), in: Wiener Jb. für Kunstgeschichte 50 (1997) 23-40; Max Dvořák über Oskar Kokoschka: eine handschriftliche Fassung des Vorworts zu,Variationen über ein Thema' (1920/21), in: Oskar Kokoschka - aktuelle Perspektiven, hg. v. Patrick Wer kner (Wien 1998) 34-40; Max Dvořák, in: Klassiker der Kunstgeschichte 1. Von Winckelmann bis Warburg, hg. v. Ulrich Pfisterer (München 2007) 214-226; Max Dvořák and the history of Medieval art, in: Journal of art historiography 2 (2010) : http://www.gla. ac.uk/media/media_152487_en.pdf; Max Dvořák und die Revision der Mittelalter-Kunstgeschichte, in: Die Etablierung und Entwicklung des Faches Kunstgeschichte in Deutschland, Polen und Mitteleuropa (Kraków 2010, im Druck). - Der Autor vorliegender Studie bereitet eine Gesamtdarstellung von Dvořáks intellektueller Biografie vor.

6 Folgende zusammenfassende Studien zu Dvořák seien hier genannt: Jaromír Neum an N, Das Werk Max 
pragmatischen Gründen ausgeklammert wird Dvořáks Tätigkeit in der Denkmalpflege, deren angemessene Würdigung den Rahmen der vorliegenden Arbeit sprengen würde ${ }^{7}$.

\section{BIOGR A F IE}

\section{I.I Raudnitz: Jugend auf Schloss Lobkowitz und frühe Prägung}

„Fährt man mit der Staatsbahn von Prag nach Dresden, kommt man an dem Raudnitzer Schlosse vorbei. Es ist ein großer imposanter Barockbau der zweiten Hälfte des 17. Jahrhunderts, dessen ruhige und etwas nüchterne Formen auf einen jener lombardischen Architekten aus der Schule Tibaldis hinweisen, die damals in ganz Mitteleuropa beschäftigt wurden. Das Schloss hat eine weit zurückreichende Vergangenheit. Es stand an der Stelle des jetzigen Baues früher schon ein anderes Schloss und vor diesem eine Burg, die wir bis in das I3. Jahrhundert zurückverfolgen können. Damals gehörte sie den Bischöfen, später Erzbischöfen von Prag, deren Sommerresidenz sie gewesen ist. [...] Ernst von Pardubitz, der Freund und Ratgeber Karls IV., hielt dort den [...] Nikolaus di Rienzi

Dvořáks und die Gegenwart, in: Acta historiae artium 8 (1962) 177-213; Sandor RADnót I, Die Historisierung des Kunstbegriffs: Max Dvořák, in: Acta historiae artium academiae scientiarum hungaricae 26 (1980) 125-142; Hans Berthold Busse, Kunst und Wissenschaft. Untersuchungen zur Ästhetik und Methodik der Kunstwissenschaften bei Riegl, Wölfflin und Dvorák (Mittenwald 1981) 85-108; Irmgard Емм в R Iсн, Max Dvořák und die Wiener Schule der Kunstgeschichte, in: Max Dvoř́́ K, Kunstgeschichte als Geistesgeschichte (Leipzig 1989) 311-359; Jan BAкоš, Die epistemologische Wende eines Kunsthistorikers, in: L'art et les révolutions, XXVII e congrès internationale d'histoire de l'art. Actes, 5 (Strasbourg 1992) 53-72; DERs, Max Dvořák: a neglected re-visionist, in: Wiener Schule. Erinnerung und Perspektiven (Wiener Jb. für Kunstgeschichte 53, 2004) 55-71; Mitchell Schwarzer, Cosmopolitan Difference in Max Dvorák's Art Historiography, in: Art Bulletin 74 (1992) 669-678; Norbert Sснмітz, Kunst und Wissenschaft im Zeichen der Moderne. Exemplarische Studien zum Verhältnis von klassischer Avantgarde und zeitgenössischer Kunstgeschichte in Deutschland (Alfter 1993) 255-324; Marie Benešová, Max Dvořák, in: La scuola viennese di storia dell'arte, hg. v. Marco Pozzet to (Gorizia 1996) 81-87; Riccardo MARchi, Max Dvořák e la storia dell'arte come parte della Geistesgeschichte, in: Max Dvoř ́́к, Idealismo e naturalismo nella scultura e nella pittura gotica (Milano 2003) 107-197; Matthew Rampley, Max Dvořák: art history and the crisis of modernity, in: Art history 26 (2003) 214-237; Edwin Lachnit, Die Wiener Schule der Kunstgeschichte und die Kunst ihrer Zeit. Zum Verhältnis von Methode und Forschungsgegenstand am Beginn der Moderne (Wien/ Köln/Weimar 2005) 91-98; vgl. auch: Fritz Fellner, Doris A. Cor Radini, Österreichische Geschichtswissenschaft im 20. Jahrhundert. Ein biographisch-bibliographisches Lexikon (VKGÖ 99, Wien 2006) $102 f$.

7 Eine umfassende kritische Darstellung Dvořáks als Denkmalpfleger bietet Sandro Scar rocchia, Denkmalpflege und Moderne: Die Lehre Max Dvořáks, in: Max Dvořá K, Schriften, Vorlesungen und Vorträge zur Denkmalpflege 1905-1921 (Drucklegung in Vorbereitung). Siehe die bereits erschienene italienische Ausgabe dieser Einleitung zur Dvořák-Edition: Sandro Scar rocchia, Max Dvořák: conservazione e moderno in Austria (1905-1921) (Milano 2009). Zu weiterer Literatur zu Dvořák als Denkmalpfleger vgl. Anm. 69. 
gefangen [...]."8 So beschreibt der am 24. Mai I 874 geborene Max Dvořák selbst den geschichtsträchtigen Ort, an dem er seine Kindheit und Jugend verbrachte: das auf einer Anhöhe über der Elbe errichtete Schloss in Raudnitz (Roudnice nad Labem) nördlich von Prag, das sich im I9. Jahrhundert noch immer im Besitz der mit der spätmittelalterlichen und frühneuzeitlichen Geschichte Böhmens und der Habsburger eng verbundenen Fürstenfamilie Lobkowitz befand.

Dvořáks Vater Max (I 843-I908) war - wie schon der Großvater Josef (I796-I874) in Raudnitz als fürstlicher Archivdirektor tätig und auch für die umfangreiche Bibliothek zuständig. Er hatte unter anderem über die Baugeschichte des Schlosses publiziert und Briefe Kaiser Leopolds I. an Wenzel Eusebius von Lobkowitz ediert ${ }^{9}$. Die eigene familiäre Herkunft muss den jungen Max also ebenso wie die Umgebung des Adelsschlosses, in dem er wie ein „Hausgenosse“ erzogen wurde ${ }^{10}$, schon früh für historische Traditionszusammenhänge und die Zeugnisse kultureller Überlieferung empfänglich gemacht haben. In Raudnitz begegnet er aber auch bereits Werken der bildenden Kunst: in der qualitätvollen fürstlichen Sammlung, die er später als Kunsthistoriker im Rahmen der Böhmischen Kunsttopografie erstmals wissenschaftlich katalogisiert ${ }^{11}$. Ihr Glanzstück war die aus dem Besitz Erzherzog Leopold Wilhelms stammende „Heuernte“ von Pieter Bruegel d. Ä., über den Dvořák Anfang I 920 einen seiner letzten Texte verfasst ${ }^{12}$.

Für die „Erkenntnis des allgemeinen Verlaufes der historischen Entwicklung“ besonders wertvoll nennt er in einem Aufsatz von 1907 die in Raudnitz befindlichen Porträts der Vorfahren des Dienstherrn seines Vaters, darunter eine überhaupt erst von Dvořák in ihrer Bedeutung erkannte Serie spanischer Bildnisse des I6. und I7. Jahrhunderts ${ }^{13}$. Über

8 Max Dvořá к, Spanische Bilder einer österreichischen Ahnengalerie (1907), in: DE rs., Gesammelte Aufsätze zur Kunstgeschichte (München 1929) $209 \mathrm{f}$.

9 Max Dvořák [d. Ä.], Geschichte des Raudnitzer Schloss-Baues 1652-1684 (Prag 1873); Ders., Maria Loretto am Hradschin zu Prag (Prag 1883); Ders., Briefe Kaiser Leopolds I. an Wenzel Eusebius, Herzog in Schlesien zu Sagan, Fürsten von Lobkowitz, 1657-1674 (Wien 1894).

10 Hugo Roкүта, Max Dvořák und seine Schule in den böhmischen Ländern, in: Österreichische Zs. für Kunst und Denkmalpflege 28/3 (1974) 82.

11 Max Dvořák, Bohumil Matějкa, Topographie der historischen und Kunst-Denkmale im Königreiche Böhmen von der Urzeit bis zum Anfange des XIX. Jahrhundertes 27. Der politische Bezirk Raudnitz II. Raudnitzer Schloss (Prag 1910), hier wird im Vorwort (unpag.) darauf verwiesen, dass die Arbeiten bereits 1900 begonnen worden waren (von Dvořák stammen die Abschnitte 1-11, 80-167, 168-210, 292-322, 323-327). Zuerst tschechisch erschienen als: Soupis památek historických a uměleckých v politickém okrese roudnickém, 2. Zámek roudnický (Praha 1907); 1939 bzw. 1948 enteignet und teilweise in der Prager Nationalgalerie ausgestellt, wurde die Lobkowitz'sche Sammlung inzwischen restituiert. Sie befindet sich heute auf Schloss Nelahozeves (Mühlhausen).

12 Max Dvoř́́к, Pieter Bruegel der Ältere (1920), in: Ders., Kunstgeschichte als Geistesgeschichte (wie Anm. 2) 217-257.

13 Dvořá , Spanische Bilder (wie Anm. 8) 225. Zum Rang dieser Porträtserie vgl. auch Franz WiCK- 
das genealogische Interesse hinaus sieht Dvořák diese „Ahnengalerie“ als „eine ununterbrochene historisch entstandene Reihe von Dokumenten [...], durch welche die Wandlungen des Kulturlebens des böhmischen Adels vom Anfang des XVI. Jahrhunderts bis in die Gegenwart illustriert werden“. Sie veranschaulicht für ihn den folgenreichen Wandel, den die „Hispanisierung der führenden Klassen“ Europas im I7. Jahrhundert, eine wesentliche Voraussetzung der Gegenreformation, bewirkt hatte ${ }^{14}$. Die Spanierin Polyxena von Lobkowitz, die I6I8 nach dem Prager Fenstersturz den kaiserlichen Statthaltern Zuflucht gewährt hatte, vertrete geradezu paradigmatisch diesen Prozess ${ }^{15}$. Ein solcher Schluss vom einzelnen Kunstwerk auf den großen historischen Zusammenhang ist für Dvořáks Denken insgesamt symptomatisch, auch wenn die hier noch wichtige konkrete historische Kontextualisierung in späteren Arbeiten - gerade auch den „geistesgeschichtlichen" - in den Hintergrund treten wird.

Aber nicht nur die neuzeitliche, auch die mittelalterliche Vergangenheit seiner Heimat regt Dvořáks wissenschaftliches Interesse an. In der Studie über „Die Illuminatoren des Johann von Neumarkt" (I902), mit der er sich habilitierte, ist das erste Kapitel den Handschriften des I 3. und I4. Jahrhunderts aus der ehemaligen Bibliothek des Raudnitzer Augustinerchorherrenklosters gewidmet, die seit der Säkularisation im Prager Nationalmuseum aufbewahrt werden ${ }^{16}$. Auch hier geht es Dvořák nicht um eine bloße Bestandsaufnahme, er sucht Argumente für seine - heute noch gültige - These, dass die Sonderstellung der böhmischen Malerei der zweiten Hälfte des I 4. Jahrhunderts durch die Beziehung nicht nur zu Frankreich, sondern vor allem auch zu Italien begründet sei. Die Eingangspforte italienischer Kunst in West- und Nordeuropa sei der päpstliche Hof in Avignon gewesen, dem Dvořák eine Schlüsselstellung zuweist ${ }^{17}$. Gerade das Augusti-

Hoff, Gutachten zu Dvořák anlässlich der Besetzung der Wiener Lehrkanzel nach dem Tod Alois Riegls (08.07.1905): Bei einer Inventarisierung der Kunstschätze im Schlosse Raudnitz hat er [Dvořák] über 40 bisher ganz unbekannte spanische Bilder entdeckt aus der Zeit Philipp II. und Philipp III., so dass dieses österreichische Schloss an Besitz an alten spanischen Bildern gleich neben der Gallerie von Madrid kommt. UAW, Phil. Fak., PA Julius von Schlosser.

14 Dvořá к, Spanische Bilder (wie Anm. 8) 211, 226.

15 Ebd. 225f; Polyxena, Tochter der aus spanischem Hochadel stammenden Maria Maximiliana Manrique de Lara y Mendoza, war in zweiter Ehe mit Zdenko Adalbert von Lobkowitz verheiratetet. Durch sie kam Raudnitz 1592 von den Rosenbergs in den Besitz der Lobkowitz.

16 Max Dvořá K, Die Illuminatoren des Johann von Neumarkt (1902), in: Ders., Gesammelte Aufsätze (wie Anm. 8) 74-207, hier v. a. 87-107. Schon zuvor war erschienen: Max Dvořá K, Knihovna Augustiniánského kláštera v Roudnici, in: Český časopis historický 6 (1900) 118-131.

17 Vgl. Franz Wiскноғғ, Commissionsbericht über das Habilitationsgesuch des Herrn Dr. Max Dvořák, 08.03.1902: Zum ersten Male wird in streng wissenschaftlicher Weise die Bedeutung des päpstlichen Hoflagers in Avignon für die Entwicklung der europäischen Kunst gezeigt, nachgewiesen, wie sich dort italienische und französische Kunst durchdringen und zu einem neuen Stile verbinden, und wie von dort aus weithin wirkende Anstösse zu einem naturalistischen Kunstschaffen ausgehen. UAW, Phil. Fak., PA Max Dvořák. Die Avignon-These stieß 


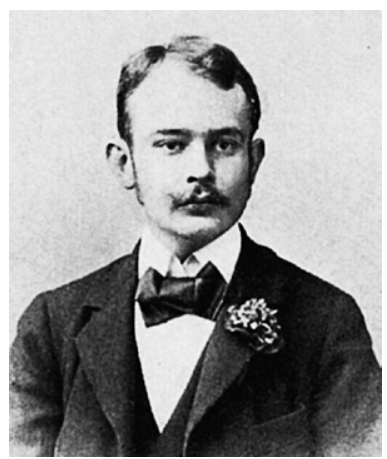

Abb. II: Max Dvoŕák I8g7 in Paris

nerkloster in seiner Geburtsstadt musste für ihn diese transnationale Beziehung nahelegen: Es war durch den Prager Bischof Johann IV. von Dražice nach dessen Rückkehr aus Avignon gegründet worden, einen Teil der Konventskirche und die Brücke über die Elbe errichtete der aus Avignon berufene Architekt Maître Jean, und aus Südfrankreich waren auch die meisten neuen Codices der Bibliothek importiert worden. „Durch den Welthandel mit Handschriften werden die Grenzen der provinziellen Entwicklung vollständig durchbrochen“"18: Raudnitz wird für den jungen Dvořák zum Symbol einer gesamteuropäischen Kunst des I4. Jahrhunderts, die sich nicht lokal abschottete, sondern durch überregionale Vernetzungen geprägt war. Der Gegenwartsbezug ist offenkundig: Dvořák transzendiert hier die über die nationale Physiognomie der böhmischen Kunst geführten Debatten zwischen tschechischen Historikern und etwa einem Deutschnationalen wie Josef Neuwirth, der damals an der deutschen Karl-Ferdinands-Universität in Prag Kunstgeschichte unterrichtete und den vermeintlich wesentlich deutschen Charakter der böhmischen Kunst unter Karl IV. betonte ${ }^{19}$. Eine mit Dvořáks Auffassung vergleichbare, die Zersplitterung der Monarchie in Nationalitäten überwindende Funktion der bildenden Künste erhoffte sich in diesen Jahren der österreichische Kultusminister Wilhelm Ritter von Hartel auch für die Gegenwart ${ }^{20}$.

\section{I.2 Von Prag nach Wien: ein Historiker wird Kunsthistoriker}

Max Dvořák sollte Nachfolger seines Vaters als fürstlicher Archivar und Bibliothekar werden $^{21}$. Nach der I 892 am Raudnitzer Gymnasium absolvierten Matura geht er daher nach Prag, wo er vier Semester an der tschechischen Karl-Ferdinands-Universität Geschichte

bald auf Kritik. Vgl. bereits Eugen DostáL, Čechy a Avignon. Př́spěvky ke vzniku českého umění iluminátorského v XIV. století, in: Časopis Matice moravské 46 (1922) 1-106. Dazu: Marta Filipová, The Construction of National Identity in the Historiography of Czech Art (Ph. D., University of Glasgow, 2008) 196 (http://theses.gla.ac.uk/791/01/2009Filipovaphd.pdf [22. 1. 2010]).

18 Dvoř́́ K, Illuminatoren (wie Anm. 16) 76.

19 Josef Neuwirth, Forschungen zur Kunstgeschichte Böhmens 1-3 (Prag 1896). Zu Dvořáks Reaktion auf Neuwirth siehe Filipová, Historiography (wie Anm. 17) 181-185.

20 Vgl. Carl Schorske, Die Fakultätsbilder von Gustav Klimt und die Krise des liberalen Ich, in: Gustav Klimt. Der Beethoven-Fries und die Kontroverse um die Freiheit der Kunst, hg. v. Stephan Koja (München 2006) 13-26.

21 Karl Maria Swовода, Vortrag zum 30. Todestag von Max Dvořák. Gehalten an der Universität Wien, in: Österreichische Zs. für Kunst und Denkmalpflege 28/3 (1974) 74. 
bei Jaroslav Goll, dem Vertreter einer strengen historisch-kritischen Methode, sowie bei Josef Emler und Antonín Rezek belegt. In dieser Zeit entwickeln sich Freundschaften zu seinen Kommilitonen Josef Pekař und Josef Šusta ${ }^{22}$. Dvořák bewegen in Prag starke Zweifel an der Richtigkeit seiner Studienwahl. Er liest begeistert Nietzsche und interessiert sich für die zeitgenössische französische und skandinavische Literatur und Kunst ${ }^{23}$. Auf Anraten Golls wechselt er I 894 nach Wien und besucht - im Übrigen gemeinsam mit seinem Landsmann und nachmals bedeutenden Historiker Gustav Friedrich - 1895-1 897 den 2I. Ausbildungskurs des IÖG, dessen ordentliches Mitglied er wird und für das er I 896 auch eine Forschungsreise nach Böhmen unternimmt ${ }^{24}$. Am 3 I. März I 897 promoviert er in Wien, im selben Jahr besteht er am IÖG die Staatsprüfung ${ }^{25}$.

Die Wiener Studienjahre bedeuten für Dvořák dennoch die endgültige Wendung von der Geschichtswissenschaft zur Kunstgeschichte. Auf der einen Seite veröffentlicht er mehrere quellenkritische Studien zur böhmischen Landesgeschichte, die vor allem im von Goll und Rezek begründeten „Český časopis historický“ (Tschechische Historische Zeitschrift) erscheinen ${ }^{26}$. Auch das Thema der unveröffentlicht gebliebenen Dissertation sind „Quellenuntersuchungen zu Cosmas von Prag“"27, über ihn, den Verfasser der mittelalterlichen „Chronica Boemorum“, publiziert er I 899 und I 90 I tschechisch verfasste Beiträge $^{28}$. I 90 I erscheint dann in den MIÖG ein Artikel über die Urkundenfälschungen Kaspar Schlicks (um I 395/77-I 449), dem Reichskanzler Kaiser Sigismunds ${ }^{29}$ - eine, wie Engelbert Mühlbacher, der Direktor des Instituts, urteilt, Musterarbeit auf dem Gebiete der Diplomatik, in der sich der Verfasser durch eine sichere Methode in der Behandlung der Originale auszeichnet. Scharfsinnig hat er die im Auftrag des Kanzlers angefertigten Fälschungen

22 Max Dvořá к, Listy o životě a umění. Dopisy Jaroslavu Gollovi, Josefu Pekařovi a Josefu Šustovi, hg. v. Jaromír Pečírka (Praha 1943). In seinen Erinnerungen gedachte Šusta auch Dvořák, vgl. Josef Šusta, Mladá léta učňovská a vandrovní. Praha - Vídeň - Řím. Vzpomínky II (Praha 1963); Zur Prager Zeit: Rокута, Dvořák (wie Anm. 10) 84.

23 Swoboda, Vortrag (wie Anm. 21) 76.

24 Vgl. Wickнoff, Commissionsbericht, 08.03.1902 (wie Anm. 17); Leo Santifaller, Das Institut für österreichische Geschichtsforschung. Festgabe zur Feier des zweihundertjährigen Bestandes des Wien Haus-, Hof- und Staatsarchivs (Veröff. des IÖG 11, Wien 1950) 119; Lнот ку, Geschichte des Instituts (wie Anm. 1) 245 und 271f. Auch Dvořáks Freund Šusta hatte 1893-1895 den Ausbildungskurs in Wien besucht, vgl. ebd. 269.

25 Vgl. UAW, Phil. Fak., PA Max Dvořák.

26 Vgl. Bibliographie der Schriften Max Dvořáks, in: Dvoř ́́ , Aufsätze (wie Anm. 8) 371-373.

27 Vgl. Max Dvořák, Curriculum vitae, 02.11.1901. UAW, Phil. Fak., PA Max Dvořák; Benesch, Dvořák (wie Anm. 3) 160. Benesch gibt irrtümlich „Urkundenfälschungen des Reichskanzlers Schlick“ als Thema der Dissertation an.

$28 \mathrm{Vgl}$. Anm. 26.

29 Max Dvořák, Die Fälschungen des Reichskanzlers Kaspar Schlick, in: MIÖG 22 (1901) 51-107. Laut Dvořá к, Curriculum vitae (wie Anm. 27), verfasste er den Aufsatz 1898. 


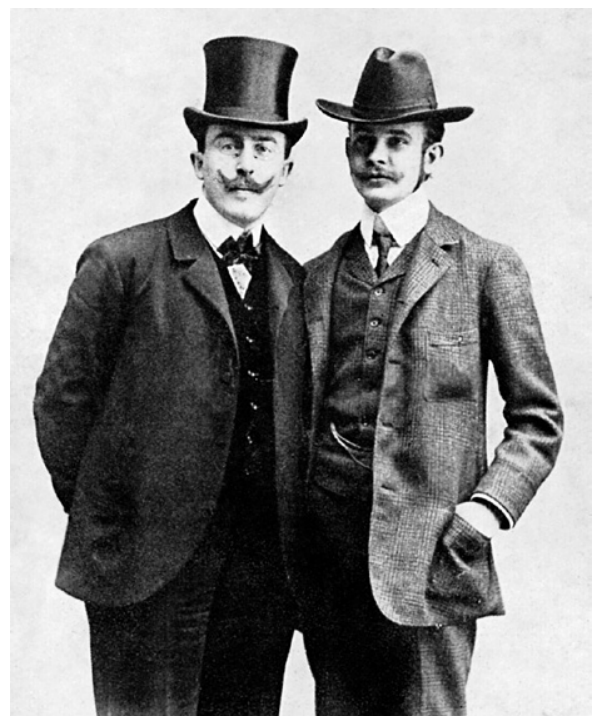

Abb. I2: Die jungen Herren Historiker Josef Šusta und Max Dvoŕák Igoo in Wien nachgewiesen und ibre Entstehung und ihre Wirkung aus der allgemeinen politischen Lage erklärt ${ }^{30}$.

Diese erste deutschsprachige Publikation Dvořáks sollte jedoch gleichzeitig seine letzte als Historiker sein. Während der Institutsjahre entschloss sich der Gefertigte, sich ganz der Kunstgeschichte zu widmen, berichtet er selbst in einem Lebenslauf ${ }^{31}$. Bei dem dreijährigen Kurs des IÖG, zu dessen Lehrprogramm seit der Neuordnung durch Theodor von Sickel (I 874) auch Kunstgeschichte zählte, hört er Franz Wickhoff ${ }^{32}$ sowie Alois Riegl ${ }^{33}$. Als Student betreut Dvořák die Fotosammlung des „Kunsthistorischen Apparats“, der sich im neuen Universitätsgebäude an der Ringstraße im Geschoss über den Räumlichkeiten des IÖG befand ${ }^{34}$. Schon I 896 verfasst er eine begeisterte Zeitungsrezension über Wickhoffs ein Jahr zuvor erschienenes Hauptwerk „Die Wiener Genesis“, deren Neubewertung der antiken römischen Kunst als Vorläufer des modernen Illusionismus er „das Bedeutendste“ nennt, „was seit Jahren in der Kunstgeschichte geschrieben wurde“ ${ }^{35}$. Anfang I 898 wird Dvořák Assistent Wickhoffs ${ }^{36}$, und sein Lehrer wird sein väterlicher Freund werden. In diesen Jahren verlagert sich Dvořáks Forschungsschwerpunkt, gefördert durch Reisestipendien nach Paris (Herbst und Winter I 897/98), Südfrankreich (I 899) und Rom (drei Monate I900 und zwei Monate I90I) ${ }^{37}$, auf die Geschichte der mittelalterlichen Buchmalerei, vor allem des I4. Jahrhunderts. Er folgt damit Wickhoffs Bemühungen um eine Gesamtinventarisierung des Denkmälerbestands, die schließlich in dem I905 in Angriff genommenen „Beschreibende[n] Verzeichnis der

30 Vgl. Wiскноғғ, Commissionsbericht, 08.03.1902 (wie Anm. 17).

31 Dvořá к, Curriculum vitae (wie Anm. 27).

32 Seit 1885 ao. Professor, seit 1891 o. Professor für Kunstgeschichte.

33 Seit 1894 ao., seit 1897 o. Professor für Kunstgeschichte.

34 Rокүта, Dvořák (wie Anm. 10) 85.

35 D. [= Max Dvořák], Ein bahnbrechendes Buch, in: Politik 35, Nr. 311 (11.11.1896) 1f.

36 Vgl. UAW, Phil. Fak., PA Max Dvořák.

37 Dvoř́n, Curriculum vitae (wie Anm. 27). 
illuminierten Handschriften in Österreich“ ${ }^{\text {realisiert wird }}{ }^{38}$. Schon die Hausarbeit für das IÖG ist diesem Themenbereich entnommen: „Miniaturen des Evangeliars des Johann von Troppau in der Wiener Hofbibliothek“39. Dvořák publiziert I 900 den Aufsatz „Byzantinischer Einfluss auf die Miniaturmalerei im Trecento" 40 , I90 I dann die schon erwähnte Habilitationsschrift „Die Illuminatoren des Johann von Neumarkt“, welche die Fragestellung der Institutsarbeit aufgreift ${ }^{41}$. In der Folge arbeitet er nur noch über fachspezifisch kunsthistorische Themen; das gilt auch für seine allerdings immer seltener werdenden tschechisch geschriebenen Beiträge ${ }^{42}$. Ab I905 veröffentlicht er nur noch auf Deutsch.

\section{I.3 Wien: Universitätslehre und Denkmalpflege in der Nachfolge Alois Riegls und Franz Wickhoffs}

Dvořáks Position als in Wien habilitierter Tscheche erschwert anfangs seine akademische Laufbahn. I904 wird er einerseits als neuer Professor an der tschechischen Universität Prag mit dem Argument nicht in Erwägung gezogen, dass er vorwiegend in Wien tätig sei ${ }^{43}$. Als er nach Riegls Tod 1905 in Wien zum außerordentlichen Professor berufen wird ${ }^{44}$, führt dies andererseits zu Protesten deutschnationaler Studenten und zu kritischen Zeitungsberichten (eine unrühmliche Rolle spielt dabei offenbar der schon erwähnte, aus Prag kommende Josef Neuwirth, seit I 899 Kunstgeschichte-Professor an der Wiener Technischen Hochschule $\left.{ }^{45}\right)$. Wickhoff hält jedoch zu Dvořák und ist demonstrativ bei dessen Antrittsvorlesung im Hörsaal des IÖG anwesend ${ }^{46}$. I905 übernimmt Dvořák (ebenfalls als Nachfolger Riegls) die Funktion des Generalkonservators in der k. k. Zentralkommission für Erforschung und Erhaltung der Kunst- und historischen Denkmale (ab I9I I/I 3: Staats-

38 Vgl. Wicк ноғf, Gutachten zu Dvořák, 08.07 .1905 (wie Anm. 13): [...] für das von mir initiierte Verzeichnis der Miniaturhandschriften in Österreich hat er [Dvořák] zwei Bände der Miniaturen im Königreiche Böhmen fast vollendet, zwei Foliobände deren Veröffentlichung leider wegen Geldmangels noch hinausgeschoben werden musste.

39 Dvoř́n, Curriculum vitae (wie Anm. 27).

40 In: MIÖG Erg.-Bd. 6, 1901 792-820. Von Benesch, Dvořák (wie Anm. 3) 161, irrtümlich als Institutshausarbeit bezeichnet.

41 Vgl. Dvoř Áк, Illuminatoren (wie Anm. 16) 78 Anm. 1: Der Aufsatz entstand im Zusammenhang mit den unter Wickhoffs Leitung durchgeführten Arbeiten „zum Zwecke einer kunsthistorischen Katalogisierung sämtlicher Miniaturhandschriften in österreichischen Bibliotheken“.

42 Vgl. Filipová, Historiography (wie Anm. 17) 181-185.

43 Klement Benda, Rozmach oboru. Zitiert nach: Filipová, Historiography (wie Anm. 17) 191. Die Professur bekam Bohumil Matějka.

44 Sein Dienstverhältnis begann am 01.10.1905. Vgl. UAW, Phil. Fak., PA Max Dvořák.

45 Vgl. den Brief Dvořáks an Josef Šusta vom 09.07.1905, in: Dvořák, Listy (wie Anm. 22) 150. Dazu Filipová, Historiography (wie Anm. 17) 182 und 191.

46 Roкyта, Dvořák (wie Anm. 10) $86 f$ (nach dem Nachruf von Matějček vom 19.02.1921) 89 (nach dem Augenzeugenbericht Jaroslav Helferts). 
denkmalamt), dem er sich, im engen Kontakt zum österreichischen Thronfolger Erzherzog Franz Ferdinand, ab ı 9 го Protektor der Zentralkommission, in den folgenden Jahren mit großer Intensität widmet. I 909 erhält Dvořàk schließlich auf Empfehlung von Heinrich Wölfflin einen Ruf an die Universität Basel, den er aber abschlägt ${ }^{47}$.

In eine Zeit persönlicher Schicksalsschläge - ein Jahr zuvor waren Dvořáks Frau Gisela und seine Schwester Marie gestorben ${ }^{48}$ - fallen die Querelen um die Nachfolge des am 6. April 1909 gestorbenen Wickhoff ${ }^{49}$. Die Fakultätskommission hatte sich mit überwiegender Mehrheit dem Bericht des Historikers Emil von Ottenthal angeschlossen, der für das frei gewordene Ordinariat als Ersten den etwas älteren Julius von Schlosser und als Zweiten Dvořàk vorschlug 50 (dabei war während der Beratungen betont worden, dass die nationale Stellung Dvořaks [...] für die Fakultät kein Bedenken mit sich bringe $\left.{ }^{51}\right)$. Da Schlosser schon I 90 I abgelehnt hatte, die Arbeit am Kunsthistorischen Museum zugunsten der Universität aufzugeben, sollte diesmal wohl Dvořák zum Zug kommen. In der Abstimmung der Philosophischen Fakultät am 3. Juli I 909 wird dann allerdings der v. a. von den Naturwissenschaftlern favorisierte Josef Strzygowski, damals Professor in Graz, gewählt ${ }^{52}$. Strzygowski war ein deklarierter Gegner der spezifischen Wiener kunsthistorischen Tradition. In „Orient oder Rom“ (I90I) lehnte er das in Wickhoffs „Wiener Genesis“ entwickelte Modell einer inneren Selbstverwandlung der antik-römischen zur spätantiken Kunst vehement ab und erklärte dagegen den Übergang zum Mittelalter als die Folge einer Überwältigung der antiken Mittelmeerkultur durch aus dem „Orient“ kommende Kräfte ${ }^{53}$. In späteren Texten zielt seine Polemik auch gegen Riegls ebenfalls I90 I erschienene „Spätrömische Kunstindustrie“ 54 . Dvořák war schon 1902 in einer scharfen, wenn auch sachlich bleiben-

47 Vgl. Bericht der Kommission zur Wiederbesetzung der durch den Tod Hofr. Wickhoffs erledigten Lehrkanzel für Kunstgeschichte, 03.07.1909. UAW, Phil. Fak., PA Josef Strzygowski.

48 15.05.1908 Tod der Schwester Marie an Tuberkulose; 27.11.1908 Tod seiner Frau Gisela an den Folgen der Geburt der zweiten, nach ihr benannten Tochter Gisela. Vgl. eine Brief an Gustav Glück: [...] ich lebte in der letzten Zeit in einem solchen Wirbelsturm der traurigsten Ereignisse, dass mir jetzt noch alles wie ein böser Traum erscheint. Siehe Briefe von Franz Wickhoff und Max Dvořák an Gustav Glück, in: FS Karl M. Swoboda zum 26. Jänner 1959 (Wien 1959) $124 \mathrm{f}$.

49 Vgl. dazu auch: Höflechner, Etablierung (wie Anm. 1) 49-51.

50 Bericht der Kommission, 03.07.1909 (wie Anm. 47).

51 Bericht der Sitzung der Fakultätskommision zur Besetzung der Lehrkanzel für Kunstgeschichte nach Hofrat Wickhoff, 16.06.1909. UAW, Phil. Fak., PA Strzygowski.

52 Für Strzygowski stimmten 25 von 48 Anwesenden (da sich die Sitzung bis in die späten Abendstunden gezogen hatte, war bei der erst um 23 Uhr stattfindenden Abstimmung nur mehr ein Teil der Fakultätsmitglieder anwesend), für den Kommissionsvorschlag pro Schlosser bzw. Dvořák nur 19. Vgl. Bericht des Dekans an das Ministerium, 12.07.1909. UAW, Phil. Fak., PA Josef Strzygowski.

53 Josef Strzygowski, Orient oder Rom. Beiträge zur Geschichte der spätmittelalterlichen und frühchristlichen Kunst (Leipzig 1901).

54 Josef Strzygowski, Rezension zu Riegl, Spätrömische Kunstindustrie, in: Byzantinische Zs. 11 (1902) 263- 
den Rezension von „Orient oder Rom“ als Verteidiger der Wiener Position aufgetreten ${ }^{55}$.

Die Interessen der mit der Kunstgeschichte institutionell eng verbundenen Historiker konnten 1909 allerdings offenbar nicht negiert werden. Ottenthal, Emil Reisch, Alfons Dopsch und der Philologe Hans von Arnim unterzeichnen ein Minoritätsvotum gegen Strzygowski, dem vor allem methodische Fahrlässigkeit vorgehalten wird ${ }^{56}$. Sie plädieren für die Fortführung der von Thausing, Wickhoff, Riegl seit drei Jahrzehnten mühsam aufgerichteten Grundlagen streng wissenschaftlicher Führung des kunstgeschichtlichen Unterrichts ${ }^{57}$. In

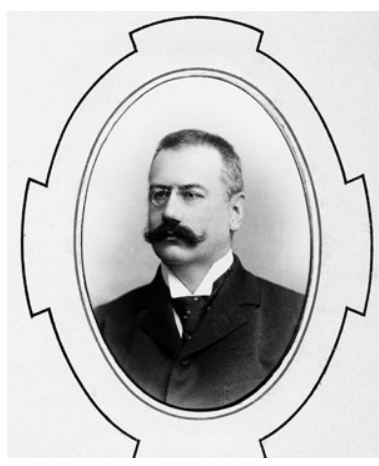

Abb. 13: Franz Wickhoff diesem Zusammenhang wird ausdrücklich die so ausgezeichnet erprobte Tradition der Wiener kunstgeschichtlichen Schule angesprochen, die von Strzygowski gewaltsam zerrissen würde ${ }^{58}$ - soweit ich sehe, eines der frühesten bekannten Zeugnisse für den später v. a. durch Schlosser kanonisierten Begriff der „Wiener Schule“59. Der am 7. Juli 1909 ausgesprochenen Empfehlung der Fakultät, in Würdigung der im Bericht der Kommissionsmajorität angeführten, die Bedürfnisse des Instituts für österreichische Geschichtsforschung betreffenden Momente auch Dvořák zum ordentlichen Professor zu ernennen (Schlosser hatte sich inzwischen zurückgezogen $)^{60}$, wird vom Ministerium schließlich stattgegeben.

266; DERs., Altchristliche Kunst, in: Religion in Geschichte und Gegenwart (1908) 381-397; DErs., Antike, Islam und Occident, in: Neue Jahrbücher 23 (1909) 354-372. Zu der Kontroverse vgl. Jas Elsner, The Birth of Late Antiquity: Riegl and Strzygowski in 1901 in: Art History 25 (2002) 358-379; Carola JäGGI, „Ex oriente lux“. Josef Strzygowski und die „Orient oder Rom“-Debatte um 1900, in: Semra ÖGEL, Gregor WEDEKIND, Okzident und Orient (Istanbul 2002) 91-111.

55 Erschienen in: Göttingische gelehrte Anzeigen 164/2 (1902) 693-711.

56 Vgl. Minoritätsvotum gegen die Berufung Josef Strzygowskis vom 06.07.1909: [...] dass Strzygowski es vielfach versäumt, die Einzeltatsachen kritisch festzustellen, dass er häufig willkürliche Combinationen nachhängt, ohne den widersprechenden Tatsachen gerecht zu werden. [...] Er zeige eine auffallige Unsicherheit in der stilistischen Beurteilung und Scheidung der Bildwerke. Über Ähnlichkeit der Motive übersieht Strzygowski vollständig die Verschiedenheit des individuellen Stilcharakters. Nur so sind seine Theorien über orientalische Herkunft des romanischen Stils und über das Auftauchen altägyptischer Einflüsse in spätrömischen Bildwerken erklärlich. Generell kritisiert wird die Art, wie Strzygowski luftige Hypothesen übereinandertürmt [...], sowie dieser schlecht gezügelte Hang, auf unsicheren Grundlagen Hypothesen aufzubauen. UAW, Phil. Fak., PA Julius von Schlosser.

57 Minoritätsvotum (wie Anm. 56).

58 Ebd.

59 Filı pová, Historiography (wie Anm. 17) I 7 I, zitiert die Verwendung des Begriffs in einem von Vincenz Kramář verfassten Nachruf auf Wickhoff von 1909, verweist aber gleichzeitig darauf, dass Kramár schon 1905, und zwar in Bezug auf Dvořák, von „Wiener Schule“ gesprochen hatte.

$60 \mathrm{Vgl}$. Bericht des Dekans an das Ministerium, 12.07.1909. UAW, Phil. Fak., PA Julius von Schlosser. Die Empfehlung wurde von der Fakultät mit 32 von 49 Stimmen ausgesprochen, bei 13 Gegenstimmen und 4 Enthaltungen. 
Ab Oktober 1909 sind also Dvořák, der als Garant der Tradition der Wiener Schule der Kunstgeschichte berufen worden war, und Strzygowski, der streitbare Gegner ebendieser Tradition, Kollegen an derselben Universität. Dieser Antagonismus wird die Geschichte der Wiener Kunstgeschichte über den Tod Dvořáks hinaus, bis zur Emeritierung Strzygowskis 1934, bestimmen. Strzygowski betreibt sofort nach der Berufung die Unabhängigkeit seiner Lehrkanzel ${ }^{61}$, die als „I. Kunsthistorisches Institut“ bezeichnet wird, für das I9 I I eine eigene Wohnung gegenüber der Universität angemietet wird (Wien I, Franzensring I 2; 922 übersiedelt das Institut nach Wien 9, Hörlgasse 6). Dvořáks „Kunsthistorischer Lehrapparat“, Teil des IÖG, verbleibt in den Räumlichkeiten im Hauptgebäude am Ring. Die Aufteilung der Geldmittel und Bücherankäufe sowie die Abgrenzung der Arbeitsfelder der beiden Lehrkanzeln sind auch weiterhin ständiger Konfliktstoff, etwa als Strzygowski I9I 2 (letztlich ohne Erfolg) die Gründung eines eigenen Auslandsinstitutes für kunstgeschichtliche Forschungen auf dem Balkan, in Osteuropa und in ganz Asien vorschlägt und damit auch die Kompetenzen neu ordnen möchte ${ }^{62}$.

Trotz solcher interner Streitigkeiten und neben seinen Verpflichtungen in der akademischen Lehre engagiert sich Dvořák mit großem Einsatz auch in der Organisation langfristig angelegter wissenschaftlicher Projekte. Er redigiert ab I9 I o das Rezensionsorgan „Kunstgeschichtliche Anzeigen“ und führt die von Wickhoff initiierte Katalogisierung der illuminierten Handschriften in Österreich weiter ${ }^{63}$. Er wird Mitarbeiter bei den vom Deutschen Verein für Kunstwissenschaft geplanten „Monumenta artis Germaniae“. Dazu kommen seine umfassenden Aufgaben als Generalkonservator der Denkmalpflege-Zentralkommission. In dieser Funktion unternimmt er in den Ferienmonaten zahlreiche Reisen in die österreichischen Kronländer. In dem von ihm schon 1907 begründeten „Kunstgeschichtlichen Jahrbuch“ der Zentralkommission erscheinen seine Kommentare zu von ihm begutachteten Restaurierungsprojekten wie der Prager Burg, dem Wawel in Krakau (Kraków), dem Dom von Aquileja (Aquileia) oder dem Diokletianspalast in Split ${ }^{64}$. 1907 begründet er auch die „Österreichische

61 Vgl. etwa: Regulativ für die Benützung der Sammlungen bei den beiden Lehrkanzeln für Kunstgeschichte an der k.k. Universität in Wien (1911). UAW, Phil. Fak, PA Julius von Schlosser. Vgl. dazu allgemein HöF LECHNER, Etablierung (wie Anm. 1) 51-53.

62 Vgl. UAW, Phil. Fak. Akt 782 aus 1911/12 (in: PA Josef Strzygowski); UAW, Phil. Fak. 311 (Prof.Coll. Sitzungsprotokolle 1908/09-1912/13): Sitzungen vom 11.05. und 15.07.1912, 18.01. und 09.11.1913.

63 Beschreibendes Verzeichnis der illuminierten Handschriften in Österrreich 1-3, hg. v. Franz WICKHOF F (Leipzig 1905-1907), Bände 6-7, fortgeführt von Max Dvoř Á (Leipzig 1911-1917). Siehe auch Lнотsку, Geschichte des Instituts (wie Anm. 1) 310 und 341.

64 Vgl. Max Dvořák, Restaurierungsfragen, I. Die Prager Königsburg, in: Kunstgeschichtliches Jb. der k. k. Zentralkommission 2 (1908) Beibl., Sp. 1-8; Restaurierungsfragen, II. Das Königsschloss am Wawel, ebd. Sp. 105-112; Die Mosaikenfunde von Aquileja, ebd. 3 (1909) Beibl., Sp. 97f; Restaurierungsfragen, 3. Spalato, ebd. Sp. 117-142; Die Restaurierung des königlichen Schlosses auf dem Wawel in Krakau, ebd. 8 (1909) Sp. 
Kunsttopographie“65. Diese Hinweise müssen genügen: Im Rahmen der vorliegenden Darstellung kann, wie gesagt, Dvořáks praktische Tätigkeit in der staatlichen Denkmalpflege ebenso wenig näher beleuchtet werden wie seine diesbezüglichen theoretischen Reflexionen, die er unter anderem in den Aufsätzen „Francesco Borromini als Restaurator“ (1907) ${ }^{66}$ und „Denkmalkultus und Kunstentwicklung“ (1910) ${ }^{67}$ sowie im populären „Katechismus der Denkmalpflege“68 entwickelte ${ }^{69}$. In den Jahren von I 909 bis zu seinem Tod nimmt Dvořák jedenfalls seine doppelte Verantwortung als Universitätsprofessor und als leitender Funktionär der Denkmalpflege mit höchstem Engagement wahr und geht dabei offenbar an die Grenzen seiner Belastbarkeit.

\section{I.4 Erster Weltkrieg und Ende der Monarchie: Dvoŕáks letzte Jahre}

Das Ende der Habsburgermonarchie i 9 I 8 zwingt Dvořák, den in Wien lehrenden Tschechen, zu einer schwierigen Entscheidung. Er hatte sich einerseits immer zu seiner tschechischen Nationalität bekannt und behielt die tschechische Schreibweise seines Namens bei, den er also nicht - wie viele andere Zugezogene - eindeutschte. Andererseits vertrat er eine antinationalistische und habsburgfreundliche Einstellung. In einer während des Ersten Weltkriegs verfassten Notiz bezeichnet er als dessen eigentliche[n] Grund den nationalen Egoismus und dessen Folge, den Imperialismus, und er bekennt sich gegen nationale Intoleranz. Aus der historischen Distanz könne man in der historischen Entwicklung der

261-277; Der Diokletianische Palast in Spalato, ebd. Sp. 520-538; Die neuaufgedeckten Mosaiken in der Basilika zu Aquileja, ebd. Sp. 575-581.

65 Österreichische Kunsttopographie 1-17, red. v. Max Dvoř́́ (Wien 1907-1918).

66 In: Kunstgeschichtliches Jb. der k.k. Zentralkommission 1 (1907) 13-28. Wieder abgedruckt in: DvoŘá K, Gesammelte Aufsätze (wie Anm. 8) 250-270.

67 In: Kunstgeschichtliches Jb. der k.k. Zentralkommission 4 (1910). Wieder abgedruckt in: DvořÁ K, Gesammelte Aufsätze (wie Anm. 8) 271-278.

68 Wien 1916.

69 Neben der in Anm. 7 genannten Arbeit von Sandro Scarrocchia vgl. auch: Walter Frodu, Max Dvořáks „Katechismus der Denkmalpflege“, in: Österreichische Zs. für Kunst und Denkmalpflege 28 (1974) 90-105; Eva Frodl-Kraft, Die österreichische Kunsttopographie. Betrachtungen sub specie fondatoris, ebd. 114-130; Geza Hajós, Riegls Gedankengut in Dvořáks Einleitung zur österreichischen Kunsttopographie, ebd. 138143; Herta Ku ben, Max Dvořák als Denkmalpfleger in der Nachfolge Alois Riegls. Ein Beitrag über Inhalt, Aufgaben, Ziele und Probleme österreichischer Denkmalforschung und Denkmalpflege am Beginn des 20. Jahrhunderts (unpubliz. Magisterarbeit, Universität Wien, 1993); Theodor BrücKLER, Ulrike Nimeth, Personenlexikon zur Österreichischen Denkmalpflege (Wien 2001) 54-55 (Artikel „Max Dvořák); Theodor BrüCKLER, Thronfolger Franz Ferdinand als Denkmalpfleger. Die „Kunstakten“ der Militärkanzlei im Österreichischen Staatsarchiv (Kriegsarchiv) (Wien 2009); Andreas Lenne, Georg Dehio, Alois Riegl, Max Dvořák: a threshold in theory development, in: Conservation and preservation. Interactions between theory and practice, hg. v. Michael S. FALSER, Wilfried Lipp, Andrzej Tomaszewski (Florenz 2010) 69-80. 
Künste nur schwer nationale Eigenarten erkennen, es sei das zeitlich Gemeinsame größer als das national Trennende. ${ }^{70}$ Schon in seinen frühen Arbeiten zur Kunst des I4. Jahrhunderts hatte Dvořák ja, wie erwähnt, besonders die überregionalen Beziehungen betont. Wenn er I9I5-I7, mitten im Krieg, in dem Aufsatz „Idealismus und Naturalismus in der gotischen Malerei und Skulptur"71 mit großer Emphase das von christlichem Universalismus geprägte mittelalterliche Europa beschreibt, in dem Idee und Realität versöhnt gewesen seien, so kann man diese rückwärtsgewandte Utopie als Dvořáks persönliches konservatives Gegenbild zur Katastrophe der Gegenwart lesen.

Eine in ihrer Ambivalenz schwer aufzulösende Haltung zeigt Dvořáks Beitrag zu dem I9I6 vom Kriegshilfsbüro des k.k. Ministeriums des Innern herausgegebenen „Kriegsalmanach“72. Auf der einen Seite frappiert die Wahl ausgerechnet von Goyas „Desastres de la guerra“ als Thema für dieses „auf den Weihnachtstisch der opferfreudige[n] Bevölkerung "73 gelegte Buch. Bewusst scheint Dvořák also jeglichen pseudopatriotischen Ton zu verweigern. Goyas schonungslose Grafiken (die allerdings im Almanach nicht abgebildet werden ${ }^{74}$ ) bedeuten, wie Dvořák ausführt, keine Siege verherrlichende „Kriegsapotheosen“, sondern geben „ein Bild des Krieges, wie es schauriger kaum denkbar ist [...], eine Paraphrase der Erschütterung [...], welche die Schatten des Krieges in einer fühlenden Seele hervorgerufen und mit der sich [...] in leidenschaftlichen Protesten heiße Wünsche nach einer neuen besseren Menschheit verbunden haben. " 75 Auf der anderen Seite spricht schon die Mitwirkung bei diesem offiziösen Projekt für Dvořáks Nähe zu staatlichen Institutionen. Vor allem aber vertritt Dvořák in dem - I928 von den Herausgebern der „Gesammelten Aufsätze“ bezeichnenderweise unterschlagenen und deshalb bisher unberücksichtigt gebliebenen - Schlussabschnitt des Textes sehr wohl eine militante Österreich-Ideologie, die er auf forcierte Weise mit seinen persönlichen Überzeugungen verbindet. In der kriegerischen Auseinandersetzung zwischen den Mittelmächten und den europäischen „Peripheriemächten“ sieht er nämlich genau jenen ewigen Gegensatz

70 Max Dvořá , Kunst und Nationalismus (Fragment), IKWA.

71 Max Dvořá к, Idealismus und Naturalismus in der gotischen Skulptur und Malerei, in: Ders., Kunstgeschichte als Geistesgeschichte (wie Anm. 2) 41-148 (zuerst in: HZ 23 [1918] 1-62, 185-246).

72 Max Dvořák, Eine illustrierte Kriegschronik vor hundert Jahren oder der Krieg und die Kunst, in: Kriegsalmanach 1914-1916, hg. v. Karl Kов ALD (Wien 1916) 40-51. Wieder abgedruckt (ohne die letzten Absätze) in: Dvořák, Gesammelte Aufsätze (wie Anm. 8) 242-249. Zu dem „Almanach“ vgl. Eberhard SAuerManN, Literarische Kriegsfürsorge. Österreichische Dichter und Publizisten im Ersten Weltkrieg (Wien/Köln/ Weimar 2000) 127-131.

73 Kriegsalmanach 1914-1916 (wie Anm. 73), Vorwort des Leiters des Kriegshilfsbüros Eduard Prinz von und zu Liechtenstein.

74 Der gesamte Almanach ist ausschließlich mit Bildnissen der kaiserlichen Familie und offiziellen Postkarten für das Rote Kreuz, das Kriegshilfsbüro und das Fürsorgeamt illustriert.

75 Dvoř ́́, Gesammelte Aufsätze (wie Anm. 8) 242, 244, 249. 
zwischen Geist und Materie am Werk, den er mit fast denselben Worten in seinen „geistesgeschichtlichen "Spätschriften als Motor der Kunstgeschichte begreift. Nur projiziert Dvořák im „Kriegsalmanach“ seinen emphatischen Spiritualismus nicht auf das christliche Mittelalter oder visionär-expressive Künstler wie El Greco oder Tintoretto, sondern auf das kriegführende Österreich-Ungarn. Seit Beginn des Weltkriegs ging es, so Dvořák, nicht nur um Politik und Wirtschaft, „sondern nicht minder um ein Ringen einer älteren und einer neueren Geisteswelt: dem liberal-individualistischen Materialismus trat ein sozial-ethischer Imperativ, dem naturwissenschaftlichen Positivismus ein geschichtsphilosophischer Idealismus entgegen und wer tiefer blickte, konnte nicht zweifeln, welcher von diesen beiden Welten der Sieg von Anfang an beschieden war" ${ }^{\text {"76. }}$.

Nach Kriegsende erhält Dvořák die Staatsbürgerschaft der neuen Republik Österreich. Für Universitätsprofessoren galt die Regelung nicht, dass nur Deutsche Beamte sein könnten. Als ihn I9I9 tschechische Freunde zu einem Wechsel an die Prager Universität bewegen wollen, lehnt er es ab, die Wiener Lehrkanzel zu verlassen. Wohl als Antwort auf kritische Stimmen betonte Matějček später, dass Dvořák sich seinem Volk nicht entfremdet hätte und Tscheche, genauer: ein „tschechischer Kosmopolit“, geblieben sei $^{77}$. Eine ambivalente Haltung der Vereinnahmung zeigt umgekehrt Julius von Schlosser, wenn er später in seiner Geschichte der Wiener Schule der Kunstgeschichte - von ihm bezeichnenderweise als „Rückblick auf ein Säkulum deutscher Gelehrtenarbeit in Österreich“ untertitelt - bemerkt, Dvořák sei zwar „tschechischer Erde entsprossen“, aber „dem Wiener-Österreicher-Deutschtum fast restlos gewonnen“ worden ${ }^{78}$.

I9I9 engagiert sich Dvořák auch publizistisch stark in der Debatte um die Forderung des italienischen Staats nach Kriegsreparationen durch Kunstwerke aus Wiener Sammlungen ${ }^{79}$. Nachdem er 1920 einen Ruf nach Köln ausgeschlagen hatte, bewilligt das Ministerium die Aufwertung seiner Lehrkanzel zu einem selbstständigen, dem nunmehr „II. Kunsthistorischen Institut"80. Dvořáks letztes Lebensjahr ist geprägt durch große Wertschätzung - bei seinem berühmt gewordenen Vortrag „Greco und der Manierismus“ am

76 Dvořá к, Eine illustrierte Kriegschronik (wie Anm. 72) 49-51.

77 Übersetzung des Nachrufs bei Roкy та, Dvořák (wie Anm. 10) 86f. Vgl. zu diesem Fragenkomplex v. a. FiLIPová, Historiography (wie Anm. 17) 193f.

78 Schlosser, Wiener Schule der Kunstgeschichte (wie Anm. 1) 209.

79 Vgl. Max Dvořák, Ein offener Brief an die italienischen Fachgenossen, in: Die Entführung von Wiener Kunstwerken nach Italien, hg. von Hans Tietze (Wien 1919) 3-9. Die Verteidigung des österreichischen Standpunkts machte er 1919 sogar zum Thema einer Vorlesung über die von den Italienern beanspruchten Kunstwerke. Vgl. Max Dvořá к, Erklärung ausgewählter Kunstwerke, Vorlesung, SS 1919, IKWA. Vgl. den kritischen Beitrag zu Dvořáks Engagement: Jonathan Blower, Max Dvořák and Austrian Denkmalpflege at war, in: Journal of art historiography 1 (2009): http://www.gla.ac.uk/media/media_139127_en.pdf.

80 UAW, Phil. Fak., PA Max Dvořák (Staatsamt für Inneres und Unterricht. Unterrichtsamt. An Phil. Dekanat. 19.03.1920 [Z. 5352-Abt. 2]). 


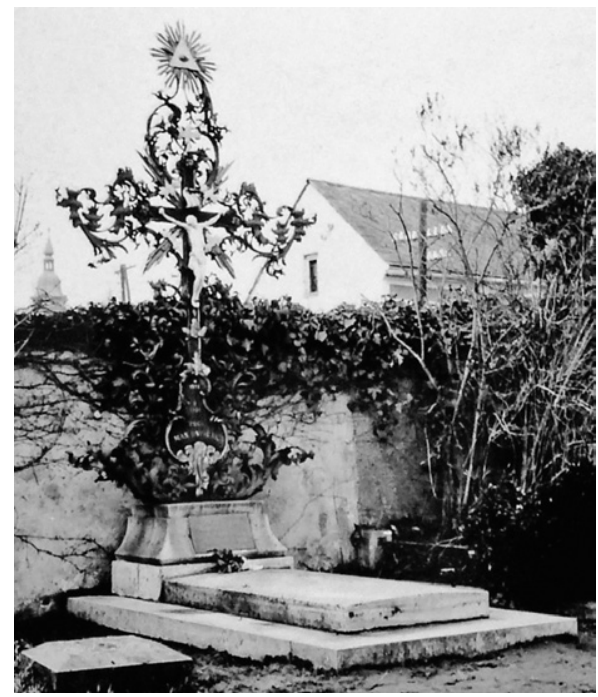

Abb. I4: Grab Max Dvoŕáks in Grussbach (Hrušovany)

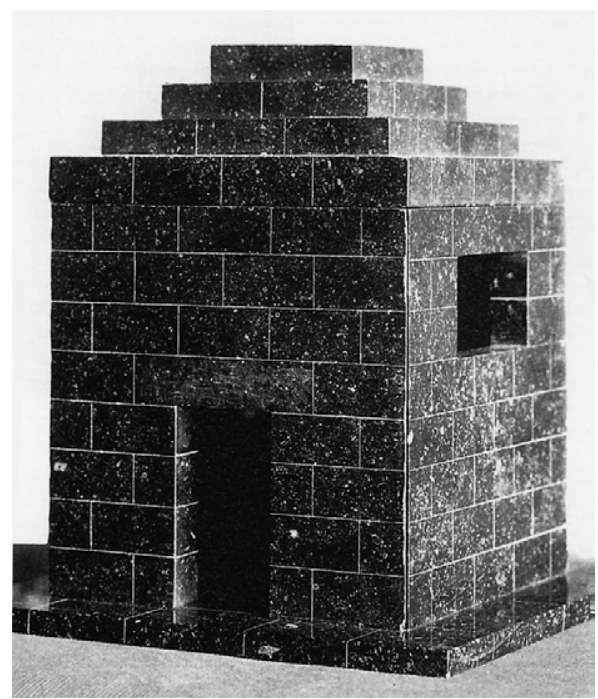

Abb. I5: AdolfLoos, Entwurf eines Mausoleums für Max Dvoŕák

28. Oktober I920 im Museum für Kunst und Industrie waren laut dem Bericht seines Schülers Johannes Wilde angeblich 800 Hörer anwesend ${ }^{81}$-, aber auch durch physische Überlastung und gesundheitliche Schwächung. Sein Schüler Graf Carl Khuen-Belasi lädt ihn daher an den Wochenenden zur Erholung auf Schloss Emmahof (Emín zamék) in Grussbach (Hrušovany nad Jevišovkou) bei Znaim (Znojmo) ein.

Hier, im Adelssitz nahe der neuen österreichisch-tschechoslowakischen Grenze, stirbt der erst 46-jährige Dvořák am 8. Februar I92 I an einem Schlaganfall ${ }^{82}$. Er hinterlässt seine zweite Ehefrau, Rosa geb. Jovanovic-Seatovic, und zwei Töchter aus erster Ehe, Hermine und Gisela. Die Seelenmesse wird in der Jesuitenkirche, Dvořáks Wiener Lieblingskirche ${ }^{83}$, gelesen. Nur ein Jahr früher hatte er in einer Studie über die „Entwicklungsgeschichte der barocken Deckenmalerei in Wien“ Andrea Pozzos Fresken gerühmt, die, „wie durch einen

81 Vgl. Johannes Wilde, Brief an seine Familie (29.10.1920). Briefe von Johannes Wilde aus Wien, Juni 1920

- Februar 1921, hg. v. Karoly KокA I, in: Wiener Jb. für Kunstgeschichte 56 (2010, im Druck). Ich danke Herrn Kokai für die freundliche Erlaubnis, aus den von ihm erstmals publizierten und übersetzen Briefen Wildes vorab zitieren zu dürfen. Der Vortrag publiziert in: Dvoř ́́ K, Kunstgeschichte als Geistesgeschichte (wie Anm. 2) 259-276.

82 Über die näheren Umstände von Dvořáks Tod berichtet einen Tag danach Wilde (er weilte damals ebenfalls auf Emmahof, wo er - durch Dvořáks Vermittlung - die Bibliothek ordnete) in einem Brief an seine Eltern. Vgl. Koка , Briefe (wie Anm. 81).

83 Vgl. Wilde, Brief an die Eltern (15.02.1921); KoKaI, Briefe (wie Anm. 81). 
Zauberstab berührt“, diesen barocken Kirchenraum „in ein hinreißendes Crescendo“ zum Himmel hin steigern ${ }^{84}$. Seine letzte Ruhestätte befindet sich am Dorffriedhof von Grussbach. Das Grab ziert ein von Franz Fürst von und zu Liechtenstein, Präsident der k.k. Zentralkommission seit I9 Io, gestiftetes spätbarockes schmiedeeisernes Kreuz ${ }^{85}$.

Nicht ausgeführt wurde hingegen ein von Adolf Loos entworfenes Mausoleum von lakonischer Monumentalität. Für dieses waren Fresken von Oskar Kokoschka vorgesehen ${ }^{86}$, über dessen jüngste Werke, in denen er Vorboten eines „neuen deutschen Idealismus" sehen wollte, Dvořák einen seiner allerletzten Texte geschrieben hatte ${ }^{87}$. Noch diese gegensätzliche Gestaltung seines Andenkens scheint sinnfällig auf jene Spannung zwischen Traditionsbewusstheit und Modernitätserfahrung zu verweisen, die sein Denken als Kunsthistoriker, wie im Folgenden skizziert werden soll, zeit seines Lebens bewegt hatte.

\section{WISSENSCHAFTLICHES WERK}

\section{II.I Kunstgeschichte als Entwicklungsgeschichte des modernen Naturalismus (ca. I903-I9II)}

Wie die publizierten Texte und die Manuskripte seiner Vorlesungen bis etwa I9 I z zeigen, ist Dvořák in dieser Zeit methodisch ganz seinen Lehrern Wickhoff und Riegl, Klassikern der Wiener Schule, verpflichtet ${ }^{88}$. Kunstgeschichte als Wissenschaft bedeutet für ihn die autonome Entwicklungsgeschichte der künstlerischen Form in universalhistorischer Perspektive. Das bezeugt auch das Hauptwerk dieser ersten Periode seiner Arbeit, „Das Rätsel der Kunst der Brüder van Eyck“ (1903) ${ }^{89}$. Hier stellt Dvořák das evolutionistische Para-

84 Max Dvoř́́к, Zur Entwicklungsgeschichte der barocken Deckenmalerei in Wien (Wien 1920) 10. Wieder abgedruckt in: Dvořá к, Gesammelte Aufsätze (wie Anm. 8) 233.

85 Eva Frodl-Kraft, Das Grabmal Max Dvořáks, in: Österreichische Zs. für Kunst und Denkmalpflege 28 (1974) 144.

86 Ernst Münz, Gustav Künstler, Der Architekt Adolf Loos (Wien 1964) 189, Nr. 61 (mit Abb. des Architekturmodells).

87 Max Dvořá , Oskar Kokoschka. Variationen über ein Thema. Vorwort zur Lichtdruckmappe (Wien 1921).

88 Dieser Verpflichtung gaben auch Dvořáks Nachrufe auf seine Lehrer Ausdruck, in denen er seine eigenen methodologischen Grundsätze reflektiert, außerdem setzte er sich für die Publikation ihrer Schriften ein. Vgl. Max Dvoř ́́ к, Alois Riegl, sowie ders., Franz Wickhoff. Beides in: Dvořár, Gesammelte Aufsätze (wie Anm.8) 279-314.

89 Max Dvořák, Das Rätsel der Kunst der Brüder Van Eyck (München 1925). Zuerst erschienen als Aufsatz in: Jb. der Kunsthistorischen Sammlungen des Allerhöchsten Kaiserhauses 24 (1903) 161-317. Neuausgabe: Wien 1999; Vgl. dazu: Frey, Max Dvořáks Stellung (wie Anm. 3) 5-10; Artur Rosenauer, Das Rätsel der Kunst der Brüder Van Eyck. Max Dvořák und seine Stellung zu Wickhoff und Riegl, in: Wien und die Entwicklung der kunsthistorischen Methode. Akten des XXV. Internationalen Kongresses für Kunstgeschichte I/1 (Wien/Köln/Graz 1984) 45-52; Schmitz, Kunst und Wissenschaft (wie Anm. 6) 262-273; AurenhamMER, Dvořák und die Revision der Mittelalter-Kunstgeschichte (wie Anm. 5). 
digma der Wiener Schule an einer (bis heute) ungelösten Streitfrage auf die Probe. Kann der voraussetzungslos, eben als ein „Rätsel“ erscheinende Naturalismus der niederländischen Maler des I 5. Jahrhunderts historisch abgeleitet werden?90 Dabei verwirft Dvořák, immerhin doch ein gelernter Historiker, alle kultur- und sozialgeschichtlichen Erklärungsmodelle (niederländischer Volkscharakter, Aufstieg des Bürgertums, wirtschaftliche Prosperität, „Verweltlichung der Kunst“ usw.) als „transzendente“, also den künstlerischen Bereich verlassende Parallelisierungen ${ }^{91}$. Die Antwort liegt allein in der Immanenz der Kunstgeschichte: Jan van Eycks revolutionäre Öffnung gegenüber der empirischen Wirklichkeit war keine Zäsur, sondern „die langsam gereifte Frucht der ganzen langen vorangehenden Entwicklung der gotischen Malerei“92. Seit ihren Anfängen im I2. Jahrhundert habe diese die Wiedergabe der sichtbaren Welt immer mehr perfektioniert, bis sie - wie dies Dvořák schon in seinen Studien über die böhmische Buchmalerei aufgezeigt hatte ${ }^{93}$ - im I 4. und frühen I 5. Jahrhundert ihre naturalistischen Interessen mit den Darstellungstechniken des italienischen Trecento verband. Eine lückenlose genetische „Entwicklungskette “94 führt also bis zum Genter Altar, zur Kunst der Brüder Van Eyck.

Damit ist das Kontinuum jedoch nicht zu Ende: „Zwischen den Skulpturen von Chartres und dem Genter Altare, zwischen dem letzteren und Rembrandt, zwischen Rembrandt und der Kunst unserer Tage liegt eine nicht minder geschlossene und einheitliche Entwicklung, als etwa zwischen dem Äginetenfriese, der Ringergruppe in den Uffizien, dem Titusbogen und den Odysseuslandschaften im Vatikan."95 Das Mittelalter bedeutet keinen Rückschritt, sondern ist eine notwendige, wenn nicht überhaupt die entscheidende Phase in der die Malerei der Gegenwart vorbereitenden Entwicklung. Das universalhistorische (und gleichzeitig übernationale) Panorama, in dem Dvořák die antike und die nachantike Kunst erfasst, ist wie bei Riegl und Wickhoff teleologisch ausgerichtet. Das Ziel - und gleichzeitig auch der Standpunkt der retrospektiven Beurteilung - ist die „Kunst unserer Tage“, unter der Dvořák 1904 noch den Naturalismus bzw. den Impressionismus als dessen Vollendung versteht. Bis zu seinen spätesten Schriften, über alle Revisionen und Krisen hinweg, bleibt Dvořáks Rekonstruktion der Kunsthistorie von einer solcherart aktualisierenden, von der Moderne aus argumentierenden Perspektive bestimmt. Er knüpft hier v. a. an Wickhoff an (dessen „Wiener Genesis“ entstammt ja auch das

90 Dvoř́́ K, Rätsel (wie Anm. 89) 18.

91 Ebd. 14.

92 Ebd. 237.

93 Vgl. v. a. Dvořák, Illuminatoren (wie Anm. 16) 167-207 („Italienischer Einfluss nördlich der Alpen im 14. Jahrhundert").

94 Dvoř́n, Illuminatoren (wie Anm. 16) 14.

95 Ebd. 241. 
zitierte Modell der antiken Kunstentwicklung96), der eine „Geschichte des Naturalismus“ vom spätantiken Illusionismus über die „malerischen“ Positionen der Barockmalerei bis zu den Impressionisten geplant hatte ${ }^{97}$. Mit Wickhoff, der selbst als Maler dilettierte und I 900 bei der bekannten Kontroverse um das Fakultätsbild der „Philosophie“ gegen seine Professorenkollegen die Partei Gustav Klimts ergriff ${ }^{9}$, teilte Dvořák das Engagement für zeitgenössische Kunst.

Das Modell einer vom Standpunkt des stilistischen Fortschritts ${ }^{99}$ - das heißt der Perfektionierung der naturalistischen Darstellung - erklärten Kunstgeschichte, dessen Validität Dvořák im Van-Eyck-Text an einem Ausnahmefall beweisen wollte, überträgt er ab dem Wintersemester I904/05 in seinen Vorlesungen auf die gesamte abendländische Kunstgeschichte. Dabei interessieren ihn - entsprechend dem Wiener Programm der Revalorisierung vermeintlicher Verfallsperioden - vor allem antiklassische Stile, die er als entwicklungsgeschichtlich notwendige Wendepunkte legitimiert. So konzentrieren sich seine Mittelalter-Vorlesungen ${ }^{100}$ nicht wie die Van-Eyck-Studie auf die Spätzeit, sondern auf die schon durch Wickhoff und Riegl neu bewertete Schwellenzeit zwischen Spätantike und Frühmittelalter, über deren Skulptur er schon 1903 einen Wickhoff gewidmeten Aufsatz verfasst hatte ${ }^{101}$. Die europäische Malerei des I 8. Jahrhunderts wiederum, über das er eine größere Arbeit plante ${ }^{102}$, wird als Voraussetzung für die das I9. Jahrhundert bestimmende, laut Dvořák bis in die Gegenwart fortdauernde Dichotomie zwischen dem Klassizismus und fortschrittlichen Richtungen (Romantik, Naturalismus, Impressionismus) gesehen (namentlich erwähnt er Jean-François Millet, Édouard Manet, James McNeill Whistler) ${ }^{103}$. Auch hier gelangt er zur Schlussfolgerung, dass die Entwicklung

96 Franz Wiскноғғ, Römische Kunst (Die Wiener Genesis) (Berlin 1912).

97 Dvořák, Franz Wickhoff (wie Anm. 88) 311.

98 Alice $\mathrm{S}_{\text {твов }}$, Zu den Fakultätsbildern von Gustav Klimt, in: Albertina-Studien 2 (1964), 138-169; Schorske, Fakultätsbilder (wie Anm. 20); Lachnit, Wiener Schule (wie Anm. 6) 40-47; Klimts symbolistisches Pathos dürfte Wickhoffs ästhetischen Vorstellungen allerdings wohl wenig entsprochen haben, wie er sie 1897 formuliert hatte (völlige Relativierung des Bildsujets, Aufhebung aller Werthierarchien und externen Referenzen als Signatur der Moderne). Seine Sympathien gehörten den französischen, v. a. aber den englischen Künstlern des späten 19. Jahrhunderts. Vgl. Franz Wıскноғғ, Über moderne Malerei (1897), in: DERs., Abhandlungen, Vorträge und Anzeigen 2, hg. v. Max Dvoř́́ (Berlin 1913) 47f.

99 Max Dvoř́́, Geschichte der barocken Kunst in Italien, Vorlesung (WS 1905/06) 608. IKWA.

100 Max Dvořá K, Geschichte der mittelalterlichen Kunst I, Vorlesung (WS 1906/07); Ders., Geschichte der mittelalterlichen Kunst II, Vorlesung (SS 1907); DERs., Geschichte der abendländischen Kunst im Mittelalter, Vorlesung (WS 1910/11). Alle: IKWA. Dazu ausführlich: Auren ham mer, Revision (wie Anm. 5).

101 Max Dvoř ́́ K, Les Aliscans (1903), in: Ders., Gesammelte Aufsätze (wie Anm. 8) 4-18.

102 Bericht der Kommission, 03.07 .1909 (wie Anm. 47): Wegen seiner Arbeiten in der Denkmalpflege konnte auch ein fast abgeschlossenes Buch über die malerischen Probleme des 18. Jahrh. noch nicht dem Druck übergeben werden.

103 Max Dvořá , Die malerischen Probleme des 18. Jahrhunderts, Vorlesung (SS 1910). IKWA. 
der modernen Kunst vollkommen einheitlich wie in vorangehenden Zeiten sei. In ihr habe sich der künstlerische Subjektivismus nach einer tausendjährigen Entwicklung endgültig durchgesetzt ${ }^{104}$. Vor allem aber arbeitet sich Dvořák an einer Neuinterpretation des Barock ab. Er folgt Riegl, dessen Barock-Vorlesungen er 1907 herausgab ${ }^{105}$, indem er den entscheidenden Umbruch von der Renaissance zum „optischen Subjektivismus“ des Barock (und damit wiederum zur Moderne) schon um I520/30, mit Michelangelo und Correggio, ansetzt, bezieht aber auch die venezianische Malerei des I6. Jahrhunderts mit ein ${ }^{106}$. Auf diese „Umwertung“ des italienischen Cinquecento - es sollte nicht die letzte in der Entwicklung seines Denkens sein - zielt auch das wichtigste wissenschaftliche Projekt der Frühzeit, eine (unvollendet gebliebene) Monografie über Tintoretto, an der Dvořák seit 1900 arbeitet ${ }^{107}$. Sie sollte den Venezianer als einen der Urväter der rein malerischen Bestrebungen des I9. Jahrhunderts herausstellen, den Ausgangspunkt jener Entwicklung ${ }^{108}$, die zu Velazquez und Rembrandt und zur Kunst unserer Tage geführt hat ${ }^{109}$.

Es ist bezeichnend für Dvořáks Deutungshorizont, dass er sich in seiner Kritik an überlieferten klassizistischen Dogmen ausdrücklich auf das Urteil der modernen Künstler beruft. Das wird schon im Aufsatz „Poslední renaissance“ (Die letzte Renaissance) von I 902 deutlich, der den neuen Blick etwa von John Ruskin, Edgar Degas oder Constantin Meunier auf die Barockkunst betont ${ }^{110}$. Auch Dvořáks „modernes“ Tintoretto-Bild hat seinen Ursprung in einer Neubewertung durch zeitgenössische Künstler. So präsentierte bezeichnenderweise die Wiener Secession 1903 im Rahmen einer Ausstellung über die „Entwicklung des Impressionismus in Malerei und Plastik“ (bis zu Vincent van Gogh, Paul

104 Dvoř ́́ , Die malerischen Probleme des 18. Jahrhunderts 1910 (wie Anm. 103) 531, 525.

105 Alois Riegl, Die Entstehung der Barockkunst in Rom, hg. v. Anton Burda, Max Dvoř Á (Wien 1907).

106 Max Dvořá к, Grundriss einer Geschichte der malerischen Probleme in der Neuzeit, Vorlesung (WS 1904/05); Ders., Geschichte der barocken Kunst in Italien 1905/06 (wie Anm. 99); DERs., Geschichte der italienischen Barockkunst, Vorlesung (WS 1909/10); Alle: IKWA.

107 Wicкноғғ, Gutachten zu Dvořák, 08.07 .1905 (wie Anm. 13): Gegenwärtig arbeitet er an einer groß angelegten Biographie Tintorettos, welche das Problem der Entstehung der impressionistischen Malerei behandeln wird, und die auf eine Reihe von Bänden angelegt ist, welche auch die Cultur des damaligen Venedigs schildern werden; Bericht der Kommission, 03.07 .1909 (wie Anm. 47): Für eine grosse Biographie des Tintoretto hat er das archivalische und monumentale Material aus Deutschland, Italien und Frankreich bereits ausgeschöpft und verarbeitet, die Bereisung von Spanien und England verzögerte sich insbesondere durch Arbeiten im Interesse der Erhaltung der heimischen Kunstdenkmäler. Vgl. zum Tintoretto-Projekt allgemein Aurenh a m me R, Dvořák, Tintoretto und die Moderne (wie Anm. 5) 12-21.

108 Max Dvoř ́́ к, Tintoretto. Vortrag am 15. Januar 1914 im Österreichischen Museum für Kunst und Industrie in Wien. IKWA.

109 Vgl. Dvořá к, Geschichte der barocken Kunst 1905/06 (wie Anm. 106) 24.

110 Max Dvořá к, Poslední renaissance [„Letzte Renaissance“], in: Český časopis historický 8 (1902) 30-51. Die entsprechenden Passagen sind übernommen in: Dvoř ́́ K, Geschichte der barocken Kunst 1905/06 (wie Anm. 106) 16-21. 
Gauguin und Paul Cézanne) ein Gemälde Tintorettos im ersten, den historischen Vorläufern gewidmeten Raum ${ }^{111}$. Wie forciert Dvořáks Strategie der modernistischen Aktualisierung (wenigstens in den Vorlesungen) mitunter ausfallen konnte, zeigt seine Analyse der lagernden Quellnymphe in der Illustration von „Rebekka am Brunnen“ in der „Wiener Genesis“. Belegte diese Figur für Wickhoff noch das Weiterleben klassischer Formen in der Spätantike, so erinnert Dvořák das mit wenigen Farbstrichen auf den Purpurgrund des Pergaments gesetzte Figürchen in ihrer Flächigkeit, der Negation jeglicher plastischer Modellierung an keine Geringere als an Manets „Olympia“!112

Der frühe Dvořák verteidigt an sich konsequent die Autonomie der Kunst, um die Selbstständigkeit der Kunstgeschichte als wissenschaftliche Disziplin zu begründen nicht zuletzt gegenüber der Geschichtswissenschaft, mit der die Wiener Schule doch auch institutionell eng verbunden war. Vermeintlich äußere Faktoren wie Material und Technik, aber auch Ikonografie und Funktion sind für ihn, entsprechend Riegls bekanntem Ausspruch ${ }^{113}$, nur „Reibungskoeffizienten“ der immanenten Entwicklung der Kunst. So leugnet er 1906 beispielsweise jeglichen kausalen Zusammenhang zwischen der neuen christlichen Religion und dem formalen „Stilwandel“ von der antiken zur mittelalterlichen Kunst. Diese könne nur als eine innere Selbstverwandlung der klassischen Tradition beschrieben werden ${ }^{114}$. Schon im frühen Johann von Neumarkt-Aufsatz hatte Dvořák Henry Thodes Giotto-Buch, das die malerischen Neuerungen um I 300 als Folge der franziskanischen Spiritualität deutet, als „Religionsüberschätzung “kritisiert ${ }^{115}$. Dennoch verrät nicht zuletzt die Van-Eyck-Studie eine noch immer ambivalente Haltung gegenüber der Relevanz der Realhistorie. Auf der einen Seite bekundet Dvořák deutlich seine Skepsis gegenüber kulturgeschichtlichen Parallelisierungen und (ganz entgegen seiner eigenen Praxis) Erläuterungen nach „Analogien der Tagesereignisse“116. Auf der anderen Seite ergänzt er die kunsthistorische Analyse aber sehr wohl durch lange Exkurse in die politische, v. a. aber die Wirtschafts- und Kulturgeschichte. So begründet er das Interesse an künstlerischer Innovation und Internationalisierung im frühen I 5 . Jahrhundert durch ein an Frankreich orientiertes Luxusbedürfnis der prosperierenden bürgerlichen Kultur der südlichen Niederlande. Und er vergleicht dieses Phänomen gegenwartsbezogen mit dem

111 Entwicklung des Impressionismus in Malerei und Plastik, Ausstellungskatalog (Wien 1903) 23, Kat. Nr. 1. Vgl. Aurenhammer, Dvořák, Tintoretto und die Moderne (wie Anm. 5) 14.

112 Dvoř́́ , Geschichte der mittelalterlichen Kunst I 1906/07 (wie Anm. 100) 249.

113 Alois RiegL, Spätrömische Kunstindustrie (Wien $\left.{ }^{2} 1927\right) 9$.

114 Dvořák, Geschichte der mittelalterlichen Kunst I 1906/07 (wie Anm. 100) 17.

115 Dvořák lehnt es daher ab, einen „kausalen inneren Zusammenhang zwischen dem neuen Religionsleben und Glauben und der parallelen formalen Kunstentwicklung konstruieren zu wollen“. Dvořá K, Illuminatoren (wie Anm. 16) 175.

116 Vgl. Dvořá к, Rätsel (wie Anm. 89)16f. 
aktuellen „kunstgewerblichen Stil“ Englands, der ebenfalls auf ein neues gesellschaftliches Bedürfnis geantwortet habe ${ }^{117}$.

\section{II.2 Abstraktion, Konstruktion, Idealstil: Krise des Naturalismus-Paradigmas (ca. I9I2-I9IS)}

Schon Dagobert Frey wies I921/22, in der ersten Gesamtdarstellung von Dvořáks Lebenswerk, auf die „lange, fast beängstigende Pause in der äußeren Produktion“ hin, die zwischen dem Van-Eyck-Text von I903 und dem I9 8 erschienenen Aufsatz „Idealismus und Naturalismus in der gotischen Malerei und Skulptur“ festzustellen sei, in dem der "geistesgeschichtliche“ Dvořák zum ersten Mal fassbar wird ${ }^{118}$. Bis heute wird die Transformation von der formalistischen Frühzeit zu jener Spätphase, die man gemeinhin mit Dvořáks Namen verbindet, gerne als ein unvermittelter Wechsel der wissenschaftlichen Paradigmen verstanden. Tatsächlich publizierte Dvořák in diesen I 5 Jahren wenig, abgesehen von Rezensionen in den „Kunstgeschichtlichen Anzeigen“ und von Beiträgen zu aktuellen Fragen der Denkmalpflege im Organ der Zentralkommission ${ }^{119}$. Das liegt zum einen natürlich an der schon beschriebenen Doppelbelastung als Professor und Generalkonservator, verrät aber sicher auch eine tiefer gehende Krise, eine Infragestellung der bisherigen methodischen Prämissen. Mit welcher Konsequenz Dvořák während dieser nur scheinbaren „Pause“ an der Revision seiner kunsthistorischen Positionen arbeitete, zeigen die vollständig erhaltenen Vorlesungsmanuskripte dieser Jahre auf faszinierende Weise. Auch und gerade wenn er über ein Thema las, das er schon einmal behandelt hatte, wiederholte er sich im Hörsaal nie, sondern setzte immer neu zur Analyse an, überprüfte und korrigierte seine früheren Ansichten zur mittelalterlichen Kunst, der frühniederländischen Malerei oder der italienischen Kunst von Giotto bis zum Barock ${ }^{120}$. Die Abfolge der Vorlesungen belegt dabei - das kann hier nur angedeutet werden -, dass die vermeintliche scharfe Zäsur in Dvořáks intellektueller Biografie in Wahrheit das Ergebnis eines allmählichen, aber keinesfalls friktionsfreien Prozesses der Neu- und Uminterpretation war. Schon Otto Benesch, dem die Manuskripte in dem durch Wilde und Swoboda in den I $920 e r-J a h r e n$ geordneten Nachlass bereits zugänglich waren, hatte I 924 richtig erkannt,

117 Ebd. 200-203.

118 Frey, Max Dvořáks Stellung (wie Anm. 3) 11.

119 Vgl. die Bibliographie seiner Schriften in: Dvořá K, Gesammelte Aufsätze (wie Anm. 8) 371-381.

120 Vgl. Max Dvořá K, Geschichte der abendländischen Kunst im Mittelalter I-II, Vorlesung (WS 1913/14, SS 1914); DERS., Geschichte der abendländischen Kunst im Mittelalter I und II, Vorlesung (WS 1913/14, SS 1914); DERS., Die Anfänge der niederländischen Malerei, Vorlesung (SS 1912); DERs., Geschichte der italienischen Skulptur und Malerei im Zeitalter der Renaissance I-II, Vorlesung (WS 1911/12, SS 1912); DERs., Geschichte der italienischen Barockkunst, Vorlesung (WS 1912/13); DERs., Geschichte der italienischen Malerei und Skulptur im 14. und 15. Jahrhundert, Vorlesung (WS 1914/15); DERs., Tizian und Tintoretto, Vorlesung (SS 1914). Alle Manuskripte: IKWA. 
dass in der mittleren Periode von Dvořáks Schaffen „immer deutlicher die anfangs latente allgemein geistesgeschichtliche Grundlage die Behandlung der formalen künstlerischen Probleme durchdringt"121.

Dieser Prozess wurde wiederum durch die Erfahrung der zeitgenössischen Kunst in Bewegung gehalten. Der frühe Dvořák hatte, überspitzt formuliert, das historische Kontinuum von einem schon erreichten „Ende der Kunstgeschichte“ aus betrachtet: dem Impressionismus, in dem er den Naturalismus zur Vollendung gebracht fand. Eben dieser Fluchtpunkt der Geschichte - und damit die Reduktion von Kunstgeschichte auf eine Geschichte der Perfektionierung der Naturdarstellung - musste aber spätestens um I 9 Io ins Wanken geraten. Seit I9I 2 entwickelt Dvořák daher ein neues Verständnis der Moderne, das offensichtlich auf expressionistische und abstrakte Tendenzen antwortet und sich auf zeitgenössische kulturpessimistische und spiritualistische Ideologien bezieht. Die konkreten Wege von Dvořáks Moderne-Rezeption sind noch zu erforschen. Hier muss der Hinweis auf Hans Tietze genügen, seinen Freund und Mitarbeiter in der Zentralkommission, der gemeinsam mit seiner Frau Erica Tietze-Conrat I 909 von Oskar Kokoschka porträtiert wurde und I9 I I/ I 2 den Almanach des „Blauen Reiter“ rezensierte ${ }^{122}$.

Im Oktober I 9 3 eröffnet Dvořák eine Vorlesung über mittelalterliche Kunst mit einer Zeitdiagnose, die in die damals weit verbreitete neuidealistische Kritik am Materialismus des vergangenen Jahrhunderts einstimmt, wie sie zum Beispiel auch Wassily Kandinskys „Das Geistige in der Kunst“ (I9II) prägte. Der positivistische Fortschrittsglaube, der Primat der Naturwissenschaften und die Technikidolatrie des I9. Jahrhunderts seien jetzt genauso obsolet geworden wie ihre künstlerischen Äquivalente, Naturalismus und Impressionismus. Dvořák konstatiert eine tiefe Wandlung [...] der geistigen Kultur. [...] In den Wissenschaften macht sich das Bedürfnis nach vertiefender Synthese einerseits und nach neuer philosophischer Durchbildung aller Wissenschaften anderseits immer mehr bemerkbar, und selbst in Fragen der Technik und der materiellen Kultur kann gegenüber dem einseitigen Utilitarismus der letzten Jahrzehnte eine große Reaktion beobachtet werden ${ }^{123}$.

Mit der Absage an den Naturalismus fällt der Parameter für Dvořáks bisherige (und oft ziemlich einseitige!) Rekonstruktion der Kunstgeschichte: die „Naturwahrheit“. An seine Stelle tritt in den Vorlesungen dieser Jahre vor allem die subjektive Freiheit des Künstlers, der die Darstellung der Wahrnehmungswelt in Idealkompositionen transzendiert ${ }^{124}$. Die

121 Benesch, Dvořák (wie Anm. 3) 171.

122 Hans Tietze, Der Blaue Reiter, in: Die Kunst für Alle 27 (1911/12), wieder abgedruckt in: Ders., Lebendige Kunstwissenschaft. Texte 1910-1954, hg. von Almut Krapf-Weiler u. a. (Wien 2007) 38-44. Vgl. zur Beziehung zu Dvořák: Hans Tietze, Geisteswissenschaftliche Kunstgeschichte, in: Die Kunstwissenschaft der Gegenwart in Selbstdarstellungen, hg. v. Johannes JA HN (Leipzig 1924) 183-198.

123 Dvoř́́ к, Geschichte der abendländischen Kunst im Mittelalter I 1913/14 (wie Anm. 120) 10 und $12 f$.

124 Vgl. Dvořá к, Tintoretto, Vortrag (1914) (wie Anm. 108) 99. 
Analysen betonen den Eigenwert einer naturfernen, abstrakten Gestaltung, ihre rein spirituelle Gesetzmäßigkeit ${ }^{125}$ oder aprioristische kompositionelle Gesamterfindung ${ }^{126}$. Auf der anderen Seite spielt nun auch der in den frühen Texten völlig vernachlässigte Bildinhalt eine neue Rolle. So betont Dvořák I9I4 in einem Vortrag über Tintoretto, der gewissermaßen den Schlussstrich unter das inzwischen aufgegebene Monografie-Projekt zieht, nicht mehr die protoimpressionistischen Effekte, sondern die dichterische Fantasie des Künstlers. Tintoretto gestaltet die überlieferten christlichen Themen in einem großen erzählenden Idealstil neu ${ }^{127}$, den er bis zur visionären Expression, bis zum Übermenschlichen und Übernatürlichen steigert ${ }^{128}$. Die reine Form wird hier als Medium der Erzählung aus ihrer Selbstreferenzialität befreit, wird zum Ausdruck, zur Sprache, die den Ideen zu folgen hat ${ }^{129}$.

Dvořák sieht im I6. Jahrhundert, das er weiterhin als Beginn des Barock versteht, auch um I9I2/I5 einen entwicklungsgeschichtlich entscheidenden Schritt zur modernen Kunst. Relevant ist für ihn jetzt aber bezeichnenderweise der subjektive Idealismus der nachklassischen Cinquecento-Künstler, durch den das - deutlich Züge des I9. Jahrhunderts tragende - materialistische und religiös indifferente Quattrocento überwunden worden sei. Der Protagonist dieses neuen großen Stils ist Michelangelo, sein übersteigertes Pathos, seine die Wirklichkeit verachtende Souveränität, die etwa das Fresko des „Jüngsten Gerichts“ auszeichnet ${ }^{130}$. Dvořáks kunsthistorische Neubewertungen sind selbst offensichtlich einer zeitgenössischen „geistigen Wende“ verpflichtet. Auf analoge Weise sieht er auch die idealistischen Neuerungen der Kunst des I 6. Jahrhunderts in einer tiefgreifende [n] Wandlung im Geistesleben, vor allem in den religiösen Umbrüchen der Epoche begrün$\operatorname{det}^{131}$. Gegenüber dem Primat der Kunstautonomie in den frühen Schriften bedeutet dieser, wenn auch vorerst nur angedeutete geistesgeschichtliche Horizont eine wichtige Neupositionierung.

Es ist nicht leicht zu konkretisieren, welche Avantgarde Dvořák um I9I2/I 5 als das Telos der künstlerischen Gesamtentwicklung ansah. Entsprechend Riegls Forderung nach der Notwendigkeit der historischen Distanz bei der Beurteilung aktueller Kunst (der so-

125 Max Dvoř́́ K, Tizian-Fragment (ca. 1914) 17. IKWA.

126 Dvořá , Geschichte der italienischen Barockkunst 1912/13 (wie Anm. 120) 626.

127 Dvoř ́́ K, Tintoretto, Vortrag 1914 (wie Anm. 108) 77.

128 Ebd. 83.

129 Ebd. 80. Zur Tintoretto-Deutung in der mittleren Periode Dvořáks ausführlich Aurenh ammer, Dvořák, Tintoretto und die Moderne (wie Anm. 5) 21-28.

130 Dvorák, Tizian und Tintoretto 1914 (wie Anm. 120) 164. Vgl. v. a. Ders., Geschichte der italienischen Barockkunst 1912/13 (wie Anm. 120) 13-525.

131 Vgl. Dvořá , Tizian und Tintoretto 1914 (wie Anm. 120) 131; De r s., Tintoretto, Vortrag 1914 (wie Anm. 108) 97. 
genannten „Dreigenerationenlehre“132) hielt sich Dvořák bei der Erwähnung zeitgenössischer - und hier insbesondere österreichischer - Künstler zurück. Dennoch äußerte er I9I 3: Was allen neuen Richtungen in der Malerei gemeinsam ist, ist das Hinausgehen über die einfache Naturbeobachtung durch künstlerische Abstraktion und Konstruktion, ist Stil in eigentlicher Bedeutung des Wortes ${ }^{133}$. Indem Dvořák hier Abstraktion als Synonym von „Stil“ und Gegensatz von Natur begreift, orientiert er sich offensichtlich an der Terminologie in Wilhelm Worringers „Abstraktion und Einfühlung“"von I909 ${ }^{134}$. Worringers so einflussreiche Schrift, die man als eine geschickte Montage von Riegls Konzept des autonomen Kunstwollens einerseits und der Ästhetik der Einfühlung von Theodor Lipps andererseits lesen kann, wird damit in den Diskurs der Wiener Schule der Kunstgeschichte gleichsam wieder zurückgeführt.

Dass Dvořák „Stil“ und „Konstruktion“ vielleicht gar nicht auf den Wiener Frühexpressionismus oder die „mystisch-innerliche Konstruktion“ des Blauen Reiter bezieht, sondern vielmehr einen neuklassizistischen „retour à l'ordre“ vertritt, zeigt sein Vortrag über Gegenwartsarchitektur von I9I 2. Hier preist er nicht nur ausgerechnet die DeutschRömer Hans von Marées und Anselm Feuerbach als Leitfiguren der neuen Malerei (was ihn übrigens mit Worringer verbindet ${ }^{135}$ ), sondern auch die klassizierenden Bauten der zeitgenössischen deutschen Reformarchitektur ${ }^{136}$. In Entwürfen von Bruno Schmitz und Martin Dülfer oder in Alfred Messels Pergamonmuseum sieht er Beispiele des neuen tektonischen Stils einer "Letzten Renaissance“ (so der Titel des Vortrags), die an die sozusagen vorletzte Renaissance, den Neoklassizismus um I 8oo, anknüpft. Dvořák wendet

132 Dazu: Hans Tietze, Die Methode der Kunstgeschichte. Ein Versuch (Leipzig 1913) 53; ebd. wird zitiert Alois RiegL, Entwurf einer gesetzlichen Organisation der Denkmalpflege in Österreich (Wien 1903).

133 Dvořá K, Geschichte der abendländischen Kunst im Mittelalter I 1913/14 (wie Anm. 120) 11. Zu Dvořáks veränderter Sicht der Moderne vgl. auch die Deutung der neo- und antiimpressionistische [n] Bewegung der letzten Jahre in Max DvořÁ K, Entwicklung der modernen Landschaftsmalerei, Vorlesung (WS 1914/1915) 365-367.

134 Wilhelm Worringer, Abstraktion und Einfühlung (München 1908). Zur späteren Kritik Dvořáks an Worringers völkerpsychologischen Begriffshypostasierungen vgl. Aurenhammer, Revision (wie Anm. 5). - Zu Worringer vgl. Invisible cathedrals. The expressionist art history of Wilhelm Worringer, hg. v. Neil H. Donahue (University Park 1995); Wilhelm Worringers Kunstgeschichte, hg. v. Hannes BöHringer (München 2002); Claudia ÖHlschläGer, Abstraktionsdrang. Wilhelm Worringer und der Geist der Moderne (München 2005).

135 Vgl. Magdalena Bushart, Der Geist der Gotik und die expressionistische Kunst. Kunstgeschichte und Kunsttheorie 1911-1925 (München 1990), 20-22.

136 Max Dvořá к, Die letzte Renaissance (1912), hg. von Hans Aurenhammer, in: Wiener Jb. für Kunstgeschichte 50 (1997) 9-22. Dazu ausführlich: Aurenhammer, Dvořák und die moderne Architektur (wie Anm. 5). Vgl. jetzt auch: Jindřich Vy bíral, The Vienna School of Art History and (Viennese) modern architecture, in: Journal of art historiography 1 (2009): http://www.gla.ac.uk/media/media_139133_en.pdf; Scar rocchia, Denkmalpflege und Moderne (wie Anm. 7) Kapitel 3, 2. 
sich vehement gegen den Historismus des I9. Jahrhunderts, aber auch gegen den seiner Ansicht nach bloß vordergründig modernen funktionalistischen Materialismus technischer Nutzbauten, wie ihn in Wien Otto Wagner vertrete. Auch als Architekt bedeutet hier Michelangelo für Dvořák die wesentliche historische Referenz. I91 2/ I 3 rühmt er die Neue Sakristei und den Ricetto der Biblioteca Laurenziana als Keimzellen der barocken (und damit auch: der modernen) Baukunst, weil hier Architektur nicht - wie im I9. Jahrhundert - auf Material und Konstruktion reduziert, sondern als Kunst verstanden werde, als künstlerischer Ausdruck einer reinen Tektonik, wie dies Dvořák auch von der Baukunst der Gegenwart erwartet ${ }^{137}$.

\section{II.3 Kunstgeschichte als Geistesgeschichte (ca. I9I6-I92I)}

Bereits in den Jahren I9I2-I9I5 hatte sich Dvořák also von der durch Wickhoff und Riegl begründeten kunsthistorischen Tradition gelöst, der seine erste Schaffensperiode verpflichtet gewesen war. In den letzten fünf Jahren seines Lebens radikalisiert Dvořak diese methodische Wende, wobei die Vorlesungsmanuskripte zeigen, dass eine klare Trennlinie zur vorangegangenen Phase nicht immer leicht zu ziehen ist. Mit der „Geistesgeschichte“ orientiert er sich jetzt an einem aktuellen Wissenschaftsmodell, vor allem aber sucht er nach einer neuen Konzeption von Geschichte, um das evolutionistische Paradigma der Wiener Schule zu überwinden. Er rekonstruiert (zumindest tendenziell) Kunstgeschichte nicht mehr als ein lückenloses Entwicklungskontinuum, sondern als einen konfliktreichen Prozess, der durch einen letztlich überhistorischen Antagonismus von Idealismus und Naturalismus in einem „ewigen Ringen zwischen Materie und Geist“ 138 in dialektischer Bewegung gehalten wird. Schon I9I3 sah er die mittelalterliche Stilgeschichte - aber nicht nur diese - als Schauplatz des Kampf[es] zwischen der Materie und dem Geiste, zwischen Seele und Körper, zwischen dem irdischen Dasein und [der] Ewigkeit ${ }^{39}$. In diesem Kampf bedeutet seine eigene, mit überschwänglicher Identifikation verbundene Entscheidung für die Geistesgeschichte natürlich eine eindeutige Parteinahme. Diese erträumt ein nebulöses geistiges Zukunftsreich, kann aber auch, wie vorhin erwähnt, I 9 I 6 ganz konkret sogar die österreichische Kriegsführung als Kampf für eine neue geistige Kultur legitimieren ${ }^{140}$.

137 Dvořák, Geschichte der italienischen Barockkunst 1912/13 (wie Anm. 120) 385-387. Dazu: AurenHAMMER, Dvořák und die moderne Architektur (wie Anm. 5), $36 \mathrm{f}$.

138 Max Dvorák, Über Greco und den Manierismus, in: Ders., Kunstgeschichte als Geistesgeschichte (wie Anm. 2) 276.

139 Max Dvořác, Geschichte der abendländischen Kunst im Mittelalter I (WS 1913/14), Typoskript von Carola Bielohlawe 229. IKWA.

140 Vgl. oben Anm. 76. Zur „geistesgeschichtlichen“ Phase Dvořáks vgl. auch: Schmitz, Kunst und Wissen- 
Dvořáks späte Analysen beziehen formdeskriptive Kategorien auf weltanschauliche Typen. Den Geist-Materie-Dualismus sieht er beispielsweise in Malerei und Skulptur im Wechsel naturalistischer und abstrakter Tendenzen ausgedrückt. Dasselbe gilt in der Architektur für den Gegensatz zwischen dem die Materie betonenden Massenbau und dem „entmaterialisierten“ Gliederbau - hier wird der Kurzschluss von der Beschreibung des Sichtbaren zur Divination eines in der Form angeblich manifesten „Geistes“ besonders augenfällig ${ }^{141}$. Über einem solcherart binär organisierten Grundriss errichtet Dvořák hoch spekulative geistesgeschichtliche Konstruktionen. Diese sind - vor allem in den mit hoher Sachhaltigkeit die Widersprüche der behandelten Gegenstände entwickelnden Vorlesungen, weniger in den auf populäre Wirkung zugespitzten späten Vorträgen - im Detail allerdings weitaus differenzierter, als der Schematismus erwarten ließe. Das unterscheidet Dvořák auch von zeitgleichen plakativeren Positionen wie etwa der Expressionismus-Theorie von Paul Fechter, der I9I4 im Anschluss an Worringers Begriffspaar von Einfühlung und Abstraktion ${ }^{142}$ die gesamte Kunstgeschichte auf ein Hin und Her von „Stil und Naturalismus“"verkürzte ${ }^{143}$.

Auch wenn ihn das Problem des Entwicklungskontinuums nicht loslässt ${ }^{144}$, sucht Dvořák jetzt nicht mehr vorrangig nach genetischen Ableitungen und kausalen Erklärungen. Sein eigentliches Thema ist die inkomparable „Eigenart“ der künstlerischen Phänomene ${ }^{145}$, die er als Ausdruck des Verhältnisses „zu transzendenten Ideen einerseits, zu den realen Tatsachen und Gütern der Natur und des Lebens andererseits“ begreift ${ }^{146}$. Diese Wendung zum hermeneutischen Sinn-Verstehen verdankt sich natürlich dem geisteswissenschaftlichen Paradigmenwechsel des frühen 20. Jahrhunderts und seiner HistorismusKritik. Dvořák beruft sich ausdrücklich auf Wilhelm Windelband, Heinrich Rickert und Wilhelm Dilthey ${ }^{147}$, an dessen „Typen der Weltanschauung“ ja bei allen Unterschieden auch seine Klassifizierung gegensätzlicher Geisteshaltungen erinnert ${ }^{148}$. Das geistesgeschichtliche „Vermögen des Sich-Einfühlens“ in historische Kunstwerke preist Dvořák

schaft (wie Anm. 6) 273-324; Artur Rosenauer, Nachwort, in: Max Dvořák. Kunstgeschichte als Geistesgeschichte (Berlin 1995) 278-283; De Marchi, Dvořák (wie Anm. 6).

141 Vgl. schon Dvořá K, Geschichte der abendländischen Kunst im Mittelalter I 1913/14 (wie Anm. 139) 207209.

142 Worringer, Abstraktion und Einfühlung (wie Anm. 134).

143 Paul Fechter, Expressionismus (München 1914). Dazu: Bushart, Der Geist der Gotik (wie Anm. 136).

144 Vgl. Aurenhammer, Revision (wie Anm. 5).

145 Dvoř ́́, Idealismus und Naturalismus (wie Anm. 71) 44, 46.

146 Ebd. 49.

147 Max Dvořá , Idealismus und Realismus in der Kunst der Neuzeit, Vorlesung (WS 1915/16) 12. IKWA.

148 Wilhelm Dilt hey, Die Typen der Weltanschauung und ihre Ausbildung in den philosophischen Systemen, in: Ders., Weltanschauung, Philosophie und Religion (Berlin 1911). Vgl. auch Hermann Nohl, Die Weltanschauung der Malerei (Jena 1908). 
I920 in einem Vortrag mit dem für ihn charakteristischen Optimismus als den eigentlichen Gewinn kunstwissenschaftlicher Arbeit: „Und dann verwandelt sich die Handbücher-Weisheit in wahre und lebendige Seelenbildung, in der auf allen Gebieten des geistigen Lebens die Brücke zu einer besseren Zukunft der Menschheit zu suchen ist. "149

Dvořáks Neuorientierung wird zunächst in seinen Vorlesungen deutlich. Bereits deren Titel offenbaren die geänderte Zielsetzung: I9 I 5/I 6 thematisiert er „Idealismus und Realismus in der Kunst der Neuzeit“, I916/I7 liest er „Über das Verhältnis der Kunst des I7. und I 8. Jahrhunderts zu den gleichzeitigen geistigen Strömungen“150. Hier geht es ihm bei der Analyse künstlerischer Phänomene um Verschiedenheiten in der grundsätzlichen Stellung der Menschen zur Kunst und nicht nur zur Kunst, sondern zu allem, was die Grundlage und den wichtigsten Inhalt des Lebens bedeutet, zu Gott und Natur, zur Moral, Wissenschaft, Literatur, zu sozialen und politischen Idealen ${ }^{151}$. Ein letztes Mal, mit neuen methodischen Koordinaten, behandelt er I9I7/1 8 die mittelalterliche Kunst ${ }^{152}$. Von I9I8/I9 bis I920/2 I schließlich beschäftigt ihn die italienische Renaissancekunst in einem dreisemestrigen Zyklus, der nach seinem Tod veröffentlicht wurde ${ }^{153}$.

Erstmals außerhalb des Hörsaals bekannt wird der „geistesgeschichtliche“ Dvořák durch den I9I 8 in der „Historischen Zeitschrift“ erschienenen Aufsatz „Idealismus und Naturalismus in der gotischen Skulptur und Malerei“, in dem er zum Thema der frühen Van-Eyck-Studie von 1904 zurückkehrt, aber nun den wesentlich idealistischen Charakter der gotischen Kunst betont, ja aus diesem, mit einer für seine späte Denkweise typischen dialektischen Volte, sogar die naturalistische Antithese hervorgehen lässt ${ }^{154}$. I 923 wurde dieser Text in den Sammelband „Kunstgeschichte als Geistesgeschichte“ aufgenommen, der Dvořáks postumen Ruhm begründen wird. Die hier vereinten späten Aufsätze und Vorträge sind Vorarbeiten für ein noch von Dvořák geplantes Buchprojekt, das „die wichtigsten Wendepunkte der Kunstentwicklung des Abendlandes seit der späten Antike (...) ihrem Wesen nach" charakterisieren und auf die allgemeine Geistesgeschichte zurück-

149 Max Dvořá к, Kunstbetrachtung. Vortrag, gehalten in Bregenz. Sommer 1920. IKWA.

150 Dvořá , Idealismus und Realismus in der Kunst der Neuzeit 1915/16 (wie Anm. 147); Ders., Über das Verhältnis der Kunst des 17. und 18. Jahrhunderts zu den gleichzeitigen geistigen Strömungen I-II, Vorlesung (WS 1916/17, SS 1917). IKWA.

151 Ebd. I $7 f$.

152 Max Dvoř ́́к, Geschichte der abendländischen Kunst im Mittelalter, Vorlesung (WS 1917/18). IKWA. Vgl. dazu Aurenhammer, Revision (wie Anm. 5).

153 Max Dvořák, Italienische Kunst der Renaissance, Vorlesung (WS 1918/1919); Ders., Die Kunst der Hochrenaissance, Vorlesung (WS 1919/1920); DERs., Die Entwicklung der Barockkunst, Vorlesung (WS WS 1920/21). IKWA. Alle publiziert in: Max Dvoř Áк, Geschichte der italienischen Kunst im Zeitalter der Renaissance. Akademische Vorlesungen 1-2 (München 1927, Neuausgabe: Wien 2004).

154 Dvořák, Idealismus und Naturalismus (wie Anm. 71); Vgl. dazu v. a. De Marchi, Dvořák (wie Anm. 6). 
führen sollte ${ }^{155}$. Diese Geschichte des „Geistigen in der Kunst“ führt von der Katakombenmalerei als Ausdruck eines radikalen frühchristlichen Spiritualismus ${ }^{156}$ über das Spätmittelalter bis in das I6. Jahrhundert, dem weiterhin Dvořáks besondere Affinität gilt. In den beiden 1920 geschriebenen Texten zu Pieter Bruegel und zu El Greco ${ }^{157}$ entwickelt er seine für die Kunstgeschichtswissenschaft wohl nachhaltigste Neubewertung: die „Entdeckung“ des Manierismus als eigenständiger Stilphase zwischen Renaissance und Barock, die er seit I9I7 von der negativen Konnotation als epigonaler Verfallszeit, als Dekadenz der Renaissance befreit hatte. Auch diese seine letzte Revision der Deutung der Cinquecento-Kunst ist durch die aktuelle, nunmehr expressionistische Moderne geprägt. Nicht mehr impressionistische Effekte, auch nicht der große Stil interessieren ihn jetzt, sondern der „manieristische Expressionismus“ von Künstlern wie El Greco oder dem späten Tintoretto, für die das künstlerische Medium, „losgelöst von allen naturalistischen Funktionen, ein unabhängiger Ausdruck des geistigen Inhalts" geworden ist ${ }^{158}$.

Das Spätwerk Dvořáks erscheint auf den ersten Blick wie eine Rückkehr zu jener Kulturgeschichte des I9. Jahrhunderts, die er seit dem frühen Johann von NeumarktAufsatz vehement abgelehnt hatte ${ }^{159}$, wobei vielleicht auch die Stigmatisierung solcher Ansätze im „Methodenstreit“ um Karl Lamprecht eine Rolle spielte ${ }^{160}$. I9I7 hingegen lobt Dvořák begeistert Karl Schnaases früher von ihm als alte Scharteken abgetane Bände der „Geschichte der bildenden Künste“, die jeweils durch kulturgeschichtliche Exkurse eingeleitet werden ${ }^{161}$. Der frühe Dvořák hatte Schnaases Parallelisierungen von Kulturund Kunstgeschichte noch mit einem „Dampfmotor“ verglichen, „bei dem der Transmissionsriemen abhanden gekommen“ sei $^{162}$. Ist Dvořák jetzt also wieder zum (geistesgeschichtlichen) Historiker geworden? Das wäre ein Missverständnis. Auch in den letzten

155 Johannes Wilde, Karl Maria Swoв оdA, Vorwort der Herausgeber, in: Dvoř ́́ к, Kunstgeschichte als Geistesgeschichte (wie Anm. 2) IX.

156 Vgl. dazu Aurenhammer, Revision (wie Anm. 5).

157 Dvořá , Bruegel (wie Anm. 12); Dvořá к, Greco (wie Anm. 138).

158 Dvořá , Geschichte der italienischen Kunst II (wie Anm. 153) 159; Zum Greco-Vortrag vgl. auch: Peter K. KLEIN, El Greco's „Burial of the of Orgaz“ and the concept of mannerism of the Vienna School, or: Max Dvořák and the occult, in: El Greco of Crete, hg. v. Nikos Chatzenikolau (Iraklion 1995) 507-532. Zur Tintoretto-Interpretation des späten Dvořák Aurenhammer, Dvořák, Tintoretto und die Moderne (wie Anm. 5) 28-36.

159 Dvořá , Illuminatoren (wie Anm. 16) $175 f$.

160 Die Relevanz dieser wissenschaftspolitischen Auseinandersetzung für die Wiener Schule betonte Georg VASOLD, Alois Riegl und die Kunstgeschichte als Kulturgeschichte (Freiburg i. Br. 2004).

161 Dvořá к, Geschichte der abendländischen Kunst im Mittelalter 1917/18 (wie Anm. 152) 13. Siehe hingegen die kritische Haltung in DERs., Geschichte der abendländischen Kunst im Mittelalter 1910/11 (wie Anm. 100) 45. Vgl. Karl Schna ASE, Geschichte der bildenden Künste (Düsseldorf 1843-1865).

162 DvoŘ ́́ , Rätsel (wie Anm. 89) 8f. 
Texten geht es nicht um eine konkrete, Beziehungen suchende kulturhistorische Kontextualisierung. Auch der späte Dvořák bleibt im Grunde Formalist, nur will er aus der Analyse der künstlerischen Form unmittelbar den weltanschaulichen Sinn erschließen. Die Form selbst ist, wie es im Bruegel-Aufsatz von I 920 heißt, „die Inkarnation des geistigen Verhältnisses zur Umwelt“163. Schon Riegl hatte behauptet, dass das „Kunstwollen“ zu den anderen einzelnen Objektivationen des „Kulturwollens“ (Religion, Literatur, Philosophie, Wissenschaft, Staat und Recht) „schlechtweg“ parallel organisiert sei ${ }^{164}$. Er versagte den Kunsthistorikern jede diesbezüglich weiter gehende Spekulation und sah dagegen in der Erfassung der „Weltanschauung“ die „Zukunftsaufgabe“ einer vergleichenden Kulturgeschichte ${ }^{165}$. Dvořák überschreitet diese methodische Grenze, indem er als Kunsthistoriker allgemeine Formstrukturen zu geistesgeschichtlichen Kategorien, zur „Weltanschauung“ in Beziehung setzt, etwa wenn er Höhendrang und Tiefenzug der frühchristlichen Basilika als Ausdruck der die Materie transzendierenden christlichen Weltflucht liest ${ }^{166}$.

Es ist eine alte Binsenwahrheit, dass die Gegenwartskunst uns [...] die Augen für die künstlerischen Absichten der Vergangenheit öffnet ${ }^{167}$. So folgt Dvořák auch in der Neubewertung El Grecos dem Urteil der modernen Künstler, für die der kretische Maler, vermittelt vor allem durch Julius Meier-Graefe, zur Identifikationsfigur geworden war ${ }^{168}$. Der Aktualitätsbezug von Dvořáks letzter Wende ist offenkundig. Erregt sieht er im Manierismus (ebenso wie im frühen Mittelalter) den Spiegel seiner eigenen krisenhaften Gegenwart: „ein scheinbares Chaos, wie uns unsere Zeit als Chaos erscheint"169. Er vergleicht sogar die Reformation des I6. Jahrhunderts mit der zeitgenössischen Bewegung „gegen den Kapitalismus“, also mit der Revolution von I9I $7^{170}$. Dieses Chaos aber bedeute, so Dvořák am Ende seines Greco-Vortrags, das Ende der materialistischen Kultur und scheine „nach

163 Dvoř́n, Bruegel (wie Anm. 12) 250.

164 Riegl, Spätrömische Kunstindustrie (wie Anm. 113) 400-405.

165 Alois Riegl, Naturwerk und Kunstwerk 1, in: Ders., Gesammelte Aufsätze (Wien 1929) 49-61. Vgl. dazu: Wolfgang Keмp, Alois Riegl (1858-1905), in: Altmeister moderner Kunstgeschichte, hg. v. Heinrich Dilly (Berlin 1990) 47-51; De Marchi, Dvořák (wie Anm. 6) 115.

166 Dvořá к, Geschichte der abendländischen Kunst im Mittelalter 1917/18 (wie Anm. 152) 279-281. Siehe dazu Aurenhammer, Revision (wie Anm. 5).

167 Dvořák, Geschichte der abendländischen Kunst im Mittelalter 1917/18 (wie Anm. 152) 742.

168 Vgl. Veronika Schroeder, El Greco im frühen deutschen Expressionismus. Von der Kunstgeschichte als Stilgeschichte zur Kunstgeschichte als Geistesgeschichte (Frankfurt/M. 1998); Johannes RössLER, Rhythmus, Symbol des Lebens. Die deutsche El-Greco-Rezeption von den Anfängen bis zu Julius Meier-Graefes ,Spanischer Reise‘ (1910), in: Marburger Jb. für Kunstwissenschaft 36 (2009) 391-411.

169 Dvoř́́ к, Greco (wie Anm. 138) 270.

170 Ebd. 269. 
der Richtung eines neuen, geistigen, antimaterialistischen Weltalters“ zu weisen ${ }^{171}$. Der geistesgeschichtliche Kunsthistoriker ist hier zum Propheten geworden.

Trotz solcher ebenso emphatischer wie weltfremder Aktualisierungen darf man Dvořák jedoch nicht auf das naheliegende Etikett ,expressionistischer Kunsthistoriker` reduzieren. Dagegen spricht nicht nur die größere Differenziertheit seiner Vorlesungen, sondern auch ein auf den ersten Blick eindeutig „expressionistischer“ Text, Dvořáks letzte Publikation überhaupt: das I92 I erschienene Vorwort zu Oskar Kokoschkas Grafikmappe „Das Konzert", welche die wechselnden Empfindungen einer Frau beim Hören von Musik darstellt $^{172}$ (die Porträtierte ist Kamilla, die Frau von Dvořáks Assistenten Swoboda, die, I934 von ihrem Mann geschieden, I943 als Jüdin nach Theresienstadt deportiert und ermordet wurde $\left.{ }^{173}\right)$. Diese Variationen über ein Thema vergleicht Dvořák mit Claude Monets Getreideschober-Serie und sieht hier den erhofften Umschlag vom Materialismus des I9. Jahrhunderts zum „Zukunftsreich“ des Idealismus angekündigt. Radikale Abstraktion ist für ihn also nur ein krisenhafter Übergang. Für die kommende Zeit erwartet er einen den expressionistischen Subjektivismus überwindenden, wieder zum Ausgleich mit der Natur gelangten „Idealstil“174. Er antizipiert hier die tatsächliche spätere Entwicklung Kokoschkas, der zu einem erbitterten Gegner der Abstraktion wurde, weil diese die Darstellung des Menschen vernachlässige ${ }^{175}$. Der von der Erfahrung der antagonistischen Moderne so affizierte Dvořák sympathisiert also offenbar doch vor allem mit einem konservativen Ausgleich der Gegensätze. Bezeichnenderweise sieht er in seiner letzten Vorlesung ausgerechnet im Manierismus, als dessen Entdecker er doch bis heute bekannt ist, eine Gefahr, die durch die Syntheseleistung des Barock überwunden werden musste. ${ }^{176}$

Der „expressionistische“ Duktus der späten Texte Dvořáks, vor allem der pathetisch übersteigerten Vorträge, beförderte gleich nach seinem Tod die Popularität, ließ seine Ansichten aber auch bald als „démodé“ erscheinen. Schon die Vertreter der nüchtern-szientistischen „Neuen Wiener Schule“ distanzierten sich von Dvořák ${ }^{177}$. Ernst Gombrich kritisierte scharf die „physiognomic fallacy“, die Illusion einer durch den visuellen Charakter der Form unmittelbar offenbarten Erkenntnis, wie sie der für die geistesgeschichtliche

171 Ebd. 270, 276.

172 Dvořá K, Kokoschka (wie Anm. 87).

173 Vgl. den Beitrag von Alena Janatková in diesem Band. Außerdem: Oskar Kokoschka. Das Konzert. Variationen über ein Thema. Hommage à Kamilla Swoboda, hg. v. R. Gra f Betrusy-Huc (Salzburg 1988).

174 Vgl. dazu Aurenhammer, Dvořák über Kokoschka (wie Anm. 5).

175 Schon 1920 gestaltete Kokoschka in dem Gemälde ,Macht der Musik' dasselbe Thema, das er auch im Grafikzyklus variiert: nur ist es jetzt in einer monumentalen Allegorie mit wenigen Figuren gestaltet, nicht zersplittert in Einzelnotate psychischer Reaktion.

176 Dvoř́x, Geschichte der italienischen Kunst II (wie Anm. 153) 199.

177 Guido Kaschnitz von Weinberg, Alois Riegl: Spätrömische Kunstindustrie (Rezension von 1929), in: DERs., Kleine Schriften zur Struktur (Berlin 1965) 12. 
Kunstgeschichte ebenso wie für die expressionistische Ideologie grundlegenden Kategorie der "Wesensschau“ zugrunde liegt ${ }^{178}$. Nachfolge fand Dvořáks geistesgeschichtlicher Ansatz hingegen, sozusagen vom Kopf auf die Füße, vom idealistischen Überbau auf den Unterbau der Klassengesellschaft gestellt, in Tendenzen der marxistischen Kunstgeschichte, etwa bei seinem Schüler Frederick Antal ${ }^{179}$. In der Annahme einer direkten „Wesensschau" liegt zweifellos, das sollte die Kunstgeschichte der I920er- und I93oer-Jahre bis zum Überdruss beweisen, die Begrenztheit und die Gefährdung von Dvořáks Ansatz. Dennoch imponiert sein Zeit seines Lebens mit Konsequenz verfolgter Anspruch, die Nähe zur Eigenart der analysierten Kunstwerke mit einer allgemeinen geschichtsphilosophischen Perspektive zu verbinden und dabei die eigene Interpretation immer wieder in Auseinandersetzung mit der Kunst der Gegenwart zu überdenken und zu revidieren. Dvořák selbst spricht in Bezug auf die ihrer Endlichkeit und Geschichtlichkeit bewusst werdende historische Erkenntnis von einem „ununterbrochene[n] Weiterschreiten und eine[r] unerschöpfliche[n] Regeneration" 180 .

178 Ernst H. Goмв вich, Wertprobleme und mittelalterliche Kunst (1937), in: Ders., Meditationen über ein Steckenpferd. Von den Wurzeln und Grenzen der Kunst (Frankfurt/M. 1988) 131-139; Zum Verhältnis des frühen Gombrich zur Geistesgeschichte vgl. Hans Auren ham mer, Ernst Gombrich, Giulio Romano und die Neue Wiener Schule der Kunstgeschichte (im Erscheinen); Zur Denkfigur der „Wesensschau“ vgl. v. a. Regine Prange, Die erzwungene Unmittelbarkeit. Panofsky und der Expressionismus, in: Idea 10 (1991) 221-251.

179 Vgl. z. B. Frederick Antal, Florentine Painting and its Social Background. The bourgeois republic before Cosimo di Medici's Advent to Power: XIV and early XV centuries (London 1947); Dazu Károly Kóк AI, Impulse der Wiener Schule der Kunstgeschichte im Werk von Frederick Antal, in: Wiener Schule. Erinnerung und Perspektiven (= Wiener Jb. für Kunstgeschichte 53 (2004) 109-119.

180 Dvorák, Über die dringendsten methodischen Erfordernisse der Erziehung zur kunstgeschichtlichen Forschung, in: Wiener Jb. für Kunstgeschichte 27 (1974) 13f. (zuerst in: Die Geisteswissenschaften [Leipzig 1914]). 


\title{
Martin Wutte (I876-I948)
}

\author{
EIN K ÄRNTNER HISTORIKER UND DIE IĀNUSKÖPFIGKEIT IN DER \\ NATIONALEN FRAGE
}

\section{E I N LE IT UNG}

I. Es fällt schwer, der Auffassung zuzustimmen, dass Martin Wutte mit seiner wohl bekanntesten Publikation „Kärntens Freiheitskampf ${ }^{\prime \prime}$ zum Pionier der Zeitgeschichtsforschung in Österreich wurde². Leichter ist es, ihn als einen Vertreter jener österreichischen Geschichtswissenschaft zu klassifizieren, deren Tun nicht nur von wissenschaftlicher, sondern seit jeher von national- und/oder parteipolitischer Pflichterfüllung motiviert ist. Noch leichter ist es, nachzuweisen, dass Wuttes Schriften zur „nationalen Frage“ in Kärnten ${ }^{3}$ für mehrere Historiker- und Politikergenerationen Orientierungsmaßstab waren. „Kärntens Freiheitskampf" bildete dabei zweifellos lange Zeit die Kaiserstraße

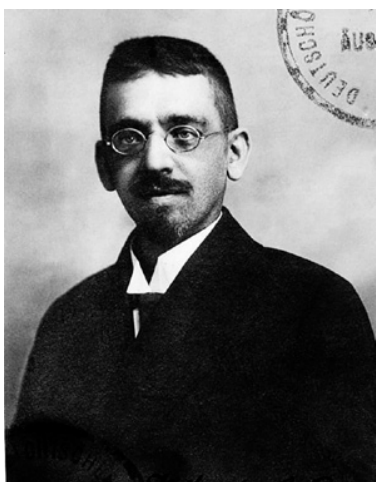

Abb. I6: Martin Wutte, um I9I9 der Landeshistoriografie. Die Auseinandersetzungen zur „nationalen Frage“ und damit zusammenhängend zu den Ereignissen rund um den „Kärntner Abwehrkampf“ scheinen nach wie vor ein Thema ad infinitum zu sein. Ein erster großer Konflikt brach, begleitet von medialem Getöse, I 969 aus. Anlass waren Thesen, die in Kärnten im Bildungshaus

1 Martin Wutte, Kärntens Freiheitskampf (Klagenfurt 1922; umgearbeitete und vermehrte Auflage Weimar 21943; verbesserter Neudruck der zweiten umgearbeiteten und vermehrten Auflage von 1943, Archiv für Vaterländische Geschichte und Topographie 69, Klagenfurt 1985). Dem Herausgeber Karel Hruza danke ich für eine ausgiebige redaktionelle Bearbeitung.

2 Wilhelm Neumann, Einleitung zur Neuauflage. Martin Wutte. Sein Leben und seine Leistung für Kärnten, in: Wutte, Freiheitskampf (1985) (wie Anm. 1) XV-XXIII, hier XVIII und XXIII.

3 Siehe dazu: Kärnten und die nationale Frage 1-5: 1 Aussiedlung - Verschleppung - nationaler Kampf, hg. v. Stefan Karner, Andreas Moritsch ( $\dagger) ; 2$ Nationale Frage und Öffentlichkeit, hg. v. Werner Drobesch, Augustin Malle; 3 Politische Festtagskultur - Einheit ohne Einigkeit?, hg. v. Ulfried Burz, Heinz-Dieter Poнl; 4 Kärnten und Wien. Zwischen Staatsidee und Landesbewusstsein, hg. v. Claudia Fräss-Ehrfeld, Helmut Rumpler ; 5 Kärnten und Slowenien - „Dickicht und Pfade“, hg. v. Stefan Karner, Janez SterGAR (Klagenfurt/Celovec/Ljubljana/Laibach 2005). 
Tainach/Tinje von Zunftkollegen aus Wien präsentiert worden waren. Zum einen wurde der Lehrsatz, wonach es ohne „Abwehrkampf“ keine Volksabstimmung gegeben hätte, infrage gestellt, zum anderen die Ansicht vertreten, dass das Plebiszit vom Io. Oktober 1920 von den damals politisch und militärisch führenden Akteuren weniger als ein Sieg für Österreich, sondern als ein Sieg für das Deutschtum betrachtet wurde. Damit lagen in Kärnten besondere Bedingungen vor, die auch eine Neubeurteilung der Geschichte Österreichs im Rahmen des nationalsozialistischen Großdeutschland erfordern. Diese Thesen entzündeten in den folgenden Jahrzehnten wiederholt heftige Dispute. Es waren Konfrontationen, die weder in der Diktion noch in der Argumentationsmethodik, weder in ihrem Umfang noch in ihrer Wirkung in der Öffentlichkeit, mit anderen Historikerkontroversen in Österreich vergleichbar sind; nicht zuletzt deshalb, weil diese Auseinandersetzungen von einer Redundanz gekennzeichnet sind. Um diese Haltung nicht zu kultivieren, sei lediglich eine Publikation angeführt, in der alle relevanten Studien, Monografien, Aufsätze mit Pro- und Kontrastimmen usw. zu diesem breiten Forschungsfeld angeführt sind ${ }^{4}$. Aus Aktualitätsgründen ist es angebracht, zu erwähnen, dass Schulbroschüren, Internetseiten des offiziellen politischen Kärnten und Diskussionsforen rund um die 90-Jahr-Jubiläumsfeier in Erinnerung an die Volksabstimmung zeigen, dass manche Interpretationen rund um die Jahre I9I 8 bis 1920 und weit darüber hinaus in der Zwischenzeit korrigiert oder andere Akzente gesetzt wurden.

2. In der Geschichtswissenschaft, die sich mit brisanten Themata der Kärntner Landeshistoriografie beschäftigt, wird nicht selten der Vorwurf laut, dass Ereignisse nur verkürzt dargestellt und/oder mithilfe reduzierter, sinnentstellender Belege das Bild vergangener Geschehnisse verfälschen. In dieser Studie wird deshalb mitunter in extenso zitiert.

3. Um der science community den Einstieg zu weiterführenden Forschungen zu erleichtern, werden dort, wo es dem Verfasser möglich war, entsprechende Wegweiser aufgestellt. Dabei sei an Ausführungen von Gerhard Roth, dem immer wieder an österreichischer Geschichte Leidenden ${ }^{5}$, erinnert, der über das Archivwesen pointiert sinnierte: „Jedes existierende Archiv ist ein Fragment dieses imaginären Gesamtarchives, ein schlafendes Gedächtnis, aus dem manches verdrängt, in dem manches zerfallen, zerbröselt, also vergessen, anderes durch seine Beamten manipuliert, gefälscht, entfernt wurde - das jedoch insgesamt noch immer ein codierter Aufbewahrungsort von allen Geschehnissen ist. “6

4 Die Kärntner Volksabstimmung 1920 und die Geschichtsforschung. Leistungen, Defizite, Perspektiven, hg. v. Hellwig Valentin, Susanne Haiden, Barbara Maier (Klagenfurt 2002).

5 Vgl. dazu Gerhard Rотн, Das doppelköpfige Österreich. Essays, Polemiken, Interviews, hg. v. Kristina Pfoser-Schewig. Mit einem Vorwort von Josef Haslinger und Kommentaren von Gerfried Sperd (Frankfurt/M. 1995).

6 Gerhard Roтн, Die Stadt (Frankfurt/M. 2009) 235. 
4. Der Beitrag versteht sich als ein Porträtentwurf ${ }^{7}$. Als Leitlinie dient ein Gedankengang von Marc Bloch, einem Zunft- und Zeitgenossen Wuttes: „Geschichte selbst sollte darauf verzichten, sich wie ein richtender Erzengel zu gebärden, sie könnte uns dann sogar helfen, von diesem Fehler abzulassen."

\section{RAHMENBEDINGUNGEN DER LANDESHISTORIOGRAFIE}

Sieht man von Spezifika rund um die „nationale Frage“ ab, gibt es zu historisch-politischen Themata der Kärntner Landesgeschichte grundsätzlich signifikante Kontroversen. Es sind zum einen Meinungsverschiedenheiten „zwischen der deutschnationalen und der 68erGeschichtsschreibung "9. Zum anderen ist es aber mehr als nur ein Generationenkonflikt „von der Gnade später Geburt voll Erfassten“"10 mit Zeitgenossen des langen I9. und kurzen 20. Jahrhunderts. Letzten Endes - cum grano salis - scheinen alle Divergenzen in der Frage zu münden, ob denn das „politische Kärnten“, ehemals selbstständiges Reichsherzogtum; das sechste im Deutschen Reich und zugleich das älteste auf österreichischem Territorium $^{11}$, nicht verspätet in Österreich angekommen ist. Die These vom „Sonderfall Kärnten“ innerhalb der österreichischen Republikgeschichte ist ausreichend nachvollziehbar $^{12}$. Der in Wien sozialisierte und seit 1975 vorwiegend an der Alpen-Adria-Universität

7 Der Verfasser hält sich weitestgehend an das vorgegebene Konzept dieses Sammelbandprojektes. Vgl. das Vorwort des Herausgebers, in: Österreichische Historiker 1900-1945. Lebensläufe und Karrieren in Österreich, Deutschland und der Tschechoslowakei in wissenschaftsgeschichtlichen Porträts, hg. v. Karel Hruza (Wien/ Köln/Weimar 2008) 10.

8 Marc Bloch, Apologie der Geschichte oder Der Beruf des Historikers, hg. v. Lucien Febrve (Stuttgart ${ }^{3}$ 1992) 137. Zur Entstehungsgeschichte ebd. die Einleitung von Friedrich J. Lucas (1974) $15 f$.

9 Ernst Hanisch, Der forschende Blick. Österreich im 20. Jahrhundert: Interpretationen und Kontroversen, in: Carinthia I, 189 (1999) 567-583, hier 568f.

10 Wilhelm Neumann, Zur Gegenwart von Vergangenheit - Arbeitsbericht zur Zeitgeschichte in Kärnten, in: Carinthia I, 195 (2005) 477-487, hier 486. Ausführlicher zum Generationenstreit mit entsprechenden Literaturverweisen: Ulfried BuRz, Geschichtsschreibung zwischen den Fronten. Nationalsozialismus in Kärnten Replik auf Peter Gstettner und Wilhelm Neumann, in: Kärntner Jb. für Politik 2003, 215-238, zu Neumann bes. 220-232; zur Reaktion Neumanns siehe DE Rs., Zur Gegenwart $485 f$.

11 Friedrich Leitner, Zeittafel, in: Broschüre zur Sonderschau 1000 Jahre Kärnten. Geschichte - Kultur Wirtschaft, hg. v. Amt der Kärntner Landesregierung, der Kammer der gewerblichen Wirtschaft für Kärnten, Geschichtsverein für Kärnten (Klagenfurt o. J. [1976]) 11; ferner: Das ist Kärnten. Geschichte, Bestand, Entwicklung, hg. v. der Kärntner Landesregierung, Konzept Otto Polley, Redaktion Trude Polley, Klagenfurt 1970) 30.

12 Eine konzise Zusammenfassung bei Hellwig Valentin, Der Sonderfall. Kärntner Zeitgeschichte 19182004/08 (aktualisierte und erweiterte Neuauflage Klagenfurt/Celovec/Ljubljana/Laibach/Wien/Dunaj 2009) $15 f$. 
Klagenfurt lehrende, nunmehr emeritierte Ordinarius für Neuere und Österreichische Geschichte, Helmut Rumpler, spannt den zeitlichen Bogen weiter: „Im Rückblick auf die Geschichte findet sich vieles, was die politische Zugehörigkeit Kärntens zu Österreich als ungerechtes Schicksal, als Belastung, ja als Unglück erscheinen lässt. [...] Die Kärntner Geschichtsschreibung hat, dem politischen Empfinden einer breiten Öffentlichkeit folgend, dieses Geschichtsbild vertieft und aus der historischen Verbindung Kärntens mit Österreich eine durch diese Verbindung verursachte ,Leidensgeschichte ${ }^{\text {'13 }}$ gemacht. " ${ }^{14}$ Unabhängig davon, dass Rumpler hinsichtlich des Zeitrahmens der „Passionsgeschichte“ vage bleibt, ließen sich für die Zeit nach der I 848er-Revolution bis in die jüngere Gegenwart zahlreiche Belege bringen, die die Einschätzung des „Österreich-Historikers“ stützen. Ob die generalisierende These auch bei einer Gesamtbeurteilung der politischen Geschichte vor dem Revolutionsjahr I 848 haltbar ist, wäre aber noch breiter auszuleuchten. Niemand Geringerer als Wutte, dessen Bild vom politischen Österreich des späten I 9. und mittleren 20. Jahrhunderts markant von einem gesamtdeutschnationalen Denken überlagert war, relativiert in einem I94I veröffentlichten inhalts- und aufschlussreichen Aufsatz die Vorstellung von einer seit I 335 andauernden Leidensgeschichte. Der Kärntner Historiker spricht ausdrücklich von hausgemachten Fehlentwicklungen im Lande und zeigt Verständnis für die Reformen der „Kaiserin“ Maria Theresia ${ }^{15}$. Und dass diese Regentin eine bedeutungsvolle Symbolgestalt für das zugegeben schwer definierbare „Österreichtum“16 schlechthin ist, dürfte in Historikerkreisen keinen Proteststurm auslösen.

Dass die Verbindung zwischen Kärnten und Österreich mehr einer temporären Poussade gleichkommt, deutete 1985 Alfred Ogris, damals Kärntner Landesarchivdirektor, $\mathrm{an}^{17}$ : „Vom Jahre I9I 8, dem Ende der österreichisch-ungarischen Monarchie, spannt sich

13 Helmut Rumpler, Kärnten und Österreich. Eine unbeglichene historische Rechnung, in: Liebe auf den zweiten Blick. Landes- und Österreichbewußtsein nach 1945, hg. v. Robert Kriech B Aume R (Schriftenreihe des Forschungsinstituts für politisch-historische Studien der Dr. Wilfried-Haslauer-Bibliothek 6, Wien/Köln/ Weimar 1998) 141-148, hier 144.

14 Helmut Rumpler, Die nationale Frage im Spannungsfeld von kärntnerischem Landespatriotismus, österreichischem Staatsbewusstsein und völkischem Nationalismus 1918-1938, in: Kärnten und die nationale Frage 4 (wie Anm. 3) 9-82, hier 10.

15 Martin Wutte, Beiträge zur Verwaltungsgeschichte Kärntens, in: Carinthia I, 131 (1941) 86-120, hier 119.

16 Jüngst dazu eine Sicht von außen: William M. Johnston, Der österreichische Mensch. Kulturgeschichte der Eigenart Österreichs (Studien zu Politik und Verwaltung 94, Wien/Köln/Graz 2010). Der US-Historiker, ausgewiesener Kenner der österreichischen Kulturgeschichte, hat 370-373 eine „Allgemeine Bibliographie zum Österreichertumsdiskurs 1910-1967“ und 339-367 eine „Bio-Bibliographie der Essayisten zum Österreichertum" zusammengestellt.

17 Zu Ogris siehe Wilhelm WAdL, „Porträt eines Vielseitigen“, in: Kärntner Landesgeschichte und Archivwissenschaft. FS für Alfred Ogris zum 60. Geburtstag, hg. v. DEms. (Archiv für Vaterländische Geschichte und Topographie 84, Klagenfurt 2001) 13-20. 
aber auch eine weite Brücke zurück ins Jahr I 335, als die Habsburger am 2. Mai dieses Jahres von Kaiser Ludwig dem Bayern die Belehnung mit Kärnten, dem ältesten der österreichischen Herzogtümer, erwirken konnten. Dieses historische Ereignis, das da und dort fälschlicherweise zum gedankenlosen Schlagwort ,Kärnten 650 Jahre bei Österreich gedieh, war die Voraussetzung für den teilweisen Gleichschritt, in den die Kärntner Geschichte später mit der österreichischen geriet und als deren Spätfolgen zweifellos auch die Ereignisse in Kärnten nach dem Ersten Weltkrieg zu betrachten sind. "18

Geteiltes Leid ist bekanntlich halbes Leid und vermutlich kommt deshalb in der Konfrontations- und politischen Festtagskultur Kärntens mehr als in anderen Bundesländern ein Kollektivismus zum Tragen ${ }^{19}$. Termini wie „Heimattreue“, „Landesbewusstsein“20 und „Landespatriotismus“ sind bei politischen Festtagen ein fester Bestandteil des Wortschatzes im öffentlichen Raum, wie auch Hinweise auf Einzigartigkeiten des Landes, wo „Pomonens schönster Tempel steht“21. Wieweit ein derartiges Selbstbewusstsein ein Spezifikum der Kärntner Gesellschaft widerspiegelt oder ein konstitutiver Faktor eines jeden österreichischen Bundeslandes im Verhältnis zum politischen Zentrum Wien ist, das ist bis heute allerdings nicht systematisch erforscht worden. Für und in Kärnten drängt sich die Frage auf, ob einer der herausragendsten Landeshistoriografen, Martin Wutte, der seiner Heimat nahezu bedingungslos verbunden war, tatsächlich nur dem „politischen Empfinden einer breiten Öffentlichkeit" gefolgt war oder ob er nicht selbst initiativ Geschichtsbilder vorgegeben hat.

Der Kronzeuge, der aktiv in einem zentralen Hauptkapitel der „nationalen Frage“ - Grenzkampf und Volksabstimmung - als geistiger Mitstreiter involviert war, nahm zur Wechselbeziehung von Politik und Wissenschaft jedenfalls einen klaren Standpunkt ein. I 946 konsta-

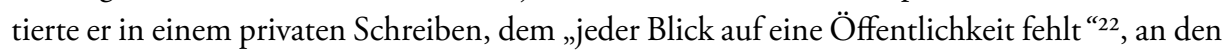

18 Alfred Ogris, Vorwort in: Wilhelm WadL, Das Jahr 1945 in Kärnten (Klagenfurt 1985) 5f.

19 Beispielsweise: „Die Kärntner Geschichtswissenschaft würde sich einer schweren Unterlassungssünde schuldig machen, wollte sie zu dieser von außen in das Land hereingetragenen Diskussion, die beträchtliche Unruhe auslöste, nicht Stellung nehmen." Wilhelm Neumann, Abwehrkampf und Volksabstimmung in Kärnten 1918-1920. Legenden und Tatsachen (Kärntner Landesarchiv 2, Klagenfurt ${ }^{2} 1985$ ) 9; ferner DE Rs., in: Carinthia I, 166 (1976) 78; Beipiele für Reaktionen im Kollektiv, in: Carinthia I, 183 (1993) 670; ebd., 185 (1995) 611-612.

20 Vgl. dazu Claudia Fräss-Ehrfeld, Das Kärntner Landesbewußtsein, in: Kärnten. Von der deutschen Grenzmark zum österreichischen Bundesland, hg. v. Helmut Rumple R unter Mitarbeit v. Ulfried Burz (Geschichte der österreichischen Bundesländer seit 1945, Schriftenreihe des Forschungsinstitutes für politischhistorische Studien der Dr. Wilfried-Haslauer-Bibliothek Salzburg 6/2, Wien/Köln/Weimar 1998) 777-801.

21 Teilvers der dritten Strophe des „Kärntner Heimatliedes“ (Landeshymne).

22 Wilhelm Neumann, Martin Wutte und sein Urteil über die nationalsozialistische Slowenenpolitik in Kärnten und Krain aufgrund seiner Denkschrift vom 19. September 1943, in: Carinthia I, 176 (1986) 9-40, hier 22. 
literarischen „Wort-Führer Kärntens“23, Josef Friedrich Perkonig: Ich habe auch später immer wieder meine eigene Meinung vertreten, auch vor [Friedrich] Rainer ${ }^{24}$, so z. B. den Grundsatz, daß die Wissenschaft der Politik vorausgehen müsse und nicht umgekehrt. ${ }^{25}$

Der Standpunkt des Geisteswissenschaftlers ist nicht nur im Allgemeinen, sondern im Detail bedeutungsvoll, wenn in Erinnerung gerufen wird, was Wutte rund eineinhalb Dezennien zuvor geschrieben hat: „Die Landesregierung stimmte daher durch Beschluß vom 25. Februar 1925 dem Vorschlage der Direktion des Landesarchives auf Vereinigung des Landesregierungsarchives mit dem Landesarchive grundsätzlich unter der Bedingung zu, daß der Landesregierung auch künftighin ein sicherer Einfluss auf die Besetzung der Beamtenstellen im Archive zukomme. ${ }^{26}$ Die veröffentlichte Bemerkung ${ }^{27}$ des historisch-politisch gebildeten Gelehrten deutet die Verwobenheit zwischen einer wichtigen gesellschaftspolitischen Institution in Kärnten mit der Landespolitik an. Es ist eine Landespolitik, in der im Landtag seit I 86 I zur Volksgruppenfrage seit jeher klare Kräfteverhältnisse vorherrschen und parteiübergreifend mehr oder weniger kongruente politische Wege beschritten wurden. Das gilt nicht nur für das deutschnationale, deutschfreiheitliche oder das bürgerlichkonservative, sondern auch für das sozialistische respektive sozialdemokratische Lager ${ }^{28}$.

\section{ALte UND NEUE WEgE ZUR (AUTO-)Biografie WUTtES}

Der Untertitel dieses Beitrags enthält eine These. Aus Verständnisgründen ist eine Vorbemerkung angebracht: In der seit republikanischer Zeit belegten römischen Ikonografie

23 Vgl. Klaus Amann, Der Wort-Führer Kärntens. Josef Friedrich Perkonig und der „Anschluß“, in DERs., Die Dichter und die Politik. Essays zur österreichischen Literatur nach 1918 (Himberg 1992) 133-151.

24 Zu Rainer (u.a. Gauleiter von Salzburg und Kärnten, Reichsstatthalter, Oberster Kommissar der Operationszone Adriatisches Küstenland) siehe: Maurice Williams : Gau, Volk und Reich. Friedrich Rainer und der österreichische Nationalsozialismus. Eine politische Biographie nach Selbstzeugnissen, deutsche Bearbeitung v. Ulfried Burz, Claudia Fräss-Ehrfeld (Archiv für Vaterländische Geschichte und Topographie 90, Klagenfurt 2005).

25 Wutte an Perkonig, zitiert nach Neumann, Urteil (wie Anm. 22) 22.

26 Martin Wutte, 25 Jahre Kärntner Landesarchiv, in: Carinthia I, 119 (1929) 112-134, hier 122; vgl. Alfred OgRIs, 100 Jahre Kärntner Landesarchiv, in: 100 Jahre Kärntner Landesarchiv 1904-2004, hg. v. DEms. (Carinthia I, 194, 2004) 15-33, hier 26.

$27 \mathrm{Zu}$ Strategien öffentlich-politischer Partizipation vgl. Rolf-Bernhard Essıg, Der Offene Brief. Geschichte und Funktion einer literarischen Form von Isokrates bis Günter Grass (Würzburg 2000).

28 Zur Kärntner Spielart des Sozialismus, der sich in der „nationalen Frage“ von Anbeginn im Windschatten deutschnationaler Politik bewegte: Hellwig Valentin, Nationalismus oder Internationalismus? Arbeiterschaft und nationale Frage mit besonderer Berücksichtigung Kärntens 1918-1934 (Archiv für vaterländische Geschichte und Topographie 83, Klagenfurt 2000); Knut Lenmann-Horn, Meist erfolgreich. 44 Jahre Landeshauptmannpartei SPÖ Kärnten 1945-1989 (Klagenfurt 2003). 
wird der Iānuskopf vorwiegend mit zwei, manchmal aber auch mit vier bärtigen Gesichtern dargestellt. Im Kult der antiken Gesellschaft hatte diese römische Gottheit, die in der griechischen Entsprechung kein Pendant kennt, eine „praktisch ausschließlich“ öffentlich-politische Funktion. Der Mythos kürt Iānus zu einer urrömischen Gottheit, den Urkönig von Latium, „der über die Aborigenes herrscht und in seinem Palast auf dem Ianiculum den nach Westen geflohenen Saturnus aufnimmt, der den Ackerbau und damit die Zivilisation nach Latium bringt“. Die Doppelköpfigkeit gilt als Symbol für Anfang und Durchgang, für Ein- und Ausgänge, für Türen und Tore, für Pro und Kontra, später im öffentlichen Bewusstsein auch als Ausdruck für Zweigesichtigkeit. Eine Iānus-Statue, eine der ältesten Roms (2. Jh. v. Chr.), trug als Attribute einen Schlüssel und einen $\operatorname{Stab}^{29}$.

Wutte ist im Zusammenhang mit der „nationalen Frage“ in Kärnten zweifellos ein bedeutender Schlüsselträger. Sein mehrmals publiziertes Opus eximium „Kärntens Freiheitskampf“30, das argumentativ an die jeweiligen Zeitumstände angepasst wurde, bildet dabei das Hauptportal. Zahlreiche andere Publikationen Wuttes eröffnen rund um die „nationale Frage“ weitere Zugänge zum Selbstverständnis eines Teiles der „Kärntner Wissenschaft“31. Es kommt daher nicht von Ungefähr, dass Wutte immer wieder im Fokus zahlreicher Kontroversen zur jüngeren Kärntner Landesgeschichte stand, aber auch im Mittelpunkt von Würdigungen, wie auch von mitunter überzogenen Polemiken ${ }^{32}$. Und

29 Fritz Graf, Ianus [sic] in: Der Neue Pauly. Enzyklopädie der Antike 5: Gru-Iug, hg. v. V. Hubert Cancik, Helmuth Schneider (Stuttgart/Weimar 1998) Sp. 858-861, hier Sp. 859.

30 Wie Anm.1.

31 Dieser Terminus dürfte von Wilhelm Neumann (1968-1980 Direktor des Kärntner Landesarchivs) stammen, siehe Wilhelm Neumann, Tausend Jahre Kärnten - kein Anlaß zur Diskussion!, in: Carinthia I, 166 (1976) 73-80, hier 74. Wer, vor allem unter welchen Kriterien, der „Kärntner Wissenschaft“ zuzurechnen ist, das erläutert Neumann genauso wenig wie Martin FritzL, „Für Volk und Reich und deutsche Kultur“. Die „Kärntner Wissenschaft“ im Dienste des Nationalismus (Disertacije in razprave 29/Dissertationen und Abhandlungen 29, Klagenfurt/Celovec 1992) bes. 33-117, der diesen Terminus unter Anführungszeichen verwendet.

32 Würdigungsschriften und kontroversielle Standpunkte zu Wutte (in Auswahl) : Die erste umfangreiche schriftliche Laudatio wurde anlässlich des 60. Geburtstages Wuttes in Form einer Festschrift (Archiv für vaterländische Geschichte und Topographie 24/25, Klagenfurt 1936) veröffentlicht. Post mortem wurde dem Gelehrten in der Carinthia I, 139 (1949) im Vorwort von Gotbert Moro, 8-10 in einem Nekrolog von Hans Pirchegger, „Mein Freund Martin Wutte“, und 10-12 durch Josef Gölles, Martin Wutte zum Abschied. Grabrede des Direktors des Geschichtsvereines für Kärnten, Anerkennung gezollt. Zur Würdigung Wuttes siehe auch: Martin Wutte (1876-1948) zum Gedächtnis. FS zur Anbringung der Gedenktafeln in Klagenfurt und Obermühlbach (Klagenfurt 1988). Wissenschaftliche Standards missachtend und mitunter in der Kritik überzogen ist FritZl, „Die „Kärntner Wissenschaft“ (wie Anm. 31), zu Wutte bes. 33-117. Deutlich differenzierter, aber mit einer methodischen Unzulänglichkeit - Vernachlässigung des Zeitrasters - üben Kritik an Wutte: Karl Stuhlpfar rer, Volksabstimmungsfeiern und Geschichtsbild, in: Kärnten. Volksabstimmung 1920. Voraussetzungen. Verlauf, Folgen (Studien zur Geschichte und Gesellschaft in Slowenien, Österreich 
trotzdem ist eine umfassende Biografie des gebürtigen Kärntners bis heute ein Desideratum. Grobe Bausteine zum Werdegang Wuttes und dessen Stellenwert in der Kärntner Historiografie hat Peter Tosoni in seiner im Jahr 1966 an der Universität Graz approbierten Doktorarbeit zusammengetragen ${ }^{33}$. Diese informiert über verschiedene Funktionen und Tätigkeiten Wuttes, dessen Schulzeit, Studium und Wirken als Lehrer. Sie gibt Einblicke in den Arbeitsalltag des Gelehrten und fürsorglichen Familienmenschen ${ }^{34}$. Darüber hinaus enthält die akademische Schrift eine chronologische Zusammenstellung aller vom Historiker und Geographen verfassten Arbeiten. Das Schriftenverzeichnis wurde „durchgesehen, verbessert und ergänzt so daß es jetzt als vollständig gelten kann". ${ }^{35}$

Der interpretative Teil der Dissertation ist von einer hagiografieähnlichen Diktion geprägt. Eine eigenständige Interpretation der Schriften Wuttes unterblieb. Wuttes I947 verfasstes Curriculum vitae Mein Lebenslauf wurde von Tosoni unreflektiert übernommen. Dem Dissertanten stand dabei die vollständige Version des Autografs zur Verfügung und nicht nur jener „Lebenslauf“, der nach einer „von der Schriftleitung getroffene[n] Auswahl“ erstmals 1949 publiziert wurde ${ }^{36}$. Im Jahr 2004 begründete einer der wirkungsmächtigsten Fürsprecher Wuttes, der unlängst verstorbene Wilhelm Neumann ${ }^{37}$, diese Maßnahme. Der Lebenslauf Wuttes „wurde in der Carinthia I I949, um nationalpolitisch bekennende Passagen gekürzt, gedruckt, kaum aus Zensurrücksichten auf die Besatzungsmacht, eher, um die damals anlaufende internationale Diskussion der Kärntner Grenzfrage nicht zu belasten; unsere I 988 verfaßte Gedächtnisschrift ${ }^{38}$ bietet den vollständigen Text“-39

Der zwar ausgewiesene, aber nicht näher erläuterte Texteingriff bei der Erstveröffentlichung von Wuttes Autobiografie unterminiert ein wissenschaftliches Grundprinzip, näm-

und Italien 1, Wien/München/Kleinenzersdorf 1981) 13-25; Hanns HAAs, Kärnten 1919. Eine österreichische Kontroverse, in: Neues Forum, Dezember 1972, 45-49. Siehe zuletzt auch Fritz Fellner, Doris A. Corradini, Österreichische Geschichtswissenschaft im 20. Jahrhundert. Ein biographisch-bibliographisches Lexikon (VKGÖ 99, Wien 2006) 465f.

33 Der Dissertant wurde dabei vom damaligen Direktor des Kärntner Landesarchivs Gotbert Moro und Ilse Manhart unterstützt, die nicht nur eine graduierte Historikerin, sondern auch die jüngste Tochter Wuttes ist. Ilse Manhart hat Tosoni „zahlreiches Material zur Verfügung“ gestellt, siehe Peter Tosoni, Martin Wutte Leben und Werk eines Kärntner Historikers (Diss. Graz 1966) Vorwort.

34 Dazu Tosoni, Wutte (wie Anm. 33) 57-60.

35 Ebd. 120. Hervorhebung nach Vorlage.

36 Martin Wutte, Mein Lebenslauf, in: Carinthia I, 139 (1949) 3-7.

37 1968-1980 Direktor des Kärntner Landesarchivs. Zur Selbstdarstellung siehe Wilhelm Neumann, Mein Weg als Landeshistoriker und Archivar, in: 100 Jahre Kärntner Landesarchiv (wie Anm. 26) 47-59; DERs., Erinnerungen an Krieg und Gefangenschaft 1939-1947, in: Carinthia I, 199 (2009) 607-639.

38 Martin Wutte, Mein Lebenslauf, in: Martin Wutte (1876-1948) zum Gedächtnis (wie Anm. 32).

39 Neumann, Mein Weg (wie Anm. 37) 47. Der Vollständigkeit halber ist anzumerken, dass 1988 in der genannten Festschrift (wie Anm. 32) in der Autobiografie Wuttes zwei Jahresangaben korrigiert wurden: vgl. Wutte, Lebenslauf 1949 (wie Anm. 36) 4f., und Ders., Lebenslauf 1988 (wie Anm. 38) 13. 
lich die Quellenkritik. Das ist ein Beleg für die Vorstellung, wonach Geschichtsschreibung eine staats- oder landespolitische Zweckfunktion zu erfüllen hat. Im gegenständlichen Fall mag das daran liegen, dass Wutte selbst eine unmissverständliche Auffassung von einer Funktion des Forschungsgegenstandes Geschichte hatte. Noch nach seinen Erfahrungen mit dem politischen Alltag in der Habsburgermonarchie, in der Ersten Republik, im Dollfuss-Schuschnigg-System, im „Großdeutschen Reich“, in der beginnenden Zweiten Republik, hält der Historiker in seinem Lebenslauf unbeirrt fest: „1907 bis 1938 war ich ehrenamtlicher Sekretär des Geschichtsvereines, dem der kulturhistorische Teil des Landesmuseums gehörte. I9I4 bis I938 leitete ich ehrenamtlich die Mitteilungen des Geschichtsvereines, die Carinthia I. Die großen, anscheinend entscheidenden Ereignisse, denen wir entgegengingen, riefen in mir die Überzeugung wach, daß auch die Geschichtsforschung der Gegenwart dienen müsse ${ }^{40}$. Darum war ich bestrebt, nicht bloß selbst so viel als möglich solche Probleme zu behandeln, die die Zustände und Ereignisse der Gegenwart aus der Vergangenheit erklären, sondern auch Mitarbeiter für derartige Studien zu gewinnen. Solche Mitarbeiter fanden sich nicht bloß für die Carinthia I, sondern auch für verschiedene Gemeinschaftsarbeiten." ${ }^{41}$ Der Standpunkt des Historikers, der sich an einer zweckbestimmten Geschichtsforschung orientierte, deckt sich mit jenen Ansichten, die für die Nationalgeschichtsschreibung des ausgehenden 19. bis zur Mitte des 20. Jahrhunderts richtungweisend waren; - die Schriftleitung der Carinthia war dieser Tradition offensichtlich noch im Jahr I 949 verpflichtet.

Der Eingriff in ein vom Autor selbst verfasstes Curriculum vitae ist aus zwei Gründen schwerwiegend. Erstens, weil eine eigenhändig geschriebene Lebensgeschichte nicht nur über den beruflichen oder privaten Werdegang einer Person, naturgemäß aus deren subjektiver Sichtweise, Auskunft gibt, sondern auch über besondere Interessen, Hobbys, politische Aktivitäten und Weltanschauungen informieren kann. Zweitens: das Autograf, am Lebensabend erstellt, ist eine authentische Quelle erster Ordnung, die entscheidende Informationen enthalten kann, um mögliche Bekenntnisse oder Rechtfertigungen in ein größeres Ganzes einzuordnen. Im Nachlass Wuttes war eine Instruktion, die darauf abzielte, eine allfällige Veröffentlichung des Lebenslaufes an politische Gegebenheiten anzupassen, nicht auffindbar ${ }^{42}$.

$40 \mathrm{Zu}$ den postulierten Gegenwartsaufgaben der Geschichtswissenschaft vgl. Fritz Fellner, Geschichtsschreibung und nationale Identität. Probleme und Leistungen der österreichischen Geschichtswissenschaft (Wien/ Köln/Weimar 2002) bes. 13-35 und 145-172.

41 Wutte, Lebenslauf 1949 (wie Anm. 36) 6.

42 Im Typoskript (Kopie !) sind acht Auslassungszeichen bei Absätzen bzw. Zeilen eingefügt, die im Erstdruck von „Mein Lebenslauf“ fehlen. Wer diese Korrekturzeichen setzte, konnte nicht eruiert werden. Vgl. KLA, NL Wutte (= künftig NLW) Schachtel 1,6. In seinem Testament hielt Wutte fest: Der wissenschaftliche, handschriftliche Nachlass gehört dem Geschichtsverein, ebenso die dem Landesarchiv zur Aufbewahrung übergebene Sammlung 
Exkurs zum Nachlass und der Sammlung Wutte: Der umfangreiche „wissenschaftliche Nachlass“ Wuttes befindet sich heute im Kärntner Landesarchiv und erreichte diese Institution stufenweise: im Mai 1986 war es ein Teil mit einem summarischen Verzeichnis, jedoch ungeordnet; im Juni I 990 und Juni 1996 folgten weitere Materialien; im Mai 2009 übermittelte ein Enkel Wuttes dem Geschichtsverein für Kärnten „formlos“ einen Restbestand aus dem wissenschaftlichen Nachlass; - Übersetzungen von Akten der jugoslawischen Friedensdelegation (1919). Der Kärntner Geschichtsverein übergab dieses Schrifttum „mit Beschluss vom 2 I. April 2009“ (!) im selben Jahr dem Kärntner Landes$\operatorname{archiv}^{43}$. Schon der voluminöse Nachlass-Katalog ${ }^{44}$ dokumentiert das ungemein große Arbeits- und Wirkungsfeld Wuttes: eine enorme Publikationstätigkeit zu einer Zeit, wo es keine Unterstützung durch elektronische Hilfsmittel gab; eine Sammelleidenschaft von für die Geschichtsforschung relevanten Materialien; einen sich weit erstreckenden Briefverkehr mit dem In- und Ausland, wobei auffällt, dass die Jahreskorrespondenz ab I 938 im Vergleich zur vorangegangenen deutlich geringeren Umfang hat ${ }^{45}$. Persönliche Dokumente Wuttes, wie Dekrete, Zeugnisse und ein „Meldungsbuch“, die sein erster Biograf als Belegstellen anführt, sind nicht in diesem Nachlass enthalten ${ }^{46}$.

Wutte selbst hat in den Jahren I 943 und I 945 eine „Volkspolitische Sammlung“ dem Kärntner Landesarchiv unter Wahrung des Eigentumsrechts überlassen. Im Zuge der Übersiedlung des Kärntner Landesarchivs in einen Neubau „wurde der ursprünglich aus

Wutte und die nationalpolitischen Druckschriften, ausgenommen jene, die meine Kinder behalten wollen. Siehe NLW, Schachtel 1,7 (Kopie des Testaments).

43 Wilhelm WAdL, Einleitung, in: KLA 684, Katalog Nr. 258 (NLW) Mai 2009, 2f.

44129 Din-A4-Seiten. „Entstehungszeit/Laufzeit: 1900 ca. bis 1949, Umfang: 47 Archivkartons, 9 Großformat-Mappen; ca.12 flm. “ Das Inhaltsverzeichnis des Katalogs weist aus (Stand 16.06.2009): Lebensdokumente. Wissenschaftliche Korrespondenz. Politische Korrespondenz. Privatkorrespondenz. Werkmanuskripte - Vorträge. Werkmanuskripte - Materialsammlungen. Materialsammlungen - Zettelsammlungen. Materialsammlungen - handschriftl. Notizen - Korrespondenz. Materialsammlungen zu folgenden Bereichen : Ortsgeschichte, Territorialgeschichte, Wirtschaft, Verfassung und Verwaltung, Kärnten, Nationalpolitisches, Landgerichte, Persönlichkeiten, Verwaltungsgeschichte Kärntens. Veröffentlichungen Wuttes. Sammlungen - Zeitungen. Zeitungsausschnitte. Sammlungen - Slowenische Propagandaschriften. Übersetzungen von slowenischen Abhandlungen betreffend Kärnten. Sammlung Kärntner Volksabstimmung. Varia. Sonderdrucke (nicht von Wutte). Varia, Duplikate. Zeitungen und Zeitungsausschnitte (meist Artikel Wuttes). Karten. Belgrader Akten. Angaben nach: KLA, 684, Katalog Nr. 258 (NLW).

45 Der - nachweisbare - Briefverkehr Wuttes mit dem langjährigen Freund Hans Pirchegger erstreckt sich nur auf den Zeitraum 1918 bis 1934 . Weiterführende Erkenntnisse könnte der Nachlass Pirchegger, der im Landesarchiv Steiermark aufbewahrt wird, liefern. Siehe dazu Alois Ke r n B Aue R, Hans Pirchegger (1875-1973). „Der“ Landeshistoriker, in: Österreichische Historiker (wie Anm. 7) 225-246.

46 Unter „Ungedruckte Quellen“ führt Tosoni, Wutte (wie Anm. 33) I I9, an: „Die Bestände des Familienarchivs Wutte, Klagenfurt. Der Nachlaß Wuttes, im Landesarchiv Kärnten, dessen Benützung mir von Hofrat Dr. G. Moro ausnahmsweise gestattet wurde.“ 
elf Faszikeln bestehende Bestand in 27 Archivkartons, Überformate in zwei Großformatfaszikel verpackt“. Bei diesem Schrifttum handelt es sich um „(Zeitungen, Zeitungsausschnitte, Broschüren, handschriftliche Notizen, Übersetzungen aus slowenischen Publikationen und Pressemedien) hauptsächlich zu den Themenbereichen: Erster Weltkrieg, Kärntner Abwehrkampf und Volksabstimmung, Friedenskonferenz in Paris, Minderheitenproblematik, Bevölkerungsstatistik, Deutschtumspflege“. Später wurde dieser Bestand ergänzt, 2005 neu verzeichnet, 2006/2007 revidiert $^{47}$.

\section{VON DER „GESCHICHTE IM ICH“ ZUM „ICH IN DER GESCHICH T E“ 48}

Einschätzungen und Klassifikationen zu Wutte, sowohl von Fürsprechern als auch Kontrahenten, erfolgten bis 1988 auf der Basis seiner Publikationen und des verkürzten Autografs. Biografische Selbstbeschreibungen - vorwiegend in der westeuropäischen Frühneuzeitforschung als „Ego-Dokumente“ bezeichnet - geben, kurz gesagt „Auskunft über die Selbstsicht eines Menschen“, allgemeiner formuliert: ein Mensch deklariert oder verbirgt sich gezielt ${ }^{49}$.

Ein Vergleich zwischen der verkürzten Fassung und dem vollständigen Lebenslauf Wuttes sowie Ergänzungen und Fragestellungen erlauben es, Konturen seiner Psychografie zu schärfen. Im ersten Abschnitt von „Mein Lebenslauf“50 umreißt der Verfasser

47 Wilhelm WadL, in: KLA 683, Katalog Nr. 235, (Sammlung Wutte) 3f.

$48 \mathrm{Vgl}$. Michael Mitter auer, Lebensgeschichte sammeln. Probleme um Aufbau und Auswertung einer Dokumentation zur popularen Autobiographik, in: Biographieforschung. Gesammelte Aufsätze der Tagung des Fränkischen Freilandmuseums am 12. und 13. Oktober 1990, hg. v. Hermann Heidrich (Bad Windsheim 1991) 17-35, zitiert nach: Vom Lebenslauf zur Biographie. Geschichte, Quellen und Probleme der historischen Biographik und Autobiographik, hg. v. Thomas Win ke Lbauer (Schriftenreihe des Waldviertler Heimatbundes 40, Waidhofen an der Thaya 2000) 175.

49 Winfried Schulze, Ego-Dokumente. Annäherung an den Menschen in der Geschichte? Vorüberlegungen für die Tagung „Ego-dokumente“, in: Ego-Dokumente. Annäherung an den Menschen in der Geschichte?, hg. v. DEMs. (Quellen und Darstellungen zur Sozial- und Erfahrungsgeschichte 2, Berlin 1996) 11-30, hier 14 .

50 Darin sind biografische Eckdaten enthalten: 15.12.1876 geboren als ältester Sohn - neben weiteren sieben Geschwistern - des Bauern Martin Wutte in Obermühlbach (Gemeinde Frauenstein) und der Anna Wutte, geb. Ertl. Die Vorfahren Wuttes gehörten überwiegend dem Bauern- und Gewerbestand an. Wutte absolvierte seine Volksschulzeit in Obermühlbach. Dem Wunsche der Mutter folgend - Wutte sollte Pfarrer werden besuchte der Jugendliche unterstützt von einem hochachtbaren Priester, Pfarrer Johann Ubelacker, anschließend 1888/89-1891/92 das fürstbischöfliche Knabenseminar „Marianum“ in Klagenfurt, ab 1892/93 das Widmaneum in Villach, ab 1893/94 Zögling dieses Konvikts, legte er an dieser Bildungsanstalt 1896 die Reifeprüfung mit Auszeichnung ab. Es folgte das Studium der Geschichte und - zunächst - Germanistik, und 
seine Familiengeschichte. Über den gleichnamigen Vater erfährt der Leser zwar, dass dieser „hochangesehen und zwanzig Jahre Bürgermeister von Obermühlbach“ war. In welchem Zeitraum der höchste politische Repräsentant die Gemeinde vertrat und welcher Ideologie er verbunden war, bleibt aber gegenstandslos. Martin Wutte senior, der I908 verstarb $^{51}$, dürfte eine ausreichende Steuerleistung erbracht haben, denn diese Bedingung oder die Erfüllung von bestimmten Bildungs-Kriterien, die Zugehörigkeit zur Aristokratie, zum Klerus, dem Offiziersstand, oder eine Ehrenbürgerschaft oder Mitgliedschaft in einer politischen Gemeinde waren bis 1907 Voraussetzung dafür, um überhaupt aktiv oder passiv ein Wahlrecht ausüben zu können. Obwohl der Gasthof des Vaters, laut Auskunft des Sohnes, gut besucht wurde, hatte die zehnköpfige Familie wegen notwendiger Bauprojekte große Schulden. „I935 ging das väterliche Anwesen in fremde Hände über“, ein Ereignis, das Wutte „sehr schwer“ trafs2.

Die Schilderung des Alltags im väterlichen Gastronomiebetrieb erschließt einen weiteren Abschnitt der Sozialisationsgeschichte des Landeshistorikers ${ }^{53}$. Für Wutte dürfte der zweimal genannte Schiller ein Vorbild gewesen sein. Der Repräsentant der Weimarer Klassik, wie Wutte studierter Historiker, zudem weithin bekannter Schriftsteller, war Vertreter eines Ideals, das auf Moralität, Neigung zur Pflicht, der Betonung der Freiheit - was immer das auch sein mag - u.a. immer wieder rekurrierte. Schiller, der in breiten Kreisen, weit über das deutsche Bürgertum hinaus, höchste Anerkennung fand, war

dann der Geografie an der Universität Graz. Tätigkeiten als zweiter Assistent beim Geografen Eduard Richter; 1901 Erwerb des Doktorats der Philosophie, 1902 der Lehrbefähigung für Geschichte und Geografie, 1904 für den Unterricht in deutscher Sprache im Untergymnasium; 1902 Heirat mit Ernestine Hoffmann, Lehrerin in Graz: Dem glücklichen Lebensbund entsprossen vier Mädchen, wovon eines wenige Tage nach der Geburt starb; 1901 bis 1903 Supplent an der Oberrealschule (Keplerstraße) in Graz; 1903/1904 Unterrichtstätigkeit an der Lehrerbildungsanstalt in Marburg; ab 1904 am Gymnasium (heute Europagymnasium) Klagenfurt; $1907-$ 1938 ehrenamtlicher Sekretär des Geschichtsvereines für Kärnten; 1914-1938 ehrenamtlicher Schriftleiter der Zeitschrift Carinthia I; 1919 Sachverständiger für Kärnten in der deutschösterreichischen Delegation bei den Friedensverhandlungen in Saint-Germain-en-Laye; Mitglied des Nationalpolitischen Ausschusses der Kärntner Landesregierung; Beirat der österreichischen Sektion der Abstimmungskommission und des Kärntner Heimatdienstes; 1922 als Gymnasialprofessor Übertritt in den Ruhestand und Ernennung zum Direktor des Kärntner Landesarchivs. Alle Angaben nach: Wut te, Lebenslauf 1949 (wie Anm. 36) 3-7, hier 3 und 5. Hervorhebungen nach Vorlage.

51 Tosoni, Wutte (wie Anm. 33) 116.

52 Wutte, Lebenslauf 1949 (wie Anm. 36) 3. Hervorhebungen nach Vorlage.

53 Ebd. 3f.: „Am Stammtisch der ,Trinkstube“ wurde nicht nur allabendlich politisiert und über alle möglichen bäuerlichen Angelegenheiten gesprochen, sondern es kam ab und zu bei gehobener Stimmung zu förmlichen literarischen Abenden, an denen der nachmalige Schwiegervater meiner Schwester Mitzi, Josef Horn, ein hochintelligenter Bauer und Sägebesitzer, Gedichte von Schiller, Anastasius Grün, Herwegh u.a. frei aus dem Gedächtnis deklamierte. Auch mein Vater suchte Sonntag nachmittags gerne ein ruhiges Plätzchen aus, um Schiller zu lesen." 
möglicherweise der Spiritus Rector für den Titel von Wuttes Schlüsselwerk „Kärntens Freiheitskampf“.

Selbst definiert Wutte sein dreijähriges Schüler-Dasein im fürstbischöflichen Knabenseminar in Klagenfurt ${ }^{54}$ als eine Zeit, die in ihm einen nachhaltigen Eindruck hinterlassen hat. Davon erfährt eine größere Öffentlichkeit allerdings erst I98855. Eine breitere Erörterung zum angeführten Problemfeld Priestermangel unterbleibt. Das aus dem Rückblick gespeiste Resümee des 7I-jährigen, der über den Mangel an „deutschen Priestern“ lamentiert, streift an ein Thema, das in Kärnten noch heute präsent ist. Demnach haben nationalslowenische Geistliche die Bevölkerung slawisiert, "gar oft und immer wieder“ gegen die Wünsche der Bevölkerung gehandelt und versucht, „in ihrem Wirkungskreise mit aller Macht ,ein Königreich Slowenien' in Kärnten aufzurichten ... "56. Auch wenn für diese Argumentation tatsächlich zahlreiche Belege nachweisbar sind, ist eine flächende-

54 Siehe dazu: Johann Unterluggauer, Bischof „Deo Gratias“. Kahns Leben und Werk (Klagenfurt 1952). Zur Baugeschichte dieses Internats und späteren Priesterseminars und die damit eng verbundene religionsund nationalpolitische Frage, die in der jüngeren Kärntner Landesgeschichte eine wesentliche Rolle spielte, bes. 54-66.

55 Wutte, Lebenslauf 1988 (wie Anm. 38) 14f.: „Im Marianum lernte ich eine neue Seite des Lebens kennen: die nationale. Es kam dort zu heftigen Streitigkeiten zwischen den deutschen und slowenischen Zöglingen, an denen ich mich lebhaft beteiligte. Sie riefen in mir ein lebhaftes Nationalgefühl hervor und hatten daher für meine weiteren Lebensanschauungen tiefgreifende Folgen. Wir wurden gezwungen, bei einem slowenischen Heißsporn slowenische Sprachkurse zu besuchen. Sie hatten den Zweck, künftigen deutschen Priestern die Kenntnis der slowenischen Sprache zu vermitteln, damit sie später in gemischtsprachigen Pfarren verwendet werden könnten. Doch fehlte uns deutschen Zöglingen das Verständnis für die Wichtigkeit deutscher Priester in gemischtsprachigen Pfarren, die damals, auch solche mit überwiegend deutscher Bevölkerung, fast durchaus mit slowenischen Geistlichen besetzt waren. Der Leiter des Kurses hatte wenig Interesse, uns die slowenische Sprache beizubringen, und bestärkte eher unsere Abneigung. So blieb mir die slowenische Sprache verschlossen, was ich später lebhaft bedauerte."

56 Beispielsweise dazu: Viktor Mıьтsсніnsку, Kärntens hundertjähriger Grenzlandkampf. Eine zusammenfassende Darstellung (Wien 1937) 50f. Miltschinsky, einer der führenden Repräsentanten innerhalb des deutschnationalen Lagers in Kärnten vor und nach dem Zweiten Weltkrieg, zu Wutte (ebd. 8, Hervorhebung nach Vorlage): „Wer immer nun aber eine Arbeit über Kärnten unternimmt, der kann an den grundlegenden größeren und kleineren Werken des Kärntner Historikers und Gelehrten Dr. Martin Wutte nicht vorbei, und so ergab sich zwangsläufig die Notwendigkeit, Hofrat Dr. Wutte um seine Unterstützung zu bitten. Wie immer, wenn es gilt, der Kärntner Heimat und dem deutschen Volke zu dienen, hat er auch diesmal seine Mithilfe nicht versagt und durch wertvolle Winke und Ratschläge, sowie auch durch freundliche Überlassung von Material unsere Schrift gefördert.“ Ferner zu Miltschinsky: DE Rs., Kärnten - Ein Jahrhundert Grenzlandschicksal (Eckart-Schriften 2, Wien 1959), und DERs., Kärntner Treue. Ein vaterländisches Bühnenspiel in drei Teilen (sechs Bildern) (Eckart-Schriften 22 A, Wien 1967). 1930 vom Autor verfasst, wurde das Drama 1931 am Wiener Burgtheater uraufgeführt. Erwähnenswert ist, dass Miltschinsky einem Hauptdarsteller die Aufgabe zuteilt, auf die besondere Bedeutung der italienischen Politik für die „Kärntner Frage“ hinzuweisen. Dieses Forschungsfeld ist von der Geschichtsschreibung bis heute äußerst stiefmütterlich behandelt worden. Vgl. ebd. Vorwort, 2 und $9 f$. 
ckende systematische Forschungsarbeit, die internationalen wissenschaftlichen Standards entspricht, zu dieser schwerwiegenden Behauptung von der Geschichtsschreibung noch nicht erbracht worden ${ }^{57}$. Dabei wäre zu berücksichtigen, dass der im Zuge der Revolution von I 848 erhobene Ruf nach Gleichberechtigung der Nationen in Kärnten die slowenischsprachige Geistlichkeit sehr schnell in eine Defensiv-Rolle gedrängt sah. Dem Klerus kam in einem der brisantesten Probleme des 19. und beginnenden 20. Jahrhunderts, der „sozialen Frage“, ein nicht geringer Stellenwert zu. Der weit verbreitete Analphabetismus und der dadurch bedingte geringe Bildungsstand verweisen auf ein Dilemma, von dem in Kärnten zwar nicht nur, aber vor allem die südlichen Landesteile in besonderem Ausmaß betroffen waren ${ }^{58}$. Mitverantwortlich dafür ist die kleinbäuerliche Struktur zu machen, die in einem Land, in dem im I9. Jahrhundert und noch am Beginn des 20. Jahrhunderts knapp zwei Drittel der Bevölkerung im ländlichen Raum einer Beschäftigung nachgingen, besonders zu beachten ist. Aufgrund der drückenden körperintensiven Arbeitsbedingungen in der Land- und Forstwirtschaft war ein Bildungserwerb ungemein erschwert.

Eine Conditio sine qua non für jeden Bildungserwerb ist die Sprache. Wichtige Bildungsträger und -vermittler waren, wie überall in den Agrarräumen Österreichs, lange Zeit in erster Linie geistliche Würdenträger, altgediente Offiziere und erst ab der Mitte des I9. Jahrhunderts zusehends ausgebildete Lehrer. Bei einer weiteren wichtigen Aufgabe der katholischen Kirche, der Seelsorge, wurde aus verständlichen Gründen die ortsübliche Alltagssprache verwendet. Vor I 848 und noch nach dem Ende des Ersten Weltkrieges das gilt in Kärnten zumindest für das ländliche Gebiet südlich der Drau - herrschte in diesem Raum vorwiegend die slowenische Sprache vor. Die im Zuge der I 848er-Revolution oft propagierte Parole nach Gleichberechtigung in allen Lebensbereichen bedeutete konsequenterweise auch eine Forderung nach Emanzipation beim Sprachgebrauch. In Kärnten, dessen Landespolitik seit I 848 von Anbeginn von deutschnational-liberalen, antiklerikalen Gruppierungen dominiert wurde, sahen diese politische Eliten ihre gesellschaftliche Stellung durch dieses Postulat gefährdet. An der Schul- und Sprachenfrage entzündete sich ein Dauerkonflikt, der teilweise bis in die jüngste Landesgeschichte Kärntens reicht. Dabei blieben sich Exponenten der jeweiligen Seite zwar seit jeher einander nichts schuldig, aber das zahlenmäßig kleine slowenische Intellektuellenmilieu hatte aufgrund der politischen Rahmenbedingungen einen geringeren Gestaltungsraum.

57 Zur Wirkungsgeschichte vgl. Martin Wutte, Oskar Loвmeyer, Die Lage der Minderheiten in Kärnten und in Slowenien (Klagenfurt 1926) bes. 63-69 die Kapitel „Geistlichkeit und Seelsorge“, „Entlassungen und Ausweisungen“.

58 Zum Alphabetisierungsgrad in Kärnten (1910) im Vergleich zu anderen Regionen der Habsburgermonarchie siehe: Die Habsburgermonarchie 1848-1918 9,2: Soziale Strukturen. Die Gesellschaft der Habsburgermonarchie im Kartenbild. Verwaltungs-, Sozial- und Infrastrukturen; nach dem Zensus von 1910, bearb. v. Helmut Rumpler, Martin Seger u.a., kartographische Umsetzung Walter Lie bhart (Wien 2oio), zu Kärnten 228. 
Die Interessen der slowenischsprachigen Landesbevölkerung, gleich ob mit oder ohne Verknüpfung nationaler Ziele, wurden lange Zeit hauptsächlich von Klerikern wahrgenommen, die über die erforderliche Schrift- und Sprachkompetenz verfügten. Den geistlichen Würdenträgern standen Politiker, zunächst vorwiegend aus dem deutschnationalliberalen, später auch aus dem sozialdemokratischen Lager gegenüber. In Kärnten zeitigte diese Auseinandersetzung vor allem für den slowenischen Klerus eine dramatische, nach I 9 I 8 eine die Existenz bedrohende Entwicklung59.

Zurück zur „Geschichte im Ich“: Nach einer kurzen Darstellung der weiteren Gymnasialzeit ${ }^{60}$ skizziert Wutte sein Studium an der Universität Graz ${ }^{61}$ und führt Lehrende an: „Franz v. Krones, der liebenswürdige Vertreter der österreichischen Geschichte, Johann Loserth, bekannt als Geschichtsschreiber der innerösterreichischen Gegenreformation, vor allem aber der Geograph Eduard Richter“62, den Wutte ausführlich würdigt: „Als Mensch und Gelehrter gleich ausgezeichnet, wurde Richter ein Bahnbrecher auf dem Gebiete der historischen Geographie, von der Akademie der Wissenschaften mit der Herausgabe eines historischen Atlas der österreichischen Alpenländer betraut. Ich wurde zu seinem 2. Assistenten bestellt. So kam ich in das Fahrwasser der historischen Geographie, das ich zeit meines Lebens nicht mehr verließ. Richter hat mir auch den Weg zum Studium der sprachlichen und völkischen Entwicklung meines Heimatlandes gewiesen, indem er mir

59 Ausführlicher dazu: Peter G. Tropper, Nationalitätenkonflikt. Kulturkampf. Heimatkrieg. Dokumente zur Situation des slowenischen Klerus in Kärnten von 1914 bis 1921 (Das Kärntner Landesarchiv 28, Klagenfurt 2002) bes. 24-27 und 30-33.

$60 \mathrm{Ab}$ der fünften Gymnasialklasse erhielt Wutte ein „von der zuständigen Kommission der k. k. Kärntner Landesregierung“ finanzierten Stiftsplatz. Dekret im Familienarchiv Wutte, Schachtel V, zitiert nach Toson I, Wutte (wie Anm. 33) 8.

61 „Am 30. August 1896 gewährte die k. k. Landesregierung Wutte ein jährliches Stipendium in der Höhe von 250 Gulden aus dem Studienkonviktsfond für die Dauer der ordentlichen Universitätsstudien. “ Dekret im Familienarchiv Wutte, Schachtel V, zitiert nach Toson I, Wutte (wie Anm. 33) 8.

62 Wutte, Lebenslauf 1949 (wie Anm. 36) 5. Tosoni nennt weitere Lehrer: Franz Martin Mayer, Anton Mell, Adolf Bauer und Hans von Zwiedineck-Südenhorst. Letztgenannter war laut Tosoni „ein Vertreter der gesamtnationalen Verbundenheit innerhalb der deutsch-österreichischen Historiographie. Er huldigte einer ausgeprägten deutschnationalen Geschichtsanschauung verbunden mit dem Wunsche seine Heimat Österreich einem kommenden großdeutschen Staate einverleibt zu sehen. Dies waren Gedanken, die auch den jungen Wutte bewegten." Tosoni informiert auch über den Studienabschluss: Demnach hat Wutte einen Teil seines Studiums im März 1901 mit der Promotion abgeschlossen; das Dissertationsthema lautete: „Die Reformation und Gegenreformation in Villach“. Für die Ablegung des ersten und zweiten Rigorosums hatte der Dissertant von der k. k. Landesregierung in Klagenfurt im Oktober 1900 einen Zuschuss von 500 Kronen erhalten. Im „Februar 1901 verlieh ihm die k. k. steiermärkische Statthalterrei 800 Kronen für das Studienjahr 1901 aus dem Maria Wiltschen Stiftungsstipendienfond.“ 1902 schloss Wutte seine akademische Laufbahn mit einer Hausarbeit und der Lehramtsprüfung aus Geschichte und Geografie als Hauptfächer und Germanistik als Nebenfach, ab. Angaben nach Toson I, Wutte (wie Anm. 33) 12f. Tosoni verweist auf entsprechende Dekrete im Familienarchiv Wutte, Schachtel V. 
I 898 eine Seminararbeit über die sprachlichen Verhältnisse Kärntens und zwei Jahre später eine geographische Darstellung des Klagenfurter Beckens als Hausarbeit für die Lehramtsprüfung gab. So bestimmte Richter meine wissenschaftliche Laufbahn. Wissenschaftliche Exkursionen unter Führung Richters ins Enns- und Murtal, zum Großglockner, nach Venedig und Triest erweiterten meinen Horizont." 63

Im 1949 veröffentlichten Lebenslauf endet die Darstellung der Studienzeit mit dem Hinweis auf Wuttes Mitgliedschaft im akademischen Historikerklub. Dort hatte er Hans Pirchegger, den „bekannten steirischen Historiker, einen gleichgesinnten Kameraden, mit dem mich gleichartige Lebensschicksale in treuer Freundschaft verbanden“, kennengelernt. Im Lebenslauf von 1988 schließt das Studentenzeitkapitel mit dem Hinweis: „In dieser Zeit nahm ich auch schon am völkischen Schutzverein ,Südmark' tätigen Anteil.“64 Dieser Satz ist aber für eine nachvollziehbare Interpretation der weiteren Selbstdarstellung Wuttes unabdingbar: „In den Jahren I90 I bis I903 war ich Supplent an der Oberrealschule in der Keplerstraße in Graz, im Schuljahr I903/04 Professor für Geschichte, Geographie und Deutsch in der Lehrerbildungsanstalt in Marburg. Meine Ernennung an diese Anstalt wurde in der deutsch geschriebenen, aber im slowenischen Sinn gehaltenen Marburger Zeitung ,Draupost' mit den Worten begrüßt: ,Auch einer, der nicht hingehört!' Ich hatte als einziger Deutscher im Lehrkörper einen schweren Stand, da ich versuchte, die deutschen Zöglinge gegen die parteiische Behandlung, der sie seitens einzelner Professoren ausgesetzt waren, in Schutz zu nehmen."65

Neumann hat zwar 1985 in der Einleitung zur Neuauflage des Buches „Kärntens Freiheitskampf“ auf Wuttes Marburger Erfahrung ${ }^{66}$ hingewiesen. Eine Ursachenforschung war ihm aber kein Anliegen. Die unmittelbar an das „Marburger Zitat“ anschließenden Sätze könnten aufgrund des fehlenden Absatzes ${ }^{67}$ zur Schlussfolgerung führen, dass zwischen dem Draupost-Artikel und der Lehrtätigkeit Wuttes ein unmittelbarer Zusammenhang besteht. Das entbehrt aber aufgrund des Zeitrasters jeder Logik. Vermutlich war man in Marburg von Wuttes „tätigen Anteil“ zugunsten des „völkischen Schutzverein[es] ,Südmark““ schon vor dessen Lehrtätigkeit in der Draustadt unterrichtet. Eine endgültige Antwort bleibt einer künftigen Forschung vorbehalten; zu ersten neuen Details rund um Wuttes „Schutzarbeit“ in deutschnationalen Vereinen siehe unten.

63 Wutte, Lebenslauf 1949 (wie Anm. 36) 5.

64 Wutte, Lebenslauf 1988 (wie Anm. 38) 13. Im handschriftlichen Autograf (Kopie) wird die Südmark nicht unter Anführungszeichen genannt.

65 Wutte, Lebenslauf 1949 (wie Anm. 36) 5; Ders., Lebenslauf 1988 (wie Anm. 38) 14. Hervorhebungen nach Vorlage.

66 Neumann, Einleitung (wie Anm. 2) XV.

67 In der handschriftlich verfassten Autobiografie (Kopie) ist ebenfalls kein Absatz eingefügt. NLW, Schachtel 1,6 (Mein Lebenslauf) 5. 
Der Junglehrer Wutte fühlte sich jedenfalls in Marburg offensichtlich nicht wohl, denn: „Zu meiner und meiner slowenischen Kollegen Freude wurde ich schon 1904 ans Gymnasium nach Klagenfurt versetzt." Dass Wutte selbst aktiv diesen Umstand mitgestaltete, indem er einen Antrag auf Versetzung gestellt hatte, darüber berichtete sein Biograf Tosoni unter Hinweis auf entsprechende Dokumente ${ }^{68}$. Über seine Arbeit als Lehrer reflektierte Wutte selbst ${ }^{69}$, und Tosoni bringt ein Beispiel dafür, in welcher Form die Schüler dem Lehrer ihre Wertschätzung demonstrierten ${ }^{70}$. Vorgesetzte Behörden haben Wuttes Lehrtätigkeit offensichtlich nicht nur unter Berücksichtigung fachdidaktischer Kriterien beurteilt. Denn „trotz seiner verdienstvollen pädagogischen Tätigkeit wurde Wuttes Gesuch um Verleihung des Direktorposten vom Staatsamt für Inneres und Unterricht in Wien abschlägig beschieden; daran änderte sich auch nichts, als die Kärntner Landesregierung in Wien ihr Befremden darüber zum Ausdruck brachte“. ${ }^{71}$ Wann und für welche Schule sich der Lehrer um diese Leitungsfunktion beworben hatte, ist nicht bekannt. Wutte dürfte diesen Schritt auf seiner Karriereleiter vermutlich I909/ I 9 Io oder I9I8/I9I9 gesetzt haben, denn zu dieser Zeit war der angestrebte Direktorposten am einstigen k. k. Staats- und Realgymnasium bzw. dem späteren Staatsgymnasium in Klagenfurt vakant ${ }^{72}$. An dieser Schule ${ }^{73}$ hat Wutte mit mehreren Unterbrechungen von 1904 bis 1922 unterrichtet ${ }^{74}$.

68 Ernennungsdekret im Familienarchiv Wutte, Schachtel V, zitiert nach Toson I, Wutte (wie Anm. 33) 15.

69 Wutte, Lebenslauf 1949 (wie Anm. 36) 5f.: „Hier war ich bestrebt, auch die slowenischen Schüler gerecht zu behandeln und namentlich ihre sprachlichen Schwierigkeiten zu berücksichtigen. Der Unterricht in der Geschichte hat mir viel Freude gemacht. Die Schüler folgten ihm gern, da ich gewohnt war, frei vorzutragen, und oft an die heimatliche Geschichte anknüpfte.“

70 „Wie beliebt Wutte bei seinen Schülern war, zeigt sich daran, daß anläßlich der Genesung Wuttes von einer schweren Lungenentzündung, die IIIb Klasse 80 Kronen dem Deutschen Schulverein spendete. “ Toson I, Wutte (wie Anm. 33) 15; Tosoni verweist auf einen Wochenbericht des Deutschen Schulvereins, Folge 20, 16.05.1918.

71 Tosoni, Wutte (wie Anm. 33) 15f.

721910 und 1919 erfolgte, bedingt durch den Übertritt der jeweiligen Schulleiter in den Ruhestand, ein Wechsel in der Direktion.

73 Das heutige „Europagymnasium Klagenfurt“ zählt zu den ältesten Bildungsanstalten Österreichs. Es kann auf eine Vielzahl prominenter Schulbesucher zurückblicken, die weit über Kärnten hinaus Bekanntheit erlangten.

74 1910/11 war der Pädagoge „zwecks Vollendung einer wissenschaftlichen Arbeit beurlaubt und zwar handelt es sich hier um die Kärntner Gerichtsbeschreibungen “. 1919 war Wutte als Sachverständiger für Kärnten in der deutsch-österreichischen Friedensdelegation in Saint-Germain-en-Laye tätig. Im August 1920 (!) wurde er „,für die Dauer des Schuljahres 1921/22 beurlaubt“, um Dokumente „aus der Zeit des Kämpfens um die Einheit Kärntens" zu sammeln und wissenschaftlich aufzubereiten. Angaben nach Tosoni, Wutte (wie Anm. 33) 6 und 25; Tosoni verweist auf entsprechende Dekrete. In den Hauptkatalogen des „k. k. Staats- Realgymnasiums“ bzw. „Staatsgymnasiums Klagenfurt“ wird Wutte im Schuljahr 1909/10 als teilweise „beurlaubt“ geführt. 1920/21 erteilte er in zwei Klassen Unterricht in Geografie und Geschichte. Ich danke dem Direktor des Europagymnasiums Klagenfurt, Prof. Mag. Gerhard Hopfgartner, für die Einsichtsgenehmigung in die Kataloge. 
Warum die Wiener Zentralstellen Wutte die Führungsposition, gleich an welcher Schule, verwehrten, wäre noch zu recherchieren. Dass aus dieser Ablehnung aber ein Stück persönlicher Leidensgeschichte des Historikers resultierte, kann wohl nicht als Spekulation abgetan werden. Wutte selbst hat in seinem Lebenslauf zum gescheiterten Vorhaben mit keinem Wort Bezug genommen. Die Übernahme der Leitung des Kärntner Landesarchivs im Jahr I923 hat aber seine gesellschaftliche Reputation gewiss nicht geschmälert und bot die besten Voraussetzungen, um sich der Geschichtsforschung widmen zu können; und nicht zuletzt dürfte sich diese Berufsfunktion auch finanziell deutlich positiv zu Buch geschlagen haben.

Wutte setzt seine Lebenslaufgeschichte mit der Schilderung seiner Tätigkeiten im Geschichtsverein für Kärnten fort und erwähnt, dass er als Schriftleiter der Carinthia „eine große Zahl von kleinen Mitteilungen, Anzeigen, Besprechungen, Nachrufen u. dgl. zu schreiben“ hatte, „so daß die Zahl meiner Veröffentlichungen auf rund 500 stieg. Etwa die Hälfte davon erschien in der Carinthia I. Zahlreiche volkspolitische und geschichtliche Aufsätze ließ ich zur Zeit des Kärntner Freiheitskampfes in der ,Kärntner Landsmannschaft' und in den Kärntner Tagesblättern erscheinen. "75

Exkurs zum Schriftenverzeichnis Wuttes: Von den angesprochenen Veröffentlichungen in der Carinthia, die zwischen 1906 und 1949 erschienen, darunter acht post mortem ${ }^{76}$, sind 3 I Prozent als Literaturbesprechungen und rund vierzehn Prozent als Nekrologe oder Grußadressen ausgewiesen ${ }^{77}$. Rund ein Viertel der insgesamt 500 Veröffentlichungen sind als Beiträge für Festnummern, Zeitungsartikel in Tages- und Wochenzeitungen und Monatszeitschriften zu klassifizieren ${ }^{78}$; davon sind ein knappes Drittel allein in der Zeit

75 Wutte, Lebenslauf 1949 (wie Anm. 36) 6. Ebd. wurde an dieser Stelle eine Anmerkung durch die Redaktion der Carinthia gesetzt: „Ein von der Tochter Martin Wuttes, Frau Dr. Ilse Manhart, zusammengestelltes und von ihrem Vater noch überprüftes vollständiges Schriftenverzeichnis kann wegen des großen Umfanges in diesem Rahmen nicht veröffentlicht werden. Eine Abschrift wurde dankenswerterweise dem Geschichtsverein für Kärnten überlassen."

76 Die Carinthia I (Jahrgänge 134, 135) ist in den Jahren 1944, 1945, 1946 nicht erschienen. Ersatzweise wurden für die Jahre 1944 und 1945 den Mitgliedern des Kärntner Geschichtsvereines der 29. und 30. Band aus der Reihe „Vaterländische Geschichte und Topographie“ übermittelt, 1947 der 134. und 135. Jahrgang nachgereicht, 1948 folgten die Jahrgänge 136-138. Beiträge Wuttes wurden 1949 post mortem in der Carinthia I, veröffentlicht.

77 Die zwei zuletzt genannten Textsorten sind vor dem Hintergrund, dass Wutte Sekretär des Geschichtsvereines für Kärnten war, zu interpretieren.

78 Bei rund einem Dutzend der angeführten Veröffentlichungen fehlt eine namentliche Kennzeichnung. Der Verfassername ist anonymisiert: beispielsweise mit „e“, „x“ oder „von einem deutschen Bauernsohn“, „ein Klagenfurter“, „Ekkehart“ oder „Carinthiacus“. Unter letztgenanntem Pseudonym hat Wutte 1925 einen „Bericht aus Kärnten“, in: Deutsche Rundschau 51 (1925) 242-247, verfasst. Ein Jahr später übte er vielleicht deshalb Kritik an der Schrift „Die Lage der Slowenen unter Österreich und jener der Deutschen im Königreiche der Serben, Kroaten und Slowenen“. Wutte: „Der Verfasser wagt es nicht, seinen Namen zu nennen, sondern 
des „Kärntner Freiheitskampfes“ publiziert worden ${ }^{79}$. Thematisch hat sich Wutte mit dem Bildungs-, Statistik- und Verkehrswesen und Teildisziplinen der Geschichtswissenschaft beschäftigt: Diplomatie-, Lokal-, Militär-, Presse-, Rechts-, Siedlungs-, Vereins- und Wirtschaftsgeschichte, historische Geografie, Karthografie, Heimat- und Volkskunde; Bildbeschreibungen in kunsthistorischen Bänden und Beiträge für Lehrbuchsammlungen runden sein publizistisches Schaffen ab. Einen herausragenden Forschungsschwerpunkt bildet die Beschäftigung mit Sprachen- und Nationalitätenthemata. Ungeachtet der Frage, wie diese Veröffentlichungen zu spezifizieren sind, der Frage nach der Qualität und des quantitativen Umfanges etc., lassen sich aus dem Schriftenverzeichnis drei Erkenntnisse ableiten.

Erstens: Wutte war nicht nur im Wissenschaftsbetrieb, sondern im öffentlichen historisch-politischen Raum, zwar vor allem in Kärnten ${ }^{80}$, aber auch darüber hinaus, präsent. Er war, modern ausgedrückt, ein überaus aktiver Medienmensch.

Zweitens: Wuttes Credo, dass die Geschichtsforschung der gegenwärtigen Politik dienen müsse, ist nicht graue Theorie geblieben. Schon während des Ersten Weltkrieges leistete er, wie viele seiner Zeitgenossen aus dem Gelehrten- und Intellektuellenkreis ${ }^{81}$, Beiträge, die auf eine moralische Aufrüstung der Frontsoldaten und Zivilbevölkerung abzielten $^{82}$; während des Zweiten Weltkrieges ist Wuttes Publikationsarbeit anderweitig gebunden, lediglich fünf mit Wutte signierte Artikel erschienen in Presseorganen ${ }^{83}$.

zeichnet sich mit dem Decknamen, Carinthiacus‘. Doch dürfte er kaum ein Kärntner sein, denn mehrfache Ungenauigkeiten, Fehler und sonstige Kennzeichen lassen in dem Verfasser mit großer Wahrscheinlichkeit ein Mitglied jenes Kreises von Laibacher Politikern vermuten, die schon einmal soviel Unheil über Kärnten gebracht haben. “ Zitiert nach Wutte, Lobmeyer, Minderheiten in Kärnten und Slowenien (wie Anm. 57) 6.

79 Prozent- und Größenangaben wurden vom Verfasser auf der Grundlage des von Tosoni zusammengestellten „Verzeichnis[ses] der Schriften Wuttes in chronologischer Reihenfolge“ errechnet.

80 Wutte hat, bedingt durch seine Funktion „als Konservator der Zentralkommission für Erhaltung der Kunstund historischen Denkmäler für Oberkärnten (1913 bis 1921)“ zahlreiche Herrschafts-, Stadt- und Marktarchive in Oberkärnten und „gelegentlich meiner Forschungen für den historischen Atlas“ Archive in Unterkärnten kennengelernt. Im Zuge dieser Besuche veranlasste er „Besitzer, ihre Archive käuflich oder unter Vorbehalt des Eigentumsrechtes dem Landesarchiv zur Aufbewahrung zu überlassen“, so Wutte, Lebenslauf 1949 (wie Anm. 36) 7.

81 Vgl. dazu: Österreich und der Große Krieg 1914-1918. Die andere Seite der Geschichte, hg. v. Klaus Amann, Hubert Lengauer (Wien 1989) bes. 23-192.

82 Hinweise auf dementsprechende Beiträge bei Tosoni, Wutte (wie Anm. 33) Schriftenverzeichnis 126-128.

83 Zeitgemäße Erinnerungen, in: Kärntner Grenzruf, 19.06.1940, Nr. 169 5; Die Kärntner Frage in St. Germain, in: Kärntner Grenzruf, Sonderbeilage 20 Jahre Volksabstimmung, 10.10.1940 6f.; Klagenfurt, Stadt der Treue, in: Kärntner Zeitung, 09.10.1942, Nr. 278 Titelseite f.; Heinrich Ritter von Srbik, in: Kärntner Zeitung, 19./20.12.1942, Nr. 349/350 Titelseite f.; Hans Kloepfer und Kärnten, in: Kärntner Zeitung, 11.07.1944, Nr. 1893. 
Drittens: Wutte hat, sieht man von den Veröffentlichungen in seiner „Hauszeitschrift“, der Carinthia I, einigen anderen Publikationen in Kärnten ${ }^{84}$ und Zeitungsartikeln in Kärntner Printmedien $a b$, mehr in wissenschaftlichen und populärwissenschaftlichen Zeitschriften außerhalb Österreichs, nämlich in Deutschland, publiziert ${ }^{85}$. Zahlenmäßíg gilt das auch für seine Beiträge in Tages- und Wochenzeitungen. Fünf nachweisbaren Artikeln in Grazer und Wiener Zeitungen stehen sechs gegenüber, deren Haupt-Redaktionshäuser in Deutschland liegen. Zu beachten ist, dass umfangreiche Aufsätze - teilweise gemeinsam mit einem anderen Autor - im Handwörterbuch des Grenz- und Auslanddeutschtums (HWB) veröffentlicht wurden ${ }^{86}$. Selbst die I 943 publizierte Auflage seines Hauptwerkes „Kärntens Freiheitskampf“ erschien nicht in der „Ostmark“, sondern in $\mathrm{Weimar}^{87}$.

Im Verbindungsgeflecht zwischen Kärnten und dem „deutschen Mutterland“ ${ }^{\text {“88 kam }}$ Wuttes Publikationstätigkeit in verschiedenen Blättern deutscher Schutzvereine vermutlich eine Schlüsselfunktion $\mathrm{zu}^{89}$. Von Wuttes Mitarbeit im „Deutschen Schulverein“90

84 Darunter fallen beispielsweise Jahresberichte von Schulen oder anonymisierte Flugschriften.

85 Bei den Titeln der Veröffentlichungen blieben wissenschaftliche Spezifikationskriterien unberücksichtigt, weil dem Verfasser der vorliegenden Studie nicht alle (rund 120) Veröffentlichungen zur Verfügung standen.

86 Handwörterbuch des Grenz- und Auslanddeutschtums 3, hg. v. Carl Petersen, Paul Hermann Ruth, Hans Schwalm (Breslau 1938). Dieser Band erschien in 8 Lieferungen, Redaktionsschluss für die Kärnten-Teile waren 05.03 und 05.04.1940, vgl. ebd. 636; Details zu Wuttes Autorenschaft in: Toson I, Wutte (wie Anm. 33) Schriftenverzeichnis 151f., oder: Martin Wutte, Verzeichnis seiner Schriften, Kärntner Landesbibliothek, o. J., o. O. [Klagenfurt], Sign. II 2213.

87 Dort im Verlag Böhlau, zur Verlagsgeschichte siehe www.boehlau.at. (letzter Zugriff 30.07.2010).

88 Wutte, Freiheitskampf 1922 (wie Anm. 1) 192.

89 Vgl. Tosoni, Wutte (wie Anm. 33) Schriftenverzeichnis 121-147; ferner Martin Wutte, Die Notwendigkeit der Schulvereinsarbeit. Mit besonderer Berücksichtigung auf Kärnten. Mit einer Karte, in: Der getreue Eckart, Halbmonatsschrift für das deutsche Haus, Heft 17/18 (Wien 1924) 688-691.

90 Zum Schulverein: Werner Droвesch, Der Deutsche Schulverein 1890-1914. Ideologie, Binnenstruktur und Tätigkeit einer nationalen Kulturorganisation unter besonderer Berücksichtigung Sloweniens, in: Geschichte und Gegenwart 12 (1993) 195-212; ferner die aufschlussreiche quellenreiche Mikrostudie: DERs., Das slowenische Vereinswesen in Klagenfurt 1848-1938. Nationale Selbstbehauptung und Assimilierung der Slowenen im städtischen Bereich, in: Österreichische Osthefte 33 (Wien 1991) 426-465; ein Abriss zur Geschichte des Deutschen Schulvereines stammt aus der Feder Wuttes: „Ein Kärntnergruß dem Deutschen Schulvereine! Zur Erinnerung an die Hauptversammlung am 7. und 8. Juni 1908 in Klagenfurt“, undatierte Broschüre, 3-6, in: NLW, Schachtel 28, 909; siehe ferner KLA, Sammlung Wutte, Schachtel 26, 205: „Deutscher Schulverein Südmark (Satzungen, Materialien, Schriftverkehr, Tagungen, Jahresberichte)“ 1909, 1938. Von der quantitativen Überlegenheit des deutschen Vereinswesen gegenüber dem slowenischen berichtete Wutte bereits in der Erstauflage von „Kärntens Freiheitskampf“, wobei seine Methodik zu hinterfragen ist, weil die staatliche Zuordnung slowenischer Vereine nicht klar erkennbar ist: „In den letzten Friedensjahren gab es in den gemischtsprachigen Teilen nicht weniger als 285 deutsche, aber - nach slowenischer Angabe - nur 131 slowenische Vereine. Dabei ist diese Zahl sicher zu hoch gegriffen, da bei der Behörde nur 67 slowenische Vereine angemeldet waren. Bezeichnend ist die Verbreitung der nationalen Schutzvereine. Während 
erfährt eine an Geschichte interessierte breitere Öffentlichkeit allerdings erst im Jahr I 988, nun durch den vollständig veröffentlichten Lebenslauf; Wutte gibt über seine Mitarbeit in diesem Schutzverein eine allgemein gehaltene Auskunft ${ }^{91}$. Während er dabei auf Aktivitäten der allslowenischen Volkspartei und der allslowenischen Volksbewegung in Kärnten hinwies, schenkte er der Kehrseite der Medaille keine Beachtung. Wenige Jahre vor dem Verfassen seines Lebenslaufes hatte Wutte sein Wissen über die Geschichte des „Alldeutschen Verbandes“ und der „Deutschen Volkspartei“ in Kärnten in einem Aufsatz detailreich ausgebreitet: „Anfang September I 886 hielt Schönerer ${ }^{92}$ die erste Versammlung in Klagenfurt ab. Er griff bei dieser Gelegenheit den Deutschen Klub ${ }^{93}$ heftig an. Da es in Kärnten keine Judengefahr gab, so wurde hier Schönerers Auftreten als unnötige Störung in einem Kampfgebiet empfunden. Man verurteilte es, dass er auch in Kärnten, das damals in schwerem Kampfe mit Klerikalen und Slowenen stand, gegen den Deutschen Klub zu Felde zog. Die ,Freien Stimmen', die sich damals als deutschnationales Blatt bezeichneten und schon unter Leitung J. W. Dobernigs standen, erklärten, nicht Schönerianer zu sein, Steinwender ${ }^{94}$ allein sei der berufene Führer der Deutschen in Kärnten. Das war damals. Später wurde Steinwender auch in Kärnten wegen seiner Sprunghaftigkeit selbst von nationalen Kreisen scharf abgelehnt. In den folgenden Jahren sprach Schönerer wiederholt noch in Versammlungen in Kärnten, so I 887 in Klagenfurt,

es nämlich im gemischtsprachigen Kärnten kurz vor dem Kriege 42 Ortsgruppen der ,Südmark‘ mit 2153 Mitgliedern gab, waren an slowenischnationalen Schutzvereinen nur 16 Ortsgruppen der ,Slovenska Straža (Slowenische Wacht) in Laibach und 6 Ortsgruppen des slowenischen Schulvereines (Cyrill- und Methodverein) angemeldet."Wut te, Freiheitskampf (1922) (wie Anm. 1) 9.

91 Wutte, Lebenslauf 1988 (wie Anm. 38) 15: „Nebenbei war ich im Deutschen Schulverein tätig. In den Jahren 1911-1916 war ich Obmann des Kreises XVI Kärnten des Schulvereines. Seine Hauptaufgabe war, die deutsche Sprache an den utraquistischen Schulen gegen die immer mehr zunehmenden Angriffe zu schützen, der sie seitens der slowenischnationalen Bewegung ausgesetzt war. Es war dies umso notwendiger, als seit 1908 die neugegründete allslowenische Volkspartei auch in Kärnten Fuß faßte und diese im Sinne des 1848 aufgestellten slowenischen Nationalprogramms mit Aufgebot aller Kräfte nach Vereinigung aller von Slowenen bewohnten Gebiete zu einem einheitlichen Verwaltungsgebiet strebte, ein Programm, dessen Erfüllung die Zerreißung Kärntens und die Angliederung Südkärntens an Slowenien zur Folge gehabt hätte, was weder im Interesse der Deutschen noch der Slowenen Kärntens lag. Jeder Rückgang der deutschen Sprache in Kärnten war somit ein Erfolg der allslowenischen Bewegung auf dem Weg zur Slowenisierung Südkärntens als Vorbereitung zu dessen Anschluß an Slowenien. “ Hervorhebung nach Vorlage.

92 Zu Schönerer vgl. Andrew G. Whiteside, Georg Ritter von Schönerer. Alldeutschland und sein Prophet (Graz/Wien/Köln 1981) 162-165, zur Tätigkeit schlagender Studentenverbindungen an der Universität Graz in der Studienzeit Wuttes, 214 zu Kärnten, und zuletzt das Poträt von Friedel Moll, Michael WLadika, Georg von Schönerer (1842-1921). Ein alldeutscher Politiker aus dem Waldviertel, in: Waldviertler Biographien 3, hg. v. Harald Hitz u.a. (Horn/Waidhofen an der Thaya 2010) 121-150 (freundlicher Hinweis von Karel Hruza).

93 Anm. Burz: Der „Deutsche Klub“ hatte sich nach den Reichsratswahlen von 1885 gebildet.

$94 \mathrm{Zu}$ Steinwender siehe Lothar Нӧвецт, Otto Steinwender. Porträt eines Nationalliberalen (Wien 1992). 
dann nach seiner Rückkehr ins politische Leben in Feldkirchen (I 894), in Plimitschhof und Feldkirchen (I 895), Sachsenburg, Nikelsdorf, Kleinkirchheim und Kirchbach (I 896), Gmünd (I 897), Wegscheide bei Hollenburg und Buchscheiden (I 898), Weitensfeld (I 899), Villach (1903). “95 Und dann erwähnt Wutte, dass seit I902 unter Führung von Dr. Hans Angerer „ein Verein der Alldeutschen in Kärnten, der Anhänger Wolfs und Schönerers umfasste“, bestand ${ }^{96}$. Zur Gründungsgeschichte der Deutschen Volkspartei hielt Wutte fest: „Auf einem I 892 in Klagenfurt abgehaltenen Kärntner Parteitag kam die Mißstimmung gegen die Untätigkeit des Deutschen Klubs ${ }^{97}$ gegenüber den Slawisierungsversuchen der Regierung zum Ausdruck und wurde die Neuorganisierung der Partei beschlossen. Dazu scheint es jedoch nicht gekommen zu sein. Am 28. Oktober I 893 hielt der Deutsche Verein die letzte Versammlung ab. Da er sich vom Alt-Liberalismus nicht loslösen konnte, wurde am I 8. März I 894 in Klagenfurt der ,Deutsche Volksverein für Kärnten' gegründet, der im wesentlichen die Grundsätze der Deutschnationalen Partei des Abgeordnetenhauses im Lande zur Geltung bringen wollte ${ }^{98}$. Im folgenden Jahre mußte der liberale Reichsratsabgeordnete von Klagenfurt, V. v. Rainer, zurücktreten und wurde an seiner Stelle J. W. Dobernig gegen einen liberalen Wahlwerber gewählt. Im gleichen Jahre kam es, zum Teil auf Grund von Anregungen aus Kärnten zur Gründung der Deutschen Volkspartei. Ihr Programm wurde I 896 in einer Vertrauensmännerversammlung in Wien aufgestellt und auch in Kärnten beifälligst aufgenommen."999

Welcher Tätigkeit Wutte im Deutschen Schulverein vor seiner Zeit als Obmann nachging, ist ungeklärt. Nachweisbar ist, dass der Historiker knapp ein Dutzend Beiträge in Zeitschriften dieses Vereines oder vergleichbarer Organisationen veröffentlicht hat. Dazu zwei Fallbeispiele: Bei den folgenden Artikeln, die in einem Absatz wortwörtlich identisch sind, handelt es sich um verkürzte Versionen eines umfangreicheren Aufsatzes, der in der

95 Martin Wutte, Der gesamtdeutsche Gedanke in Kärnten, in: Carinthia I, 130 (1940) 3-80, hier 60f. Hervorhebungen nach Vorlage. Wutte führt als Literaturverweis an: „Vgl. E. Pichl, G. Schönerer, Bd. 1-6, Neudruck, München (1938) Bd. 4, S. 616.“

96 Wutte, Der gesamtdeutsche Gedanke (wie Anm. 95) 61.

97 Anm. Burz: gemeint war der Deutsche Klub im Österreichischen Reichsrat.

98 An dieser Stelle gibt Wutte einen Beleghinweis: „Freie Stimmen Nr. 34 vom 20. März 1894.“

99 Wutte, Der gesamtdeutsche Gedanke (wie Anm. 95) 61. Zur (Wirkungs-)Geschichte politischer Organisationen im öffentlichen Raum Kärntens siehe: Avguštin Malle, Vereine in Kärnten, in: Die Habsburgermonarchie 1848-1918 8,1 : Politische Öffentlichkeit und Zivilgesellschaft. Vereine, Parteien und Interessenverbände als Träger der politischen Partizipation, hg. v. Helmut Rumpler, Peter Ur banitsch (Wien 2006) 451-501. Malle weist auf den ersten politischen slowenischen Verein „Slovensko politično društvo ,Trdnjava“" [Slowenischer politischer Verein „Festung“] hin, der am 16.11.1869 gegründet wurde und durch die Organisation von Massenversammlungen („Tabori“) in Kärnten hervortrat. Der Verein „Trdnjava“ stellte 1875 seine Vereinstätigkeit ein. Erste politische liberal-deutschnationale Vereine wurden im April 1869 in Klagenfurt gegründet. Angaben nach ebd. 486 bzw. 462 . 
Carinthia I I 906 veröffentlicht worden ist ${ }^{100}$. Es gibt aber auch Ergänzungen, die, deutlich erkennbar, für ein ausgewähltes Lesepublikum gedacht waren. Denn während Wutte in seinem Carinthia-Aufsatz sine ira et studio zwar ebenso dem Deutschtum in Kärnten eine kulturelle und wirtschaftliche Überlegenheit attestierte, verfiel er in seinen Ausführungen in den zwei 1907 und 1909 veröffentlichten Artikeln ${ }^{101}$ in eine Cum-studio-Darstellung, die mit einer Bilanz und - was für einen Geschichtswissenschaftler fragwürdig ist - mit nationalpolitischen Arbeitsaufträgen schlossen. In der 1907 erschienen Veröffentlichung gab der Historiker zunächst einen kurzen Überblick über die Geschichte Kärntens seit dem sechsten Jahrhundert, wobei die Einleitung beachtenswert scheint: „Kärnten, das heute zu drei Vierteln von Deutschen bewohnt wird, war vom 6. bis zum 9. Jahrhundert ein rein slawisches Land.“ Dann wird die Landesgeschichte bis zur „Einwanderung der Bayern“ skizziert, wodurch nach Ansicht des Verfassers „die Kultur, die materielle sowohl als auch die geistige“, gehoben wurde. Nach einem kultur- und sprachhistorischen Abriss schließt der Autor, gleichzeitig das nächste Kapitel einleitend, mit dem Resümee: „Die ersten Anfänge einer slowenischen Literatur überhaupt wurden außerhalb Kärntens gemacht und fallen erst in die Zeit der Reformation, d. i. in die zweite Hälfte des 16. Jahrhunderts. Und auch dieses erste Erwachen des geistigen Lebens bei den Slowenen war von kurzer Dauer. Erst seit dem Beginn des I9. Jahrhunderts ist ein neuer Aufschwung zu verzeichnen. Aber noch immer ist die gesamte slowenische Literatur verhältnismäßig sehr erbärmlich."Wutte zieht daraus einen Schluss, untermauert mit statistischem Material, wobei allerdings jede methodische Erläuterung fehlt ${ }^{102}$. Erst nach den Forschungsarbeiten

100 Vgl. Martin Wutte, Die sprachlichen Verhältnisse in Kärnten auf der Grundlage der Volkszählung von 1900 und ihre Veränderungen im 19. Jahrhundert, in: Carinthia I, 96 (1906) 153-178.

101 Martin Wutte, Die Fortschritte des Deutschtums in Kärnten und ihre Ursachen, in: Das Deutschtum im Auslande. Monatsblatt des Allgemeinen Deutschen Schulvereins zur Erhaltung des Deutschtums im Auslande, E.V. 26 (Juli 1907) Nr. 7 Sp. 85-89, und De Rs., Die deutsche Besiedlung Kärntens, in: Südmark-Jb. 1909 85-93.

102 Wutte, Fortschritte des Deutschtums (wie Anm. 101) Sp.87: „Mit dieser geistigen Ueberlegenheit des Deutschtums verbindet sich eine wirtschaftliche, wie sie aus folgendem hervorgeht. Die wichtigste Beschäftigung der Bewohner von Kärnten ist die Landwirtschaft. Ein Vergleich der deutschen Landwirtschaft mit der slowenischen zeigt, dass gegenwärtig durchschnittlich auf jeden Deutschen 2,8 ha mit 17 Kronen Reinertrag und rund 3,9 Kronen Grundsteuer entfallen, auf jeden Slowenen aber nur 1,9 ha mit 10 Kronen Reinertrag und 2,3 Kronen Grundsteuer. Aehnlich steht es mit der Viehzucht. Sieht man von den Städten ab, so kommen auf die 157000 Bewohner der reindeutschen Bezirke 16000 Pferde und 150000 Rinder, während auf die 161000 Bewohner der gemischten und slowenischen Bezirke nur 14000 Pferde und 94 000 Rinder entfallen (Zählung von 1900). Noch ungünstiger fällt der Vergleich für die Slowenen aus, wenn man Gewerbe und Industrie in Betracht zieht. Alle größeren Betriebe und auch die Mehrzahl der kleineren sind in deutschen Händen. Die Erwerbssteuer beträgt bei Deutschen 1 Krone für den Kopf, bei den Slowenen 0,4 Kronen. - Im Jahre 1906 gab es in Kärnten 132 deutsche Spar- und Darlehnskassen (= 83 v. H.) mit unbeschränkter Haftung und nur 27 slowenische, während die deutschsprechende Bevölkerung nur 75 
von Walther Fresacher, deren Ergebnisse in den I950er-Jahren publiziert wurden, lässt sich schlüssiger nachvollziehen, weshalb slowenischsprachige Bauern gegenüber ihren deutschsprachigen Pendants - statistisch gesehen - eine geringere wirtschaftliche Wertschöpfung erbrachten. Vor I950 orientieren sich Arbeiten zur Sozial- und Wirtschaftsgeschichte der Kärntner Agrargesellschaft an allgemein gehaltenen Analysemodellen ${ }^{103}$.

Ursachen für die bestehenden sozioökonomischen Verhältnisse im gemischtsprachigen Gebiet sind, kurz zusammengefasst, in der Rechtslage der Bauernschaft zu suchen, die vor den theresianisch-josephinischen Reformmaßnahmen jahrhundertelang von zwei unterschiedlichen Rechtskonstruktionen bestimmt war: „Freistiftrecht“ und „Kaufrecht“. In Kärnten war die vorwiegende Besitzform durch die „Freistift“, ein nicht vererbbares Recht, geprägt. Das bedeutete, dass das „Freistiftrecht“ bei der Übernahme eines Besitzes eine zeitweilige, für den aktuellen Besitzer im besten Fall bis zu dessen Ableben, nur eine Nutznießung gestattete. Demgegenüber begründete das „Kaufrecht“ ein Eigentumsrecht. Der Eigentümer konnte ohne Einschränkungen über den Tod hinaus über Grund und Boden verfügen. Das ermöglichte eine Planung unter Generationsperspektiven. Im gemischtsprachigen Gebiet dominierte das „Freistiftrecht“ bis weit über die Mitte des I 8 . Jahrhunderts hinaus. Nach der Grundentlastung von I 848 zeigt diese Region erneut eine Besonderheit. Neben dem rustikalen Grundbesitz, eine Besitzform, die den Bauern zum Eigentümer macht, gibt es hier zahlreiche Dominikalgüter. Das sind land- und forstwirtschaftliche Liegenschaften, die noch nach der Überwindung des Feudalsystems weiter bestanden. Solche Dominikalbesitzungen charakterisiert umfangreicher Waldbesitz, mit dem in der Regel lukrative Servitutsrechte verbunden waren ${ }^{104}$. Im südlichen Kärnten verfügten über solche großflächigen und wirtschaftlich lukrativen Güter einige wenige, meist Eigentümer von ehemaligen Grundherrschaften. Das gemischt- und vor allem slowenischsprachige Gebiet weist hingegen vorwiegend eine kleinbäuerliche Struktur auf ${ }^{105}$.

v. H. betrug. In demselben Jahre zählte man 16 deutsche Spar- und Darlehnskassen mit beschränkter Haftung und nur eine slowenische, acht deutsche Gewerbsgenossenschaften und keine slowenische, 20 deutsche landwirtschaftliche Wirtschaftsgenossenschaften und zwei slowenische, 13 deutsche Sparkassen und keine slowenische. Die Deutschen huldigen also dem Fortschritte viel mehr als die Slowenen und zeigen auch darin ihre Ueberlegenheit."

103 Vgl. beispielsweise O. Moro (mit einem Beitrag von U. Sсна Bus), Volksordnung, in: Handwörterbuch des Grenz- und Auslanddeutschtums 3 (wie Anm. 86) 599-603.

104 Vgl. Walther Fresacher, Der Bauer in Kärnten 1-3: 1 Die persönliche Stellung des Bauers in Kärnten; 2 Das Freistiftrecht; 3 Das Kaufrecht (Archiv für vaterländische Geschichte und Topographie 31, 39, 43/44 Klagenfurt 1950, 1952, 1955); Janko Pleterski, Slowenisch oder deutsch? Nationale Differenzierungsprozesse in Kärnten (1848-1914). Übersetzungen aus dem Slowenischen Franci Zwitt er. Bearb. und Einleitung Valentin Sim a (Klagenfurt/Celovec 1996) 18-30, 110-145.

105 Eine aufschlussreiche Karte dazu, ergänzt durch den „Planungsatlas Lavanttal“, in: Elisabeth LiCHTEnBERGER, Der Strukturwandel der sozialwirtschaftlichen Siedlungstypen in Mittelkärnten, in: Geographischer 
In der Zeit der beginnenden Modernisierung der Land- und Forstwirtschaft resultierte daraus im Wirtschaftsleben Kärntens von Anbeginn ein großer Wettbewerbsnachteil für die slowenische Volksgruppe. Wutte deutet zwar die unterschiedlichen Vermögensverhältnisse zwischen der deutsch- und der slowenischsprachigen Agrargesellschaft an, aber eine systematische Ursachenforschung unterbleibt. Stattdessen bemüht er eine Diktion, die einem Kulturdarwinismus das Wort schreibt ${ }^{106}$ und ein gewaltiges Bruchstück der „nationalen Frage“ nur oberflächlich streift. „Diese Ueberlegenheit des deutschen Nachbarn ist es, die in Kärnten den Fortschritt der deutschen Sprache in alter und neuer Zeit gefördert hat und die heute noch dem Kärntner Slowenen die Kenntnis der deutschen Sprache so wertvoll erscheinen lässt, daß er sie auf irgend eine Weise lernen will. Gegenwärtig kommt die Schule dem Bedürfnis der Slowenen, deutsch zu lernen, nach. Aber nicht immer war es so. [...] Nur die wenigen slowenischen Führer sind gegen die Erlernung der deutschen Sprache, die große Masse der slowenischen Bevölkerung hat sich wiederholt für dieselbe ausgesprochen. Im Jahre I 859 z. B. verlangten sämtliche slowenischen Schulgemeinden die Einführung der deutschen Unterrichtssprache. Bei der Durchführung des Reichsvolksschulgesetzes (I 869/I87I) gab es keine einzige slowenische Gemeinde, welche nicht die Notwendigkeit der Erlernung der deutschen Sprache anerkannt hätte. Viele verlangten auch ausdrücklich die deutsche Unterrichtssprache."107 Denn aus welchem Personenkreis sich die Vertreter der erwähnten „slowenischen Schulgemeinden“ rekrutierten, wurde von Wutte nicht hinterfragt. Für eine Geschichtsforschung, die sich lokalpolitischer Fragen annimmt und sich mit dem Zeitraum I 848 bis 1907 befasst, ist das aber von zentraler Bedeutung. Denn aufgrund des Zensusprinzips, das nur „Ehren-, Intelligenz- und Steuerwählern" ein aktives und passives Wahlrecht zugestand, blieb das überwiegende Gros der Bevölkerung von politischen Alltagsentscheidungen bis I 907 ausgeschlossen ${ }^{108}$. Es waren Vermögende und andere Privilegierte, zum Großteil Sympathieträger des deutschen Volkstums oder mit diesem aus wirtschaftlichen oder politischen Überlegungen verbunden, die bis zu diesem Jahr Entscheidungen in der Schul- und Sprachenfrage trafen. Die

Jahresbericht aus Österreich 27 (1957/1958) 61-128, zitiert nach PLETERSKI, Slowenisch oder deutsch? (wie Anm. 104) 113.

106 Wutte, Fortschritte des Deutschtums (wie Anm. 101) Sp. 87: „Damit stimmt auch der Eindruck überein, den man von deutschen und slowenischen Gegenden gewinnt. Dort große, schöne Gehöfte, stockhohe Häuser, geräumige Wirtschaftsgebäude mit Dutzenden von stattlichen, rassereinen Rindern, wohlgepflegte Obst- und Gemüsegärten, gut bebaute Aecker, Verwendung moderner Maschinen, hier kleine, ebenerdige Häuschen, oft mit dem Stall verbunden, in diesen einige wenige unansehnliche Rinder, kleine, wenig fruchtbare und schlecht gepflegte Felder, starres Festhalten an der althergebrachten Arbeitsform."

107 Ebd. Sp. 88.

108 Ausführlich zur Situation auf landespolitischer Ebene: Vasilij MeLIK, Wahlen im alten Österreich am Beispiel der Kronländer mit slowenischsprachiger Bevölkerung (Anton Gindely-Reihe zur Geschichte der Donaumonarchie und Mitteleuropas 3, Wien/Köln/Weimar 1997) zu Kärnten 246-256, 318. 
I9I9 veröffentlichte und bis weit in die Gegenwart wirkende Studie „Die utraquistische Volksschule in Kärnten“, die aussagekräftiges Quellenmaterial birgt, muss vor diesem Hintergrund interpretiert werden ${ }^{109}$.

Die Ausführungen Wuttes im „Monatsblatt des Allgemeinen Deutschen Schulvereines“ erinnern an den politischen Auftrag der „Südmark“, bilanzieren deren Wirken als positiv und enden mit einer Kritik an slowenisch-nationalen Aktivisten ${ }^{110}$. Ein Jahr zuvor hatte sich Wutte in einer weiteren Schrift der „Südmark“ vorwiegend mit sprachlichen, sozialen und wirtschaftlichen Verhältnissen in Kärnten auseinandergesetzt. Das bedeutungsvolle Adjektiv „landfremd“, das später immer wieder in seinen Publikationen verwendet wurde und dessen mental-psychologische Wirkung bis in die Gegenwart reicht ${ }^{111}$, hat seine Geburtsstunde: „Allerdings stehen an der Spitze der Bewegung noch meist landfremde Leute. Aber diese besitzen bereits in verschiedenen Landesteilen einen starken Anhang." Und Wutte wirft einen warnenden Blick in die Zukunft, weil die künftige Verkehrserschließung Kärntens Richtung Süden das Deutschtum bedroht, und bringt nicht nur seine Sicht der Dinge, sondern formuliert nationalpolitische Ziele ${ }^{112}$. In einer

109 Martin wutte, Die utraquistische Volksschule in Kärnten. Zur 50jährigen Jubelfeier des Reichsvolksschulgesetzes vom 14. Mai 1869 (Klagenfurt 1919). Einen aufschlussreichen Überblick zur Schulgeschichte im 20. Jahrhundert bietet: Theodor DoмеJ, Das Schulwesen für die Bevölkerung Südostkärntens, in: Die Kärntner Slovenen 1900-2000. Bilanz des 20. Jahrhunderts hg./izd. Andreas Moritsch, redaktionelle Betreuung/uredila Tina BAHovec (Unbegrenzte Geschichte - Zgodovina brez maja 7, Klagenfurt/Celovec/ Ljubljana/Laibach/Wien/Dunaj 2000) 29-66.

110 Wutte, Fortschritte des Deutschtums (wie Anm. 101) Sp. 89: „Die wirtschaftliche Stärkung des Deutschtums in den deutsch-slowenischen Ländern ist hauptsächlich Aufgabe des Vereins ,Südmark'. Erst 17 Jahre besteht die ,Südmark' und doch kann sie schon auf Erfolge hinweisen. Abgesehen von den vielen Unterstützungen, die bedrängten Volksgenossen in slowenischem Gebiet gewährt wurden, hat die deutsche Sprache in mehreren Gemeinden, in denen Südmarkortsgruppen gegründet wurden, bedeutend zugenommen, auch in solchen, wo sie früher zurückgegangen ist. In jüngster Zeit denkt man auch daran, an besonders wichtigen Punkten Deutsche anzusiedeln; das ist jedoch sehr schwierig und braucht vor allem viel Geld. Daß aber die deutsche Sprache aus der Schule nicht verschwinde, dafür sorgt der, Deutsche Schulverein', allen voran die rührige Ortsgruppe in Klagenfurt und ihr Obmann Direktor Steinlechner, der sich um das Deutschtum in Kärnten durch seine aufopfernde Tätigkeit Verdienste erworben hat, wie kein zweiter. In den 25 Jahren des Bestehens hat der Schulverein 187000 Kronen für Schulzwecke in Kärnten gespendet, 25 Unterstützungen für Schulhausbauten in den Grenzgemeinden gewährt und sich dadurch einen maßgebenden und schwer zu beseitigenden Einfluß auf die Unterrichtssprache dieser Schulen verschafft. Zehn Unterstützungen fallen in die Umgebung von Klagenfurt, wo die deutsche Sprache tatsächlich auch die größten Fortschritte gemacht hat. An diesen Schulvereinsunterstützungen stolpern die slowenisch-nationalen Heißsporne, wenn sie in den Grenzgemeinden gegen die Schule mit deutscher Unterrichtssprache Sturm laufen.“

111 Zur Wirkungsgeschichte ein erster entsprechender Literaturhinweis bei PLETERSKI, Slowenisch oder deutsch? (wie Anm. 104) 44.

112 Martin Wutte, Zur Sprachenkarte von Kärnten, in: Mitteilungen des Vereines Südmark, 6. Nebelmonds Nr. 3 (Graz 1906) 99-101: [...],,wenn einmal die Karawankenbahn Kärnten mit Krain verbinden wird, so 
Werbeschrift des Deutschen Schulvereins, in der er für Ergänzungen verantwortlich zeichnet, werden die Hoffnungen, die mit der neuen Bahn verknüpft werden, artikuliert ${ }^{113}$. Diese Überlegungen Wuttes, die teilweise an gegenwärtig noch immer bestehende politische Imponderabilien erinnern, entbehren trotz der Problematik, die jede Beurteilung im Nachhinein birgt, nicht einer Bizarrerie. Ein Motiv für diese Argumentation ist ein wichtiges Ursachenmoment und die wohl zentralste Triebfeder jedes hegemonialen Nationalismus: die Furcht, Führungspositionen in der Gesellschaft zu verlieren. In Kärnten haben über Jahrhunderte vorwiegend Angehörige der deutschsprechenden Mehrheitsbevölkerung diese Vorrangstellung eingenommen. Wutte spricht einen zentralen Katalysator für die „geistige und wirtschaftliche Überlegenheit der Deutschen“ an. Es ist ein Deutschtum, das „in Kärnten seit dem frühen Mittelalter bis auf die neueste Zeit einen ununterbrochenen Fortschritt der deutschen Sprache“114 gesichert hat.

I 9 3 veröffentlichte Wutte einen Artikel, der erneut von erfolgreicher Deutschtumsarbeit zu berichten weiß und darüber hinaus auch ein beachtenswertes Stück deutscher Schutzarbeitsgeschichte in Kärnten enthält. Wutte beschreibt zunächst den Werdegang deutscher Schutzvereine und erinnert an den besonderen Beitrag Kärntens. Als Beleg dafür wird eine Aussage eines prominenten Zeitzeugen aus dem deutschnationalen Lager he-

\footnotetext{
werden unsere Slowenen ohne Zweifel an Krain, dem Herd der Agitation, noch mehr Rückhalt finden als bisher. Dazu droht nach Eröffnung der Bahn noch eine zweite Gefahr. Krainische Arbeiter sind schon jetzt trotz der ungünstigen Verbindung mit Krain in Kärnten in großer Zahl zu treffen. Sie scheuen nicht die lange Eisenbahnfahrt oder den beschwerlichen Weg über die Pässe, um Arbeit zu finden. Nach Eröffnung der Karawankenbahn wird die Einwanderung krainischer Arbeiter sicher stärker werden. Wenn also die neue Bahnverbindung mit Triest für die Erhaltung und Stärkung der deutschen Minderheiten im Süden der Monarchie von Nutzen sein wird, für die gegenwärtige Stellung des Deutschtums in Kärnten kann sie gefährlich werden. Eine Förderung der deutschen Sprache durch die neue Bahn läßt sich insofern erwarten, als erfahrungsgemäß Industrie, Handel und Verkehr der Verbreitung der deutschen Sprache günstig sind; denn gerade dort, wo Industrie, Handel und Verkehr am stärksten sind, ist die Zunahme der deutschsprechenden Bevölkerung am größten: in der Umgebung von Klagenfurt, in Ferlach, am Wörthersee. [...] Damit ist ein Fingerzeig gegeben, wie sich die nationale Arbeit zu gestalten hat. In erster Linie werden die deutschen Minderheiten an der Sprachgrenze und in den Sprachinseln wirtschaftlich durch ausgiebigere Unterstützungen zu stärken sein, wenn sie sich erhalten und weiter entwickeln sollen. In dieser Hinsicht ist gewiß zu wenig geschehen und kann in Zukunft auch leicht mehr geschehen. Hand in Hand mit der wirtschaftlichen Kräftigung wird der nationale Sinn zu wecken und wach zu halten sein, mehr, als dies bisher geschehen ist. Sehr zu begrüßen wäre eine tatkräftige Besiedlungsarbeit, wozu die neuen Bahnen Gelegenheit genug bieten würden.“

113 K. Trost (†) ergänzt von Dr. M. Wutтe, Aufgaben der deutschen Schutzvereine in Kärnten, in: Flugschriftensammlung. Deutscher Schulverein, Wien, VI. Linke Wienzeile, Werbschrift Nr. 95, o. D. [1910 ?] 6, aus: NLW, Schachtel 28, 936: „Möge uns deutschen Kärntnern der Blick durch das zweite große Loch nach Norden, das die Tauernbahn durch das Grenzgebirge geschlagen hat, in der nationalen Arbeit ermutigen, und das Bewußtsein, daß ein Millionen-Brudervolk hinter den Bergen steht, uns stets wachsam und treu auf dem gefährdeten Grenzposten erhalten!“
}

114 Wutte, Besiedlung Kärntens (wie Anm. 101) 91. 
rangezogen. In der Folge macht Wutte Angaben zu Gründungsjahren von Ortsgruppen, schildert Vorgänge rund um die Ortsgruppentagung in Klagenfurt, die am I I. Dezember I 887 über die Bühne ging, und deutet Konflikte innerhalb der Organisation im Zeitraum I 887 bis I 899 an. Nach einem kurzen Hinweis auf die Bedeutung der Wanderlehrer für die Werbearbeit des Deutschen Schulvereines, der Darlegung der finanziellen Aufwendungen und Leistungen dieser Organisation - teilweise en détail - schließt Wutte mit Überlegungen, die der zweiten Ethnie in Kärnten eine sekundäre Bedeutung beimisst ${ }^{115}$. Iānus Wutte blickt dann getrost in die Zukunft, wenn eine wirtschaftliche und geistige Überlegenheit des Deutschtums im Land bestehen bleibt. In einem Land, in dem Vorgenerationen der slowenischen Volksgruppe als Teil der Karantanen, zumindest seit dem sechsten Jahrhundert, gleichsam als „Aborigines“ siedelten. Erst rund zwei Jahrhunderte später, konkret 828, führte Kaiser Ludwig der Fromme „die fränkische Grafschaftsverfassung in Karantanien ein, wodurch das bayerische Recht auf die meisten, obgleich nicht alle Bewohner des Landes ausgedehnt wurde". ${ }^{116}$

Resümee: Die zitierten Veröffentlichungen Wuttes charakterisiert eine Ausdrucksweise, die sich kaum von jenem Propagandastil unterscheidet, der in Kampfschriften eines radikalen Deutschnationalismus kultiviert wurde. In wissenschaftlichen und populärwissenschaftlichen Schriften hat Wutte eine vergleichbare Diktion vermieden. Vor diesem Hintergrund erfordert die Doppelgesichtigkeit des Iānuskopfes eine neue Definition.

115 Martin Wutte, Kärnten und der Deutsche Schulverein. (Mit vier Bildern, ausgeführt vom Zeichenlehrer Max Bradaczek) in: Südmark-Kalender (Ausgabe Klagenfurt 1913) 1-8, hier 1, 3, 4 und 8: „Steinwender stand auch an der Spitze jenes Ausschusses, der im Mai 1880 die ersten Schritte zur Gründung des Deutschen Schulvereines unternahm. Im Juli 1880 fand in Wien die gründende Versammlung des ersten deutschen Schutzvereines statt, im folgenden Jahre war er bereits so weit erstarkt, daß man an die Gründung von Ortsgruppen außerhalb Wiens schreiten konnte. Das Bewußtsein, daß ein Kärntner an der Wiege des Schulvereins gestanden, hat nicht wenig zur Verbreitung des Schulvereins in Kärnten beigetragen, wie Dobernig auf dem Ortsgruppentage in Klagenfurt 1887 ausführte. [...] Erst als es in der Hauptversammlung zu Troppau 1899 zu einem Ausgleich kam, ging es mit dem Schulverein auch in Kärnten wieder vorwärts. “ Anschließend verfasst Wutte ein Stück zur Organisationsgeschichte des Schulvereines, die darüber hinaus topografische Zuordnungen und Gründungsdaten für den Zeitraum 1902 bis 1911 enthält: „118 Ortsgruppen stehen 215 Gemeinden gegenüber, von denen aber (!) 61 eine slowenische Mehrheit aufweisen. Die Zahl der Mitglieder betrug 1881: 274, 1890: 2257, 1900: 2450, Ende 1911: 9500. Der Deutsche Schulverein ist also einer der stärksten Vereine in Kärnten geworden, wenn nicht der stärkste. [...] Wenn auch das Schulwesen in den deutschen Gemeinden, namentlich in den Grenzgemeinden, mit der Entwicklung des Schulwesens auf der slowenischen Seite der Sprachgrenze gleichen Schritt hält, wenn der deutsche Kärntner dem slowenischen wie bisher wirtschaftlich und geistig überlegen bleibt, dann dürfen wir getrost in die Zukunft blicken, dann werden unserem Lande jene unseligen Sprachenkämpfe erspart bleiben, die unsere Nachbarländer und unser Reich zerrütten."

116 Herwig Wolfram, Grenzen und Räume. Geschichte Österreichs vor seiner Entstehung (Österreichische Geschichte 378-907, Wien 1995) 304. 
IV : K ̈̈RNTEN, DEUTSCHLAND, ÖSTERREICH UND WUTTE

Die Veröffentlichungen Wuttes in Printmedien Deutschlands haben sein Entree ins öffentliche Leben nationalpolitischer Kreise im nördlichen Nachbarstaat gewiss nicht erschwert. Vor I9I8/I9I9 wurden damit erste Fäden eines Netzes gesponnen, das ab I9I9 weitmaschiger und dichter wird. In Kärnten war Wutte im Beziehungsgeflecht von Entscheidungsträgern nationalpolitischer Interessen spätestens 1918/1919 tief eingebunden. Unmittelbar an die detailarme Schilderung seiner Tätigkeit im Schulverein artikulierte Wutte in seinem Lebenslauf selbstbewusst und zutreffend: „Die fortgesetzte Beschäftigung mit der historischen Geographie Kärntens und der Entwicklung der sprachlichen und völkischen Verhältnisse des Landes befähigten mich, nach dem ersten Weltkrieg in den geistigen Kampf um Kärntens Freiheit und Einheit einzugreifen. Ich wurde daher I9I9 als Sachverständiger für Kärnten an der Seite des politischen Vertreters, des nachmaligen Ministers Vinzenz Schumy, in die deutschösterreichische Delegation für die Friedensverhandlungen in St. Germain entsendet und wurde Mitglied des Nationalpolitischen Ausschusses der Landesregierung sowie Beirat der österreichischen Abstimmungskommission und des Kärntner Heimatdienstes, der die Vorarbeiten für die Abstimmung leitete. Der Abstimmungstag brachte auch mir eines der eindrucksvollsten Erlebnisse. Kärnten hatte nach fast zweijährigem Kampf, in dem geistige Waffen den Kampf mit der Faust unterstützt und vielfach unterbaut hatten, gesiegt. "117

Die Mitwirkung Wuttes in der deutsch-österreichischen Friedensdelegation wurde einer breiteren Öffentlichkeit nur kryptisch über das Buch „Kärntens Freiheitskampf“ vermittelt, denn Wutte verlor über seine Teilnahme expressis verbis keinen Satz ${ }^{118}$. Ergänzend ist anzuführen, dass die Erstauflage von „Kärntens Freiheitskampf“ nur einen „Literaturnachweis (Auswahl)“ enthält. Auf einen Anmerkungsapparat wurde, vermutlich aus Zeitund Kostengründen, verzichtet; Quellenverweise werden im Text gegeben. In der Auflage von 1943 wurden weitestgehend formale Kriterien einer wissenschaftlichen Publikation eingehalten. Die quellenkritische Problematik von „Kärntens Freiheitskampf“ fasste Helmut Rumpler prägnant zusammen: „Wutte war als Wissenschafter auch Zeitzeuge und

117 Wutte, Lebenslauf 1949 (wie Anm. 36) 6f. Hervorhebungen nach Vorlage.

118 Ebd. Wutte, Freiheitskampf (1922) (wie Anm. 1) IIIf.: „Als Quellen dienten zahlreiche Akten und Schriften, zum Teil auch persönliche Erlebnisse. Die Schilderung der militärischen Ereignisse und die militärischen Skizzen stellte Herr Oberst Ludwig Hülgerth, der ehemalige Landesbefehlshaber von Kärnten, bei. Herr Oberleutnant in der Reserve Hans Stein acher lieferte den Stoff für die Darstellung der Ziele und Arbeiten der Landesagitationsleitung und des Kärntner Heimatdienstes. "Das Vorwort endet mit dem Hinweis, eine „wichtige Ergänzung der folgenden Darstellung ist Josef Friedrich Perkonigs packendes Buch ,Heimat in Not““, in dem Perkonig „mit der kundigen Feder des Chronisten“ Erlebnisse aus dem Rosental aus „der ereignisreichen Zeit von 1918 bis zur Volksabstimmung“ schildert. Hervorhebungen nach Vorlage. 
darüber hinaus auch politischer Mitspieler. Nicht wenige seiner zentralen Befunde fließen aus seiner politischen Überzeugung, sind weder durch Quellen noch durch Argumente belegt oder gestützt. Wuttes Verdienst war es, den „Kärntner Standpunkt“ in seiner historischen Entwicklung und tagespolitischen Zuspitzung in voller Breite dargestellt und zur Geltung gebracht zu haben.“119 Was unter „Kärntner Standpunkt“ zu verstehen ist, lässt Rumpler offen. Gemeint ist aber wohl jene Position, die maßgebende Politiker und Landeshistoriker mehrheitlich seit jeher einnehmen, wenn es um die Sichtweise von „Abwehrkampf“, Volksabstimmung und Kerngedanken zur „nationalen Frage“ geht.

$\mathrm{Zu}$ Schumy, einem schillernden Politiker, gibt es zahlreiche akademische Schriften, die vom Nachlass, der sich im Archiv des Instituts für Österreichische Zeitgeschichte in Wien befindet, profitierten ${ }^{120}$. Zur Geschichte des Nationalpolitischen Ausschusses, zu dessen personeller Zusammensetzung, zu dessen Entscheidungskompetenzen und Wirkung, stützt sich die Historiografie auf einige wenige Ausführungen Wuttes, die er, ehemaliges Mitglied des Ausschusses, in der Erstauflage von „Kärntens Freiheitskampf “ darbot $^{121}$. Die Rezipienten des Buches erfuhren so nur Allgemeines über Abschnittsleiter, Verbindungsmänner und Vertrauensleute in der Zone I ${ }^{122}$. Wuttes Zurückhaltung lässt sich mit den damaligen nach wie vor unsicheren außenpolitischen Verhältnissen erklären. Denn als er zwischen 1920 und 1922 an „Kärntens Freiheitskampf“ arbeitete, war ein möglicher Anschluss Österreichs an das „Weimar-Deutschland“, trotz des im Vertrag von St-Germain-en-Laye festgelegten Anschlussverbotes der einstigen kurzlebigen Republik „Deutschösterreich“, ein zentrales politisches Thema geblieben. In zwei Bundes-

119 Rumpler, Nationale Frage (wie Anm.14) 18.

120 Vgl. Ursula Benedikt, Vinzenz Schumy 1878-1962. Eine politische Biographie (masch. Phil. Diss. Wien 1966); Lothar Нӧвецt, Vinzenz Schumy, in: Von Figl bis Fischer. Bedeutende Absolventen der „BOKU“ Wien, hg. v. Manfried Welan, Gerhard Poschacher (Graz 2005) 205-211.

121 Wutte, Freiheitskampf (1922) (wie Anm. 1) 133f.: „Die Leitung der Propaganda übernahm die LandesAgitationsleitung, ein Ausschuß, gebildet aus Vertretern der politischen Parteien und der maßgebenden Behörden des Landes, der dem Nationalpolitischen Ausschusse der provisorischen Landesversammlung bis zu dessen Aufösung im März 1920 angegliedert war. In der konstituierenden Versammlung der Landes-Agitationsleitung am 22. August 1919 in Spittal an der Drau wurde Landesrat Max Burger zum Vorsitzenden und Oberleutnant Hans Steinacher zum Geschäftsführer gewählt. Der Sitz der Landes-Agitationsleitung war ab September 1919 in St. Veit an der Glan. Die Grundlinien der Propagandatätigkeit wurden in den periodischen Beratungen eines Beirates festgestellt. Die Leitung der Arbeitstätigkeit blieb dem Geschäftsführer überlassen. Da die Südslawen in der Zone I jede Propagandatätigkeit mit allen Mitteln verfolgten und jede Äußerung gegen den südslawischen Staat als Hochverrat bestraften, mussten naturgemäß die ganze Tätigkeit der Landes-Agitationsleitung, ihr Dasein und ihre Organe geheim bleiben. So ist die Landes-Agitationsleitung, die Vorläuferin des Kärntner Heimatdienstes, niemals öffentlich in Erscheinung getreten, so dass die Südslawen noch im Juni 1920 über den Bestand dieser Organisation nicht im geringsten unterrichtet waren und selbst die Öffentlichkeit in Kärnten nur wenig von ihr wusste."

122 Ebd. 135. 
ländern Österreichs hatte es entsprechende Abstimmungen gegeben: I92 I stimmten in Tirol 98 Prozent der Optanten für einen Anschluss an Deutschland, 99 Prozent waren es im Mai 1922 bei einer vergleichbaren Abstimmung in Salzburg. Eine österreichische Bundesregierung demissionierte nicht zuletzt wegen eines weiteren geplanten Plebiszits in der Steiermark. Aus Kärnten waren schon zuvor warnende Stimmen ${ }^{123}$ gekommen. Das Thema Anschluss fließt auch in den autobiografischen Lebenslauf Wuttes ein. Der Historiker bekennt sich zur Anschlussidee, die aber wegen befürchteter negativer außenpolitischer Implikationen behutsam zu vertreten war; seine Perspektive dazu - a posteriori betrachtet - muss ambivalent gedeutet werden ${ }^{124}$, weil jeder Anschluss Österreichs an Deutschland, wie auch jener im März I938, die Kärntner Volksabstimmung vom ıo. Oktober 1920 konterkarierte. Denn beim Plebiszit war ja die Entscheidung zu treffen, ob man territorial bei „Oesterreich/Avstrija“ bleiben oder sich „Jugoslavija/Jugoslawien“ anschließen wollte. I922 wollte Wutte vermutlich in dieser außenpolitisch heiklen ungewissen Situation exponierte Gegner des SHS-Staates nicht gefährden. Ein Briefwechsel mit Suitbert Lobisser erschließt ein weiteres Ursachenmoment, warum Wutte Zurückhaltung geübt hatte. Lobisser, ein weit über Kärnten hinaus bekannter bildender Künstler, arbeitete 1927 an „Kartons für das Gedächtnisbild im L.H. [= Landhaus, Anm. Burz] Sitzungssaal“. Im Zuge dieses Projektes ersuchte er den Leiter des Kärntner Landesarchivs um Unterstützung. Das Bittschreiben ist nicht nur ein Beleg aus erster Hand, welche Vorstellungen der Maler mit seinem Werk verknüpfte, sondern dokumentiert ein gewichtiges Stück der Identität Kärntens seit I 920: Das Bild ist in drei Gruppen aufgelöst, von denen die linksseitige die Kampfbereitschaft, die rechte den Willen zur Einigkeit, die mittlere endlich das um das Geschehen interessierte Kärntner Völkchen darstellt. Bei jeder dieser Gruppen werden Porträts eingeführt, bei den Kämpfern ca 7, (davon habe ich bereits Fritz, Kronegger, Arneitz), bei der Abstimmung 4, (Dr. Steinacher ist schon da). Auch bei der Mittelgruppe könnte ich einige anbringen. (Nicht alle Figuren sind infolge ihrer Körperstellung zum Porträt geeignet) - Ich möchte Sie nun bitten, mir für die noch fehlenden Porträts für alle drei Gruppen Namen zu nennen. Ich brauche z.B. einen Vertreter der Klagenfurter Studentschaft, einen etwa der damaligen Regierung, oder polit. Vertretung in Paris, einen Vertreter der Klagenfurter oder Ferlacher-Bleiburger Abwehrkämpfergruppe. ${ }^{125}$

123 Ausführlicher Walter Goldinger, Dieter Binder, Geschichte der Republik Österreich 1918-1938 (Wien 1992) $81 \mathrm{f}$.

124 Wutte, Lebenslauf 1988 (wie Anm. 38) 16f. „Obwohl seit dem Zusammenbruch des alten Österreich ein begeisterter Anhänger eines friedlichen und ruhigen Anschlusses, besser Zusammenschlusses Österreichs mit dem Deutschen Reich, glaubte ich doch, dass sich Kärnten in dieser Frage zurückhalten müsse, da das Verhalten Jugoslawiens und Italiens gegenüber der Anschlußbewegung keinen Zweifel aufkommen ließ, daß diese beiden Staaten im Falle eines übereilten Anschlusses sofort Kärnten besetzen würden.“

125 Lobisser an Wutte, St. Paul im Lavanttal, 04.11.1927, KLA, NLW, Schachtel 1, 90. 
Wuttes Antwort kam postwendend: So sehr auch die Anbringung von Porträts nahe liegt, so möchte ich Ihnen doch dringend raten, davon abzusehen. Die Auswahl ist ausserordentlich schwer und schwere Verstimmungen sind unvermeidlich. [...] Ich bin seinerzeit, als ich den ,Kärntner Freiheitskampf verfasste, vor derselben Frage gestanden und mit [Ludwig] Hülgerth ${ }^{126}$ übereingekommen, Namen soweit als möglich zu verschweigen, darum Ihr vergeblicher Versuch, Namen zu finden! Das hat natürlich auch nicht den Beifall der Beteiligten gefunden, aber doch schwere Verstimmungen vermieden, wie sie z.B. Perkonigs Buch ${ }^{127}$, das Persönlichkeiten hervortreten lässt, hervorgerufen hat. ${ }^{128}$ Bei der Neuauflage von „Kärntens Freiheitskampf“ im Jahr I943 war eine Rücksichtnahme vor allem auf außenpolitische Rahmenbedingungen augenscheinlich nicht mehr notwendig. Wutte führte nun zahlreiche Akteure des nationalpolitischen Ausschusses, des Heimatdienstes, namentlich an.

In der Historiografie ist es bis heute eine der umstrittensten Fragen, wieweit maßgebliche Funktionäre, höhere Militärs oder Politiker I9I8 bis I920 in Kärnten, egal ob es ein „Kampf“ mit „geistige[n] Waffen“ war oder ob sie „den Kampf mit der Faust unterstützt"haben ${ }^{129}$, für Österreich oder nicht in erster Linie für ein größeres Deutschland aktiv waren ${ }^{130}$. Dabei müssen die außerordentlichen politischen Rahmenbedingungen besonders berücksichtigt werden. Ein Teil des Landes durchlebte hautnah einen verlängerten Konflikt, der mit Waffengewalt ausgetragen wurde, eine Besatzungsmacht, die die längste Zeit eine brutale Repressionspolitik gegenüber der Bevölkerung ausübte. Hinzu kam, dass die überwiegende Mehrheit der Zeitgenossen von der Existenzfähigkeit des neuen Staates Österreich unmittelbar nach I 9 I 8 und lange Zeit darüber hinaus nicht überzeugt war. Kärntens historisch gewachsene Landeseinheit war I9 8 bis I 920 konkret bedroht. Ein Anschluss an den wirtschaftlich und außenpolitisch bedeutsameren Nachbarn Deutschland schien gegenüber einem „Staat, den niemand wollte“, eine lohnende

126 Anm. Burz: Hülgerth war 1918/1919 offizieller militärischer Oberbefehlshaber des Landes Kärnten; $1934-$ 1936 Landeshauptmann von Kärnten, 1936-1938 Vizekanzler der ständestaatlichen Republik Österreich. Vgl. Evelyne Webernig, Der Landeshauptmann von Kärnten. Ein historisch-politischer Überblick (Klagenfurt 1987) 82-84.

127 Anm. Burz: Josef Friedrich Perkonig, Heimat in Not (Klagenfurt 1921).

128 Wutte an Lobisser, Klagenfurt, 07.11.1927, KLA, NLW, Schachtel 1, 90.

129 Wutte, Lebenslauf 1988 (wie Anm. 38) 15.

130 In der einschlägigen Historiografie werden dazu immer wieder Ausführungen von Hans Ste inaCher, Sieg in deutscher Nacht. Ein Buch vom Kärntner Freiheitskampf (Wien 1943) 6, 7, 317, 401, 413, zitiert, die aufgrund der damaligen gesellschaftlichen Rahmenbedingungen zu Recht als problematisch gelten. Im NL Steinacher, BAK, lassen sich ausreichend Belege dafür finden, dass der nicht nur in Kärnten aktive Volkstumskämpfer 1943 das schrieb, wofür er 1920 tatsächlich gekämpft hat: in erster Linie für „sein“ Kärnten, dann für ein Großdeutschland und erst dann, wenn überhaupt, für ein Österreich. Zu biografischen Eckdaten siehe Hans-Adolf Jасовson, Hans Steinacher. Bundesleiter des VDA 1933-1937 (Boppard am Rhein 1970) bes. XI-XVIII. 
Alternative. Erst Ende der I 920er-Jahre sollte sich langsam ein österreichisches Staatsbewusstsein entwickeln, das durch das Dollfuß-Schuschnigg-Regime unter anderem deshalb Brüche erlebte und inkonsistent blieb, weil es zum einen über weite Strecken staatlich quasi von oben herab verordnet worden war. Zum anderen, weil einem größeren Teil der Bevölkerung seit dem März I933 die politische Mitarbeit verwehrt blieb. Wutte und die Mehrzahl der führenden „Abwehrkämpfer“ waren von Anbeginn, nicht zuletzt aufgrund der Erfahrungen mit dem austrofaschistischen Ständestaat, über 1938 hinaus einer gesamtdeutschen Idee verhaftet. Dass Deutschland seit 1933 ebenfalls keine demokratische Regierung hatte, schien im Zeitalter vieler antidemokratischer Regierungen als vernachlässigbares Übel zu gelten.

Wuttes Resümee in seinem Vorwort zur zweiten Auflage von „Kärntens Freiheitskampf ist daher nicht ein zeitbedingtes Bekenntnis, ein notwendiger Kniefall vor den neuen Machthabern, sondern beruht auf einer schon vor und nach I9I 8 verstärkt gewachsenen Überzeugung ${ }^{131}$. In der I 985 publizierten Fassung fehlt dieser Textteil; auch die Danksagung des Autors, an „Stellen und Persönlichkeiten, die die Arbeit unterstützt und die Herausgabe des Buches ermöglicht haben“.'132 Was Wutte unter Deutschland verstand, in dem Österreich mehr als nur marginalisiert wird, lässt sich beispielhaft anhand der von ihm gewählten Terminologie und seinen Überlegungen in einem Ende I 930 verfassten Schreiben an einen Leipziger Publizisten ableiten: Wir völkisch fühlenden Deutschösterreicher kämpften schon im alten Österreich gegen die Gleichsetzung von ,Deutschland' und ,Deutsches Reich: Wir verstanden und verstehen unter, Deutschland' das, was der Name sagt, das, deutsche Land'; jetzt würden wir sagen der zusammenhängende Raum, in dem sich deutscher Volks- und Kulturboden decken. Es ist auch nicht logisch, das Deutsche Reich allein als Deutschland zu bezeichnen. Das Deutsche Reich ist höchstens, Kleindeutschland; also ein Teil Deutschlands, nicht das ganze Deutschland. Leider hat sich der Name ,Deutschland' im Sinne von ,Deutsches Reich'so fest eingefressen, dass beispielsweise die reichsdeutschen Siedler

131 Wutte, Freiheitskampf (1943) (wie Anm. 1) Vorwort zur zweiten Auflage, XI : „Kaum ein Viertelhundert liegt der Kärntner Freiheitskampf hinter uns und schon gehört er in unserer raschlebenden Zeit der Geschichte an. Wohl verschwindet das Ringen um das kleine Fleckchen Erde hinter den großen, auch für Kärnten entscheidenden Ereignissen des Jahres 1938 und dem überwältigenden Geschehen des neuen Weltkrieges. Dennoch hat es an und für sich an Bedeutung nicht verloren, im Gegenteil, erst heute, wo das letzte, von Kärnten heißersehnte Ziel: die Vereinigung mit dem Mutterlande erreicht ist, erkennt man seine volle Bedeutung und wird klar, daß die Kärntner, viele bewußt, manche unbewußt, in ihrem Freiheitskampf nicht bloß um die Grenze ihrer Heimat, sondern auch um die Grenze Großdeutschlands gekämpft haben.“

132 Vgl. Wutte, Freiheitskampf (1943) (wie Anm. 1) XII, mit Neumann, Einleitung (wie Anm. 2) XVII: „Abgesehen von wenigen Passagen mit zeitbedingter Phraseologie, die hier den an solcher Kontrolle Interessierten offen mitgeteilt seien, vgl. die Seiten : 38, 90, 167, 224, 268, 283, 343, 411, 415f., konnte die Neuauflage unverändert bleiben.“ Auf zwei weitere Texteingriffe weist lediglich die Überschrift - „Aus dem Vorwort zur zweiten Auflage“ - hin. Ebd. XIII (Hervorhebung Burz). 
in Kärnten vom Landvolk als ,Deutschländer' bezeichnet werden. Dem völkisch denkenden Österreicher aber gibt das jedesmal einen Stich. Nur jene kleine Gruppe, die einen, österreichischen Menschen' konstruieren und aus gewissen politischen Gründen im Gegensatz zum deutschen Menschen stellen wollen, ist damit einverstanden. Alle aber, die für das deutsche Volk im Zusammenschluss das einzige Heil der Zukunft erblicken, sollten endlich einmal aufhören, vom ,Deutschland' im Sinne von ,Deutschem Reiche'zu sprechen. ${ }^{133}$

Bei einer Definition des Deutschland-Begriffes, im Sinne Wuttes, dass es ein geografischer Raum ist, in dem sich „deutscher Volks- und Kulturboden decken“, drängt sich geradezu die Frage auf, wie dies für Kärnten zu interpretieren ist. Denn hier siedelte seit Jahrhunderten eine große slowenischsprachige Volksgruppe, lange vor der bayerischfränkischen Landnahme, die im neunten Jahrhundert erfolgte. Seine Sicht der Dinge erläuterte Wutte in einem Briefwechsel mit dem - nach 1945 politisch umstrittenen Völkerrechtsgelehrten Theodor Veiter: Die Annahme eines slowenischen Kulturvolksbodens in Kärnten ist nach meiner Meinung unhaltbar und wäre höchst gefährlich. Volkskunde, Siedlungsgeschichte, Kunstgeschichte und moderne Statistik zeigen, daß es kein geschlossenes slowenisches Gebiet, weder sprachlich noch völkisch in Kärnten gibt. Volkskundlich ist ganz Südkärnten vom deutschen Brauchtum u.s.w. - zu schweigen von höherer Kultur - durchtränkt. Und der Historiker erinnert, ohne Detailangaben zu machen, an Aufsätze von Hermann L'Estocq und an Georg Grabers Darstellungen über „Deutsche Einflüsse in Brauchtum, Sitte und Sage der Slowenen“.'134 Und er warnt davor einen, wenn auch kleinen slowenischen Volkskulturboden anzunehmen, denn damit wird von Kärnten ein Stück abgetrennt. Das steht mit der seit I 848 bewährten Kärntner Landes-Politik in Widerspruch ${ }^{135}$.

Wenige Wochen später spricht Wutte von einer slowenischen Volksgemeinschaft, die sich, um die Zugehörigkeitsfrage juridisch zu klären, konstituieren müsste: Das ist nur möglich durch einen Kataster und den wollen die slowenisch-nationalen Führer nicht, da sie die Zwischenstufe der ,Windischen ${ }^{136}$ für sich in Anspruch nehmen, die nicht zu ihnen gehö-

133 Wutte an Wilhelm Volz, Klagenfurt, 01.12.1930, KLA, NLW, Schachtel 44, 1488. Volz war u.a. geschäftsführender Vorsitzender der „Stiftung für deutsche Volks- und Kulturbodenforschung“ in Leipzig.

134 Vgl. allgemein: Sagen und Märchen aus Kärnten, hg. u. gesammelt v. Georg Graber (Graz 1935).

135 Wutte an Theodor Veiter, Klagenfurt, 18.01.1938, KLA, NLW Schachtel 2, 202.

136 Anm. Burz: Vgl. dazu: Martin Wutte, Deutsch - Windisch - Slowenisch (o. O. [Klagenfurt], o. J. [1927]; Wilhelm Neumann, Das nationale Problem aus deutschkärntner Sicht, in: Kärnten (wie Anm. 20) 463493, zur „Windischen“-Theorie bes. 482-489; kontroversiell: Andreas Moritsch, Nationale Ideologien in Kärnten, in: Kärntner Slowenen/Koroški Slovenci 1900-2000. Bilanz des 20. Jahrhunderts, hg. v. DEMs. (Unbegrenzte Geschichte - Zgodovina brez meja. Historische Reihe der Abteilung für Geschichte Ost- und Südosteuropas an der Universität Klagenfurt und des Bildungsheimes Sodalitas in Tainach/Tinje 7/Zgodovinska serija Oddelka za zgodovino vzhodne in jugovzhodne Evrope na Univerzi v Celovcu in Doma prosvete Sodalitas v Tinjah/Tainach 7, Klagenfurt/Celovec/Ljubljana/Laibach/Wien/Dunaj 2000) 9-28, bes. 19-27. 
ren, auch nicht zu ihnen gehören wollen und sich daher nur durch irgend einen Zwang in die slowenische Volksgemeinschaft eingliedern liessen. Wutte hat ein klares überschaubares Ordnungssystem vor Augen. Er fordert einen nationalen Kataster für Deutsche und Slowenen, denn: Dadurch würde das Renegatentum ausgeschaltet, das sind jene charakterlosen Konjunktur-Menschen, die je nach Bedarf heute da und morgen dort ihre Geschäfte machen ${ }^{137}$. Ungeachtet der Problematik, die jeder Bekenntniszwang birgt, hat Wutte eine mögliche Alternative, ein mögliches Bekenntnis zu Österreich, nicht einmal andeutungsweise angerissen. Seine Ansichten, wenige Wochen vor dem Anschluss Österreichs an NS-Deutschland formuliert, sind in diesem

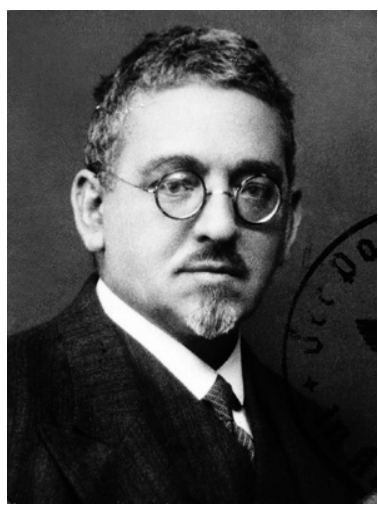

Abb. I7: Martin Wutte um 1930 Zusammenhang doppelt bedeutsam.

Dass weitere Reflexionen über den gescholtenen „österreichischen Menschen“ unterblieben, ist nicht weiter verwunderlich, gehörte Wutte doch einer Generation an, die mit dem Terminus „gesamtösterreichisches Denken“ wenig anzufangen wusste. Die Idee vom Deutschtum als Leitkultur war nicht nur in der Geschichtswissenschaft des Vielvölkerstaates weit verbreitet. Und Wutte bewegte sich zeitlebens in einem deutschnationalen Milieu, in dem für ein gesamtösterreichisches Denken, das auf eine Gleichberechtigung aller Volksstämme abzielte, kein Platz war. In der Staatsmetropole Wien hat man spätestens 1867 mit dem Staatsgrundgesetz, dessen Prinzipien teilweise in die Verfassung der Republik Österreich einflossen, ein theoretisches Gerüst geschaffen. Das wurde von Repräsentanten des deutschnationalen Lagers, das in Kärnten federführend agierte, abgelehnt. Es galt, die politisch und wirtschaftlich dominante Stellung des Deutschtums weiterhin abzusichern. Das österreichische Wien mit seinem Beamtenapparat und einer Herrscherdynastie, die zu einem Gutteil die Nationalitäten gleichberechtigt zu behandeln suchten, geriet nicht zuletzt deshalb zu einem Feindbild, ein Feindbild, das Wutte nicht nur in seinem Buch „Kärntens Freiheitskampf" kräftig bedient hat ${ }^{138}$.

Ein enger Geistesfreund Wuttes und langjähriger politischer Spitzenrepräsentant des Landes Kärnten begründete 1933, offensichtlich die aktuelle politische Situation vor Augen, prägnant die Anti-Wien-Haltung; - die 1943/1985 publizierten Versionen von „Kärntens Freiheitskampf“ sind ihm gewidmet. Arthur Lemisch beginnt seine Überlegungen mit einem Zitat: ,Wozu nach den traurigen Ereignissen der letzten Woche ... Ersatz für

137 Wutte an Veiter, o. O. 12.02.1938, KLA, NLW Schachtel 2, 202.

138 Vgl. entsprechende Passagen in: Wut te, Freiheitskampf (1943) (wie Anm. 1) 36, 52, 59f., 67, 80, 82ff., 112, 114, 125, 173ff., 296, 323, 333f., 337, 341, 349, 350, 362, 377, 382, 385, 411. 
den deutschen Bruder, um den man sich ein Jahrzehnt lang bemüht hat', ich meine wir werden uns auch noch weiter um ihn bemühen müssen, denn der Gang der Geschichte kann durch einige verrückt gewordene Leute doch nicht aufgehalten werden. Torquemadas Zeiten sind vorüber gegangen, auch der heutige Kärntnerische Torquemada wird nicht ewig seine Geissel schwingen. Das Unglück Deutschösterreichs ist und bleibt die Bindung mit der schwarz-roten Grosstadt Wien, von der wir niemals loskommen werden. Die westlichen Alpenländer allein können, weil Finanzen, Militär, die Frage der Bundeshauptstadt und so vieles Andere mitsprechen, allein nichts anfangen. Tragen wir also unser Geschick mit Geduld, körperliche Waffen gegen die Bedrücker vermag man nicht aufzubringen. Aber die Bäume der Vaugoin-SchumyFey-Dollfuss Regierung werden auch nicht in den Himmel wachsen. Mit deutschem Gruss.!139

Wenige Wochen später stieß Wutte, in einem Dankschreiben für die Übermittlung eines Bildbandes, „Das Antlitz der Grenzlande“, in ein ähnliches Horn. Er berichtet von Kämpfen im Grenzland und ordnet diesen eine klare Funktion zu: Der Bildband ist einer der wenigen Lichtpunkte in dieser so traurigen Zeit des Bruderzwistes und ein neuerlicher Beweis, dass die in gemeinsamer Not geschlungenen Bande zwischen unserem Mutterlande und unseren Grenzgebieten trotz aller Widerwärtigkeiten der Gegenwart fortbestehen, wie ich denn durchaus überzengt bin, dass auch diese furchtbare Krise unseres Volkstums überstanden werden wird. Es hätten ja auch gerade die Kämpfe um unser Grenzland gar keinen Sinn, wenn der Gedanke des Zusammenschlusses Österreichs mit dem Reiche für ewig begraben sein sollte. So bin ich der sicheren Hoffnung, dass die jetzt gebundenen guten Geister auch bei uns bald wieder an die Oberfläche kommen werden, um an der Verwirklichung des Gedankens ein Volk ein Reich weiter zu arbeiten. ${ }^{140}$

Wuttes Engagement für das Deutschtum resultierte gewiss zu einem guten Teil aus seinen Reiseerlebnissen, über die er in seinem Lebenslauf, ohne sich allerdings in Details $\mathrm{zu}$ verlieren, kurz berichtet ${ }^{141}$. Seine resümierende Darstellung ist nicht nur im Zusammenhang mit der bis heute wenig behandelten Forschungsfrage, wer, in welchem Umfang, unter welchen Kriterien die Propaganda für die Volksabstimmung 1920 in Kärnten mitfinanzierte, von Bedeutung. Erste Erkenntnisse, die Wuttes Einsatz auch auf diesem volkspolitischen Schauplatz belegen und die heftige Kritik provozierten, liegen seit den I $990 e r-J a h r e n$ vor $^{142}$. Ein Schreiben des Landeshistorikers an ein „Hauptvorstandsmit-

139 Lemisch an Wutte, St. Veit an der Glan, 10.06.1933, KLA, NLW, Schachtel 1, 84. Lemisch war 1918-1921 Landesverweser von Kärnten, 1927-1931 Landeshauptmann. Vgl. Webernig, Landeshauptmann (wie Anm. 125) 71 und $78 \mathrm{f}$.

140 Wutte an Karl von Loesch, Klagenfurt, 17.07.1933, KLA, NLW, Schachtel 1, 91.

141 Wutte, Lebenslauf 1949 (wie Anm. 36) 7: „In die Zeit nach 1920 fallen auch zahlreiche Reisen, die ich zu wissenschaftlichen und völkischen Tagungen unternahm, so nach Wien, Graz, Innsbruck, Salzburg, Linz, München, Berlin, Witzenhausen, Flensburg, Köln, Bamberg, Leipzig, Stuttgart und Regensburg. Leider waren sie alle nur von kurzer Dauer." Hervorhebung nach Vorlage.

142 Vgl. Ulfried Burz, Die nationalsozialistische Bewegung in Kärnten (1918-1933). Vom Deutschnationalis- 
glied“ des Volksbundes für das Deutschtum im Ausland (= VDA) belegt nicht nur Wuttes nationalpolitische Grundeinstellung, sondern auch ein breiteres Engagement in Subventionsbelangen, denn so soll Kärntens Einheit unter deutscher Führung erhalten bleiben. Eine Zertrümmerung Kärntens wäre ja nicht bloss für die Kärntner der Ruin, sondern auch ein schwerer Verlust für das gesamte Deutschtum. [...] Wir brauchen dringend eine Stärkung unseres Agitationsfondes. Schon seit längerer Zeit stehen wir mit dem Schutzbund für Grenzund Auslandsdeutschtum in Berlin in Fühlung. Allein trotz allen Entgegenkommens ist der Schutzbund leider nicht in der Lage, uns eine Unterstützung zu geben, da er in Deutschland selbst genug zu tun hat. Ferner haben wir uns an die deutschösterreichische Mittelstelle Berlin gewendet und haben die Absicht, uns auch an einzelne vermögendere Deutschösterreicher im Reiche zu wenden ${ }^{143}$. Weiterführendes über Wuttes Tätigkeiten als (Mit-)Organisator von finanziellen Transfers aus Deutschland nach Kärnten lässt sich möglicherweise mithilfe von Materialien aus der „Sammlung Wutte“ gewinnen ${ }^{144}$.

In Kärnten stand Wutte mit maßgeblichen Exponenten deutschnationaler Ideologie nach der gemeinsamen Arbeit innerhalb des nationalpolitischen Ausschusses weit über die „Abwehrkampfzeit“ hinaus in enger Verbindung. Es waren Spitzenkräfte aus Kultur, Politik oder amtlichen Behörden Kärntens ${ }^{145}$. Mit Fritz, Kraus, Lemisch, Perkonig und Steinacher stand Wutte in Zeiten nachhaltiger politischer Umbrüche wiederholt in engerer brieflicher Verbindung, vergleichsweise intensiver mit Perkonig und Steinacher;

mus zum Führerprinzip (Das Kärntner Landesarchiv 23, Klagenfurt 1998) 30-38. Kritik daran übt Wilhelm Neumann, ,Deutschnationalismus' in der Kärntner Geschichtsschreibung?, in: Carinthia I, 192 (2002) 463-498, hier 484-488; Kontroversiell dazu Burz, Geschichtsschreibung zwischen den Fronten (wie Anm. 10) $230 \mathrm{f}$.

143 Wutte an Dr. (?) Speier, Klagenfurt, 07.04.1920, KLA, NLW, Schachtel 2, 161.

144 Vgl. Findkatalog „Tagung des Deutschen Schutzbundes, Berlin 3.-5. Jänner 1922 (Unterlagen)“; „Tagung für Deutschtumspflege, Witzenhausen bei Kassel, 1.-3. März 1924 (Unterlagen)“; „Tagung des Gesamtvereines der deutschen Geschichts- und Altertumsvereine, Regensburg 30. Aug.-4. Sept. 1927 (Unterlagen)“; „Tagungen in Regensburg, Cham, Wien, Berlin (Unterlagen) 1927, 1929“; „Deutsche Mittelstelle für Volksund Kulturbodenforschung (ab 1927 Stiftung für deutsche Volks- und Kulturbodenforschung) Tagungsunterlagen, 1925, 1930“; „Tagung der deutschen Volksgruppe und Kulturpolitische Tagung, Stuttgart 1930 (Unterlagen) 1930“ Angaben nach: KLA, Sammlung Wutte, Katalog Nr. 235, Schachtel 21, 175-180.

145 In einer künftigen Prosopografieforschung wäre neben dem erwähnten Vinzenz Schumy der Werdegang von Hans Angerer, Max Burger, Gustav Frank, Karl Fritz, Josef Glantschnig, Ludwig Hülgerth, Franz X. Kohla, Sepp König, Silvester Klinge (Praschek) (?), Franz Kraigher, Felix Kraus, Viktor Kommetter, Arthur Lemisch, Julius Lukas, Valentin Maierhofer, Alois Maier-Kaibitsch, Siegmund Knaus, Peter Melcher, Josef Friedrich Perkonig, Franz Pichler-Mandorf, Franz Reinprecht, Hans Steinacher, Ferdinand Wolsegger näher auszuleuchten. Zum Lebensweg einiger Genannter geben Nachrufe, Würdigungsschriften oder Veröffentlichungen in der Carinthia I erste aufschlussreiche Informationen. Siehe die Register für die Jahrgänge 101-125, 126-145 und 146-180 der Carinthia I (Klagenfurt 1936, 1958, 1991). 
mit letztgenanntem Duumvirat, dem Kern einer „Gemeinde der Getreuen“146, über die austrofaschistische Ständestaatzeit hinweg.

In der Institutionsgeschichte nationalpolitischer Vereine nahm der Kärntner Heimatbund, I924 gegründet, eine Schlüsselrolle ein. Über Wuttes Tätigkeit in diesem Verein, der nur mit großen Einschränkungen als Vorläufer des nach 1945 gegründeten Kärntner Heimatdienstes zu betrachten ist ${ }^{147}$, wurde eine breitere Öffentlichkeit erst im I 988 veröffentlichten Lebenslauf informiert ${ }^{148}$. Von der „Heimattreue“ ist im öffentlichen Raum Kärntens bei politischen Festtagen immer wieder die Rede. Die Ansicht, wonach ein kollektives homogenes Heimatbewusstsein möglich ist, ist gerade am Beispiel Kärntens ein Widerspruch per se. In diesem Land wurde und wird ein deutschnationaler, ein slowenischnationaler, ein „windischer“, ein erst in den letzten Jahrzehnten entstandener österreichnationaler Wertekanon je nach persönlicher Neigung erdacht, entworfen, propagiert, akzeptiert oder verworfen. Eine Ideologie der Homogenisierung läßt zwangsläufig einer Heterogenität des Terminus „Heimat“ keinen Freiraum. Und es ist aber keine originelle Erkenntnis, dass der Heimatbegriff vielseitig definierbar ist ${ }^{149}$.

146 Burz, nationalsozialistische Bewegung (wie Anm. 142) 162.

147 Die Organisations- und Wirkungsgeschichte zur Frühzeit dieser in Kärnten gesellschaftspolitisch bedeutsamen Institutionen sind ein Desideratum. Die von zahlreichen methodischen Unzulänglichkeiten geprägte Darstellung von Martin Fritzl, Der Kärntner Heimatdienst. Ideologie, Ziele und Strategien einer nationalistischen Organisation (Disertacije in razprave 22/Dissertationen und Abhandlungen 22, Klagenfurt/ Celovec 1990) setzt sich mit der Geschichte dieses 1957 gegründeten Vereines auseinander. Dessen lange Zeit federführender Obmann, Dr. Josef Feldner, hat in den letzten Jahren eine nachhaltige, vielbeachtete Kehrtwendung in der „nationalen Frage“ vollzogen. Vgl. dazu aktuell: Josef FE LDNER, 90 Jahre KHD Kärntner Heimatdienst. Eine Dokumentation (Klagenfurt 2010).

148 Wutte, Lebenslauf 1988 (wie Anm. 38) 16: „Von 1924-30 war ich Obmann des Kärntner Heimatbundes, der die Interessen der heimattreuen deutsch und slowenisch sprechenden Bevölkerung des Abstimmungsgebietes zu betreuen hatte. Als solcher suchte ich versöhnlich und ausgleichend zu wirken, namentlich gelegentlich der Verhandlungen über die von den deutschen Parteien den Slowenen angebotene Kulturselbstverwaltung. Es war das nicht leicht, da die Heimattreuen die bösen Erfahrungen, die sie zur Zeit der jugoslawischen Besetzung von Dezember 1918-10. Oktober 1920 gemacht hatten, nicht vergessen konnten und die Laibacher Nationalisten durch eine planmäßige Propaganda eine irredentistische Bewegung in Südkärnten großzuziehen suchten und alle Vorbereitungen für eine Neuaufrollung ihrer Ansprüche auf Südkärnten trafen. In diesem Sinne waren auch namhafte slowenische Fachleute - Historiker, Geographen, Volkskundler und Sprachforscher - tätig. Davon abgesehen, entwickelte sich die slowenische Wissenschaft nach Gründung der Laibacher Universität zu einer sehr beachtenswerten Höhe und konnten ihre Leistungen, die vielfach auch für Kärnten von Bedeutung waren, nicht übersehen werden. Es musste daher die slowenische wissenschaftliche Literatur verfolgt und, wenn nötig, zurückgewiesen werden. Es gelang, einen kleinen Kreis von Fachleuten zu gewinnen, die sich dieser Aufgabe im Rahmen der Carinthia I unterzogen. Unbewußt leisteten wir durch diese meist in der Carinthia I erschienenen Arbeiten eine wichtige Vorarbeit für die Abwehr der Gebietsansprüche, die Jugoslawien 1947 gegenüber Kärnten stellte.“

149 Vgl. dazu Meinungen von Personen des öffentlichen Lebens in Kärnten - „mit ausländischer Beteiligung“ - 
Für Wutte und seine Gesinnungsgemeinschaft hieß „Heimattreue“ aber in erster Linie ein bedingungsloses Festhalten an der Kärntner Landeseinheit, dem alle anderen „Heimaten“ unterzuordnen waren. Aufgrund der vorherrschenden politischen Kräfteverhältnisse waren damit Anliegen der slowenischen Volksgruppe vor allem in kulturpolitischen Fragen von Anfang an mit Einschränkungen konfrontiert. Jener Personenkreis, der I 920 das Selbstbestimmungsrecht gesetzmäßig ebenso in Anspruch genommen und für den SHSStaat optiert hatte, galt aber in führenden Kreisen des politischen Kärntens als nicht heimattreu. Ein „heimattreues Selbstbestimmungsrecht“, das eine klassische contradictio in adjecto ist, war kein Thema öffentlicher Diskussion, ebenso die einseitige Definition des Heimattreuebegriffes, der die Assimilation der slowenischsprachigen Bevölkerung gewiss nicht entschleunigt hat. Auch wenn für den Anpassungsprozess der Slowenen mehrere Ursachenmomente heranzuziehen sind, wie die Unterbrechung der Immigration nach Kärnten aus slowenischen Siedlungsgebieten südlich der Karawanken, eine starke Emigrationsbewegung bereits um I900 ${ }^{150}$, ein Protestverhalten gegen die Vereinnahmung nationalslowenischer Funktionäre usw. sprechen die Zahlen eine allzu deutliche Sprache. Den für das Jahr I 9 Io geschätzten rund 65.00o Angehörigen der slowenischen Volksgruppe in Kärnten ${ }^{151}$ standen nach der letzten konventionell geführten Volkszählung in Österreich (200I) knapp I 3.000 Personen mit slowenischer Sprache gegenüber. Dass die Assimilierten im politisch lange Zeit deutschnational-liberal bestimmten Land einem deutschen Kärnten zugerechnet worden sind, mag Wutte begrüßt haben. Dass in der slowenischsprachigen Bevölkerung Kärntens damit aber vermutlich mehrheitlich ein Bekenntnis zur „Nation Österreich“ verknüpft war, ist keine kühne These, wie schon ein Überblick zur Geschichte der Slowenen im Verbund des Habsburgerstaates, zeigt ${ }^{152}$.

quer über alle politischen Lager hinweg: Heimat, bist du ... Sichtweisen, hg. v. Ulfried Burz, Gerda Kr AINer, Wolfgang LeHofer (Klagenfurt 1999).

150 Die Slowenen hatten 1900 und 1910 in der cisleithanischen Reichshälfte den mit Abstand größten negativen Wanderungssaldo. Siehe dazu Peter Vodopivec, Bevölkerungsentwicklung und demographische Prozesse in den von den Slowenen besiedelten Gebieten (I860-1914) in: Demographic Changes in the Time of Industrialization (1750-1918), hg. v. Ioan Bolovan, Rudolf GräF, Harald Heppner, Ioan Lumperdean (Transylvanian Review 18, Supplement 1, 2009) 380-390, hier 380.

151 Basis ist das Kärnten in den Grenzen von 1920.

152 Vgl. Peter Vodopivec, Von den Anfängen des nationalen Erwachens bis zum Beitritt in die europäische Union, in: Slowenische Geschichte. Gesellschaft - Politik - Kultur, hg. v. Dems., Peter Šт in, Vasko SimoNit I (Veröff. der Historischen Landeskommission für Steiermark 40/Zbirka Zgodovinskega Časopisa 34, Graz 2008) bes. 283-296. 


\section{WUTTE IM NATIONALSOZIALISTISCHEN GROSSDEUTSCHLAND}

Das Autograf Wuttes, in der I 949 veröffentlichten Version, endet mit Bemerkungen über Gesundheitsprobleme, die den Eintritt in den Ruhestand notwendig machten, und einem kurzen Rückblick auf sein bisheriges Leben: „Im Jahre $1939^{153}$ mußte ich infolge eines Herzleidens in den Ruhestand treten. Mein Leben naht dem Ende. Es hat mir viel stille und beglückende Arbeit gebracht. Ich strebte nach Wahrheit, suchte, meiner Heimat zu nützen, und fand, daß Wahrheit die beste Stütze im Kampfe um die Heimat ist. "154

Die Schlussbemerkungen können zur Annahme verleiten, dass Wutte in seinen letzten Lebensjahren nur mehr passiv am Geschehen einer von einschneidenden Ereignissen ausgefüllten Zeit teilgenommen hat. Für an historisch-politischen Themata Interessierte war Wutte aber weit über das Jahr 1939 hinaus auf mehreren Ebenen physisch und durch seine Veröffentlichungen in der Carinthia I ${ }^{155}$ und anderen Kärntner Printmedien ${ }^{156}$ gegenwärtig. Des Weiteren war er für Zeitgenossen durch seine Tätigkeit als Mitarbeiter der

153 Ein erster Hinweis - nach der NS-Zeit - auf Wuttes Eintritt in den Ruhestand, der „krankheitshalber 1938“ erfolgt sein soll, stammt von Hermann WiesSNER, Das Kärntner Landesarchiv in den Jahren 1938 bis 1945, in: MÖSTA 1 (1948) 475-482, hier 481. Wiessner studierte in den 1920er Jahren Geschichte und fungierte in der Zeit des Ständestaates als Bezirksschulinspektor. Nach 1938 wurde er Direktor „einer jüdischen Sammelschule“. Angaben nach Wilhelm WAdL, Das Kärntner Landesarchiv (Reichsgauarchiv Kärnten) in der NS-Zeit, in: Österreichs Archive unter dem Hakenkreuz (MÖSTA 54, 2010) 563-586, hier 568. Für einen Sonderdruck sei dem Autor herzlichst gedankt. Neumann führte in seiner Einleitung zu Kärntens Freiheitskampf (1985) (wie Anm. 2) XVII aus, dass Wutte 1939 „wegen seines ihn zeitlebens begleitenden Herzleidens vorzeitig in den Ruhestand“ getreten ist. WADL, Landesarchiv 566, präzisierte: „im Mai 1939“.

154 Wutte, Lebenslauf 1949 (wie Anm. 36) 7. Zum Vergleich eine Sentenz - sie wird Mark Twain zugeordnet -, in der der Wahrheitsbegriff breiter definiert und Grundbeschaffenheiten des „homo sapiens“ wohl treffend charakterisiert werden: „Noch niemals sah ich einen Menschen, der wirklich die Wahrheit sucht. Jeder, der sich auf den Weg gemacht hatte, fand früher oder später, was ihm Wohlbefinden gewährte. Und dann gab er die weitere Suche auf."

155 Die Zeitschrift konnte 1944 und 1945 „kriegsbedingt“ nicht mehr erscheinen, denn der Geschichtsverein erhielt - im Gegensatz zum 1942 begründeten „Institut für Kärntner Landesforschung - keine Papierzuteilungen“ mehr. WADL, Landesarchiv (wie Anm. 153) 581. Ergänzend ist anzufügen, dass die Schriftleitung der Carinthia I 1942 dieses Problem dank mehrerer Subventionsgeber lösen konnte: „In ganz besonderem Maße haben die Herausgabe unserer Veröffentlichungen des Jahres 1942 ermöglicht und unterstützt: die Alpenländische Forschungsgemeinschaft in Innsbruck (Univ.-Prof. Dr. Raimund von Klebelsberg, Innsbruck), die Gaupropagandaleitung der NSDAP in Kärnten und das Museum des Reichsgaues Kärnten (Museumsdirektor Dr. phil. habil. Walter Frodl); hiefür sei ihnen auf das herzlichste gedankt.“ Anonymes Zitat in: Carinthia I, 132 (1942) 2. Hervorhebung nach Vorlage. Zur letzten, in der Kriegszeit veröffentlichten Carinthia I (1943) vgl. ebd. 1 die Vorbemerkung.

156 Im Schriftenverzeichnis bei Toson I, Wutte (wie Anm. 33) 153-155, sind mehr als zwei Dutzend Publikationen aus den Jahren 1939-1944 angeführt, darunter einige umfangreichere Aufsätze. Selbst wenn für den überwiegenden Teil dieser Schriften Sammlungs- und Recherchetätigkeiten vor 1939 zu berücksichtigen sind, ist Wutte bemerkenswert produktiv geblieben. 
seit Herbst 1939 unter dem Namen Reichsgauarchiv firmierenden Institution präsent. Dass Wutte dem Reichsgauarchiv, wie in einer fachrelevanten Publikation angegeben, bis Kriegsende als Leiter vorstand ${ }^{157}$, scheint durch neuere Forschungsergebnisse relativiert. Hermann Wiessner, der am I. September 1945 die Direktion des Kärntner Landesarchivs übernehmen durfte, konstatierte I948, dass Wutte im November 1939 erneut die wissenschaftliche Aufsicht über das Archiv erhielt, als der zwischenzeitliche Leiter „Dr. Karl Starzacher ${ }^{158}$ als höherer SS-Funktionär mit der Umsiedlung der Kanaltaler mit dem

157 Wolfgang LeEsCH, Die deutschen Archivare 1500-1945 1: Verzeichnis nach ihren Wirkungsstätten (München u.a.1985) 168.

158 Anm. Burz: Starzacher gehörte dem engeren Verwandtschaftskreis Wuttes an. Starzacher (1913-1945), Absolvent des IÖG, war am 1. Januar 1937 als „Landesarchivar 2. Klasse“ am Kärntner Landesarchiv angestellt worden. Unterstützt hatte ihn der Direktor des IÖG, Hans Hirsch, siehe Manfred Sтоу, Das Österreichische Institut für Geschichtsforschung 1929-1945 (MIÖG Erg.-Bd. 50, Wien/München 2007) 119, 134, 143. Seit August 1938 zeichnete Starzacher Schreiben mit „derzeit Leiter des Landesarchivs“. Angaben nach: WADL, Landesarchiv (wie Anm. 153) 565f. Zum Werdegang des Neffen Wuttes steht der Forschung derzeit nur Fragmentarisches zur Verfügung. In einer mit 22.05.1941 datierten Abschrift einer „Denkschrift über die Wege, die besetzten Gebiete Kärntens kulturell und völkisch in den Altgau Kärnten und das Reich einzugliedern“ brachte der Archivar und SS-Offizier Überlegungen zu Papier, die für sich sprechen : „Lösung 2: Eine andere Lösung der Frage der slowenischen Intelligenz wäre deren vollständige Vernichtung durch Erschießung oder sonstige Beseitigung, die aber dadurch nicht zweckmäßig ist, weil die Erfassung der tatsächlichen Intelligenz dem Apparate der Gestapo durch die schwierigen Erkundigungsverhältnisse nicht möglich ist und andererseits eine Vernichtung weder im Willen des Reichsführers SS gelegen noch unter den augenblicklichen Verhältnissen tragbar ist.“ Quelle: BAB, R 4901, 13425. Die gesamte Denkschrift wurde 1980 vollinhaltlich publiziert in: Tone Ferenc, Quellen zur nationalsozialistischen Entnationalisierungspolitik in Slowenien 1941-1945/Viri o nacistični raznarodovalni politiki v Slovenij (Maribor 1980) 115-119; weitere Quellen mit Starzacher-Bezug: 171, 173, 261, 283, 295f., 298, 405, 431, 433, 438, 578. Im Juli 1941 wies Starzacher in einem anderen Memorandum, in dem die Umsetzung deutscher Interessen thematisiert wurde, auf positive Vorbilder in der jüngeren Vergangenheit hin: Dabei steht fest, daß eine sichere Verdeutschung durch systematische Arbeit auf lange Sicht nach den in Kärnten bereits mit den Slowenen gemachten Erfahrungen erreicht werden kann. Quelle: Gedächtnisschrift über die Besprechung von SS-Oberstubaf. [= Obersturmbannführer] Maier-Kaibitsch, SS-Unterstuf. [= Untersturmführer] Dr. Starzacher mit SS-Hauptstuf. [= Hauptsturmführer] Dr. Walter am 21. und 22.7.1941 in Veldes, Parkhotel, gez. Dr. K. Starzacher. BAB, R 4901, 13425. Wiessner, Landesarchiv (wie Anm. 153) 481, berichtet über den Tod des SS-Offiziers: „Beim Zusammenbruch im Mai 1945 fand Dr. Karl Starzacher bei den ausgebrochenen Unruhen in Oberitalien den Tod ...". Vgl. dazu Pier Arrigo Car nier, Lo sterminio mancato. La dominazione nazista nel Veneto orientale 1943-1945 (Milano 1982) 238: „A Pordenone, cadde sotto una misteriosa raffica il dott. Starzacher, collaboratore del Deutsche Berater di Udine. Per un certo periodo, il dott. Starzacher, aveva diretto in Carinzia l'ufficio di trasmigrazione degli sloveni. "Präziser WADL, Landesarchiv (wie Anm. 153) 568, der auch auf Carnier verweist: „Am 28. April 1945 wurde Dr. Karl Starzacher in der Nähe von Pordenone - wahrscheinlich aufgrund einer Personenverwechslung - von italienischen Partisanen erschossen. " Siehe dazu auch: Alfred Ogris, 100 Jahre Kärntner Landesarchiv (wie Anm. 26) 26. Ogris stützt sich auf ein Dokument des KLA, Amt der Kärntner Landesregierung, PA Karl Starzacher, Pers. Zl. 1031; biografische Eckdaten zu Starzacher in: STOY, Institut 341; Das Kanaltal. Mit Beiträgen von Viktor Paschinger, Karl Starzacher, Walther Fresacher, Otto Demus, Felix Kraus und Martin Wutte/ 
Amtssitz in Tarvis, später in Udine, betraut“ worden war. „Auf die Dauer seiner Abwesenheit führte die wissenschaftliche Leitung des Archives wieder Landesarchivar i. R., Hofrat Dr. Wutte, während die administrative Leitung des Archives Regierungsrat [Emmerich] v. Zenegg überantwortet wurde.“ ${ }^{159}$ Das „provisorische Interregnum der beiden alten Herren dauerte von Jänner I 940 bis Juli I 942 "160 und dürfte Anfang August I 942 geendet haben ${ }^{161}$. Denn „Anfang August 1942 teilte Starzacher der Reichsarchivverwaltung mit, dass er ,die Leitung des Reichsgauarchivs Kärnten in Klagenfurt' wieder übernommen habe und ,meine Aufgabe neben meiner anderen Betrauung durchführen kann. Der Reichsführer SS ist mit dieser im Interesse des Archivs liegenden Einteilung einverstanden “". ${ }^{162}$ Starzacher konnte seine Funktion nur für kurze Zeit persönlich wahrnehmen, weil er „am I. März I943 [...] wieder zur Waffen SS“ eingerückt war, um Aufgaben in der neu errichteten „Operationszone Adriatisches Küstenland“ „ab Herbst 1943 beim sogenannten ,Deutschen Berater“ in Udine“163 zu übernehmen. „Damit lastete die gesamte Verantwortung für die Auslagerung der Archivbestände auf dem damals 64jährigen Emmerich Zenegg von und zu Scharffenstein, der teilweise vom Krankenbett aus die Bergeaktionen leitete. " ${ }^{164}$

Ungeachtet der verworrenen Leitungsverhältnisse innerhalb der Führungsetage des Reichsgauarchivs in der NS-Zeit stellt sich die Frage, welche Aufgaben Wutte in dieser Zeit wahrnahm oder als Beamter wahrnehmen musste, um nicht allfälligen Sanktionen ausgesetzt zu werden. Nachweisbar ist, dass er bereits vor dem „Eintritt in den Ruhestand" versucht hatte, sein Arbeitspensum, wohl in erster Linie aus Gesundheitsgrün$\operatorname{den}^{165}$, zu reduzieren. Nachweisbar ist auch, dass Wutte in den ersten zwei Jahren nach dem „Anschluss“ trachtete, eine allzu große Nähe zu Politika seiner Zeit zu vermeiden.

La Valcanale. Con contributi di Viktor Paschinger [...], hg. v. Martin Wutte. Für den Druck eingerichtet auf Basis der vorhandenen Andrucke und Manuskripte von Wilhelm WADL. Übersetzt ins Italienische von Raimondo Domenig (Archiv für Vaterländische Geschichte und Topographie 97, Klagenfurt am Wörthersee 2009) 215.

159 Wiessner, Landesarchiv (wie Anm. 153) hier 481.

160 WADL, Landesarchiv (wie Anm. 153) 567 mit Verweis auf KLA, Archivregistratur, Zl. 200/1942.

161 Ich möchte jedoch nicht scheiden, ohne Ihnen für das große Verständnis und Entgegenkommen, das Sie gegenüber meinen Wünschen und Bitten in Angelegenheiten des Reichsgauarchivs Klagenfurt und seiner Aufgaben in der kurzen Zeit meiner Amtstätigkeit gezeigt haben, den wärmsten Dank auszusprechen. Wutte an den Generaldirektor der Staatsarchive und Kommissar für den Archivschutz [Dr. Ernst Zipfel], o. O., 24.08.1942, KLA,Archivregistratur 200/1942.

162 WADL, Landesarchiv (wie Anm. 153) 567, und KLA, Archivregistratur, Zl. 192/1942.

163 WADL, Landesarchiv (wie Anm. 153) 567 mit Verweis auf KLA, Archivregistratur, Zl. 73/1944.

164 WADL, Landesarchiv (wie Anm. 153) 567.

165 Nachweisbar ist, dass Wutte im Frühjahr 1938 aufgrund von akuten Herzproblemen im Krankenhaus stationär behandelt werden musste und anschließend rekonvaleszent war. 
Mitverantwortlich dafür könnte auch der neue, von einem spezifischen Geltungsbedürfnis charakterisierte Stil der neuen NS-Machthaber in der Öffentlichkeit gewesen sein. Das nicht selten zur Schau getragene Potentatentum dürfte bei Wutte, wie bei anderen Zeitgenossen, die der NS-Bewegung vor dem I I. März I 938 nicht nur ablehnend gegenüberstanden, bereits kurze Zeit nach dem „inneren und äußeren Anschluss“ Österreichs an das NS-Deutsche Reich einen Umdenkprozess ausgelöst haben. Es ist eine unverdächtige zeitgenössische Quelle, ein Geheimbericht über den Parteiaufbau in der Ostmark, in der lapidar angemerkt wird: Die meisten dieser Leute haben seit der Schulentlassung bis zu ihrem heutigen Lebensalter (ca. 20 bis 25 Jahre) kaum irgendeine positive Tätigkeit ausgeübt. Mit den sog. illegalen Kämpfern hat man durchwegs Schwierigkeiten, da dieselben einerseits entweder ganz hoch besoldete Posten beanspruchen, die sie auf Grund ihrer Kenntnisse jedoch nie bekleiden können, während andere trotz ihrer Schulbildung (Doktorgrade) am liebsten Wachdienste, Ordonnanzdienste oder Postverteilungsdienste machen wollen. Setzt man nun illegale Kämpfer auf bestimmte Posten, so beginnen sie zu fordern. Die Leistung steht jedoch in keinem Verhältnis zu ihren Forderungen. Einmal auf einen bestimmten Posten gesetzt, entwickelt sich bei vielen der Größenwahn. ${ }^{166}$

Wutte war - nach heutigem Forschungsstand - nicht wie andere prominente Kärntner, die sich in der "nationalen Frage“ exponiert hatten ${ }^{167}$, weder Mitglied irgendeiner illegalen NS-Formation noch ein „Märzveilchen“"168; seine Frau war seit dem Juni 1938 NSDAP-Mitglied ${ }^{169}$, Wuttes Beitritt erfolgte im Oktober I942, was unten näher thematisiert wird.

Es waren in jedem Fall auch gesundheitliche Probleme ${ }^{170}$, die den Landeshistoriker im Mai 1938 drängten, die Mitarbeit im großen Sammelbandprojekt „Handwörterbuch des Grenzland- und Auslanddeutschtums“" (= HWB) aufzukündigen ${ }^{171}$ : Ich lege daher die Teil-

166 BAK, Sammlung Schumacher 302 I. Unterstreichung wie im Original. Der Bericht datiert mit 03.08.1938.

167 Beispielsweise dazu: Alois Maier-Kaibitsch, führender Funktionär des Kärntner Heimatbundes, der seit 01.01.1934 Mitglied der illegalen NSDAP war. Quelle: BAB, BDC, PA Alois Maier-Kaibitsch; Josef Friedrich Perkonig, NSDAP-Mitglied seit dem 01.11.1938, geführt auch in der Dateikarte des Nationalsozialistischen Lehrerbundes (NSLB), Mitglied seit 1934. Angaben nach BAK, NS 12/Anhang 63 Kärnten, NSLB-Datei, Buchstabe P.; Hans Steinacher, Eintrittsantrag vor dem Verbot der NSDAP in Österreich (19.06.1933). Der Antrag wurde aus formalen Gründen - Zuständigkeitsfrage - erst am 01.05.1940 positiv beschieden. Angaben nach: Alfred Elste, Kärntens braune Elite mit einem Beitrag von Siegfried Pucher (Klagenfurt/Celovec/Ljubljana/Laibach/Wien/Dunaj 1997) 150-155.

168 Die Bezeichnung von Zeitgenossen für Personen, die unmittelbar nach dem „Anschluss“ der NSDAP beigetreten sind bzw. beitreten wollten.

169 Eintrag im „Entnazifizierungsakt“: Erna Wutte, Wies [!] 26.11.75 Haush. = Ehefrau v. Martin Wutte. Mitglied $\operatorname{der}$ NSDAP: 6.38 - 45, rosa Karte 6.160.396. Quelle: KLA, Klagenfurter Stadtarchiv II, 274, 1.

$170 \mathrm{Vgl}$. Anm. 162.

171 Zum HWB siehe Willi Овеккиоме, Geschichte, Volk und Theorie. Das „Handwörterbuch des Grenz- 
redaktion für den Artikel "Kärnten“, soweit sie mir überhaupt noch zustehen sollte, zurück. ${ }^{172}$ Das HWB-Redaktionskomitee, das bis 1939/1940 in Kiel beherbergt war, reagierte nahezu postwendend. Man könne zwar auf eine formelle Entlastung von der Teilredaktion, aber auf die weitere Mitarbeit nicht verzichten. Der rekonvaleszente Wutte sah sich erneut in die Pflicht genommen: Ich werde trotzdem zunächst versuchen, die paar umgearbeiteten Artikel ins reine zu bringen. Die Konzepte liegen in Gabelsberger Stenographie vor, so dass ich sie selbst diktieren muss. ${ }^{173}$ Dass der gesundheitlich angeschlagene Gelehrte zu dieser Zeit die Mitarbeit an historischen Themata, die in aktuelle politische Gegebenheiten hineinreichten, gezielt unterbinden wollte, kann einem Schreiben an die Redaktion des HWB entnommen werden, in dem die Frage des Kärntner Schulwesens und deren Aufbereitung für den Sammelband zur Disposition stand. Der Historiker, der ersucht worden war, einen weiterführenden Beitrag über die Besonderheiten von Kärntner Bildungseinrichtungen zu schreiben, führte dazu aus: Die Darstellung reicht bis zum Scheitern des KulturSelbstverwaltungsentwurfes, betrifft also eine bereits der Vergangenheit angehörende Episode [...]. Die weitere Entwicklung ist ein Politikum, ich möchte sie daher nicht behandeln, da ich infolge meiner langen Krankheit nicht im Laufenden blieb, heute zu wenig Verbindungen mit den massgebenden Stellen habe und daher nicht weiss, wie man sich dazu stellt. Vielleicht ist es aber überhaupt am besten, das heikle Thema der Schule mit dem Scheitern der Autonomieverhandlungen zu schliessen. [...] Für die Zeit 1933 bis I938 und die unmittelbare Gegenwart wären andere Mitarbeiter zu gewinnen, was ja vielleicht schon geschehen ist. Mir fehlt da die nötige Personenkenntnis. Heil Hitler! ${ }^{174}$

Als Wutte im Dezember 1938 informiert wurde, dass der Beitragsartikel Kärnten aus der alphabetischen Anordnung genommen und „Kärnten“ als Nachtrag im III. Band des HWB veröffentlicht werden würde, dokumentiert der Entwurf des Antwortschreibens einen verärgerten Gelehrten und ein Kapitel Kärntner Wissenschaftsgeschichte: Ihr Schreiben vom 2I. Dezember v. J. [1938, Anm. Burz] hat mich sehr unangenehm überrascht. Es ist geradezu eine Tragikomödie, daß der Artikel „Friaulisch-windische Marken“, gegen den ich mich von Anfang an aus sachlichen, wenn auch anderen Gründen gesträubt habe, jetzt wieder zerrissen werden muß, was neuerliche Umarbeitungen - für mich wäre es die vierte!

und Auslanddeutschtums“, in: Geschichtsschreibung als Legitimationswissenschaft 1918-1945, hg. v. Peter Sснӧтt LER (Frankfurt/M. 1997) 104-127. Das HWB zielte darauf ab, den gegenwärtigen Stand unseres Wissens über den geographischen Raum und die Schicksale, über die Herkunft, Siedlung, kulturelle, soziale, politische, rechtliche und wirtschaftliche Lebensbedingungen des gesamten Grenz- und Auslanddeutschtums [...] zu dokumentieren. Angaben nach: Aus den Vertrags- und Arbeitsrichtlinien des HWB, in: KLA, NLW, Schachtel 11, 367.

172 Wutte an die Hauptredaktion des HWB, z. Hd. Paul H. Ruth, Klagenfurt, 24.05.1938, KLA, NLW, Schachtel $11,371$.

173 Wutte an Ruth, Klagenfurt, 02.07.1938, ebd.

174 Wutte an die Hauptredaktion des HWB, Klagenfurt, 30.09.1938, ebd. 
- zur Folge haben dürfte. Und nun soll „Kärnten“ außerhalb der alphabetischen Reihe erscheinen, was ganz der Anlage des HWB. widerspricht. Ich weiß nicht, wer die säumigen Mitarbeiter sind, aber ich bin froh, daß ich dafür keinerlei Verantwortung trage. Der Grund dieser neuen Schwierigkeiten scheint mir nicht allein in den wegen des Umbruches notwendig gewordenen Umänderungen zu liegen, sondern auch darin, daß die Hauptred. von Kiel aus weder in sachlicher noch in personeller Hinsicht genügend Einblick in die schwierigen Kärntner Verhältnisse hat, vor allem nicht in den außerordentlichen, jetzt mehr denn je fühlbaren Mangel an wissenschaftlichen Arbeitskräften [...]. Wenn ich trotz aller dieser Mühseligkeiten und Mißhelligkeiten, die Jahre hier ausgeharrt und trotz der schwierigsten Verhältnisse auch in letzter Zeit mitgearbeitet habe, so nur, weil ich mich meiner Heimat Kärnten gegenüber verpflichtet halte, die Erfahrungen, die ich auf Grund einer 4ojährigen Beschäftigung mit den Kärntner Problemen gesammelt habe, in einem Standardwerk, wie es das HWB. ist, niederzulegen, so viel es in meinen bescheidenen Kräften steht. Schließlich ist mir auch das HWB. nicht gleichgültig, da ich doch an seiner Wiege gestanden bin und wiederholt mitgeholfen habe, das ertrinkende Kind aus dem Wasser zu ziehen. Aus diesem Grunde glaube ich auch berechtigt zu sein, Ihnen einmal offen zu schreiben, wie sich das Vorgehen des HR. bei einem alten Mitarbeiter ausgewirkt hat. [...] Ich hoffe nun, daß der Artikel Kärntens wenigstens im heurigen Jahr erscheinen kann und würde mich freuen, wenn ich wenigstens die Korrektur meiner Texte bald bekommen würde. Beste Neujahrsgrüße und Heil Hitler! ${ }^{175}$

Die Hoffnung des Gelehrten auf eine baldige Veröffentlichung des Kärnten-Beitrages im HWB sollte noch mehr als ein Jahr strapaziert werden. Im März I 940 reklamierte ein iānusköpfiger Wutte die Aufnahme eines Literaturverweises in das HWB: Ich ersuche nochmals, den Roman Hülgerths aufzunehmen, er gehört zu jenen Männern, die wesentlich dazu beigetragen haben, dass Südkärnten heute zum Reiche gehört, und ist tot. Es wäre kleinlich und unhistorisch, wollte man ihn wegen seines späteren Verhaltens in dieser Zeit ${ }^{176}$ streichen. Allenfalls könnte ja in dem von Gatterer zu behandelnden Abschnitt ein Wort des Bedauerns, dass H. sich von den Politikern der Systemzeit missbrauchen ließ, einfügen. The in tem Nachruf, der worassichtich im Oktoberheft der Garinthia I erscheinen wirct, auch so gemacht. ${ }^{177}$ Der von Wutte Ende 1940 publizierte Nachruf enthält akzentuierte Aussagen. Sie belegen, dass er seine Distanz zu jüngst vergangenen Ereignissen, die aktuelle Politika implizierten, aufgegeben hat ${ }^{178}$. Wutte entfaltete in diesem Nachruf zum einen drei Feind-

175 Wutte an die Hauptredaktion des HWB, Klagenfurt, 02.01.1939, ebd.

176 Anm. Burz: in dieser Zeit in Gabelsberger Schrift nachgetragen.

177 Wutte an die Hauptredaktion des HWB, Klagenfurt, 06.03.1940, KLA, NLW, Schachtel 11, 371. Gestrichener Satz nach Vorlage.

178 Martin Wutte, Ludwig Hülgerth, in: Carinthia I, 130 (1940) 382-385: „Im Lande selbst huldigten viele, namentlich die starke Partei der Sozialdemokraten, dem Schlagwort ,Nie wieder Krieg', andere wieder scheuten den Waffenkampf, da sie in den eingebrochenen Banden serbische Truppen, also Ententetruppen, ver- 
bilder - den Sozialismus ${ }^{179}$, das Judentum, die Staatsmetropole Wien -, die rund drei Jahre später in „Kärntens Freiheitskampf“, wenngleich in unterschiedlichem Ausmaß ${ }^{180}$, immer wieder bemüht werden. Zum anderen vernachlässigte der Historiker die Zeitperspektive, wenn er als Beleg für Hülgerths gesamtdeutsches Denken ein persönliches, Jahre zurückliegendes Gespräch anführt. Denn als Hülgerth - im März I934- Landeshauptmann wurde, herrschten innen- und außenpolitische Rahmenbedingungen vor, die mit jenen des Jahres I 940 nicht vergleichbar sind. Und es ist mehr als unwahrscheinlich, dass Hülgerth, der aufgrund seiner exponierten politischen Funktion nicht nur über die inneren Verhältnisse im nationalsozialistischen Nachbarstaat gut unterrichtet war, sein gesamtdeutsches Denken vor diesem Erfahrungshorizont nicht deutlich relativiert hat ${ }^{181}$. Ein Österreich, das im Ständestaatsystem als besserer deutscher Staat propagiert wurde, war in diesem Kontext für den Offizier keine theoretische Größe, sondern eine logische, allerdings auch die einzige Alternative gegenüber einem möglichen nationalsozialistisch geführten „Gesamtdeutschland“. Aber auch diese Überlegungen sind letztlich ebenfalls nur Spekulation.

Hatte Wutte I938/I939 noch versucht, die „neue Zeit“ durch den nicht zuletzt aus Gesundheitszuständen bedingten Eintritt in den „Ruhestand“ zu durchleben, wurde er nach seiner Reaktivierung, wie schon seit I938, als „wissenschaftlicher Amtsgutacher“182

\footnotetext{
muteten, die nach dem Waffenstillstand vom 3. November volle Bewegungsfreiheit besaßen. Und die Wiener Regierung, namentlich die Staatsämter für Heerwesen und für Äußeres, die sich damals in Händen von Juden befanden, verfolgte mit äußerstem Widerstreben die immer wieder aufflackernden Kämpfe in Kärnten und suchte sie immer wieder zu hindern. [...] Hülgerths Verdienste haben damals seitens der Staatsregierung keine Anerkennung gefunden. Sie grollte dem Manne, der es als Landesbefehlshaber gewagt hatte, gegen ihren Willen für die Freiheit des Kärntnerlandes zu kämpfen. [...] Leider ließ sich Hülgerth nach seinem Übertritt in den Ruhestand bewegen, noch einmal in die Öffentlichkeit zu treten und ging er in seinem letzten Lebensabschnitt Wege, die ihn von den deutschdenkenden Kärntnern zu ihrem tiefsten Leidwesen trennten. Hülgerth war Soldat und wurde Politiker; er hat als Politiker geirrt und dem Rufe der Systemleute Folge geleistet, die ihn als Aushängeschild benützten und schließlich kaltstellten. Aber auch in dieser traurigsten und beschämendsten Periode der österreichischen Geschichte hat Hülgerth in seinem Innern einen Funken gesamtdeutschen Denkens bewahrt und im Innersten seines Herzens - ich weiß es aus einer Äußerung gelegentlich seines Amtsantrittes als Landeshauptmann - gehofft, dass sich die feindlichen Brüder dereinst wieder vereinen werden. 1934 wurde Hülgerth zum Feldmarschalleutnant ernannt, 1934-1937 war er Landeshauptmann in Kärnten, 1937 Vizekanzler.“
}

179 Wutte hat in „Kärntens Freiheitskampf“ von 1943 eine 1930 von Hans Lagger im Auftrag der sozialdemokratischen Landesparteivertretung herausgegebene Broschüre nicht einmal erwähnt. Bereits Alfred OGRIS, Kärntens Freiheitskampf als Beitrag zur Staatswerdung Österreichs in den Jahren 1918-1920, in: Carinthia I, 176 (1986) 41-60, hier 45, hat diesen Umstand zu Recht moniert.

180 Zum latenten Antisemitismus siehe Wutte, Freiheitskampf (1943) (wie Anm. 1) 90, 167, 224. In der Ausgabe von 1985 sind diese Stellen retouchiert. Auf diese „Passagen mit zeitbedingter Phraseologie“ wurde ebd. ohne konkreten Inhaltsbezug hingewiesen.

$181 \mathrm{Zu}$ Hülgerth siehe Anm. 126.

182 Beispiele dazu bei WADL, Landesarchiv (wie Anm. 153) $581 \mathrm{f}$. 
mit zahlreichen Aufgaben konfrontiert. In einer Abschrift des Tätigkeitberichtes, den ich im Sinne der Kärntner Archivordnung an den Reichsstatthalter erstattet habe ${ }^{183}$, resümierte er u.a.: So hatte ich, abgesehen von 2 streng vertraulichen Denkschriften vom März 1942, der Reihe nach zu verfassen: Auf Ersuchen des Grenzlandamtes 4 Denkschriften über das Mießtal, Windischgraz und Mahrenberg, das Aßlinger Dreieck und Oberkrain, auf Ersuchen des Regierungspräsidenten Pawlowski eine Denkschrift über Kärntens Eigenständigkeit ${ }^{184}$. Dem Bericht waren Beilagen in Form von sechs Sonderdrucken angefügt, vermutlich Ausführungen Wuttes, die bereits veröffentlicht worden waren. Über den Inhalt der 2 streng vertraulichen Denkschriften ist bis heute nichts bekannt geworden.

I985 hat Neumann ein weiteres Tätigkeitsfeld des in die Jahre gekommenen Wutte erschlossen. Ausführlich schildert er dessen Engagement kurz vor Kriegsende und nach dem 8. Mai 1945 und dass der Historiker „sein Ziel mit staunenswerter Energie und ohne Rücksicht auf seine Person“ für das in seinen territorialen Grenzen gefährdete Kärnten verfolgt hat. Dass Wutte keine Rücksicht auf seine Gesundheit nahm, war zweifellos der Fall. Hinsichtlich der Autorenschaft von relevantem Schrifttum hielt sich der historischpolitisch gebildete Gelehrte nach dem Kriegsende bedeckt. Zutreffend ist, dass „beim Lesen der Memoranden sowie anderer in dieser Zeit ohne Verfasserangabe erschienener gleichgerichteter Publikationen [...] jedem mit dem Stil von Wutte Vertrauten klar [wird], daß hier zumindest mit seiner Mitarbeit zu rechnen ist. “185

I 986 setzte sich Neumann eingehender mit Wutte und dessen Wirken in der NSZeit auseinander und lieferte eine erste Ergänzung zum I949 verkürzten Autograf Wuttes $^{186}$. Neuman bedauert, dass „in Wuttes posthum gekürzt veröffentlichtem Lebensbericht $^{187}$ [...] leider ein für uns heute wichtiger Satz weggelassen [wurde]; darin heißt es: ,Über meine Stellung zum Nationalsozialismus und was ihm folgte mich zu äußern, wäre verfrüht.“" 188 Im Zentrum der Studie steht eine von Wutte unterfertigte, mit I9. September 1943 datierte Denkschrift, der etliche Beilagen ${ }^{189}$ angefügt sind, die an seinen

183 Wutte an den Generaldirektor der Staatsarchive, o. O. 24.08.1942, KLA, Archivregistratur Zl. 200/1942.

184 Martin Wut te, Bericht über meine Tätigkeit als wissenschaftlicher Leiter des Reichsgauarchivs Kärnten vom Jänner 1940 bis Juli 1942, Klagenfurt, 14.08.1942, KLA, Archivregistratur Zl. 200/1942, Hervorhebungen nach Vorlage.

185 Neumann, Einleitung (wie Anm. 2) XIX und XXI.

186 Neumann, Urteil (wie Anm. 22).

187 Anm. Burz: Verweis auf Wutte, Lebenslauf 1949 (wie Anm. 36) 3-7.

188 Wutte, Lebenslauf 1949 (wie Anm. 36) 3-7, zitiert nach Neumann, Urteil (wie Anm. 22) $21 f$.

189 Dabei handelt es sich um einen „Beschluss der vorläufigen Landesversammlung vom 28. September 1920“, eine „Proklamation des österreichischen Vertreters der Plebiszitkommission vom November 1920“, eine „Kundmachung der Kärntner Landesregierung vom 18. November 1920“ zwei „Führerreden“ im Reichstag (17.05.1933, 20.01.1938 ?) und eine „Erklärung des Landesrates Maier-Kaibitsch als Vertreter der Landesregierung 27. März 1938.“ Angaben nach Neumann, Urteil (wie Anm. 22) 17. 
ehemaligen Schüler ${ }^{190}$, Gauleiter Friedrich Rainer, gerichtet war. Dessen politische und administrative Befugnisse waren seit dem ıo. September 1943 durch eine „Führeranordnung“ deutlich ausgedehnt worden ${ }^{191}$. Für Neumann mutet die Denkschrift „wie eine explosionsartige Äußerung seit langem gehegter Gedanken an, zu deren Unterbauung vor allem die zeitlich jüngeren Beilagen (4-6) sehr zielbewusst bereitgehalten und eingesetzt wurden. Auslösendes Moment war der zwischen 3. und 9. September I 943 vollzogene Abfall Italiens und die folgende territoriale Veränderung, wodurch nun auch der bisher italienische Teil von Krain mit Laibach in die Zuständigkeit des Gauleiters von Kärnten fiel. Wutte hat, wie viele mit den Verhältnissen vertraute Kärntner, die Aufteilung Sloweniens zwischen Deutschland und Italien nach dem außenpolitischen ,Betriebsunfall' des Jugoslawienfeldzuges als einen Fehlgriff angesehen [...]. “Eine Erörterung zu einer alternativen Aufteilung Sloweniens unterbleibt, ebenso eine, wenigstens ansatzweise, Erklärung, was Neumann unter „Betriebsunfall“192 versteht. Unmissverständlich ist seine Einschätzung, dass Wutte zielorientiert gehandelt hat: „Er [Wutte] tritt hier aus seiner Funktion als

190 Wutte hat Rainer im k. k. Staatsgymnasium Klagenfurt 1914-1918 in Geografie und Geschichte unterrichtet. Angaben nach Hauptkatalog (wie Anm. 74).

191 Rainer wurde „Oberster Kommissar für das Adriatische Küstenland“. Ausführlicher dazu: Karl ST U HL PFA RRER, Die Operationszonen des „Alpenvorland“ und „Adriatisches Küstenland“ 1943-1945 (Publikationen des Österreichischen Instituts für Zeitgeschichte und des Instituts für Zeitgeschichte der Universität Wien 7, Wien 1969) bes. 44-75; hier 46; ferner mit neuem Quellenmaterial Michael WEDE K IN D, Nationalsozialistische Besatzungs- und Annexionspolitik in Norditalien 1943 bis 1945. Die Operationszonen,Alpenvorland“ und ,Adriatisches Küstenland' (Militärgeschichtliche Studien 38, München 2003) bes. 58-66.

$192 \mathrm{Zu}$ einem anderen folgenschweren Ereignis, das sich in Kärnten ereignet hat, setzt Neumann, Urteil (wie Anm. 22) 13, die Anm. 12, nämlich zu den Deportationen von mehr als 1000 slowenischen Landsleuten in den Jahren 1941 und - vor allem - im April 1942. Proteste prominenter Zeitgenossen gegen diese Repressalien sind nachgewiesen worden, siehe dazu Alfred Ogris, Der kirchliche Protest aus Klagenfurt gegen die Aussiedlung von Kärntner Slowenen im Jahre 1942, in: Carinthia I, 182 (1992) 441-453. Das von Neumann ins Spiel gebrachte und von Kärntner Medien in der Zwischenzeit wiederholt abgedruckte Protestschreiben Perkonigs gegen die Deportation slowenischer Familien verdient - quellenkritisch betrachtet - nicht einmal das Prädikat „äußerst mangelhaft“. Neumann verweist als Belegstelle auf den „6. Bd. der Ausgewählten Werke, Landschaft und Mensch, Klagenfurt 1967, S. 334-342“. Dort heißt es: „Aus der Denkschrift, betreffend die Aussiedlung von Kärntner Slowenen. (Brief an Dr. Friedl [!] Rainer, Gauleiter von Kärnten, 1941 bis 1945 [!]). “ Im KLA, NL Perkonig, befinden sich in der Schachtel VIII (Politische Korrespondenz 1939-19??) zahlreiche Entlastungsschreiben zugunsten Perkonigs betreffend Verhalten während der NS-Zeit. Diese Schreiben datieren zwischen Dezember 1945 und August 1946 und stammen u.a. von Herta Fischer (ehem. Geschäftsführerin der Reichskulturkammer, Klagenfurt), Martin Wutte und Gotbert Moro. Im selben Faszikel ist auch der Brief Perkonigs an Rainer, in Form eines eigenhändig verfassten Konzeptes (fol. 1-10), als Typoskript und Durchschrift (fol. 1-10) enthalten; ferner ein 17 Seiten umfassendes Typoskript, dazu die 21 Seiten eigenhändig verfasste Vorlage und ein handschriftliches 37-seitiges Konzept, aus dem ein 21-seitiges Typoskript resultiert. Erstgenannte schriftliche Aufzeichnungen firmieren unter Losef Friedrich Perkonig. Meine Haltung. Die Zweitgenannten unter der Überschrift Wenn ich Nazi gewesen wäre... Bei allen genannten Schriften fehlen Datums- und Ortsangaben. 
Historiker völlig heraus und setzt einen wohldurchdachten politischen Akt!"193 Die Anregungen Wuttes „scheinen aber auch“ neben der sich verschlechternden Kriegslage und des Partisanenkampfes „bei Gauleiter Dr. Rainer nicht wirkungslos und ohne Eindruck geblieben“ zu sein. „Einen Hinweis darauf“ sieht Neumann in der „späte[n] Antwort Gauleiter Rainers an Wutte“, die Rainer I 945 während seines Gefängnisaufenthaltes in Nürnberg verfasst und ausdrücklich „für das Kärntner Landesarchiv zu Handen des Hofrates Dr. Martin Wutte oder seines Nachfolgers" bestimmt hatte, und dass diese Aufzeichnungen aber „damals Wutte und das Landesarchiv freilich nicht erreicht" haben ${ }^{194}$.

Neumann bringt ein weiteres Beispiel zu Wuttes Wirken in der NS-Zeit. Der 67jährige, deutlich binnen kürzester Zeit gealterte Wutte ${ }^{195}$ hatte an der Ausstellung „Kärnten. Zwölfhundert Jahre Grenzland des Reiches“ mitgearbeitet, die am 8. Oktober I943 in der Landesgalerie Klagenfurt eröffnet wurde. In diesem Zusammenhang wird von Neumann ein weiteres mögliches kulturpolitisches Engagement Wuttes, das der slowenische Historiker Bogo Grafenauer dem Jahr 1944 zugeordnet hat, infrage gestellt. Dieser habe sich - so Neumann - in einer Rezension seines „Abwehrkampfes“196 „sehr scharf gegen meine Würdigung des Werkes von Martin Wutte ,Kärntens Freiheitskampf' gewendet, ihm tendenziöse Verzerrung der Wahrheit und Begeisterung für politischen Extremismus vorgeworfen. Denn Wutte habe in der Einleitung zu einem Sammelband ,Kärnten I 200 Jahre Grenzland des Reiches', der im Mai 1945 in Laibach in Druck gewesen sein soll und von dem sich die Korrekturspalten erhalten hätten, die natürliche und historische Aufgabe Kärntens darin gesehen, ,treuer Wächter zu sein an Deutschlands Südgrenze. Das ist Kärntens heilige Pflicht. Diese Pflicht erfüllt zu haben, ist sein Stolz, sie im Großdeutschen Reich Adolf Hitlers erfüllen zu dürfen, sie auch in Zukunft zu erfüllen sein Wille'; die hier kursiv gedruckten Stellen habe Wutte selbst unterstrichen. Grafenauer meint, solches noch ,Ende I944' zu schreiben, spreche gegen Wuttes Befähigung zur wissenschaftlichen Erforschung der Zeitgeschichte und zeuge auch nicht von aufrechtem Rückgrat vor den zeitgenössischen, Größen‘. Diese Einleitung stehe in engstem Zusammenhang mit Wuttes Werk über den Kärntner Freiheitskampf und werde noch durch die Aussage vervollständigt, daß ,heute der schmale

193 Neumann, Urteil (wie Anm. 22) 20.

194 Ebd. 26f. Zitat aus der Niederschrift, deren erste Seite als Faksimile in der Neumann-Studie 32 abgedruckt ist. Der Autor merkt an, dass ihm eine Xerokopie der Niederschrift Anfang der 1970er-Jahre „von privater Seite übergeben" worden ist, die im KLA hinterlegt wurde.

195 Das ergibt ein Vergleich von Fotografien, die im NL Wutte vorhanden sind, mit einer Fotografie, die rund um die Verleihung des Wissenschaftspreises an Wutte im Oktober 1942 gemacht wurde, in: CARniER, Lo sterminio mancato (wie Anm. 158) 192 [d]; dasselbe Bild in: Kärntner Zeitung, 12.10.1942 Nr. 2813.

196 Neumann, Abwehrkampf (wie Anm. 19, Erstauflage Klagenfurt 1970). Zur Rezension siehe Bogo GraFEnAUER, Zgodovinski časopis 25 (1971) 328-331, zitiert nach der zweiten Auflage 1985 von Neumann, Abwehrkampf 158. 
jugoslawische Damm zwischen den Karawanken und der Adria zerschlagen ist; das Fenster zum Süden ist geöffnet. Kärnten steht vor neuen und großen Aufgaben'."197

Neumann meint, dass „zu den Laibacher Korrekturspalten deren Zeitansatz sich doch wesentlich anders darstellt. Das in Kärnten befindliche Material bietet keinen Hinweis auf den von Grafenauer erwähnten Sammelband, allerdings existiert mit demselben Titel ein im damaligen NS-Gauverlag, Zweigverlag Krainburg, I 943 gedruckter ,Führer durch die Ausstellung Kärnten zwölfhundert Jahre Grenzland des Reiches‘, die vom Institut für Kärntner Landesforschung der Universität zusammen mit dem Reichsgauarchiv und Gaumuseum in neun Räumen der Burg in Klagenfurt veranstaltet wurde. "198 Die von Grafenauer Wutte unterstellte Textpassage weise auffallende Parallelen zu Ausführungen auf, die in einem Pressebericht in der „Kärntner Zeitung “199 anlässlich der I 200-JahreAusstellung in Klagenfurt veröffentlicht worden $\operatorname{sind}^{200}$.

Im Zeitungsartikel wird Wutte als Festredner genannt und dessen „aufschlußreiche[n] Erläuterungen und Einführung in die Ausstellung" hervorgehoben. Die Schlußfolgerungen im Artikel ohne Verfasserangabe enthalten keine wörtlichen Zitate. Inhaltlich wird auf eine „Grenze von besonderer Wichtigkeit“ hingewiesen, die immer von verschiedensten Völkern bedroht war, „weil über sie bedeutende Verkehrswege gehen. [...] Heute ist das Fenster nach dem Süden weit aufgestoßen, Kärnten steht vor großen neuen Aufgaben. Von einer höheren Warte betrachtet, erscheinen jedoch die jüngsten Kämpfe und die neuen Aufgaben des Landes nur als ein natürlicher Teil seines tausendjährigen Grenzlandkampfes. Kärntens geschichtliche Sendung ist und bleibt: treuer Wächter an des Reiches Südgrenze zu sein. Diese Pflicht erfüllt zu haben, ist des Kärntners Stolz, sie im Großdeutschen Reich Adolf Hitlers erfüllen zu dürfen, seine Freude, sie auch in Zukunft zu erfüllen, sein Wille. Und Sinn und Zweck der Ausstellung ist es, den Kärntner darin zu bestärken.“201 In einer „Vor-

197 Neumann, Urteil (wie Anm. 22) $10 f$.

198 Ebd. 11. Ergänzend bzw. korrigierend zu Neumann, vgl. Führer durch die Ausstellung. Kärnten. Zwölfhundert Jahre Grenzland des Reiches [ohne Verfasserangabe] 743 [Hier ist ein Hakenkreuzsymbol eingefügt, Anm. Burz] (Klagenfurt 1943). Im Katalog wird zudem angemerkt: „Für die Ausstellung ,Kärnten 1200 Jahre Grenzland des Reiches'schufen im Auftrage des Gauleiters und Reichsstatthalters Dr. Friedrich Rainer die wissenschaftlichen Grundlagen das Institut für Kärntner Landesforschung in Verbindung mit dem Reichsgauarchiv und dem Gaumuseum, die organisatorischen und technischen Voraussetzungen das Gauhauptamt für Volkstumsfragen in Verbindung mit der Stadt Klagenfurt. “ Der Hinweis auf die Universität Graz, an die das Institut für Kärntner Landesforschung wenigstens formal gebunden war, stammt von Neumann. Angaben nach „Führer [...]“ in: KLA, NLW, Schachtel 40, 1238. Zum Institut für Kärntner Landesforschung ausführlicher: Ferenc, Quellen (wie Anm.158) Dokument-Nr. 89, 148, 152, 196 und 207.

199 Anm. Burz: Untertitel: Amtliche Tageszeitung des Gaues Kärnten der NSDAP und aller Behörden mit dem ,Amtlichen Anzeiger‘ für den Reichsgau Kärnten, Ausgabe Villach und Oberkärnten.

200 Neumann, Urteil (wie Anm. 22) 11.

201 Kärnten 1200 Jahre Grenzland des Reiches [ohne Verfasserangabe], in: Kärntner Zeitung, 09./10.10.1943, 
schau auf die Ausstellung“ berichtete die „Kärntner Zeitung“ davon, dass Wutte bei der I 200-Jahre-Ausstellung für die Gestaltung zweier Räume verantwortlich gewesen sei ${ }^{202}$. Im Ausstellungskatalog wird spezifiziert ${ }^{203}$. Der papierene „Führer durch die Ausstellung“ endet mit einer Danksagung an den physischen „Führer“: „So wurde Kärnten von der Gefahr, die ihm von Seiten der Jugoslawen auch nach der Volksabstimmung drohte, durch den Führer befreit." ${ }^{204}$ Das Fazit Neumanns: „Unabhängig davon, wie genau der Pressebericht die Worte des Sprechers wiedergibt, folgt daraus, daß das von Grafenauer gebotene Zitat fast wörtlich schon mehr als ein Jahr früher anzusetzen ist; sich dieses Datum vom 8. Io. I943 zu merken wird sich noch als wichtig erweisen." 205

Eine ähnlich gehaltene Sympathiekundgebung Wuttes für Adolf Hitler findet sich in einem I940 publizierten voluminösen Carinthia-Aufsatz. Wutte rekurrierte darin u. a. auf die „Friedensdiktate von Versailles und St. Germain“, die allen Hoffnungen auf einen baldigen Anschluss ein Ende machten. Anschließend beschreibt er ein Stück „realer“ Geschichte: „Trotz des Verbots und trotz des volksverräterischen Treibens der Systemregierung und ihrer Gewaltmaßnahmen blieb der heiße Wunsch nach Vereinigung mit dem Mutterlande auch in Kärnten in allen Schichten der Bevölkerung ungebrochen erhalten. Doch wußte niemand, wie der Anschluß herbeigeführt werden sollte. Nur über eines war man sich im Grenzlande Kärnten klar: Erst wenn das Deutsche Reich aus dem tiefen Verfall wieder zu Macht und Stärke gelangt ist, kann dem Widerstand der Feindmächte getrotzt werden und ist ein Anschluß ohne ernste Gefährdung der Grenzgebiete durch die Nachbarn möglich. Das staatsmännische Genie Adolf Hitlers hat diese Voraussetzung geschaffen, den Anschluß vollzogen und den Sehnsuchtstraum der Kärntner erfüllt. [...] 47 Kärntner haben ihre Treue zu Führer und Volk mit ihrem Tode besiegelt und drei führende Kärntner Nationalsozialisten haben an den Vorbereitungen zur Heimkehr der Ostmark ins Reich wesentlichen Anteil genommen. Tausendfach erscholl in den Umbruchstagen des März I938 der Ruf: Ein Volk, ein Reich, ein Führer! und 99.69 v. H. der Abstimmenden stimmten am 9. April [sic] für den Anschluß an das Deutsche Reich Adolf Hitlers."206

Nr. 279f. 7. Ich danke an dieser Stelle ausdrücklich Herrn Karl-Heinz Girl von der Bibliothek der AlpenAdria-Universität Klagenfurt für dessen Hilfe bei Kopierarbeiten von Zeitungsartikeln.

202 Kärnten zwölfhundert Jahre Grenzland des Reiches. Eine Vorschau auf die Ausstellung in der Kärntner Landesgalerie in Klagenfurt [ohne Verfasserangabe], in: Kärntner Zeitung, 08.10.1943, Nr. 2783.

203 Raum VIII: Freiheitskampf und Volksabstimmung. Vorgeschichte; Raum IX: Neue Bedrohung Kärntens nach der Volksabstimmung, Angaben nach: Führer durch die Ausstellung (wie Anm. 198) 13-15.

204 Ebd. 16. [ohne Verfasserangabe].

205 Neumann, Urteil (wie Anm. 22 ) 11.

206 Wutte, Der gesamtdeutsche Gedanke (wie Anm. 95) 70. Hervorhebungen nach Vorlage. 
I94I dankte Wutte - „für den Geschichtsverein für Kärnten“ - erneut dem überaus prominenten Zeitgenossen für „das befreite Mießtal“ und nahm mehrmals Bezug auf den neuen politischen Messias ${ }^{207}$.

Zwei Jahre später schließt auch die Monografie „Kärntens Freiheitskampf“ mit einer ähnlich gehaltenen Einschätzung der Fähigkeiten des staatsmännischen Genius Adolf Hitler. Wutte verknüpft jüngst Vergangenes mit der Gegenwart, akklamiert eine weitere historisch-politische Realität; für seine überschaubare Welt ${ }^{208}$. Ob er dem „Führer“ diese Anerkennung aus zeitbedingt opportunen Gründen, unfreiwillig oder aus Überzeugung zollte, wird sich vermutlich nie restlos klären lassen. Aber spätestens nach der Wutte anvertrauten „wissenschaftlichen Oberleitung des Reichsgauarchivs“209 war er ohnedies nur mehr bedingt ein freier Wissenschafter. Der formale Beitritt zur NSDAP im Oktober $1942^{210}$ hat seine „Bewegungsfreiheit“ zumindest sicherlich nicht vergrößert. Neumann überlässt Wutte die Erklärung, was zum Parteieintritt motivierte, indem er einen Brief Wuttes, der mit 17. Dezember I946 datiert, ungekürzt veröffentlichte. An dieser Stelle wird Wuttes Rechtfertigung nur auszugsweise zitiert: Sie haben mir einmal geschrieben, daß ich immer den geraden, mir selbst vorgezeichneten Weg gehe. Das scheint nun für die letzten Jahre nicht zuzutreffen. Ich war immer deutschfreiheitlich und habe von dieser meiner Gesinnung nie ein Hehl gemacht, suchte aber stets mäßigend zu wirken. Radikalismus, der mit

207 Martin Wutte (für den Geschichtsverein für Kärnten, Klagenfurt im Mai 1941), Gruß an das befreite Mießtal, in: Carinthia I, 133 (1941) 1f.: „Erst mußte der starke Mann kommen, der es von diesen Banden löste, mußte Kärnten heimgeführt werden in sein Mutterland, mußten die Fesseln von St. Germain und Versailles zersprengt werden, dann erst konnte auch für Dich der Tag der Erlösung kommen. [...] Geschmückt mit den Fahnen des Führers, des Reiches und der Heimat bist Du in den Schoß der Mutter zurückgekehrt, erfüllt mit heißem Dank für den Führer, der auch Dir die goldene Freiheit gebracht hat.“

208 Wutte, Freiheitskampf (1943) (wie Anm. 1) 415: „Erst wenn das Reich aus seinem Verfall zu Macht und Stärke gelangt war, konnte der Anschluß an das Mutterland ohne Gefährdung Kärntens erfolgen. Diese Voraussetzung hat das staatsmännische Genie Adolf Hitlers erfüllt. Als in den Tagen des Umbruchs der Nationalsozialismus die auf verräterische Abwege geratene österreichische Regierung hinwegfegte und der Führer Kärnten einführte ins Reich, stand dieses dank der Voraussicht und Energie des Führers da in schimmernder Wehr. Die jugoslawische Regierung war daher eine der ersten, die dem Anschluß bedingungslos zustimmte. Laibach mußte es erleben, daß die Drohung, Jugoslawien werde sich im Falle des Anschlusses Südkärnten holen, gar nicht erwogen wurde. So wurde Kärnten, durch die Rückgliederung des Mießtales geeint und durch Oberkrain erweitert, durch die Tat unseres Führers für immer von der drohenden jugoslawischen Gefahr befreit und die Frucht des Kärntner Freiheitskampfes für alle Zukunft gesichert.“

209 Reichsstatthalter Rainer an Wutte, Klagenfurt, 15.07.1942, G.Z. II/13.059/42, KLA, NLW, Schachtel 56, 1585.

210 Mitgliedsnummer: 9197361, NSDAP, Gauleitung Kärnten, Ortsgruppe Klagenfurt; Aufgenommen am 01.10. 1942, Ausstellungsort: München, 20.10.1942, bestätigt durch Reichsschatzmeister Franz Xaver Schwarz. Die (Mitglieds-)Beitragswertmarken sind vom 10.10.1942 - ausgenommen jene für Juli, August und September 1944 - bis Dezember 1944 geklebt. Für 1945 fehlen die Beitragswertmarken. Angaben nach KLA, NLW, Schachtel 1, 3; vgl. Neumann, Urteil (wie Anm. 22) 23: „Aufgenommen am 1. Oktober 1942, München, den 20. Oktober 1942, Reichsleitung: Schwarz, Reichsschatzmeister, eindeutig bestätigt; die Marken sind ab diesem Monat geklebt.“ 
Gewalt und nicht mit Gründen der Überzeugung sein Ziel zu erreichen sucht, war mir stets verhaßt. Das war einer der Hauptgründe, warum ich den Nationalsozialismus von Anfang an ablehnte, wiewohl ich einzelne seiner Ziele mit Begeisterung aufnahm. Ich habe mich auch bis 1942 geweigert, Pg. [Parteigenosse, Anm. Burz] zu werden. Und Wutte konstatiert, dass er einer Bitte des Gauleiters entsprechen wollte, weil dieser mitteilen ließ, dass er [Wutte] in die Partei, berufen 'werde. Um Rainer, den ehemaligen Schüler, anlässlich der Abstimmungsfeier, in deren Rahmen Wutte der erste Kärntner Wissenschaftspreis verliehen werden sollte, nicht in eine peinliche Lage zu versetzen, sagte er den Beitritt zur Partei nach einigem Zögern zu, doch nur unter der Bedingung, daß ich gewisse Überzeugungen, die ich mir im Verlaufe meines Lebens erworben habe, vorbehalte(n) und gewisse Grundsätze des Nationalsozialismus, wie den der Totalität, die dem Menschen die Glaubens- und Gewissensfreiheit, der Wissenschaft die Freiheit der Lehre nehme, ablehnen dürfe. Es war eine gewisse Schwäche von mir, aber wer hätte unter den gegebenen Umständen anders gehandelt? Ich habe auch später immer wieder meine eigene Meinung vertreten, auch vor Rainer, so z. B. den Grundsatz, daß die Wissenschaft der Politik vorausgehen müsse und nicht umgekehrt. Das mag auch der Grund gewesen sein, daß ich wohl mitarbeiten durfte, aber von den neugeschaffenen wissenschaftlichen Institutionen ausgeschaltet wurde und nicht einmal zu den Beratungen über deren Einrichtung beigezogen wurde ${ }^{211}$.

Über den Stellenwert der apostrophierten freien Wissenschaft in der und für die zeitgenössische Gesellschaft hat Wutte im Frühjahr 1939 offensichtlich keine Reflexionen angestellt, als er um die Aufnahme in den Reichsbund für Deutsche Vorgeschichte angesucht hat. In den Satzungen des Reichbundes, der sich als Vertreter „der Gesamtheit der Vereine und Gesellschaften für Vorgeschichte im Reichsgebiet" definierte, ist von der Freiheit der Wissenschaft keine Rede mehr: „Seine [= Reichsbund, Anm. Burz] Aufgabe ist, auf der Grundlage der nationalsozialistischen Weltanschauung eine arbeitsfähige Front aller Freunde deutscher Vorgeschichte herzustellen, die Kulturgüter der deutschen Vorzeit zu erforschen, zu schützen und zu pflegen und die gewonnenen wissenschaftlichen Erkenntnisse in lebendiger Form an weiteste Kreise des deutschen Volkes weiterzugeben. [...] Er erstrebt dabei engste Zusammenarbeit mit den Denkmalämtern und Museen, mit den Nachbarwissenschaften und im besonderen mit den Schulungsorganisationen der NSDAP und des Staates. “212 Wuttes Anliegen wurde kurze Zeit später positiv erledigt ${ }^{213}$.

211 Neumann, Urteil (wie Anm. 22) 22.

212 Die Satzungen sind im NLW, in der Schachtel 1 aufbewahrt, wie die Mitgliedskarte Nr. 1329 für Herrn Landesarchivdirektor Dr. Martin Wutte. Das Eintrittsdatum ist vordatiert: Eingetreten 1.1.1939, [Ausgestellt] : Berlin 25.3.1939. Geklebt sind zwei Marken für zwei Halbjahrsbeiträge (1939); weitere Beitragsmarken sind im Mitgliedsbuch zum einen nicht vorhanden, zum anderen wurden - deutlich erkennbar - Seiten aus diesem Mitgliedsbuch abgetrennt.

213 Schreiben der Reichsleitung des Reichsbundes für Deutsche Vorgeschichte an Wutte, Berlin, 07.03.1939, 
Exkurs zum Institut für Kärntner Landesforschung und zur Kärntner Wissenschaftlichen Gesellschaft: Bei der kryptischen Anmerkung in Wuttes Brief an Perkonig, dass er von den neugeschaffenen wissenschaftlichen Institutionen ausgeschaltet wurde und nicht einmal zu den Beratungen über deren Einrichtung beigezogen worden sei, handelt es sich mit hoher Wahrscheinlichkeit um die Kärntner Wissenschaftliche Gesellschaft und das Institut für Kärntner Landesforschung der Universität Graz, deren Konstituierung bzw. Gründung am Io. Oktober I942 ${ }^{214}$ im Großen Wappensaal des Landhauses in Klagenfurt bekannt gegeben wurde. Zur Geschichte des Landesforschungsinstitutes hat Tone Ferenc I980 bereits Wesentliches publiziert ${ }^{215}$. Ergänzend ist anzufügen, dass Wutte im Zuge der wissenschaftlichen Bearbeitung der aus Belgrad eingetroffenen Akten und der daraus sich ergebenden wissenschaftlichen Aufgaben ersucht worden war, diese Arbeiten als Forschungsauftrag im Rahmen des Instituts für Kärntner Landesforschung zu übernehmen ${ }^{216}$.

Zur Entwicklungsgeschichte der Kärntner Wissenschaftlichen Gesellschaft lässt sich ein aussagekräftiges Detail zu Strategien des NS-Regimes im damaligen Wissenschaftsbetrieb erschließen. In einer hausinternen Anfrage, ob die Vereinssatzungen dieser Gesellschaft denn gesetzeskonform wären, monierte der zuständige Sachbearbeiter: Grundsätzlich wäre in der Satzung das Führerprinzip und die Reichsbürgerschaft für die Mitglieder der Gesellschaft zu verankern. Kritik übt der Beamte am Punkt I, 2, des Entwurfes der Vereinssatzungen: Er [der Verein, Anm. Burz] steht unter dem Schutze des Gauleiters und Reichsstatthalters in Kärnten und ist an seine Weisungen gebunden. Dieser Satzungsentwurf motivierte einen bemerkenswerten Einspruch des Beamten. Gleichzeitig dokumentiert er ein gewichtiges Stück perfider nationalsozialistischer Wissenschaftspolitik: zu Satz I, 2: In dieser Form muss der Satz zu Missverständnissen Anlaß geben. Es ist doch sicherlich nicht gemeint, daß die wissenschaftliche Eigenverantwortlichkeit der im Verein tätigen Forscher ausgeschaltet und daß auch hinsichtlich des abzugebenden wissenschaftlichen Urteils das Weisungsrecht gegeben sein soll. Dann könnte ja von einer Wissenschaft im eigentlichen Sinne nicht mehr die Rede sein. Entweder betont man hier nur die staatliche, Aufsicht' oder begrenzt das Weisungsrecht genauer und in einer Weise, die an der echten Wissenschaftlichkeit der Gesellschaft keinen Zweifel läßt. Z. B. würde diese dadurch nicht beeinträchtigt werden, daß der

KLA, NLW, Schachtel 1, 2: Wir danken Ihnen für Ihr Schreiben vom 21.2.1939 und bitten Sie, beiliegendes Formular ausgefüllt an uns zurückzusenden. Im Anschluss daran erhalten Sie die, Mannus'-Zeitschrift sowie die Mitgliedskarte zugesandt.

214 Oberregierungsrat und Schulrat Dr. Georg Graber hat seine Arbeit am Institut für Kärntner Landesforschung der Universität Graz bereits - per Erlass - am 1. August aufgenommen. Schreiben des Kurators der wissenschaftlichen Hochschulen in Graz und Leoben an den Reichsminister für Wissenschaft, Erziehung und Volksbildung, Graz, 21.09.1942, BAB, R 4901, 13425.

215 Ferenc, Quellen (wie Anm.158), Dokument-Nr. 89, 148, 152, 196 und 207.

216 Rainer an Wutte, Klagenfurt, 15.07.1942, G.Z. II/13.059/42, KLA, NLW, Schachtel 56, 1585. 
Gauleiter der Gesellschaft bestimmte wissenschaftliche Aufgaben stellt an deren Lösung der Gau interessiert ist. Ferner ist z. B. denkbar, dass die ,Veröffentlichung' eines wissenschaftlich einwandfreien Ergebnisses einer Forschung aus bestimmten politischen anderen Gründen nicht zweckmäßig ist ${ }^{217}$.

Die Vereinsstatuten der Kärntner Wissenschaftlichen Gesellschaft wurden anlässlich der Wappensaalrede des Gauleiters Rainer 1942 verlesen, aber nicht, im Unterschied zur Rede, ein Jahr später schriftlich veröffentlicht ${ }^{218}$. Die vom Sachbearbeiter reklamierte Änderung der Satzung hinsichtlich des Weisungsrechtes blieb gegenstandslos. Die Kärntner Wissenschaftliche Gesellschaft stand also unter dem Schutze des Gauleiters und Reichsstatthalters in Kärnten und war an dessen Weisungen gebunden ${ }^{219}$. Ob Wutte in dieser Gesellschaft mitgearbeitet hat, wäre noch zu eruieren. Faktum ist, dass er anlässlich des GründungsFestaktes nicht nur den ersten Wissenschaftspreis, den diese Einrichtung vergab und der von Gauleiter Rainer gestiftet worden war, erhalten hat. I944 nämlich deutete Gotbert Moro $^{220}$ eine engere Vernetzung zwischen der Wissenschaftlichen Gesellschaft und dem Institut für Kärntner Landesforschung an: „Es war nur selbstverständlich, daß Doktor Wutte von zuständiger Seite gebeten wurde, sein schon allein durch den Stoff hiezu geeignetes Buch als ersten Band der Veröffentlichungen der Kärntner Wissenschaftlichen Gesellschaft ,Kärntner Forschungen I‘ der Schriften des 1942 begründeten Instituts für Kärntner Landesforschung der Universität Graz in Klagenfurt, herauszugeben. Er hat dieser Bitte gerne entsprochen und damit ist sein Werk gewissermaßen richtunggebend für alle weiteren geschichtswissenschaftlichen Arbeiten in Kärnten geworden: nämlich zu Nutz und Frommen der Heimat und des Volkes nicht nur die reine Wahrheit zu erforschen und sie weitesten Kreisen des ganzen Volkes zu erschließen, sondern darüber hinaus auch die Verbindung mit dem Leben, mit der Gegenwart nicht zu verlieren, so wie Martin Wutte selbst immer (nach dem Urteil eines berufenen Gelehrten über ihn), Geschichte und Gegenwart zu verbinden gewußt hat‘ “" 221 Tatsächlich wusste Wutte Geschichte und Gegenwart zu verbinden. Denn für sein Buchprojekt „Kärntens Freiheitskampf“ erfuhr er weitreichende Unterstützung durch Zunftkollegen, die in relevanten Schlüsselpositionen des NS-Systems tätig waren. Einen Zentralschlüssel, für den Zugang zu den dafür notwen-

217 REM, interner Akt, 02.09.1942, BAB, R 4901, 2615. Hervorhebung nach Vorlage.

218 „Rede des Gauleiters Dr. Friedrich Rainer zur Konstituierung der Kärntner Wissenschaftlichen Gesellschaft am 10. Oktober 1942 im Großen Wappensaal des Landhauses zu Klagenfurt“, in: Carinthia I, 133 (1943) $12-14$.

219 KLA, Sicherheitsdirektion (Vereinsakten), Kärntner Wissenschaftliche Gesellschaft in Klagenfurt, Satzungen, Schachtel 11, Nr. 402.

220 1958-1967 Direktor des Kärntner Landesarchivs.

221 Gotbert Moro, Martin Wutte: „Kärntens Freiheitskampf“. Eine Würdigung der umfassenden Neuauflage des großen Werkes, in: Kärntner Zeitung, 10.10.1944, Nr. 2802. 
digen Ressourcen, bildete ein Forschungsauftrag von Reichsstatthalter Rainer ${ }^{222}$, auf den Wutte kurze Zeit später im Stil eines Beamten reagierte 223 . Die Frage, wie und unter welchen Umständen Wutte zu den angesprochenen Akten gekommen ist, kann an dieser Stelle nur kurz ausgeleuchtet werden. Der Transfer von ausländischem Kulturgut nach Berlin und Kärnten fand vermutlich auf dem noch immer weiten Forschungsfeld „Nationalsozialistischer Kunst- und Kulturraub“ statt $^{224}$. In einer einschlägigen quellenmächtigen und mit zahlreichen weiterführenden Literaturhinweisen versehenen Monografie gelangte die Autorin zur Erkenntnis, dass die Geschichtsforschung zur Rolle deutscher Archivare und Archive im NS-System erst langsam einen Überblick gewinnt. „Die Ergebnisse der neueren Forschung lassen sich dahin gehend zusammenfassen, daß sich die deutschen Archivare während der Jahre des Nationalsozialismus nicht, wie von ihnen nach dem Krieg gerne angeführt, in einer unpolitischen Nische aufgehalten hatten. Im Gegenteil, Arbeiten wie die Auskunftstätigkeit für ,Ariernachweise‘ [...]“225 konfrontierten sie zwangsläufig mit einem Ideologem des Nationalsozialismus, dem rassischen Antisemitismus.

Im Fall Wutte gilt es, zunächst einmal festzuhalten, dass er expressis verbis davon spricht, dass auf seine Bitte hin, die „Belgrader Akten“ zur Verfügung gestellt wurden. Wutte war demnach am Beutezug nach neuen Erkenntnissen zu „Abwehrkampf“ und

222 Rainer an Wutte, Klagenfurt, 15.07.1942, G.Z. II/13.059/42, KLA, NLW, Schachtel 56, 1585: Im März l. J. habe ich anlässlich Ihrer Betrauung mit der wissenschaftlichen Oberleitung des Reichsgauarchivs den Wunsch ausgesprochen, daß sie sich mit der wissenschaftlichen Bearbeitung der aus Belgrad eingetroffenen Akten und der daraus sich ergebenden wissenschaftlichen Aufgaben befassen mögen. Da nunmehr das Institut für Kärntner Landesforschung in das Stadium der Verwirklichung tritt, bitte ich Sie, diese Arbeiten als Forschungsauftrag im Rahmen des Instituts zu übernehmen.

223 Wutte an Rainer, Klagenfurt, 15.07.1942, KLA, NLW, Schachtel 56, 1585: Zu Ihrem Schreiben vom 15. Juli 1942, Gesch.Zl. II/13.059/42 teile ich, von einem kurzen Urlaub zurückgekehrt, mit, daßich den größten Teil der gegenwärtig im Reichsgauarchiv Kärnten befindlichen Belgrader Akten, die mir auf meine Bitte vom Außenamt zur Benützung für die Neuauflage meines Buches „Kärntens Freiheitskampf“ zur Verfügung gestellt wurden, insbesondere die Akten der jugoslawischen Friedensdelegation sowie die Akten der bei der Laibacher Landesregierung bestandenen Kommission für die Friedenskonferenz und der Abteilung für die besetzten Gebiete, soweit sie Kärnten betreffen, bereits durchgearbeitet und wissenschaftlich auch schon für die diplomatischen Abschnitte des Buches ausgiebig verwertet habe. Vom Buch selbst ist bereits ein Drittel gesetzt. Die ersten 8 Druckbogen sind auch schon korrigiert.

224 Zum Raub kultureller Wertgegenstände, vor allem von Büchern, siehe Murray G. HALl, Christina KösTNER, „... allerlei für die Nationalbibliothek zu ergattern ... “ Eine österreichische Institution in der NS-Zeit (Wien/Köln/Weimar 2006), mit Kärnten-Bezug 428-448 (freundlicher Hinweis von Karel Hruza).

225 Astrid M. Eckert, Kampf um die Akten. Die Westalliierten und die Rückgabe von deutschem Archivgut nach dem Zweiten Weltkrieg (Transatlantische Historische Studien 20, Stuttgart 2004) bes. 121-147, hier 143, Kursivsetzung nach Vorlage. Vgl. aber auch die relevanten Beiträge in: Das deutsche Archivwesen und der Nationalsozialismus - 75. Deutscher Archivtag 2005 in Stuttgart, red. v. Robert Kretzschmar u.a. (Tagungsdokumentationen zum Deutschen Archivtag 10, Essen 2005) (freundlicher Hinweis von Karel Hruza), und in: Österreichs Archive (wie Anm. 153). 
Volksabstimmung aktiv beteiligt. In dieser Jagdgesellschaft besonderer Art wirkte Ludwig Bittner mit, der mit Wutte schon in den I930er-Jahren Briefverkehr unterhalten hatte. Bittner war per Dekret Anfang August I94I zum Direktor des Reichsarchivs Wien ernannt worden; durch das Kampfabkommen zwischen der Großdeutschen Volkspartei und der NSDAP, abgeschlossen vor dem Verbot der NS-Bewegung (I9. Juni I933), galt er seit dem I 5 . Mai 1933 als Mitglied der NSDAP226. Bittner wiederum hatte auf fachlicher Ebene „ein besonders gutes Verhältnis“ zu Ernst Zipfel, dem Generaldirektor der preußischen Staatsarchive und des Reichsarchivs Potsdam²7, seit dem 22. Juli I 942 „Kommissar für den Archivschutz, das heißt Raub von Archivgut in eroberten Ländern “. ${ }^{228}$ Und schon „wenige Tage nach dem Überfall auf Jugoslawien (6. April I94I) begannen die deutschen Archivare mit Überlegungen zu - aus ihrem Blickwinkel so bezeichneten - ,Archivschutzmaßnahmen'“" Das damit verbundene Ziel ist unschwer nachvollziehbar: „Wer Quellen hat, kann Geschichte schreiben. Wer Akten besitzt, hat die Macht der Interpretation. “229

Rund um die neue „Archivsituation“ ist allerdings zu beachten, dass die Monografie „Kärntens Freiheitskampf“ keineswegs ein „reines“ Auftragswerk war. Das ist anhand eines Briefes von Wutte, der rund acht Monate vor dem „Anschluss“ datiert, indirekt nachweisbar. Darin erwähnte Wutte, dass seine Monografie I 933 nachgedruckt wurde, weil die (später abgesagte) VDA-Tagung in Klagenfurt ${ }^{230}$ vor der Tür stand. Und Wutte spricht von einer geplanten Neuauflage, ergänzt durch Quellenmaterial diplomatischen Inhalts ${ }^{231}$. Und auch nur ein oberflächlicher Blick in den Nachlass Wuttes zeigt, dass er nach der Erstauflage von „Kärntens Freiheitskampf“ fortwährend Material für die Zweitauflage dieses Buches sammelte, das nicht zuletzt deshalb nach wie vor über weite Strecken ein unerlässliches Werk zur Kärntner Volksabstimmung von I 920 darstellt.

226 Ausführlich zu Bittner Thomas Just, Ludwig Bittner (1877-1945). Ein politischer Archivar, in: Österreichische Historiker (wie Anm. 7) 283-305, hier 296 und 298.

227 Herbert Hutterer, Thomas Just, Zur Geschichte des Reichsarchivs Wien 1938-1945, in: Das deutsche Archivwesen (wie Anm. 225) 313-325, hier 314.

228 Ernst KleE, Das Personenlexikon zum Dritten Reich. Wer war was vor und nach 1945 (Frankfurt/M. 2005) 697. Kursivsetzung nach Vorlage.

229 Eckert, Kampf (wie Anm. 225) 9.

230 Anm. Burz: Die Tagung des Volksbundes für das Deutschtum im Ausland war für Pfingsten 1933 geplant. Die damaligen politischen Verhältnisse veranlassten die Bundesregierung, die Veranstaltung abzusagen. Wutte war über Interna dieses hochbrisanten Politikums gut unterrichtet. In seinem NL, Schachtel 40, 1233, befindet sich die Niederschrift (Durchschlag 70 Bl.) der am 08.05.1933 im Sitzungssaal der Kärntner Landesregierung stattgefundenen Beratung. Vgl. dazu ausführlicher Alfred OGris, Anschlußideen in Kärnten während der Zwischenkriegszeit (1918-1938), in: Das Jahr 1938 in Kärnten und seine Vorgeschichte. Ereignisse -Dokumente - Bilder, hg. v. DEMs., Wilhelm WADL (Das Kärntner Landesarchiv 15, Klagenfurt 1988) 13-39, hier 33f.

231 Wutte an Viktor Miltschinsky, Klagenfurt, 07.1937, KLA, NLW, Schachtel 1, 113. 
Die Sichtung und Übersetzung der Belgrader Akten wie auch des Quellenmaterials aus dem Reichsarchiv Wien und der 3287 Fotokopien von Akten des Nationalarchives in Paris $^{232}$, die Wutte zur Verfügung gestellt wurden, erforderte viel Zeit ${ }^{233}$. Vor diesem Hintergrund ist es verständlich, dass sich die Veröffentlichung von „Kärntens Freiheitskampf“ verzögerte, wie Wutte in seinem Bericht vom I4. August 1942 festhielt ${ }^{234}$. Das Gesuch um Papierzuteilung zeigte dank Unterstützung von höchsten wissenschaftlichen und politischen Stellen im „Reich“ schließlich seine Wirkung. Ein Teil des Manuskriptes lag seit Mitte Oktober 1942 beim Propagandaministerium, von dessen Empfehlung es abhängen wird, ob die Wirtschaftsstelle des Deutschen Buchhandels das Papier bewilligt ${ }^{235}$. Im Konzept eines Eilbriefes an Joseph Goebbels nannte der zuständige Sachbearbeiter Details ${ }^{236}$, und der Böhlau-Verlag erhielt kurze Zeit später eine Benachrichtigung in der Sache ${ }^{237}$. In seinem - 1985 verkürzt wiedergegebenen ${ }^{238}$ - Vorwort zur zweiten Auflage von „Kärntens Freiheitskampf" deutete Wutte die gesamte Breite der Unterstützung, die sein Buchprojekt

232 Wutte an Rainer, Klagenfurt, 25.01.1943, KLA, NLW, Schachtel 56, 1585.

233 Anm. Burz: Für Übersetzungsarbeiten konnte Wutte auf sprachkompetentes Personal zurückgreifen.

234 Wutte, Bericht (wie Anm. 184): Das Buch sei bereits zu einem Drittel gesetzt. Leider ist wider alles Erwarten vor wenigen Tagen das Gesuch um Papierbewilligung abschlägig beschieden worden. Im selben Bericht drückte Wutte den Wunsch aus, daß die Originale samt allen übrigen, nicht übersetzten Akten hier bleiben. Bei den angesprochenen Akten handelt es sich um 1.) Akten der Landesregierung in Laibach: a) Kommission für die Friedenskonferenz (5 Fasz.); b) Abteilung für das besetzte Gebiet (18 Fasz. und 7 Protokolle). 2.) Die Akten der jugoslawischen Friedensdelegation in Paris (81 Fasz.), zwar schön verpackt, aber in gänzlicher Unordnung. Die Kärntner Akten konnten aus der Masse herausgesucht und gesondert werden, ohne befürchten zu müssen, daß irgend eine Ordnung gestört wird. 3.) Akten der jugoslawischen Sektion der Abstimmungskommission (22 Fasz. und 3 Protokollhefte).

235 Eberhard Kranzmayer [Institut für Kärntner Landesforschung, Klagenfurt] an [Heinrich] Harmjanz (REM), Klagenfurt, 27.01.1943, BAB, R 4901, 13425. An dieser Stelle bedanke ich mich bei Archivoberrätin Frau Undine Völschow, die mich bei meinen Recherchen überaus kompetent und jede Norm weit übersteigend unterstützt hat.

236 Büro Harmjanz (REM) an Goebbels, Berlin, 17.02.1943. Ebd.: Ungefähr 150 Druckseiten sind bereits gesetzt. Trotz zweimaliger Empfehlung seitens des Reichsstatthalters in Kärnten ist von der Wirtschaftsstelle des Deutschen Buchhandels das Papier für dieses grundlegende und gerade jetzt für den Volkstumskampf hochaktuelle Buch bis heute nicht bewilligt worden.

237 REM an den Böhlau-Verlag Hermann in Weimar, Berlin, 26.02.1943. Ebd.: Das o.a. Manuskript wird in der Anlage zurückgesandt. Im Einvernehmen mit dem Auswärtigen Amt wird mitgeteilt, dass gegen die Veröffentlichung keine Bedenken bestehen, sofern folgende textliche Abänderungen vorgenommen werden: 1 . Unter $B$ VIII, Seite 3, Mitte, ist in dem Satz,Diese Grenze weist die von Slowenen bewohnten Teile von Görz, Krain, Triest und Istrien Italien zu und stand daher im Widerspruch zu Wilsons Selbstbestimmungsrecht der Völker' der letzte Teil ,... und stand daher ... der Völker'zu streichen. 2. Unter C, Seite 35, Mitte, ist die Stelle, die zum Geiste des Friedensvertrages in krassem Widerspruch standen und beseitigt werden mussten'zu streichen, da sie den Eindruck einer positiven Beurteilung des Geistes des Friedensvertrages macht.

238 Siehe Anm. 132. 
erfahren hatte, nur an ${ }^{239}$. Das genaue Veröffentlichungsdatum der Neuauflage von 1943 konnte bis dato nicht festgestellt werden. Das offizielle kulturpolitische Kärnten jedenfalls wusste Wuttes Verdienste um die Landeshistoriografie - vor der Veröffentlichung seines Hauptwerkes - im öffentlichen Raum zu würdigen. Das hat den Weg zur geplanten Publikation von „Kärntens Freiheitskampf“ wohl nicht verengt. Am 5. Juni I 943 erhielt Wutte in der Aula des Reichsgaumuseums den von der Karl-Franzens-Universität Graz verliehenen Mozart-Preis der Johann Wolfgang Goethe Stiftung und gleichzeitig ein Ehrendoktorat. Letzteres dürfte unter hohem zeitlichen Druck organisiert worden sein, denn erst am I. Juni I 943 wurde die Ernennung von staatlicher Seite per Telegramm genehmigt ${ }^{240}$.

Inwieweit weitere Textpassagen in „Kärntens Freiheitskampf“ vor dem endgültigen Publikationstermin I943/I944 zensuriert worden sind oder ob Wutte zum Abfassen einschlägiger zeitbedingter Phrasen genötigt worden ist, respektive diese aus freien Stücken formuliert hat, wäre noch zu klären. Auf dem Weg der außergewöhnlichen Unterstützung bei der Verwendung von ausländischen Archivmaterialien ist dem historisch-politisch gebildeten Gelehrten vermutlich eine Büchse der Pandora mitgegeben worden, die das nationalsozialistische Regime spätestens I 944 öffnete. In der Ausgabe der „Kärntner Zeitung“ vom ıo. Oktober 1944 prangt am Titelblatt die Überschrift „Vermächtnis des Kärntner Freiheitskampfes“241, am I I. Oktober, ebenfalls auf der Titelseite: „Der Gauleiter: ,Ich rufe den Geist der Kärntner Abwehrkämpfer“" usw.

Moro besprach an diesen beiden Tagen in zwei aufeinander folgenden Artikeln Wuttes Monografie. Der Rezensent erinnerte an Besonderheiten des Deutschtums in Kärnten ${ }^{242}$,

239 Wutte, Freiheitskampf (1943) (wie Anm. 1) XII : „Zum Schlusse danke ich herzlichst allen jenen Stellen und Persönlichkeiten, die mich in meiner Arbeit unterstützt und die Herausgabe des Buches ermöglicht haben, vor allem dem Herrn Gauleiter und Reichsstatthalter Dr. F. Rainer in Klagenfurt, der Archivkommission des Auswärtigen Amtes und Herrn Generaldirektor der Staatsarchive und Kommissar für den Archivschutz Dr. Zipfel in Berlin, die mir die Belgrader Akten zugänglich gemacht haben, ferner den Übersetzern zahlreicher diplomatischer Akten und Denkschriften [...].“

240 Reichsminister Bernhard Rust an Karl Pollheim, Rektor der Universität Graz, Berlin, 01.06.1943, UAG, ED 2. 41 (Martin Wutte): Indem ich mein Telegramm vom heutigen Tage bestätige, erkläre ich mich mit der von der Rechts- und Staatswissenschaftlichen Fakultät der Universität Graz in Aussicht genommenen Ehrenpromotion des Landesarchivars von Kärnten Hofrat Dr. Martin Wutte einverstanden. Hervorhebungen nach Vorlage. Am Deckblatt dieses Konvoluts ist handschriftlich angemerkt hat alles Kärnten gemacht. Im Kontext des Ehrendoktorrats, das eine „Rechts- und Staatswissenschaftliche Fakultät“ verliehen hat, ist das doppelt von Bedeutung. Wutte wurde im selben Jahr auch „Ehrenmitglied der Universität Innsbruck“. Angaben nach Wut t E, Gedächtnisschrift (wie Anm. 32) 66. Zur „doppelte[n] Ehrung“ im Juni 1943 siehe: Mozartpreis an Dr. Martin Wutte überreicht. Dr. Wutte - Ehrendoktor der juridischen Fakultät der Universität Graz - Eine Feierstunde im Gaumuseum in Anwesenheit des Gauleiters [ohne Verfasserangabe], in: Kärntner Zeitung, 07.06.1943, Nr. 1565.

241 Für den Artikel zeichnet Reichshauptstellenleiter Albert Merklein verantwortlich.

242 Gotbert Moro, Martin Wutte: „Kärntens Freiheitskampf“. Eine Würdigung der umfassenden Neuauflage 
zudem verknüpfte er Vergangenes mit Gegenwärtigem ${ }^{243}$. Seine Ausführungen sind im Lichte der Wirkungsgeschichte, die per se eine „reale“ Dimension schafft, zu interpretieren. Und die Wirkungsgeschichte ist bekanntlich seit jeher ein gewichtiger Sauerteig bei Mythenbildungen und hat im Kalkül, nicht nur von Politikern, keine geringe Funktion. Es bleibt eine offene Frage, ob sich Wuttes Fernsicht in den Süden von I $943^{244}$ nach dem Mai I945, nach der Kenntnisnahme der historisch-politischen Verlassenschaft des NSRegimes, nicht neuerlich revidiert hätte. I943 blickte er hoffnungsfroh in die Zukunft: „Die neuen Bahnen legten den Verkehr über die Kärntner Gebirgspässe lahm. Erst das Auto eröffnet dem Paßverkehr eine neue Zukunft. Die moderne Technik wird endlich auch den - sechsten! - Plan des Loibltunnels, der bereits weit vorgetrieben ist, verwirklichen, nicht nur, um die kürzeste Verbindung zwischen Klagenfurt mit Krain herzustellen, sondern auch, um den Handel mit den nördlichen Adriahäfen zu erleichtern. Auch dazu gab ein politisches Ereignis den Anlaß: die Angliederung Oberkrains an Kärnten. Für die Zukunft aber eröffnet der neue Tunnel den kürzesten Weg Kärntens zur Adria und die besten Aussichten auf eine neue Blütezeit des Handels und Verkehrs zwischen Kärnten und dem Meere." ${ }^{245}$

Weniger offen scheint die Frage, ob Wuttes Schriften zur „nationalen Frage“ einen fruchtbaren Boden abgegeben haben, auf dem das NS-System problemlos seine Ideologie ausbauen konnte. Das Wutte anzulasten, wäre unhistorisch, wie auch die Vorstellung, dass jenes nationalpolitische Gedankengut, das der Nationalsozialismus in radikalster Form aufbereitet hatte und umzusetzen wusste, binnen weniger Jahre entstanden wäre. Das Testament Wuttes dokumentiert jedenfalls einen nachdenklichen, leiderfüllten Gelehrten: Und nun bin ich bereit. Schwer wird mir das Scheiden von der Heimat und den Meinen,

des großen Werkes, in: Kärntner Zeitung, 09.10.1944, Nr. 279 3: „Wie ein Dank des Gefeierten für alle verdienten Würdigungen mutet es an, daß er [= Wutte, Anm. Burz] sein 1922 erschienenes Werk ,Kärntens Freiheitskampf nun in zweiter ,umgearbeiteter und vermehrter 'Auflage herausgab. [...] Eben jene Deutschen haben, wie Wutte hervorhebt - auch dank der klugen Politik ihrer Führer - als Wächter an Deutschlands südlichster Grenze ihr Volkstum in diesem Grenzstreifen des deutschen Volks- Sprach- und Kulturbodens und die Wahrung der Einheit schon damals gesichert und, so die Voraussetzungen für die großen Ereignisse der Jahre 1918 bis 1920 und 1938‘ geschaffen.“Anm. Burz: In diesem Zusammenhang ist zu erwähnen, dass die Zweitauflage von Kärntens Freiheitskampf in der Carinthia I nie einer Buchbesprechung unterzogen wurde. Zur Erstauflage vgl. die Rezension von August Ja кsсн, Dr. Martin Wutte, Kärntens Freiheitskampf, in: Carinthia I, 113 (1923) 72-75.

243 Gotbert Moro, Martin Wutte: „Kärntens Freiheitskampf“, in: Kärntner Zeitung, 10.10.1944, Nr. 2802 : „Mehr denn je wird jeden Deutschen in der Gegenwart dieses Buch wie eine Lehre berühren. Denn Kärnten hat zu jener Zeit, wie unsere Nation in der Gegenwart, einen Kampf um Sein oder Nichtsein geführt und es hat ihn, da es ,seine Rettung in eigener Tat suchte', mit Erfolg bestanden.“

244 Vgl. die Perspektiven in den Jahren 1906 und 1910, Anm. 112 und 113, in der vorliegenden Studie.

245 Martin Wutte, Kärntens Wege zum Meer in alter und neuer Zeit, in: Carinthia I, 133 (1943) 97-105, hier 105. 
leicht der Abschied von dieser Welt voll Gewalt und Ungerechtigkeit. Der Tod wird mir Erlöser sein von innerem Zwiespalt, der mich oft quält, und schwerer Sorge um die Zukunft. Gott schütze die Heimat, segne die Meinen und führe die Kinder in eine glücklichere Zukunft. ${ }^{246}$

Martin Wutte starb am 30. Januar 1948 in Kärnten. Auf seinem Grabstein steht von ihm testamentarisch bestimmt - das mehrfach deutbare Wort „Daheim“247. Es ist eine Heimat, in der Wutte in letzter Konsequenz immer einem Deutschtum den Vorzug gab, einem Deutschtum, das seine dominante gesellschaftliche Stellung in Kärnten seit jeher zu verteidigen wusste. Darüber soll auch der Hinweis Wuttes auf den hohen Anteil jener slowenischsprachigen Landsleute, die letztlich den für Kärnten und Österreich positiven Ausgang der Volksabstimmung vom ı. Oktober 1920 herbeigeführt haben, nicht hinwegtäuschen ${ }^{248}$. Der Leit- und Schlusssatz in Wuttes „Lebenslauf“ muss vor dem Hintergrund, dass der Landeshistoriker Bewohner einer Region am Schnittpunkt dreier Kulturen war, nicht weiter kommentiert werden. „Mein Wahlspruch war Richard Wagners Wort: Deutsch sein, heißt eine Sache um ihrer selbst willen tun. “249

246 Handschriftlich verfasstes Testament (Kopie), Klagenfurt, 15.04.1947, KLA, NL Wutte, Schachtel 1,7.

247 Das Grab Wuttes befindet sich am Friedhof seines Heimat- und Geburtsortes Obermühlbach, Gemeinde Frauenstein.

248 „Von den rund 22000 für Österreich abgegebenen Stimmen stammten etwa 12000 von Stimmberechtigten mit deutscher Umgangssprache und 10.000 von Stimmberechtigten mit slowenischer Umgangssprache." Wutte, Freiheitskampf (1943) (wie Anm. 1) 398.

249 Wutte, Lebenslauf 1988 (wie Anm. 38) 17. 



\title{
Heinrich (Ritter von) Srbik (I878-I95I)
}

\author{
„MEINE LIEBE GEHÖRT BIS ZU MEINEM TOD MEINER FAMILIE, \\ DEM DEUTSCHEN VOLK, MEINER ÖSTERREICHISCHEN HEIMAT UND \\ MEINEN SCHÜLERN"1
}

I.

Heinrich (Ritter von) Srbik ${ }^{2}$ wird in der Literatur häufig als der „größte“, „bedeutendste“ oder „prominenteste“ österreichische Historiker des 20. Jahrhunderts bezeichnet $^{3}$. Diese Superlative verdankt er gewiss den beiden mehrbändigen Werken „Metternich“4 - das erste großangelegte mit Empathie, ja Sympathie verfasste Porträt der bête noire der vorausgegangenen bürgerlichen Geschichtsschreibung, das seinem Verfasser schon den Status eines „Mandarins“ der deutschsprachigen Historikerzunft nach Art von Friedrich Meinecke eintrug - und

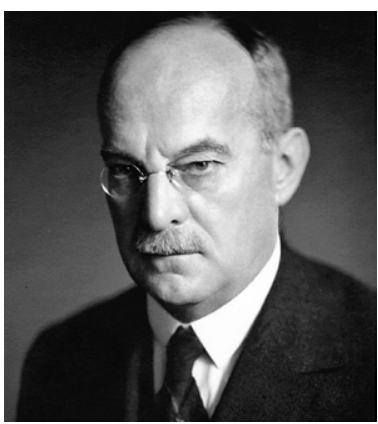

Abb. I8: Heinrich von Srbik

1 BAK, N 1323/21, fol. 55, Johanna von Srbik, Parte für ihren Gatten Heinrich, Zitat aus seinem Letzten Willen. - Für die Durchsicht des Manuskripts bin ich besonders Martin Peters zu Dank verpflichtet. Für die vorbildliche Betreuung im Archiv der ÖAW danke ich Stefan Sienell.

$2 \mathrm{Zu}$ ihm vgl. die unten in der Bibliografie (= Bibl.) in Auswahl angegebenen Werke. Eine Auswertung der Lebenserinnerungen Srbiks (niedergeschrieben in Ehrwald 1945-1946), die von Fritz FelLNer und Doris Alice Cor RAdin i ediert als Manuskript im Archiv der ÖAW aufbewahrt werden, war mir aus urheberrechtlichen Gründen nicht möglich.

3 Vgl. etwa Derndarsky, Historie (Bibl.) 153 Anm. 1 mit Literatur; auch ders., Österreich (Bibl.) iv.

4 Heinrich von SR вiк, Metternich. Der Staatsmann und der Mensch 1-2 (München 1925). Bd. 3 gab Taras Borodajkewycz aus dem Nachlass heraus: Quellenveröffentlichungen und Literatur. Eine Auswahlübersicht (München 1954); vgl. u.a. Derndarsky, Österreich (Bibl.) 89-92; Fritz Fellner, Geschichte als Wissenschaft. Der Beitrag Österreichs zu Theorie, Methodik und Themen der Geschichte der Neuzeit, in: Ders., Geschichtsschreibung (Bibl.) 36-91, hier 56; Ders., Srbik (2002) (Bibl.) 335f.; Moos, Bildungsbürgertum (Bibl.) 19-86; Pitcher, Srbik (Bibl.) 89-147; Hans Schleier, Die bürgerliche deutsche Geschichtsschreibung der Weimarer Republik. I. Srömungen - Konzeptionen - Institutionen, II. Die linksliberalen Historiker (Akademie der Wissenschaften der DDR, Schriften des Zentralinstituts für Geschichte 40, Berlin 1975) 188-190, 378; Sweet, Writing (Bibl.) 43-45; Charles Zorgbibe, Metternich. Le séducteur diplomate (Paris 2009) 503f. 
„Deutsche Einheit“5, wobei namentlich der erste Band dieses insgesamt vierbändigen Opus freilich über weite Strecken eher ein ideologisches als ein wissenschaftliches Werk darstellt, wie auch schon gleich nach Erscheinen festgestellt worden ist ${ }^{6}$. In beiden Arbeiten versuchte Srbik vordem als inkompatibel angesehene Einstellungen und Haltungen (Metternichs Antinationalismus und den Deutschnationalismus einerseits bzw. die großdeutsche und die kleindeutsche Strömung andererseits) miteinander zu versöhnen. Persönlich war der „Mandarin“ Srbik weit weniger versöhnlich gestimmt; auf veröffentlichte Kritik reagierte er typischerweise mit einer Replik, in der er seinen eigenen Standpunkt in beleidigtem Tonfall wiederholte ${ }^{7}$, und der Insubordination Viktor Bibls

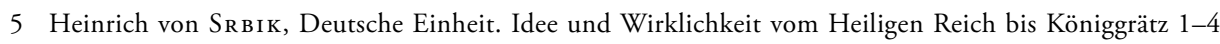
(München 1935-1942, 1-2 München ${ }^{2} 1936$, 1-2 München ${ }^{3} 1940$ ); vgl. dazu De Rndarsky, Österreich (Bibl.) bes. zweiter Teil; DERs., „Idee“ (Bibl.) 192-204; Moos, Bildungsbürgertum (Bibl.) 87-124; Pitcher, Srbik (Bibl.) 148-207; Karen Schönwälder, Historiker und Politik. Geschichtswissenschaft im Nationalsozialismus (Historische Studien 9, Frankfurt/M./New York 1992) 91-98; Dies., Srbik (Bibl.) 532-539; SWEET, Writing (Bibl.) 37, 48-50, 55 f.

6 Vgl. etwa VAlsecchi, Srbik (Bibl.) bes. 68f. („È una concezione politica, non soltanto scientifica. Il sentimento politico condiziona l'interpretazione storica, e la piega alle sue esigenze“, ,atto di fede“, „questo impulso sentimentale“, „un'opera [...], che [...] ha tutto l'ampio volo di un'epopea“) und Golo MANN, Deutscher Historismus, in der Exilantenzeitschrift „Mass und Wert“ 1, Heft 3 (Januar/Februar 1938) 479-498, hier 486f.; vgl. Tilmann Lah me, Golo Mann. Biographie (Frankfurt/M. 2009) 131.

7 Am bekanntesten sind dabei wohl seine Kontroversen mit Hedwig Hintze (über die Wertung der Großen Französischen Revolution, vgl. etwa Gerhard A. Rit te R, Friedrich Meinecke und seine emigrierten Schüler, in: Friedrich Meinecke, Akademischer Lehrer und emigrierte Schüler. Briefe und Aufzeichnungen 1910-1977, eingel. und bearb. v. Gerhard A. Rit ter [Biographische Quellen zur Zeitgeschichte 23, München 2006] 13-111, hier 86f.), dem selbst großdeutsch empfindenden Grazer Historiker Raimund Friedrich Kaindl (vgl. etwa Herbert DACHs, Österreichische Geschichtswissenschaft und Anschluß 1918-1930 [Veröff. des Historischen Instituts der Universität Salzburg, Wien/Salzburg 1974] 125, 191-193: „,ungemein scharfer Konflikt mit R. Fr. Kaindl“; Fritz Fellner, Die Historiographie zur österreichisch-deutschen Problematik als Spiegel der nationalpolitischen Diskussion, in: DERs., Geschichtsschreibung [Bibl.] 145-172, hier 155, 158f.; Martin-Fritz KNOR, Raimund Friedrich Kaindl und die Wiener Schule [Dipl. GüttenbachPinkovac/Wien ${ }^{2}$ 1999] 94-96, 104-108, 115-126, 133-138; zu Kaindl allgemein siehe zuletzt Alexander Pinwinkler, Raimund Friedrich Kaindl [1866-1930]. Geschichte und Volkskunde im Spannungsfeld zwischen Wissenschaft und Politik, in: Österreichische Historiker 1900-1945. Lebensläufe und Karrieren in Österreich, Deutschland und der Tschechoslowakei in wissenschaftsgeschichtlichen Porträts, hg. v. Karel HrUZA [Wien/Köln/Weimar 2008] 125-154) sowie den beiden „kleindeutschen“ Historikern Erich Brandenburg und Fritz Hartung (vgl. etwa Pitcher, Srbik [Bibl.] 181-192). Zuletzt hielt es der Parteigenosse

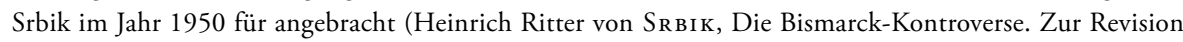
des deutschen Geschichtsbildes, in: Wort und Wahrheit 5 [1950] 918-931, hier 925-929), dem Mitwisser des 20. Juli 1944 und KZ-Häftling Ritter „weitgehende Blickbindung“ sowie übergroßen „Positivismus und Realismus" vorzuwerfen; dass des durchaus konservativen Protestanten Ritters Replik (Gerhard Ritte R, Zur "großdeutschen" Frage, in: Wort und Wahrheit 6 [1951] 142-144) überhaupt abgedruckt wurde, haben die beiden Herausgeber der erzkatholischen „Monatsschrift für Religion und Kultur“, ein katholischer Priester sowie ein vormaliger Nazijournalist und nunmehriger CIA-Agent (der in seiner Dissertation Hitlers Ostpolitik 
am eigenen Wiener Institut begegnete er mit unversöhnlichem Hass noch über das Grab hinaus $^{8}$. Srbik wurden in seiner Wiener Zeit zunächst viele öffentliche Auszeichnungen zuteil; umso bitterer muss er seine letzten, in seinem Tusculum im tirolerischen Ehrwald zugebrachten Jahre fern der Wiener Universität und Akademie empfunden haben. Zwar war Srbik der NSDAP erst nach dem „Anschluss“ beigetreten, doch zumindest die von ihm während der NS-Zeit bekleideten hohen Funktionen eines Präsidenten der Akademie der Wissenschaften in Wien und eines Reichsratsmitglieds hatten 1945 eine Entlassung Srbiks als Universitätslehrer zur Folge gehabt ${ }^{9}$, und angesichts einer solchen offiziellen Vergangenheit hielt es Srbik offenbar auch nicht für geraten, sich überhaupt im Machtbereich der sowjetischen Besatzungstruppen aufzuhalten. Diese letzten Jahre im Tiroler „Exil“ werden in biografischen Skizzen nicht selten als „Tragödie“ bezeichnet; und die meisten Biografen beeilen sich auch zu versichern, Srbik sei kein Nationalsozialist gewesen, sondern vielmehr ein persönlich völlig integrer ${ }^{10}$ (National-)Konservativer, der sich zunächst aus persönlicher Naivität und Gutmütigkeit Illusionen über die Nationalsozialisten hingegeben habe, zu diesen dann aber bald nach dem „Anschluss“ tief enttäuscht auf Distanz gegangen sei. Diese vielen eher apologetisch gestimmten Autoren scheinen aber regelmäßig weder das tatsächliche Ausmaß von Srbiks NS-Engagement noch auch die eigentliche Natur seiner angeblich konservativen Weltanschauung näher untersuchen zu wollen; diese Fragestellungen werden daher in den Mittelpunkt der vorliegenden Arbeit gerückt werden ${ }^{11}$.

seinerseits gefeiert hatte), dabei als einen kaum verdienten Akt der Gnade Srbik zuliebe dargestellt; vgl. auch Pitcher, 252-262.

8 Vgl. v.a. SR B I K, Metternich 3 (wie Anm. 4) 11-20. Zur Kontroverse Srbik vs. Bibl im allgemeinen siehe zuletzt Karsten Jeditsschкa, Die „Parteiamtliche Prüfungskommission zum Schutze des nationalsozialistischen Schrifttums“. Zensurfelder und Arbeitsweise am Beispiel des Münchner Lektors Ulrich Crämer, in: Archiv für Geschichte des Buchwesens 62 (2008) 213-226, hier 221-223 mit Literatur.

9 Tatsächlich scheint Srbik aber doch wegen einer - irrtümlichen - Einschätzung als „Illegaler“ entlassen worden zu sein, vgl. Derndarsky, Österreich (Bibl.) 186-188, 200, 207 Anm. 47; ders., Historie (Bibl.) 163, 166.

10 Vgl. etwa auch Jan Eckel, Hans Rothfels. Eine intellektuelle Biographie im 20. Jahrhundert (Moderne Zeit. Neue Forschungen zur Gesellschafts- und Kulturgeschichte des 19. und 20. Jahrhunderts 10, Göttingen 2005) 347 Anm. 64.

11 Dass das NSDAP-Mitglied Srbik kein Nationalsozialist gewesen sei, haben nicht nur (unisono) andere ehemalige Parteigenossen sowie weitere ehemalige Schüler Srbiks, sondern auch solcher Art von Befangenheit unverdächtige Autoren wie De R NDARS x und Moos behauptet. Scharfe Kritik an Srbik ist nach dessen Tod bislang allein von eher weit links stehenden Autorinnen und Autoren geäußert worden, wobei in diesen Fällen natürlich die Vermutung naheliegt, dass die eigene Positionierung im politischen Spektrum eine Unterscheidung zwischen rechts („konservativ“) und rechtsextrem („faschistisch“, „,nazistisch“) erschwert. Die Verfasserin dieses Beitrags ist demgegenüber der Auffassung, dass so sorgfältig wie nur möglich differenziert werden sollte. 
II.

Heinrich (von) Srbik wurde am ıo. November I 878 in Wien als Sohn des Beamten im Finanzministerium, Kunstexperten und Kupferstichsammlers Dr. Franz Joseph von Srbik (I 84I-I9I0) geboren. Seine Mutter Walpurga (I 847-I 898) war die jüngste Tochter ${ }^{12}$ des im Zuge der Thun-Hohenstein'schen Universitätsreform ${ }^{13}$ mit Ostern I 850 nach Wien berufenen, früh verstorbenen westfälischen katholischen Historikers Wilhelm Heinrich Grauert (I 804-1852) ${ }^{14}$. Er besaß einen Zwillingsbruder, den Glaziologen Robert (gest. I 948) ${ }^{15}$ sowie einen weiteren, älteren Bruder (Franz Joseph, I 877-I958) und eine ältere Schwester (Ludmilla, I 875-1956). Der Großvater Franz Seraphicus (I 807-1 897) war am I 2. August I 868, also nur zehn Jahre vor Heinrichs Geburt, in den Ritterstand erhoben worden. Der Historiker hielt auch noch nach der Aufhebung des Adels I $919^{16}$ an diesem

12 Heinrich von Sr вік, Ein Schüler Niebuhrs: Wilhelm Heinrich Grauert (SB Wien 176, Wien 1914) 3-63, hier 4; Fellner, Srbik (2002) (Bibl.) 331.

13 Rainer Leitner, Das Reformwerk von Exner, Bonitz und Thun: Das Österreichische Gymnasium in der Zweiten Hälfte des 19. Jahrhunderts. Kaderschmiede der Wiener Moderne, in: Zwischen Orientierung und Krise. Zum Umgang mit Wissen in der Moderne, hg. v. Sonja Rinofne R-Kreidl (Studien zur Moderne 2, Wien/Köln/Weimar 1998) 17-69; Werner OgR Is, Die Universitätsreform des Ministers Leo Graf Thun-Hohenstein. Festvortrag anläßlich des Rektorstages im Großen Festsaal der Universität Wien am 12. März 1999 (Wiener Universitätsreden N. F. 8, Wien 1999); Martina Pesditsche , Zur Geschichte des Instituts für Alte Geschichte, Altertumskunde und Epigraphik der Universität Wien (anläßlich seines 125jährigen Bestehens), in: Die Sprache 39,3 (Chronicalia Indoeuropaea: Sonderheft) (1997 [2002]) 2 Anm. 4 mit Literatur; Peter Woznia , Count Leo Thun: A Conservative Savior of Educational Reform in the Decade of Neoabsolutism, in: Austrian History Yearbook 26 (1995) 61-81.

14 Martina Pesditscheк, Die Professoren der Alten Geschichte an der Universität Wien (Diplomarbeit Wien 1996) 9-14; Dies., Geschichte (wie Anm. 13) 3 mit Anm. 6; vgl. aus Srbiks eigener Feder Sr в I , Schüler Niebuhrs (wie Anm. 12) 3-63; DERs., Geist und Geschichte vom deutschen Humanismus bis zur Gegenwart 1-2 (München/Salzburg 1950/51), hier 1, 219f.; vgl. 2, 93-95.

15 Wolfgang Neuner, Srbik Robert von, in: ÖBL 13 (Wien 2007) 59f. Auch dieser Zwillingsbruder hatte sich zunächst als Historiker betätigt (vgl. Robert Ritter von SR в I , Maximilian I. und Gregor Reisch, hg. v. Alphons Lнотsку [AÖG 122,2, Schriften des DDr. Franz Josef Mayer-Gunthof-Fonds 1, Graz/Wien/Köln 1961], Vorwort von Heinrich R. v. SR вік † und Alphons Lнотsку), und seine eigene „Empfindsamkeit“ und Streitsucht stand der seines Zwillingsbruders offenbar um nichts nach, vgl. etwa Ein General im Zwielicht. Die Erinnerungen Edmund Glaises von Horstenau 1: K. u. k. Generalstabsoffizier und Historiker, 2: Minister im Ständestaat und General im OKW, 3: Deutscher Bevollmächtigter General in Kroatien und Zeuge des Untergangs des „Tausendjährigen Reiches“, hg. v. Peter Brouce к (VKGÖ 67, 70 und 76, Wien/Köln/Graz 1980, 1983 und 1988), hier 1 45, 403, 547 („ein bescheidener Geist, allerdings sehr ehrgeizig und menschlich unangenehm“).

16 Reinhard Binder-Krieglstein, Österreichisches Adelsrecht 1868-1918/19. Von der Ausgestaltung des Adelsrechts der cisleithanischen Reichshälfte bis zum Adelsaufhebungsgesetz der Republik unter besonderer Berücksichtigung des adeligen Namensrechts (Rechtshistorische Reihe 216, Frankfurt/M. u.a. 2000) bes. 141-237, 267-270; Berthold Waldstein-Wartenberg, Das Adelsaufhebungsgesetz von 1919, in: FS Hanns Leo Mikoletzky (MÖSTA 25, Wien 1972) 306-314. 
Titel als Namensbestandteil fest ${ }^{17}$, und eine erwogene Namensänderung in Serbik stellte er wegen der Gefahr eines Verlusts dieses Prädikats zurück ${ }^{18}$.

Nach einem Besuch des Gymnasiums der Theresianischen Akademie als Externist in Wien ${ }^{19}$, wo er unter anderem auch Geschichtsunterricht des Ranke-Biografen und Spezialisten für die Ära Metternich Eugen Guglia (I857-I9I9) ${ }^{20}$ genoss $^{21}$, studierte Srbik ab dem Wintersemester I 897/98 Geschichte und Germanistik an der Universität Wien ${ }^{22}$.

„Die durch die Badeniwirren ausgelöste nationale Erregung unter den Deutschen der Monarchie erfaßte auch ihn ${ }^{23}$. Im Herbst I 898, zu Beginn seines dritten Semesters, trat er als Fuchs in den wehrhaften Verein Deutscher Studenten ,Gothia', eine Verbindung, die auf dem Boden unbedingter Satisfaktion stand, den Säbel als Waffe führte und Schläger und Bestimmungsmensur ablehnte. Er trat damit in einen Kreis strengster deutschnationaler Gesinnung. Das bestimmende Idol der ,Gothia' war Georg Ritter von Schönerer “24, dessen Lehre in einer Formulierung von Srbiks späterem Freund Wilhelm Schüssler besagte, dass „es fünf erklärte Feinde des deutschen Volkes gebe: das Haus Habsburg, das

17 Nach Derndarsky, Österreich (Bibl.) 2-4 zeigt dies, „wie konservativ und im Grunde auch antiegalitär Srbik eingestellt war"; tatsächlich beweist dieses Verhalten nicht mehr und nicht weniger, als dass Srbik an eigenen Privilegien festhalten wollte; zur Familie siehe auch Art. „\$ Srbik“ in: Wiener Genealogisches Taschenbuch [1] (1926) 362f.; Hans Heinrich Rr v. SR BIK, Srbik, in: Genealogisches Handbuch des Adels: Adelige Häuser B 9 (Limburg an der Lahn 1970) 356-358.

18 Srbik an Emil von Ottenthal am 25.02.1919, in: Srbik, Korrespondenz (Bibl.) Nr. 71; De Rndarsky, Österreich (Bibl.) 4-11; vgl. auch das Antwortschreiben Ottenthals vom 04.03.1919, in: Srbik 119f. Nr. 72, der unter der Bedingung der Beibehaltung des Adelsprädikats die Namensänderung ausdrücklich empfahl, und Srbik 139 Nr. 83, woraus hervorgeht, wie wichtig der Adelstitel für ihn war.

19 Derndarsky, Österreich (Bibl.) 11 Anm. 20, 17.

20 ÖBL 2 (1959) $105 f$.

21 Derndarsky, Österreich (Bibl.) 18f.; Fellner, Srbik (2002) (Bibl.) 331; Sweet, Writing (Bibl.) $38 f$.

22 Ernst Kirchshofer, Geschichte des philologisch-historischen Seminars an der Universität Wien 1849-1900 (unpubl. Diss. Wien 1948) 49-51 führt Srbik nur im WS 1898/99 und SS 1899 in seinem Mitgliederverzeichnis des Seminars; Mitgliederverzeichnis des Historischen Seminars der Universität Wien 1872-1928, hg. v. Oswald Reduich (Wien 1928) 13.

23 Der in Galizien geborene Ministerpräsident des österreichischen Teils der k. u. k. Monarchie Kasimir Felix Graf (Kazimierz Feliks Hrabia) Badeni erließ am 05.04.1897 eine Sprachenverordnung, die ab 1901 zu einer völligen Gleichstellung von Deutsch und Tschechisch in allen Teilen Böhmens und Mährens geführt hätte; dies resultierte in zahlreichen „deutschnational orientierten Demonstrationen“, an denen laut DER NDARSKY, Historie (Bibl.) 154 auch Srbik teilnahm. 1947 erklärte Srbik laut Andreas Posch diesem gegenüber allerdings, dass er die „Badeni-Tage“ nur „als Augenzeuge, nicht als Teilnehmer“ erlebt habe (Posch, Srbik [Bibl.] 189).

24 Borodajkewycz, Srbik (1978) (Bibl.) 5. Zu Schönerer vgl. zuletzt ausführlich Friedel Moll, Michael Wladika, Georg von Schönerer (1842-1921). Ein alldeutscher Politiker aus dem Waldviertel, in: Waldviertler Biographien 3, hg. v. Harald Hitz u.a. (Horn/Waidhofen an der Thaya 2010) 121-150; Andrew G. Whiteside, Georg Ritter von Schönerer. Alldeutschland und sein Prophet (Graz/Wien/Köln 1981); Michael Wladika, Hitlers Vätergeneration. Die Ursprünge des Nationalsozialismus in der k.u.k. Monarchie (Wien/Köln/Weimar 2005). 
deutschfeindlich sei, die katholische Kirche, deren Priester nur in den slawischen Gebieten für ihr Volkstum einträten, das Christentum, das die Kampfeslust lähme, natürlich die Juden, die in Wien massenhaft einströmten, und nicht zuletzt die Slawen, die als Todfeinde schlechthin vernichtet werden müßten" 25 . Die Nationalsozialisten betrachteten Schönerer später als Praecursor Ducis, sodass man die „Gothia“, die I 907 den Status einer Burschenschaft erhielt, berechtigterweise als eine protonazistische Gesinnungsgemeinschaft ansprechen kann ${ }^{26}$. Srbik „bekleidete bereits im Sommersemester I 900 das Amt des Sprechers. I 903 wurde er zum Alten Herren ernannt und nahm in den folgenden Jahren stets regen Anteil an den Geschäften des Bundes ${ }^{27}$. Es gab kaum eine größere Veranstaltung[,] bei der er fehlte. [...] als die Bundesbrüder sich nach dem Kriege wieder sammelten, schrieb er noch kurze Zeit vor seinem Ableben ,... und ich werde der Gothia in dem kargen Rest meines Lebens ein liebevolles und treues Andenken bewabren' " 28 Die grundsätzliche Akzeptanz der Schönerer'schen Prämissen musste bei Srbik nun freilich ein starkes Minderwertigkeitsgefühl auslösen, war sich Srbik doch des Umstandes bewusst, dass sein

25 Wilhelm Schüssler, Preußen und Österreich in der deutschen Geschichte (Historisch-politische Hefte der Ranke-Gesellschaft 12/13, Göttingen 1963) 54.

26 Vgl. etwa die Vorlesung des späteren Srbik-Freundes Wilhelm BAuer, Georg Ritter von Schönerer (Schriften zu den Klagenfurter Hochschulwochen 1941, hg. Das Deutsche Volksbildungswerk, NS-Gemeinschaft „Kraft durch Freude“, Gau Kärnten, Klagenfurt 1941), die mit folgendem Satz schließt : „Niemand wird ihm aber den Ruhm streitig machen können, wichtigster Wegbereiter geworden zu sein für den Größeren, der nach ihm kam. Und der kam ebenfalls aus der Ostmark“ (BAU ER 24). Srbik hat Schönerer später selbst einen Aufsatz in einer NS-Illustrierten gewidmet: Heinrich Ritter von SR в I к, Die äußere Politik Österreich-Ungarns zur Zeit Georg Ritter von Schönerers, in: Die Pause 7, Heft 7 (1942) 5-9, [29]. Dieser fiel nicht völlig unkritisch aus, aber da ein Praecursor Ducis gegenüber dem Dux selbst ohnedies gewisse Defizite aufzuweisen hat, muss diese Reserviertheit Srbiks gar nicht als Ausdruck einer Opposition gegenüber dem Regime gewertet werden. Im Zusammenhang mit diesem Aufsatz kam es bei Srbik wieder einmal „zu persönlichen Differenzen“, diesmal „mit einem Bundesbruder“ von der nunmehrigen „Kameradschaft“ Gothia, die ihn schlussendlich zum Austritt aus dieser bewogen, siehe Wra betz, Srbik (Bibl.) 29; vgl. auch Borodajkewycz, Srbik (1978) (Bibl.) 11; Srbik, Korrespondenz (Bibl.) Nr. 350 (14.11.1942).

27 1911/12 fungierte er als dessen Obmann, vgl. Horst Grimm, Leo Besser-Walzel, Die Corporationen. Handbuch zu Geschichte, Daten, Fakten, Personen (Frankfurt/M. 1986) 370; Derndarsky, Österreich (Bibl.) 25-27, 174f., 257; Harald Lönnecker, „Das Thema war und blieb ohne Parallel-Erscheinung in der deutschen Geschichtsforschung“. Die Burschenschaftliche Historische Kommission (BHK) und die Gesellschaft für burschenschaftliche Geschichtsforschung e. V. (GfbG) (1898/1909-2009). Eine Personen-, Institutions- und Wissenschaftsgeschichte (Darstellungen und Quellen zur Geschichte der deutschen Einheitsbewegung im neunzehnten und zwanzigsten Jahrhundert 18, Heidelberg 2009) 55; vgl. auch BORODAJKEWYCZ, Srbik (1978) (Bibl.) 5f.; PAsteiner, Geschichtsauffassung (Bibl.) 62f., 65, 71f., 65, 261f.

28 Wrabetz, Srbik (Bibl.) 29. 1947 äußerte Srbik sich gegenüber dem katholischen Priester und Theologen Andreas Posch angeblich allerdings ganz anders: „Die Schönerer-Richtung schien mir schon damals [d.h. 1897] grundverfehlt wie auch später stets. Es war engstirnige Bierbankpolitik der Rauschebärte“; PoscH, Srbik (Bibl.) 189. 
Großvater väterlicherseits zunächst ein „tschechischer Bauernbub“29 gewesen war. Srbik bog sich nun die eigene Familiengeschichte so zurecht, dass er diesen Großvater zum „Kulturdeutschen“30 avancieren ließ, der mit einer Deutschböhmin [Sophie, geb. Wagner] verheiratet war und seine Kinder deutsch erzog ${ }^{31}$. Andererseits suchte Srbik nun zeit seines Lebens jeden Anschein von (bei seinem Familiennamen ja naheliegender) Slawophilie auf das Peinlichste zu vermeiden - er vertrat in Hinkunft bis zu seinem Lebensende unbeirrbar die Auffassung, die Deutschen hätten die slawischen Völker von Mitteleuropa bzw. „Zwischeneuropa“ zu „führen“ oder zu „leiten“, gerade so, als ob diese Blinde, in anderer Weise Behinderte oder unmündige Kinder gewesen wären ${ }^{32}$.

Etliche Jahre später, I909, gründeten dann Herman „Haupt [...], die Historiker [...] Srbik (Burschenschaft Gothia Wien I 899) und Friedrich Meinecke (Burschenschaft Saravia

29 Borodajkewycz, Srbik (1978) (Bibl.) 4.

30 Ebd. Quod licuit auo, non licuit Hebraeo: Für geborene Juden schloss Srbik später eine Entwicklung zum „Kulturdeutschen“ ausdrücklich aus, siehe SR BIK, Einheit 3 (wie Anm. 5) 20 f.

31 Srbik an Emil von Ottenthal, siehe Srbik, Korrespondenz (Bibl.) Nr. 71 (25.02.1919).

32 Siehe ausführlich unten S. 287f. aus Anlass der Vorstellung seiner „gesamtdeutschen Geschichtsauffassung.“ Man vergleiche Srbiks Verhalten etwa mit jenem von Herbert (Edlem von) Stourzh (dem Vater des prominenten österreichischen Historikers Gerald Stourzh), der in ähnlicher Weise einen geadelten Beamten mit slawischem Namen zum Vater hatte, dabei gleichzeitig einem „deutschliberalen“ Elternhaus entstammte und nach 1918 als Anschlussbefürworter „,vorübergehend Mitglied der Großdeutschen Volkspartei“ war; Herbert Stourzh entwickelte sich in der Folge zu einem entschiedenen Gegner von „Rassismus, Faschismus und Nationalsozialismus“, wobei er in seinen einschlägigen Schriften mitunter freilich auch selbst recht naiv-wirklichkeitsfern argumentierte; interessanterweise war Herbert Stourzh 1917 seiner zukünftigen ersten Frau, einer Pastorentochter, zuliebe vom römisch-katholischen zum evangelisch-lutherischen Glauben übergetreten, an dem er dann auch nach seiner schon 1924 erfolgten Scheidung von seiner ersten Frau festhielt; vgl. dazu Gerald Stourzh, Herbert Stourzh als politischer Schriftsteller, in: Herbert Stourzh, Gegen den Strom. Ausgewählte Schriften gegen Rassismus, Faschismus und Nationalsozialismus 1924-1938, hg. v. Gerald Stourzh (Studien zu Politik und Verwaltung 66, Wien/Köln/Graz 2008) 11-39, bes. 11-14, 19. Alphons Lhotsky fühlte sich bei einer ähnlich gelagerten familiären Konstellation sogar ausdrücklich „als Mährer slawischen Stammes“, der dann natürlich zu Srbik sowie dessen Freunden Hirsch und Bauer „kritischer stand“, siehe Erich Zöllner, Zur Wissenschaftsauffassung Alphons Lhotskys, in: Beiträge zur neueren Geschichte Österreichs, hg. v. Heinrich Fichtenau, Erich Zöllner (Veröff. des IÖG 20, Wien/Köln/Graz 1974) 536 549, hier 539 bzw. 546. Gleichwohl hielt sich der menschlich vornehme Lhotsky unmittelbar nach Srbiks Tod an die Maxime De mortuis nil nisi bene, was Srbiks unkritischer Schüler Hamann dann sofort zu dessen Reinwaschung auszunützen trachtete, vgl. Ham an N, Kriegs- und Nachkriegserinnerungen (Bibl.) 378. Ein anderer einschlägiger Fall aus einer Generation vor Srbik war der Historiker Anton Gindely: „Zu den Neutralen, deren Inneres keiner Nation allein angehörte, zählt der Historiker Anton Gindely, der Sohn eines deutschen Vaters und einer tschechischen Mutter, geboren 1829, gestorben 1892 als Professor der deutschen Universität in Prag und böhmischer Landesarchivar"; SR в IK, Geist 2 (wie Anm. 14) 111. Werner KaEgI, Jacob Burckhardt. Eine Biographie 5: Das neuere Europa und das Erlebnis der Gegenwart (Basel/Stuttgart 1973) 177 Anm. 83, bemerkte zu dessen Behandlung durch Srbik: „Burckhardt hätte wohl mit etwas größerer Wärme von Gindely gesprochen, als es Srbik tat.“ 
Berlin I 882), der Freiburger Pathologe Ludwig Aschoff (Burschenschaft Alemannia Bonn I 885 ) sowie einige andere, historisch interessierte Burschenschafter nach ersten Gesprächen im Sommer 1908 [...] in Frankfurt a. M. die ,Burschenschaftliche Historische Kommission`, deren Gründung schon Heinrich von Treitschke - Alter Herr der Bonner Burschenschaft Frankonia, der auch Friedrich Nietzsche angehörte - in den achtziger Jahren des I9. Jahrhunderts gefordert hatte“33. Wohl schon von diesem Anlass her datierte Srbiks lebenslange freundschaftliche Verbundenheit mit Meinecke, die allerdings unter anderem darunter litt, dass sich Srbik diesem seinem Freund stets in irgendeiner Hinsicht überlegen fühlen musste ${ }^{34}$.

Was nun Srbiks Studium selbst anlangt, so absolvierte er - nach einem üblichen einjährigen Vorbereitungskurs - von I 899 bis I90 I gemeinsam mit seinen späteren Freunden Hans Hirsch ${ }^{35}$ und Wilhelm Bauer ${ }^{36}$ den 23. Ausbildungskurs am IÖG ${ }^{37}$, und schloss diesen aufgrund der Institutsarbeit „Die Bestrebungen der österreichischen Herzöge nach Ausbildung einer Landeskirche“38 und abschließender Prüfung I90 I „mit Auszeichnung“ $\mathrm{ab}^{39}$. Die akademischen Lehrer in diesem Kurs waren Engelbert Mühlbacher ${ }^{40}$, Oswald Redlich ${ }^{41}$ und Alfons Dopsch ${ }^{42}$. Von ihnen allen erhielt Srbik eine hervorragende Ausbildung in den exakten historischen Hilfswissenschaften; hingegen war die Wahl von

33 Harald Lönnecker, Besondere Archive, besondere Benutzer, besonderes Schrifttum. Archive akademischer Verbände, in: Der Archivar 55,4 (2002) 311-317, hier 313; http://www.studentenhistoriker.de/studentengeschichte.htm; http://www.burschenschaft.de/geschichte/gfbg.html; DERs., Thema (wie Anm. 27) 116, 130 (Srbik war bei der Gründung nicht persönlich anwesend, sondern sicherte nur brieflich seinen Beitritt zu), 343f.; DERS., Symposium. 100 Jahre Gesellschaft für burschenschaftliche Geschichtsforschung, http :// hsozkult.geschichte.hu-berlin.de/termine/id=12236.

34 Siehe weiter unten Anm. 185, S. 305 und $321 \mathrm{f}$.

$35 \mathrm{Zu}$ ihm siehe Andreas ZajIC, Hans Hirsch (1878-1940). Historiker und Wissenschaftsorganisator zwischen Urkunden- und Volkstumsforschung, in: Österreichische Historiker (wie Anm. 7) 307-417; Manfred SToY, Das Österreichische Institut für Geschichtsforschung 1929-1945 (MIÖG Erg.-Bd. 50, Wien 2007) passim.

36 Zu ihm siehe Heiss, „Wiener Schule der Geschichtswissenschaft“ (Bibl.) bes. 403-406; Martin Scheutz, Wilhelm Bauer (1877-1953). Ein Wiener Neuzeithistoriker mit vielen Gesichtern. „Deutschland ist kein ganzes Deutschland, wenn es nicht die Donau, wenn es Wien nicht besitzt“, in: Österreichische Historiker (wie Anm. 7) 247-281; Stoy, Institut (wie Anm. 35) passim.

37 Derndarsky, Österreich (Bibl.) 17-20; Alphons Lнотsкy, Geschichte des Instituts für österreichische Geschichtsforschung 1854-1954 (MIÖG Erg.-Bd. 17, Graz/Köln 1954) 279-283.

38 Veröffentlicht unter dem Titel: Die Beziehungen von Staat und Kirche in Österreich während des Mittelalters (Forschungen zur inneren Geschichte Österreichs 1,1, Innsbruck 1904, ND Leipzig 1938); Lнотsку, Geschichte des Instituts (wie Anm. 37) 281; vgl. Derndarsky, Österreich (Bibl.) 23f.

39 Derndarsky, Österreich (Bibl.) 21f.

40 Siehe zuletzt WeBER, Lexikon (Bibl.) 398f.

$41 \mathrm{Zu}$ ihm siehe zuletzt die Beiträge in MIÖG 117 (2009) 399-428.

42 Moos, Bildungsbürgertum (Bibl.) 13; vgl. Derndarsky, Österreich (Bibl.) 22f. Zu Dopsch siehe zuletzt Thomas Buchner, Alfons Dopsch (1868-1953). Die „Mannigfaltigkeit der Verhältnisse“, in: Österreichische Historiker (wie Anm. 7) 155-190. 

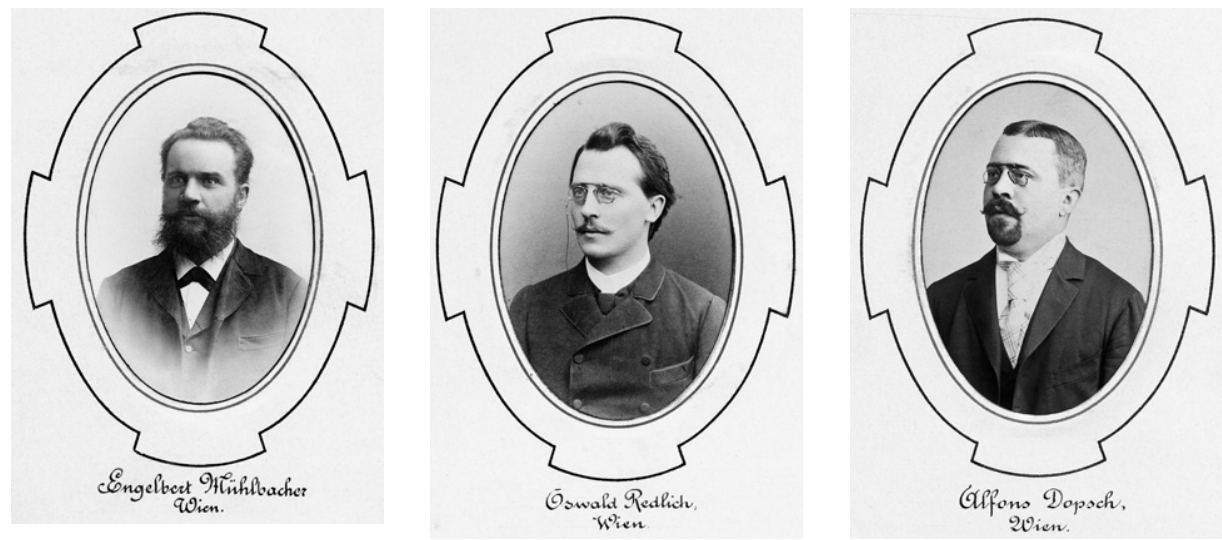

Abb. I9, 20 und 2I: Engelbert Mühlbacher, Oswald Redlich und Alfons Dopsch im Jahr I893

historischen Themen mit einem Gegenwartsbezug, die auch ein breiteres Publikum anzusprechen vermochten, an diesem Institut nicht Teil des Programms.

Srbik hat sich später bitter darüber beklagt, dass ihm ein entsprechendes geistes- und kulturwissenschaftliches Rüstzeug an der Universität Wien nicht mitgegeben worden sei $^{43}$. I90 I/o2 leistete Srbik dann ein Einjährigen-Freiwilligen-Jahr beim Heer, und zwar bei der Artillerie in Salzburg und Tirol ${ }^{44}$, und promovierte am 28. November I 902 aufgrund seiner von Redlich und Dopsch begutachteten Dissertation über „Burggraf Friedrich III. von Nürnberg “45 an der Universität Wien zum Dr. Phil. ${ }^{46}$

III.

Seit dem I. Oktober 1902 war Srbik als Mitarbeiter der „Kommission für Neuere Geschichte Österreichs“ zur Unterstützung Ludwig Bittners bei dessen Erstellung eines Repertoriums der österreichischen Staatsverträge ${ }^{47}$ und seit I. September 1903 speziell für die Edition der

43 Siehe Moos, Bildungsbürgertum (Bibl.) 13f.; SweEt, Writing (Bibl.) 39.

44 Herbert Dachs, Österreichische Geschichtswissenschaft und Anschluß 1918-1930 (Wien/Salzburg 1974) bes. 115-129, hier 115; Derndarsky, Österreich (Bibl.) 22 Anm. 8, 24, 46.

45 Handschriftliche Diss. Wien 12. Juni 1901; vgl. Franz Gebauer, Verzeichnis über die seit dem Jahre 1872 an der Philosophischen Fakultät der Universität in Wien eingereichten und approbierten Dissertationen 1 (Wien 1935) 74 Nr. 835.

46 Derndarsky, Österreich (Bibl.) 22.

47 Fritz Fellner, „... ein wahrhaft patriotisches Werk“. Die Kommission für Neuere Geschichte Österreichs 18972000 (VKGÖ 91, Wien/Köln/Weimar 2001) 47; Lнотsку, Geschichte des Instituts (wie Anm. 37) 281. 
mit Holland abgeschlossenen Staatsverträge angestellt ${ }^{48}$. Neben dieser Beschäftigung wurde er ab dem I. April I 904 am IÖG tätig, und zwar offiziell als Praktikant der Universitätsbibliothek, das heißt als Bibliothekar, was „nach seiner eigener [sic] Bekundung, die Funktion eines Assistenten' bedeutete“ ${ }^{49}$; Leiter des Instituts war mittlerweile Emil von Ottenthal ${ }^{50}$.

Offenbar vom Drang beseelt, dereinst ein Historiker mit breiter Publikumswirkung nach Art Leopold von Rankes ${ }^{51}$ zu werden, studierte er nun auf eigene Faust die klassischen Werke dieses Meisters ${ }^{52}$. Bis zum Ende der Monarchie veröffentlichte er dann aber gleichwohl nur wissenschaftliche Studien, die thematisch ganz dem Geschmack seines Lehrers Dopsch entsprachen, gegen den er allem Anschein nach bald einen Widerwillen empfand ${ }^{53}$. So erfolgte 1907 eine Habilitation Srbiks für Österreichische Geschichte auf Grundlage der Arbeit „Der staatliche Exporthandel Österreichs von Leopold I. bis Maria Theresia. Untersuchungen zur Wirtschaftsgeschichte Österreichs im Zeitalter des Merkantilismus" ${ }^{54}$, und gleich war er in Graz als möglicher Extraordinarius für Neuere Geschichte in Nachfolge Hans von Zwiedinecks von Südenhorst ${ }^{55}$ im Gespräch, jedoch erwies sich seine mangelnde Lehrerfahrung als hinderlich ${ }^{56}$. I 9 Io erweiterte Srbik aufgrund seiner thematisch bereits als

48 Fellner, „... ein wahrhaft patriotisches Werk“ (wie Anm. 47) 54; Ders., Srbik (2002) (Bibl.) 331.

49 Derndarsky, Österreich (Bibl.) 29f.; Lнотsкy, Geschichte des Instituts (wie Anm. 37) bezeichnet Srbik 281, 322 ausdrücklich als „Assistent“, 290 aber als „Bibliothekspraktikant“; laut 322 gehörte er „dem Status der Beamten der Universitätsbibliothek an, in der er am 5. Jänner 1911 zum Amanuensis ernannt wurde“, zu seinen Aufgaben siehe 335-338; 1909 hielt Srbik für Dopsch die Übungen zur Quellenkunde; Lнотsку, $321 \mathrm{f}$.

50 Siehe zuletzt Susanne Lichtmannegger, Emil von Ottenthal (1855-1931). Diplomatiker in der Tradition Theodor von Sickels und Julius von Fickers, in: Österreichische Historiker (wie Anm. 7) 73-95.

51 Für Ranke (und insbes. auch dessen tiefe Religiosität) ist sehr aufschlussreich Alexander Demandt, Ranke unter den Weltweisen, in: DERs., Geschichte der Geschichte. Wissenschaftshistorische Essays (Historica minora 1, Köln/Wien 1997) 253-266.

52 Siehe Moos, Bildungsbürgertum (Bibl.) $14 \mathrm{f}$.

53 Vgl. für spätere Gesten der Animosität zwischen den beiden Gelehrten etwa Friedrich ENGEL-Janosi, ... aber ein stolzer Bettler. Erinnerungen aus einer verlorenen Generation (Graz 1974) 102; MA-Kircher, Dopsch (Bibl.) 139; Peter Schött le R, Lucie Varga - eine österreichische Historikerin im Umkreis der „Annales“ (1904-1941), in: Lucie VA RGA, Zeitenwende. Mentalitätshistorische Studien 1936-1939 (Suhrkamp Taschenbuch Wissenschaft 892, Frankfurt/M. 1991) 13-110, hier 37; SToy, Institut (wie Anm. 35) $142 f$.

54 (Wien/Leipzig 1907, ND Frankfurt/M. 1969); zu den Einzelheiten des Habilitationsvorganges siehe DER NDARSKy, Österreich (Bibl.) 31-33; vgl. auch DERs., „Idee“ (Bibl.) 189; LнотSкy, Geschichte des Instituts (wie Anm. 37) 281, 322.

55 Fellner, Corradini, Geschichtswissenschaft (Bibl.) 476; Walter Höflechner, Vom Historischen Institut der Karl-Franzens-Universität Graz, in: Forschungen zur Landes- und Kirchengeschichte. FS Helmut J. Mezler-Andelberg zum 65. Geburtstag, hg. v. dems., Herwig Ebner, Othmar Pick L, Annelies Redik, Hermann Wiesflecker, Inge Wiesflecker-Friedhuber (Graz 1988) 209-222, hier 214; Andreas MölZER, Hans von Zwiedineck-Südenhorst. Corpsstudent, Gelehrter und Politiker (Schriftenreihe des Steirischen Studentenhistoriker-Vereines 5, Graz 1981).

56 Derndarsky, Österreich (Bibl.) 33-35. 
Habilitationsvortrag angeschnittenen Studie „Wilhelm von Schröder. Ein Beitrag zur Geschichte der Staatswissenschaften "57 seine Venia auf Allgemeine Geschichte ${ }^{58}$. I 9 I 2 konnte er dann auch noch endlich eine Edition der österreichischen Staatsverträge mit den Niederlanden von I 668 bis 1722 im Druck vorlegen 59 , was ihm übrigens eine Ehrenmitgliedschaft in der Historische Genootschap te Utrecht ${ }^{60}$ eintrug, und auf der Basis all dieser Publikationen wurde Srbik dann auf einen Grazer Professorenposten berufen, nämlich per I. Oktober I9I2 auf ein neu eingerichtetes Extraordinariat für Allgemeine Geschichte, wobei er vor allem mittelalterliche Geschichte zu lesen hatte ${ }^{61}$.

IV.

Mit der Aussicht auf eine endlich gesicherte Existenz ehelichte Srbik am I4. September I9I 2 in Brixen Johanna Nissl, Tochter des Innsbrucker Professors für Kirchenrecht Anton Niss ${ }^{62}$, die er bei Familie Ottenthal kennengelernt hatte. Dieser Verbindung entstammten die Töchter Walpurga (geb. I 9 I 4) und Elisabeth (geb. I 924) sowie der Sohn Hans Heinrich (I916-1988)63. In Graz etabliert, versprach Srbik seinen Freunden Bauer und Hirsch, sich um eine Karriere der beiden an seinem nunmehrigen Wirkungsort zu bemühen ${ }^{64}$, aber als nach Kurt Kasers ${ }^{65}$ Berufung nach Czernowitz ein Ordinariat frei wurde, griff er verständlicherweise selbst zu, trat am I. April I9I7 in Graz eine ordentliche Professur für Neuere und Wirtschaftsgeschichte ${ }^{66}$ an und wechselte so „vom Mittelalter in die Neuzeit“67. Während des Weltkrieges diente Srbik von I9I5 bis I9I 8 jeweils in den Sommerferien trotz Befreiung vom Kriegsdienst wegen seiner Eigenschaft als akademischer Lehrer freiwillig

57 (SB Wien 114,1, Wien 1910).

58 Derndarsky, Österreich (Bibl.) 36; Ders., „Idee“ (Bibl.) 189.

59 Österreichische Staatsverträge. Niederlande 1 (VKGÖ 10, Wien 1912).

60 Derndarsky, Österreich (Bibl.) 41; vgl. Srbik, Korrespondenz (Bibl.) Nr. 8.

61 Derndarsky, Österreich (Bibl.) 36f.; Höflechner, Institut (wie Anm. 55) 217; Lhotsky, Geschichte des Instituts (wie Anm. 37) 281, 322.

62 Nikolaus Grass, Nissl Anton, in: ÖBL 7 (1978) 135; Gerhard Oвеr коғler, Die Geschichtlichen Fächer an der Philosophischen Fakultät der Universität Innsbruck 1850-1945 (Forschungen zur Innsbrucker Universitätsgeschichte 6, Innsbruck 1969) 85.

63 Art. „\$Srbik“, in: Wiener Genealogisches Taschenbuch (wie Anm. 17) 363; De r N DARsky, Österreich (Bibl.) 38; Srbik, Korrespondenz (Bibl.) Nr. 75 Anm. 2; vgl. Fellner, Srbik (2002) (Bibl.) 332.

64 Derndarsky, Österreich (Bibl.) 40-47.

65 Fellner, Corradini, Geschichtswissenschaft (Bibl.) 214; Höflechner, Institut (wie Anm. 55) 215; WEBER, Lexikon (Bibl.) 290f.

66 Derndarsky, Österreich (Bibl.) 46, 48-52; vgl. ders., „Idee“ (Bibl.) 189.

67 Höflechner, Institut (wie Anm. 55) 214. 
in der Armee, und zwar bei der Artillerie in Tirol ${ }^{68}$. Auf diese Weise stellte er völlig außer Zweifel, dass er trotz seinem verdächtigen Familiennamen ${ }^{69}$ Serbien und allen anderen Feinden der Monarchie das „Sterbien“wünschte. An der Universität Graz freundete er sich mit dem weit rechts stehenden Geografen Robert Sieger ${ }^{70}$ an und trat I9I7 gemeinsam mit diesem dem neu gegründeten slawophoben Verein „Mitteleuropäischer Staatenbund“ bei, der auf einem „Herrenrecht der Deutschösterreicher“ bestand ${ }^{71}$. I9I7 erschien von Srbik auch eine weitere Monografie mit einem Thema ganz in der Linie Dopschs, „Studien zur Geschichte des österreichischen Salzwesens "72. Wenn es auf den ersten Blick auch reichlich kurios und eskapistisch anmutet, dass ein österreichischer Historiker im Krisenjahr I9I7 über kein anderes Thema als die Geschichte des einheimischen Salzwesens zu publizieren wusste, so verfügen diese wirtschaftshistorischen Arbeiten Srbiks tatsächlich auch noch heute über einen weit größeren Informationswert als viele seiner späteren ideologisch befrachteten Publikationen - schließlich war Dopsch der einzige österreichische Historiker, der mit der so zukunftsträchtigen französischen „Annales“-Schule in Kontakt stand ${ }^{73}$. Erst I 9 I 9 erfolgte an der Universität Graz die Einrichtung eines eigenen Seminars für Neuere Geschichte $^{74}$, und I92 I unterstützte Srbik gemeinsam mit seinem Kollegen Wilhelm Erben die dann gleichwohl neuerlich aus frauenfeindlichen Gründen abgelehnte Habilitation der Professorentochter Mathilde Uhlirz ${ }^{75}$.

V.

Srbiks erster historischer Aufsatz mit Zeitbezug erschien I919, also nach dem Ende der Monarchie, und handelte vordergründig nicht über die gerade geschehene, sondern über

68 Zu Srbiks Militärzeiten siehe General im Zwielicht 1 (wie Anm. 15) 403 Anm. 384; Derndarsky, Österreich (Bibl.) 48-50; Lönnecker, Thema (wie Anm. 27) 56, 186.

69 Vgl. Srbik, Korrespondenz (Bibl.) Nr. 132 (24.07.1925): Ich habe trotz meines slawischen Namens seit Jahrzehnten den nationalen Kampfgegen die Feinde des Deutschtums [...] mitgekämpft [...].

70 Siehe zuletzt Gregor Gatscher-Riede, Sieger, Robert d. J., in: ÖBL 12 (2005) 238.

71 Derndarsky, Österreich (Bibl.) 53f.; Moos, Bildungsbürgertum (Bibl.) 10.

72 (Forschungen zur inneren Geschichte Österreichs 12, Innsbruck 1917).

73 Vgl. bes. Sснӧтtler, Varga (wie Anm. 53) 19-21, 36-38. Srbik selbst hat gemäß einer bei Pitcher, Srbik (Bibl.) 265 Anm. 38, wiedergegebenen Auskunft von Taras (von) Borodajkewycz nach 1918 keinerlei Interesse an Wirtschaftsgeschichte mehr gezeigt.

74 Höflechner, Institut (wie Anm. 55) 214.

75 Fritz Fellner, Frauen in der österreichischen Geschichtswissenschaft, in: Fellner, Geschichtsschreibung (Bibl.) 92-128, hier 98; zu Uhlirz siehe zuletzt Anne-Katrin Kunde, Mathilde Uhlirz (1881-1966). Jenseits der Zunft. Prozesse der Selbstbehauptung in Leben und Wissenschaft, in: Österreichische Historiker (wie Anm. 7) 461-491, hier 470 und 474. 
die österreichische Revolution von I 848. Er basierte auf zwei Vorträgen, „die der Verfasser im Dezember I9I 8 an Sprechabenden der deutschen Studentenschaft beider Grazer Hochschulen gehalten“ hatte ${ }^{76}$. Der Verfasser scheint am ehesten den Sozialdemokraten nahezustehen; er beurteilt die Große Französische Revolution von 1789 und die österreichische Revolution von I 848 viel positiver, als dies ein Konservativer von damals hätte tun können, und gibt sich am Schluss auch recht wenig liberal-bürgerlich, bezeichnet er es hier doch als „Ruhmestitel eines Teils der Wiener Studentenschaft, daß sie die Notwendigkeit erkannten [sic], den Wohlfahrtsstaat und den sozialen Rechtsstaat auch für die Arbeiter zu schaffen, zu einer Zeit, da Dynastie, Kirche und Adel und zum großen Teil auch das Bürgertum im Proletariate nur Pöbel sahen. Eine Fülle bedeutsamer sozialpolitischer Anregungen ist während der Revolution in Österreich entstanden [...]; Gedanken der Sozialreform, denen wie dem demokratischen Prinzip des allgemeinen Wahlrechts die Zukunft gehörte, und an denen die Studentenschaft lebendigen Anteil hatte. Nach 70 Jahren, unter dem Eindrucke der weit gewaltigeren Umwälzungen der Gegenwart, erkennen wir heute mit voller Klarheit, welcher starke Wegbereiter der politischen und sozialen Gestaltung der deutschen Volksgeschicke die Revolution des Jahres I 848 gewesen ist "77. „Die politischen Ideen“, die die Revolutionsführer vertraten, waren für Srbik damals „im Kerne alle lebensfähig, und kein Geringerer als Erzherzog Johann hat [...] die gedenkenswerte Äußerung getan, die heute wie eine Prophezeiung klingen mag: ,Es scheint schon in den Sternen bestimmt zu sein, daß die Menschheit einmal in der Republik ihr Heil finden wird [... $]^{\text {“"78 }}$. Das Ancien Régime des Hauses Habsburg wird durchwegs in dunklen Farben gemalt, nur Metternich bringt Srbik schon damals offenkundige Sympathie entgegen ${ }^{79}$; und während über die slawischen Völker nur böse Worte fallen, äußert sich Srbik über jüdische Belange so gemäßigt wie später nicht mehr. Ganz sachlich schreibt er: „Besonders gedrückt war die materielle Existenz der meisten jüdischen Hörer; da ihnen fast alle bürgerlichen Berufe verschlossen waren, wandten sich die vielen, die aus Böhmen und Ungarn nach Wien zogen, mit Vorliebe dem ärztlichen Berufe zu. Noch war die österreichische Judenschaft vorwiegend deutschgesinnt, und ihre studierende Jugend

76 Heinrich Ritter von SR BIK, Die Wiener Revolution des Jahres 1848 in sozialgeschichtlicher Beleuchtung, in: Schmollers Jb. für Gesetzgebung, Verwaltung und Volkswirtschaft im Deutschen Reiche 43, 3. Heft (1919) $19-58=829-868$.

77 Ebd. $58=868$.

78 Ebd. $57=867$.

79 Ebd. 29 = 839: „Innerlich verwachsen mit der Aufklärung [...], ein logischer Egoist, wie ihn sein Leibarzt Dr. Jäger nannte, voll Geist und Selbstgefälligkeit, war Metternich ein viel zu feiner Kopf, um nicht zu erkennen, daß Unbeweglichkeit staatsverderbend wirke, aber er war zu alt und ruhebedürftig geworden, er hatte nicht mehr die Kraft und Elastizität, das System zu ändern. “ Für dieses vergleichsweise freundliche Urteil mochten vielleicht mündliche Äußerungen seiner Lehrer Guglia und August Fournier die Basis gelegt haben. 
wurde zu einem Sauerteige der revolutionären Gärung; es sei etwa an das Leben [Adolf] Fischhofs und [Ludwig August von] Frankls als Beweis, welch große Rolle die jüdischen Mediziner spielten, erinnert." 80 Später kommt Srbik dann zwar den Erwartungen seiner zweifellos scharf antisemitisch eingestellten Auditorien entgegen, indem er von „volksfremden Männern“ spricht, welche „die Führung an sich zu reißen trachteten“: „,bei einzelnen mag wohl auch ehrlicher alttestamentarischer Fanatismus wirksam gewesen sein, in so manchem aber dürfen wir nur den gewissenlosen, profitgierigen Volksbetörer sehen", wobei ein solcher aber dann doch „von den vielen geistig und ethisch hochstehenden Revolutionären seiner eigenen Rasse wie Fischhoff [sic] durch einen Abgrund getrennt ist" ${ }^{\text {" }}$. Als Srbik diesen Aufsatz in den Satz gab, schien es noch durchaus plausibel, dass die österreichischen Sozialdemokraten, deren Führungspersonal zu einem guten Teil jüdischer Herkunft war, geradeso wie die Sozialdemokratie im Deutschen Reich auf die Dauer eine führende politische Rolle einnehmen würden. Da sich Srbik sonst immer sehr abfällig, ja hasserfüllt über die jüdisch geführte österreichische Sozialdemokratie geäußert hat ${ }^{82}$, sollte man in diesem Aufsatz Srbiks am besten nur das Dokument eines äußerst geschickten Opportunismus sehen, das uns davor warnen sollte, seine späteren politischen und sonstigen Äußerungen jeweils zum Nennwert zu nehmen ${ }^{83}$.

I 920 erschien die erste Monografie des „neuen“, publikums- und zeitbezugsorientierten Srbik, „Wallensteins Ende. Ursachen, Verlauf und Folgen der Katastrophe. Auf Grund

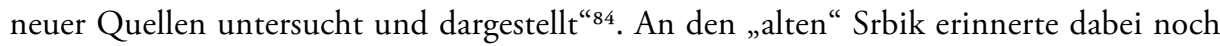
die sorgfältigste Berücksichtigung von und Grundlegung durch Primärquellen; allerdings übersah er gleichzeitig ein wichtiges auf tschechisch veröffentlichtes Stück Sekundärliteratur, ein eindrückliches Beispiel für das Desinteresse, das die deutschen „Führer“ den von ihnen gemäß Srbik und Konsorten so wohltätig „geleiteten“ slawischen Völkern tatsächlich entgegenbrachten. Srbik war später mit diesem Werk selbst so wenig zufrieden ${ }^{85}$, dass

80 Ebd. 35f. $=845 f$.

81 Ebd. 54f. $=864 \mathrm{f}$.

82 Vgl. bes. Srbik, Korrespondenz (Bibl.) Nr. 83 (29.11.1919): Sie [nämlich die österreichische Sozialdemokratie] steht unter jüdischer Führung, ist von jüdischem, undeutschen Denken durchtränkt und fördert immer mehr auf Kosten des Deutschtums den Giftstoff im Volk, das Judentum, Ich bin kein Gegner Wiens schlechthin, sondern Gegner des jüdisch-roten Wiens; und Nr. 132 (24.07.1925): Ich [...] arbeite seit drei Jahren an der hiesigen Universität mit andern gegen internationales Judentum und Sozialdemokratie.

83 Vgl. auch MA-Kircher, Dopsch (Bibl.) 142: „Die Lektüre der Briefe Srbiks vermittelt in der Zeit des karrieremäßigen Aufstiegs noch den Eindruck einer Persönlichkeit, die [...] wenig dem Zufall überließ. Jede Rezension wurde organisiert, wenn nicht persönlich, so über die Seilschaften seiner Freunde. Srbik betrieb Politik, lange vor seiner Berufung zum Unterrichtsminister."

84 (Wien 1920); vgl. Derndarsky, „Idee“ (Bibl.) 190.

85 Für die Defizite vgl. vor allem Pitcher, Srbik (Bibl.) 84-87; Sweet, Writing (Bibl.) 41-43. Gemäß der feinsinnigen Analyse des Werkes durch Droz, Srbik (1978) (Bibl.) 57f. „Wallenstein apparaissait dans ce 
er in seiner Tiroler „Exil“-Zeit eine vermehrte und verbesserte Auflage vorbereitete, die er dann auch schon im Herbst 1947 abschloss und die postum erschien ${ }^{86}$.

VI.

Mit I. Oktober I 922 erfolgte Srbiks Berufung zum ordentlichen Professor für Geschichte als Nachfolger August Fourniers ${ }^{87}$ an die Universität Wien; als deren Folge konnte er eine Dienstwohnung im Schloss Schönbrunn beziehen ${ }^{88}$. „Daß er damit auch seinen Großvater Grauert beerbte, welcher der erste Inhaber der Fournier-Kanzel gewesen war, mag ihm eine zusätzliche Genugtuung bedeutet haben." $89 \mathrm{Zu}$ den ersten seiner Wiener Hörer gehörte der spätere Schriftsteller Heimito von Doderer, der sich von Srbiks Unterricht zumindest vorerst wenig angetan zeigte: was ist diese ganze Gelehrsamkeit gegen eine halbe Seite aus einem Dialog von Oscar Wilde, notierte er nach einer Vorlesung Srbiks im November $1922^{90}$, und innerhalb seines „Geschichtsstudiums liegen die Veranstaltungen von Oswald Redlich und Alfons Dopsch an erster Stelle - die bei Heinrich Ritter von Srbik werden zwar ebenfalls erwähnt, allerdings häufiger mit dem Hinweis ,gestrichen/ versäumt “"91. Auch Walter Jambor stellte dem Vortragenden ein denkbar schlechtes Zeugnis aus ${ }^{22}$. Gleichwohl muss Srbik über eine gewisse Art von Charisma verfügt haben, das

livre comme la première personnalité ,gesamtdeutsch“" (zu diesem Begriff siehe ausführlich weiter unten S. 286-293).

86 Wallensteins Ende. Ursachen, Verlauf und Folgen der Katastrophe. Vermehrte und verbesserte Auflage (Salzburg ${ }^{2}$ 1952); die Herausgabe besorgte Taras v. BORODAJK EW YCZ.

87 Fellner, Corradini, Geschichtswissenschaft (Bibl.) 127f.; Weber, Lexikon (Bibl.) 154.

$88 \mathrm{Zu}$ den Einzelheiten der Berufung siehe Derndarsky, Österreich (Bibl.) 70-76; vgl. auch Fellner, Srbik (2002) (Bibl.) 334; Höflechner, Institut (wie Anm. 55) 215; Wiener Zeitung 15.09.1922, 1.

89 Derndarsky, Österreich (Bibl.) 76.

90 Vgl. etwa MA-Kircher, Dopsch (Bibl.) 143. Doderers späterer Beitritt zur NSDAP am 1. April 1933 ist nach dem Urteil dieser Autorin nicht einem entsprechenden Einfluss Srbiks zuzuschreiben. Einen solchen nimmt gleichwohl Doderers Biograf an, vgl. Wolfgang Fleischer, Das verleugnete Leben. Die Biographie des Heimito von Doderer (Wien 1995, $\left.{ }^{2} 1996\right)$ 139, 191, 231, 272; aber Doderers „spätere Behauptung“, beim Parteieintritt ,ausschließlich Heinrich von Srbiks Vision des Dritten Reichs vor Auge gehabt zu haben“ (ebd. 191, vgl. 231 : „In seiner Selbstverteidigung nach dem Zweiten Weltkrieg berief sich Doderer ausschließlich auf dieses ,Mißverständnis' durch die Reichsidee, als hätte es sich gewissermaßen um den Irrtum einer akademischen Lehrmeinung gehandelt“), ist mit größter Wahrscheinlichkeit bloß selbstrechtfertigende Dichtung und nicht Wahrheit, und vermag so keineswegs eine tatsächliche Prägung von Doderers sogenanntem „Denken“ durch Srbik zu erweisen.

91 Matthias Meyer, Genealogie, Geschichte und Gregor. Zur Funktion von Geschichtlichem in Doderers Merowingern, in: „Excentrische Einsätze“. Studien und Essays zum Werk Heimito von Doderers, hg. v. Kai Luenrs (Berlin/New York 1998) 206-224, hier 218.

92 Walter Jам вов, Die Schatten werden länger, in: Österreich in Geschichte und Literatur 3,1 (1959) 1-16, 
viele seiner Hörer dazu brachte, seiner Person und seiner Lehre völlig unkritisch gegenüberzustehen.

VII.

Als Srbik endlich nach Wien zurückkehrte, ging er bereits mit seinem besten und berühmtesten Werk schwanger. Erich Marcks ${ }^{93}$ hatte ihn 1920 eingeladen, für einen von ihm selbst und Karl Alexander von Müller ${ }^{94}$ herausgegebenen Sammelband einen Beitrag über Metternich zu verfassen. Während der Niederschrift dieses Aufsatzes ${ }^{95}$ war Srbik klar geworden, dass er sich durch eine umfängliche Neubewertung dieses Staatsmannes sowohl bei der Historikerzunft wie beim breiten Lesepublikum entscheidend zu profilieren vermöchte. Indem Metternich sich in der ersten Hälfte des I9. Jahrhunderts der Revolution widersetzt und entgegengestemmt hatte, die dann schließlich doch - zum alleinigen Vorteil des Bürgertums - gekommen war, hatte er ja de facto auch den Anfängen jener Revolution von I9I8 gewehrt, deren Auswirkungen nun auch für das Bürgertum bereits höchst schmerzlich gewesen waren und in der Zukunft noch gravierender zu werden

hier 7: „Srbik ist als akademischer Lehrer wohl einer der schlechtesten Methodiker seines Standes gewesen. Er konnte [...] nur schwer persönlichen Kontakt finden, zur Studentenschaft im Hörsaal hatte er überhaupt keine Beziehung. Der Verfasser erinnert sich genau der ersten Begegnung mit Srbik im Wintersemester 1941/42 anlässlich einer fünfstündigen Vorlesung über das Zeitalter der Reformation. Die Enttäuschung der zahlreichen erstsemestrigen Lehramtskandidaten (in pädagogischer und rhetorischer Hinsicht) war allgemein."

93 Siehe zuletzt Bernd Faulen bach, Marcks, Erich, in: Historikerlexikon. Von der Antike bis zur Gegenwart, hg. v. Rüdiger von Bruch, Rainer A. Müller (München ${ }^{2} 2002$ ) 208-210; Peter Fuchs, Marcks, Erich, in: NDB 16 (Berlin 1990) 122-125; We ber, Lexikon (Bibl.) 363f.; Ulla-Britta Vollhardt, Marcks, Erich, in: Weiss, Personenlexikon (Bibl.) $312 \mathrm{f}$.

94 Werner Schelling, Karl Alexander von Müller (1882-1964). Ein Beitrag zur Geschichte der Geschichtswissenschaft und des politischen Denkens in Deutschland (Diss. Wien 1975); Margareta Kinner, Karl Alexander von Müller (1882-1964). Historiker und Publizist (München 1997); Hans Wolfram v. Hentig, Müller, Karl Alexander v., Historiker, in: NDB 18 (1997) 440-442; Monika Stoer mer, Die Bayerische Akademie der Wissenschaften im Dritten Reich, in: Leopoldina-Symposion. Die Elite der Nation im Dritten Reich - Das Verhältnis von Akademien und ihrem wissenschaftlichen Umfeld zum Nationalsozialismus, vom 9. bis 11. Juni 1994 in Schweinfurt, hg. v. Christoph J. Scriba (Acta historica Leopoldina 22, Halle a. d. Saale 1995) 89-111; Winfried Schulze, Karl Alexander von Müller (1882-1964). Historiker, Syndikus und Akademiepräsident im „Dritten Reich“, in: Denker, Forscher und Entdecker. Eine Geschichte der Bayerischen Akademie der Wissenschaften in historischen Portraits, hg. v. Dietmar Willoweit unter Mitarbeit von Ellen Latzin (München 2009) 281-306, 390-393.

95 Heinrich von $S_{\text {R BIK }}$, Metternich, in: Meister der Politik. Eine weltgeschichtliche Reihe von Bildnissen 2, hg. v. Erich Marcks, Karl Alexander von Müller (Stuttgart/Berlin 1922) 355-400; vgl. Derndarsky, Österreich (Bibl.) 79f.; DERs., „Idee“ (Bibl.) 190f. 
drohten ${ }^{96}$. Nachdem er auch schon seine im November 1922 gehaltene Antrittsvorlesung Metternich gewidmet hatte ${ }^{97}$, gelang es Srbik schließlich bereits 1925, zwei höchst voluminöse Bände „Metternich“ der Öffentlichkeit vorzulegen ${ }^{98}$, die sich jetzt freilich im Gegensatz zu seinen früheren Monografien ganz vorwiegend nur auf schon publiziertes Material stützten.

„Metternich“ ist jenes Werk Srbiks, das sich am besten liest ${ }^{99}$. Keinen Vorzug stellt aber die geringe Distanz zwischen Autor und Objekt dar. Auch versucht Srbik seinen Titelhelden nicht aus Metternichs eigener, sondern vielmehr aus des Verfassers eigener Zeit heraus zu verstehen und zu rechtfertigen; allzu bemüht versucht er dessen Relevanz für die eigene Gegenwart zu erweisen. Humor und Ironie fehlen auch hier so wie in allen anderen Schriften Srbiks völlig. Eine souveräne Art von Geschichtsschreibung, wie sie etwa für Jacob Burckhardt ${ }^{100}$ typisch ist, liegt auch hier nicht vor.

Srbik hat sich in diesem Werk selbst als gemäßigten Konservativen bezeichnet ${ }^{101}$, was von seinem Zielpublikum gewiss mit Wohlgefallen aufgenommen worden ist, doch muss diese Selbstbeschreibung natürlich hinterfragt werden. Definiert man Konservativismus nicht etwa bloß als Bestreben, eigene Privilegien zu bewahren, sondern als grundsätzlich rationale und menschenfreundliche Skepsis gegenüber nicht zwingend gebotenen Ver-

96 Vgl. etwa Ma-Kircher, Dopsch (Bibl.) 141: „Srbiks Darstellung eines erzkonservativen Protagonisten sprach die Einstellungen und Ängste weiter bürgerlicher Bevölkerungskreise an, die sich mit der sozialen und politischen Situation nach dem Umbruch nicht zurechtgefunden hatten." Einschlägig ist hier etwa auch die spätere große Wertschätzung Metternichs durch den konservativen US-Historiker Peter Viereck, vgl. zuletzt Reba N. Soffer, History, Historians, and Conservatism in Britain and America. The Great War to Thatcher and Reagan (Oxford 2009) 247f.

97 Heinrich von SR B IK, Metternichs Plan einer Neuordnung Europas 1814/15. Antrittsvorlesung, gehalten an der Universität Wien am 16. November 1922, in: MIÖG 40 (1924/25) 109-126.

98 Beachtung verdient dabei auch die Wahl des Verlages, nämlich F. Bruckmann aus München. In diesem Verlag war Houston Stewart Chamberlains antisemitisches Machwerk „Die Grundlagen des neunzehnten Jahrhunderts“ (München 1899) erschienen, was Srbik gewiss bekannt war, und im Salon des Verlegersohnes Hugo, der übrigens 1917 bei F. Bruckmann vorübergehend ausgeschieden war, um einen eigenen, weniger erfolgreichen Verlag zu gründen, hatte am 23.12.1924 „Adolf Hitler seinen ersten Auftritt vor einem bildungsbürgerlichen Publikum“ (siehe jetzt Wolfgang Martyn kewicz, Salon Deutschland. Geist und Macht 1900-1945 [Berlin 2009] 13 und passim), was Srbik gewiss nicht bekannt gewesen ist. Zu den beiden Verlagen Bruckmann siehe auch Anne Bechsтедт, Anja Deutsch, Daniela Stöppel, Der Verlag F. Bruckmann im Nationalsozialismus, in: Kunstgeschichte im „Dritten Reich“. Theorien, Methoden, Praktiken, hg. v. Ruth Heftrig, Olaf Peters, Barbara Schellewald (Schriften zur modernen Kunsthistoriographie 1, Berlin 2008) 280-311.

99 Golo Mann, Geschichte und Geschichten (Frankfurt/M. 1961) 488, meint jedoch: „formlos, schleppend“, vgl. auch SweEt, Writing (Bibl.) 44 mit Literatur.

100 Siehe zuletzt Kurt Meyer, Jacob Burckhardt. Ein Portrait (München 2009).

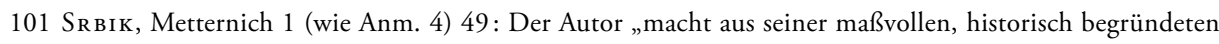
konservativen Überzeugung kein Hehl“. 
änderungen, deren Vor- und Nachteile schwer abgeschätzt werden können, und erklärt man also Odo Marquards Satz „Es kommt nicht darauf an, die Welt zu verändern, sondern sie zu verschonen“ zum typischen Credo eines Konservativen, so ist der sich (fast) immer für einen Idealisten ausgebende Srbik zeit seines Lebens nicht als Konservativer anzusprechen gewesen ${ }^{102}$, denn er hat immer wieder bedenkenlos Lieblingsideen propagiert, die mit der Wirklichkeit nicht kompatibel waren. So fantasierte er etwa Ende I9I9 in einem Brief an seinen Freund Bauer von einem Anschluß Deutschland-Österreichs an Bayern und ein wittelsbachsches Königtum, dem dann noch ein hohenzollernsches Kaisertum über einem "großen einigen Alldeutschland" folgen sollte ${ }^{103}$; das war genauso realitätsfremd wie Träumereien von einem kommunistischen Paradies als Folge einer proletarischen Revolution - und Srbik selbst hat tatsächlich noch kurz vor seinem Tod an eine offenbar ziemlich paradiesische sozialistische Zukunft zu glauben vorgegeben ${ }^{104}$. Dazu gesellt sich die Beobachtung, dass unzählige eindeutige Konservative wie etwa Johan Huizinga ${ }^{105}$, Gerhard Ritter ${ }^{106}$ und Wilhelm Röpke ${ }^{107}$ trotz zum Teil gewaltiger (aus heutiger Sicht höchst „politisch unkorrekter“) Skepsis auch gegenüber Demokratie und Republik ${ }^{108}$ den

102 Wenn SR вік, Metternich 2 (wie Anm. 4) 567f. sich mit den Worten „Einstweilen gewinnt es oft den Anschein, daß der tote Staatsmann einen scharfen Blick in die Zukunft warf" die Auffassung Metternichs zu eigen macht, dass „das Volk als Menge immer ein Kind bleiben werde [...], leicht zu verführen und launenhaft", so liegt hier keineswegs eine in letzterem Sinn konservative Grundanschauung, sondern einfach ein Elitendiskurs vor - heute sprechen sich die gewiss nicht der Marquard'schen Maxime verpflichteten europäischen Eliten und die von ihnen bezahlten „Experten“ mit im Wesentlichen denselben Argumenten gegen Volksabstimmungen und für das Verbot sogenannter ,populistischer“ und „rassistischer“ Parteien aus.

103 Srbik, Korrespondenz (Bibl.) Nr. 83.

104 Siehe unten Anm. 276.

105 Siehe zuletzt Horst Lademacher, Johan Huizinga (1872-1945), in : Europa-Historiker. Ein biographisches Handbuch 1, hg. v. Heinz Duchнardt, Małgorzata Morawiec, Wolfgang Schmale, Winfried SCHulze (Göttingen 2006) 179-213.

106 Siehe zuletzt Christoph Cornelissen, Gerhard Ritter. Geschichtswissenschaft und Politik im 20. Jahrhundert (Schriften des Bundesarchivs 58, Düsseldorf 2001); Martina Pesditsche K, Barbar, Kreter, Arier. Leben und Werk des Althistorikers Fritz Schachermeyr 1-2 (Saarbrücken 2009) 433 Anm. 2198 mit Literatur.

107 Siehe jetzt v.a. Helge Peune rt, Röpke, Wilhelm, in: NDB 21 (2003) 734f., und Hans Jörg Hennecke, Wilhelm Röpke. Ein Leben in der Brandung (Stuttgart 2005).

108 Für einen keineswegs liebevollen Blick auf den deutschen Konservativismus vor 1945 vgl. etwa die beiden Monografien Jerry Z. Muller, The Other God That Failed. Hans Freyer and the Deradicalization of German Conservatism (Princeton 1987); Raimund von dem Bussche, Konservatismus in der Weimarer Republik. Die Politisierung des Unpolitischen (Heidelberger Abhandlungen zur mittleren und neueren Geschichte N.F. 11, Heidelberg 1998). Kritisch zur konservativen deutschen Opposition, die aus dem NS-Reich in den Ständestaat geflüchtet war, Elke SEEFried, Reich und Stände. Ideen und Wirken des deutschen politischen Exils in Österreich 1933-1938 (Beiträge zur Geschichte des Parlamentarismus und der politischen Parteien 147, Düsseldorf 2006). Für eine grundsätzliche Unvereinbarkeit von Konservativismus und 
Nationalsozialismus ganz instinktiv als abstoßend empfanden, was auf Srbik nun gewiss nicht zutrifft. Srbik war auch weiterhin offenbar aktives Mitglied einer protonazistischen Burschenschaft; aber es stimmt, dass der „Metternich“ nicht im Mindesten den (Un-)Geist des Schönerer'schen Habsburg-Kannibalismus atmet und auch nicht von einem Sozialdemokraten (oder Liberalen) verfasst zu sein scheint. Ein Grund für diesen Stimmungswechsel war wohl, dass dem Bürgertum nach immensen Vermögensverlusten durch eine gigantische Inflation und angesichts einer weiter bestehenden realen Gefahr verfassungskonformer Ermöglichung einer „Diktatur des Proletariats" an der Wahlurne ${ }^{109}$ die k. u. k. Monarchie nun

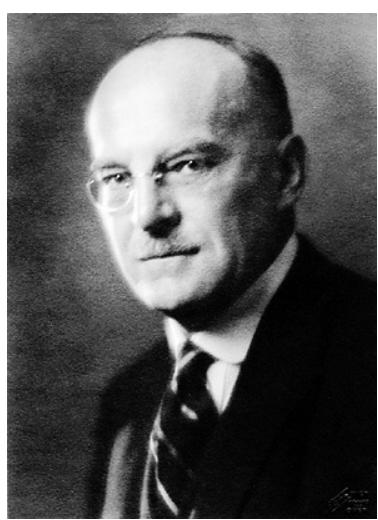

Abb. 22: Heinrich von Srbik um

I927 in der Tat geradeso wie dem höheren Adel als verlorenes Paradies erscheinen musste. Auch hatte sich Srbiks Hoffnung auf Heilande aus den Häusern der Wittelsbacher und Hohenzollern mittlerweile als trügerisch erwiesen - und als österreichischer Bundeskanzler fungierte mittlerweile kein Otto Bauer und kein Julius Deutsch, sondern der „Prälat ohne Gnade“ Ignaz Seipel. Zusätzlich dürfte Srbik bald - wohl spätestens mit seiner Ernennung zum Professor - zur Auffassung gelangt sein, dass Obrigkeiten grundsätzlich größter Respekt entgegenzubringen sei ${ }^{110}$. Im Übrigen ist der „Metternich“ doch von einem strikt deutschnationalistischen und nicht etwa von einem legitimistischen Standpunkt aus geschrieben ${ }^{111}$. So mag man denn den Verfasser des „Metternich“ nicht als Konservativen, sondern vielmehr als einen im Kern opportunistischen Schönerianer mugged by reality betrachten.

I 925 wurde dann auch gleich zum Jahr des glanzvollen Schlagers einer Doppelberufung ${ }^{12}$, als die Universitäten Bonn und Köln gleichzeitig bei ihm vorfühlten, hier in Bezug auf die

Nationalsozialismus siehe aber nun Sven-Uwe Sснмітz, Konservativismus (Elemente der Politik, Wiesbaden 2009) 118-126.

109 Vgl. SR в I к, Metternich 2 (wie Anm. 4) 567f. „Einstweilen gewinnt es oft den Anschein, daß der tote Staatsmann einen scharfen Blick in die Zukunft warf, wenn er lehrte, daß die ungebundene Freiheit zur Despotie der stärksten Partei führe."

110 Solcher Respekt auch vor der Obersten Obrigkeit hat den nicht praktizierenden, laut Selbsteinschätzung bloß romantische[n\} Katholik[en] (General im Zwielicht 1 [wie Anm. 15] 548) dann auch in der NS-Zeit vor einem Kirchenaustritt bewahrt.

111 Man vergleiche Srbiks Bekenntnis von Ende 1919 in Srbik, Korrespondenz (Bibl.) Nr. 83: ich war und bin immer ein Feind der Klerikalen und war nie ein Freund der Habsburger.

112 So Willy Andreas anerkennend, in: Srbik, Korrespondenz (Bibl.) Nr. 149. 
Nachfolge von Justus Hashagen ${ }^{113}$, dort in Bezug auf jene von Aloys Schulte ${ }^{114}$. Letzterer hatte eine konfessionell gebundene Professur inne und war besonders bemüht, Srbik, den beide Universitäten primo loco nominiert hatten, zur Annahme des Rufes zu bewegen. Er erreichte sogar, als Srbiks Antworten hauptsächlich das konfessionelle Moment als Hindernis angaben ${ }^{115}$, dass Srbik eine ungebundene persönliche Professur angeboten wurde. Nach längeren Verhandlungen entschied sich Srbik allerdings, in Gallien, das heißt Österreich, der Erste zu bleiben, zumal ihm hier nun umfangreiche Zulagen und persönliche Verbesserungen wie auch eine Assistentenstelle zugesagt wurden ${ }^{116}$.

I 928 erhielt Srbik auch noch einen Ruf als Nachfolger Hermann Onckens ${ }^{117}$ nach München, obwohl er gar nicht auf der Vorschlagsliste stand, und lehnte wieder $\mathrm{ab}^{118}$. I 934 wäre Srbik wohl einverstanden gewesen, nach Basel zu gehen, als sich Werner Näf ${ }^{119}$ offenbar nur unverbindlich nach einer solchen Bereitschaft erkundigte, da er sich im damals noch strikt antinationalsozialistischen Ständestaat sichtlich nicht wohl fühlte $^{120}$. „Eine andere Gelegenheit zur Übersiedlung, und zwar nach Berlin, sollte sich relativ schnell bieten, weil das Dritte Reich sehr geneigt war, Srbik zu einer wissenschaftlichen Galionsfigur zu machen. "121 Walter Franks ${ }^{122}$ Angebot, dem mittlerweile dort auf

113 Hashagen ging im April 1926 von Köln nach Hamburg; Weber, Lexikon (Bibl.) 208; Art. „Hashagen, Justus“, in: 150 Jahre Rheinische Friedrich-Wilhelms-Universität zu Bonn 1818-1968. Verzeichnis der Professoren und Dozenten der Rheinischen Friedrich-Wilhelms-Universität zu Bonn 1818-1968, hg. v. Otto WENIG (Bonn 1968) 107.

114 Schulte emeritierte in Bonn 1925, behielt den Lehrstuhl jedoch bis 1928; siehe zuletzt Stefan Jor DAN, Konrad Repgen, Schulte, Aloys, in: NDB 23 (Berlin 2007) 687-689; Luise Schorn-Schütte, Schulte, Aloys, in: Historikerlexikon. Von der Antike bis zur Gegenwart, hg. v. Rüdiger vom BruCH, Rainer A. Müller (München ${ }^{2}$ 2002) 301; Weber, Lexikon (Bibl.) 539f.; Art. „Schulte, Aloys“, in: 150 Jahre (wie Anm. 113) 283.

115 Srbik meinte, dass er zwar katholisch sei, jedoch auf Freiheit der Forschung und Lehre allergrößten Wert lege und konfessioneller Politik stets fernbleiben würde; Srbik, Korrespondenz (Bibl.) Nr. 132; vgl. auch Gerald Stourzh, Wandlungen des Österreichsbewußtseins im 20. Jahrhundert und das Modell Schweiz, in: Schweiz - Österreich. Ähnlichkeiten und Kontraste, hg. v. Friedrich Koja, Gerald Stourzh (Studien zu Politik und Verwaltung 14, Wien/Köln/Graz 1986) 11-32, hier 21.

116 Derndarsky, Österreich (Bibl.) 92-97.

117 Siehe v.a. Geschichte in Heidelberg. 100 Jahre Historisches Seminar. 50 Jahre Institut für Fränkisch-Pfälzische Geschichte und Landeskunde, hg. v. Jürgen Miетнке (Berlin u.a. 1992) passim, bes. 128-137; Klaus Schwabe, Hermann Oncken, in: Deutsche Historiker 2, hg. v. Hans-Ulrich Wehler (Göttingen 1971) 81-97; WeBER, Lexikon (Bibl.) 424f.

118 Derndarsky, Österreich (Bibl.) 97f.; Helmut Heiber, Walter Frank und sein Reichsinstitut für Geschichte des neuen Deutschlands (Quellen und Darstellungen zur Zeitgeschichte 13, Stuttgart 1966) 578.

119 Siehe zuletzt Edgar Bonjour, Näf, Werner, in: NDB 18 (Berlin 1997) 696.

120 Derndarsky, Österreich (Bibl.) 109f.

121 So ebd. 110.

122 Siehe zuletzt Michael GrütTnER, Biographisches Lexikon zur nationalsozialistischen Wissenschaftspolitik 
seine Initiative hin zwangsenthobenen Oncken nachzufolgen, schlug Srbik I 935 jedoch ebenso aus ${ }^{123}$.

Das „Metternich“-Werk katapultierte aber Srbik nicht nur an die Spitze der deutschsprachigen Historikerzunft, es wurde auch zum erhofften Publikumserfolg, mit dem mittelbaren Resultat, dass der hochbegabte und hochgebildete konservativ-legitimistische Schriftsteller Hanns Saßmann ${ }^{124}$ ein „Metternich“-Drama verfasste, das 1929 am Burgtheater mit dem Starschauspieler (und späteren NS-Gegner) Raoul Aslan in der Hauptrolle zur Aufführung gelangte ${ }^{125}$. Nicht zuletzt der auf diese Weise erlangten Popularität ist wohl auch der Umstand zuzuschreiben, dass der großdeutsch orientierte Bundeskanzler Johann Schober ${ }^{126}$ Srbik als Bundesminister für Unterricht in sein drittes Kabinett

(Studien zur Wissenschafts- und Universitätsgeschichte 6, Heidelberg 2004) 51; KLEE, Personenlexikon (Bibl.) $160 f$.

123 Karsten Jeduitsch ка, Wissenschaft und Politik. Der Fall des Münchner Historikers Ulrich Crämer (19071992) (Ludovico Maximilianea Universität Ingolstadt-Landshut-München, Forschungen und Quellen, Forschungen 219, Berlin 2006) 402; Srbik, Korrespondenz (Bibl.) Nr. 274; vgl. auch De R N DARsky, Österreich (Bibl.) 110-117; Heiber, Frank (wie Anm. 118) 699f.; Gernot Heiss, Von Österreichs deutscher Vergangenheit und Aufgabe. Die Wiener Schule der Geschichtswissenschaft und der Nationalsozialismus, in: Willfährige Wissenschaft. Die Universität Wien 1938-1945, hg. v. Dems., Siegfried Matt L, Sebastian MeissL, Edith Saurer, Karl Stuhlpfarrer (Österreichische Texte zur Gesellschaftskritik 43, Wien 1989) 39-76, 46f., 68 Anm. 81; Friedrich Meinecke, Werke 6: Ausgewählter Briefwechsel, hg. v. Ludwig Denio, Peter Classen (Stuttgart 1962) 154. Laut Adam v. WANDRUsZKa, Österreichs Stellung in der deutschen und europäischen Geschichte, in: Österreich zwischen Deutschland und Europa (Schriftenreihe der Vereinigung Vorarlberger Akademiker 3, Bregenz 1962) 9-24, hier 9 erklärte Srbik seinen damaligen Verbleib in Wien seinen Studenten gegenüber so, „daß er in Österreich , an der Front' bleiben und sozusagen nicht zum ,Generalstab“ nach Berlin gehen wolle“, womit natürlich nur gemeint sein konnte, dass er den „Anschluss“ Österreichs an Nazideutschland lieber vor Ort in Wien (natürlich auch nur mit der Feder) erkämpfen als in Berlin bloß strategisch mitvorbereiten wollte, und das ist denn auch eine völlig plausible Erklärung. Wandruszka selbst suggeriert dem Leser freilich vielmehr, Srbik habe eigentlich aus Abscheu vor dem Nationalsozialismus nicht nach Berlin gehen wollen, was jedoch nicht zutrifft (siehe unten). Gemäß Borodaj Kew ycz, Srbik (1978) (Bibl.) 10 fürchtete Srbik (zumindest auch), an der Universität Berlin in eine Schlangengrube zu geraten: „als ihn die Berliner Universität 1935 als Nachfolger des gestürzten Hermann Oncken auf den ersten geschichtlichen Lehrstuhl Deutschlands berief, lehnte er diese einem Österreicher noch nie zuteil gewordene Auszeichnung ab, als er erkannte, daß ihn eitle akademische Intriganten vor ihren eigenen Wagen spannen wollten“. Außer Zweifel steht, dass Solidarität mit dem von seinem eigenen Schüler Frank mit unerbittlichem Hass verfolgten Oncken keine Rolle spielte.

124 Saßmann verfasste auch ein vergleichsweise kluges Buch über das Wesen des in seinen Augen typisch österreichischen Menschen: Das Reich der Träumer. Eine Kulturgeschichte Österreichs vom Urzustand bis zur Republik (Berlin 1932), das dann für einige Jahre in Nazideutschland verboten war; vgl. Klaus Amann, Zahltag. Der Anschluß österreichischer Schriftsteller an das Dritte Reich (Bodenheim 1996) 155.

125 Auch dieses Schauspiel war wiederum so erfolgreich, dass Saßmann Metternich schließlich noch in zwei weiteren Theaterstücken auf die Bühne brachte: „Haus Rothschild“ und „1848“.

126 Art. „Schober, Johann“ in: Österreich-Lexikon 3 (Bibl.) 156f.; G[ertrude] EnderLe-Burcel, Schober Johannes, in: ÖBL 10 (Wien 1994) 423-425 mit Literatur; Rainer Hu BERT, Schober. „Arbeitermörder“ 
holte. Als solcher amtierte er vom I6. Oktober 1929 bis zum 25. September I930; er war freilich nur zweite Wahl ${ }^{127}$ nach dem Mediziner Anton Eiselsberg ${ }^{128}$ gewesen. Unter seine Ägide fiel unter anderem auch die Berufung des gebürtigen Wieners und Sohnes des klassischen Philologen Johannes Vahlen (Karl) Theodor Vahlen ${ }^{129}$ an die Technische Hochschule in Wien, der später das Amt Wissenschaft im REM leiten sollte und mit dem Srbik auch dann noch Kontakt hatte ${ }^{130}$. Nach diesem einen Jahr - länger hatte das dritte Kabinett Schober nicht gehalten - kehrte Srbik „enttäuscht und verbittert“ zurück an die Universität Wien ${ }^{131}$, I932/33 fungierte er dann als Dekan der Philosophischen Fakultät und I 936/37 als Senator ${ }^{132}$. Diese nun gehäufte Übernahme repräsentativer und administrativer Ämter könnte den Verdacht nahelegen, dass es für Srbik nach dem „Metternich“ keine große wissenschaftlich-publizistische Agenda mehr gegeben hat. Das Gegenteil ist richtig; auch schon in den I920er-Jahren und erst recht dann in den I93oer-Jahren und bis an sein Lebensende widmete sich Srbik immer wieder einem zentralen Thema, das als sein eigentliches Lebensthema anzusprechen ist, nämlich der von ihm selbst so genannten „gesamtdeutschen Geschichtsauffassung“.

VIII.

Wie schon der Terminus „gesamtdeutsche Geschichtsauffassung“ selbst nahelegt, handelte es sich dabei weniger um ein wissenschaftliches als um ein ideologisches Projekt. Es ist evident, dass er mithilfe dieser Ideologie selbst Geschichte zu schreiben hoffte. Srbik trat dabei keineswegs bloß für ein staatliches Zusammengehen des Deutschen Reiches und „Deutschösterreichs“ ein - das jedenfalls von I9I 8 bis 1933 so gut wie alle „Deutschösterreicher“ mit Ausnahme der Legitimisten und von I9I 8 bis I945 so gut wie alle Deutschen mit Ausnahme Oswald Spenglers ${ }^{133}$ befürworteten -, einem solchen

und „Hort der Republik“. Biographie eines Gestrigen (Böhlaus zeitgeschichtliche Bibliothek 15, Wien/Köln 1990) (zu Srbik 266, 382f., bezeichnet Srbik ausdrücklich als „parteilos“).

127 Derndarsky, Österreich (Bibl.) 99-104; siehe auch Wiener Zeitung 17.10.1929, 1; Neue Freie Presse 17.10.1929, 2.

128 Art. „Eiselsberg, Anton Frh. von“, in: Österreich-Lexikon 1 (Bibl.) 309; ÖBL 1 (1957) 236.

129 Grütt ner, Lexikon (wie Anm. 122) 176f.; Klee, Personenlexikon (Bibl.) 637.

130 SснӧnwёLder, Srbik (Bibl.) 529f.; Srbik, Korrespondenz (Bibl.) Nr. 249 bes. Anm. 2, Nr. 265 und 272.

131 „Die Verelendung Österreichs untersagte jede größere Kultur- und Wissenschaftspolitik, die Mühlsteine der egoistischen Proporzpolitik der Christlichsozialen und Sozialdemokraten zerrieben jede sachliche Arbeit“, BorodajKewycz, Srbik (1978) (Bibl.) 10.

132 Derndarsky, Österreich (Bibl.) 104.

133 Vgl. Oswald Spengler, Preußentum und Sozialismus (München 1920) 28 = Politische Schriften (München 1933) 28: „... auch Wien ist eine Schöpfung spanischen Geistes. Nicht die Sprache allein schafft ein Volk. 
Großdeutschland sollten nach Srbik auch alle Siedlungsgebiete der deutschen Diaspora, das heißt nicht weniger als ganz Mitteleuropa und „Zwischeneuropa “134 "angegliedert" werden; die dort wohnhaften nichtdeutschen Völkerschaften sollten unter Beseitigung ihrer zumeist gerade erst etablierten mittel- und osteuropäischen Nationalstaaten allesamt unter deutsche „Führung“ gestellt werden. Insofern basierte Srbiks Doktrin prinzipiell auf jener von Schönerers Alldeutscher Bewegung, der Srbik offenbar auch noch Ende I9I9 verpflichtet blieb ${ }^{135}$. Nun gab es aber noch ein weiteres wichtiges Element in Srbiks Ideologie, nämlich die sogenannte „Ehrenrettung“ der Habsburgermonarchie, wobei Srbik deren Ehre freilich nur in den Augen von Deutschnationalisten à la Schönerer retten wollte. So pries er an Altösterreich genau das, was in den Augen anderer, der Monarchie zum Teil durchaus wohlgesinnter Beobachter ${ }^{136}$ zu deren Untergang geführt hatte: die „Führung“ der Slawen durch die Deutschen, das heißt: die mangelnde Gleichstellung des slawischen Elements mit dem deutschen, und die Expansionspolitik auf dem Balkan ${ }^{137}$, die unweigerlich zu einem Konflikt mit Russland führen musste. In diesem Zusammenhang lobte Srbik insbesondere auch noch, dass in der k. u. k. Monarchie das „übernationale“ und „universalistische“ Denken des Heiligen Römischen Reichs deutscher Nation fortgelebt habe; dies stellte für Srbik offenbar einen durchwegs positiv zu beurteilenden und zeitlos gültigen Anspruch der Deutschen auf „Führung“ Europas, wenn nicht (wie der Terminus „universalistisch“ ja nahelegt) der ganzen Welt dar ${ }^{138}$.

Hier wurde ein Volk, das österreichische, durch den Geist des Hofes, dann der Geistlichkeit, dann des Adels geschaffen. Es ist den übrigen Deutschen innerlich fremd geworden, unwiderruflich [...]. Dies Volk ist habsburgisch und spanisch, auch wenn niemand vom Hause Habsburg mehr leben sollte; möge sein Verstand nein sagen, sein Instinkt bejaht es."

134 Das „etwa durch die Linien Danzig-Triest und Riga-Odessa bestimmt ist und durch das Streudeutschtum für uns gekennzeichnet ist“; Heinrich von $\mathrm{S}_{\mathrm{R} \text { в I }}$, Mitteleuropa. Das Problem und die Versuche seiner Lösung in der deutschen Geschichte (Weimar 1937, ${ }^{2} 1938$ ) 5. Vgl. zu diesem Begriff bes. auch Hans Hecker, „Die Tat" und ihr Osteuropa-Bild 1909-1939 (Köln 1974) 158-178.

135 Damals schwärmte er in einem Brief an Bauer von einem zukünftigen hohenzollernschen Kaisertum über einem "großen einigen Alldeutschland“, während er eine Wiederkehr der Habsburger entschieden ablehnte; Srbik, Korrespondenz (Bibl.) Nr. 83; vgl. Derndarsky, Historie (Bibl.) 155 Anm. 8.

$136 \mathrm{Vgl}$. etwa Hans Kонn, AEIOU: Some reflections on the meaning and mission of Austria, in: The Journal of Modern History 11 (1939) 513-527, hier 516 (wo auch sehr kritisch zu Srbik).

137 In analoger Weise schrieb Srbiks Freund Glaise-Horstenau 1934, Österreichs Aufgabe sei es, Sprungbrett zu sein für den Ausdehnungstrieb der Nation in militärisch-politischer, religiöser und wirtschaftlicher Hinsicht, und pries der Schriftsteller Bruno Brehm 1938 die „Kolonisierungsarbeit der österreichischen Deutschen im Südosten“, vgl. Klaus AmA N N, Die Brückenbauer. Zur „Österreich“-Ideologie der völkisch-nationalen Autoren in den dreißiger Jahren, in: Österreichische Literatur der dreißiger Jahre. Ideologische Verhältnisse. Institutionelle Voraussetzungen. Fallstudien, hg. von Klaus Amann, Albert Berger (Wien/Köln 1990) 60-78, hier 64, 71. Bereits Golo Mann erkannte, dass „unter deutscher Kulturführung“ faktisch „unter deutscher Obergewalt" bedeutet: MAnn, Historismus (wie Anm. 6) 483.

138 Ganz explizit heißt es am Ende von Heinrich Ritter von SR BIK, Das Reich und Mitteleuropa, in: Forschun- 
Wenn Derndarsky pointiert formuliert, Srbik sei „eher als deutscher Großösterreicher denn als österreichischer Großdeutscher zu bezeichnen“139, so geht dieses Urteil zwar in die richtige Richtung ${ }^{140}$, bringt aber nicht zum Ausdruck, dass sich Srbik unter anderem auch das „kostbare“ deutsche Blut „an der Wolga“ und „in den baltischen Ländern“141 angelegen sein ließ, das dem Hause Österreich niemals untertan gewesen war. Srbiks Motto lautete offenbar vielmehr: „Heute führen wir Mitteleuropa, und morgen die ganze Welt“, und mit „wir“ war keineswegs ein supranational empfindendes Haus Habsburg, sondern das deutsche Volk gemeint. Als Folge von Srbiks stilistischem Unvermögen (bzw. der bis I938, das heißt bis zum „Anschluss“, auch noch gebotenen Zurückhaltung) erschloss sich dieser Sachverhalt nicht jedem; viele oberflächliche Leser Srbiks, und zwar nicht nur nazistische Heißsporne ${ }^{142}$, sondern vermutlich auch Carl Friedrich Goerdeler und Otto von Habsburg, hielten ihn aufgrund seiner universalistischen „Reichs“-Terminologie für einen verkappten Legitimisten, Theokraten oder Supranationalisten, während er tatsächlich stets ein deutscher Super-Nationalist gewesen ist.

Es liegt auf der Hand, dass Srbik hier (soweit dies Geisteswissenschaftler überhaupt tun können ${ }^{143}$ ) mit Dynamit hantierte und der Versuch einer Realisierung seines „gesamt-

gen und Fortschritte 20, Heft 13/14/15 (Mai 1944) 100-102: „Vom Schicksal ist uns die alte Reichspflicht wieder auferlegt: mit sittlicher Kraft die Macht zur Schaffung einer gerechten Völkerordnung in unserm alten und ewig jungen Erdteil zu verwenden. Macht und Geist, Wille und Ethos, das alte deutsche Königreich und die Ideenkraft des alten deutschen Heiligen Kaiserreichs, die Erkenntnis der Unentbehrlichkeit eines starken, verantwortungserfüllten deutschen Volkes für den Erdteil und für die Welt - all dies muß und wird die große Bewährungsprobe bestehen, die den nationalen und den universalen Geist wieder vereinen soll.“ „Dieser Aufsatz wurde am 23. September 1943 im Großdeutschen Rundfunk verlesen.“

139 Derndarsky, Historie (Bibl.) 168.

140 Weitere nicht apologetische und m. E. im Großen und Ganzen korrekte, wenn auch nicht immer sehr konkrete oder präzise Interpretationen und Zusammenfassungen der „gesamtdeutschen Geschichtsauffassung “ finden sich bei Ingo HaA , Historiker im Nationalsozialismus. Deutsche Geschichtswissenschaft und der „Volkstumskampf“ im Osten (Kritische Studien zur Geschichtswissenschaft 143, Göttingen 2000) 221, 238 (resümiert, dass Srbik mit seiner gesamtdeutschen Geschichtsauffassung „die Zerschlagung der neuen slawischen Nationalstaaten und die Restitution der deutschen Hegemonialstellung in Ostmittel- und Südosteuropa begründete[n]"); Heiss, Vergangenheit (wie Anm. 123) 46f.; Ders., Pan-Germans, Better Germans, Austrians: Austrian Historians on National Identity from the First to the Second Republic, in: German Studies Review 16,3 (Oct., 1993) 411-433, hier 413; SснӧNwÄLdER, Srbik (Bibl.) 532-539; vgl. auch dies., Historiker (wie Anm. 5) 93, $221-$ 223, 269, 272f.; DIEs., „Lehrmeisterin der Völker und der Jugend“. Historiker als politische Kommentatoren, 1933 bis 1945, in: Geschichtsschreibung als Legitimationswissenschaft 1918-1945, hg. v. Peter SchöttLeR (Suhrkamp-Taschenbuch Wissenschaft 1333, Frankfurt/M. 1997) 128-165, hier 143.

141 Siehe unten S. 289.

142 Vgl. zuletzt Jeditsch na, Prüfungskommission (wie Anm. 8) 221-223 mit Literatur; ausführlicher unten S. 314-316 und Anm. 305.

143 Vgl. etwa Cathrin Friedrich, Erich Brandenburg - Historiker zwischen Wissenschaft und Politik (Leipziger Beiträge zur Wissenschaftsgeschichte und Wissenschaftspolitik, Leipzig 1998) 217 mit Literatur. 
deutschen“ Konzepts unweigerlich zu einem Krieg des um „Deutschösterreich“ erweiterten Deutschen Reiches schlussendlich mit nahezu allen anderen Staaten Europas führen musste ${ }^{144}$; das ist keine vaticinatio ex eventu besserwisserischer Nachgeborener, sondern ist so durchaus auch von Srbiks Zeitgenossen empfunden worden, so etwa vom den Nationalsozialisten selbst nur allzu nahestehenden Erich Brandenburg. Dieser machte es Srbik - was höchsten Respekt gebietet - noch im Jahr I936 zum Vorwurf, dass er sich nicht zu einer „restlosen Anerkennung des Strebens der Ungarn und Tschechen, ja sogar der Italiener, nach einem nationalen Staat entschließen könne“, und sah klar, dass Srbik „in eine gefühlsmäßig begründete, aber mit den Realitäten des Lebens in unversöhnlichem Widerspruch stehende Ideologie geraten sei“"145, worauf der unbelehrbare Srbik Brandenburg emotionsgeladen beschuldigte, „auf die Millionen Deutscher“ zu vergessen, „die als Volksgruppen und Volkssplitter verzahnt und verklammert mit Fremdnationalen lebten und leben müssen, - auf die Millionen im Sudetenraum, auf die Außenglieder und Vorposten kostbaren Bluts in Ungarn, Rumänien, in Bessarabien und an der Wolga, in den baltischen Ländern, in Südslawien und Südtirol“; ebendort, so perorierte er, sei angesichts dieses „kostbaren“ deutschen Blutes „die nationalstaatliche Lebensform eine Unmöglichkeit“"146.

144 Es ehrt die Zunft der deutschsprachigen Historiker allgemein, dass Srbik für seine „gesamtdeutsche Geschichtsauffassung“ zumindest vor der gewaltsamen Errichtung des „Protektorates Böhmen und Mähren“ kaum Zulauf erhielt; Henry Cord Meyer, Mitteleuropa in German Thought and Action 1815-1945 (International Scholars Forum 4, The Hague 1955) 300-307 erwähnt an Historikern mit ähnlichen öffentlich geäußerten Ansichten aus Deutschland nur Wilhelm Schüssler/Schüßler und Martin Spahn; an Österreichern Harold Steinacker und weiters Heinrich Kretschmayr sowie den mit Srbik verfeindeten Kaindl; im Wesentlichen dieselben Historikernamen nennt Jacques Droz, L'Europe centrale. Évolution historique de l'idée de „Mitteleuropa“ (Paris 1960) 258-261. Wie wir jetzt wissen, findet sich allerdings just auch im nicht zur Publikation gelangten „fünften Band“ der „Deutschen Geschichte im neunzehnten Jahrhundert“ des als katholischer NS-Gegner geltenden Franz Schnabel die „Kombination einer auf das deutsche Volkstum gegründeten, ,gesamtdeutschen' Staatsauffassung mit der föderalistischen, auf Ostmitteleuropa gerichteten Reichsidee, einer positiven Wertung der Habsburgermonarchie und einem kulturnational begründeten Primat des ,Deutschtums “ “ und eine Argumentation, die darauf hinausläuft, „den slawischen Völkern Osteuropas das Recht auf den souveränen Nationalstaat abzusprechen“; die „Verdrängung der Slawen“ wird sogar als „große Tat des Deutschtums im Mittelalter“ bezeichnet, und dies alles liest man im Übrigen gleich neben antisemitischen Anspielungen, vgl. Thomas Hert felder, Franz Schnabel und die deutsche Geschichtswissenschaft. Geschichtsschreibung zwischen Historismus und Kulturkritik (1910-1945). Zweiter Teilband (Schriftenreihe der Historischen Kommission bei der Bayerischen Akademie der Wissenschaften 60, Göttingen 1998) 712-721. Für analoge Tendenzen in der deutschen Publizistik vgl. Droz, 256f., und Hecker, „Die Tat“ (wie Anm. 134) 155-178.

145 Vgl. Friedrich, Brandenburg (wie Anm. 143) 111-122, 202-218. Brandenburg stand schon ursprünglich nicht links, war aber prinzipiell ein Liberaler und kein Konservativer.

146 Heinrich Ritter von SR вік, Zur gesamtdeutschen Geschichtsauffassung. Ein Versuch und sein Schicksal, in: HZ 156 (1937) 229-262, hier 232-234. Bemerkenswerterweise ist bei Srbik nie von einem „kostbaren“ Blut der Deutschschweizer die Rede - dass diese partout nicht einem gesamt- oder großdeutschen staatlichen oder 
Srbiks dergestalte Ergüsse in dieser Replik erbosten wiederum den konservativen NS-Gegner und späteren Mitwisser des 20. Juli und KZ-Häftling Gerhard Ritter; in einem am 24. Juli 1937 verfassten Brief an Srbik ${ }^{147}$ heißt es unter anderem: Die Gefahren, die Deutschland von außen umringen, sind nicht geringer, sondern noch viel größer geworden als jemals zur Bismarckzeit. [...] In einem solchen Augenblick von "mitteleuropäischen“ Zukunftszielen zu hören, von Aufgaben des „Donauraums“ unter deutscher Führung, wirkt stark beunruhigend. [...] Sie werden sich ohne Zweifel der politischen Tragweite der Sätze bewußt sein, verehrter Herr von Srbik, die Sie in der "Historischen Zeitschrift“ I 56, S. 237 niederschrieben: wo Sie als Zukunftsziel "gesamtdeutscher" Politik folgendes bezeichnen: „Das Deutsche Reich der feste nationalstaatliche Kern der Erdteilsmitte, mit ihm in festester nationaler Lebensgemeinschaft verbunden das heutige rein deutsche Österreich, ferner angegliedert auf der Grundlage der Achtung ihrer Staatlichkeit und der Achtung ungehemmten Lebensrechtes ihrer Völker die ostmitteleuropäische Staatenwelt" [...] Ferner: [„]Der Einwand wiegt doch allzu leicht, daß die verhältnismäßig kleinen, mit volksfremden Minderheiten durchsetzten Einzelstaaten die Vorteile eines mitteleuropäischen Reiches unter deutscher Führung nicht einsehen " [...] Man wird diese Sätze in Prag, in Warschau, Budapest und Belgrad, sicher auch in Paris und London und Rom mit großer Aufmerksamkeit lesen. Man wird sich insbesondere fragen, was das "angegliedert“ zu bedeuten hat, im Munde eines sehr bekannten, als Vertrauensmann des heutigen Deutschland international bekannten ${ }^{148}$ Historikers, eines Gelehrten von großem Ruf und eines ehemaligen österreichischen Staatsmannes ${ }^{149}$.

staatsähnlichen Gebilde „angegliedert“ sein wollten, stellte für die „gesamtdeutsche Geschichtsauffassung“ eine Peinlichkeit dar, die man am besten mit Schweigen überging.

147 Gerhard Ritter. Ein politischer Historiker in seinen Briefen, hg. v. Klaus Sch wabe, Rolf Reichardt (Schriften des Bundesarchivs 33, Boppard am Rhein 1984) 323-328, Nr. 78; Ritter war lebensklug genug, diesen Brief letztlich nicht an den Adressaten abzuschicken, weil er doch keine Wirkung haben, sondern den Empfänger nur ärgern und gegen Ritter einnehmen würde.

148 D.h., in den Augen Ritters nahm Srbik damals bewusst die Interessen von Nazideutschland wahr.

149 Ritter hatte sich Srbik gegenüber schon in einem Brief vom 25.09.1932 als Gegner eines Primats des Völkischen über die Staatsräson im Bismarckischen Sinne zu erkennen gegeben, der im Hitlerismus [...] eine ganz große Gefahr für unsere Zukunft sah (Ritter, Historiker [wie Anm. 147] 251 Nr. 38); als sich Srbik später für eine Mitwirkung an Walter Franks „Reichsinstitut für Geschichte des neuen Deutschlands“ entschieden hatte, war er in den Augen Ritters, dieses entschiedenen Gegners von Frank (vgl. zuletzt Klaus ScH WA BE, Geschichtswissenschaft als Oppositionswissenschaft im nationalsozialistischen Deutschland. Gerhard Ritter und das „Reichsinstitut für Geschichte des neuen Deutschland“, in: Historische Debatten und Kontroversen im 19. und 20. Jahrhundert. Jubiläumstagung der Ranke-Gesellschaft in Essen, 2001, hg. v. Jürgen ElverT, Susanne Krauss [Historische Mitteilungen Im Auftrage der Ranke-Gesellschaft 46, Stuttgart 2003] 8295), schon gerichtet: Über den Wiener Kollegen mußte ich meine bisherige gute Meinung leider ändern; aber die Österreicher sind ja wohl mit andern Maßstäben zu messen, als andere Menschen, zumal wenn sie slawisches Blut in den Adern haben (Ritter am 15.11 .1935 an Oncken; Ritter, Historiker, 285 Nr. 59). Ritter hat seine neue Haltung zu Srbik und dessen Ideologie dann natürlich auch nach 1945 nicht geändert, vgl. das imperialisti- 
Auch Srbiks Intimus Wilhelm Schüßler ${ }^{150}$, der seine 1937 erschienene Schrift „Mitteleuropa als Wirklichkeit und Schicksal“ mit dem Satz beschloss „Und so glauben wir mit dem österreichischen Historiker Heinrich v. Srbik, daß Mitteleuropa, dieser einzige Schauplatz gesamtdeutscher Geschichte, erst sinnvoll gestaltet werden kann, wenn in diesem Raum der Reichsgedanke, der Staatsgedanke und der Volksgedanke eine Verschmelzung eingehen zu einer höheren Wirklichkeit - auf die das deutsche Schicksal seit einem Jahrtausend weist "151, sah offenkundig im Krieg des Deutschen Reiches mit all seinen Nachbarn jenen Preis, der für die Realisierung der Srbik'schen Mitteleuropa-Version gezahlt werden müsste, wobei er diesen aber nicht für zu hoch fand: Drohend bemerkte er, dass nur eine Erfüllung aller Forderungen Konrad Henleins „den Frieden im Herzraum Mitteleuropas sichern“ könne; der Umstand, dass die ,jungen Völker des Ostens“ ihrer „Pflicht der Dankbarkeit“ gegenüber den Deutschen nicht nachkämen ${ }^{152}$, sei kein Grund für eine „Verzichtstimmung“ der Deutschen, weil durch „Nichtstun die Gefahren der Zukunft“ ohnehin nicht gebannt werden könnten. Im Hinblick auf die Gefahren, die den Deutschen nun aber gerade durch ein

sche Gerede vom Donauraum, wie es die Wiener Historikerschule damals aufbrachte [...] Mein Aufsatz sollte den Deutschen zum Bewußtsein bringen, wo der Anfang der großen Katastrophe war: im Wiederaufleben des Wiener Imperialismus, das heißt vor allem im Vorgehen gegen die Tschechen. Daß das keine nachträgliche Konstruktion ist, könntest Du aus einem Brief ersehen, den ich im Juli 1937 voller Sorge an meinen Kollegen von Srbik schrieb, in dem ich ihn genau in diesem Sinne warnte (Ritter am 17.07.1947 an den Bruder Hellmut Ritter; ebd. 436 Nr. 147), Ich habe [...] Srbik [...] dringend gewarnt vor großdeutschen Machtphantasien (Ritter am 20.06.1961 an Fritz Epstein; ebd. 552 Nr. 230). Gleichwohl stellte der herzensgute Ritter im Jahr 1946 auf eine Bitte von Srbiks Sohn hin, der das damalige Schicksal seines Vaters in den dunkelsten Farben gemalt hatte, dem Wiener Kollegen eine Art Persilschein aus, indem er trotz der Kautele, über seine politische Haltung im einzelnen [...] nicht näher orientiert zu sein, schlussendlich behauptete: Für die Ausnutzung seines Schrifttums als propagandistisches Hilfsmittel nationalsozialistischer Ostpolitik ist er nicht selbst verantwortlich zu machen. Sie stellt vielmehr einen Mißbrauch dar (BAK, N 1166, 327, 26.03.1946), und äußerte sich auch öffentlich, in einem Aufsatz, dementsprechend: „Politisch hat das Buch [,Deutsche Einheit'] (und das Wiener politisch-historische Schrifttum dieser Jahre überhaupt) als willkommene Unterstützung der großdeutschen Pläne Hitlers gewirkt, wohl auch seine Machtpolitik auf dem Balkan geistig vorbereiten helfen. Doch ging mindestens das Letztere weit über die Absichten des Verfassers hinaus" (Gerhard Rit t e R, Deutsche Geschichtswissenschaft im 20. Jahrhundert, in: Geschichte in Wissenschaft und Unterricht 1 [1950] 81-96, 129-137, hier 134); dafür empfing Ritter dann noch im Jahr 1950 den sprichwörtlichen „Dank vom Hause Habsburg“ sive Srbik, siehe oben Anm. 7. Zu Ritters Ansichten über Srbiks „Utopien“ vgl. auch noch Cor Nelissen, Ritter (wie Anm. 106) 278-291; Jürgen Elvert, Mitteleuropa! Deutsche Pläne zur europäischen Neuordnung (19181945) (Historische Mitteilungen, Beiheft 35, Stuttgart 1999) 293-295. Zum Vorwurf der „Kriegshetzerei“ gegenüber Srbik vgl. auch Derndarsky, Österreich (Bibl.) bes. 195, 207 Anm. 47.

150 Siehe zuletzt Michael Buddrus, Sigrid Fritzlar, Die Professoren der Universität Rostock im Dritten Reich. Ein biographisches Lexikon (Texte und Materialien zur Zeitgeschichte 16, München 2007) 379f.; Klee, Personenlexikon (Bibl.) 563; Weber, Lexikon (Bibl.) 536f. Siehe unten Anm. $199 f$. 151 Wilhelm Schüsster, Mitteleuropa als Wirklichkeit und Schicksal (Köln 1937) 62.

152 Ebd. 59. 
„Tun“ erwachsen könnten, zitierte der außenpolitische Experte Schüßler bloß ein Wort des älteren Helmuth von Moltke: „Im Kriege ist alles gefährlich“"153, das heißt, für ihn befand sich Deutschland zumindest schon in einem „kalten Krieg“, gegen dessen Umwandlung in einen heißen er offenbar gar nichts einzuwenden hatte. Für Österreich bedeutete eine Verwirklichung des „gesamtdeutschen“ Konzepts seit Ende Januar I933 die Vereinigung mit einem nationalsozialistischen Deutschland; demgemäß hätte ein österreichischer Konservativer, der über die Umstände der nationalsozialistischen Herrschaft im „Reich“ so gut informiert war, wie dies Srbik angesichts seiner ständigen Kontakte und Aufenthalte ebendort tatsächlich gewesen sein muss, die Propagierung eines solchen Konzepts bald sistiert und sich eher der legitimistischen Position angenähert - dies haben ja schließlich auch eher links stehende Intellektuelle wie Joseph Roth, Leo Perutz oder Ernst Karl Winter getan. Srbik aber gab seine Absicht auf, der Monografie über Metternich eine solche über Kaiser Franz Joseph folgen zu lassen - er wollte jetzt eben gerade die Legitimisten nicht legitimieren ${ }^{154}$ -, und intensivierte noch seine Propaganda zugunsten der „gesamtdeutschen Geschichtsauffassung"; insbesondere erschienen I935 - wiederum bei F. Bruckmann verlegt - zwei umfängliche Bände „Deutsche Einheit“155. Dieses Werk ist von Srbik unzweifelhaft als Plädoyer zugunsten eines baldigen „Anschlusses“ intendiert gewesen ${ }^{156}$ und ist in Österreich

153 Ebd. 60.

154 Vgl. Taras v. Borodajkewycz, Rezension von: Srbik, H. v.: Aus Österreichs Vergangenheit, in: Wiener Geschichtsblätter 9 (69), 3 (1954) 69f. („die Ungunst der Zeitverhältnisse ließ ihn diesem Plan entsagen“). Srbik hatte dem Monarchen 1931 einen sehr respektvollen Aufsatz gewidmet: Franz Joseph I., Charakter und Regierungsgrundsätze, in: HZ 144 (1931) 509-526. Srbiks Lob für den Kaiser hat allerdings einen falschen Zungenschlag - er funktioniert ihn gleichsam zum Ahnherren seiner "gesamtdeutschen Geschichtsauffassung“ um. Den letzten Kaiser aus dem Haus Habsburg hat Srbik andererseits überhaupt nicht geschätzt, siehe Alexander SPItZm ÜLlER, „... und hat auch Ursach, es zu lieben.“ (Wien/München/Stuttgart/Zürich 1955) 283.

155 Srbik konnte sich hierbei auf die von ihm selbst herausgegebene fünfteilige Quellenedition „Quellen zur deutschen Politik Österreichs“ (Oldenburg 1934-1938) stützen. Die beiden ersten Bände der „Deutschen Einheit“ sind bei den Nationalsozialisten im „Reich“ zum Teil mit gemischten Gefühlen aufgenommen worden, Eberhard Achter berg, Gesamtdeutsche Geschichtsbetrachtung, in: Nationalsozialistische Monatshefte 7,79 (Oktober 1936) 927-929, hier 928f. merkte kritisch an: „Im beginnenden Zeitalter des völkischen Bewusstseins kann keine übernationale Idee mehr Völker verschiedenen Blutes vereinen und die gemeinsame Grundlage ist nicht die ,Kulturnation', der man ,beitreten' kann, sondern das ,Volk', in das man ,hineingeboren ' wird“, um dann doch versöhnlich zu enden: „In diesem Bekenntnis zum Volk vereinigen wir uns mit Srbik und allen, die an der Aufgabe einer gesamtdeutschen Geschichtsbetrachtung mitarbeiten wollen, und bei dieser Arbeit wird das Volk als Inbegriff aller Kräfte des Blutes und des Bodens die große Leitidee sein.“ Zur „völkischen“ Argumentationsweise Srbiks selbst vgl. S. 306f.

156 Vgl. Heinrich von SR вік, Großdeutsche und kleindeutsche Geschichtsauffassung, in: Deutsche Arbeit 34, Heft 8 (August 1934) 385-389, hier 389: „Deutsche Geschichte als fortlebende Gegenwart und Zukunft, über aller Liebe zu den Teilen die tiefe Liebe zum Ganzen, zur uns beseelenden gesamtdeutschen Idee stärken wir dieses Glaubensbekenntnis in uns, dann wird die Arbeit der deutschen Historiker [also Srbiks] dereinst vielleicht als Vorbote einer neuen Zeit in der Geschichte unseres Volkes genannt werden.“ 
auch allgemein so verstanden worden. Man vergleiche etwa die lobende Erwähnung von Srbik und dessen zweibändigem Werk im unmittelbar auf den Abschnitt „der Führer im Volk“ folgenden Paragrafen „deutsches Geschichtsbewußtsein“ der I 937 notabene in Graz verlegten ziemlich unverblümten NS-Propagandaschrift „Schicksalsstunde Europas“157 des österreichischen NS-Literaten Karl Anton Prinz Rohan ${ }^{158}$. In seinen Memoiren von 1954 hat dieser in einem Kapitel mit dem Titel „Führende Clercs“ Srbik dann wohl implizit das Verdienst zuerkannt, den „Anschluss“ herbeigeschrieben zu haben ${ }^{159}$. Auch Schüssler, der alte Mitstreiter Srbiks, seit jeher ein Kriegshetzer und Antisemit ${ }^{160}$, konzedierte in seinem Nachruf, in dem er weiterhin auch von „deutschem Sendungsbewußtsein im Osten und Südosten“, ja „ungeheuren Taten und Opfern der Deutschen Habsburgs in Südosten“ schwärmte, dass die Wirkung der „Deutschen Einheit“ „gerade bei der Intelligenz, die dem Nationalsozialismus kritisch oder ganz ablehnend gegenüberstand, ausblieb und seine ,Deutsche Einheit" als Propaganda betrachtet wurde“161.

157 Karl Anton Prinz Rohan, Schicksalsstunde Europas (Graz ${ }^{2}$ 1937) 331. Rohan sah es in diesem Werk als seine Aufgabe an, auf den Adel und das Großbürgertum protreptisch im Sinne des Nationalsozialismus einzuwirken, vgl. etwa „Aber daß der Nationalsozialismus obsiegen konnte, und zwar in völlig offener Feldschlacht freiester Demokratie, und daß er auch nach den radikal antisemitischen Maßnahmen so ungeheure Abstimmungserfolge zu erzielen vermochte, beweist, daß die Zeit für Dissimilation reif war. Wenn in geistreichen Diskussionen die Behauptung gewagt wird, daß es schon deshalb keine Judenfrage gebe, weil der Rassebegriff wissenschaftlich nicht feststehe, dann hat wohl der Nationalsozialismus recht, wenn er auf die einfache Tatsache des Blutsinstinkts des Volkes hinweist. [...] Denn jeder Arier, auch der Judenfreund, weiß, und zwar mit der gleichen Gewißheit, mit der er weiß, daß er lebt, daß der Jude etwas anderes, etwas Artfremdes ist; und jede bodenständige, traditionsgebundene, vom Liberalismus unberührte arische Frau weiß es beim Gedanken an ein Kind von einem jüdischen Vater“ (ebd. 342f.).

158 Vgl. zu diesem etwa Amann, Zahltag (wie Anm. 124) bes. 168-170.

159 Karl Anton Rohan, Heimat Europa. Erinnerungen und Erfahrungen (Düsseldorf/Köln 1954) 234: „Selten gewinnen Geschichtsforscher jene Autoritätsfülle, die sie dazu beruft, als Hüter der Vergangenheit, sozusagen als Gedächtnis der Nation, durch ihr Lebenswerk an Gegenwart und Zukunft und also am politischen Schicksal ihres Volkes mitzugestalten. Heinrich von Srbik ist für Österreich und im weiteren Sinne für das ganze Deutschtum zu einem solchen Lehrmeister geworden. Keiner, neben Seipel und Hofmannsthal, hat unsere Generation stärker beeinflußt als er, der große Österreicher, Deutsche und Europäer. Als er nach Jahren des Schweigens nach 1945 noch einmal vor seinem Tod das Wort nahm, bekannte er sich zur Reichsidee als dem großen und unvergänglichen Vermächtnis der Vergangenheit an Gegenwart und Zukunft.“

160 In seinen Memoiren, in denen er sich als allerchristlichsten NS-Gegner präsentiert, gibt es sogar ein eigenes Kapitel „Mein Leben mit Heinrich von Srbik“, in dem der Leser erfährt, dass Srbik ihm 1937 „den Ehrennamen seines jüngeren ,Bruders im Norden““ [gab]; Wilhelm SchüssLER, Sonne über Gewitter. Einige Erinnerungen ([Bensheim 1965]) 110-115. Ebd. 109 befürwortet der Autor indirekt einen „numerus clausus als Gerechte [sic] Lösung“ für Studenten jüdischer Herkunft in Deutschland und verweist mit Wohlgefallen auf eine antisemitische Bemerkung Meineckes; vgl. zu dieser Pesditscheк, Barbar (wie Anm. 106) 646. Zu Schüsslers Kriegstreiberei siehe schon oben S. 291f.

161 SChüssler, Gedächtnis (Bibl.) 289; vgl. auch DERs., Sonne (wie Anm. 160) 112. 
IX.

Auch sonst suchte Srbik zwischen 1933 und 1938 die Interessen der Nationalsozialisten in Österreich und dem Dritten Reich zu vertreten und zu fördern. So publizierte er regelmäBig in „Die Warte“162, dem Nachfolgeorgan der mittlerweile verbotenen Zeitschriften „Der Anschluß“ und „Deutsche Einheit“, deren einziger Erscheinungszweck die Herbeiführung des „Anschlusses“ war ${ }^{163}$, trat im einschlägigen „Deutschen Klub“ und im „ÖsterreichischDeutschen Volksbund“ (der „Die Warte“ herausgab) aktiv auf ${ }^{164}$ und beteiligte sich auch am Zustandekommen des sogenannten Juliabkommens von $1936^{165}$, das den Interessen der österreichischen Nationalsozialisten weitgehend entgegenkam ${ }^{166}$. 1937 unterstützte er mit seiner Unterschrift das schlussendlich gescheiterte Projekt der Etablierung eines „deutschnationalen Vereins“ mit Namen „Deutsch-Sozialer Volksbund“, der in den Worten Papens „der Österreich-Ideologie und dem Legitismus wirksamer als bisher" begegnen sollte ${ }^{167}$. Bei der Unterschriftenaktion „Österreichische Deutsche zur Saarabstimmung“ am I3. Januar I 935 ,unterschrieben zum großen Befremden vaterländischer Kreise Leute wie [Josef] Nadler und Srbik, Viktor Geramb, Prinz Rohan, Max Mell, Friedrich Schreyvogl u.a.“, und dies sogar im Gegensatz zu Edmund Glaise-Horstenau, Oswald Menghin und Bruno Brehm ${ }^{168}$. Schon zuvor hatte Srbik „eine Erklärung gegen den status quo [...] in der in Österreich verbotenen ,Germania‘ Papens“ abgegeben ${ }^{169}$. Als Srbiks „Freund“ Meinecke ebenfalls

162 Ebenso beachtenswert war Srbiks „Mitarbeit [bei] und Förderung“ der Zeitschrift „Volk und Reich“ (seit 1925), siehe Moos, Bildungsbürgertum (Bibl.) 131f. Weniger eindeutig war (s)eine Mitwirkung bei der Zeitschrift „Schönere Zukunft“, vgl. zu dieser Peter Eppe L, Zwischen Kreuz und Hakenkreuz. Die Haltung der Zeitschrift „Schönere Zukunft“ zum Nationalsozialismus in Deutschland 1934-1938 (VKGÖ 69, Wien/ Graz 1980), wo 324-328 speziell zu Srbik.

163 Vgl. Moos, Bildungsbürgertum (Bibl.) 134; Sigurd Paul Sснеichl, Literatur in österreichischen Zeitschriften der dreißiger Jahre. Mit einem bibliographischen Anhang, in: Österreichische Literatur der dreißiger Jahre. Ideologische Verhältnisse. Institutionelle Voraussetzungen. Fallstudien, hg. v. Klaus Am AnN, Albert Berger (Wien/Köln 1990) 178-211, hier 205.

164 Vgl. Moos, Bildungsbürgertum (Bibl.) 132-135; zum „Deutschen Klub“ siehe jetzt auch Jakob Sт Uснц Iк, Der arische Ansatz. Erich Frauwallner und der Nationalsozialismus (SB Wien 797, Wien 2009) 124, 128.

165 Dazu jetzt grundlegend Gabriele Volsansky, Pakt auf Zeit. Das Deutsch-österreichische Juli-Abkommen 1936 (Böhlaus zeitgeschichtliche Bibliothek 37, Wien 2001).

166 Vgl. Srbik, Korrespondenz (Bibl.) Nr. 289: An der Vorbereitung des Abkommens am 11. Juli war ich nicht ganz unbeteiligt. Den Eintritt in die Regierung habe ich bereits im Mai abgelehnt, da damals die Situation noch nicht reif genug war [...]. Jedenfalls ist das Abkommen ein Anfang, dessen innerpolitischer Ausbau noch fehlt, aber wohl mit innerer Gesetzlichkeit kommen muss.

167 Siehe Volsansky, Pakt (wie Anm. 165) 87f.

168 Amann, Zahltag (wie Anm. 124) 127.

169 Walter Ferber, Geist und Politik in Österreich. Die Intelligenz und der Nationalsozialismus vor dem Anschluß (Konstanz 1955) 22. 
I 935 als Herausgeber der HZ ausgebootet wurde ${ }^{170}$, war er selbst als Nachfolgekandidat im Gespräch und publizierte trotz der nunmehrigen Ideologisierung und dem dramatischen Niveauverlust ${ }^{171}$ dieses Organs unter dem neuen Herausgeber Karl Alexander von Müller unbekümmert weiter darin, und zwar sogar einen offenen Brief an Walter Frank betreffend die Eröffnung von dessen „Reichsinstitut für Geschichte des neuen Deutschlands“ ${ }^{172}$, dem sich Srbik ebenfalls 1935 zur Empörung vieler Kollegen wie Oncken und Ritter als

170 Diesen Umstand erklärte Srbik auf dem 8. Internationalen Historikerkongress in Zürich im Spätsommer 1938 seinem langjährigen Briefpartner Näf und Edgar Bonjour (1898-1991) auf deren entrüstete Frage hin, „warum man denn Meinecke so sang- und klanglos aus der Redaktion der Historischen Zeitschrift entlassen habe“, mit dem für beide „konsternierenden“ Bemerken: Ja, nicht wahr, Meinecke hatte doch eine ganze Anzahl jüdischer Schüler, siehe Karl Dietrich Er dm an n, Die Ökumene der Historiker. Geschichte der Internationalen Historikerkongresse und des Comité International des Sciences Historiques (Abh. Göttingen 3. Folge 158, Göttingen 1987) 244 mit Brief Bonjours an Erdmann vom 17.03.1976. Zu den Vorgängen rund um die HZ vgl. bes. Kinner, Müller (wie Anm. 94) 211-242; Meinecke, Briefwechsel (wie Anm. 123) 156; Gerhard A. Rit te R, Die Verdrängung von Friedrich Meinecke als Herausgeber der Historischen Zeitschrift 1933-1935, in: Historie und Leben. Der Historiker als Wissenschaftler und Zeitgenosse. FS für Lothar Gall zum 70. Geburtstag, hg. v. Dieter Hein, Klaus Hildebrand, Andreas Schulz (München 2006) 65-88, hier 73, 81f.; Ritter, Meinecke (wie Anm. 7) 26; Hans Roth fels, Die Geschichtswissenschaft in den dreißiger Jahren, in: Deutsches Geistesleben und der Nationalsozialismus. Eine Vortragsreihe der Universität Tübingen mit einem Nachwort von Hermann Diem, hg. v. Andreas Flit ne r (Tübingen 1965) 90-107, hier 102-106; Ursula Wiggershaus-Müller, Nationalsozialismus und Geschichtswissenschaft. Die Geschichte der Historischen Zeitschrift und des Historischen Jahrbuchs 1933-1945 (Studien zur Zeitgeschichte 17, Hamburg 2000) 57-76; Reinhard Wiтtмann, Wissen für die Zukunft. 150 Jahre Oldenbourg Verlag (München 2008) 267f.; auch Derndarsky, Österreich (Bibl.) 116f.; Heiber, Frank (wie Anm. 118) 284f., 293, 295f., 299-301, 304.

171 Vgl. z.B. Heiber, Frank (wie Anm. 118) 307, vgl. 684f.; Ritter, Deutsche Geschichtswissenschaft (wie Anm. 149) 130.

172 Srbik an Frank, Wien, I6.ı..1935, in: HZ 153 (1936) 221f.: „Mit dem Institut weiß ich mich darin eins, die deutsche Geschichte nicht vom Standpunkt des partikularen Staates, sondern des einheitlichen Volkes aus anzusehen und wissenschaftlich zu ergründen und darzustellen. Der gesamtdeutsche geschichtliche Gedanke vereint uns, und ich empfinde von dieser Grundlage aus die sittliche Pflicht, dem Institut zu Dienst zu stehen, soweit nur immer meine Kräfte reichen. Der Angehörige einer älteren Generation, die traditionsgebundener ist, kann die Wissenschaftsauffassung eines jüngeren Geschlechts nicht in jedem einzelnen Zug teilen, das gemeinsame volkhafte Denken und Wollen aber wird und muß die Brücke schlagen. Ich bin gewiß, daß das Institut die wertvollen deutschen Wissenschaftsüberlieferungen, das Festhalten an der strengen Forschungsmethode, den unbedingten Wahrheitswillen und den universalen Blick mit dem heißen Drang nach der Formung des volkhaften Denkens und Wollens durch die Geschichtswissenschaft vereinen und daß es einen Zusammenklang der alten und der neuen Bildungskräfte, eine Harmonie kämpfender und Rankescher erkennender Wissenschaft anstreben und, so Gott will, erreichen wird. In diesem Sinne bitte ich auf meine volle Bereitschaft zur Mitarbeit zu zählen und in meiner Teilnahme an den Arbeiten des Instituts ein Symbol der innigen und unlösbaren Verbundenheit des Südostdeutschtums und des Reichsdeutschtums zu sehen. “ Vgl. Derndarsky, Österreich (Bibl.) 117f. bes. Anm. 91; vgl. Heiber, Frank (wie Anm. 118) 274, 307; Heiss, Vergangenheit (wie Anm. 123) 47; Srbik, Korrespondenz (Bibl.) Nr. 274. 
einer von ganz wenigen angesehenen Historikern als „Renommierfachmann“"173, das heißt Mitglied des Sachverständigenbeirats (und zwar Gutachter für die „Forschungsabteilung Nachkrieg, insbesondere Geschichte der nationalsozialistischen Bewegung“) zur Verfügung gestellt hatte; eben Frank gegenüber nahm der gleich I 935 zum Ehrenmitglied des besagten Instituts ernannte Srbik dann 1938 im Anschluss an einen gescheiterten Vermittlungsversuch zugunsten von Oncken, Franks von ebendiesem mit abgrundtiefem Hass verfolgten akademischen Lehrer, eine völlig servile Haltung ein ${ }^{174}$.

Srbik hat sich also in der Zeit zwischen 1933 und 1938 in seinen Handlungen nicht etwa nur wie ein „Sympathisant“ des Nationalsozialismus verhalten ${ }^{175}$, sondern vielmehr wie ein fest entschlossener Nationalsozialist, der den „Anschluss“ an das „Gelobte Land“ Nazideutschland aktiv herbeiführen wollte, und der Schluss liegt auf der Hand, dass er eben schon damals ein solcher gewesen ist, zumal man ja a priori durchaus erwarten sollte, dass der real existierende Nationalsozialismus auf Mitglieder einer seit jeher weit „rechts“ stehenden Burschenschaft wie der „Gothia“ höchst anziehend gewirkt hat. Gegen eine solche Einordnung spricht nicht, dass sich Srbik selbst vor I 938 niemals uneingeschränkt zum Nationalsozialismus bekannt hat, sondern sich entweder als Nichtnationalsozialisten bezeichnete, dem vieles am Nationalsozialismus Respekt abnötigte ${ }^{176}$, oder sich umgekehrt als dessen Pseudokritiker ausgab, dem vieles an ihm nicht gefiel ${ }^{177}$, woraus man dann freilich ableiten konnte, dass ihm noch viel mehr am Nationalsozialismus sehr wohl gefiel. Schließlich war Srbik bis 1938 Beamter in einem Staat, in dem die NSDAP offiziell verboten war und der seinen Angestellten in selbst totalitärer Weise die Mitgliedschaft in einer anderen (wenn auch seit 1936 der NSDAP nach und nach immer weniger feindlich gesinnten) Einheitspartei, nämlich der Vaterländischen Front, vorschrieb ${ }^{178}$. Außerdem

173 Derndarsky, Historie (Bibl.) 161 ; vgl. Heiber, Frank (wie Anm. 118) 267 („,Sachverständigenbank‘ der Geschichtsklitterung“), 597, 611, 693f.; Рiтcher, Srbik (Bibl.) 210-215.

174 Heiber, Frank (wie Anm. 118) 212 mit Anm. 1 und 222f. (,jenes [...] ängstliche Zurückweichen vor Franks Stirnrunzeln“); vgl. auch Derndarsky, Österreich (Bibl.) 166. Srbik hatte sich übrigens 1937 sogar in einem an Hitler selbst gerichteten Brief für Frank eingesetzt: Heı ber, Frank (wie Anm. 118) 577f., 716, 900f., 904.

175 So kritisch Graf-Stuhlhofer, Opportunisten (Bibl.) 153f. Beim Terminus „Sympathisant“ mag man doch eher an eine Person denken, die bloß den verbotenen „Völkischen Beobachter“ mit klammheimlicher Freude las.

176 Srbik, Korrespondenz (Bibl.) Nr. 288; vgl. SснӧnwäLder, Historiker (wie Anm. 5) 321 Anm. 50.

177 Vgl. Wan druszka, Stellung (wie Anm. 123) 9f.: „Wissen Sie, meinte er, ich bin 57 Jahre alt, und draußen geschieht doch auch sehr viel, wo ich nicht mitmachen kann. Ein anderes Wort ist mir noch aus dem gleichen Zusammenhang in Erinnerung [...]: Wissen Sie, es ist ja so vieles nicht erfreulich, was draußen geschieht, aber schließlich ist es doch die Zukunft." Dies bestätigt, dass Srbik im Nationalsozialismus damals natürlich keineswegs eine victa causa gesehen hat.

178 Vgl. dazu Irmgard Bärnthaler, Die Vaterländische Front. Geschichte und Organisation (Wien/Frankfurt/M./Zürich 1971) 105f., $146 f$. 
gab sich Srbik, wiewohl tatsächlich zur Konversation in keiner einzigen lebenden Fremdsprache (auch nicht Französisch!) befähigt ${ }^{179}$, gerne als Befürworter einer internationalen wissenschaftlichen Kooperation aus - so setzte er sich Anfang der I93oer-Jahre für einen Literaturaustausch mit den Siegermächten Frankreich und Belgien ein ${ }^{180}$ und vertrat nach seinem Ausscheiden aus der Regierung von I93 I bis 1935 Österreich als Mitglied der I 922 als Unterorganisation des Völkerbundes gegründeten Commission (auch: Comité) Internationale de Coopération Intellectuelle, der unter anderem auch Johan Huizinga, Marie Curie und Albert Einstein angehörten ${ }^{181}$-, aber selbst unter den schon etablierten Historikern des Dritten Reiches waren die überzeugten Nationalsozialisten bei Weitem in der Minderzahl ${ }^{182}$, sodass sich damals ergo weder für einen prinzipiellen Opportunisten noch für einen Geltungsmenschen ein allzu eifriges und einseitiges Bekenntnis zum Nationalsozialismus empfahl.

Gleichwohl ist in dieser Periode Srbik offensichtlich sowohl von vielen Nazis selbst wie auch von NS-Gegnern als ein ziemlich überzeugter Nationalsozialist wahrgenommen

179 Vgl. Srbik, Korrespondenz (Bibl.) Nr. 326: [...] meine sprachliche Gewandtheit in französischer (und englischer) Konversation zu gering ist; als Bonjour im Spätsommer 1938 auf dem 8. Internationalen Historikerkongress in Zürich den mit einem Gefolge junger deutscher Historiker, die wir maliziös seine Knüppelgarde nannten, auftretenden Srbik als Vertreter des Gastgeberlandes mit dessen französischem Kollegen Pierre Renouvin (1893-1974) bekannt machte und sich der Biograf Metternichs einer Konversation mit der Begründung entzog, dass er kein Französisch verstehe (Erdmann, Ökumene [wie Anm. 170] 244), muss also gar keine (Not-)Lüge vorgelegen sein, mit deren Hilfe Srbik einem unangenehmen Gespräch über den „Anschluss“ aus dem Weg gehen wollte; entsprechende Vorhaltungen wollte ja auf besagtem Kongress laut ER DMANN, 245 später der Däne Aage Friis (1870-1949) sowohl Srbik wie dessen Landsmann Harold Steinacker gemacht haben. (Jetzt haben Sie hundertausende [sic] deutscher Südtiroler den Italienern preisgegeben, und jetzt lassen Sie in Deutschland mit raffinierter Bosheit hunderttausende von Juden verhungern, etwas viel Schlimmeres als wenn die Bolschewiken ihre Feinde sofort totschlagen. Und das geschieht nicht in einem barbarischen Osteuropa, sondern in Staaten, die wir als Zentralplätze menschlicher Kultur betrachten.)

180 Vgl. Matthias Stein в ACh, Des Königs Biograph. Alexander Cartellieri (1867-1955). Historiker zwischen Frankreich und Deutschland (Jenaer Beiträge zur Geschichte 2, Frankfurt/M. 2001) 217. Während seines „Wiener Semesters“ im Frühling 1947 fiel dem Schweizer Historiker Jean Rudolf von Salis bei „der Besichtigung der Bibliothek des Historischen Seminars“ freilich auf, „daß die Standardwerke der englischen und französischen Geschichtswissenschaft fehlten“, wofür sich ihm folgende Erklärung aufdrängte: „Heinrich von Srbiks Geschichtsbild und politisches Bekenntnis waren großdeutsch gewesen. [...] Das alte Österreich-Ungarn und der Balkan waren hier ein Gegenstand umfangreicher wissenschaftlicher Forschung. Die westliche und die überseeische Welt aber scheinen abseits von der Aufmerksamkeit gelegen zu haben." So Jean Rudolf von SALIS, Grenzüberschreitungen. Ein Lebensbericht 1: 1901-1939, 2: 1939-1978 (Zürich 1975/78), hier 2 277; tatsächlich könnten die bemerkten Lücken in der Bibliothek aber auch einfach auf Devisenmangel und Unterdotierung beruht haben.

181 Derndarsky, Österreich (Bibl.) 245f.; NäF, Srbik (Bibl.) 99f.; Christoph Struupp, Johan Huizinga. Geschichtswissenschaft als Kulturgeschichte (Göttingen 2000) 269; Erdmann, Ökumene (wie Anm. 170) 244.

182 Vgl. etwa Schwa be, Geschichtswissenschaft (wie Anm. 149) 82-86. 
worden. Am 30. April 1936 wurde Srbik von der Universität München gleichzeitig mit dem NS-Dichter Josef Weinheber der mit jeweils Io.ooo RM dotierte „Wolfgang Amadeus Mozart-Preis für deutsches Volkstum in Österreich, Ungarn, auf dem Balkan und in Italien“ verliehen, der „zu Recht als eine Art reichsdeutscher Staatspreis für die nationale Literatur Österreichs bezeichnet" wurde ${ }^{183}$. Jean Rudolf von Salis ${ }^{184}$ wollte von einem Besuch bei Srbik in dessen Wohnung im Schloss Schönbrunn im Herbst I936 wegen dessen augenscheinlicher NS-Gesinnung „tief betroffen“ und „ziemlich niedergeschlagen“ zurückgekommen sein ${ }^{185}$, Ritter hat ihn 1937 einen „als Vertrauensmann des heutigen Deutschland international bekannten Historiker" angesprochen ${ }^{186}$, und dass Bundeskanzler Schuschnigg Srbik im Zusammenhang mit dem Juliabkommen 1936 einen Ministerbzw. den Vizekanzlerposten angeboten ${ }^{187}$ und ihn schließlich noch Anfang 1938 für einen

183 Vgl. die ausführliche Darstellung bei Amann, Zahltag (wie Anm. 124) 108-112, gemäß der Srbik des Weiteren „in Erwartung des Geldes“ sogleich „einen Kraftwagen“ erwarb; aber die Auszahlung des Preises erfolgte tatsächlich nach langem Hin und Her erst im Dezember desselben Jahres, während „Prof. v. Srbik“ schon im Juli „auf Bezahlung des Kraftwagens gedrängt“ worden war; zumindest die lange Verzögerung der Überweisung des Preisgeldes war also wirklich etwas, was „draußen geschah“ und „nicht erfreulich“ für Srbik war. 1938 war Srbik dann übrigens imstande, einer später in Theresienstadt zu Tode gebrachten jüdischen Akademikerin eine Villa in Wien-Währing abzukaufen, vgl. Derndarsky, Österreich (Bibl.) 195.

184 Vgl. zuletzt Urs Bit te R Li, Jean Rudolf von Salis. Historiker in bewegter Zeit (Zürich 2009).

185 Vgl. SALis, Grenzüberschreitungen 1 (wie Anm. 180) 162: „Ich war tief betroffen, als dieser angesehene Fachmann mit süffisant mitleidigem Lächeln über Meinecke sprach, der gar nicht begreifen könne, daß die deutsche Jugend nach dem ,Umbruch' sich etwas ,ungebärdig' benommen habe.“ Und 485 : „Von meinem Besuch bei Professor Heinrich von Srbik im Schloß Schönbrunn [...] kam ich ziemlich niedergeschlagen zurück; es war mir schwer verständlich, daß der Biograph Metternichs am Dritten Reich wenig oder nichts auszusetzen fand."

186 Ritter, Historiker (wie Anm. 147) 328 Nr. 78.

187 Vgl. etwa Moos, Bildungsbürgertum (Bibl.) 136; Srbik, Korrespondenz (Bibl.) Nr. 289; SToy, Institut (wie Anm. 35) 129 mit Literatur. Laut Schuschnigg apud Moos lehnte Srbik „ohne daß es zu Verhandlungen gekommen wäre, rundweg ab unter Berufung auf seine ausschließlich wissenschaftlichen Interessen und seine Absicht, sich aus der Politik herauszuhalten“, was Moos seltsamerweise nicht für eine Ausrede hält, vgl. Srbiks eigene briefliche Formulierung (Srbik, 461 Nr. 289) Den Eintritt in die Regierung habe ich bereits im Mai abgelehnt, da damals die Situation noch nicht reif genug war, und Boroda Kew ycz, Srbik (1978) (Bibl.) 10 („[...] versagte er sich einem System, dem er seine Zustimmung nicht geben konnte“) sowie auch Bä RNTH ALER, Vaterländische Front (wie Anm. 178) 143f. für die Information, dass Srbik auch noch im Sommer 1937 gegenüber einem Gesinnungsgenossen „nicht an den wahren Verständigungswillen der Regierung“ zu glauben vorgab. Etwas ganz anderes liest man wieder einmal bei Posch, Srbik (Bibl.) 189f.: „Gerade weil Srbik in allen Kreisen hoch angesehen war, wurde er vom Kanzler Schuschnigg 1935 [sic] eingeladen, das Amt eines Vizekanzlers zu übernehmen. Vom Gewicht seiner Persönlichkeit hoffte man sich einen Ausgleich der scharf aufgeflammten inneren Gegensätze. Srbik hätte dieses Opfer der inneren Befriedung zuliebe gebracht, aber als Bedingung stellte er eine weitgehende Amnestie und die Wiedereinberufung des gewählten Parlaments. Seine Berufung scheiterte damals an diesen Bedingungen, die aber, wie man heute wohl überall erkennen wird, seinem Einblick in die politischen Notwendigkeiten und Möglichkeiten das beste Zeugnis ausstellen.“ 
von drei der „nationalen Opposition“ zugestandenen Staatsratsposten vorgesehen hat ${ }^{188}$, erklärt sich natürlich auch nur aus einer langjährigen Einschätzung Srbiks als Vormann der österreichischen Befürworter eines baldigen „Anschlusses“ an Nazideutschland.

X.

Nach dem Advent von 1933 bis I 938 dürfte Srbik im Frühjahr und Sommer I 938 dann tatsächlich Wochen, ja Monate der Euphorie durchlebt haben, und insofern mag Reinalter Srbik mit Recht als zu dieser Zeit „von einem fremden Willen usurpiert“ bezeichnet haben ${ }^{189}$. Der „Minister a.D.“ brannte in dieser Zeit ein Feuerwerk von Jubelartikeln in diversen Zeitungen und Zeitschriften vom „Völkischen Beobachter“ abwärts oder aufwärts $a b^{190}$, beschloss auch private Briefe mit „Heil Hitler!“191 und konnte es sich auch nicht versagen, Näf, einem langjährigen und gewiss nie selbst als naziphil erschienenen Briefpartner, von der einmaligen Tat eines Österreichers vorzuschwärmen ${ }^{192}$, worauf dieser seinen Enthusiasmus dann auch demonstrativ nicht teilte ${ }^{193}$. In diese Periode fallen auch seine jeweilige Annahme der Bestellung bzw. „Wahl“194 (am I. April I938 in einer außerordentlichen Gesamtsitzung) zum Präsidenten der Akademie der Wissenschaften in Wien - der damalige „Reichsstatthalter“ Seyß-Inquart ${ }^{195}$ und der damalige

188 Volsansky, Pakt (wie Anm. 165) 101.

189 Reinalter, Srbik (Bibl.) 82f.

190 SCHÖNWÄLdER, Srbik (Bibl.) 532, 534 mit ausführlichen Quellenzitaten; vgl. dies., Historiker (wie Anm. 5) 183, 350 Anm. 299, 364 Anm. 573f.; Piтcher, Srbik (Bibl.) 197; zum Inhalt vgl. noch Heiss, Vergangenheit (wie Anm. 123) 50; eine einschlägige Bibliografie bis Anfang 1938 bei Wilhelm Deutsch, Verzeichnis der Schriften Heinrichs von Srbik, in: Monatsblatt des Vereines für Geschichte der Stadt Wien 20 (1938) 173 (Nr. 10/12: „Festgabe Heinrich von Srbik zu seinem 60. Geburtstag am 10. Nov. 1938 dargebracht").

191 Pitcher, Srbik (Bibl.) 209 Anm. 3 nach einer persönlichen Mitteilung Wandruszkas; der letzte private Brief Srbiks an Wandruszka mit einem solchen Gruß datierte vom 18.08.1938.

192 Srbik, Korrespondenz (Bibl.) Nr. 310 vom 12.04.1938.

193 Aber wird das Resultat des großdeutschen nationalen Staates nicht mit teuersten menschlichen und menschheitlichen Werten erkauft?, Brief vom 23.04.1938, vgl. Srbik, Korrespondenz (Bibl.) Nr. 311 sowie Peter STADLER, Die „Deutsche Frage“ in der deutschschweizerischen Geschichtswissenschaft nach 1945, in: Deutsche Geschichtswissenschaft nach dem Zweiten Weltkrieg (1945-1965), hg. v. Ernst Schulın, Elisabeth MüLLer-Luckner (Schriften des Historischen Kollegs, Kolloquien 14, München 1989) 236; vgl. auch Peter STADler, Das schweizerische Geschichtsbild und Österreich, in: Schweiz - Österreich. Ähnlichkeiten und Kontraste, hg. v. Friedrich Koja, Gerald Stourzh (Studien zu Politik und Verwaltung 14, Wien/Köln/Graz 1986) 33-47, hier 45.

194 Herbert Matis, Zwischen Anpassung und Widerstand. Die Akademie der Wissenschaften in den Jahren 1938-1945 (Wien 1997) 16.

195 Hingerichtet in Nürnberg; siehe zuletzt D[ieter-]A[nton] Binder, Seyss-Inquart Arthur, in: ÖBL 12 (Wien 2005) 213f. mit Literatur; Art. „Seyß-Inquart, Artur“, in: Klee, Personenlexikon (Bibl.) 580. 
Unterrichtsminister Menghin ${ }^{196}$ hatten zunächst geplant, das „Führerprinzip“ auch sogleich auf die Akademie in Wien anzuwenden, aber der strukturkonservative Srbik insistierte auf einer in Bezug auf ihren Ausgang natürlich gar nicht zweifelhaften „Wahl“, sodass nach außen hin eine tatsächlich gar nicht gegebene Kontinuität vorgetäuscht wurde - und der „Ernennung zum Mitglied des großdeutschen Reichstags durch den Führer und Reichskanzler“ (ebenfalls im April 1938) ${ }^{197}$, der dann die Aufnahme in die NSDAP per I. Mai 1938 folgte. „In Anerkennung seiner Verdienste um die deutsche Einheit erhielt er die niedrige Mitgliedsnummer 6.104.788.“198 Am I8. August I938 hat Srbik zum letzten Mal in einem privaten Brief an Wandruszka mit „Heil Hitler!“

196 Siehe zuletzt Pesditsche k, Barbar (wie Anm. 106) bes. 208 Anm. 1133 mit Literatur.

197 Im Rechtfertigungsschreiben vom 03.09.1945 heißt es, daß ich ohne mein Wissen und meinen Willen auf die Wablliste gesetzt worden bin und erst durch den Rundfunk von dieser Tatsache erfahren habe. [...] Zur Annahme der Reichstagsmitgliedschaft bewog mich nicht zuletzt das Interesse der Akademie der Wissenschaften, deren Wohl mir anvertraut wurde (De R N DARsky, Historie [Bibl.] 171f.); bei Posch, Srbik (Bibl.) 190 liest man: „Eines Morgens las er in der Zeitung seine Ernennung zum Mitglied des Reichstages. “Laut Reimann, Srbik (Bibl.) 68 nahm Srbik das „Mandat“ vielmehr nur aus Furcht vor Repressalien gegen sich und auch seine Familie an: „Beinahe hätte er Glück gehabt. Die Parteigrößen in Berlin stießen sich an seinem Namen, auch war er nicht Parteimitglied. [...] Die Entscheidung dürfte Hitler selbst gefällt haben. Für ihn war ein so hochgeschätzter Mann wie Srbik als Reichstagsabgeordneter eher ein Glücksfall“; vgl. demgegenüber den Bericht Glaises von Horstenau über eine Unterredung mit Hitler: Ich sprach über dynastische, Staaten- und Volkstumsgeschichte und erwähnte den Namen Srbik, der Hitler offenbar sehr wenig - wenn überhaupt etwas - sagte, General im Zwielicht 2 (wie Anm. 15) 287.

198 Graf-Stuhlhofer, Opportunisten (Bibl.) 154. Den 01.05.1938 als Aufnahmedatum bestätigt Srbik in seinem Rechtfertigungsschreiben vom 03.09.1945 übrigens auch selbst und tritt damit gegen den Vorwurf der Illegalität auf, DER NDARsKy, Österreich (Bibl.) 494. Srbik erhielt eine weitaus niedrigere Mitgliedsnummer als z.B. Rudolf Egger (vgl. Martina Pesditsснек, Wien war anders - Das Fach Alte Geschichte und Altertumskunde, in: Geisteswissenschaften im Nationalsozialismus [wie Anm. 36] 287-316, hier 300f.) oder Franz Miltner (vgl. Martina Pesditsche k, Franz Miltner, in: Lebensbilder I - Klassische Archäologen und der Nationalsozialismus, hg. v. Gunnar Brands, Martin Maischberger [Menschen - Kulturen - Traditionen. Studien aus dem Forschungscluster des Deutschen Archäologischen Instituts 2, Rahden/Westf. 2012] 177-191); siehe dort auch allgemein zur Aussagekraft von Mitgliedsnummer und Beitrittsdatum. Zu Srbiks Parteieintritt vgl. auch Reinalter, Srbik (Bibl.) 82f. und Schönwälder, Historiker (wie Anm. 5) $320 f$. Anm. 50. In seinem Aufnahmeantrag vom 29.05.1938 berief Srbik sich darauf, während der Systemzeit „nationalsozialistische Studenten und junge Gelehrte“ gefördert und „Nationalsozialisten durch Intervention und sonstige Hilfe“ unterstützt zu haben, und führte „Begründung und Führung der ,gesamtdeutschen Geschichtsauffassung “ als „sonstige Tätigkeit für die NSDAP“ an; DerndArsky, 139; vgl. Gernot Heiss, Pan-Germans, Better Germans, Austrians: Austrian Historians on National Identity from the First to the Second Republic, in: German Studies Review 16,3 (Oct., 1993) 411-433, hier 413; Ota Konrád, Geisteswissenschaften nach den Umbruchsjahren 1918 und 1938. Die Deutsche Universität in Prag und die Universität in Wien im Vergleich, in: Wissenschaft macht Politik. Hochschule in den politischen Systemumbrüchen 1933 und 1945, hg. v. Sabine Schleiermacher, Udo Schagen (Wissenschaft, Politik und Gesellschaft 3, Stuttgart 2009) 193-218, hier 207 mit Anm. 56. 
gezeichnet, zu Herbstbeginn muss der besagte euphorische Zustand ${ }^{199}$ also beendet gewesen $\operatorname{sein}^{200}$, aber aus welchem Grund?

Dass sich Srbik durch die allgemeine Unfreiheit, die kriegstreiberische Politik oder die Verbrechen an den Juden abgestoßen gefühlt hat, kann mit Sicherheit ausgeschlossen werden. Zum einen muss ihm die Herrschaftspraxis der Nationalsozialisten aufgrund seiner häufigen Aufenthalte im und vielfältigen Kontakte zum Dritten Reich vor I 938 bereits auf das Beste bekannt gewesen sein, zum anderen hat er gerade diese drei genannten zentralen Aspekte der nazistischen Machtausübung auch in den Jahren nach 1938 keineswegs etwa nur im Rahmen von Akademieveranstaltungen ${ }^{201}$, sondern vielmehr immer wieder auch ohne

199 Bei Posch, Srbik (Bibl.) 190 liest man einmal mehr eine aller schriftlichen Evidenz widersprechende Behauptung („Das Märzereignis des Jahres 1938 weckte in ihm viel mehr bange Sorge als Freude“). Über die Erzählung Schüßlers, Srbik sei am Abend des 15. März 1938 „von Sorge beschattet“ gewesen und habe als Folge eines Zustands der Seele, „in welchem sie dunkel[,] aber bestimmt die Zukunft voraussieht“, nicht zu sprechen vermocht (Wilhelm Schüssler, Sonne [wie Anm. 160] 113; vgl. auch PASteiner, Geschichtsauffassung [Bibl.] 222), braucht man wohl überhaupt nicht erst lange zu deliberieren - was immer Schüßler über die NS-Zeit zu berichten weiß, gehört gerade so in die Kategorie des Märchens wie z.B. die „Erinnerungen “ Fritz Schachermeyrs an diese Zeit, siehe Pesditsche к, Barbar (wie Anm. 106) 271, $375 f$., 668. Allerdings will sich auch WANDRUSZKA, Stellung (wie Anm. 123) 10 daran erinnern, dass sein akademischer Lehrer schon im März 1938 durchaus nicht so jubelte, wie ich das eigentlich von ihm erwartet hatte, und, darauf angesprochen, die Erklärung gab: Ach, wissen Sie, [...] ich weine eben doch der österreichischen Staatlichkeit manche Träne nach; diese angebliche elegische Stimmung könnte aber jedenfalls noch nicht gut durch eine Enttäuschung über den real existierenden Nationalsozialismus bedingt gewesen sein; Srbik mag sich bloß nach der endlichen Erreichung eines so lange und inständig angestrebten Ziels für kurze Zeit im sprichwörtlichen „schwarzen Loch“ befunden haben.

200 Auch Schüßler erwähnt in einem Brief vom 22.09.1938 kleine[n] Wünsche $u[$ nd] Bedenken, die Srbik einige Zeit zuvor geäußert haben muss; Srbik, Korrespondenz (Bibl.) Nr. 320. Einschlägig ist hier wohl auch der etwas elegisch anmutende Grundton von Heinrich Ritter von SR BIK, Stirb und werde, in: Das Innere Reich 5, 1. Halbjahresband (April-September 1938) $118 \mathrm{f}$.

201 Dass Srbik bei solchen Anlässen regelmäßig den Erwartungen der Partei voll entsprach und sich höchst regimekonform äußerte, beweist für sich genommen wenig, zumindest wenn man Srbiks späterer Beteuerung Glauben schenken wollte, dass er durch die Ausübung seines Präsidentenamtes bloß Schlimmeres zu verhüten bestrebt war - offizielle Reden im Rahmen von Akademieveranstaltungen sind ja zudem prinzipiell gesellschaftlich irrelevant und konnten daher auch grundsätzlich gar keinen Schaden anrichten. Für Srbiks Akademieansprachen bzw. auch Amtsführung als Akademiepräsident während der NS-Zeit im Allgemeinen vgl. bes. Franz Graf-Stuhlhofer, Die Akademie der Wissenschaften in Wien im Dritten Reich, in: Leopoldina-Symposion. Die Elite der Nation im Dritten Reich - Das Verhältnis von Akademien und ihrem wissenschaftlichen Umfeld zum Nationalsozialismus, vom 9. bis 11. Juni 1994 in Schweinfurt, hg. v. Christoph J. Scriba (Acta historica Leopoldina 22, Halle a. d. Saale 1995) 133-159; Matis, Anpassung (wie Anm. 194) passim; Gerhard Oвек коғler, Politische Stellungnahmen der Akademie der Wissenschaften in Wien in den Jahren der NS-Herrschaft, in: Arbeiterbewegung - Faschismus - Nationalbewußtsein. FS zum 20jährigen Bestand des Dokumentationsarchivs des österreichischen Widerstandes und zum 60. Geburtstag von Herbert Steiner, hg. v. Helmut Konrad, Wolfgang Neugebauer (Wien/München/Zürich 1983) 115-126, 446-448. 


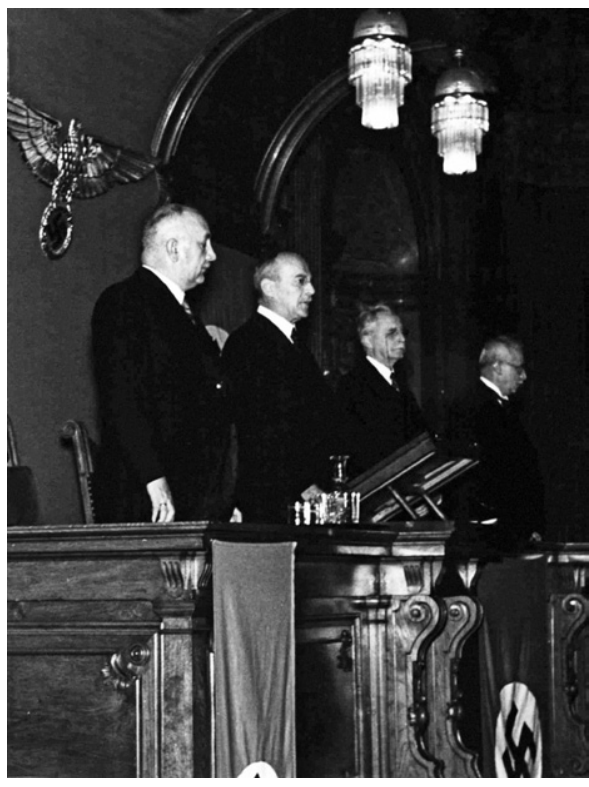

Abb. 23: Das Präsidium der Akademie, die Professoren Ernst Späth, Srbik, Egon (Ritter von) Schweidler und Hans Hirsch (v.l.n.r.), bei der Eröffnung der Feierlichen Sitzung der Akademie der Wissenschaften in Wien am 23. November 1938

jeden äußeren Anlass und ergo zweifellos höchst freiwillig und aus einem inneren Drang heraus gerechtfertigt oder gepriesen. Dafür seien im Folgenden nur einige wenige charakteristische Beispiele aufgeführt:

Die totalitäre Inanspruchnahme des Einzelnen durch die nationalsozialistische „Volksgemeinschaft“ hat Srbik etwa wie folgt begrüßt: „Wir wissen uns hiermit im Einklang mit dem Totalitätsbegriff, dessen Wirklichwerden auf politischem und sozialem Gebiet wir mit tiefem Empfinden und Wollen erleben. Erschüttert und erhoben begreifen wir das Wesen der deutschen Volksgemeinschaft, die Erhöhung der gesellschaftlichen Lebensebene von Millionen Deutscher und die Angleichung der bisherigen Klassen, das Heraufkommen eines neuen Volkszeitalters von organischer Natur. [...] Beide Horte der Kultur [sc. deutsche Universität und deutsche Technische Hochschule] [...] sind nun durch den Gedanken der Dienstpflicht der Wissenschaft am Volkstum innerlich verknüpft."202

Hinsichtlich der Kriegspolitik hat Srbik etwa in dem wenige Tage nach dem „Anschluss“203 verfassten Nachwort zur 2. Auflage seiner Broschüre „Mitteleuropa“ den „Führer“ gleich zu weiterer Aktion aufgefordert: „Adolf Hitler selbst weiß es und hat es erklärt, daß ein völliges Sichdecken von Nation und Staat für das deutsche Volk eine Unmöglichkeit ist, so wie wir dies für Ostmitteleuropa betont haben. Die organische Gliederung Mitteleuropas aber, das ,neue Gestaltungsprinzip, das von dem deutschen Gesamtvolk für die durch Schicksalsgemeinschaft verbundene gesamte Erdteilsmitte ausgehen soll', das ist auch heute noch, so sehr wir diesem Ziele näher gekommen sind, die Aufgabe der Zukunft. Der feste Glaube, daß sie vom deutschen Volk gelöst werden wird,

202 Heinrich Ritter von $S_{\text {R B I }}$, Geleitwort, in: Die deutschen Technischen Hochschulen. Ihre Gründung und geschichtliche Entwicklung (München 1941) XI-XIV, hier XIIIf.

203, „... [ als durch die elementare Macht des nationalen Willens, der die erdrückende Mehrheit des deutschen Volks in Österreich erfüllte, und durch die unvergleichliche Entschluß- und Tatkraft des deutschen Führers eine neue Epoche für Mitteleuropa und für die deutsche Volksgemeinschaft heraufgeführt wurde“; Heinrich von SR B I K, Mitteleuropa (wie Anm. 134, ${ }^{2} 1938$,) 41. 
lebt in uns, und ihr mit ganzer Seele zu dienen, ist unsere heilige Pflicht. “204 Als der „Führer" bzw. das „deutsche Volk“ einen Teil dieser „Aufgabe“ ein Jahr später wirklich „gelöst" hatten, feierte Srbik die Annexion Böhmens und Mährens nicht nur auf die damals gemeinhin übliche Weise ${ }^{205}$, er sprach nunmehr den Tschechen auch so eindeutig wie nie zuvor die Fähigkeit zur Staatsbildung ab: „Das Nationalitätenrecht der Monarchie war diesseits der Leitha eine höchst bedeutsame Leistung, aber das tschechische Volk beugte sich so wenig den realen Notwendigkeiten, wie es dies als Herr eines national gemischten Staates verstanden hat. Die eigenen staatsbildenden und staatserhaltenden Kräfte der intellektuell und wirtschaftlich sehr begabten Nation reichten offensichtlich niemals aus. Immer bedurfte sie einer deutschen Hand der Kraft und der Gerechtigkeit zu ihrem eigenen Wohl." 206

Im 1942 erschienenen vierten Band der „Deutschen Einheit“ sind keineswegs nur die berüchtigten zwei letzten Seiten obszön, die Hitlers Kriegspolitik und deren Resultate feiern und die Näf so gerne ungeschrieben geblieben gehabt hätte ${ }^{207}$, sondern beleidigen auch andere Passagen in elementarer Weise Verstand und Geschmack. „Die Stunde“ des Zweiten, von Bismarck begründeten Reiches „schlug“ für Srbik „vor allem deshalb, weil es schließlich Weltpolitik großen Stils ohne das Fundament des einheitlichen deutschen Volksgedankens trieb. Im zweiten Reich traten Volk und Staat, Geist und Staat auseinander. Es fehlte [...] das beseelende und beflügelnde realgeistige Dasein. Nur ein Beweis sei angeführt. [...] In der weit überwiegenden Mehrheit des deutschen Volkes [...] verengte sich in diesem zweiten Reich der Volksbegriff so sehr auf den Bundesstaat, daß irrig von der Vollendung der deutschen Einheit gesprochen und daß irrig ,Deutschland' mit ,Deutsches Reich“ gleichgesetzt wurde, als ob nicht Millionen gleichwertiger deutscher Volksgenossen auf uraltem deutschen Volks- und Kulturboden außerhalb des Reiches lebten und für das Gesamtvolk arbeiteten, kämpften und litten. Der Deutsche Österreichs wurde oft als ,Österreicher', der Deutsche Rußlands als ,Russe ${ }^{\text {‘208 }}$ vom ,Deutschen', dem Angehörigen des Reiches, abgehoben [...], das neue Reich vergaß der deutschen Sendung Österreichs und der anderen ,Auslanddeutschen'. [...] Den deutschen Österreichern blieb

204 Ebd. 42. Dass „Lösungen“ nach Art der vorgeschlagenen ins Verderben führen müssen, ist jedenfalls Ritter zur selben Zeit schon klar gewesen; vgl. Gerhard Rit te R, Großdeutsch und kleindeutsch im 19. Jahrhundert, in: Schicksalswege deutscher Vergangenheit. Beiträge zur geschichtlichen Deutung der letzten hundertfünfzig Jahre. FS für Siegfried A. Kaehler, hg. v. Walther Нu в ат ссн (Düsseldorf 1950) 177-201, hier $200 f$.

205 „Die Standarte des Führers ward auf der Burg in Prag aufgezogen, Ereignisse von unfaßbarer Größe füllten diese Tage“; Heinrich Ritter von SR в I , Deutsche Führung - der Segen des böhmischen Raumes, in: Sudetendeutsche Monatshefte (Mai 1939) 225-228, hier 228.

206 Ebd. 227f. Der letzte der zitierten Sätze ist auch im Original gesperrt gedruckt.

207 Vgl. Derndarsky, Historie (Bibl.) $162 \mathrm{f}$.

208 Vermutlich eine subtile Rechtfertigung des Überfalls auf die Sowjetunion. 
nahezu allein die Wahrung der Südostverpflichtung des deutschen Volkes überlassen."209 Gefeiert wird der Umstand, „daß Österreich am Lebensabend Franz Josephs mit Hekatomben von Blutopfern in die gesamtdeutsche Gemeinschaft wieder eingetreten ist "210, erlebte das deutsche Volk doch auf diese Weise „wieder seine Geschichte und den Lebens- und Ordnungsraum seines ersten, seines ,heiligen Reiches“ " mit der Folge, dass „der volksdeutsche Gedanke und Wille [...] durch den Einheitsschöpfer von Volk und Reich, den Sohn des deutschen Österreich, zur Wirklichkeit geworden " ist ${ }^{211}$.

Bei Srbiks Einstellung gegenüber Juden ist schon Derndarsky aufgefallen ${ }^{212}$, dass bald nach dem „Anschluss“ klar antisemitische Aussagen nicht mehr bloß in seinen privaten Briefen $^{213}$, sondern auch in seinen (mehr oder weniger wissenschaftlichen) Veröffentlichungen aufscheinen. Ein eindeutiges Bekenntnis zum Rassenantisemitismus findet sich etwa im 1942 erschienenen dritten Band der „Deutschen Einheit“: „Die Ablehnung des Judentums beruhte wie von alters her auf wirtschaftlichen und sozialen [...], und auf religiösen Motiven, aber in ihr wirkte sich auch nach wie vor die instinktive Abneigung gegen fremdes Blut und seine seelisch-geistige Eigentümlichkeit aus. [...] Aufklärung und Menschheitsidee hatten zur Assimilationsbewegung und zur bürgerlichen Emanzipation der Juden aus dem Ghetto geführt, aber der Glaube, daß sie nun ihr eigenes Volkswesen aufgeben und in das Wirtsvolk innerlich eingehen werden, hatte sich im ganzen als nicht richtig erwiesen. Gewiß, es gab immer wieder Juden, die deutsches Wesen bewunderten, innerlich erlebten und liebten, und durch Blutmischung ist wohl auch im Einzelfall nach einigen Generationen eine Aufsaugung von Juden durch das Volk erreicht worden, zu dem sie sich bekannten. Aber eine wirkliche Einschmelzung des reinblütigen Juden in den fremden Volkskörper [...] erwies sich als Unmöglichkeit. [...] Blieb doch selbst in

209 SR вік, Einheit 4 (wie Anm. 5) 481.

210 Umgekehrt ließ Srbik in der dritten Berliner Rede von 1936 „Hekatomben von Reichsdeutschen auch für Österreich“ fallen. Vermutlich begeistert rief er damals aus: „Schicksalsverbundenheit bis zum Letzten! Russische Gegnerschaft gegen Österreich-Ungarn hatte sich auf Deutschland, französische und englische Gegnerschaft gegen Deutschland hatte sich auf Österreich ausgedehnt!“; Heinrich Ritter von SR B I , Österreich in der deutschen Geschichte (München 1936, $\left.{ }^{2} 1936,{ }^{3} 1938,{ }^{4} 1943,{ }^{5} 1944\right) 77$.

211 SR BIK, Einheit 4 (wie Anm. 5) 482.

212 Derndarsky, Historie (Bibl.) 162.

213 Dass der Antisemitismus beim privaten Umgang mit Srbik eine höchst bedeutsame Rolle gespielt haben muss, erhellt auch aus dem Umstand, dass sein enger Freund Bauer als eigenen Beitrag für die Srbik zu dessen 60. Geburtstag gewidmete Festschrift von 1938 eine antisemitische Polemik ausgewählt hat: Wilhelm BAuE R, Zur Judenfrage als gesamtdeutscher Angelegenheit zu Beginn des 19. Jahrhunderts, in: Gesamtdeutsche Vergangenheit. Festgabe für Heinrich Ritter von Srbik zum 60. Geburtstag am 10. November 1938, hg. v. Dems., Ludwig Bittner, Taras von Borodajkewycz, Otto Brunner, Wilhelm Deutsch, Lothar Gross, Hans Hirsch, Reinhold Lorenz (München 1938) 236-247 (wo u.a. den „Bastarden des Geistes“ wie Heinrich Heine „geradezu satanische Ausfälle wider das Christentum“ zugeschrieben werden). 
dem größten wissenschaftlichen Vorkämpfer des christlich-germanischen Gedankens, in Friedrich Julius Stahl, ein starkes Erbgut jüdischer Gedanken- und Gefühlswelt und eine bestimmte innere Fremdheit gegenüber dem deutschen Denken erhalten. Und immer wieder kam die zur Abstraktion, zur Analyse, zur rein gedanklichen Konstruktion neigende jüdische besondere Geistesart zur Geltung, und der dialektisch-kritische Scharfsinn überwog nur allzuoft die schöpferische Fähigkeit ${ }^{214}$. [...] Konservativismus und gesellschaftszersetzende Agitation durch eine schneidend harte und kalte, advokatorische Art der Publizistik und Rede - immer blieb doch ein untilgbares Merkmal der eigenen Rasse in den Juden wirksam. "215 Selbst bei seiner etwas halbherzigen Verteidigung Meineckes gegen einen profilierungssüchtigen Jungnazi in der $\mathrm{HZ}^{216}$ versäumte er keineswegs gleich zu Beginn die Klarstellung, dass er selbst im Gegensatz zum Angegriffenen sehr wohl Rassenantisemit sei ${ }^{217}$. Wenn für Srbik zu dieser Zeit das singuläre Verbrechen

214 Nach 1945 schrieb Srbik dann nur mehr von einem „mehr aufnehmenden als originär schaffenden Stahl“; SR BIK, Geist 1 (wie Anm. 14) 399.

215 Sr вік, Einheit 3 (wie Anm. 5) 20f.; vgl. für diese Passage bes. die Analyse bei Christian Gerbel, Zur ,gesamtdeutschen " Geschichtsauffassung, [zu] der akademischen Vergangenheitspolitik der Zweiten Republik und dem politischen Ethnos [sic] der Zeitgeschichte, in: Transformationen gesellschaftlicher Erinnerung. Studien zur „Gedächtnisgeschichte“ der Zweiten Republik, hg. v. DEms. u.a. (Reihe Kultur.Wissenschaften 9, Wien 2005) 86-130, hier 90f., der Srbik aus diesem Anlass nicht zu Unrecht mit Schachermeyr vergleicht, siehe zu dessen Rassenlehre Pesditscheк, Barbar (wie Anm. 106) 307-314. Im selben Band der „Deutschen Einheit“ sucht $S_{\text {R в г к }}$ 81f. übrigens sogar auch noch Kaiser Franz Joseph als gefühlsmäßigen Antisemiten zu erweisen: „Das Bürgertum Wiens ließ sich von Menschen eines Fremdvolkes führen, das in Österreich ebenso dynastisch und staatspatriotisch auftrat, wie es sich im deutschen Nationalverein nationalstaatlich und österreichfeindlich betätigte. Der Kaiser [...] fühlte zwar eine innere Fremdheit gegenüber dem Judentum und empfand es als störend, daß sich in seinem geliebten Ischl ,die Badegäste und die Juden ' um seine Person drängten, aber er glaubte doch staatlichen Notwendigkeiten zu gehorchen, wenn er dem gesellschaftlichen und dem Machtauftrieb der Juden freie Bahn ließ." Des Weiteren ließ Srbik auch noch Goethe

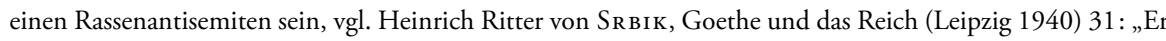
war überzeugt von den fortdauernden Eigenschaften der Rasse und empfand lebendig die Artverschiedenheit des Deutschen und des Juden."

216 Heinrich Ritter von SR BIк, Rezension von: Gerhard Schröder, Geschichtsschreibung als politische Erziehungsmacht (Diss. Heidelberg 1939), in: HZ 162 (1940) 335-339, hier $338 f$.

217 „Seit vielen Jahren stehe ich auf einem ganz anderen politischen Feld als Meinecke. Ich habe seine Wandlung vom Konservativen zum Demokraten und Anwalt der Weimarer Republik nicht mitgemacht, seine Anschauungen in der Rassenfrage nicht geteilt, [...] und ich glaube nicht an das ,Eiland reiner Wissenschaft ${ }^{\star}[\ldots]$ und hege nicht die Leidenschaft zum reinen Geist [...]"; dabei ist Meinecke nach heutigen Begriffen selbst Antisemit gewesen, und zwar sogar noch nach 1945, vgl. Pesditsche K, Barbar (wie Anm. 106) 646. All dieser Rassenantisemitismus hinderte Srbik im Übrigen nicht daran, mit Kollegen jüdischer Herkunft wie Hans Rothfels oder Friedrich Engel-Janosi namentlich vor deren Emigration geradezu freundschaftliche Beziehungen zu unterhalten, vgl. Srbik, Korrespondenz (Bibl.) Nr. 318f. (welche Briefe ein Versprechen Srbiks bezeugen, sich für Rothfels um eine Stelle im englischsprachigen Ausland zu bemühen, nachdem Anstrengungen im Inland keinen Erfolg gebracht hatten; ECKEL, Rothfels [wie Anm. 10] 194f.; vgl. auch Derndarsky, 
des Holocaust auch noch unvorstellbar gewesen sein mag, so hat er hier doch wie auch im Fall der Tschechen auf einen wehrlos auf dem Boden liegenden Gegner brutal eingetreten.

Srbik ist des Weiteren offenkundig der Meinung gewesen, dass die von ihm die längste Zeit behaupteten besonders „kostbaren“ geistig-seelischen Anlagen des deutschen Volkes genetisch bedingt waren. „Bluterbe“ war eines seiner Lieblingswörter, und der Begriff diente evidentermaßen nicht nur zur Erklärung äußerlicher Eigenschaften. Er hat sich schließlich im zweiten Band seines Spätwerks „Geist und Geschichte“ äußerst respektvoll $^{218}$ über die nationalsozialistische Rassendoktrin und deren Ahnherren geäußert ${ }^{219}$ und sich von dieser schließlich nur in einer Art und Weise distanziert ${ }^{220}$, die wohl auch noch den Beifall eines Houston Stewart Chamberlain, Julius Evola oder Alfred Rosenberg hätte finden können ${ }^{221}$. Freilich hat Srbik in der Regel immer „völkisch“ und nicht

Österreich [Bibl.] 130f., 487f.) und dann auch noch Srbiks Brief an Rothfels (Korrespondenz Nr. 375 von Mitte Februar 1949, vgl. Winfried Schulze, Deutsche Geschichtswissenschaft nach 1945 [München 1989] 128f.) bzw. das durchaus warmherzige Gedenken von Hans Rothfels (Rotнғels, Geschichtswissenschaft [wie Anm. 170] 95) einerseits und von Engel-Janosi sowohl in seinem Nachruf auf Srbik (ENGEL-JANOSI, Srbik [Bibl.] 78f.) als auch in seinen Memoiren (DERs., Erinnerungen [wie Anm. 53] 101, 155, 158) andererseits. Es war Srbik auch peinlich, die „unarischen“ Mitglieder der von ihm nunmehr präsidierten Akademie mit von ihm selbst gefertigten Briefen von ihrem Hinauswurf in Kenntnis zu setzen - deshalb suchte er diese über Dritte zu einem freiwilligen Austritt zu bewegen. Srbik war hier das Opfer seiner bürgerlichen Erziehung, in der rüpelhaftes Verhalten gegenüber tatsächlich nicht im mindesten „artfremden“ Angehörigen der eigenen Gesellschaftsschicht nicht vorgesehen war.

218 Bemerkenswerterweise respektvoller als 1910 in einer Rezension, vgl. Heinrich Ritter v. SR BıK: Historische und politische Aufsätze von Otto Hintze, in: Zs. für die österreichischen Gymnasien 61 (1910) 1114-1116, hier 1115 („[...] wo ein kräftiges Wörtlein für die Bedeutung der romanisch-germanischen Kulturwelt gegenüber Gobineau und Chamberlain eingelegt und gezeigt wird, durch wie mannigfache Momente die alten Rassen vermischt, verändert, neue Rassen teils durch das Staatsband selbst gebildet werden").

219 So heißt es etwa über Ludwig Schemann, Gobineaus Übersetzer und eifrigsten Propagandisten im deutschen Sprachraum: „Dieser ehrliche Wahrheitssucher von heißer Volks- und Vaterlandsliebe hat sich als Verfasser der ,Rassenfrage im Schrifttum der Neuzeit' [...] einige wissenschaftliche Verdienste erworben“" (SR BIK, Geist 2 (wie Anm. 14) 357f.).

220 Ebd. 360: „Die historische Empirie erkennt vielmehr Lösungen des Geistigen vom Biologischen und Rückwirkungen des Geistes auf das Bluterbe, und dieselbe Empirie lehrt die Rassenmengung in allen Völkern nicht etwa nur unter dem Gesichtspunkt verderblicher ,Entnordung ' und notwendiger ,Aufnordung', sondern oftmals auch als werteschaffend beurteilen. [...] Begegnung mit fremder Art bedeutet keineswegs nur Überfremdung, sie kann vielmehr die eigene Art zu geläuterter Bewußtheit und zu erhöhter Ebene führen [...]. Die Lehre aber von der deutschen Auserwähltheit und Sendung [...], der Hymnus auf das nordische Blut führten durch Überspannung und Maßlosigkeit und durch die Suggestion im Seelenleben der Masse zur unheilvollen Verdrängung der Abendland- und Menschheitsvorstellung der edelsten deutschen Geisteszeiten [...]. “Vgl. 238 auch den Satz „Die geistigen Tendenzen sind auch naturhaft bestimmt“.

221 Vgl. Pesditscheк, Barbar (wie Anm. 106) 310-312. 
„nordisch“ argumentiert ${ }^{222}$; dafür lassen sich zwei Gründe ausmachen: Zum einen hatte die Sprachwissenschaft das Slawische gerade so als Sprachzweig der indogermanischen Sprachfamilie erwiesen wie das Germanische, und da es zu Srbiks Lebzeiten üblich war, von der indogermanischen Natur einer Sprache auf eine „nordische“ Herkunft von deren Sprechern zu schließen, hätte eine „nordische“ Argumentation Srbik dem Verdacht ausgesetzt, das Ursprungsvolk seines Großvaters mit Namen Srbik durch ein Spielen über die „nordische“ Bande letztlich doch auf ein und dieselbe Stufe mit dem deutschen Volk stellen zu wollen. Zum anderen ist der „nordische Gedanke“ an der Universität Wien schon in den I920er-Jahren von einem anderen Ordinarius vertreten worden, der auf Srbik in höchstem Maße antipathisch wirken mußte, nämlich vom Kunsthistoriker Josef Strzygowski ${ }^{223}$. Dieser Ikonoklast bekämpfte so gut wie alles, was einem Strukturkonservativen wie Srbik heilig sein musste: er lehnte die „römische Machtkunst“ und das Barock als „unnordisch“ ab und verwarf auch die traditionellen Strukturen und Rituale des Universitäts- und Akademiebetriebs; dementsprechend suchte ihm Srbik nach Möglichkeit zu schaden ${ }^{224}$, und eine Übernahme seiner Argumentation und Terminologie verbot sich von selbst.

Schon die soeben angeführten wenigen, aber durchaus typischen Zitate lassen allein den Schluss zu, dass der längst wohletablierte „Mandarin“ Srbik, der sich ja nicht erst durch ein anpasserisches Verhalten einen Platz an der Sonne erkämpfen musste, alle einen nach üblichem Sprachgebrauch genuinen Nationalsozialisten ausmachenden inhumanen und in letzter Konsequenz verbrecherischen Ressentiments geteilt hat und darum selbst als genuiner Nationalsozialist anzusprechen ist. Eine solche Bewertung Srbiks entspricht einer offenen und verdeckten Rechtfertigung des Nationalsozialismus in seinem Spät-

222 Vgl. das Urteil „Er lehnt eine Bewertung rassischer Triebkräfte in der Geschichte ab“ in seinem Gau-Akt, Graf-Stuhlhofer, Opportunisten (Bibl.) 154 mit Anm. 25.

223 Vgl. zu diesem die Literatur bei Pesditscheк, Barbar (wie Anm. 106) 461 Anm. 2360 und jetzt weiters noch Carola JäGgi, Ex Oriente Lux: Josef Strzygowski und die ,Orient oder Rom'-Debatte um 1900, in: Okzident und Orient = Sanat Tarihi Defterleri/Kunsthistorische Hefte 6 (2002) 91-109; Suzanne L. MarCHAND, German Orientalism in the Age of Empire. Religion, Race, and Scholarship (Cambridge 2009) 403-410; Götz Роснат, Gerhard Sснміdт, Georg Vasold, Der Beitrag der Kunstgeschichte zur Ausformung der Humanwissenschaften, in: Geschichte der österreichischen Humanwissenschaften 5: Sprache, Literatur und Kunst, hg. v. Karl Aснам (Wien 2003) 418-444, hier bes. 418-424; Ulrich Tragatschnig, Josef Strzygowski. Ein Kunsthistoriker zwischen Modernität und „Nordstandpunkt“, in: Kunst und Wissenschaft aus Graz 2: Kunst und Geisteswissenschaften aus Graz. Werk und Wirken überregional bedeutsamer Künstler und Gelehrter: vom 15. Jahrhundert bis zur Jahrtausendwende, hg. v. Karl AcHAM (Wien/Köln/ Weimar 2009) 593-608.

224 Vgl. Josef Strzygowsкi, Geistige Umkehr. Indogermanische Gegenwartsstreifzüge eines Kunstforschers (Kultur und Sprache 11, Heidelberg 1938) 251: „Als ich die Altersgrenze erreichte und zurücktrat, wurde das Institut in so mutwilliger Weise zerstört, daß der sterbende Humanismus damit wohl eine seiner letzten Heldentaten verrichtet haben dürfte. [...] Der schuldige Teil war der damalige Dekan H. v. Srbik.“ 
werk ${ }^{25}$ und drängt sich ja im Übrigen schon immer wieder bei einer Lektüre der Dissertation von Moos auf, in der man zum Beispiel liest: „Ohne sichtbaren Widerstand paßt sich Srbik der innenpolitischen Gestaltung und dem außenpolitischen Ausgreifen des nationalsozialistischen Staates an, ohne erkennbare Auseinandersetzung macht er dem rassischen Grundprinzip des Nationalsozialismus Zugeständnisse, die in der Judenfrage nicht weit hinter der offiziellen Lesart zurückbleiben“226, oder „Seine Sicht des Judentums [...] zeigt eine nahezu vorbehaltlose Anpassung “227, doch falls Moos, der auch sehr prägnant bei Srbik nicht einmal eine „Distanzierung durch Schweigen“ konstatieren konnte ${ }^{228}$, schon selbst einen analogen Schluss gezogen haben sollte, so wollte er ein solches Resultat seiner Untersuchung jedenfalls nicht in entsprechende klare Worte fassen.

Als Grund für Srbiks offenkundige Entfremdung vom und Enttäuschung über den Nationalsozialismus kann nun andererseits höchst plausibel gekränkte Eitelkeit vermutet werden ${ }^{229}$. Angesichts seiner eingebildeten Verdienste um den „Anschluss“ mochte er auf ein neues Ministeramt, ja vielleicht gar auf das Amt einer „Grauen Eminenz“ à la Metternich am Hofe des „Führers“ selbst gehofft haben; spätestens Anfang Herbst hatte er sich dann aber wohl eingestehen müssen, auf rein dekorative Posten ohne jeden bedeutenden Einfluss abgeschoben worden zu sein. Weiters musste sich Srbik durch die bald einsetzende systematische Substitution des Wortes „Österreich“ durch „Ostmark“ besonders getroffen

225 Siehe unten S. 318-323.

226 Moos, Bildungsbürgertum (Bibl.) 174.

227 Ebd. 176.

228 Ebd. 141.

229 Als Parallele kommt etwa das Verhalten Martin Heideggers in Betracht, der als Rektor der Universität Freiburg (21.04.1933-27.04.1934) zunächst ungefähr ein Jahr lang das NS-Regime mit feurigsten Reden unterstützte, dann aber in dieser Hinsicht weitgehend verstummte und laut Ritter „seit dem 30. Juni 34 heimlich ein erbitterter Gegner des Nazitums war und auch den Glauben an Hitler, der ihn 1933 zu seiner verhängnisvollen Verirrung geführt hat, vollständig verloren hatte“ (Ritter, Historiker [wie Anm. 147] 409 Nr. 132). Nun hat Heidegger zwar Ritter gegenüber den sog. „Röhm-Putsch“ als auslösendes Moment für seinen Rückzug angegeben (vgl. ebd. 265 Anm. 3), viel plausibler ist aber die Annahme, dass der gemäß eigener Einschätzung größte Philosoph aller Zeiten (vgl. ebd. 319 Nr. 76) zunächst gehofft hatte, den Praeceptor Germaniae, ja den Praeceptor Ducis spielen zu können, und es dann als schwere Kränkung der eigenen Person empfand, dass die Nationalsozialisten auf seine Empfehlung, „das feine Porzellan entzwei“ zu schlagen, d.h. einen radikalen nationalen Sozialismus nach Art von Maos späterer „Kulturrevolution“ einzuführen und Deutschland völlig zu entchristlichen, einfach nicht eingegangen waren, siehe Ernst Nolte, Martin Heidegger. Politik und Geschichte im Leben und Denken (Berlin/Frankfurt/M. 1992) 146f.; zur höchstrangigen Radikalität von Heideggers damaligem sog. „Denken“ vgl. auch Daniel Morat, Von der Tat zur Gelassenheit. Konservatives Denken bei Martin Heidegger, Ernst Jünger und Friedrich Georg Jünger 1920-1960 (Veröffentlichungen des Zeitgeschichtlichen Arbeitskreises Niedersachsen 24, Göttingen 2007) 119-139; Peter Traw ny, Die Autorität des Zeugen. Ernst Jüngers politisches Werk (Berlin 2009) 132-138. Im Übrigen schien im Sommer 1938 „das Ansehen der Partei in der Öffentlichkeit“ auch ganz generell „gesunken zu sein“, vgl. etwa Radomír LuzA, Österreich und die großdeutsche Idee in der NS-Zeit (Forschungen zur Geschichte des Donauraumes 2, Wien/Köln/Graz 1977) 82. 
fühlen, zeigte sie doch an, dass man höheren Orts seiner höchstpersönlichen „Ehrenrettung Österreichs“ nicht die geringste Bedeutung beimaß und ergo seine zahllosen Schriften zur "gesamtdeutschen Geschichtsauffassung" nicht in der erhofften Weise rezipiert hatte ${ }^{230}$. Auch die Äußerungen seiner größten Apologeten weisen eindeutig in die eine Richtung, dass ihn von allen Aspekten der nazistischen Herrschaftsausübung im vormaligen Österreich am weitaus meisten die Missachtung und Geringschätzung österreichischer Besonderheit in Gegenwart und insbesondere Vergangenheit enttäuscht hat ${ }^{231}$. Auch sonst ist Srbik immer wieder „Opfer“ kleinerer Kränkungen und Zurücksetzungen geworden: So übte die Funktion des NSDAP-Beauftragten der Akademie zunächst der Botaniker Fritz Josef Knoll ${ }^{232}$ aus $^{233}$; der Gauleiter Josef Bürckel, dessen „rachsüchtige Methode, durch seine Saarpfalz-Freunde über die Köpfe der Österreicher hinweg zu regieren“, in der Wiener NSDAP auch sonst wenig Begeisterung hervorrief ${ }^{234}$, verhinderte „durch unmittelbares Eingreifen“ einen Einsatz Srbiks als Redner just auf einer Gaukulturwoche Saarpfalz, die vom I. bis 9. Oktober 1938 stattfand $^{235}$; und in einem Brief von Srbik an Ferdinand Bilger aus dem Februar I $944^{236}$ findet sich die Klage, dass ihn der „Völkische Beobachter“ im Dezember 1943 erneut um Mitwirkung gebeten, das von ihm gelieferte (und offenbar keineswegs als regimekritisch intendierte) Manuskript mit dem Titel „Geschichtswissenschaft und Politik“ dann aber nicht abgedruckt habe ${ }^{237}$. Anfang 1945 brachte Srbik selbst

230 Vgl. diesbezüglich bes. das Glaise-Zitat in Anm. 197.

231 Vgl. Ham an n, Kriegs- und Nachkriegserinnerungen (Bibl.) 372-377; Posch, Srbik (Bibl.) 190: „Vollends entrüstet war er über die in jenen Jahren so beliebte Herabwürdigung Österreichs und seiner Dynastie." Siehe auch die durch einen Brief von Ferdinand Bilger an Srbik bezeugte im Vertrauen gemachte Aussage Srbiks, dass er eigentlich immer österreichischer würde: Srbik, Korrespondenz (Bibl.) Nr. 311, und weiters Albert MassiCzex, Die Situation an der Universität Wien März/April 1938, in: Wien 1938, hg. v. Dems. (Forschungen und Beiträge zur Wiener Stadtgeschichte 2; Wien 1978) 216-229, hier 224f., der ebenfalls eine in Privatgesprächen geäußerte Kritik Srbiks erwähnt und dann leider als einziges konkretes Ziel von dessen Kritik den Umstand nennt, dass der NSDAP-Beauftragte für die Akademie zunächst nicht Srbik selbst, sondern der Botaniker Fritz Josef Knoll gewesen ist (siehe unten). Massiczek kritisiert übrigens seinerseits an Srbik, dass „das öffentliche Bekenntnis, daß man Jahre hindurch öffentlich einiges falsch gemacht hatte, [...] auch nach dem Sturz des NS-Regimes aus[blieb]“.

232 Vgl. General im Zwielicht 2 (wie Anm. 15) 585 Anm. 42.

233 Vgl. Massicze K, Situation (wie Anm. 231) 225: „Man kann sich vorstellen, was ein Ritter von Srbik fühlte, als er zwischen sich und Hitler den Botaniker Knoll als Führer zwischengeschaltet wußte. “ Doch genoss Srbik dann schon wenig später in der Formulierung von Oве r коғler, Politische Stellungnahmen (wie Anm. 201) 120 „bei den Nazis derartiges Vertrauen, dass er die Funktion des NSDAP-Beauftragten der Akademie“ von Knoll übernehmen konnte, siehe Matis, Anpassung (wie Anm. 194) $19 f$.

234 Luza, Österreich (wie Anm. 229) 98.

235 BAB, R 15/35, Bl. 99 (Bericht von Reichsamtsleiter im Amt Rosenberg Matthes Ziegler, vgl. zu diesem KleE, Personenlexikon [Bibl.] 694).

236 Srbik, Korrepondenz (Bibl.) 553 Nr. 364.

237 Und zwar mit der Begründung, dass die Schriftleitung im Fall eines Abdrucks die größten Schwierigkeiten 
seine nunmehrige Unzufriedenheit mit dem Nationalsozialismus gegenüber dem alten Freund Glaise von Horstenau schließlich wie folgt auf den Punkt: Vor dem I3. März I938 war man der gefeierte Historiker, seither ist man nur mehr ein vergreister Trottel ${ }^{238}$.

Nun ist natürlich grundsätzlich denkbar, dass der genuine Nationalsozialist Srbik angesichts solcher persönlicher Frustrationen bisweilen nicht nur die Faust in der Tasche geballt hat - als eben eine solche Ohnmachtshandlung und nicht mehr ist doch wohl sein sporadisches Geschimpfe auf die Preußen und sein gelegentlicher Lobpreis der k. u. k. Vergangenheit zu werten -, sondern auch stärker wider den Stachel gelöckt hat. Dergleichen hat augenscheinlich sein Schüler Borodajkewycz getan, der in den I96oer-Jahren traurige österreichweite Bekanntheit durch den Umstand erlangte, dass er seine Vorlesungen damals noch immer mit antisemitischen Bemerkungen „würzte“, und seither sicherlich zu Recht als typisches Beispiel für einen alten unbelehrbaren Nazi gilt. Borodajkewycz war schon in jungen Jahren illegal in die Partei eingetreten ${ }^{239}$, aber er nahm Demütigungen von deren Seite nicht immer treu ergeben hin: „Als er [...] einen gewünschten Bezugsschein nicht oder nicht gleich erhielt - was I 943 selbst für prominentere Nationalsozialisten schwierig war - ließ er sich aus persönlicher Verärgerung darüber zu abfälligen Bemerkungen über die Spinnstoffsammlung hinreißen, und äußerte schließlich sogar Zweifel am Endsieg“, und der deshalb am 7. Juli I 943 erfolgte Ausschluss aus der NSDAP wurde auf seine umgehende Remonstration hin drei Monate später tatsächlich annulliert und in einen Verweis umgewandelt ${ }^{240}$. Allerdings mag Borodajkewycz überhaupt eine aufmüpfigere Natur als sein verehrter akademischer Lehrer gewesen sein.

Srbiks Nachfolger Hantsch dürften vergleichbare Äußerungen seines Vorgängers jedenfalls eher nicht bekannt gewesen $\operatorname{sein}^{241}$, und abwegig scheint die verbreitete, gar nicht einmal nur auf die üblichen Apologeten beschränkte Auffassung ${ }^{242}$, dass Srbik durch die

erleiden würde. Srbik quittierte die Absage in besagtem Brief mit dem Bemerken, dass gerade dieses Blatt wenig meinen Beifall findet. Jedoch war er immer und gerade erst zuvor zu einer Veröffentlichung darin bereit gewesen. Nach dem Krieg erschien dann von Srbik übrigens ein Aufsatz mit einem ganz ähnlichen Titel „Geschichtswissenschaft und Gegenwartspolitik“ - in: Universitas 4 (1949) 647-650.

238 General im Zwielicht 3 (wie Anm. 15) 484.

239 Gerard Eric Kasemir, Die Borodajkewycz-Affäre 1965. Spätes Ende für „wissenschaftlich“ vorgetragenen Rassismus (unpubl. Dipl. Wien 1994) 16.

240 Ebd. $23 \mathrm{f}$.

241 Hantsch, Srbik (1951) (Bibl.) 132: „Mag sein, daß er diesen Widerspruch nicht so klar und kräftig zu äußern wagte, wie es geboten gewesen wäre [...].“ - Zu Hantsch siehe den Beitrag von Johannes Holeschofsky in diesem Band.

242 Vgl. Fritz Fellner, Geschichtsstudium in Kriegs- und Nachkriegsjahren, in: Erinnerungsstücke. Wege in die Vergangenheit. Rudolf Vierhaus zum 75. Geburtstag gewidmet, hg. v. Hartmut Lenmann, Otto Gerhard Oexle (Wien/Köln/Weimar 1997) 49-77, hier 55, 61; Fellner, Srbik (2002) (Bibl.) 339f. (wo ausdrücklich betont wird, dass es „nur wenige Dokumente, die derart deutliche Kritik an Hitlers Kriegspolitik 
Wiedergabe einer abschätzigen Äußerung Bismarcks über Napoleon I. im Rahmen einer Vorlesung über Bismarcks Außenpolitik ${ }^{243}$ Ende Juni I94I Hitlers gerade erst erfolgten Überfall auf die Sowjetunion zu verurteilen beabsichtigte: Srbik wollte ja selbst sogar schon lange vor I94I das „kostbare“ deutsche Blut im Baltikum und an der Wolga an ein großdeutsches Reich „angliedern“, und er war gemäß späterer Aussage seines Schülers Reinhold Lorenz sogar „especially pleased with the German victories in Russia through the fall and winter of I94I-42. Srbik had considered Hitler's invasion of the Soviet Union not only in accord with Germany's vital interests but also as a necessary step in defending European civilization against Bolshevishm" ${ }^{244}$. So stellt besagtes Zitat wohl nur einfach einen Akt der Bosheit gegenüber der von Srbik ja auch sonst recht wenig geschätzten Grande Nation ${ }^{245}$ und deren „Allerweltsherrscherdünkel“ dar - für Srbik war ja vielmehr das deutsche Volk mit der Weltführung beauftragt worden ${ }^{246}$.

öffentlich bekundet haben“, gebe); Moos, Bildungsbürgertum (Bibl.) 153; Reımann, Srbik (Bibl.) 62; Wandruszka, Srbik (1978/79) (Bibl.) 360.

243 Auch im Druck erschienen: Heinrich R. v. SR BIк, Die Außenpolitik des Deutschen Reiches 1871 bis 1890 (Soldatenbrief Nr. 2, Wien [1943]). Dieses Werk schließt 69f. wie folgt: „Die Politik seiner [nämlich Bismarcks] Nachfolger führte schließlich zu einer Weltkoalition gegenüber den Mittelmächten, zum Untergang des zweiten Kaiserreiches und zum Untergang der Donaumonarchie. Bismarck selbst hat im Jahre seines Rücktritts, im Jahre 1890, in einer Äußerung über Napoleon I. die zwanzig Jahre seiner außenpolitischen Führung des Reiches charakterisiert. Er sagte: ,Napoleon I. ging zugrunde, weil er, pochend auf seine kriegerischen Erfolge, mit allen Staaten Händel anfing, statt Frieden zu halten. Das Kriegsglück machte ihn rauflustig und übermütig. Er begab sich in seinem Allerweltsherrscherdünkel in Gefahren ohne Ende und kam darin um. Seine große Schöpfung ging nach kurzem Bestand in Brüche, weil er die erste Tugend des Staatsmannes, die weise Mäßigung nach den größten Erfolgen gegenüber den anderen Völkern nicht übte und Europa in einen Krieg nach dem anderen verwickelte, während ich nach 1871 den Frieden zu erhalten mich bemühte."“

244 Pitcher, Srbik (Bibl.) 218 Anm. 23. Im letzteren Sinn hat sich Srbik auch mehrfach öffentlich geäußert, so hat er in der Eröffnungsansprache auf der Feierlichen Jahressitzung der Akademie der Wissenschaft in Wien am 02.06.1943 (vgl. zu dieser bes. Ger bel, Geschichtsauffassung [wie Anm. 215] 88f.) u.a. von einem „Kampf der Seele gegen die Maschine, der Liebe gegen den Haß“ gesprochen (Heinrich Ritter von SR BIк, Eröffnungsansprache, in: ÖAW, Almanach für das Jahr 1943 = 93 [1943] 171-174, hier 172); waren für Srbik 1943 die Sowjetbürger offenbar seelenlose Maschinen, so hatte er diesen ein Jahr zuvor immerhin noch den Status von Pflanzen, ja vielleicht sogar Tieren zuerkannt, als er aus einem angeblichen Feldpostbrief eines Schülers beifällig zitierte, dass in der Sowjetunion „alles geistige Leben erloschen ist“ und „das rein Vegetative, Triebhafte vorherrscht" (Heinrich Ritter von SR BIK, Eröffnungsansprache, in: ÖAW, Almanach für das Jahr 1942 = 92 [1942] 169-172, hier 170).

245 Vgl. etwa Moos, Bildungsbürgertum (Bibl.) 67, 150-153.

246 Laut Hamann, Kriegs- und Nachkriegserinnerungen (Bibl.) 379-391 hat Srbik allerdings tatsächlich konstant und just auch öffentlich echte Regimekritik geübt, sich über den Antisemitismus der Nazis lustig gemacht (380) und „noch während des Krieges“ die Aussage getan: „Jeder, der ein Gefühl für Recht und Anstand besitzt, muß sich in Grund und Boden schämen für das, was jetzt alles tagtäglich im Namen unseres Volkes geschieht“ (385). Das Problem mit dieser Art von Evidenz ist, dass Hamanns Srbik eine geradezu heiligmäßige Lichtgestalt ist - fundamental antinazistisch, geradezu frankophil (371f.) und philosemitisch 
Richtig ist, dass sich Srbik bisweilen für vom Nationalsozialismus verfolgte Persönlichkeiten eingesetzt hat ${ }^{247}$; am bekanntesten ist wohl sein (notabene erfolgloses ${ }^{248}$ ) Eintreten bei seinem Kompatrioten Seyß-Inquart zugunsten des berühmten niederländischen (Kultur-)Historikers Johan Huizinga; dieser „bürgerlich-konservative“ NS-Gegner der ersten Stunde ${ }^{249}$, der seinerseits von 1929 bis 1942 der Abteilung „Letterkunde“ der Koniklijke Nederlandse Akademie van Wetenschappen vorgestanden war, war von deutschen Besatzungsorganen als Geisel inhaftiert worden. Dazu ist zu sagen, dass es 1945 wohl kaum irgendein NSDAP-Mitglied in gehobenerer Position gegeben hat, das nicht einem oder einer Verfolgten eine Wohltat erwiesen haben wollte; solche Interventionen erfolgten wohl nicht selten aus Berechnung oder Geltungsdrang, sie waren für die Intervenienten mit keinem Risiko verbunden und können deshalb auch nicht als Indiz für eine grundsätzlich NS-kritische Haltung angesehen werden. Interessanterweise hat Srbik selbst diese Art von Interventionen in seinem Rechtfertigungsschreiben vom 3. September $1945^{250}$ überhaupt nicht erwähnt, in Sonderheit auch nicht in dessen Paragrafen Io, seiner aus heutiger Sicht eher kurios anmutenden angeblichen Erfolgsbilanz als Akademie-Präsident ${ }^{251}$.

(380), niemals slawophob (371), couragiert, ironisch, humorvoll, ein begnadeter akademischer Lehrer, von dessen Unterricht „niemand“ etwas durch Zuspätkommen versäumen wollte (369), und offenbar mit einem solchen Charisma begabt, dass ihn die zahlreichen Nazispitzel, die man „an ihren säuerlich-aufmerksamen Mienen“ erkannte (370), letztlich doch nie wegen seiner so zahlreichen „unzeitgemäßen Äußerungen“ (369f.) denunzierten und ins KZ brachten. Dieser Superman Srbik kann mit dem Publizisten, Briefeschreiber und auch dem akademischen Lehrer Doderers und Jambors (siehe oben S. 279f.) namens Heinrich Ritter von Srbik leider unmöglich identisch gewesen sein. Vgl. auch schon Derndarsky, Fall (Bibl.) 164 Anm. 44 („nicht immer widerspruchsfrei“; gemeint ist wohl: in sich widerspruchsfrei).

247 Vgl. Hamann, Kriegs- und Nachkriegserinnerungen (Bibl.) 390f.; Wandruszka, Srbik (1978/79) (Bibl.) $359 f$.

248 Vgl. Anton van Der Lem, Johan Huizinga. Leven en werk in beelden \& documenten (Amsterdam 1993) 271, und siehe auch Strupp, Huizinga (wie Anm. 181) 42 Anm. 100, der Srbiks Intervention „nur eine untergeordnete Rolle“ zuschreibt.

249 Letztlich wegen seiner konservativen Grundhaltung übergossen die linken Meisterdenker Max Horkheimer, Theodor Wiesengrund-Adorno und Herbert Marcuse in ihrer privaten Korrespondenz bzw. in einer Rezension den ihnen sehr wohl als „Gegner des Faschismus“ bekannten Gelehrten (notabene im Jahr 1936!) mit Hohn, vgl. Iring Feтscher, Jan Huizinga und Elie Halévy als frühe Diagnostiker des Totalitarismus, in: Diktatur und Diskurs. Zur Rezeption des Totalitarismus in den Geisteswissenschaften, hg. v. Stefano Poggi, Enno Rudolph (Kultur - Philosophie - Geschichte 4, Zürich 2005) 9-36, hier 15-18; dies wirkt umso abstoßender, als sich Adorno seinerseits zu Beginn der Nazizeit den neuen Herren anzubiedern versucht und etwa das Verbot des „Negerjazz“ begrüßt hatte; vgl. La h me, Mann (wie Anm. 6) 292. Zu Huizinga siehe zuletzt Horst Lademacher, Johan Huizinga (1872-1945), in: Europa-Historiker. Ein biographisches Handbuch 1, hg. v. Heinz Duchiardt, Małgorzata Morawiec, Wolfgang Schmale, Winfried Schulze (Göttingen 2006) 179-213.

250 Derndarsky, Fall (Bibl.) 171-176.

251 Ebd. 174f.: So habe ich - um nur weniges anzuführen - die Beteilung des Dichters Max Mell mit dem Grill- 
parzerpreis gegen den Einspruch des Reichsministers Göbbels [!] aufrechterhalten, habe den Angriff des Reichspropagandaamtes gegen die weitere Herausgabe des "Archivs für österreichische Geschichte“ durch die Akademie abgewehrt, wie ich auch als Vorsitzender der „Kommission für neuere Geschichte Österreichs" die [...] verlangte Änderung des Namens in „Kommission für neuere Geschichte der Ostmark“ abwies und verhinderte; als weiteres Beispiel für wenigstens einige bescheidene Erfolge nennt er die Ermöglichung der Abraham-a-S[ancta]-ClaraAusgabe [...]. Die Akademie hat durch diese [...] Edition eine Ehrenpflicht gegenüber dem großen Augustinereremiten [...], eine Ehrenpflicht gegenüber der Heroenzeit Altösterreichs erfüllt. Schließlich verweist er noch auf eine Episode, die sich durch ein halbes Jahr bis in den Januar 1945 hinzog: auf die Anklage, die von Wien aus gegen mich beim Reichsminister Rust erhoben wurde, da ich für den greisen Erzherzog Eugen, den letzten Kurator und das langjährige Ehrenmitglied der Akademie[,] eine Glückwunschadresse der Akademie, [sic] zur Vollendung seines achtzigsten Lebensjahres verfaßte und ihm überreichte [...]. Nach hartem Ringen ist es mir gelungen, mir und der Akademie die gebührende schriftliche Genugtuung des Ministers Rust und des Reichsleiters Schirach zu erkämpfen; was den zuletztgenannten Erfolg anlangt, hat Srbik völlig übersehen, dass ihm vielmehr ein Ausbleiben der „Genugtuung“ von seiten der Herren Rust und Schirach zur Ehre gereicht hätte. Was Mell betrifft, so war dieser als prononciert katholischer Dichter und Schriftsteller natürlich nicht bei allen Nationalsozialisten wohlgelitten; er hat aber seinerzeit als Weggenosse Srbiks den „Anschluss“ an Nazideutschland gleichfalls herbeizuschreiben versucht und 1937 (wie vor ihm Srbik und Weinheber) den Mozart-Preis zugesprochen bekommen; als ihm der Grillparzer-Preis verliehen wurde, war er noch Anwärter auf die Parteimitgliedschaft; vgl. etwa Christoph Heinrich Binder, Großdeutsche Sehnsüchte und nationalsozialistische Wirklichkeit. Max Mells Haltung in den Jahren 1933 bis 1945, in : Blätter für Heimatkunde 63 (1989) 3-9 und bes. Karl Müller, Zäsuren ohne Folgen. Das lange Leben der literarischen Antimoderne Österreichs seit den 30er Jahren (Salzburg 1990) 288-301. Über die Art und Weise, wie Srbik die Preisverleihung an Mell gegen den Willen von Goebbels letztlich doch durchsetzte, kursierten verschiedene Versionen; bei Spitzzm ü lle R, Ursach (wie Anm. 154) 404 heißt es: „Als [...] hierauf die Akademie unter Srbiks Vorsitz den Beschluß faßte, in diesem Jahr den Grillparzerpreis überhaupt nicht zu verleihen, lenkte das Propagandaministerium ein, da ein solches Vorgehen gerade im Gedenkjahr des 150. Geburtstages des Dichters unliebsames Aufsehen erregt hätte. "Laut Walter Tном As, Bis der Vorhang fiel. Nach Aufzeichnungen aus den Jahren 1940 bis 1945 (Dortmund 1947) 163f. senkte Srbik hingegen „den Preis so, daß er sich der Genehmigungspflicht der Berliner Aufsichtsbehörde entzog“, und ist Goebbels zu dessen maßloser Verärgerung richtig düpiert worden; es ist die letztere Version, die besser zu der Aktenlage passt, siehe Archiv der ÖAW, Grillparzerpreis 1941. Die Glückwunschadresse an den Erzherzog ist im Übrigen von allen Parteigenossen unter den Akademiemitgliedern einstimmig gebilligt worden, vgl. LuZA, Österreich (wie Anm. 229) 206. So sieht man denn in diesen Aktionen am besten einfach bloß Schelmenstreiche, die die Wiener Nazis mit Srbik als ihrem Vormann den Nazis aus dem „Reich“ spielten. SpItzMÜLLER, 404 hebt als ein weiteres Beispiel für Srbiks „Mannesmut“ als Akademiepräsident noch hervor, dass in der „ersten Sitzung der Akademie nach dem Anschluß“ „der Generalsekretär der Akademie“ einen „Jahresbericht verlas“, in dessen Rahmen auch drei jüngst verstorbene Akademiemitglieder jüdischer Herkunft gewürdigt wurden. „Als ich Srbik nach der Sitzung fragte, wie er dies zustandegebracht habe, teilte er mir mit, daß in der Tat die Eliminierung der Würdigung der drei jüdischen Gelehrten von der Gauleitung gefordert worden war, daß er aber erklärt habe, in diesem Falle die Sitzung nicht abhalten zu können, da er die Akademie durch die Verschweigung dieser Namen nicht international blamieren könne. “Aber 1938 waren eben „die letzten Masken“ noch nicht gefallen, „die man sich damals noch vorhielt, um das Ausland nicht das wahre Gesicht sehen zu lassen“ (Тномаs, 50), und in Sonderheit mochte Srbik damals um seine eigene Reputation in den noch freien Teilen Europas gefürchtet haben. Nicht erwähnt hat Srbik hier natürlich etwa sein Eintreten für den dezidierten NS-Literaten Erwin Guido Kolbenheyer (1878-1962), der am 27.05.1941 zum Ehrenmitglied der Gesamtakademie gewählt wurde, womit Srbik vermeinte, „ein starkes 
Im Wesentlichen richtig ist auch, dass Srbiks „gesamtdeutsche Geschichtsauffassung“ von radikalnazionalsozialistischer [sic] Seite als katholisch-universalistisch heftig angegriffen wurde und er selbst sich in extremen Parteikreisen den Ruf eines Klerikalen und Legitimisten erwarb ${ }^{252}$, wobei er bemerkenswerterweise selbst just noch in seinem Rechtfertigungsschreiben vom 3. September 1945 Wert auf die Feststellung legte, dass ich weder das noch das andere war und bin ${ }^{253}$. Wie man sieht, hat Srbik von dieser Einschätzung gewusst und unter ihr gelitten - es spricht Bände, dass er die prinzipiell ja sehr ehrenvolle faktische Einstufung als österreichischer konservativer Nichtnazi ${ }^{254}$ ganz reflexartig auch noch nach Kriegsende weit von sich gewiesen hat. Seine beiden wohl schärfsten Kritiker in dieser Hinsicht waren Hermann Löffler einerseits und Ulrich Crämer andererseits.

Von Löffler wurde er „in seiner Geisteshaltung“ als mit der „Katholischen Geschichtsschreibung“ verwandt charakterisiert: „Die Richtung, die Srbik vertritt, pflegt man oft als die groß-und gesamtdeutsche Geschichtsauffassung zu bezeichnen. Zweifellos richtig ist gewesen, ihn vor dem Anschluss Österreichs als österreichischen nationalen Historiker im Gegensatz zum Dollfuss-Schuschnigg-System herauszustellen, es ist aber falsch, in ihm den Schöpfer und Bewahrer einer großdeutschen Geschichtsauffassung zu erblicken. Srbik ist katholischer österreichischer Historiker, der im ganzen in universalistischen Ideen des I. Reiches lebt, das heißt, er ist eng mit der katholischen Reichsideologie, der Habsburgischen Tradition und schließlich der Mitteleuropa-Idee katholischer Prägung verwandt. Srbiks Geschichtsbild kommt nicht vom Volke ${ }^{255}$, sondern wird von dieser Reichsidee her bestimmt, wie besonders anschaulich sein letztes großes Werk, ,Deutsche Einheit', bisher 2 Bände, und seine Berliner Vorträge $1937^{256}$ zeigten. Die Aufgaben eines einheitlich deutsch bestimmten Geschichtsbildes kann aber nur der Überwindung

Gegengewicht zu schaffen, das die Preisverleihung an Mell an Bedeutung übertreffe“ (Archiv der ÖAW, Grillparzerpreis 1941).

252 So Srbik in seinem Rechtfertigungsschreiben vom 03.09.1945, vgl. Derndarsky, Historie (Bibl.) 173f.

253 Ebd. 174.

254 Natürlich konnte ein österreichischer Konservativer prinzipiell auch Atheist und Republikaner sein, aber in den damaligen Zeitläuften musste auch ein solcher Konservativer dem Klerus und dem Erzhaus um vieles näher stehen als den Nazis.

255 Vgl. Der ndarsky, „Idee“ (Bibl.) 196: „Die Nennung des Volks darf nicht darüber hinwegtäuschen, daß Srbik insgesamt nur sporadisch darauf Bezug nahm.“

256 Damit sind drei Vorträge vom Dezember 1935 sowie Januar und Februar 1936 gemeint, siehe SCHÖNẅ̈LDER, Historiker (wie Anm. 5) 91, 318 Anm. 6, und dies., Srbik (Bibl.) 532 mit Anm. 13; vgl. auch HeIBER, Frank (wie Anm. 118) 691 Anm. 2; vollständig wiedergegeben sind diese in SR BIK, Österreich in der deutschen Geschichte (wie Anm. 210); vgl. Fellner, Srbik (2002) (Bibl.) 338; und als Kuriosum auch die unter dem Titel Heinrich R. v. SR BIK, Österreich in der Geschichte (München 1936) erschienene 29seitige Schrift der Revolutionären Sozialisten (Heinz Gittig, Tarnschriften 1933 bis 1945 [München/New Providence/London/Paris 1996] 133 Nr. 0613). 
der österreichischen katholisch gebundenen Srbik-Schule gelten, denn die Geschichtsauffassung, die eine katholische übernationale „Reichsidee“ als diskutabel und nur durch die ,böse` Macht (Preußen) überwunden ansieht, ist für den Nationalsozialismus untragbar." 257

Noch aggressiver äußerte sich in einem internen Gutachten Ulrich Crämer, der sich im Zwist zwischen Srbik und Bibl um Metternich ganz auf Bibls Seite schlug: Srbik sei ein Rattenfänger von Hameln, mit allen Mitteln echt jesuitischer Verdrehungskunst mache er aus Schwarz Weiß; der kleine Metternich habe es als Meister der Intrige und Verstellung sogar verstanden, selbst den Führer zu täuschen ${ }^{258}$. Auch die Dozentenschaft der Universität Wien stand Srbik kritisch gegenüber ${ }^{259}$. Wirklich geschadet haben ihm solche im Rahmen der NS-Polykratie ja überhaupt nicht unüblichen Attacken und Feindseligkeiten aber offenbar nicht, er erhielt unter anderem I 942 das Goldene Treudienstehrenzeichen und 1943 die Goethe-Medaille für Kunst und Wissenschaft verliehen ${ }^{260}$.

257 Hermann Löffler, Die Lage in der deutschen Geschichtswissenschaft. Vortrag gehalten am 17.03.1941 auf der Tagung der Kulturreferenten des Amtes III C des Reichssicherheits-Hauptamtes, in : Joachim LERChenmueller, Die Geschichtswissenschaft in den Planungen des Sicherheitsdienstes der SS. Der SD-Historiker Hermann Löffler und seine Gedenkschrift „Entwicklung und Aufgaben der Geschichtswissenschaft in Deutschland“ (Archiv für Sozialgeschichte, Beiheft 21, Bonn 2001) $256 f$.

258 Jedlitschка, Prüfungskommission (wie Anm. 8) 221-223. Vgl. auch Ulrich Crämer, Der große Friedrich. Eine Betrachtung des 17. August 1936, in: Vergangenheit und Gegenwart 26 (1936) 454-469, und u.a. die weitere bei Derndarsky, Historie (Bibl.) 165 erwähnte Kritik von NS-Seite, der unbedingt auch noch Heft 2 des 16. Jahrgangs der Martin Bormann nahestehenden Zeitschrift „Die Weltliteratur“ (vgl. zu dieser jetzt Frank-Rutger Hausmann, [Rez. zu:] Nationalsozialismus als Ersatzreligion: Die Zeitschriften „Weltliteratur“ und „Die Weltliteratur“ [1935/1944] als Träger nationalsozialistischer Ideologie; zugleich ein Beitrag zur Affäre Schneider/Schwerte/Josef Thomik. Bearb. und hrsg. von Josef Schreier. Geleitwort von Hugo Dyserinck. - Aachen [...] 2009 [...], in: Informationsmittel (IFB) : digitales Rezensionsorgan für Bibliothek und Wissenschaft [letzter Zugriff 12.04.2010]) aus dem Jahr 1941 an die Seite zu stellen ist, in dem gleich in mehreren Beiträgen heftige Kritik an der „Wiener Schule“ von Srbik und Nadler geübt wurde, vgl. Ludwig Jeduicka, Vorgeschichte und Geschichte des Zweiten Weltkriegs, in: Österreichische Zeitgeschichte im Geschichtsunterricht. Bericht über die Expertentagung von 14. XII. bis 16. XII. 1960 in Reichenau (Wien 1961) 60-82, hier 81 und Holger Dainat, Germanistische Literaturwissenschaft, in: Die Rolle der Geisteswissenschaften im Dritten Reich 1933-1945, hg. v. Frank-Rutger Hausm ann unter Mitarbeit von Elisabeth Müller-Luckner (Schriften des Historischen Kollegs, Kolloquien 53, München 2002) 63-86, hier 84. Auch das Amt Rosenberg stellte zwar fest, dass Srbik „als Forscher und Charakter nicht zu beanstanden“ sei, bemängelte aber in ähnlicher Weise, dass seine „Geschichtsauffassung [...] jedoch zu sehr auf dem universalistischen Reichsgedanken“ beruhe; BAB, NS 18/307, B1. 52, 55; vgl. Helmut Heiber, Universität unterm Hakenkreuz I: Die Professoren im Dritten Reich. Bilder aus der akademischen Provinz (München/London/ New York/Paris 1991) 376. Vgl. weiters u.a. auch Sснӧnwälder, Historiker (wie Anm. 5) 313 Anm. 105 für ein Schreiben aus dem „Stab des Stellvertreters des Führers“ an das Amt Rosenberg vom 26.02.1941, in dem Srbik mit anderen Historikern konfessioneller Bindungen verdächtigt wurde.

259 Heiss, Vergangenheit (wie Anm. 123) 55.

260 Derndarsky, Österreich (Bibl.) 84 Anm. 2. 
Gar keine für Srbik böse Spätfolge hatte schließlich auch der Umstand, dass ihm der Verschwörer des 20. Juli 1944 Goerdeler $^{261}$ - zweifellos in der Hoffnung, in ihm tatsächlich jenen katholisch-legitimistischen Konservativen vorzufinden, als der er in den Augen mancher Nationalsozialisten galt - einen Besuch abstattete, der „anscheinend ohne wesentliches Ergebnis“262 blieb. Dieser offenbar nicht von Srbik selbst gesuchte Kontakt trug ihm zwar nach dem Scheitern der Verschwörung Wohnungsdurchsuchungen in Schönbrunn und Ehrwald ein ${ }^{263}$, als sich aber seine völlige Unschuld erwiesen hatte, stand er bei den Nazis wieder oder vielleicht noch mehr als zuvor in der Gnade: als einer seiner Hörer, der Gründer und ehemalige Führer der sog. „Kaisertreuen Volkspartei bzw. des Kaisertreuen Volksverbands“ Gustav Wolff, der bereits „eine Reihe von kleineren Vorstrafen, die alle auf seine politische Tätigkeit“" zurückgingen, ausgefasst hatte, schließlich Ende I944 wegen $\$$ I 39 Abs. I RStGB., also unterlassener Verbrechensanzeige, angeklagt war - es wurden ihm nun Kontakte zu ehemaligen Angehörigen seines Verbandes und Mitwisserschaft an deren illegalen politischen Aktivitäten vorgeworfen -, sprach ihn das Oberlandesgericht Wien mit der Begründung frei, dass ihm in Hinblick auf den (augenscheinlich als sehr positiv angesehenen) Einfluss seines akademischen Lehrers eine solche Tat nicht zugetraut werden könne ${ }^{264}$. Srbik erhielt weiters I944 das Kriegsverdienstkreuz 2. Klasse und schließlich noch Anfang I 945 jenes I. Klasse, laut Srbiks eigener Auskunft vom 2. März 1945 wegen seiner Vortragstätigkeit vor militärischen Kreisen [...], die als Stärkung der Reichsidee und des Wehrgedankens angesehen worden sei ${ }^{265}$.

261 Siehe umfassend zuletzt Marianne Meyer-Krahmer, Carl Goerdeler und sein Weg in den Widerstand. Eine Reise in die Welt meines Vaters (Freiburg 1989); Ines Reich, Carl Friedrich Goerdeler. Ein Oberbürgermeister gegen den NS-Staat (Köln/Weimar/Wien 1997); Gerhard Ritter, Carl Goerdeler und die deutsche Widerstandsbewegung (Stuttgart ${ }^{4} 1984$ ).

262 Ebd. 519.

263 HaAg, Srbik (Bibl.) 1143; Reinalter, Srbik (Bibl.) 82; Ritter, Goerdeler (wie Anm. 261) 300f., 519; vgl. dazu auch das Schreiben BAK, N 1166, 334, in dem sich Ritter 1949 bei Srbik für dessen Auskünfte über Goerdelers Besuch in Wien bedankt, der im Frühjahr 1944 stattgefunden habe; Jan Zim merman , Die Kulturpreise der Stiftung F.V.S. 1935-1945. Darstellung und Dokumentation (Schriften der Alfred Toepfer Stiftung F.V.S., Hamburg 2000) 99.

264 Verfahren OJs 481/44, in: Nationalsozialismus, Holocaust, Widerstand und Exil 1933-1945. Online-Datenbank. K. G. Saur Verlag http://db.saur.de (letzter Zugriff 09.12.2009).

265 Derndarsky, Österreich (Bibl.) 180 mit Anm. 111; ders., Historie (Bibl.) 165 mit Anm. 50. Am sog. „Kriegseinsatz“ der Deutschen Geisteswissenschaften wirkte Srbik jedoch nicht mit; Frank-Rutger HausMANN, Der „Kriegseinsatz“ der Deutschen Geisteswissenschaften im Zweiten Weltkrieg (1840-1945), in: Deutsche Historiker im Nationalsozialismus, hg. v. Winfried Schulze, Otto Gerhard Oexle, Gerd Helm, Thomas Отт (Frankfurt/M. 1999) 63-86, hier 78; Frank-Rutger Hausmann, „Deutsche Geisteswissenschaft“ im Zweiten Weltkrieg. Die „Aktion Ritterbusch“ (1940-1945) (Studien zur Wissenschaftsund Universitätsgeschichte 12, Heidelberg ${ }^{3}$ 2007) 24 mit Beleg, dass durchaus angedacht war, Srbik zur Mitarbeit einzuladen. 
XI.

Anfang März 1945 konnte sich Srbik dank einer mit Ende April befristeten Urlaubserlaubnis, die er im Hinblick auf einen Bronchialkatarrh beantragt hatte ${ }^{266}$, aus dem schon von der Roten Armee bedrohten Wien auf seinen Zweitwohnsitz in Ehrwald zurückziehen. Dort erlebte er dann nicht nur das Kriegsende, sondern auch seine umgehende Entlassung. Er wurde per I. Oktober 1945 vom Dienst enthoben und erhielt schon von April I 945 an bis März 1948 keinerlei Bezüge; darüber hinaus wurde er von französischen Besatzungsorganen mehrmals in Haft genommen und musste sich zunächst wöchentlich bei der Gendarmerie melden. Schließlich wurde er als minderbelastet eingestuft und am I7. März I948 in den dauernden Ruhestand versetzt ${ }^{267}$; Ende I 948 lebte auch seine Mitgliedschaft in der Österreichischen Akademie der Wissenschaften wieder auf ${ }^{268}$. Dass er nun gleichwohl in Ehrwald verblieb und Wien offenkundig bis an sein Lebensende gemieden hat, dürfte wohl in einer verständlichen Furcht vor sowjetischen Besatzungsorganen begründet gewesen sein. Srbik entfaltete in seiner „Exil“-Zeit eine ganz erstaunliche Produktivität. Die zweite, vermehrte und verbesserte Auflage von „Wallensteins Ende“ und der dritte „Metternich“-Band, beide postum von Borodajkewycz herausgebracht, wurden schon erwähnt. Srbik publizierte auch viele Aufsätze, von denen freilich wiederum ein Gutteil nur Glaubensbekenntnisse gewesen sind $^{269}$. Er übernahm auch 1946 vom Ver-

266 DeRNDARSKY, Österreich (Bibl.) 494 (Rechtfertigungsschreiben Srbiks vom 03.09.1945). Bereits am 25.02.1945 kündigte Srbik Bauer gegenüber an, sich aus gesundheitlichen Gründen nach Ehrwald begeben zu wollen, Eduard Pernkopf sollte nach seinem Willen die Obsorge über die Akademie [...] übernehmen; dabei beteuerte er, nur zwei Wochen Aufenthalt in Tirol und nicht Fahnenflucht zu planen: Srbik, Korrespondenz (Bibl.) Nr. 374.

267 Zu den Unbillen, denen Srbik damals ausgesetzt war, vgl. etwa Fellner, Srbik (2002) (Bibl.) 340; hier findet sich 344 auch folgendes Urteil: „[...] es wurde seine Geschichtsauffassung, sein Lebenswerk verfemt, verurteilt“; „Ihm, dem Historiker, [...] ist nicht nur politisch nach 1945 Unrecht geschehen, sondern wird von einer jüngeren Generation bis heute Verständnislosigkeit entgegengebracht, weil man aus der Selbstgerechtigkeit der eigenen ideologischen Position heraus sich den Blick auf die historische Situation, in der Srbik gewirkt hat, wirken mußte, verstellt." Vgl. dazu vielmehr S. 289-291.

268 Gernot Heiss, Von der gesamtdeutschen zur europäischen Perspektive? Die mittlere, neuere und österreichische Geschichte, sowie die Wirtschafts- und Sozialgeschichte an der Universität Wien 1945-1955, in: Zukunft mit Altlasten. Die Universität Wien 1945 bis 1955, hg. v. Margarete Grandner, Gernot Heiss, Oliver Raтнкоцв (Querschnitte 19, Innsbruck/Wien/München/Bozen 2005) 189-210, hier 190; vgl. MATIs, Anpassung (wie Anm. 194) 15 Anm. 12.

269 Vgl. etwa Heinrich (Ritter von) SR в Iк, Schöpferische Geschichtserkenntnis. Vom „Umschreiben“ der Geschichte, in: Wissenschaft und Weltbild 3 (1950) 49-53; Ders., Das Problem der österreichischen Geschichtsschreibung, in: Wissenschaft und Weltbild 3 (1950) 374-376, 422-425 (schließt 425 mit dem altbekannten Credo „Eine übernationale Ordnungsidee für das Zusammenleben im ostmitteleuropäischen Raum und die Führung, nicht Beherrschung der Gleichberechtigten durch den deutschen Stamm in Österreich wäre eine Notwendigkeit und ein Segen für alle gewesen“); DERs., Bismarck-Kontroverse (wie Anm. 7); 
ein für Geschichte der Stadt Wien die Aufgabe, den ersten Teilband „Die geschichtliche Stellung Wiens I740-I9I 8 “ eines auf zehn Bände angelegten Werkes über die Monarchie zwischen I740 und I9 I 8 zu verfassen, doch „fern von Wien und seinen Quellen“ ging die Arbeit an diesem Projekt nicht recht voran; das entsprechende Buch erschien erst postum I962, wobei der Abschnitt über die Periode I 895-191 8 von Srbiks ehemaligem Assistenten Reinhold Lorenz ergänzt zu werden hatte ${ }^{270}$.

Besonders hervorzuheben ist aber das zweibändige, „Friedrich Meinecke in alter Verehrung“ gewidmete Werk „Geist und Geschichte vom deutschen Humanismus bis zur Gegenwart “271, eine Geschichte der deutschen Geschichtsschreibung unter zum Teil exzessiver, aber in jedem Fall höchst inkonsequenter Berücksichtigung der nationalen und auch internationalen Geistesgeschichte; Srbik hat dabei auf älteren eigenen Vorlesungskonzepten aufgebaut ${ }^{272}$. Er spielt in diesem aus heutiger Sicht doch nur mehr bedingt brauchbaren Werk die Rolle eines allwissenden und unfehlbaren Arbiter, dem justament auch ein Richteramt über die Geschichte und Geschichtsschreibung der jüngsten Vergangenheit, das heißt über den Nationalsozialismus und dessen Gegner zukommt. „Geist“ scheint am ehesten als Synonym für „Irrationalismus“ verwendet zu sein ${ }^{273}$ - so werden zum Beispiel weder Hermann Samuel Reimarus noch Bruno Bauer erwähnt bzw. vorgestellt, während andererseits zum Beispiel der eher als antisemitischer Schriftsteller denn als Historiker bekannte Gustav Freytag auf mehreren Seiten abgehandelt wird und auch ein gewisser katholischer Theologe namens Johann Adam Möhler mehrfach Erwähnung

DERs., Die Böhmische Tragödie. Beiträge der Geschichtswissenschaft zur deutsch-tschechischen Schicksalsfrage, in: Universitas 5 (1950) 1045-1051 (1049 „Es kann nicht stark genug unterstrichen werden, [...] welche Lebensbedrohung nicht nur für das Sudetendeutschtum, sondern auch für den Gesamtstaat, für Mitteleuropa und den Kontinent in der Doppelpoligkeit der [...] Forderung des Tschechentums und der wachsenden Gravitation dieses ganz im österreichischen Raum lebenden Kleinvolkes nach Rußland lag und welche historische Schuld die Tschechen traf, da sie [...] den Willen zum Ausgleich mit den Deutschen [...] nicht mit genügender Stärke verfolgten“); DERs., Zukunftswege der Geschichtswissenschaft. Vom Positivismus des 19. Jahrhunderts zur Universalgeschichte der Gegenwart, in: Universitas 7 (1952) 137-140.

270 Siehe Rudolf Till, Rezension von: Heinrich Srbik, Reinhold Lorenz, Die geschichtliche Stellung Wiens 1740-1918 (Wien 1962), in: Wiener Geschichtsblätter 18 (78) Nr. 2 (1963) 179f., der den Band abschließend wie folgt charakterisiert: „Ein Werk von hoher, ja höchster Warte einer universalen Geschichtsbetrachtung geschrieben, vielleicht manchmal zu hoch, so daß die Konturen der Wiener Geschichte dabei verblassen.“

2711 (Salzburg 1950), 2 postum hg. v. Taras von BorODAJ KEWyCz (Salzburg 1951).

$272 \mathrm{Zu}$ Ende gebracht werden konnte dieses Unternehmen nur durch willig verrichtete Kärrnerdienste von ihm treu ergebenen Schülern: „Bei jedem Besuch von Innsbruck aus in Ehrwald habe ich damals [...] Bücher aus der Innsbrucker Universitätsbibliothek, die Franz Huter und Hans Kramer für ihn entliehen hatten, mitgebracht, und ich besitze noch viele Briefe und Postkarten, in denen er, wie er sich selbst einmal nannte, als ,unverbesserlicher Bettler um Gefälligkeiten', mir seine Bücher- und Zeitschriftenwünsche mitteilte“; Wandruszka, Srbik (1978/79) (Bibl.) 361f.; vgl. auch Pitcher, Srbik (Bibl.) $222 f$.

273 Vgl. die groteske Definition von „Geist“ durch Heidegger; Nolt e, Heidegger (wie Anm. 229) 127, 167. 
findet, von dem es anerkennend heißt, dass er „die Kirche liebte und ihrer Lehre als Wahrheit durch Forschung [...] diente und [...] die Aufklärung überwand"274. Dafür tadelt er am NS-Gegner Oswald Spengler das Fehlen der „Gewißheit, daß der Geist die stärkste aller Mächte ist“, und er vermisst „das Bekenntnis zur Liebe und das sittliche Verantwortungsgefühl“275, das heißt genau jene Art von Leerformeln und Phrasen, die sein eigenes Alterswerk durchzieht ${ }^{276}$. Auch sonst nützt Srbik die Gelegenheit, gegenüber vor Kurzem verstorbenen alten Gegnern das letzte Wort zu behalten: So ist der „nur logische Denker Brandenburg [...] der volksbewegten Geschichtsschau und dem historischen Idealismus“ (offenbar Srbiks selbst) „nicht gewachsen gewesen“277, und Strzygowski „war kein philosophisch veranlagter Denker“278 wie offenbar Srbik selbst. Nur in Tönen des höchsten Lobes preist er hingegen die eigene „gesamtdeutsche Geschichtsauffassung “279, die schlussendlich als NS-Opfer dargestellt wird: „... an ihrem Bodengewinn war nicht zu zweifeln, als der Nationalsozialismus, der ihr eine Zeitspanne lang eine freilich nur äußere Stütze zu werden geschienen hatte, ihre Wissenschaftsgrundsätze schwer verletzte und dann das deutsche Volk ins Verderben führte. "280 - Was mit dem letzten Satz gemeint ist, muss unklar bleiben; klar ist aber wohl schon geworden, dass das Werk solide und ausführlich nur über die Idiosynkrasien des Autors ${ }^{281}$ informiert.

274 SR BIK, Geist 2 (wie Anm. 14) 40. Dass ein katholischer Theologe seine eigene Kirche liebte, ist sicherlich eine interessante Information - es ist ja durchaus denkbar, dass die meisten seiner Kollegen ihrer eigenen Kirche mit Gleichgültigkeit oder Hass begegnen. Allerdings hätte man gerne näher gewusst, wie es diesem Genie gelang, gleichsam im Alleingang die Aufklärung zu überwinden. Einen Hinweis auf die Art und Weise liefert aber vielleicht schon die weitere Angabe, dass er der „Wahrheit“ der Lehre seiner Kirche durch „Forschung“ diente: wer einer bestimmten schon feststehenden „Wahrheit“ durch „Forschung“ dienen will, wird die Resultate der Letzteren immer wieder manipulieren oder missachten müssen.

275 Ebd. 322.

276 Ebd. 336 hat Srbik der Spengler'schen Weltsicht auch insgesamt eine dezidierte Absage erteilt. Nach einem Aufruf, sich immer vor Augen zu halten, „wie unendlich viel die deutsche Kultur für die Weltkultur bedeutet hat und bedeuten wird“, ergeht er sich in folgendem Credo: „Wir glauben nicht an Spenglers deterministischen Fatalismus, glauben nicht an den dauernden Untergang des Abendlandes, sondern an eine weltgeschichtliche Zeitenwende, in der ein Neubau der uralten, zwischen den Westen und den Osten gestellten Völkergemeinschaft aus ihrem eigenen Wesen heraus erfolgen wird, eine Synthese des christlich-universalen, überindividuellen Menschheitsgedankens und seiner Gliedhaftigkeits- und Liebesidee, seines organischen Sozialdenkens mit einem undogmatischen, nicht marxistisch-orthodoxen Sozialismus. Wir glauben nicht an eine zwingende, pessimistische [sic!] morphologische Gesetzmäßigkeit, sondern an die Lebenskraft des abendländischen Menschen kraft seines Geistes!“ Einen „undogmatischen, nicht marxistisch-orthodoxen Sozialismus" hatte es im Übrigen in Deutschland schon zwischen 1933 und 1945 gegeben.

277 Ebd. 14.

278 Ebd. 307.

279 Ebd. 346-348.

280 Ebd. 348.

281 Geradezu obszön ist Srbiks Bestimmung von „Kern des Wesens und der Pflicht“ der Geschichtswissenschaft 
Dem Nationalsozialismus wird nun nicht nur eine Verletzung von Srbiks Wissenschaftsgrundsätzen vorgeworfen (wobei vielleicht erst eben diese Verletzung „das deutsche Volk ins Verderben führte“), es ist dann auch reichlich abstrakt von einer „Umwertung aller Werte“, „schweren Versündigungen an der Menschlichkeit, an der Gottesvorstellung und an der Liebe, am Recht, an der Moral und der Kultur, an der Geistesmission des deutschen Volkes in der Welt" die Rede ${ }^{282}$. Der Nationalsozialismus hatte laut Srbik „auf historischem Gebiet fast nur“, aber immerhin doch „darin recht, daß das deutsche Volk in der Verteilung der Welt zu spät gekommen und in ungünstigen Raumverhältnissen zu leben gezwungen sei“283; was die NS-Geschichtswissenschaft anlangt, erwähnt er unter anderem Rosenberg, Alfred Baeumler und Ludwig Klages sowie die „historiographischen Leistungen Christoph Stedings ${ }^{284}$, Walter Franks, Otto Westphals ${ }^{285}$

(ebd. 379), wofern man historische Forschung prinzipiell auf Kosten von Steuerzahlern und nicht bloß als privates Hobby betrieben sein lassen will: dieser sei „das möglichst reine Erkennen innerhalb der unüberwindbaren Schranken der Erkenntnisfähigkeit“, und weiters bleibe „die sittliche Aufgabe eines nie versiegenden, immer wieder neu einsetzenden Bestrebens nach Beantwortung von Fragen, die in völlig eindeutiger Weise niemals zu beantworten sind“.

282 Ebd. 362.

283 Es fällt schwer, in diesem scheinbar unscheinbaren Satz etwas anderes als eine verkappte Rechtfertigung von Hitlers Ost-, also Kriegspolitik zu sehen. Dass ein „Volk ohne Raum“ das Recht hat, sich auf Kosten anderer Völker auszudehnen, hatte Srbik höchst verklausuliert schon in „Österreich in der deutschen Geschichte“ (wie Anm. 210) 9 dargelegt: „Erst durch Menschenwerk werden die Räume auch zu befördernden, aber nicht zu gesetzlich zwingenden Faktoren der Staatsbildung, und die Natur der raumerfüllenden Bevölkerung wird zwar von den Eigenschaften des Raumes beeinflußt, sie verbindet und überwölbt aber auch Räume, dank der Idee, die aus einer rein rational nicht völlig bestimmbaren Quelle innewohnt, und dank der inneren Gesetzlichkeit ihres Wachstums, ihres Ausdehnungsbedürfnisses und der Hemmnisse, die ihr von anderen Völkern bereitet werden."

284 Vgl. Ritter, Geschichtswissenschaft (wie Anm. 149) 130: „das phantastische, dicke Buch von Christoph Steding (Nachlaß eines Frühverstorbenen), Das Reich und die Krankheit der europäischen Kultur' : ein Pamphlet gegen die angeblich ,dekadente‘ Kultur der ,neutralen Nationen' (Schweiz, Holland, skandinavische Völker). Wenige Schriften haben die neue deutsche Historie im Ausland so schwer in Verruf gebracht wie diese." Vgl. zu diesem Werk zuletzt Karlheinz Weissmann, Armin Mohler. Eine Biographie (Schnellroda 2011) 51f., 54, 56.

285 Vgl. Heinrich Ritter von SR вік, Rezension von: Otto Westphal, Das Reich. Aufgang und Vollendung 1. Germanentum und Kaisertum (Stuttgart, Berlin 1941), in: Göttingische Gelehrte Anzeigen 205 (1943) 102-121. Srbik hat dieses Machwerk außerordentlich respektvoll besprochen, eine prinzipielle Zustimmung zu Westphals grundsätzlich antiuniversalistischer Einstellung wäre einer Selbstaufgabe gleichgekommen; vgl. zu dieser Rezension Moos, Bildungsbürgertum (Bibl.) 156f. („Übermaß an Verständnisbereitschaft“); Reinalter, Srbik (Bibl.) 87f.; S CHÖNwäLder, Historiker (wie Anm. 5) 219, 320 Anm. 32, 363 Anm. 551f.; Westphal war im Jahr 1943 übrigens gar nicht mehr akademischer Kollege, sondern freier Schriftsteller - er hatte seine universitäre Karriere wegen des Vorwurfs von Handlungen gegen $\$ 175$ StGB (homosexuelle Handlungen) frühzeitig im Jahr 1937 beenden müssen; vgl. zu Westphal bes. Klee, Personenlexikon (Bibl.) 672; Heiber, Frank (wie Anm. 118) passim; Hochschulalltag im „Dritten Reich“. Die Hamburger Universität 1933-1945 1-3, hg. v. 
oder Gustav Pauls 286 “ und deklariert sich als „weit entfernt, in all dem nur Ungeist zu sehen“, wenngleich er „den Einschlag von Irrgeist und eine Gefährdung der Sittlichkeit in dieser Wissenschaftsrichtung“ erkenne ${ }^{287}$. Ganz am Ende dieses Abschnitts über den Nationalsozialismus heißt es: „Wenn wir gleichwohl würdigten, daß auch die nationalsozialistische Welle in der deutschen Historie manche gesunde Erkenntnisfortschritte für die Erkenntnis der deutschen Volksgeschichte und für die abendländische und europäische Lebensgliederung gebracht hat, so konnte sie doch das deutsche Volk nicht zu seinen echten Urgründen zurückgeleiten und ihm nicht die kulturelle Führung Europas erringen helfen. “288 Die beiden zuletzt zitierten, deutlich verharmlosend-apologetisch wirkenden Sätze haben natürlich ganz zu Recht schon aufmerksame Leser wie Derndarsky ${ }^{289}$ und Hofer ${ }^{290}$ verstört; aber noch bedenklicher sollte stimmen, dass Srbik in „Geist und Geschichte“ den Nationalsozialismus als „der große Rückschlag gegen Liberalismus und Christentum, internationalen Sozialismus, Kommunismus und Judentum “ bezeichnet ${ }^{291}$ - da von all diesen Begriffen für Srbik (und die meisten seiner Leser) allein „Christentum" positiv besetzt war, scheint dem Nationalsozialismus hier sogar eher ein recht großes Kompliment gemacht zu werden.

Am bemerkenswertesten aber ist das hier über Meinecke ausgesprochene Urteil - wer meint, Srbik werde seinem alten Mitmandarin, dem das gesamte Werk ja gewidmet ist, wegen dessen NS-Gegnerschaft vielleicht eine größere und bessere Urteilskraft als sich selbst zuschreiben, geht ganz fehl. Srbik schließt seine Eloge vielmehr mit der Einschränkung, Meinecke sei „der brutalen Wirklichkeit nicht ganz gewachsen gewesen“; dieser habe als allzu großer Idealist Geschichte zu wenig als „Handeln von Männern, die mitten in der bewegten, der Taten bedürftigen Welt stehen“, bzw. nicht genügend als Kampf

Eckart Kause, Ludwig Huber, Holger Fischer (Hamburger Beiträge zur Wissenschaftsgeschichte 3, I-III, Berlin/Hamburg 1991) passim.

286 Die „historiographischen Leistungen“ Gustav Pauls hießen „Grundzüge der Rassen- und Raumgeschichte des deutschen Volks“ und „Die räumlichen und rassischen Gestaltungskräfte der deutschen Geschichte“. Als ob diese Titel nicht schon für sich sprächen, bietet Srbik auch noch eine sorgfältige Charakteristik: „Paul fußt auf [Hans F. K.] Günthers Rassenlehre und geopolitischer Grundlage, also auf,Blut und Boden', und sucht die Brücke von der biologischen zur vorwiegend staatlichen Volksgeschichte zu schlagen“; SR Bıк, Geist 2 (wie Anm. 14) 407 Anm. 41.

287 Ebd. 363.

288 Ebd. 364.

289 Derndarsky, Historie (Bibl.) 167: „So jedenfalls wird der Eindruck vermittelt, daß der Nationalsozialismus als tendenziell positiv mit gewissen Auswüchsen, statt prinzipiell negativ mit gewissen Ausnahmen zu sehen wäre."

290 Walther Hofer, H. von Srbiks letztes Werk, in: HZ 175 (1953) 55-66, hier 64; vgl. Heiber, Frank (wie Anm. 118) 580.

291 Srbik, Geist 2 (wie Anm. 14) 363. 
„auch der Bedürfnisse und derben Willenstendenzen der Männer und Völker als zugleich natürlicher und geistiger Individualitäten " begriffen und auch nicht hinlänglich bemerkt, wie „das Überblutmäßige durch das Blutmäßige in der Geschichte immer wieder gebunden“"werde ${ }^{292}$. Wer so schreibt, muss sich wohl selbst für einen größeren Realisten als den Gemaßregelten halten. Srbik und Meinecke hatten sich nun aber insbesondere in ihrer Haltung zum Nationalsozialismus unterschieden; demgemäß scheint Srbik sich hier just eine realistischere Einschätzung dieser Bewegung als Meinecke zuzuerkennen. Das macht nur und genau dann Sinn, wenn man nicht etwa den Nationalsozialismus als närrische und wirklichkeitsfeindliche Ideologie auffasst, sondern vielmehr den NS-Standpunkt einnimmt, gemäß dem den „derben Willenstendenzen“ von „brutaler“ Rotfront und Reaktion, Slawen und Weltjudentum realistischerweise nicht durch Ideen, sondern nur durch „Taten“ wie die Einrichtung von Konzentrations- und Vernichtungslagern sowie präventive Angriffskriege Einhalt geboten werden konnte.

Aber selbst wenn sich Srbik hier ganz ohne solche Hintergedanken bloß einfach zum historischen Realismus bekannt haben sollte - dies war offenbar zwingend geboten, um sich Meinecke irgendwie als überlegen zu erweisen -, wirkt diese Stelle wie ein erratischer Block inmitten seiner unzähligen Aufrufe zu Sittlichkeit, Ethos, Liebe und Gottesebenbildlichkeit und nicht minder häufigen Elogen auf den „Geist“; ein erratischer Block ${ }^{293}$ freilich,

292 Ebd. 291-293.

293 Immerhin hat sich Srbik in seinen nicht (?) für die Öffentlichkeit bestimmten autobiografischen Aufzeichnungen von 1945-1946 zumindest einmal für eine Dosis von politischem Realismus ausgesprochen, was freilich keineswegs mit einem Plädoyer für historischen Realismus gleichgesetzt werden kann. Bei FELLNER, Srbik (2002) (Bibl.) 339 liest man: „Srbik stand zwischen den Fronten, er fühlte sich abgestoßen von dem Radikalismus des Hitler-Regimes, aber er vermochte es auch nicht, sich mit den radikalen Aktivitäten des deutschen Widerstandes zu identifizieren. Ich habe, so bekannte er in seinen Erinnerungen, das Extrem in keiner Hinsicht je geliebt. Es kam mit meiner Veranlagung für das dem denkenden Menschen erreichbare, begrenzte Maßvon Gerechtigkeit und Objektivität nicht überein, es widersprach meiner Neigung für das Ebenmaß und die ruhige Überlegung der Gegensätze, es widersprach auch der Dosis von politischem Realismus, die meinen deutschen Idealvorstellungen beigemischt waren [sic] [,] und es verletzte die mir im Blut liegende österreichische Seite meiner Überzeugung. " Leider geht aus diesem Zitat nicht hervor, ob Srbik an dieser Stelle seiner Erinnerungen tatsächlich selbst die Bewegung des 20. Juli als „extrem“ abgelehnt hat oder ob nur Fellner die Verbindung dieser Passage mit den Ereignissen des 20. Juli hergestellt hat. Einschlägig ist aber in jedem Fall das nicht publizierte abschätzige Urteil Srbiks über Kaiser Karl, das bei SpIt zm ü Ller, Ursach (wie Anm. 154) 283f. überliefert ist: „Resümierend bemerkte Srbik, in einer solchen Lage müsse ein Herrscher Eisen im Blut haben, und das habe eben [...] Kaiser Karl gefehlt. "Von den Trägern der Macht verlangte Srbik in seinem gedruckten Werk üblicherweise Attitüden wie Ethos, Geistigkeit, Innerlichkeit und Liebe. Besagtes Diktum Srbiks verstrickte den tiefgläubigen Katholiken Spitzmüller, der sowohl ein recht unkritischer Bewunderer Kaiser Karls als auch ein solcher Srbiks gewesen ist, in Gewissensnöte; sehr zu Recht schreibt er am angegebenen Ort: „Es bleibt die Frage offen, ob Eisen im Blut mit christlicher Nächstenliebe vereinbar ist." 
der den Schluss nahelegt ${ }^{294}$, dass es sich bei seinen idealistischen Rhetorik-Schwaden um einen doch ziemlich bewussten groß angelegten Vernebelungsversuch handelt, durch den verborgen werden sollte, dass es in seinen politisch relevanten Schriften eigentlich nur um die Verherrlichung ${ }^{295}$ und Rechtfertigung nackter deutscher Machtausübung geht. So gilt demgemäß schlussendlich wohl für Srbik selbst dessen eigenes abschließendes Urteil über den Proto-Nazi Heinrich von Treitschke, dieser habe „selbst einen Ausdruck des Verlangens eines machtlosen und zerteilten Volkes nach Einheit und nach Macht" dargestellt ${ }^{296}$.

Auch die frömmelnden Aussagen seiner letzten Jahre, in denen er Klio offenbar nur mehr die Rolle einer Ancilla theologiae zudachte ${ }^{297}$, beruhen dann vielleicht nur auf opportunistischer Anbiederung an die katholische Restauration. Tatsächlich hat Srbik auch als Mensch ein Maskenspiel betrieben - als weich, mimosenhaft, integer, versöhnlich, idealistisch und weltfremd beschreiben ihn in der Regel seine Zeitgenossen, sodass man ihm schon die Geschäftsfähigkeit absprechen möchte; doch ist just die zuallermeist so und nicht anders beschriebene Persönlichkeit binnen weniger Jahre vom Bibliothekar zu einem „Mandarin“ der österreichischen und deutschen Geschichtswissenschaft und dann zu einem Minister und Akademiepräsidenten aufgestiegen, und ebendiese Persönlichkeit hat keinen Anlass für eine polemische Auseinandersetzung gemieden und etwa seine Kontroverse mit Bibl so weit getrieben, dass der Kontrahent de facto aus dem Kreis der Wissenschaft und der Wissenschaftler ausgestoßen wurde.

I 949 gab es für Srbik, der jedes Eingeständnis einer eigenen Schuld von sich wies ${ }^{298}$ und auch keinerlei Verständnis für eine kritischere Sicht seines Verhaltens vor I 945 bei

294 Da kein aufrichtiger Idealist gleichzeitig auch Realist sein kann, ein überzeugter Realist aber aus opportunistischen Gründen eine idealistische Gesinnung verbal vortäuschen mag.

295 Vgl. etwa seine Formulierung „Radetzkys herrliche Armee und ihr vom Heer vergötterter großer Führer“; SR BIK, Metternich 2 (wie Anm. 4) 314.

296 SR BIK, Geist 1 (wie Anm. 14) 398; Srbik hat dieses Urteil offenkundig als Kompliment gemeint, hat er Treitschke doch auch als „großen Charakter“ gewürdigt (394), ihn „grandios [...] als Mensch“ bezeichnet (397) und an ihm „Menschheitssinn und Verantwortungsbewußtsein“ gerühmt (398).

297 Vgl. Sr ві к, Geist 2 (wie Anm. 14) 378: „Unsere Hoffnung auf geistig-seelische Genesung kann nur in einer Rückkehr zum ,Ewigen im Menschen' durch Wiederherstellung des Verhältnisses des Menschen zur höheren Seinsform im Bewußtsein seiner Kreatürlichkeit, seiner Ebenbildschaft Gottes und einer Weltordnung durch Erkenntnis in tiefstem Leid und unermeßlicher Katastrophe des enthumanisierten Kosmos erwachsen “; 380 : „Wir können und wollen nicht schlechthin zur Goethe- und Rankezeit zurückkehren, aber diese leuchtenden Gestirne vermögen uns zu sagen, daß es [...] eine Ehrfurcht vor dem Göttlichen im Menschentum gibt und geben muß; daß alles Leben Kampf auch des Ewigen um sein gedankliches und sittliches Fortbestehen in uns ist und daß aus dem Tod neues Leben nicht nur im Sinn des Sterbens und Geborenwerdens aller Natur wird, sondern daß auch die höchsten Idealwerte im Neuen fortleben“; vgl. auch DE Rs., Zukunftswege (wie Anm. 269) 140 .

$298 \mathrm{Vgl}$. etwa den folgenden Schlussparagrafen seines Rechtfertigungsschreibens vom 03.09.1945: Ich bitte das Staatsamt nicht um Gnade, sondern um Gerechtigkeit, da ich mich reinen Gewissens weiß und reine Hände habe. 
anderen erkennen ließ, wieder einen Anlass, um sich beleidigt fühlen zu können: In diesem Jahr bemühte sich das NS-Opfer Walter Goetz ${ }^{299}$ um Srbiks Wiederwahl in die Historische Kommission der Bayerischen Akademie der Wissenschaften, der Srbik seinerzeit vom ıо. Juli 1942 bis zu Kriegsende sogar als Präsident vorgestanden war ${ }^{300}$; als dieser Versuch erfolglos blieb, bezeichnete Srbik die Zurückweisung als eine unverdient schwere Kränkung meiner Person ${ }^{301}$. I950 unterstützte Srbik auch noch die Gründung der „RankeGesellschaft“302, die namentlich in ihren ersten Jahren eindeutig „braun angehaucht“303 war und alte Kumpane Srbiks wie Schüssler, Karl Alexander von Müller und Harold Steinacker zu ihren Gründungsmitgliedern zählte.

Ich mag geirrt haben, aber mein Irren war in jedem Fall weder verächtlich, noch nach meinen Begriffen strafbar, da ich mich weder gegen geschriebene noch gegen ungeschriebene Gesetze vergangen habe und Österreich durch einundvierzig effektive Jahre (ohne besondere Anrechnung der Kriegsjahre) nach meinen besten Kräften gedient habe (Derndarsky, Historie [Bibl.] 176). Als Resultat seines angeblichen schweren inneren Ringens und seiner angeblichen „schmerzerfüllten Grübelei“, von der alle seine Apologeten wie Hamann und Wandruszka zu berichten wissen, hatte sich also offenbar praktischerweise ein völliger Freispruch seiner eigenen Person ergeben.

$299 \mathrm{Zu}$ diesem grundlegend Wolf Volker Weigand, Walter Wilhelm Goetz 1867-1958. Eine biographische Studie über den Historiker, Politiker und Publizisten (Schriften des Bundesarchivs 40, Boppard am Rhein 1992).

300 Heiber, Frank (wie Anm. 118) 257; Schönwälder, Srbik (Bibl.) 529; Schulze, Geschichtswissenschaft (wie Anm. 217) 36, 145f. (Ersuchen um Rücktritt, das „nicht ohne langanhaltende ,Bitterkeit ' hingenommen“" wurde); Zimmer mann, Kulturpreise (wie Anm. 263) 99; vgl. SRbiK, Korrespondenz (Bibl.) Nr. 345 und 350 Anm. 2.

301 Schulze, Geschichtswissenschaft (wie Anm. 217) 129, 153 Anm. 21; vgl. auch Weigand, Goetz (wie Anm. 299) 352.

302 Vgl. Michael SALewsri, Die Ranke-Gesellschaft und ein halbes Jahrhundert, in: Historische Debatten und Kontroversen im 19. und 20. Jahrhundert. Jubiläumstagung der Ranke-Gesellschaft in Essen, 2001, hg. v. Jürgen Elvert, Susanne Krauss (Historische Mitteilungen Im Auftrage der Ranke-Gesellschaft 46, Stuttgart 2003) 124-142, hier 125: „Zwar nicht formell, aber ideell war auch Heinrich Ritter von Srbik mit von der Partie, und Rein war stolz darauf, den berühmten österreichischen Historiker [...] auf seiner Seite zu wissen. Er zitierte ihn in seinem Gründungsaufruf: ,Dem von Ihnen geplanten Unternehmen stehe ich mit lebendigstem Interesse und inniger Sympathie gegenüber. Der Wert einer historisch-politischen Monatsschrift, die dem unerhörten Überwuchern der Propaganda auf wissenschaftlichem Weg entgegentreten soll, erscheint auch mir aus dringender Notwendigkeit zu bejahen $[\ldots]^{\text {'. }}$ "

303 So jetzt auch das Urteil von SALEwski (ebd.) 131; vgl. auch schon Walther Hofer, Der mißbrauchte Ranke. „Konservative Revolution“ in der deutschen Geschichtsschreibung?, in: Der Monat 7, Heft 84 (1955) 542-547; SchulZE, Geschichtswissenschaft (wie Anm. 217) 205. 
XII.

Nach dreitägiger Krankheit starb Srbik am I6. Februar I95 I in Ehrwald ${ }^{304}$. „Unter den vielen Kondolenten aus Wissenschaft und Kunst befinden sich auch der deutsche Bundespräsident Professor Heuß und der Chef des Hauses Habsburg. “305 Beim „Leichenbegängnis Srbiks in Ehrwald“ aber waren „weder die Akademie der Wissenschaften noch die Wiener Universität noch die Regierung direkt vertreten“. ${ }^{306}$ Die Gemeinde Ehrwald hat später eine Verkehrsfläche, nämlich den Dr.-Heinrich-Srbik-Weg nach ihm benannt ${ }^{307}$.

Gleichsam offiziell rehabilitiert wurde Srbik, als sein 80. Geburtstag am I7. November 1958 an seiner ehemaligen Wirkungsstätte, der Universität Wien, im Kleinen Festsaal gefeiert wurde. Eingeladen hatte zwar der „Allgemeine Deutsche Kulturverband“, jedoch sprachen als offizielle Vertreter der Universität sowohl der damalige Rektor Erwin Schneider als auch der damalige Dekan Albin Lesky „Worte des Grußes im Gedenken an Heinrich v. Srbik“308. Dabei äußerte der Rektor den folgenden Wunsch: „Mögen sich noch viele Generationen vor seinem Schatten neigen. “309 I970 gab es sogar die Bestrebung, eine Büste Srbiks im Arkadenhof des Hauptgebäudes der Universität Wien aufzustellen $^{310}$. Wenn dieser Plan schlussendlich auch nicht realisiert wurde, so ist es doch bis heute, wie schon gleich zu Beginn erwähnt, die Communis opinio gewesen, dass Srbik tatsächlich als ein Biedermann anzusehen ist, der Brandstiftern nur aus Naivität und Gutherzigkeit Kost und Logis in seiner Wohnung gewährt hat, sieht man von einigen wenigen dissidenten Autorinnen und Autoren ab, die freilich eher schon in jedem Biedermann eo ipso einen Brandstifter zu sehen scheinen.

Hingegen hoffe ich hier - ganz ohne die zuletzt genannte automatische Gleichsetzung zu akzeptieren - gezeigt zu haben, dass Srbik in Wirklichkeit selbst ein Brandstifter in der Maske eines Biedermannes gewesen ist, ein in seinen Äußerungen niemals vertrauenswür-

304 Gschliesser, Srbik (Bibl.) 233.

305 Wrabetz, Srbik (Bibl.) 30; vgl. Posch, Srbik (Bibl.) 193 („,...] daß aber die Schreiben Ottos von Habsburg und Erzherzogs Eugen sich durch besondere Herzlichkeit auszeichnen und dankbar der Verdienste gedenken, die der große Historiker Srbik sich um das Andenken Österreichs und seiner Dynastie erworben hat“) und SPItzmüLler, Ursach (wie Anm. 154) 405 („hat [...] den großen Toten in sehr warmer und objektiver Weise gewürdigt").

306 Spitzmüller, Ursach (wie Anm. 154) 405.

307 http://de.wikipedia.org/wiki/Heinrich_von_Srbik (letzter Zugriff 08.03.2010).

308 BAK, N 1323, 21.

309 Wrabetz, Srbik (Bibl.) 30. Bei dem so von Wrabetz wiedergegebenen Wunsch des Rektors handelte es sich übrigens um die Abwandlung eines ursprünglich auf Ranke gemünzten Srbik-Zitates „Vor seinem Schatten mögen sich noch viele Geschlechter in Ehrfurcht neigen!"; genau dies wünschte seinem Lehrer WANDRuszka, Srbik (1978/79) (Bibl.) 365.

310 Pitcher, Srbik (Bibl.) 263 Anm. 36. 
diger, „Hekatomben von Blutopfern“ zugunsten der eigenen Ideale oder eher Ideologeme bedenkenlos in Kauf nehmender Konjunktur-Ritter voll gerade für genuine Nationalsozialisten typischer Ressentiments. Eine Persönlichkeit dieses Zuschnitts als Konservativen zu bezeichnen entwürdigt das Andenken der vielen zweifelsfrei konservativen NS-Gegner vom Schlage eines Johan Huizinga, Gerhard Ritter oder Wilhelm Röpke.

\section{B I B L IO G R A F I E}

Arduino Agnelli, Heinrich Ritter von Srbik (Gli Storici 3, Napoli 1975).

Ders., La genesi dell'idea di Mitteleuropa (Trieste 2005) passim.

C. Antoni, Heinrich von Srbik e l'unità della storia tedesca, in: Studi Germanici 2 (I937) 46-75.

Peter Aufgebauer, Art. „Srbik, Heinrich von“, in: Literatur-Lexikon: Autoren und Werke deutscher Sprache I I, hg. v. Walther KILLY (Berlin I998) I 25.

Wilhelm BAuer, Heinrich Srbik, in: Almanach der ÖAW Io I (I95 I) 327-37 I = DERs., Heinrich Srbik (I878-195I), in: NÖB I2 (1957) I7I-I93.

Horst Berndt, Historiker und ihre Gegenwart. Friedrich Meinecke I 862-1954 - Heinrich Ritter v. Srbik 1878-195 I, in: Leben und Leistung II. Fortsetzung der Burschenschaftlichen Doppelbiographien, Heidelberg 1965. Im Wartburg-Gedenkjahr 1967 (Darstellungen und Quellen zur Geschichte der deutschen Einheitsbewegung im neunzehnten und zwanzigsten Jahrhundert 7 , Heidelberg 1967) i 96-234.

Horst Walter Blan Ke, Die wissenschaftliche Korrespondenz eines Historikers: Heinrich von Srbik, in: Storia della storiografia I7 (I990) IOI-I09.

Taras Borodajkewycz, Gedenken an Heinrich von Srbik, in: Freie Argumente (I976) Heft i I, 47-49.

Ders., Heinrich Ritter von Srbik. Ein Gedenkblatt zu seinem ıoo. Geburtstag, in: Heinrich Ritter von SR вік, Zwei Reden für Österreich (Eckart-Schriften 67, Wien I 978) 4-I 2.

John W. Boyer, Comment: Heinrich von Srbik, in: Paths of Continuity. Central European Historiography from the I930s to the I950s, hg. v. Hartmut LeHmann, James Sheenan (Washington D.C. I994) I 87-195.

Georg BROD, Heinrich von Srbik. Ein Vorkämpfer der gesamtdeutschen Geschichtsauffassung, in: Der Türmer 34 (1936) 65f.

Art. „Srbik, Heinrich Ritter von“, in: Österreich-Lexikon in drei Bänden 3, hg. v. Ernst BrUCKMÜLLER 2 (Wien 2004) 245.

Otto Brunner, Heinrich Srbik. Ein Nachruf, in: Wiener Geschichtsblätter 6= 66,2 (I95 I) 32.

Erich Cermak, Beiträge zur Geschichte des Lehrkörpers der Philosophischen Fakultät der Universität Wien zwischen 1938 und 1945 (unpubl. Diss. Wien 1980) 308-3 Io.

Art. „Srbik Heinrich von“, in: Felix Czeı ke, Historisches Lexikon Wien 5 (Wien ND 2004) 275.

Michael Derndarsky, Österreich und die „Deutsche Einheit“. Studien zu Heinrich von Srbik und seiner gesamtdeutschen Geschichtsauffassung (unpubl. Habil. Klagenfurt 1989).

Ders., Der Fall der gesamtdeutschen Historie. Heinrich von Srbik im Spannungsfeld von Wis- 
senschaft und Politik, in: Kultur und Politik in Österreich und Ungarn, hg. v. Péter Hanák, Waltraud Heinde, Stefan Malfèr, Éva Somogyi (Begegnungen an der Donau, Wien/Köln/ Weimar 1994) I 53-176.

Ders., Zwischen „Idee“ und „Wirklichkeit“. Das Alte Reich in der Sicht Heinrich von Srbiks, in: Imperium Romanum - irregulare corpus - Teutscher Reichs-Staat. Das Alte Reich im Verständnis der Zeitgenossen und der Historiographie, hg. v. Matthias Schnettger (Veröff. des Instituts für Europäische Geschichte Mainz - Abteilung Universalgeschichte - Beiheft 57, Mainz 2002) I 89-205.

Jacques Droz, Heinrich von Srbik $\dagger$, in: Revue Historique 207 (I952) I Iff.

Ders., Heinrich Ritter von Srbik et la conception gesamtdeutsch de l'histoire allemande, in: Austriaca. Cahiers Universitaires d'Information sur l'Autriche $N^{\circ}$ 6, Quatrième Année (Mai-Juin I 978) 5 I-77.

Friedrich Engel-Janosi, Heinrich von Srbik (I878-195I), in: Journal of Central European Affairs I I (I95I) $78 \mathrm{f}$.

Bernd Faulen bach, Srbik, Heinrich Ritter von (I878-1951), in: Historikerlexikon. Von der Antike bis zur Gegenwart, hg. v. Rüdiger vom Bruch, Rainer A. Müller (München ${ }^{22002)}$ 3I4-3I6.

Fritz Fellner, Heinrich Ritter von Srbik (I878-195I), in: Paths of Continuity. Central European Historiography from the I930s to the I 950 , hg. v. Hartmut Lehmann, James Sheehan (Washington D.C. I994) I7I-I 86.

Ders., Art. „Srbik, Heinrich von“, in: DBE 9 (München 1998) $424 \mathrm{f}$.

Ders., Geschichtsschreibung und nationale Identität: Probleme und Leistungen der Österreichischen Geschichtswissenschaft (Wien/Köln/Weimar 2002).

Ders., Heinrich von Srbik - „Urenkelschüler Rankes“, in: Fellner, Geschichtsschreibung 330-345.

Fritz Fellner, Doris A. Corradini, Österreichische Geschichtswissenschaft im 20. Jahrhundert. Ein biografisch-bibliographisches Lexikon (VKGÖ 99, Wien 2006).

Art. „Srbik, Heinrich (Ritter von)“, in: Fellner, Corradini, Geschichtswissenschaft 385 f.

[Günther] F[RAnZ], Srbik, Heinrich Ritter von, in: Biographisches Wörterbuch zur deutschen Geschichte 3 S-Z, bearb.v. Dems., Karl Bost, Hanns Hubert Hof mann (München ${ }^{2}$ I995) 27 I 8f.

Helga FrÜHWald, Großdeutsch und Gesamtdeutsch bei Heinrich von Srbik (unpubl. Diss. Univ. Wien 1965).

Silvio Furlani, La scomparsa di un grande storico: Heinrich von Srbik, in: Nuova Rivista Storica 35,6 (I95I) I66-I72.

Josef Gölles, Heinrich Ritter von Srbik, in: Carinthia I I 44 (1954) Io2gf.

Franz Graf-Stuhlhofer, Opportunisten, Sympathisanten und Beamte. Unterstützung des NSSystems in der Wiener Akademie der Wissenschaften, dargestellt am Wirken Nadlers, Srbiks und Meisters, in: Wiener Klinische Wochenschrift I Io, Heft 4-5 (I998) I 52-I 57.

Oswald von Gschliesser, Universitätsprofessor Dr. Heinrich Ritter von Srbik, in: Ders., Tirol - Österreich. Gesammelte Aufsätze zu deren Geschichte (Innsbruck 1965) 233-238.

John HaAG, Srbik, Heinrich von, in: Encyclopedia of Historians and Historical Writing 2, hg. v. Kelly Boyd (London/Chicago I 999) I I 42-I I 44.

Othmar Hageneder, Eine Existenzkrise des Österreichischen Instituts für Geschichtsforschung 
im Jahre 1940? Zu einem Briefwechsel zwischen Ludwig Bittner und Heinrich von Srbik, in: MIÖG II 2 (2004) 399-4II.

Günther Hamann, Kriegs- und Nachkriegserinnerungen eines Studenten an Heinrich Ritter von Srbik, in: Anzeiger ÖAW, Phil.-Hist. Kl. I I 5 (1978 [1979]) 366-395.

Hugo Hantsch, Heinrich v. Srbik $\dagger$, in: Wissenschaft und Weltbild 4 (I95 I) I 3 If.

Ders., [Heinrich Srbik,] in: Die Feierliche Inauguration des Rektors der Wiener Universität für das Studienjahr I95I/52 (I952) 5I-54.

Gernot Heiss, Die „Wiener Schule der Geschichtswissenschaft“ im Nationalsozialismus: „Harmonie kämpfender und Rankescher erkennender Wissenschaft"?, in: Geisteswissenschaften im Nationalsozialismus. Das Beispiel der Universität Wien, hg. v. Mitchell G. Ash, Wolfram Niess, Ramon Pils (Göttingen 2010) 397-426.

Karl G. Hugelmann, Heinrich Ritter von Srbik, in: Deutsche Universitätszeitung 6, Heft I 3 (I95I) I 5 .

Heinrich Ritter von Srbik, Die wissenschaftliche Korrespondenz des Historikers 191 2-1945, hg. v. Jürgen Kämmerer (Deutsche Geschichtsquellen des 19. und 20. Jahrhunderts 55, Boppard am Rhein 1987).

Alois Kernbauer, Grazer Geschichtsforscher von europäischem Rang, in: Kunst und Wissenschaft aus Graz 2: Kunst und Geisteswissenschaften aus Graz. Werk und Wirken überregional bedeutsamer Künstler und Gelehrter: vom I 5 . Jahrhundert bis zur Jahrtausendwende, hg. v. Karl Аснам (Wien/Köln/Weimar 2009) 559-576, hier 574-576.

Eberhard Kessel, Heinrich von Srbik. Repräsentativer österreichischer und deutscher Historiker, in: Deutsche Universitätszeitung 6, Heft 8 (195 I) 8-Io.

Ernst KleE, Das Personenlexikon zum Dritten Reich. Wer war was vor und nach I945? (Frankfurt/M. 2003) 593.

Ota Konrád, Německé bylo srdce monarchie ... Rakušanství, němectví a střední Evropa v rakouské histografii mezi válkami (Praha 20I2).

[Hans-Christof] K[RAus], Srbik, Heinrich Ritter von, in: Lexikon des Konservatismus, hg. Caspar v. Schrenck-Notzing (Graz/Stuttgart I996) 523-525.

Manfred Lang, Heinrich Ritter von Srbik: Ein gesamtdeutscher Historiker, in: Akzente (Zs. des Bundes sozialistischer Akademiker) Heft I/2 (1988) I 7 f.

Klaralinda MA-Kircher, Dopsch - Redlich - Srbik. Zum „constituierenden Teil einer Lebensgeschichte“, in: „Flügel und Extreme“. Aspekte der geistigen Entwicklung Heimito von Doderers, hg. v. Kai Luehrs-Kaiser, Gerald Sommer (Schriften der Heimito von Doderer-Gesellschaft I, Würzburg 1999) I 3 I-I 50 .

Armin Mohler, Karlheinz Weissmann, Heinrich von Srbik, in: Armin Mohler, Karlheinz Weissmann, Die konservative [sic] Revolution in Deutschland 1918-1932. Ein Handbuch (Graz $\left.{ }^{6} 2005\right) 359$.

Ludwig Moos, Bildungsbürgertum, Nationalproblem und demokratisches Zeitalter. Studien zum Werk Heinrich Ritters von Srbik (Diss. Freiburg i. Br. 1967).

Karl Alexander Müller, Gesamtdeutsche Geschichtsauffassung. Heinrich Ritter von Srbik, in: DERs., Zwölf Historikerprofile (Stuttgart/Berlin I935) 40-47.

Werner NäF, Heinrich Ritter von Srbik (I878-I95I), in: HZ I73 (I952) 95-IOI. 
Josef Michael Pasteiner, Die gesamtdeutsche Geschichtsauffassung Heinrich Ritter von Srbiks und ihr Beitrag zur Geschichtstheorie (unpubl. Diss. Univ. Wien I980).

John Harold Joseph Pitcher, Heinrich Ritter von Srbik and the evolution of gesamtdeutsch historiography (PhD Diss. Tulane University 1975).

Art. „Srbik, Dr. Heinrich“, in: Das Jahrbuch der Wiener Gesellschaft. Biographische Beiträge zur Wiener Zeitgeschichte, hg. v. Franz Planer (Wien ${ }^{[2]}$ I929) 592.

Andreas Posch, Heinrich Ritter von Srbik †, in: ZHVSt 43 (I952) I87-I94.

Hermann Raschhofer, Heinrich von Srbik, in: Volk und Reich I4 (I938) 864f.

Viktor Reimann, Heinrich von Srbik, in: Ders., Fünf ungewöhnliche Gespräche (Wien I99I) 60-IOI.

Helmut Reinalter, Heinrich Ritter von Srbik, in: Deutsche Historiker 8, hg. v. Hans-Ulrich Wehler (Kleine Vandenhoeck-Reihe I478, Göttingen I982) 78-95.

Gerhard Ritter, Der gescheiterte Vermittler. Zum Gedächtnis Heinrich von Srbiks, in: Die Neue Zeitung 7. Jg., Nr. 46 (23.2.195I) 4.

Ronald J. Ross, Heinrich Ritter von Srbik and „Gesamtdeutsch“ History, in: The Review of Politics 3I (I969) 88-I07.

Theodor Schieder, Heinrich von Srbik $\dagger$, in: Geschichte in Wissenschaft und Unterricht 2 (I95 I) I29-I 32 .

Franz Schna BeL, Heinrich Ritter von Srbik. Io.I I.I 878-I6.2.195 I, in: Bayerische Akademie der Wissenschaften. Jb. I95 I (München 1952) I63-170.

Karen SCHÖNẄ̈LDER, Heinrich von Srbik. „Gesamtdeutscher“ Historiker und „Vertrauensmann“ des nationalsozialistischen Deutschland, in: Geschichte der Kaiser-Wilhelm-Gesellschaft im Nationalsozialismus. Bestandsaufnahmen und Perspektiven der Forschung 2, hg. v. Doris KaufMANN (Göttingen 2000) 528-544.

Wilhelm Schüssler, Zum Gedächtnis Heinrichs Ritter v. Srbiks (I878-I95I), in: Südostforschungen I 2 (I953) 287-29I.

Art. „Heinrich Ritter von Srbik. Historiker“, in: Götz von SELle, Ostdeutsche Biographien. 365 Lebensläufe in Kurzdarstellungen (Würzburg 1955) 309.

Paul R. Sweet, The Historical Writing of H. von Srbik, in: History and Theory 9, I (I970) 37-58.

Art. „Srbik, Heinrich, v.“, in: Österreicher der Gegenwart. Lexikon schöpferischer und schaffender Zeitgenossen, hg. v. Robert TeICHL (Wien I95I) $290 \mathrm{of}$

Franco Valsecchi, Heinrich von Srbik e la concezione unitaria della storia tedesca, in: Rivista storica italiana [ $54=$ =] Serie 5, Vol. 2, Fasc. 3 (30 Sett. 1937) 45-69.

Adam WandruszKa, Heinrich Ritter von Srbik †, in: MIÖG 59 (I95I) 228-236.

Ders., Heinrich Ritter von Srbik - Leben und Werk, in: Anzeiger ÖAW, Phil.-Hist. Kl. I I 5 (I 978 [I979]) 352-365.

Wolfgang Weber, Biographisches Lexikon zur Geschichtswissenschaft in Deutschland, Österreich und der Schweiz. Die Lehrstuhlinhaber für Geschichte von den Anfängen des Faches bis 1970 (Frankfurt/M./Bern/New York/Nancy 1984) 56If.

Hermann Weiss, Srbik, Heinrich Ritter v., in: Ders., Personenlexikon 1933-I945 (ND Wien 2003) 438. 
Peter Wrabetz, Heinrich Ritter von Srbik (Gothia-Wien I 899-1903). Zu seinem neunten Todestag am 16.2.1959, in: Burschenschaftliche Blätter 74, Heft 2 (I959) $29 f$. 


\section{Gustav Pirchan (I88I-I945)}

EIN PRAGER HISTORIKER ZWISCHEN DEUTSCHEN UND TSCHECHEN

Der I88I in Wien geborene Prager Mediävist Gustav Pirchan ist eine weitgehend in Vergessenheit geratene Person ${ }^{1}$. Dies verwundert, wenn man bedenkt, dass Pirchan von 1933 bis 1945 Inhaber des Lehrstuhls für mittelalterliche Geschichte an der Deutschen Universität in Prag war. Nach dem Studium und dem Besuch des IÖG als außerordentliches Mitglied war er seit 1907 als Archivar im Statthalterei-Archiv bzw. seit I9I8/I9 im Archiv des Innenministeriums der Tschechoslowakei beschäftigt. Hier arbeitete er über zwei Jahrzehnte mit tschechischen Kollegen zusammen. Zudem wirkte er von I 9 I7 bis I940 als Geschäftsführer des Vereines für Geschichte der Deutschen in Böhmen (VGDB) ${ }^{2}$. Pirchan

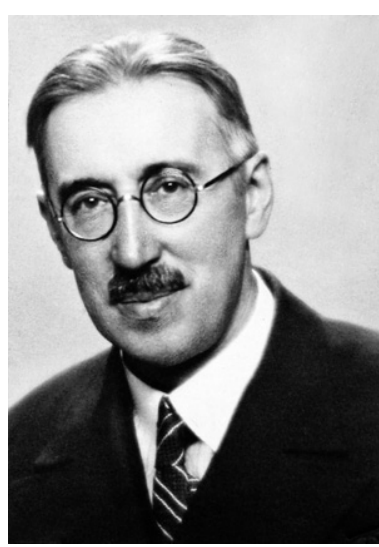

Abb. 24 : Gustav Pirchan $1938 / 39$ stand somit mit zentralen Institutionen der deutschen Geschichtswissenschaft in den böhmischen Ländern bzw. in der Tschechoslowakei in Verbindung und prägte sie mit $^{3}$.

1 Außer dem kurzen apologetischen Nachruf von Kurt Oberdorffer, Gustav Pirchan zum Gedenken, in: Der Archivar 2 (1949) 80f., und den lexikalischen Erwähnungen in: Biografický slovník archivářu českých zemí [Biografisches Lexikon der Archivare der böhmischen Länder], hg. v. Jaroslava Hoffmannová, Jana Pražáková (Praha 2000) 493; Biographisches Lexikon zur Geschichte der böhmischen Länder 3, hg. v. Ferdinand Seibt, Heribert Sturm (München 2000) 225; Fritz Fellner, Doris A. Corradini, Österreichische Geschichtswissenschaft im 20. Jahrhundert. Ein biographisch-bibliographisches Lexikon (VKGÖ 99, Wien 2006) 318f., wurden Pirchans Person und Werk bis heute nicht gewürdigt.

2 Zum VGDB vgl. Nina Lohmann, „Eingedenk der Väter, unerschütterlich treu unserem Volke!“: Der Verein für Geschichte der Deutschen in den Sudetenländern im Protektorat Böhmen und Mähren, in : Die Deutschen und das östliche Europa. Aspekte einer vielfältigen Beziehungsgeschichte. FS für Detlef Brandes zum 65. Geburtstag, hg. v. Dietmar Neutatz, Volker Zimmermann (Essen 2006) 25-46; Hans Lemberg, Der Verein für Geschichte der Deutschen in Böhmen, in: Mit unbestechlichem Blick ... Studien von Hans Lemberg zur Geschichte der böhmischen Länder und der Tschechoslowakei. Festgabe zu seinem 65. Geburtstag, hg. v. Ferdinand Seibt, Jörg K. Hoensch, Horst Förster, Franz Machilek, Michaela Marek (München 1998) 91-115; Kurt Oberdorffer: Der Verein für Geschichte der Deutschen in Böhmen 1862-1938, in: Bohemia. Jb. des Collegium Carolinum 3 (1962) 9-29.

3 Zur Geschichtswissenschaft in den böhmischen Ländern siehe: Ota KonráD, Dějepisectví, germanistika a 
Als Forscher ist der Schüler von Emil Werunsky ${ }^{4}$ vor allem für seine Habilitationsschrift zur zweiten Romreise Kaiser Karls IV. bekannt, die zugleich auch Pirchans Magnum Opus darstellt 5 .

Pirchan erlebte mehrere unterschiedliche politische Regime. Seine Kindheit und Jugend, Studium, Promotion und der Beginn seines beruflichen Werdegangs fanden noch in der Habsburgermonarchie statt. Er wuchs in Ostböhmen als Sohn eines deutschen Beamten in tschechischer Umgebung auf und besuchte zunächst auch tschechische Schulen. Diesem Umstand verdankte Pirchan seine sehr guten Kenntnisse der tschechischen Sprache. In die Zeit der k. k. Monarchie fallen auch Studienaufenthalte im Deutschen Reich (Leipzig, Heidelberg), eine einjährige Studienreise nach Italien und die Mitgliedschaft im Österreichischen Historischen Institut in Rom. In der Ersten Tschechoslowakischen Republik (I918-1938) setzte sich Pirchans Karriere sowohl im Archiv als auch an der Universität fort. So beförderte die tschechoslowakische Regierung I 92 I den vierzigjährigen Pirchan zum Archivdirektor. Im selben Jahr wurde er an der Deutschen Universität in Prag habilitiert. Zwölf Jahre später erfolgte seine Berufung zum außerordentlichen Professor an seine Alma Mater. Zu jenem Zeitpunkt schied Pirchan aus dem Archivdienst aus. Obwohl er vollständig in die deutsche Geschichtswissenschaft integriert war, unterhielt Pirchan auch Kontakte zu tschechischen Institutionen und den mehrheitlich tschechischen Kollegen im Archiv. Dabei bediente er sich bereitwillig des Tschechischen.

slavistika na Německé univerzitě v Praze 1918-1945 [Geschichtsschreibung, Germanistik und Slavistik an der Deutschen Universität in Prag 1918-1945] (Praha 2011); Pavel Kolář, Geschichtswissenschaft in Zentraleuropa: die Universitäten Prag, Wien und Berlin um 1900 1-2 (Leipzig 2008); Die „sudetendeutsche Geschichtsschreibung “1918-1960. Zur Vorgeschichte und Gründung der Historischen Kommission der Sudetenländer, hg. v. Stefan Albrecht, Jiří Malíře, Ralph Melville (Veröff. des Collegium Carolinum 114, München 2008); Pavel Koláǩ, Eine Brutstätte der Volksgeschichte? Überlegungen zur Geschichte der Prager deutschen Historiographie 1918-1938 im Gesamtkontext der deutschsprachigen Geschichtswissenschaft, in: Geschichtsschreibung zu den böhmischen Ländern im 20. Jahrhundert. Wissenschaftstraditionen - Institutionen - Diskurse, hg. v. Christiane Brenner, K. Erik Franzen, Peter Haslinger, Robert Luft (Bad Wiesseer Tagungen des Collegium Carolinum 28, München 2006) 109-135; Pavel Kolář, Die Geschichtswissenschaft an der Deutschen Universität Prag 1882-1938: Entwicklung der Lehrkanzeln und Institutionalisierung unter zwei Regimen, in: Universitäten in nationaler Konkurrenz. Zur Geschichte der Prager Universitäten im 19. und 20. Jahrhundert, hg. v. Hans Lemberg (Veröff. des Collegium Carolinum 86, München 2003) 85-114; Ferdinand Sеiв T, Geschichtswissenschaft in der Tschechoslowakei 1918-1938, in: Kultur und Gesellschaft in der Ersten Tschechoslowakischen Republik, hg. v. Dems., Karl BosL (Bad Wiesseer Tagungen des Collegium Carolinum 9, München/Wien 1982) 269-287.

4 Zu Werunsky vgl. den Nachruf: Gustav Pirchan, Prof. Dr. Emil Werunsky, in: ZSG 6 (1943) 102-107; Pavel KolÁř, Nährboden falscher Innovation, in: Vorlesung, Seminarium, Repetitorium. Universitäre geschichtswissenschaftliche Lehre im internationalen Vergleich, hg. v. Gabriele Lingelbach (München 2006) 89-128, hier 116-119.

5 Gustav Pirchan, Italien und Kaiser Karl IV. in der Zeit seiner zweiten Romfahrt (Quellen und Forschungen aus dem Gebiete der Geschichte 6,1-2, Prag 1930). 
In der Zeit des Protektorats Böhmen und Mähren (I939-1945) wirkte er nur noch an der inzwischen umbenannten Deutschen Karls-Universität ${ }^{6}$. So sehr Pirchan die Veränderungen von I938/39 begrüßte, bereiteten sie ihm auch Enttäuschungen: Die im April I 939 beantragte Mitgliedschaft in der NSDAP lehnte die Partei aufgrund der Nürnberger Rassengesetze ab, da Pirchans Ehefrau einen jüdischen Urgroßvater hatte. Tragisch war Pirchans kurzer letzter Lebensabschnitt in der im Mai 1945 von der deutschen Okkupation befreiten Tschechoslowakei. Im Alter von 64 Jahren starb er im September 1945 als internierter Deutscher im ehemaligen NS-Konzentrationslager Theresienstadt an Herzschwäche.

Die Meinungen über Pirchan als Historiker und Menschen fielen nach seinem Tod fast ausschließlich positiv aus. Kurt Oberdorffer beschrieb ihn im offiziösen Nachruf als „hochkultivierten, jeder Zeit toleranten und hilfsbereiten Mann, der außerhalb seines wissenschaftlichen und archivarischen Arbeitsfeldes geradezu scheu jegliche Öffentlichkeit mied“. Er pries ihn als „feinen Stilisten“, als „künstlerisch fein empfindenden Forscher“. Der Autor sagte ihm zum einen rührende Geschäftigkeit nach, charakterisierte ihn andererseits aber auch als „weltentlegenen Gelehrten“" . An einem anderen Orte würdigte er ihn als Person, der für ihre Bemühung um die Verständigung mit tschechischen Historikern viel zu danken sei $^{8}$. Auch tschechische Kollegen beurteilten Pirchan überwiegend positiv. So erinnerte sich Karel Kazbunda an ihn als gemäßigten Deutschen, einen außergewöhnlich gebildeten Menschen ${ }^{9}$. Im tschechischen Standardwerk zur Geschichtsschreibung in den böhmischen Ländern zählt ihn der Autor František Kutnar zur versöhnlicheren älteren Generation von Prager deutschen Historikern, die sich von der jüngeren nationalistischeren unterschieden habe. Pirchans Habilitationsschrift würdigt er als wertvolle Arbeit aufgrund eines genauen und umfangreichen Archivstudiums ${ }^{10}$. Eva Hahn wiede-

6 Alena MíšKová, Die Deutsche (Karls-)Universität vom Münchener Abkommen bis zum Ende des Zweiten Weltkrieges (Universitätsleitung und Wandel des Professorenkollegiums) (Praha 2007); Ota Konrád, Geisteswissenschaften an der Deutschen Universität in Prag (1938/39-1945), in: Universitäten und Hochschulen im Nationalsozialismus und in der frühen Nachkriegszeit, hg. v. Karen Bayer, Frank Sparing, Wolfgang Woelk (Stuttgart 2004) 219-248; Ders., Die deutschen Hochschullehrer in Prag vor und nach 1938/39. Versuch einer Bestandsaufnahme, in: Die „Volksdeutschen“ in Polen, Frankreich, Ungarn und der Tschechoslowakei. Mythos und Realität, hg. v. Jerzy Koснаnows кi, Maile SAch (Einzelveröff. des Deutschen Historischen Instituts Warschau 12, Osnabrück 2006) 147-162.

7 Oberdorffer, Pirchan (wie Anm. 1) 80f. Zu Oberdorffer siehe: Jiří Němec, Kurt Oberdorffer, in: Handbuch der völkischen Wissenschaften. Personen - Institutionen - Forschungsprogramme - Stiftungen, hg. v. Ingo HaAr, Michael Fahlbusch, Matthias Berg (München 2008) 444-448.

8 Oberdorffer, Verein (wie Anm. 2) 29.

9 Mé archivní poslání ve Vídni [Meine Aufgabe als Archivar in Wien] Bl. 148f. ANM, NL Kazbunda, K. 32.

10 František Kutnar, Jaroslav Marex, Přehledné dějiny českého a slovenského dějepisectví [Geschichte der tschechischen und slowakischen Geschichtsschreibung im Überblick] (Praha 22009) 954 und 957. 
rum bezeichnete ihn aufgrund der Analyse ausgewählter Texte als einen „der rhetorisch militanten ,Väter' der sudetendeutschen völkischen Geschichtsideologie" ${ }^{11}$.

Diese unterschiedlichen Äußerungen über den Forscher, die mehrmaligen Regimewechsel zu seinen Lebzeiten und die deutsch-tschechische Arbeitsumgebung im Archiv lassen nach Pirchans Einstellung, insbesondere nach seiner Position zu den deutsch-tschechischen Beziehungen fragen. Mehrere Beiträge des Prager Historikers waren nämlich der Geschichte der Deutschen in Böhmen und des VGDB gewidmet. Es drängt sich die Frage auf, wie sich Pirchan, durch seine Biografie ein Kenner des deutsch-tschechischen Zusammenlebens, zu diesem Punkt in historischer Perspektive äußerte. Der vorliegende Beitrag kann aufgrund der unzureichenden Quellenlage Pirchans Biografie nur grob aufzeigen. Er will zudem das historiografische Werk des Historikers betrachten ${ }^{12}$.

\section{JUGEND UND STUDIUM}

Gustav Pirchan wurde am 3. Februar i88 I als Sohn von Gustav und Adelheid (geb. Hansmann) in Wien geboren. Seine Kindheit und auch den Großteil seines weiteren Lebens verbrachte er jedoch in Böhmen, wo sein Vater im nordostböhmischen Jitschin (Jičín) als Eisenbahnbeamter wirkte ${ }^{13}$. Dort lernte Pirchan in der tschechischen Volks-

$11 \mathrm{http}: / /$ www.bohemistik.de/bskizzen.html.

12 Die folgenden Archivbestände wurden herangezogen: UAP - PA Gustav Pirchan; NA - NL Anton Blaschka, PA Gustav Pirchan, Úřad říšského protektora [Amt des Reichsprotektors] (ÚŘP), Prezidium ministerstva vnitra [Präsidium des Innenministeriums] (PMV), Archivní registratura Čechy Morava [Archivregistratur Böhmen Mähren] (AR-ČM), Archivní registratura Archiv ministerstva vnitra [Archivregistratur des Archivs des Innenministeriums] (AR-AMV), Předsednictvo ministerské rady [Vorsitz des Ministerrats] (PMR); MÚA, AAVČR - NL Wilhelm Wostry, NL Josef Pfitzner, NL Heinz Zatschek, NL Bedřich Mendl, NL František Roubík, NL Václav Novotný, NL Otakar Odložilík, Společnost pro podporování německé vědy, umění a literatury v Čechách [Die Gesellschaft zur Förderung deutscher Wissenschaft, Kunst und Literatur in Böhmen] ; Archiv Národního Muzea (ANM) [Archiv des Nationalmuseums] - NL Kazbunda ; Státní oblastní archiv (SOA) Litoměřice, pobočka Děčín [Staatliches Gebietsarchiv Leitmeritz, Zweigstelle Tetschen - Bodenbach]. Rodinný archiv (RA) [Familienarchiv] Clam-Gallasů, NL Josef Bergl; BAB - R; BAB - BDC. Herzlich bedanken möchte ich mich bei Hana Štěríková und Adam Dobeš für Fotografien aus den Prager Archiven, bei Lukas Dovern für zahlreiche Kopien aus Zeitschriften und Büchern in Münster. Hilfreiche und willkommene Hinweise gaben Michael Brabänder, Detlef Brandes, Rolf Lehr, Nina Lohmann, Jan Kahuda, Zdeňka Kokošková, Alena Míšková, Eduard Mühle, Jana Ratajová, Milada Sekyrková und Petr Šafařík. Dem Herausgeber danke ich für zahlreiche Hinweise und die Vermittlung der Porträtfotografie Pirchans. Viel Dank gebührt den drei hauptsächlich für diese Studie benutzten Prager Archiven (UAP, NA, MÚA) und ihren Archivaren für die ausgezeichneten Arbeitsbedingungen.

13 Im WS 1903/04 gab Pirchan in seinem Verzeichnis der besuchten Vorlesungen als Beruf des Vaters Kaiserlicher Rat, Inspektor und Verkehrs-Vorstand der k. k. priv. böhm. Commercialbahnen, Jitschin an. Zuvor nannte er entweder: Inspektor der k. k. priv. öst.-ung. Staatseisenbahngesellschaft Jitschin oder Inspektor der k. k. priv. böhm. Commercialbahnen Jitschin. UAP, Philosophen im Studienjahr 1899/1900-SS 1904. 
schule und im Untergymnasium in Jitschin Tschechisch ${ }^{14}$. Anschließend besuchte er von I 895 an das deutsche Gymnasium im nahen Arnau (Hostinné), wo er am I4. Juli i 899 das Maturanten-Zeugnis erhielt.

Der tschechische Historiker Karel Kazbunda ${ }^{15}$, der ebenfalls aus Jitschin stammte und dessen Vater am dortigen tschechischen Gymnasium Lehrer war, erinnerte sich in seinen Memoiren an Pirchan, den er von klein auf kannte ${ }^{16}$. Kazbundas Mutter empfahl ihrem Sohn damals, sich Pirchan aufgrund seiner ausgezeichneten Schulnoten sowie seines feinen Benehmens und Auftretens zum Vorbild zu nehmen. Später überzeugte sich Kazbunda anhand der Schulzeugnisse im Archiv davon, dass Pirchan in Jitschin durchgängig sehr gute Noten hatte. Als Erwachsener erfuhr Kazbunda später, dass Pirchans Mutter streng deutschnational und antitschechisch eingestellt gewesen sei und darauf gedrängt habe, dass ihr Sohn eine deutsche Schulbildung erhalte und an der deutschen Universität studiere $^{17}$.

Während Pirchan in seinen Studienbüchern immer den Namen und Beruf des Vaters angeben musste, enthalten sie keine Informationen über seine Mutter. In der Zwischenkriegszeit lebte sie in Eggenburg in Österreich, wo Pirchan sie regelmäßig besuchte. Auch

14 Von Geburt ein Deutscher, ist er auch der böhmischen Sprache vollständig in Wort und Schrift mächtig, da er nicht nur die Volksschule, sondern auch das Untergymnasium zu Jitschin an der dortigen böhmischen Volksschule und an dem k.k.-böhmischen Obergymnasium stets mit Auszeichnung absolviert hat. Köpl an das k. k. StatthaltereiPräsidium, 01.05.1908. NA, AR-ČM, PA Pirchan, Sig. II, K. 4, Inv.-Nr. 20. Pirchan selbst erwähnt in den verschiedenen Fassungen seines Lebenslaufs den Besuch der tschechischen Schulen nicht.

15 Zu Kazbunda vgl. Stanley B. Winters, In Remembrance Karel Kazbunda 1888-1982, in: Austrian History Yearbook 17 (1981) 581-582.

16 Mé archivní poslání ve Vídni, Bl. 148. ANM, NL Kazbunda, K. 32.

17 Ebd. Diese Information erhielt Kazbunda von dem Historiker Rudolf Koss. Dieser entstammte einer Prager deutschen Familie, studierte Geschichte und Philosophie an der Deutschen Universität und besuchte das IÖG in Wien. 1912 wurde er an der Prager deutschen Universität für österreichische Geschichte habilitiert. Wie seine beiden Kollegen Bergl und Pirchan wirkte Koss an der Übergabe von Archivalien aus den Wiener Archiven an die Tschechoslowakei mit. Von 1918 bis zu seinem Tod 1929 arbeitete er als Archivar im Böhmischen Landesarchiv. Von seinen guten Beziehungen zu den tschechischen Kollegen zeugen u.a. die Nekrologe von Kazbunda und Mendl. Deutsche nationalistische Kreise machten Koss seine nicht eindeutige nationale Haltung zum Vorwurf. So scheiterte Koss' Berufung zum Professor an der Deutschen Universität 1920 an dem Protest des Althistorikers Heinrich Swoboda, der Koss vorwarf, sich während seines Studiums in den ersten sechs Semestern zur tschechischen und nur in den letzten drei zur deutschen Sprache bekannt zu haben. Zudem verwies Swoboda auf einen angeblich „protschechoslowakischen“ Aufsatz Koss' im Prager Tagblatt vom 09.11.1918. Vgl. Kolář, Die Geschichtswissenschaft (wie Anm. 3) 108; Ders., Geschichtswissenschaft in Zentraleuropa 1 (wie Anm. 3) 204 (Kolár gibt fälschlich Karl Maria Swoboda als den Protestierenden an, doch handelt es sich nach einem Hinweis Karel Hruzas um den älteren Heinrich Swoboda); Karel KazBUndA in: Český časopis historický (ČČH) 35 (1929) 450f; Bedřich MendL in: Časopis archivní školy (ČA ̌̌) 7 (1930) 124f; Alena Pazde rová, Rudolf Koss, in: Sborník prací členů socialistického svazu mládeže Státního ústředního archivu (Praha 1985) 54-93. 
Pirchans Ehefrau, die am 23. März I 894 geborene Elisabeth (Else) Stradal aus Teplitz (Teplice), wohnte nach dem Zweiten Weltkrieg zunächst dort. Pirchan heiratete erst spät, im Alter von 45 Jahren, am 6. Juli I 926. Die Ehe blieb kinderlos, war anscheinend jedoch glücklich ${ }^{18}$. Pirchan litt seit jungen Jahren an Gelenkrheumatismus und hatte Herzprobleme. Dies war auch der Grund dafür, dass er während des Ersten Weltkrieges nicht als Soldat diente. So ist in seiner Dienstkartei unter der Rubrik Militärverhältnisse „wegen Herzfehler dienstuntauglich“ vermerkt. Wiederholt erhielt er in den Sommermonaten zusätzlichen Erholungs- und Krankenurlaub aufgrund seiner eingeschränkten Gesundheit.

Im WS I 899/I 900 begann Pirchan das Studium der Geschichte, Geografie und Philosophie an der k. k. deutschen Carl-Ferdinands-Universität in Prag, welches er nach zehn Semestern im SS 1904 erfolgreich beendete. Er belegte vor allem Veranstaltungen bei dem Althistoriker Julius Jung sowie dem Mediävisten Emil Werunsky und bei Adolf Bachmann, der zur Geschichte Österreichs bzw. der Habsburgermonarchie in unterschiedlichen Epochen las. Wesentlich weniger Lehrveranstaltungen besuchte er beim Neuzeitler Ottokar Weber. Seit dem SS I 902 nahm Pirchan auch regelmäßig an hilfswissenschaftlichen Vorlesungen, Seminaren und Übungen bei Samuel Steinherz teil ${ }^{19}$. Der Schwerpunkt von Pirchans Studium lag somit auf alter und mittelalterlicher Geschichte sowie Historischen Hilfswissenschaften und spiegelte seine Interessen und Vorlieben wider. Bei den Geografen hörte er ausschließlich und kontinuierlich Oskar Lenz. Im Juni I 904 erhielt er die Lehramtsbefähigung für die Fächer Geschichte und Geografie, im September desselben Jahres das Abschlusszeugnis der Philosophischen Fakultät. Nach der Beendigung des Magisterstudiums in Prag immatrikulierte sich Pirchan im WS I904/05 in Leipzig, wo er bei Karl Lamprecht und Gerhard Seeliger Lehrveranstaltungen belegte. Im SS 1905 setzte er sein Studium in Heidelberg bei Erich Marcks fort. In den Semesterferien besuchte er in den Sommermonaten seine Eltern, die inzwischen im südmährischen Znaim (Znojmo), unweit der Grenze zu Niederösterreich, lebten ${ }^{20}$. In Wien schrieb er sich im WS I905/06 ein und wurde zugleich außerordentliches Mitglied des 26. Ausbildungskurses (I905-I907) am IÖG, wo zu seinen Kurskollegen unter anderem

18 Blaschka berichtete seiner Frau, dass Pirchan in seinem Aktenschrank ein „riesengroßes“ Bild seiner zukünftigen Frau aufbewahre. Diese Information hatte die Reinigungsfrau des Archivs den Kollegen Blaschkas verraten. In Briefen an die Kollegen Bergl, Zatschek und Wostry schrieb die Ehefrau oft auch einige Zeilen oder unterschrieb mit. Blaschka an Lili, 13.03.1926. NA, NL Blaschka, Karton 3, Inv.-Nr. 8.

19 Zu Steinherz siehe Peter Artt, Samuel Steinherz (1857-1942) Historiker. Ein Rektor zwischen den Fronten, in: Prager Professoren 1938-1948. Zwischen Wissenschaft und Politik, hg. v. Alena MíšKovÁ, Monika Glettler (Veröff. zur Kultur und Geschichte im östlichen Europa 17, Essen 2001) 71-101.

20 Pirchan an Oskar Lenz, 09.09.1905. Handschriftenabteilung der Staatsbibliothek zu Berlin - Preußischer Kulturbesitz. Sammlung Ludwig Darmstadter, 2 i 1905 (19); NA, AR-ČM, PA Pirchan, Sig. II, K. 4, Inv.-Nr. 20. 
der spätere Prager Archivar Josef Borovička gehörte ${ }^{21}$. Für dessen Besuch erhielt er ein Stipendium der Gesellschaft zur Förderung deutscher Wissenschaft, Kunst und Literatur in Böhmen ${ }^{22}$. Im Gesuch um das Stipendium betonte er seine Verbundenheit mit Böhmen und die Absicht, dort in Zukunft tätig werden zu wollen ${ }^{23}$.

Nach der Rückkehr nach Prag promovierte Pirchan bei Bachmann und Werunsky mit einer Arbeit „über den Ausdruck nobilis in einigen baierischen Rechtsquellen des Frühmittelalters"24. Das zweistündige Fachrigorosum zur Mediävistik und Geschichte Österreichs sowie das einstündige Rigorosum zur Philosophie legte er am 27. Juni 1906 bei seinen beiden akademischen Lehrern ab, beide Male mit ausgezeichnetem Erfolg. So wurde er am 9. Juli 1906 zum Doktor der Philosophie promoviert. Anschließend wirkte Pirchan ein Schuljahr lang vom I 5. September I906 bis I 5. Juli I907 als Vertretungslehrer an der deutschen Staatsoberrealschule in Brünn, wo er wöchentlich I9 Stunden Deutsch, Geografie und Geschichte unterrichtete ${ }^{25}$.

\section{STAATSARCHIVAR IN DER HABSBURGERMONARCHIE UND IN DER TSCHECHOSLOWAKEI}

Mit Erlass des k. k. Ministers des Innern vom I3. August 1907 wurde Pirchan zum staatlichen Archivpraktikanten im k. k. Statthalterei-Archiv in Prag ernannt, wo er am 3I. August 1907 seinen Dienst antrat. Seit jener Zeit lebte er in einer kleinen Zwei-

21 Pirchan schrieb keine Hausarbeit und legte auch die Abschlussprüfung nicht ab. Im nachfolgenden 27. Kurs (1907-1909) wurden Wilhelm Wostry und Václav Hrubý ausgebildet. Vgl. Leo Santifaller, Das Institut für österreichische Geschichtsforschung. Festgabe zur Feier des zweihundertjährigen Bestandes des Wiener Haus-, Hof- und Staatsarchivs (Veröff. des IÖG 11, Wien 1950) 129 und 131f.; Alphons Lнотsку, Geschichte des Instituts für österreichische Geschichtsforschung 1854-1954 (MIÖG Erg.-Bd. 17, Graz/Köln 1954) 349 und 352f. (ebd. ist Gustav Pirchan im Register irrtümlich als „Hans Pirchan“ aufgenommen).

22 Vgl. hierzu: Die Gesellschaft zur Förderung Deutscher Wissenschaft, Kunst und Literatur in Böhmen (Deutsche Akademie der Wissenschaften in Prag): Materialien zu ihrer Geschichte und Inventar des Archivbestandes 1891-1945, hg. v. Alena Miš́ová, Michael Neumüller (Praha 1994); Josef Hemmerle, Die Gesellschaft zur Förderung Deutscher Wissenschaft, Kunst und Literatur in Böhmen, in: Vereinswesen und Geschichtspflege in den böhmischen Ländern, hg. v. Ferdinand Sегі т (München 1986) 231-247.

23 Pirchan an die Gesellschaft, 18.02.1905, Dankschreiben Pirchans, 17.04.1905. Gutachten von Bachmann, Jung, Weber. MÚA, Gesellschaft zur Förderung Deutscher Wissenschaft, Kunst und Literatur in Böhmen, PA Pirchan, K. 38.

24 Disertace pražské university 1882-1945 II. Německá universita [Die Dissertationen der Prager Universität 1882-1945 II. Die Deutsche Universität], bearb. v. Milena VÝвоrná (Praha 1965) 21. Pirchans Dissertation liegt weder im UAP noch in der Nationalbibliothek (Národní knihovna) in Prag vor.

25 Vgl. das positive Verwendungszeugnis vom 01.09.1907 über Pirchans Tätigkeit als Lehrer. NA, AR-ČM, PA Pirchan, Sig. II, K. 4, Inv.-Nr. 20. 
zimmerwohnung in der Karpfengasse [Kaprova] 6 im Zentrum der Prager Altstadt, nur wenige Meter vom Moldauufer und Altstädterring-Platz entfernt ${ }^{26}$. Sowohl ins Archiv im Pálffy-Palais in der Waldsteingasse [Valdštejnská] auf der Prager Kleinseite als auch zur Universität und Universitätsbibliothek im Klementinum konnte er bequem zu Fuß gehen. Für zweieinhalb Jahre nahm der Junggeselle Pirchan vor seiner Hochzeit 1926 den jüngeren deutschen Archivkollegen Anton Blaschka ${ }^{27}$ in seiner kleinen Wohnung im „Dienstmädchenzimmer" auf ${ }^{28}$.

Am IÖG in Wien unterzog er sich vom 24. bis 26. März I 908 mit vorzüglichem Erfolg der für den staatlichen Archivdienst seit I 896 vorgeschriebenen Ergänzungsprüfung ${ }^{29}$. Im deutschen Direktor des Statthalterei-Archivs, Karl Köpl ${ }^{30}$, fand Pirchan einen Förderer. Köpl berichtete dem Ministerium, dass er sich in Gesprächen mit den Prüfern der Kommission (Emil von Ottenthal, Oswald Redlich und Alfons Dopsch) anlässlich der Sitzung des k. k. Archivrats, dem er angehörte, von Pirchans außergewöhnlich gutem Erfolg überzeugen konnte und seine feste Anstellung im Archiv befürworte ${ }^{31}$.

Für das Jahr I9I2 beantragte Pirchan mit Erfolg einen einjährigen Studienurlaub, um Archive im Ausland besuchen zu können ${ }^{32}$. Er begründete den Antrag damit, dass ihm seine bisherige vierjährige Dienstzeit ausreichende Einblicke in die Amtstätigkeit des Statthalterei-Archivs gegeben habe und er andere Archive im In- und Ausland genauer kennenlernen wolle, um so zu reicherer Erkenntnis zu gelangen. Zudem böte ihm die Reise zu den hervorragendsten Archiven Deutschlands, Italiens und Frankreichs (Paris) [...] die glückliche Möglichkeit, sein wissenschaftliches Werk der Vollendung näher zu führen, mit dessen Vorarbeiten er seit geraumer Zeit in seinen freien Stunden beschäftigt sei. In diesem

26 Während der Studienzeit lebte er seit dem WS 1901/02 im Deutschen Studentenheim. UAP, NU FF, Philosophen im WS 1901/02-SS 1904.

$27 \mathrm{Zu}$ Blaschka siehe Stefan Lenr, Deutsche und tschechische Archivare in der Ersten Tschechoslowakischen Republik. Ein beziehungsgeschichtlicher Beitrag, in: Bohemia. Zs. für Geschichte und Kultur des böhmischen Länder 48 (2008) 412-439, hier 423-430.

28 Blaschka lebte die ersten Jahre in Prag getrennt von seiner Ehefrau, die in ihrem gemeinsamen Heimatort Oberprausnitz [Horní Brusnice] in Ostböhmen wohnte. Klicman an das PMV, 25.01.1927. NA, AR-ÚAMV, PA Blaschka, Sig. IX/2, K. 135, Inv.-Nr. 84.

29 Während Pirchan die paläografische Aufgabe in der Klausurarbeit und in der mündlichen Prüfung sehr befriedigend ablegte, bestand er beide Teile in der Diplomatik sowie im mündlichen Teil zur Chronologie und Archivkunde mit vorzüglichem Erfolg. Prüfungszeugnis vom 26.03.1908. NA, AR-ČM, PA Pirchan, Sig. II, K. 4, Inv.-Nr. 20.

$30 \mathrm{Zu} \mathrm{Köpl} \mathrm{vgl.} \mathrm{Jaroslav} \mathrm{Prokeš,} \mathrm{Archiv} \mathrm{ministerstva} \mathrm{vnitra} \mathrm{a} \mathrm{vědecké} \mathrm{bádání} \mathrm{[Das} \mathrm{Archiv} \mathrm{des} \mathrm{Innenministeri-}$ ums und die wissenschaftliche Forschung], in: Sborník archivu ministerstva vnitra (SAMV) 9 (1936) 7-53.

31 So erhielt er von allen Universitätsprofessoren, welche bei dieser Prüfung als Kommissäre fungierten, [...] die Versicherung, dass Dr. Gustav Pirchan unter allen Kandidaten, welche sich bisher dieser Prüfung unterzogen haben, diese am besten bestanden habe. Köpl, 01.05.1908. NA, AR-ČM, PA Pirchan, Sig. II, K. 4, Inv.-Nr. 20.

32 Pirchan an k.k.-Ministerium des Inneren, 07.10.1911. NA, AR-ČM, PA Pirchan, Sig. II, K. 4, Inv.-Nr. 20. 
Zusammenhang teilte er mit, dass ihm Werunsky die Abfassung des vierten Bandes seiner "Geschichte Karls IV. und seiner Zeit" ${ }^{33}$ angeboten habe und er diese Arbeit ohne eingehende Studien in italienischen und deutschen Archiven nicht durchführen könne. Zudem betonte er den Vorteil des Studienaufenthaltes, der ihn in die Lage versetze, seine italienischen und französischen Sprachkenntnisse zu vervollkommnen. Über Pirchans Studienreise liegen keine näheren Informationen vor. Er wird jedoch vorwiegend in Italien und dort in Rom gearbeitet haben, da er für I9 I I/ I 2 zum außerordentlichen und für I 9I 2/I 3 zum ordentlichen Mitglied des Österreichischen Historischen Instituts in Rom ernannt wurde. Auch nach dem Ersten Weltkrieg führten Pirchan zahlreiche Studienund Urlaubsreisen nach Italien ${ }^{34}$.

Erstmalig nahm Pirchan noch vor dem Ersten Weltkrieg am I 3. Deutschen Historikertag, der im September I9I 3 in Wien stattfand, teil. Wie bereits bei der Studienreise nach Italien, hoffte er auch in diesem Fall aus den Verhandlungen eine fachwissenschaftliche Belehrung [zu] gewinnen sowie mannigfache Anregung und Erweiterung des Gesichtskreises [zu] erfahren. Zur Begründung seines Urlaubsantrags führte er außerdem an, dass er als Absolvent des Wiener IÖG den Veranstaltern dieses Kongresses als Schüler oder Kollege persönlich sehr nahe stehe ${ }^{35}$. Den Ausbruch des Ersten Weltkrieges mit der Kriegserklärung Österreich-Ungarns an Serbien erlebte Pirchan unweit von Triest während eines Krankenurlaubs in einem Kurbad. Bereits am 9. Juni I9I4 hatte er sich wegen eines fieberhaften Gelenk- und Muskelrheumatismus' krank gemeldet, der ihn laut ärztlichem Attest für längere Zeit bettlägerig machte. Den am 3. Juli I 9 I 4 angetretenen vierwöchigen Krankenurlaub im Solkurbad bei Triest verlängerte er bis zum I 5 . August I9 I $4^{36}$.

Während der Kriegszeit leistete Pirchan wie bereits zuvor Dienst im Archiv. Nach dem Umbruch von I9I 8 und der Entstehung der Tschechoslowakei wurde er in das inzwischen umbenannte Archiv des tschechoslowakischen Ministeriums des Inneren über-

33 Emil Werunsky, Geschichte Kaiser Karls IV. und seiner Zeit 1-3 (Innsbruck 1880-1892). Des Weiteren legte Werunsky folgende Publikationen zu Karl IV. vor: Ders., Die italienische Politik Papst Innozenz' VI. und König Karls IV. 1353/54 (Wien 1878); DE Rs.: Der erste Römerzug Kaiser Karls IV. (1354-1355) (Innsbruck 1878); DERs., Excerpta ex registris Clementis VI et Innocentii V summorum pontificum historiam s.r. imperii sub regimine Karoli IV illustrantia (Innsbruck 1885).

34 Neben einem längeren Studienaufenthalt 1925 sind bisher folgende weitere Studien- und Urlaubsreisen nach Italien belegt: 1928 Florenz, 1934 u.a. Palermo, Rom, 1936 Venedig, 1937 Mailand, 1938 Verona sowie eine Reise nach Jugoslawien in den 1920er-Jahren und 1935 ein längerer Aufenthalt in Frankreich (Paris, Avignon, Straßburg). Am 05.03.1937 hielt Pirchan auf Einladung des Akademischen Vereines deutscher Historiker in Prag einen Vortrag über seine Reise nach Frankreich. UAP, FF NU, Historisches Seminar, K. 67.

35 Pirchan an das k.k. Statthalterei-Präsidium, 06.09.1913. NA, AR-ČM, PA Pirchan, Sig. II, K. 4, Inv.-Nr. 20.

36 Ebd. NA, AR-ČM, PA Pirchan, Sig. II, K. 4, Inv.-Nr. 20. 
nommen ${ }^{37}$. Mit dem neuen tschechischen Direktor Ladislav Klicman hatte er seit 1907 im Statthalterei-Archiv zusammengearbeitet. Kurz nach der Entstehung der Tschechoslowakei berichtete Klicman dem Ministerium, dass Pirchan sich vor dem Krieg zwar gerne als in nationalen Fragen neutraler Wissenschaftler präsentiert, während des Krieges seine Objektivität aber völlig verloren habe. Da er Mitglied mehrerer deutschnationaler Organisationen und ein Freund des „Landeshauptmanns für Deutschböhmen“ Rudolf Lodgman von Auen sei, der die Abtrennung der deutsch besiedelten Gebiete von der Tschechoslowakei betreibe, könne er zu verschiedenen vertraulichen Arbeiten im Archiv trotz seiner guten Tschechischkenntnisse nicht hinzugezogen werden ${ }^{38}$. Ungeachtet dieser kritischen Einschätzung waren die Beziehungen zwischen den beiden Archivaren in der folgenden Zeit kollegial und Klicman kam Pirchan mehrmals wohlwollend entgegen.

Hierzu seien einige Beispiele angeführt. Pirchan hielt sich I 92 I regelmäßig in Wien auf, um Archivalien böhmischer Provenienz für die Prager Archive zu übernehmen. Gleichzeitig lief sein Habilitationsverfahren an der Deutschen Universität Prag, über dessen erfolgreichen Verlauf sich Klicman ihm gegenüber erfreut zeigte. Die Wiener Aufenthalte konnte Pirchan dank Klicman zeitlich so gestalten, dass sie ihn bei seinen Vorbereitungen auf die Habilitation nicht behinderten ${ }^{39}$. 1924 befürwortete Klicman einen sechstägigen Diensturlaub, damit Pirchan am deutschen Historikertag in Frankfurt am Main teilnehmen konnte ${ }^{40}$. Die Fürsprache eines Antrags auf finanziellen Zuschuss an das zuständige Ministerium begründete er mit Pirchans Dozentur an der Deutschen Universität und seiner Geschäftsführerschaft des VGDB ${ }^{41}$.

Als Pirchan ein Jahr später einen zusätzlichen vierwöchigen Urlaub zu Studienzwecken in italienischen Archiven und Bibliotheken beantragte, um seine Habilitationsschrift zu ergänzen und für den Druck vorzubereiten, unterstützte der tschechische Archivdirektor auch dieses Gesuch. Er empfahl dem Innenministerium sogar, Pirchan in dieser Zeit weiterhin sein Gehalt auszubezahlen ${ }^{42}$. Die Herausgabe der Habilitationsschrift unterstützte das tschechoslowakische Ministerium für Schulwesen und Bildung mit einem Betrag

37 Zur Geschichte des Archivs des Innenministeriums siehe Josef Kollmann, Archiv ministerstva vnitra v 1. 1918-1945 [Das Archiv des Innenministeriums in den Jahren 1918-1945], in: Sborník archivních prací (SAP) 45 (1995) 511-688 (mit der älteren Literatur). Eine kurze Bestandsübersicht liefert Josef BergL, Das Archiv des Innern in Prag, in: MVGDB 64 (1926) 40-49, 81-86.

38 Kollmann, Archiv (wie Anm. 37) 521.

39 Klicman an Pirchan, 07.01.1921. NA, AR-ÚAMV, PA Pirchan, Sig. IX/2, K. 137, Inv.-Nr. 84.

40 Vgl. hierzu Gustav Pirchan, Bericht über die Versammlung Deutscher Historiker und Geschichtslehrer in Frankfurt am Main vom 30. September bis 4. Oktober 1924, in: MVGDB 62 (1924) 263-278.

41 Klicman an das Innenministerium (IM), 16.09.1924. NA, AR-ÚAMV, PA Pirchan, Sig. IX/2, K. 137, Inv.-Nr. 84.

$42 \mathrm{Klicman}$ an das IM, 18.09.1925. Ebd. 
von I 8.000 Kronen ${ }^{43}$. Ende Oktober 1925 bat Pirchan von Florenz aus Klicman, seinen Forschungsaufenthalt noch um weitere fünf Tage zu verlängern ${ }^{44}$. Dieser beantragte daraufhin beim Ministerium zusätzlich zwei Wochen Urlaub für Pirchan ${ }^{45}$, die umgehend genehmigt wurden. Privat schrieb ihm Klicman, dass er, auch wenn er seine Arbeiten früher beenden werde, nicht eher zurückkommen, die Zeit genießen und auf der Rückreise seine Mutter in Eggenburg besuchen solle ${ }^{46}$. Als Pirchan seinem Vorgesetzten über seine finanziellen Probleme berichtete, stellte ihm Klicman sofort bereitwillig Geld zur Verfügung ${ }^{47}$. Pirchans dienstliche Laufbahn setzte sich auch in der Tschechoslowakei erfolgreich fort. Im April I92 I ernannte die tschechoslowakische Regierung ihn zum Archivdirektor zweiter Klasse in der siebten Rangklasse ${ }^{48}$. Zwei Jahre später erfolgte die Beförderung zum Staatsarchivdirektor erster Klasse in der sechsten Rangklasse ${ }^{49}$ und 1927 zum Obersektionsrat mit Rückwirkung zum 2. Dezember 1926 durch den Präsidenten der Tschechoslowakei ${ }^{50}$. Er war in den I 92oer-Jahren stellvertretender Direktor des Archivs und leitete dieses für den wiederholt erkrankten Klicman. Nach seiner Ernennung zum außerordentlichen Professor für mittelalterliche Geschichte an der Deutschen Universität schied Pirchan 1933 auf eigenen Wunsch aus dem staatlichen Archivdienst aus. Innenminister Jan Černý sprach ihm bei dieser Gelegenheit seinen Dank und Anerkennung für sehr fleißige und ausgezeichnete Dienste aus ${ }^{51}$. Der tschechische Historiker Otakar Odložilík ${ }^{52}$ erinnerte sich an Pirchans Tätigkeit im Archiv wie folgt: „Nach dem Vorstand der älteste Beamte, saß er in einem vor Besuchern und unnötigem Verkehr geschützten Arbeitszimmer. Gewöhnlich arbeitete er an langen Denkschriften für das Innenministerium oder andere Behörden, wofür gründliche Vorbereitungen, scharfe Auffassungsgabe

43 Schul- und Bildungsministerium an das Dekanat der Philosophischen Fakultät (PF) der DU, 31.01.1931. UAP, FF NU, PA Pirchan, K. 50.

44 Pirchan an Klicman, 20.10.1925. NA, AR-ÚAMV, PA Pirchan, Sig. IX/2, K. 137, Inv.-Nr. 84.

45 Klicman an das IM, 23.10.1925. Ebd.

46 Klicman an Pirchan, 24.10.1925. Ebd.

47 Ebd.

48 IM an Pirchan, 24.04.1921. Ebd.

$49 \mathrm{IM}$ an Pirchan, 01.08.1923. Ebd.

50 NA, ÚŘP, 114-209-8/71; UAP, FF NU, PA Pirchan.

51 Černý an Pirchan, 31.03.1933. NA, AR-ÚAMV, PA Pirchan, Sig. IX/2, K. 137, Inv.-Nr. 84.

52 Zu Odložilík siehe Peter Brock, Otakar Odložilík, 1899-1973, in: Central European History 7 (1974) 279281; Otakar Odıožılík. Deníky z let 1924-1948 1-2 [Tagebücher aus den Jahren 1924-1948 1-2], hg. v. Milada Se кy коvá (Praha 2002/3); Vzájemná korespondence Václava Novotného, Jaroslava Prokeše a Otakara Odložilíka [Die gegenseitige Korrespondenz von Václav Novotný, Jaroslav Prokeš und Otakar Odložilík], hg. v. DERs., in: SAP 51 (2001) 85-274; DIEs., Několik stránek ze života Otakara Odložilíka (Pražské archivy k životu Otakara Odložilíka [Einige Seiten aus dem Leben Otakar Odložilíks (Die Prager Archive zum Leben Otakar Odložilíks)] in: SAP 44 (1994) 34-67. 
und Konzentration erforderlich waren" ${ }^{53}$. Auch Klicman lobte Pirchan in den jährlichen Qualifikationsbeschreibungen, denen er bis zu seiner Ernennung zum Obersektionsrat I 927 unterlag, als ausgezeichneten Beamten ${ }^{54}$.

Außerhalb des Archivdienstes begegnete Pirchan seinen tschechischen Kollegen auch in anderen, überwiegend tschechischen Fachinstitutionen, denen er angehörte. Als I 923 in die Kommission für das Tschechoslowakische Historische Institut in Rom keine deutschen Mitglieder berufen wurden, nahm der Akademische Senat der Deutschen Universität dies zum Anlass für eine Beschwerde. Das tschechoslowakische Schulministerium antwortete, dass es die Initiative der Deutschen Universität begrüße und geneigt sei, Deutsche in die Kommission aufzunehmen. Es bat darum, geeignete Personen zu benennen, die die tschechische Sprache beherrschen und bereits in italienischen Archiven und Bibliotheken gearbeitet hatten ${ }^{55}$. Eine hierzu einberufene Kommission der Philosophischen Fakultät schlug neben dem Privatdozenten Pirchan die Professoren Steinherz, Wilhelm Wostry und Hans Hirsch vor. Allein Pirchan erfüllte die beiden genannten Kriterien $^{56}$ und so ernannte ihn das Schulministerium I 924 zum Mitglied der Kommission ${ }^{57}$. Während einer Italienreise I 934 bedankte sich Pirchan beim Leiter des Tschechoslowakischen Historischen Instituts in Rom, Bedřich Mendl, für dessen Unterstützung. In Rom wohnte er damals im Institutsgebäude ${ }^{58}$. Überdies war Pirchan Gründungsmitglied der Tschechoslowakischen Archivgesellschaft (Československá archivní společnost, ČAS; I924-I94I) ${ }^{59}$. Zwar war die Satzung dieser Organisation ohne Beteiligung deutscher Archivare ausgearbeitet worden, doch legte die tschechische Seite Wert darauf, alle Archivare der Republik ohne Ansehen der Nationalität an dieser Berufsvertretung zu beteiligen ${ }^{60}$. Pirchan und sein Kollege Josef Bergl ${ }^{61}$ nahmen sowohl an der konstituierenden

53 Otakar OdLožı́ík, Ein tschechischer Nachruf auf sudetendeutsche Historiker, in: Wissenschaftlicher Dienst Ost-Mitteleuropa 5 (1955) 111-117, hier 114.

54 NA, AR-ÚAMV, PA Pirchan, Sig. IX/2, K. 137, Inv.-Nr. 84.

55 Schul- und Bildungsministerium an das Rektorat der DU, 15.06.1923. UAP, FF NU, K. 67, Tschechoslowakisches Institut in Rom 1923.

56 Steinherz und Hirsch besaßen keine Tschechischkenntnisse und Wostry hatte nicht in italienischen wissenschaftlichen Einrichtungen gearbeitet. Dekan der PF an das Rektorat der DU, 11.12.1923. Ebd.

57 Klicman an das IM, 20.06.1924. - NA, AR-ÚAMV, PA Pirchan, Sig. IX/2, K. 137, Inv.-Nr. 84.

58 Pirchan wollte auch Šusta schreiben und ihm seine ersten Eindrücke über das Institut mitteilen. Pirchan an Mendl, o. D. MÚA, NL Mendl K. 4, Inv.-Nr. 249, Sig. IIb1.

59 Bisher sind nur die Anfänge der ČAS bearbeitet. Vgl. hierzu Jan KAHUDA, K počátkům zájmové organizace českych archivářů [Zu den Anfängen der Interessenorganisation der tschechischen Archivare], in: Pocta Josefu Kollmannovi. Sborník k životnímu jubileu, hg. v. Alena PAzderová (Praha 2002) 125-135.

60 Václav Hrubú, Ze společnosti Archivní školy [Aus der Gesellschaft der Archivschule], in: Časopis archivní školy 2 (1924) 225-227, hier 225.

$61 \mathrm{Zu} \mathrm{Bergl} \mathrm{vgl.} \mathrm{Lehr,} \mathrm{Archivare} \mathrm{(wie} \mathrm{Anm.} \mathrm{27)} \mathrm{415-420;} \mathrm{Jaroslav} \mathrm{Prokeš,} \mathrm{Archiv} \mathrm{ministerstva} \mathrm{vnitra} \mathrm{v} \mathrm{Praze}$ 
Sitzung der Gesellschaft am 3 I. Januar I 924 als auch an den folgenden Versammlungen teil ${ }^{62}$. Pirchan hatte in der Gesellschaft, der später auch Blaschka und andere deutsche Stadtarchivare und Historiker angehörten, über mehrere Jahre (I 929-I940) das Amt des Kassenwarts inne ${ }^{63}$. Zudem waren Pirchan und Bergl Mitglieder des Arbeitsausschusses, der 1934 aus Anlass des 300-jährigen Todestages Albrechts von Waldstein (Valdštejn) eine große Ausstellung über den Feldherrn und dessen Zeit in Prag organisierte ${ }^{64}$.

Pirchans Kollegen- und Freundeskreis ging aus seiner beruflichen Tätigkeit und seinem Engagement im VGDB hervor. Es handelte sich um die Kollegen Bergl und Blaschka im Archiv sowie die Prager deutschen Universitätsprofessoren und Mitglieder des VGDB. So arbeitete Pirchan über Jahre eng mit Wostry65, dem Obmann des Vereines seit 1927, zusammen. Beide hatten bei Bachmann und Werunsky studiert. Auch mit Heinz Zatschek ${ }^{66}$

v letech 1935-1937 [Das Archiv des Innenministeriums in Prag in den Jahren 1935-1937], in : SAMV 11 (1938) 7-34, hier 9-14.

62 Anwesenheitsliste. UAP, Archivní škola [Archivschule, AŠ], K. 1.

63 NA, Československá archivní společnost (ČAS) [Tschechoslowakische Archivgesellschaft], K. 1-2; UAP, AŠ, K. 1. An den tschechischsprachigen Publikationen, die im Časopis archivní školy [Zs. der Archivschule] erschienen, beteiligten sich die deutschen Archivare - bis auf zwei Ausnahmen - jedoch nicht. Auch die regelmäßigen Vorträge zu archivwissenschaftlichen oder geschichtlichen Themen in der Archivgesellschaft wurden ausschließlich von tschechischen Archivaren und Historikern gehalten. Vgl. hierzu das Verzeichnis der Vorträge und Referenten der ČAS bei Jan KAHUdA, Z historie organizace našich archivářu [Aus der Geschichte der Organisation unserer Archive], in: Archivní čtvrtletník 8 (2000) 110-125, hier 122-125, und http://www.cesarch.cz/clanky. php?key=1162. Die Ausnahmen waren der bereits erwähnte Rudolf Koss (vgl. Anm. 17) und Emil Schieche. Zu Schieche siehe Lenr, Deutsche und tschechische Archivare (wie Anm. 27) 430-432; Ders., „Den deutschen Einfluß beträchtlich steigern. "Archivare und Archive im Protektorat Böhmen und Mähren (1939-1945), in : Archivar 61 (2008) 370-376, und http://www.archive.nrw.de/archivar/hefte/2008/ausgabe4/ARCHIVAR-04-2008_ Internet.pdf. Rudolf Koss, Listiny z archivu markrabat Moravských ve vídeňském státním archivu, in: ČAŠ 1 (1923) 1-12; Emil Schieche, Svidnický formulář Jana ze Středy, in: ČAŠ 5 (1927) 110-159. Außerdem lieferte Bergl in einem anderen Periodikum einen Beitrag über die Judaica-Bestände im Archiv des Innenministeriums. Josef BergL, Judaica v archivu ministerstva vnitra v Praze, in: SAMV 6 (1933) 1-64.

64 Pirchan wird in einer Mitgliedsliste des Arbeitsausschusses der Ausstellung aufgeführt. So wie auch Bergl, wird ihn Jaroslav Prokeš, der Geschäftsführer des Ausschusses für die Ausstellung, zur Wahl vorgeschlagen haben. Prokeš an Bergl, 27.12.1933. SOA Litoměrice, pobočka Děčín, RA Clam-Gallasů, NL Bergl, K. 667-668.

$65 \mathrm{Zu}$ Wostry vgl. Karel HruzA, „Wissenschaftliches Rüstzeug für aktuelle politische Fragen.“ Kritische Anmerkungen zu Werk und Wirken der Historiker Wilhelm Weizsäcker und Wilhelm Wostry, in: ZfO 54 (2005) 475-526, hier 494-521; DERs., Wilhelm Wostry, in: Handbuch der völkischen Wissenschaften (wie Anm. 7) 772-776; Nina Lohmann, : „Heimat und Volk“. Der Historiker Wilhelm Wostry zwischen deutschböhmischer und sudetendeutscher Geschichtsschreibung, in: Die sudetendeutsche Geschichtsschreibung (wie Anm. 3) 127-150; Dies., Wilhelm Wostry und die „sudetendeutsche“ Geschichtsschreibung bis 1938, in: Acta Universitatis Carolinae - Historia Universitatis Carolinae Pragensis (AUC - HUCP) 44 (2004) 45-145.

66 Zu Zatschek siehe Karel Hruza, Heinz Zatschek (1901-1965). „Radikales Ordnungsdenken“ und „gründliche, zielgesteuerte Forschungsarbeit“, in: Österreichische Historiker 1900-1945. Lebensläufe und Karrieren in Österreich, Deutschland und der Tschechoslowakei, hg. v. DEms. (Wien 2008) 677-792. 
und den anderen sudetendeutschen Historikern unterhielt er gute Beziehungen. Mit Wostry duzte er sich, die Eheleute Zatschek und Pirchan luden sich gegenseitig zum Tee ein. Solche Besuche sind auch mit Elisabeth (Lili) und Josef Pfitzner belegt ${ }^{67}$. Im Herbst I 938 wurden Pirchan und Wostry von ihren Gattinnen zum Historikerkongress nach Zürich begleitet. Wie selbstverständlich pflegte Pirchan in der Zwischenkriegszeit aber auch Kontakte zu tschechischen Mitarbeitern. Kazbunda erinnerte sich in seinen Memoiren daran, Pirchan anlässlich eines gemeinsamen Essens 1933 auf der Prager Kleinseite zu dessen Berufung zum Professor gratuliert zu haben. Öfters habe er ihn auch im Universitätsarchiv und im deutschen Theater getroffen ${ }^{68}$. Ebenso wie Bergl und Blaschka schrieb Pirchan seinen tschechischen Kollegen in deren Muttersprache. Im Nachlass Kazbundas finden sich ein Glückwunschtelegramm zu dessen 50. Geburtstag und ein längerer Brief, in dem Pirchan die gemeinsame Kindheit in Jitschin reflektierte ${ }^{69}$. Auch Otakar Odložilík behielt Pirchan in sehr guter Erinnerung. So ging dieser, solange er im Archiv arbeitete, von Zeit zu Zeit zu einer kurzen Unterhaltung in Pirchans Arbeitszimmer hinüber; die Gespräche fand er jedes Mal anregend und interessant. Pirchan habe so gut tschechisch gesprochen, dass man ihn von einem geborenen Tschechen nicht habe unterscheiden können ${ }^{70}$. Im März 1935 notierte Odložilík in seinem Tagebuch, dass er am Samstagabend bei den Pirchans zu Besuch war ${ }^{71}$. Ansonsten sind solche privaten Besuche, wie sie unter den deutschen Kollegen stattfanden, jedoch nicht belegt. Zudem sind die Kontakte zu den tschechischen Kollegen nach 1938/1939 allem Anschein nach abgebrochen ${ }^{72}$.

\section{AN DER DEUTSCHEN UNIVERSITÄT IN PRAG}

Pirchan wurde I92 I mit seiner Arbeit zur zweiten Romreise Karls IV. für allgemeine Geschichte des Mittelalters an der Deutschen Universität in Prag habilitiert und durch einen Erlass des zuständigen tschechoslowakischen Ministeriums vom 2 I. Mai I92 I als Privatdozent bestätigt. Die Gutachten Hirschs, Steinherz' und Werunskys zollten seiner

67 Else Pirchan an Lili Pfitzner 29.03. und 02.12.1935. MÚA, NL Pfitzner.

68 Mé archivní poslání ve Vídni, Bl. 148f. ANM, NL Kazbunda, K. 32.

69 Pirchan an Kazbunda, 23.01.1938. ANM, NL Kazbunda, K. 12, Inv.-Nr. 607.

70 Odložılík, Nachruf (wie Anm. 53) 114.

71 Eintragung zum 25.03.1935. Odložılík, Deníky 1 (wie Anm. 52) 653.

72 So liegen in den Nachlässen tschechischer Historiker nach 1939 keine Briefe und Postkarten Pirchans mehr vor. Václav Vojtíšek erinnerte sich, dass ihm Pirchan in der Zeit des Protektorats aus dem Weg gegangen sei. Karel Hruza, „Einige Deutsche habe ich auch wirklich gern empfangen“ - Ein Bericht des tschechischen Historikers Václav Vojtíšek aus dem Jahr 1966 über deutsche Fachkollegen in Prag, in: Bohemia. Zs. für Geschichte und Kultur des böhmischen Länder 49 (2009) 96-163, hier $148 f$. 
Arbeit volle Anerkennung ${ }^{73}$. Wie auch in anderen Beurteilungen wurden Pirchans unermüdlicher Fleiß, seine Gründlichkeit, der Umfang seiner Kenntnisse und die Vielseitigkeit seiner Interessen positiv hervorgehoben. Mehrere Italienreisen, die ihn in die Staatsarchive und Bibliotheken nach Mantua, Florenz, Pisa, Lucca, Siena und Venedig geführt hatten, machten ihn zu einem ausgezeichneten Kenner der dortigen Archive. Nach der Habilitation begann Pirchan im WS I92I/22 seine über zwanzigjährige Lehrtätigkeit (WS I921/22 bis zum WS I944/45) 74 an der Deutschen Universität in Prag mit einer zweistündigen Vorlesung zu Italien im Zeitalter Dantes. In den ersten zwei Unterrichtsjahren waren seine vier Vorlesungen ausschließlich Italien gewidmet und speisten sich aus seinen Arbeiten zur Habilitationsschrift. Bis zum SS I 925 las er jeweils zwei Stunden pro Semester. Danach lehrte er bis zum WS I930/3 I nur einstündig, vom SS I93 I bis zum SS I 933 wieder zweistündig. Nach der Ernennung zum außerordentlichen Professor umfasste Pirchans Lehrdeputat kontinuierlich fünf Stunden pro Semester. Praktisch bedeutete dies, dass er seit 1933 in der Regel drei Lehrveranstaltungen anbot. Gewisse Vorlesungen wiederholte Pirchan mehrfach, wobei die Titel teilweise variierten ${ }^{75}$.

In seiner Lehrtätigkeit konzentrierte sich Pirchan schwerpunktmäßig auf das I4. Jahrhundert, ohne jedoch das I3. und I 5. Jahrhundert außer Acht zu lassen. Geografisch interessierten ihn vor allem Italien, die deutschen Länder und hier insbesondere Böhmen, welches für Pirchan zu diesen gehörte, sowie die böhmischen Verflechtungen mit den Nachbarregionen. Thematische Schwerpunkte bildeten das Papsttum im Mittelalter, die böhmischen Länder unter den Luxemburgern, insbesondere unter Karl IV., und der Humanismus. Immer wieder behandelte Pirchan kulturgeschichtliche Themen ${ }^{76}$. Erstmalig im SS I939, also nach der Entstehung des Protektorats Böhmen und Mähren, las Pirchan zur Geschichte des „deutschen Volkes“ im I 4. Jahrhundert. Diese Hinwendung zur „deutschen“ Geschichte und in gewisser Weise zur „Volksgeschichte“ wird auch an anderen Lehrveranstaltungen deutlich, so zur deutschen Stadt, zum deutschen Staat, zur deutschen Geschichte usw. Außerdem bot er im WS I939/40 eine Vorlesung zum Judentum des Abendlandes im Mittelalter an. Der Titel einer Lehrveranstaltung zu Italien lautete nun „Die italienischen Führerstaaten des I 4. und I 5. Jahrhunderts“77.

73 In der PA im UAP liegen diese nicht vor. Die Personalakte Pirchans im Schulministerium wurde nach dem Zweiten Weltkrieg skartiert.

74 Insgesamt handelt es sich bis zum WS 1943/44 um 91 Lehrveranstaltungen. Die Vorlesungsverzeichnisse für das SS 1944 und das WS 1944/45 lagen mir nicht vor. UAP, Ordnung der Vorlesungen an der Deutschen Universitat zu Prag (1919-1939/40); Ordnung der Vorlesungen an der Deutschen Karls-Universitat zu Prag (1939/40-1944/45).

75 „Dante und seine Zeit“, „Allgemeine Geschichte des Mittelalters im 14. Jahrhundert“.

76 So las er beispielsweise zu Dante und Petrarca sowie zur Renaissance.

77 Vgl. Ordnung der Vorlesungen an der Deutschen Karls-Universität zu Prag (1939/40-1944/45). 
In der Zeit von 1933 bis 1945 beteiligte sich Pirchan insgesamt an I9 Promotionsverfahren, zumeist jedoch als Zweitgutachter. Nur drei Historiker schrieben ihre Doktorarbeit bei ihm ${ }^{78}$. Keiner der drei Doktoranden Pirchans war im eigentlichen Sinne des Wortes sein Schüler. Ruth Kestenberg hatte bereits zuvor in Deutschland ihr Studium weitgehend abgeschlossen. Wilhelm Kukula hatte während seines Studiums von I928I 934 keine Lehrveranstaltungen bei Pirchan besucht. Erst nachdem er bereits einige Jahre als Lehrer gearbeitet hatte und sich erneut im WS I938/39 an der Prager Universität einschrieb, belegte er Pirchans Seminare und Vorlesungen. Karl Meinlschmidts Promotionsthema ging von Zatschek aus, der dann aber nach Wien wechselte, so dass Pirchan die Betreuung der Arbeit übernahm. Während zwei seiner Doktoranden Wostry als Zweitgutachter hatten, trat Pirchan in elf Fällen bei Zatscheks Schülern als Koreferent auf ${ }^{79}$. Zu diesen zählten neben biografischen Studien zu Herrscherpersönlichkeiten auch mehrere (volks-)politisch ausgerichtete Beiträge ${ }^{80}$.

Wissenschaftlich als Historikerin wirkte in der Folgezeit nur seine Doktorandin Ruth Kestenberg-Gladstein ${ }^{81}$, die sich jedoch der Geschichte der Juden in Böhmen ${ }^{82}$ widmete und somit keine Forschungen Pirchans fortführte ${ }^{83}$. Sie war die Tochter des jüdischen

78 Es waren dies: 1933/34 Ruth Kestenberg (1910-2002) mit einer Arbeit zu „Pseudojoachim in Böhmen, die Geschichte einer Prophezeiung“, 1938/39 Wilhelm Kukula (*1916) mit einer direkt zu Pirchans Spezialgebiet gehörenden Untersuchung zu „Peter Wurst, ein Rat Kaiser Karls IV.“ sowie 1941/42 Karl Meinlschmidt (*1916) mit seiner Dissertation unter dem Titel „Genealogisch-erbbiologische Untersuchungen der Salier“ mit dem Sozialanthropologen Karl Valentin Müller als Zweitgutachter. Zu dem „Rassenforscher“ Müller siehe Andreas Wiedemann, Die Reinhard-Heydrich-Stiftung in Prag (1942-1945) (Hannah-Arendt-Institut für Totalitarismusforschung. Berichte und Studien 28, Dresden 2000) 63-67; Eduard KuBŮ, „Die Bedeutung des deutschen Blutes im Tschechentum“. Der wissenschaftspädagogische Beitrag des Soziologen Karl Valentin Müller zur Lösung des Problems der Germanisierung Mitteleuropas, in: Bohemia. Zs. für Geschichte und Kultur des böhmischen Länder 45 (2004) 93-114.

$79 \mathrm{Zu}$ den von Pirchan betreuten und begutachteten Dissertationen vgl.: Disertace (wie Anm. 24) 87-138.

80 So etwa die Titel der Dissertationen: Heinrich II. von England in Gegnerschaft zum Reich, Theoderich der Große in volksgeschichtlicher Sicht, Volksbewusstsein im Elsass in seiner Abwehrstellung gegen Frankreich. Vgl. ebd.

$81 \mathrm{Zu}$ ihr vgl. Dorothea Kuhrau-Neumärker, In memoriam Ruth Gladstein, in: Ruth Kestenberg-GladSTEIN, Neuere Geschichte der Juden in den böhmischen Ländern. Heraus aus der „Gasse“. Böhmens Juden im 19. Jahrhundert, hg. v. Dorothea Kuhrau-Neumärker (Münster/Hamburg/London 2002) 1-5.

82 Ruth Kestenberg-Gladstein, Neuere Geschichte der Juden in den böhmischen Ländern. Das Zeitalter der Aufklärung, 1780-1830 (Schriftenreihe wissenschaftlicher Abhandlungen des Leo-Baeck-Instituts 18, Tübingen 1969).

83 Auch bei ihr stammte die Idee zum Thema nicht von Pirchan. Sie hatte zuvor in Berlin und Frankfurt am Main Geschichte und Germanistik studiert und begann bei Erich Caspar auf Anregung von Ernst Kantorowicz ihre Dissertation über die joachitischen Prophetenkommentare. Infolge der „politischen Umwälzung“ verließ sie dann Deutschland, um an der Deutschen Universität in Prag ihr Studium zu beenden. In Prag wurde sie im WS 1933/34 immatrikuliert und studierte hier zwei Semester. Herr Professor Pirchan, bei dem ich 
Musikpädagogen und SPD-Politikers Leo Kestenberg, der I 933 nach dem Machtantritt der Nationalsozialisten Deutschland mit seiner Familie verlassen musste und bis 1938 in der demokratischen Tschechoslowakei Zuflucht fand ${ }^{84}$. Dass Pirchan sie, die Tochter eines bekannten jüdischen Emigranten, kurz nach seiner Berufung auf den Lehrstuhl als seine erste Doktorandin aufnahm, spricht für seine im Vergleich zu vielen seiner deutschen Kollegen liberale und damals auch mutige Haltung gegenüber antisemitisch eingestellten Studenten und Professoren, zumal in konservativen und reaktionären deutschen Kreisen in der Tschechoslowakei Vorbehalte gegen politische und jüdische Flüchtlinge aus Deutschland virulent waren ${ }^{85}$.

\section{BERUFUNGSVERHANDLUNGEN ZUM AUSSERORDENTLICHEN PROFESSOR}

Im Dezember 1929 erhielt der Inhaber des Lehrstuhls für allgemeine Geschichte des Mittelalters an der Deutschen Universität in Prag, Theodor Mayer, einen Ruf an die Universi-

die Ehre habe zu arbeiten, regte dann an, das Thema auf Böhmen zu beschränken, da sie keinen Zugang mehr zu den Handschriften im Deutschen Reich hatte. Curriculum vitae Ruth Kestenberg, 12.12.1934. UAP, FF NU, Studentenpersonalien, PA Ruth Kestenberg, K. 84, Inv.-Nr. 999.

84 Kestenberg fand als Musikreferent im tschechoslowakischen Schulministerium eine Anstellung. Zu Kestenberg siehe Hana Vlhová-Wörner, Felix Wörner, Leo Kestenberg und die Prager Gesellschaft für Musikerziehung, in: Leo Kestenberg. Musikpädagoge und Musikpolitiker in Berlin, Prag und Tel Aviv, hg. v. Susanne Fontaine, Ulrich Mahlert, Dietmar Schenk, Theda Weber-Lucks (Rombach Wissenschaft, Reihe Litterae 144, Freiburg im Br. u.a. 2008) 205-243, vgl. auch seine Autobiografie Leo Kestenberg, Bewegte Zeiten. Musisch-musikantische Lebenserinnerungen (Wolfenbüttel u.a. 1961). Ruths damaliger Verlobter und späterer Ehemann, Dr. Tunja Gladstein, zur damaligen Zeit ein staatenloser russischer Jude, verließ mit ihr Deutschland. In der Tschechoslowakei stellte ihn Staatspräsident Masaryk als Privatbibliothekar an. KuHRAUNeumärker, Ruth Gladstein (wie Anm. 81) 2.

85 In den 1920er- und 1930er-Jahren ist es wiederholt zu Ausschreitungen von deutschen Antisemiten gegen jüdisch-deutsche Wissenschaftler an der Deutschen Universität in Prag gekommen. Auch an dem Professorenkollegium der Philosophischen Fakultät gingen diese Konflikte nicht unbeachtet vorbei. Kolár spricht in diesem Zusammenhang für die Zwischenkriegszeit von einem zunehmenden „Antagonismus zwischen der altliberalen und teilweise jüdischen Gelehrtengeneration einerseits und der jüngeren Generation der nationalistisch und zunehmend auch antisemitisch gesinnten Wissenschaftler andererseits“. Die Konflikte artikulierten sich u.a. bei Entscheidungen im Professorenkollegium und bei Berufungskommissionen und führten zur Bildung von Gesinnungskoalitionen. KolÁř, Geschichtswissenschaft in Zentraleuropa 1 (wie Anm. 3) 46f.; DERs., Brutstätte (wie Anm. 3) 114. Vgl. auch den bezeichnenden Brief Bergls an Blaschka (siehe Anm. 94). Zu antisemitischen Tendenzen und Ausschreitungen siehe Alena MíšKová, Deutsche (Karls-)Universität (wie Anm. 6) 32-36, 39-42; Dies., Die Lage der Juden an der Prager Deutschen Universität, in: Judenemanzipation - Antisemitismus - Verfolgung in Deutschland, Österreich-Ungarn, den Böhmischen Ländern und in der Slowakei, hg. v. Jörg K. Hoensch, Stanislav Biman, Lubomír Lipták (Essen 1999) 117-129; Hruza, Zatschek (wie Anm. 66) 706-708, 764. 
tät in Gießen. I930 begannen deshalb offiziell die Verhandlungen über seine Nachfolge ${ }^{86}$. Pirchan war von Anfang an als ein Kandidat im Gespräch, der alle Bedingungen erfüllte. Seine Vorzüge lagen klar auf der Hand: Da Werunsky der Vorgänger Mayers gewesen war, stand Pirchan als dessen Schüler und als Deutscher aus Böhmen für die Fortsetzung einer gewissen Tradition. Dank der Beherrschung des Tschechischen und seiner guten Kontakte zu den tschechischen Archivkollegen war er ausländischen Bewerbern gegenüber im Vorteil. Da Pirchans Berufung in der Zuständigkeit des tschechoslowakischen Schulministeriums lag, waren seine Beziehungen dorthin zweifelsohne wichtig. So offenkundig diese positiven Vorzeichen für ihn waren, gab es aber auch Schwächen in Pirchans Bewerberprofil. Nicht zu Unrecht hatte er das Image eines gründlichen und sorgfältig arbeitenden Wissenschaftlers, was bei weniger wohlwollender Betrachtung aber auch als Langsamkeit interpretiert werden konnte. Auch wurde Pirchan keine herausragende Leistungsfähigkeit nachgesagt ${ }^{87}$. So lag 1929 seine mittlerweile acht Jahre alte Habilitationsschrift immer noch nicht gedruckt vor. Mehrmals erhielt er zusätzlichen Diensturlaub, ließ wiederholt mit Berufung auf die Fertigstellung der Arbeit seine Lehrveranstaltungen an der Deutschen Universität ausfallen ${ }^{88}$. Zudem wurde die Drucklegung vom tschechoslowakischen Schulministerium großzügig bezuschusst. Dennoch erschien das Werk - gerade noch rechtzeitig in der Endphase der Verhandlungen um die Mayer-Nachfolge - erst im Herbst $1930^{89}$.

Neben Pirchan machte sich der ehrgeizige Hirsch-Schüler Pfitzner ${ }^{90}$, der erst kurz

86 Zu den Verhandlungen zur Berufung Pirchans siehe Pirchans PA im UAP sowie auf dieser aufbauend Kolář, Geschichtswissenschaft in Zentraleuropa 1 (wie Anm. 3) 219-222. Informationen dazu enthalten überdies die Korrespondenzen in den Nachlässen Pfitzner, Blaschka, Zatschek, Mayer und Hirsch.

87 Pfitzner bezeichnete ihn in einem Brief an Hirsch vom 02.05.1934 als „Fauler“. MÚA, NL Pfitzner.

88 Im WS 1922 sowie im SS 1925 und 1929. UAP, FF NU, PA Pirchan.

89 Noch im Juni 1930 waren Pirchan und Blaschka mit dem Erstellen des Registers beschäftigt. Blaschka berichtete Bergl am 01.06.1930 (NA, NL Blaschka, K. 6, Inv.-Nr 12) Folgendes: Schneller, als ich mich dessen versah, ist das Donnerwetter über mich hereingebrochen. Heute früh gegen elf Uhr ging ich in die Kanzlei von Pirchan, um nachzusehen, ob ich nicht mit etwas behilflich sein könnte. Wär ich doch lieber ich weiß nicht wohin gegangen! Er hatte eine größere Menge Literaturhinweise fertig geklopft und da diese natürlich unübersichtlich sind, wenn sie nicht alphabetisch eingereicht werden, so erbot ich mich, sie auseinanderzuschneiden. Nachdem es zu Streitigkeiten darüber gekommen war, wie diese bibliografischen Angaben zu ordnen sind, sprang er [Pirchan] auf, brüllte mich an wie ein großer Fleischerhund und schlug mit den Fäusten auf den Tisch-und wies mich vermutlich aus dem Zimmer. Er kam mir dann in Ihre Kanzlei nach und sagte, er wolle mir die Zettel einreihen helfen. Er habe nicht ausgeschlafen und ich ja. [...] Hätte Herr Prof. Wostry nicht wiederholt gewünscht, ich solle dazuschauen, ich wäre vielleicht imstande, die Registerzettel in den Ofen zu werfen. Nun, ohne spezielle Einladung wird er mich jetzt nicht so bald in seiner Kanzlei sehen. Was kann ihn denn im Unterbewusstsein so gegen mich aufbringen? Ich kann doch nicht dafür, wenn ich vom Herrn Chef [Klicman] oder von Herrn Wostry nach dem Fortgang der Arbeit gefragt werde, nicht die verbindliche Zusage geben zu können, dass sie „morgen“ fertig sein werde.

$90 \mathrm{Zu}$ Hirsch siehe Andreas H. ZAJIC, Hans Hirsch (1878-1940). Historiker und Wissenschaftsorganisator 
zuvor den neu gegründeten Osteuropa-Lehrstuhl an der Deutschen Universität in Prag erhalten hatte, große Hoffnungen auf den Mittelalterlehrstuhl'19. Der Berufungskommission für die Nachfolge Mayers gehörten zunächst Mayer selbst, der Althistoriker Arthur Stein ${ }^{92}$, die Historiker Zatschek und Wostry, der Slawist Gerhard Gesemann sowie die Germanisten Erich Gierach und Herbert Cysarz an. ${ }^{93}$ Es bildeten sich zwei Lager heraus, eines um Mayer (der von Gesemann unterstützt wurde), welches Pfitzner favorisierte, und ein anderes um Wostry, das sich für Pirchan engagierte ${ }^{94}$. In der ersten Fassung des

zwischen Urkunden- und Volkstumsforschung, in: Österreichische Historiker (wie Anm. 66) 307-417. Zu Pfitzner vgl. Kolář, Geschichtswissenschaft in Zentraleuropa 1 (wie Anm. 3) 233--264; Frank Hadler, Volksgeschichte für die „Deutschen im Sudentenland“. Zur Konzeption der sudetendeutschen Spielart eines Paradigmas deutscher Historiographie in den 30er Jahren, in: Historische West- und Ostforschung in Zentraleuropa zwischen dem Ersten und dem Zweiten Weltkrieg - Verflechtungen und Vergleich, hg. v. Matthias Middell, Ulrike Sommer (Geschichtswissenschaft und Geschichtskultur im 20. Jh. 5, Leipzig 2004) 133-149; Ders., Vojtěch Šustek, Josef Pfitzner (1901-1945) Historiker. Geschichtsprofessor und Geschichtspolitiker, in: Prager Professoren 1938-1948 (wie Anm. 19) 105-135. Zur Tätigkeit Pfitzners im Proktorat siehe: Josef Pfitzner a protektorátní Praha v letech 1939-1945 [Josef Pfitzner und Prag während des Protektorats 1939-1945] 1 : Deník Josefa Pfitznera. Úřední korespondence Josefa Pfitznera s Karlem Hermannem Frankem [Das Tagebuch Josef Pfitzners. Die amtliche Korrespondenz Josef Pfitzners mit Karl Hermann Frank], 2: Měsíční situační zprávy Josefa Pfitznera [Die Monatsberichte von Josef Pfitzner], hg. v. Alena MíškovÁ, Vojtěch Šustex (Documenta Pragensia monographia. Volumen 11/1-2, Praha 200/1).

91 Der intrigante Pfitzner hatte am 21.12.1929 Hirsch nach Wien berichtet, dass Mayer den Ruf nach Gießen erhalten habe. Letzterer, Zatschek und er selbst hätten sich sogleich zusammengesetzt, um die Nachfolgefrage zu erörtern. Unisono seien sie, so Pfitzner, der Meinung gewesen, dass Pirchan ausgeschaltet werden müsse. Im Januar 1930 meinte Pfitzner noch, dass Zatschek ein unbedingter Gegner des Pirchanprojektes sei. Vgl. Pfitzner an Hirsch, 21.12.1929, 10.01.1930. MÚA, NL Pfitzner. Zu Pirchans Bewerbung siehe auch Manfred Stoy, Das Österreichische Institut für Geschichtsforschung 1929-1945 (MIÖG Erg.-Bd. 50, Wien/München 2007) 223f. Die ebd. gemachte Aussage, Zatschek wäre Mayers Nachfolger in Prag geworden, hat HruZA, Zatschek (wie Anm. 66) 720, bereits korrigiert.

$92 \mathrm{Zu}$ Stein siehe den Beitrag von Klaus Wachtel in diesem Band.

$93 \mathrm{Zu}$ Gierach und Gesemann siehe Ota Konrád, Eine lange Feindschaft. Die Prager Professoren Erich Gierach und Gerhard Gesemann in der tschechoslowakischen Republik und im Nationalsozialismus, in : AUC HUCP 43 (2003) 173-191.

94 Aufschlussreich und charakteristisch für das Prager deutsche Universitätsmilieu sind auch Bergls Äußerungen über die Verhandlungen: Von dem Judenkandidaten aus Breslau wußte ich schon früher. Allein entgegen der Ansicht Zatscheks bin ich überzeugt, daß er Dr. Pirchan keineswegs gefährlich werden kann und wird. Den Mann wollen die Juden und ihre Anhänger nicht an der Stelle Pfitzners im Vorschlag haben. Gegen Pirchan sind ja die Juden keineswegs, im Gegenteil, ihn möchten sie gern für sich reklamieren. Dies ist ja die größte Befürchtung Wostrys und des großen Mannes Gierach, daß Dr. Pirchan zu den Juden hinüberschwenken wird, sobald er im Kollegium sitzen wird, daß auf ihn in national-christlichen Belangen kein Verlaß sein wird. Das verriet mir noch vor meiner Abreise der Plauderer Gesemann. Bergl an Blaschka, 19.06.1930. NA, NL Blaschka, K. 6, Inv.-Nr.6. Der erwähnte „Judenkandidat“ ist der Breslauer Mediävist Richard Koebner, der von 1930 bis 1933 für Hermann Aubin dessen Breslauer Lehrstuhl für mittelalterliche Geschichte, Verfassungs- und Wirtschaftsgeschichte sowie geschichtliche Landeskunde vertrat. Bergls Vermutung bestätigte sich. Koebner wurde trotz des gut passenden Profils für 
Berufungsvorschlages wurde Pfitzner noch aequo loco mit dem Wiener Privatdozenten Otto Brunner vor Pirchan genannt. Im März I 930 verließ Mayer jedoch Prag, um seinem Ruf nach Gießen Folge zu leisten und dadurch veränderte sich das Kräfteverhältnis in der Kommission deutlich zugunsten von Pirchan. Bereits zuvor war es Wostry gelungen, Zatschek für Pirchan zu gewinnen ${ }^{95}$. Pfitzner, so lautete die Argumentation, habe bereits einen Lehrstuhl inne und seine Umbesetzung sei derzeit nicht hilfreich. Die Kommission legte die Endfassung ihres Berufungsvorschlages im Dezember 1930 dem Professorenkollegium und anschließend dem Ministerium vor. An erster Stelle standen nun der Innsbrucker außerordentliche Professor Adolf Helbok, an zweiter Brunner und an dritter aequo loco Pirchan und der Freiburger Privatdozent Hermann Heimpel.

Die sich lange hinziehenden Berufungsverhandlungen um die Mayer-Nachfolge waren auch Gesprächsstoff der deutschen Archivkollegen Pirchans. Bergl berichtete Blaschka im Juni I 930 aus Karlsbad, dass er auch schon das Ergebnis der Sitzung des geschlossenen Professorenkollegiums von anderer Seite bereits erfahren habe ${ }^{96}$. Demnach solle die Kommission den Vorschlag derart umarbeiten, dass Pfitzner ganz herausfalle. Sollte Wostry auch weiterhin ein mutiger Knabe bleiben, so könnte Pirchan laut Bergl an die zweite Stelle in der Liste aufrücken, ja sogar die erste Stelle wäre nicht ausgeschlossen. Wichtig sei es jetzt, dass die eine oder andere gute Rezension zu Pirchans Werk erscheine. Klicman besprach mit Bergl diese Frage ebenfalls und wünschte, dass auch eine positive Besprechung in einer nichtdeutschen Zeitschrift publiziert werde ${ }^{97}$. Die Berufung Pirchans an die Universität war nämlich auch mit der Frage der Nachfolge Klicmans im Archiv des Innenministeriums verbunden. Pirchan hätte als dienstältester Beamter nach Klicman und stellvertretender Direktor grundsätzlich gute Aussichten auf diese Stelle gehabt. Dass in der Tschechoslowakischen Republik das zentrale Staatsarchiv des Landes von einem Deutschen geleitet würde, war in jener Zeit allerdings schwer vorstellbar ${ }^{98}$.

Prag nicht in die engere Wahl gezogen und wird in den Kommissionsberichten nicht genannt. 1933 erfolgte Koebners Entlassung und er emigrierte nach Palästina. Zu ihm siehe Jehoshua Arieli, Richard Koebner Zeitwende und Geschichtsbewußtsein, in: Richard Koebner: Geschichte, Geschichtsbewußtsein und Zeitwende. Vorträge und Schriften aus dem Nachlaß, hg. vom Institut für Deutsche Geschichte der Universität Tel Aviv (Gerlingen 1990) 22-48; Eduard MüHle, Für Volk und Deutschen Osten. Der Historiker Hermann Aubin und die deutsche Ostforschung (Schriftenreihe des Bundesarchivs 65, Düsseldorf 2005) 100-104, 212. 95 Sechs Tage vor der ersten Kommissionssitzung teilte Pfitzner Hirsch diese soeben von Mayer erfahrene Neuigkeit mit. Pfitzner an Hirsch, 20.02.1930. MÚA, NL Pfitzner. Alena Míšková danke ich an dieser Stelle herzlich für die Möglichkeit, in ihr Manuskript der Edition der Korrespondenz zwischen Pfitzner und Hirsch Einblick zu nehmen, sowie für Fotografien der Briefe und Postkarten Pirchans an Pfitzner.

96 Bergl an Blaschka, 09.06.1930. NL Blaschka, K. 6, Inv.-Nr. 12.

97 Bergl an Blaschka, 19.06.1930. Ebd.

98 Bereits am 28.06.1919 schrieb Klicman an das Präsidium des Innenministeriums über Pirchan: Er ist ein sehr gut qualifizierter Beamter, aber er ist ein Deutscher, Mitglied des Deutschen Casinos und ein Freund des bekannten 
Pirchans Berufung auf den universitären Mittelalterlehrstuhl bot daher eine elegante Möglichkeit für die 1934 erfolgte ${ }^{99}$, politisch opportune Neubesetzung des Archivdirektorpostens mit Jaroslav Prokeš ${ }^{100}$.

Obwohl Pirchan im Kommissionsbericht vom Dezember I930 wie gesehen erst an dritter Stelle vorgeschlagen wurde, geht aus den Korrespondenzen der deutschen Prager Historiker hervor, dass man bereits mit Pirchan als neuem Lehrstuhlinhaber rechnete. Somit steht seine Berufung an die Deutschen Universität für einen Trend, den zuletzt Pavel Kolár beobachtet hat: Das tschechoslowakische Schulministerium bevorzugte einheimische gegenüber ausländischen Bewerbern ${ }^{101}$. Pirchan war der einzige Kandidat, der die tschechoslowakische Staatsbürgerschaft besaß und die tschechische Sprache beherrschte. Überdies konnte sich das Ministerium über die Zuverlässigkeit und Loyalität des Kandidaten gegenüber dem tschechoslowakischen Staat bei Pirchans tschechischen Vorgesetzten bestens informieren. Zweifelsohne war der von den Prager deutschen Professoren an erster Stelle nominierte Helbok als Exponent der deutschen „Volksgeschichte“ und wegen seiner sonstigen Aktivitäten aus Sicht des tschechoslowakischen Schulministeriums kein geeigneter Bewerber. Die Behörde begründete Pirchans Nominierung dann auch explizit damit, einen „einheimischen“ Bewerber fördern zu wollen ${ }^{102}$. Bereits am 28. Januar I93 I zog das Schulministerium beim Präsidium des Innenministeriums bezüglich der Berufung Pirchans Erkundigungen ein. Die Innenbehörde bezeichnete den Kandidaten in ihrer Antwort als ausgezeichneten Archivbeamten ${ }^{103}$, doch sei sie bereit, ihn für die Erlangung der Professur aus seinem Amt scheiden zu lassen. Allerdings zogen sich die Verhandlungen zwischen dem Finanz-, Innen- und Schulministerium und Pirchan noch länger hin und seine Ernennung erfolgte erst im Frühjahr $1933^{104}$.

Dr. Lodgman. In den heutigen Verhältnissen, und sicherlich noch viele Jahre wäre es eine auch politisch höchst problematische Sache, dass die Leitung des Archivs des Innenministeriums - des wichtigsten von allen staatlichen Verwaltungsarchiven - auch nur vorübergehend ein Deutscher führen sollte. Und es wird sicherlich noch viel Zeit vergehen, bis sich zeigen wird, ob die böhmischen Deutschen wirklich loyale Bürger und damit auch loyale und zuverlässige Beamte unserer Republik sind. Pirchan vertrat jedoch Klicman auch in der Folgezeit. NA, PMV, PA Jan Opočenský, K. 26.

99 Vgl. Odložılík, Nachruf (wie Anm. 53)114.

$100 \mathrm{Zu}$ Prokeš siehe Josef Kollmann, Dr. Jaroslav Prokeš, archiváŕ, historik, učitel [Dr. Jaroslav Prokeš, Archivar, Historiker und Lehrer], in: Paginae Historiae 5 (1997) 123-155; Milada SE ку коvé, Život a dílo archiváře a historika Jaroslava Prokeše [Das Leben und Werk des Archivars und Historikers Jaroslav Prokeš], in: SAP 39 (1989) 395-465.

101 „Am Ende [wurde] in der Regel eine inländische, fachlich jedoch weniger angesehene Lehrkraft berufen.“ KolÁŘ, Geschichtswissenschaft in Zentraleuropa 1 (wie Anm. 3) 46.

102 Schulministerium an PMV, 28.01.1931. NA, PMV, PA Pirchan, K. 268.

103 Ebd.

104 Bei den Verhandlungen, die Pirchan mit dem Schulministerium führte, zeigte er sich der Behörde zufolge bei seinen Forderungen nicht besonders zurückhaltend. Auch in den Gesprächen zwischen dem Schulminis- 
Jüngere, engagierte Kollegen wie Zatschek und Pfitzner waren bereits vor ihm in Prag zum Zuge gekommen. Es scheint, dass Pirchan von anderen Universitäten keine Rufe erhalten hat. Noch vor der Ernennung zum Professor erfolgte seine Wahl zum außerordentlichen Mitglied der Gesellschaft zur Förderung Deutscher Wissenschaft, Kunst und Literatur in der Tschechoslowakei ${ }^{105}$, die ihn bereits zuvor gefördert hatte und in deren Schriftenreihe seine Habilitationsschrift erschienen war ${ }^{106}$. In der Zeit des Protektorats Böhmen und Mähren wurde Pirchan von Adolf Hitler im September I94I zum außerordentlichen Professor im Reichsdienst ernannt. Zum I. April I944 übernahm Pirchan von Zatschek die Funktion des geschäftsführenden Direktors des Historischen Seminars der Universität, die er bis zum Kriegsende im Mai 1945 innehatte ${ }^{107}$.

\section{V. „IN DEN DIENST GESAMTDEUTSCHER KULTURARBEIT GESTELLT. “108 IM VEREIN FÜR GESCHICHTE DER DEUTSCHEN IN BÖHMEN}

Neben seiner Alma Mater war Pirchan institutionell vor allem mit dem VGDB verbunden, dem er kurz nach seinem Eintritt in das Statthalterei-Archiv I 907 beigetreten war ${ }^{109}$. Noch vor dem Ersten Weltkrieg wurde Pirchan auf der Vollversammlung des Vereines am I 8. Dezember I9I 3 in dessen Ausschuss gewählt ${ }^{110}$. Zuvor schon hatte er das Amt des

terium und dem Finanzministerium wurde angeführt, dass bei Missachtung von Pirchans Forderungen die Gefahr bestehe, keinen „heimischen“ Bewerber für den Lehrstuhl zu erhalten. NA, Předsednictvo ministerské rady (PMR) [Vorsitz des Ministerrats], PA Pirchan, K. 853.

105 Zur Gesellschaft vgl. Josef Hemmerle, Die Gesellschaft zur Förderung Deutscher Wissenschaft, Kunst und Literatur in Böhmen, in: Vereinswesen und Geschichtspflege in den böhmischen Ländern, hg. v. Ferdinand Seiвt (München 1986) 231-247; Michael Neumüller, Geschichtswissenschaft und Heimatforschung. Forschungen und Publikationen der Deutschen Gesellschaft der Wissenschaften und Künste bzw. der Deutschen Akademie der Wissenschaften in Prag 1919-1945, in: Die böhmischen Länder in der deutschen Geschichtsschreibung seit dem Jahre 1848 1, hg. v. Dems. u.a. (Ústí nad Labem 1996) 81-102.

106 Gutachten vom 27.11.1932 Gustav Becking, Wostry, Steinherz u.a. MÚA, Gesellschaft zur Förderung Deutscher Wissenschaft, Kunst und Literatur in Böhmen, PA Pirchan, K. 38.

107 Hruza, Zatschek (wie Anm. 66) 725; Oberdorffer, Pirchan (wie Anm. 7) 81.

108 Pirchan über die Aufgabe des VGDB in seiner Rede zur 75-Jahr-Feier des Vereines im Oktober 1937 in Prag. Gustav Pirchan, 75 Jahre!, in: MVGDB 76 (1938) 6-12, hier 6.

109 Vgl. Mitteilungen der Geschäftsleitung. Nachtrag zum Verzeichnis der Mitglieder, in: MVGDB 46 (1907/08) 417; Lemberg, Verein (wie Anm. 2) 220.

110 Bericht über die am 18. Dezember 1913 abgehaltene Hauptversammlung des Vereines für Geschichte der Deutschen in Böhmen, in: MVGDB 52/53 (1913) 619-622, hier 622. Vgl. Oberdorffer, Verein (wie Anm. 2) 23. 
Abb. 25: Gustav Pirchan ${ }^{111}$ auf dem I. Archivschulungskurs in Eger (Cheb) 1928

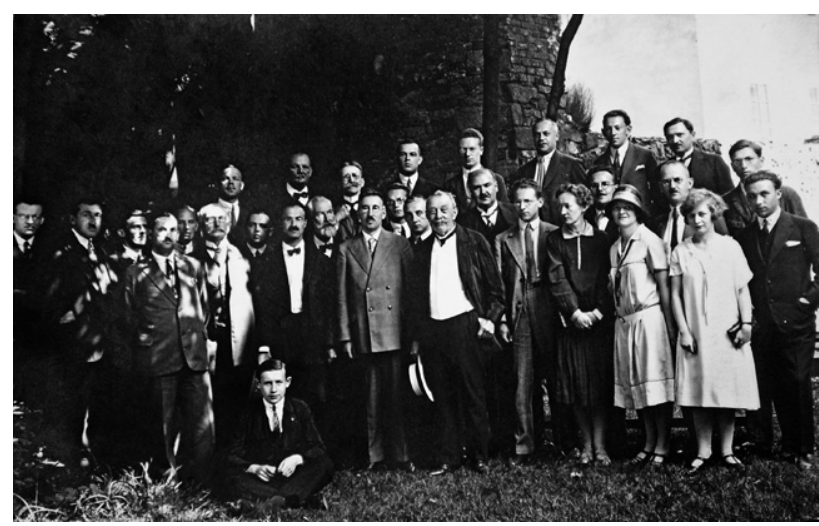

Rechnungsprüfers innegehabt ${ }^{112}$. Seit I9I7 war er dann Geschäftsführer ${ }^{113}$. Dieses Amt war mit organisatorischen Fragen und mit einer umfangreichen Korrespondenz mit den Mitgliedern, Autoren und Verlagen befasst und wird Pirchan neben seinen dienstlichen Verpflichtungen und Forschungsarbeiten viel Zeit gekostet haben. Für die Mitteilungen des VGDB verfasste Pirchan als Geschäftsführer mehrfach Jahresberichte über die Tätigkeit des Vereines, die er alljährlich auf der Vollversammlung vortrug ${ }^{114}$. In den Mitteilungen publizierte er auch mehrere Aufsätze und Rezensionen. ${ }^{115}$

Außer dem hauptberuflichen Dienst im Staatsarchiv wirkte Pirchan neben anderen zudem als Organisator des nichtstaatlichen Archivwesens der deutschen Gemeinden in der Tschechoslowakei. Auf einer am 4. April 1925 in Brüx (Most) gehaltenen Tagung hatten deutschböhmische Archivare die Bildung einer Abteilung für Archiv- und Musealwesen und Denkmalpflege innerhalb des VGDB angeregt ${ }^{116}$. Pirchan oblag die Geschäftsführung der sich in der Regel zwei- bis dreimal jährlich treffenden Abteilung, die ein gutes Scharnier zwischen Prag und den dortigen deutschen Universitätsprofessoren und Staatsarchivaren sowie den Archivaren und der „Heimatforschung“ in der Provinz darstellte. Mehrmals organisierte die Abteilung Schulungswochen für Archivare in den deutschen

111 Pirchan ist die sechste Person von rechts in der ersten Reihe.

112 Ebd.; MVGDB 51 (1912) 143.

113 Oberdorffer, Verein (wie Anm. 2) 23.

114 Antonín Kostrán, Die „Mitteilungen des Vereines für Geschichte der Deutschen in Böhmen“ in der Tschechoslowakischen Republik (1918-1938), in: Die böhmischen Länder (wie Anm. 105) 103-113.

115 Siehe Abschnitt VII.

116 Bedřich JenšovskÝ, Archivní sekce Spolku pro dějiny Němců v Čechách [Archivabteilung des VGDB], in: ČAŠ 3 (1926) 180; Kurt Oberdorffer, Aus dem Archivwesen der sudetendeutschen Städte: Die Archivlehrgänge, in: Archivstudien. Zum siebzigsten Geburtstage von Woldemar Lippert, hg. v. Hans BeschorNER, Wilhelm u. Bertha von BAEnsch (Dresden 1931) 174-178. 
Gebieten. Beim ersten Archivschulungskurs, der vom 29. Juni bis zum 3. Juli 1928 in Eger (Cheb) stattfand, sprach Pirchan über Stadtverfassung und -verwaltung im Rahmen der böhmischen Landesverfassung vom I6. bis I9. Jahrhundert, über die verschiedenen öffentlichen Archive Böhmens und ihre Bestände sowie über Privatarchive und die Entwicklung der Schrift vom Mittelalter bis zur Neuzeit ${ }^{117}$. Zwei Jahre später traf man sich in Mährisch-Trübau (Moravská Třebová). Pirchan behandelte hier in einem Vortrag Grundfragen des Archivwesens und der Archivorganisation. Sein zweiter Beitrag war der Entwicklung der Verfassung und der öffentlichen Verwaltung in den böhmischen Ländern seit dem I6. Jahrhundert gewidmet ${ }^{118}$. Am 27. August 1935 sprach Pirchan beim Archivlehrgang in Reichenberg (Liberec) über Grundbegriffe der Archivwissenschaft sowie über die Bedeutung der Archive für „unsere“ Wissenschaft ${ }^{119}$.

\section{IM PROTEKTORAT BÖHMEN UND M ̈̈HREN}

Die großen politischen Veränderungen in der zweiten Hälfte der I 93oer Jahre, die sich in einem zunehmenden Druck des NS-Regimes und der Henlein-Bewegung auf die Tschechoslowakei äußerten, wirkten sich zwangsläufig auch auf Pirchan aus. Am I. Kongress der tschechoslowakischen Historiker nahm er im Frühjahr 1937 noch als Gast teil ${ }^{120}$. Aktiver beteiligte er sich als langjähriger Geschäftsführer des VGDB an den umfangreichen Vorbereitungen für das 75-jährige Vereinsjubiläum im Herbst I937. Dieses war auch als nationale Einheitsdemonstration der Sudetendeutschen gedacht. Die Vorarbeiten der von Pirchan mitherausgegebenen Vereinsfestschrift beanspruchten seine Zeit spätestens seit März I935 ${ }^{121}$. In dieser legte er einen zusammenfassenden essayistischen Beitrag zu den Sudetendeutschen vor. Er gehörte zu denjenigen Autoren, die die Gelegenheit der zweiten Auflage nach dem Umbruch 1938/39 nutzten, um „frei und offen“ die neuen Zustände zu begrüßen und mit der Tschechoslowakei der Zwischenkriegszeit abzurech-

117 Bericht über den Archivschulungskurs in Eger 29. Juni bis 3. Juli 1928, in: Die Archivabteilung des Vereins für Geschichte der Deutschen in Böhmen (1925-29) (Komotau 1930) 29-36.

118 Arbeitsplan für den Archivlehrgang 1930 in Mährisch-Trübau, in: MVGDB 68 (1930) 80.

119 Arbeitsplan für den Archivlehrgang am 26. und 27.08.1935 in Reichenberg, in: MVGDB 73 (1935) 104.

120 Vgl. hierzu seinen Bericht Gustav Pirchan, I. Kongress der tschechoslowakischen Historiker, in: ZSG 1 (1937) 126-128. Zum Kongress siehe Karel Stroukal, Ir Congrès des Historiens tchécoslovaques (Prague 1937), in: Bulletin of the International Committee of Historical Sciences 10 (1938) 138-140. Otakar ODložılík, O německé historiografii v Československu [Über die deutsche Historiografie in der Tschechoslowakei], in: První sjezd československých historiků 1937. Přednášky a debaty, hg. v. František KuTnaR (Praha 1938) 109-116, sprach über die Entwicklung der deutschsprachigen Geschichtswissenschaft in der Tschechoslowakei.

121 Pirchan an Pfitzner, 05.03.1935. MÚA, NL Pfitzner. 
nen $^{122}$. Auf der Feier, die vom I6. bis I 8. Oktober 1937 in Prag stattfand, sprach Pirchan als Geschäftsführer des Vereines zu dessen historischer Entwicklung und Aufgaben ${ }^{123}$.

Im April 1938 trat er der Sudetendeutschen Partei in Prag bei. Zuvor war er allem Anschein nach und im Unterschied zu vielen seiner deutschen Prager Kollegen ${ }^{124}$ politisch nicht organisiert gewesen. Seine im Mai 1939 beantragte NSDAP-Mitgliedschaft lehnte im September 1939 das „Gaugericht“ mit dem Argument ab, seine Ehefrau sei nicht frei von jüdischem Rasseeinschlag, ihr Urgrossvater Jude. Auch die Unterstützung durch Ortsgruppen- und Kreisleiter sowie Pirchans Mitgliedschaft in der Sudetendeutschen Partei und anderen „,ölkischen“ Organisationen änderten an dieser Ablehnung nichts ${ }^{125}$. Zweifelsohne bedeutete die nicht „reinrassische“ Herkunft seiner Frau und seine fehlende NSMitgliedschaft für ihn im Protektorat ein Manko ${ }^{126}$. Die überwiegende Mehrheit seiner

122 Lemberg, Verein (wie Anm. 2) 228.

12375 Jahre!, in: MVGDB 76 (1938) 6-12. Zum Ablauf der Feier siehe Kurt Oberdorffer, Die 75-Jahrfeier des Vereines für Geschichte der Deutschen in Böhmen, in: MVGDB 75 (1937) 123-125.

124 Blaschka gehörte Anfang der 1920er-Jahre der Deutschen Christlichsozialen Volkspartei in der Tschechoslowakei an. Rudolf Schreiber war zu Beginn der 1930er-Jahre Reichsjugendleiter dieser Partei. Bergl gehörte 1934 dem Bund der Landwirte an. Im Zweiten Weltkrieg waren sie alle Mitglieder der NSDAP. SOA Litoměřice, pobočka Děčín. RA Clam-Gallasů, NL Bergl, K. 669; Die „sudetendeutsche Geschichtsschreibung“" (wie Anm. 3) 225, 262-263.

125 Auf die Frage: Ist der Ehegatte frei von jüdischem oder farbigem Rasseeinschlag?, gab Pirchan an: arisch nach den Nürnberger und den Dozentengesetzen (ein nichtarischer getaufter Urgroßvater). Das Gaugericht berichtete an das NSDAP-Mitgliedschaftsamt Folgendes: Trotz der Tatsache, daß die Ehefrau Pirchans nicht frei vom jüdischen Rasseeinschlag ist, haben der zuständige Ortsgruppenleiter und der Kreisleiter den Aufnahmeantrag befürwortet, weil der Ahnenpaß des Antragstellers selbst den Vorschriften des deutschen Dozentenbundes entspricht. Aus dem Fragebogen ist ersichtlich, daß der Urgroßvater der Ehegattin des Antragstellers Jude und sie daher nicht frei vom jüdischen Rasseeinschlag ist. Dies bildet einen zwingenden Ablehnungsgrund. Der Aufnahmeantrag des Dr. Gustav Pirchan ist daher trotz Befürwortung durch den Ortsgruppenleiter und Kreisleiter und trotz seiner Mitgliedschaft bei der SdP und anderen völkischen Organisationen abzulehnen. Im Oktober 1940 erklärte sich die NSDAP-Reichsleitung, vertreten durch das Mitgliedschaftsamt der NSDAP in München, mit der Aufnahmeablehnung einverstanden. NSDAP, Gauleitung Sudetenland, Gaugericht an das Kreisgericht der NSDAP, 14.09.1939. NA, NSDAP, Sign. 123-433-2/44,45, K. 433; BAB, BDC PK: Pirchan, Gustav 03.02.1881; Mitgliedschaftsamt der NSDAP, 03.10.1940. Im UAP, NL Pirchan befinden sich genealogische Unterlagen zur Familie seiner Ehefrau Elisabeth, geb. Stradal, die Karl Stradal 1915 zur Erstellung einer Familienchronik betrieben hatte. In diesen Dokumenten finden sich keine Hinweise darauf, dass Elisabeth Pirchan einen jüdischen Urgroßvater hatte. UAP, FF NU, NL Pirchan, K. 96, Inv.-Nr. 115.

126 Ein ähnlicher Fall war der Breslauer Historiker Aubin, dessen Ehefrau ebenfalls einen jüdischen Urgroßvater (,jüdischer Mischling 2. Grades“) hatte. So wie auch Aubin bekannt war, dass Ehemänner jüdischer und halbjüdischer Frauen aus den Ämtern gedrängt wurden, wird dies auch Pirchan gewusst haben. Die „Arisierung" an der Prager Universität erlebte er mit. Vgl. Eduard Mühle, Für Volk (wie Anm. 94) 106-108; DERs., Hermann Aubin, der ,deutsche Osten` und der Nationalsozialismus - Deutungen eines akademischen Wirkens im Dritten Reich, in: Nationalsozialismus in den Kulturwissenschaften 1: Fächer - Milieus - Karrieren, hg. v. Hartmut Lehmann, Otto Gerhard Oexle (Göttingen 2004) 531-591, hier 578-579. 
deutschen Prager Kollegen, wenn man von den zahlreichen verfolgten jüdischen Wissenschaftlern der Prager Universität absieht ${ }^{127}$, waren nämlich in der Zeit des Protektorats aktive NSDAP-Mitglieder, die sich bereitwillig in den Dienst der Partei stellten und eine antitschechische Politik unterstützten ${ }^{128}$. Im Herbst I938, als die „Sudetenkrise“ kulminierte, nahm Pirchan als Besucher am internationalen Historikerkongress in Zürich teil ${ }^{129}$. Er traf dort mehrere Kollegen, tschechische wie auch deutsche. Im Unterschied zu den aktiveren sudetendeutschen Vertretern Pfitzner ${ }^{130}$, Wostry, Eduard Winter ${ }^{131}$ und Wilhelm Weizsäcker ${ }^{132}$ trat er jedoch nicht mit einem eigenen Vortrag auf ${ }^{133}$.

Pirchan gehörte zu den sogenannten „geflohenen“ deutschen Professoren, die Prag in der Sudetenkrise 1938 verlassen hatten ${ }^{134}$. Seine „Flucht“ war aber von anderer Art als

127 Vgl. hierzu das Kapitel zur „Arisierung“ und politischen Säuberung sowie die biografische Übersicht über die Dozenten, welche die Universität im Rahmen der „Arisierung“ verlassen mussten. Míš́xová, Deutsche (Karls-) Universität (wie Anm. 6) 58-76, 285-290.

128 Genannt sei hier nur Schreiber, der personelle Umbesetzungen im Prager Stadtarchiv und im Historischen Institut initiierte. Andere deutschböhmische Historiker wie beispielsweise Weizsäcker und Blaschka profitierten von „arisiertem“ jüdischem Besitz. Pfitzner gestaltete als Primator-Stellvertreter die Politik gegenüber Tschechen und Juden in Prag maßgeblich mit. Odložilíks positive Erinnerungen an Schreiber sind bezüglich dessen Verhaltens im Protektorat nicht zutreffend. Zu Weizsäcker Hruza, „Wissenschaftliches Rüstzeug“ (wie Anm. 65) 486-488. Zu Blaschka und Schreiber siehe Lenr, Deutscher Einfluß (wie Anm. 63) 373374; Ders., Deutsche und tschechische Archivare (wie Anm. 27) 434-435. Zu Pfitzner siehe Anm. 90.

129 Vgl. hierzu den tschechischen Bericht von Karel STlOU KAL, VIII. mezinárodní kongres věd historických v Curychu [8. Internationaler Kongress der historischen Wissenschaften in Zürich], in: ČČH 34 (1938) 503-531.

130 Pfitzner hielt seinen angekündigten Vortrag („Der grenz- und auslandsdeutsche Gedanke im Jahre 1848“) jedoch nicht.

131 Zu Winter siehe Jiří NĚmec, Eduard Winter (1896-1982). „Eine der bedeutendsten Persönlichkeiten der österreichischen Geistesgeschichte unseres Jahrhunderts ist in Österreich nahezu unbekannt“ in: Österreichische Historiker (wie Anm. 66) 619-675; DERs., Eduard Winter, in: Handbuch der völkischen Wissenschaften (wie Anm. 7) 763-766.

132 Zu Weizsäcker vgl. Joachim BAHLCKE, Wissenschaft im sudetendeutschen Volkstumskampf. Zur hochschulpolitischen Tätigkeit des Prager Rechtshistorikers Wilhelm Weizsäcker in der Zeit vom Münchener Abkommen 1938 bis zum Ende des Zweiten Weltkrieges, in: Wissenschaft in den böhmischen Ländern 1939-1945, hg. v. Antonín Kostlán (Praha 2004) 118-135; Hruza, „Wissenschaftliches Rüstzeug“ (wie Anm. 65) 479-494.

133 Wostry widmete sich einem aktuellen politischen Thema („Das Problem des Nationalitätenstaates in der böhmischen Revolution des Jahres 1848“). Zudem hielten von den Prager Professoren der Althistoriker Arthur Stein und der Rechtshistoriker Otto Peterka Vorträge. Von tschechischer Seite nahmen zwei ehemalige Archivkollegen Pirchans teil: Prokeš und Václav Čejchan. Weitere Prager Mitwirkende, die Pirchan persönlich kannte, waren Mendl und Odložilík. Zum Programm des Historikertages vgl. Résumés des communications présentées au Congrés de Zurich (1938), in: Bulletin of the International Committee of Historical Sciences 10 (1938) 145-726.

134 Vgl. hierzu Věra Vомáč коvÁ, Německá universita v Praze mezi Mnichovem a 15. březnem 1939 [Die Deutsche Universität in Prag zwischen München und dem 15. März 1939], in: AUC - HUCP 15 (1963) 3-19; 
diejenige der Prager Kollegen. Pirchan befand sich zu jener Zeit auf der Rückreise vom Historikerkongress in der Schweiz über Italien und Österreich, wo er seine Mutter in Eggenburg besuchte. Die Reise und einen anschließenden fünfwöchigen Urlaub hatte er bereits im Juni 1938 beantragt ${ }^{135}$. Im November 1938 sprach er sich zusammen mit weiteren „deutscharischen“ Hochschullehrern und Wissenschaftlern aus „volkstumspolitischen " Gründen und nach einem offenen Bekenntnis zu Hitler ${ }^{136}$ für die Verlegung der Prager Universität ins Sudetengebiet aus. Auf der Hauptversammlung der tschechoslowakischen Archivgesellschaft erschien Pirchan zum letzten Mal im April i938. Für die Sitzungen im März 1940 und die vorerst letzte im Juni I94I ließ er sich entschuldigen $^{137}$. Bereits Anfang November 1938 hatte er schriftlich auf sein Amt im Ausschuss der Vereinigung verzichtet ${ }^{138}$. Allem Anschein nach erschien ihm zu diesem Zeitpunkt die Mitgliedschaft in einer tschechoslowakischen Organisation unpassend.

Aufgrund des Antrags auf eine NSDAP-Parteimitgliedschaft und Änderungen beziehungsweise Ergänzungen für die Vereinsfestschrift zum Sudetendeutschtum sowie anderer publizistischer Äußerungen wird man feststellen können, dass Pirchan die Zäsuren vom September 1938 und März I 939 begrüßte. Im August I 939 suchte er nach einem Titelbild für die in zweiter Auflage erscheinende Vereinsfestschrift über das Sudetendeutschtum. Er und seine Kollegen dachten monatelang über ein "Sinnbild des Sudetendeutschtums“ nach, ohne jedoch etwas Passendes zu finden. Dann hatte Pirchan den Einfall, ein Bild heranzuziehen, das Hitler beim Einzug in das Sudetenland zusammen mit einem älteren

Alena MíšKovÁ, Deutsche Professoren aus den böhmischen Ländern. „Flüchtlinge“ in der Zeit vor und nach den Münchner Verhandlungen, in: Prager Professoren (wie Anm. 19) 27-43; Dies., Deutsche (Karls-) Universität (wie Anm. 6) 48-58; Hruza, Zatschek (wie Anm. 66) 763-765.

135 Schreiben des zuständigen Dekans vom 28.06.1938. UAP, FF NU, PA Pirchan, K. 50. Pirchan teilte dem Dekan regelmäßig seinen Aufenthaltsort (29.10. Lugano, 10.10. Verona, 21.10. Eggenburg) mit und kehrte auf Anforderung des Prodekans am 02.11.1938 zurück nach Prag. Auch von Wostry ließ er sich wiederholt über die Lage informieren.

136 Sie erklärten feierlich, dass sie freudig bereit seien, für Führer und Volk alle ihre Kräfte einzusetzen. Abdruck der Erklärung bei HruzA, Zatschek (wie Anm. 66) 782-784.

137 Zápisy valné hromady [Protokolle der Hauptversammlung] 13.04. und 29.04.1938, 13.06.1941. NA, ČAS, K. 1.

138 Am 09.04.1939 verzichtete Pirchan erneut auf seine Mitgliedschaft. Der Ausschuss bedankte sich daraufhin bei ihm für seine verdienstvolle Tätigkeit. Doch dann erschien Pirchan bei Archivdirektor Bedřích Jenšovský und meinte, er sei falsch verstanden worden und möchte als Angehöriger des neu errichteten Protektorats auch weiterhin im Ausschuss der Gesellschaft präsent sein. Anfang Dezember 1939 resignierte er dann noch einmal auf sein Amt als Kassenwart und erklärte, dass er ebenso wie die anderen deutschen Archivare des Protektorats weiterhin der Gesellschaft als Mitglied angehöre. Protokoll über die Sitzung des Ausschusses der Archivgesellschaft vom 01.12.1939 und 19.01.1940. Archiv hlavního města Prahy [Archiv der Hauptstadt Prag], Archivní společnost, K. 1. Jan Kahuda danke ich für den Hinweis auf diese Quelle. 
sudetendeutschen Bauwerk zeigt ${ }^{139}$. Im Frühjahr I 940 bereitete er einen Vortrag über das Judentum in der Geschichte Prags für die Volksbildungsstätte vor und nahm kurz darauf an einer Besprechung über den „Einsatz der Geisteswissenschaften im Krieg“ teil. Um seine Mitwirkung an dieser Veranstaltung hatte ihn sein Prager Vorgänger Theodor Mayer gebeten. Zwei Jahre später besuchte er schließlich zwei Tagungen zu diesem Thema. So nahm Pirchan am 4. und 5. Mai I 942 an einer Konferenz zur „Germanischen Raumerfassung und Staatenbildung“ in Weimar teil. Die dortigen Vortragenden „behandelten den germanischen Einfluss auf Staat, Recht und Sprache Europas"140. Vom I8. bis 2I. November 1942 trafen sich in Marburg 43 Mittelalterhistoriker (von 92 eingeladenen), unter ihnen Pirchan, um über die Kontinuität „germanischer“ Leistungen in der Geschichte zu diskutieren ${ }^{141}$. Im gleichen Jahr hielt er im Juli im Auftrag des Deutschen Zentralinstituts für Erziehung und Unterricht vor tschechischen Lehrkräften zwei Vorträge über Böhmen als „Glied des mittelalterlichen Kaiserreiches“ und „Böhmen und Mähren unter Karl IV.“. In diesen betonte er die Verbundenheit Böhmens mit dem Reich und die Leistungen des „Deutschtums“"142. Wie auch die anderen Prager Kollegen publizierte er während des Krieges drei Beiträge in dem offiziösen Blatt des Reichsprotektors Böhmen und Mähren ${ }^{143}$. Letztlich griff Pirchan hier jedoch nur frühere Schriften auf, welche bereits in nationalistischem Ton verfasst waren und die Leistungen des „Deutschtums“ hervorhoben.

Während des Krieges gehörte Pirchan der Historischen Kommission der Sudetendeutschen Anstalt für Landes- und Volksforschung an ${ }^{144}$. Im März 1944 ernannte ihn der Deutsche Staatsminister für Böhmen und Mähren, Karl Hermann Frank, zum Mitglied eines Editionsrates für geschichtliche Quelleneditionen in Böhmen und Mähren, in der Reinhard-Heydrich-Stiftung engagierte sich Pirchan jedoch nicht ${ }^{145}$, unterhielt aber zu dort aktiven Persönlichkeiten wie Zatschek Beziehungen. So schrieb Pirchan diesem bei-

139 Pirchan an Bergl, 15.08.1939, 04.03.1940. SOA Litoměřice, pobočka Děčín, RA Clam-Gallasů, NL Bergl, K. 670 .

140 Frank-Rutger Hausmann, Deutsche Geisteswissenschaft im Zweiten Weltkrieg. Die „Aktion Ritterbusch“ (1940-1945) (Heidelberg ${ }^{32007)} 180$.

141 Ebd. $184 f$.

142 Pirchan an Dekan, 25. und 26.08.1940; 27.04.1942, 27.06.1942. UAP, FF NU, PA Pirchan, K. 50.

143 Vgl. hierzu allgemein Petr Š́ propagandy a soudobé sudetoněmecké historiografie [Das Blatt des Reichsprotektors Böhmen und Mähren im Kontext der nationalsozialistischen Propaganda und zeitgenössischen sudetendeutschen Historiografie], in: AUC - HUCP 44 (2004) 147-211.

144 Ota Konrád, Die sudetendeutsche Anstalt für Landes- und Volksforschung 1940-45, in: Die „sudetendeutsche Geschichtsschreibung" (wie Anm. 3) 71-95, hier 77.

145 Erlass des Deutschen Staatsministers für Böhmen und Mähren über geschichtliche Quellenveröffentlichungen in Böhmen und Mähren vom 06.03.1944. NA, ÚŘP, 114-201-8. Andreas Wiedemann, Reinhard-Heydrich-Stiftung (wie Anm. 78); MíšKová, Deutsche (Karls-) Universität (wie Anm. 6) 162-171, 244-246. 
spielsweise, dass er an der Trauerfeier für den stellvertretenden Reichsprotektor Reinhard Heydrich teilgenommen habe und dass ihm Zatscheks Rückberufung von Wien nach Prag in diesem Augenblick - wohl auch aus „volkspolitischen“ Gründen - sehr wünschenswert erscheine ${ }^{146}$. In einem Nachruf auf seinen „Doktorvater“ Werunsky hob Pirchan dessen nationale Gesinnung, der er in seinem Einsatz für das „Sudetendeutschtum“ Ausdruck verliehen habe, und dessen NSDAP-Mitgliedschaft hervor ${ }^{147}$.

In der Hauptversammlung des Jahres I94I war der VGDB bereits in „Verein für Geschichte der Deutschen in den Sudetenländern“ umbenannt und gleichgeschaltet worden. Der neue Geschäftsführer Rudolf Schreiber legte nun den Geschäftsbericht über die Vereinstätigkeit von 1938-1940 vor ${ }^{148}$. Auch für die nächsten Jahre wird Pirchan nicht mehr unter den Mitgliedern der Vereinsleitung genannt. Aus welchen Gründen er nach über zwanzig Jahren aus dem aktiven Vereinsleben ausschied, ist bis heute unklar. Es bleibt offen, ob er aus eigenem Entschluss, aus gesundheitlichen Gründen oder aber auf Drängen von anderer Seite, beispielsweise wegen seiner fehlenden NSDAP-Mitgliedschaft, I94I keine Aufnahme in den Ausschuss des Vereines mehr fand ${ }^{149}$. Da „Vereinsführer“ Wostry Pirchan nahestand, wird es sich jedoch wahrscheinlich um Pirchans eigene Entscheidung gehandelt haben. So wurde Pirchan auch wiederholt als Archivfachmann für verschiedene leitende Ämter vorgeschlagen, die er unter Berufung auf seine schlechte Gesundheit jedoch ablehnte ${ }^{150}$. Er publizierte aber weiterhin in den Organen des Vereines und nahm beispiels-

146 Heute habe ich bei der Trauerfeier für den verewigten Reichsprotektor viel und herzlich an Sie gedacht, als der Rektor mit den eigenen Worten dem Dahingegangenen sein inniges Verständnis für Hochschule und Wissenschaft darlegte. Vor allem Sie, verehrter Herr Professor, sind ja berufen, das Vermächtnis zur Tat werden zu lassen und Ihre Rückberufung erhält damit einen noch viel tieferen und ernsteren Sinn als sie vordem schon hatte. Pirchan an Zatschek, 08.06.1942. MÚA, NL Zatschek, Sig. IIb1, K. 5 Inv.-Nr. 327.

147 Pirchan, Werunsky (wie Anm. 4) 106.

148 Rudolf Schreiber, Aus dem Verein für Geschichte der Deutschen in den Sudetenländern, in: ZSG 5 (1941/42) 335-336. Hans Lemberg, Von den Deutschböhmen zu den Sudetendeutschen, in: Geschichtsschreibung zu den böhmischen Ländern (wie Anm. 3) 95-108, hier 105, führt fälschlich an, dass Pirchan nach der Gleichschaltung 1939 weiterhin die Funktion des Geschäftsführers innegehabt habe. Den letzten Tätigkeitsbericht erstatte Pirchan auf der Hauptversammlung des Vereines am 01.04.1938 für die Jahre 1936/37. Gustav Pirchan, Bericht über die Tätigkeit des Vereins für Geschichte der Deutschen in Böhmen im 74. und 75. Vereinsjahre 1936/37, in: ZSG 2 (1938) 135-137, sowie parallel in: MVGDB 76 (1938) 75-77.

149 Aufgrund der neuen Vereinssatzung wurden die Ausschussmitglieder nicht mehr gewählt, sondern vom „Vereinsführer“ Wostry ernannt. Vgl. HruzA, „Wissenschaftliches Rüstzeug“ (wie Anm. 65) 509, und: Die Jahrestagung des Vereins für Geschichte der Deutschen in den Sudetenländern 1941, in: MVGDS 80 (1943) 106-113, hier 107-108.

150 Vorschläge für die Weiterführung der Archivalientrennung im Protektorat Böhmen und Mähren, Meinert an Wagner (IM), 04.1940. BAB, R 1506/35, Bl. 32; Meinert an Zipfel, 30.06.1940. BAB, R1506/ 40, Bl. 30; Vorschläge für eine Rückforderung von sudetendeutschem Archivmaterial aus den Prager und Brünner Archiven. Rudolf Schreiber, 03.10.1938. BAB, BDC Ahnenerbe, PA Rudolf Schreiber. Zum Archivwesen im Protektorat siehe Lehr, Deutscher Einfluß (wie Anm. 63) 370-376. 
weise auch an der Jahrestagung des Vereines im Dezember I 94I teil, auf der der Staatssekretär und SS-Gruppenführer Karl Hermann Frank eine „richtungsweisende Rede“ hielt ${ }^{151}$.

Vergleicht man Pirchans Verhalten im Protektorat mit dem der anderen Prager deutschen Historiker, erscheint er verhältnismäßig unauffällig. Bergl beurteilte sein Auftreten im November 1939 als ganz klug: Man sieht ihn nicht und hört nichts von ihm. Bergl fand es sehr schön, dass er nicht nach Ämtern und Ehrenstellen ausgeht und den Herrgott einen guten Mann sein lässt ${ }^{152}$. Im April 1939 schrieb Pirchan dem tschechischen Kollegen František Roubík noch auf Tschechisch. In dem Brief gab er der Hoffnung Ausdruck, noch einiges für die gemeinsame Arbeit leisten zu können, die der Jahrhunderte alten gemeinsamen Geschichte gewidmet sei ${ }^{153}$. Zwei Gutachten über die tschechischen Historiker Rudolf Holinka und Josef Tichý, die Pirchan auf Anforderung des Dekans der Philosophischen Fakultät 1942 erstellte, waren fachlich neutral bzw. im Fall des Pekař-Schülers Holinka sogar äußerst positiv ${ }^{154}$.

Der tschechische nationalistische Historiker Václav Vojtíšek sprach Pirchan anders als vielen anderen deutschen Historikern ein gewisses Maß an Zurückhaltung $\mathrm{zu}^{155}$. So habe er sich von der Politik ferngehalten und im Protektorat nicht Karriere gemacht. Pirchan sei, so Vojtíšek, kein „Faschist“ gewesen; diese politische Gruppierung hätte ihm dennoch nähergestanden als die Tschechen ${ }^{156}$. Nach Aussage Vojtíšeks ging Pirchan ihm während des Krieges aus dem Wege, erst kurz vor Ende der deutschen Okkupation habe er Vojtíšek angesprochen. Pirchan habe dabei auf seinen unpolitischen Charakter, sein ausschließliches Interesse an der Wissenschaft und seine Herzprobleme hingewiesen. Während viele Reichsdeutsche Prag rechtzeitig vor Kriegsende verließen, fiel dies dem mit der Stadt verbundenen Pirchan zweifelsohne schwer, und so blieb er. Pirchan war kein NSDAP-Mitglied, verfügte aus seiner Dienstzeit im Archiv über Kontakte zu Tschechen und beherrschte deren Sprache; zudem hatte seine Ehefrau einen jüdischen Urgroßvater. Er machte sich daher begründete Hoffnungen, den Umbruch unbeschadet zu überstehen. Eine Woche vor dem Prager Aufstand im Mai 1945 teilte Pirchan Vojtíšek mit, dass er seine böhmische Arbeitsumgebung sehr schätze ${ }^{157}$.

151 Vgl. Die Jahrestagung des Vereins für Geschichte der Deutschen in den Sudetenländern 1941, in: MVGDS 80 (1943) 106-113, hier 107-108.

152 Bergl an Blaschka, 03.11.1939. NA, NL Blaschka K. 6, Inv.-Nr. 12.

153 Pirchan an Roubík, 15.04.1939. MÚA, NL Roubík, Sig. IIb, Inv.-Nr. 236.

154 Über Tichý sagte Pirchan aus, dass er von vertrauenswürdigen Gewährsmännern als ruhiger, verläßlicher junger Forscher geschildert werde. Gutachten vom 15.11.1942. UAP, FF NU, Gutachten über die Dozenten der geschlossenen tschechischen Philosophischen Fakultät, K. 95.

155 Hruza, „Einige Deutsche“ (wie Anm. 72) $148 \mathrm{f}$.

156 Ebd. 158.

157 Ebd. 148f.; Míš́xová, Deutsche (Karls-) Universität (wie Anm. 6) 237. 
Das Ende der Besatzung war für die deutsche Bevölkerung im Protektorat mit Entrechtung und Zwangsaussiedlung verbunden. Pirchan wurde im Mai 1945 in Prag festgenommen. Zatschek berichtete seinem Kollegen Wilhelm Bauer, dass Pirchan vor den Augen seiner Frau auf der Prager Polizei massiv misshandelt und dann von ihr getrennt worden sei $^{158}$. Am 24. Mai 1945 überführte man ihn aus dem Prager Gefängnis Pankrác in das ehemalige Konzentrationslager Theresienstadt, welches nun als Internierungslager für Deutsche diente. Dort verstarb Gustav Pirchan am 22. September in der Kleinen Festung ${ }^{159}$.

Der tschechische Kollege Kazbunda erinnerte sich nach dem Krieg in seinen Memoiren an Pirchans trauriges Ende: Das Schicksal, welches diesen gemäßigten Deutschen, einen außergewöhnlich gebildeten Menschen, danach in der Folge des durch Hitler zerstörten Zusammenlebens beider Nationalitäten traf, war extrem unverdient und traf jeden schwer, der ihn näher kannte ${ }^{160}$. Der 1948 aus der kommunistischen Tschechoslowakei in die USA emigrierte Historiker Otakar Odložilík ${ }^{161}$ traf sich während seiner Europareisen in den I $950 e r$ und I96oer Jahren mindestens dreimal mit Pirchans Witwe ${ }^{162}$.

\section{VII. „IM DIENSTE UNSERES VOLKES. “163 DER HISTORIKER}

Pirchans historiografisches Werk ist, obgleich nicht besonders umfangreich, zeitlich breit angelegt und deckt die Epochen Mittelalter, Frühe Neuzeit und Neuere Geschichte ab. Seine wissenschaftliche Hauptleistung machen die Forschungen zu Kaiser Karl IV.

158 Zatschek an Bauer, 04.10.1945. Zitiert nach HruzA, Zatschek (wie Anm. 66) 691.

159 SOA v Litoměřicích. Internační středisko Terezín [Internierungslager Theresienstadt], Inv.-Nr. 189. - OвеRDorffer, Pirchan (wie Anm. 1) 80, nennt den 22.06.1945, Santifaller, Institut (wie Anm. 21) 129, den 22. oder 23.07.1945 als Todestag. Der Todesschein ist jedoch auf den 22.09.1945 ausgestellt. Vgl.;.

160 Mé archivní poslání ve Vídni, Bl. 148 f. ANM, NL Kazbunda, K. 32. Kazbunda (an Roubík, 10.02.1963. MÚA, NL Roubík, Sig. IIb, Inv.-Nr. 145) erinnerte sich nostalgisch an seine Wiener Zeit in jungen Jahren während und nach dem Ersten Weltkrieg. Während seines letzten Aufenthaltes in Österreich 1947 spürte er, dass man sich ihm gegenüber sehr kühl verhalten habe. Dies erklärte er sich als eine Folge der Vertreibung der Deutschen aus der Tschechoslowakei, die er als einen Fehler bezeichnete.

161 Odložilík wurde schon Anfang der 1930er-Jahre an die Karls-Universität als Professor berufen und schied damals aus dem Archivdienst aus. Siehe auch Anm. $52 \mathrm{f}$.

162 Erstmals trafen sie sich 1956 in Österreich. Beide schickten von dort Blaschka, einem ehemaligen Kollegen der beiden Archivare, der inzwischen in Halle lebte, eine Postkarte mit gemeinsamen Grüßen. Acht Jahre später begegneten sich Frau Pirchan und Odložilík erneut, diesmal in Augsburg, und wiederum schrieben sie Blaschka. Aus einem Brief Odložilíks geht hervor, dass er sich mit Pirchans Ehefrau danach noch einmal in Göttingen traf. In einer Postkarte aus Rom erwähnte Odložilík Blaschka gegenüber, dass er bei dem Wort „Italien“ sofort an Pirchan gedacht habe und dass er Pirchans Witwe schreiben werde. Odložilík und Else Pirchan an Blaschka, 25.07.1956, 01.08.1964; Odložilík an Blaschka, 11.02.1961, 11.01.1969.

163 Pirchan über den VGDB, in: MVGDB 70 (1932) 120. 
aus. Wenn man bedenkt, dass Pirchan an der zweibändigen Schrift „Italien und Kaiser Karl IV. in der Zeit seiner zweiten Romfahrt“ über zwanzig Jahre gearbeitet hat ${ }^{164}$, kann man es mit gutem Grund als sein eigentliches Lebenswerk bezeichnen ${ }^{165}$. Die Besprechungen von Pirchans Buch fielen einheitlich positiv aus ${ }^{166}$. Die Rezensenten zeigten sich von der Fülle des bewältigten Materials ${ }^{167}$ und der Breite der Darstellung beeindruckt. Pirchan schilderte schwerpunktmäßig das politische Geschehen, zeichnete aber auch die Persönlichkeiten des Kaisers und anderer Akteure nach und untersuchte das Itinerar der Romreise Karls. Ausführliche Exkurse zu den norditalienischen Stadtstaaten sowie Landschafts- und Städtebilder wiesen ihn als Italien- und Kulturhistoriker aus. Mehrere Autoren kritisierten allerdings Pirchans Ausdrucksweise; das Buch wurde nicht als leichte Lektüre empfunden ${ }^{168}$. Pfitzner zufolge habe Zatschek das Buch mit dem Redlichs über Rudolf von Habsburg ${ }^{169}$ verglichen und somit hoch gelobt. Mayer dagegen charakterisierte die Arbeit laut Pfitzner nur „als fleissige Sammlung aller möglichen Details ohne grossen Gedanken“170. Aus dem Arbeitsgebiet der Habilitationsschrift gingen auch weitere Studien hervor. So ein kurzer Beitrag in einer Festschrift für Oswald Redlich zur Datierung der ersten drei Briefe, die Petrarca an Karl IV. geschrieben hat ${ }^{171}$. Daneben

164 Pirchans Studienreise nach Italien 1911 belegt, dass er bereits vor dem Ersten Weltkrieg mit intensiven Forschungen zu diesem Thema begann.

165 Vgl. als neuere Darstellung zum Thema Ellen Widder, Itinerar und Politik. Studien zur Reiseherrschaft Karls IV. südlich der Alpen (Forschungen zur Kaiser- und Papstgeschichte des Mittelalters. Beihefte zu J. F. Böhmer, Regesta Imperii 10, Köln/Weimar/Wien 1993). Frau Widder bezeichnet in einem Schreiben vom 06.02.2011 an den Autor Pirchans Werk, welches eine ganze Reihe neuer Quellenfunde bot, als monumental und in seiner positivistischen Faktenfülle bis heute unübertroffen.

166 Václav NovotnÝ, in: Časopis Matice moravské 54 (1930) 436-444; Lotte Hüttebräuker, in: NA 49 (1932) 597f.; Friedrich Bock, in: MIÖG 46 (1932) 115-117; Paul Pıur, in: HZ 146 (1932) 549-551. Pirchan stand mit Bock und Novotný in Kontakt. Letzteren kannte er seit 1907 aus dem Archiv und bedankte sich auf Tschechisch sehr bewegt bei Novotný für die gute Besprechung: Ich kann Ihnen in Worten nicht ausdrücken, wie glücklich ich bin für die Sympathie, die Sie über mein Buch geäußert haben. Es ist zugleich eine Äußerung ihrer wertvollen Humanität, und ich schätze diese Sympathie wie das kostbare ideale Geschenk, das ich mit dankbarem und bescheidenem Herzen annehme [...]. Brief vom 30.01.1931. MÚA, NL Novotný, K. 14.

167 PiUr (wie Anm. 166) 550.

168 Novotný (wie Anm. 166) 437, begann seine sonst positive Besprechung mit den Worten, dass Pirchans Buch keine leichte Lektüre sei. Laut PIUR (wie Anm. 166) 551, schwankte die Diktion „zwischen stark gefühlsbetonter, durch Genitivvoranstellungen, Häufung von Bildern und schmückenden Beiworten ins Poetische gehobener Sprache und nüchternem Alltagston in einer [...] öfters unerträglichen Weise unvermittelt hin und her“. Bock (wie Anm. 166) 115, schrieb von einer ,individuell gestalteten Sprache, die zuweilen an Manieriertheit“ streife.

169 Oswald Redich, Rudolf von Habsburg. Das deutsche Reich nach dem Untergang des alten Kaisertums (Innsbruck 1903).

170 Pfitzner an Hirsch, Prag, 20.03.1930. MÚA, NL Pfitzner.

171 Gustav Pirchan, Die Abfassungszeit der ersten drei Briefe Petrarcas an König Karl, in: MIÖG Erg.-Bd. 11 (1929) 374-385. Vgl. Pirchan an Bauer, 18.02.1928. AÖAW, NL W. Bauer. 
legte Pirchan in den Jahren I938-I944 drei kulturgeschichtliche Aufsätze zur Geschichte des Spätmittelalters in Böhmen vor ${ }^{172}$.

Zwei mithilfe von Archivalien in den I920er-Jahren geschriebene und heimatgeschichtlich ausgerichtete Beiträge zur Frühen Neuzeit behandeln das Verhältnis der Tachauer und Pfraumburger Untertanen zu ihren Herren im I7. Jahrhundert ${ }^{173}$. Eine weitere Studie aus den I920er-Jahren untersucht ${ }^{174}$, wie sich die Divergenz der staatlichen und kirchlichen Grenzen nach Österreichs Verlust des Großteils von Schlesien an Preußen in den Schlesischen Kriegen (I740-1763) in der Folgezeit auf die Beziehungen zwischen beiden Staaten und der katholischen Kirche auswirkte ${ }^{175}$. In diesen drei Aufsätzen erscheint Pirchan als positivistisch arbeitender Archivar und Historiker, der sich solide mit den Quellen auseinandersetzt, ohne aber größere Fragestellungen aufzuwerfen und ohne seine Arbeiten in einen breiteren Forschungskontext zu stellen. Ein anderes Gebiet, auf dem sich Pirchan profilierte, ist die Geschichte der Deutschen in Böhmen, insbesondere die historische Entwicklung des Zusammenlebens von Deutschen und Tschechen ${ }^{176}$. Diese Arbeiten richteten sich nicht nur an das wissenschaftliche Fachpublikum, sondern an die breitere deutsche Öffentlichkeit. In diesen Zusammenhang gehören auch zwei historiografiegeschichtliche Beiträge über den VGDB ${ }^{177}$.

172 Gustav Pirchan, „Rhetor et poeta“, in: ZSG 2 (1938) 218-229. ND in: Der Ackermann aus Böhmen des Johannes von Tepl und seine Zeit, hg. v. Ernst Schwarz (Wege der Forschung 143, Darmstadt 1968) 387-402; Gustav Pirchan, Prokop Waldvogel. Ein Prager Goldschmied als Schreibkünstler in Avignon, in: ZSG 5 (1941/42) 131-150; DERs., Karlstein, in: ZGS 7 (1944) 56-90. ND in: Prager Festgabe für Theodor Mayer, hg. v. Rudolf Schreiber (Forschungen zur Geschichte und Landeskunde der Sudetenländer 1, Salzburg 1953) 56-90.

173 Gustav Pirchan, Menschen und Schicksale in Pfraumbergs Vergangenheit, in: Burg und Stadt Pfraumberg in tausendjähriger Vergangenheit. Ein Zeit- und Gegenwartsbild (Pfraumberg 1925) 98-120; DERs., Die Tachauer im Abwehrkampfe wider Husmann, ihren Erbherrn, in: 600-Jahr-Feier Tachau 1329-1929, hg. v. Josef Stritzl (Tachau 1929) 83-93.

174 Gustav Pırchan, Über die Beziehungen Österreichs zur katholischen Kirche in Schlesien, in: Jb. des VGDB 1 (1926) 147-163.

175 Diese Arbeit entstand im Zusammenhang mit Gutachten, die Pirchan für das Innenministerium über die Besitzrechte der kirchlichen Güter erstellte. Hierbei ging es u.a. um die Frage, ob die in Österreich-Schlesien befindlichen kirchlichen Güter der Breslauer Diözese oder dem 1777 errichteten Erzbistum Olmütz gehören.

176 Gustav Pirchan, Deutschböhmens Daseinskampf in der Geschichte, in: Deutsche Kultur in der Welt. Unabhängige Zs. für geistige, politische und wirtschaftliche Ziele deutscher Arbeit im In- und Auslande 5 (1919) H. 1/2, 4-13; Ders., Böhmen und das Reich (Prag 1931); Ders., Das Sudetendeutschtum im Wandel der Jahrhunderte. Rückblick und Zusammenfassung. in : Das Sudetendeutschtum. Sein Wesen und Werden im Wandel der Jahrhunderte. FS zur Fünfundsiebzigjahrfeier des Vereins für Geschichte der Deutschen in Böhmen. hg. v. Dems., Wilhelm Weizsäcker, Heinz Zatscheк (Brünn/Prag/Leipzig/Wien 1937) 563-594, (Brünn/Prag/Leipzig/Wien ${ }^{2} 1939$ ) 601-649.

177 Der Beitrag in den MVGDB ging auf einen von Pirchan gehaltenen und erweiterten Vortrag zum 60. Vereinsjubiläum 1921 zurück. Der Verfasser zeichnete darin kenntnisreich, jedoch national befangen, die Ge- 
Pirchans früheste erhaltene Publikation mit dem Titel „Deutschböhmens Daseinskampf in der Geschichte“ stammt aus der Zeit des politischen Umbruchs des Jahres I 91 8, der in der Entstehung des selbstständigen Staates Tschechoslowakei am 28. Oktober I 9 I 8 gipfelte. Der Beitrag war noch vor der Unabhängigkeit des Landes im Sommer I9I 8 geschrieben worden und erschien nach einem Aufsatz von Lodgman von Auen zur "Selbstbestimmung Deutschböhmens“ in derselben Zeitschrift ${ }^{178}$. Pirchans Aufsatz widmet sich der Frage des Zusammenlebens von Deutschen und Tschechen und generell der Geschichte der Deutschen in den böhmischen Ländern. Diesem Thema galt auch ein im August 1926 während der Sudetendeutschen Kulturwoche gehaltener Vortrag über „Böhmen und das Reich“. Letztmalig widmete sich Pirchan dem „Sudetendeutschtum“ in der bereits erwähnten Vereinsfestschrift von 1937.

Bei der Lektüre von „Deutschböhmens Daseinskampf“ spürt man die emotionale Anspannung, mit welcher der Beitrag geschrieben wurde. Pirchan vereinfacht hier das Jahrhunderte währende friedliche Zusammenleben der beiden Volksgruppen in Böhmen zu einer vermeintlichen Bedrohung der Deutschen durch die Tschechen. So ringe „seit Jahrhunderten des Tschechentums gesammelte Kraft" um die vollständige Besitzergreifung des ganzen Landes ${ }^{179}$. Immer wieder zögen tschechische Sturmwellen über das deutschböhmische Land und richteten sich gegen alles Deutsche ${ }^{180}$. Die Tschechen seien „feindselig wider jegliches Deutschböhmen, feindselig wider seine deutschen Prediger, feindselig wider jeden öffentlichen deutschen Sprachgebrauch“181. „Deutschböhmens Sendung in der Geschichte“ sieht Pirchan in der Abwehr der tschechischen Angriffe und dem Schutz des deutschen Volkstums. Der Beitrag wirkt wie eine Umkehrung der These Palackýs von den friedliebenden Slawen bzw. Tschechen und den aggressiven Germanen bzw.

schichte des Vereines seit 1861 nach. Wie auch in seinen anderen Beiträgen zu den Deutschen in Böhmen ging er von einer vermeintlichen defensiven Reaktion und Abwehr der deutschen Geschichts- und Heimatforschung mit Blick auf die vornehmlich von Palacký geprägte und als bedrohlich empfundene nationaltschechische Geschichtsschreibung aus. Dementsprechend setzte sich der Text kritisch mit Palackýs politischem und geschichtlichem Werk sowie den Polemiken auseinander, die die Vereinsvorstände Höfler und Schlesinger gegen den tschechischen Historiker und das staatsrechtlich-föderalistische Programm der Tschechen ins Feld geführt hatten. Gustav Pirchan, Der Verein für Geschichte der Deutschen in Böhmen im Wandel der Zeitgeschichte, in: MVGDB 61 (1923) 69-115; Gustav Pirchan, 60 Jahre deutsche Geschichtsforschung in Böhmen, in: Böhmerlandjahrbuch 5 (1924) 16-20.

178 Pirchan, Deutschböhmens Daseinskampf (wie Anm. 176) 4. Vgl. hierzu auch Wilhelm Wostry, Sudetendeutsche Geschichte 1918-1938. Forschung und Darstellung, in: Deutsche Ostforschung. Ergebnisse und Aufgaben seit dem Ersten Weltkrieg, hg. v. Herman Aubin (Leipzig 1943), 488-530, hier 499-500.

179 Pirchan, Deutschböhmens Daseinskampf (wie Anm. 176) 5.

180 „Denn politisch-nationaler Kampf wider alles deutsche Sonderwesen im Lande, und Kulturkampf im weitesten Sinn, nicht nur Abwehr, wider das reichsdeutsch-österreichische Mitteleuropa, das ist die Achse, um die [...] die aufsteigende Linie der tschechischen Geschichte immer wieder kreist." Ebd. 11.

181 Ebd. 9. 
Deutschen. Pirchan verfällt wiederholt in eine schablonenhafte Schwarzweißmalerei ${ }^{182}$. Epochen wie die Hussitenzeit ${ }^{183}$ und die Phase des böhmischen Ständestaates, die in der tschechischen Geschichtsschreibung traditionell positiv konnotiert sind, werden von Pirchan einseitig negativ dargestellt. Zeiten, in denen sich das Land deutschen Einflüssen öffnete (unter den Přemysliden und Luxemburgern sowie unter den Habsburgern), beschreibt er dagegen undifferenziert als erfolgreiche historische Entwicklungsabschnitte. Zudem bemüht sich Pirchan, tendenziell Kontinuitäten herauszuarbeiten. Diese sind einerseits die kontinuierliche germanische bzw. deutsche Besiedlung des Landes und die deutsche „Kulturleistung“, aus denen er ein Heimatrecht ableitet, und zum anderen der bereits erwähnte Kampf der Tschechen gegen die Deutschen.

Auf einen während der "Sudetendeutschen Kulturwoche“ in Reichenberg im August 1926 gehaltenen Vortrag ging Pirchans I93 I erschienene Schrift „Böhmen und das Reich“ zurück. Sie war bereits versöhnlicher gehalten und betrachtete die deutsch-tschechischen Beziehungen differenzierter als zuvor, wenn auch vom deutschen Standpunkt aus. Pirchan begann seinen Beitrag ähnlich wie zuvor mit der germanischen Besiedlung Böhmens in der Zeit vor der slawischen Landnahme und sprach von Böhmen als dem „Herzen Germaniens“ und als „germanischer Festung“"184. Anschließend ging er auf die Beziehung Böhmens zum Römisch-deutschen Reich ein, welche er als ein Problem der Zugehörigkeit des Landes zu Ost oder West darstellte ${ }^{185}$. Inzwischen sah Pirchan den Sinn und Inhalt der Geschichte des tschechischen Volkes nicht mehr primär in dem „zu Zeiten hoch auflodernden nationalen Kampf wider das Deutschtum“, sondern in der ,jahrhundertelangen Auseinandersetzung der tschechisch-slawischen Seele mit der

182 Zu Palacký und seiner Geschichtsphilosophie siehe Jiří Ko ̌̌alka, František Palacký (1798-1876). Der Historiker der Tschechen im österreichischen Vielvölkerstaat (Studien zur Geschichte der österreichisch-ungarischen Monarchie 30, Wien 2007).

183 So wird das Hussitentum einseitig als „furchtbarster Ansturm des Willens der Nation zum volksreinen tschechischen Nationalstaate“, die Hussiten als Kämpfer „gegen das Deutschtum und deutsche Wesen“, als „Sturmflut“ gegen die Deutschen dargestellt. Nach der Hussitenzeit strömte „zur Heilung der Wunden der Volkseinbuße [...] alsbald [...] frisches heilkräftiges Blut der ,Herzkammer Germaniens' zu“. Pirchan, Deutschböhmens Daseinskampf (wie Anm. 176) 8.

184 Gustav Pirchan, Böhmen und das Reich (Prag 1931) 1.

185 Wenig überzeugend wirkt es, wenn Pirchan schreibt, dass das tschechische Volk auf seinem geschichtlichen Wege wiederholt vor dem Problem seiner kulturgeografischen west-östlichen Mittelstellung gestanden habe. Das Schicksalsproblem Böhmens sah Pirchan darin, ob das Land „national slawisch und kulturell ostchristlich“ werde und ob „ein römisch-deutscher Kaiser oder ein byzantinisch-slawischer Zar das Szepter“ führen werde. Außer den Slawenaposteln im Großmährischen Reich im 9. Jahrhundert (die letztlich auch eine Bindung an die katholische Kirche suchten) wird man bis zum Aufkommen einer modernen tschechischen Nationalbewegung und dem Panslawismus im 19. Jahrhundert den östlichen Einfluss auf Böhmen weitgehend als gering veranschlagen können. Pirchans Beitrag selbst zeigt dessen deutliche Zugehörigkeit zur westlichchristlichen Kultur auf. Ebd. 3. 
Kultur des romanisch-germanischen Westens"186. Böhmen und das Reich seien kontinuierlich durch ein Lehensverhältnis verbunden gewesen. Zugleich betonte der Historiker aber auch die selbstständige Politik des böhmischen Adels und der böhmischen Fürsten und Könige sowie ihre Einflussnahme auf die Reichspolitik ${ }^{187}$. Pirchan zeichnete sodann die Entwicklung der tschechischen historischen Forschung zu den staatsrechtlichen Beziehungen nach und stellte bei zeitgenössischen tschechischen Historikern wie Václav Novotný und Jan Kapras einen ähnlichen Standpunkt zu dieser Frage wie seitens der deutschen Forschung fest ${ }^{188}$. Neben dem vermeintlich dominanten deutschen Einfluss verschwieg Pirchan nicht die kulturellen Einwirkungen anderer europäischer Regionen auf Böhmen ${ }^{189}$. Die Hussitenzeit wird „als politischer und ideeller Bruch mit dem Westen" dargestellt, obwohl sie - wie auch Pirchan bekannt gewesen sein musste - von den Lehren des englischen Theologen John Wyclif inspiriert war. Während die staatsrechtlichen Beziehungen Böhmens zu Deutschland spätestens I 866 definitiv abbrachen, wies Pirchan darauf hin, dass „nicht die Beziehungen von Fürsten und Staaten, sondern tief im Boden und gleich tief in den Menschenseelen wurzelnde, freundliche oder gegensätzliche Kulturbeziehungen von Volk zu Volk [...] die letzten Fragen historischer Entwicklungen “ entscheiden ${ }^{190}$. Beide Völker, Deutsche und Tschechen, seien „ihren eigentümlichen Weg gegangen: die Deutschen, mit ihrer Schaffenskraft vor allem der engeren Heimat zu gewandt, dabei durch ihre Stammeseigenheit oft mehr unbewußt als bewußt dem großen Mutterlande verbunden"191. Pirchan kann nicht überzeugen, wenn er für die Zeit nach I 848 vom „Ringen [der Tschechen] um das Vorrecht der tschechischen Sprache“192 schreibt: Die tschechischen Forderungen beschränkten sich tatsächlich auf eine - bis I 9 I 8 nie gewährte - vollständige Gleichberechtigung mit der deutschen Sprache ${ }^{193}$. Die

186 Ebd. 4.

187 „In der Ausübung seines Fürstentumes im Lande blieb er von jeglicher Einschränkung durch den Lehensherrn frei.“ Ebd. 7; „ [...] deutlich dafür, daß das Land Böhmen, unbeschadet der inneren Machtstellung der einheimischen Dynastie und unbeschadet der inneren Selbständigkeit der Krone des Königreiches, durch alle Jahrhunderte als Lehen mit dem deutschen Reiche verbunden war." Ebd. 12.

188 Ebd. 11.

189 So lag im Zeitalter Karls IV. „auf dem Lande Böhmen der stärkste Abglanz abendländischer Zeitkultur, einer Kultur, zu der Italien, Süd- und Nordfrankreich, v.a. aber doch wieder die deutschen Lande [...] ihr Wertvollstes beigetragen haben “. Ebd. 10.

190 Ebd. $12 \mathrm{f}$.

191 Ebd. 13.

192 Ebd. 14.

193 Die Einführung des Tschechischen als „innerer“ Amtssprache neben dem Deutschen unter dem Ministerpräsidenten Badeni scheiterte 1897 an vehementen Protesten deutschnationaler Kräfte in Böhmen. Zur Sprachenfrage vgl. Peter Haslinger, Sprachenpolitik, Sprachendynamik und imperiale Herrschaft in der Habsburgermonarchie 1740-1914, in: ZfO 57 (2008) 81-111; Hans Mommsen, 1897: Die Badeni-Krise 
Sendung der Sudetendeutschen in der Tschechoslowakei sah er darin, die Beziehungen zum „heiligen Reiche deutscher Kultur“ aufrecht und lebendig zu halten. „Es geht dabei vor allem um die Festigung und Vertiefung des eigenen Volkstums, nicht um die Gefährdung eines anderen, es ist dies ein Ringen, in dem Gewalt gar nichts [...] gilt"194.

Im Beitrag von 1937 sprach Pirchan wie zuvor von Böhmen als einem Zweivölkerstaat, dessen wesentliches Kennzeichen die nationale Spannung sei. Diese sei jedoch „durchaus nicht nur gegensätzlich“ und könne „im Zeichen höherer kulturgemeinschaftlicher Ziele und vor allem im Zeichen einer den Völkerzwist mildernden Staatskunst gelöst werden“195. Es sei „eine Spannung, bei der das Emporkommen des einen Volkes nicht durch den Niedergang des anderen bedingt sein muß“196. Es gelte „den gerechten Ausgleich von Volk zu Volk“ zu suchen sowie „auf gemeinsam erlebter Geschichte und gemeinsam geschaffener Kultur die völkerverbindende, höhere politische Gemeinschaft zu bauen“. Palackýs Worte vom Zwang immerwährenden Widerstreits des tschechischen Volkes wider deutsches Wesen scheinen ihre Geltung verloren zu haben ${ }^{197}$. Die Sudetendeutschen, das zweite historische Volk im tschechoslowakischen Staate, sollten „nicht ,ein Keil' zwischen dem tschechischen Siedlungsgebiete und der übrigen deutschen Welt, sondern ,ein Band' zwischen beiden" sein ${ }^{198}$. Wie in der Version von I 9 I 8 sprach Pirchan in diesem Text auch von einem „schroffen Gegeneinander“, welches der dem Geiste der Romantik entsprossene nationale Gedanke verursacht habe. Gleichzeitig bezeichnete er jedoch die vorhergehenden Epochen des Humanismus, der Reformation und Gegenreformation sowie der Aufklärung als ein langes Zeitalter des Miteinanders ${ }^{199}$.

In der zweiten Auflage vom Sommer 1939 gehörte Pirchan ebenso wie Weizsäcker, Pfitzner und Cysarz zu den Autoren, die die Gelegenheit nutzten, „frei und offen“ das NS-Regime zu begrüßen und mit der Tschechoslowakei der Zwischenkriegszeit „abzurechnen“200. Bezeichnenderweise fehlten in Pirchans Beitrag gegenüber der ersten Auflage nun mehrere Passagen ${ }^{201}$. Dazu zählte der Satz, die Idee des tschechoslowakischen Staates könne keine andere sein, als beiden Völkern einen vollwertigen politisch-

als Wendepunkt in den deutsch-tschechischen Beziehungen, in: Wendepunkte in den Beziehungen zwischen Deutschen, Tschechen und Slowaken 1848-1989, hg. v. Detlef Brandes (Essen 2007) 111-118.

194 Pirchan, Böhmen und das Reich (wie Anm. 184) 15.

195 Pirchan, Sudetendeutschtum 1937 (wie Anm. 176) 571.

196 Ebd.

197 Ebd. 594.

198 Ebd. 593.

199 Ebd. 590.

200 Lemberg, Verein (wie Anm. 2) 228.

201 U.a. „Und die Zeiten, da man mit romantischen Hypothesen oder gar mit Fälschungen auf Geschichte und Geist der Völker erfolgreich und nutzbringend zu wirken vermochte, sind endgültig vorbei." Pirchan, Sudetendeutschtum 1937 (wie Anm. 176) 567. 
kulturellen Lebensraum zu gewähren. Der „überwiegend jüdisch-bolschewistischen Propaganda“ gab Pirchan die Schuld daran, dass „die hellsichtigen tschechischen Kräfte“ in der Zwischenkriegszeit nicht die Oberhand gewonnen hätten ${ }^{202}$. Die von ihm begrüßte Errichtung des Protektorats Böhmen und Mähren führe das tschechische Volk wieder in den Verband des Deutschen Reiches zurück und ermögliche ihm eine vermeintlich gedeihliche Zukunft ${ }^{203}$.

Wie ernst Pirchan diese Aussagen im Sommer 1939 gemeint hat, sei dahingestellt. Die zuletzt angeführten Passagen stehen mit der zuvor geforderten „Gleichberechtigung“ beider Völker in Böhmen jedoch nicht mehr im Einklang. Die Feststellung, durch die Schaffung des Protektorats sei „das uralte Problem eines Raumes mit zwei Völkern wesentlich vereinfacht" worden, übersieht, dass dies auf Kosten und gegen den Willen der Tschechen geschah. Andererseits enthält aber auch die Fassung von 1939 wohlwollende Worte über die Tschechen ${ }^{204}$. Zudem ließ Pirchan den Text von 1937 weitgehend unverändert und ergänzte ihn lediglich um den Zeitabschnitt nach I9I 8.

Die anderen in jener Zeit (1938-1944) publizierten Texte Pirchans sind sachlich gehalten. Dem aufmerksamen Leser entgeht jedoch nicht, dass der durch den „nationalen Kampf" zwischen Deutschen und Tschechen offensichtlich aufgewühlte Pirchan immer wieder das nationale Element hervorhebt ${ }^{205}$. Ein kurzer Beitrag aus dem Jahr 1938 be-

202 Pirchan, Sudetendeutschtum 1939 (wie Anm. 176) 645.

203 Ebd. 647.

204 Pirchan sprach beispielsweise über den „von Natur aus friedfertigen Nationalismus der Tschechen“, von der „reichbegabten Wesensart der Tschechen“ sowie über „die hellsichtigen tschechischen Kräfte“, die angeblich einer ,jüdisch-bolschewistischen Propaganda“ unterlagen. Ebd. 642.

205 Im Text über Prokop Waldvogel spricht Pirchan vom „deutschen Goldschmied“, der „urgermanischen Erbes waltend“ der „deutschen Buchdruckerkunst, dieser Weltleistung deutschen Geistes“, zu Leben und Gedeihen verholfen habe. Pirchan, Prokop Waldvogel (wie Anm. 172) 145. Bezeichnend für Pirchans Stil ist auch der folgende Satz: „Im aufsteigenden fünfzehnten Jahrhundert, da deutsche Eigenart auf mannigfachsten Sonderwegen um Durchbruch und Entfaltung rang, stand nicht nur der bildende Künstler im Kampfe um eine neue Erfassung und harte, klare Darstellung der Erscheinungswelt, auch an den mancherlei Arbeitsstätten des hohen und schlichteren Kunstgewerbes grübelte und schaffte deutscher Geist, um den Elementen neue künstlerische und gemeinnützige Ausdrucksformen abzulauschen.“ Ebd. 131. Pirchan, „Rhetor et poeta“ (wie Anm. 172) 229, plädierte „im Sinne schärferer Erfassung deutscher Eigenart, im Sinne sorgfältigerer Umgrenzung deutschen Bodens innerhalb der Überflutung durch fremdes Kulturgewell“ unter Berufung auf Hans Hirsch für „eine einheitliche nationale Geschichtsschreibung, die die Vorrausetzung ist für jenes verfeinerte, veredelte und vertiefte Nationalgefühl“ sei. Der Wechsel des Wohnortes des Johannes von Saaz (Žatec) nach Prag im Jahre 1411 war ihm ein Beleg dafür, dass sich der Ackermannsdichter bei praktischen Entschlüssen keineswegs vom Bewusstsein seiner Volkszugehörigkeit habe leiten lassen. Der allem Anschein nach freiwillige Wegzug aus der deutschen in die tschechische Umgebung musste Pirchan zufolge „doch wohl aus Gründen erfolgt sein, die mit der deutschen Seele diese Mannes nichts gemein haben konnten. Die deutsche Seele unseres Johannes aber lebt in seiner Dichtung fort“. Ebd. 221. Gutenbergs Buchdruck bezeichnete er 1942 als eine „der stolzesten Erfindungen aus germanischem Geiste, eine technisch-wirtschaftliche Leistung des deutschen Bürgertums, 
fasste sich beispielsweise mit Johannes von Tepl, dem Autor des „Ackermanns von Böhmen“. Pirchan interpretierte dessen Werk, verglich ihn mit Dante und behandelte klassische Fragen wie die der zeitlichen Verortung (in Mittelalter oder Frühhumanismus) und des Vorliegens autobiografischer Züge ${ }^{206}$. Ein Aufsatz zu Prokop Waldvogel fasste die vorhandenen Kenntnisse über den aus Prag stammenden und im I 5. Jahrhundert in Avignon wirkenden Goldschmied zusammen ${ }^{207}$. Dieser stellte Buchstabenstempel her, praktizierte jedoch keinen Buchdruck in der Art Gutenbergs. Pirchan zeigte sich hier als guter Kenner der Buchdruckerkunst. Im zweiten Teil der Studie berichtete er über seine mehrmonatige (!) erfolglose Suche nach Unterlagen zu Prokop Waldvogel im Prager Stadtarchiv ${ }^{208}$, um dann über den Prager Bürger und Messerschmied Georg Waldvogel zu berichten, bei dem er eine verwandtschaftliche Verbindung mit Prokop vermutete.

Der letzte Beitrag Pirchans erschien I 944 und war seinem Lehrstuhlvorgänger Theodor Mayer zum 6o. Geburtstag gewidmet ${ }^{209}$. In ihm behandelte der Prager Historiker die Frage, ob Karl IV. den Bau der Burg Karlstein (Karlštejn) für die Reichskleinodien oder Reliquien plante, ob diese also seinem „Reichsdenken“ entsprungen sei. Pirchan betonte ausdrücklich, dass der Kaiser die Burg für die Reliquien bauen ließ und dabei an seine dynastischen Nachfolger, Böhmen und „sein Volk“ dachte und erst zu einem späteren Zeitpunkt die Reichskleinodien nach Karlstein bringen ließ ${ }^{210}$. Somit blieb er in seiner letzten Arbeit dem Grundsatz strenger Quellenkritik treu und gab sich nicht für eine propagandistisch ausgerichtete Geschichtsschreibung her ${ }^{211}$. Zudem zeigte er sich noch einmal als guter Kenner der Zeit Karls IV. Dass Pirchan der Versuchung des NS-Regimes aber durchaus nicht konsequent widerstand und sich mit seinen Texten gelegentlich in dessen Dienst stellte, zeigt ein Beitrag von 1942. Darin schrieb er in Bezug auf die Prager Burg als Herrschersitz unter anderem von der „mythischen Kraft, die den Königsge-

die schon den Zeitgenossen als ruhmvoller Sieg des deutschen Vaterlandes galt." Gustav Pirchan, Aus der Frühzeit des Buchdruckes, in: Böhmen und Mähren 3 (1942), 102-103, hier 103.

206 Ebd. (wie Anm. 172).

207 Pirchan, Prokop Waldvogel (wie Anm. 172).

208 Der leitende Gedanke des Beitrags lag Pirchan zufolge darin, der Spur Prokops in den heimischen Geschichtsquellen nachzugehen, um so diese „schwankende Gestalt aus der Vorzeit deutscher Druckkunst der deutschprager Volksgeschichte, in der sie einst wurzelte“, näherzubringen. Ebd. 145.

209 Pirchan, Karlstein (wie Anm. 172). Zur Festschrift vgl. HruzA, „Wissenschaftliches Rüstzeug“ (wie Anm. 65) 516f.; Helmut Maurer, Theodor Mayer (1883-1972). Sein Wirken vornehmlich während der Zeit des Nationalsozialismus, in: Österreichische Historiker (wie Anm. 66) 494-530, hier 500. Vgl. auch einen Brief Mayers an Pirchan v. 07.01.1945, in dem er meinte, man solle Karl IV. nicht verfälschen. Stadtarchiv Konstanz, NL Mayer.

210 Pirchan, Karlstein (wie Anm. 172) 64, 67, 87.

211 Andererseits schrieb er in dem Text auch, „alle Betrachtungen deutscher Geschichte, alle Beurteilung deutscher Könige und Kaiser erhalte Maß und Wertung vom Reichsgedanken aus“. Ebd. 87. 
schlechtern der Germanen durch den Glauben an den göttlichen Ursprung ihres Geblüts zu eigen war“212. Immer wieder betonte der Verfasser die enge Verbundenheit sowie die Stellung Böhmens im „Schutze des Reiches“ während des Mittelalters. Und „nach wie vor [waltete] das Gebot einer größeren, weiträumigeren Reichsidee“ über dem einstigen Königs- und Kaisersitze. „Die Gestalt des Führers“ im Fenster des Prager Schlosses habe „diesem raumpolitischen Gesetze neuen sinnbildlichen Ausdruck verliehen“213.

Im Zusammenhang mit der Entwicklung der Prager Universität musste das „Sudetendeutschtum "laut Pirchan in der Zwischenkriegszeit zwei Jahrzehnte lang schwer um seine Hochschule kämpfen. Die Befreiung von der angeblich mit „unverhüllter Schroffheit“ „alleinherrschenden tschechischen Staatsnation“ habe erst das Dritte Reich gebracht, welches die Deutsche Karls-Universität am 4. November 1939 wieder zu einer Reichsuniversität machte ${ }^{214}$. Dass gut zwei Wochen später die tschechischen Hochschulen geschlossen und deren Dozenten und Studenten verfolgt wurden, verschwieg Pirchan dabei ebenso wie den grundlegenden Wandel, dem die Deutsche Universität angesichts politischer und rassistischer „Säuberungen“ unterlag ${ }^{215}$.

Im März I 942 bewertete Pirchan die Dissertation „Genealogisch-erbbiologische Untersuchungen der Salier" seines Doktoranden Meinlschmidt ${ }^{216}$ mit sehr gut; sie eröffne bemerkenswerte Ausblicke, auch wenn sie die Begriffe der Rassen-und Volkszugehörigkeit nicht genau trenne und unter der schlechten Quellenlage leide ${ }^{217}$. Zudem ermögliche sie es, Rückschlüsse auf günstige oder üble Erbanlagen [...] sowie den Ursprung und die Erbträger der Krankheitskeime zu erfassen. Meinlschmidt hatte die Arbeit als Untersuchung des salischen Kaiserhauses im Sinne einer „rassischen“ Geschichtsbetrachtung geschrieben. In ihr wurden die Salier in ihren blutlichen Zusammenhängen und ihrer Blutentwicklung betrachtet. Als Ergebnis stellte Meinlschmidt unter anderem fest, dass sich die Blutmischung mit Frauen rassenfremder Blutzusammensetzung unheilvoll auf die Salier und auch andere deutsche Herrschergeschlechter ausgewirkt habe. Pirchan bezeichnete im Gutachten die Frage nach den erbbiologischen Grundlagen führender Persönlichkeiten und Geschlechter als eine der vornehmsten, aber auch schwierigsten Aufgaben unserer neuen Geschichtsbetrach-

212 Gustav Pirchan, Sinn und Sendung, in: Böhmen und Mähren 3 (1942) 300-301, hier 300.

213 Ebd. 301.

214 Gustav Pirchan, Die deutsche Karlsuniversität Prag in sechs Jahrhunderten, in: Böhmen und Mähren 4 (1943) 12-14, hier 14.

215 Vgl. hierzu Míš́Ková, Deutsche (Karls-) Universität (wie Anm. 6) 58-76, 255-256.

216 Das Promotionsthema vergab Zatschek, der dann aber zum SS 1941 nach Wien wechselte, so dass Pirchan die Betreuung der Arbeit übernahm.

217 Des Weiteren monierte Pirchan, dass eine notwendige Überprüfung der Arbeit durch einen rassenbiologischen Fachmann nicht erfolgt sei und der Verfasser bei seinen biologischen Schlüssen nicht immer die erforderliche Vorsicht walten ließ. Gutachten Pirchans über die Dissertation „Genealogisch-erbbiologische Untersuchung der Salier“ vom 04.03.1942. UAP, FF NU, Dissertationen, Nr. IV/130, Karl Meinlschmidt. 
tung $^{218}$. Bereits zuvor hatte er sich in einer Rezension über ein Buch seines Kollegen Zatschek positiv zu dem erbbiologisch-genealogischen Ansatz geäußert ${ }^{219}$.

Pirchan schrieb in allen seinen Beiträgen zum Sudetendeutschtum und zum VGDB von „unserem“ oder dem „deutschen Volk“ sowie von Böhmen als einem Zweivölkerland. Das „Volk“ bezeichnete er als „die allgemein bedingende Kraft“ für „jegliche Schöpfung und Leistung auf dem weiten Gebiete der Lebenskultur“220. „Träger der Ideen“ seien „bestimmte Persönlichkeiten“221. In einem anderen Kontext sprach er davon, dass es die „Weltanschauung der führenden Männer auf allen Gebieten“ sei, dank derer sich Entwicklung vollziehe, und auch auf diesem Gebiet sei „der Kampf der Vater der Dinge“222. Volksgeschichte beschrieb Pirchan wie folgt: „Wenn heute eine tiefer schürfende Volksgeschichte alle unmittelbaren und mittelbaren bevölkerungsgeschichtlichen Quellen erfassend, die Linie des Ringens um die Volks- und Bodengrenze örtlich und zeitlich genauer durch die sudetendeutsche Geschichte hin verfolgt; nur so kann sie, bis zu den Wurzeln unseres heutigen Volkstums vordringend, den Kampf der Sprachen und Kulturen um Menschen und Boden schärfer ins Licht stellen"223.

Pirchan hatte bereits auf dem Historikertag in Frankfurt am Main 1924 Vorträge von volksgeschichtlich arbeitenden Historikern gehört ${ }^{224}$. Auch wenn er in seinen Texten zum Sudetendeutschtum von „Volk“ sprach, betrieb er aber selbst explizit keine interdisziplinäre oder „,innovative“ Volksgeschichte ${ }^{225}$. Allenfalls hinsichtlich der Bezogenheit auf das „Deutschtum“ könnte man in Pirchans sudetendeutschen Beiträgen Hinweise auf volks-

218 Ebd. Auch das Gutachten Anton Ernstbergers vom 21.02.1942 schloss mit dem Gesamturteil sehr gut. Der Fachvertreter der „Volksbiologie“ Karl Valentin Müller stellte Mängel vom Standpunkt der Erbbiologie fest und vergab nur das Prädikat rite. Vgl. Gutachten vom 04.03.1942. Ebd.

219 „Den Abschluß des Buches aber bildet eine Untersuchung, die von dem verschärften Blicke des heutigen Geschichtsforschers Zeugnis gibt, eine Untersuchung des erbbiologischen Verhängnisses, das über die erbgesunden Karolinger durch die Krankheitskeime einiger Ehefrauen so verheerend hereinbrach, das Herrschergeschlecht dem Untergang weihte und Staat und Stämme mit ernstem Verfalle bedrohte." Gustav Pirchan, Heinz Zatschek, Wie das erste Reich der Deutschen entstand (Prag 1940), in: ZSG 4 (1940) 229f., hier 230.

220 Pirchan, Der Verein (wie Anm. 177) 69.

221 Ebd. 70.

222 Ebd. 74.

223 Pirchan, Sudetendeutschtum 1937 (wie Anm. 176) 572.

224 Rudolf Kötzschke sprach über „Nationalgeschichte und Landesgeschichte“, Helbok über den „Aufbau der geschichtlichen Landesforschung aus einer gesamtdeutschen Siedlungsforschung“ und Aubin über „Stand und Ziel der historischen Geographie in der Rheinprovinz“. Vgl. Pirchan, Bericht über die Versammlung (wie Anm. 40) 273-277.

225 Zur Volksgeschichte vgl. Willy Овевквоме, Volksgeschichte. Methodische Innovation und völkische Ideologisierung in der deutschen Geschichtswissenschaft 1918-1945 (Kritische Studien zur Geschichtswissenschaft 101, Göttingen 1993); DERs., Entwicklungen und Varianten der deutschen Volksgeschichte (1900-1960), in: Volksgeschichten im Europa der Zwischenkriegszeit, hg. v. Manfred Het t LING (Göttingen 2003) 65-95. 
geschichtliche Denkweisen sehen. In seiner Hauptschrift zu Karls IV. zweiter Italienfahrt erscheint er dagegen als traditionell arbeitender Historiker der Politik- und Verfassungsgeschichte, der zudem an kulturellen Fragen Interesse zeigt und sich keineswegs auf das „Deutschtum“ beschränkt.

Pirchan schrieb von I9 10 bis I943 30 Rezensionen ${ }^{226}$. Diese geben - ohne hier die vollständige Erfassung aller seiner Buchkritiken zu beanspruchen - auch Hinweise auf das wissenschaftliche Profil des Forschers. Zwei Sachgebiete stechen hervor. Dies sind zum einen neun Buchbesprechungen zur mittelalterlichen Geschichte Böhmens und Karls IV. ${ }^{227}$, zum anderen sechs zum Archivwesen ${ }^{228}$. Die Rezensionen der ersten Jahre beschränken sich fast ausschließlich auf das böhmische Früh- und Spätmittelalter. Wäh-

226 Außer den in den folgenden Fußnoten genannten Besprechungen sind dies Gustav Pirchan, Rudolf Köstler, Die väterliche Ehebewilligung. Eine kirchenrechtliche Untersuchung auf rechtsvergleichender Grundlage (Stuttgart 1908), in: Juristische Vierteljahresschrift 43 (1911) 59-62; DERs., Jb. des deutschen Vereins für Familienkunde für die Tschechoslowakische Republik 1 (1930), in: MVGDB. Beilage für Archiv- und Musealwesen und für Denkmalpflege 69 (1931) 387f.; DERs., Rudolf Lehmann, Geschichte des Wendentums in der Niederlausitz bis 1815 im Rahmen der Landesgeschichte (Langensalza 1930), in: MVGDB 71 (1933) 180f.; DERs., Johannes Engelmann, Untersuchungen zur klösterlichen Verfassungsgeschichte in den Diözesen Magdeburg, Meißen, Merseburg und Zeitz-Naumburg (Beiträge zur mittelalterlichen und neueren Geschichte 4, Jena 1933), in: MVGDB 73 (1935) $150 \mathrm{f}$.

227 Gustav Pirchan, Gustav Friedrich, Codex diplomaticus et epistolaris regni Bohemiae (Bd.1, 1. u. 2. Hälfte, Prag 1904 u. 1907), in: Historische Vierteljahrschrift. Zs. für Geschichtswissenschaft und für lateinische Philologie des Mittelalters 13 (1910) 213-218; Ders., Fritz Vigener, Kaiser Karl IV. und der Mainzer Bistumsstreit (Trier 1908), in: ebd. 429; DERs., Johan Kapras, Liber conscientiae civitatis Novobydžoviensis ab anno MCCCXI-MCCCCLXX cum privilegis et actibusa de redimend libertate (Neu-Bydschov 1907), in: Juristische Vierteljahresschrift 42 (1910) 102-105; DERs., Emil Werunsky, Die landrechtlichen Reformen König Ottakars II. in Böhmen und Österreich, in: MIÖG 29 (1908) 253-290, in: Juristische Vierteljahresschrift 42 (1910) 179-182; Ders., Willy Scheffler, Karl IV. und Innocenz VI. Beiträge zur Geschichte ihrer Beziehungen 1355-1360 (Berlin 1912), in: Deutsche Literaturzeitung für Kritik der internationalen Wissenschaft 35 Nr. 30 (1914) 1899-1900; DERs, Siegfried Grotefend, Die Erwerbungspolitik Kaiser Karls IV. (Berlin 1909), in: Historische Vierteljahrschrift. Zs. für Geschichtswissenschaft und für lateinische Philologie des Mittelalters 18 (1916) 335; DERs., Samuel Steinherz, Ein Fürstenspiegel Karls IV. (Prag 1925), in: MVGDB 64 (1926) 70-73; Ders., Josef Pfitzner, Kaiser Karl IV. (Potsdam 1938), in: ZSG 3 (1939) 178-180. Die Besprechung erschien auch parallel in den MVGDS 1 [77] (1939) 117-120; Ders., Franz Meltzer, Die Ostraumpolitik König Johanns von Böhmen (Beiträge zur mittelalterlichen und neueren Geschichte 12, Jena 1940), in: HZ 165 (1942) 373-375.

228 Gustav Pirchan, Archivalische Zeitschrift (1928, 1929, 1930), in: MVGDB. Beilage für Archiv- und Musealwesen und für Denkmalpflege 69 (1931), 171-179; DERs., Časopis archivní školy IV, V, VI, VII, VIII, in: ebd. 179-188; DERs., Archivalische Zeitschrift (1931), in: ebd. 371-375; DErs., Archivstudien. Zum siebzigsten Geburtstage von Woldemar Lippert, hg. v. Hans Beschorner, Wilhelm u. Bertha von Baensch (Dresden 1931), in: ebd. 375-381; Ders., Willy Flach, Geschichte der preußischen Archive (Greiz 1930), in: ebd. 381-383; DERs., Gesamtinventar des Wiener Haus-, Hof- und Staatsarchivs, hg. v. Ludwig Bittner (2 Bde., Wien 1937), in: ZSG 2 (1938) 139f. 
rend Pirchan bis I9I6 sieben Besprechungen vorlegte, war es in den I920er-Jahren nur eine einzige. Dies lässt sich mit seiner Arbeit an der Habilitationsschrift und deren Drucklegung erklären. Zu Beginn der 3oer-Jahre schrieb er dann eine ganze Reihe von archivwissenschaftlichen Buchkritiken. 1933 und 1935 folgten mehrere Rezensionen zur mittelalterlichen Geschichte Thüringens ${ }^{229}$. Es erscheint verwunderlich, dass Pirchan trotz seiner Kontakte und Sprachkenntnisse und im Unterschied beispielsweise zu Blaschka nahezu keine tschechischen Publikationen besprach. Ausnahmen bilden zwei lateinische Quelleneditionen tschechischer Autoren aus dem Jahre i9 Io und die auf die Zusammenfassung des Inhalts beschränkte Sammelbesprechung von fünf Jahrgängen der tschechischen Archivzeitschrift. Italienische Autoren und Literatur zu Italien im Spätmittelalter fehlen bis auf eine Ausnahme ${ }^{230}$. Obwohl Pirchan zweifelsohne kulturgeschichtlich interessiert war, legte er in diesem Bereich nur zwei Buchbesprechungen vor ${ }^{231}$.

Die Berichte zu den deutschen Historikertagen in Frankfurt am Main I924, Breslau I 926 und Erfurt 1937 zeigen deutlich die Verbundenheit Pirchans mit der deutschen Geschichtswissenschaft ${ }^{232}$. Die positive Würdigung des I9. Historikertages in Erfurt sowie die anerkennende Besprechung von „Neueren Anschauungen der deutschen Historiker zur Beurteilung der deutschen Kaiserpolitik des Mittelalters“ zeigen ihn als einen Historiker, der den geschichtswissenschaftlichen Entwicklungen im Dritten Reich keineswegs ablehnend gegenüberstand ${ }^{233}$. Nach 1938 rezensierte Pirchan vor allem die Werke seiner

229 Gustav Pirchan, Willy Flach, Die Urkunden der Vögte von Weida, Gera und Plauen bis zur Mitte des 14. Jh. (Greiz 1930), in: MVGDB. Beilage für Archiv- und Musealwesen und für Denkmalpflege 69 (1931) 383f.; Sammelbesprechung: DERs., Friedrich Schneider, Armin Tille, Einführung in die Thüringische Geschichte (Jena 1931), in: MVGDB 71 (1933) 175-178; DERs, Werner Ronneberger, Das Zisterzienser-Nonnenkloster zum Heiligen Kreuz bei Saalburg a. d. Saale (Beiträge zur mittelalterlichen und neueren Geschichte 1, Jena 1932), in: ebd., hier 178; DERs., Hans Eberhardt, Die Anfänge des Territorialfürstentums in Nordthüringen, nebst Beiträgen zur Geschichte des nordthüringischen Reichsgutes (Beiträge zur mittelalterlichen und neueren Geschichte 2, Jena 1932), in: ebd., hier 178; DERs., Alfred Thoß, Die Geschichte der Stadt Greiz von den Anfängen bis zum Ausgang des 17. Jahrhunderts mit besonderer Berücksichtigung der Rechts-, Verfassungs- und Wirtschaftsentwicklung (Beiträge zur mittelalterlichen und neueren Geschichte 3, Jena 1933), in: MVGDB 73 (1935) $151 f$.

230 Gustav Pirchan, Arturo Cronia, Čechy v dějinách italské kultury [Böhmen in der Geschichte der italienischen Kultur], in: ZSG 2 (1938) 141-142. Bezeichnenderweise wirft Pirchan dem Autor vor, nur die tschechisch-italienischen Kulturbeziehungen zu behandeln, ohne die deutschböhmisch-italienischen Verflechtungen zu berücksichtigen.

231 Gustav Pirchan, Arturo Cronia, Čechy (wie Anm. 230); Ders., Ivo Striedinger, Der Goldmacher Marco Bragadino (München 1928), in: MVGDB. Beilage für Archiv- und Musealwesen und für Denkmalpflege 69 (1931) 385-387.

232 Gustav Pirchan, Bericht über die Versammlung (wie Anm. 40); Ders., Bericht über den Historikertag zu Breslau vom 3.-9.10.1926, in: MVGDB 65 (1927) 10-27; Ders., Der 19. Deutsche Historikertag, in: MVGDB 75 (1937) 86-90.

233 Gustav Pirchan, Friedrich Schneider, Neuere Anschauungen der deutschen Historiker zur Beurteilung der deutschen Kaiserpolitik des Mittelalters, in: ZSG 2 (1938) 315-316. 
sudetendeutschen Kollegen ${ }^{234}$, unter anderem eine Festschrift für den überzeugten sudetendeutschen Nationalsozialisten Gierach im Jahr I943 ${ }^{235}$. Eine Besprechung des Werkes Pfitzners über Karl IV. war insgesamt wohlwollend, enthielt aber auch einige Kritik ${ }^{236}$. So betrachtete Pfitzner laut Pirchan den Kaiser zu sehr aus der Sicht der aktuell vorherrschenden Ansichten, statt die Zeitumstände, in denen Karl IV. lebte, stärker zu berücksichtigen. Pirchan störte dabei nicht, dass der Autor Fragen nach dem Volkstum und auch „Problemen rassen- und erbbiologischer Art“ nachging. Auf Kritik des Rezensenten stieß vielmehr Pfitzners negative Bewertung der Persönlichkeit Karls. Pirchan selbst hob immer wieder positive Eigenschaften und die Leistungen Karls IV. hervor, den er unter anderem als „verantwortungsbewussten Walter seines hohen Amtes für den allgemeinen Frieden, für die Sicherung der Ostflanke des deutschen Lebensraumes“ würdigte. Außerdem hielt er Pfitzner entgegen, dass es beispielsweise Zatschek „bei einer bewussten volksgeschichtlichen Einstellung " in seinem Lebensbild des Kaisers gelungen sei $^{237}$, diesen als aktiven Gestalter seines Zeitalters zu kennzeichnen. Es war also vornehmlich die kritische Darstellung der Persönlichkeit des Kaisers und nicht die volksgeschichtliche Ausrichtung des Autors, die dem Rezensenten missfiel.

VIII. FA ZIT

Der gebürtige Wiener Gustav Pirchan, der seine Kindheit im ostböhmischen Jitschin in tschechischer Umgebung verbrachte, war von seinem Studienbeginn I 899 bis zu seinem Lebensende ein Prager Deutscher. Regelmäßige Studienreisen führten ihn außer nach Deutschland und Österreich auch nach Italien, Frankreich, Jugoslawien und in die Schweiz und erweiterten seinen Blickwinkel. Seine berufliche Laufbahn begann er als Archivar noch in der Habsburgermonarchie. Obwohl er sich I9I 8 spürbar negativ gegenüber den Tschechen geäußert hatte, überstand er den Umsturz, der mit der Entstehung der Tschechoslowakei in demselben Jahr verbunden war, unbeschadet und wurde in den folgenden Jahren vom tschechischen Archivdirektor Klicman protegiert und bis

234 Gustav Pirchan, Eduard Winter, Tausend Jahre Geisteskampf im Sudetenraum. Das religiöse Ringen zweier Völker (Salzburg/Leipzig 1938), in: Leipziger Vierteljahrschrift für Südosteuropa 3 (1939) 311-313; DERs., Heinz Zatschek, Wie das erste Reich der Deutschen entstand (Prag 1940), in: ZSG 4 (1940) 229-230.

235 Gustav Pirchan, Wissenschaft im Volkstumskampf. FS, Erich Gierach zu seinem 60. Geburtstag überreicht von Freunden, Schülern und Fachgenossen, hg. v. Kurt Oberdorffer, Bruno Schier, Wilhelm Wostry (Reichenberg 1941), in: ZGS 6 (1943) 381-383.

236 Gustav Pirchan, Josef Pfitzner, Kaiser Karl IV (wie Anm. 227).

237 Heinz Zatscheк, Karl IV., in: Gestalter Deutscher Vergangenheit, hg. v. Peter Richard Rohden (Potsdam/ Berlin 1937) 172-185. 
zum Obersektionsrat befördert. Die Berufung zum Professor an die Deutsche Universität in Prag verdankte Pirchan neben dem Einsatz der Kollegen Wostry und Zatschek nicht zuletzt auch dem Wohlwollen des tschechoslowakischen Schulministeriums.

Seine Karriere verlief gemessen an vielen Prager Kollegen wenig spektakulär. So stand er an Zahl der Publikationen, an Engagement, Einfluss und Ämtern im Schatten sowohl des älteren Wostry als auch Pfitzners und Zatscheks, die beide einer jüngeren Generation angehörten. Pirchan begnügte sich im VGDB und im Archiv mit einer sekundären Rolle. Auch an der Deutschen Universität in Prag fielen Pirchans wissenschaftliches „Machtkapital“238 und Prestige gering aus. Trotz einer mehrjährigen Tätigkeit als Professor (1933-1945) gründete er keine Schule in seinem Umfeld. Auch der Forschung gab er nach seiner Habilitationsschrift, die 1930 erschien, keine wesentlichen Impulse mehr. Die Gründe dafür, dass Pirchan keine größere Aktivität entfaltete, waren vielfältig. Der Dienst im Archiv schränkte bis 1933 seine Zeit für wissenschaftliche Forschungen ein. Immer wieder wurde seine Leistungsfähigkeit zudem durch gesundheitliche Probleme beeinträchtigt. Aber auch ein gewisser Hang zum Perfektionismus und persönliche Vorlieben wie die wiederholten mehrmonatigen Urlaubs- und Studienreisen werden dazu beigetragen haben, dass Pirchan wenig als exponierter Forscher hervortrat. Sein kultiviertes und zurückhaltendes Auftreten haben ihm jedoch auch Sympathien eingetragen. Dass Pirchan weitgehend in Vergessenheit geraten ist, liegt in seinem frühen Tod, dem Ende der Deutschen Universität in Prag I 945 und dem Fehlen eines Schülerkreises begründet.

Man wird Pirchan zu den traditionellen deutschböhmischen Historikern rechnen dürfen, deren Sozialisation sich noch in der alten k.k. Monarchie vollzog. Darin unterschied er sich von der radikaleren, jüngeren Historiker-Generation, zu der man beispielsweise Pfitzner, Zatschek und Schreiber zählen kann. Von dem Kreis der Prager deutschen Historiker hob sich Pirchan durch seine Arbeit und sein Interesse für Italien sowie kulturgeschichtliche Fragen ab. Pirchans Hauptwerk zur zweiten Romfahrt Karls IV. folgte keinen politischen Moden und behielt seinen Wert über die Jahre. Er legte aber auch populistische und nationalistische Beiträge vor - und dies bereits vor der Zeit des Protektorats. I9I 8 und 1939 trat er in seinen Schriften als Vertreter einer das Deutschtum verherrlichenden Geschichtsschreibung auf, welche die Tschechen und ihre Geschichte einseitig bewertete. Sicherlich wurde Pirchans Urteil durch seine deutschnationale akademische Sozialisation und das politische Tagesgeschehen des deutsch-tschechischen „Volkstumskampfes“ bestimmt. Andererseits ergibt sich ein differenzierteres Bild, wenn man Pirchans gesamtes Werk betrachtet und es mit den Publikationen anderer deutscher Autoren in Böhmen vergleicht. So finden sich in seinen Schriften auch anerkennende

238 Dazu zählt KolÁŘ, Geschichtswissenschaft in Zentraleuropa 1 (wie Anm. 3) 56-62, die Mitgliedschaft in Kommissionen und akademische Ämter, die Zahl der Promovierenden und Habilitanden. 
und versöhnliche Äußerungen gegenüber den Tschechen sowie unpolitische Beiträge. Zudem unterhielt Pirchan lange Zeit gute und freundschaftliche Kontakte zu tschechischen Kollegen, sodass sich einige auch noch nach dem Mai 1945 positiv über ihn äußerten.

Außer dem Antrag auf NSDAP-Mitgliedschaft schweigen die Quellen weitgehend über Pirchans Einstellung gegenüber dem NS-Regime nach 1939. Die Annexion der „Resttschechei“ mit der Bildung des Protektorats begrüßte und untermauerte Pirchan propagandistisch in wenigen, kurzen Publikationen. Mit diesen trug er dazu bei, die NSHerrschaft über die Tschechen zu legitimieren. Sein bereits zuvor konstruiertes Bild der historischen Entwicklung Böhmens eignete sich dafür gut: Die Tschechen befänden sich traditionell und kontinuierlich in einer gegenüber dem Deutschen Reich untergeordneten Stellung und hätten davon im geschichtlichen Prozess profitiert. Der „völkisch-rassischen" Geschichtsbetrachtung des NS-Regimes stand er in Gutachten und Rezensionen I940-I942 aufgeschlossen gegenüber. Deutlich wird jedoch auch, dass er ideologisch nicht an „vorderster Front“ stand. Ohne Zweifel ist ihm dieses Verhalten positiv anzurechnen, auch wenn er bereits in den Jahren vor 1938 keine Neigung gezeigt hatte, sich gegenüber anderen hervorzutun.

Insgesamt ist Pirchan seinem ebenfalls gemäßigten und im Wesen eher versöhnlichen denn militanten Generationskollegen Wostry an die Seite zu stellen. Wie dieser verblieb er bei seinen Forschungen in den traditionellen Bahnen, in die ihn seine Ausbildung in Prag und Wien geführt hatte. Ähnlich wie andere deutschböhmische Autoren (über-) betonte Pirchan die politischen, kulturellen und ökonomischen „Leistungen“ der Deutschen in den böhmischen Ländern. Er bediente sich jedoch weder der sich in den I93oer Jahren als neues Paradigma durchsetzenden „Volksgeschichte“ noch der „rassisch“ determinierten Geschichtsschreibung der Nationalsozialisten. Dass er beide Richtungen aber nicht ausdrücklich verwarf, wird angesichts des politisch-gesellschaftlichen Kontexts und Pirchans deutschnationaler Einstellung nicht verwundern. Im Protektorat nahm er - wie bereits zuvor in der Zwischenkriegszeit - keine besonders exponierte Stellung ein und hielt sich von einer aktiven wissenschaftspolitischen Partizipation am NS-Regime fern. Diese wurde allem Anschein nach auch nicht von ihm gefordert. Pirchans Beispiel zeigt somit auch die vorhandenen Spielräume für das Verhalten von Historikern in der Zeit des Nationalsozialismus auf. Die Mehrzahl seiner deutschen Prager Kollegen engagierte sich nämlich freiwillig und aus Überzeugung für das NS-Regime. 
EXKURS ZU GUSTAV PIRCHANS WERK „ITALIEN UND KAISER KARL IV.“ Tomáš Borovský

In den meisten allgemeinen Übersichtswerken erscheint Gustav Pirchan als Autor eines einzigen Buches. Die Konzeption des zweiteiligen Werkes „Italien und Kaiser Karl IV. in der Zeit seiner zweiten Romfahrt“ zeigt gut Pirchans Profil als Wissenschaftler. Auf den ersten darstellenden und synthetisierenden Band folgt der zweite, der außer Registern und Verweisen auf Quellen und Literatur ferner eine Serie von kleineren Studien enthält, in denen der Autor Einzelproblemen nachgeht, die mit seinem zentralen Thema zusammenhängen und somit nachträglich die Schlüsse belegen, die im ersten Band enthalten sind. Der erste Band unterscheidet sich ziemlich deutlich vom übrigen Werk Pirchans, insbesondere was die Breite der gewählten Perspektive angeht. Während Pirchan sich in seinen bekannteren Studien als Historiker präsentiert, der präzise und konkret formulierte Fragen analysiert (so etwa in den Artikeln über das Sudetendeutschtum, in dem er seine umfangreichen Kenntnisse als Wissenschaftler in den Dienst von nationalen Zielen der Gegenwart stellt), so zeigt ihn das Werk „Italien und Kaiser Karl IV.“ als einen Autor, der es vermag, sich der auf die Faktografie ausgerichteten politischen Geschichte ebenso zu widmen wie etwa der plastisch dargestellten Charakteristik des Milieus der italienischen Städte in der Mitte des I4. Jahrhunderts.

Die Gliederung des Buches in fünf Teile folgt der chronologischen Reihenfolge der Ereignisse von den politischen Vorbereitungen des Feldzugs und den Verhandlungen mit der päpstlichen Kurie (I: Vorgeschichte) über Karls Verhandlungen in Wien, die Alpenüberquerung und die Ankunft in Norditalien (II: der Feldzug in der Lombardei), das komplizierte Lavieren zwischen lokalen Machthabern auf dem Weg nach Rom (III: Des Kaisers Eingreifen in Toskana) bis zum eigentlichen Aufenthalt in Rom (V: Der Kaiser in Rom) und die umfangreiche Schilderung von Karls Rückreise (V: Des Kaisers Rückkehr). Im Rahmen der einzelnen Kapitel begnügt sich Pirchan aber nicht mit der schlichten Schilderung der historischen Entwicklung, sondern er versucht sich um die Vermittlung eines Gesamtbildes des politischen und geografischen Raumes, in den die Geschehnisse eingebettet waren. Obwohl die Hauptfigur des Buches Kaiser Karl IV. ist, zieht am Leser eine ganze Schar von weiteren Akteuren vorüber, die mehr oder weniger genau vorgestellt und in die Handlungsstränge einbezogen werden, ohne dass dies jedoch die Aufmerksamkeit von der Hauptachse der Geschehnisse allzu sehr ablenken würde. Analoges lässt sich feststellen, was die Exkurse betrifft, die scheinbar nur am Rande den Verwaltungssystemen der italienischen Städte gewidmet sind. Pirchans Art der Skizzierung eines Gesamtbildes besteht nicht aus langen Passagen, die um eine erschöpfende Schilderung von einzelnen Themenbereichen bestünden, sondern aus kurzen und inhaltlich dichten Absätzen, manchmal auch nur Sätzen, in denen der Autor auf lapidare und äußerst präzise 
Weise gewisse Personen (vgl. vor allem in den Exkursen im zweiten Band) oder Milieus charakterisiert. Obwohl im Buch die Schilderung der politischen Verhandlungen und die „histoire evenementielle“ den meisten Platz einnehmen, schafft es Pirchan auch beim Darstellen von Einzelereignissen den Eindruck der Vollständigkeit und einer lebendigen Skizzierung zu vermitteln, ohne dass dies auf Kosten der Genauigkeit oder um den Preis einer phantasiegesteuerten Interpretation der Quellen geschähe (vgl. z.B. die Schilderung von Karls Ankunft in einzelnen italienischen Städten). ${ }^{239}$ Der ständige direkte Rückbezug auf die Quellen als natürliche Grundlage des „wahrheitlichen Charakters“ der Darstellung bleibt erhalten, die enthaltenen Interpretationen betreffen vorwiegend die Ebene des politischen Geschehens und Fragen zur Verwaltung oder Textanalyse. Dagegen hält sich Pirchan von der Skizzierung abstrakterer geschichtlicher Prozesse fern.

Dank „Italien und Kaiser Karl IV.“ und Pirchans intensiven Forschungen in italienischen Archiven und Bibliotheken können frühere Arbeiten über diese Ära von Karls Herrschaft als überholt gelten. Das Werk unterscheidet sich von diesen auch durch sein spezifisches Verständnis der Person des Kaisers. Karl IV. zieht nicht nach Italien als „deutscher" Kaiser, der dort die in entfernter Vergangenheit begründete Herrschaft römischdeutscher Kaiser und Könige zu erneuern trachtet, sondern als Schlichter, Realist und führender Gestalter der aktuellen Politik, der auf die Festigung der kaiserlichen Macht bedacht ist, von der er das Wohl des ganzen Reiches abhängig sieht. Nach einer umfangreichen Schilderung aller Verhandlungen Karls über die Restitution des Kirchenstaates und die Rückkehr der Kurie nach Avignon schließt er den Erzählstrang in Form einer dramatischen Abkürzung ab, indem er mit knappen Worten den vollkommenen Misserfolg des Kaisers konstatiert. ${ }^{240}$ Gewissermaßen sind für die Charakterisierung von Pirchans Herangehensweise möglicherweise die Verhältnisse Italiens am wichtigsten, wie dies schon aus dem Titel des Buches hervorgeht - also ein Land, das durch Stadtstaaten gekennzeichnet ist, die eine lange geteilte Vergangenheit und Kultur verbindet, welche damals vor allem auf dem Gebiet der Literatur, feststellbar war.

Pirchans wissenschaftliches Werk wurde von den Rezensenten ausnahmslos als kultiviert eingeschätzt, als Werk, dem der Versuch um eine zurückhaltende und objektive Darstellung des untersuchten Stoffes zu eigen ist, das in analytischer Hinsicht gründlich durchdacht ist und den breiten kulturellen Horizont des Autors offenbart. ${ }^{241}$ Dieser Einschätzung kann man auch heute noch zustimmen. Pirchan gehörte zu den Historikern, die ihre Interpretationen auf einer breiten Quellen- und Literaturgrundlage basieren lie-

239 Pirchan, Italien und Kaiser Karl IV. (wie Anm. 5) 240-249.

240 Ebd. 439f.

241 Vgl. z.B. Novotný, Rezension (wie Anm. 166), ferner auch Josef Šusta in: Český časopis historický 44 (1938) $558 f$. 
ßen und die nicht nur sehr versierte Kenner der klassischen politischen Geschichte, sondern auch der Kulturgeschichte sind. Trotzdem darf nicht vergessen werden, dass auch sein Werk von einer gewissen Janusköpfigkeit gekennzeichnet ist. ${ }^{242}$ Sein zweites Gesicht zeigte sich beispielsweise in Arbeiten zum Sudetendeutschtum, über die oben bereits berichtet wurde.

242 Vgl. dazu Otto Gerhard Oexle, „Zusammenarbeit mit Baal“. Über die Mentalitäten deutscher Geisteswissenschaftler 1933 - und nach 1945, in: Historische Anthropologie 8 (2000) 1-27. 



\section{Adolf Grohmann (1887-1977)}

ORIENTALIST UND HISTORIKER

I. Spätestens seit der deutschen Wiedervereinigung und der damit verbundenen Frage der unterschiedlichen Betrachtung der jüngsten deutschen Vergangenheit durch die Historikerzunft der beiden Deutschland ist die Geschichte der deutschen historischen Wissenschaft ein fester Bestandteil zeithistorischer Forschung in Deutschland, aber auch in Österreich ${ }^{1}$. Dabei lagen die Schwerpunkte der Forschung auf der Zeit des Nationalsozialismus nahe, sei es auf der Ebene der Institutionengeschichte, sei es auf der Ebene der Forschungsprodukte und der Lehre. Das Fach Geschichte schien als nahezu prädestiniert für die Fragestellung der ideologischen Beeinflussung bzw. in der ideologischen

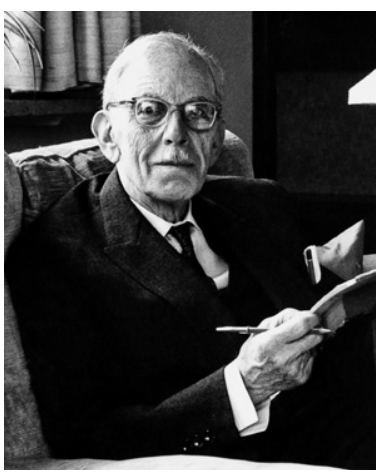

Abb. 26: Adolf Grohmann Vorbereitung der Standpunkte der NS-Herrschaft. Erst einige Jahre später begann man sich für andere Fächer geisteswissenschaftlicher Forschung zu interessieren, und inzwischen hat das zur Verfügung stehende Schrifttum längst großen Umfang angenommen. Die Orientalistik gehört zu den Fächern, die erst nach den historischen Wissenschaften in den Fokus moderner wissenschaftshistorischer Forschung geraten sind, wobei zu bedenken ist, dass die heutige Vorstellung von dem Lehr- und Unterrichtsfach Orientalistik sich erheblich von der etwa des späten I9. Jahrhunderts unterscheidet ${ }^{2}$. Von einer linearen

1 Vgl. hierzu den Überblick und die Literaturangaben hauptsächlich für Österreich von Karel Hruza, Österreichische Historiker 1900-1945. Zum Stand der Forschung, in: Österreichische Historiker 1900-1945, Lebensläufe und Karrieren in Österreich, Deutschland und der Tschechoslowakei in wissenschaftsgeschichtlichen Porträts, hg. v. DEMs. (Wien/Köln/Weimar 2008) 13-38. Ihm sei herzlich gedankt für viele Anregungen und nützliche Hinweise bei der Arbeit an diesem Aufsatz.

2 Ich verwende die Bezeichnung Orientalistik hier ausdrücklich immer als einen Sammelbegriff für jedwede wissenschaftliche Auseinandersetzung mit Religion, Kultur und Geschichte der Region, die zu dem betreffenden Zeitpunkt als „Orient“ bezeichnet wurde und wird. Die Zuschreibung des damit gemeinten geografischen Raumes variiert natürlich im Laufe der Jahrzehnte, muss daher immer neu definiert werden. Für dementsprechende Ausführungen besteht im Rahmen dieses Aufsatzes keine Möglichkeit. 
Entwicklung eines immer als solches bezeichneten Faches „Orientalistik“ darf man jedoch nicht ausgehen, dies käme einer „invented tradition“ gleich ${ }^{3}$. Sollte Wissenschaftsgeschichte auch die Verfehlungen des jeweiligen Faches thematisieren, so verortete man die der wissenschaftlichen Orientalistik zunächst an einem anderen Thema, und zwar bei der angenommenen Unterstützung von Kolonialismus und Imperialismus. Die Übertragung der postkolonialen Kritik auf das Studienfach Orientalistik wurde von manchen Autoren ab den I96oer-Jahren verfochten, einem breiteren Kreis bekannt wurde sie jedoch erst mit dem vielfach umstrittenen Angriff des amerikanisch-palästinensischen Literaturwissenschaftlers Edward Said auf das Fach. In seinem Buch „Orientalism“ schrieb Said der Orientalistik einen wesentlichen Beitrag am Kolonialismus zu und erschütterte damit die bis dahin sorgfältig gehütete Vorstellung von der Orientalistik als gänzlich apolitischer Wissenschaft ${ }^{4}$. Obwohl gerade der deutschsprachigen Orientalistik im Buch von Said ein gewisser Unbedenklichkeitsgrad ausgestellt wurde, einerseits weil Deutschland erst spät in den Besitz von Kolonien gelangt war, andererseits weil die Forschungen der deutschen Orientalistik hauptsächlich auf dem Gebiet der Philologie lägen, war die deutsche Orientalistik in ihrem Selbstverständnis entrüstet ${ }^{5}$. Gleichzeitig bestand ein ähnliches Bedürfnis wie bei den historischen Wissenschaften, Orientalistik als Fach vollkommen unpolitisch wirken zu lassen. Nach 1945 war die Wissenschaftshistorie bestrebt, die Verbindung der Orientalisten zum Nationalsozialismus so gering wie möglich darzustellen: „Wenn überhaupt, so ist Orientalistik von der Forschung bisher als Wissenschaftsdisziplin wahrgenommen worden, die für das Zusammenspiel von Wissenschaft, Politik und Ideologie im NS nur von geringem theoretischem wie praktischen Nutzen war. "6 Der Forschungsgegenstand der Orientalistik wurde der Kollaboration mit dem Regime aus inhaltlichen Gründen für unverdächtig erklärt und jeglicher Zusammenhang der Wissenschaftler selbst mit Politik in Eigen- wie in Fremdaussagen verschwiegen. Es entstand der Eindruck, dass sowohl in Bezug auf den Inhalt der Forschungen selbst als auch in Bezug auf die handelnden Personen die Verbindungen zur Politik im Allgemeinen und dem Nationalsozialismus im Besonderen nicht groß gewesen seien ${ }^{7}$. So kam es nach I945 zu kei-

3 So nennt es, in Anlehnung an Eric Hobsbawm, Ursula Wоковск, German Orientalism. The study of the Middle East and Islam from 1800 to 1945 (London/New York 2009) 35.

4 Edward W. SAID, Orientalism (London 1973, seither viele Auflagen). Einen guten Überblick über die gesamte Debatte, die längst den Rahmen reiner Wissenschaftsgeschichte verlassen hat, gibt: Orientalism. A Reader, hg. v. Alexander Lyon MACFIE (Washington/New York 2000), dort v.a. seine „Introduction“, 1-8.

5 Vgl. die wütende und nahezu beleidigte Kritik: Hartmut FäHndR ICH, Orientalismus und „Orientalismus“: Überlegungen zu Edward Said, Michel Foucault und westlichen „Islamstudien“, in: Die Welt des Islams 28 (1988) 178-186.

6 Ekkehard ElLinger, Deutsche Orientalistik zur Zeit des Nationalsozialismus 1933-1945. (Edingen-Neckarhausen 2006) 1.

7 Als Ausnahme wurde jedoch stets auf die Person von Carl Heinrich Becker verwiesen, der einerseits Orien- 
ner selbstreflektierenden Auseinandersetzung mit der eigenen Geschichte, dies allerdings unabhängig von fachlicher Ausrichtung. „Als beinahe einheitliches Grundmuster, soweit die Quellen Eindeutigkeit erlauben, zeigt sich in der Selbsteinschätzung die Behauptung, die wissenschaftliche Tätigkeit fernab und möglichst unbehelligt von der rassischen Weltanschauung der Nationalsozialisten bis zum bitteren Kriegsende fortgesetzt zu haben. "8

Wissenschaftshistorisch galten lange Zeit die Untersuchungen von Johann Fück und Rudi Paret als die maßgeblichen Darstellungen zur Geschichte der deutschen Orientalistik, die sich streng am Werk der beschriebenen Persönlichkeiten orientierten. Inzwischen haben bedeutsame Publikationen dem geschilderten Missstand abgeholfen und versuchen, das weite Feld der Orientalistikgeschichte vom I9. Jahrhundert bis in die erste Hälfte des 20. Jahrhunderts in moderner Weise darzustellen ${ }^{10}$. In der Bezeichnung Orientalistik inbegriffen sind selbstverständlich in Teilaspekten der Orientalistik ausgebildete Wissenschaftler mit einem historisch-hilfswissenschaftlichen Schwerpunkt, wobei zu bedenken ist, dass diese meist nicht eine klassisch-historische Ausbildung hatten, sondern von der semitischen bzw. orientalischen Philologie kamen. Als ein solcher hat Adolf Grohmann zu gelten, der vor allem mit seinen Forschungen zur arabischen Papyrologie in Verbindung gebracht wird. Er entwickelte in seinen Studien und späteren Arbeiten die Verbindung der Disziplinen der Orientalistik mit den Historischen Hilfswissenschaften auf einem hohen Niveau.

II.

Adolf Grohmann wurde am I. März I 887 in Graz als Sohn des Kaufmanns Alois Grohmann geboren ${ }^{11}$. Über seine Kindheit und schulische Ausbildung ist nur so viel bekannt,

talist war, andererseits als Bildungsminister in der Weimarer Republik ein hohes politisches Amt ausübte. Vgl. Alexander Ha Ridi, Das Paradigma der „islamischen Zivilisation“ - oder die Begründung der deutschen Islamwissenschaft durch Carl Heinrich Becker (1876-1933) (Mitteilungen zur Sozial- und Kulturgeschichte der islamischen Welt 19, Würzburg 2005).

8 Monika Glettrer, Tschechische, jüdische und deutsche Professoren in Prag, in: Prager Professoren 19381948. Zwischen Wissenschaft und Politik, hg. v. DERs., Alena MišKová (Veröff. zur Kultur und Geschichte im östlichen Europa 17, Essen 2001) 13-27, hier 21.

9 Johann Fück, Die arabischen Studien in Europa bis in den Anfang des 20. Jahrhunderts (Leipzig 1955); Rudi Paret, Arabistik und Islamkunde an deutschen Universitäten. Deutsche Orientalisten seit Theodor Nöldeke (Wiesbaden 1966).

10 Hier zu nennen sind für das 19. und das 20. Jahrhundert mit Angaben zu Literatur und einer genaueren Diskussion der Wissenschaftshistorie der Orientalistik: Ludmila Hanisch, Die Nachfolger der Exegeten. Deutschsprachige Erforschung des Vorderen Orients in der ersten Hälfte des 20. Jahrhunderts (Wiesbaden 2003); Sabine MAnGold, Eine „weltbürgerliche Wissenschaft“ - Die deutsche Orientalistik im 19. Jahrhundert (Stuttgart 2004); Ellinger, Orientalistik (wie Anm. 6). Ganz neu ist die umfassende Monografie von Wокоеск, Orientalism (wie Anm. 3), die allerdings stark auf den Arbeiten von Hanisch und Ellinger aufbaut.

$11 \mathrm{Zu}$ Grohmann selbst ist wenig geschrieben worden, vgl. den Nachruf von Hans Ludwig GotтsCHALк in: 
dass er die Unterstufe des Gymnasiums seiner Geburtsstadt besuchte und ab I 903 seine Gymnasialstudien in Prag fortsetzte, wohin seine Eltern übersiedelt waren. I907, also erst mit zwanzig Jahren, absolvierte Grohmann die Matura mit Auszeichnung und begann in Wien an der Philosophischen Fakultät Orientalistik zu studieren ${ }^{12}$.

Bis hin zum I9. Jahrhundert stellte Orientalistik an den Universitäten insgesamt eine Hilfswissenschaft der Theologie dar. Das Interesse an semitischen Sprachen beruhte zunächst auf dem erhofften Erkenntnisgewinn zum Verständnis der Bibel. Ein Interesse an der Religion des Islam, wenn überhaupt vorhanden, enthielt in der Regel die Anstrengung, den Islam als falsche Religion zu diffamieren und ihren Propheten Muhammad als einen falschen Propheten zu entlarven ${ }^{13}$. Als im späten I8. und frühen I9. Jahrhundert die Ruinenfunde von Persepolis allgemein bekannt wurden, löste dies eine Begeisterung für das antike Persien aus, in dessen direkter Nachfolge dessen klassischen Erbes man sich in Europa sehen mochte ${ }^{14}$. Das 19. Jahrhundert brachte die durch die Humboldt'schen Reformen ausgelöste Aufwertung der Philosophischen Fakultäten und die Konzentration auf die Forschung an den Universitäten ${ }^{15}$. In der Umgebung der forschenden und lehrenden Universitäten entwickelte sich alsbald die in weiterer Folge als „deutsch“ apostrophierte arabische Philologie, deren größter Protagonist Heinrich Leberecht Fleischer war ${ }^{16}$. Gleichzeitig mit der Anbindung der Forschung an die Universitäten verschwand der klassische Privatgelehrte, der in der Orientalistik das i 8. Jahrhundert dominiert hatte, in Österreich etwa repräsentiert durch den ungemein produktiven Joseph von HammerPurgstall, der sein gesamtes Berufsleben im österreichischen Staatsdienst verbracht hatte,

Almanach der ÖAW 1978 (Wien 1979) 331-341. Zuletzt erschienen: Lucian Reinfandt, The Political Papyrologist: Adolf Grohmann (1887-1977), in: Sources and Approaches across Disciplines in Near Eastern Studies. Proceedings of the 24th Congress of L'Union Européenne des Arabisants et Islamisants, hg. v. Verena Klemm et al. (Series Orientalia Lovanensia Analecta 215, Leuven 2011) 251-269. Den Beitrag hat mir der Autor vor Drucklegung zur Verfügung gestellt, wofür ich mich herzlichst bedanken möchte. - An wesentlichen Archivalien zu Grohmann existieren in folgenden Archiven Materialien: Archiv der ÖAW (= AÖAW), phil-hist. Klasse, PA Grohmann. Herbert Eisenstein vom Institut für Orientalistik an der Universität Wien fertigte ein Grobinventar des umfangreichen Nachlasses Grohmanns an, der bis heute unbearbeitet im AÖAW bewahrt wird; UAW, PA Grohmann, Rigorosenakt, UAP, PA Grohmann; UAI, PA Grohmann. Allen Archiven danke ich herzlich für die freundliche Unterstützung.

12 Goтtschalk, Grohmann (wie Anm. 11).

13 Maxime Rodinson, Die muslimische Welt im Spiegel des Westens, in: Ders., Die Faszination des Islam (München 1985) 18-104.

14 Hamid Tafazoli, Der deutsche Persien-Diskurs. Von der frühen Neuzeit bis in das neunzehnte Jahrhundert (Bielefeld 2007) v.a. 322-366.

15 Hans Lentze, Die Unterrichtsreform des Ministers Graf Leo Thun-Hohenstein (SB Wien 239,2, Wien 1962).

16 Zu ihm Ignaz Goldziner, Art. „Fleischer, Heinrich Leberecht“, in: ADB 48 (1904) 584-594; Johann W. Fück, Art. „Fleischer, Heinrich Leberecht“, in: NDB 5 (1961) $231 \mathrm{f}$. 
jedoch nie mit der Universität verbunden war $^{17}$. Die Auseinandersetzung mit dem Orient erfolgte in den deutschsprachigen Ländern auf dem Wege der Grammatik und der Poesie. Anders als für britische und französische Orientalisten spielte die Bereisung des Orients in den deutschsprachigen Ländern im Fachgebiet der Orientalistik eine untergeordnete Rolle. Islamische Geschichte wurde im Allgemeinen als arabische Geschichte der klassischen Zeit verstanden und hatte, da ihre Erforschung in einem posttheologischenphilologischen Fach wurzelte, keinen direkten Bezug zu den historischen Wissenschaften: „Indeed the weak point of Arabic studies in nineteenth-century Germany was that historiography and philology did not come together but rather lived in constant danger of falling victim to a silent animosity [...]. "18 Die Fragen der Historischen Hilfswissenschaften und der historischen Quellenkritik berührte die Orientalistik aus diesem Grund nur am Rande. Die Notwendigkeit, sich mit Historischen Hilfswissenschaften zu beschäftigen, wurde erst mit dem Moment offenbar, als man sich mit arabischen Archivalien zu beschäftigen begann. Da die Auseinandersetzung mit diesen zu einem viel späteren Zeitpunkt erfolgte als die Entwicklung der quellenkritischen Methode in den europäischen historischen Wissenschaften, kann man diese Ungleichzeitigkeit der Entdeckung und Entwicklung von Methoden der Quellenbearbeitung als einen Grund dafür annehmen, dass die Disziplinen Orientalistik und Geschichte sich nicht stärker verschränkten. Archivalien kamen erstmals in der Form arabischer Papyri in das Interessenfeld der Orientalisten, ein Trend, der unter anderem in Wien mitbegründet wurde.

In die Tradition der universitären Orientalistik im deutschsprachigen Raum ordnete sich auch das Orientalische Institut an der Universität Wien ein, an dem Grohmann von I 907 bis I9I I studierte. I 886 wurde das Institut unter unklaren Umständen gegründet, jedenfalls ist ihm kein Gründungsprozess in den Akten nachzuweisen. Es wurden fünf Fachbereiche in das neu gegründete Institut integriert: Vergleichende Sprachwissenschaft, repräsentiert durch Friedrich Müller ${ }^{19}$, Ägyptologie durch Leo Reinisch ${ }^{20}$, Indologie durch Georg Bühler ${ }^{21}$, einem weltbekannten Gelehrten der Indologie, Geschichte des

17 Zu ihm Sibylle Wentкer, Joseph Freiherr von Hammer-Purgstall. Ein Leben zwischen Orient und Okzident, in: Joseph von Hammer-Purgstall. Grenzgänger zwischen Orient und Okzident, hg. v. Hannes D. Galter et al. (Graz 2008) 1-12.

18 Josef van Ess, From Wellhausen to Becker: The Emergence of Kulturgeschichte in Islamic Studies, in: Islamic Studies: A Tradition and its Problems. Seventh Giorgio Levi Della Vida Biennial Conference, hg. v. Malcolm H. KerR (Malibu 1980) 27-51.

19 Zu ihm Rüdiger Sснмітт, Art. „Müller, Friedrich“, in: NDB 18 (1997) 378f.

20 Zu ihm Rainer Voigt, Art. „Reinisch, Simon Leo“, in: NDB 21 (2003) 372f.; G. Böнm/G. Thausing, Art. „Reinisch, Simon Leo“, in: ÖBL 9 (Wien 1988) $50 \mathrm{f}$.

21 Zu ihm Willibald Kirfel, Art. „Bühler, Johann Georg“, in: NDB 2 (1955) 726f.; Art. „Bühler, (Johann) Georg“, in: ÖBL 1 (Wien 1957) 125. 
Vorderen Orients sowie Historische Hilfswissenschaften durch Josef von Karabaček ${ }^{22}$, den Direktor der Hofbibliothek und Vermittler der Papyrussammlung Erzherzog Rainer nach Wien, und zu guter Letzt die Semitistik, die in erheblicher Breite von David Heinrich Müller ${ }^{23}$ bestritten wurde.

Grohmann hatte bereits in Prag in seinen letzten beiden Gymnasialjahren Arabisch, Persisch und Türkisch in Privatstunden gelernt ${ }^{24}$. Demzufolge richtete er seinen Studienplan in Wien hauptsächlich philologisch aus und hörte bis zur Ablegung des Doktorates I9II daselbst Arabisch, Aethiopisch, Hebräisch, Syrisch bei Hofrat Prof. Dr. D.H. Müller, Arabisch, Aethiopisch bei Prof. Dr. M. Bittner, Arabisch ferner bei Prof. Dr. R. Geyer, Aethiopisch-Koptisch bei Prof. Dr. H. Junker und neben anderen Studien auch arabische Paläographie bei Hofrat Prof. Dr. J. v. Karabaček ${ }^{25}$. Als seine Hauptlehrer darf man wohl Karabaček und Müller bezeichnen. Karabaček führte Grohmann in das Gebiet der Historischen Hilfswissenschaften sowie der arabisch-islamischen Geschichte bis etwa I 250 ein, und Müller vermittelte Grohmann seine philologisch-semitistische Ausbildung mit einem starken Akzent auf der Südsemitistik. Beide Spezialisierungen bestimmten Grohmanns wissenschaftlichen Werdegang wesentlich.

Karabaček war als namhafter Orientalist spezialisiert auf Historische Hilfswissenschaften und einer der Mitbegründer des Instituts für Orientalistik an der Universität Wien. Über viele Jahre hielt Karabaček an der Universität Vorlesungen über Geschichte des Orients und ihre Hilfswissenschaften. Sein hauptsächlicher Wirkungskreis war jedoch weniger die Universität als die Hofbibliothek in Wien, deren Leiter er war ${ }^{26}$. Fachlich hatte Karabaček zunächst auf dem Gebiet der orientalischen Numismatik gearbeitet, bevor er sich anderen Historischen Hilfswissenschaften in der Orientalistik zuwendete, wie der Paläografie, die er an der Universität ebenfalls unterrichtete. Die historischen Vorlesungen Karabačeks konzentrierten sich auf die Geschichte der islamischen Frühzeit bis hin zum Ende des Kalifats durch die mongolischen Eroberungen. Einen besonderen Schwerpunkt legte Karabaček auf Staatsordnungen in der islamischen Geschichte ${ }^{27}$. In den I 88oer-Jahren kam auf seine wesentliche Vermittlung die Sammlung der Papyri Erz-

22 Zu ihm Gabriele Mauthe, Die Direktion Josef Karabaček an der k. k. Hofbibliothek in Wien (1899-1917) (Wien, phil. Diss. 2000) mit Literatur; Hans L. Goтtschalк, Art. „Karabaček, Joseph Ritter von“, in: NDB 11 (1977) 140; Art. „Karabaček Joseph von“, in: ÖBL 3 (Wien 1965) $228 f$.

23 Zu ihm E. Gotтschalk, Art. „Müller David Heinrich von“, in: ÖBL 6 (Wien 1975) 410f.; Stephan ProCHÁzKa, Art. „Müller, David Heinrich von“, NDB 18, 354 f.

24 UAW, PA Grohmann, fol. 07.

25 UAW, Phil.Rig.Akten PN 3216.

26 Siehe dazu sehr ausführlich Mauthe, Direktion (wie Anm. 22).

27 Etwa las er im SS 1908 „Die historische Chronologie der muhammedanischen Völker“ (Vorlesungsverzeichnis der Universität Wien SS 1908, 54) und im WS 1908/09 „System der muhammedanischen Dynastien mit besonderer Beziehung auf die Staatsaltertümer“" (Vorlesungsverzeichnis der Universität Wien WS 1908/09, 57. 
Abb. 27: Josefvon Karabaček 1893

Abb. 28: David H. Müller
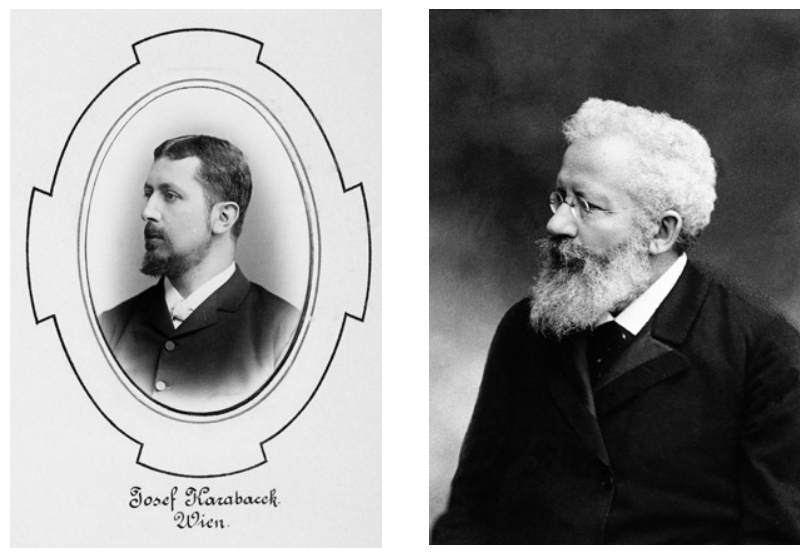

herzog Rainer nach Wien, die zum Hauptbetätigungsfeld Karabačeks hinsichtlich Paläografie, Geschichte und Papyrologie wurde ${ }^{28}$. Grohmann besuchte bei Karabaček fraglos die zweisemestrige Vorlesung über arabische Paläografie, die dieser regelmäßig hielt.

Grohmanns zweiter Lehrer war der Arabist David Heinrich Müller ${ }^{29}$. In Galizien geboren, erhielt eine klassische jüdische Ausbildung und studierte nach absolvierter Matura an der Philosophischen Fakultät in Wien, an der er I 875 promoviert wurde. Bereits I 876 habilitierte sich Müller in Semitistik, wurde zum Extraordinarius für dieses Fach ernannt und wirkte, inzwischen Ordinarius geworden, an der Gründung des Orientalischen Institutes an der Universität Wien mit. Die Vorlesungen Müllers wiesen eine große Breite der behandelten Sprachen auf: Jedes Semester las er entweder arabische Grammatik oder veranstaltete eine Lektüreübung arabischer Texte. Darüber hinaus hielt er hebräische und syrische Sprachübungen ab. Seine dritte Vorlesung war zumeist der semitischen Epigrafik und Schriftgeschichte gewidmet ${ }^{30}$. Neben seiner Lehr- und Forschertätigkeit an der Universität Wien war Müller jedoch auch einer der wenigen, die sich auf wissenschaftliche Expeditionen begaben, nämlich auf die sogenannte Südarabien-Expedition, die von der Kaiserlichen Akademie der Wissenschaften finanziert wurde. Die Kommission zur Erforschung der afrikanischen und asiatischen Sprachen stellte am 4. Mai I 898 den von den Herren Karabaček, Müller und Reinisch unterzeichneten Antrag auf Erforschung

28 Zur Geschichte der Sammlung vgl. Helene Loebenstein, Hermann Har rauer, Die Papyrussammlung der Österreichischen Nationalbibliothek (Wien 1983).

$29 \mathrm{Zu}$ ihm siehe Anm. 23.

30 Z.B. las er im WS 1907/08 „Interpretation babylon.-assyr. Keilinschriften“ (Vorlesungsverzeichnis der Universität Wien WS 1907/08, 55) und im WS 1908/09 „Semitische Epigraphik und Schriftgeschichte“ (Vorlesungsverzeichnis der Universität Wien WS 1908/09, 57), fortgesetzt im SS 1909 (Vorlesungsverzeichnis der Universität Wien SS 1909, 54). 
Südarabiens und der Insel Sokotra ${ }^{31}$. Die Begründung dafür lautete, dass die Erforschung Ägyptens und Mesopotamiens durch verschiedene groß angelegte Expeditionen erfolgt sei, Südarabien und das sabäische Altertum aber noch weitgehend unerschlossen seien. Österreichische Gelehrte hätten einen bedeutenden Anteil an der bisherigen Erforschung Südarabiens. Daher lege es aber unserem Vaterlande die Pflichten auf das Begonnene fortzufübren und zu einem glücklichen Abschlusse zu bringen. Wir stellen daher den Antrag, daß die kais. Akademie der Wissenschaften eine Expedition entsenden möge, um Südarabien und Sokotra in archäologischer, epigraphischer, linguistischer, geographischer, ethnographischer und naturhistorischer Beziehung zu erforschen ${ }^{32}$.

Aus den vorhandenen Informationen nahm man an, dass die Expedition reiche epigrafische Ausbeute bieten würde, die zur Kenntnis von Sprache, Topografie und Geschichte der arabischen Halbinsel beitragen könnte. Die Geografie des Hamdānī, die Müller zum Teil herausgegeben hatte ${ }^{33}$, sollte anhand von neuen Vermessungen einer Überprüfung unterzogen werden. Weiters sollte die Gegend botanisch wie auch geologisch untersucht werden. Ganz besonders obliegt es der Expedition, sich dem Studium der Mahra-Sprache, so wie der, wie es scheint mit ihr verwandten Sprache der Ureinwohner von Sokotra zu widmen ${ }^{34}$.

Die epigrafischen Erträgnisse dieser Expedition sowie die Aufarbeitung der sogenannten Sammlung Glaser wurden dem jungen Adolf Grohmann zur Betätigung, indem er bereits während des Studiums zu Hilfsarbeiten in der Sammlung Eduard Glaser ${ }^{35}$ in der Hofbibliothek herangezogen und mit der Aufarbeitung des epigrafischen Materials, aber auch der geografisch-ethnografischen Notizen Glasers betraut wurde. Dieser war 1908 gestorben, und D. H. Müller hatte sich mit den Erben in Verbindung gesetzt, um seinen Nachlass wissenschaftlich betreuen zu lassen ${ }^{36}$. Die Sammlung wurde I9I I von der Kaiserlichen Akademie der Wissenschaften angekauft, nachdem sie sich verpflichtet hatte, einen Teil der Stiftung von Horace (von) Landau für die Anschaffung zu verwenden. Aus

31 AÖAW, Südarabische Kommission, Schreiben vom 04.05.1898.

32 Ebd.

33 David Heinrich Müller, Die Burgen und Schlösser Südarabiens nach dem Îklîl des Hamadânī 1-2 (SB Wien 94,1 und 97, Wien 1879-1881).

34 AÖAW, Südarabische Kommission, Schreiben vom 04.05.1898.

35 Zu ihm Egon Koмorzynsкi, Art. „Glaser, Eduard“, in: NDB 6, 429f. Glaser hatte bei Müller studiert und von mehreren Reisen nach Südarabien Hunderte altsüdarabische Inschriften nach Europa gebracht. Er gilt als einer der bedeutendsten Erforscher Altsüdarabiens. Sein Nachlass ist bis heute nur zum Teil ausgewertet. Zu Glaser im Zusammenhang mit der österreichischen Orientalistik vgl: Gertraud STur M, Leben für die Forschung: Das Ethnologenehepaar Wilhelm und Marie Hein in Südarabien (1901/02) (Sammlung Eduard Glaser 15, Wien 2007) bes. 37f.

36 Die Sammlung verblieb bis 1939 in Depoträumen der Nationalbibliothek. Seit 1996 ist sie im AÖAW untergebracht. Vgl. Yukiko SA K A BE et al., Bestandbericht Sammlung Glaser, unpubl. Verzeichnis (im Druck) (freundl. Hinweis von Dr. Stefan Sienell). 
den Mitteln der Stiftung Landau wurde Grohmann ab dem Mai I9I3 mit monatlich I oo Kr. bezahlt ${ }^{37}$. Die Räumlichkeiten der Sammlung Glaser lagen in der Hofbibliothek neben den der Papyrussammlung, und ein Kontakt mit dieser großen Sammlung war schon deshalb nahezu unvermeidlich. Darüber hinaus hatte die Lehre von D. H. Müller, Karabaček und Rudolf Geyer ${ }^{38}$ für Grohmann die Brücke zur späteren Nationalbibliothek und der Papyrussammlung längst gelegt.

III.

I 9 I 4 begleitete Grohmann eine Ausgrabungskampagne unter Ernst Sellin ${ }^{39}$ nach Syrien und Palästina. Sellin hatte sich als Theologe und Archäologe einen Namen gemacht und grub neben dem biblischen Jericho auch die antike Stadt Sichem aus. Die Reise war der erste Kontakt Grohmanns mit dem realen Orient, dem Grohmann in der weiteren Folge treu bleiben sollte. Bei dieser Gelegenheit reiste Grohmann auch nach Ägypten und bekam die Gelegenheit, den Grabungsbetrieb bei Gizeh kennenzulernen, der von dem in Wien tätigen Ägyptologen Hermann Junker geleitet wurde ${ }^{40}$. Im Gegensatz zu vielen seiner Kollegen bereiste Grohmann den Orient recht häufig für längere Aufenthalte und kooperierte später mit ägyptischen Institutionen in seinem Fachgebiet. Neben einem vielfältigen Interesse für islamische Geschichte und Kunstgeschichte begann sich Grohmann zunehmend mit arabischen Papyri zu beschäftigen. Grohmann schreibt in seinem Festschriftbeitrag für Alois Musil ${ }^{41}$, dass er die Anregung zur näheren Beschäftigung mit Papyri von Musil selbst bekommen hatte, als er von seiner ersten Orientreise zurückgekehrt

37 Diese Zahlung wurde erst im Dezember 1917 auf Betreiben Karabačeks eingestellt. AÖAW Hilfskontobuch 1914-1925, 192 und 205 (freundl. Hinweis von Dr. Stefan Sienell).

38 Zu ihm vgl. Nikolaus Rhodokanakis, Nachr. „Rudolf Geyer“, in: Almanach der ÖAW 80 (1930) 193200 ; F. Lochner von Hütten bach, Art. „Geyer Rudolf“, in: ÖBL 1, (Wien 1957) $434 f$.

$39 \mathrm{Zu}$ ihm vgl. Georg Sauer, Art. „Sellin, Ernst Franz Max“, in: Biographisches-Bibliographisches Kirchenlexikon 9 (Herzberg 1995) Sp. 1370-1372.

40 Adolf Grohmann, Nachruf „Hermann Junker“, in: Almanach der ÖAW 112 (1962) 341. Zu Junker vgl. Gertrud Thausing, Art. „Junker, Hermann“, in: NDB 10 (1974) 692f.

41 Tschechischer Orientalist, Forschungsreisender und Ethnograf, zu ihm Karl Johannes BAu e , Alois Musil. Wahrheitssucher in der Wüste (Perspektiven der Wissenschaftsgeschichte 5, Wien 1989). Detailreich, aber monarchistisch-tendenziös ist das Buch von Erich FeIgl, Musil von Arabien. Vorkämpfer der islamischen Welt (Wien 1985). Dass das Verhältnis zwischen Musil und Grohmann als einem Schüler von Karabaček und Müller fremd blieb, ist neben Musils schroffer Persönlichkeit auch dem für Musil sehr kränkenden Umstand geschuldet, dass sowohl Müller als auch Karabaček seine bedeutenden Entdeckungen in Syrien zunächst nicht glaubten und erst durch eine Bilddokumentation umgestimmt werden konnten. Daher ist vielleicht auch Grohmanns Nachruf auf Musil persönlich etwas zurückhaltend geraten: Adolf Groнmann, Nachruf „Alois Musil“, in: Almanach der ÖAW 94 (1944) 232-251. 
war $^{42}$. Dies scheint jedoch eher eine höfliche Geste gegenüber dem Gefeierten gewesen zu sein und ist nicht sehr wahrscheinlich, denn Karabaček dürfte in seinen Vorlesungen das Interesse an Papyri hinlänglich geweckt haben. Auch wenn wir den genauen Zeitpunkt nicht ansetzen können, so darf man doch davon ausgehen, dass Grohmann sich seit seiner Promotion immer stärker mit Papyri beschäftigte.

Da er nach seinem Studium nicht gleich eine Stelle an der Universität fand und seine Bezahlung an der Sammlung Glaser nicht ausreichte, musste Grohmann an der k. u.k. Öffentlichen Lehranstalt für Orientalische Sprachen Arabischstunden geben ${ }^{43}$. Daneben arbeitete Grohmann wissenschaftlich, so dass er sich I9I5 habilitieren konnte. Der Bericht der Kommission vom I I. Dezember I9I5 befürwortet die Ernennung zum Privatdozenten unter der Venia „Sprach- und Altertumskunde des Vorderen Orients“. Die zusätzliche Spezialisierung mit besonderer Berücksichtigung des südsemitischen Zweiges (arabische, südarabische und abessinische Gruppe), die Grohmann sich in seinem Antrag gewünscht hatte, gewährte die Kommission nicht, womöglich war sie ihr zu eng gefasst ${ }^{44}$. Das Vorlesungsprogramm, das Grohmann in seinem Antrag auf Habilitation in Aussicht stellte, zeigt die fachliche Ausrichtung Grohmanns: I. Südsemitische Epigraphik, Sabäisch-minäisch, altäthiopisch. 2. Einführung in die äthiopische Kirchenpoesie. 3. Mehri-Texte. 4. Vergleichende Lektüre arabischer, äthiopischer und koptischer Texte. 5. Einführung ins Arabische und Neuarabische (mit Sprechübungen). 6. Islamkundliche Themen. 7. Einführung in die Altorientalische Archäologie. 8. Kolonial- und Kolonisationsfragen im Vorderen Orient. 9. Zusammenfassende Kollegien und Übungen ${ }^{45}$. Grohmann war zur Zeit seiner Habilitation noch eindeutig philologisch geprägt, mit einem starken Akzent auf dem Gebiet der Südsemitistik, wie er sie durch seine Studien bei D. H. Müller kennengelernt und durch seine intensive Arbeit an den Notizbüchern der Sammlung Glaser vertieft hatte.

Die Publikationen Grohmanns reflektieren dieses Interesse ebenfalls ${ }^{46}$. Von den acht Publikationen, die Grohmann als Liste seinem Habilitationsantrag beilegte, waren allein

42 Adolf Grohmann, Arabische Papyri aus der Sammlung C. Wessely im Orientalní ústav in Prag, in : Archív Orientalní 10 (1938) 149.

43 Goтtsснацк, Grohmann (wie Anm. 11). Ab 1867 wurden sogenannte „externe Kurse“ der damaligen k. u. k. Orientalischen Akademie für einen öffentlichen Unterricht in Arabisch, Persisch und Türkisch ausgelagert, die mit der Zeit den Charakter eines zweijährigen Lehrganges bekamen. Öffentliche Lehranstalt für Orientalische Sprachen, Wien IX, Boltzmanng. 16 (im Gebäude der Konsularakademie) (Wien 1935) 3-5.

44 UAW, PA Grohmann, fol. 18f.

45 Ebd. fol. 08.

46 Schriftverzeichnisse Grohmanns in: Goттsснацк, Grohmann (wie Anm. 11), seine deutschsprachigen Schriften in: Bibliographie der deutschsprachigen Arabistik und Islamkunde 14, hg. v. Fuat SEzGin (Veröff. des Institutes für Geschichte der Arabisch-Islamischen Wissenschaften A 3, Frankfurt/M. 1992) 160-166. 
vier äthiopistischen Inhalts ${ }^{47}$, eine südarabischen Inschriften gewidmet ${ }^{48}$, eine die Übersetzung einer arabischen Grammatik ${ }^{49}$ sowie eine Arbeit, die sich im Vergleich verschiedener Quellen bediente, was in weiterer Folge zu Grohmanns Hauptthematik werden sollte ${ }^{50}$.

Am ı6. April ı916 erfolgte die Bestätigung des Ministeriums über die Ernennung Grohmanns zum Privatdozenten ${ }^{51}$. Ab dem WS i916/i7 las Grohmann regelmäßig vier bis fünf Stunden an der Philosophischen Fakultät in der Sektion der Orientalischen Philologie. Im ersten Jahr las er eine zweisemestrige Einführung in die semitische Epigrafik, eine Übung zur Koranlektüre, eine Geschichte der äthiopischen Literatur sowie einen Einführungskurs ins Arabische ${ }^{52}$. Im darauffolgenden Jahr las er die Fortführung seines ArabischElementarkursus, eine Übung zu Hamdānīs Șifat Ğazìrat al-Arab mit Erläuterungen zu Geografie, Volkskunde und Geschichte Südarabiens und eine Vorlesung über altsüdarabische Inschriften. Zusätzlich dazu begann Grohmann seine Lehre auf dem Gebiet der arabischen Urkundenlehre, wobei er fraglos auf das Material der Papyrussammlung Bezug nahm ${ }^{53}$. Im März I9I7 konnte Grohmann eine feste Stelle an der Hofbibliothek antreten, er wurde nach der Pensionierung Karabačeks Leiter der orientalischen Abteilung der Papyrussammlung. Grohmann scheint in dieser Zeit überhaupt begonnen zu haben, auch mit seinen Vorlesungen die Lücke zu füllen, die durch die Pensionierung Karabačeks und seinen Tod im Oktober I9I 8 gerissen worden war. Karabaček hatte stets in der Sektion Geschichte eine Einführung in die arabische Paläografie gelesen, ab dem Sommersemster I9I9 übernahm Grohmann diese neben seinen anderen Vorlesungen. Nicht ganz klar ist, warum im Juni I9 8 eine Kommission einen Antrag auf die Erteilung eines fünfstündigen Lehrauftrages an Grohmann stellte, da sich der Umfang seines Lehrdeputats bereits auf fünf Unterrichtseinheiten belief und später auch nicht gesteigert wurde. Die Kommission

47 Adolf Grohmann, Eine Alabasterlampe mit einer Geezinschrift, in: Wiener Zs. für die Kunde des Morgenlandes 25 (1911) 410-22; DERs., Reste einer neuen Rezension der Kindheitsgeschichte Jesu in den Tâamra Îyasûs, in: Wiener Zs. für die Kunde des Morgenlandes 28 (1914) 1-15; DE Rs., Über den Ursprung und die Entwicklung der äthiopischen Schrift, in: Archiv für Schriftkunde I,2 (1915) 57-87; DE Rs., Äthiopische Marienhymnen, herausgegeben, übersetzt und erläutert (Abhandlungen der sächsischen Gesellschaft der Wissenschaften 68,4, Leipzig 1919).

48 Adolf Groнmann, Göttersymbole und Symboltiere auf südarabischen Denkmälern (Denkschriften ÖAW 58,1, Wien 1914) 1-104.

49 Adolf Grohman , Il „Kitab al-âgurrûmiyyah“ (Biblioteca di Studi coloniali 17, Roma 1911).

50 Adolf Groнmann, Die im Äthiopischen, Arabischen und Koptischen erhaltenen Visionen Apa Schenutes von Atripe, in: Zs. der Deutschen Morgenländischen Gesellschaft 67 (1913) 187-267 und 68 (1914) 1-46.

51 Sein Habilitationsvortrag wurde später publiziert: Adolf Groнman N, Katabânische Herrscherreihen, in : Anzeiger der ÖAW, phil-hist. Kl. 53 (1916) 41-49.

52 Vorlesungsverzeichnis der Universität Wien, WS 1916/17 und SS 1917.

53 Ebd. WS 1917/18 und SS 1918. 
begründete diesen Antrag mit dem Tod des a.o. Professors für Orientalische Sprachen Max Bittner ${ }^{54}$, der der Hauptträger des Unterrichts in diesem Fach an der Universität Wien gewesen war. Die Studierenden kämen schließlich in den überwiegenden Fällen ohne Vorkenntnisse in den einschlägigen Sprachen an die Universität und seien auf Elementarunterricht innerhalb des Studiums angewiesen. Bittner hatte in seinen Vorlesungen in der Tat eine enorme Bandbreite bei den unterrichteten Sprachen. In der Studienzeit Grohmanns hatte Bittner Osmanisch-Türkisch, klassisches sowie neues Persisch, Syrisch, Äthiopisch und nicht zuletzt klassisches Armenisch unterrichtet ${ }^{55}$. Bei der Erteilung des Lehrauftrages an Grohmann dachte man vor allem an Arabisch mit seinen vielen Dialekten und an Syrisch-Aramäisch. Rudolf Geyer würdigte Grohmanns wissenschaftliche Leistungen in seinem Bericht an die Kommission: Auf allen den angeführten Gebieten hat sich Grohmann durch aussergewöhnlichen Fleiss, treffsichere Beobachtungsgabe und strenge philologische Genauigkeit hervorgetan und auch als Privatdozent die auf ihn gesetzten Erwartungen in keinster Weise enttäuscht ${ }^{56}$. Auf die Verbindung zu Karabaček und der Übergabe der Vorlesungen zu Historischen Hilfswissenschaften im Bereich der Orientalistik ging die Kommission nicht ein. Gleichwohl scheint man versucht zu haben, Grohmann fester an die Universität Wien zu binden, allerdings ohne Erfolg, denn im Juni I92 I erhielt Grohmann die ersehnte Berufung als außerordentlicher Professor an die Deutsche Universität in Prag. Vorausgegangen war diesem Ruf der Antrag einer Kommission dieser Universität, die seit I 892 bestehende Lehrkanzel für Semitische Philologie wieder zu besetzen ${ }^{57}$. Die Kommission definierte 1920 die Lehr- und Forschungsbereiche der Lehrkanzel folgendermaßen: Das besondere Forschungsgebiet der semitischen Philologie verbreitet sich nun in ziemlich scharfer Abgrenzung I) über das Südsemitische, d.i. die klassische Schriftsprache der Araber mit dem sogenannten, Vulgärarabisch;, über das Äthiopische oder das Ge'es und über das Idiom der sabäo-minäischen Inschriften; 2) über das Mittelsemitische, d.i. das Hebräische des A.T. mit seinen Ausläufern, der Mischna und dem Rabbinischen, über das Phönikische mit dem Punischen und den anderweitigen Resten der kanaanitischen Dialekte; 3) über das Nordsemitische, d.i. das Ostaramäische oder Syrische mit dem Mandäischen und das Westaramäische oder Palästinensisch-Aramäische mit dem Targumischen und Samaritanischen; endlich 4) über das Ostsemitische, das ist die Sprache der assyrisch-babylonischen Keilinschriften ${ }^{58}$.

Angesichts der Breite des Faches hatte die Kommission beschlossen, das Fach in ein Ordinariat und zwei Extraordinariate zu teilen. Das Ordinariat sollte die Bezeichnung

$54 \mathrm{Zu}$ ihm Fritz Rudolf Kraus, Art. „Bittner, Max“, in: NDB 2 (1955) 282.

55 Vorlesungsverzeichnis der Universität Wien, WS 1907/09 - SS 1919. Nicht umsonst wurde er in Anlehnung an den sprachkundigen Kardinal als österreichischer Mezzofanti bezeichnet.

56 UAW, PA Grohmann, fol. 34.

57 UAP, PA Grohmann, Kommissionsbericht vom 04.03.1920.

58 Ebd. 
„Professur für semitische Philologie und Islamforschung“ führen, das erste Extraordinariat „Professur für semitische Philologie mit besonderer Berücksichtigung des Hebräischen und Aramäischen“ und schließlich das zweite Extraordinariat „Professur für arabische Paläographie und Kulturgeschichte des Orients“. Grohmann wurde auf das zweite Extraordinariat berufen ${ }^{59}$. Mit Prag durch seine Schuljahre gut vertraut, zögerte Grohmann nicht, von seiner Position in der Papyrussammlung zurückzutreten, auch wenn er bekundete, dass es ihn schmerze, diese reiche Sammlung zurückzulassen. Kurz nach seiner festen Zusage in Prag erhielt Grohmann die Ernennung zum außerordentlichen Professor an der Universität Wien ${ }^{60}$. Diese musste Grohmann ausschlagen, weil er in Prag schon fest zugesagt hatte und sich in seinem Wort gebunden fühlte ${ }^{61}$.

IV.

Die Situation der Prager Universitätslandschaft ist in der Geschichte der mitteleuropäischen Universitäten einmalig62. I 882 wurde die I 348 von Karl IV. gegründete älteste Universität Mitteleuropas in Prag wegen der zu eskalieren drohenden Nationalitätenkonflikte zwischen Tschechen und Deutschen mit kaiserlichem Dekret in eine k.k. Deutsche Karl-Ferdinands-Universität und eine k. k. Böhmische Karl-Ferdinands-Universität geteilt. Dies bewirkte eine strenge Teilung der Unterrichtssprachen, allerdings verblieb die große Menge der Institute und Gebäude bei der Deutschen Universität, während für die Tschechische Universität erst mit der Zeit Gebäude errichtet und Institute gegründet wurden ${ }^{63}$. Unter deutschösterreichischen Professoren war die Deutsche Universität eine beliebte Zwischenstation auf dem Karriereweg an eine bedeutsamere Universität, die Tschechische Universität zog hingegen vermehrt jüngere tschechische Wissenschaftler an. Mit dem Ende des Ersten Weltkrieges wurde die Trennung der beiden Universitäten noch verschärft, ein gleichzeitiges Einschreiben an beiden Universitäten, das bislang möglich

59 Ebd. Kommissionsbericht 04.1920.

60 UAW, PA Grohmann, fol. 36, eigenhändiger Brief Grohmanns.

61 Ebd.

62 Vgl. hierzu die Überblicke bzw. Detailstudien: Alena MıšKová, Die Deutsche (Karls-)Universität vom Münchener Abkommen bis zum Ende des Zweiten Weltkrieges (Universitätsleitung und Wandel des Professorenkollegiums) (Prag 2007); Pavel Kola ̌̌, Geschichtswissenschaft in Zentraleuropa. Die Universitäten Prag, Wien und Berlin um 1900 1-2 (Berlin 2008), hier 1 40-45; Glettler, Professoren (wie Anm. 8) 13-27; Peter Hilsch, Heidrun Dolezal, Daten zur Entwicklung der Prager Universitäten, in: Universitäten in nationaler Konkurrenz. Zur Geschichte der Prager Universitäten im 19. und 20. Jahrhundert, hg. v. Hans Lemberg (Veröff. des Collegium Carolinum 86, München 2003) 9-18.

$63 \mathrm{Hilsch/Dolezal,} \mathrm{Daten} \mathrm{(wie} \mathrm{Anm.} \mathrm{62)} 13$. 
gewesen war, wurde verboten ${ }^{64}$. Die Errichtung der Tschechoslowakei brachte eine jähe Bedeutungseinbuße für die Deutsche Universität: Die sogenannte Lex Mareš erklärte die tschechische Karls-Universität zur alleinig berechtigten Nachfolgerin der Gründung von I 348, nachdem auch bei der Teilung der Universitäten beide dieses Erbe für sich hatten in Anspruch nehmen können. Die Deutsche Karl-Ferdinands-Universität blieb bestehen und durfte sich nur noch „Deutsche Universität Prag“ nennen ${ }^{65}$. Die Gegensätze zwischen Tschechen und Deutschen verstärkten sich und „Nationalismus, Nationalsozialismus und Antisemitismus fanden bereits in den Zwanziger Jahren Gehör in den Reihen eines Teiles der Deutschen Studentenschaft"66.

In die Fremde war Grohmann mit seinem Umzug nach Prag nicht gegangen, sondern er traf dort Bekannte aus Wien wieder: Der Professor für Keilschriftforschung an der Karls-Universität, Bedřich (Friedrich) Hrozný, war einer seiner akademischen Lehrer gewesen ${ }^{67}$. Der spätere Autor des maßgeblichen Werkes zur persischen Literatur in deutscher Sprache, Jan Rypka, hatte zusammen mit Grohmann studiert und arbeitete im Prager Unterrichtsministerium ${ }^{68}$. Auch Alois Musil hatte sich nach dem Ersten Weltkrieg in seine ursprüngliche Heimat begeben, Grohmann kannte auch ihn aus seinen Lehrveranstaltungen, auch wenn Musil stets an der Theologischen Fakultät gelesen hatte. Trotz der relativ großen personellen Besetzung konnte in keiner Weise von einem ordentlich ausgestatteten Institut in Prag die Rede sein. Notorischer Geldmangel verhinderte unter anderem die Ausstattung mit einer Fachbibliothek. Aus diesem Grund bekam Grohmann den Umzug nach Prag bezahlt, weil er seine Bibliothek (an die ıooo Bücher) mitnahm, ohne die weder er noch seine Studenten arbeiten konnten ${ }^{69}$. Erst 1923 beschloss das Professorenkollegium der Philosophischen Fakultät der Deutschen Universität, dem neu gegründeten Seminar für orientalische Philologie ${ }^{70}$ geeignete Räumlichkeiten für die Aufstellung einer Seminarbibliothek zur Verfügung zu stellen ${ }^{71}$.

64 Ebd.

65 Ebd. 14.

66 MišKová, (Karls-)Universität (wie Anm. 62) 32.

67 Zu ihm vgl. Dušan Zbavitel, Die Orientalistik in der Tschechoslowakei (Prag 1959).

68 Vgl. s. Nachruf von Felix TAuer, in: Der Islam 46,1 (1970) 303-306.

69 UAP, PA Grohmann.

70 Schreiben der Politischen Landesverwaltung in Prag vom 05.10.1922, beginnend mit dem Wintersemester 1922/23 die Errichtung eines Seminars für orientalische Philologie mit zwei Abteilungen genehmigt, von denen das eine vorläufig vom Honorar Prof. Dr. Grünert, das zweite von Prof. Dr. Adolf Grohmann zu führen ist. Dies war eine der Bedingungen Grohmanns für seine Zusage gewesen, dem Ruf nach Prag zu folgen. UAP, Phil. Fak. RXXI, Sem. Phil, K. 66.

71 Ebd. Schreiben vom 23.06.1923. Die Bibliothek wuchs trotzdem nicht rasant, 1928 bestand die Bibliothek aus 402 Bänden. Ebd. Schreiben vom 25.01.1928. 
Am 25. Oktober I92 I hielt Grohmann seine Antrittsvorlesung mit dem Titel „Neue Ergebnisse aus den Arabischen Papyri“ und kündigte seine Lehrveranstaltungen für das WS I92I/22 an, die noch nicht im Vorlesungsverzeichnis aufscheinen konnten: Arabische Grammatik für Anfänger (2 St.), Arabische Paläografie (2 St.), Geschichte des arabischen Kalifats bis zum Sturze der Omajjaden (I St.), Seminaristische Übungen: Interpretation leichter arabischer Prosatexte (2 St. $)^{72}$. Grohmann setzte damit das Lehrkonzept fort, das er in Wien begonnen hatte und in seiner gesamten Berufslaufbahn mehr oder weniger beibehalten sollte. Er bot einen gewissen Vorlesungszyklus: Regelmäßig las er einen Anfängerkurs Arabisch sowie Äthiopisch über ein ganzes Jahr hinweg. Daran schloss er bestimmte Sprachübungen zur Syntax beziehungsweise zu Text- und Inschriftenlektüre an. Darüber hinaus las Grohmann ergänzende Vorlesungen zu Lektüre und Interpretation arabischer Dichtung, zu Kunst des alten Orients, zu Geschichte des Kalifats bis zum Ende des Omajadenreiches, zu semitischer Epigrafik und arabischer Numismatik ${ }^{73}$.

Grohmann hatte als Extraordinarius an der Deutschen Universität begonnen, aber bereits 1922 stellte eine Kommission den Antrag auf Beförderung des a.o. Professors zum Ordinarius, dem mit Rechtswirksamkeit zum 31. Dezember 1923 zugestimmt wurde ${ }^{74}$. Die Kommission begründete ihren Antrag vor allem mit dem großen wissenschaftlichen Fleiß, den Grohmann an den Tag legte, so ist in erster Linie auf die gross angelegte Arbeit ,Südarabien als Wirtschaftsgebiet'75 hinzuweisen. [...] Es enthält folgende Hauptabschnitte: I. Das Land, 2. Die Bewohner, 3a) Die Urproduktion, 3b) Mineralschätze und Bergbau, 4) Jagd, Fischerei, Viehzucht und Bienenzucht, 5) Die Landwirtschaft. Grohmanns Arbeit zeichnet sich durch sorgfältige und kritische Benützung des überaus reichen Quellenmaterials, das uns die arabischen Schriftsteller und die moderne Reiseliteratur bieten, aus, und er bietet uns in dieser Arbeit gegenwärtig wohl das beste Werk über den klassischen antiken Kulturboden des alten Südarabien als modernes Wirtschaftsgebiet ${ }^{76}$. Die Arbeit, die sich über nahezu zwanzig Jahre hinzog, fußte vor allem auf der Bearbeitung und Auswertung der Glaser'schen Tagebücher, die der junge Grohmann begonnen hatte. Ein Rezensent stellte fest, dass es die Entzifferung der südarabischen Inschriften der Sammlung Glaser gewesen war, „which led the author to realize the importance of a knowledge of medieval and modern South Arabia for an adequate understanding of the ancient [...]"77. Grohmanns wissenschaftliche Hauptleistung besteht in der akribischen Suche und Zusammenführung von Quellen in verschiedenen Sprachen und ihrer inhaltlichen Verknüpfung. Seine Fachgebiete erstreck-

\footnotetext{
72 UAP, PA Grohmann.

73 Ordnung der Vorlesungen an der Deutschen Universität in Prag, WS 1921/22-SS 1925.

74 UAP, PA Grohmann, Schreiben vom 20.05.1927.

75 Adolf Grohman n : Südarabien als Wirtschaftsgebiet 1-2 (Wien 1922, Brünn 1933).

76 UAP, PA Grohmann.

77 R. Levy, Rez. ohne Titel, in: Journal of the Royal Asiatic Society 4 (1934) $352 f$.
} 
ten sich auf die südarabischen Quellen, die er einerseits aus dem Blickwinkel der Epigrafik bearbeitete oder unter Zuhilfenahme späterer arabischer Quellen zu interpretieren versuchte. Auch wenn er bis zum Ende seiner Lehrtätigkeit Äthiopisch unterrichtete, so fand seine wissenschaftliche Beschäftigung mit der Äthiopistik mit der Edition von Marienhymnen I9I9 ihr Ende ${ }^{78}$. Die Beschäftigung mit der Sammlung Glaser fand ebenfalls ihren Niederschlag in Publikationen ${ }^{79}$. Mit Nikolaus Rhodokanakis ${ }^{80}$, dem Betreuer der Sammlung, stand Grohmann in engem Kontakt und widmete ihm einen für seine Verhältnisse warmherzigen Nachruf, in dem er dessen Arbeit für die Sammlung nach dem Tod von D. H. Müller hervorhob und sich langer Gespräche mit Rhodokanakis über die Inschriftenmaterialen erinnerte ${ }^{81}$.

V.

Trotz der Breite seiner Forschungen konzentrierte sich Grohmann ab den I $920 e r-J a h r e n$ bis zu seinem Lebensende vollkommen auf das Studium arabischer Papyri und den daraus resultierenden Erkenntnissen für andere Fächer, unter anderem als eine unschätzbare Quelle für die Wirtschaftsgeschichte, die ihm eine gewissermaßen vorislamische Wirtschaftsstruktur erschlossen, die durch die arabische Eroberung nicht zerstört worden war. Dabei schuf er bedeutende Editionen umfangreicher Bestände, die hier nur exemplarisch angeführt werden können, nämlich Papyri aus der Sammlung Erzherzog Rainer in Wien, aus dem Ägyptischen Museum in Kairo, aus den Staatlichen Museen in Berlin sowie die Sammlung seines Amtsvorgängers an der Papyrussammlung in Wien, C. Wessely ${ }^{82}$. An den Papyri erarbeitete eine allgemeine Einführung in die arabischen Papyri und mehrere grundsätzliche Aufsätze zur Papyrusforschung an sich. Auch privat lebte sich Grohmann mehr und mehr in seiner neuen Heimat ein und hatte als tschechoslowakischer Professor um die tschechoslowakische Staatsbürgerschaft anzusuchen; dem kam er I 927 nach $^{83}$.

78 Grohmann, Äthiopische Marienhymnen (wie Anm. 47).

79 Etwa: Adolf Groнmann, Zur Archäologie Südarabiens, in: Handbuch der altarabischen Altertumskunde, hg. v. Fritz Номmel, Nikolaus Rhodoкаna is (Kopenhagen 1927) 143-176.

80 Zu ihm vgl. F. Lochner v. Hüttenbach, Art. „Rhodokanakis Nikolaus“, in: ÖBL 9 (Wien 1988) 113f.

81 Adolf Grohmann, Nachruf Nikolaus Rhodokanakis, in: Almanach der ÖAW 96 (1946) 81-105.

82 Adolf Grohmann: Corpus Papyrorum Raineri III Series Arabica, 3 Teile in 2 Bd. (Wien 1923/24); Ders., Arabische Papyri aus den staatlichen Museen zu Berlin, in: Der Islam 22 (1934) 1-68; Ders., Arabic Papyri in the Egyptian Library 1-6 (Kairo 1934-1962); Ders., Arabische Papyri aus den Staatlichen Museen zu Berlin, in: Der Islam 22 (1934) 1-68; Ders., Arabische Papyri aus der Sammlung C. Wessely im Orientalischen Institute zu Prag, in: Archiv Orientální 10 (1938) 149-162; 11 (1940) 242-289; 12 (1941) 1-112; 14 (1943) 161-260.

83 Grohmann behauptete, dass er als Professor eigentlich das Anrecht auf die Verleihung der tschechischen 
Bereits I92 I hatte er geheiratet und war Vater zweier Kinder, Irmelin (geb. I922) und Erwin (geb. I923), geworden.

I 928 wurde auch an der (tschechischen) Karls-Universität ein Orientalisches Institut (Orientální ústav) gegründet. Dieses hatte den klaren Auftrag, sich vor allem den Wirtschaftsbeziehungen mit dem Orient zu widmen, womit es sich in der Aufgabenstellung stark von dem Seminar für semitische Philologie an der Deutschen Universität unterschied $^{84}$. Als Publikationsorgan des Instituts wurde die Zeitschrift Archiv Orientální gegründet, als dessen Hauptherausgeber Hrozný fungierte, Grohmann neben Musil, Rypka und anderen jedoch als Mitherausgeber aufschien und wohl auch Mitglied des Institutes wurde, das zu den monatlichen Institutssitzungen hinzugezogen wurde ${ }^{85}$. Grohmann nahm dokumentierterweise jedoch nur ein einziges Mal an einer Sitzung der Mitglieder des Institutes teil, und zwar am I4. April I93 I, als er über seine Reise nach Ägypten berichtete, auf der er den Grundstein zu seiner langjährigen Kooperation mit der äyptischen Nationalbibliothek legte, deren Papyri er im Laufe der Jahre er herausgab ${ }^{86}$.

Grohmann hatte mit der Unterstützung des Orientální ústav I930 eine Forschungsreise nach Ägypten unternommen. In der ägyptischen Nationalbibliothek erstellte er eine Liste von 600 Stücken, von denen er I 85 für die Publikation vorbereitete. In Verhandlungen mit dem Erziehungsministerium konnte er erreichen, dass er mit der Publikation dieser Papyri betraut wurde. Die Publikation sollte unter ägyptischer Leitung erfolgen ${ }^{87}$. Grohmann nutzte den Aufenthalt auch für Reisen nach Fayyum, einem der Hauptfundorte der Papyri aus der Sammlung Erzherzog Rainer, und stellte dort fest, dass die frühislamischen Städte mehrheitlich auf den Ruinen alter griechischer Städte errichtet worden waren und nicht dort, wo sich die Städte heute befinden. Auch nach der Schließung der Karls-Universität 1939 konnte die Zeitschrift Archiv Orientální weitergeführt werden. Sie

Staatbürgerschaft habe, außerdem habe er laut Auskunft der Gesandtschaft der Republik Österreich seine österreichische Staatsbürgerschaft verloren. UA Prag, Deutsche Universität, PA Grohmann, Schreiben vom 20.05.1927. Der Ausgang dieses Antrags ist nicht bekannt, fest steht lediglich, dass sich Grohmann unter Berufung auf seine österreichische Staatsbürgerschaft nach 1945 wiederum um Anstellung in Österreich bemühte.

84 Siehe dazu Zваviтеl, Orientalistik (wie Anm. 67). Der Autor nimmt nur auf das Institut der tschechischen Karls-Universität Bezug und nicht auf die Tätigkeiten Grohmanns und anderer deutschsprachiger Orientalisten in Prag.

85 Im Vorwort der ersten Ausgabe wurden die Ziele der Zeitschrift definiert: „The aim of the Czechoslovak Institute (Orientální ústav) in Prague (Praha) which has been founded by the munificent endowment of the President of the Czechoslovak Republic, T. G. Masaryk, on the occasion of his seventeenth birthday anniversary, is to start and keep scientific and economic relations with the Orient." Siehe: Archiv Orientální 1 (1929) o.S.

86 Archiv Orientální 3 (1931) 191.

87 Der erste Band der Papyri erschien bereits 1934: Grohman n, Arabic Papyri, 1 (wie Anm. 82). Im Vorwort des ersten Bandes, der König Fuad I. gewidmet ist, beschreibt er ebenfalls den Hergang dieser großen Unternehmung. 
wurde sogar den Krieg hindurch von Hrozný herausgegeben, wobei Grohmann weiterhin als Mitherausgeber auftrat. Dies wird damit zusammenhängen, dass man die Agenden des tschechischen Orientalischen Instituts Grohmann übergeben hatte ${ }^{88}$.

Der Papyrussammlung in Wien blieb Grohmann trotz seiner Berufung nach Prag verbunden. Er stand in engem Kontakt zu seinen Nachfolgern in der Papyrussammlung, dem früh verstorbenen Theodor Seif ${ }^{89}$ und den Koptologen Walter Till ${ }^{90}$. Weiters beteiligte er sich selbstverständlich an der Festschrift für die Nationalbibliothek $1926^{91}$ und verhandelte 1930 über einen Ankauf von einigen Hundert Papyri für die Bibliothek ${ }^{92}$. Dies dürfte er auch in weiterer Folge vermittelt haben, denn die Akten der Österreichischen Nationalbibliothek verzeichnen Grohmanns Vermittlung beim Ankauf von Papyri³.

VI.

Am 2. August 1939 wurde die Deutsche Universität in Prag in die Verwaltung des Deutschen Reiches übernommen. Nach der sogenannten brutalen „Sonderaktion Prag“, die dem Widerstand gegen die deutsche Besatzung folgte, wurde die tschechische Universität von den deutschen Machthabern im November 1939 geschlossen. Die Deutsche Universität bekam den Status einer „Frontuniversität“ zugesprochen und wurde für die Interessen des Rasse- und Siedlungshauptamtes eingespannt ${ }^{94}$. Allgemeine Aussagen zur Haltung der deutschen Professoren zu den politischen Ereignissen lassen sich laut Monika Glettler nicht machen, allerdings verblieb ihr Großteil eher passiv. „So läßt es sich erklären, daß sich die Hochschullehrer aus Angst vor den KZ's sowie als Überlebensstrategie und Selbstschutz durch geschicktes Lavieren zu behaupten versuchten, daß es aber kaum überzeugte Kollaborationen gab."95

Wo keine Tagebücher oder umfangreiche Privatkorrespondenz vorliegen, ist es schwierig bis unmöglich, Aussagen über Weltanschauung zu treffen. Auch erlaubt das vorhandene

88 MıšKova, Deutsche (Karls-)Universität (wie Anm. 62), 166.

$89 \mathrm{Zu}$ ihm vgl. H. Reitterer, Art. „Seif Theodor“, in: ÖBL 12 (Wien 2005) 134.

90 Loebenstein/Harrauer, Papyrussammlung (wie Anm. 28).

91 Adolf Groнmann, Bibliotheken und Bibliophilen im islamischen Orient, in: FS der Nationalbibliothek in Wien. Hrsg. zur Feier des 200jährigen Bestehens des Gebäudes (Wien 1926) 431-442. Nahegelegen hätte natürlich ein Beitrag über Papyri. Allerdings war Grohmann verhindert gewesen, den Artikel fertigzustellen, und so veröffentlichte er den ursprünglich als Festschriftartikel geplanten Artikel: Neue Beiträge zur arabischen Papyrologie, in: Anzeiger der phil.-hist. Klasse der ÖAW 85 (1948) 228-234.

92 Reinfandt, Papyrologist (wie Anm. 11) Anm. 10.

93 ÖNB, Archiv, Allgemeine Verwaltungs- und Korrespondentenakten, 38/1939.

94 Glettler, Professoren (wie Anm. 8) 15-24.

95 Ebd. 18. 
Material keine eindeutigen Schlüsse über Grohmanns Haltung zu den Nationalsozialisten und der deutschen Besetzung der Tschechoslowakei. Bestimmte Planungen und eine Reise Grohmanns im Oktober 1935 nach Berlin, wo er im Rahmen von Kontakten zur NOFG um reichsdeutsche Unterstützung für die Dozenten und Professoren der Deutschen Universität ansuchte, zeigen, dass er keine Berührungsängste mit dem nationalsozialistischen Deutschland besaß; und fest steht auch, dass Grohmann der NSDAP mit Wirkung vom I. Dezember 1938 beitrat und dass er weiters Mitglied der Deutschen Dozentenschaft, des Deutschen Kulturverbands, des Bundes der Deutschen und des NSKK war ${ }^{96}$. Der Parteieintritt Grohmanns erfolgte jedenfalls zu einem späten Zeitpunkt. Die deutschen Professoren wollten fast durchgehend der NSDAP beitreten, jedoch wurde jeder Antrag einzeln geprüft, auch wenn zuvor eine Mitgliedschaft der Sudetendeutschen Partei (SdP) vorgelegen hatte. Funktionäre und Mitglieder der SdP, die vor dem I 5. März I 938 die Mitgliedschaft besessen hatten, wurden aber bevorzugt. Insgesamt zwölf Lehrende traten mit dem I. Dezember 1938 der Partei bei und besaßen dadurch ein geringeres Ansehen, da man sie durchwegs für Opportunisten hielt, die aus Karrieregründen eine Parteimitgliedschaft angestrebt hatten ${ }^{97}$.

Unklar bleiben muss an dieser Stelle, ob Grohmann mehr als indirekt an der Schaffung des sogenannten „Jüdischen Zentralmuseums“ beteiligt war ${ }^{98}$. An diesem gespenstisch anmutenden Unternehmen, wo jüdische Wissenschaftler aus den Verlassenschaften der deportierten und vernichteten jüdischen Gemeinden aus Böhmen und Mähren ein Museum errichteten, das das Judentum nach seiner angestrebten vollständigen Vernichtung in gleichsam ethnografischer Weise dokumentieren sollte, hatte Grohmann vermutlich keinen gestalterischen Anteil, aber er las ab dem SS 1939 gemeinsam mit dem Privatdozenten Karl Jahn ${ }^{99}$ eine Vorlesung über „Die geschichtlichen Grundlagen der Judenfrage“ bzw. über „Die rassischen und geschichtlichen Grundlagen der Judenfrage“"100. Dirk Rupnow muss offen lassen, wie Grohmanns Verbindung zur SS war, allerdings befand sich das Orientalische Seminar teilweise in dem Gebäude der SS-Standortkommandantur und Grohmann hatte nachweislich auch Kontakt mit der SS. Das Seminar wurde wie andere

\footnotetext{
96 Zu 1935 siehe Ota Kon ráD, Dějepisectví, germanistika a slavistika na Německé univerzitě v Praze 19181945 [Geschichtsschreibung, Germanistik und Slavistik an der Deutschen Universität in Prag 1918-1945] (Praha 2011) 85. Die Mitgliedschaften bei MıšKová, (Karls-)Universität (wie Anm. 62) 300. Grohmanns Mitgliedsnummer lautete 6652055.

97 Ebd. 268.

98 Dazu ausführlich: Jan Björn Роттнаsт, Das jüdische Zentralmuseum der SS in Prag: Gegnerforschung und Völkermord im Nationalsozialismus (Berlin 2002); Dirk Rupnow, Täter - Gedächtnis - Opfer. Das „Jüdische Zentralmuseum“ in Prag 1942-1945 (Wien 2000).

$99 \mathrm{Zu}$ ihm vgl. J. T. P. De Bruijn, Art. „Jahn, Karl Emil Oskar“, in: Encyclopaedia Iranica, 14 (New York 2008) $391 \mathrm{f}$.

100 Rupnow, Täter (wie Anm. 98) 150, bes. Anm. 424.
} 
auch in die Reinhard-Heydrich-Stiftung eingegliedert, als dessen Leiter Grohmann ab I 943 in den Vorlesungsverzeichnissen aufschien ${ }^{101}$. Wieweit Grohmann eine aktive Rolle in diesem Institutsverband spielte, lässt sich derzeit nicht feststellen, zumal sein Personalakt an der Universität in Prag bereits I930 endet.

Die Biografie Grohmanns hält neben einem möglicherweise aus Opportunismus erfolgten Parteibeitritt auch Details bereit, die vermuten lassen, dass er nicht nur ein stiller Mitläufer war, sondern bereit war, mit dem Regime zu kooperieren, wenn er das Gefühl hatte, es könnte der Sache seines Instituts dienen. Zum einen betrifft das die zumindest unrühmliche Rolle Grohmanns im Zusammenhang mit dem Schicksal der deutsch-jüdischen Arabistin Hedwig Klein ${ }^{102}$. Peter Freimark hat in den I980er-Jahren noch mit Zeitzeugen gesprochen und die traurige Geschichte dieser deutschen Arabistin aufgeschrieben, der auch diese Darstellung folgt. Klein hatte von I93 I bis I935 in Hamburg Islamwissenschaft, Semitistik und Englische Philologie studiert. Obwohl Juden seit dem I 5. April I 937 nicht mehr zur Promotion zugelassen wurden, gelang es Klein, unter Berufung auf ihren im Ersten Weltkrieg gefallenen Vater sich zur Promotion anzumelden, und das Rigorosum konnte am I 8. Dezember I 937 stattfinden. Die Promotionsurkunde wurde Klein jedoch nicht mehr ausgestellt. Sie verließ daraufhin nicht das Land, auch wenn man ihr das nahelegte. Ihre beiden Lehrer Carl Rathjens ${ }^{103}$ und Arthur Schaade ${ }^{104}$ setzten sich für sie ein, über Rathjens Vermittlung bekam Klein eine wissenschaftliche Stelle in Bombay. Über ihren Reisevorbereitungen brach jedoch der Zweite Weltkrieg aus, und Kleins Schiff verließ Amsterdam nicht in Richtung Indien, sondern fuhr nach Hamburg zurück. Schaade vermittelte Klein daraufhin als wissenschaftliche Hilfskraft an das Wörterbuchprojekt von Hans Wehr ${ }^{105}$. I94I konnte Hedwig Klein noch von einem Abtransport in ein Konzentrationslager unter Berufung auf kriegswichtige Tätigkeit zurückgestellt werden, aber am I I. Juli 1942 wurde sie offenbar mit dem ersten Transport, der von Hamburg direkt nach Auschwitz ging, mitgeschickt. Dort verliert sich ihre Spur, wann sie in Auschwitz umgekommen ist, bleibt unbekannt.

101 Ebd. 148-150. und Andreas Wiedemann, Die Reinhard-Heydrich-Stiftung in Prag (1942-1945) (Hannah-Arendt-Institut für Totalitarismusforschung. Berichte und Studien 28, Dresden 2000) $50 \mathrm{f}$.

102 Peter Freimark, Promotion Hedwig Klein - zugleich ein Beitrag zum Seminar für Geschichte und Kultur des Vorderen Orients, in: Hochschschulalltag im „Dritten Reich“. Die Hamburger Universität 1933-1945, Teil II. Phil. Fak., hg. v. Eckart Krause (Berlin 1991) 853-864.

103 Vgl. den Nachruf von H. v. Wissman N, in: Der Islam 46,1 (1970) 55-63.

104 Vgl. den Nachruf v. Albert Dietrich, in: Der Islam 31,1 (1953) 1-3.

105 Autor des bekannten arabisch-deutschen Wörterbuches: Hans WEHR, Arabisches Wörterbuch für die Schriftsprache der Gegenwart (Erstauflage Leipzig 1952, zahlreiche bisher). Wehr schreibt in seinem Vorwort (VII) eine Danksagung: „Dankbar verwendete Beiträge z.T. von größerem Umfang stellten zur Verfügung [...], Fräulein Dr. H. Klein, [...].“Vgl. s. Nachruf von Wolfdietrich Fischer, in: Der Islam 59,1 (1982) $1-3$. 
Da Schaade und Rathjens glaubten, dass Klein nach Theresienstadt gebracht worden war, wandten sie sich an den Ordinarius für Semitistik in Prag, Adolf Grohmann, um Hilfe. Als Rathjens zum zweiten Mal an Grohmann schrieb, ob er so freundlich sein könne, sich nach Kleins Verbleib zu erkundigen, um sie weiter in dem Wörterbuchprojekt von Hans Wehr beteiligen zu können, beschied ihm Grohmann eine abweisende Antwort: „Grohmann antwortet mit einer ,Heil Hitler' grüßenden Postkarte vom 25. I 2. I 942 (Poststempel 25. I I. I942) halbherzig und teilt mit, daß er Nachricht geben wolle, wenn er etwas erfahren habe. Er fügt hinzu: ,Ich glaube aber nicht, dass eine weitere Mitarbeit der Genannten in Frage kommt, schon aus Prestigegründen. “" $106 \mathrm{Ob}$ Grohmann tatsächlich etwas für Hedwig Klein hätte tun können, ist ungewiss, seine Verweigerung, dies zu tun, ist jedoch bezeichnend für seine sonst nicht ausgesprochene politische Haltung. Es blieb nicht nur bei passivem Einverständnis für das Regime, Grohmann wurde auch aktiv für das NS-Regime tätig. I940 und I94I ließ Grohmann sich offenbar ohne großen Widerstand in die Requisition von jüdischen Buchbeständen involvieren. ${ }^{107}$ Bereits am I6. Mai I 940 besuchte er gemeinsam mit der Gestapo die jüdische Kultusgemeinde in Prag, wobei 20.000 Bände requiriert wurden, darunter auch einige Handschriften. Die Bücher wurden in der Ortskommandantur der SS untergebracht und vom Dozenten für Iranistik Karl Jahn, der an der Universitätsbibliothek arbeitete, geordnet ${ }^{108}$. In einem Bericht an den Rektor der Universität, Wilhelm Saure ${ }^{109}$, in dem er darüber hinaus eifrig auf weitere Möglichkeiten der Requisition hinwies, schrieb Grohmann am 25. März I94I über den Bücherraub an der Kultusgemeinde in MährischOstrau: Auftragsgemäß habe ich meine zur Besichtigung der Bibliothek der jüdischen Kultusgemeinde in Mährisch-Ostrau bestimmte Dienstreise am Sonntag, I6. März, angetreten und am Dienstag nachts beendet. Die in einem Lager aufgestellte Bücherei umfaßt 4800 Bände, und zwar Hebraica, Judaica, englische und romanistische Literatur sowie Belletristik. Die Hebraica und Judaica habe ich an Hand eines Verzeichnisses und nach Besichtigung zur Gänze übernommen, ebenso die Judaica. Aus der englischen, französischen und Werken der deutschen Literatur habe ich das Brauchbare und gut Erhaltene ausgewählt, u.zw. für das deutsche und romanische Seminar unserer Universität, und eine Gesamtkonsignation aller zu übernehmenden Werke aufgestellt; auf Grund dieser soll dann der Abtransport nach Prag erfolgen. Es wird sich hiebei um etwa 3000 Bücher handeln. Unter diesen befinden sich viele Werke, die nur schwer zu haben

106 Freimark, Promotion (wie Anm. 102) 857. Ellinger, Orientalistik (wie Anm. 6) 68-70. Damit unterschied sich Grohmann etwa von Harold Steinacker, der sich mit einem Brief für (den ihm gut bekannten) Arthur Stein einsetzte, siehe den Beitrag von Klaus Wachtel in diesem Band.

107 Ellinger, Orientalistik (wie Anm. 6) 163.

108 MiškovÁ, (Karls-)Universität (wie Anm. 62) 122.

$109 \mathrm{Zu}$ ihm vgl. Michael GrütTner, Biographisches Lexikon zur nationalsozialistischen Wissenschaftspolitik (Studien zur Wissenschafts- und Universitätsgeschichte 6, Heidelberg 2004) 145f.; MıšKova, (Karls-)Universität (wie Anm. 62) 96-149 und 315. 
sind, so daß eine entschiedene Bereicherung der Bestände meines Institutes bevorsteht. Ich habe mich beim Spediteur Weißhuhn in Mährisch-Ostrau gleichzeitig um die Transportkosten erkundigt und erfahren, daß diese bezüglich Ostrau-Prag etwa I6o RM betragen würden. Ich bitte daher, den Auftrag erteilen zu wollen, die Bücherei nach Prag zu überführen. Die SS setzt sich bereits diesbezüglich mit der Stapo Ostrau in Verbindung, doch ist dies lediglich Formsache. Alle Einzelheiten habe ich bereits mit NSKK-Oberstaffelführer Dr. Heinrich verabredet. Bei dieser Gelegenheit habe ich auch erfahren, daß über das Schicksal der Bibliothek der Kultusgemeinde in Brünn, die die Stapo beschlagnahmt hat, noch nichts entschieden ist. Es würde sich empfehlen, wenn wir grundsätzlich das Interesse der Karls-Universität hiefür bekanntgäben ${ }^{110}$.

VII.

Von diesen beiden Ereignissen abgesehen lassen sich keine weiteren Kooperationen Grohmanns mit dem deutschen Regime aus den Akten nachweisen, was aber auch mit der dünnen Aktenlage zusammenhängen mag. Zudem verhielt sich Grohmann unauffällig und änderte auch an seiner Unterrichtspraxis nichts, wie er auch während des Krieges weiterhin fleißig publizierte. Die Verbindung zur Nationalbibliothek in Wien riss während der Kriegsjahre nicht ab. Durch den Krieg wurden die Bestände der Papyrussammlung stark in Mitleidenschaft gezogen, bereits 1939 mussten die Ausstellungsräume geräumt werden. Grohmann konnte sich jedoch der Schwierigkeiten ungeachtet Papyri für seine Forschungen ausleihen, wie er es bereits seit seinem Weggang aus Wien getan hatte. I943 lieh er 2 7 Papyri aus, die über das Kriegsende hinaus im Panzerschrank des Orientalischen Instituts in Prag verblieben und erst nach langwierigen Verhandlungen I949 durch die tschechische Gesandtschaft in Wien an die Nationalbibliothek zurückerstattet wurden ${ }^{111}$.

Als immer mehr abzusehen war, dass der Zweite Weltkrieg nicht auf einen „Endsieg“ der Deutschen zusteuerte, entschloss sich Grohmann, nicht den Einmarsch der Roten Armee in Prag abzuwarten, sondern mit seiner Familie Böhmen zu verlassen. Dies tat er sehr überlegt. Bereits am I7. Februar 1945 richtete er einen ungeschminkten Brief an den Rektor der Deutschen Universität in Prag: [...] seit I9I4 habe ich aus allen Ländern Europas und der Übersee zur arabischen Diplomatik, Wirtschafts- und Rechtsgeschichte ein Urkundenmaterial in Photographien und Abschriften gesammelt, das in seiner Art als einzigartig be-

110 UAP, Akten des Rektors, zitiert nach: Gerhard Oвев коғLеR, Orchideenfächer im Faschismus, in: Jb. 1990 (Dokumentationsarchiv des österreichischen Widerstandes, Wien 1990) 45-49, hier 45.

111 Murray G. Hald, Christina Köst ner, „... allerlei für die Nationalbibliothek zu ergattern ...“ Eine österreichische Institution in der NS-Zeit (Wien/Köln/Weimar 2006) 374-378. ÖNB, Archiv, Allgemeine Verwaltungs- und Korrespondenzakten, 1139/1946 und 427/1947. 
zeichnet werden darf und schlechterdings unersetzlich ist, zumal die Originale zum Teil bereits nicht mehr existieren. Es sichert und ermöglicht Deutscher Forschung die führende Stellung auf diesem Wissensgebiete. Leider sind diese Bestände seit der Intensivierung der Luftangriffe der unmittelbaren Gefahr der Feindeinwirkung ausgesetzt, und so habe ich mich entschließen müssen, das Material nach Kärnten zu bringen [...] ${ }^{112}$. Es gelang ihm jedoch nicht, alle seine Manuskripte außer Landes zu schaffen, erst I949 wurden ihm die letzten Kisten aus dem Orientalischen Institut übergeben, jetzt allerdings stilisierte Grohmann sich zu einem Internationalisten, der seine Materialien im Interesse internationaler Forschung wieder in seinen Besitz bringen wollte ${ }^{113}$. Er selbst nutzte einen Forschungsaufenthalt in Österreich und quartierte sich bei seiner inzwischen verheirateten Tochter Irmelin ein. Genauso überlegt, wie er seine Flucht aus Böhmen betrieben hatte, bemühte er sich jetzt um die Wiedereingliederung in Österreich.

Von seinem neuen Quartier aus ließ sich Grohmann vonseiten des Orientalischen Institutes in Prag einen „Persilschein“ über sein Verhalten während der Zeit des Nationalsozialismus ausstellen: Professor Vincenc Lesný bestätigte ihm mit Schreiben vom 2. August I945: Die Direktion des Orientalischen Institutes in Prag III, Lazenska 4, bestätigt, dass Herr Professor Dr. Adolf Grohmann während der Kriegszeit als Direktor des Institutes dieses vor der Verschmelzung mit dem Deutschen Institute bewahrte, dass er für die finanzielle Sicherung des Institutes sorgte, dass er das Vermögen des Institutes ungeschmälert in die tschechischen Hände überführte und dass er in jedem Falle die Belange des Orientalischen Institutes zu dessen wissenschaftlichen Vorteil wahrte. Ferner bestätigt der jetzige Direktor des Institutes gerne, dass Herr Prof. Dr. Grohmann sich gegen uns, die tschechischen Mitglieder des Institutes, sich stets rücksichtsvoll und korrekt verhielt und dass er mit uns, den Angestellten, tschechisch sprach $^{114}$. In gleicher Weise äußerte sich Zdeněk Fafl: Ich bestätige gerne als damaliger Geschäftsführer des Orientalischen Institutes, dass Sie als Leiter des Institutes in der Kriegszeit stets die Interessen des Institutes vertreten und verteidigt haben. Sie sind für die Aufrechterhaltung des Institutes energisch eingetreten und haben die Gefahr der Auflösung des Institutes bzw. seiner Eingliederung in andere Institute abzuwenden gewusst. Sie haben auch für die finanzielle Selbständigkeit des Institutes gesorgt und dem Institute regelmässige Subventionen des Schulministeriums gesichert, so dass das Vermögen des Institutes ungeschmälert erhalten werden konnte. Dadurch wurde ermöglicht, dass das Institut seine wissenschaftliche Tätigkeit in der Kriegszeit fortsetzen und seine Publikationen weiter herausgeben konnte. Ich benütze

112 BAB, R 31/548; Ellinger, Orientalistik (wie Anm. 6) 73, hier zit. nach Reinfandt, Papyrologist (wie Anm. 11).

113 Sie [die Lebensarbeit Grohmanns bzw. die Bearbeitung der Materialien] hat effektiv internationalen Charakter und dient der internationalen Wissenschaft. AÖAW, phil.-hist. Kl., PA Grohmann, Schreiben Grohmanns an den Generalsekretär der ÖAW, Joseph Keil, vom 28.07.1948.

114 AÖAW, phil-hist. Kl., PA Adolf Grohmann, Schreiben vom 02.08.1945. 
die Gelegenheit, um Ihnen, sehr geehrter Herr Professor, für die loyale Zusammenarbeit in den letzten Jahren herzlich zu danken und Ihnen meine besten Wünsche für die Zukunft und Ihre weitere wissenschaftliche Tätigkeit auszusprechen ${ }^{115}$. Auch wenn beide Schreiben bis auf den etwas herzlicheren letzten Satz des zweiten sich merkwürdig formelhaft auf ähnliche Inhalte beziehen, so erreichte Grohmann doch nach einigen Jahren die Rückgabe seiner Arbeitsmaterialien aus Prag, wobei er nicht davor zurückscheute, die Gremien der ÖAW, deren korrespondierendes Mitglied er seit 1937 war, in Anspruch zu nehmen ${ }^{116}$.

Grohmann versuchte nun, an einer österreichischen Universität Fuß zu fassen. Im Oktober 1945 richtete er ein schriftliches Gesuch an den Dekan der Philosophischen Fakultät in Innsbruck: Infolge der Ereignisse des 8. Mai I945 in Prag hat die Tätigkeit der deutschen Professoren der Prager Karlsuniversität, der ich als Ordinarius für semitische Philologie und Kulturgeschichte des Orients angehörte, ein Ende gefunden. Ich bin daher mit meiner Familie zu meiner verheirateten Tochter hierher übersiedelt, nachdem ich noch durch die Prager österreichische Gesandtschaft ein Gesuch um Wiedereinstellung in den österreichischen Staatsdienst an das Staatsministerium für Unterricht und Kultus in Wien I gerichtet hatte, wie dies auch die wenigen anderen Kollegen, die ebenfalls Österreicher sind, getan haben. Ich habe ja vor meiner Berufung nach Prag als Dozent für Sprachen und Altertumskunde des vorderen Orients und Leiter der orientalischen Abteilung der Papyrussammlung der Nationalbibliothek seit I9I6 im österreichischen Staats- bzw. Bundesdienst gestanden (Ich bin am I.3.I887 in Graz geboren und dort heimatberechtigt). Es würde mir eine besondere Freude sein, meine Lehrtätigkeit an Ihrer Fakultät wieder aufnehmen zu können, um die Nachfolge meines lieben, leider von uns gegangenen Freundes August Haffner anzutreten. Dem Vernehmen nach ist sein Lehrstuhl ja noch frei, und ich wäre bereit, ihn schon in diesem Wintersemester zu übernehmen, wenn die philosophische Fakultät diesen Wunsch äußert. [...] Ich darf bei dieser Gelegenheit wohl daran erinnern, daß Haffner schon einige Jahre vor seinem Tode daran gedacht hat, mich neben seiner Lehrkanzel für einen zweiten orientalistischen Lehrstuhl in Vorschlag zu bringen und mich auch für seine eigene Nachfolge nach Erreichung der Dienstgrenze in Aussicht genommen hatte $[\ldots]^{117}$.

Manches an diesem Schreiben ist bemerkenswert: Die Selbstverständlichkeit, mit der Haffners Nachfolge für sich reklamiert wurde und die vollkommene Ignorierung der Veränderung der Umstände durch einen verlorenen Krieg, im Zuge dessen sich Grohmann mit

115 Ebd.

116 AÖAW, phil-hist. Kl., PA Adolf Grohmann.

117 UAI, PA Grohmann, Schreiben vom 03.10.1945. Ein ganz ähnliches Schreiben richtete Grohmann auch an die Universität Wien, hier seine Vorzüge in Betreff der Papyrussammlung der Nationalbibliothek herausstreichend, sowie die Tatsache, dass er seit 1937 Mitglied der ÖAW war. UAW, PA Grohmann, Schreiben vom 02.08.1945, fol. 40 . 
dem nun abgesetzten Regime hervorragend arrangiert hatte. August Haffner ${ }^{118}$ war einige Jahre vor Grohmann mit einer Dissertation über ein arabistisches Thema promoviert wor$\operatorname{den}^{119}$. Ab I 906 lehrte er an der Universität Innsbruck. Sein Hauptinteresse bestand neben der arabischen Lexikografie auch in der Bearbeitung der äthiopischen Überlieferung des Hexaemerons des Heiligen Epiphanius von Zypern, wovon das fast fertiggestellte Manuskript jedoch verschollen blieb. Die Verbundenheit Grohmanns mit der Äthiopistik zu Beginn seiner Karriere lassen Kontakte zwischen den beiden sehr wahrscheinlich werden. Nur hatte sich Grohmann im Laufe der Zeit mehr oder weniger vollständig von der Äthiopistik abgewandt. Die Fakultät fasste gleichwohl auf der Basis von Grohmanns Ausführungen am 9. November 1945 den Beschluss, den Besetzungsvorschlag für das seit dem Ausscheiden von Prof. August Haffner vakante Ordinariat für Semitische Sprachen zu machen ${ }^{120}$. Das zuständige Ministerium lehnte jedoch die Wiederbelebung der Lehrkanzel an der Universität Innsbruck aus budgetären Gründen ab.

Daraufhin beantragte die Fakultät im Juli I 947 erneut die Besetzung der Lehrkanzel, als Interimslösung aber auf jeden Fall die Erteilung eines Lehrauftrages im Umfang des Lehrdeputats eines Ordinarius: Da in Wien der Wunsch geäussert wurde, Professor Dr. Grohmann solle sich auch der Papyrussammlung der Nationalbibliothek annehmen, so wird weiter beantragt, dass er die Vorlesungen an der Innsbrucker Universität jeweils im Winter-Semester abzuhalten hätte und im Sommer-Semester für die Tätigkeit an der Nationalbibliothek beurlaubt sein würde ${ }^{121}$. Auch wenn sich Grohmann bald darauf um die Erteilung der Venia docendi an der Innsbrucker Universität bemühte ${ }^{122}$, scheiterte auch dieser Plan, Grohmann an diese Universität zu bringen. Grohmanns finanzielle Situation kann durchaus prekär gewesen sein zu dieser Zeit, eine Pension erhielt er frühestens ab I 953 auf der Basis des sogenannten Gmundner Abkommens ${ }^{123}$. I 949 besserte sich Grohmanns Lage, als er von der Faculty of Arts der Fuad I University in Kairo in der Eigenschaft als Gastprofessor auf den Lehrstuhl für islamische Geschichte und Archäologie berufen wurde.

118 Zu ihm Art. „Haffner August Otto Wilhelm“, in: ÖBL 2 (Wien 1959) 141.

119 UAW, Phil.Rig.Akten PN 715.

120 UAI, PA Grohmann, Schreiben vom 10.11.1945.

121 Ebd. Schreiben vom 15.07.1947.

122 Ebd. Schreiben vom 21.07.1947.

123 Dieses Abkommen vom 27.04.1953 regelte die Pensionsversorgung ehemals deutscher Beamter, die entweder während des Zweiten Weltkrieges oder danach nach Österreich gekommen waren. Vgl. Manuela Hoffmann, Entstehung und wirtschaftliche Konsequenzen des deutsch-österreichischen Vermögensvertrages (Unpubl. Diss. Kassel 2007). Online abrufbar: http ://deposit.ddb.de/cgi-bin/dokserv?idn=991042476\&dok_var=d1\&dok_ext=pdf\&filename=991042476.pdf [21.03.2010]. 
VIII.

Die heute Cairo University genannte Hochschule war I 908 als private Universität gegründet worden und 1925 bereits verstaatlicht worden. Trotz der Berufung nach Kairo hielt Grohmann an der Idee zumindest einer Gastprofessur in Innsbruck fest. Ab I950 unterrichtete er dort, kam jedoch bald mit seinem Lehrauftrag in Kairo in Konflikt, weshalb er für die WS I950/5I und I951/52 um Karenz ohne Bezüge bat ${ }^{124}$. Grohmanns gute Verbindungen nach Kairo ermöglichten auch die Anstellung des ägyptischen Professors Murad Kamil für ein Gastsemester an der Universität Innsbruck ${ }^{125}$. Kamil teilte nahezu alle seine Forschungsinteressen mit denen Grohmanns und publizierte im Anschluss an seine Tätigkeit in Österreich und in Deutschland ${ }^{126}$. Grohmann hatte bereits in Prag arabischen Gelehrten die Möglichkeit vermittelt, als Gastprofessoren bzw. Assistenten im Ausland zu arbeiten. I954 erhielt Grohmann in Innsbruck einen siebenstündigen Lehrauftrag für jedes SS ab I955 im Themenbereich „Semitistik mit besonderer Berücksichtigung der arabischen Paläografie ${ }^{127}$. Als Grohmanns Lehrauftrag an der Cairo University auslief, beantragte man vonseiten der Fakultät einen siebenstündigen Lehrauftrag für jedes Semester unter der Bezeichnung Arabisch und Korankunde. Bereits 1949 hatte Grohmann in seinen Anträgen für die Erteilung eines Lehrauftrages bekanntgegeben, welche Lehrveranstaltungen er zu halten beabsichtige: Auf dem Gebiet der reinen Philologie wollte er Einführungen in das Hebräische, Arabische, Äthiopische bieten, hinzu kamen Spezialvorlesungen über arabische Syntax, das Neuarabische sowie Einführungen in die arabische und äthiopische Literaturgeschichte. In das Gebiet der klassischen Historischen Hilfswissenschaften lassen sich Grohmanns Vorlesungen über semitische Epigrafik, arabische Paläografie, Numismatik und Sphragistik sowie arabische Diplomatik und islamische Chronologie einordnen. Darüber hinaus las Grohmann auch über arabische Geschichte und Kunstgeschichte, wobei einzuschränken ist, dass er diese nur bis zum Sturz des Abbasidenkalifats I 258 führte, dies durchaus im Geist der Zeit, der die arabische Geschichte mit dem Mongoleneinfall des I3. Jahrhunderts enden ließ und die folgenden Jahrhunderte als durch Türken und Perser verfremdet betrachtete. Zu den historischen Vorlesungen traten eine ganze Reihe von Übungen zu vergleichender Textlektüre in verschiedenen Sprachen ${ }^{128}$. 1962 erlosch Grohmanns Lehrbefugnis an der Universität Innsbruck, weil

124 UAI, PA Grohmann, Schreiben vom 02.07.1950 und 30.08.1951.

125 Ebd. Schreiben vom 19.01.1952.

126 Murad Kamil, Amharische Kaiserlieder (Wiesbaden 1957); Ders., Aspects de l'Égypte copte (Berlin 1965); DERS., Catalogue of all manuscripts in the Monastery of St. Catherine on Mount Sinai (Wiesbaden 1970), um nur einige zu nennen.

127 UAI, PA Grohmann, 29.11.1954.

128 Ebd. Verzeichnis der Vorlesungen, um 1949. 
er das 75 . Lebensjahr vollendet hatte ${ }^{129}$. Grohmanns Versuch, eine weiterführende Finanzierung für seine Forschungen zu erhalten, wurde vom Ministerium mit der Begründung abgelehnt, dass er über ein ausreichendes Einkommen verfüge ${ }^{130}$.

I96I wurde Grohmann in vertraulicher Wahl zum wirklichen Mitglied der ÖAW gewählt. Die Antragsteller meinten Grohmann durchaus etwas Gutes tun zu müssen, hatte er es doch in Innsbruck in den Jahren nach dem Krieg nicht so einfach gehabt: Die erfolgte Vermehrung der Zahl der wirklichen Mitglieder böte nun die erwünschte Gelegenheit, die Leistungen dieses international anerkannten österreichischen Gelehrten durch die Wabl zum wirklichen Mitglied zu würdigen ${ }^{131}$.

In den I96oer-Jahren publizierte Grohmann weiterhin kontinuierlich, darunter auch mehrere Arbeiten monografischen Umfangs, die in Handbüchern oder Sammelreihen veröffentlicht wurden. Dazu zählen das Werk „Arabien“, das eine Zusammenschau der Forschungen Grohmanns zum alt-südarabischen Raum bot ${ }^{132}$, und weiters seine Beiträge zu arabischer Chronologie und arabischer Papyruskunde, die im Handbuch der Orientalistik erschienen ${ }^{133}$. Darüber hinaus veröffentlichte Grohmann die Papyri der Gießener Universitätsbibliothek ${ }^{134}$. Obwohl Grohmann Böhmen hatte verlassen müssen, publizierte er dennoch weiter in der Zeitschrift Archiv Orientální, so auch in der Ausgabe, die als Festschrift für Bedřich Hrozný diente ${ }^{135}$. Eine Zusammenschau seiner Tätigkeit auf dem Gebiet der Papyrologie publizierte er ebenfalls in Prag, seine „Einführung und Chrestomathie zur arabischen Papyruskunde“136, in der er das nötige Handwerkszeug präsentierte. Eine Geschichte der Funde und Fundstätten sowie eine Beschreibung der bedeutenderen Papyrussammlungen leiten das Buch ein. Grohmann gab eine hilfswissenschaftliche Einführung zu den Schreibmaterialien, der Schrift und Sprache der Papyri, zur Diplomatik von Papyrusurkunden und zu Nachbarwissenschaften wie Numismatik und Chronologie. Kleinere Arbeiten veröffentlichte Grohmann in diversen Festschriften ${ }^{137}$,

129 Ebd. Schreiben vom 19.07.1962.

130 Ebd. Schreiben vom 15.11.1962.

131 AÖAW, phil-hist. Kl., PA Adolf Grohmann, Wahlunterlagen, Zl. 563/61.

132 Adolf Groнmann, Arabien (Handbuch der Altertumswissenschaft Abt. 3. 3,1 = Kulturgeschichte des Alten Orients 3,4, München 1963).

133 Adolf Groh mann, Arabische Chronologie 2. Arabische Papyruskunde. Mit Beiträgen von Joachim May R und Walter C. Till (Handbuch der Orientalistik Erg.-Bd. 2,1, Leiden 1966).

134 Adolf Groh mann, Die arabischen Papyri der Gießener Universitätsbibliothek. Texte aus den Sammlungen Papyri Bibliothecae Universitätis Gissensis (Gießen 1960).

135 Adolf Groнmann, Einige bemerkenswerte Urkunden aus der Sammlung der Papyrus Erzherzog Rainer an der Nationalbibliothek zu Wien, in: Archiv Orientální 18/3 (1950/51) 80-119.

136 Adolf Grohmann, Einführung und Chrestomathie zur arabischen Papyruskunde (Monografie Archiv Orientální 13, Prag 1954).

137 Etwa: Adolf Grohmann, Die Bronzeschale M. 388-1911 im Viktoria-und-Albert-Museum, in: Aus der 
genauso wie er sich in mehreren Publikationen an der Zeitschrift „Bustan“ beteiligte, die von der Österreichischen Orient-Gesellschaft Hammer-Purgstall in Wien für ein breiter angelegtes Publikum ins Leben gerufen worden war ${ }^{138}$.

Berühmt auch über die Kreise der Spezialisten der arabischen Papyrologie hinaus wurde Grohmann jedoch mit seinem zweibändigen Werk über arabische Paläografie, das als das Ergebnis jahrzehntelangen Sammelns und Ordnens betrachtet werden kann ${ }^{139}$. Wie weit die Arbeit Grohmanns an diesem Themengebiet zurücklag, äußerte er selbst in seinem Vorwort zum ersten Teil. Wesentliche Inspiration zu dem Thema hatte er durch die Vorlesungen Karabačeks erhalten. Den Mangel an einem umfassenden Handbuch zur arabischen Paläografie zu beheben wurde Grohmanns Wunsch spätestens zu dem Moment, als er im März I9I7 die arabische Papyrussammlung in Wien zur Betreuung bekam: „,...] da wurde mir bald klar, welch bestimmende Rolle diesem Material für die Entwicklung der Geschichte der arabischen Schrift zukam. "140 Umfangreiche Sammeltätigkeit hatte Grohmann neben Wien an die großen Papyrussammlungen in Berlin, Gießen, Hamburg, Kairo, London und Oxford geführt. In den Urkunden fand Grohmann den Schlüssel zur paläografischen Systematisierung der arabischen Schrift, da die Frage der Schriftentwicklung bei Urkunden-, Inschriften- sowie Buchschriften bei der arabischen Schriftkunde ähnlich sei. „In den arabischen Urkunden tritt uns nämlich - wenigstens zunächst und in alter Zeit - nicht etwa eine bestimmte Art Schrift entgegen, etwa eine ausschließlich oder auch nur hauptsächlich für Urkunden verwendete Urkundenschrift, sondern wir finden in Handschriften und Urkunden dieselben Schriften verwendet" ${ }^{141}$.

Grohmann versuchte aus einer größtmöglichen Zahl an beobachteten Einzelfällen allgemeine Erkenntnisse und gültige Leitsätze zu gewinnen, ein Verfahren, das er als induktiv bezeichnete. Allgemeine Sätze könnten so aufgestellt werden und mit den Beispielen verifiziert werden. Wenngleich sich alle Rezensenten über den Meilensteincharakter von

Welt der Islamischen Kunst. FS für Ernst Kühnel (Berlin 1959) 125-138; DERs., Die Bronzeschale M. 31-1954 im Victoria-und-Albert-Museum, in: Beiträge zur Kunstgeschichte Asiens. In Memoriam Ernst Diez (Istanbul 1963) 283-287; DERs., Der Beamtenstab der arabischen Finanzverwaltung in Ägypten in früharabischer Zeit, in: Studien zur Papyrologie und antiken Wirtschaftsgeschichte. Friedrich Oertel zum 80. Geburtstag gewidmet, hg. v. Horst Braunert (Bonn 1964) 120-134; Ders., Die Bauinschrift der Moschee des Ahmad Ṭūlūn (265/879), in: Studies in Islamic art and architecture in honour of K.A.C. Creswell (London 1965) 84-93.

138 Adolf Grohmann, Die Entstehung des Koran und die ältesten Koran-Handschriften, in: Bustan (1961) 33-38; DERs., Die dekorative Rolle der arabischen Schrift, in: Bustan (1962) 35-41; DE Rs., Die frühislamische Besiedlung Nordafrikas durch die Araber, in: Bustan (1967) 3-7.

139 Adolf Grohmann, Arabische Paläographie 1-2 (ÖAW Denkschriften 94,1-2, Graz/Wien/Köln 19671971).

140 Ebd. 1 VII.

141 Ebd. 12. 
Grohmanns Werk einig waren, so stieß die Beliebigkeit des Materials auf gewisse Kritik $^{142}$. Auch konnte Grohmann nicht sein gesamtes Material verwenden. Der erste Teil der Arabischen Paläographie ist vor allem kulturgeschichtlich interessant, weil er eine genaue Analyse der Behandlung der arabischen Schrift im arabischen Schrifttum vornimmt. Der größere Teil nimmt die Behandlung der Frage nach den Beschreibstoffen, den Schreibstoffen usw. ein, was überhaupt erst eine Einleitung zur eigentlichen Schriftgeschichte darstellte. Im zweiten Band beleuchtete Grohmann, durch immerhin 269 Abbildungen und 66 Tafeln unterstützt, die Entwicklung der Inschriften-Paläografie. Das Hauptgewicht lag jedoch auf der Küfī-Schrift, die Schriften Nashīi und Tulut wurden auf wenigen Seiten abgehandelt. Die Buchschrift wurde einem dritten Band vorbehalten, den Grohmann nur noch zu einem kleinen Teil bearbeiten konnte, da er am 2 I. September 1977 im Alter von 90 Jahren starb. Seine Frau Maria war bereits am 5. April I 970 gestorben, von ihm betrauert als die Gefährtin, die über nahezu so Jahre jedes seiner Manuskripte gelesen hatte ${ }^{143}$. Mit der Tochter Irmelin wurde die Überlassung des wissenschaftlichen Nachlasses Grohmanns an die Österreichische Akademie der Wissenschaften vereinbart, bis auf die Dubletten aus der Bibliothek Grohmanns, die an die Tochter in die Schweiz überstellt wurden ${ }^{144}$.

Der dritte Band der Arabischen Paläographie, der sich nunmehr mit der Buchschrift befassen sollte, blieb unvollendet. Hans Gottschalk berichtete als Obmann der Arabischen Kommission, dass das 88 Seiten umfassende Manuskript samt den Abbildungen in dieser Form nicht für eine Drucklegung geeignet sei und in der Bibliothek der Akademie verwahrt bleiben sollte ${ }^{145}$. I98 I wandte sich die deutsche Orientalistin Annemarie Schimmel $^{146}$ an den Generalsekretär der ÖAW, Manfred Mayrhofer. Sie habe sich die Materialen des dritten Bandes der Arabischen Paläographie bei der Tochter in der Schweiz abgeholt und wolle daraus ein „schönes Buch“ machen ${ }^{147}$. Skeptisch äußerte sich zu diesem Vorhaben Raif Khoury, ein deutscher Papyrologe, der den unfertigen dritten Teil der Paläografie nur in die Hände von einschlägigen Experten legen wollte ${ }^{148}$. Nachdem kein auswärtiger Mitarbeiter dafür finanziert werden konnte, unterblieb das Unternehmen der Herausgabe des dritten Bandes der Arabischen Paläographie schließlich.

142 So z.B., Simon Digby, in: Bulletin of the School of Oriental and African Studies 37,2 (1974) 524.

143 Grohmann, Arabische Paläographie 2 (wie Anm. 139), Frontispiz und Vorwort.

144 AÖAW, Benutzermappe Bestand Grohmann, Schreiben vom 27.04.1979.

145 Ebd. Schreiben vom 16.01.1978.

146 Der Schwerpunkt ihrer Forschung befand sich auf dem Gebiet der arabisch-indo-persischen mystischen Dichtung und nicht auf dem Gebiet der Historischen Hilfswissenschaften.

147 AÖAW, phil.-hist. Klasse, PA Grohmann, Schreiben vom 21.09.1981.

148 Ebd. Schreiben vom 25.08.1980. 
IX.

Adolf Grohmann lebte ein langes, fleißiges Gelehrtenleben, das einige Zäsuren aufweist. Geboren in die Spätphase der Habsburgermonarchie, erlebte er die erste große europäische Katastrophe des 20. Jahrhunderts, den Ersten Weltkrieg, in der relativen Absicherung einer Stelle an der Hofbibliothek, die nach der Gründung der Österreichischen Republik zur Nationalbibliothek wurde. Trotz der schwierigen Nachkriegssituation durfte Grohmann damit rechnen, das wissenschaftliche Erbe seines Lehrers Karabaček antreten zu dürfen. Seine Berufung an die Deutsche Universität in Prag machte diesen Warteprozess unnötig. In Prag forschte und lehrte Grohmann unbehelligt und unangefochten durch 25 Jahre. Das Ende des Zweiten Weltkrieges bedeutete nun eine Katastrophe für Grohmann. Als Deutscher und Nationalsozialist verließ er Böhmen, wo er nahezu sein halbes Leben verbracht hatte, und bekam in der Folge keine feste Anstellung an einer Universität, auch wenn er bis zu seinem 75. Lebensjahr in Innsbruck und in Kairo lehrte. Mit dem Verlust seines Sohnes Erwin in den letzten Kriegsmonaten bezahlte Grohmann selbst einen hohen persönlichen Preis. Seine politische Weltanschauung lässt sich nicht genau bestimmen, sein Hang zu politischem Opportunismus und die Wendigkeit, sich den jeweiligen politischen Situationen anzupassen, werden aus seinen Schreiben sichtbar ${ }^{149}$. Grohmanns politische Ansichten sowie seine Haltung zum Nationalsozialismus sind durch eigene Aussagen nicht belegt. Allerdings lässt seine offenbar willige Bereitschaft, sich an Requisitionen jüdischen Eigentums der Kultusgemeinden in Prag und Mährisch-Ostrau darauf schließen, dass er die Verhältnisse eher schätzte als ablehnte, sie jedenfalls für „sein“ Institut zu nutzen wusste. Von einem passiven Rückzug Grohmanns während des NS-Regimes kann nach allem keine Rede sein, sondern von einem Ausnutzen gebotener oder erstrittener Handlungsspielräume ${ }^{150}$. Nach dem Zweiten Weltkrieg hüllte sich Grohmann jedenfalls, wie so viele andere, in Schweigen über seine eigene Vergangenheit. Diese Widersprüchlichkeiten bleiben jedoch nicht nur bei Grohmann selbst zurück. Es scheint rückblickend

149 Ellinger macht hier spürbar seinem Ärger Luft, wenn er Grohmanns Bemühungen, seine Forschungsmaterialien nach dem Krieg zu retten, mit seinem Verhalten während des Krieges gegenüberstellt: „Es gehört zu den besonderen Perversionen eines Vertreters des geisteswissenschaftlichen Rationalismus, daß er, der zuvor noch ohne Skrupel einen Menschen [gemeint ist Hedwig Klein] dem nationalsozialistischen Prestige geopfert hatte, nichts anderes im Sinn hatte, als sein Forschungsmaterial in Sicherheit zu bringen. "Ellinger, Orientalistik (wie Anm. 6) 73.

150 Das Beispiel Grohmanns widerlegt durchaus, zusammen mit vielen anderen, die oben zitierte Aussage Monika Glettlers, wonach es an der Deutschen Universität in Prag „kaum überzeugte Kollaborationen“ mit dem Regime gegeben hätte, vgl. zusätlich auch die relevanten biografischen Porträts in: Prager Professoren 1938-1948 (wie Anm. 8) ; Österreichische Historiker 1900-1945 (wie Anm. 1); Karel Hruza, „Wissenschaftliches Rüstzeug für aktuelle politische Fragen. "Kritische Anmerkungen zu Werk und Wirken der Historiker Wilhelm Weizsäcker und Wilhelm Wostry, in: ZfO 54 (2005) 475-526. 
bizarr, wenn zwei Hamburger Weggefährten der jüdischen Studentin Hedwig Klein, nämlich Hans Gottschalk und Albert Dietrich, später, als sie gewiss Kenntnis bekommen hatten von sowohl Kleins traurigem Schicksal als auch von Grohmanns Unwillen, ihr zu helfen, ihrerseits nur warmherzige Worte über Grohmann fanden, Dietrich in seiner Glückwunschadresse an Grohmann anlässlich seines 70. Geburtstages ${ }^{151}$ und Gottschalk in seinem Nachruf auf Grohmann ${ }^{152}$. Zu alledem hatte Hans Gottschalk als Jude Hamburg verlassen müssen, um der Verfolgung zu entgehen. Später äußerte er als Ordinarius für Arabistik in Wien Verständnis für Grohmanns Lage nach dem Zweiten Weltkrieg. Dass dies allgemein so praktiziert wurde, die NS-Affinität in der Regel zu verschweigen, hat Ellinger deutlich vorgeführt ${ }^{153}$.

Grohmann widmete nahezu seine gesamte Lebensenergie der Arbeit. Wie ernsthaft und genau er diese betrieb, ist aus seinen zusammenfassenden Arbeiten ersichtlich, die allesamt monografischen Charakter haben. Der Hauptakzent lag bei Grohmann wohl mehr auf der Forschung als auf der Lehre. Seine Lehre schrieb (zumindest von den Titeln her) die Themen seiner eigenen Lehrer fort, und er hat auch keinen fassbaren Schülerkreis aufgebaut. Inhaltlich half ihm die Lehre fraglos, das in rastloser Sammeltätigkeit zusammengetragene Material zu monografischen Überblicken zu formen. In den Beurteilungen seiner Schriften in Rezensionen wird Grohmann als fleißiger, gewissenhafter Wissenschaftler gelobt. Ob er darüber hinaus durchwegs beliebt war, lässt sich nicht gänzlich beantworten. Eine kurze Notiz in einem Briefwechsel zwischen Heinz Zatschek, Professor für Mittelalterliche Geschichte und Historische Hilfswissenschaften in Prag, und seinem Kollegen Hans Hirsch in Wien macht dies deutlich: Zatschek teilte Hirsch mit, er habe in den Jahren 1929, I930 von Kollegen allerhand über Grohmann gehört, was für diesen belastend ist, und bat um ein Urteil, ob unter diesen Umständen Grohmann für [das Amt des Universitätsrektors] tragbar wäre. Hirsch wollte die Vergangenheit Grohmanns auf sich beruhen lassen, aber vielleicht hatten diese Gerüchte doch die Auswirkung, dass Grohmann nicht zum Rektor der Deutschen Universität in Prag gewählt wurde. ${ }^{154}$

Grohmann, der sich von den Disziplinen der Geschichtswissenschaft und der Orientalistik sein Rüstzeug geholt hatte, bewegte sich an einer schmalen Schnittstelle der beiden

151 Albert Dietrich, Glückwunsch zum 70. Geburtstag von Professor Adolf Grohmann, in: Der Islam 33,1-2 (1957) 1f. Dieses Heft diente gleichzeitig als eine Art Festschrift. Dietrich hatte Peter Freimark in einem Brief von 22.06.1986 seine Erinnerungen an Hedwig Klein mitgeteilt. Freimark, Promotion (wie Anm. 102) Fn. 3 .

152 Gottschalk, Grohmann (wie Anm. 11).

153 Ellinger, Orientalistik (wie Anm. 6) 444.

154 Schreiben vom 16.02.1938 (IÖG, Archiv, NL Hans Hirsch) und vom 25.02.1938 (AAVČR, Osobní fond Heinz Zatschek, Inv.-Nr. 188). Den Hinweis auf die beiden Briefe verdanke ich Karel Hruza, wofür ich mich herzlich bedanke. 
Fächer und wurde somit beim fortschreitenden Auseinanderdriften der Fächer in beiden eigentlich zum Außenseiter. Die Orientalisten nahmen ihn als Historiker wahr, die Historiker als Philologen. Das könnte der Grund sein, warum Grohmann heute nicht in dem $\mathrm{Maß}$ gewürdigt wird, wie das vergleichbaren Orientalisten zukommt. Grohmann gehört zu einer Gruppe von Wissenschaftlern, die, ungemein gebildet und belesen, komplexe Wissensgebiete mit großer Übersicht bewältigten. Sein Fach verlor im Laufe seiner Karriere stark an Bedeutung, genauso wie die selbstverständliche Sicherheit in benachbarten Fachrichtungen den immer mehr sich spezialisierenden Wissenschaften verloren ging. 


\title{
Karl Maria Swoboda (I889-I977)
}

\author{
„VON EINEM KULT URGESCHICHTLICH-BIOLOGISCHEN \\ PERSPEKTIVISMUS HER“ 1
}

Sie können sich die Freude vorstellen, dass ich Nachfolger Max Dvoŕáks werde, schrieb der Kunsthistoriker Karl Maria Swoboda ${ }^{2}$ im April 1946 von Wien aus an einen tsche-

1 Karl Maria Swоводa, Die gegenwärtige Lage der Menschheit (Typoskript 106 S.) 105, Institut für Kunstgeschichte der Universität Wien, Archiv. Zu diesem Text siehe auch Aurenhammer, Zäsur (wie Anm. 2) 51f. Hans H. Aurenhammer danke ich für die großzügige Zusendung einer Kopie. - Vorliegender Beitrag entstand im Zusammenhang mit dem von der Deutschen Forschungsgemeinschaft geförderten Projekt „Kunsthistoriographien im gesellschaftspolitischen Umbruch: Kunstgeschichte in Böhmen und Mähren 1930 bis 1950“ am Kunstgeschichtlichen Seminar der Humboldt-Universität zu Berlin. Für Literaturhinweise und sorgfältige Redaktion herzlichen Dank

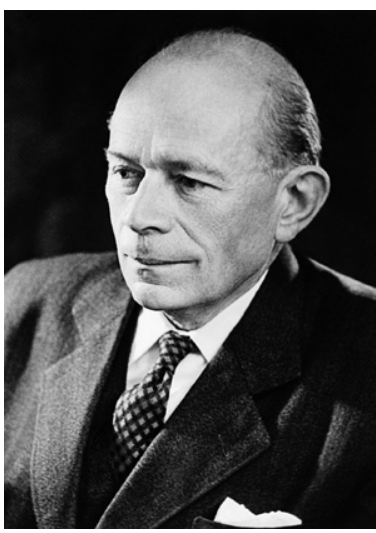

Abb. 29: Karl Maria Swoboda an Karel Hruza, diesem und Paul Herold (Wien) danke ich zudem für die Übersendung von Aktenkopien aus dem Archiv des IÖG.

2 Karl M. Swoboda (28.01.1889 Praha-Vinohrady-11.07.1977 Rekawinkel bei Wien; in der Literatur werden auch andere Geburtsdaten angegeben, die hier verzeichneten wurden Swobodas eigenhändigem Lebenslauf von 1913 entnommen, siehe IÖG, Archiv: Institutsakten 29. Ausbildungskurs 1911-1913), Sohn des österreichischen Staatsbeamten und Vizepräsidenten der Postdirektionen in Prag und später in Graz Karl Maria Swoboda (1857 Leitmeritz-1942 Graz) und seiner Ehefrau Berta (geb. Müller), Enkel von Václav Svoboda (1817-1881, Arzt in Leitmeritz), besuchte das deutsche Staatsgymnasium auf der Prager Kleinseite, 1908/09 Militärdienst, 1913-1934 verheiratet mit Kamilla geb. Rabl, Hutmacherin (1885-1942), 1940 verheiratet mit Hermine geb. Hein, Sängerin (1896-1986), Sohn Michael (geb. 1916). Zu Swoboda siehe Fritz FellNer, Doris A. Corradini, Österreichische Geschichtswissenschaft im 20. Jahrhundert. Ein biographischbibliographisches Lexikon (VKGÖ 99, Wien 2006) 407; Hans H. Auren h a m mer, Zäsur oder Kontinuität? Das Wiener Kunsthistorische Institut im Ständestaat und im Nationalsozialismus, in: Wiener Schule und die Zukunft der Kunstgeschichte, hg. v. Michael Viktor Schwarz (Wiener Jb. für Kunstgeschichte, Wien 2005) 11-54; Hans H. Aurenhammer, Das Wiener Kunsthistorische Institut nach 1945, in: Zukunft mit Altlasten. Die Universität Wien 1945 bis 1955, hg. von Margarete Grandner, Gernot Heiss, Oliver Rath коlв (Querschnitte 19, Innsbruck u.a. 2005) 174-188; Hans H. Aurenhammer, Hans Sedlmayr und die Kunstgeschichte an der Universität Wien 1938-1945, in: Kunstgeschichte an den Universitäten im Nationalsozialismus, hg. v. Jutta Held, Martin Papen в rocк (Kunst und Politik 5, Göttingen 2003) 161-194; Sigrid Canz, Karl Maria Swoboda (1889-1977) Kunsthistoriker. Wissenschaftler zwischen Wien 
chischen Kollegen nach Prag³ Im Wiener „großen Zusammenhang des geistig-histori-

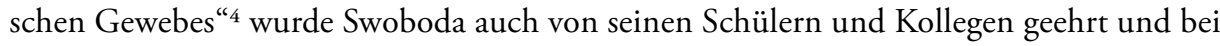
gegenseitiger Zitierung mit der Aura Dvořáks ummantelt: Swobodas Stellung in der Wiener kunsthistorischen Schule erschien im Kontext von Dvořáks „Kunsthistorikernachwuchs aus Böhmen“ und Swoboda als der Verwalter von dessen „geistige[m] Erbe“5; ein Forscher von „wissenschaftliche[r] Exaktheit“, der selbst bei „der äußeren Beschränkung auf ,lokale‘ Kunstphänomene zu einer Erweiterung seines Gesichtskreises“ gelangt und „seelische Grundhaltungen“ zu „Grundlagen einer Weltgeschichte der bildenden Kunst“ gemacht habe ${ }^{6}$; ein Kunsthistoriker, der entgegen der „Gefahr der Simplifizierung [...] vor allem die Unterscheidung zwischen ,Kerngebiet' und ,Peripherie“" verfolgt und somit eine „ganz neue Bewertung der böhmisch-mährischen Kunst“ eingeleitet habe ${ }^{7}$. Als „Absolvent des Instituts für österreichische Geschichtsforschung“"war Swoboda demnach in der Lage, „das ganze Gebiet [der Kunstgeschichte] in globaler Weite zu überblicken“ und

und Prag, in: Prager Professoren 1938-1948. Zwischen Wissenschaft und Politik, hg. v. Monika Glettler, Alena Mišková (Veröff. zur Kultur und Geschichte im östlichen Europa 17, Essen 2001) 175-190; Günter Busch : Karl Maria Swoboda (1969), in: Günter Busch, Hinweis zur Kunst. Aufsätze und Reden (Hamburg 1977) 240-244; Erich Bachmann, Dr. Karl M. Swoboda 80 Jahre, in: Mitteilungen des Adalbert Stifter Vereins 17 (1969) unpaginiert; Renate Wagner-Rieger, Karl M. Swoboda, in: MIÖG 85 (1977) 429-431, und in: Österr. Hochschulzeitung (September 1977) 19; Dies., In Memoriam Karl M. Swoboda, in: Karl Maria Swоводa, Die Gotik von 1150 bis 1300. Textfassung unter Mitarbeit von Maria Buchsвaum (Geschichte der bildenden Kunst in 8 Bänden, hier 2, Wien 1977) 5f.; FS Karl M. Swoboda zum 28. Januar 1959 (Wien 1959) 5-16; Dresslers Kunsthandbuch. Das Buch der lebenden deutschen Künstler, Altertumsforscher, Kunstgelehrten und Kunstschriftsteller 2 (Berlin 1930) 1300; Lebenslauf: Deutsche Universität, Philosophische Fakultät, Kunsthistorisches Institut, K. 63 (Lehrkanzel für Kunstgeschichte 1931-32), UAP. Schriftenverzeichnis: Karl M. SwоводA, Kunst und Geschichte. Vorträge und Aufsätze (MIÖG Erg.-Bd. 22, Wien/Köln/ Graz 1969) 258-265.

3 [...] a mužete si predstavit radost, že se stávám nástupcem Maxe Dvoŕáka. Swoboda an Antonín Matějček, Wien, 26.04.1946, Archiv Národní Galerie, Praha [Archiv der Nationalgalerie, Prag] (= ANG), Korrespondenz Antonín Matějček, Sign. AA 3571/409. Swoboda wurde am 27.06.1946 mit Rechtswirksamkeit vom 01.05.1946 zum ordentlichen Professor der Wiener Universität ernannt, siehe Aurenhammer, Zäsur (wie Anm. 2) 50, Anm. 153.

4 So Busch, Swoboda (wie Anm. 2) 242.

5 So Otto Benesch, Karl Maria Swobodas Stellung in der Wiener kunsthistorischen Schule, in: FS Swoboda (wie Anm. 2) 5f. In Verbindung mit Dvořáks Wirken am IÖG erscheint ebd. auch die österreichische Redaktion der „Denkmäler der deutschen Kunst“, herausgegeben vom Deutschen Verein für Kunstwissenschaft, und die Orientierung der Wiener Schule nach der nordischen Kunst.

6 So Otto Demus, Karl Maria Swoboda als Forscher, in: FS Swoboda (wie Anm. 2) 7-11. Die von der Dogmatik einer orthodoxen Nachfolge befreiten Methoden habe Swoboda auf das Ganze der Kunstgeschichte ausgedehnt, so das Fazit.

7 So Renate Wagner-Rieger, Karl Maria Swoboda als Lehrer, in: FS Swoboda (wie Anm. 2) 12-16. Als Vorstand des am schlechtesten untergebrachten Instituts der gesamten Universität Wien sei Swoboda unermüdlich um eine Lösung der Raumfrage bemüht gewesen. 
die „Verbindung von Forschung und Lehre in seltener Vollkommenheit“ zu verwirklichen - eine „Vaterfigur voll von Autorität und Stabilität“8.

Tatsächlich hatte Swoboda seinen professionellen Werdegang in die Spuren Dvořáks gelenkt, bei dem er I9I 3 in Wien mit einer Dissertation über „Das Florentiner Baptisterium" promoviert wurde und als dessen Assistent er seit I9I 4 arbeitete. I92 I hatte er schließlich die traurige Pflicht, seine tschechischen „Generations“-Kollegen der Jüngeren Wiener Schule der Kunstgeschichte telegrafisch über das plötzliche Ableben Dvořáks und den Termin der Beisetzung zu informieren. Swobodas folgende Jahre waren von einer intensiven Tätigkeit als Mitherausgeber der Schriften Dvořáks bestimmt. Ich bin mit der Sichtung des großen literarischen und wissenschaftlichen Nachlasses Dvoráks beschäftigt, mit dessen Herausgabe ich mit meinem Freund Johannes] Wilde von der Witwe betraut wurde ${ }^{10}$. Im Zusammenhang mit diesem Publikationsprojekt wurde ebenfalls die Prager Dvořák-Fraktion konsultiert - denn nicht zuletzt dank Dvořák war Swoboda auch mit der tschechischsprachigen Kunsthistoriografie recht gut vertraut ${ }^{11}$. Zu der Nachlassaufarbeitung zählte zudem die Herausgabe der kleineren Schriften Alois Riegls, womit ein ursprüngliches Vorhaben Dvořáks und Wildes realisiert wurde ${ }^{12}$. I934 wurde Swoboda als Ordinarius für Kunstgeschichte an die Prager Deutsche Universität berufen. In seiner Antrittsvorlesung in Prag stützte er sich erneut auf die Wiener Schule der „Kunstgeschichte als Geistegeschichte“, wie Dvořáks Studien zur abendländischen Kunstent-

8 So Wagner-Rieger, In Memoriam (wie Anm. 2) 5f. Karl Maria Swoboda, Geschichte der bildenden Kunst 1-9 (Wien/München 1976-1984) wurde nach schriftlichen Aufzeichnungen des Autors und Mitschriften seiner Hörer realisiert. Alphons Lнотsку, Geschichte des Instituts für österreichische Geschichtsforschung 1854-1954 (MIÖG Erg.-Bd. 17, Graz/Köln 1954) 359, urteilt: „Swoboda ist ein vorzüglicher Lehrer, der auf seine Vorlesungen und Übungen größte Sorgfalt und Mühe wendet.“ Swobodas Prager Schülerin Johanna von Herzogen berg, Bilderbogen. Aus meinem Leben (Lebensbilder zur Geschichte der böhmischen Länder 7, München 1999) 75, bemerkt: „Seine Studenten setzte er in der Forschung über die Kunst in Prag an, und es wurde Bedeutendes geleistet. Der Ordinarius war ein glänzender Organisator von Arbeiten, die dann auch publiziert wurden, ihre bahnbrechenden Ergebnisse sind bis heute gültig. "

9 Swoboda an Matějček, Telegramm 09.02.1921. ANG (wie Anm. 3).

10 Swoboda an Matějček, Wien 03.03.1921. ANG (wie Anm. 3). Swoboda und Wilde gaben heraus: Max Dvořá K, Kunstgeschichte als Geistesgeschichte (Studien zur abendländischen Kunstentwicklung) (München 1924, ND Berlin 1995); Ders., Das Rätsel der Kunst der Brüder van Eyck (ND München 1925); Ders., Geschichte der italienischen Kunst im Zeitalter der Renaissance, Akademische Vorlesungen 1-2 (München 1926/27); DERs., Gesammelte Aufsätze zur Kunstgeschichte (München 1929).

11 Tschechischsprachige Literatur zur Kunstgeschichte sei weder in den Wiener Bibliotheken noch bei den Wiener Buchhändlern erhältlich, hieß es zur Begründung der wiederholten Buchnachfragen. Swoboda an Matějček, Wien 07.10. und 04.11.1929. ANG (wie Anm. 3).

12 Alois Riegl, Gesammelte Aufsätze, bearb. und mit einer Einleitung v. Hans Sedlmayr (Augsburg/Wien 1929). 
wicklung von den Herausgebern Swoboda und Wilde bezeichnet worden waren ${ }^{13}$. Bezog sich Swobodas Freude über die I 946 erfolgte Berufung an die Wiener Universität als Nachfolger Max Dvoŕáks - so die Selbstpositionierung, tatsächlich handelte es sich um die Nachfolge des wegen seiner politischen Vergangenheit emeritierten Hans Seldmayr ${ }^{14}$ - auf eine ideelle Fortsetzung der wissenschaftlichen Arbeiten seines Lehrers Dvořák? Nachfolgende Ausführungen betreffen einen sehr fern von Dvořák auszumachenden Werdegang des Kunsthistorikers Swoboda, der auch von der Gründung der Südostdeutschen Forschungsgemeinschaft (SODFG) am I7. Oktober I93 I in Wien tangiert wurde. Sie sind unter anderem als ein Beitrag zur Intellektuellengeschichte der Kunsthistoriografie im Nationalsozialismus intendiert, indem die fachlichen Diskurse aus der Perspektive öffentlicher Wissenschaftsstrategien von Handelnden in komplexen Situationen betrachtet und die Genese und Funktion wissenschaftlicher Konzeptionen im konkreten Praxisfeld beurteilt werden ${ }^{15}$.

\section{KUNSTGESCHICHTE IM DIENST DER VOLKSDEUTSCHEN FORSCHUNGSGEMEINSCHAFTEN}

Swoboda, der I 889 in Prag als ältester Sohn des östereichischen Staatsbeamten und gebürtigen Leitmeritzers Karl Maria Swoboda und seiner Ehefrau Berta geboren wurde, wuchs in einem deutschnationalen Elternhaus auf, wobei die Familie jedoch väterlicherseits tschechischer Herkunft war. Diese familiäre Situation sollte Anfang der I 93 oer-Jahre in einen persönlichen Konflikt münden, der mit dem Scheitern seiner I9I 3 geschlossenen Ehe mit der evangelisch getauften Jüdin Kamilla Rabl einherging, deren Leben nach der Scheidung später im KZ Theresienstadt sein bitteres Ende fand. Der Schulzeit am deutschen Staatsgymnasium folgten 1909 Studien der Kunstgeschichte an der Deutschen Universität in Prag, die von Swoboda, der im Übrigen die tschechische Sprache beherrschte, nach dem Umzug seiner Familie noch 1909 in Graz und schließlich 1909/10 in Wien fortgesetzt wurden. In Graz lernte er auch Josef Strzygowski kennen, der dort I 892 den Lehrstuhl für Kunstgeschichte begründet hatte und I909 zum Leiter des I. Kunsthisto-

13 „Es geht also hier darum, von einer gefestigten Basis aus die Forderung nach Einordnung der Kunstgeschichte in eine allgemeine Geistesgeschichte neu zu erfüllen [...]“ Karl Maria SwоворA, Neue Aufgaben der Kunstgeschichte (Brünn/Prag/Leipzig/Wien 1935) 11-23, hier 21. Swoboda habe das geistige Erbe dieses Lehrers stets hochgehalten, folgert Benesch, Swobodas Stellung (wie Anm. 5) 6, unter Verweis auf die zitierte Stelle aus „Neue Aufgaben der Kunstgeschichte“. Zu Max Dvořák vgl. den Beitrag von Hans H. Aurenhammer in diesem Band.

14 Siehe Aurenhammer, Sedlmayr (wie Anm. 2).

15 Vgl. Jutta Held, Zur Kunsthistoriographie der Kunstgeschichte im Nationalsozialismus, in: Kunstgeschichte an den Universitäten (wie Anm. 2) 9-15. 
rischen Instituts der Universität Wien in Konkurrenz zum II. Wiener Kunsthistorischen Institut (mit Max Dvořák und Julius Schlosser als den Exponenten) berufen wurde ${ }^{16}$. Swoboda nahm - möglichweise einem Rat Dvořáks folgend - I9I I-I9I3 am 29. Ausbildungskurs des IÖG in Wien teil und wurde zu einem Historiker, insbesondere zu einem Mediävisten ausgebildet ${ }^{17}$. Er erweiterte so nicht nur seinen Ausbildungshorizont und erhob sich damit über „gewöhnliche“ Kunsthistoriker, sondern stellte sich auch in die Tradition der Kunsthistoriker und IÖG-Mitglieder Dvořák und Schlosser. Die Einbindung in das weit gespannte Netzwerk des Instituts sollte ihm sowohl bei seiner Berufung nach Prag als auch bei seiner Rückkehr nach Wien von Nutzen sein. I923 habilitierte sich Swoboda mit der Arbeit „Römische und romanische Paläste“ und begann als Privatdozent zu lehren. Während seiner Assistenz bei Julius Schlosser ist ihm I926 ein Lehrauftrag zugeteilt worden, um gegenüber Schlossers italienischem Forschungsfeld („Terra madre Italia“) die österreichische Kunstgeschichte zu betreiben, wie dies auch von Strzygowski angemahnt worden war $^{18}$.

Swobodas Weltanschauung, sein Wertesystem und das Ringen um eine Fixierung des persönlichen, wissenschaftlichen und privat motivierten Standpunktes werden um 1932/33 in dem unpublizierten kulturkritischen Essay Die gegenwärtige Lage der Menschheit - beziehungsweise Die Not unserer Tage, auf die sich der erste Abschnitt seiner Bestandsaufnahme bezieht - auf verwirrende Weise offenbar ${ }^{19}$. Das vermeintliche Versagen der unsere Kultur tragenden Ideen ${ }^{20}$ wurde dort als gesellschaftliche Formlosigkeit ${ }^{21}$ angezeigt: Die Formprobleme wurden mit Heimatlosigkeit, voller Vereinsamung des Einzelnen ${ }^{22}$, dem Verlust konstitutiver Rollen im Gesellschaftsleben wie Stand/Stadt/Familie, Wandlungen in Recht und Moral, dem Menschen vor dem Nichts in der Philosophie identifiziert. Das Kunstwerk ist in ein Jenseits der gesellschaftlichen Formen [...] geraten, ist heimatlos geworden ${ }^{23}$. Unter diesen

16 Vgl. Canz, Swoboda (wie Anm. 2) 176f.

17 Vgl. Leo Santifaller, Das Institut für österreichische Geschichtsforschung. Festgabe zur Feier des zweihundertjährigen Bestandes des Wiener Haus-, Hof- und Staatsarchivs (Veröff. des IÖG 2, Wien 1950) 135 und 305-307; Lнотsку, Geschichte des Instituts (wie Anm. 8) 358-362; IÖG, Archiv: Institutsakten 29. Ausbildungskurs 1911-1913. Seine bei Dvořák verfasste Hausarbeit „Beschreibendes Verzeichnis der romanischen Wandmalereien in Kärnten und Steiermark" wurde mit vorzüglich bewertet. Während er auch in den anderen kunstgeschichtlichen Prüfungen mit vorzüglich abschloss, erreichte er in den historischen Fächern fast durchgehend befriedigend oder sehr befriedigend und als Gesamtnote sehr befriedigend.

181927 erinnerte der Institutsdirektor Oswald Redlich das Ministerium nochmals an den Lehrauftrag, vgl. Lнотьку, Geschichte des Instituts (wie Anm. 8) 332.

19 Swовода, Die gegenwärtige Lage (wie Anm. 1).

20 Ebd. 2.

21 Ebd. 7.

22 Ebd.

23 Ebd. 15. 
Verhältnissen sah der Verfasser nach dem katastrophale[n] Ende einer „neuzeitlichen Entwicklung“ - unter Bezug auf Oswald Spenglers kulturpessimistische Schrift „Untergang des Abendlandes“ (I9I8) - wieder das Mittelalter heraufziehen ${ }^{24}$. Und nun verrinnt das alles mit diesem Strom im Nichts ${ }^{25}$. Die Lösung der Formprobleme wurde an den über unser „kulturelles System “ hinauswirkenden Kräfte $[n]$ festgemacht ${ }^{26}$, und zwar anstelle von Ideen/ Programmen/Parteibekenntnissen an den großen europäischen Menschenverbänden ${ }^{27}$ wie dem Staat, der katholischen Kirche (mit Perspektive im kultisch-mythischen Katholizismus), dem Nationalsozialismus (fremd, aber mit Ausblick durch sein Hinausgreifen über das eigene Kultursystem) und den historischen Wissenschaften aufgrund ihrer Geburt durch Fragen nach Hintergründen volklicher, rassischer Art ${ }^{28}$ : Die Erlösungsphantasien zielten auf Neue Perspektiven ${ }^{29}$, und mit ihnen auf die genialen Vollbringer [...] die eigentlichen Träger des geschichtlichen Geschehens ${ }^{30}$, hervorgegangen aus dem Zusammenstoßen von polar verschiedenen Charaktertypen bzw. Rassentypen ${ }^{31}$, auf die Züchtung von Genies ${ }^{32}$. Über vierzig Seiten beanspruchen die biologistischen Ausführungen zu den neuen Perspektiven in Blickrichtung auf Genie und „Rasse“, sie enden mit handschriftlichen Notizen zur Judenfrage, die Swoboda in Hinsicht auf seine 1934 geschiedene Ehe zu analysieren suchte ${ }^{33}$. Aufgrund

24 Ebd. $24 \mathrm{f}$.

25 Ebd. 19.

26 Ebd. 28 (Überschrift Abschnitt 28-60).

27 Ebd. 54.

28 Ebd. 59.

29 Ebd. 61 (Überschrift Abschnitt 61-106).

30 Ebd. 71.

31 Ebd. 72.

32 Ebd. 74f. In Swobodas Text finden sich unter anderem Verweise auf Werke folgender Autoren: Gottfried Benn, Otto Brunner, James Frazer, Leo Frobenius, Fritz Graebner, Martin Heidegger, Karl Jaspers, Sören Kierkegaard, Wolfgang Köhler, Ernst Kretschmer, Lucien Lévy-Bruhl, Wilfried Menghin, Friedrich Nietzsche, José Ortega y Gasset, Erik Peterson, Max Scheler, Oswald Spengler, Ernst Troeltsch, Alfred Vierkandt, Max Weber und Otto Weiniger.

33 Siehe Swовода, Typoskript, (wie Anm. 1) : „Natürlicher Charakter“, Verhältnis des heutigen Europäers zum Christentum. Mein Christentum: Jedenfalls hinter, mehr, vor der Ration, vorwissenschaftlich. Als geleugnete, unterdrückte, bekämpfte Herkunft empfunden. Aber doch Teil von mir. In der denkenden, überlegenden Sphäre meines Selbst ist es mir unmittelbar undenkbar. Ablehnung aller rationalen Anerkennung des Christentums, Dogma etc. Meine Metaphysik ist keine christliche Metaphysik. Daher mein persönliches Verhältnis zum Juden: Bewußtsein der vorhandenen, wenn auch unterdrückten „natürlichen "Verschiedenheit. Das dagegen ankämpfende moderne Freiheitsgefühl (letzten Endes zwar antik-christlicher Herkunft) kämpft gegen die religiöse Kluft: Der sogenannte Judenfimmel. Daher meine Ehe. Hat also eine Art unbenennbar erlösende Absicht. Des fernsten, mir noch innerlich erreichbaren Fremden. Analog meiner Sklavenbefreiung - Tendenz den Sklaven gegenüber und ähnlichen Erlebnissen am eigenen Leib. [...] Frage der Hinstellung zur Kulturfrage. Christentum meine Metaphysik, nicht Kultur als Selbstzweck, nicht Geschichte als Form für sich. Tendenz zum Genie. Erlösung durch Genies. Geniezucht. Zunächst. Von daher Einstellung zum Staats-Volks-Gedanken bestimmt. Staat zurücktretend (nur gegebenes Verwirklichungsmittel 
dieser Ausführungen wird Swoboda von Hans H. Aurenhammer als „nihilistischer rechter Intellektueller" charakterisiert ${ }^{34}$. Swobodas Haltung war zwar von einer nüchternen Einschätzung der Folgen des nationalsozialistischen Lebensstils bestimmt: das Zurückdrängen der Frau aus allen Lebensbereichen, wo sie nicht ihrer Natur nach geradezu unentbehrlich ist, das beherrschende Hervortreten von Männerbünden, [...] das Bedürfnis dieser Gruppen nach straffer Führung, der darin liegende kriegerische Zug, das Streben nach körperlicher Ertüchtigung zu diesem Zweck; Dinge, die wohl latent im Deutschen früher schon da waren, jetzt aber in einer Weise bestimmend geworden sind, dass zu ibren Gunsten bisherige Lebensnotwendigkeiten zurückgestellt werden ${ }^{35}$. Trotz solch klarer Beobachtung des Nationalsozialismus sollte Swoboda eben dieser Ideologie zuarbeiten. Er selbst schränkte seine negative Kritik an der sozialen Widersinnigkeit des Nationalsozialismus sogleich ein: widersinnig aber nur von den verschiedenen möglichen Standpunkten des bisherigen „kulturellen Systems“, vielleicht aber nicht von solchen eines sich formierenden anderen ${ }^{36}$. Sein Gesinnungswandel vom Kulturpessimismus zum aktiven Nihilismus wurde in demselben Essay pathetisch mit Erneuerungsvisionen kraft Zerstörung begründet: Hier sind Impulse und Ergebnisse auf das Neue hin fassbar. Triebkraft ist die europäische Notlage, wie im kirchlichen und politischen Leben. Am bewußtesten formuliert von Nietzsche in seinem Begriff des aktiven Nihilismus. Im Absehen von allem dem bisherigen "System“ angehörenden, Zerschlagen von allen in dieses bindenden Fesseln liegt der Weg. [...] Die europäische Geschichte tritt zurück (trotz Weltkrieg I) hinter

ihm heute fremder Absichten). Blutzufuhr. Blutreinheit. Zur erneuten Kreuzungsfähigkeit. Für Isolierung NordSüddeutschlands. Hebung des Bauern. Aufösung der Städte. Senkung des Niveaus der materiellen Kultur. Doppelte Moral. Wissenschaft - Volk. Trennung der Schule, der Hochschule vom Staat, der zu selbstbestimmt ist. Autonomie. Von hier gesehen sieht das Judenproblem aus: kein von unten her, mit zweiter Moral züchtbares Volk. Durch Ressentiment zusammengehalten (bei wohl gegebenen rassischen Naturgrundlagen). Gegen Zionismus, als praktisch undurchführbar. Für Gewinnung von selbstentscheidenden modernen Menschen aus orthodoxem Reservoire. Also eigentlich für Ghettojudentum. Gegen massenhafte willkürliche Vermischung. Gebietsweise verschieden. Im Westen und Süden bei zurückgehender Zuwanderung für Assimilierung. In Deutschland und bei uns für Dissimilierung, die ja beim freien Menschen aus Opposition den "Sprung" nur verlockend machen wird. Im Osten für Dissimilierung, aber von den Juden ausgehend. Hier sind sie (schon in der Tschechoslowakei) das Genieformat latentoffen [?]. Von der Vermischungs- und Geniezeugungsfähigkeit müßten hier die Maximen abhängen. Also innerlich: christlicher Judenfreund, bei Bewußtheit der Verschiedenheit, die nicht endlos sein soll, sondern der Hervorbringung eines Gemeinsamen, der Genierasse, dient. Äußerlich: auf der gehobenen Stufe, Geniestufe, fällt das Judenproblem weg. Politisch: Für Dissimilation bei uns, dabei aber gegen alle unchristlichen Mittel, gegen alles Diffamierende: also tunlichst unpersönlich, durch Konsens aller Betroffenen. [...] Der selbstentscheidende Jude ist vorbei, der Ghettojude versteht mich ohnehin nicht. Kamilla Swoboda emigrierte 1938 nach Prag, anders als der gemeinsame Sohn Michael Swoboda weigerte sie sich zu fliehen, wurde 1939 deportiert und starb 1942 in Theresienstadt. Siehe Aurenhammer, Zäsur (wie Anm. 2) 51f., Anm. 162; Edwin Lachnit, Fragmentarisches zu Kamilla Swoboda, in: Oskar Kokoschka - Das Konzert. Variationen über ein Thema, hg. v. Reinhold Graf Bethusy-Huc (Salzburg 1988) 13f.

34 Aurenhammer, Zäsur (wie Anm. 2) 52.

35 Siehe Karl Maria SwоводA, Die gegenwärtige Lage (wie Anm. 1) $52 \mathrm{f}$.

36 Siehe ebd. 53. 
das Interesse an der Urgeschichte und an allen jenseits des als "System“ durchblickbaren Stückes der Geschichte der Hochkulturen. Die Erde wird um neuer derartiger Erkenntnisse willen überall aufgerissen; eine unerhörte prähistorische Ausgrabungstätigkeit. Innerhalb des „europäischen Systems" geht das Interesse für alle Geschichte im eigentlichen, längsschnittmäßigen Sinn zurück. Überall beginnt man nach den Hintergründen volklicher, rassischer Art, in strengeren Bereichen zunächst nach den konstanten Eigenschaften einzelner, die Geschichte tragender Menschengruppen zu fragen ${ }^{37}$. Es war dieses Gebiet des wissenschaftlichen Denkens, dem Swoboda die letztlich entscheidende Rolle ebenfalls in Hinsicht auf seine persönlichen Erlösungsphantasien einräumte. An einer solchen „wissenschaftlichen“ Orientierung hielt er sich während seines Prager Ordinariats fest.

Wenn auch Swobodas Vorstellungen der Lektüre Friedrich Nietzsches, Sören Kierkegaards, Ernst Kretschmers oder Spenglers entsprungen waren, sollten sie letztlich in eine rassenideologische Kunstgeschichte mit besonderer deutscher Prägung münden. Der Werdegang dieser Kunstgeschichte wurde auch von den Volksdeutschen Forschungsgemeinschaften im Zuge der deutschen Volks- und Kulturbodenforschung mitgestaltet, einem Großprojekt aus der Zeit der Weimarer Republik, das Geografen, Landeskundler und Volkstumspolitiker begründet hatten ${ }^{38}$. Im Kontext der Volksabstimmungen und territorialen Abtretungen in den Grenzgebieten des Deutschen Reiches und Österreich-Ungarns waren diese Begriffe zu machtpolitischen Instrumenten entwickelt worden und bestimmten nachfolgend die interdisziplinäre Forschungsstrategie bei der Zusammenarbeit zwischen Vertretern der Geografie und der Geschichte. Gemeinsame politische Zielsetzung war die Revision der Versailler Friedensverträge. Die „volkstumspolitischen“, großdeutsch orientierten Strategien der Organisation wurden ausschließlich durch die Berliner Ministerien und den „Verein für das Deutschtum im Ausland“ finanziert ${ }^{39}$. Die deutsche Volks- und Kulturbodenforschung hatte Grundlagen für die Grenzland- und Großraumforschung geschaffen, diese Forschungsstrategie kennzeichnete dann auch die kunstgeografischen Raumkonzeptionen. Seit der Gründung der Südostdeutschen Forschungsgemeinschaft (SODFG) am I7. Oktober I93 I in Wien war Swoboda zusammen mit Geografen, Historikern, Germanisten, Volkskundlern in deren Arbeitsausschuss tätig und für den Arbeitsbereich Kunstgeschichte der Tschechoslowakei verantwortlich ${ }^{40}$. Zu den Aufgaben und Funktionen der SODFG zählte die wissenschaftliche Begründung einer gesamt-

37 Siehe ebd. 57-59.

38 Siehe Michael Fanцbusch, Wissenschaft im Dienste nationalsozialistischer Politik? Die „Volksdeutschen Forschungsgemeinschaften“ von 1931-1945 (Baden-Baden 1999) 55-64 (Hintergründe der NS-Volkstumsund Kulturpolitik).

39 Ebd. 40.

40 Siehe Aurenhammer, Zäsur (wie Anm. 2) 50; Fahlbusch, Wissenschaft (wie Anm. 38) 247-275, 288 292. 
deutschen Auffassung durch geografisch-historische Argumente ${ }^{41}$. Solche „Bereicherung“ um die örtliche, geografische Dimension wurde von Swoboda in seiner Forschung und Lehre an der Deutschen Universität in Prag weiterverfolgt ${ }^{42}$. Die Zielvorstellungen von wissenschaftlicher Planmäßigkeit und neuer Wissenschaftsorganisation wurden für Swobodas eigene wissenschaftliche Tätigkeit in Kooperation mit den kulturwissenschaftlichen Nachbardisziplinen bestimmend. Diese Kooperation war allerdings schon durch ein tragfähiges Netzwerk von Kontakten zu Instituten und Volksgruppenführungen auf diversen Funktionsebenen in den ihm wohl vertrauten strukturellen Eigenarten der Volksdeutschen Forschungsgemeinschaften vorgebildet. Bereits 1932 bei einer Exkursion in die Westslowakei zwecks Ausbau von Kontakten zu den tschechoslowakischen, vorzugsweise aus Prag kommenden Deutschtumsforschern, Geografen, Statikern, Historikern, Rechtshistorikern, Kunsthistorikern, Volkskundlern und Linguisten hat der von Heinrich Gerhard Franz ${ }^{43}$ begleitete Swoboda aus der Perspektive des deutschen Anteils über die kunsthistorische Stellung des Pressburger Gebietes geurteilt und diese als Rezeptivität ohne Kraft eingestuft ${ }^{44}$. Im Rechenschaftsbericht über die geleistete praktische Grenzlandarbeit der SODFG wurde dann von deren Leiter, dem Geografen Hugo Hassinger, am I. November I 933 die Unterstützung von Volksdeutschen und der deutschen Kultur als wichtigstes Aufgabengebiet genannt, das seit zwei Jahren gerade in Kooperation mit der Prager Deutschen Universität ausgebaut werde ${ }^{45}$. Dabei ging es ebenfalls um die Stärkung einer Universität, deren Stellung 1920 mit ihrer Aberkennung als Nachfolgerin der von Karl IV. gegründeten Universität ideell erheblich geschwächt worden war. Der Konflikt zwischen den beiden Prager Universitäten sollte zunächst im Herbst I 934 im „Insignienstreit“ kulminieren ${ }^{46}$.

\section{DAS PRAGER ORDINARIAT}

Seit November I93 I sind Swobodas Bemühungen um eine Berufung an die Prager Deutsche Universität als Nachfolger Alois Grünwalds ${ }^{47}$ und dessen Vertreters I930-I934, Ed-

41 Ebd, $263 \mathrm{f}$.

42 Siehe Swoboda, Neue Aufgaben (wie Anm. 13) 21-23.

$43 \mathrm{Zu}$ ihm siehe Fellner, Corradini, Geschichtswissenschaft (wie Anm. 2) 128.

44 Siehe Fahlbusch, Wissenschaft (wie Anm. 38) $288 f$.

45 Siehe ebd. 199.

46 Siehe Karel Hruza, Der deutsche Insignien- und Archivalienraub aus der Prager Universität 1945. Mit einem Briefwechsel zwischen dem Universitätsarchivar Heinz Zatschek und dem Präsidenten der Monumenta Germaniae Historica Theodor Mayer, in: Bohemia. Zeitschrift für Geschichte und Kultur der böhmischen Länder 48 (2008) 349-411, hier 355-358.

$47 \mathrm{Zu}$ ihm siehe Biographisches Lexikon zur Geschichte der böhmischen Länder 1: A-H, hg. v. Heribert ST U R (München/Wien 1979) 482. 
mund Wilhelm Braun ${ }^{48}$, in Swobodas Briefen an Antonín Matějček dokumentiert ${ }^{49}$. Das Prozedere sah im ersten Schritt des Berufungsverfahrens einen Vorschlag der Fakultät vor, der in einem zweiten Schritt der Bestätigung der tschechoslowakischen Regierung bedurfte. In der Fakultät war sich Swoboda der Unterstützung „unseres“ Historikers und besten Beraters und Förderers in der Prager Sache, Hans Hirsch, gewiss ${ }^{50}$. Der Direktor des IÖG Hirsch bildete zusammen mit dem Volkskundler Viktor Geramb, dem Geografen Fritz Machatschek und Hassinger als Vorsitzendem den vierköpfigen Vorstand der SODFG, in deren Arbeitsausschuss Swoboda mitwirkte. Im Schulministerium benötigte Swoboda zudem der Fürsprache seiner tschechischen Kunsthistoriker-Kollegen aus der Wiener Zeit, der Dvořák-Schüler, die für ihn beim Sektionsleiter im Kulturbereich, Zdeněk Wirth, eintraten ${ }^{51}$. Dieser Fürsprache wusste sich Swoboda auch unter Hinweis auf die gemeinsame Interessenlage der „aus dem alten Österreich und der Tschechoslowakei“ Stammenden gegenüber den an Übergewicht gewinnenden „Reichsdeutschen“ an der Prager Deutschen Universität zu vergewissern. Die reichsdeutschen Herren der Fakultät werden sich für ihre Kandidaten auch in diesem Fall mit allem Gewicht einsetzen und es wird gewiß des größten Nachdrucks bedürfen, wenn ich als erster gefragt werden soll, was nach der ganzen Sachlage und aus den genannten Gründen so wichtig wäre. Ich bitte Sie,

$48 \mathrm{Zu}$ ihm siehe ebd. 136f. Gemäß Swobodas brieflichen Hinweisen wurde die Suppleantur Dir. Brauns von tschechischer wie von Wiener Seite mit Unbehagen verfolgt, weil angeblich gewisse maßgebliche Personen die Suppleantur als definitive Lösung ansahen. Swoboda an Matějček, Wien, 14.01.31. ANG (wie Anm. 3).

49 Antonín Matějček (1889-1950) hatte Kunstgeschichte an der Tschechischen Universität in Prag studiert, bei Max Dvořák in Wien promoviert und war dort seit 1912 in der Zentralkommission für Denkmalschutz tätig; nach 1918 war er Professor für Kunstgeschichte an der Kunstgewerbeschule in Prag, 1920 lehrte er an der Akademie der bildenden Künste in Prag, 1926 war er Dozent, 1927 außerordentlicher Professor und seit 1930 Ordinarius für Kunstgeschichte an der Karlsuniversität in Prag, 1949 Leiter der Kunstabteilung im Schulministerium. Zu ihm siehe Luboš HlaváčEK, Antonín Matějček a jeho škola [Antonín Matějček und seine Schule], in: Kapitoly z českého dějepisu umění [Kapitel aus der tschechischen Kunstgeschichte] 2, hg. v. Rudolf Chadra B A, Josef Krása, Rostislav Švách A, Anděla Horová (Praha 1987) 152-160. Zu Swobodas Berufungsverfahren Ota KonráD, Dějepisectví, germanistika a slavistika na Německé univerzitě v Praze 1918-1945 [Geschichtsschreibung, Germanistik und Slavistik an der Deutschen Universität in Prag 1918-1945] (Praha 2011) 51f., und zuletzt Alena Janat Ková, Die Berufung von Karl Maria Swoboda an das Kunsthistorische Institut der Prager Deutschen Universität. Konferenzakten „Aufbruch und Krise. Das östliche Europa und die Deutschen nach dem Ersten Weltkrieg“, Oldenburg (Bundesinstitut für Kultur und Geschichte der Deutschen im östlichen Europa, 09.-11. März 2009).

50 Swoboda an Matějček, Wien, 05.11.1931. ANG (wie Anm. 3). Zu Hirsch, der 1918-1926 in Prag als Ordinarius wirkte, siehe Andreas ZAJIC, Hans Hirsch (1878-1940). Historiker und Wissenschaftsorganisator zwischen Urkunden- und Volkstumsforschung, in: Österreichische Historiker 1900-1945. Lebensläufe und Karrieren in Österreich, Deutschland und der Tschechoslowakei in wissenschaftsgeschichtlichen Porträts, hg. v. Karel Hruza (Wien/Köln/Weimar 2008) 307-417.

51 Swoboda an Matějček, Wien, 05.11.1931. ANG (wie Anm. 3). Zu Wirth siehe Vlasta Dvoř ́́ кovÁ, Zdeněk Wirth, in: Kapitoly z českého dějepisu umění 2 (wie Anm.49) 126-138. 
nun das zu tun, was Sie für recht und nützlich halten. Sie wissen. lieber Freund, welche Vorsichten da wegen der nationalen Verhältnisse zu üben sind. In meinem Fall besonders, da ich von den sudetendeutschen Herren der Fakultät, vor allem von Professor [Wilhelm] Wostry kandidiert worden bin und mir deren Wohlwollen nicht verscherzen möchte ${ }^{52}$. Der Historiker Wostry vertrat als Ordinarius die Tschechoslowakische Geschichte und war zwischen I 930 und 1943 geschäftsführender Direktor des Historischen Seminars. Inhaltlich favorisierte Wostry eine Landesgeschichtsforschung, wie sie in den böhmischen Ländern zuvor in den Geschichtsvereinen mit einem kulturgeschichtlichen Ansatz von der Sozial- und Wirtschaftsgeschichte über die Volkskunde, Familien- und Siedlungsforschung bis hin zur Geistes- und Kunstgeschichte verfolgt worden ist. Die universitäre deutschböhmische Landesgeschichtsforschung war dabei durchaus ein Beitrag zur deutschen „Volks- und Kulturbodenforschung“. Wostry war in der Nord- und Ostdeutschen Forschungsgemeinschaft (NOFG), die mit der SODFG am „Volkstumsprojekt“ eng kooperierte, für das Gebiet Böhmen und Mähren zuständig. Außeruniversitär engagierte sich Wostry als Obmann des Vereines für Geschichte der Deutschen in Böhmen und Schriftleiter der Vereinszeitschrift MVGDB ${ }^{53}$. Nach der Machtergreifung Hitlers wirkte sich die außenpolitische Sachlage auch auf die Dreieckskonstellation zwischen reichsdeutschen, sudetendeutschen und tschechoslowakischen Interessen im Berufungsverfahren an die Deutsche Universität entscheidend aus. Im Übrigen habe ich nur die große Sorge, daß die allgemeinen politischen Verschiebungen die Auslandsberufungen hemmen oder gar verhindern könnten. Da solche Befürchtungen gegenwärtig wohl berechtigt sind, wäre tunlichs[t] Beschleunigung meiner Sache recht sehr geboten. Darf ich Sie bitten, auch in diesem Sinne zu wirken! Empfehlen Sie mich bitte Herrn Sektionschef Wirth ganz ergebenst ${ }^{54}$. Die Zurückhaltung der tschechoslowakischen Regierung bei Auslandsberufungen ließ das Verfahren ins Stocken geraten, weitere Verzögerungen wurden durch Konkurrenzkämpfe zwischen reichsdeutschen und sudetendeutschen Interessengruppen an der Universität bewirkt. Ich habe in den letzten acht Monaten sehr wenig Positives, gar nichts direkt über meine Prager Sache gehört. Ich hörte nur von Schwierigkeiten allgemeiner Art, die angesichts der veränderten politischen

52 Swoboda an Matějček, Wien, 21.06.1932. ANG (wie Anm. 3).

$53 \mathrm{Zu}$ Wostry siehe Karel Hruza „Wissenschaftliches Rüstzeug für aktuelle politische Fragen. “ Kritische Anmerkungen zu Werk und Wirken der Historiker Wilhelm Weizsäcker und Wilhelm Wostry, in: ZfO 54 (2005) 475-526, hier 494-525; Nina Lohmann, „Heimat und Volk.“ Der Historiker Wilhelm Wostry zwischen deutschböhmischer und sudetendeutscher Geschichtsforschung, in: Die „Sudetendeutsche Geschichtsschreibung“ 1918-1960. Zur Vorgeschichte und Gründung der Historischen Kommission der Sudetenländer, hg. v. Stefan Albrecht, Jiří Malí Ř, Ralph Melville (Veröff. des Collegium Carolinum 114, München 2008) 127-149, hier 130-137. Zu Wostry und der SODFG siehe FAнlвusch, Wissenschaft (wie Anm. 38) 187, zur Kooperation ebd. 246.

54 Swoboda an Matějček, Wien, 17.05.1933. ANG (wei Anm. 3). 
Lage Auslandsberufungen machen; dann, daß mein Akt vom Ministerium des Inneren aus eben diesem Grund dem Unterrichtsministerium zurückgestellt sei, daß er aber nun kürzlich wieder, mit einem neuen Gutachten des Sektionschefs Wirth seinen Weg ins Ministerium des Inneren von neuem angetreten habe ${ }^{55}$. Letztlich brachte die seitens der Regierung durchgesetzte Bevorzugung sogenannter „einheimischer Kandidaten“ bei gleichzeitigem Fehlen von geeignetem „einheimischen Nachwuchs sudetendeutscher Nationalität“ noch im selben Jahr den Durchbruch im Berufungsverfahren an die Deutsche Universität. Unter der Voraussetzung, dass Swoboda kein NSDAP Mitglied sei ${ }^{56}$, wurde dieser mit dem Erwerb der tschechoslowakischen Staatsangehörigkeit am 31. 7. I934 vom Staatspräsidenten zum Ordinarius an der Deutschen Universität ernannt und am 29. 9. 1934 im Dienst verei$\operatorname{digt}^{57}$. Im Wintersemester I934/35 hatte Swoboda seine Prager Lehrtätigkeit begonnen, I 935 wurde er Mitglied der „Kunstgeschichtlichen Kommission“ der Deutschen Gesellschaft der Wissenschaften und Künste für die Tschechoslowakische Republik und I936 Kuratoriumsmitglied der deutschen Sektion der Modernen Galerie in Prag 58 .

Im Herbst 1934 hielt Swoboda seine Antrittsvorlesung als Ordinarius für Kunstgeschichte und präsentierte sich am neuen Tätigkeitsort mit dem programmatischen Vortrag

55 Swoboda an Matějček, Wien, 30.12.1933. ANG (wie Anm. 3).

56 Einem Brief Gerhard Gesemanns an Hermann Theodor Beenken vom 18.05.1939 ist zu entnehmen: Als wir seinerzeit in März 1933 die Absicht hatten, Sie an die deutsche Universität zu berufen, wollten wir an die erste Stelle [Kurt] Gerstenberg aus Halle setzen, doch wurde mir im damaligen tschechoslowakischen Schulministerium vom Sektionschef der Hochschulabteilung gesagt, daß man Herrn Gerstenberg aufkeinen Fall berufen könne, da er, wie man erfahren, Mitglied der NSDAP sei. Warburg-Archiv Hamburg, Akte Lehrstuhl Kunstgeschichte, zitiert nach der Datenbank des Projekts „Geschichte der Kunstgeschichte im Nationalsozialismus“ (GKNS-WEL). Im Lebenslauf von Beenken finden sich weitere Hinweise: Von Anfang 1933 bis zum Frühjahr 1934 wünschten mich Rektor und Philos. Fakultät der Deutschen Universität Prag für den dortigen Kunsthistor. Lehrstuhl zu gewinnen. Im März 1933 war der damals designierte Prager Rektor bei mir in Leipzig und bat mich ausdrücklich, nicht in die NSDAP einzutreten, um meine Berufung nach Prag nicht zu erschweren, die im deutschen Interesse erwünscht sei. Ebd., zitiert nach GKNS-WEL. Gesemann war 1933/34 Prorektor der Deutschen Universität in Prag, zu seinem offiziellen „Bericht für das Studienjahr 1933/34“ siehe CAnz, Swoboda (wie Anm. 2) 178.

57 Daß ich sogleich bei meiner Ernennung um die tschechoslowakische Staatsbürgerschaft ansuchen werde, habe ich Ministerialrat Hawelka bei meiner Unterredung mit ihm schon fest zugesagt. [...] Meine Mutter meinte, daß mein Akt dank Ihrer beider Intervention jetzt vom Innen- und vom Außenministerium aufrecht erledigt sei und nun noch ins Ministerium gehe [...]. Swoboda an Matějček, Wien, 23.06.1934. ANG (wie Anm. 3). Tatsächlich hatte Swoboda mit dem Erwerb der tschechoslowakischen Staatsbürgerschaft die österreichische aufgegeben, wie es das erneute Ansuchen um die österreichische Staatsbürgerschaft von 1945 dokumentiert, siehe Aur EN HAMmer, Zäsur (wie Anm. 2) 51, Anm. 159. Zum tschechoslowakischen Diensteid siehe Schreiben des Ministeriums für Schulwesen und Volkskultur vom 29.09.1934 an Swoboda, Abschrift in deutscher Übersetzung, beglaubigt vom Kunsthistorischen Institut der Universität Wien am 25.02.1955, ÖstA/AdR, Personalakt, fol. 67, vgl. Canz, Swoboda (wie Anm. 2) 175, Anm. 1.

58 Siehe Canz, Swoboda (wie Anm. 2) 181. 
„Neue Aufgaben der Kunstgeschichte“59. Ausgangspunkt war jene kulturpessimistische Haltung, die Swoboda mit „Interessenwandlungen“, „Wertverschiebungen im zeitgenössischen Kunstleben, Kunstbetrieb“, „Neuerungen und neue Situationen im Sammelwesen, Musealwesen, in der Denkmalpflege, endlich [mit dem] Neue[n] in der zeitgenössischen Kunst selbst“ quittierte ${ }^{60}$. Von den tendenziös herausgestrichenen „Wandlungen“ wurde der Blick zielsicher auf die handlungsorientierten Perspektiven für Kunsthistoriker auf dem Gebiet der bildenden Kunst gerichtet: „Diese neue Situation stellt die Kunstgeschichte vor Fragen, die früher nicht vorhanden waren. Etwa: Läßt sich der die bisherige Geschichte der europäischen Architektur tragende Begriff des architektonischen Kunstwerkes erweitern, um mit ihm zugleich auch die Werke der neuen Architektur erfassen zu können, ihren Technizismus, ihr Maschinenmäßiges etwa? [...] Für das Großteil des jüngsten Kunstgewerbes, das seine Leistung allein in der technischen und Materialvollwertigkeit, wie in dem strengen Zweckentsprechen seiner Objekte sieht, sind die Kunstgewerbemuseen im Sinne ihrer ursprünglichen Absicht belanglos geworden. Welche Orientierung ergibt sich diesen Museen in dieser neuen Lage? Bei welchen Zielsetzungen können sie sich dem heutigen öffentlichen Sammelwesen am sinnvollsten einordnen, den künstlerischen Erfordernissen der Allgemeinheit am besten dienen? Mit dieser letzten Frage berühren wir ein weiteres Quellgebiet neuer Aufgabenstellungen: Das Verhältnis der Kunst, des ganzen überlieferten Kunstbesitzes zur Gesellschaft, Gesellschaft im weitesten Sinn, also etwa als kulturelle Schichtung und Organisation des Volkes genommen, [...] selbst die führenden Persönlichkeiten haben heute zur bildenden Kunst kein inneres Verhältnis mehr. Sie ist ihnen fremd; alte wie neue Kunst. [...] Im wesentlichen liegen aber die Gründe jenes Mißverständnisses tiefer, in der Struktur der Gesellschaft selbst, werden nur mit deren Änderung aus der Welt kommen. "61 Gegenüber der bescheinigten materialistischen Haltung sprach Swoboda von einer notwendigen Kunsterziehung der Gesellschaft. Damit gelangte er zur entscheidenden Forderung an seine Fachdisziplin: „Die Kunstgeschichte hat die Pflicht, zu erwägen und zu erforschen, unter welchen Bedingungen die bildende Kunst bei den möglichen und bei den tatsächlich im Zuge befindlichen gesellschaftlichen Wandlungen ihren angestammten und natürlichen Platz im kulturellen Leben zurückzugewinnen vermöchte."62 Was Swoboda vorschwebte, war ein Neuordnen des Materials, um gegen vermeintliche Missstände in seinem eigenen Fachgebiet anzutreten: „Der rapid sich steigernden Entwurzelung des Kunstwerkes aus seinem

59 Der Vortragstext erschien eingangs zum Sammelband von Swobodas Vorträgen aus den Jahren 1932-1934 unter demselben Titel, siehe Swовода, Neue Aufgaben (wie Anm. 13) 11-23.

60 Swoвoda, Neue Aufgaben (wie Anm. 13) 11.

61 Ebd. $12 \mathrm{f}$.

62 Ebd. 13. 
gesellschaftlichen Lebensraum entspricht ein enormes Fluktuieren und steigerndes sich Erweitern des Kunstinteresses innerhalb und außerhalb der Wissenschaft. [...] erst in der jüngsten Zeit wirkte sich der historische Relativismus auf eine Kunstgeschichte ,aller Zeiten und Völker' hin voll aus. Das hat auch Nachteile: Qualitative Stufungen, die früher, wenn auch ohne wissenschaftliche Begründung, doch ,gesehen' waren, wurden dadurch nivelliert, Geringes an Hochwertiges herangeschoben. [...] Es ist bezeichnend, daß in der eben erschienenen [...] Geschichte der Kunstgeschichte annähernd der halbe Raum der Kunst der Vorzeit und der farbigen Völker eingeräumt ist. In den letzten Jahren folgen aber die Gebietserweiterungen Schlag auf Schlag. Nach der Kunst des Kindes, der Blinden, der Irren lernten wir in einer kürzlich erschienenen Arbeit auch die Kunst der Sträflinge kennen. [...] Das Verwirrende des gegenwärtigen Zustandes liegt nicht so sehr an der Stoffülle als an der Ordnungslosigkeit des Stoffes, sowohl was die horizontale Ordnung, nach der Verschiedenartigkeit der Objekte, ausmacht, als in der Vertikalen, nach den Unterschieden ihrer Qualität."63 Die Neuordnung sollte allerdings über die allgemeine Geistesgeschichte hinaus um die neuen Dimensionen der Wissenschaft vom Menschen in seiner „psychophysischen Totalität“ und um die örtliche, geografische Dimension erweitert werden. Die Fragestellung sollte demnach lauten: Welches ist trotz allem geschichtlichen Wandel der sich gleichbleibende Charakter der Kunst eines Volkes, einer Landschaft, einer Stadt - wobei „geniale Anläufe“ Dvořáks und Wilhelm Pinders in ein ausgreifendes „Theoriensystem“ überführt werden sollten. Wie in der Theorie waren auch auf dem Gebiet der angewandten Kunstgeschichte neue Werteskalen, gesteigerte Systematisierung, Planmäßigkeit und Institutionalisierung angesagt ${ }^{64}$.

Die über das vorgefundene kunsthistorische System hinausgreifenden Kräfte sollten also von „psychophysischer Totalität“ sein. Bereits mit dieser Zielsetzung lässt sich die radikale Abkehr von jenem kunsthistorischen Verständnis ausmachen, das die Herausgeber von Dvořáks Studien zur abendländischen Entwicklung 1924 unter „Kunstgeschichte als Geistesgeschichte“ präsentiert hatten. Mit seiner geistesgeschichtlichen Perspektive hatte Dvořák den historischen Kontext neu entdeckt. Jegliches völkische Kunstverständnis wie jenes von Wilhelm Worringer war ihm hingegen fremd, daher hatte sich Dvořák von Worringers interpretatorischem Ansatz distanziert: „Ohne Rücksicht auf den jeweiligen historischen Tatbestand und in willkürlicher Beschränkung auf einen allerdings sehr charakteristischen Zug der mittelalterlichen Kunst legte Worringer seinen glänzend geschriebenen Betrachtungen einen völkerpsychologisch konstruierten Begriff des gotischen Formwillens zugrunde, der alles, was die neuen nordischen Völker aus eigener Kraft künstlerisch erfunden haben, vom altorientalischen und klassischen Kunstschaffen un-

63 Ebd. 15 f.

64 Ebd. 21. 
terscheidet“, hieß es in der Einleitung zu „Idealismus und Naturalismus in der Gotik“. Unter Anspielung auf Worringers „Formprobleme der Gotik“ lautete Dvořáks abschließendes Urteil: „So blendend Worringers Beweis auf den ersten Blick erscheinen mag, so verwandelt sich doch bei näherer Betrachtung sein Ausgangspunkt, eine a priori existierende, der Wirklichkeit und daher auch jedem Naturalismus feindlich gegenüberstehende ,gotische' Konzentration der Kunst der neuen Völker auf Momente der übersinnlichen Ausdruckssteigerung in eine willkürliche Konstruktion, die [...] dem komplizierten historischen Sachverhalte gegenüber noch phantastischer ist als die abstrakten Stilbegriffe der Romantiker“.65 Die mit Dvořáks Namen unlösbar verbundene "Geistesgeschichte“ konnte kaum ernsthaft um unhistorische Dimensionen erweitert werden. Swobodas Zielrichtung bediente vielmehr mit der örtlichen, geografischen und volksspezifischen Dimension die Interessen der Volksdeutschen Forschungsgemeinschaften und darüber hinaus des Deutschen Reiches. Im Dienst dieser Interessen wurde ebenfalls das neue „Theoriensystem“ entworfen: „In diesem Bezirk neuer wissenschaftlicher Planung wird aber eine entsprechende Rücksichtnahme auf die neuen Methoden und die Theorien der in Frage kommenden Nachbarschaftswissenschaften, das ist vor allem die Geschichte, die Philologie, die Altertumskunde, aber auch die Völkerkunde, Prähistorie und Anthropologie, notwendig sein"66. Die methodische Modernisierung sollte ebenfalls die angewandte Kunstgeschichte neu strukturieren: „Wäre es nicht richtig, Tabellen der als besonders hochwertig erkannten Kunstwerke systematisch anzulegen und für die Erhaltung dieser Kunstwerke, und zwar nicht nur im materiellen Sinn, sondern auch für die Erhaltung der von diesen Kunstwerken ursprünglich intendierten Wirkungsabsicht, der erkannten großen Qualität entsprechend zu sorgen? Oder: Wäre es nicht zweckmäßig, Institute zu schaffen, in denen die technischen Möglichkeiten für die Erhaltung, aber auch für die Reproduktion der Kunstwerke zu Forschungs- und Bildungszwecken kontrolliert würden, um sie auf einen, den technischen Fortschritten entsprechenden, möglichst hohen Niveau zu erhalten?“67. Solche „Planung und Ordnung“, „Steigerung des Bewußtseins vom Ganzen, vom Organismus der Wissenschaft, seinen hauptsächlichen Wachstums- und

65 Dvořák, Kunstgeschichte (wie Anm. 10) 47, vgl. Wilhelm Worringer, Formprobleme der Gotik (München 1911). Dvořáks Aufsatz „Idealismus und Naturalismus“war gemäß Magdalena Bushart, Der Geist der Gotik und die expressionistische Kunst. Kunstgeschichte und Kunsttheorie 1911-1925 (München 1990) 20, als Gegenentwurf zu Worringers „Formproblemen“ konzipiert. Dvořáks Opposition zum nationalen Kunstverständnis wird von Michaela MARE K, Kunstgeschichte zwischen Wissenschaft und Dienst am Staat, in: Grenzen überwindend. FS für Adam S. Labuda, hg. v. Katja Bernhardt, Piotr Piotrowski (Berlin 2006) 79-97, hier 89, in Zusammenhang mit der Unabhängigkeit der Wiener Wissenschaftler von nationalen Rücksichten gebracht.

66 Swоводa, Neue Aufgaben (wie Anm. 13) 22.

67 Ebd. 
Entfaltungsbedürfnissen, die gesteigerte Verantwortung des an der Wissenschaft Teilhabenden für die sich daraus ergebenden Verpflichtungen " und moderne Systematisierung der Kunstgeschichte bedeuteten auch die kontrollierte Vereinheitlichung der Werteskala und deren mediale Vervielfältigung ${ }^{68}$. Wenn es hieß, für die Kunstgeschichte „ihren angestammten und natürlichen Platz im kulturellen Leben zurückgewinnen "69, so ging es doch um deren neuartigen Stellenwert in der Kulturpolitik. Die ideelle Orientierung hin auf Neuordnung der Museen und neue Zielsetzungen des Sammelwesens war bereits Vorzeichen von späteren Umstrukturierungen der kunsthistorischen Praxis an den staatlich verwalteten Kultureinrichtungen im Protektorat Böhmen und Mähren.

Während seiner Prager Lehrtätigkeit durchschritt Swoboda die Kunstgeschichte nach Stilepochen, die von Überblicksdarstellungen zu den „Sudetenländern“ und von national akzentuierten Veranstaltungen („Die Kunst der neuen Nationen des Mittelalters/Romantik [sic]“, WS I938/39; „Deutsche Kunst der Gotik“, SS I939) begleitet wurden. Während der brisanten Zeit 1938/39, der erzwungenen Abtretung der „sudetendeutschen“ Grenzgebiete an das Deutsche Reich und der Überführung der Tschechoslowakei von der „Ersten“ in die „Zweite“ Republik übte Swoboda die Funktion als Dekan der Philosophischen Fakultät der Deutschen Universität in Prag aus. Seine Funktionsausübung ist in der Zeit der Münchener Verhandlungen (I6. 9.-I7. I I. I938) durch die Absenz zusammen mit anderen deutschen Professoren wie den Historikern Wilhelm Weizsäcker ${ }^{70}$, Heinz Zatschek ${ }^{71}$ und Gustav Pirchan ${ }^{72}$ markiert: Die „Flucht“ ins Reich war als Reaktion auf die seitens der tschechoslowakischen Regierung gestellte Forderung nach ihrer Unterschrift unter eine Erklärung gegen Henleins Proklamation und der Erneuerung des Treuegelübdes erfolgt. In Vorbereitung der späteren Übernahme der Deutschen Universität in die Reichsverwaltung wurde dann der Erlass des Rektorats über Abstammungsnachweis und Logenerklärung vom I 2. August 1939 vom Dekan Swoboda nach acht Tagen weitergeleitet $^{73}$. Die Intensivierung der interdisziplinären Zusammenarbeit innerhalb der Fakul-

68 Ebd.

69 Ebd.

70 Zu ihm siehe Joachim BAнцске, Wilhem Weizsäcker (1886-1961) Jurist. Rechtsgeschichte und Volksgemeinschaft, in: Prager Professoren (wie Anm. 2) 391-411; HruzA, Wissenschaftliches Rüstzeug (wie Anm. 53) 479-494.

71 Zu ihm siehe Karel Hruza, Heinz Zatschek (1901-1965). „Radikales Ordnungsdenken“ und „gründliche, zielgesteuerte Forschungsarbeit“, in: Österreichische Historiker (wie Anm. 50) 677-792.

$72 \mathrm{Zu}$ Pirchan siehe den Beitrag von Stefan Lehr und Tomáš Borovský in diesem Band.

73 UAP, Deutsche Universität, Philosophische Fakultät, K. 95 (1938/39). Zum Konflikt mit der tschechoslowakischen Regierung siehe Alena Mıš́ová, Die Deutsche Universität im Zweiten Weltkrieg, in: Universitäten in nationaler Konkurrenz. Zur Geschichte der Prager Universitäten im 19. und 20. Jahrhundert, hg. v. Hans Lem berg (Veröff. des Collegium Carolinum 86, München 2003) 177-193, hier 179. Die o.g. Professoren trafen sich in Wien in der sudetendeutschen Anmeldestelle. 
tät wurde im Protektorat durch die Einführung gemeinsamer tabellarischer Stundenplanübersichten formalisiert, die dem Vorlesungverzeichnis beigefügt erschien (erstmals für das erste Trimester I94I). Weitere Kooperationen zwischen den Instituten sind auch aus gemeinsam durchgeführten Promotionsverfahren ersichtlich, so beispielsweise bei Erich Bachmann in der Konstellation Swoboda und Wostry ${ }^{74}$. Personell wurde die Lehre der Kunstgeschichte mit dem Wintersemester I94I/42 bis zum Sommersemester I 943 durch Hans Werner Hegemann (bevorzugt mit Themen zur Barockarchitektur) und im Wintersemester I 944/45 durch Hegemann zusammen mit Bachmann gestärkt. Die Entwicklung des Kunsthistorischen Instituts wurde von der persönlichen Etablierung Swobodas begleitet: Im SS I 942 war sein privater Wohnort in Prag-Streschowitz, im WS I942/43 war das konfiszierte Schwarzenbergpalais angegeben, im SS I943 war als Adresse des Instituts schließlich das Rudolfinum verzeichnet ${ }^{75}$.

\section{FORSCHUNG UND DAS PRAXISFELD DER PUBLIKATIONEN}

I937 wurde anlässlich der 75-Jahr-Feier des Vereins für Geschichte der Deutschen in Böhmen die Festschrift „Das Sudetendeutschtum. Sein Wesen und Werden im Wandel der Jahrhunderte“ veröffentlicht, in der unterschiedliche Fachdisziplinen ihre Forschungen zum „Sudetenraum“vorlegten. Swoboda übernahm die Kunstgeschichte, wobei sein Beitrag deutlich dem Verein als „Diskursgemeinschaft“ (Jutta Held) verhaftet war ${ }^{76}$. In argumentativem Zusammenhang mit dem „Sudetenraum“ wurde die Kunstgeschichte Böhmens und Mährens als die einer deutschen Sonderlandschaft behandelt. Das vorgegebene „gemeinschaftliche“ Ziel der Forschungsbeiträge wurde am Schluss der Publikation von Pirchan formuliert: „Es gilt auf gemeinsam erlebter Geschichte und gemeinsam geschaffener Kultur die völkerverbindende, höhere politische Gemeinschaft zu bauen." Hier ließen sich noch versöhnliche Töne der Bemühungen um einen tschechisch-deutschen Ausgleich innerhalb der Tschechoslowakei 1937 vernehmen ${ }^{77}$.

74 Disertace pražské university 1882-1945 II. Německá universita [Die Dissertationen der Prager Universität 1882-1945 II. Die Deutsche Universität], bearb. v. Milena VÝ воRná (Praha 1965) 106.

75 Siehe Personal- und Vorlesungsverzeichnisse der Deutschen (Karls-)Universität Prag 1934 bis 1945, UAP.

76 Karl Maria Swовода, Zum deutschen Anteil an der Kunst der Sudetenländer, in: Das Sudetendeutschtum. Sein Wesen und Werden im Wandel der Jahrhunderte. FS zur Fünfundsiebzigjahrfeier des Vereins für Geschichte der Deutschen in Böhmen 1: Mittelalter, 2: Neuzeit, hg. v. Gustav Pirchan, Wilhelm Weizsä́кев, Heinz Zатsснек (Brünn/Prag/Leipzig/Wien 1937), hier 1 209-249. Wiederveröffentlichung im ersten Band der Reihe „Beiträge zur Geschichte der Kunst im Sudeten- und Karpathenraum“ (Brünn/Prag/ Leipzig/Wien 1938).

77 Siehe Hans Lem вe Rg, Der deutsche Aktivismus in der Ersten Tschechoslowakischen Republik und sein letzter Versuch einer deutsch-tschechischen Verständigung. 50 Jahre seit 1937, in: Letzter Versuch zum deutsch-tschechischen 
Swoboda äußerte sich „Zum deutschen Anteil an der Kunst der Sudetenländer“. Mit Letzteren waren „grob Böhmen und Mähren“ als historische deutsche Gebiete gemeint. Die „künstlerische Eigenart des Sudetengebietes“ wurde durch eine „Einheit der politischen Geschichte“ erklärt. Die Thematisierung des Sudetengebietes als „Teilstück und Abhängige eines übergeordneten politischen Gebildes, des Alten Römischen Reiches deutscher Nation “bediente deutschnationale Interessen. In diesem Kontext entstand Swobodas Darstellung über die gewinnbringende „Einordnung in das Reichsgefüge“ von der „empfangenden“ zur „führenden“ Rolle innerhalb der „gesamten Reichskunst“78. Das „Deutschtum“ war zwar weiterhin die übergeordnete Kategorie der Kunstbetrachtung. Das Volkstum vereinte nämlich nach Swobodas Verständnis die Kulturwissenschaften zu einer übergreifenden Wissenschaft von den Nationen. Das Kunstverständnis sollte sich jedoch nicht länger - wie beispielsweise noch bei dem Kunsthistoriker Joseph Neuwirth ${ }^{79}$ - primär nach den „deutschen Trägern“ richten, nämlich den Künstlern wie Parler $^{80}$, den Dientzenhofern ${ }^{81}$, Braun ${ }^{82}$, Brokoff ${ }^{83}$ oder dem Bauherrn, der Gemeinde. Vielmehr ging es ihm um eine allgemeine Abhängigkeit von „bodenständigen Wesenszügen“ mit dem Vorteil, selbst bei der Auswahl und Umformung das von „außen her“ Dargebotene aufzunehmen. In diesem Kontext stand ein Hinweis auf das tschechische Schrifttum ${ }^{84}$, der sich auf einen Kompromiss bezog, der die nationalen und sprachlichen Vereinnahmungen von Kunst seitens der Deutschen und der Tschechen außer Kraft setzen sollte ${ }^{85}$. Der Hinweis

Ausgleich (Schriftenreihe der Seliger-Gemeinde, München 1987) 3-26, vgl. auch Mark K, Kunstgeschichte (wie Anm. 65) 96. In der zweiten Auflage des „Sudetendeutschtums“ von 1939 zitierte Pirchan (649) triumphierende Worte des dem Nationalsozialismus verhafteten Dichters Erwin Guido Kolbenheyer: „Ein Drang und Traum der Väterwelt Saatweis ist aufgegangen In mir und fruchtet meine Zeit, bis all ihr Erbe ist befreit Und all ihr Sehnen.“

78 Siehe Swoвoda, Anteil (wie Anm. 76) 209f., und „Beiträge“ (wie Anm. 76) 11.

$79 \mathrm{Zu}$ ihm siehe Biographisches Lexikon zur Geschichte der böhmischen Länder 3: N-SCHY, hg. v. Ferdinand Seib t u.a. (München/Wien 2000) $45 f$.

80 Peter Parler (um 1332 Schwäbisch Gmünd oder Köln am Rhein-1399 Prag) wurde 1353 von König Karl IV. als Dombaumeister nach Prag berufen, siehe Ulrich Thiе me, Felix Becker, Allgemeines Lexikon der bildenden Künstler von der Antike bis zur Gegenwart 26 (München 1992) 243-245.

81 Von der Familie Dientzenhofer, einer aus der Umgebung von Aibling in Bayern stammenden Baumeisterfamilie, haben sich Christoph Dientzenhofer (1655-1722) und sein Sohn Kilian Ignaz D. (1689-1751) in Prag niedergelassen, siehe Thieme, Becker, Lexikon 9 (wie Anm. 80) 239-243.

82 Matthias Bernhard Braun von Braun (1684-1738) wurde von Graf Franz Anton von Sporck 1704 nach Böhmen berufen und war als Bildhauer in Prag und Böhmen tätig, siehe Biographisches Lexikon 1 (wie Anm. 47) 138, und Thieme, Becker, Lexikon 4 (wie Anm. 80) $550 f$.

83 Ferdinand Maximilian Brokoff (1688-1731) arbeitete als Bildhauer in Prag, Böhmen und Schlesien, siehe Biographisches Lexikon 1 (wie Anm. 47) 149, und Thiе me, Becker Lexikon 5 (wie Anm. 80) $52 f$.

84 Siehe Swoводa, Anteil (wie Anm. 76) 209, und „Beiträge“ (wie Anm. 76) 11. Ebd. wird in Anm. 2 verwiesen auf: Dějepis výtvarného umění v Čechách 1-2 [Geschichte der bildenden Kunst in Böhmen 1-2] (Prag 1931, 1935).

85 Sogleich 1918 erklärte der nunmehr als Beamter des tschechoslowakischen Schulministeriums agierende 
auf die „čechoslovakische“ Kunstgeschichte und die Methoden der Kunstgeografie integrierte die tschechischen Kollegen, womit Swoboda bezeichnenderweise anstelle der Konfrontation die protektionistische Geste bediente ${ }^{86}$. In die politische Geschichte wurde die Kunst nach typologischen Gesichtspunkten eingebettet ${ }^{87}$. Mit der „deutsche[n] Kolonisation des gesamten Ostraumes“"88 wurden unter den „deutschen Sonderformen europäischer Kunst“ im I3. Jahrhundert die aus verschiedenen deutschen „Kunstlandschaften“ eingeführten Kunsttypen präsentiert ${ }^{89}$. Der kulturelle Aufstieg des „kolonisierten Ostraumes“ im I4. Jahrhundert und die führende Rolle der „Sudetenländer“ innerhalb der Reichskunst wurden in der Konstellation des „deutschen Kaisers“ Karl IV. und des aus Schwäbisch Gmünd kommenden Peter Parler gleichsam versinnbildlicht ${ }^{90}$. Die Machtverschiebung von Prag nach Südböhmen und Mähren nach I 400 wurde mit einer rezeptiven Haltung gegenüber allen Wendungen der „deutschen Spätgotik“ identifiziert ${ }^{91}$. Aufgrund der skizzierten Abhängigkeiten der Kunst von der politischen Geschichte forderte Swoboda ein wissenschaftliches Denken in großen politischen Einheiten unter Berücksichtigung der kirchen- und wirtschaftsgeschichtlichen Bindungen, das Erklärungen der stilgeschichtlichen Prozesse sowie örtlichen und landschaftlichen Sonderbildungen biete und die Teilnahme unterschiedlicher Völker an den künstlerisch-historischen Prozessen des erneuten Hervorholens, Entfaltens, Umdeutens, Neudeutens, Zerdeutens in historisch-politischer Abhängigkeit sehe ${ }^{92}$. Mit ihrer Prägung durch „realhistorische Einheiten“ schwebte Swoboda letztlich eine Kunstgeschichte des durch seine „Grenzen

Václav Vilém Štech die einheimische Kunst in ihrer Einzigartigkeit als Produkt von Künstlern unterschiedlicher Nationen zur Repräsentantin des neuen Nationalstaates, siehe Václav Vilém Š Tech, Smysl země [Der Sinn des Bodens], in: Včera. Výbor článků z r. 1910-1920 [Gestern. Auswahl von Artikeln aus den Jahren 1910-1920] (Praha 1921) 232-245; vgl. Marek, Kunstgeschichte (wie Anm. 65) 83f.

86 Bei Aurenhammer, Institut nach 1945 (wie Anm. 2) 178, heißt es „die neue Ideologie des deutschen ,Schutzes' für die Tschechen“.

87 Die Durchsetzung der sogenannten Reichskunst wurde im Zusammenhang mit dem „reichskirchlichen, doppelchörigen Kirchentypus“, mit Kloster Hirsau und dem basilikalen süddeutschen Grundrisstypus des 12. Jahrhunderts dargestellt, siehe Swовода, Anteil (wie Anm. 76) 210-213, und „Beiträge“ (wie Anm. 76) 12-15.

88 Adam LABUDA, „... eine von sinnvollen Zweckgefühlen erfüllte, herbe und großartige Kolonialkunst ...“ Zum kunsthistorischen Diskurs über Ostmitteleuropa, in: Zs. für Kunstgeschichte 56 (1993) 1-17.

89 Siehe Swовода, Anteil (wie Anm. 76) 213-216, und „Beiträge“ (wie Anm. 76) 15-18.

90 Siehe Swoв oda, Anteil (wie Anm. 76) 216-220, und „Beiträge“ (wie Anm. 76) 18-22.

91 Siehe Swoв оda, Anteil (wie Anm. 76) 220-223, und „Beiträge“ (wie Anm. 76) 22-25. Die sogenannte „Spätgotik“ stellte eine national bedingte Stileinheit vor, die der französischen Gotik gegenübergestellt wurde, siehe Kurt Gersten Berg, Deutsche Sondergotik. Eine Untersuchung über das Wesen der deutschen Baukunst im späten Mittelalter (München 1913).

92 Bevorzugt waren die Epochen der kulturpolitischen Hochzeiten, die Kunst unter Karl IV. und zur Zeit der österreichischen Dominanz im Barock, siehe Swовода, Anteil (wie Anm. 76) 223-227, und „Beiträge“ (wie Anm. 76) 25-31. 
umschlossenen [deutschen] Volkstums“ in Auseinandersetzung mit dem Fremden vor. Damit wurden die übergreifenden Raumkonzeptionen des „Westostgefälles der europäischen Kultur“ und des „Ostraums“ eingeführt. Diese Raumkategorien waren wesentlicher Faktor in der Methodik der Darstellung, sie wurden durch biologistisch-rassistische Betrachtungen betreffend „Das Sudentenländische“, „Das Tschechische“ und „Das Sudetendeutsche" ergänzt ${ }^{93}$.

Swobodas Aufsatz war insofern programmatisch, als er für seine weiteren Forschungen wie auch die seiner Mitarbeiter die Methoden vorgab und eine entsprechende Terminologie prägte. Dabei entgegnete Swoboda den tschechischen Kunsthistorikern, die den politischen Begriff der „čechoslovakischen“ Kunst auf die Kunstgeschichte der böhmischen Länder übertragen und in diesem Sinne auch den landespezifischen Charakter einer Kunstgeschichte unterschiedlichster Provenienz auf die tschechoslowakische Perspektive verengt hatten ${ }^{94}$. Swoboda wollte hingegen die von ihm so bezeichnete Kunstgeschichte der Sudetenländer in historischem Zusammenhang mit dem römisch-deutschen Reich „in ihrem Wesen als vom deutschen Volkstum bestimmte Kunst“ deuten"5. In seinem Text wurde die geografisch-historische Begründung von sogenannten historisch gewachsenen Strukturen eines deutschen Kulturbodens verfolgt. Wenn unter den „Sudetenländern“ Böhmen und Mähren zusammengefasst als das „Teilstück und Abhängige eines übergeordneten politischen Gebildes, des alten Römischen Reiches deutscher Nation“ bezeichnet erschienen ${ }^{96}$, so wurde mit dem historischen Kontext des Vielvölkerreiches unter vermeintlich „deutscher“ Führung - obgleich es in Wirklichkeit ein monarchisch geführtes und ständisch geprägtes Gebilde von vor- beziehungsweise übernationalen Charakter gewesen war - auch der aktuelle großdeutsche raumpolitische Gedanke evoziert. In der Diskursgemeinschaft des Vereines gewann die Raumbegrifflichkeit insbesondere durch die Mundartforschung und die Rechtsgeschichte einen wissenschaftlich-systematischen Rückhalt ${ }^{97}$. Swoboda wählte den Raum in den Überschriften einzelner Kapitel zur strukturierenden Kategorie seines Beitrags. Das Kapitel „Westostgefälle der europäischen Kultur" handelte von einer grundsätzlichen kulturellen und künstlerischen Raum-

93 Siehe „Das Sudentenländische“ in Swо вода, Anteil (wie Anm. 76) 233-238, und „Beiträge“ (wie Anm. 76) 35-41, „Das Tschechische“ 239-241 und 41-43, „Das Sudetendeutsche“ 241-242 und 43-44.

94 Siehe Die čechoslovakische Kunst von der Urzeit bis zur Gegenwart. Eine Auswahl hervorragender Werke der Architektur, Plastik, Malerei, sowie des Kunstgewerbes in der Čechoslovakei. Zusammengestellt von Zděněk Wirth, begleitet von dems., Vojtěch Birnbaum, Antonín Matějček, Josef Schránil (Prag 1926) 5-24.

95 Siehe Swo в oda, Anteil (wie Anm. 76) 240, und „Beiträge“ (wie Anm. 76) 42.

96 Siehe Swоводa, Anteil (wie Anm. 76) 210, und „Beiträge“ (wie Anm. 76) $11 \mathrm{f}$.

97 Siehe Pirchan, Sudetendeutschtum 1939 (wie Anm. 77) 608-611, 611: „... in seiner sächsischen und süddeutschen Fassung vorrückend, eroberte [...] das deutsche Stadtrecht mit all seiner in Rats- und Rechtsbüchern verkörperten Rechtskultur nicht nur die Grenzstriche, sondern den gesamten Machtbereich der Přemysliden.“ 
bewegung, die auch das Verhältnis der „deutschen Reichskunst“ zum „Sudetengebiet“ kunstgeschichtlich als „übernationale, gesamteuropäische Mission des Deutschen Reiches nach Osten“ mit „ausgesprochen deutschem Kunstwollen“ spezifizierte ${ }^{98}$. Das Kapitel „Der deutsche Ostraum“ wurde durch Begriffe wie „kunstgeschichtliches Außeneuropa“, „Außengrenze des Abendlandes“, „Randcharakter“ eingekreist und mit Vorstellungen von „Sonderstilen“, „Verwilderung der Grundformen der Kunstwerke“, „Vervielfältigung der Einzelheiten, des Ornaments“, „Häufung der architektonischen Kleinformen“ in Verbindung gebracht. Eine solche Fixierung vertrat Swoboda aufgrund der neuen Erforschung des "deutschen Ostens“ seitens der Historiker. Dabei berief er sich auf Hermann Aubin ${ }^{99}$, den ersten stellvertretenden Leiter der NOFG mit zusätzlicher Zuständigkeit für die Arbeitsgebiete Niederschlesien und Oberschlesien, der mit der SODFG am „Volkstumsprojekt“ eng kooperierte ${ }^{100}$. Aubin war dann auch Mitarbeiter der SS-Forschungsgemeinschaft „Ahnenerbe“ und Mitglied der Sudetendeutschen Anstalt für Landes- und Volksforschung in Reichenberg ${ }^{101}$. Es war Aubin, der 1932 mittels geopolitischer Motive befand, dass das Deutsche Reich einem angeblichen Doppeldruck von Slawen und Romanen seit dem Mittelalter ausgesetzt gewesen sei. Hinsichtlich des deutschen Ostens vertrat er Ansichten über angebliche „Überflutung“ durch slawische Barbaren, der entsprechende Text ist bei Swoboda als Literaturhinweis angegeben ${ }^{102}$. Auf Aubin wurde ebenfalls der Begriff „Grenzraum“ zurückgeführt, der sich auf die „Grenzraumländer der Reichsgrenze“ bezog und im Zusammenhang mit dem künstlerischen „Westostgefälle“ durch Randcharakterzüge ausgewiesen erschien ${ }^{103}$. Der „Ostraumcharakter“ der Kunst im Sudetengebiet wurde von Swoboda letztlich mit den „deutschen Sonderformen“ identifiziert ${ }^{104}$. Für die Deutung des „deutschen Charakters“ dieser Kunst - das sogenannte Ausdruckmäßige, Expressive, das Formen-Umdeuten und sich Beziehen auf andere Völker - standen Pinder und dessen Charakteristik der deutschen Züge der „Kunst des deutschen Kaiserreichs“ ein ${ }^{105}$. Mit Pinder hat sich Swoboda den höchst prominenten Rückhalt in der Kunstgeschichte des „Dritten Reiches“ gesucht. Swobodas Begrifflichkeit reflektierte Pinders ei-

98 Siehe Swoв оda, Anteil (wie Anm. 76) 227-229, und „Beiträge“ (wie Anm. 76) 29-31.

99 Siehe Swoв oda, Anteil (wie Anm. 76) 229-233, und „Beiträge“ (wie Anm. 76) 31-35.

100 Siehe Faнlbusch, Wissenschaft (wie Anm. 38) 187; zur Kooperation 246.

$101 \mathrm{Zu}$ Aubin siehe Eduard Müнle, Für Volk und deutschen Osten. Der Historiker Hermann Aubin und die deutsche Ostforschung (Schriften des Bundesarchivs 65, Düsseldorf 2005).

102 Siehe Fanlbusch, Wissenschaft (wie Anm. 38) 69. Von Aubin wird bei Swoboda folgende Literatur angegeben: Hermann Au Bin, Die Ostgrenze des alten deutschen Reiches. Entstehung und staatsrechtlicher Charakter, in: Historische Vierteljahresschrift 28 (1933) 225-272; DERs., Die Erforschung der deutschen Ostbewegung (Deutsches Archiv der Landes- und Volksforschung 1, 1937).

103 Siehe Sw ов орA, Anteil (wie Anm. 76) 232, und „Beiträge“ (wie Anm. 76) 34.

104 Siehe Swoв oda, Anteil (wie Anm. 76) 229, und „Beiträge“ (wie Anm. 76) 31.

105 Siehe Swoв оda, Anteil (wie Anm. 76) 224f., und „Beiträge“ (wie Anm. 76) 26f., mit Verweis auf Wilhelm 
gene Beschreibung deutscher Kunst aus dessen Nähe zum Expressionismus. Das Deutsche in der Kunst, in Pinders Sinne eine über die völkischen Grenzen hinausgreifende, durch den „deutschen Boden“ begründete Qualität, wurde für Swobodas kunsthistorisches Verständnis richtungweisend ${ }^{106}$. Pinder und Hans Jantzen hatten die Raumkonzeptionen als Forschungsapparat der Kunstgeschichte systematisch eingesetzt und in Publikationsprojekten wie den Reihen der „Ausstrahlungen“ und der „Sonderleistungen“ der deutschen Kunst zum weitflächigen Untersuchungsfeld koordiniert ${ }^{107}$. Schließlich hat Swoboda in seinem Beitrag von 1937 die biologistisch-rassistische Einordnung abschnittweise abgehandelt. Das „Sudetenländische“ wurde durch einen einheitlichen Menschenschlag im Zusammenhang mit der Randlage des Gebiets als „Vorgeschichtliches“, „Vorindogermanisches" gedeutet, den interpretatorischen Bezugsrahmen gab die psychopathologische Konstitutionstypologie des deutschen Psychiaters Kretschmer über Körperbau und Charakter vor ${ }^{108}$. Entsprechend war die Rede von „Rundschädeln, Menschen der sogenannten alpinen Rasse“, die sich als alte Rasse „durch das Andersrassige der zugewanderten Tschechen und Deutschen in vorherrschender Weise durchschlagen" ${ }^{109}$. Swobodas Kulturpessimismus äußerte sich hier in Phantasien über die Vorherrschaft von Triebkräften einer vorgeschichtlichen Rasse-, Körper- und Charaktertypik. Die kunsthistorische Qualifizierung des „Sudetenländischen“ hieß „schwere, breite Massigkeit“, „dunkle, dumpfe, aber volltönende Formen“"110. Gegenüber dem „Sudetenländischen“ wurde einerseits das „Tschechische“ als „labil“ umschrieben, es sollte sich im „Zersetzen, Zerlegen der dargebotenen Formen“ artikulieren"11. Andererseits wurde das „Sudetendeutsche“ gemäß der „Kulturbodenforschung“ im deutschen Grenzraum nochmals durch die stärkeren grundherrschaftlichen, kirchenpolitischen und wirtschaftsgeschichtlichen Bedingungen gedeutet, die letztlich in der Gewichtung als entscheidend galten. Damit blieb auch alle phantastische Rassentypologie doch nur eine Beimischung in den kulturellen Raumkonzeptionen als der entscheidenden Kategorie in Swobodas Kunstverständnis ${ }^{112}$.

Pinder, Die Kunst der deutschen Kaiserzeit bis zum Ende der staufischen Klassik (Vom Werden und Wesen deutscher Formen: geschichtliche Betrachtungen 1, Leipzig 1935).

106 Siehe Jutta Hesd, Kunstgeschichte im „Dritten Reich“. Wilhelm Pinder und Hans Jantzen an der Münchner Universität, in: Kunstgeschichte an den Universitäten (wie Anm. 2) 17-59, hier 18-25 (Politische und fachpolitische Positionierungen).

107 Ebd. 32-40 (Raumkonzeptionen).

108 Auch für Sedlmayr wurde Kretschmers Typenlehre zum konstitutiven Bestandteil seiner Kunstgeschichte, Aurenhammer, Zäsur (wie Anm. 2) 19.

109 Swовода, Anteil (wie Anm. 76) 233-238, und „Beiträge“ (wie Anm. 76) 39f.; zu Kretschmer gibt es den Verweis auf Ernst Kretschmer, Geniale Menschen (Berlin 1929).

110 Swoвоda, Anteil (wie Anm. 76) 233, und „Beiträge“ (wie Anm. 76) 35.

111 Swоводa, Anteil (wie Anm. 76) 210, und „Beiträge“ (wie Anm. 76) 12.

112 Auf die kunsthistorische Volkstumsforschung reagierte Wirth mit dem Vortragsmanuskript „Kunst und 
Swobodas Eintreten für die volkspolitischen Interessen wurde mit seiner im Auftrag der Deutschen Gesellschaft der Wissenschaften und Künste in Prag ${ }^{113}$ getätigten Herausgeberschaft der „Beiträge zur Geschichte der Kunst im Sudeten- und Karpathenraum“ besiegelt. Der Wiederveröffentlichung seines Aufsatzes „Zum deutschen Anteil an der Kunst der Sudetenländer“ als erster Band stellte Swoboda ein zweiteiliges Vorwort voran, das zum Juni und zum November 1938 in Prag datiert ist ${ }^{114}$; zwischen diesen Terminen wurde die Abtretung der „sudetendeutschen“ Grenzgebiete an das Deutsche Reich erzwungen und die Tschechoslowakei von der „Ersten“ in die „Zweite“ Republik überführt.

Im Juni 1938 gaben die Verdienste der Gesellschaft der Wissenschaften und Künste und Neuwirths „Forschungen zur Kunstgeschichte Böhmens“ die Tradition für die kunstgeschichtlichen Untersuchungen zu Deutschtumsfragen gegenüber einer angeblichen nationalen Indifferenz seitens der tschechoslowakischen Kunstgeschichte vor, wobei für Ergänzungen des tschechischen Schrifttums der Dank an Josef Cibulka und an Matějček erging. Programmatisch wurde die Schriftenreihe der übergeordneten Kategorie des Volkes als dem natürlichen Kunstträger und den Deutschtumsfragen im Sinne einer Einordnung in das natürliche Gefüge der Geisteswissenschaften als einer deutschen Gesamtwissenschaft verpflichtet. Das Stichwort lautete „deutsche Sonderlandschaft“. Im November I938 wurden - „von Stolz und Freude erfüllt“ - im nationalsozialistischen Sprachduktus die machtpolitischen Eingriffe als „Weg heim ins wiedererstandene großdeutsche Reich“ gefeiert: Aus der Perspektive Prags mit seiner Stellung als Hauptstadt nunmehr der Zweiten Republik dürfte diese Parteinahme umso schärfer Swobodas eigene Positionierung herausstellen. Sie ist allerdings zugleich bezeichnend für eine Gleichschaltung der

Land“, einer „čechoslovakischen“ Kunstgeschichtsversion über die seit Urzeiten wirkende, assimilierende Kraft Böhmens, die unterschiedliche Stämme und mit der Umgebung zusammengewachsene Künstler zu einem ethnisch einheitlichen Volk vereint und der Kunst den besonderen Status einer eigenwilligen Gruppe innerhalb Mitteleuropas verliehen habe. Handschriftlicher Vermerk: Škola Mánesa [Mánes-Schule], 04.01.1944. Archiv Ústavu dějin umění AV ČR [Archiv des Kunsthistorischen Instituts der Akademie der Wissenschaften der Tschechischen Republik], Zdeněk Wirth, W-A-40. Konkret wandte sich Wirth gegen Otto Kletzl Die deutsche Plastik in Böhmen und Mähren, in: Pantheon XII (1939) 128-134, und gegen alle „künstlichen Konstruktionen“, die das Kunstschaffen in Prag vom 13. bis zum 15. und vom 17. bis zum 19. Jahrhundert unter dem Vorzeichen der politischen Machtverhältnisse (nämlich der Einbindung Böhmens in Großreiche) sehen wollten.

$113 \mathrm{Zu}$ dieser Gesellschaft und späteren „Deutschen Akademie der Wissenschaften in Prag“ siehe Alena Mišková, Michael Neumüller, Společnost pro podporu německé vědy, umění a literatury v Čechách (Německá akademie věd v Praze)/Die Gesellschaft zur Förderung deutscher Wissenschaft, Kunst und Literatur in Böhmen (Deutsche Akademie der Wissenschaften in Prag) 1891-1945 (Práce z dějin české akademie věd/Studia historiae academiae scientiarum bohemicae, Praha 1994) 40-41.

114 Swовора, Karl Maria, Zum deutschen Anteil an der Kunst der Sudetenländer (Beiträge zur Geschichte der Kunst im Sudeten- und Karpathenraum 1, Brünn/Prag/Leipzig/Wien 1938). Das Buch ist Pinder, dem „Geschichtsschreiber der deutschen Kunst“, zum sechzigsten Geburtstag gewidmet. 
Deutschen Universität in Prag, die vom Herbst 1938 an bis März beziehungsweise Ende I939 dauerte ${ }^{115}$. Pinder wurde von Swoboda nochmals wegen seiner wissenschaftlichen Verfechtung der „deutschen Kulturmission im Osten“ als vorbildhaft für die „deutschen Kulturarbeiten im Sudeten- und Karpathenraum“ im Zusammenhang mit der Reihe der „Beiträge“ herausgestrichen. Mit dieser politischen Bezugnahme hat sich Swoboda dem Direktor des Kunsthistorischen Instituts der Universität Wien, Hans Sedlmayr, an die Seite gestellt ${ }^{116}$. Als Konsequenz aus der veränderten politischen Lage sollte eine neuartige Zusammenarbeit von Tschechen und Deutschen verwirklicht werden und in der Forschung eine verstärkte Einbeziehung der „östlichen Vorländer deutscher Kultur“ erfolgen. Konkret wurde etwa der Karpathenraum in die neue Publikationsreihe aufgenommen ${ }^{117}$.

Als zweiter Band der Reihe erschienen 1939 die von Swoboda zusammen mit seinem Schüler Bachmann ${ }^{118}$, einem Mitarbeiter im „Ahnenerbe“ der SS, durchgeführten Forschungen. Präsentiert wurden die „Studien zu Peter Parler“, nämlich die „Gemeinschaftsarbeit" der Fachschaft im Kunstgeschichtlichen Seminar der Deutschen Universität in Prag unter Swobodas Leitung zur Baugeschichte des gotischen Veitsdomes, die Bachmann weitergeführt hatte, und Swobodas bereits I 938 publizierter Aufsatz über „Klassische Züge in der Kunst Peter Parlers" ${ }^{119}$. Die Kunst des Prager Dombaumeisters Parler wurde als „Klassik in der Gotik“, als eine Vorwegnahme der Renaissance im späten I4. Jahrhundert qualifiziert. Parlers Leistung wurde in dem Zergliedern des „Gedankens der

115 Alena MıšKová, Deutsche Universität (wie Anm. 46) 165-175, hier 168.

116 Seldmayr beglückwünschte Pinder nach dem geschehenen „Elementarereignis“ der „neue[n] deutschen Einheit“ [dem „Anschluss“ Österreichs an das Deutsche Reich am 12. März 1938] mit Hitlers Namen, siehe Hans Sedlmayr, Vermutungen und Fragen zur Bestimmung der altfranzösischen Kunst, in: FS Wilhelm Pinder zum sechzigsten Geburtstage überreicht von Freunden und Schülern (Leipzig 1938) 9-27, hier 9. Dazu auch Aurenhammer, Zäsur (wie Anm. 2) 12f.

117 Siehe Swовода, Beiträge (wie Anm. 76) 7-9. Auf diese Darstellung der geografischen, politischen, ,völkischen“ und künstlerischen Entwicklung der Kunstlandschaft Mähren beruft sich Heinrich Gerhard Franz, Die deutsche Barockbaukunst Mährens (Ausstrahlungen der deutschen Kunst. Deutsche Kunst im böhmisch-mährischen Raum, München 1943) 6-9 und Anm. 1.

118 Der in Karlsbad gebürtige Bachmann studierte in Prag bei Swoboda, war ebendort 1938-1940 Assistent am Kunsthistorischen Institut der Deutschen Universität, 1941 Habilitation, 1944/45 korrespondierendes Mitglied der Deutschen Akademie der Wissenschaften in Prag, 1946 Ausweisung aus der Tschechoslowakischen Republik, siehe: Biogramme der Mitglieder der Historischen Kommission der Sudetenländer im Gründungsjahr 1954, bearb. v. K. Erik Franzen, Helena Peřinová, in: „Sudetendeutsche Geschichtsschreibung“ (wie Anm.53) 219-276, hier 224.

119 Karl Maria Swoв оda, Erich Bachmann, Studien zu Peter Parler (Beiträge zur Geschichte der Kunst im Sudeten- und Karpathenraum 2, Brünn/Prag/Leipzig/Wien 1939) [7] (Vorbemerkung). - An dieser Stelle soll erwähnt werden, dass sich Swoboda zusammen mit Otto Kletzl auch als „Sachbeirat“ am UFA-Film „Peter Parler - Dombaumeister zu Prag“ (Buch und Regie Werner Buhre, 1941, Länge ca. 19 Minuten) beteiligt hat. Der Film verherrlicht den „genialen deutschen Menschen“ Parler und den „deutschen nationalen“ Stil der Spätgotik. 
klassischen Kathedrale“ gesehen, wobei „er das künstlerisch zu realisieren imstande [war], was dem ganzen gotischen Kunstdenken auf dem regelmäßigen Weg der Kathedralenkunst als ein ferner unerreichter Traum erscheinen musste, das Klassische in seiner von der klassischen Kathedralgotik unerreichten Reinheit“. Mit der Idee der Spätstile wurde die Klassik als vermeintliche Überwindung der französischen Kathedralgotik und eine wesentlich deutsche subjektive Hochleistung in späten Zeiten präsentiert ${ }^{120}$. Auch der dritte Band war „dem eingeschlagenen Programm und den Gedankengängen des ersten Bandes dieser Reihe" verpflichtet ${ }^{121}$. Diese Arbeit folgte systematisch den Zielsetzungen der „kunstgeschichtlichen Volksforschung“, indem „die spätstaufische Baukunst des böhmischen Raums im Zusammenhang mit folgendem großen übergreifenden geschichtlichen Vorgang von Bedeutung [ist]: Im I3. Jahrhundert vollzieht sich die Durchdringung des ostdeutschen Gebiets mit deutschen Siedlern, die schließlich dem Reich auch volklich ganz neue Provinzen, ja ein zweites Deutschland eintrug. [...] Es gibt heute in vollkommen tschechischen Landstätten Innerböhmens, mitten im tschechischen Siedlungsgebiet, Pfarrkirchen aus dem I3. Jahrhundert, die alle Eigenschaften des sächsischen bzw. donauländischen Übergangstils haben. "122 Nach Vorgaben seines Lehrers Swoboda wurden diese Gebiete als süddeutsche und norddeutsche Einflussbereiche bearbeitet. Zentrale Rolle spielten dabei die der Tradition des Gründers des Neuklosters von Citeaux verpflichteten Zisterzienser, die als ein „deutscher Orden“ an der „deutschen Rücksiedlung hervorragend beteiligt" gewesen seien ${ }^{123}$. Pikanterweise wurde innerhalb des deutschen Einflussbereiches auch die Prager Synagoge in einem eigenen Kapitel behandelt ${ }^{124}$.

Zusammenfassend wurden die Beziehungen des sogenannten Sudetenraumes als Abhängigkeit von den umliegenden Kunstlandschaften gedeutet. Damit - so der Schlusssatz - habe die kunstgeschichtliche Sonderuntersuchung Ergebnisse geliefert, die mit denen der Volksforschung übereinstimmten ${ }^{125}$. Umgekehrt ließe sich sagen, dass die Kunstgeschichte einen Beitrag zur Volksforschung geliefert hatte. Die 194I erschienenen „Sudetenländische[n] Kunsträume im I3. Jahrhundert. Ein Beitrag zur kunstgeschichtlichen Volksforschung im deutschen Südosten" waren als vierter Band der Reihe analog

120 Karl Maria Swо водa, Klassische Züge in der Kunst des Prager Deutschen Dombaumeisters Peter Parler, in: ders., Bachmann, Studien zu Peter Parler (wie Anm 119) 9-25, hier 9 und 25. Die Plastik galt dabei als die Verkörperung dieses künstlerischen Wesens. Zum Begriff des „Klassischen“ siehe ebd. 10 die Literaturangabe Hans Rose, Klassik als künstlerische Denkform (München 1937).

121 Die Studie wurde 1938 abgeschlossen, ein Dank ging außer an Swoboda auch an Hans Hirsch, siehe Erich Bachmann, Eine spätstaufische Baugruppe im mittelböhmischen Raum (Beiträge zur Geschichte der Kunst im Sudeten- und Karpathenraum 3, Brünn/Prag/Leipzig/Wien 1941) [6] (Vorwort).

122 Ebd. 9.

123 Ebd. 114.

124 Ebd. 40-55.

125 Ebd. 114. 
zu den historischen, sprach- und rechtsgeschichtlichen Untersuchungen der sudetendeutschen Volksforschung intendiert. Diese Arbeit sollte der Einleitung zufolge „vor allem die übergreifenden geschichtlichen Vorgänge von gesamtdeutscher Bedeutung “ darstellen, nämlich „die deutsche Wiederbesiedlung des deutschen Ostens“ und die „Feststellung der stilgeschichtlichen Bezüge und der kunstlandschaftlichen Zusammenhänge“, die auf einer Karte der „kunstlandschaftlichen Bauströmungen des I3. Jahrhunderts im Sudetenraum“ mit drei kunstlandschaftlichen Einflussbereichen (bayerisch-ostmärkisch, norddeutschsächsisch, fränkisch) dokumentiert waren ${ }^{126}$. Sie zeigten „nächstliegende Herkunftsund vor allem Durchgangsgebiete von Formen, die mitunter aus ganz anderen Welten stammen“"127. Wegen lückenhafter Nachweise ging es letztlich „keineswegs in jedem Fall [um] den konkret-geschichtlichen Wanderungsverlauf und die eindeutige Herkunft der Bauformen, sondern zuvörderst [um] stilistische Zusammenhänge und den beiläufigen und den vermuteten Formengang und es ist ohne weiteres zuzugeben, dass dieser erste Versuch in manchem anfechtbar ist" ${ }^{128}$, jedoch deckungsgleich mit den Siedlungsschüben der Kolonisationszeit und der Verbreitung der deutschen Stadtrechte sei: Böhmen und Mähren erschienen dabei in deutsche Einflussbereiche aufgelöst. „Die Kirchenbauten des Christoph Dientzenhofer" im fünften Band präsentierten eine formalstilistisch definierte Bautengruppe, die einige böhmische und fränkische Barockkirchen vereinte und damit die Einflussbereiche im Zusammenhang mit der Kulturbodenforschung thematisierte. Diese Baugruppe stand exemplarisch für das Werk des deutschen Volkstums, das „allgemein im Verlauf der abendländischen Kunstgeschichte die Formen des Südens und des Westens in den späten Phasen der Stilentwicklung [...] ins Malerische [...] aufgelöst und damit noch ein letztes Mal die in dem Stil erhaltenen Möglichkeiten ausgeschöpft und zu Ende entwickelt“ habe. In dieser Volkstumsspezifik wurde Christoph Dientzenhofer, der als Schöpfer dieser Bautengruppe auftrat, mit Peter Parler gleichgesetzt ${ }^{129}$. Konkret handelte es sich um eine Entgegnung auf die von Mai bis September 1938 in Prag gezeigte Ausstellung „Prager Barock“ des tschechischen Kunstvereins „Umělecká beseda“, die als ein gewichtiges politisches Prestigeprojekt der tschechoslowakischen Regierung konzipiert gewesen war und letztlich zur finalen Präsentation jenes Schicksalsjahres wurde ${ }^{130}$. Die Kohärenz

126 Siehe Erich Bachmann, Sudetenländische Kunsträume im 13. Jahrhundert. Ein Beitrag zur kunstgeschichtlichen Volksforschung im deutschen Südosten (Beiträge zur Geschichte der Kunst im Sudeten- und Karpathenraum 4, Brünn/Prag/Leipzig/Wien 1941) [11] (Einleitung) und 36-97 (Kapitel II. zu den Einflussbereichen der deutschen Kunstlandschaften). Die Studie wurde 1939 abgeschlossen.

127 Bachmann, Baugruppe (wie Anm. 121) 98.

128 Ebd. 102.

129 Siehe Heinrich Gerhard Franz, Die Kirchenbauten des Christoph Dientzenhofer (Beiträge zur Geschichte der Kunst im Sudeten- und Karpathenraum 5, Brünn/Prag/Leipzig/Wien 1942) 95.

130 Obgleich diese Ausstellung nach Ansicht von Franz, Kirchenbauten (wie Anm. 129) 5f., reich an hervorra- 
einer epochenübergreifenden, „sudetenländischen“ Kunstgeschichte wurde formalstilistisch durch „spät“-gotische und „spät“-barocke Wesenszüge ausgewiesen. Gleichermaßen wurde auch im sechsten Band der Beiträge unter dem Titel „Studien zur Barockarchitektur in Böhmen und Mähren“ der Zusammenhang mit den „gesamtdeutschen“ Einflussgebieten und Fragen der Rezeption in „enge[r] und untrennbare[r] Verbundenheit mit der innerdeutschen Entwicklung“ als „Untereinheit des Gesamtdeutschen“weiterverfolgt ${ }^{131}$.

Seit dem Frühjahr I 940 wurde die Idee von interdisziplinären Forschungsgemeinschaften umgesetzt, die den kriegspolitischen Zielen des Dritten Reiches verpflichtet waren ${ }^{132}$, wobei die Kunstgeschichte erst I94I dem „Gemeinschaftswerk“ beitrat. Unter der Führung von Pinder und Richard Sedlmaier wurde die Publikationsreihe „Die deutsche Kunst und ihr Wirkungskreis“ initiiert, die einerseits „Die deutsche Kunst an den Rändern des Reiches (Ausstrahlungen)“ und andererseits „Sonderleistungen deutscher Kunst (Erstleistungen)“ zum Thema hatte. Mit dieser Konzeption wurde die völkische Kunstgeschichte in eine groß dimensionierte Raumforschung europäischen Zuschnitts überführt, in der ausdrücklich der „Mischcharakter“ der europäischen „Rassen“ und Kultur anerkannt war. Der seit I940 politisch propagierte Europagedanke sollte durch ein kunsthistorisches Forschungsunternehmen gestützt werden, das den kulturellen Führungsanspruch Deutschlands fundierte (Kunstgeschichte der Peripherie) ${ }^{133}$. Dieses Engagement ging mit neuen Aufgaben einher, die I94I auch der Prager Universität zugesprochen wurden: Prag sollte als wissenschaftliches Zentrum in südöstlicher Richtung wirken und dabei die Ostforschung in Verbindung mit der Rassenforschung verfolgen ${ }^{134}$. Swoboda wurde sogleich im Januar I94I in den „Vorbereitenden Ausschuss der kunstgeschichtlichen Arbeitsgemeinschaft des Kriegseinsatzes“ berufen und nahm auch an entsprechenden Tagungen

gendem Material gewesen sei, so sollte sie doch den Besucher über den deutschen Charakter des böhmischen Barock hinweggetäuscht haben. Zum Memorandum gegen die Ausstellung „Prager Barock“ seitens Sedlmayr als „versuchter geistiger Raub eines Kronjuwels der deutschen Kunst“ und zu dessen Vorschlägen praktischer Gegenmaßnahmen wie einer Tagung und Verteilung von Prospekten siehe Aurenhammer, Sedlmayr (wie Anm. 2) 192, Anm. 128. Zum Stellenwert der Ausstellung in der Barockforschung siehe Sláva barokní Čechie [Der Ruhm des barocken Böhmens], Ausstellungskatalog der Nationalgalerie Prag, hg. v. Vít VLNAS (Praha 2001) 43-45.

131 Die enthaltenen Studien hießen „Unbekannte Kirchenentwürfe des Kilian Ignaz Dientzenhofer im Archiv der Prager Burg“ und „Studien zum Schloß- und Palastbau der Barockzeit in Böhmen und Mähren“, siehe Heinrich Gerhard Franz, Studien zur Barockarchitektur in Böhmen und Mähren (Beiträge zur Geschichte der Kunst im Sudeten- und Karpathenraum 6, Brünn/Prag/Leipzig/Wien 1943), hier 105f. Als letzter Band der „Beiträge“ folgte Erich Bachmann, Gotische Plastik in Böhmen und Mähren von Peter Parler (Beiträge zur Geschichte der Kunst im Sudeten- und Karpathenraum 7, Brünn/Prag/Leipzig/Wien 1943).

132 Siehe Frank-Rutger Hausmann, „Deutsche Geisteswissenschaft“ im Zweiten Weltkrieg. Die „Aktion Ritterbusch“ 1940-1945 (Schriften zur Wissenschafts- und Universitätsgeschichte 12, Heidelberg ${ }^{32007) ~ 198-211 . ~}$

133 Siehe Held, Kunstgeschichte im „Dritten Reich“ (wie Anm. 106) 32-40.

134 Siehe Mišková, Deutsche Universität (wie Anm. 115) 169. 
teil ${ }^{135}$. In der Reihe „Ausstrahlungen“ war Swoboda für den „Sudetenraum“ zuständig. Die vorgeschlagenen Autoren und ihre Themen waren Swoboda: „Deutsche Kunst in Böhmen und Mähren“, Edmund Wilhelm Braun: „Die deutsche Bildhauerei des Barock im Sudetenraum“, Otto Kletzl: „Die Parler'sche Kunst in Böhmen und Mähren“, Johann Joseph Morper: „Die deutsche Barockbaukunst in Böhmen und Mähren“, Erich Bachmann: „Die Kunstgeographie des böhmisch-mährischen Raumes“ und Hans W. Hegemann: „Die deutsche Barockbaukunst im Ostraum“. Der Gesamtplan sah im Dezember I94I zusätzlich die Themen „Die Malerei in Böhmen und Mähren im I4. und I 5. Jahrhundert“, „Deutsche Barockmaler in Böhmen und Mähren“, „Deutsche Maler des I9. Jahrhunderts in Böhmen und Mähren“ vor, spezifiziert war das Thema „Die deutschen Barockbildhauer in Prag"136. Bis I 944 erschienen vier Bände, zwei davon wurden von Swoboda herausgegeben: Hegemanns „Die deutsche Barockkunst Böhmens“ (I943) und Heinrich Gerhard Franz’ „Die deutsche Barockbaukunst Mährens“ (I943) ${ }^{137}$. Hegemann, seit 1932 NSDAP-Mitglied ${ }^{138}$, sah den „Böhmendeutschen“ durch das „dramatische Kräftespiel“ und die slawische „Wildsüße“ gestärkt hervorkommen, gleich „Rübezahl und sein Zwergenreich“, was Phantasien von einer Erneuerung durch die Wildheit unkultivierter „Rassen“ Ausdruck verlieh und eine landschaftliche Analogie in „wilden Felsbildungen“ hatte: soweit die „rassischen und landschaftlichen Voraussetzungen des böhmischen Barock“"139. Stilgeschichtlich wurde die Auseinandersetzung mit dem Fremden - den italienischen Bauformen wie Säule, Pilaster, Gebälk - als eine Verlebendigung und Steigerung der statischen Form umschrieben, die auch die Befreiung ganzer Kirchenfassaden und Kirchenräume aus der vermeintlich in Erstarrung verkommenen Endform des italienisch-böhmischen Barock meinte. Die Konstruktion einer Weiterentwicklung des Barock in Böhmen mündete in Vorstellungen von „Raumverschmelzung“ mit dem „urdeutschen plastischen Gefühl für Masse“. Die Konjunktur einer „verinnerräumlichten Haltung “ des Interpreten ${ }^{140}$ - die explizit auf Pinder Bezug nahm, für den die räumliche Zentrumsbetonung eines jeden Raumjoches den alten Wesenszug deutscher Architektur

135 Siehe Aurenhammer, Sedlmayr (wie Anm. 2) 169; Hausmann, „Deutsche Geisteswissenschaft“ (wie Anm. 132) 184f., 187.

136 Siehe Ders., Neues Quellenmaterial zum Kunstgeschichte-Programm im „Kriegseinsatz der Geisteswissenschaften“ (1941), in: Kunstgeschichte an den Universitäten (wie Anm. 2) 231-242.

137 Zum Zusammenhang des Barockbegriffs mit der deutschsprachigen Kunstgeschichtsschreibung siehe Alena Janat kovÁ, Barockrezeption zwischen Historismus und Moderne. Die Architekturdiskussion in Prag 1890-1914 (Studien und Texte zur Geschichte der Architekturtheorie, Berlin/Zürich 2000) 131-146.

138 Siehe MiškovÁ, Deutsche Universität (wie Anm. 115) 175. Hegemann hatte sich 1939 am Berliner kunsthistorischen Institut habilitiert.

139 Siehe Hans Werner Hegemann, Die deutsche Barockkunst Böhmens (Ausstrahlungen der deutschen Kunst. Deutsche Kunst im böhmisch-mährischen Raum, München 1943) 6-8.

140 Ebd. 31f., 34. 
vorstellte $^{141}$ - verlief letztlich konform zur zeitgenössischen Raumforschung und deren Interessenlage. Franz ging ebenfalls in seiner Darlegung vom Raum aus, der in geografischer, politischer und völkischer Hinsicht verstärkt die kunstgeschichtliche Forschung bestimme. Der Raum Böhmen war demnach „integrierender Bestandteil des Reiches [...] in jeder Hinsicht geschlossener, auch der größere Block, das geschichtlich Vorherrschende, das das politische Zentrum entfaltende der beiden Länder. Mähren ist das kleinere, mit offeneren Grenzen“ und von „völlig destruktive[m] Charakter des Ostraumes“ mit „willenlose[r] Aufnahmebereitschaft“ im „Ost-West-Gefälle“, die den Zugezogenen grenzenlose Freiheit an gestalterischen Möglichkeiten geboten hätte ${ }^{142}$. Der thematisierte Kunstimport aus den Zentren Wien und Prag nach Mähren wurde durch „Auflösungserscheinungen des Raumes“ identifiziert ${ }^{143}$, den politisch-ideologischen Reichskontext gaben die „Wiedergeburt der Reichsidee“ nach den Türkenkriegen und der vermeintliche „Reichsstil“ des älteren Fischer von Erlach (Hans Sedlmayr) ${ }^{144}$.

\section{KULTURVERWALTUNG, MUSEEN UND DENKMALPFLEGE}

Wie bei den Publikationen kam die Kulturbodenforschung ebenso in der Praxis der staatlich verwalteten Kultureinrichtungen - Museen, Universitäten, Denkmalpflege auf unterschiedlichen Ebenen während des Protektorats zum Tragen. Der Umgang mit der im Protektorat befindlichen Kunst und Kultur wurde in der Verordnung des Reichsprotektors zum Schutze der Kulturdenkmäler im Protektorat vom I. Oktober I940 grundsätzlich reguliert: Kulturdenkmäler durften aus dem Protektorat bis auf weiteres nur mit Genehmigung des Reichsprotektors ausgeführt werden. Als Kulturdenkmäler galten Gegenstände von künstlerischem oder heimatlichem Wert oder von besonderer

\section{Ebd. 29.}

142 Siehe Heinrich Gerhard Franz, Die deutsche Barockkunst Mährens (Ausstrahlungen der deutschen Kunst. Deutsche Kunst im böhmisch-mährischen Raum, München 1943) $6 f$.

143 Ebd. 35, 52.

144 Hinweise auf Hans Sedlmayr, Österreichische Barockarchitektur (Wien 1930); ders., Fischer von Erlach der Ältere (München 1925). Vgl. Helmut Lorenz, Der habsburgische „Reichsstil“ - Mythos und Realität, in: Akten des XXVII. Internationalen Kongresses für Kunstgeschichte in Berlin 1992 2, hg. v. Thomas Gaentgens (Berlin 1993) 163-172; Hans Sedlmayr, Die politische Bedeutung des deutschen Barock. Der „Reichsstil“, in: Gesamtdeutsche Vergangenheit. Festgabe für Heinrich Ritter von Srbik zum 60. Geburtstag, hg. v. Wilhelm Bauer, Ludwig Bittner, Taras von Borodajkewycz, Otto Brunner, Wilhelm Deutsch, Lothar Gross, Hans Hirsch, Reinhold Lorenz (Wien 1938) 126-156; Helmut LoRENZ, Dichtung und Wahrheit - Das Bild Johann Bernhard Fischers von Erlach in der Kunstgeschichte, in: Fischer von Erlach und die Wiener Barocktradition, hg. v. Friedrich Polle r ross (Wien 1995) 129-146; Aurenhammer, Zäsur (wie Anm. 2) 23-25. 
Bedeutung für die Wissenschaft ${ }^{145}$. Diese Schutzmaßnahme zum Verbleib der Kunst- und Kulturgüter war ein wichtiger Faktor in der deutschen Kunst- und Museumspolitik im Protektorat ${ }^{146}$. Sie diente der sichtbaren Bekräftigung beziehungsweise Offenbarung von Optionen der Kulturbodenforschung. Die Verordnung betraf ebenso die Bestände der Kultureinrichtungen wie die Zugänge an für weniger als die Hälfte des eigentlichen Preises veräußerten Kunstwerken, und alle Objekte aus dem konfiszierten „Juden- und Feindvermögen“, denen im Protektorat der Status von Reichseigentum eingeräumt wurde ${ }^{147}$. Für diese Zwecke wurden die Zentralstelle für jüdische Auswanderung nach dem Wiener Vorbild beziehungsweise die verwaltende Treuhandstelle der Vermögensangelegenheiten geschaffen ${ }^{148}$. Unter diesen Rahmenbedingungen nahm die Fachkompetenz der Kunsthistoriker durchaus einen entscheidenden Stellenwert ein: Wissenschaftler und Museumsleiter wurden von dem zuständigen Sachbearbeiter im Amt des Reichsprotektors als Gutachter konsultiert, aufgrund ihrer wissenschaftlichen Arbeit und Gutachtertätigkeit wurden sie als „Sonderbeauftragte“ mit Sonderrechten beispielsweise für das „reichseigene Kunstgut" ausgestattet ${ }^{149}$. Das Quellenmaterial vermittelt sogar den Eindruck, dass manche Rahmenbedingungen erst aufgrund von entsprechenden Hinweisen beziehungsweise Wunschvorstellungen der Fachleute geschaffen wurden. Erste Anstöße zur Reorganisation der Verwaltung von Kulturgütern im Protektorat kamen sogleich nach seiner Konstituierung seitens des langjährigen Geschäftsführers des Verbandes deutscher

145 Verordnung zum Schutze der Kulturdenkmäler im Protektorat Böhmen und Mähren vom 1. Oktober 1940. Siehe auch Jan Björn Роттнаsт, Das Jüdische Zentralmuseum der SS in Prag. Gegnerforschung und Völkermord im Nationalsozialismus (Frankfurt/M./New York 2002) 194; NA, Úřad ř́ršského protektora 1939_ 1945 [Amt des Reichsprotektors 1939-1945], K. 535.

146 Siehe Роттнаsт, Zentralmuseum (wie Anm. 145) 193-204.

147 Die Verkaufsmodalitäten waren aufgrund des $\$ 934$ der Reichsbürgergesetze festgelegt. Die Landesgalerie prosperierte unter der schützenden Hand des Protektoratsministeriums wie noch nie in ihrer hundertfünfzigjährigen Geschichte, siehe Vít Vlnas, Josef Cibulka (1886-1968) Kunsthistoriker. Zwischen Resistenz und Zusammenarbeit, in: Prager Professoren (wie Anm. 2) 153-173.

148 Siehe Роттнаsт, Zentralmuseum (wie Anm. 145) 66-128, 204-216.

149 Diese Sonderrechte aus dem Protektoratsamt öffneten auch für Swoboda manche Tür, so wurde bei der Gestapo der Zugang und gesonderte Verfügungsgewalt über eingezogene Kunstgüter erzielt und der Zugang zu den Lagerstätten des sogenannten „Auswanderungsfonds“ gewährt, um dort für die Landesgalerie wertvolle Kunstobjekte als nunmehr proklamiertes „Rechtseigentum“ auszusuchen. Swoboda wandte sich zudem am 12.01.1942 direkt an den Reichsprotektor mit folgendem Anliegen: Aus Gründen der Aussonderung museumswichtiger Kunstobjekte erlaubt sich der Gefertigte darauf hinzuweisen, daß auch bei der Zentralstelle des Auswanderungsamtes [= Zentralstelle für jüdische Auswanderung] beschlagnahmte Kunstwerke, gegenwärtig sogar in größerer Zahl vorhanden sein sollen. Auch mit der Gestapo wurde seitens des Reichsprotektors beziehungsweise des zuständigen Sachbearbeiters Reinhold direkt Kontakt aufgenommen, um Anspruch auf Kunstgegenstände aus dem besagten „Juden- und Feindvermögen“ zu erheben, dem stattgegeben wurde, siehe Роттнаsт, Zentralmuseum (wie Anm. 145) $196 f$. 
Museen in der Tschechoslowakei, Rudolf Hönigschmid ${ }^{150}$ : Weil Böhmen und Mähren über die völkischen Grenzen hinweg einheitliche Kunstlandschaften von ausgeprägt deutschem Charakter und alles auf dem Boden des Protektorats an Kunst-und Kulturdenkmalen [...] in weitaus überwiegendem Masse deutschen Ursprunges sei, wäre auch in der Denkmal- und Museumspflege wieder für die unverfälschte Erhaltung deutschen Kunst- und Kulturbesitzes $z u$ sorgen $^{151}$. Das betraf aber gleichermaßen die objektbezogene Ebene der verwalteten Kunst und Kultur, die Kunstobjekte, deren Aufbewahrung und Exposition. Zur Herausstellung des deutschen Kulturschaffens wurden Konzeptionen für die Hängung wie für die Beschriftung von Kunstwerken auf Ausstellungen entwickelt. Kunstwerke waren nach eindeutigen Maßgaben der Kulturbodenforschung auszuweisen, wie es in Swobodas Fachgutachten zur Beschriftung der Kunstwerke in der Prager Böhmisch-Mährischen Landesgalerie vom I. Januar I94I ausführlich dargelegt wurde ${ }^{152}$. Umstrukturierungen einzelner Museen waren ebenso aktuell wie die komplexe Veranschaulichung der besiedlungs- und kulturgeschichtlichen Vergangenheit Böhmens in gegenseitiger Abstimmung einzelner Ausstellungen der maßgeblichen Museen Prags. Dabei wurde durchaus die Raumforschung instrumentalisiert. Im Zusammenhang mit der geplanten Neugestaltung der Vor- und Frühgeschichtsabteilung des Böhmischen Landesmuseums (des vormaligen tschechoslowakischen „Nationalmuseums“) wurden etwa Konzepte zu einer Kontextualisierung der in Prag befindlichen öffentlichen Sammlungen mit der Exposition des

150 Hönigschmid studierte an der Deutschen Universität in Prag Kunstgeschichte, war 1922-1945 Geschäftsführer des Verbandes deutscher Museen in der Tschechoslowakei, 1925-1936 Leiter des staatlichen Denkmalamtes für Böhmen, 1936 Museumsinspektor, 1938 NSDAP-Mitglied, 1938-1940 in der Dienststelle des Reichsstatthalters Konrad Henlein Beauftragter für den Denkmalschutz, 1940-1945 Gauoberverwaltungsrat und Leiter des Denkmalamtes des Reichsgaues Sudetenland in Reichenberg (Liberec), siehe Biogramme (wie Anm.118) 235.

151 Hönigschmid an den Reichsprotektor, 24.03.1939. NA, Úřad říšského protektora 1939-1945, K. 536. Allerdings wurde dieser Meinung auch widersprochen: So hatte Dr. Hetsch, Kustos der Staatlichen Kunstsammlungen in Dresden, der an ihn herangetragenen Offerte im Zusammenhang mit dem Einbau deutscher Fachkräfte in die Leitung und Verwaltung der wichtigen kulturellen Einrichtungen im Protektorat entgegengesetzt, dass die einschlägigen hiesigen Einrichtungen unbeschadet des starken deutschen Interesses, das an ihnen besteht, Einrichtungen der Protektoratsregierung, d. h. also der Tschechen sind. 29.08.1939. NA (wie oben), K. 534.

152 Die Möglichkeit, „český“ mit „tschechisch“ oder „böhmisch“ übersetzen zu können, sei bei der Kennzeichnung von Kunstwerken in der Vergangenheit von tschechischer Seite planmäßig zur Irreführung des Altreiches und noch viel mehr des Auslandes missbraucht worden. Beispielhaft wurde von Swoboda die den propagandistischen Zwecken dienende Ausstellung der Barock in Böhmen genannt, die eine der größten deutschen Kulturleistungen des Raumes in einen böhmischen=tschechischen Barock umgefälscht habe. Dieser Betrug muß durch eine Ausmerzung der Beschriftung český mistr, česká škola ein für allemal unmöglich gemacht werden. Swoboda an den Reichsprotektor, Fachgutachten zur Beschriftung der Kunstwerke in der Prager Gemäldegalerie, Prag, 18.01.1941. NA (wie Anm. 151), K. 536. 
Landesmuseums vorgelegt, um vor dem Hintergrund der geographisch-naturkundlichen und insgesamt "geopolitischen "Bedingtheiten über die seit der Urzeit [...] reiche besiedlungs- und kulturgeschichtliche Vergangenheit Böhmens mit ihren vielfachen Verflechtungen, Ausstrahlungen und Beeinflussungen zusammenhängend und anschaulich zu unterrichten ${ }^{153}$

Die kunsthistorische Inszenierung des Dritten Reiches kam zeichenhaft in der baulichen Realität Prags als dem Machtzentrum des Reichsprotektors zur Anschauung. Das monumentale Czernin-Palais, das in der Tschechoslowakei dem Außenministerium zu Repräsentationszwecken gedient hatte, wurde nunmehr vom Reichsprotektor als Außenstelle des Deutschen Reiches beansprucht. Die von Swoboda im Auftrag der Prager Deutschen Akademie der Wissenschaften initiierte Reihe „Prager Forschungen zur Kunstgeschichte“ wurde I940 im Volk und Reich-Verlag mit Morpers „Das Czerninpalais in Prag“ als dem ersten (und einzigen erschienenen) Band eingeleitet. Die aufwendige Veröffentlichung der baugeschichtlichen Untersuchung unter anderem auf über hundert großformatigen Hochglanzfotografien - davon über die Hälfte vom „,heutigen Bau“, jedoch möglichst wenige von Pavel Janáks verpönten Umbau der Zwischenkriegszeit ${ }^{154}$ - diente letztlich den Zwecken seiner damaligen repräsentativen Funktion ${ }^{155}$. Der Handlungsraum der universitären Kunstgeschichte wurde in großzügigster Weise neu definiert: Das Rudolfinum, das von der Böhmischen Sparkasse zur Förderung der Kultur Böhmens finanziert auch als Gemäldegalerie für die Zwecke der Sammlungen der Gesellschaft patriotischer Kunstfreunde einschließlich eines Kupferstichkabinetts gebaut worden war ${ }^{156}$, wurde während des Protektorats neu ausgebaut. I943 wurde es für die neu gegründete Graphische Sammlung und das Kunsthistorische Institut der Universität maßgerecht eingerichtet. Swoboda favorisierte seine Vorstellung einer Zusammenführung der musealen Einrichtung mit dem Universitätsinstitut im Rudolfinum als Restitution der „alten deutschen Kunstanstalt“157.

153 Der Direktor des Pommerschen Landesmuseums an den Reichsprotektor, Stettin, 20.06.1941, Typoskript, 33 S., NA (wie Anm. 151), K. 534.

154 [...] die höchst unerfreuliche Erweiterung des Czernin-Palais [...] in dem hier völlig landfremden Ziegelrohbau ausgeführt [...] Der Reichsprotektor an den Ministerpräsidenten in Prag, 19.09.1939, NA (wie Anm. 151), K. 535.

155 Siehe Johann Joseph Morper, Das Czerninpalais in Prag (Prager Forschungen zur Kunstgeschichte 1, Prag 1940) unpaginiertes Vorwort.

156 Siehe Jindřich Vyвíral, „Městu na ozdobu, umění ke cti, sobě pro slávu“. Tři kapitoly o architektuře Rudolfina [Der Stadt zur Zierde, der Kunst zu Ehren, sich selbst zum Ruhm. Drei Kapitel über die Architektur des Rudolfinum], in: Umění 39 (1991) 384-401.

157 Die Bildergalerie patriotischer Kunstfreunde wurde 1796 gegründet, ihre Sammlungen zogen 1885 in das Rudolfinum um, 1929 mussten sie jedoch ausziehen, zum neuen provisorischen Ausstellungsort wurde 1931 die Stadtbibliothek am Marienplatz, siehe Obrazárna v Čechách 1796-1918. Katalog výstavy, uspořádané Národní galerií v Praze u prŕležitosti dvoustého založení Obrazárny Společnosti vlasteneckých přátel umění v Čechách [Die Bildergalerie in Böhmen. Katalog der Ausstellung, organisiert von der Nationalgalerie in Prag 
Er warb dafür auch mit möglichen Vorteilen einer aus Anregungen im Umgang mit Originalen schöpfenden Lehre, dem Mitwirken der Studierenden beim Aufbau von Ausstellungen sowie der gemeinsamen Nutzung der expandierenden - um die Lehner- sowie die Bestände des tschechischen kunsthistorischen Instituts erweiterten ${ }^{158}$ - Universitätsibibliothek ${ }^{159}$. Zweifelsohne hatte diese Lösung ebenso in der Personalunion Swobodas als des Leiters beider Einrichtungen eine gewichtige Ursache. Das bereits genehmigte Projekt für den Neubau der die Sammlungen alter und moderner Kunst zusammenfassenden Staatsgalerie nach dem Entwurf von Josef Gočár musste hingegen den Planungen für die deutschen Hochschulen auf dem Letná-Plateau weichen, weil die architektonische Gestaltung des neuen Museums [Gočárs] in keiner Weise den Anschauungen und Maßstäben [...] bei einem derart bestimmten öffentlichen Bauvorhaben heute im Deutschen Reich entsprach ${ }^{160}$.

Mit der Gründung der Graphischen Sammlung wurde ein deutlicher Schritt zur Durchsetzung deutscher Kulturinteressen im Protektorat getan. In seinem Brief vom I 8. November I94I eröffnete Swoboda dem Reichsprotektor sein Konzept für die neu zu gründende Sammlung, die nach seiner Vorstellung den Status eines selbstständigen Instituts des Protektorats erhalten sollte. Die Sammlung sollte durch die Übergabe von Zeichnungen, Aquarellen, Holzschnitten, Kupferstichen, Radierungen usw. aus den Beständen der Landesgalerie (2 I.00o Blatt), der deutschen und der tschechischen Sektion der Modernen Galerie (I0.000 Blatt), des Landesmuseums (77.000 Blatt) und des Kunstgewerbemuseums der Handels- und Gewerbekammer ( 50 Blatt) entstehen. Damit sollte letztlich auf institutioneller Ebene die „Germanisierung“ dieser gesamten Bestände realisiert werden. Für die Aufbautätigkeit wollte Swoboda während der ersten zwei Jahre zeitgünstige Ankäufe aus reichseigenen, nämlich beschlagnahmten Beständen an verschiedenen Orten tätigen und dafür jeweils 660.00o Kronen zur Verfügung haben (und weiterhin jährlich 300.000 Kronen). Swobodas Vorstoß wurde durch seine Beauftragung mit der Errichtung des Kupferstichkabinetts im Rudolfinum als den Anfang einer Neuordnung der Museumsbestände in Prag brieflich vom Reichsprotektor im April 1942 belohnt ${ }^{161}$. Das neu gegründete Kupferstichkabinett war zwar formal an die Landesgalerie angebun-

anlässlich des 200. Jahrestages der Gründung der Bildergalerie der Gesellschaft patriotischer Kunstfreunde in Böhmen], hg. v. Vít Vlnas (Praha 1996).

158 Ferdinand Josef Lehner (1837-1914), Stifter der Lehner-Kunsthistorischen Anstalt an der Prager Karlsuniversität, hinterließ seine Bibliothek dem Kunsthistorischen Institut der (tschechischen) Karl-FerdinandsUniversität, siehe Nová Encyklopedie českého výtvarného umění 1 [Neue Encyklopedie der tschechischen bildenden Kunst 1], hg. v. Anděla Horová (Praha 1995) 442, und Biographisches Lexikon zur Geschichte der böhmischen Länder 2: I-M, hg. v. Heribert Sт U м (München/Wien 1984) 414. Siehe den Brief Swobodas an Matějček mit der Mitteilung über die Bibliotheksverlegung, Prag, 18.11.1943. ANG (wie Anm. 3).

159 Swoboda an den Reichsprotektor, 18.11.1941. ANG (wie Anm. 155).

160 Der Reichsprotektor, Abschrift, Prag, 19.09.1939. NA (wie Anm. 151), K. 535.

161 Der Reichsprotektor, 16.04.1942, im Auftrage gez. Fitzek. ANG (wie Anm. 155). 
den, durch die Trennung der leitenden Funktionen und seinen selbstständigen Status als Protektoratsinstitut entstand allerdings neben dem tschechischen Personalbetrieb der Galerie ein eigener deutscher Personalbetrieb der Graphischen Sammlung ${ }^{162}$. Im Juni 1943 erging an die Direktion dieser Sammlung die Genehmigung des Staatssekretärs für die Tätigung von Ankäufen auch wertvoller deutscher Grafik aus Mitteln des Sonderfonds des „Führers“163. Die Wechselausstellungen der Graphischen Sammlung im Rudolfinum wurden direkt von der Abteilung Kulturpolitik im Staatsministerium finanziell unterstützt ${ }^{164}$, und noch 1944 wurden im Rudolfinum nacheinander drei Ausstellungen ausgerichtet. Diese mitten in der Kriegszeit betriebene Selbstdarstellung wurde gegenüber dem Schattendasein der Landesgalerie in der deutschsprachigen wie tschechischsprachigen Presse werbeträchtig gefeiert. Die erste Ausstellung der „Deutsche[n] Handzeichnungen aus der Romantik“" wurde am I8. März 1944 durch den Leiter der Abteilung Schulwesen des Deutschen Staatsministeriums, Ministerialrat Dr. Heckel, eröffnet und vom Minister für Schulwesen und Volksbildung, Emanuel Moravec, eine Woche später aufgesucht. Swoboda kündigte in seiner Eröffnungsrede die zukünftigen Ausstellungen der Ankäufe der Graphischen Sammlung an sowie thematisch ausgerichtete Expositionen der Zeichnungen des Künstlerkreises um Rudolph II., Grafik der Dürer-Zeit, Zeichnungen deutscher Barockmaler, sudetendeutsche Grafik, Handzeichnungen von Josef Mánes und Rembrandt-Zeichnungen in der „deutschen Kulturanstalt“165. Am 2. Juni 1944 folgte dann die Ausstellung der in den Jahren I943/44 getätigten „Ankäufe“, die Zeichnungen deutscher, niederländischer, französischer, italienischer wie auch böhmischer Provenienz vereinte und damit kulturpolitisch den reichsdeutschen Europagedanken abbildete ${ }^{166}$. Die dritte Ausstellung der Graphischen Sammlung präsentierte den zeichnenden Rembrandt mit

162 Arbeitsbericht Cibulkas, Brief an das Ministerium für Schulwesen und Volksbildung vom 24.05.1945, gez. 06.06.1945 (Typoskript, 18 S.) 2 (Úloha ředitelství a poměr okupantů ke galerii [Die Aufgabe der Direktion und das Verhältnis der Besetzer zur Galerie]). Archiv des Kunsthistorischen Instituts (wie Anm. 112) Josef Cibulka, Galerie 1939-1961, K. 30, Inv. Nr. 1347.

163 Siehe den Brief Swobodas an das Ministeramt Seyß-Inquart, zu Händen des Staatssekretärs Dr. Kajetan Mühlmann in Berlin, 18.06.1942. ANG (wie Anm. 155).

164 Brief Swobodas an den Deutschen Staatsminister für Böhmen und Mähren, Abteilung Kulturpolitik, Herrn Oberregierungsrat Ing. Zankl, 19.10.1943. ANG (wie Anm. 155).

165 Siehe den Zeitungsartikel von Albert Комма, Deutsche Handzeichnungen aus der Romantik, in: Der neue Tag vom 19.03.1944; Günter Busch, Deutsche Handzeichnungen der Romantik. Zur ersten Ausstellung der Graphischen Sammlung Prag. ANG (wie Anm. 155).

166 Siehe die Zeitungsartikel: Zur Ausstellung der Graphischen Sammlung in Prag, in: Der neue Tag vom 07.06.1944; Busch, Handzeichnungen (wie Anm. 165), und anonym. Eine im Prager Rudolfinum untergebrachte neue Einrichtung stellt die Graphische Sammlung dar, die mit wertvollen Blättern bekannt machen und bestehende Freundschaften zwischen Menschen und Kunstwerken vertiefen will, in: Prager Wochenschau vom 15.08.1944. ANG (wie Anm. 155). 
über hundert Handzeichnungen in „originalgetreuen Lichtdrucken“, womit zugleich jene kulturkonservative Ideologie von der deutschen Kunst dargeboten wurde, wie diese Julius Langbehns „Rembrandt als Erzieher. Von einem Deutschen“ (I 890) propagiert hatte ${ }^{167}$.

Swobodas Machtposition hatte sich schon in Juli 1940 abgezeichnet, als er mit der Aufsichtsfunktion in der damals noch so bezeichneten Nationalgalerie beziehungsweise der Böhmisch-Mährischen Landesgalerie betraut wurde. Der tschechische Galeriedirektor war anzuweisen, alle Ankäufe, nicht nur die in der sogenannten „Ankaufskommission" verhandelten Angelegenheiten, einstweilen mit dem Professor für Kunstgeschichte an der deutschen Karls-Universität, K. M. Swoboda, vorher zu besprechen ${ }^{168}$. Es ist bekannt, dass der tschechische Galeriedirektor Cibulka mit Swoboda in der Ankaufskommission und darüberhinaus bei der Sicherstellung von Kunstwerken sehr effizient kooperierte ${ }^{169}$. Der weitere Kompetenzenzuwachs Swobodas erfolgte bemerkenswerterweise im Zusammenhang mit dem Wirken Reinhard Heydrichs als stellvertretender Reichsprotektor seit September 194I. An ihn hatte sich nämlich Swoboda im November I94I direkt mit seinem Anliegen gewandt, das dem künstlerischen Range Prags entsprechende und noch fehlende Kunsthistorische Institut der deutschen Karls-Universität zusammen mit einer neu zu gründenden Graphischen Sammlung im Rudolfinum unterzubringen ${ }^{170}$. Für das SS I 943 war gemäß dem Vorlesungsverzeichnis dann auch bereits das Rudolfinum als Institutsadresse angegeben ${ }^{171}$. Heydrich veranlasste ebenfalls, bei den Grabungen auf der Prager Burg Professor Dr. Swoboda, de[m] beste[n] deutsche[n] Kenner der Baugeschichte der Burg, die wissenschaftliche Leitung der gesamten Arbeiten auf der Burg zu übertragen ${ }^{172}$; und zwar mit der Option, dass die Grabungsergebnisse in einem großen wissenschaftlichen Werk zur Geschichte der Burg zusammengefasst würden, und dieser fachwissenschaftlichen Veröffentlichung eine für die weite Verbreitung bestimmte, reich bebilderte Billigversion der Burggeschichte trete, die den deutschen Charakter der Burg mit ihrer Entstehung klar zum Ausdruck zu bringen habe. Forschung und Publikation waren damit unmittelbare Auftragsarbeiten Heydrichs. Die Ernennung Swobodas zum Vorsitzenden des Bauausschusses wurde erst im Juni I943, also ein ganzes Jahr nach dem Tod Heyd-

167 Siehe den Zeitungsartikel Günter Busch, Der zeichnende Rembrandt. Zur 3. Ausstellung der Graphischen Sammlung Prag. ANG (wie Anm. 155).

168 Der Reichsprotektor an das Ministerium für Schulwesen und Volkskultur, zu Händen des Präsidialchefs Dr. Š́p. 30.07.1940. NA (wie Anm. 145), K. 536.

$169 \mathrm{Zu}$ ihm siehe Klement Benda, Josef Cibulka, in: Kapitoly z českého dějepisu umění 2 (wie Anm. 49) 161170; Vlnas, Josef Cibulka (wie Anm. 147).

170 Swoboda an den Reichsprotektor, 18.11.1941. ANG (wie Anm. 155).

171 Sommer-Semester 1943, 104. UAP (wie Anm. 75).

172 Der Reichsprotektor, Sachbearbeiter Dr. von Both, 21.02.1942. NA (wie Anm. 145), K. 537. 
richs, vollzogen ${ }^{173}$. Damit wurde unter äusserer Wahrung der Autorität des Staatspräsidenten das staatspolitisch wichtigste Denkmal unter die deutsche Führung Swobodas gestellt. Und sogar die deutschen Sachverständigen aus dem Amt des Denkmalamtes sollten nur beratend hinzugezogen werden. Für seine Amtsführung ließ sich Swoboda im Schwarzenbergpalais in der Prager Innenstadt ein Arbeitszimmer einrichten. Das mit weiteren Schwarzenberg'schen Besitztümern als „staatsfeindliches Vermögen “ konfiszierte Palais ${ }^{174}$ hatte er allerdings schon früher zum Wohnsitz erwählt, wie dies die neue Anschrift des Direktors des Kunsthistorischen Instituts im Vorlesungsverzeichnis für das WS I942/43 ausweist ${ }^{175}$. Um die deutschen Interessen im Dombauverein des Prager Veitsdomes zu vertreten, wurde Sowboda zusammen mit Professor [Karl Friedrich] Kühn als Vertreter des Denkmalamtes und Obersektionsrat Kraus als Vertreter des Schulministeriums in dessen Kunst-Sektion tätig; auf Swobodas Anfrage hin wurde dann die Aufnahme der Genannten in das übergeordnete Direktorium des Dombauvereins erwirkt ${ }^{176}$. Nach der Aufhebung der Stiftung „Moderne Galerie“ beantragte Swoboda, den bisher vom Unterzeichneten als dem Kurator der Deutschen Sektion der Modernen Galerie verwalteten reichseigenen Kunstbesitz in der Landesgalerie Prag gesondert zu verwalten ${ }^{177}$. Der Auftrag - in wörtlicher Übernahme von Swobodas Formulierung - den bisher im Rahmen der Deutschen Sektion der aufgelösten Modernen Galerie von Ihnen verwalteten reichseigenen Kunstbesitz von jetzt an im Rahmen der Böhmisch-Mährischen Landesgalerie gesondert zu verwalten, wurde am 26. November 1942 durch den Reichsprotektor erteilt ${ }^{178}$. Allerdings wurde Swobodas an das deutsche Staatsministerium gerichtete Anliegen, als Verwalter des reichseigenen Kunstgutes in Böhmen und Mähren [...] einen Rundstempel mit dem Hoheitszeichen und der Umschrift „Verwalter des reichseig. Kunstgutes in B. und M. " führen zu dürfen, nicht in der gewünschten Form aufgenommen ${ }^{179}$. Es hieß, daß Swoboda nicht Leiter einer selbständigen Reichsdienststelle mit hoheitlichen Funktionen sei ${ }^{180}$ - eine Einschränkung, die auch den mit dem „Kriegsverdienstkreuz II. Kl.“ für die Neugestaltung des Museumswe-

173 Von Both, 06.1943. NA (wie Anm. 145), K. 537.

174 Die von der Staatspolizeistelle Linz ausgesprochene Beschlagnahme des Schwarzenbergschen Vermögens soll nach der Entscheidung des Führers auch hinsichtlich der im Protektorat gelegenen Vermögensteile aufrecht erhalten bleiben. Der Leiter der Gruppe Justiz I/9 E I 14/41 g, Prag, 23.04.1941. NA (wie Anm. 145), K. 536. Das Heeresmuseum hat das Schwarzenberg-Palais am Hradschin übernommen [...] Heeresmuseum Prag an den Treuhänder der Schwarzenberg'schen Besitzungen, Prag, 31.10.1941. NA (wie Anm. 145), K. 535.

175 Winter-Semester 1942/43, 104 . UAP (wie Anm. 75).

176 Swoboda an den Reichsprotektor, Prag, 02.06.1942. NA (wie Anm. 145), K. 537.

177 Swoboda an den Reichsprotektor, Prag, 13.11.1942. NA (wie Anm. 145), K. 535.

178 Von Both an Swoboda, Prag, 26.11.1942. NA (wie Anm. 145), K. 535.

179 Swoboda an von Both, Prag, 27.11.1943, Swoboda. NA (wie Anm. 145), K. 535.

180 Abteilung I. An die Abteilung III. im Hause, Prag, den 31. Dezember 1943. NA (wie Anm. 145), K. 535. 
sens im Protektorat im deutschen Sinne ausgezeichneten Edmund Wilhelm Braun ${ }^{181}$ als den Sonderbeauftragten für Museumsfragen im Protektorat betraf ${ }^{182}$. Dennoch wurde durch den deutschen Staatsminister für Böhmen und Mähren Karl Hermann Frank erst (!) am 28. September I 944 bestimmt, dass der vorher mit der Verwaltung des im Rahmen der deutschen Sektion der aufgelösten Modernen Galerie verwalteten reichseigenen Kunstbesitzes beauftragte Swoboda nunmehr zum Verwalter des reichseigenen Kunstgutes in den Prager Museen bestellt werde ${ }^{183}$. Swoboda gab sich jedoch schon im Juni 1944 in einem Schreiben an das Ministerium für Wirtschaft und Arbeit als ständiger Berater des Staatsministers für alle musealen Angelegenheiten in Prag, Beauftragter für das reichseigene Kunstgut bei den Prager Sammlungen, Vorsitzender des Bauausschusses auf der Prager Burg und Kurator des Veitsdomes zu erkennen, und vermutlich füllte er wirklich noch vor seiner Bestellung diese Funktionen an den kulturpolitisch bedeutendsten Objekten bereits mit hohem Maß an Eigeninitiative aus ${ }^{184}$. Indem sich Swoboda nämlich als Ordinarius für Kunstgeschichte an der Prager Deutschen Universität deutlich in der Kulturbodenforschung positioniert hatte, wurde seine Standortbestimmung auf politischer Ebene mit neuen Handlungsspielräumen in dem kunsthistorischen Praxisfeld der Museen und der Denkmäler belohnt. Seine Machtstellung hatte aber letztlich ihre Ursache in der Bedeutung von Kunstgeschichte bei der intendierten „Germanisierung“ Böhmens und Mährens: Kunstgeschichte war ein öffentlicher Faktor der Kulturpolitik des Protektorats.

Trotz seines deutlich fassbaren Engagements für das NS-Regime geriet Swoboda ins Visier des Sicherheitsdienstes der SS in Prag. Im März I 945 wurde er in einem Bericht Stimmung und Haltung der Hochschullehrer einer oppositionellen Gruppe von Professoren zugezählt, die angeblich eine Entpolitisierung der Wissenschaft befürworteten und eine nationalsozialistische Hochschulgemeinschaft, die Dozenten und Studenten umfasst, ablehn$\operatorname{ten}^{185}$. Swoboda wurde hierbei auch von seiner Vergangenheit eingeholt, denn der Vermerk über ihn lautet: Professor Dr. Karl Swoboda, Kunsthistoriker. In erster Ehe mit einer Jüdin verheiratet. Sohn angeblich auf der Feindseite. Sein Institut ist Treffpunkt von Ausländern, vor allem Bulgaren. Eine Nichtarierin, ein Fräulein Cohen, die Studiensondergenehmigung hat, hört bei ihm. Swoboda hält besonders engen Kontakt mit den Prager Konsulaten.

181 Braun an Dr. Heckel, 25.09.1942. NA (wie Anm. 145), K. 534.

182 Von Both an Braun über den Kopfstempel des Sonderbauftragten für das Museumswesen, Prag, 20.04.1944. NA (wie Anm. 145), K. 534.

183 Heckel an Swoboda, Prag, 28.09.1944. NA (wie Anm. 145), K. 535.

184 Swoboda an das Ministerium für Wirtschaft, 05.06.1944. ANG (wie Anm. 155).

185 Bericht des SD-Leitabschnitts Prag, verfasst zwischen 15. und 22.03.1945 von Walter Jacobi, für das RSHA in Berlin und zur Kenntnisnahme K. H. Franks, NA, Německé státní ministerstvo pro Čechy a Moravu 110 4-529. Den Hinweis auf diese Quelle gab und den Quellentext übermittelte mir dankenswerterweise Karel Hruza. 
Konsequenzen hatte der Bericht für Swoboda wegen der baldigen Kriegsniederlage der Deutschen keine mehr.

Swobodas Aufbruch aus seinen Verwirrungen vom Anfang der I930er-Jahre endete I 945 zwar im Gefängnis, dieser Aufenthalt sollte allerdings nicht von langer Dauer sein. Wie Cibulka, der tschechische Direktor der Landesgalerie, sah sich Swoboda ebenfalls genötigt, bei den Kunsthistorikerkollegen und den Mitgliedern der Ankaufskommission Erklärungen einzuholen, dass er mit den Nationalsozialisten nicht zusammengearbeitet habe ${ }^{186}$. In seinem Arbeitsbericht hat sich Cibulka ausführlich positiv über Swoboda und dessen Verhältnis zur Galerie geäußert: Um die tschechische Direktion zu schützen habe Swoboda, dem in Wien aufgrund seiner Ehe angeblich keinerlei Wirkungsmöglichkeiten offenstanden, die Graphische Sammlung gegründet und es somit überhaupt erst ermöglicht, dass die Gemälde und Skulpturen weiterhin in tschechischer Verwaltung - allerdings unter seiner Aufsicht - verblieben ${ }^{187}$. Die großen Mengen an beschlagnahmtem Kulturgut, die von der Gestapo, der Schutzpolizei und aus den Lagern des „Zentralamts für die endgültige Regelung der Judenfrage“ während des gesamten Krieges in die Galerie strömten, lassen allerdings die Rolle Cibulkas zumindest zwiespältig erscheinen $^{188}$. Swobodas eigene Rolle war als Verwalter des reichseigenen Kunstbesitzes in der Ankaufskommission der Galerie wie in allen Prager Museen hingegen insofern festgelegt, als er hier wie auch mit seinen wissenschaftlichen Arbeiten eindeutig im Dienst des „Dritten Reiches“ stand. Über Cibulkas positive Wertschätzung mag daher die Interdependenz zwischen der Bescheinigung seiner eigenen Integrität mit jener von Swoboda mitbestimmt haben. Mancher für Swoboda enthüllender Sachverhalt scheint

186 Canz, Swoboda (wie Anm. 2) 187; zu Cibulka siehe die Erklärung des Betriebsrates der Nationalgalerie vom 06.06.1945, gez. Josef Karda, Jaromír Pešina, Karel Steklý; Erklärung Matějčeks vom 18.06.1945; Erklärung der Ankaufskommission vom 18.06.1945, gez. Matějček, Wirth, Václav Butta, Jan Krčmář, Kamil Novotný. Archiv Kunsthistorisches Institut, Josef Cibulka (wie Anm. 162).

187 Prof. Swoboda ist nie Mitglied der NSDAP gewesen. Weil er als Ehemann einer böhmischen Jüdin keine Professur in Wien erhalten konnte, war er den tschechischen Fachleuten dafür dankbar, dass sie ihm zur Zeit der Ersten Republik im Schulministerium gegenüber einem uns unwillkommenen deutschen Nationalsozialisten zum Professorenlehrstuhl verhalfen. Anders als die übrigen Professoren der Deutschen Universität hatte er zur Zeit der Ersten Republik regen Kontakt zu seinen tschechischen Kollegen. Daher wollte er den Unterzeichneten nicht des Direktorenstuhls entledigen [...] und er löste die Situation derart, dass er einen Teil der Galerie - die Graphikseiner deutschen Leitung unterstellte, um den anderen Teil der Galerie - die Gemälde und Skulpturen - in der Verwaltung des Unterzeichneten zu belassen, allerdings unter deutscher Aufsicht. Josef Cibulka, Arbeitsbericht (wie Anm. 162) (Übersetzung aus dem Tschechischen).

188 Viele jüdische Sammler und „Staatsfeinde“ ließen ihre Schätze zwar freiwillig in die Galerie deportieren, und sie wurden auch nach dem Krieg in ihrem Vertrauen auf Rückerstattung nicht enttäuscht - sofern es allerdings überhaupt noch jemanden gab. Dennoch verlor gerade unter Cibulka die Herkunft eines Kunstwerks in dem Moment, in dem es im Galerieverzeichnis aufgeführt wurde, an Bedeutung. VLNAs, Josef Cibulka (wie Anm. 147) 170f. 
zudem in der nationalsozilistischen Bürokratie verdeckt geblieben zu sein. So dürfte Cibulka kaum realisiert haben, dass die von ihm vehement zurückgewiesene Kunstpräsentation der Landesgalerie im Sinne der Kulturbodenforschung gerade auf der Grundlage von Swobodas Gutachten durchgesetzt worden ist ${ }^{189}$. Da Swoboda gemäß der Meldung des Sicherheitsdienstes der SS vom März I945 als judenfreundlich und oppositionell galt ${ }^{190}$, hatte sich für ihn schon am I6. Mai I945 auch der Tschechische Nationalrat verbürgt $^{191}$. Swobodas Dank für das uneingeschränkte Engagement seitens der tschechischen Kunsthistorikerkollegen in seiner Sache wurde im vertrauten Ton an Matějček mit dem Versprechen des eigenen Entgegenkommens verbunden: [...] vergebens habe ich mich seit einer Woche bemüht Sie zu treffen, um Ihnen in meinem und auch im meiner Frau Namen innigst für unsere Befreiung zu danken, Ich war in diesen Tagen oft mit den Gedanken bei Ihnen, daß sich in Zeiten der Not die wahren Freunde bewähren. [...] Ich habe auch an Sekt. Chef Wirth geschrieben, daß ich stets zum Schutze und zur Wiedererlangung in die čsl. Republik gehörenden Kunstgutes voll zur Verfügung stehe ${ }^{192}$. Als sich nach der Konstituierung der Republik Österreich im April I945 das IÖG schließlich in „der allerschwierigsten Lage" befand ${ }^{193}$, da vom alten Lehrkörper aus politischen Gründen einzig Leo Santifaller verbleiben konnte, wurde Swoboda I946, nunmehr Direktor des Kunsthistorischen Instituts, Mitglied des IÖG-Lehrkörpers ${ }^{194}$. Im Studienjahr I954/55 amtierte er als Dekan seiner Fakultät, I960 wurde er emeritiert. Die fortlaufende Beschäftigung mit biologistischen Konzepten, ethnologischen Schematismen und kultumorphologischen Schematisierungen ist allerdings in Swobodas Wiener Vorlesungen weiterhin nach I946 dokumentiert ${ }^{195}$; die Wiedergabe solcher Konzepte wurde jedoch von seiner Schülergeneration nicht mehr weitertradiert.

$189 \mathrm{Zu}$ Cibulkas Zurückweisung vgl. seine handschriftlichen Notizen anlässlich einer Begehung der Galerie am 11.12.1940 in Anwesenheit von Reinhold und Swoboda, der - wie Cibulka festhielt - sich in Schweigen hüllte. Josef Cibulka, In memoriam. Archiv des Kunsthistorischen Instituts, Cibulka (wie Anm. 162), zu Swobodas Gutachten vgl. Anm. 152. Die Anweisung zur Beschriftung der Kunstwerke erfolgte auf Umwegen vom Amt des Reichsprotektors (Sachbearbeiter Reinhold) über das Ministerium für Schulwesen und Volkskultur.

190 Siehe Anm. 185 und Miš Ková, Deutsche Universität (wie Anm. 73) 191.

191 Zum Antrag des Tschechischen Nationalrats (Česká národní rada) und des Landesnationalausschusses in Böhmen (Zemský národní výbor v Čechách) auf Enthaftung Swobodas vom 16.05.1946 vgl. die Kopie in : UAW, Dekanat, ZI 1191 ex 1944/45: Ansuchen um die österreichische Staatsbürgerschaft Swobodas, Prag, 24.09.1945; siehe auch Aurenhammer, Zäsur (wie Anm. 2) 51, Anm. 159.

192 Swoboda an Matějček, Prag 28.05.1945. ANG (wie Anm. 3).

193 So Lhотsкy, Geschichte des Instituts (wie Anm. 8) 384.

194 Ebd. und Aurenhammer, Institut nach 1945 (wie Anm. 2) 174-177.

195 Siehe Aurenhammer, Zäsur (wie Anm. 2) 52. 


\section{RESÜ MEE}

Der junge Swoboda hatte mit der Ausbildung am IÖG seinen Horizont als Kunsthistoriker erweitert und damit denselben Weg wie Dvořák und Schlosser eingeschlagen. Das Netzwerk des IÖG wurde für seine Berufung nach Prag und seine weitere Forschungsstrategie mit der Ausrichtung auf die so genannte sudetendeutsche Kulturbodenforschung wichtig. Diese Forschungsperspektive hatte allerdings nicht länger den komplizierten historischen Sachverhalt im Blick, sie wurde vielmehr unter ideologischen und biologistischen Vorzeichen entwickelt und im Praxisfeld der Publikationen bestimmend. Obgleich Swoboda nicht der NSDAP beitrat, war er in unterschiedlichen, oben angeführten Verantwortungsbereichen auf hoher Ebene politisch im Deutschen Reich und letztlich auch für das NS-Regime tätig. Unter seiner Ägide wurde eine Inszenierung der Kunstgeschichte für Legitimationszwecke des Protektorats Böhmen und Mähren vorangetrieben. Nach 1945 wurde das IÖG-Netzwerk nochmals für Swobodas Berufung nach Wien entscheidend. Der Kontext dieser Einbindung hatte also durchaus eine Kontinuität im wissenschaftlichen Werdegang und der Karriere des Kunsthistorikers Swoboda bewirkt. Swobodas persönlicher Gesinnung eines nihilistischen rechten Intellektuellen mag es zudem geschuldet sein, dass sich diese Kontinuität durch eine unheimliche und hintergründige Flexibilität unter verschiedenen politischen Systemen auszeichnete.

I 966 erinnerte sich der tschechische Historiker Václav Vojtíšek an seine ehemaligen deutschen Kollegen in Prag. Es mag nicht verwundern, dass er Swoboda - nicht immer korrekt - wie folgt gedachte: „Im Jahr I 934 kam er nach Prag. In Prag hatte er unter den Tschechen, die in Wien studiert hatten, Bekannte und diese Bekanntschaften weiteten sich im Kontakt mit den Fachleuten aus. Ich habe nie erfahren, welche politische Linie er vertrat. Aber er trat in die SdP und die NS[DA]P ein. Während des Faschismus schrieb er auch offizielle Publikationen über Prag und über die böhmische Kunst, die er als Produkt deutscher Kunst und deutscher Arbeit ansah. Erklärungen in diesem Sinne trug er den höchsten Würdenträgern der NS[DA]P und des Dritten Reiches vor, wenn diese Prag besuchten, und er pflegte auch SA-Uniform zu tragen. Nach dem Krieg bewirkten einige tschechische Fachleute, dass K. S. in Prag bleiben konnte [...], aber er ging nach Wien an die Universität und hat sich dort angeblich auf schönste Weise eingerichtet." ${ }^{196}$

196 Karel HruzA, „Einige Deutsche habe ich auch wirklich gern empfangen“ - Ein Bericht des tschechischen Historikers Václav Vojtíšek aus dem Jahr 1966 über deutsche Fachkollegen in Prag, in: Bohemia. Zs. für Geschichte und Kultur der böhmischen Länder 49 (2009) 96-163, hier 120 und 150. 
Johannes Holeschofsky

\section{Hugo Hantsch (I895-I972)}

EIN GROSSÖSTERREICHISCHER VERFECHTER DER REICHSIDEE

\section{Einleitung}

Der Ordinarius für Allgemeine Geschichte der Neuzeit an der Universität Wien 1922-I945, Heinrich von Srbik, wurde zu Beginn der Zweiten Republik all seiner wissenschaftlichen Funktionen enthoben und kurzfristig von französischen Besatzungsorganen inhaftiert. Sein Lehrstuhlnachfolger, der Benediktinerpater Hugo Hantsch, saß während des NS-Regimes zeitweise als Häftling im KZ Buchenwald und wurde mit einem Publikationsverbot belegt ${ }^{1}$. Dennoch wurden Srbik und sein Schüler Hantsch in der österreichischen Historiografiegeschichte in einen ideellen Zusammenhang gebracht und meist gemeinsam

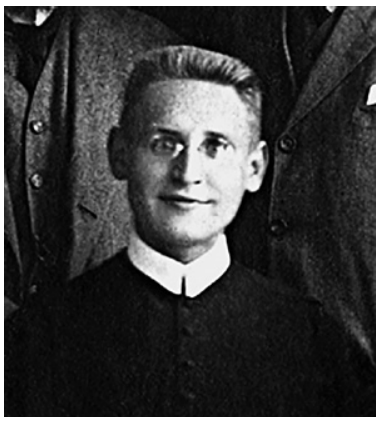

Abb. 30: Hugo Hantsch um 1920 gelobt bzw. getadelt ${ }^{2}$. Wer Hantsch rühmt, sieht auch in

1 Zu Hugo Hantsch: NL im Stiftsarchiv Melk (= StA Melk, NL HH), enthält außer den Jugendtagebüchern vor allem Material zur Zeit nach 1945, unter anderem vier Kartons mit Korrespondenz. Die einzige monografische Biografie ist ungedruckt: Christof Tölg, Ideologie und Politik im Werk von Hugo Hantsch (1918-1938) (Diplomarbeit Wien 1988). Weiters siehe die Nekrologe: Günther Ha manN, in: ÖGL 10 (1972) 529-538, sowie in: ÖAW Almanach 123 (1973) 338-367 (wird im Folgenden zitiert); R[obert] A. KANN in: ÖGL 10 (1972) 538f.; Jean Rudolf von SALIs, in: ÖGL 10 (1972) 540; Fritz Posch, in: ZHVSt 73 (1972) 153-159; Gerald STou RzH, in: Austrian History Yearbook 9/10 (1975) 507-514; Heinrich Lutz, in: MIÖG 81 (1973) 231-240. Siehe ferner Fritz Fellner, Doris A. Corradini, Österreichische Geschichtswissenschaft im 20. Jahrhundert. Ein biographisch-bibliographisches Lexikon (VKGÖ 99, Wien 2006) 166f.; Fritz Fellner, Österreichs historische Mission und die Reichsidee. Werk und Wirken des Historikers Hugo Hantsch in der Diskussion um ein österreichisches Geschichtsbewußtsein, in : Brennpunkt Mitteleuropa. FS für Helmut Rumpler zum 65. Geburtstag, hg. v. Ulfried Burz (Klagenfurt 2000) 83-96. Zu Hantschs Wirken als Vorsitzender der Kommission für Neuere Geschichte Österreichs 1947-1967 in der Nachfolge Srbiks siehe Fritz Fellne r, Franz Adlgasser, Doris Corradini, „... ein wahrhaft patriotisches Werk.“ Die Kommission für Neuere Geschichte Österreichs 1897-2000 (VKGÖ 91, Wien/Köln/Weimar 2000) 122-161. Zu Srbik siehe den Beitrag von Martina Pesditschek in diesem Band.

2 Differenzierter äußerte sich zu dieser Frage Christian Ger bel, Zur „gesamtdeutschen “ Geschichtsauffassung, der akademischen Vergangenheitspolitik der Zweiten Republik und dem politischen Ethos der Zeitgeschichte, 
Srbik einen angeblich von jüngeren Historikern missverstandenen, verleumdeten „liberalen Großdeutschen "3 oder auch österreichischen Patrioten ${ }^{4}$. Wer dagegen Srbiks Weg zum Nationalsozialismus durch seinen Deutschnationalismus wie auch seine reaktionäre Haltung ${ }^{5}$ vorherbestimmt sieht, der ordnet auch Hantsch, allenfalls in einer „österreichischeren, antipreußischen Variante“6, Srbiks gesamtdeutscher Historikerschule zu.

Hat Hantsch sich je zur „gesamtdeutschen Geschichtsauffassung“ im Sinne Srbiks und Harold Steinackers bekannt und hat er sie geteilt? Und stellen die Deutungen Srbiks und Hantschs der Reichsidee nur zwei Kehrseiten derselben Medaille dar oder beruhen Unterschiede - trotz manch gemeinsamer Begrifflichkeit und Feindbild - auf letztlich verschiedenen Weltanschauungen?

in: Transformationen gesellschaftlicher Erinnerung. Studien zur „Gedächtnisgeschichte“ der Zweiten Republik, hg. v. Dems., Manfred Lechner, Dagmar C.G. Lorenz u.a. (Kultur 9, Wien 2005) 86-130, hier 99-102. Weiters zu Hantsch und seiner Reichsidee, die europäischen Aspekte von Hantschs Gedankengut würdigend, Arno Sт rонмеуе R, Österreichische Geschichte der Neuzeit als Raumgeschichte. Ein Versuch, in: Was heißt „österreichische“ Geschichte? Probleme, Perspektiven und Räume der Neuzeitforschung, hg. v. Dems., Martin Scheutz (Wiener Schriften zur Neuzeit 6, Wien 2008) 167-199, hier 176. Zu Hantsch, im Kontext der „gesamtdeutschen Geschichtsschreibung“, doch mit einem Verweis auf Hantschs Rolle als Opfer des NS-Regimes, Monika Glettrer, Die Bewertung des Faktors Deutschland in der österreichischen Historiografie, in: Ungleiche Partner? Österreich und Deutschland in ihrer gegenseitigen Wahrnehmung. Historische Analysen und Vergleiche aus dem 19. und 20. Jahrhundert, hg. v. Michael Gehler, Rainer F. Sснмidt, Harm-Hinrich BRAndT u.a. (Stuttgart 1996) 55-72, hier $69 f$.

3 Hamann, Nekrolog (wie Anm. 2) 331.

4 Fritz Fellner, Heinrich von Srbik - „Urenkelschüler Rankes“, in: Ders., Geschichtsschreibung und nationale Identität. Probleme und Leistungen der österreichischen Geschichtswissenschaft (Wien/Köln/Weimar 2002) 330-345, hier 343f. Den Anfang zur apologetischen Deutung Srbiks als „österreichischen Patrioten“ machte aber Hantsch selbst, der Srbik nach 1945 immer wieder in Schutz nahm. Vgl. StA Melk, NL HH, K. 7/61, Gutachten Hantschs über Srbik vom 19.12.1947. Hantsch bezieht sich ausdrücklich auf Srbiks Metternich-Biografie, die er als „Beweis“ für Srbiks „österreichpatriotische“ Gesinnung anführt.

5 Günther Fellner, Österreichs Geschichtswissenschaften vom „Anschluß“ zum Wiederaufbau, in: Unterdrückung und Emanzipation, hg. v. Rudolf G. Ardelt (FS für Erika Weinzierl zum 60. Geburtstag, Wien/ Salzburg 1985) 321-339, hier 338. Mit der „gesamtdeutschen Geschichtsauffassung“ in ideologischem Zusammenhang gesehen wird Hantsch auch in Anton Staudinger, Zur „Österreich“-Ideologie des Ständestaates. Vorgeschichte, Hintergründe und Folgen, in: Protokoll des Symposiums in Wien am 10. und 11.6.1976 (Wissenschaftliche Kommission des Theodor-Körner-Stiftungsfonds und des Leopold-Kunschak-Preises zur Erforschung der österreichischen Geschichte 1918-1938 4, Wien 1977) 198-240, hier 204-206.

6 Gernot Heıss, Im „Reich der Unbegreiflichkeiten“. Historiker als Konstrukteure Österreichs, in: ÖZG 7 (1996) 455-478, hier 467. Ferner DERs., Von der gesamtdeutschen zur europäischen Perspektive? Die mittlere, neuere und österreichische Geschichte, sowie die Wirtschafts- und Sozialgeschichte an der Universität Wien 1945-1955, in: Zukunft mit Altlasten. Die Universität Wien 1945-1955, hg. v. DE ms., Margarethe Grandner, Oliver Ratн коlв (Querschnitte 19, Wien 2005) 189-210, hier 206-209. 


\section{JUGEN D}

Hugo Hantsch wurde am I 5 . Januar I 895 als viertältestes Kind deutschböhmischer Eltern in Teplitz-Schönau (Teplice-Šanov) geboren. Er hatte noch acht Geschwister. Der Vater war Beamter der Prager Eisenbahnindustriegesellschaft, das Elternhaus wurde als gutbürgerlich beschrieben. Hantschs Onkel mütterlicherseits, der Abt des Benediktinerstiftes Melk Amand John, machte Hugo bei Ferialaufenthalten schon sehr früh mit dem Ordensleben bekannt ${ }^{7}$. Hantschs Eintritt als Novize in das Kloster Melk nach der Matura in Teplitz I 9 I 3 scheint familiär vorherbestimmt und entsprach dem ausdrücklichen Wunsch der Mutter $^{8}$, der allerdings auch vom jungen Hugo bejaht wurde, welcher in den tradierten Regeln der altehrwürdigen Ordensgemeinschaft ein Sicherheit spendendes Koordinatensystem vorfand, das ihm freilich gerade in seiner Festigkeit bisweilen zu schaffen machen sollte. Doch war Hantsch schon früh ein ausgesprochener Konservativer und Ordnungsdenker. Nationalitätenkrawalle, die er während seiner Prager Gymnasialzeit erlebt hatte, sollen ihn in ihrer agitatorischen Irrationalität zutiefst abgestoßen haben ${ }^{9}$. Für sich selbst und andere verlangte der junge Geistliche eine besonders gewissenhafte Ausübung der Ordensregeln, was ihm unter seinen Mitbrüdern die als Schimpfwort gemeinte Bezeichnung "Jesuit" einbrachte ${ }^{10}$. Wenn man zwei Messen hört, heißt es Heuchelei? Ja, warum dann überhaupt ins Kloster?, empörte sich Hantsch über seine Mitbrüder, die ihre religiösen Pflichten offensichtlich vernachlässigten. Der Musterschüler maturierte mit Auszeichnung, nur in Mathematik musste er sich mit einem „Gut“ begnügen, und der junge Theologiestudent wiederholte eine Prüfung freiwillig, weil sie nicht die erhoffte Auszeichnung eingetragen hatte $^{11}$. Immer wieder brandmarkte der Novize sein Laster, zu viele Geschichten zu lesen, weltliche Literatur war gemeint, als schwarzen Punkt im Gewissen ${ }^{12}$.

Die Vielfalt seiner Interessen und Talente, welche die Anpassung an die schulischen und klösterlichen Gemeinschaften samt deren Normen sicherlich erleichterte, ließ nicht nur eine einzige Karriere als denkbar erscheinen. Musikalität war in hohem Maße vorhanden ${ }^{13}$, ebenso Interesse an den schönen Künsten, der Literatur; auch eine lyrische Ader zeigte sich $^{14}$. Geschichte stieß, wiewohl ein reges Interesse am Zeitgeschehen offensichtlich ist, die Lektüre

\footnotetext{
7 Hamann, Nekrolog (wie Anm. 1) 345.

8 StA Melk, NL HH, K. 7/51 Tagebuch (= Tb.) 1, Eintrag 07.06.1913.

9 Hamann, Nekrolog (wie Anm. 1) 340.

10 StA Melk, NL HH, K. 7/51 Tb. 3, Eintrag 09.09.1914.

11 Ebd. Tb. 4, Eintrag 18.10.1915.

12 Ebd. Eintrag 07.01.1918.

13 Ebd. Tb. 4, Eintrag 20.11.1915.

14 Ebd.
} 
Herodots den jungen Hantsch begeisterte ${ }^{15}$ und er auch bei der Deutschmatura ein historisches Thema wählte ${ }^{16}$, ausgeprägt erst in der Melker Novizenzeit hinzu: Die Beschäftigung mit der Stiftsgeschichte führte zu einem allseits gelobten Vortrag vor den Mitbrüdern, der Prior ermunterte Hantsch zu eigenen Studien ${ }^{17}$. Zwischenzeitlich erwog dieser aber auch ein Psychologiestudium ${ }^{18}$. Als er vor der Wahl zwischen dem endgültigen Eintritt ins Kloster und dem Weltpriestertum stand, begann für ihn eine Phase des Schwankens; schon den Maturanten hatte eine kurze Romanze grundsätzlich am Priesterberuf zweifeln lassen. Das vorrangige Motiv für das Weltpriestertum war Heimweh, der Wunsch, im geliebten Böhmen nahe von Eltern und Verwandtschaft bleiben zu können ${ }^{19}$. Auch Angst war da, ihm würde, wenn der Abt stirbt, als seinem Verwandten nichts Gutes zuteil werden ${ }^{20}$. Und dann tauchte da noch der Wunsch nach mehr persönlicher Autonomie und Selbstverwirklichung auf, ein Streben, dem Hantsch selbst mit reservierter Scheu gegenüberstand und von dem er sich schnell und willig abbringen ließ ${ }^{21}$. Schließlich wurde der Einfluss von Autoritätspersonen gesucht und bejaht, um die Entscheidung nicht selbst fällen zu müssen: Die Patres des Prager Emmaus-Klosters rieten dem Novizen, Mönch zu werden, und Hantsch folgte, wie befreit, diesem Rat ${ }^{22}$.

Seinen Geschwistern gab der junge Mann, trotz seiner Zweifel über den eigenen einzuschlagenden Lebensweg, früh Sicherheit und Halt. So sorgte er sich um den Bruder Josef („Pepi“), der als Zensor nach Feldkirch ging und betreute ihn als Student von seinem Studienort Innsbruck aus aufs fürsorglichste, ermahnte ihn und erteilte ihm Ratschläge, war besorgt über ausbleibende Antworten per Post ${ }^{23}$.

Auch Gerechtigkeit war ihm ein Anliegen. Als ein Jesuit nach Melk kam, um alte Handschriften zu studieren, und von den Benediktinern aufgrund der traditionellen Rivalität der beiden Orden mit Reserviertheit empfangen wurde, schrieb der Novize, er möge es nicht, wenn Gäste unterschiedlich aufgenommen würden: Für alle habe das Prinzip benediktinischer Gastfreundschaft zu gelten ${ }^{24}$. Die Vielfältigkeit der Welt war für den jungen Geistlichen kein Ärgernis, auch überwog die Neugier manchmal die Angst vor dem Unbekannten. In der Literatur wird hervorgehoben, dass Hantsch freundschaftliche bzw. korrekte Verhältnisse zu protestantischen, jüdischen und slawischen Mitbürgern unterhielt ${ }^{25}$. Zwischen

15 Ebd. Tb.1, Eintrag 10.12.1912.

16 Ebd. Eintrag 19.06.1913.

17 Ebd. Tb. 2, Eintrag 26.11.1913.

18 Ebd. Tb. 1, Eintrag 15.01.1913.

19 Ebd. Tb. 4, Eintrag 16.08.1917.

20 Ebd.

21 Ebd.

22 Ebd. Eintrag 01.09.1917.

23 Ebd. Eintrag 04.12.1915

24 Ebd. Eintrag 12.09.1916.

25 Hamann, Nekrolog (wie Anm. 1) $340 f$. 
einem getauften Mitschüler jüdischer Abstammung und Hantsch entspann sich aber ein Dialog, den ein heutiger Leser wohl nur mit kritischer Distanz lesen kann. Der Mitschüler fragte den Maturanten Hantsch, ob er an eine jüdische Nation glaube. Dieser verneinte und begründete: Erstens gebe es keine gemeinsame Sprache; zweitens: Wäre das gemeinsame Band die Religion, würde das auch nichts nützen, da ohnehin kein Jude mehr glaube. Es gäbe allerdings eine semitische Rasse, aber keine jüdische Nation, wie etwa eine deutsche, der Jude bleibt auch nach der Taufe ein Jude ${ }^{26}$. Er wisse allerdings nicht, schränkte Hantsch dann ein, ob er mit dieser Ansicht Recht habe, und müsse Autoritäten befragen ${ }^{27}$. Hier wird ein katholischer Antisemitismus sichtbar, der keiner Untermauerung durch biologistische Theorien bedurfte und dennoch dem schönerianischen „ob Jud ob Christ ist einerlei...“ zum Verwechseln ähnlich sieht: Denn wohl könnte die Taufe theoretisch die „Schande“ der falschen Geburt reinwaschen, aber praktisch eben nicht, da die Juden gleichsam zum Unglauben determiniert seien. Diese Theorien, die er offensichtlich von seinem Umfeld übernommen hatte, verwendete der Maturant jedoch nicht, um den Schulkollegen herabzuwürdigen, sondern er versuchte anscheinend ernsthaft, sich der Frage anzunehmen. Auch fällt auf, dass ihm hier von seinem Mitschüler das Vertrauen entgegengebracht wurde, diese heikle Frage mit überlegenem Wissen und Objektivität zu entscheiden. Das endgültige Urteil aber wollte Hantsch nicht selber fällen, dafür mussten „Autoritäten“ herangezogen werden. Antworten auf wichtige Fragen des irdischen Lebens existierten also, und sie waren gedeckt durch den katholischen Glaubensschatz und die Überlieferung.

Über die Gräuel des Weltkrieges, der ein Jahr nach seiner Matura ausbrach, gab sich der junge Hantsch keinerlei Illusionen hin, der Tummelplatz internationaler Politik war für ihn kein frischfröhliches Tournament nationalistischer Blutrünstigkeit: [...] wahrlich, der Krieg ist ein Schrecken, schrieb er I9I 4 und bemerkte auch keine Spur der so oft beschriebenen Jubel- und Aufbruchsstimmung: [...] auf den Gesichtern las man nicht überall Kriegslust, die meisten waren getrübt und bleich, beschrieb er einrückende Rekruten ${ }^{28}$. Gott erbarme sich des Volkes, das um ein Kriegsende fleht. Freilich tun das nicht alle, wohl aber viele notierte er $1917^{29}$. Er verfolgte das Kriegsgeschehen jedoch als glühender Patriot und war fest von der Kriegsschuld der Entente überzeugt, eine Überzeugung, an der er ein Leben lang festhielt und die den erfahrenen Geschichtsprofessor in den I960er-Jahren sogar veranlasste, in seinem Alterswerk „Berchtold“ so etwas wie eine „Alleinunschuldthese" bezüglich des Anteils der Doppelmonarchie am Kriegsausbruch aufzustellen. Die Österreichischen Diplomaten sehen sich aufgrund der unzweifelhaften Beteiligung Belgrads

26 StA Melk, NL HH, K. 7/51 Tb. 1, Eintrag 22.06.1913.

27 Ebd.

28 Ebd. Tb. 3, Eintrag 27.07.1914.

29 Ebd. Tb. 4, Eintrag 10.01.1917. 
gezwungen, ein Ultimatum zu stellen, schrieb Hantsch in den Sommertagen des Jahres I9I $4^{30}$. Kurzfristig wurde eine Einberufung auch der jungen Geistlichen überlegt. Hier siegte der jugendliche Patriot über den früh um die Leiden des Krieges Wissenden: $O h$, dass ich doch auch in den Krieg ziehen dürfte. ${ }^{\beta 1}$ Dann unterblieb jedoch der Einberufungsbefehl ${ }^{32}$ und Hantsch studierte, da er Lehrer am Melker Stiftsgymnasium werden wollte, von I9I4-I9I 8 Theologie am jesuitischen Collegium Canisianum in Innsbruck.

\section{DER WERDENDE HISTORIKER - PRÄGUNGEN IN INNSBRUCK UND W I E N}

Die Auflösung der Habsburgermonarchie und ihre Folgen muss der junge Hantsch wie viele seiner Zeitgenossen als fundamentale Erschütterung empfunden haben; leider brechen die Jugendtagebücher zu dieser Zeit ab. Hantsch blieb in Innsbruck und begann I 9 I 8 an der dortigen Universität ein bis 1922 dauerndes Studium der Geschichte, Germanistik und Geografie (Lehramt). Er promovierte I92 I mit dem noch ganz seiner vorangehenden Laufbahn verpflichteten Thema „Die rechtlichen Grundlagen in der klösterlichen Aufnahmeordnung des heiligen Benedikt“. Seine akademischen Lehrer im historischen Fach waren vor allem der klerikale „ultramontane“ Ignaz Philipp Dengel, ein Schüler Ludwig von Pastors, sowie sein Doktorvater, der Mediävist Steinacker ${ }^{33}$. Hantsch behielt beide Professoren trotz ihrer unterschiedlichen Weltanschauungen als hervorragende Lehrende in Erinnerung. Steinacker, unter seinen Studenten als glänzender Redner beliebt, war ungarndeutscher Protestant und Sohn des ungarn- und ausgleichsfeindlichen deutschnationalen Politikers Edmund Steinacker. Er gilt als der eigentliche Vater der „gesamtdeutschen Geschichtsauffassung“, die zwischen „österreichischer“ und „preußischer“ Geschichtsauffassung vermitteln und somit den Anschluss Österreichs von 1938 vorbereiten sollte. Steinacker diente das hochmittelalterliche Regnum der Ottonen, Salier und Staufer als idealisiertes Vorbild eines kommenden großdeutschen Nationalstaates ${ }^{34}$. Die religiöse Di-

30 Ebd. Tb. 3, Eintrag 26.07.1914.

31 Ebd. Eintrag 30.07.1914.

32 Ebd. Eintrag 03.08.1914.

33 Zu Steinacker vgl. Renate Spreitzer, Harold Steinacker (1875-1965). Ein Leben für „Volk und Geschichte“, in : Österreichische Historiker 1900-1945. Lebensläufe und Karrieren in Österreich, Deutschland und der Tschechoslowakei in wissenschaftsgeschichtlichen Porträts, hg. v. Karel Hruza (Wien/Köln/Weimar 2008) 191-223; Anna Scha de R, Harold Steinacker (1875-1965). Sein Weg in den Nationalsozialismus (phil. Diss., Klagenfurt 1997).

34 Harold Steinacker, Vom Sinn einer gesamtdeutschen Geschichtsauffassung, in: Ders., Volk und Geschichte. Ausgewählte Aufsätze und Reden (Brünn/München/Wien, 1943) 89-110, hier 100-102, 107-110. 
mension der Reichsidee wurde insofern bejaht, als sie die mittelalterlichen Imperatoren befähigt habe, der Germanisierungspolitik in Osteuropa die nach den damaligen Vorstellungen unbedingt notwendige christliche Legitimierung zu verleihen ${ }^{35}$. Bismarcks Kampf gegen Österreich wurde als „tragisch“ bezeichnet, aber als machtpolitisch „unvermeidliche Vorstufe“ zu einem alle geschlossenen deutschsprachigen Siedlungsgebiete umfassenden Großdeutschland gerechtfertigt, das wieder als Hegemonialmacht einen künftigen mitteleuropäischen Staatenbund anführen sollte. Dabei näherte sich Steinacker schon in den I $920 e r-J a h r e n$ weit stärker als später Srbik biologistischem, sozialdarwinistischem Gedankengut. Die „Nationswerdung“ durch „Nationserweckung“ wurde einem „rauschhaften Verbrüderungserlebnis“ im Ersten Weltkrieg zugeschrieben, das im kollektiven Unbewussten stattgefunden und allen Deutschen endgültig deutlich gemacht habe, dass „Blut zu Blut" gehöre ${ }^{36}$. Insofern war für Steinacker der Erste Weltkrieg nicht nur der Untergang einer heilen alten Welt, sondern auch der verheißungsvolle Aufgang einer dynamischen neuen. Steinackers politisches Hauptziel war während der Zwischenkriegszeit der Anschluss, nach 1938 verfocht er öffentlich die Osteuropa-Politik des NS-Regimes. Allerdings unterscheidet sich die deutschnationale Programmatik Steinackers vor I9I4 deutlich von jener der cisleithanischen Schönerianer. Einen Anschluss „Deutschösterreichs“ anzustreben war ja für einen Ungarndeutschen sinnlos, und an „Umvolkung“ dachte vor dem Ersten Weltkrieg selbst Steinacker noch nicht. So lag sein Ziel, wie das seines Vaters Edmund, der trotz seiner protestantischen Konfession übrigens sehr mit dem von Rom abweichenden „Deutschkatholizismus“ geliebäugelt hatte ${ }^{37}$, in der Zurücknahme des „Ausgleiches“ von I 867. Alle Hoffnung richtete sich dabei auf den Thronfolger Franz Ferdinand, in dessen engsten Beraterkreis Edmund Steinacker aufgestiegen war. Harold Steinacker schrieb in einer Würdigung seines Vaters, dieser und Franz Ferdinand hätten die gleichen politischen Ziele gehabt: engstes Bündnis mit Deutschland, Revision des Ausgleichs sowie „gleiches Recht für alle Nationen, aber Abstufung nach Wert und Treue für die Monarchie“38.

Nach Beendigung seiner Innsbrucker Studien ging Hantsch, dessen Lust an historischer Forschung durch Steinacker geweckt worden war, zunächst nach Mainfranken und arbeitete zwei Jahre lang als Archivar im Hausarchiv der Familie Schönborn im fränkischen Schloss Wiesentheid; anschließend besuchte er als außerordentliches Mitglied den

35 Ebd. 100-102.

36 Harold Steinacker, Die volksdeutsche Geschichtsauffassung, in: Ders., Volk und Geschichte (wie Anm. 34) 111-148, hier 127-135.

37 Harold Steinacker, Edmund Steinacker (1839-1929), Lebensbildnis eines ungarländischen deutschen Volksführers, in: Austro-Hungarica. Ausgewählte Aufsätze und Vorträge zur Geschichte Ungarns und der öst.-ung. Monarchie (Buchreihe der Südostdeutschen Historischen Kommission 8, München 1963) 312-322, hier 313.

38 Ebd. 322. 
I923-I925 laufenden 34. Ausbildungskurs am IÖG in Wien, ohne die Abschlussprüfung abzulegen ${ }^{39}$. Zu seinen Kurskollegen gehörten unter anderen Franz Huter und Alphons Lhotsky. Zum Förderer seiner frühen wissenschaftlichen Laufbahn wurde Srbik ${ }^{40}$. Srbik stand zu dieser Zeit auf einem ersten Höhepunkt seines Ansehens als Gelehrter. I925 erschien der erste Band seiner monumentalen Metternich-Biografie. In seiner Jugend Schönerianer und Angehöriger der schlagenden Burschenschaft Gothia ${ }^{41}$, errang Srbik durch sein Buch über Metternich auch in „vaterländischen“ und klerikalen Kreisen als „Apologet“ nicht nur des konservativen Prinzips im Allgemeinen, sondern Metternichs und damit auch der Habsburgerdynastie im Besonderen eine Respektabilität, die er zumindest bis 1938 beibehielt ${ }^{42}$. Tatsächlich ist das Werk eine partielle Apologie Metternichs.

Srbik war bestrebt, Metternich vom Stigma, das ihm die kleindeutsche Historiografie angeheftet hatte, abwechselnd ein gesinnungsloser Ränkeschmied und ein reaktionärer „Prinz der Finsternis“ zu sein, zu befreien und ihn als einen Denker zu präsentieren, der sich unter anderem an seinem protestantischen Lehrer Christoph Wilhelm von Koch, dem protestantischen Historiker Arnold Heeren und dem virtualistischen Kant-Schüler und Kant-Kritiker Karl Wilhelm Bouterwek, einem großen Vorbild seines zweiten Lehrers Niklas Vogt, orientierte ${ }^{43}$. Als Kernprogramm von Metternichs ideologischem „System“, das ihm Srbik postum zuschrieb, wurde das „Apostolat der gesellschaftlichen Erhaltung" genannt ${ }^{44}$.

Dieses zeige sich in der engen Verbindung von innenpolitischer Stabilität mit außenpolitischer Existenzfähigkeit eines Staates und in der dadurch begründeten Gehorsamsverpflichtung des einzelnen Staatsbürgers gegenüber der Staatsgewalt, die allein durch das positive Recht legitimiert ist. Srbiks Lob des Staatskanzlers als „Staatsmoralisten“ stellte hier Metternich als Geistesverwandten Leopold von Rankes dar. Wo er aber Metternich bescheinigen musste, dass dieser versucht habe, Politik nach naturrechtlich fundierten Prinzipien zu machen, da entzog der Biograf dem Dargestellten das Wohlgefallen. Metternichs rein statischem, rationalistischem Denken sei die irrationale Dynamik der

39 Siehe Hamann, Nekrolog (wie Anm. 1) 348; Leo Sant ifaller, Das Institut für österreichische Geschichtsforschung. Festgabe zur Feier des zweihundertjährigen Bestandes des Wien Haus-, Hof- und Staatsarchivs (Veröff. des IÖG 11, Wien 1950) 143; Alphons Lнотsку, Geschichte des Instituts für österreichische Geschichtsforschung 1854-1954 (MIÖG Erg.-Bd. 17, Graz/Köln 1954) 371.

40 Siehe Hamann, Nekrolog (wie Anm. 1) 348.

41 Ludwig Moos, Bildungsbürgertum, Nationalproblem und demokratisches Zeitalter. Studien zum Werk Heinrich Ritters von Srbik (Freiburg i. Br. 1967) 7.

42 Siehe Werner NäF, Nekrolog Heinrich von Srbik, in: HZ 173 (1952) 95-102, hier 97.

43 Heinrich Ritter von SR вік, Metternich. Der Staatsmann und der Mensch 1 (Unveränderter fotomechanischer ND der ersten Auflage von 1925, München 1957) 350-414.

44 Srbik, Metternich (wie Anm. 43) 414-420. 
völkischen Idee verschlossen geblieben ${ }^{45}$. Dennoch habe Metternich zumindest einmal Österreichs „deutsche Aufgabe“ wahrgenommen, indem er ihm anlässlich des Wiener Kongresses Bayern sichern wollte: Da sei ihm letztendlich Kaiser Franz in den Rücken gefallen $^{46}$.

IV. FRÜHWERK UND HABILITATION

Hantsch schrieb nun, großteils unter der Ägide Srbiks, drei Monografien, aufgrund derer er schließlich I930 habilitiert wurde. Zunächst verfasste er das Werk „Der deutsche Bauernkrieg“" ${ }^{47}$. Wer nun, so beginnt das Buch mit einer von seinen zeitgenössischen Fachkollegen oft gestellten „Entscheidungsfrage“, trug Schuld an einem frühneuzeitlichen „Reichszerfall“? Karl V. konnte in der Sichtweise Hantschs im beginnenden 16. Jahrhundert nichts mehr tun, um die kaiserliche Zentralgewalt zurückzugewinnen. Denn seit den letzten Staufern hätten die Fürsten bereits die Macht im Reich an sich gerissen, den Kaiser auf Reichsebene nolens volens zum Titularherrscher gemacht: „Man brauchte ihn nicht, also schätzte man ihn nicht. “48 Außerdem hätten den Habsburger vordringliche Probleme der Gesamtchristenheit, allen voran die Türkengefahr, wieder und wieder von der deutschen Bühne ferngehalten, und nicht etwa die Verfolgung dynastischer Eigeninteressen ${ }^{49}$. Das aufstrebende Landesfürstentum hätte aber in seiner raffenden Ländergier nicht die Aufrechterhaltung rechtlicher Normen garantieren können, die es selbst am meisten infrage gestellt habe ${ }^{50}$. In dieses bereits vorhandene moralische Vakuum, auf innerdeutschen spätmittelalterlichen Entwicklungen basierend, stieß nun laut Hantsch der „alleszersetzende“ Renaissancegeist des Individualismus ${ }^{51}$. Eine verwirrende Fülle neuen Wissens sei vom Mächtigen, den kein Korrektiv mehr in die Schranken gewiesen habe, rücksichtslos missbraucht worden, um den Schwächeren zu übervorteilen: das von den als Helfershelfern der Machthaber fungierenden Berufsbeamten angewendete neue, römische Recht, tradiertes Gewohnheitsrecht ersetzend, sowie die sich Uneingeweihten entziehenden Innovationen der Finanzmärkte ${ }^{52}$. Mit dem Großkapital ging Hantsch besonders hart

\footnotetext{
45 Ebd. 341f.

46 Ebd. 203.

47 Hugo Hantsch, Der deutsche Bauernkrieg (Würzburg 1925).

48 Ebd. 7.

49 Ebd. 5.

50 Ebd. $7 f$.

51 Ebd. 6.

52 Ebd. 43f.
} 
ins Gericht: Die „Gier nach Mammon“ sah er überall um sich greifen ${ }^{53}$. Der niedere Adel sei durch diese Entwicklungen bedroht worden: gefangen im eigenen überalterten Ehrenkodex, habe er sich durch Städte und Landesfürstentum in „seiner Freiheit betrogen und seiner Rechte beraubt“, in seinen Einkünften eingeschränkt gefühlt ${ }^{54}$. Doch in seiner Not habe er Willkür mit Willkür vergolten, zum Fehderecht aus nichtigem Anlass gegriffen, im Raubrittertum und Strauchdiebstahl geendet ${ }^{55}$. Gier und Hass, nach Augustinus die beiden Todsünden, hätten sich in logischer Abfolge überall ausgebreitet. Dabei wären die Schwächsten, die zumeist keine Möglichkeit zur ständischen Organisation besaßen, die Bauern also, am meisten zu Schaden gekommen. Freilich war dieses frühneuzeitliche Bauerntum keine homogene Masse: Noch vor Günther Franz betonte Hantsch das Selbstbewusstsein, das Pochen auf alte Rechte durch wohlhabende Bauern im schwäbischen Kerngebiet der großen Revolte ebenso wie deren drohende Übervorteilung durch rechtliche Neuerungen, unterließ aber auch nicht den Seitenblick auf ärmere Bauern, die durch bäuerliche Erbteilungen zu kurz gekommen waren, und auf innerbäuerliches Konfliktpotenzial ${ }^{56}$. Das Zusammenspiel von städtischen und ländlichen Unterschichten, auch eine der am hartnäckigsten behaupteten Thesen marxistischer Bauernkriegsforschung, war für Hantsch eine Tatsache.

Nur ein Stand war für den katholischen Historiker in seiner Gesamtheit integer und moralisch geblieben: der Klerus. Er war und blieb für Hantsch Träger „aller geistigen Kultur des deutschen Volkes" ${ }^{\text {57 }}$. Dass die Geistlichkeit auch weltlichen Besitz angehäuft hatte, war für Hantsch kein Frevel gegen die Natur des Christentums, sondern zivilisatorische Notwendigkeit ${ }^{58}$. Doch hätte die Kirche, laut Hantsch selbst unter einzelnen dekadenten Renaissancepäpsten ihrer Weltmission getreu, ihre hochmittelalterliche Macht verloren und damit auch die Möglichkeit, ihren moralischen Anspruch durchzusetzen ${ }^{59}$. Aber reich sei sie immer noch gewesen, in Deutschland zumindest. „Auf diese Weise kam ein Gegensatz, ein Widerspruch in die bestehenden Verhältnisse." ${ }^{00}$ Und der sei nun ausgenutzt worden: Gräuelpropaganda und maßlose Polemik hätten alle Besitzgier und alles Ressentiment, das die Stände entzweite, gebündelt, sie gegen die Kirche gerichtet und diese zum Sündenbock gemacht. Antiklerikalismus sei zum kleinsten gemeinsamen Nenner der deutschen Nation geworden, der sich freilich im Anti erschöpfte, über Destruktion nicht hinausgereicht

53 Ebd. 44.

54 Ebd. 19.

55 Ebd. 19 f.

56 Ebd. 72.

57 Ebd. 32.

58 Ebd. 33.

59 Ebd. 34.

60 Ebd. 
habe ${ }^{61}$; Antiklerikalismus gleichsam als frühneuzeitlicher "Sozialismus der Dummen“. Prädikanten, verwahrloste, neiderfüllte, ungebildete Verwalter eines Kirchengutes, das ihre Habsucht anstachelte, hätten Mordlust verbreitet und Hass geschürt. Dass dieser, latent immer vorhanden, sich nun derart massiv manifestierte, daran sei teilweise ein Missverständnis schuld gewesen ${ }^{62}$. Aus Luthers „schwer verständlicher“ Schrift „Freiheit eines Christenmenschen“ seien nun auch wirtschaftlich-politische Forderungen abgeleitet worden, die Ablehnung der Leibeigenschaft etwa, die über des Reformators „erbarmungslosen Kampf mit der alten Kirche“ hinausgegangen seien ${ }^{63}$. Doch ein einheitliches, in sich geschlossenes Programm zum Aufbau einer neuen gesellschaftlichen Ordnung sei nicht entstanden ${ }^{64}$, von der Ausnahme des „Propheten“ Thomas Müntzer abgesehen, der allerdings für Hantsch als wirrer Endzeitschwärmer Diesseits und Jenseits verwechselte ${ }^{65}$. Weitgehend folgte Hantsch der Interpretation des Bauernkrieges durch Johannes Janssen in dessen scharfer Polemik gegen eine orthodox-lutherische Historiografie, die den Bauernkrieg von der reformatorischen Bewegung und dem Gedankengut Martin Luthers abgrenzte ${ }^{66}$. Allerdings sah Hantsch die Rolle Luthers nun differenzierter, ohne ihn aber als Verteidiger der weltlichen Ordnung aufzufassen oder gar Sympathien für seine Theologie zu bekunden. Im festgestellten Zusammenspiel aller aufrührerischen Stände ergab sich ein weiterer Berührungspunkt mit der marxistisch-leninistischen Analyse, die bekanntlich in auch innermarxistisch umstrittener Berufung auf Friedrich Engels von einer gemeinsamen „frühbürgerlichen Revolution“ des „bürgerlichen“ Luthertums und des ausgebeuteten „gemeinen Mannes“ sprach ${ }^{67}$. Auf eine Gesamtschau der damals verwertbaren Literatur aufgebaut, besitzt Hantschs Darstellung der Bauernkriege vielleicht einen Vorteil gegenüber den Arbeiten berühmter Einzelforscher, die vor allem von intensiven Quellenstudien über eine spezifische Region ausgehen. Die Kernfrage der Gesamtbetrachtung des Jahres I 525/26, warum die Idee des sozialen Aufruhrs Menschen aus so heterogenen Besitzverhältnissen und mit so unterschiedlichen politischen Vorstellungen zeitgleich zu einer flächenübergreifenden Protestbewegung bündelte, wird durch Hantschs Hinweis auf den Antiklerikalismus als „kleinsten gemeinsamen Nenner" auf eine Weise beantwortet, die Anklang bei heutigen Frühneuzeithistorikern fand ${ }^{68}$.

61 Ebd. 31f.

62 Ebd. $113 f$.

63 Ebd.

64 Ebd. $136 f$.

65 Ebd. $272 f$.

66 Johannes Janssen, Geschichte des deutschen Volkes seit dem Ausgang des Mittelalters. Zustände des deutschen Volkes seit dem Beginn der politisch-kirchlichen Revolution bis zum Ausgang der sozialen Revolution von 1525 2, hg. v. Ludwig von Pastor (Freiburg i. Br. $\left.{ }^{5} 1915\right)$ 498-552.

67 Siehe Friedrich Winterhager, Bauernkriegsforschung (Darmstadt 1981) 125-146.

68 Vgl. etwa Hans-Jürgen Goertz, Deutschland 1500-1648. Eine zertrennte Welt (Paderborn 2004) 144-146. 
Und dies unabhängig von der Tatsache, dass Hantschs Sichtweise, die katholische Kirche sei „unverschuldet“ zum Sündenbock gemacht worden, wohl damals ebenso wenig ungeteilte Zustimmung fand, wie sie es heute tut. Literarisch mehr als „populärhistorisch“, teilweise von barocker Sprachpracht, in großen Zügen zeichnend, klar Partei ergreifend und dennoch abwägend analysierend, ist dieses Buch ein durchaus originelles Frühwerk des jungen Historikers, in vielem bereits ein „typischer Hantsch“. Srbik lobte es sehr, vor allem deshalb, weil es sich einer stiefmütterlich behandelten Epoche widmet ${ }^{69}$. Stiefmütterlich, das bedeutete aus Sicht des konservativen Srbik: vorwiegend durch linke, sozialistische und marxistische Studien erschlossen, eine konservative Entgegnung täte not. Und tatsächlich malte Hantsch in einem Seitenstrang seiner Gesamterzählung, in seiner Beschreibung der hussitischen Einflüsse auf die bäuerlichen Bewegungen vor I 525, ein erschreckendes Menetekel einer aus dem slawischen Osten kommenden revolutionären Ideologie, die auch im Reich an Ein-

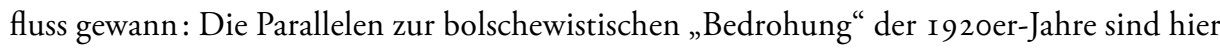
nicht nur zwischen den Zeilen angedeutet, sie werden ausdrücklich hergestellt ${ }^{70}$. In diesem Punkt trafen sich Hantsch und sein berühmter Lehrer.

I 926 erschien „Jakob Prandtauer. Der Klosterarchitekt des österreichischen Barock“, die kunsthistorische Arbeit über den Baumeister des Stiftes Melk, eine Auftragsarbeit des Stiftes, eine Apotheose des österreichischen Barockkünstlers und gleichzeitig eine Verteidigung von dessen künstlerischer Originalität gegen Attacken namhafter österreichischer Kunsthistoriker $^{71}$. Der in der Habilitationskommission von Hantsch tätige Kunsthistoriker Julius Schlosser würdigte die ausgezeichnete historisch-philologische Grundlage der Arbeit, die stilkritisch freilich manches zu bemängeln gebe. Insgesamt sei sie jedoch als wichtiges Werk anzuerkennen ${ }^{72}$.

I929 erschien Hantschs Monografie über den Reichsvizekanzler Reichsfreiherr (seit I70 I Reichsgraf) Friedrich Karl von Schönborn-Buchheim (I674-I746), ein im Vergleich zum Buch über die Bauernkriege streng wissenschaftliches, den erforschten Quellen folgendes Werk. Schönborn wurde von seinem Oheim Lothar Franz, dem Erzbischof und Kurfürsten von Mainz und Reichserzkanzler, gegen den Willen des Kaisers auf den Posten des Reichsvizekanzlers am Wiener Hof gebracht und geriet früh in das Spannungsfeld zwischen den Interessen seines eigenen Hauses und denen des Monarchen, während er das höfische Prestige seiner eigenen Position gegenüber den rein österreichischen Behörden zu wahren hatte. Tölg behauptete, Hantsch habe mit dieser Arbeit - wenngleich vorüber-

69 UAW, PA Hugo Hantsch, Referat Srbiks zur Habilitation Hantsch, 07.1929.

70 Наnтsсh, Bauernkrieg (wie Anm. 47) 84.

71 Hugo Hantsch, Jakob Prandtauer. Der Klosterarchitekt des österreichischen Barock (Wien 1926).

72 UAW, PA Hugo Hantsch, Protokoll der Besprechung von Hantschs Werken durch die Habilitationskommission 10.07.1929. 
gehend - die „gesamtdeutsche Geschichtsauffassung“ Srbiks übernommen ${ }^{73}$. Trifft das zu? Tatsächlich rühmte Srbik in seinem Habilitationsgutachten an dem Werk, dass der Autor mit Freimut die Spannungen zwischen Kaiser und Reichsinteresse anspreche sowie die offensichtliche Verhüllung des Hausinteresses durch das Reichsinteresse bei Josef I. bemängle ${ }^{74}$. Und als in der Besprechung der Habilitationskommission Alfons Dopsch missgünstig einwendete, er wundere sich sehr, dass Hantsch sich nicht in Innsbruck habilitiere, wo er ja offensichtlich hingehöre, da beruhigte ihn Srbik, Hantsch sei eher sein, Srbiks, eigener Schüler als der des klerikalen Dengel ${ }^{75}$. Allerdings kritisierte Hantsch die habsburgischen Partikularbestrebungen vor allem dort, wo sie sich gegen die Kurie richteten, wo es um einen Besitzstreit um alte Reichslehen in Italien ging. Der Historiker stieß sich hier also nicht am mangelnden deutschen, sondern am mangelnden katholischen Einheitsgefühl Josefs I., anders übrigens als sein Protagonist, der Kleriker Schönborn, der voll und ganz die kaiserliche Partei ergriff ${ }^{76}$.

Entscheidend für das Verständnis der Biografie ist, dass Schönborn, zunächst Vertreter des sehr dynastiebewussten Oheims, der das Prestige des eigenen Hauses mit dem des Reiches gleichsetzte und die eigenen Interessen gegen die Habsburger gewahrt wissen wollte, schließlich im Lauf seiner persönlichen Entwicklung zum loyalen österreichischen Patrioten wurde. Er erkannte, dass nur oder vielmehr nicht einmal der Kaiser das traditionsbehaftete, oft als eigentlicher Kern des Reiches bezeichnete dritte Deutschland vor dem Partikularinteresse vornehmlich Preußens schützen konnte ${ }^{77}$ und dass „Kaiser und Reich eine untrennbare Einheit“ bildeten ${ }^{78}$. Ein anderes Kaisertum als das habsburgische war für Schönborn aber undenkbar ${ }^{79}$. Der Mann aus dem rheinländischen Geschlecht vermochte mit der Reichsvizekanzlei eine seit der Einrichtung einer österreichischen Hofkanzlei I 620 mit mehr Würde als Macht versehene Institution allein durch die Integrität und Kraft seiner Persönlichkeit und durch das Gehör, das er bei Josef I. und Karl VI. wegen seiner kritischen Loyalität fand, wesentlich aufzuwerten ${ }^{80}$. Nun wurde das „konservative Genie“ zum antipreußischen Rufer in der Wüste und somit zum Gottseibeiuns der zeitgenössischen preußischen Politik sowie der protestantisch-kleindeutschen

73 Tölg, Ideologie (wie Anm. 1) 15f. Dies aufgrund einer Widmung Hantschs an Srbik, in der der Autor sein Buch tatsächlich als einen „Beitrag zu einer gesamtdeutschen Geschichtsauffassung“ bezeichnete.

74 UAW, Referat Srbik (wie Anm. 69).

75 UAW, Protokoll (wie Anm. 72).

76 Hugo Hantsch, Friedrich Karl Graf von Schönborn (1674-1746). Einige Kapitel zur politischen Geschichte Kaiser Josefs I. und Karls VI. (Salzburger Abh. zu Wissenschaft und Kunst 2, Augsburg 1929) 92-119.

77 Ebd. 357.

78 Ebd.

79 Ebd. 358.

80 Ebd. $73 f$. 
Historiografie ${ }^{81}$. Niemals, so Schönborn, könnte die „teutsche Libertät“ gegen den Kaiser ausgespielt werden, genauso wenig wie die Glieder eines Körpers gegen das Haupt, „die Strahlen gegen die Sonne“82. Niemals aber dürfte der Kaiser seinerseits danach trachten, legibus solutus, abgelöst von der geschriebenen „Reichsverfassung“ von der Goldenen Bulle bis zum Westfälischen Frieden, zu agieren, den föderalistischen Rechtsstaat, denn ein solcher war und blieb für Schönborn wie für Hantsch das Reich, in einen straff zentralistisch aufgebauten Machtstaat zu transformieren - selbst dann nicht, wenn dies die Position des Reiches im internationalen Mächtekonzert gestärkt hätte. Niemals hätte Schönborn, der protestantischerseits während der Reichskrise anlässlich des Regensburger Konventes von I722, als längst vergessene Frontstellungen aus der Zeit des Dreißigjährigen Krieges die Reichsstände spalteten, als „Warmonger“ verschrien war, je daran gedacht, den deutschen Protestantismus etwa „mit anderen als geistigen Waffen anzugreifen"83. Die Möglichkeit einer Beugung des Reiches unter das habsburgische „Servitut“ war im beginnenden I8. Jahrhundert hypothetisch. Real aber war das Kalkül kaiserlicher Berater, dass sich Österreich auf Kosten der wehrlosen kleinen Reichsteile mit Preußen arrangierte, um einen mächtigen Bundesgenossen zu gewinnen; real war erstmals das Aufkeimen des von der "gesamtdeutschen Geschichtsauffassung“ später in seiner kooperativen Form eines machtvollen deutsch-deutschen Mächtebündnisses stets gewürdigten österreichisch-preußischen Dualismus. Hantsch sah eine fünfte Kolonne Preußens sowie des internationalen Protestantismus am Wiener Hof ihre Wühlarbeit verrichten, einen teils bestochenen, jedenfalls aber egoistischen österreichischen Hofadel, der keinen Bezug mehr zu der Reichsidee als Idee einer universalen Rechtsordnung hatte ${ }^{84}$. Der „nur-österreichische Partikularismus“ des Wiener Hofes wurde also nicht zuletzt als Bahnbrecher des österreichisch-preußischen Konsenses getadelt! Erbittert und vergeblich kämpfte Schönborn gegen die Politik Karls VI., die Pragmatische Sanktion durch einzelne Hausverträge zu sichern. Dieser seiner Meinung nach unnötige, freiwillige Rechtsverzicht bedeutete für den Reichsvizekanzler ein Eingeständnis kaiserlicher Schwäche. Aber genauso war die Anerkennung der Pragmatischen Sanktion durch die Reichsstände, um die sich Karl VI. so emsig bemühte, für Schönborn vom reichsrechtlichen Standpunkt aus überflüssig: Der Reichsvizekanzler „leitete das Recht des Hauses, über die Nachfolge zu bestimmen, aus

81 Ebd. 265-280.

82 Ebd. 357.

83 Ebd. 361.

84 Ebd. 50-53, vgl. bereits Hantschs Sichtweise von Schönborns Vorgänger als Reichsvizekanzler, Dominik Andreas Graf Kaunitz, ebd. 109f. Vgl. die Einschätzungen der „Verfechter des alten Systems“, der Aufrechterhaltung des habsburgisch-preußisch-protestantischen Bündnisses aus der Zeit des Spanischen Erbfolgekriegs, der partikularistischen Politik Johann Wenzel Wratislaw von Mitrowitz', Georg Ludwig von Sinzendorfs, aber auch Prinz Eugens, ebd. 142-147. 
staatsrechtlichen Quellen ab, aus den vom Reich gegebenen Privilegien“ des Mittelalters ${ }^{85}$ ! Auf die „reichsverräterische“ Politik der protestantischen Stände, die in die Allianz von Hannover mündete, musste der Kaiser seinerseits aus reiner Notwehr mit der Neuauflage des habsburgisch-spanischen Bündnisses, ja mit einem „Revival“ des katholischen Konfessionalismus aus dem frühen I7. Jahrhundert antworten, so sah es der alte Reichspatriot und „gute Teutsche“, so sah es sein Biograf ${ }^{86}$. Überhaupt die Habsburger: Gütig und wohlwollend waren sie in Hantschs Darstellung, Karl VI. zumindest nach seiner Kaiserkrönung, in Edelmut bisweilen selbst auf ihre Selbstverteidigung vergessend ${ }^{87}$. Dieser Zug habsburgischer Politik wurde allerdings von Schönborn gerügt. Resignierend und vergeblich empfahl er schließlich, angesichts des reichsständischen Widerstandes gegen die vom Kaiser angestrebte reichsrechtliche Anerkennung der Pragmatischen Sanktion, durch das Reich eine Kette österreichischer Besatzungen zu legen, um die schwächeren Stände gegen die Einschüchterungsversuche habsburgfeindlicher Reichsstände stärker zu verteidigen, und, nebenbei, die Durchsetzung habsburgischer Interessen zu sichern ${ }^{88}$. Unverfälschte Machtpolitik, urteilte Hantsch, aber als Ultima Ratio der Verteidigung der österreichischen Hausinteressen vorgesehen, scheiternd am streng rechtlichen Denken des Kaisers ${ }^{89}$. Nicht dynastisches Eigeninteresse, nicht absolutistische Machtgier war für Hantsch der innerste Antrieb der kaiserlich-habsburgischen Politik, nicht übertriebene Konfliktscheu ihr Hemmschuh. Stärke und Schwäche, Größe und Tragik der Habsburger auf dem Kaiserthron lag für den Historiker vielmehr in ihrer Selbstverpflichtung auf eine von den anderen Reichsständen schon vor der Zeit des habsburgischen Kaisertums herbeigezwungene und dann jahrhundertelang mit Füßen getretene Rechtsordnung, die sich in ihrem eigenen Rahmen nur durch Rechtsmittel verteidigen ließ.

Von einer gleichmäßigen Verteilung österreichischer und preußischer Schuld am Reichszerfall, wie Srbik ihn im Werk seines Habilitanden sehen wollte, kann in summa keine Rede sein. Hat also Hantsch bei Srbik den Eindruck zu erwecken versucht, er habe dessen „gesamtdeutsche Geschichtsauffassung“ übernommen? Hat Srbik Hantschs Arbeit zu flüchtig gelesen und den Kerngedanken nicht erfasst? Andererseits stellte Srbik selbst in seinem Habilitationsgutachten fest, dass Schönborn im Laufe der Jahre immer österreichischer wurde ${ }^{90}$. Hat er Hantsch, wie dieser später ihm, bewusst Deckung gegeben, die ideologischen Unterschiede großzügig tolerierend? Hans Uebersberger sprach sich in der Habilitationskommission grundsätzlich für die Habilitation Hantschs aus, bemängelte

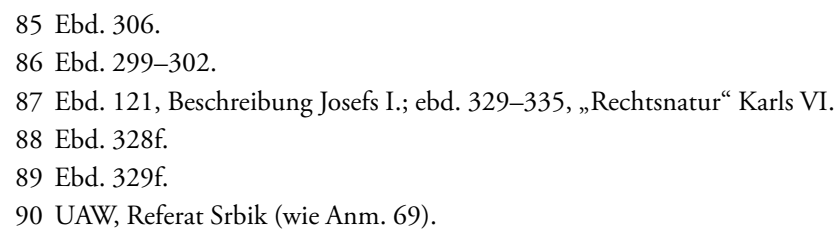


aber dessen „ungenügende Kenntnis“ der osteuropäischen Literatur. Die Venia docendi wurde schließlich vom Professorenkollegium mit 48 Befürwortungen, 4 Enthaltungen und I Gegenstimme betreffend die persönliche Eignung, 46 Ja-Stimmen, 3 Enthaltungen und 2 Gegenstimmen bezüglich der fachlichen Eignung erteilt ${ }^{91}$. Als Mitglieder der Habilitationskommission zeichneten der Referent Srbik sowie Hans Hirsch, Wilhelm Bauer, Alfred Francis Přibram, Gustav Turba, Uebersberger und der Kunsthistoriker Schlosser als Sachverständiger für die Arbeit über Prandtauer ${ }^{92}$; die Kommissionsmitglieder hatten Hantsch einstimmig vorgeschlagen ${ }^{93}$.

\section{HANTSCHS INTERPRETATION DER REICHSIDEE}

In den folgenden Jahren schien die Karriere des Privatdozenten Hantsch etwas zu stagnieren. Er hielt Vorlesungen, unter anderem über das Zeitalter der Stuarts und Tudors, verweilte zwischenzeitlich zu Forschungen in England, versuchte vergeblich, Nachfolger Dengels in Innsbruck zu werden ${ }^{94}$.

I 933 veröffentlichte er in der prominenten Reihe „Geschichte der führenden Völker“, herausgegeben von Heinrich Finke im katholischen Verlag Herder, die Darstellung „Entwicklung Österreich-Ungarns zur Großmacht“. An dieser Stelle soll an die in der Einleitung formulierte Fragestellung angeknüpft werden und Hantschs Buch mit dem ersten, I 935 erschienenen Band von Srbiks Opus „Deutsche Einheit“ kontrastiert werden, das Srbik selbst als sein Hauptwerk betrachtete. Hantsch rechtfertigte die habsburgischen Landerwerbungen im Westen, das spanische und burgundische Erbe also, damit, dass sie rechtlich einwandfrei geschehen seien. Habsburg habe damit notgedrungen den mittelalterlichen Konflikt zwischen dem Reich und Frankreich übernehmen und sich aus Selbstverteidigungsgründen gegen dessen nationale Expansionspolitik wenden müssen ${ }^{95}$. Srbik dagegen kritisierte, Maximilian I. habe durch die Übernahme des burgundischen Erbes erst den neuzeitlichen französisch-deutschen Konflikt heraufbeschworen und das übrige Reich in seinen eigensüchtigen Kampf hineingezerrt ${ }^{96}$. Die spanische Hausmachtspolitik der Habsburger habe dem Reich einen notwendigen „festen nationalen Kern“ verwehrt und so zur Zerklüftung Deutschlands beigetragen; Srbik missbilligte in diesem Zusam-

\footnotetext{
91 UAW, Protokoll (wie Anm. 72).

92 Ebd.

93 Ebd.

94 TöLg, Ideologie (wie Anm. 1) 17.

95 Hugo Hantsch, Die Entwicklung Österreich-Ungarns zur Großmacht (Geschichte der führenden Völker 15, Freiburg i. Br. 1933) $26 f$.

96 Heinrich Ritter von SR вік, Deutsche Einheit 1 (München 1935) 39.
} 
menhang insbesondere die Teilung der Habsburger in zwei Linien durch Karl V. ${ }^{97}$ Für Hantsch trug an der zunehmenden Zerrüttung des Reiches die Uneinigkeit der Stände die Alleinschuld, die habsburgische Teilung sei aus Gründen der Staatsräson unvermeidlich gewesen und habe hervorragend funktioniert ${ }^{98}$. Den katholischen wie protestantischen Konfessionalismus machte Srbik gleichermaßen für den Tiefstand der deutschen Macht im I7. Jahrhundert verantwortlich, er würdigte jedoch auch die Gegenreformation, insofern sie „deutsche Kulturgüter geschaffen“ habe ${ }^{99}$. Hantsch sah in der Gegenreformation ausdrücklich keine nationale, sondern eine staatliche und politische Tat, an der er aus ethischer Sicht so manche übertriebene Grausamkeit missbilligte ${ }^{100}$.

Friedrich der Große war für Srbik aufgrund seiner aufklärerisch-rationalistischen Denkweise und seiner französischen Sprechweise kein echter Deutscher. Durch den Raub Schlesiens habe er die Habsburgermonarchie „entdeutscht“. Für sein „heldisches“, zukunftsweisendes Verhalten im Siebenjährigen Krieg wurde er wiederum als vorbildlich hingestellt ${ }^{101}$. Hantsch dagegen fokussierte vor allem den „Mangel jeder formalen Rechtsgrundlage“ für Friedrichs Attacke. Nie „hätte ein Reichsfürst sich über das Reichsrecht mit Gewalt in den Besitz eines Mitstandes setzen“ dürfen ${ }^{102}$. Für Srbik beging Kaiser Franz II. I 804 durch die Erklärung des Kaisertums Österreich eine Usurpation ${ }^{103}$, für Hantsch übertrug er berechtigterweise aufgrund der immerwährenden treuen Verteidigung der Christenheit durch seine Dynastie die Reichsidee, die die anderen Stände in ihrer Selbstsucht längst verraten hätten, auf das Kaisertum Österreich ${ }^{104}$. Srbik wollte „mit Fug“ die reindeutschen Länder der Habsburgermonarchie in staatsrechtlicher, die übrigen habsburgischen Länder in völkerrechtlicher Verbindung mit dem neuen Deutschland sehen. Er legte so ein klares Bekenntnis zur Anschlussidee ab, die im Widerspruch zur Pragmatischen Sanktion, nicht aber zur Landesherrschaft der Habsburger an sich steht ${ }^{105}$. Zum partikularistischen Verräter an der deutschen Einheit wurde für ihn Felix zu Schwarzenberg ${ }^{106}$. Für Hantsch hingegen lebte die alte übernationale Reichsidee im österreichischen Kaiserstaat als legitimem Nachfolger des Heiligen Römischen Reiches Deutscher Nation weiter ${ }^{107}$. Dies war gleichbedeutend

97 Ebd. 43.

98 Hantsch, Entwicklung (wie Anm. 95) 34-36.

99 Srвiк, Deutsche Einheit (wie Anm. 96) 52.

100 Hantsch, Entwicklung (wie Anm. 95) 59.

101 S R BIK, Deutsche Einheit (wie Anm. 96) 99-106.

102 Hantsch, Entwicklung (wie Anm. 95) 99.

103 SR BIK, Deutsche Einheit (wie Anm. 96) 161-163.

104 HantsCH, Entwicklung (wie Anm. 95) $146 f$.

105 SR BIK, Deutsche Einheit (wie Anm. 96) 382. Ebd. spricht sich Srbik für die „großdeutsche“ Lösung im Sinne Vinckes und gegen die „großösterreichische“ im Sinne Mühlfelds aus.

106 Ebd. 397f.

107 Hantsch, Entwicklung (wie Anm. 95) 152. 
mit einer Absage an einen modernen, geschlossenen deutschen Nationalstaat, in dem letztlich auch Srbik den berechtigten Vollender des machtvollen Kaisertums mittelalterlichen Ursprunges sah, das er freilich auf irgendeine Art und Weise mit der Beibehaltung der habsburgischen Landesherrschaft kombinieren wollte.

Zur Interpretation der Reichsidee lässt sich zusammenfassend feststellen, dass Srbik den Habsburgern Beifall zollte, sofern sie ihrer gesamtdeutschen Aufgabe gerecht wurden. Diese hätte einerseits in der Verfolgung der „deutschen Einheit“ bestanden, andererseits aber in Anknüpfung an die imperiale und koloniale „Mission“ des deutschen Hochmittelalters in Mittel- und Osteuropa. Die religiöse Legitimierung schadete nicht, soweit sie ihnen dabei nicht im Wege stand. Verzettelten sie sich in außerdeutsche Missionen und eigendynastische Interessen, so trugen sie ebenso am Reichszerfall Schuld wie etwa der „Partikularismus“ der protestantischen deutschen Reichsfürsten. Nach I 804 hätten sie sich die Reichsidee widerrechtlich angeeignet. Srbik betonte dabei in der Tradition seines Vorbildes Ranke, dass ein Historiker alles in seinem historischen Zusammenhang $\mathrm{zu}$ verstehen habe und keine unmittelbaren Werturteile fällen dürfe ${ }^{108}$. Letzten Endes waren jedoch „deutsch“ oder „undeutsch“ seine eigenen, allem anderen übergeordneten Kriterien der Weltanschauung.

Hantsch dagegen sah die Reichsidee unmittelbar im göttlichen Recht begründet, als ethisch verstandenen Auftrag zur Herstellung und Verteidigung der christlichen Rechtsordnung. Indem die Habsburger ihre ererbte Verpflichtung, Schirmherr der Christenheit zu sein, immer wahrgenommen hätten, hätten sie auch gleichzeitig zwangsläufig ihrer deutschen Herkunft alle Ehre gemacht und gesamtdeutsche Interessen vertreten. Für Hantsch konnte zwischen diesen und jenen der übernationalen europäischen Völker- und Rechtsgemeinschaft kein Widerspruch bestehen. Der österreichische Staatsgedanke sei der legitime Nachfolger des alten übernationalen Reichsgedankens, damit werde, wie aus seiner Argumentation hervorgeht, das Problem der Rolle Österreichs in einem neu geordneten Deutschland letztlich zu einem Sekundärproblem.

Ideengeschichtlich sympathisierte Srbik mit einer spezifisch deutschen, katholischen Tradition, in der protestantische und neukantianische Elemente sich mengten und die erkenntnistheoretisch Platon vor Aristoteles den Vorzug gab (Tübinger Schule) ${ }^{109}$. Neuscholastik und „Ultramontanismus“ wurden abgelehnt. Moralisch im Sinn Srbiks war es, dass ein Staatsbürger sich nicht gegen die Staatsgewalt auflehnte, andererseits verlangte die völkische deutsche Nationalstaatsidee gebieterisch nach dem ethnisch reinen Groß-

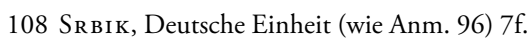

109 Heinrich Ritter von SR вік, Geist und Geschichte vom deutschen Humanismus bis zur Gegenwart 2 (München/Salzburg 1950) 62-64. Srbik würdigt Hermann von Grauert und den Theologen und Kirchenhistoriker Sebastian Merkle, kontrastiert die beiden anschließend mit Ludwig von Pastor. 
deutschland und stellte so den loyalen österreichischen Staatsdiener vor einen Gewissenskonflikt. Hantsch dagegen befand sich durchaus auf dem Boden der thomistischen Lehrer der Neuscholastik, die in ihrer radikalen Form die Reichsidee als Idee eines Reiches Gottes auf Erden interpretierten ${ }^{110}$. Moralisch sei es, kirchlich fundamentierte Prinzipien so weit wie möglich in Politik umzusetzen.

Zusammenfassend kann man als vorläufige Hypothese formulieren, dass Hantsch sich zwar anlässlich seiner Habilitierung zu Srbiks „gesamtdeutscher Geschichtsauffassung“ bekannt, sie aber offensichtlich nie, auch nicht in österreichischer Nuancierung, geteilt hat. Deshalb verwahrte sich Hantsch nach dem Zweiten Weltkrieg dagegen, Großdeutscher gewesen zu sein, und nannte sich selbst einen Großösterreicher ${ }^{111}$. Bekannte sich

110 So in Österreich vor allem Joseph Eberle und Richard Kralik. Dieter Breuning, Die Vision des Reichs. Deutscher Katholizismus zwischen Demokratie und Diktatur 1929-1934 (München 1969) 25-38. Die katholische Politik auf metaphysischen Grundlagen wurde vom Mainstream des Hierarchie und Dogma verpflichteten Denkens des politischen Katholizismus in Österreich und der Weimarer Republik vertreten. Abweichler gab es nur nach ganz rechts (Srbik, Alfred Böhm, Othmar Spann), sowie später nach links (Ernst Karl Winter, Alfred Missong u.a.). Gemeinsam war dem dogmatisch gebundenen Katholizismus auch das Festhalten an der Reichsidee in ihrer naturrechtlichen Grundlage. Umstritten war jedoch, wie weit religiös fundamentierte Rechtsvorstellungen in die Politik eingreifen sollten. Die vom jesuitischen „Probabilismus“ geprägten Sozialpolitiker, die in der kirchlichen Hierarchie sowie in der Christlich-Sozialen Partei dominierten, traten dafür ein, mit der herrschenden Staatsform bis zu einem gewissen Grad einen „Modus vivendi“ einzugehen. $\mathrm{Zu}$ akzeptieren sei jede nichttotalitäre Staatsform. Das Reich Gottes sei nicht auf Erden vorzufinden, Staat und Gesellschaft seien voneinander zu trennen. Mit dieser pragmatischen Grundlinie rechtfertigte Ignaz Seipel sowohl den „Vernunftrepublikanismus“ der 1920er-Jahre als auch die umstrittene Kritik an der „Parteienherrschaft als Scheindemokratie“ in seiner Spätzeit, verzichtete aber dabei keineswegs auf die Umsetzung katholischer Glaubensinhalte in die Politik, soweit dies realisierbar erschien. Unter diesen Voraussetzungen bedeutete das Bekenntnis zur Reichsidee etwa auch führender deutscher Zentrumspolitiker kein antirepublikanisches Programm, sondern eher ein allgemein gehaltenes Bekenntnis zu „christlich-abendländischer“ Politik, vgl. ebd. 151-154.

111 Großdeutschtum und Großösterreichertum „fein säuberlich zu trennen“ ist zwar, auch aufgrund der juristisch vielfach unklaren Übergänge zwischen Staatsrecht und Völkerrecht, Bundesstaat und Staatenbund, extrem schwierig. Doch erfolgte die Abgrenzung vom modernen Nationalstaat gerade auch durch die habsburgische Dynastie in ihrem Sendungsbewusstsein unter Berufung auf eine „sakrale“ Lesart von Reichsidee und Reichsgeschichte. Vgl. auch Helmut Rum PLer, Österreichs Zeitgeschichte: deutsche Kontinuität?, in: Kontroversen um Österreichs Zeitgeschichte. Verdrängte Vergangenheit, Österreichs Identität, Waldheim und die Historiker, hg. v. Gerhard Вотz (Studien zur historischen Sozialwissenschaft 8, erweiterte Neuauflage, Frankfurt/M. 2008) 354-365, hier 356f. Der Begriff „großösterreichisch“ ist indes keineswegs mit dem Deutschzentralismus des Neoabsolutismus gleichzusetzen, sondern stammte vielmehr aus dem Vormärz und wurde auch in einer „föderalistischen“ Version verfochten. Alexander Freiherr von Helfert sprach auch von einer „großösterreichischen“ Nation, die mehrere Volksstämme, darunter auch den „deutschen“, umfasse. Vgl. Gerald Stourzh, Der Umfang der österreichischen Geschichte, in: Probleme der Geschichte Österreichs und ihrer Darstellung, hg. v. Herwig Wolfram, Walter Ронц (Veröff. der Kommission für die Geschichte Österreichs 18, Wien I99I) 3-27, hier 8. 
aber nicht Hantsch wie Srbik zu einem „Gesamtdeutschtum“, und hob er nicht wie dieser die Leistungen der Habsburger für das „gesamte Deutschtum“ hervor?

Bei einer frappierenden Ähnlichkeit des Vokabulars ergeben sich doch unterschiedliche interpretative Kontexte. So schrieb Hantsch über die Entscheidungsschlacht am Kahlenberg I683: „Es war ein christlich abendländisches und vor allem deutsches Ereignis. Aus allen deutschen Gauen strömten Kontingente und freiwillige Kämpfer herbei."112 Hantsch sah hier einen seltenen Erfolg des Kaisers in seiner tradierten Rolle als Schirmherr des Alten Reiches, dessen Appell für ein letztes Aufflammen des christlich-abendländischen Gemeinschaftsgefühls gesorgt habe, das gleichzeitig auch ein gesamtdeutsches gewesen sei. Im Übrigen war die vorwiegende Zusammensetzung des Reichsheeres aus Kaiserlichen und Reichskontingenten eine Tatsache. Srbik schrieb dagegen, „Männer aller deutschen Stämme, Katholiken und Protestanten [...] kämpften unter der Lehens- und Blutfahne des deutschen Königs“; und später: „[...] wenn die Preußen auch nicht dabei waren, so doch später in Ofen"113. Die Überwindung des konfessionellen Konfliktes als Aufbau eines österreichisch-preußischen Einverständnisses, das machtpolitisch eine unvermeidliche Vorstufe der „deutschen Einheit“ war - dieser wichtige zusätzliche Gedankenansatz unterscheidet Srbik und Hantsch selbst bei einer sonst so scheinbar täuschenden Ähnlichkeit der Begrifflichkeit. Der Hinweis auf das "gesamte Deutschtum“ findet sich innerhalb der damaligen Geschichtswissenschaft eben nicht nur bei Srbik und Steinacker, sondern taucht etwa auch bei Dengel auf, der im Rahmen der Kontroverse um Raimund Friedrich Kaindls Ansichten in polemischer Frontstellung gegen Srbik unter anderem eine "gesamtchristliche“ als „gesamtdeutsche" Geschichtsauffassung forderte ${ }^{114}$. Die Ähnlichkeit ist hier ausschließlich eine des Vokabulars!

In der HZ kritisierte Hans Haußherr 1937 einige Fehler in Hantschs Buch und meinte, derartige Schlampereien würden das Urteil „in die Zuverlässigkeit des Verfassers“ doch „bedenklich erschüttern“115. Man müsse sich aber vor Augen halten, dass Hantsch Pionierarbeit zu leisten gehabt habe. „Es gibt noch keine bedeutende Geschichte des Habsburgerstaates“(!). Dann aber rühmte Haußherr die im Ganzen doch ohne weitere gröbere Schnitzer erfolgte Arbeit des österreichischen Gelehrten, deren Vorzüge sich vor allem bei der Schilderung des Zeitalters Josefs I. und Karls VI. erwiesen hätten. Insgesamt aber meinte der deutsche Historiker, es sei beklagenswert, dass österreichische und

112 Hantsch, Entwicklung (wie Anm. 95) 75.

113 SR BIK, Deutsche Einheit (wie Anm. 96) 72.

114 Martin Fritz Knorr, Raimund Friedrich Kaindl und die Wiener Schule (Diplomarbeit Wien 1998) 97101; Alexander Pinwinkler, Raimund Friedrich Kaindl (1866-1930). Geschichte und Volkskunde im Spannungsfeld zwischen Wissenschaft und Politik, in: Österreichische Historiker (wie Anm. 33) 125-154, hier 140-146.

115 Hans Haussherr, Rezension von: Hantsch, Entwicklung (wie Anm. 97), in: HZ 155 (1937) 592-594. 
preußische Sichtweisen trotz Srbiks „mutigen“ Vorstößen noch immer so weit auseinanderklafften, stufte dieses Buch also als eine von Srbik durchaus unabhängige Arbeit ein ${ }^{116}$. Dagegen verfasste Wilhelm Schüssler, ein alter Freund Srbiks und Verfechter der „Gesamtdeutschen Geschichtsauffassung“, I935 eine zustimmende Kritik und lobte das „glänzende Werk“, welches meisterhaft das „Herauswachsen des österreichischen Staatsgedankens aus dem deutschen Reichsgedanken“ behandle ${ }^{117}$. Die eher allgemein gehaltene Rezension zeigt aber eine Zäsur nicht der Grundeinstellung, sondern der öffentlichen Wahrnehmung und auch der Selbstpräsentation des Historikers Hantsch. Bis dato wurde er, wiewohl durchaus eigenes Gedankengut vertretend, doch vor allem als „SrbikMann" betrachtet und dementsprechend behandelt. Er tat auch nichts, um diesem Urteil entgegenzutreten, sondern genoss die Gunst der Verbindungen seines Mentors. Von nun an aber hisste Hantsch die eigene Flagge und segelte gegen sich stetig verstärkenden Gegenwind an.

VI. EINE GESCHICHTE ÖSTERREICHS, TEIL I

Hantsch erarbeitete während einer umfangreichen universitären und außeruniversitären Tätigkeit in Graz ab 1935 den ersten Band seiner Geschichte Österreichs, der einen gewaltigen Bogen von den Spuren der Veneto-Illyrer in Österreich bis zu Wallensteins Ende in Eger schlägt. Sein I 937 erschienenes Werk grenzt sich von den älteren, eher handbuchartigen Gesamtdarstellungen durch den essayistischen Stil und die vielen dezidierten Stellungnahmen ab. Das Buch war aber nicht nur unter den Gesamtdarstellungen der Geschichte Österreichs ein Novum, sondern auch singulär in Hantschs eigenem, umfangreichen CEuvre. Denn Hantsch vernachlässigte gezwungenermaßen sein Lieblingsthema, die „Reichsidee als Menschheitsidee“. Gezwungenermaßen, da ja die österreichischen Herrscher des Mittelalters über weite Strecken nicht die römisch-deutsche Kaiser- oder Königskrone trugen. Weiters aber trachtete er danach, nicht nur die moralische Existenzberechtigung, sondern auch die Lebensfähigkeit und frühe Selbstständigkeit der politischen Herrschaftsbildung im Donauraum gegenüber dem Reich aufgrund erfolgreicher Hausmachtpolitik herauszustreichen. Hantsch stellte sich hier eindeutig auf die Seite der Autoren der „Österreichischen Aktion“ wie Ernst Karl Winter, die die machtpolitische Eigenständigkeit Österreichs im Mittelalter als Vorläufer des

\section{Ebd.}

117 Wilhelm Schüssler, Rezension von: Hantsch, Entwicklung (wie Anm. 95), in: Historische Vierteljahrsschrift 29 (1935) $815 f$. 
späteren Kleinstaates zu beweisen versuchten ${ }^{118}$. Gewisse Parallelen gibt es auch zur preuBisch-kleindeutschen Historiografie in der Tradition Heinrich von Sybels, die ebenfalls eine frühe Selbstständigkeit Österreichs und damit eine frühe Scheidung der deutschen von der österreichischen Staatsbildungsgeschichte beweisen wollte ${ }^{119}$. Hauptgegner des Hantsch-Werkes war der ideologische Mainstream seiner damaligen österreichischen Fachkollegen, die, deutschnational und mit dem Nationalsozialismus liebäugelnd, die mittelalterliche Schicksalsverbundenheit der „Ostmark“ mit dem „gesamten Deutschland“ sowie die Angewiesenheit der „Deutschen des Donauraumes“ auf Hilfe aus dem Reich hervorhoben. Dabei betonten die "Gesamtdeutschen“, sich in die „ghibellinische“ Tradition Julius von Fickers stellend, die Machtfülle des mittelalterlichen Kaisertums von den Karolingern bis zu den Staufern. Es ist an dieser Stelle sinnvoll, auf den 1936 erschienenen Sammelband „Österreich - Erbe und Sendung im Deutschen Raum“ hinzuweisen, der ganz der Würdigung der „gesamtdeutschen Geschichtsauffassung“ dienen sollte und in dem vor allem Hirsch und Otto Brunner die vorherrschende Richtung der damaligen österreichischen Mediävistik vertraten; ein Beitrag Hantschs fehlte. Aufschlussreich ist der Vergleich der Beiträge Hirschs, Brunners und auch Steinackers mit dem 1937 erschienenen Werk Hantschs.

In Hantschs Darstellung nützten hervorragende österreichische Herrschergestalten des Mittelalters die naturräumlich günstigen Gegebenheiten zur frühen und selbstständigen Herrschaftsbildung im „Donauraum“120, während Brunner seinen Zweifel anmeldete, ob eine solche Gelegenheit für die Babenberger und Habsburger überhaupt bestanden hätte ${ }^{121}$. Vielmehr seien die Flachländer im ostösterreichischen Donauraum schutzlos der

118 Auch die Mitglieder der wohl von Winter gegründeten „Österreichischen Aktion“ wären hier durchaus als ursprünglich „großösterreichische Verfechter der Reichsidee“ anzusprechen. Für sie entbehrt das „Reich“ jedoch ethischer, naturrechtlicher Grundlagen, wie sie Hantsch dem Alten Reich zuschreibt, deren legitime Nachfolge die Habsburgermonarchie angetreten habe, und ist ausschließlich an Staatsbildungsversuche im Donauraum geknüpft. Vgl. Robert Holzbaue R, Ernst Karl Winter. Materialien zu seiner Biografie und zum konservativ-katholischen Denken in Österreich 1918-1938 (phil. Diss., Wien 1992) 107-111.

119 Hantsch, Geschichte Österreichs 1 (Innsbruck 1937) 379f. Literaturkritik und Polemik des Verfassers befinden sich im Anhang.

120 Ebd. 36-54.

121 Brunner kritisiert die Donauraum-Ideologie Robert Siegers, sofern sie historisch ausholt und sich nicht nur auf die Situation während des Ersten Weltkrieges beschränkt. Vgl. Robert Si EgER, Der österreichische Staatsgedanke und seine geographischen Grundlagen (Österreichische Bücherei 9, Wien/Leipzig 1918) 14-36 (der „Österreichische Staatsgedanke und seine Fassungen“) und 54-72 (die „naturräumlichen Grundlagen“ desselben); Otto Brunner, Österreich, das Reich und der Osten im späteren Mittelalter, in: Österreich. Sendung und Erbe im deutschen Raum, hg. v. Josef NADLER, Heinrich von SR BiK, Rudolf EGgER (Salzburg 1936) 61-86, hier 61. Sieger argumentierte, im „Donauraum“ sei es schon früh zu einer Großmachtbildung gekommen, die nur in engster machtpolitischer Verbindung mit dem „deutschen Mutterlande“ möglich gewesen war. Wenn sich Brunner nun gegen Siegers Donauraumidee wendet, so vor allem 
„Gefahr“ durch osteuropäische Steppenvölker ausgesetzt gewesen, die Gebiete nördlich der Donau hätten viel eher die Böhmen zur absichernden Expansion in den Süden eingeladen ${ }^{122}$. Lediglich in den zur Siedlung grundsätzlich schlecht geeigneten westösterreichischen Alpengebieten hätten sich einige östliche Ausläufer des Bajuwarentums durch das Frühmittelalter halten können, erst die Ostexpansion Karls des Großen habe die Möglichkeit zur bayerischen Ostmarkbildung gegeben ${ }^{123}$. Hantsch betonte dagegen die überwiegend friedliche Siedlung der Bayern im Frühmittelalter und ihre im Wesentlichen gewaltfreie Durchmischung mit den Slawen ${ }^{124}$.

Für Hirsch war die Wiedererrichtung und Beibehaltung der karolingischen „Ostmark“ eine der großen Leistungen der ottonischen Ostpolitik ${ }^{125}$. Hantsch kritisierte dagegen trotz seiner grundsätzlichen Würdigung der Leistung der Sachsendynastie, die Ottonen hätten die Chancen, die ihrer Politik nach der Schlacht am Lechfeld geboten worden wären, nicht ausgenützt und die Babenberger letztlich doch mit der Aufgabe der Grenzsicherung allein gelassen ${ }^{126}$. Brunner relativierte die Selbstständigkeit der Babenberger als reichshistorischen Sonderfall mit dem Hinweis auf seine Theorie, nach der die alteuropäische Herrschaft als dezentralisierter Personenverband aufzufassen sei ${ }^{127}$.

Hirsch bedauerte die „versäumte Möglichkeit“ babenbergisch-staufischer Verbundenheit während der Auseinandersetzung Konrads III. und Friedrich Barbarossas mit den Welfen. Die Eheschließung des Babenbergerherzogs Heinrich II. Jasomirgott mit der Tochter Kaiser Lothars III. und Witwe Heinrichs des Stolzen, Gertrud, hätte zu einer „Vereinigung des Kolonialgebietes mit dem bairischen Mutterland“ führen und somit also die „leidvolle Zerrissenheit des bairischen Stammes“, also das Privilegium minus, verhindern können ${ }^{128}$. Dies bestritt Hantsch. Auch für ihn war die Vorgeschichte des Privilegium minus gewissermaßen eine versäumte Gelegenheit, aber in anderer Hinsicht. Heinrich Jasomirgott, von Haus aus „keine kriegerische Natur“, habe sich vom Kaiser widerrechtlich entwenden lassen, was ihm bereits gehört hatte, Bayern also, und somit gegenüber Barbarossa und dem Reich eine übertrieben gutmütige und konziliante Hal-

auch deshalb, weil ihm eine „Staatsbildung“ im Mittelalter bzw. in der Frühen Neuzeit nicht in sein Konzept eines alteuropäischen Personenverbandstaates passt.

122 Ebd. 62-64.

123 Ebd. 63f.

124 Hantsch, Geschichte (wie Anm. 119) 26-28.

125 Hans Hirsch, Deutsches Königtum und römisches Kaisertum, in: Österreich. Sendung und Erbe (wie Anm. 121) 43-60, hier 46f. Zu Hirsch siehe Andreas ZAJIC, Hans Hirsch (1878-1940). Historiker und Wissenschaftsorganisator zwischen Urkunden- und Volkstumsforschung, in: Österreichische Historiker (wie Anm. 33) $307-417$.

126 Hantsch, Geschichte (wie Anm. 119) $34 f$.

127 Brunner, Österreich (wie Anm. 121) 65f.

128 Hirsch, Deutsches Königtum (wie Anm. 125) 54. 
tung eingenommen ${ }^{129}$. Scheint da etwas von dem „übertriebenen Edelmut“ durch, den Hantsch später so manchem Habsburgerherrscher zuschreibt? Die Echtheit des Privilegium minus sah Hantsch mit seinem Freund Konrad Josef Heilig und etlichen Historikern der kleindeutschen Tradition übrigens als erwiesen ${ }^{2}{ }^{130}$. Er stellte sich dabei in einer langen und heftigen Debatte gegen eine lange Reihe österreichischer deutschnationaler Historiker, unter anderem gegen Wilhelm Erben und Steinacker ${ }^{131}$.

Der Niederlage Přemysl Ottokars II. I 278 bei Dürnkrut wurde von Steinacker so manche Träne nachgeweint. Dem böhmischen König wäre es im Falle eines Sieges gelungen, Böhmen dem Deutschtum zu bewahren, so der protestantische Historiker mit antihabsburgischer Zielrichtung ${ }^{132}$. Hier zerbricht die Einheitsphalanx deutschnationaler Geschichtswissenschaftler. Hirsch meinte, Böhmen wäre um diese Zeit schon zu slawisch gewesen $^{133}$, Srbik argumentierte anderen Ortes, gerade das Entstehen eines mächtigen böhmisch-deutschen Großstaates, auch Österreich umfassend, hätte womöglich zu viele Deutsche dem Mutterland entfremdet ${ }^{134}$. Hantsch dagegen unterstrich die reichsrechtliche Verankerung der Aktionen des Habsburgerherrschers. Für ihn war die Entscheidung von 1278 keineswegs nur die „Wiedererrichtung des Reiches in seinen verlorengegangenen Grenzen“, auch nicht nur die Restaurierung einer „neuen einheitlichen deutschen Südostmark“, sondern die „Rettung der Eigenart und der freien Entwicklungsmöglichkeit des doch in der Hauptsache auf sich selbst gestellten deutschen Landes “135. Darüber hinaus habe der erste Habsburger auf dem römisch-deutschen Königsthron energisch versucht, eine eigene Hausmacht im Donauraum mit „harter Hand“ zu schaffen ${ }^{136}$. Brunner schrieb auch, Herzog Rudolf IV. habe sich, um Tirol zu retten, freiwillig zum Juniorpartner der Luxemburger gemacht. Er bestritt jede auf den Donauraum gerichtete Erbabsicht als Hintergedanken des Erbvertrages zwischen Karl IV. und Rudolf IV. Vor allem die albertinische Linie der Habsburger hätten sich dann fast in eine Seitenlinie der Luxemburger umgewandelt, während die Leopoldiner danach getrachtet hätten, den Erbbesitz nach Westen auszudehnen ${ }^{137}$. Erst der Untergang des mächtigen Luxemburgerreiches in Böhmen durch die Hussitenherrschaft habe den Habsburgern Tür und Tor geöffnet -

129 Hantsch, Geschichte (wie Anm. 119) 59.

130 Ebd. 61. Zu Heilig siehe den Beitrag von Helmut Maurer in diesem Band.

131 Ebd. 388.

132 Harold St einacker, Geschichtliche Voraussetzungen des österreichischen Nationalitätenproblems, in: Das Nationalitätenrecht des alten Österreich, hg. v. Gottfried-Karl Hugelmann (Wien 1934) 12.

133 Hirsch, Deutsches Königtum (wie Anm. 124) 56.

134 Heinrich Ritter von SR BIK, Österreich in der deutschen Geschichte (München 1936) 18.

135 Hantsch, Geschichte (wie Anm. 119) 105.

136 Ebd. 106.

137 Brunner, Österreich (wie Anm. 121) 70-72. 
die Habsburger wären also Profiteure eines frühen slawischen Prestigeerfolges gegen das Deutschtum gewesen ${ }^{138}$. Für Hantsch war der eigenwillige und selbstständige Nachfolger Herzog Albrechts II. nicht nur bereits darauf bedacht, den ungeliebten Oheim im Donauraum zu beerben; Rudolf IV. habe das Privilegium maius aufgrund einer nicht unberechtigten Kompensationsbestrebung gefälscht, da die Habsburger von Rechts wegen unter die Kurfürsten hätten aufgenommen werden müssen ${ }^{139}$. In dieser Gegenüberstellung wird die Front Hantschs gegen fast die gesamte „crême de la crême“ der damaligen österreichischen Geschichtswissenschaft offenbar. Darüber hinaus zeigen sich auch in der der Ehrung der „gesamtdeutschen Geschichtsauffassung“ Srbiks gewidmeten Sammlung zwei Spielarten des österreichischen Deutschnationalismus: die Brunners, der die Grundlagen habsburgischer Landesherrschaft angriff, ja beinahe ironisierte, und jene des amtierenden Direktors des IÖG Hirsch, der, ähnlich wie sein Weggefährte Srbik, ungleich vorsichtiger argumentierte.

In einem Gutachten nahm die Philosophische Fakultät der Universität Graz I938 knapp vor dem Anschluss zur geplanten Vergabe des Ordinariates an Hantsch Stellung und unterzog zu diesem Zwecke dessen „Österreichische Geschichte“ einer ausführlichen Kritik. Das Gutachten bemängelte, dass Hantschs Polemik gegen Erben und Steinacker in der Frage des Privilegium minus zu sehr durch Gegenwartsbedingungen bestimmt sei. Es kritisierte mehrmals die zu habsburgfreundliche Darstellung, etwa im Falle der spätmittelalterlichen Schweizerkriege ${ }^{140}$.

Zustimmend wurde aber Hantschs Satz zitiert: [...] der politische Großraum des Südostens konnte und durfte sich nur von der Donau her entwickeln [...] er konnte sich nur innerhalb des Reiches ausbilden, wenn er der Größe und nicht der Erniedrigung des deutschen Volkes dienen sollte. Darin liegt die entscheidende Bedeutung der Eroberung Österreichs, der deutschen Alpenländer durch den deutschen König Rudolf von Habsburg ${ }^{141}$. Allerdings: Hier wird wieder die grundlegende Gemeinsamkeit sichtbar, die Hantsch doch mit den die habsburgische Landesherrschaft bejahenden deutschnationalen Historikern teilt. Die Eroberung des Donauraumes durch ein „deutsches“ Herrschergeschlecht „vom Reiche aus“ kann aus anderer Perspektive sehr wohl als „Pangermanismus“ erscheinen, schließlich wäre ja etwa auch ein jagiellonisches Großreich vorstellbar gewesen. Dass aber andererseits Hantschs Haltung gerade wegen seiner sudetendeutschen Abkunft aus NS-Perspektive als besonderes Skandalon, ja geradewegs als „Verrat“ erscheinen musste, beweist eine

138 Ebd. $72 f$.

139 Hantsch, Geschichte (wie Anm. 119) 131.

140 ÖStA, AdR, Beilagen PA Hugo Hantsch, Zl. 2687/38, Gutachten der Philosophischen Fakultät Graz anlässlich der Verleihung des Ordinariats an Hantsch vom 24.02.1938, verfasst von Ferdinand Bilger. 141 Ebd. 
I939 erschienene Rezension von Hantschs Werk in der HZ von Mathilde Uhlirz ${ }^{142}$. Mit deutlich merkbarer Genugtuung schrieb Uhlirz: „[... Z Ziel und Zweck dieser österreichischen Geschichte war, den historischen Beweis für das Daseinsrecht eines selbstständigen österreichischen Staates zu erbringen“. Inzwischen aber sei ein „heroisches Bekenntnis zu dem im Herzen des Volkes fest verankerten Gedanken einer Schicksalsgemeinschaft mit dem deutschen Mutterlande" erfolgt. Zu den einzelnen Argumenten Hantschs meinte Uhlirz ohne detaillierte Auseinandersetzung, man müsse bei der Lektüre des Werkes nur stets dessen eingedenk sein, dass der Autor die junge Generation im „Sinne des politischen Programms der Systemzeit" habe beeinflussen wollen. Nach einer Würdigung der „beträchtlichen Kenntnisse und Fähigkeiten“ des Verfassers schrieb Uhlirz noch, es sei bedauernswert, dass dieser sich weit von „dem Fühlen seines Volkes - er ist Sudetendeutscher - vor allem aber weit von dem Fühlen der Jugend, die er zur Pflege wahrer Wissenschaft hätte heranbilden sollen, entfernt hat" ${ }^{143}$.

\section{DIE HABSBURGERMONARCHIE - EIN POTENZIELLER \\ ÖSTERREICHISCHER „COMMONWEALTH“?}

In seinem Essay „Die österreichische Staatsidee als Reichsidee“ von I 935 würdigte Hantsch zunächst die Rolle der „Deutschen Österreichs“ bei der historischen Festigung des österreichischen Staates im I6., I7. und I8. Jahrhundert. Sie hätten eine Schutz- und Erzieherrolle für die anderen Völker der „Schicksalsgemeinschaft“ des Donauraumes gespielt und dabei die Rolle eines „Sauerteiges“ übernommen, der den Staat zusammengekittet und gehalten habe. Das Phänomen des Nationalismus aber habe die Donaumonarchie vor neue Herausforderungen gestellt. „Ab I 848 galt es Mannigfaltigkeiten und Vielheiten anzuerkennen und sie innerlich durch eine gemeinsame Zielsetzung, äußerlich aber durch die gemeinsame Krone zusammenzuschließen. " ${ }^{144}$ Die Reichsidee, vom Alten Reich auf die Habsburgermonarchie übergegangen, sollte dabei helfen, in Verwirklichung einer übernationalen, christlich inspirierten Rechtsordnung den Gedanken des Nationalstaates zu überwinden. Als den hauptsächlichen Hoffnungsträger dieses Gedankens bezeichnete Hantsch den Thronfolger Franz Ferdinand. Sein Programm eines „wiederhergestellten Reiches“ habe den „richtigen, wahrhaft fortschrittlichen Gedanken der Entwicklung von

142 Mathilde Uhlirz, Rezension von: Hantsch, Geschichte (wie Anm. 119), in: HZ 159 (1939) 370-372. Zu Uhlirz siehe Anne-Katrin Kunde, Mathilde Uhlirz (1881-1966). Jenseits der Zunft. Prozesse der Selbstbehauptung in Leben und Wissenschaft, in: Österreichische Historiker (wie Anm. 33) 461-491.

143 Ebd.

144 Hugo Hantsch, Österreichische Staatsidee und die Reichsidee, in: Österreichische Rundschau. Land Volk - Kultur (1934/35) 6-15. 
der Beherrschung zur Einigung, vom nationalen Machtimperialismus zur übernationalen Kulturgemeinschaft" enthalten. Zustimmend zitierte Hantsch den Satz aus dem vorbereiteten Manifest des Thronfolgers für den Tag seiner Thronbesteigung: „In brüderlicher Liebe sollen die Völker der Donaumonarchie, die historisch und geographisch zusammengehören, nur mehr um die Palme des wirtschaftlichen und kulturellen Fortschritts wetteifern. "145 Als hauptsächliches Hindernis für Franz Ferdinands Pläne machte Hantsch drei nationalistische Gruppierungen aus: die „Verfechter der magyarischen historischen Staatsidee“, die jungtschechische Bewegung, aber auch die „starken und in geschlossenen Siedlungen lebenden“ böhmischen Deutschen, also seine nationalistisch gesinnten Landsleute. Die politische Gleichberechtigung aller Völker wäre also die Krone eines gemäßigten Fortschritts gewesen, da nur eine langsame, evolutionäre Entwicklung wahrhaft von Dauer sein könne. An dieser Stelle fallen starke ideelle Querverbindungen zum Staatsdenken eines aufgeklärten britischen Konservativismus in der Burke-Tradition auf.

Politische Gleichberechtigung der Völker also, aber dennoch eine Art „Ehrenvorsitz“ der Deutschen! Hier zitierte Hantsch zustimmend Gottfried Wilhelm Leibniz: „Den Deutschen gebührt unter allen christlichen Nationen der Vorsitz wegen des Heiligen Römischen Reiches, dessen Würde und Rechte sie auf ihr Haupt gebracht, welchem die Beschirmung des wahren Glaubens, die Vogtei der allgemeinen Kirche und die Beförderung des Besten der ganzen Christenheit oblieget.“ Dieses „Trostpflaster“ verhieß der Essayist in seiner rückwärts gerichteten Utopie nun seinen deutschsprachigen Landsleuten in einem Staat, der im Sinne einer „Menschheitsidee“ mehr als nur ein Staat hätte sein sollen. Wieder machte sich Hantschs grundsätzliche Habsburg-Nostalgie deutlich bemerkbar.

\section{METTER NICH}

Besonders aufschlussreich für Hantschs Metternich-Bild ist sein Artikel „Metternich und Europa"146. Neben der fast euphorischen Bewunderung, die er offensichtlich für diesen Staatsmann empfand, wird ein Bild des Staatskanzlers deutlich, das Srbiks berühmter Biografie verpflichtet scheint - und ihr dennoch widerspricht. So schrieb auch Hantsch Metternich ein „System“ zu, auch er betonte, dass Metternich stark durch sein Erlebnis der Französischen Revolution geprägt worden sei ${ }^{147}$. Dass Hantsch genauso wie Srbik Metternich als konservativen Staatsmann rühmte, versteht sich von selbst. Allerdings

145 Ebd.

146 Hugo Hanтsсн, Metternich und Europa, in: Neue Jahrbücher für Wissenschaft und Jugendbildung 10 (1934) 328-338.

147 Ebd. 329-331. 
heißt es bei Hantsch: „Metternich [...] hielt sich für den Verfechter einer Weltordnung, deren Grundsätze in dem ewigen Sittengesetz und in der unveränderlichen Ordnung der Dinge verankert sind“, und dann weiter: „er geht von Ewigkeitswerten aus und besitzt daher inmitten des Lärmens von Tagesmeinungen jene über den Dingen waltende innere Ruhe, die alle Menschen zeigen, die ihren Weg von den ewigen Gesetzen geleitet wissen“. An dieser Stelle zeigt sich eine starke Bewunderung für gerade jenen Metternich, von dem Srbik nichts wissen wollte, einen Metternich, der danach trachtete, „das Gute “ für die Völker zu erkennen und zu tun ${ }^{148}$. Eine solche Tat hielt aber der Platoniker Srbik für menschenunmöglich. Es war hier eine Begeisterung Hantschs für jenes Gedankengut erkennbar, das vor allem Metternichs „Chefideologe“ und „Chefpolitologe“ Friedrich von Gentz verfochten hatte. Metternich habe nicht das Prinzip "gesellschaftlicher Erhaltung“ (Srbik), sondern das der kontinuierlichen Entwicklung verfolgt, da explosive und revolutionäre Situationen vermieden werden müssten ${ }^{149}$.

IX. DIE „OSTMARKMISSION“

Hantsch befürwortete den autoritären Kurs von Kanzler Engelbert Dollfuß, und so trägt dessen nach 1945 entstandenes Porträt auch apologetische Züge ${ }^{150}$. Ob der Historiker nun allerdings die diktatorische Staatsform als notwendiges Provisorium und das Bündnis mit Mussolini und dem Heimwehr-Faschismus als unvermeidliches kleineres Übel sah, ob er sich tatsächlich die weitgehende Umsetzung von sozial-harmonischen Botschaften der christlichen Soziallehre durch den Staat in die Gesellschaft erhoffte, oder ob er primär dem „Imitationsführerkult“ um den auf seine eigenen Anhänger charismatisch wirkenden Dollfuß erlag, geht aus seiner späteren Reflexion nicht eindeutig hervor. Nun aber traten vaterländische Positionen, die er auch in seiner Frühzeit schon vertrat, zusehends akzentuierter ans öffentliche Licht. Der Auftakt zu Hantschs publizistischer, vereinspolitischer und außeruniversitärer Tätigkeit unter dem Zeichen des Kruckenkreuzes war jedenfalls eng mit seiner universitären Karriere verbunden.

Im Sommer 1933 hielt Hantsch am Katholikentag in Salzburg eine Reihe von Vorträgen zur neuzeitlichen Geschichte Österreichs, die später unter dem Titel „Österreich. Eine Deutung seiner Geschichte und Kultur“ in Buchform erschienen ${ }^{151}$. Grundgedanken und

148 Ebd. 330.

149 Ebd. 334.

150 Hugo Hantsch, Engelbert Dollfuß, in : Gestalter der Geschicke Österreichs, hg. v. Dems. (Innsbruck 1962) 611-623.

151 Hugo Hantsch, Österreich. Eine Deutung seiner Geschichte und Kultur (Innsbruck 1934). 
Sichtweise sind mit Hantschs früheren Arbeiten übereinstimmend, doch fand dieser Katholikentag unter besonderen Umständen statt: Hitlers Tausendmarksperre hatte viele der deutschen Teilnehmer vom Kommen abgehalten, man befand sich am Höhepunkt des „kalten Krieges“ zwischen Hitler und Dollfuß. So war allein die Tatsache, dass der Katholikentag dann dennoch abgehalten wurde, eine vaterländische und antinationalsozialistische Kundgebung sowie eine Sympathieerklärung für den neuen Kurs des Bundeskanzlers. Zusätzlich zur an die Dynastie der Habsburger gekoppelten Reichsidee trat nun im Denken Hantschs die „Ostmarkmission des deutschen Österreichertums“ als eine besondere Sendung des „deutschen“ Bewohners des ständestaatlichen Österreichs ${ }^{152}$. Die Aufgabe, zugleich Bollwerk gegen den Osten und Brücke zu anderen Kulturen zu sein, habe zunächst Österreich früh eine singuläre Stellung im Reich verschafft und anschließend seinen Bewohnern eine spezifische, gleichzeitig „deutsche und abendländische“ Aufgabe verliehen ${ }^{153}$. Hier wurde eine Aktualisierung der "Österreichischen Sendung" des Dollfußregimes durch Rückgriff auf das Mittelalter geboten, wobei der ständestaatliche „Ostmarkgedanke“ nun als Ergänzung und Abrundung an die Seite der Reichsidee trat ${ }^{154}$.

\section{ABGRENZUNG VOM NATIONALSOZIALISMUS UND \\ VERDEUTLICHUNG VON HANTSCHS AUFFASSUNG VOM „GESAMTDEUTSCHTUM“}

Im Aufsatz „Das gesamtdeutsche Problem“ von 1936 übte Hantsch schließlich direkte Kritik am Nationalsozialismus und explizierte, welche Rolle für ihn das „Deutschtum“ der Österreicher zu spielen hatte. Zunächst würdigte er das „gesamtdeutsche Empfinden der I920er Jahre“ als eine „schöne Erinnerung“: „Die größte Stärke aber jener Zeit, soweit es sich um das gesamtdeutsche Schicksal handelte, war unbestreitbar der Wille zum gegenseitigen Verstehen der Eigenart des Anderen. “155 Hantsch gemahnte an das „unvergessliche“ Sängerfest von Wien im Jahr I928; damals hätte man gedacht, die Zwistigkeiten um die gesamtdeutsche Frage seien nur „akademischer“ Natur, der Kern der Frage sei

\section{Ebd. $54 f$.}

153 Ebd.

154 Zur nationalsozialistischen Ostmarkideologie vgl. Heinrich Busshoff, Das Dollfuß-Regime in Österreich (Beiträge zur Politischen Wissenschaft 6, Würzburg 1968) 19.

155 Hugo Hantsch, Das gesamtdeutsche Problem, in: Monatsschrift für Kultur und Politik 1 (1936) 497-505, hier 497. Zur politischen Konstellation der 1920er-Jahre in der Ersten Republik vgl. Walter WiLtscheGG, Österreich - „der Zweite Deutsche Staat“? Der nationale Gedanke in der Ersten Republik (Graz, ${ }^{2} 1992$ ) 121-128. Zur Rolle der Großdeutschen Volkspartei Robert Lu kan, Die Großdeutsche Volkspartei und ihr Einschwenken auf Seipels Sanierungspolitik (Diplomarbeit Wien 2001) 78-80. 
bereits gelöst ${ }^{156}$. Gelöst also - für Hantsch - trotz der staatlichen Trennung. Er zitierte in diesem Zusammenhang zustimmend Hermann Oncken: „Die Bande [...] die das ganze Auslandsdeutschtum umschlingen, gehören ausschließlich der geistig-kulturellen Sphäre an. Man würde das in sich schon genug komplizierte Problem nur verfälschen, wenn man ihm ein politisches Gesicht gäbe : nicht zuletzt die Auslandsdeutschen selber würden jeden derartigen Versuch ablehnen müssen. "157 Hier haben wir also eine klare Stellungnahme Hantschs aus der Zeit vor I945, mit der er beteuerte, dass sein Bekenntnis zum „Deutschtum“ stets nur „geistig-kultureller“ Art gewesen sei. Hantsch wies nicht nur jede Aufgabe der souveränen Staatlichkeit Österreichs zurück, er warnte auch davor, der „Staatsform in ihren geistigen Grundlagen die Basis einer gesamtdeutschen Haltung, eines gesamtdeutschen Ideals“ zu geben ${ }^{158}$. Denn der „geistige Unterbau“ des NS-Regimes würde „zwei Arten deutschen Denkens und deutschen Lebens abgrundtief voneinander trennen" 159 . „Auf dieser Ebene also kann es kein gesamtdeutsches Bewusstsein geben, es gibt also nicht einmal eine deutsche Kulturgemeinschaft. "160 In diesen Zeilen grenzte sich Hantsch nicht nur vom Nationalsozialismus ab, er warnte auch implizit vor den negativen Auswirkungen, die die offizielle Ideologie des Ständestaates als „zweiter deutscher Staat“ haben konnte. In welchen Bereichen aber konnte das „gemeinsame Volkstum“ dann dennoch erhalten bleiben? Hantsch wies auf vier Bereiche hin: „gemeinsame Sprache und Dichtung“, sofern Letztere „nichts mit Politik“ zu tun hätte, „gemeinsames religiöses Empfinden“, die „,echte Reichsidee“ als „Organisationsform deutschen und zugleich abendländischen Denkens und Lebens“ und schließlich „Volkstum“ als Zusammengehörigkeitsgefühl in einer „überstaatlichen, geistig-kulturellen Sphäre“161. Dennoch meinte Hantsch anschließend: „Wir bilden einen eigenen Staat, aber wir können niemals ein eigenes Volk bilden." Aber wenn

156 Hantsch, Problem (wie Anm. 155) 479.

157 Ebd. 498.

158 Ebd. 499.

159 Ebd.

160 Ebd.

161 Ebd. 499-505. Hantsch wurde aufgrund seines Bekenntnisses zum „deutschen Volkstum“ in die Nähe „biologistischen Denkens“ gerückt, vgl. TöLG, Ideologie (wie Anm. 1) 32. Ideen einer politischen „Überlegenheit des deutschen Volkes“ hat Hantsch nie vertreten. Der ihm so wichtige ethische Gehalt der Reichsidee soll vielmehr ein friedliches Zusammenleben aller mitteleuropäischen Völker ohne Bevorzugung eines anderen, wenn auch unter „deutschem Ehrenvorsitz“ herbeiführen, wobei die Deutschen eine historisch bedingte, zeitlich begrenzte zivilisatorisch-kulturvermittelnde „Erzieherrolle“ in Osteuropa nach dem Großen Türkenkrieg gespielt hätten. Freilich taucht auch bei Hantsch der Deutschtumsbegriff als in „gleichem Blut“ oder in „Blutsverwandtschaft“ begründet auf, doch dies nur selten im Vergleich zum Hinweis auf Sprache und Kultur und gemeinsame „Geistigkeit“. Als Pangermanismus könnte man allerdings, wie erwähnt, die Befürwortung der Landesherrschaft der „deutschen“ Habsburger sehen, mit anderen Worten, den lebenslangen habsburgischen Monarchismus Hantschs. 
Hantsch das „deutsche Volkstum“ der Österreicher dann nur „geistig-kulturell“ bedingt sah, warum, so könnte man einwenden, rang er sich dann nicht zu einem österreichischen Nationsbegriff durch? Es ist in diesem Zusammenhang interessant, dass Hantsch vor 1945 bezüglich der Zeit nach I 806 nie von einer Zugehörigkeit der deutschsprachigen Österreicher zu einer deutschen „Nation“, sondern stets von einem „deutschen Volkstum der Österreicher“ sprach. Einer der prominentesten Verfechter des österreichischen Nationsgedankens in der Zwischenkriegszeit, Ernst Karl Winter, betonte, dass nur „eine eigene österreichische Nation“ zum „Träger wahrer deutscher Kultur und Geistigkeit“ werden könne ${ }^{162}$. Die Auffassungsunterschiede scheinen hier vor allem in der naturrechtlichen Grundlage von Hantschs Denken zu liegen, während der Platoniker, Neukantianer und Schüler Hans Kelsens (sowie Othmar Spanns) Winter die Idee einer Staatsnation im positiven Recht verankerte ${ }^{163}$. Darüber hinaus könnte aber auch die deutschböhmische Herkunft Hantschs eine nach 1945 anhaltende oder noch verstärkte Abneigung gegen den Begriff einer Staatsnation im französischen Sinne hervorgerufen haben. Hantsch ist wegen seiner journalistischen und essayistischen Arbeiten von I933 bis 1938 als Gesinnungsverwandter eines Dietrich von Hildebrandt einzustufen, er gehörte zu einer Reihe von Autoren, die den ideologischen und politischen Kurs des „Austrofaschismus“ loyal mittrugen und unmissverständlich Kritik am Nationalsozialismus übten.

\section{AUSSERORDENTLICHER PROFESSOR IN GRAZ - EINE POLITISCHE ERNENNUNG}

Es war Unterrichtsminister Hans Pernter persönlich, der seinen Freund und CV-Bundesbruder Hantsch zur Besetzung der Grazer Lehrkanzel für Österreichische Geschichte nach der Emeritierung Anton Mells vorsah ${ }^{164}$. Die Nachbesetzung galt als dringlich, weil

162 Ernst Karl Winter, Die Naturrechtsmetaphysik, in: Ders, Bahnbrecher des Dialogs, hg. v. Ernst Florian Winter (Gesammelte Werke 1, Wien/Frankfurt/M./Zürich 1969) 35-75. Siehe auch etwa Winters „Deutsch sein heißt: hinfinden zu Marbod und Chlodwig und zur romanisch-germanischen Synthese, die sie verwirklichten!“ zitiert nach Holzbauer, Winter (wie Anm. i i 8) I Io. Chlodwig wird hier als germanischer Begründer einer französischen Staatsnation hymnisch gefeiert. Winters radikal antipreußische Ideologie, in kämpferischer Abwehr des NS-Gedankengutes formuliert, versuchte also ebenfalls, die „Österreicher als bessere Deutsche“, ja als „bessere Germanen“ zu präsentieren, deren „historische Mission“ es gewesen sei, eine österreichische Staatsnation zu schaffen. Historisch weit ausholend, war der katholische Privatgelehrte Winter bestrebt, eine etatistisch-deutschzentralistische Version der großösterreichischen Geschichtsbetrachtung zu entwickeln.

163 Ernst Karl Winter, Mein Verhältnis zur Arbeiterbewegung, in: Ders., Arbeiterschaft und Staat (Berichte zur Kultur und Zeitgeschichte 7, Wien 1934) 83-98, hier 89.

164 StA Melk, NL HH, K. 7/61, Schreiben Hantschs an Pernter, 13.10.1947. Gerüchten zufolge, die unter 
der Lehrstuhlinhaber auch eine Vorlesung für Hörer aller Fakultäten abhalten musste ${ }^{165}$. Nicht zuletzt deshalb schien es dem Schuschnigg-Regime besonders wichtig, diesen Lehrstuhl in verlässlichen Händen zu wissen. Dabei griff man auf den jungen Privatdozenten Hantsch zurück und setzte seine Ernennung durch - und das offensichtlich gegen den geballten Widerstand der Grazer Philosophischen Fakultät. Ursprünglich hatte die zuständige Kommission geplant, den Wiener Extraordinarius Brunner mit einem Ordinariat zu „ködern“, doch entschloss sich das BMU aus finanziellen Gründen, das ehemalige Ordinariat Mells in ein Extraordinariat umzuwandeln ${ }^{166}$.

Der durch den Tod Erbens verwaiste Grazer Lehrstuhl für Mediävistik wurde im Übrigen aus Geldmangel aufgelassen und Mittelalterliche Geschichte nur durch Lehraufträge unterrichtet. Über die Ernennung Brunners schrieb das BMU in einem internen Gutachten, die Grazer Fakultät sei selbst der Ansicht, dass Brunner wohl nie sein Wiener Extraordinariat gegen das in Graz eintauschen würde. Also schied der primo loco von der Kommission vorgeschlagene deutschnationale, protestantische Sozialhistoriker und spätere Nationalsozialist a priori aus ${ }^{167}$. Vieles spricht dafür, dass der logische Nachfolger Mells aus steirischer Sicht der secundo loco gereihte Landeshistoriker Hans Pirchegger war $^{168}$. Pirchegger, ein Schüler Kaindls, hatte in der Kontroverse um seinen Mentor diesem keine Hilfe geleistet. Das BMU lehnte Pirchegger jedoch ab, indem es auf sein „vorgerücktes Alter" von bereits 60 Jahren verwies ${ }^{169}$. Schon nach dem Tod Kaindls war er gegen den vaterländisch denkenden Mell gescheitert ${ }^{170}$. Pirchegger, der sich nach 1945 als „national und sozialistisch, aber nicht nationalsozialistisch“ bezeichnete, trat „relativ spät“ ( I940) der NSDAP bei ${ }^{171}$ und wurde während der NS-Herrschaft zum außerplanmäßigen Professor ernannt ${ }^{172}$. Eine ordentliche Professur erhielt der Bruder des früheren christlichsozialen Politikers und späteren ÖVP-Landeshauptmannes Anton Pirchegger nie ${ }^{173}$.

Historikern kursierten, hätte Kanzler Schuschnigg Hantsch sogar sofort zum Ordinarius ernennen wollen: [...] Schuschnigg soll beabsichtigen, den Wien Privatdozenten P. Dr. Hugo Hantsch O.S. B. als Ordinarius nach Graz zu bringen. So Ernst Klebel an Mell am 06.10.1934; NL Ernst Klebel (Privatbesitz Burkhard Klebel) (freundlicher Hinweis von Karel Hruza und Wolfram Ziegler).

165 ÖStA, AdR, Beilagen PA Hugo Hantsch, Zl. 24817 - I,1 Stellungnahme des BMU betreffend die neu zu besetzende Lehrkanzel für Österreichische Geschichte in Graz vom 21.08.1935.

166 Ebd.

167 Ebd.

168 Alois Kern bauer, Hans Pirchegger (1875-1973). „Der“ Landeshistoriker, in: Österreichische Historiker (wie Anm. 35) 225-246, hier 238.

169 ÖStA, Stellungnahme (wie Anm. 166).

170 Kernbauer, Pirchegger (wie Anm. 169) 238.

171 Ebd. 243-246.

172 Ebd. 237-240.

173 Ebd. 
Hantsch war tertio loco in den Dreiervorschlag der Kommission für die gleichfalls ausstehende Neubesetzung des Lehrstuhls für Neuere Geschichte aufgenommen worden, im Grazer Vorschlag für Österreichische Geschichte schien sein Name nicht auf, was das BMU bemängelte ${ }^{174}$. Die Kommission hatte den steirischen Privatdozenten Fritz Popelka für die Schlüsselprofessur in Österreichischer Geschichte tertio loco genannt, während das BMU Hantsch vielmehr für ganz besonders geeignet hielt und hervorhob, dieser sei zum sofortigen Dienstantritt bereit, weitere Erkundigungen über ihn seien unnötigit5.

Der Vorschlag des Professorenkollegiums für die Besetzung der außerordentlichen Professur für Neuere Geschichte lautete schließlich: primo loco Reinhold Lorenz, Wien (also ein „gesamtdeutscher" Srbik-Schüler und späterer Nationalsozialist), secundo loco Ferdinand Bilger, Graz ${ }^{176}$. Zu dem noch an dritter Stelle gereihten Hantsch teilte man seitens der Grazer Universität lakonisch mit: Zur Aufnahme des Privatdozenten Dr. Franz (!) Hantsch könne man sich bei Anerkennung seiner wissenschaftlichen Leistungen nicht entschließen ${ }^{177}$. Franz Hantsch - wohl kaum ein zufälliger „Tippfehler“! Der ehemalige Bundesleiter der Vaterländischen Front, nunmehrige Landeshauptmann von Steiermark und lebenslange enge Freund Hantschs, Karl Maria Stepan, teilte schließlich in einem Brief an das BMU mit, dass die Sicherheitsdirektion des Landes Steiermark gegen die Ernennung Ferdinand Bilgers keine besonderen politischen Bedenken habe ${ }^{178}$. Der ehemalige SrbikSchüler und Bewunderer Heinrich von Treitschkes und spätere Nationalsozialist Bilger ${ }^{179}$ kam also im Gegenzug zur Professur, wohl auch mangels vaterländischer Konkurrenz.

Alles spricht dafür, dass die Ernennung Hantschs gegen den Willen der Grazer Fakultät regelrecht „durchgekämpft“ wurde. Die Bestellung des Parteigängers des „Ständestaates“ in dieser hochbrisanten politischen Epoche fügte sich so in eine Reihe heiß umstrittener Professorenernennungen der Zeit der Doppelmonarchie, wobei besonders die des PastorSchülers Josef Hirn und Michael Mayrs zu nennen sind. Auch damals wurden zwei „Klerikale“ gegen den erbitterten Widerstand der zuständigen Fakultät von der Ministerialbürokratie als Professoren durchgesetzt ${ }^{180}$.

174 ÖStA, Stellungnahme (wie Anm. 166).

175 Ebd.

176 ÖStA, AdR, Beilagen PA Hugo Hantsch, Zl. 25129/35, Stellungnahme der philosophischen Fakultät der Universität Graz betreffend die Besetzung der Lehrkanzel für Neuere Geschichte, 16.07.1935.

177 Ebd.

178 ÖStA, (wie Anm. 177), Stellungnahme des Landeshauptmanns für Steiermark, 02.09.1935.

179 Maria Inzко, Ferdinand Bilger als akademischer Lehrer (phil. Diss. Graz 1977). Bilger als Schüler Srbiks 238, als Verehrer Treitschkes 118-120.

180 Gerhard Овек коғle , Die Geschichtlichen Fächer an der Universität Innsbruck, 1850-1945 (Forschungen zur Universitätsgeschichte 6, Veröff. der Universität Innsbruck 39, Innsbruck 1969). „Oktroyierte Ernennungen“ klerikaler Professoren gegen den deklarierten Willen der Fakultät: Pastor 87-97, Hirn 97-100, Mayr 101-104. 
Nach dem Zerfall der Doppelmonarchie sowie den Gebietsabtretungen im Osten, die die Weimarer Republik nach dem Vertrag von Versailles akzeptieren musste, waren zahlreiche Vereine in Österreich und Deutschland entstanden, die einerseits die unter „fremder Flagge" lebenden Volksdeutschen organisatorisch zu erfassen trachteten, andererseits um Unterstützung für die „volksdeutsche Sache“ in den Mutterländern warben ${ }^{181}$. Die Grundstimmung bei diesen Vereinen war revanchistisch. Nach der Machtergreifung Hitlers in Deutschland und dem Entstehen des „Ständestaates“ in Österreich versuchten die beiden Diktaturen die Volksdeutschen für ihre ideologischen Ziele zu gewinnen und nahmen sich der „volksdeutschen Arbeit“, die in demokratisch-republikanischer Zeit mehrheitlich privat organisiert worden war, offiziell an ${ }^{182}$. Der „Austrofaschismus“ hatte in dieser Frage gegen die überlegenen Mittel des „Dritten Reiches“, aber auch wegen der Sogkraft, die durch Hitlers Machtpolitik ausgeübt wurde, einen besonders schweren Stand. Der Hauptvertreter der volksdeutschen Arbeit in Österreich, der „Deutsche Schulverein Südmark“, schwamm alsbald auch im NS-Fahrwasser ${ }^{183}$. Nun entschloss sich Kanzler Dollfuß I934, eine vaterländische Arbeitsgemeinschaft ins Leben zu rufen, die das volksdeutsche Publikum für die ständestaatliche Ideologie gewinnen sollte ${ }^{184}$. Der Österreichische Verband für volksdeutsche Auslandsarbeit (ÖVVA) entstand. Der ehemalige Unterrichtsminister Emmerich Czermak wurde zunächst zu dessen Schlüsselfigur. Inzwischen aber hatte Hantschs Freund Stepan in seiner Funktion als Bundesleiter der Vaterländischen Front eine Arbeitsgemeinschaft für das Auslandsdeutschtum ins Leben gerufen, dessen ehrenamtliche Leitung Hantsch übernahm ${ }^{185}$. 1935 wurde Hantsch, um die entstandene Doppelgleisigkeit zu beenden, Mitglied des ÖVVA-Vorstandes und schließlich Verbandsobmann. Seine Tätigkeit äußerte sich nun vor allem in Vorträgen sowie in Artikeln für die Österreichische Korrespondenz für volksdeutsche Auslandsarbeit (ÖKVDA) ${ }^{186}$, aber auch in "Spähreisen“ zu Auslandsdeutschen, um Einblicke in ihre aktuelle Lage zu gewinnen. Hantschs Tätigkeit in diesem Bereich zeigt wie auch seine Verwendung in Graz, dass er aufgrund seiner sudetendeutschen Herkunft gerade dort vom „Austrofaschismus“ eingesetzt wurde, wo es um die Gewinnung eines besonders deutschnational gesinnten Publikums für den „vaterländischen Gedanken“ ging.

181 Tölg, Ideologie (wie Anm. 1) 48. Tölg hat diese politische Tätigkeit Hantschs ausführlich dargestellt.

182 Ebd. 48f.

183 Ebd. 49.

184 Ebd.

185 Ebd. 50.

186 Ebd. 
Dass Hantsch durch seine Vortragstätigkeit alsbald zur Zielscheibe nationalsozialistischer Störversuche wurde, zeigt ein Zwischenfall aus dem Jahr I936: Hantsch hielt an der Universität Graz am 4. Dezember den Vortrag „Österreich und das Auslandsdeutschtum“. Laut dem Bericht des Rektors Adolf Zauner sei der Vortrag, solange Hantsch ganz allgemein ohne jeden politischen Einschlag gesprochen hätte, ohne den geringsten Zwischenfall verlaufen. Alle Anwesenden hörten mit gespannter Aufmerksamkeit zu ${ }^{187}$. Als der Vortragende jedoch meinte, es sei bekannt, dass sich die Hoffnungen der Südtiroler auf Österreich richteten, kam es zu lauten Zwischenrufen und Tumulten. Nun sei, so der Bericht weiter, der Ruf Wem Südtirol am Herzen liegt, der gehe erschallt, woraufhin zirka Ioo-I20 Studierende den Hörsaal in voller Ruhe, wie Zauner betont, verlassen hätten. Die verbliebenen ungefähr Ioo Zuhörer hätten eine Kundgebung für Österreich und die Regierung Schuschnigg veranstaltet ${ }^{188}$. Dieser Vorfall schlug hohe Wogen. Der Rektor sprach den illegalen nationalsozialistischen Studenten seine Missbilligung aus. Er verband aber seine Stellungnahme mit der Warnung, es würden vor allem diese Studierenden geschädigt, gegen die bereits wegen früherer Verfehlungen ein bedingter Verweisungsbeschluss ausgesprochen worden war. Es schien also, als hätte Zauner weniger die Störhandlung an sich bekrittelt, als bereits mehrmals politisch „Aufgefallene“ vor den möglichen Konsequenzen ihrer agitatorischen Aktivität gewarnt und somit zu schützen versucht ${ }^{189}$. Am I 5 . Dezember fand schließlich eine vaterländische Gegenkundgebung statt, wobei Studierende in mehrere Grazer Gaststätten eindrangen und vaterländische Lieder sangen. Auch diesen Studenten sprach nun der Rektor seine schärfste Missbilligung aus, da ein „störendes“ Absingen vaterländischer Lieder in Gaststätten kein Zeichen des Patriotismus sein könne, sondern im Gegenteil den vaterländischen Gedanken herabwürdige ${ }^{190}$. Das Vorgehen Zauners sorgte wiederum für Unmut bei den Vaterländischen, zumal sich das Liederabsingen nicht auf akademischem Boden abgespielt hatte. So schrieb der Landesleiter der VF, Alphons Gorbach: Für den Fall, daß Übergriffe der Hochschülerschaft nach alter Praxis mit zweierlei Maß gemessen würden, würde die VF ihre Studenten mit allem Nachdruck in Schutz nehmen ${ }^{191}$. Der Rektor rechtfertigte sich, er sei mit strikter Objektivität vorgegangen ${ }^{192}$. Das BMU beschloss schließlich, von offensichtlich geforderten disziplinarischen Schritten gegen Zauner abzusehen und rügte lediglich dessen wenig glückliche Wortwahl ${ }^{193}$.

187 ÖStA, AdR, Beilagen PA Hugo Hantsch, Zl. 41563 Z, Bericht des Rektorates der Karl-Franzens-Universität an das BMU vom 05.12.1936.

188 Ebd.

189 Ebd. Zl. 47/37, Stellungnahme des Rektorats der Karl-Franzens-Universität vom 09.12.1936.

190 Ebd. Zl. 43462/36, Stellungnahme des Rektorats vom 19.12.1936.

191 Ebd. Zl. 44104/36, „Grazer Volksblatt“23.12.1936.

192 Ebd. Stellungnahme des Rektors Zauner an das BMU vom 24.12.1946.

193 Ebd. Zl. 44104/1, Stellungnahme des BMU vom 30.01.1937. 


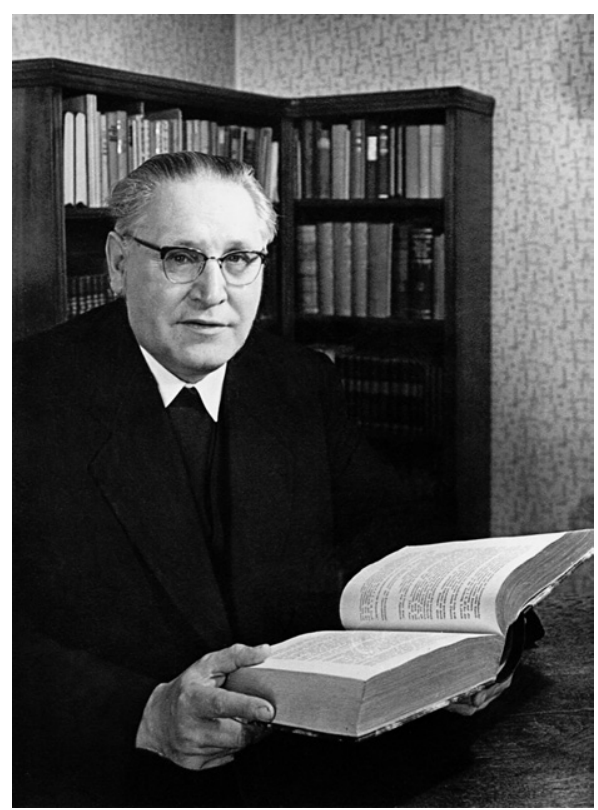

Abb. 3I: Hugo Hantsch 1958
Seine dezidierte Stellungnahme gegen den Nationalsozialismus brachte Hantsch, der kurz vor dem Einmarsch der Deutschen Wehrmacht noch die Ernennung zum Ordinarius erhielt, sehr bald nach dem Anschluss, bereits am 23. April I938, die Zwangsentlassung ein. Ende Mai wurden ihm sämtliche Bezüge gestrichen sowie das Ruhegehalt aberkannt ${ }^{194}$. Gleich darauf wurde er verhaftet und elf Monate lang in verschiedenen Gefängnissen des NSRegimes, darunter dem KZ Buchenwald, inhaftiert. Der Möglichkeit, eine Professur in New York wahrzunehmen, zog Hantsch nach seiner Freilassung die Tätigkeit als Pfarrer in der Melker Stiftspfarre Ravelsbach in Niederösterreich vor. Dort verbrachte er die Kriegsjahre, mit den Sorgen seiner kleinen Pfarre und seiner in Böhmen verbliebenen Familie beschäftigt und vom wissenschaftlichen Betrieb weitgehend zurückgezogen. Hantsch sprach später sogar von dieser für ihn „stillen Zeit“ als der „schönsten“ seines Lebens ${ }^{195}$, allerdings kamen zwei Geschwister im Zuge der Vertreibung der Sudetendeutschen I945 ums Leben ${ }^{196}$. Sein wissenschaftliches Nachkriegswerk, seine umfangreiche und für eine neue Historikergeneration vielfach prägende Tätigkeit in Forschung und Lehre werfen eine Fülle von Fragen auf, die ausführlich an anderer Stelle zu beantworten sind ${ }^{197}$. Deshalb seien hier

194 Posch, Nekrolog (wie Anm. 1) 155 f.

195 Fellner, Hantsch (wie Anm. 1) 93.

196 Es handelte sich um die Geschwister Anni und Pepi. Vgl. StA Melk, NL HH, K. 7/61, Brief des Bruders Fritz Hantsch an Hugo Hantsch vom 19.10.1949. Hantsch bemühte sich nach Kriegsende intensiv und mit Erfolg um die Verleihung der österreichischen Staatsbürgerschaft an seinen Bruder, um diesem die Ausreise aus einem tschechoslowakischen Internierungslager zu ermöglichen, ebd. - Die Korrespondenz der Jahre 1938-1945, die sich vorwiegend auf den familiären Austausch beschränkt, zeigt Hantsch als unentbehrliche Anlaufstelle seiner Verwandtschaft, er spendete dem an Magenkrebs erkrankten Vater Trost, der ihm und dem im Kriegsdienst stehenden Bruder Luis gegenüber anderen Geschwistern den Vorzug gab. StA Melk, NL HH, K. 7/61, Briefe des Vaters an Hugo Hantsch 16.06.1941 bis 14.01.1943.

197 Siehe dazu die in Arbeit befindliche Dissertation des Autors. 
nur in Kürze die wichtigsten Stationen und Funktionen seiner Laufbahn nach 1945 in Erinnerung gerufen. Nach dem Krieg übernahm Hantsch wieder seine Professur in Graz, wurde 1946 ex aequo mit Gerhard Ritter primo loco als Nachfolger Srbiks vorgeschlagen und erhielt das Ordinariat in Wien, das er, wie die Leitung des Historischen Institutes der Universität Wien, bis zu seiner Emeritierung I 966 innehatte $^{198}$. Er bekleidete 1956/57 das Amt des Studiendekans. Von 1947 bis 1967 war er Vorsitzender der Kommission für Neuere Geschichte Österreichs, von 1959 bis 1972 Obmann der Kommission der Österreichischen Akademie der Wissenschaften für Geschichte der Österreichisch-Ungarischen Monarchie. Hantschs wichtige Nachkriegswerke umfassen neben dem zweiten Band seiner "Geschichte Österreichs I648-I9I8“ (ein dritter Band zur österreichischen Republikgeschichte blieb unveröffentlicht), die umfangreiche, zweibändige Biografie über den k. u. k. Außenminister Leopold Graf Berchtold sowie den Essay „Die Nationalitätenfrage im Alten Österreich“199. Hugo Hantsch starb am 6. August 1972 in Wien.

\section{ZUSAMMENFASSUNG}

Hantsch war neben dem älteren Dengel der einzige Anhänger des „Ständestaates“ bzw. des „Austrofaschismus“ unter den Ordinarien für Geschichte zwischen I934 und I938. Obzwar von deutschnationalen, „gesamtdeutschen“ Lehrern wie Srbik und Steinacker geprägt, entwickelte er von Beginn seiner eigenständigen geschichtswissenschaftlichen Laufbahn an eine dem nationalistischen Denken entgegengesetzte Interpretation der österreichischen und europäischen Geschichte. Dabei arbeitete Hantsch epochenübergreifend und verfolgte mehrere Argumentationsstränge. Bezüglich des Mittelalters hob er die eigenständige Entwicklung des „Donauraumes“ zu einem von Deutschland unabhängigen, überlebensfähigen Staatsgebilde hervor. Er verteidigte das römisch-deutsche Kaisertum der Habsburger gegen den kleindeutschen, aber auch gesamtdeutschen Vorwurf, den Reichszerfall durch dynastisches Eigeninteresse verschuldet bzw. mitverschuldet zu haben. Hantsch stellte dagegen die These auf, die Habsburger hätten sich aus Rechtsbewusstsein an dem Kaisertum seit der Stauferzeit abgerungene, schriftlich fixierte Machtbeschränkungen gehalten und so mit dem Föderalismus auch den Missbrauch des Föderalismus durch die Reichsstände in Kauf genommen, anstatt darauf mit einer Gewaltpolitik zu antworten. Die Idee des Heiligen Römischen Reiches Deutscher Nation sah Hantsch im Kaisertum der Habsburgermonarchie ab I 804 weiterleben, die Reichsidee dabei rechtmäßig von einem deutschen Staatenbund auf den österreichischen Staat über-

198 Hamann, Nekrolog (wie. Anm. 1) 338.

199 Fellner, Geschichtswissenschaft (wie Anm. 1) $166 f$. 
gehen. Aufgrund dieser Argumentation erscheint es gerechtfertigt, Hantsch trotz seines Bekenntnisses zum deutschen Volkstum gemäß den Vorstellungen und Begrifflichkeiten der Zeit vor 1938 nicht als „Großdeutschen“, sondern als „Großösterreicher“ zu bewerten. Die Habsburgermonarchie wurde als eine Möglichkeit zur Überwindung des Nationalismus, die eine föderalistische Neuordnung Österreich-Ungarns einleiten hätte können, angesehen, basierend auf politischer Gleichberechtigung, aber unter Beibehaltung einer Art „Ehrenvorsitz“ der Deutschen, deren historisch zu betrachtende „Erzieherrolle“ und „Kulturmission“ in der frühen Neuzeit der Historiker wiederholt lobte. Den Bewohnern des „deutschen“ Österreichs schrieb er wegen der frühen Aufgabe der „Ostmark“, „Brücke und Bollwerk“ zu sein, ebenfalls eine besondere, „deutsche und europäische“ Mission zu; gleichwohl war sein Fokus, was das Einnehmen einer besonderen „österreichischen Rolle“ betrifft, ganz stark auf die Habsburgerdynastie gerichtet. Hantsch lehnte einen ethnisch geschlossenen deutschen Nationalstaat unter Einbeziehung Österreichs ab, bekannte sich aber dennoch häufig zum „deutschen Volkstum“, in einer „überstaatlichen, geistig kulturellen“ Sphäre. Oft fällt eine verblüffende Ähnlichkeit seines Vokabulars mit dem der Verfechter der "gesamtdeutschen Geschichtsauffassung“" auf, etwa in der Verwendung von Begriffen wie „Gesamtdeutschtum“, „Reichsidee“ oder auch „Ostmark“, die aber in unterschiedlichen, teils sogar entgegengesetzten interpretativen Kontexten verwendet wurden. Hantsch nahm offen gegen den Nationalsozialismus Stellung und wurde aufgrund seiner sudetendeutschen Herkunft vom „Austrofaschismus“ bzw. dem autoritären „Ständestaat“ gerade dort als Propagandist eingesetzt, wo es um die Gewinnung eines betont nationalen Publikums ging. Zusammenfassend kann Hantsch als legitimistischer, „föderalistischer“ Verfechter einer gegen den damaligen geschichtswissenschaftlichen Mainstream argumentierenden großösterreichischen Historiografie eingestuft werden, deren Konturen noch genauer zu erforschen und abzustecken wären. 


\section{Ernst Klebel (I896-I96I)}

FACETTEN EINER ÖSTERREICHISCHEN HISTORIKERKARRIERE

I.

Das nachfolgende biografische Porträt des österreichischen Historikers Ernst Klebel erhebt nicht den Anspruch, eine umfassende Rekonstruktion seines Lebensverlaufes und wissenschaftlichen Wirkens zu bieten. Dies wäre ein Vorhaben, das wegen der nicht überragenden Bedeutung des Porträtierten wohl kaum als ein gewichtiger Beitrag des zeit- und wissenschaftsgeschichtlichen biografischen Genres gelten könnte. Aber dennoch: Gerade die Biografie Klebels weist derart viele Brüche auf, dass sie als ein besonderes und durchaus interessantes Fallbeispiel innerhalb der Lebenswege österreichischer Historiker des 20. Jahrhunderts bewertet werden kann. Versucht werden soll, Klebels Sozialisation sowie sein berufliches und politisches Wirken

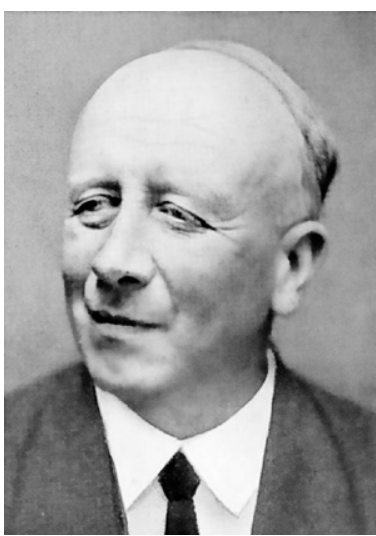

Abb.32: Ernst Klebel und dessen Umfeld darzustellen ${ }^{1}$. Der Fokus liegt gemäß

1 Ernst Klebels NL (= NL EK) wird größtenteils im NÖLA, Teile im Salzburger Landesarchiv (= SLA) sowie im OÖLA, verwahrt. Weiteres Quellenmaterial findet sich in: UAW; IÖG, Archiv, NL Hans Hirsch; ÖStA, AdR; HHStA, NL Hans Voltelini; AAVČR, NL Heinz Zatschek; MGH München, Archiv, NL Friedrich Bock; Universitätsarchiv Regensburg (= UAR), Akten der Philosophisch-Theologischen Hochschule Regensburg (die weitgehend als Vorgängerinstitution der Katholisch-Theologischen Fakultät der Universität gelten kann); Stadtarchiv Konstanz (= StadtA Konstanz), NL Theodor Mayer (= NL ThM). Das Stadtarchiv St. Pölten und das Stadtarchiv Regensburg verwahren ebenfalls Bestände zu Klebel, die nicht berücksichtigt werden konnten. Zweifelsfrei existiert zur Person Klebels Quellenmaterial, das für eine Monografie ausreichte, in diesem Rahmen aber nur teilweise herangezogen werden kann. Hinzu kommt auch ein Teil des NL, der sich im Besitz des Neffen Klebels, Burkhard Klebel, befindet, den mir dieser dankenswerter Weise zur Verfügung stellte. Mein Dank gilt zudem den Herren Mitchell G. Ash (Wien), Stefan Eminger (St. Pölten), Sören Flachowsky (Berlin), Andreas Froese (Konstanz), Franz Fuchs (Würzburg), Peter Muschol (Bad Saarow) und Hermann Spitaler (Wien) sowie meinen Kollegen Richard Corradini, Max Diesenberger und Andreas Zajic. Insbesondere danke ich schließlich dem Herausgeber Karel Hruza für wichtige Hinweise auf Literatur und Archivalien. Foliierung oder Paginierung der Archivalien werden angegeben, wobei auf die Angabe recto oder verso verzichtet wird. Ansonsten wird die Kartonnummer beziehungsweise im Fall des NL ThM die Briefnummer angegeben. 
der Ausrichtung des vorliegenden Bandes auf der Zeit bis I945. Gelegentlich wird aber auch die Zeit nach dem Untergang des Nationalsozialismus behandelt. Dass dabei viele Aspekte unberücksichtigt bleiben, ist schon alleine durch die enorme Quellenfülle, die zu Klebels Person vorliegt, bedingt. Nach einem einleitenden, allgemein-biografisch gehaltenen Kapitel sollen im dritten Kapitel einige ausgewählte Publikationen Klebels vorgestellt werden, um dann im vierten Kapitel dessen weiteren politischen und biografischen Werdegang aufzuzeigen und abschließend eine Bilanz zu ziehen.

II.

Ernst Klebel, am 24. Februar I 896 in Klagenfurt geboren, legte in seiner Heimatstadt die Matura ab und studierte anschließend 1917-1922 Kunstgeschichte und Geschichte an den Universitäten Graz und Wien. An letzterer Universität promovierte er zum Doktor der Philosophie, und in Wien absolvierte er I9I9-I92 I auch den 32. Ausbildungskurs des IÖG, als dessen ordentliches Mitglied er aufgenommen wurde. Zu seinen Kurskollegen zählten u.a. Karl Lechner und Leo Santifaller ${ }^{2}$. Zwischen 1922 und I 927 war er an der Universität Wien bei seinem Doktorvater, dem Kunsthistoriker Josef Strzygowski, Assistent ${ }^{3}$. Persönlichkeitsbildung und -entwicklung Klebels, der zeit seines Lebens le-

2 Zum IÖG siehe Alphons Lнотsку, Geschichte des Instituts für österreichische Geschichtsforschung 18541954 (MIÖG Erg.-Bd. 17, Graz/Köln 1954); Manfred Sтоу, Das Österreichische Institut für Geschichtsforschung 1929-1945 (MIÖG Erg.-Bd. 50, Wien/München 2007). Zu Lechner siehe den Beitrag von Stefan Eminger und Ralph Andraschek-Holzer in diesem Band, zu Santifaller Hannes Oвеrmair, Leo Santifaller (1890-1974). Von Archiven, Domkapiteln und Biografien, in: Österreichische Historiker 1900-1945. Lebensläufe und Karrieren in Österreich, Deutschland und der Tschechoslowakei, hg. v. Karel HruZA (Wien/ Köln/Weimar 2008) 597-617.

3 Kurze biografische, auf das Faktische beschränkte Angaben in: Kürschners Gelehrtenkalender 1961, hg. v. Werner SChuder (Berlin ${ }^{1} 1961$ ) 932; Erich Cermak, Beiträge zur Geschichte des Lehrkörpers der philosophischen Fakultät der Universität Wien zwischen 1938 und 1945 (masch. Diss. Wien 1980) 367; Fritz FelLNer, Doris A. Corradini, Österreichische Geschichtswissenschaft im 20. Jahrhundert. Ein biographischbibliographisches Lexikon (VKGÖ 99, Wien 2006) 220. Ebd. allerdings fälschlich Salzburg als Sterbeort. Gemäß mündlicher Mitteilung Burkhard Klebels vom 24.07.2009 verstarb Ernst Klebel in Regensburg und wurde nach Salzburg überführt. Keine Berücksichtung fand Klebel in: Österreicher der Gegenwart. Lexikon schöpferischer und schaffender Zeitgenossen, hg. v. Robert TеICHL (Wien 1951). Klebel selbst verfasste zudem eine Familiengeschichte, siehe SLA, Handschriften 333: Familiengeschichte Klebel - Paschali - Fosset - Erben - Brzorad. Zum IÖG-Kurs siehe Leo Santifaller, Das Institut für österreichische Geschichtsforschung. Festgabe zur Feier des zweihundertjährigen Bestandes des Wiener Haus-, Hof- und Staatsarchivs (Veröff. des IÖG 11, Wien 1950) 139f.; Lнотsку, Geschichte des Instituts (wie Anm. 2) 365f. Seine Eltern waren Dr. Wilhelm Klebel (†1907), Beamter der Kärntner Landesregierung und anschließend Bezirkshauptmann von Völkermarkt, und Anna, geborene Erben, über die Klebel ein Neffe Wilhelm Erbens (1864-1933), Professor für Mittelalterliche Geschichte und Historische Hilfswissenschaften an den Universitäten in Innsbruck [1903-1917] und in Graz [1917-1933]) war. Siehe zur Biografie Klebels weiters UAW, PA Ernst Klebel 
dig blieb, setzten aber sicherlich schon früher ein. Als Kärntner hatte er die Nachwehen des Ersten Weltkrieges, die unter anderem den Zerfall der Österreichisch-Ungarischen Monarchie mit sich brachten, an einem Brennpunkt erlebt. Das Königreich der Serben, Kroaten und Slowenen beanspruchte große Teile Südostkärntens und versuchte dies I9 I 8 und I9I9 militärisch durchzusetzen ${ }^{4}$. In einer Volksabstimmung am Io. Oktober I920, die über den Verbleib des überwiegend von Slowenen bewohnten Südkärnten entscheiden sollte, stimmten schließlich 59\% für den Verbleib bei Österreich5. Klebel, der zu dieser Zeit, wie oben erwähnt, in Graz und dann Wien studierte, wurde von Ludwig Hülgerth, seit I9 8 Landesbefehlshaber der Heimwehr von Kärnten, die Berechtigung zum Tragen des Kärntner $=$ Kreuzes für Tapferkeit zuerkannt ${ }^{6}$. Es ist sehr wahrscheinlich, dass Klebel spätestens durch diese Ereignisse im Sinn deutsch-nationalen Gedankenguts politisiert wurde ${ }^{7}$.

Durch die Neuordnung der politischen Landkarte nach I9 8 hatte ganz Mitteleuropa neue Grenzen bekommen, Österreich war von einer Großmacht zu einem Kleinstaat, der

(= PA EK) fol. 6-8; ebd. Personalbogen Ernst Klebel, Senat, S 304.610. Den Angaben ist, basierend auf einem Lebenslauf Klebels aus dem UAR, Philosophisch-Theologische Hochschule, 186/2 Klebel, Folgendes hinzuzufügen: Seit 1925 Mitarbeiter am historischen Atlas der Alpenländer für Niederösterreich, seit 1927 Mitarbeiter für den historischen Atlas für Ober- und Niederbayern, 1945 in der Gemeinde Altenmarkt bei Osterhofen/ Niederbayern Mitarbeiter beim Südost-Institut, 1948 Auftrag der Fortsetzung der Arbeiten am Historischen Atlas von Bayern, seit 10.01.1951 parallel zur Leitung des Stadtarchivs in Regensburg zugleich Leitung der Kreisbibliothek in Regensburg, siehe dazu OÖLA, NL Ignaz Zibermayr (= NL IZ), Schachtel 3, Brief Klebels an Zibermayr, Regensburg 02.02.1951 : [...] seit 10.1. habe ich zum Stadtarchiv die Leitung der Kreisbibliothek dazu erhalten. Seit März 1950 Lehrauftrag für Geschichte des Mittelalters an der Philosophisch-Theologischen Hochschule Regensburg. Hinzuzufügen ist, dass Klebel am Historischen Atlas der Alpenländer der Wiener Akademie der Wissenschaften (heute: ÖAW) mitarbeitete, siehe Ernst KLEBEL, Die Erforschung der Herrschaften und Gerichte der Alpenländer und ihre Bedeutung für die südostdeutsche Kolonisation, in : Deutsche Hefte für Volks- und Kulturbodenforschung 1 (1930/31) 58.

4 Arnold Suppan, Jugoslawien und Österreich 1918-1938 (Veröff. des österreichischen Ost- und Südosteuropa-Instituts 14, Wien/München 1996) 518-523.

5 Suppan, Jugoslawien (wie Anm. 4) 621-642.

6 Burkhard Klebel, NL EK: Legitimationskarte des Landesbefehlshabers in Kärnten vom 03.04.1920. Zu den Geschehnissen in Kärnten siehe Claudia Fräss-Ehrfeld, Kärnten 1918-1920, in: Österreich. 90 Jahre Republik, hg. v. Stefan Karner, Lorenz Mikoletzky (Innsbruck 2008) 193-202; zu Hülgerth siehe Österreichisches Personenlexikon, hg. v. Isabella Ackerl, Friedrich Weissensteiner (Wien 1992) 194, sowie Walter Wiltschegg, Die Heimwehr. Eine unwiderstehliche Volksbewegung?, hg. v. Rudolf Neck und Adam WandruszKa (Studien und Quellen zur österreichischen Zeitgeschichte 7, Wien 1985) 231-233.

7 Zur ideologischen Ausrichtung der österreichischen Historiker während der Zwischenkriegszeit im Hinblick auf die Frage großdeutscher, kleindeutscher, oder gesamtdeutscher Ausrichtung siehe Herbert DAchs, Österreichische Geschichtswissenschaft und Anschluß 1918-1930 (Wien/Salzburg 1974), bes. 1-90. Siehe auch UAW, PA EK, Lebenslauf (Typoskript) fol. 6: Ich bin in Kärnten aufgewachsen, habe schon als Volksschüler die Tätigkeit slowenischer Hetzkapläne sowie die infolge weltanschaulicher Einheit grössere Festigkeit des slowenischen Volkes kennen gelernt und bin in diesen nationalen Erkenntnissen durch den Abwehrkampf von 1919 und die Volksabstimmung 1920 bestärkt worden. 
seine deutschsprachigen Minderheiten über Zentraleuropa zerstreut sah und nur schwer in seine neue Rolle fand, geschrumpft. Es bestanden daneben aber auch weitere Probleme. So wurde etwa ein ökonomischer „Strukturbruch“, der Österreich betroffen hätte, diagnostiziert ${ }^{8}$. Klebel reagierte auf diese Umbrüche in den kommenden Jahren indifferent: er stand dem Rechtskatholizismus, dem Deutschnationalismus und schließlich dem Nationalsozialismus nahe9. Was die Rechtskatholiken anbelangt, kann man Klebel daher aufgrund dieser Mischung den „Katholisch-Nationalen“, deren politische Position vor allem antimodernistisch war, zurechnen ${ }^{10}$. Abseits der politischen Positionssuche fand sich Klebel zunächst in akademisch geprägten sozialen Gruppen. Es waren dies das der Universität Wien angegliederte IÖG, aber auch der Cartellverband $(=\mathrm{CV})^{11}$. Diese Beziehungen müssen jedoch zunehmend von einem gewissen Maß an Eigenwilligkeit konterkariert worden sein. Anders sind viele Details seiner Biografie, auf die noch eingegangen wird, nicht erklärbar ${ }^{12}$. So schrieb etwa Hans Hirsch, einer der maßgeblichen Wiener Ordinarien, dessen Wohlwollen für den akademischen Karriereverlauf von nicht zu unterschätzender Bedeutung war, sehr pointiert über Klebel. Und er war nicht der Einzige ${ }^{13}$.

8 Ernst Hanisch, Der lange Schatten des Staates. Österreichische Gesellschaftsgeschichte im 20. Jahrhundert (Österreichische Geschichte 1890-1990, Wien 1994) 277f. Österreich sei, abgesperrt von den Nachfolgestaaten mit schmaler Energiebasis, unterentwickelter Landwirtschaft und disproportionalen Industriestandorten, vor großen sozioökonomischen und politischen Problemen gestanden.

9 Mündliche Mitteilung von Hermann Spitaler von der CV-Verbindung Amelungia vom 29.07.2009 auf der Basis von Archivmaterial des Österreichischen CV. Siehe dazu auch unten Kap. IV.

$10 \mathrm{Zu}$ den Katholisch-Nationalen siehe Peter Broucex, Katholisch-Nationale Persönlichkeiten (Wiener Katholische Akademie, Miscellanea LXII, Arbeitskreis für Kirchliche Zeit- und Wiener Diözesangeschichte, Wien 1979) $2 \mathrm{f}$.

11 Genauer der CV der katholischen deutschen Studentenverbindungen, dem die österreichischen katholischen, farbtragenden, nichtschlagenden Verbindungen bis 1933 angehörten. Zur Zugehörigkeit zu den erwähnten Gruppen siehe etwa OÖLA, NL IZ, Schachtel 3, Klebel an Zibermayr, Wien 10.12.1924: Bitte die Cartellbrüder und Institutsgenossen im Linzer [recte: Oberösterreichischen] Landesarchiv bestens zu grüßen. Indem ich nochmals bestens danke, verbleibe ich mit cartellbrüderlichem Gruß.

12 Siehe Kap. IV.

13 Siehe Heinrich Ritter von Srbik. Die wissenschaftliche Korrespondenz des Historikers 1912-1945, hg. v. Jürgen Kämmerer (Deutsche Geschichtsquellen des 19. und 20. Jahrhunderts 55, Boppard am Rhein 1988) Nr. 315, 493, Hans Hirsch an Srbik, Wien 30.07.1938: [...] wenn er dann wieder wie so oft einen Unsinn macht, trifft uns nicht die Verantwortung. Er hätte das Extraordinariat für historische Hilfswissenschaften in Berlin haben können, das anzunehmen sogar ich ihm riet. Warum tat er das nicht? Jetzt muß er eben nehmen, was ihm geboten wird. Zu Hirsch siehe Andreas ZaJIC, Hans Hirsch (1878-1940). Historiker und Wissenschaftsorganisator zwischen Urkunden- und Volkstumsforschung, in : Österreichische Historiker (wie Anm. 2) 307-417. Zu Heinrich Srbik siehe den Beitrag von Martina Pesditschek in diesem Band. In diesem Zusammenhang sei erwähnt, dass Klebel eine sehr direkte Art pflegte, die vielen als nicht tragbar erschienen sein mag. Als Beispiel sei eine Postkarte an den deutschen Historiker Friedrich Bock erwähnt: Klebel wies Bock, den er nicht persönlich kannte, auf mehrere Fehler in dessen Aufsatz über das Kloster Ettal (Friedrich Bock, Die Gründung des 
III.

Seine ersten akademischen Arbeiten legte Klebel bei seinem Doktorvater Josef Strzygowski vor. Dieser leitete seit I 909 das I. Kunsthistorische Institut der Universität Wien und wurde I 933 emeritiert $^{14}$. Er wandte sich spätestens zu diesem Zeitpunkt, deutlich erkennbar an seinen Publikationen, ideologisch immer mehr dem Deutschnationalismus zu, der schließlich in einem rassistischen Lobpreis des „Nordischen“ gipfelte, das deutliche Sympathie für den Nationalsozialismus inkludierte. Was Klebels weitere kunsthistorische Arbeiten angeht, so werden diese heute als fachlich sehr gut beurteilt, auch wenn sie durch

Klosters Ettal, in: Zs. der Savigny-Stiftung für Rechtsgeschichte, KA 18 [1929] 614-618) hin. Siehe MGH, NL Friedrich Bock, Korrespondenz vor 1950, J-L, Nr. 157, Postkarte Klebels an Bock, 21.02.1931: Sehr geehrter Herr Doktor! Sie sind mir, wie ich glaube, kein ganz Fremder mehr, wenn ich Sie richtig mit dem Verfasser des schönen und interessanten Aufsatzes über Ettal gleichsetze. Eine Burg, Voernenstayn' ist mir in Niederösterreich unbekannt, ich glaube und habe hierüber auch noch mit Dr. E. Wascher, der über Oberösterreich arbeitet, gesprochen, der mir zustimmt, dass es sich um einen Schreibfehler für, Wernenstayn', das ist Wernstein bei Passau, handeln dürfte. Aus Ihrer Liste sehe ich, dass Sie Spilberg und Drozze auch nicht genau identifizieren, ersteres liegt nördlich der Donau im Machland und letzteres bei Krems. Zu Klebels Kommunikationsstil und dessen Folgen siehe auch NÖLA, NL EK, K. 6, Korrespondenz, Mappe 4 (Theodor Mayer), Brief Mayers an Klebel vom 25.08.1947: Lieber Herr Klebel! Ihr Schreiben vom 22. d. M. ist heute eingelangt, ich will es gleich beantworten. Fürs erste aber muss ich Ihnen sagen, dass sie sich im Ton wieder einmal vergriffen haben. Ich bitte Sie, sich etwas mehr im Zaum $z u$ halten, so ist eine Korrespondenz nicht zu führen.

14 Interview des Autors mit em. Univ.-Prof. Hermann Fillitz am 07.08.2009. Strzygowskis Verdienst sei es vor allem gewesen, die islamische Kunst in den Fokus der wissenschaftlichen Betrachtung gestellt zu haben. Er habe viele Objekte entdeckt, die sich heute allerdings allesamt in Berlin befinden, da in Wien damals kein Interesse daran geherrscht habe. Zu Strzygowski siehe Andreas FrüchtL, Strzygowski als Wegbereiter einer vergleichenden Weltkunstgeschichte? Untersuchung zur Genese der Strzygowskischen kunstwissenschaftlichen Methode von 1885-1889 (DA Wien 2006); Gabriele Anna Reisenauer, Josef Strzygowski und die islamische Kunst (Wien DA 2008). Zum „Nordischen“ siehe Josef Strzygowski, Aufgang des Nordens. Lebenskampf eines Kunstforschers um ein deutsches Weltbild (Beiträge zur vergleichenden Kunstforschung 12, Leipzig 1936) 111: „Es hat sich gerade in den letzten bald hundert Jahren, als die ,geschichtliche“ Auffassung auf allem Denken wie Mehltau lag, gezeigt, dass das Deutschtum dabei völlig in die Brüche gehen kann. Wir müssen wenigstens eine Zeitlang alles, was romanisch und südlich ist, zurückschieben und in Wissenschaft wie Kunst unsere eigene verlorene Natur wieder zu erkennen suchen. [...] In der Zwischenzeit aber gilt es, im Erforschen der aus Lage, Boden und Blut des Nordens geborenen, dann verlorenen und jetzt wieder zu gewinnenden Kräften und Werten ins reine zu kommen. Seit 1933, in welchem Jahre dieser Vortrag gehalten wurde, haben die breiten Massen des Volkes im Reiche in dieser Richtung große Fortschritte gemacht, nicht aber die Wissenschaft." Eine katastrophale Einschätzung Strzygowskis als Lehrer findet sich bei Gerhart B. Ladner, Erinnerungen, hg. v. Herwig Wolfram, Walter Pohl (SB Wien 617, Wien 1994) 23: „Ebenso wie die Lehrzeit bei Dopsch war auch die bei Strzygowski letzten Endes enttäuschend. Nicht nur war das chronologische Herumspringen in der Kunstgeschichte inmitten von unbeweisbaren Ableitungen später Phänomene von verlorenen früheren für einen Historiker schwer annehmbar, sondern auch war seine recht amusische, eher naturwissenschaftliche Einstellung zur Kunst für einen weitgehend ästhetisch bestimmten Kunstliebhaber auf die Dauer schwer erträglich. “ Zu Ladner siehe Österreichische Geschichtswissenschaft (wie Anm. 3) $248 f$. 
den Fortschritt der Erkenntnis naturgemäß als teilweise überholt zu gelten haben ${ }^{15}$. Zwar legte Klebel noch einige weitere kunsthistorische Arbeiten vor, die jedoch als fachlich weniger geglückt angesehen werden ${ }^{16}$. Was Klebels historische Arbeiten anbelangt, können von diesen nur einige wenige besprochen werden ${ }^{17}$.

Mit einem Stipendium des IÖG konnte Klebel I 920 in Graz für die Regesta Habsburgica arbeiten und in Kärnten epigrafische Denkmäler untersuchen ${ }^{18}$. Bekannt wurde er aber mit seinem Aufsatz über „Eine neuaufgefundene Salzburger Geschichtsquelle“ aus dem Jahr I92 ${ }^{19}$. Die Anregung dazu soll in einer Lehrveranstaltung Theodor Mayers, der damals als Privatdozent in Wien unterrichtete, gekommen $\operatorname{sein}^{20}$ : „Von seinen Seminarübungen I 920/2 I über die österreichische Annalistik hat Ernst Klebel die Anregung zu seiner großen, schwierigen Studie über diesen Gegenstand empfangen." 21 Klebel legte dann eine erste Edition dieser Quelle, die sich in einem Admonter Codex befindet, vor. Dieser sollte dann eine weitere in den MGH folgen, die kein Geringerer als Harry Bresslau, der sich bereits 1922 mit Klebels Aufsatz auseinander gesetzt hatte, besorgte $^{22}$. Bresslau hatte diese Edition auf Bitten Wilhelm Erbens, des Onkels von Klebel, in Angriff genommen. Der Ablauf der Entdeckung der Quelle ist schnell geschildert. Alphons Lhotsky berichtet, dass bereits Karl Uhlirz den Codex untersucht hatte, dessen Bedeutung jedoch nicht erkannt habe. Zuvor habe der Admonter Bibliothekar Jakob Wichner in einem Handschriftenkatalog schon auf den Codex hingewiesen ${ }^{23}$. Klebel sei

15 Interview (wie Anm. 14). Es handelt sich um folgende Arbeiten: Ernst Klebel, Friedrich Wimmer, Das Grabmal Friedrichs des Dritten im Wiener Stephansdom (Österreichs Kunstdenkmäler 1, Wien 1924); Ernst Klebel, Das alte Chorgestühl zu St. Stephan in Wien (Österreichische Kunstdenkmäler 4, Wien 1925). Klebels Dissertation: Die spätgotischen Schnitzaltäre Österreichs (Wien Diss. 1918), war dem Verfasser nicht zugänglich und auch Hermann Fillitz, Interview (wie Anm. 14) nicht bekannt.

16 Interview (wie Anm. 14). Siehe z.B. Ernst Kle Bel, Jakob Prandtauer (Manuskript St. Pölten 1944).

17 Ein Schriftenverzeichnis Klebels findet sich in: Ernst Klebel, Probleme der bayerischen Verfassungsgeschichte (Schriftenreihe zu bayerischen Landesgeschichte 57, München 1957) 481-484.

18 Lнотsкy, Geschichte des Instituts (wie Anm. 2) 304.

19 Ernst Klebel, Eine neuaufgefundene Salzburger Geschichtsquelle, in: Mitteilungen der Gesellschaft für Salzburger Landeskunde 61 (1921) 1-22. ND in Ernst Klebel, Probleme der bayerischen Verfassungsgeschichte (Schriftenreihe zur bayerischen Landesgeschichte 57, München 1957) 123-143. Hier wird die Ausgabe von 1921 zitiert.

20 Zu Mayer zuletzt Helmut Maurer, Theodor Mayer (1883-1972). Sein Wirken während der Zeit des Nationalsozialismus, in: Österreichische Historiker (wie Anm. 2) 493-530.

21 Lнотsкy, Geschichte des Instituts (wie Anm. 2) 345.

22 Annales ex Annalibus Iuvavensibus antiquis excepti, hg. v. Harry Bresslau (MGH SS 30/2, Leipzig 1934) 727-744. Schon 1922 hatte sich Bresslau mit dem Quellentext befasst, siehe DERs., Die ältere Salzburger Annalistik (Abh. Berlin 2, Berlin 1923) 3-63.

23 Codex Admontensis Nr. 718. 
aber der Erste gewesen, der die Bedeutung erkannt habe ${ }^{24}$. Emil Ottenthal, der Direktor des IÖG, stellte Klebel im Juli I92 I ein Beglaubigungsschreiben aus und machte dafür Iooo Kr[onen] flüssig, damit Klebel den Codex in Augenschein nehmen und beurteilen könne ${ }^{25}$. In seinem Aufsatz erkannte dieser, dass die Handschrift aufgrund der Orthografie auf das I2. Jahrhundert weise, man es aber mit einer frühmittelalterlichen Überlieferung zu tun habe. Er verzichtete zwar darauf, „den Urtext zu rekonstruieren“, fügte aber jeweils in Klammer ergänzend „andere Handschriften“ ein ${ }^{26}$. Bresslau erstellte in seiner Studie ein auf Klebels Arbeit beruhendes Stemma, nach welchem dessen Fund auf ältere Salzburger Annalen (74I-824) und eine fränkische Annalen-Komposition (725829) zurückgehe und verfuhr wohlwollend mit der Arbeit des jungen Historikers ${ }^{27}$. So meinte er, dass die Edition „mit einem gelehrten und höchst fleißigem Kommentar“ ausgestattet sei, und führte dann weiters aus, dass, „was in dieser Publikation eines jungen Mannes geleistet worden ist, die Kritik dessen, was man anders gemacht zu sehen wünschte, ganz zurücktreten darf "28. Die Annales Iuvavensis maximi beziehungsweise die Annales ex annalibus Iuvavensibus, wie Bresslau sie in der MGH-Edition schließlich nannte, sind eine der bedeutendsten Quellen zur frühmittelalterlichen bayerischen (und österreichischen) Geschichte. Es findet sich dort etwa zum Jahr 88 I die erste althochdeutsche Nennung von Wenia (Wien), die sich allerdings auch auf den Wienfluss beziehen könnte ${ }^{29}$. Schließlich enthält der von Klebel edierte Text bei der Nennung der

24 Alphons Lнотsку, Quellenkunde zur mittelalterlichen Geschichte Österreichs (MIÖG Erg.-Bd. 19, Graz/ Köln 1963) 145.

25 Burkhard Klebel, NL EK, Dekret Ottenthals auf Weisung des BMU vom 14.07.1921: In Gemässheit der allgemeinen Weisung des Bundesministeriums für Unterricht vom 14. Mai 1921 [...] werden Sie beauftragt, die für die österreichischen Annalen wichtigen Handschriften der Stiftsbibliotheken in St. Peter in Salzburg und in Admont einer näheren Untersuchung zu unterziehen.

26 KLebel, Geschichtsquelle (wie Anm. 19) 34.

27 Bresslau, Annalistik (wie Anm. 22). Das bestätigte auch noch Lhotsky, Quellenkunde (wie Anm. 24) 146.

28 Bresslau, Annalistik (wie Anm. 22) 3. Ebd. 4, berichtet Bresslau von Erben gebeten worden zu sein, die Edition für die MGH zu übernehmen.

29 Klebel, Geschichtsquelle (wie Anm. 19) 37: Primum bellum cum Vngaris ad Weniam. Vgl. dazu Peter CsenDES, Art. „Wien“, in: Lexikon des Mittelalters 9 (München 1998) Sp. 81, und Ders, Das Werden Wiens Die Siedlungsgeschichtlichen Grundlagen, in: Wien. Geschichte einer Stadt. Von den Anfängen bis zur ersten Türkenbelagerung (1529), hg. v. Dems., Ferdinand Opll (Wien/Köln/Weimar) 62. Klebel, Geschichtsquelle (wie Anm. 19) S. 49f. Die Wahrscheinlichkeit, dass hier ein Hydronym vorliegt, ist jedenfalls wesentlich größer, da ansonsten mit einem Kopulativkompositum im Sinne von Weniaburc (Wienburg) zu rechnen wäre. Siehe etwa die Erstnennung der Anesispurch bzw. Anesapurbc (Ennsburg) in einem Diplom Ottos II. von 977: MGH Diplomata regum et imperatorum germaniae 2. 1. Die Urkunden Otto des II., hg. v. Theodor SickeL (Hannover 1888) Nr. 167 a und b und der Stirapurhc (Steyrburg) (zwischen 985 und 991) in den Traditionen des Hochstifts Passau, hg. v. Max Heuwieser (Quellen und Erörterungen zur bayerischen Geschichte NF 6, München 1930) Nr. 93, 82. Andere Ansicht bei Herwig Wolfram, Salzburg, Bayern und Österreich. Die Conversio Bagoariorum et Carantanorum und die Quellen ihrer Zeit (MIÖG Erg.-Bd. 31, Wien/München 
Schlacht von Pressburg (907) auch die erste Nennung dieses Ortes ${ }^{30}$. Hinzu kommt die berühmte „regnum Theutonicorum“-Nennung zum Jahr 920: Bavvarii sponte se reddiderunt Arnolfo duci [sc. Herzog Arnulf von Bayern, 907-937] et regnare eum fecerunt in regno Teutonicorum ${ }^{31}$. Im entsprechenden Zeithorizont kann dies kaum als „im Reich der Deutschen “ aufgefasst werden. Es war Herwig Wolfram, der zu bedenken gab, dass es um den Herrschaftsbereich Arnulfs ging, der an slawische, wie auch romanische Gebiete heranreichte, hier also nicht die „Deutschen“, sondern die deutsch sprechenden

1995) 123 (mit der älteren Literatur), der ausführt, dass in der Quelle Flüsse, deren Identifizierung Probleme bereiten hätte können - wie etwa Seine, Inn und Lech - explizit als solche bezeichnet werden und man mit „aller gebotenen Vorsicht“ die Wenia-Nennung auf den Ort beziehen könnte.

30 KLEBeL, Geschichtsquelle (wie Anm. 19) zu 907, 37: Brezalauspure, in den MGH SS 30/2 zu 907, 742: Brezalauspurc. Die Lesung - purc von Bresslau ist richtig, vgl. etwa die Abbildung bei Bernhard ZelLeR, Nur die Annales Iuvavenses maximi nennen den Ort der Schlacht von 907: „Brezalauspurc“ (mit Abbildung), in: Schicksalsjahr 907. Die Schlacht bei Pressburg und das frühmittelalterliche Niederösterreich, hg. v. Roman Zehetmayer (Eine Ausstellung des Niederösterreichischen Landesarchivs in der Kulturfabrik Hainburg, St. Pölten 2007) 180. Klebel spricht im Anmerkungsapparat - Klebel, Geschichtsquelle (wie Anm. 19) 51 Anm. 115 - im Übrigen richtig von Brezalauspurc, was demnach wohl auf einen Flüchtigkeitsfehler hindeutet. Ebendort meint er zudem: „Also auch dieser Ort entstammt samt seinem deutschen Namen der vormagyarischen Zeit." Dazu folgende Überlegungen. Man kann hier zunächst nur von einer althochdeutschen Namensform, die wohl zudem eine Fremdbezeichnung war, sprechen. Zur purc-Nennung siehe den Art. „Burg“, in: Jacob und Wilhelm Grimm, Deutsches Wörterbuch 2. Biermörder-Dwatsch (Leipzig 1860, ND 1984) Sp. 534. Es handelt sich bei der Ortsnennung zudem um ein Possessivkompositum, dessen erster Teil Bresalaus die latinisierte Form eines slawischen Fürstennamen ist, wie es etwa auch bei Vladislav/ Wladislaus, Venceslav/Wenceslaus der Fall ist. 892 hatte König Arnulf mit Fürst Brazlavo von Siscia (Sissek, in Kroatien) einen Kriegszug nach Moravien geplant, siehe die Annales Fuldenses zu 892, hg. v. Friedrich Kurze und Heinrich Haefele (MGH SS rerum Germanicarum, Hannover ${ }^{2} 1881$ ) 121f. In ihm sehen Kurt ReINDEL, Die bayerischen Luitpoldinger. 893-989 (Quellen und Erörterungen zur Bayerischen Geschichte NF 11, München 1953) Nr. 45, und Wolfram, Salzburg (wie Anm. 29) 92, den wahrscheinlichen Gründer von Brezlauspurch. Zuletzt beschäftigte sich aus onomastischer Sicht Pavol ŽIGO, Bratislava-Braslavespurch/ Preßburg (Prešporok)/Pozsony, in: Österreichische Namenforschung 29/1-2 (2001) 219-223, mit der Frage der Herkunft der verschiedenen Namensformen. Er führt aus, dass das Urbanonym *Braslav-j grad, die älteste slawische Form sei. Dies ist tatsächlich anzunehmen. Die slawische Namensform gehe wohl auf die Zeit vor Moimir I. (um 830-846), der durch die Angliederung des Fürstentums Neutra das sogenannte Großmährische Reich begründete, zurück. Denn schon zuvor werde ein slawischer Fürst die Burg, aus der das heutige Pressburg hervorging, errichtet haben. Brezalauspurc wäre daher, wie auch alle späteren nicht slawischen Namensformen, eine Übertragung des oben genannten Urbanonyms. Ausführlich zur Schlacht von Preßburg Zdeněk MěŘínskŕ, České země od prííchodu Slovanů po Velkou Moravu 2 (Dějiny Českých zemí, Praha 2006) 957-962. Siehe zuletzt zu dieser Problematik: Bitka pri Bratislave v roku 907 a jej význam pre vývoj stredného Podunajska: zborník príspevkov z kolokvia, hg. v. Tatiana ŠTefanovičová, Drahoslav Hulínek (Bratislava 2008).

$31 \mathrm{Zu}$ Arnulf siehe Ludwig Holzfurtner, Gloriosus dux. Studien zu Herzog Arnulf von Bayern (907-937) (München 2003). 
Bayern gemeint sein müssen ${ }^{32}$. Alleine diese eine Edition Klebels ist heute noch von Bedeutung, auch wenn die Zeit über viele seiner Interpretationen hinweggegangen ist. Er steht hier zeitlich an der Spitze sicherlich weiter zu diskutierender Forschungsprobleme. Klebel arbeitete zudem an einer weiteren Edition für die MGH, nämlich an der des Schwabenspiegels, wobei Hans Voltelini lange Zeit sein Vorgesetzter war ${ }^{33}$. Klebel bekam hier allerdings, anders als noch von Bresslau, heftigen Widerstand zu spüren. Sowohl Theodor Mayer, Präsident der MGH, als auch Hans Planitz, wandten sich in einer Sitzung 1944 gegen Klebel, den sie als Mitarbeiter offenbar für nicht geeignet hielten ${ }^{34}$. Das Erscheinen der Edition, deren Bearbeitung durch ihn so starken Widerstand ausgelöst hatte, erlebte Klebel dann nicht $\mathrm{mehr}^{35}$.

32 Zuerst in Herwig Wolfram, Bayern, das ist das Land der Němci. Gedanken zu „in regno Teutonicorum“ aus Cod. 718, in: Österreichische Osthefte 33 (1991) 598-604. Siehe auch Ders., Salzburg (wie Anm. 29) 59-66, mit reichen Angaben der älteren Literatur. So zuletzt auch Roman Deutinger, Königswahl und Herzogserhebung Arnulfs von Bayern. Das Zeugnis der älteren Salzburger Annalen zum Jahr 920, in: DA 58/1 (2002) 17-68, hier 23f.

$33 \mathrm{Zu}$ Voltelini siehe Österreichische Geschichtswissenschaft (wie Anm. 3) 432. Voltelini betreute die Edition des Schwabenspiegels durch Klebel für die MGH.

34 OÖLA, NL IZ, Schachtel 3, Klebel an Zibermayr, 03.06.1944, fol. 1-3: Lieber Herr Hofrat! Wie Du vielleicht weißt, war heute Prof. [Karl Gottfried] Hugelmann hier, u. erzählte mir, Du seiest noch weit mehr der Meinung, als er, ich hätte in der Schwabenspiegelsache Theodor Mayer gegenüber verkehrt gehandelt, als ich der Sitzung vom 12.2. auswich. Mich hat diese Mitteilung gar nicht gewundert; denn ich habe schon an [Claudius von] Schwerin wie an H[erbert] Klein die Wirkung von Mayers Suada gut beobachten können. [...] Um es geradeheraus zu sagen: meine Erfahrung mit Professoren u. speziell mit denen aus und von Wien sind keine guten. Gewiß, man hat mich zu der Sitzung geladen. Mir wurde als wahrscheinlich mitgeteilt, dass dort außer Planitz, über den ich mich stets mehr ärgere, da er erst aller Lobessprüche voll war und nun so feindselig, als möglich ist, Srbik, Mayer und Dopsch zu erwarten wären. Dass statt Dopsch [Ludwig] Bittner und [Dietrich] Kralik kämen, ahnte ich nicht. [...] Srbik war stets nett zu mir, hat sich auch jetzt als ich am 18.5. bei ihm war, auch wieder nett gezeigt, aber durchboxen wird er nichts für mich, Und Mayer? Ehe ich auf dieses zähe Kapitel eingehe, noch eine allgemeine Beobachtung: wenn bei einer Sitzung 4 oder 5 Wiener Ordinarien sitzen, von denen mich einer anklagt (Planitz), dann erwarte ich von den anderen keine Gerechtigkeit. [...] Planitz hat, wie ich hinterher hörte, rundweg bestritten, was ich mit ihm beredet habe. Wenn ich mich dann dagegenstelle, gibt's höchstens Krach, aber kein Ergebnis. [...] Schon im Mai 1942 bei der Sitzung über Planitz und den Schwabenspiegel machte er [Theodor Mayer] Bemerkungen, aus denen ich irgendwie heraushörte, meine Arbeit am Schwabenspiegel erschiene ihm irgendwie fehl angewendet. „Dann steht in der Einleitung, ausgerechnet in St. Blöden erschienen. “Klebel war bis 1939 „hauptberuflich für die Ausgabe des Schwabenspiegels tätig“. Planitz wurde 1942 die Leitung der Edition übertragen, siehe Karl August EcKHARDT, Einleitung. Schwabenspiegel, Kurzform (MGH, Fontes iuris Germanici antiqui, Nova series 4/1-2, Hannover 1960-1961, $\left.{ }^{2} 1974\right) 14$.

35 Der Herausgeber würdigte in der Einleitung aber die Vorarbeiten Klebels, siehe ebd. 17: „Es ist ein Gebot wissenschaftlicher Fairneß, wenn ich bekenne, daß ich ohne die im Druck vorliegenden Arbeiten von Klebel und (Hans) Lentze die nachstehende Ausgabe entweder überhaupt nicht oder doch nur unter teilweise unzutreffenden Prämissen fertigen hätte können. Klebel hat unser Wissen um die Überlieferung des Schwabenspiegels ungemein bereichert und auch methodisch neue Wege gewiesen.“ 
Neben der Arbeit als Editor wird Klebel zudem von manchem auch als einer derjenigen, welche die Landesgeschichtsschreibung etablierten, angesehen ${ }^{36}$. Allerdings könnte man in willkürlicher Auswahl die "Geschichte des Landes ob der Enns“ von Franz Xaver Pritz (I 846), die etwa einhundert Jahre vor Klebel geschrieben worden war, oder auch die „Geschichte Nieder- und Oberösterreichs“ von Max Vancsa (I905/I927) nennen, die durchaus landesgeschichtlich ausgerichtet sind ${ }^{37}$. Klebel interessierte sich jedenfalls früh für landesgeschichtliche Fragestellungen ${ }^{38}$. Dies passte zur damals gängigen Forschungsrichtung der Volks- und Kulturbodenforschung, die von der Leipziger „Stiftung für deutsche Volks- und Kulturbodenforschung“ initiiert worden war, die „als maßgebliches Koordinationszentrum der historisch-geografischen Volks- und Raumforschung [...] die politische Disposition der jungen Landesgeschichte sichtbar" zu machen versuchte ${ }^{39}$. Das dahinter liegende geschichtspolitische Konzept legten die Herausgeber der von dieser Stiftung I930/3 I erstmals durch Wilhelm Volz und Hans Schwalm herausgegebenen „Deutsche[n] Hefte für Volks- und Kulturbodenforschung“ vor. Gefordert war eine interdisziplinäre Verschränkung aller mit dem „Deutschtum befassten Wissenschaften“, wobei dieses Forschungsziel klar mit den Folgen des Ersten Weltkrieges vor allem im Hinblick auf die Grenzen begründet wurde. Mitschwingender Tenor ist dabei immer die Vorstellung des „Deutschtums“ als homogener „Volksgemeinschaft“, auch wenn zwischen Reichs-, Grenz-, und Auslandsdeutschtum unterschieden wurde und auch die verschiedenen Facetten der

36 Matthias Werner, Zwischen politischer Begrenzung und methodischer Offenheit. Wege und Stationen deutscher Landesgeschichtsforschung im 20. Jahrhundert, in: Die deutschsprachige Mediävistik im 20. Jahrhundert, hg. v. Peter Moraw, Rudolf Schieffer (VuF 62, Ostfildern 2005) 251-364, hier $296 f$.

37 Franz Xaver Pritz, Geschichte des Landes ob der Enns von der ältesten bis zur neuesten Zeit 1-2 (Linz 1846/1847); Max VANCSA, Geschichte Nieder- und Oberösterreichs 1-2 (Allgemeine Staatengeschichte, 3. Abt. Deutsche Landesgeschichten, Stuttgart/Gotha 1905/1927). Klebel selbst meinte in seinem Aufsatz: Zur Rechts- und Verfassungsgeschichte des alten Niederösterreich, in: JbLKNÖ 28 (1939) 11-120, hier 11, die „Mehrzahl der heutigen Reichsgaue und früheren Länder im Deutschen Südosten hat seit der Romantik eine blühende Landesgeschichtsforschung“.

38 Siehe etwa ohne Anspruch auf Vollständigkeit folgende Publikationen : Ernst KLEB EL, Art. Besiedlungsgeschichte des Burgenlandes (Handwörterbuch des Grenz- und Auslandsdeutschtums 1, Breslau 1932) 673678; DERs., Die Grafen von Görz als Landesherren in Oberkärnten, in: Carinthia I 125 (1935) 59-82, 218 246; DERs., Zur Geschichte des Herzogstuhles (Über Lehenhof, Landgerichte und Burgenbesitz in Kärnten), in: Carinthia I 130 (1940) 95-128; DERs., Von den Edlingern in Kärnten, in: Archiv für vaterländische Geschichte und Topographie Kärntens 27 (1942) 9-119.

39 Willi Овевкrome, Geschichte, Volk und Theorie. Das ‘Handwörterbuch des Grenz- und Auslanddeutschtums`, in: Geschichtsschreibung als Legitimationswissenschaft 1918-1945, hg. v. Peter SснӧтTLER (Frankfurt/M. 1997) 104-127, hier 106; Ingo HaAR, Leipziger Stiftung für deutsche Volks- und Kulturbodenforschung, in: Handbuch der völkischen Wissenschaften. Personen - Institutionen - Forschungsprogramme - Stiftungen, hg. v. Dems., Michael Faнlbusch unter Mitarbeit von Matthias Berg (München 2008) 374-382. 
Geschichte der „benachbarten germanischen, romanischen und slavischen Völker“ behandelt werden sollten ${ }^{40}$. Klebel verfasste in dieser Zeitschrift den Aufsatz „Die Erforschung der Herrschaften und Gerichte der Alpenländer und ihrer Bedeutung für die südostdeutsche Kolonisation ". ${ }^{41}$ Wissenschaftssoziologisch und -historisch ist die Frage nach der „südostdeutschen Kolonisation“ sicherlich, wie viele der Themen von Klebels Studien, in die geschilderte Ausrichtung der neuen Zeitschrift gut einzuordnen. Klebel hatte schon zehn Jahre zuvor eine Studie mit verwandter Themenstellung veröffentlicht ${ }^{42}$. Es handelte sich also um ein grundsätzliches Forschungsinteresse Klebels, das sich nun gut in die geforderte neue Orientierung der Geisteswissenschaften einfügte. Mit der Frage nach der Gerichts- und Herrschaftsorganisation behandelte Klebel allerdings per definitionem Sozial- und Rechtsbeziehungen zwischen Herrschenden und Beherrschten und nur bedingt die eines imaginierten „Volkskörpers“. Ähnlich verhält es sich mit seinem an anderer Stelle publizierten Aufsatz „Herzogtümer und Marken bis 900“, in welchem er der Entstehung der Titel dux, comes, missi und praefectus, also den höchsten Herrschaftspositionen nach dem König- und Kaisertum, nachgeht ${ }^{43}$. In der Zusammenfassung kommt Klebel zu dem Ergebnis, dass sich nun „die Entwicklung des Herzogsamtes bis zu den Stammesherzögen des io. Jahrhunderts deutlicher als bisher erkennen [ließe], andererseits ließen sich die Grundgedanken im Aufbau des Karolingerreiches klarer als bisher feststellen“. Klebel meint zudem weiters, dass „von diesen Grundgedanken aus [...] [der] Weg zur Wertung des Karolingerreichs für die Geschichte der deutschen Volkswerdung “ führe ${ }^{44}$. Klebel war auch an dieser Stelle durchaus klar, dass er größtenteils nur über die Vorbedingungen, die zur Entstehung des römisch-deutschen Regnums führten, schrieb, auch wenn er das teleologisch gerichtete Erkenntnisinteresse erwähnt. Eine interessante Passage dieses Aufsatzes soll noch Erwähnung finden, in welcher er Karl den Großen beurteilt, der aufhöre ,jene liberale Idealfigur zu werden, die gesundes Volksempfinden mit Recht ablehnt “45. Mit dieser Bemerkung befand sich Klebel nur bedingt im geschichtswissenschaftlichen Mainstream. Zwar hatte Alfred Rosenberg, der „Chefideologe“ der NSDAP, Karl den Großen, den damaligen ideologischen Deutungsmustern entsprechend, mittelalterliche Herrscher

40 Wilhelm Volz, Hans Schwalm, Zum Geleit, in: Deutsche Hefte für Volks- und Kulturbodenforschung 1 (1930/31) 1-3, hier 2. Zum Gang der Forschung über die Propagandaformel der Volksgemeinschaft siehe Frank BAJOHR, Michael Wildt, Einleitung, in: Volksgemeinschaft. Neue Forschungen zur Gesellschaft des Nationalsozialismus, hg. v. DENs. (Die Zeit des Nationalsozialismus, Frankfurt/M. 2009) 7-23.

41 In: Deutsche Hefte für Volks- und Kulturbodenforschung 1 (1930/31) 57-67.

42 Die Ostgrenze des Karolingischen Reiches, in: JbLKNÖ 21 (1928) 348-380. ND, in: Die Entstehung des deutschen Reiches (Deutschland 900) (Wege der Forschung 1, Darmstadt 1956) 1-41.

43 Ernst Klebel, Herzogtümer und Marken bis 900, in: DA 2 (1938) 1-53, passim.

44 Ebd. 50 .

45 Ebd. 51. Zu Karl dem Großen siehe zuletzt Rosamond McKiтterick, Charlemagne. The Formation of European Identity (Cambridge 2008). 
ohne Beachtung des historischen Kontextes nach ihrer Rolle, genauer ihrer „Leistung“ für die „deutsche Geschichte“ zu bewerten, als negative Figur skizziert ${ }^{46}$. Dies fußte nicht zuletzt auf dem sogenannten „Blutbad von Verden“, bei welchem Karl diejenigen Sachsen, die das Christentum ablehnten, hinrichten ließ. Man sprach daher voller Emotion vom „Sachsenschlächter" Karl ${ }^{47}$. Klebel kam allerdings, seiner Themenstellung gemäß, aufgrund institutionengeschichtlicher Überlegungen zu seinem vernichtenden Urteil über Karl und nicht wegen dessen Vorgangsweise bei der Missionierung der Sachsen. Zudem hatte der Heidelberger Mediävist Karl Hampe, der wenige Tage nach Hitlers Machtantritt emeritierte, heftig gegen Rosenbergs Verdikt argumentiert und polemisiert. Hampe setzte sich durch, nicht ohne zu betonen, dass „nur Karls imperiale Politik den Zusammenschluss der Stämme [...] und damit die nationale Geschichte der Deutschen begründet" hätte ${ }^{48}$. Die Position Rosenbergs war zu dem Zeitpunkt, als Klebel den oben erwähnten Beitrag schrieb (I938), also wohl kein zentraler Bestandteil der seitens des NS-Regimes erwünschten Betrachtung des frühen Mittelalters mehr. Im selben Jahr legte Klebel jedenfalls ein klares Bekenntnis zu einer als deutsche Volksgeschichte zu betreibenden Landesgeschichte ab: „Die Geschichte des Reiches vom Ausgang der Karolingerzeit bis zur Reformation, ja bis über den Dreißigjährigen Krieg, wird also falsch beurteilt, wenn man sie nur als Kaisergeschichte sieht. So große Leistungen wie die Besiedlung des Deutschen Südostens oder der Ausbau der Hanse sind nicht vom Reich, auch nicht von den Herzogtümern der Einzelstämme, sondern zumeist von den kleinen Zellen, den Grundherrschaften und Stadtgemeinden geschaffen worden. [...] Es gibt nur einen wirklichen Gegenstand der Geschichte, die Geschichte des Gesamtvolkes, des Deutschen Volkes, seines Werdens von der Germanenzeit her über die zahlreichen Völkerschaften zu den fünf großen Stämmen und von den Stämmen über das Einigungswerk Karls des Großen zur Deutschen Nation [...].“ ${ }^{49}$ Im Hinblick auf den Sprachgebrauch der Studien Klebels, finden sich neben der oben zitierten Erwähnung des „gesunden Volksempfindens“ kaum eindeutige weitere zeittypische Wendungen ${ }^{50}$. Die Slawen hätten aber, so Klebel, in Kärnten eine gründliche „Vernichtungsarbeit“ geleistet, während sich zuvor „langobardische Einrichtungen und

46 Alfred Rosenberg, Der Mythus des 20. Jahrhunderts. Eine Wertung der seelisch-geistigen Gestaltenkämpfe unserer Zeit (München 1933) 186.

47 Ernst Schu bert, Art, „Verden, Blutbad v.“, in: Lexikon des Mittelalters 8 (München 1997) Sp. 1500f.; Wilfried Hartmann, Kaiser Karl der Große, in: Die Kaiser. 1200 Jahre europäische Geschichte, hg. v. Gerhard Hartmann, Karl Schnith (Wiesbaden 2006) 14-41, hier 29.

48 Folker Reichert, Gelehrtes Leben. Karl Hampe, das Mittelalter und die Geschichte der Deutschen (Schriftenreihe der Historischen Kommission bei der Bayerischen Akademie der Wissenschaften 79, München 2009) $266 f$.

49 Ernst Klebel, Reichsgeschichte und Landesgeschichte (Sonderdruck aus „Unsere Heimat“, Monatsblatt des Vereines für Landeskunde und Heimatbuch von Niederösterreich und Wien 3/4, Wien 1938) 1-4, hier 1 f.

50 Siehe Cornelia Schmitz-Berning, Vokabular des Nationalsozialismus (Berlin/New York 1998). 
somit Germanenreste nachweisen" ließen, was fraglos als antislawisches Pejorativum zu bezeichnen ist ${ }^{51}$.

Im Auftrag des Münchner Südost-Instituts schrieb Klebel eine „Siedlungsgeschichte des deutschen Südostens" ${ }^{52}$. Dieses Institut stand in enger Kooperation mit der SODFG, deren Gründung wesentlich von österreichischer Seite betrieben worden war und sich I93 I in Wien konstituiert hatte. Der Sache nach war sie ein Netzwerk für die Koordination der Erforschung der deutschen Volksgruppen, die nach dem Ende der k. u. k. Monarchie zu Minderheiten in den Nachbarländern geworden waren. Hans Hirsch, der die Forschungsgemeinschaft zwischen 1934 und 1939 leitete, wollte durch diese wissenschaftliche Tätigkeit aber auch „moralische Impulse“ gesetzt sehen, die zum Ziel haben sollten, das „Volksbewußtsein zu wecken und zu mehren bei bewusster Fernhaltung von allen politischen Bestrebungen "53. Diese großdeutsch motivierte wissenschaftspolitische Ausrichtung fügte sich aus österreichischer Perspektive zunächst vor allem in die Anschlussforderung, die seit 1933 aber keine Konsensbasis mehr hatte. Seit der Machtergreifung Hitlers spielte sie eine Rolle als Legitimationsmittel für dessen expansive und aggressive Außen- und Kriegspolitik. Dem Münchner Südost-Institut blieb Klebel dann auch nach Kriegsende weiterhin verbunden ${ }^{54}$.

Nach 1945 ist weder ein Paradigmenwechsel im Geschichtsbild Klebels erkennbar, noch sind Reflexionen über die Verstrickung in das NS-Regime überliefert. Es gab auch keine thematische Neuausrichtung seiner Forschungsinteressen. Klebels alter Gegner Theodor Mayer wurde dagegen nun zu einer wichtigen wissenschaftlichen Bezugsperson. Mit ihm stand er fortan in engem Briefkontakt. Mayer hatte 1945 als Nationalsozialist die Leitung der MGH abgeben müssen und war 1945/46 in Arrest genommen worden $^{55}$. In dem Briefwechsel, den die beiden pflegten, ging es aber zumeist um fachliche Fragen, während (Tages-)Politisches ausgespart blieb ${ }^{56}$. Selten wurde Kollegenschelte

51 Ernst KleBel, Die mittelalterliche deutsche Siedlung im deutsch-magyarischen und deutsch-slowenischen Grenzraum, in: Volk und Reich 10/1-2 (Berlin 1934) 31-78, hier 34: Ihre Vernichtungsarbeit scheint in dem dichtbewohnten Kärnten eine gründliche gewesen zu sein. Die slawische Ortsnamensgebung überwog von da an.

52 Ernst Klebel, Siedlungsgeschichte des deutschen Südostens (Veröff. des Südost-Instituts München 14, München 1940) 12. Siehe UAR, Philosophisch-Theologische Hochschule, 186/2 Klebel, Lebenslauf.

53 Vgl. zur Tätigkeit Hirschs Zajic, Hirsch (wie Anm.13) 244. Zur SODFG siehe Michael Fahlbusch, Südostdeutsche Forschungsgemeinschaft, in: Handbuch der völkischen Wissenschaften (wie Anm. 39) 688-697, hier 690 (zur Gründung) und 691 (Zitat Hirsch).

54 Siehe unten Anm. 131.

55 Zu Mayer siehe Maurer, Theodor Mayer (wie Anm. 20).

56 StadtA Konstanz, NL ThM, Korrespondenz mit Klebel. Neben Privatem und Fachlichem wurde einzig Unverfängliches, wie z.B. die Wahl von Angelo Giuseppe Roncalli zum Papst Johannes XXIII. (1958-1963), thematisiert, ebd. K. 4, Brief Mayers an Klebel vom 05.11.1958: Sind Sie mit der Wahl des neuen Papstes zufrieden? Der allgemeine Umschwung an der Kurie scheint ziemlich tiefgreifend zu sein, es dürfte wohl eine sehr reservierte 
betrieben ${ }^{57}$. Klebel befand sich fachlich fortan hauptsächlich im Umfeld Mayers, der, nach 1945 seiner Ämter enthoben, mit anderen seit I95 I begann, den Konstanzer Arbeitskreis für mittelalterliche Geschichte aufzubauen, auf dessen Kongressen Probleme der mittelalterlichen Reichs- und Landesgeschichte behandelt und in der Reihe „Vorträge und Forschungen" publiziert wurden ${ }^{58}$. Klebel gehörte zwar nicht zu dessen Gründungsmitgliedern, nahm aber immer wieder an den Tagungen auf der Insel Reichenau teil und hielt dort insgesamt zehn Vorträge ${ }^{59}$. Der jüngeren Mediävistik und schon gar der interdisziplinären Forschung konnte oder wollte er sich aber nicht mehr öffnen ${ }^{60}$.

Stimmung gegenüber Pius XII. bestanden haben. [...] Wie wird sich der jetzige Papst gegen Deutschland stellen? Er ist ausgesprochener Italiener, während Pius XII. mehr aristokratischer Römer war. Das wissen Sie doch alles viel genauer.

57 Über den Linzer Historikertag des Jahres 1951 meinte Mayer brieflich gegenüber Klebel Folgendes: StadtA Konstanz, NL ThM, K. 4, Brief Mayers an Klebel vom 13.11.1951: Der beste Vortrag war der von [Otto] Brunner, wurde mir gesagt. [Leo] Santifaller kam nicht, die Staatsarchivangelegenheit hat ihm wohl die Stimme verschlagen. Mit der „Staatsarchivsangelegenheit“ bezog sich Mayer auf den Raub von silbernen und goldenen Siegelkapseln, Silberdeckeln, Silberschalen, Golddeckeln und Urkunden aus dem Haus-, Hof- und Staatsarchiv durch dessen stellvertretenden Leiter Heinz Grill. Zu Santifaller, dem Generaldirektor des Staatsarchivs siehe oben Anm. 3. Zu diesem Kriminalfall vgl. Michael Hochedlinger, Thomas Just, „Diese Diebstähle sind einzig in der Geschichte aller Archive der Welt“. Die Affäre Grill 1951-1953, in: MIÖG 113 (2005) 362-388, hier 373-378. Ein wiederkehrendes Thema blieben auch die MGH, siehe StadtA Konstanz, NL ThM, Brief Klebels an Mayer vom 13.12.1957: Welche Meinung Sie über [Herbert] Grundmann als Monumenta-Chef bekommen werden, würde mich ebenfalls interessieren. Der „Schwefel“ breitet sich immer mehr aus. Heimpel war am 8.12. hier, tat sehr gemütlich und gnädig und deutete an, daß er Lust hätte, mich zur Germania Sacra zu zitieren; woran ich nicht denke. Grundmann war seit 1957 Präsident der MGH. Zu ihm siehe Arno Borst, Herbert Grundmann (1902-1970), in: DA 26 (1970) 327-353.

58 Verwiesen sei hier auf Traute Endemann, Geschichte des Konstanzer Arbeitskreises. Entwicklung und Strukturen 1951-2001 (Veröff. des Konstanzer Arbeitskreises für mittelalterliche Geschichte aus Anlaß seines fünfzigjährigen Bestehens 1951-2001, Stuttgart 2001). Aufgrund der Biografie Mayers hatten es allerdings Vertreter der MGH zunächst nicht leicht, zu den Tagungen des Arbeitskreises eingeladen zu werden, siehe Johannes Fried, Konstanz und der Konstanzer Arbeitskreis für mittelalterliche Geschichte, in: Vierzig Jahre Konstanzer Arbeitskreis für mittelalterliche Geschichte (Sigmaringen 1991) 11-28, hier 14.

59 Die Gründungsmitglieder sind aufgelistet bei Stefan Weinfurter, Standorte der Mediävistik. Der Konstanzer Arbeitskreis im Spiegel seiner Tagungen, in: Die deutschsprachige Mediävistik (wie Anm. 36) 9-38, hier 9 Anm. 3 und 10.

60 Man kann zahllose Beispiele historischer Forschung anführen, die Klebels Fachgebiet berührten, von ihm aber nicht rezipiert wurden. Zu bedenken sind dabei zwar auch die damaligen schwierigen Umstände der Beschaffung entlegener Literatur. Jedoch müssten etwa die folgenden sowie zahlreiche andere Werke in den 1950erJahren in München erreichbar gewesen sein: Ferdinand Lот, Les invasions germaniques: la pénétration mutuelle du monde Barbare et du monde Romain (Paris 1939); DERs., Études carolingiennes 1. Les Comtes d'Auvergne entre 846 et 877 (Paris 1942); 2. Les Comtes d'Autun entre 864 et 878 (Paris 1942); Heinrich Fichtenau, Mensch und Schrift im Mittelalter (Veröff. des IÖG 5, Wien 1946); Georges Dumézil, Mythes et dieux des Germains. Essai d'interprétation comparative (Paris 1939). 
IV.

Oben wurde die politische Position Klebels bereits angesprochen und soll hier nun vertieft dargestellt werden. Zunächst ist zu erwähnen, dass Klebel I92 I bis 1923 Mitglied der Großdeutschen Volkspartei war, was seiner deutschnationalen Gesinnung entsprach. ${ }^{61}$ In einem wohl 1939 selbst verfassten Lebenslauf, in Ichform geschrieben, aber nicht unterzeichnet, beschreibt Klebel dann seine Verdienste um den „Anschluss“. Bei der Interpretation dieses Selbstzeugnisses muss man die Interessenlage Klebels, dem NS-Regime seine eigene Rolle möglichst bedeutend erscheinen zu lassen, bedenken. Die NSDAP anerkannte diese Darstellung, denn Klebels Parteinummer war eine der sogenannten Sechsmillionennummern, die für die illegalen österreichischen Nationalsozialisten reserviert waren $^{62}$. Als Grund für seinen Eintritt in den christlich-konservativ geprägten CV gab Klebel an: Eine innere Krise trieb mich I923 dazu, in den C.V. einzutreten. Dabei habe er die ihm völlig unbekannte Korporation Amelungia ausgewählt ${ }^{63}$. Dort wählte er den Coleurnamen Harald ${ }^{64}$. In dieser Verbindung aber hätten Legitimisten unter der Führung Eugen Lanskes und Anhänger des Anschlusses unter der Führung von J[osef] A. Tzöbl um die Vorherrschaft gekämpft ${ }^{65}$. Bald wurde ich selbst ein Führer des Anschlussflügels [...], sah in der deutschen Studentenschaft den formellen Ausdruck unseres Anschlusswillens und kämpfte I925 bis 1933 zusammen mit Dr. Erich Führer [...]. Die inneren Kämpfe im C.V. um diese Frage [sc. den Anschluss] führten dreimal zum Dimissionsverfahren gegen mich, stets ergebnislos ${ }^{66}$. Angeblich soll Klebel mit 25 Mitgliedern der Amelungia versucht haben, eine

61 ÖSta, AdR, GA Ernst Klebel fol. 7.

62 Ebd. Personalfragebogen. Siehe auch Anm. 76.

63 UAW, PA EK, Lebenslauf (Typoskript) fol. 6.

64 Brief Hermann Spitalers von der CV-Verbindung Amelungia an den Autor vom 21.07.2009.

65 UAW, PA EK, Lebenslauf (Typoskript) fol. 6f. Tatsächlich wird Klebel im Gesamtverzeichnis des Österreichischen CV aus dem Jahr 1935 nicht mehr als Mitglied der Verbindungen Amelungia und Pflug erwähnt, siehe OeCV. Die Ehrenmitglieder, Alte Herren und Studierenden des OeCV des österr. Cartell-Verbandes der katholischen deutschen Studentenverbindungen (Wien 1935).

66 Auch Spitaler (wie Anm. 64) berichtet von einem Anschlussfügel im CV. Die Amelungia sei aber als eindeutig ,katholisch-österreichische'Vereinigung gegründet [worden] und blieb in ihrer großen Mehrheit diesem Gründungsgedanken immer treu. Klebel hat in der zweiten Hälfte der 20er Jahre gemeinsam mit einigen anderen Bundesbrüdern versucht, diese Linie zu durchbrechen. Von den geschilderten Dimissionsverfahren, die gegen Klebel angestrengt worden sein sollen, wisse man seitens der Amelungia nichts. Diese müssten allenfalls vom Pflug angestrengt worden sein. Herbert Fritz, Reinhart Handl, Peter Krause, Gerhard Taus, Farbe tragen, Farbe bekennen 1938-1945 (Wien 1988) 386: „Wegen seiner großdeutschen Haltung muß er [sc. Klebel] bereits 1933 aus den (!) CV ausscheiden. “ Der erwähnte Eugen Lanske war Gründungsmitglied der Amelungia, siehe OeCV. Die Ehrenmitglieder (wie Anm. 65) 48. Zu ihm siehe Die geistige Elite Österreichs. Ein Handbuch der Führenden in Kultur und Wirtschaft, hg. v. Marcell KLANG (Wien 1936) 529, zu Josef Alois Tzöbl ebd. 918f. Erich Führer war 1934 Verteidiger der Juliputschisten Otto Planetta und Franz Holzweber, die wegen 
großdeutsche Verbindung aufzubauen, was ihm aber nicht gestattet wurde ${ }^{67}$. In den Konventsprotokollen der Amelungia findet sich hierzu kein Hinweis ${ }^{68}$. Die Spaltung zwischen katholisch-österreichischen und großdeutschen Amelungen führte schließlich zum Zerwürfnis. Klebel meint dazu I939: Darüber zerbrach im Februar 1930 die Amelungia und ich ging mit 23 anderen zur [I92 I gegründeten] Verbindung "Pflug“, bei welcher fast alle Mitglieder für den Anschluss eintraten ${ }^{69}$. Nach 1945 soll Klebel mehrmals probiert haben, in die CV-Verbindung Amelungia, die noch heute besteht, wieder aufgenommen zu werden ${ }^{70}$. Doch zurück zu Klebels Selbstzeugnis: I933 habe ich über Druck des vaterländischen Ministers Dr. L. [udwig] Strobl auch diese Korporation [Pflug, der Verf.] verlassen müssen ${ }^{71}$. Den Grund hierfür wird man sicherlich darin sehen können, dass der CV im Rahmen der Errichtung des Ständestaates eine Klärung der Verhältnisse in Bezug auf den Nationalsozialismus herbeiführen wollte ${ }^{72}$. Klebel meint im erwähnten Curriculum Vitae weiters, er habe 1927 die NSDAP kennen gelernt und am 9. II. I927 eine Rede des Führers gehört ${ }^{73}$. Seit Herbst 1932 habe er sich in Wien zudem für die "Jungfront" regelmäßig als Propagandaredner engagiert ${ }^{74}$. Unmittelbar an den Passus, in welchem er über seine Tätigkeit

Mordes zum Tod verurteilt wurden, siehe Gerhard Jagschitz, Der Putsch. Die Nationalsozialisten 1934 in Österreich (Graz/Wien/Köln 1976) 118f.; 172.

67 Gerhard Hartmann, Der CV in Österreich (Limburg-Kevelaer ${ }^{3} 2001$ ) 344; Siegfried Schieweck-Mauk, Lexikon der CV- und ÖCV-Verbindungen. Die Korporationen und Vereinigungen des Cartellverbandes der Katholischen Deutschen Studentenverbindungen (CV) und des Cartellverbandes der katholischen österreichischen Studentenverbindungen (ÖCV) in geschichtlichen Kurzdarstellungen (Gemeinschaft für deutsche Studentengeschichte, Köln 1997) 564f.

68 Spitaler (wie Anm. 64).

69 UAW, PA EK, Lebenslauf (Typoskript) fol. 7. So bezüglich des Übertritts zur Verbindung Pflug auch Spitaler (wie Anm. 64).

70 Ebd.: Ich selbst weiß, dass er (sc. Klebel) nach 1945 wiederholt versucht hat, zur Amelungia zurückzukommen. Dies wurde aber nie genehmigt, da seine Consemester immer auf seine NS-Vergangenheit verwiesen haben.

71 UAW, PA EK, Lebenslauf (Typoskript) fol. 7. Vgl. aber auch die Darstellung bei Karl Wolfgang Schrammel, Die Geschichte der Franko-Bavaria (Wien 1998) 79: „Während sich der Großteil der Neo-Pflüger rasch in die neue Korporation einlebte, blieb der deutschnationale Dr. Ernst Klebel ein Fremdkörper im Pflug. Durch seine Weltanschauung, die von einer positiven Einstellung gegenüber dem aufkommenden Nationalsozialismus geprägt war, entstand der Ruf des Pfluges, eine Verbindung von Nazis zu sein. Klebel schied mit wenigen anderen bereits 1933 wieder aus der Verbindung aus. “ Zu Strobl siehe Die geistige Elite (wie Anm. 66) 898-900.

72 Gerhard Popp, Der Cartellverband der katholischen deutschen Studentenverbindung (CV) in Österreich. 1864-1938 2. Organisation und Öffentlichkeitswirkung (masch. Diss. Wien 1980) 498: „, [...] der Nationalsozialismus konnte sich durch die Art der Anschlußforderung nicht durchsetzen."

73 UAW, PA EK, Lebenslauf (Typoskript) fol. 7.

74 Unklar ist, was Klebel damit meinte. Möglicherweise handelte es sich um die sogenannten „Katholischen Jungakademiker“, deren Mitglied Klebel war, siehe Institut für Zeitgeschichte der Universität Wien, Kt. Do 183, NL 10, Sammlung Theodor Veiter, Mappe 1, Liste der Mitglieder. Zu den „Jungakademikern“ und ihrer politischen Programmatik siehe Anton Staudinger, Zu den Bemühungen katholischer Jungakademiker um 
als Propagandist für den Anschluss informiert, berichtet er, auch seinen zahlreichen wissenschaftlichen Arbeiten die gleiche Richtung gegeben zu haben ${ }^{75}$. Schließlich bekennt sich Klebel zum Beitritt zur NSDAP und auch dazu, Informationen aus kirchlichen Kreisen weitergegeben zu haben ${ }^{76}$. Die Verquickung katholischer, deutschnationaler und nationalsozialistischer Ausrichtung wurde für Klebel nun ein Lebensthema, das ihn - zumindest beruflich - immer wieder einholen sollte. Im Hinblick auf seine akademische Karriere lag für ihn in diesen Jahren zunächst der Schwerpunkt auf dem Bemühen, die Verleihung der Venia legendi an der Universität Wien zu erreichen. Schon 1929 hatte er um ihre Erteilung angesucht. Die Habilitationskommission hatte neben der fachlichen auch seine persönliche Eignung zu prüfen. In zwei Sitzungen am 4. Juli I 929 und am 26. Februar 1930 untersuchte sie nun sehr eingehend [...], ob ein Grund vorhanden sei, der die Habilitation des Anwärters [...] ausschließen könnte. Die Kommission, der Wilhelm Bauer, Alfons Dopsch, Hans Hirsch, Friedrich Machatschek, Carl Ludwig Patsch, Heinrich von Srbik, Gustav Turba und Hans Uebersberger angehörten, entschied mit Stimmeneinhelligkeit [...], dass ein solcher Fall nicht gegeben sei, und empfahl am I 4. Januar I93 I, die Verleihung der Venia legendi ${ }^{77}$. Laut Eigenaussage Klebels in einem Brief an Ignaz Zibermayr, den Direktor des Oberösterreichischen Landesarchivs, von 1944 habe Dopsch allerdings versucht, seine Habilitation zu verhindern ${ }^{78}$. Tatsächlich scheint zwischen

eine ständisch-antiparlamentarische und deutsch-völkische Orientierung der Christlichsozialen Partei, in: Februar 1934. Ursachen - Fakten - Folgen, hg. v. Erich Fröschl, Helge Zoitl (Thema Zeitgeschichte 2, Wien 1984) 221-231, und Anton Staudinger, Austrofaschistisches „Österreich“-Ideologie, in: Austrofaschismus. Politik - Ökonomie - Kultur 1933-1938, hg. v. Emmerich TÁlos, Wolfgang Neugebauer (Politik und Zeitgeschichte 1, Wien $\left.{ }^{5} 2005\right)$ 28-52, bes. 31-33.

75 UAW, PA EK, Lebenslauf (Typoskript) fol. 7.

76 UAW, PA EK, Lebenslauf (Typoskript) fol. 7f.: Als Parteiverbot und Illegalität jede andere Rücksicht überflüssig machte, trat ich mit 1.6.1933 der NSDAP als Mitglied bei und stellte meine wissenschaftlichen Vorträge, die ich auch in den klerikalsten Zirkeln halten konnte wie meine Kenntnisse über die inneren Vorgänge in den klerikalen Kreisen, der NSDAP zur Verfügung. Davon abweichend gab Klebel in einem im UAR, Philosophisch-Theologische Hochschule, 186/2 Klebel, verwahrten Bogen, der wohl zum Diensteintritt an der PhilosophischTheologischen Hochschule auszufüllen war, handschriftlich auf der Rückseite unter Punkt 8. den 20.05.1938 als Eintrittsdatum an.

77 UAW, PA EK fol. 31. Zu Bauer siehe Martin Scheutz, Wilhelm Bauer (1877-1953). Ein Wiener Neuzeithistoriker mit vielen Gesichtern. „Deutschland ist kein ganzes Deutschland, wenn es nicht die Donau, wenn es Wien nicht besitzt“, in: Österreichische Historiker (wie Anm. 2) 247-281; zu Dopsch siehe Thomas Buchner, Alfons Dopsch (1868-1953). Die Mannigfaltigkeit der Verhältnisse, in : ebd. 155-190; zu Machatschek siehe den Nachruf von Gustav Fochler-Hauke in: Petermanns Geographische Mitteilungen 102 (1958) 1-5; zu Patsch siehe Österreichische Geschichtswissenschaft (wie Anm. 3) 309f.; zu Turba siehe ebd. 420; zu Uebersberger ebd. 421.

78 OÖLA, NL IZ, Schachtel 3, Klebel an Zibermayr, St. Pölten, 03.06.1944, fol. 2: Über Dopsch und seine Feindseligkeit gegen mich seit je her brauche ich ja nichts zu sagen; dass meine Habilitation an ihm fast gescheitert wäre, weißt Du. Zu Zibermayr siehe Österreichische Geschichtswissenschaft (wie Anm. 3) 471. 
Dopsch und Klebel kein gutes Verhältnis geherrscht haben. In einem Protokoll der Philosophischen Fakultät der Universität Wien unter Vorsitz des Dekans Oswald Menghin sind die Bemerkungen Dopschs über die persönliche Eignung Klebels festgehalten, was ein normaler Bestandteil des Habilitationsverfahrens war. Dopsch hielt dabei mit seiner vernichtenden Meinung nicht hinter dem Berg79. Das Verhältnis zwischen den beiden war offenbar vollkommen zerrüttet, obwohl Klebel bei Dopsch seine Abschlussarbeit am IÖG geschrieben hatte ${ }^{80}$. Was für Auswirkungen das auch immer gehabt haben mag, so fällt doch der lange Zeitraum (I929-I93I) zwischen Beantragung und Erteilung der Venia auf. Zudem wurde sie nur für mittelalterliche Geschichte, nicht aber auch für Historische Hilfswissenschaften verliehen. In der gleichen Sitzung des Jahres I929 war Klebel auch von Hans Uebersberger und Oswald Redlich, zu diesem Zeitpunkt noch Direktor des IÖG, scharf kritisiert worden ${ }^{81}$. Lange währte Klebels Dasein als Privatdozent jedoch ohnehin nicht. Aufgrund seines Bekenntnisses zu den Nationalsozialisten entzog ihm Unterrichtsminister Kurt Schuschnigg, so Klebel, am I. Oktober 1934 nämlich die Habilitation $^{82}$. Schuschnigg, der Klebel persönlich gekannt haben könnte, da dieser am 24. 4. 1932

79 UAW, PA EK, Protokoll der Philosophischen Fakultät, 04.07.1929, fol. 25: Er hat Eigenschaften die sehr unangenehm werden können. Unverträglich, Tratsche, böswillige Tratsche. Man hat ihn deswegen nirgends genommen, obwohl er sachlich extrem geeignet wäre. In Kärnten, Staatsarchiv, Hofbibl., Denkmalamt, Lehrkanzel Strzygowski. Hat auch in den Hist. Verein Unfrieden getragen. [...] Auch im Institut für Geschichtsforschung missfällt mir seine Tätigkeit. Macht immer Tratschereien. Vernaderung [Paul] Heigls, den er beschuldigt, nicht krank zu sein u. die Studentenkrawalle inszeniert zu haben. [...] 2. Die Berath[ung] solange zu vertagen, bis die Disziplinarsache Heigls erledigt ist. Machte sich in unerhörter Weise über [Emil von] Ottenthal lustig. - [Julius] Schlosser hat auch ein ähnliches Urteil. Paul Heigl, Bibliothekar und Assistent am IÖG, erstattete Selbstanzeige in dieser Sache, wie aus einem Schriftstück der Disziplinarkammer der Universität Wien vom 30.12.1929, in welchem Heigl freigesprochen wurde, hervorgeht, UAW, PA EK, fol. 42. Zu Heigl siehe Christina Köstner, Paul Heigl (1887-1945). Ein politisch engagierter Bibliothekar des Instituts für Österreichische Geschichtsforschung und der Nationalbibliothek Wien, in: Österreichische Historiker (wie Anm. 2) 569-595, zu Ottenthal Susanne Lichtmannegger, Emil von Ottenthal. Diplomatiker in der Tradition Theodor von Sickels und Julius von Fickers, in: ebd. 73-95. Mit dem Historischen Verein ist der Akademische Verein deutscher Historiker in Wien, dessen Gründungsmitglied Dopsch war, gemeint. Siehe dazu Walter Bogutr, Die Gründung des akademischen Vereines deutscher Historiker in Wien vor 25 Jahren. Ein Gedenkblatt nach persönlichen Erinnerungen, in: FS des akademischen Vereines deutscher Historiker in Wien. Hg. anlässlich der Feier des 25-jährigen Bestandes (Wien 1914) 3-6. Zu Schlosser siehe den Art. „Julius Alwin von Schlosser“, in: ÖBL 10 (Wien 1994) 218f.

80 UAR, Philosophisch-Theologische Hochschule, 186/2 Klebel, Lebenslauf (Typoskript) : Die Dissertation, wie die Institutsprüfungsarbeit, letztere bei Hofrat A. Dopsch über die Landgerichte Bayerns, wurden nicht gedruckt.

81 UAW, PA EK, Protokoll der philosophischen Fakultät, 04.07.1929, fol. 25. Uebersberger: Kl. hat eine unglückselige Natur, überall hineinzupatschen. Redlich, der auf die erwähnte Causa Heigl Bezug nahm: Ich sagte Kl., daß seine Anwesenheit im Institut [sc. dem IÖG] nicht willkommen sei.

82 UAW, PA EK, Lebenslauf (Typoskript) fol. 8. 
das Ehrenband Amelungiae bekommen hat ${ }^{83}$, hatte allerdings schon am 2. Juli 1934 in einem Schreiben an den Dekan der Philosophischen Fakultät, Adolf Franke, in Aussicht genommen, Klebel die Habilitation zu entziehen ${ }^{84}$. Von Bedeutung ist das Datum des Schreibens. Denn am 25. Juli 1934 wurde Bundeskanzler Engelbert Dollfuß im Zuge des Juli-Putsches ermordet ${ }^{85}$. Klebel soll die Ermordung von Dollfuß, so berichten Mitglieder seiner ehemaligen CV-Verbindung Amelungia, mit Wohlwollen zur Kenntnis genommen haben $^{86}$. Da die österreichischen Behörden seit Ende Mai von Planungen eines bevorstehenden Putsches wussten, dürften diese nun verstärkt gegen ihre Gegner vorgegangen $\operatorname{sein}^{87}$. Minister Schuschnigg argumentierte in zitiertem Schreiben auf dieser Linie: Der Genannte sympathisiert nach Informationen, welche dem Bundesministerium für Unterricht zugekommen sind, mit dem Nationalsozialismus und beurteilt aus dieser seiner Einstellung heraus, ohne aus derselben ein Hehl zu machen, grundsätzlich und zwar fachlich - betont die österreichische Bundesregierung [...]. Da Dr. Klebel für ein historisches Fach habilitiert ist, besteht im besonderen Masse die Gefahr, dass die erwähnte Gesinnung in seiner Unterrichtstätigkeit unmittelbar oder mittelbar mindestens bei Besprechung weitausladender geschichtlicher Probleme zum Ausdruck kommt und auf diesem Wege zu einer gleichgerichteten Beeinflussung der Studierenden oder zu Ruhestörungen führt. Das Professorenkollegium der Philosophischen Fakultät, welche sich damit befassen musste, nahm die Aberkennung zur Kenntnis. Eine etwaige Fürsprache für Klebel ist nicht bekannt beziehungsweise ging nicht in das in dieser Sache erstellte Protokoll ein, obwohl Klebel selbst davon spricht, dass sich alle möglichen Stellen für mich verwendet [haben], es waren Rektor und Dekan, weiters mein Chef, Hofrat v. Voltelini, sowie Herr Minister von Srbik wie Professor Hirsch bei SektionschefLöbenstein, der Dekan angeblich auch bei Schuschnigg, es hat sich auch der frühere Unterrichtsminister Dr. Czermak für mich verwendet, wie sie sehen erfolglos ${ }^{88}$. Von den Genannten hatte sich nur Srbik nachweislich für Klebel eingesetzt, wie aus einem Brief von diesem hervorgeht $^{89}$. Klebel konzipierte drei Tage darauf ein Dankeschreiben, in welchem er sich kämp-

83 OeCV. Die Ehrenmitglieder (wie Anm. 66) 50.

84 UAW, PA EK, Bundesminister Schuschnigg an Adolf Franke, Wien 02.07.1934.

85 Jagschitz, Putsch (wie Anm. 66) 114.

86 Mündliche Mitteilung Hermann Spitalers von der CV-Verbindung Amelungia vom 29.07.2009.

87 Jagschitz, Putsch (wie Anm. 66) 90f.

88 UAW, Professorenkollegium der Philosophischen Fakultät, Sitzungsprotokolle 1932/33-1934/35, fol. 478: Protokoll am 10. November 1934 über die Sitzung des Professorenkollegiums der philosophischen Fakultät der Universität Wien. Anwesende Professoren waren u.a. Otto Brunner, Dopsch, Hugo Hassinger, Richard Meister, Josef Nadler, Hans Przibram und Srbik. Ebd. fol. 480: Widerrufung der Zulassung des Dr. Ernst Klebel als Privatdozent für Geschichte des Mittelalters. Wird zur Kenntnis genommen. Die Aufzählung der Fürsprecher in Burkhard Klebel, NL EK, Brief Klebels an Anton Mell vom 06.10.1934. Zu Emmerich Czermak siehe den Art. „Czermak, Emmerich“, in: Österreich Lexikon 1, hg. v. Ernst Brucкмüller (Wien 2004) 234.

89 Burkhard Klebel, NL EK, Brief Srbiks an Ernst Klebel vom 05.10.1934: Ich möchte Ihnen nur als Beispiel mei- 
ferisch gab und weitere politische Zusammenstöße andeutete. Er gab zudem der Hoffnung auf ein politisches Erdbeben, also wohl einen erfolgreichen Putsch der Nationalsozialisten, Ausdruck und bat um Rat, ob Srbik beziehungsweise die Fakultät es für sinnvoll hielten, gegen die Aberkennung juristisch vorzugehen. ${ }^{90}$ Gegen den Entzug ging Klebel in weiterer Folge gerichtlich vor und wählte Arthur Seyß-Inquart zu seinem Anwalt ${ }^{91}$. Klebel verlor aber letztinstanzlich vor dem Bundesgerichtshof am 7. Dezember I935. Zum Verhängnis wurde ihm, dass er in dem Verfahren unumwunden zugab, Nationalsozialist zu sein und grundsätzlich und fachlich betont die österreichische Bundesregierung und die von ihr vertretene Innen- und Außenpolitik abfällig beurteilt. Einerseits belastete sich Klebel also selbst schwer, versuchte aber auch Milderungsgründe anzuführen. So habe er bei den katholischen Hochschulwochen in Salzburg Vorlesungen gehalten und sei gegen Irrtümer der preussisch-protestantischen Geschichtsauffassung und solche [Alfred] Rosenbergs aufgetreten ${ }^{92}$.

ner Wertschätzung sagen, daß ich vorgestern bei Staatssekretär [Hans] P.[ertner] war [...] und daß ich bei diesem Anlaß auch Ihre Angelegenheit zur Sprache brachte. Zu Pertner, Staatssekretär im Unterrichtsministerium, siehe ZajIC, Hirsch (wie Anm.13) 330f.

90 Burkhard Klebel, NL EK, Entwurf eines Briefes in Gabelsberger Kurzschrift von Ernst Klebel an Srbik vom 8.10.1934 auf der Rückseite des oben zitierten Briefes: Meine Sache ist ja nur eine kleine Teilphase der augenblicklichen Entwicklung in unserer Heimat, das (!) trotz der düsteren Ereignisse in diesem einen Jahr 1934 vielleicht noch Düsternis in ihrem Schoß birgt. Jene Kreise, die beim Herrn Bundeskanzler den Erlass gegen mich durchgesetzt haben, sind noch lange nicht am Ziel ihrer Wünsche; und nur ein positives Erdbeben, um diesen Vergleich zu äußern, kann sie abhalten, ihrem Ziel zuzustreben. Auch mein Geschick hängt mit dem gesamten Geschick unseres Landes und Volkes zusammen, ja gegenüber dem, was man hier in meiner Heimat eigentlich in Stadt und Land sehen und hören kann, ist [,] was mich betroffen hat, für den Augenblick sehr wenig. (...) Entschuldigen Sie, hoch verehrter Herr Minister, wenn ich sie noch mit einer Frage belästige. Als ich mich im Juli bei einigen juristischen Freunden nach der Rechtslage erkundigte, wurde mir gesagt, ich könnte nach Ablehnung meiner Einwendung durchs Min. [isterium] ans B [undes] gericht gehen und es wären sogar einige Aussichten auf Erfolg dabei. So gering ich dies einschätze, so möchte ich mir doch die Frage erlauben, ob die Fakultät vielleicht um der politischen Bedeutung der Sache willen ein Bundesgerichtsurteil herbei geführt sehen möchte und danach mich unterrichten. Für die Übertragung aus der Gabelsberger Kurzschrift danke ich Andreas Kloner.

91 UAW, PA EK, Lebenslauf (Typoskript) fol. 8. Burkhard Klebel, NL EK, Brief Arthur Seyß-Inquarts an Klebel vom 11.11.1934, bezüglich der Einbringung der Beschwerde beim Bundesgerichtshof: Sehr geehrter Herr Doktor! Im Besitze Ihrer geschätzten Zuschrift vom 13. d. M. samt Beilage erlaube ich mir mitzuteilen, dass ich die Beschwerde an den Bundesgerichtshof frist gerecht überreicht habe. Ich behalte mir weiteren Bericht vor und zeichne in vorzüglicher Hochachtung Arthur Seyß-Inquart. Zu Seyß-Inquart, der einer der österreichischen „Brückenbauer“ der Nationalsozialisten beim „Anschluss“ war, siehe Wolfgang Rosar, Arthur Seyss-Inquart in der österreichischen Anschlußbewegung (Wien Diss. 1969); Hanisch, Schatten (wie Anm. 8) 342-345; Broucek, Persönlichkeiten (wie Anm. 10) 1; Oliver Ratнкоцв, Die Rechts- und Staatswissenschaftliche Fakultät der Universität Wien zwischen Antisemitismus, Deutschnationalismus und Nationalsozialismus, in: Willfährige Wissenschaft. Die Universität Wien 1938-1945, hg. v. Gernot Heiss, Siegfried Mattr, Sebastian Meissl, Edith Saurer, Karl Stuhlpfarrer (Österreichische Texte zur Gesellschaftskritik 43, Wien 1989) 197-232.

92 Urteil des Bundesgerichtshofes im UAW, PA EK fol. 59-62, Zitat fol. 60. 
Es lag zur Gänze im Ermessen der Behörde, die Lehrbefugnis zu widerrufen. Dieses Ermessen war nur dadurch eingeschränkt, so der Spruch des Bundesgerichtshofs, dass der Widerruf an das Vorliegen wichtiger Gründe des öffentlichen Wohles ' [ge] knüpft sein musste ${ }^{93}$. Das Urteil war demnach politisch, sicher nicht fachlich motiviert. Klebel wird im Urteilsspruch zudem in die Nähe des Juliputsches 1934 gerückt, obwohl ihm expressis verbis keine Beteiligung unterstellt wird ${ }^{94}$. Klebel selbst sah sich nach dem „Anschluss“ jedenfalls als politisch Verfolgten. Der Entzug der Lehrbefugnis sei wegen einer Reihe von Artikeln in den Zeitschriften „Weg“, „Deutsche Einheit“ und „Volk und Reich“ erfolgt, wovon allerdings im Verfahren nicht die Rede ist ${ }^{95}$. Als Nationalsozialist - und als solcher hatte er sich vor Gericht bekannt - war er nun aber zur Persona non grata geworden. Wie weit Klebels Identifikation mit dem NS-Gedankengut ging, kann nicht gesagt werden. I 938 gibt Klebel an, zwischen I932 und I934 politische Berichte nach Deutschland geliefert zu haben und führt seine Tätigkeit für den Anschluß seit I925 in Wort und Schrift und seinen Kampf gegen den Legitimismus a ${ }^{96}$. Diese Aussagen sind nicht zuletzt auch im Kontext des politischen Umschwungs zu lesen. Klebel hob nun seine politische Tätigkeit im Sinne nationalsozialistischer Ideologeme sehr stark hervor. Allerdings sind einige schon angeschnittene Bereiche, die das persönliche Umfeld Klebels betreffen, hier noch kurz genauer auszuführen. Er hatte frühzeitig Kontakte zu Personen, die in die Verbrechen des NS-Regimes verstrickt waren. Klebels Mitautor aus der Zwischenkriegszeit, Friedrich Wimmer, war I938 Staatssekretär im Kabinett Seyß-Inquart und Sturmbannführer der SS, seit 1942 SS-Brigadeführer und von I 940 bis 1945 Generalkommissar im besetzten Holland ${ }^{97}$. Seyß-Inquart, Klebels Anwalt, gehörte als einer der bekanntesten und führenden Nationalsozialisten zu den 27 Hauptkriegsverbrechern ${ }^{98}$.

93 Ebd. Zitat fol. 60.

94 Ebd. fol. 61: Der Bundesgerichtshof musste aber auch beachten, dass es sich um eine infolge der aussergewöhnlichen politischen Verhältnisse notwendig gewordene Vorschrift handelt und dass die belangte Behörde gerade nach den Ereignissen des Sommers 1934 allen Grund zur besonderen Vorsicht hatte.

95 Es ist auch fraglich, ob dies inhaltlich argumentierbar gewesen wäre. In KLEBel, Siedlung (wie Anm. 51), argumentiert dieser zwar aus deutscher Perspektive (66: „Es ist Pflicht deutscher Geschichtsforschung, sie [sc. die Besiedlung der Ostalpenländer] ebenso im geschichtlichen Bewußtsein des Gesamtvolkes zu verankern wie die Taten des Deutschen Ritterordens in Ostpreußen altbekannt sind“), nationalsozialistische Propaganda findet sich hier allerdings nicht. Vgl. auch Gernot Heiss, Von Österreichs deutscher Vergangenheit und Aufgabe. Die Wiener Schule der Geschichtswissenschaft und der Nationalsozialismus, in: Willfährige Wissenschaft (wie Anm. 91) 39-76, hier 43.

96 ÖSta, AdR, GA Ernst Klebel, fol. 7.

97 Klebel, Wimmer, Chorgestühl (wie Anm. 15). Zu Wimmer siehe Otto H. Urban, „... und der deutschnationale Antisemit Dr. Matthäus Much“ - der Nestor der Urgeschichte Österreichs? Mit einem Anhang zur Urgeschichte in Wien während der NS-Zeit, 2. Teil (Archaeologia Austriaca 86, Wien 2002).

98 Literatur zu Seyß-Inquart in Anm. 91. 
Klebel hingegen war weiterhin auf seine akademische Karriere konzentriert. Der angesprochene Entzug der Habilitation hatte zunächst jedoch seine Ziele in weite Ferne rücken und für erreichbar Gehaltenes zu Makulatur werden lassen. Am 7. April I933 war Klebels Onkel Wilhelm Erben, der ordentlicher Professor für Geschichte des Mittelalters und Historische Hilfswissenschaften an der Universität Graz gewesen war, verstorben ${ }^{99}$. Anton Mell, der ein Ordinariat für österreichische Geschichte an derselben Universität inne hatte, wollte Klebel als Nachfolger Erbens durchsetzen, fragte bei diesem aber im September I 934 nach, was seine Habilitation genau umfasse und ob er, was Mell gerüchteweise gehört habe, eine Berufung nach Salzburg anzunehmen gedenke ${ }^{100}$. Klebel antwortete Mell ausführlich, eine Berufung war aber nunmehr unmöglich ${ }^{101}$, obwohl Klebel an anderer Stelle berichtet, auf dem Berufungsvorschlag für die Nachfolge Erbens gestanden zu sein ${ }^{102}$.

Klebels politische Position zwischen Rechtskatholizismus und Deutschnationalismus wurde bereits erwähnt. Als Klebel 1934 Österreich nun Richtung Deutschland verließ, soll sich umgekehrt sein Umgang mit ebendiesen katholischen Kreisen laut Eigenaussage negativ ausgewirkt haben. Denn Theodor Mayer habe ihm, so Klebel, während seiner Vertretungsprofessur in Frankfurt, und auch in Bezug auf eine Berufung nach Freiburg im Breisgau sehr geschadet, indem er ihn in die Nähe klerikaler Kreise gerückt habe ${ }^{103}$.

99 Siehe Österreichische Geschichtswissenschaft (wie Anm. 3) 116.

100 Am 24.09.1934 wandte er sich brieflich an Klebel: Verehrter Herr Kollege! Mit der Ausarbeitung eines Dreiervorschlags für die Besetzung der Lehrkanzel nach wld. Ihrem Onkel W. Erben beschäftigt, möchte ich Ihnen vertraulich mitteilen, daß ich beabsichtige auch Ihre Persönlichkeit hierbei in Betracht zu ziehen. Zunächst allerdings nur von meinem Standpunkte aus; den der Mitglieder der akad. Kommission 227, die erst im Laufe des Okt. zusammentreten dürfte, kenne ich nicht. [...] Außerdem erlaube ich mir die Frage, ob Ihre venia legendi für mittlere Geschichte und für historische Hilfswissenschaften lautet. Weiters, ob das „Gerücht" von Ihrer demnächst bevorstehenden Berufung an die Salzb. Universität begründet ist oder nicht. Siehe Burkhard Klebel, NL EK, Brief Mells an Klebel vom 24.09.1934. Eine Berufung nach Salzburg kam nicht zustande. Zu Mell siehe Gernot Oвersteiner, Anton Mell (1865-1940). „Homo styriacus“ und „deutsches Vaterland“, in: Österreichische Historiker (wie Anm. 2) 97-124.

101 Burkhard Klebel, NL EK, Brief Klebels an Mell vom 06.10.1934.

102 UAR, Philosophisch-Theologische Hochschule, 186/2 Klebel, Lebenslauf (Typoskript) : Mehrfach war ich auf Berufungslisten für Professuren, 1934 im Herbst in Graz [...].

103 OÖLA, NL IZ, Schachtel 3, Klebel an Zibermayr, St. Pölten 03.06.1944, fol. 3: Aus Mayers seitherigem Verhalten, seinen Briefen wie seinen Redereien, über mein Ungeschick'sehe ich bloß, dass ich ihm irgend ein sehr verwickelt gesponnenes Netz zerrissen haben muß. Das war kaum für mich günstig. [Karl Gottfried] Hugelmann meinte, Du wüsstest wahrscheinlich nicht, wie Mayer sich im Altreich gegen mich benahm. Schon als ich 1934 nach Frankfurt kam, fand es Mayer für nötig, den Rektor [Walter] Platzhoff darauf aufmerksam zu machen, , wie klerikal' ich sei. 1937 wollte das Min. (Engel) mich nach Freiburg auf [Julius von] Fickers Kanzel bringen. Der Rektor [Friedrich] Metz war dafür u. nach Angabe von Engel wie von Hugelmann, denen ich in der Hinsicht absolut vertrauen kann, weil's Engel aus den Akten, Hugelmann von Mayer selbst weiß, war es Mayer, der es mit allen Mitteln zu verhindern wusste. Zu Hugelmann siehe Österreichische Geschichtswissenschaft (wie Anm. 3) 197; zu Ficker siehe ebd. 122. 
Im Wintersemester I934/35 hatte Klebel die Vertretung für den Lehrstuhl für mittlere Geschichte und historische Hilfswissenschaften in Frankfurt am Main übernommen, wobei Voltelini einer seiner Fürsprecher gewesen sein dürfte ${ }^{104}$. Anfänglich waren die Reaktionen mancher deutschen Kollegen auch noch freundlich, wie etwa ein Brief Otto Riedners belegt ${ }^{105}$. Bald aber eckte Klebel auch hier an. Im Zusammenhang mit dem Wechsel nach Freiburg ist ein Briefwechsel zwischen dem Frankfurter Rektor und dem Freiburger Dekan erhalten. Dort heißt es, Mayer habe Klebel Walter Platzhoff für die Frankfurter Professur empfohlen ${ }^{106}$. Platzhoff meldete aber von sich aus starke Zweifel an Klebel an ${ }^{107}$. Der Rektor spielte zudem auf dessen katholische Sozialisation an. Er ist ein kirchlich gebundener Katholik, was auch in seiner Geschichtsauffassung und-betrachtung zum Ausdruck kommt ${ }^{108}$. Dies hing jedoch, wie gezeigt, nicht nachweisbar mit Bemerkungen Mayers zusammen. Klebel selbst schrieb I944, dass seine CV-Mitgliedschaft eine Beru-

104 Vom Gemeindeamt Kritzendorf (bei Wien), wo Klebel wohnte, ist aus dem lokalen Melderegister ein handschriftliches Bestätigungsschreiben vom 05.11.1934 erhalten, dass Klebel diesen Wohnsitz aufgebe, um nach Frankfurt zu gehen und hiebei eine Kiste und einen Koffer mit Büchern und Schriften wissenschaftlichen Inhalts mitnehme, was man wohl so interpretieren kann, dass Klebel zunächst keineswegs daran dachte, Österreich dauerhaft zu verlassen, siehe Burkhard Klebel, NL EK, Bestätigung der Gemeinde Kritzendorf. Siehe auch ÖSta, HHSta, NL Hans Voltelini 1, Mappe 1-14, unfoliiert: Schreiben Klebels an Voltelini, Frankfurt 10.11.1934: Nun haben also Ihre gütigen Bemühungen so weit Frucht getragen, dass ich am Bestimmungsort angelangt bin [...] und übermorgen meine Antrittsvorlesung halten werde.

105 Burkhard Klebel, NL EK, Brief Riedners an Klebel vom 16.11.1934: Lieber Freund, ich freue mich, dass Du so bald wieder einen Deinen Fähigkeiten und Neigungen entsprechenden Wirkungskreis gefunden hast und wünsch Dir, dass Dein Gerechtigkeits- und Wahrheitsstreben keine Enttäuschung erlebt, die über das einem jedem von uns beschiedene Maß hinausgeht. Zu Riedner siehe Albert Reiffer, Nachruf Otto Riedner, in: ZBLG 11 (1938) 159.

106 Archiv der Universität Frankfurt am Main (=UAF) Abt. 4 Nr. 1379, pag. 3, Brief Platzhoffs an den Dekan der Universität Freiburg Prof. Hans Oppermann vom 02.04.1937: Ich kannte ihn vorher nicht. Erkundigungen die ich über ihn einzog, namentlich bei ihrem jetzigen Kollegen Theodor Mayer lauteten in wissenschaftlicher Beziehung günstig. In dieser Hinsicht und als Lehrer hat er sich sehr bewährt. Er ist in der Wiener Schule sehr gut ausgebildet, besitzt in seinem Arbeits und Interessenkreis eine nicht alltägliche Vielseitigkeit und versteht es auch seine Vorlesungen und Uebungen anschaulich zu gestalten und Resonanz bei den Studenten zu finden.

107 Ebd. pag. 3: Kl. ist sehr von sich eingenommen, seine Umgangsformen liessen mehr als in einer Beziehung zu wünschen übrig und wie hier ist es auch an anderen Orten zu Misshelligkeiten gekommen. Ich fühle mich verpflichtet, Ihnen dies mitzuteilen, damit Sie keine Enttäuschung erleben.

108 Platzhoff relativiert dann allerdings seine ablehnende Haltung im selbigen Brief leicht, ebd.: Ich möchte aber nochmals betonen, dass ich ihn nach seinen wissenschaftichen Leistungen und seiner weltanschaulichen Einstellung für einen konfessionell gebundenen Lehrstuhl als geeignet ansehe. Klebel lag mit seiner Vermutung demnach nicht falsch, dass sein Katholizismus bei der Ablehnung seiner Tätigkeit, eine Rolle spielte. Gegenüber Voltelini meinte er: Ich hoffte ja, bei einer Besetzung der F. [reiburger] Kanzel Aussichten zu haben [...]. Ende Jänner kam ich auf einmal durch einen verwickelten Zufall darauf, dass die Historiker der Univ. mich nicht haben wollten, weil ich Katholik war, siehe Brief Klebels an Voltelini, Berlin vom 15.03.1935, ÖSta, HHSta, NL Hans Voltelini 1, Mappe 1-14, unfoliiert. 
fung im Dritten Reich bisher unmöglich gemacht habe ${ }^{109}$. Mayer kamen die geschilderten Gerüchte später zu Ohren. Er verwahrte sich Klebel gegenüber dagegen in extrem scharfem Ton ${ }^{110}$. Tatsächlich war Klebel dem organisierten akademischen Laienkatholizismus auch in Deutschland treu geblieben. In Österreich war er I933, wie erwähnt, aus dem CV ausgeschlossen worden, der sich nun als ÖCV konstituierte und von den deutschen Verbindungen abspaltete. In Deutschland trat Klebel allerdings erneut einer Verbindung bei beziehungsweise war schon längst Mitglied einer solchen. Es ist bekannt, dass Klebel Mitglied der CV-Verbindung Bavaria-Berlin war. Naheliegend wäre ein Eintrittsdatum nach dem Umzug nach Deutschland (1934). Im Regensburger Universitätsarchiv finden sich im Nachlass Klebels dazu allerdings Unterlagen, die zeigen, dass er schon I923, im Jahr seines Beitrittes zur Amelungia, zur Bavaria-Berlin gestoßen war ${ }^{111}$. 1937 wollte Klebel offenbar nochmals zurück an die Universität Frankfurt, was nicht gelang, da sich sowohl die Philosophische Fakultät wie auch Rektor Walter Platzhoff aus Gründen, die Klebels fehlende Teamfähigkeit betrafen, sowie aufgrund seiner fachlichen Spezialisierung dage-

109 OÖLA, NL IZ, Schachtel 3, Brief Klebels an Zibermayr vom 03.06.1944, fol. 8: Denn das Min. hat meinen Professorentitet 1942 mit Hinweis auf meine Zugehörigkeit zum CV. abgelehnt. Und das dürfte durch die Parteikanzlei gegangen sein. Ich kann also im 3. Reich keine Carriere machen mit und ohne Mayers Wohlwollen.

110 NÖLA, NL EK, K. 6, Korrespondenz, Mappe 4 (Theodor Mayer), Brief Mayers an Klebel vom 15.06.1939: [...] dass ich den Hauptwiderstand geleistet habe, muss doch wohl ein Irrtum sein. Es war überhaupt kein „Hauptwiderstand" zu leisten, Sie sind niemals ernstlich in Frage gekommen. Sicher ist aber wohl, daß ich dabei ein Haupthindernis war, denn es wäre ganz ausgeschlossen gewesen, dass man zwei Österreicher nebeneinander gesetzt hätte. Was Ihnen Herr Platzhoff erzählt hat, weiß ich nicht. Wohl aber weiß ich, dass ich überhaupt Herrn Platzhoff auf Sie hingewiesen habe. Sie wären wohl ohne diese Empfehlung nicht nach Frankfurt gekommen. Es ist also das genaue Gegenteil richtig. [...] Es ist nicht meine Schuld, dass Sie in Frankfurt, dann in Berlin und Würzburg Schwierigkeiten gehabt haben.

111 UAR, Philosophisch-Theologische Hochschule, 186/2, Klebel: W. Kessel, Personalia, in: Academia 54/2 (1961) 67: Der scientia gehörte sein nie ermüdender Geist, der religio und der amicitia aber das Herz dieses vorbildlichen Christen und CVers. Ihm wurde der 1923 vollzogene Beitritt zu Bavaria-Berlin zu einem Lebensereignis. Er hing der Lebensgemeinschaft mit ganzer Seele an. Stets trat er in besonderem Maße für die Aktiven ein, deren aus dem Zeitgeschehen entspringende Probleme er stets erspürte und geistig klären half, die er aber auch mit Rat und Tat unterstützte. Peter Muschol, Brief an den Autor vom 18.05.2010, gibt zudem weitere Hinweise bezüglich Klebels CV-Mitgliedschaften. Klebel scheine im Bavaren-Verzeichnis mit Stand 01.01.1934 nicht auf, allerdings heiße es im ersten Gesamtverzeichnis des CV nach der Wiederbegründung (1955, Seite 76) [...] : K.D.St.V. [Katholische Deutsche Studentenverbindung im CV] Bavaria/Berlin, II. Alte Herren, A. Urphilister: 23.23.11 Klebel, Ernst, Dr. phil. a.o. Prof. d. Gesch., Maxstr. 15; Pf, Rup; (Am). Am 20.06.1953 hatte die am 06.06.1947 in Regensburg gegründete K.D.St.V. Rupertia Klebel ihr Band verliehen. [...] Im Gesamtverzeichnis 1958 wird er nicht genannt, im GV [Gesamtverzeichnis] 1961 meldet die Bavaria Berlin auf der Seite 876 unter der Rubrik UNSERE TOTEN: 23 Klebel, Ernst, Dr. phil., Hochschul-Prof. (61). Klebel selbst gibt ein Eintrittsdatum in den C.V. BERLIN (GETARNT ALS SPORT-KLUB) 1936 an, siehe Burkhard Klebel, NL EK: Meldebogen auf Grund des Gesetzes zur Befreiung von Nationalsozialismus und Militarismus vom 05.03.1946, r. Nr. 2, e. 
gen aussprachen ${ }^{112}$. Klebel selbst gibt in einem später verfassten tabellarischen Lebenslauf aber an, I937 als praktizierender Katholik nicht mehr beschäftigt worden zu sein ${ }^{113}$.

Neben den Versuchen, eine Professur zu erhalten, ist noch auf die finanzielle Unterstützung Klebels durch die Notgemeinschaft der deutschen Wissenschaft und ihre Abteilung der Österreichisch-Deutschen Wissenschaftshilfe, das heißt der Deutschen Forschungsgemeinschaft (DFG), hinzuweisen. Zwischen dem I3. November I934 und dem 24. März 1937 sind elf Schreiben der DFG erhalten, die Klebel jeweils Stipendien für die Bearbeitung des Schwabenspiegels zusprachen. Bereits das zweite Schreiben ist gezeichnet von Dr. Suchenwirth ${ }^{114}$. Es handelt sich dabei um Richard Suchenwirth, der am 4. Mai 1926 in den Wiener Sophiensälen die österreichische Hitlerbewegung (NSDAP) mitbegründet hatte, I 934 aus Österreich geflohen, amtierte er als Standartenführer der Österreichischen Legion sowie als Geschäftsführer der Reichsschrifttumskammer ${ }^{115}$. Er arbeitete im Rahmen der Österreichisch-Deutschen Wissenschaftshilfe ehrenamtlich als Referent der DFG und versorgte illegale Nationalsozialisten mit Stipendien ${ }^{116}$. Klebel

112 UAF Abt. 4 Nr. 1379, pag. 4, Schreiben (Abschrift, gezeichnet Glunz) der Philosophischen Fakultät der Universität Frankfurt an den Reichs- und Preußischen Minister für Wissenschaft, Erziehung und Volksbildung vom 29.04.1937: Die Fakultät hat auch seinerzeit, als Herr Klebel den einen Lehrstuhl für Geschichte hier vertrat, trotz der Vorzüge dieses Dozenten nicht zu der Ueberzeugung gelangen können, daß dieser sich in das Ganze gut eingefügt und hervorragend bewährt habe. Allerdings heißt es ebendort zuvor: Ein Bedürfnis nach Erteilung eines Lehrauftrages für Siedlungs- und Verfassungsgeschichte Bayerns und Oesterreichs besteht bei der Fakultät nicht. Fakultät und Universität haben im Einvernehmen mit der Stadt Frankfurt vielmehr stets Wert darauf gelegt, die Verbundenheit gerade mit der rhein-mainischen Landschaft auch in der Forschungsrichtung eines ihrer Historiker zum Ausdruck kommen zu lassen [...]. In der Sache ähnlich klingt das Schreiben Platzhoffs an denselben Minister vom 30.04.1937, siehe UAF Abt. 4 Nr. 1379, pag. 4.

113 UAR, Philosophisch-Theologische Hochschule, 186/2 Klebel: Lebenslauf (Typoskript). Terminus post quem ist das Jahr 1957, was sich aus dem ebendort angeführten, summarischen Schriftenverzeichnis ergibt.

114 Burkhard Klebel, NL EK: Typoskripte der Notgemeinschaft der Deutschen Wissenschaft, Deutsche Forschungsgemeinschaft an Klebel vom 13.08.1934, 22.10 .1934 (gezeichnet: Dr. Suchenwirth), 13.11 .1934 (gezeichnet: Dr. Suchenwirth, Herzliche Grüße), 13.11.1935, 07.03.1936, 14.3.1936 (gezeichnet: Suchenwirth), 10.06.1936 (gez. Suchenwirth.), 10.06.1936 (gez. Suchenwirth), 29.08.1936, 08.09.1936 (gez. Suchenwirth), 12.12.1936, 24.03.1937.

115 Art. Sophienbad, in: Historisches Lexikon Wien 5: Ru-Z, hg. v. Felix Czeıke (Wien 1997) 252. Suchenwirth war Historiker und hatte u.a. folgende Studien verfasst: Deutsche Geschichte. Von der germanischen Vorzeit bis zur Gegenwart (Leipzig 1937); Das Tausendjährige Österreich (München 1937); Das Buch von der deutschen Ostmark (Leipzig 1938). Zur Forschungsgemeinschaft siehe Notker Hammerstein, Die deutsche Forschungsgemeinschaft in der Weimarer Republik und im Dritten Reich. Wissenschaftspolitik in Republik und Diktatur 1920-1945 (München 1999) und vor allem Sören Flachowsky, Von der Notgemeinschaft zum Reichsforschungsrat. Wissenschaftspolitik im Kontext von Autarkie, Aufrüstung und Krieg (Studien zur Geschichte der deutschen Forschungsgemeinschaft 3, Stuttgart 2008). Beide Studien erwähnen Suchenwirth allerdings nicht.

116 Schriftliche Auskunft von Sören Flachowsky (Berlin) vom 27.09.2010: Suchenwirth war von der DFG mit der ehrenamtlichen Leitung der Österreichisch-Deutschen Wissenschaftshilfe betraut worden. Er war für die "politische 
kannte ihn schon aus der Zeit vor $1934^{117}$. In einem Schreiben der Notgemeinschaft der Deutschen Wissenschaft vom 22. Oktober 1934 teilte ihm Suchenwirth zwar mit, dass aufgrund einer Verfügung der Devisenbewirtschaftungsstelle vom 20. Oktober I934 [...] die Genehmigung zum Erwerb von Devisen nicht mehr erteilt worden [sei]. Das stellte insofern ein Problem dar, da Klebel damals noch in Kritzendorf bei Wien lebte. Suchenwirth fügte jedoch handschriftlich hinzu: Bemühe mich noch um eine günstig[e] Regelung, fürchte aber Mißerfolg! ${ }^{118}$ Keine drei Wochen später war Klebel allerdings ohnehin in Frankfurt und bekam sein Stipendium bewilligt ${ }^{119}$. Beide kannten sich demnach mit Sicherheit verhältnismäßig gut.

Nach dem „Anschluss“ I 938 wurde zudem der Widerruf der Zulassung Klebels als Privatdozent am 3I. Oktober I938 außer Kraft gesetzt ${ }^{120}$. Er wurde zudem zum Dozenten neuer Ordnung ernannt ${ }^{121}$. Eine universitäre Karriere gelang Klebel in der „Ostmark“ aber nicht mehr, obwohl das sein erklärtes Ziel gewesen sein dürfte. Denn ein Extraordinariat für historische Hilfswissenschaften in Berlin, das ihm vor dem 30. Juli 1938 angeboten worden

Würdigkeit" der von der DFG geförderten Personen verantwortlich. Siehe dazu auch BAB R 73/13476, Brief von Prof. Dr. Richard Suchenwirth (Mitglied des Reichskultursenats und Rektor der Hans Schemm-Hochschule für Lehrerbildung in Pasing vor München) an das Auswärtige Amt, z. Hd. Herrn Konsul Rother vom 06.04.1936: Betr. : Österreichisch-Deutsche Wissenschaftshilfe. Die Österreichisch-Deutsche Wissenschaftshilfe bittet wie im vergangenen Jahr auch im kommenden um Förderung ihrer Zwecke. Sie unterstützt in Österreich nationale junge Forscher, die ihrer nationalsozialistischen Einstellung wegen keine Anstellung bekommen oder eine solche verloren haben. Nur durch die Stipendien, die die Österreichisch-Deutsche Wissenschaftshilfe verleiht, ist es diesen Wissenschaftlern möglich, im Lande zu bleiben. Mit Rücksicht auf die große Gefahr der nach Österreich zielenden kulturpolitischen Bestrebungen Italiens, Frankreichs, der Tschechoslowakei und der deutschfeindlichen Haltung der österreichischen Regierung ist es ein dringendes Gebot, die nationale Wissenschaft und ihre jungen Kräfte in Österreich zu erhalten. Der gesamtdeutschen Idee kann in Österreich am besten und unauffalligsten durch kulturpolitischen Einsatz geholfen werden. Die Österreichisch-Deutsche Wissenschaftshilfe ist sich dieser Aufgabe dem Nationalsozialismus gegenüber voll bewusst. Die Mittel der Österreichisch-Deutschen Wissenschaftshilfe werden vornehmlich für die Verleihung von Forschungsstipendien, weniger für Druckzuschüsse gewährt, so dass sie unmittelbar der Lebenshaltung zugute kommen. Mit Rücksicht auf die grosse aussenpolitische Bedeutung der Zwecke der Österreichisch-Deutschen Wissenschaftshilfe bitten wir das Auswärtige Amt, womöglich die Zuschüsse des vergangenen Jahres auf RM 40.000,-- [...] aufrunden zu wollen. Für eine möglichst baldige Bewilligung wäre die Österreichisch-Deutsche Wissenschaftshilfe besonders dankbar, damit sie erfolgreich an die Weiterarbeit schreiten kann. Suchenwirth erwähnt hier allerdings nicht, dass er offenbar auch illegalen österreichischen Nationalsozialisten in NS-Deutschland Stipendien gewährte.

117 ÖSta, AdR, GA Ernst Klebel, Personalfragebogen, fol. 7: Angaben des Antragsstellers über sonstige Tätigkeit für die NSDAP: [...] Politische Berichte 1932-34 an [...] Dr. R. Suchenwirth.

118 Burkhard Klebel, NL EK: Notgemeinschaft der Deutschen Wissenschaft, Deutsche Forschungsgemeinschaft an Klebel vom 22.10.1934.

119 Ebd. Notgemeinschaft der Deutschen Wissenschaft, Deutsche Forschungsgemeinschaft an Klebel vom 13.11.1934.

120 UAW, PA EK: BMI an das Rektorat der Universität Wien, Wien vom 31.10.1938, fol. 73.

121 UAW, Personalstandesblatt Ernst Klebel, fol. 76. 
sein muss, hatte er abgelehnt ${ }^{122}$. Klebel nahm stattdessen 1939 eine Stelle am Stadtarchiv St. Pölten $a^{123}$. I94I setzten sich einige seiner Wiener Kollegen vergebens beim Reichsminister für Wissenschaft, Erziehung und Volksbildung Bernhard Rust um eine außerplanmäßige Professur für ihn ein. Namentlich waren dies Otto Brunner, Wilhelm Bauer, Heinz Zatschek und Heinrich von Srbik ${ }^{124}$. Die Fürsprache dieser systemkonformen Historiker nützte Klebel nichts. Denn nun wurde ihm seine Mitgliedschaft im CV zum Verhängnis. Beinahe ein Jahr sollte vergehen, ehe das REM gegen Klebel entschied und ein Abschreiben sandte: Mit Rücksicht darauf, dass KLEBEL dem Österreichischen CV angehört hat und wirkliche Verdienste in politischer Hinsicht, die eine Ausnahme rechtfertigen könnten, nicht vorliegen, sehe ich mich im Einvernehmen mit dem Leiter der Partei-Kanzlei veranlasst, seine Ernennung zum apl. Professor vorerst zurückzustellen. Ich werde bei gegebener Veranlassung auf die Angelegenheit zurückkommen ${ }^{125}$. Klebel führte das nach Kriegsende ins Treffen ${ }^{126}$. Während des Krieges war seine Erklärung, warum ehemalige Österreicher kaum zu Ordinarien berufen worden seien, anders ausgefallen. Mehrfach habe ich im Altreich bemerkt, dass die Art von Wissenschaft, die wir im Institut [IÖG] gelernt haben, jener Form, wie sie von Berlin ausgeht, und bei den meisten Trägern derselben den Charakter einer Art Apologetik annimmt, wesentlich überlegen ist. Deshalb will man ja auch keinen von uns im Altreich dulden ${ }^{127}$.

Von seiner Position als Archivar in St. Pölten versuchte er nun, nach dem Tod Hirschs Einfluss auf die Nachfolge der Leitung des IÖG zu nehmen. Ich war in den letzten I4

122 Der Terminus ante quem ergibt sich aus einem Schreiben von Hans Hirsch an Heinrich von Srbik, siehe Srbik, Korrespondenz (wie Anm. 13) Nr. 315, Wien, 30.07.1938, 493 : Er hätte das Extraordinariat für historische Hilfswissenschaften in Berlin haben können, das anzunehmen sogar ich ihm riet. Warum tat er es nicht? Jetzt muß er eben nehmen, was ihm geboten wird.

123 Österreichische Geschichtswissenschaft (wie Anm. 3) 220.

124 UAW, PA EK, fol. 91 und 99-101.

125 Ebd. fol. 102, 11.06.1942. Klebel las weiterhin nur als Dozent an der Universität Wien, siehe die autobiografische Skizze Heinrich Fichtenau, in: Recht und Geschichte. Ein Beitrag zur österreichischen Gesellschafts- und Geistesgeschichte unserer Zeit, hg. v. Hermann Baltl, Nikolaus Grass, Hans Constantin Faussner (Studien zur Rechts-, Wirtschafts- und Kulturgeschichte 14, Sigmaringen 1990) 43-57, hier 49.

126 Burkhard Klebel, NL EK: Meldebogen auf Grund des Gesetzes zur Befreiung von Nationalsozialismus und Militarismus vom 05.03.1946 r., Nr.14: JEDERZEIT PRAKT KATHOLIK; ALS SOLCHER VOM $V$.[ÖLKISCHEN] B.[EOBACHTER] FEB. 32 \& JAN 36 BEZEICHNET; PROF: TITEL 1932 DESHALB VERWEIGERT; ALS GEGNER DER NATIONALITÄTENPOLITIK DER NAZI VERWENDUNG ALS SPEZIALIST 1941-2 SABOTIERT. Auch Fritz Posch, in: Recht und Geschichte (wie Anm. 125) 197-219, hier 208, erwähnt, dass Klebel seine katholische Ausrichtung geschadet habe, nämlich dass „,...] damals aber auch Ernst Klebel [...] froh sein mußte, einen Stadtarchivdirektorenposten zu erreichen, nachdem er als CVer vor seinen Bundesbrüdern als Anschlußfreund nach Deutschland geflüchtet, dort aber wieder bei den Nazis in Ungnade gefallen war [...]“.

127 AAVČR, NL Heinz Zatschek, Brief Klebels an Zatschek vom 19.09.1940. Zu Zatschek siehe Karel HruZA, Heinz Zatschek (1901-1965). „Radikales Ordnungsdenken“ und „gründliche, zielgesteuerte Forschungsarbeit“, in: Österreichische Historiker (wie Anm. 2) 677-792. 
Tagen in München und Würzburg und hörte dort und auch gestern in Wien nur, dass [...] $D u$ [d.h. Heinz Zatschek] der Einzige wärest, der hier diesen Forderungen [die Leitung des Instituts im Sinne von Hirsch] entspräche. Die Angriffe des Herrn [Ernst] Zipfel gegen das Institut glaubt man in Wien und schon regen sich die alten Empfindlichkeiten. Man steht auf einmal einer von [Wilhelm] Bauer schlau vorgebrachten Kandidatur von Theodor Mayer gegenüber und untergräbt damit die im Kampf gegen Zipfel errungene Position selbst. Ich konnte den Eindruck nicht los werden, dass es Bauer gelungen ist, auch auf Srbik, scheinbar auch auf Brunner Eindruck zu machen. Ich kann nichts anderes tun, als Dir dieses geradeaus mitzuteilen und Dich zu bitten, im Interesse der Sache, der Erhaltung des Instituts, alles zu tun, um die Empfindlichkeiten, die gegen Dich [...] bestehen, zu überwinden, und Dich doch durchzusetzen. Eine neue und schwächere Auflage des Institutes Dopsch in Mayers Person schiene nur eine außerordentliche Schwächung unserer wissenschaftlichen Stellung ${ }^{128}$. Es kamen hier einmal mehr die alten Vorbehalte gegen Dopsch und dessen Schüler Mayer zum Durchbruch, wobei unklar bleibt, ob Mayer die Institutsdirektion überhaupt angestrebt hatte $^{129}$. Aber auch gegen andere hatte Klebel in diesem Zusammenhang ernste Bedenken, die er Zatschek gegenüber äußerte. Habe am Mittwoch erfahren, dass [Edmund Ernst] Stengel die Belassung der Diplomata-Abteilung [der MGH] an Deine Berufung geknüpft habe; angeblich solle Brunner Institutsvorstand werden, Mayer habe andere Pläne gefasst. Soweit wären die Dinge in Ordnung. Es spukt noch die Gefahr, dass daneben Percy [Ernst] Schramm oder [Hermann] Heimpel berufen werden; der erstere muß unbedingt verhindert werden, sonst wird Wien eine Filiale der unerfreulichen Gruppe um [Albert] Brackmann herum $^{130}$. Mit ziemlicher Sicherheit hatte Klebel keinerlei Einfluss auf die Nachfolge in der

128 Ebd. Brief Klebels an Zatschek vom 19.09.1940. Wenig später sprach sich Klebel Zatschek gegenüber erneut gegen Mayer aus. Ebd. Brief vom 03.10.1940: Ich war überrascht, auch im Staatsarchiv die gleiche BauerMayer Stimmung vorzufinden wie bei Srbik. Da ich mit Brunner seit Jänner 1939 nicht mehr gesprochen habe, weiß ich nicht, welche Position er in der Richtung und Stimmungsmache einnimmt. Die Version, am besten wäre eine Besetzung Brunner-Bauer, habe ich auch schon gehört. Zu Zipfel, Generaldirektor der preußischen Staatsarchive und Direktor des Reichsarchivs Potsdam, der nach dem „Anschluss“ die österreichische Archivorganisation neu zu ordnen gedachte, siehe Hartmut We Ber, „Heimkehr ins Reich“ unter Erhaltung der Selbständigkeit? Ludwig Bittners verlorener Kampf um eine Generaldirektion der österreichischen Archive, in : Österreichs Archive unter dem Hakenkreuz (MÖSTA 54, Wien 2010) 73-102, bes. 85-87.

129 Stoy, Institut (wie Anm. 2) $242 \mathrm{f}$.

130 AAVČR, NL Heinz Zatschek, Brief Klebels an Zatschek vom 13.10.1940. Stengel war seit 1937 Präsident der MGH in Berlin und hatte durch die Tatsache, dass am IÖG eine Arbeitsstelle der Monumenta angesiedelt war, einen gewissen Einfluss auf Personalentscheidungen an diesem Institut. Zu ihm siehe Heinrich Appelt, Edmund Ernst Stengel, in: Almanach der ÖAW 119 (1969) 387-391. Zu Schramm siehe David Tнiмme, Percy Ernst Schramm und das Mittelalter. Wandlungen eines Geschichtsbildes (Schriftenreihe der Historischen Kommission bei der Bayerischen Akademie der Wissenschaften 75, Göttingen 2006); zu Heimpel siehe Klaus P. Sommer, Eine Frage der Perspektive? Hermann Heimpel und der Nationalsozialismus, in: Historisches Denken und gesellschaftlicher Wandel. Studien zur Geschichtswissenschaft zwischen Kaiserreich 
Direktion des IÖG, die schließlich Brunner bekam. Durch seine Vorgehensweise hatte er jedoch viele der einflussreichen deutschen Historiker angegriffen, die davon früher oder später auch erfahren haben mögen. Anlass hatte dazu keiner bestanden.

Nach Kriegsende arbeitete Klebel als Mitarbeiter des Südost-Instituts. Zuvor hatte er in den Jahren I943, I944 und I945 jeweils einen dreimonatigen Urlaub vom Archivdienst in St. Pölten bekommen, um an der zweiten Auflage seiner „Siedlungsgeschichte des Deutschen Südostens" arbeiten zu können. Dieser Arbeit widmete er sich auch I945 in Arbing, einem Ortsteil Osterhofens (Landkreis Deggendorf, Niederbayern), wo das Südostinstitut sein Ausweichquartier hatte. Während dieses Aufenthaltes ging der Zweite Weltkrieg zu Ende und Klebel beschloss, in Deutschland zu bleiben ${ }^{131}$. Von dort schrieb er an seinen Kollegen Zibermayr. Die Dinge stünden nun so, daß ich weiter hier zu bleiben gedenke, ich habe zu viele "gute Freunde“, um andere Wege zur Zeit zu wählen ${ }^{132}$. 1947 hielt Klebel Vorträge beim Christlichen Bildungswerk Passau ${ }^{133}$. I948 bekam er von Max Spindler den Auftrag für die Fortsetzung der Arbeiten am Historischen Atlas von Bayern und konnte 1949 schließlich eine Stelle im Stadtarchiv Regensburg antreten ${ }^{134}$. I95 I erteilte ihm dann das Bayer. Staatsministerium für Unterricht und Kultus [...] für das S.S. I95I einen 2 stündigen Lehrauftrag [...] für Geschichte an der Philosophisch-Theologischen Hochschule in Regensburg ${ }^{135}$. 1953 wurde Klebel schließlich an diese Hochschule als Ordinarius für Allgemeine Geschichte berufen, obwohl der erhaltene Dreiervorschlag belegt, dass Klebel hinter Otto Meyer an zweiter Stelle gereiht war. Wie es dennoch zu seiner Berufung kam, muss dahingestellt bleiben ${ }^{136}$.

und deutscher Zweistaatlichkeit, hg. v. Tobias Kaiser, Steffen Kaudelka, Matthias Steinbach (Berlin 2004) 199-223; zu Brackmann siehe Günther Franz, Albert Brackmann, in: Biographisches Wörterbuch zur deutschen Geschichte 1 (Augsburg 1995) 338.

131 UAR, Philosophisch-Theologische Hochschule, 186/2 Klebel, Lebenslauf: Während des Urlaubs 1945, den ich nach Arbing bei Osterhofen, Ndb. erhalten hatte, wo das Institut eine Ausweichstelle hatte, kam der Zusammenbruch, ich blieb weiter in Arbing [...].

132 OÖLA, NL IZ, Schachtel 3, Klebel an Zibermayr, Zainach [Ortsteil der Gemeinde Osterhofen] vom 29.08.1946.

133 Ebd. Klebel an Zibermayr, Zainach 09.01.1947.

134 UAR, Philosophisch-Theologische Hochschule, 186/2, Klebel.

135 Burkhard Klebel, NL EK, Schreiben des Rektors der Philosophisch-Theologischen Hochschule Heinz Fleckenstein an Klebel vom 25.04.1951.

136 UAR, Philosophisch-Theologische Hochschule, 158 Nr. 4, Berufungsakten: Vorschlag an das Ministerium vom 13.12.1951. Nach ausführlichen Vorbesprechungen in der Sitzung vom 7.11.51 hat das Kollegium in der Sitzung vom 12. Dezember nach eingehender Beratung folgende Beschlüsse gefaßt: [...] Für die erledigte Professur für Geschichte wurde folgende Vorschlagsliste mit Mehrheit beschlossen: 1. Otto Meyer, 2. Ernst Klebel, 3. Ernst Walter Zeeden. Zu Meyer vgl. Gerhard Zimmermann, Zur dankbaren Erinnerung an Herrn Universitätsprofessor Dr. Dr. h.c. Otto Meyer, in: Historischer Verein Bamberg. Bericht 136 (2000) 7-9, und Peter Johanek, Nachruf Otto Meyer, in: DA 56 (2000) 843-845. 
Ernst Klebel verstarb I96I in Regensburg. In Gottfried Opitz, dem Geschäftsführer der MGH (1949-1969) fand Ernst Klebel nach seinem Tod einen engagierten Advokaten ${ }^{137}$. Es werden Früh- und Spätwerk gewürdigt und spezielle Forschungsinteressen Klebels aufgezählt. Mit ihm habe die „deutsche Mittelalterforschung einen markanten Vertreter verloren“. Karl Ginhart schrieb an den Regensburger Rektor mit großem Wohlwollen über Klebel, den er noch aus der Zeit des Kunstgeschichtestudiums in Wien gekannt habe ${ }^{138}$. Auch der Kodikologe und Paläograf Bernhard Bischoff tat dies. Er würdigte Klebels Quellenkenntnis, deutete aber auch an, dass Klebel von außerordentlichem Naturell war ${ }^{139}$.

\section{R E S Ü ME E}

Ernst Klebel war ein wichtiger und ein zeitweise wirkungsmächtiger Historiker ${ }^{140}$. Sein Hauptverdienst bleibt die Erstedition der ältesten Salzburger Annalistik. Die anderen

137 Gottfried Oppitz, Nachruf auf Ernst Klebel, in: DA 17 (1961) 329. Siehe auch Theodor Mayer, Ernst Klebel $\uparrow$, in: HZ 194/2 (1961) 527f., der Klebels charakterliche Eigenschaften rühmt, doch inhaltliche Defizite von dessen Arbeiten andeutet. „Bei Klebel gesellte sich zu einem überaus großen Tatsachenwissen und zu einer umfassenden Quellenkenntnis eine scharfe, kritische Durchdringung des Stoffes und eine überlegene, mitunter phantasievolle Synthese, die es ihm ermöglichte, Zusammenhänge zu erkennen und Kombinationen anzustellen. Es sei nicht verschwiegen, dass er dabei manchmal zu weit ging, aber alles was er schrieb und sagte, war in höchstem Maße anregend." Auch Alois Brusatti veröffentlichte einen Nachruf, der dem Autor vorliegt, dessen Publikationsort aber nicht zu eruieren ist.

138 UAR, Philosophisch-Theologische Hochschule, 186/2, Klebel, Brief von Karl Ginhart an Jakob Hommes vom 27.1.1961: Tief erschüttert habe ich schon gestern die Nachricht vom plötzlichen Heimgang des Herrn Prof. Dr. Ernst Klebel erhalten [...] Was Klebel dann als Historiker geleistet, wie er, begabt mit einem phänomenalen Gedächtnis, die tausend und abertausend Daten, die er immer unmittelbar aus den Quellen holte, sinnvoll zu verbinden wußte und sehr viele dunkle Zeiten dadurch aufhellte oder verworrene Fragen überzeugend klärte, das können nur die engeren Fachkollegen gebührlich würdigen.

139 UAR, Philosophisch-Theologische Hochschule, 186/2, Klebel, Brief Bischoffs an den Regensburger Rektor Jakob Hommes vom 26.01.1961: Magnifizenz, Im Namen der Philosophischen Fakultät der Universität München erlaube ich mir, Ew. Magnifizenz und dem hohen Senat der Philosophisch-Theologischen Hochschule Regensburg zum Heimgang von Professor Ernst Klebel die aufrichtigste Anteilnahme auszusprechen. Ein persönliches Wort möchte ich anfügen. Schon in meiner Studentenzeit habe ich den Verstorbenen nahe gekannt, der durch sein unerschöpfliches Wissen die Jüngeren in Erstaunen setzte. Seines Temperaments wegen mußte man manchmal Sorge um ihn haben.

140 Vgl. die Beurteilung bei Lнотsку, Geschichte des Instituts (wie Anm. 2) 365: „Ernst Klebel, anerkanntermaßen eines der begabtesten und wissenschaftlich erfolgreichsten Mitglieder des Instituts, hat sich in unzähligen großen und kleinen Publikationen, die auch nur in den Hauptzügen zu umreißen hier unmöglich ist, praktisch auf allen Gebieten vorzugsweise mittelalterlicher Geschichtsforschung [...] betätigt." Siehe auch die Bemerkung Alfons Dopschs, im Zuge von Klebels Habilitationsverfahren, UAW, PA EK, Protokoll der Philosophischen Fakultät, 04.07.1929, fol. 25: [...] sachlich extrem geeignet wäre [...]. 
Werke wurden und werden zum Teil mehr zitiert als rezipiert. Dies trifft insbesondere für die Handbuchliteratur zu. Teilweise wurden Klebels Arbeiten auch inhaltlich weitergeführt $^{141}$. Die eher zurückhaltende Rezeption Klebels hängt sicher auch mit dem Fehlen „der großen Monografie“ zusammen. Er schrieb neben der erwähnten reich kommentierten Studie zu den Salzburger Annalen kaum etwas, womit man etwa im engeren Kreis des IÖG nachhaltig reüssieren hätte können. Er widmete sich vornehmlich der frühmittelalterlichen Geschichte des südöstlichen Karolingerreichs, wobei er dieses Forschungsfeld mit einer stark siedlungsgeschichtlich ausgerichteten Betrachtungsweise bearbeitete und seine Begrifflichkeit etwa der „südostdeutschen Kolonisation“ ideologisch belastet war und vermutlich auch dadurch kaum Fortsetzer fand. Zudem wurde das frühe Mittelalter in der deutschen und österreichischen Geschichtswissenschaft über lange Zeit als Vorgeschichte des „echten, bedeutenden Mittelalters“ betrachtet, welches mit den Staufern seinen Höhepunkt gefunden hätte. In Österreich wurde die Erforschung des Frühmittelalters neben frühen Arbeiten Heinrich Fichtenaus dann vor allem von Erich Zöllner mit seiner Habilitationsschrift über „Die politische Stellung der Völker im Frankenreich“ aufgenommen, die 1950 im Druck erschien ${ }^{142}$. Neben den erwähnten Studien Michael Mitterauers, waren es dann vor allem diejenigen Herwig Wolframs, die Wien zu einem Frühmittelalterzentrum machten. Zöllners Studie war für Wolfram der Auslöser für die vertiefte Auseinandersetzung mit dem frühen Mittelalter. Auch das Erscheinen des Werkes „Stammesbildung und Verfassung“ von Reinhard Wenskus spielte eine große Rolle dabei, dem Forschungsfeld der historischen Ethnografie einen neuen Schub zu verleihen und führte zu einem Paradigmenwechsel der in diesem Wissenschaftsfeld vorherrschenden Erklärungsmodelle ${ }^{143}$. Klebel hatte zudem kaum auf dem Gebiet der am IÖG gepflegten

141 Aufgegriffen wurden Teile von Klebels Forschungsinteressen von Michael Mitterauer, Die Grafenfamilien der bayerischen Marken in der Karolingerzeit (masch. Diss. Wien 1960); Ders., Slawischer und bayerischer Adel am Ausgang der Karolingerzeit, in: Carinthia I 150 (1960) 693-726; DERs., Karolingische Markgrafen im Südosten. Fränkische Reichsaristokratie und bayerischer Stammesadel im österreichischen Raum (AÖG 123, 1963). Siehe auch Karl Gutkas, Geschichte des Landes Niederösterreich (St. Pölten/Wien ${ }^{3} 1973$ ) 569; Karl Brunner, Herzogtümer und Marken. Vom Ungarnsturm bis ins 12. Jahrhundert (Österreichische Geschichte 907-1156, Wien 1994) 511, mit acht zitierten Titeln; Heinz Dopsch, Karl Brunner, Maximilian Weltin, Die Länder und das Reich. Der Ostalpenraum im Hochmittelalter (Österreichische Geschichte 1122-1278, Wien 1999) 571, mit fünf angeführten Studien Klebels; Handbuch der bayerischen Geschichte 1. Das Alte Bayern. Das Stammesherzogtum bis zum Ausgang des 12. Jahrhunderts, hg. v. Max SpINDLER (München ${ }^{2}$ 1981) 703.

142 Erich Zöllner, Die politische Stellung der Völker im Frankenreich (Veröff. des IÖG 13, Wien 1950).

143 Siehe Heinrich Fichtenau, Das karolingische Imperium. Soziale und geistige Problematik eines Großreiches (Wien 1949); Reinhard Wenskus, Stammesbildung und Verfassung: Das Werden der frühmittelalterlichen gentes (Köln/Graz 1961). Zum Gang der Forschung siehe Herwig Wolfram, Origo. Ricerca dell'origine e dell'identità nell'alto medioevo (Labirinti 112, Trento 2008) 53-67, und Walter PoHL, Die Völkerwanderung. Eroberung und Integration (Stuttgart/Berlin/Köln 2005) $17 \mathrm{f}$. 
Hilfswissenschaften publiziert, sondern bediente sich ihrer als Allgemeinhistoriker und stand damit in der Mediävistenszene Österreichs nicht im Zentrum der wissenschaftlichen Debatten. Hinzu kommt ein sehr thesenhafter Schreibstil, der die Lektüre seiner Werke nicht erleichtert ${ }^{144}$. Um die größeren angesprochenen Arbeiten gruppierte sich eine Vielzahl kleinerer, die aber fast immer wieder denselben Forschungsgegenstand in den Fokus nahmen, in etwa: Wo lebten Deutsche und seit wann? Das NS-Regime nutzte solche Argumentationsmuster, um seinen auf Expansion, Rassismus und Ressourcenraub beruhenden Kriegsplänen Legitimation zu verleihen. Thematisch gesehen entsteht bei der Betrachtung des Gesamtwerks Klebels einerseits das Bild einer gewissen Geschlossenheit, wobei das erwähnte Fehlen einer großen Monografie auffällt, die etwa Karl Lechner, der mit Klebel in engem Kontakt stand, mit seinem Buch über die Babenberger vorlegte ${ }^{145}$. Zu bedenken ist sicher auch, dass Klebel in Österreich keine Schüler hatte und so auch deshalb in den Debatten der Geschichtswissenschaft keine wesentliche Rolle mehr zu spielen vermochte. Die wissenschaftlichen und wissenschaftsgeschichtlichen Kämpfe und Emotionen entzündeten und entzünden sich an den „großen Namen“, wie etwa Otto Brunner oder Theodor Mayer ${ }^{146}$. Klebel polarisierte eher zu Lebzeiten, wohl nicht zuletzt durch sein Auftreten ${ }^{147}$. Er dürfte eine kontroversielle Persönlichkeit gewesen sein,

144 Vgl. etwa Klebel, Siedlungsgeschichte (wie Anm. 52) 11: „Die ideellen Strömungen, die zur ,Renaissance des tschechischen und madjarischen Volksbewußtseins führten, sind viel besser bekannt als die sozialen Entwicklungen. Die Neigung einer großen Zahl deutscher Historiker, alle Forschungen einer ,Geistesgeschichte im Sinn eines relativistischen Neuhegelianismus unterzuordnen, muß dazu führen, auch die nationalen Kämpfe lediglich vom Boden der Ideenwelt, also von Herder, der Romantik oder dem Liberalismus her zu sehen. Ich glaube, dass damit das Wesen nationaler Kämpfe verkannt wird; das Wesentliche an den nationalen Kämpfen irgendeiner Epoche ist Geltung und Machtstreben, der natürliche Egoismus einer Volkseinheit. In der Auseinandersetzung zweier Volkseinheiten spielt deren Aufbau als Volkskörper die Frage der Bildung der Führerschicht die entscheidende Rolle. Die ideelle Entwicklung steht hier in zweiter Linie.“ Ebd. 12: „Germanische Siedlung geschieht nur in der Gemeinschaft. [...] Dem Germanen gilt Land und Arbeit mehr als Gold und Wohlleben.“ Ebd. 34: „Man kann ruhig den Satz wagen, wo nicht fremde Verfassungsformen einen Halt boten, kam kein größerer Slawenstaat zustande.“

145 Karl Lechner, Die Babenberger. Markgrafen und Herzöge von Österreich 976-1246 (Veröff. des IÖG 23, Wien/Graz $\left.{ }^{3} 1985\right)$. Im NÖLA, NL EK, Korrespondenz 1, Mappe 3, befinden sich zahlreiche Briefe Lechner - Klebel.

146 Vgl. etwa Gadi Algazi, Herrengewalt und Gewalt der Herren im späten Mittelalter (Historische Studien 17, Frankfurt/M. 1996), mit einer nicht vollständig überzeugenden Kritik an bestimmten Thesen Brunners.

147 Vgl. oben die Einschätzung von Dopsch im Zuge des Habilitationsverfahrens. Ginhart meinte: Wohin er sich setzte, dort sprühten Funken, siehe UAR, Philosophisch-Theologische Hochschule, 186/2, Klebel, Brief Ginharts an Jakob Hommes vom 27.01.1961. Theodor Mayer meinte 1939: Überlegen Sie aber doch einmal selbst, ob an all dem Missgeschick. dass Sie betroffen hat, nur äußere Umstände Schuld sind, ob Sie nicht selbst viel verpatzt haben. Ich verstehe Ihre Gereiztheit, aber ich glaube nicht, dass jemand mehr für Sie getan hat als ich [...], siehe NÖLA, NL EK, K. 6, Korrespondenz, Mappe 4 (Theodor Mayer), Brief Mayers an Klebel vom 15.06.1939. Dort heißt es weiters: Als ich vor einem Jahr in München war und Sie mich ins Ministerium und 
die den Konflikt nicht nur nicht scheute, sondern oft auch suchte. Die geschilderten Spannungen werden zum Teil aber auch politische Ursachen gehabt haben, die darin begründet lagen, sowohl dem katholischen, als auch dem deutsch-nationalen und später nationalsozialistischen Lager angehören zu wollen ${ }^{148}$. Beides waren Netzwerke, die neben den politischen Inhalten, die ihre Mitglieder vertraten, auch der Karriere dienlich waren, aber nach 1933 nur mehr begrenzte Schnittmengen aufwiesen. Klebel war bei den Nationalsozialisten durch seinen Katholizismus konfessionell und das hieß zugleich politisch punziert, was ihm schließlich zum massiven Karrierehemmnis wurde. Umgekehrt hatte ihn in Österreich zuvor seine nationalsozialistische Gesinnung seine berufliche Existenz gekostet.

$\mathrm{Zu}$ erwähnen ist auch nochmals das IÖG. Letztlich war dieses Institut neben seiner Tätigkeit als Ausbildungsstätte für Archivare und hoch spezialisierte Mediävisten auch eine Kaderschmiede der universitär tätigen Historiker. Dort galten die strikten Hierarchien der „Ordinarienuniversität“, die Klebel offenbar wiederholt nicht anerkannte, aber nichtsdestotrotz positive Einflussnahme der Ordinarien für seine Person erwartete. Klebel konnte, oder wollte nicht leisten, was man von ihm verlangte. Die Fähigkeit, die eigenen Handlungen distanzierend und reflektierend zu betrachten, und die Begabung, die Uneindeutigkeit einer Situation zu ertragen, waren ihm offenbar nicht immer gegeben. Es griffen dann bald Exklusionsformen im Wissenschaftsbetrieb, die er nicht mehr beeinflussen konnte, ihn aber betrafen. Eine berechenbare akademische Karriere gab es für ihn zunächst nicht mehr. Für Klebel dürfte das wechselseitige Bedingungsverhältnis von institutionellem und sozialem Kontext nicht mehr zu steuern, teils wahrscheinlich auch nicht mehr zu verstehen gewesen sein. Die vorgestellte Biografie Klebels weist durchaus

dann zur Strassenbahn begleiteten, haben Sie laut und offen geschimpft, haben erklärt, Ihr ganzes Missgeschick sei nur auf die gehässige Stimmung gegen alle Österreicher zurückzuführen. Die Leute drehten sich nach uns um und ich ersuchte Sie mehrmals, sich doch zu mäßigen. Wenn Sie das auch anderswo getan haben, hat Ihnen das jedenfalls geschadet. Mayer fügte zudem hinzu: Mit welchen Ausdrücken haben Sie damals aber Platzhoff beschimpft. Im Jahr 1947 schrieb ihm Mayer, er (Klebel) habe sich die Steine immer selber in den Weg gelegt, oft in der Gestalt von Felsen und die Komplikationen haben Sie verursacht. [...] Wie oft musste ich, wenn ich mich für Sie einsetzte, hören: Ja für Klebel muss etwas geschehen, aber bitte in keinem Fall bei uns. Dieses Urteil konnte man in München, in Wien usw. hören, siehe NÖLA, NL EK, K. 6, Korrespondenz, Mappe 4 (Theodor Mayer), Brief Mayers an Klebel vom 25.08.1947. Siehe auch ÖStA, AdR, GA Ernst Klebel, fol. 11: Allerdings ist Kleber [sic] auch auf Widerstand gestossen, da ihn seine Kombinationsgabe nicht selten zu nicht haltbaren Vermutungen verleitete. Kleber ist ein absolut integrer Charakter, stets bereit für seine politischen und wissenschaftlichen Ansichten einzustehen. Leider mangelt ihm die Gabe der Menschenbehandlung. Eine gewisse Leichtgläubigkeit gegenüber den ihm zugetragenen Berichten, hat ihn nicht selten in persönliche Konflikte verwickelt.

148 Das beobachtete schon Voltelini. ÖStA, HHStA, NL Hans Voltelini 1, Mappe 1-24, Brief Voltelinis an Klebel, Wien 29.06.1937: Cliquen werden ja auch sein und bei Ihrer katholisch-nazionalen (!) Einstellung werden Sie es doppelt schwierig haben. Um so zurückhaltender müssten Sie sein. 
Züge einer gewissen Tragik auf. Erst spät konnte er in Regensburg seine lange ersehnte Ordinarienlaufbahn antreten. In Österreich wäre dies für ihn aufgrund seines Verhaltens und seiner politischen Orientierungen wohl nicht mehr möglich gewesen. 
Stefan Eminger und Ralph Andraschek-Holzer ${ }^{1}$

Karl Lechner (I897-1975)

LANDESHISTORIKER ZWISCHEN KATHOLIZISMUS UND

NATIONALSOZIALISMUS

I POLITISCHE BIOGRAFIE UND BERUFLICH-WISSENSCHAFTLICHE KARRIERE KARL LECHNERS

\section{I.I Einleitung}

Erich Zöllner bezeichnete ihn als „hochangesehene[n], bahnbrechende[n] Vertreter der österreichischen landesgeschichtlichen Forschung “2 ; Heinrich Fichtenau sah in ihm einen ausgezeichnete [n] Historiker, der die Landesgeschichte und Landeskunde Niederösterreichs auf eine höhere Ebene erhoben und ihr Ansehen im In- und Ausland bedeutend verstärkt hat ${ }^{3}$, und Theodor Mayer erachtete seine Leistungen für die Landesgeschichte als von größter grundsätzlicher und methodischer Bedeutung; er habe mitgeholfen, die landesgeschichtliche Forschung zur Grundlage der ganzen Geschichtsforschung zu machen ${ }^{4}$. Karl Lechner gilt auch heute noch als einer der bedeutendsten Landeshistoriker Niederösterreichs.

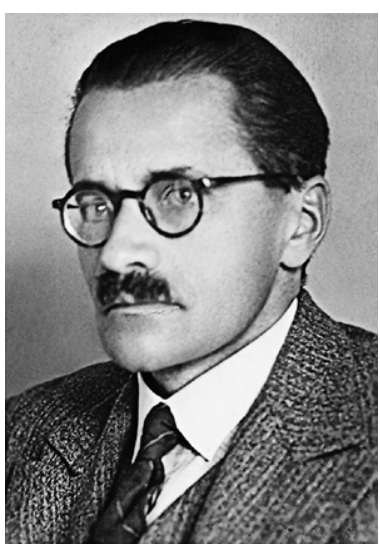

Abb. 33: Karl Lechner um 1938

1 Die Autoren zeichnen für unterschiedliche Teile des Aufsatzes verantwortlich. Der Teil I über Lechners politische Biografie und dessen beruflich-wissenschaftliche Karriere stammt von Stefan Eminger, der Teil II über Lechner als Begründer der mediävistischen Regionalforschung in Niederösterreich wurde von Ralph Andraschek-Holzer verfasst. Stefan Eminger ist überdies Roman Eccher für wertvolle Hilfestellungen bei der Recherche im ÖStA/ AdR verpflichtet, für anregende Diskussionen über den „Neuland“-Kreis dankt er Sebastian Meissl.

2 Erich Zöllner, Karl Lechner †, in: MIÖG 83 (1975) 565-568, hier 565. Zu Lechner zuletzt Fritz FeldNer, Doris A. Corradini, Österreichische Geschichtswissenschaft im 20. Jahrhundert. Ein biographischbibliographisches Lexikon (VKGÖ 99, Wien 2006) 250f.

3 UAW, Phil. Fak., PA Karl Lechner (= UAW, PA KL), Schreiben des IÖG an das Dekanat der Phil. Fak. der Universität Wien vom 30.07.1968.

4 Stadtarchiv Konstanz, NL Theodor Mayer, Schreiben Mayers an Lechner vom 06.06.1959. Die gesamte Korrespondenz Mayers mit Lechner befindet sich nun auch in Kopie im NÖLA, NL Karl Lechner (= NÖLA, NL $\mathrm{KL})$. 
Als Archivar (I923-I962) und Direktor des NÖLA (I940-I962), als Generalsekretär des Vereins für Landeskunde von Niederösterreich (= VfLKNÖ) (I927-I970) und als Schriftleiter diverser landeskundlicher Publikationsorgane (I927-I972/I975) hat er es zudem geschafft ${ }^{5}$, über große politische Zäsuren des 20. Jahrhunderts hinweg - I934, I938, I945 - in Amt und Funktion bleiben zu können, bis er nach dem Zusammenbruch des NS-Systems auch zum Universitätslehrer (1948-1972) aufstieg. Ausgehend von der These, dass wissenschaftliches Forschen und Arbeiten nicht abgekoppelt von gesellschaftspolitischen Strömungen und in Abhängigkeit von Institutionen und gruppensoziologischen Prozessen stattfindet ${ }^{6}$, möchte der folgende erste Teil des Aufsatzes einen Beitrag leisten, das Verhältnis von Wissenschaft, Politik und Gesellschaft genauer zu vermessen.

Zwei Netzwerke von Beziehungen bilden die Leitlinie der Untersuchung. Sie gruppieren sich um Lechners Engagement im katholischen Bund „Neuland“ und um seine Tätigkeit im Verein für Landeskunde von Niederösterreich. Das breite Spektrum der bislang noch zu wenig thematisierten politischen Aktivitäten katholisch-deutschnationaler Intellektuellenkreise, darunter nicht zuletzt von Historikern, in den krisengeschüttelten I930er-Jahren bildet einen Schwerpunkt dieser Arbeit. Weitere Themenbereiche widmen sich Fragen von Lechners Haltung zu Demokratie und „Ständestaat“, zu Rassismus, Nationalsozialismus und Großraumdenken, zu Entnazifizierung und Zweiter Republik. Ein Hauptaugenmerk liegt auch auf Lechners Deutung der österreichischen Geschichte sowie auf der Frage, ob, und wenn ja, inwiefern die politischen Brüche Modifizierungen dieser Interpretationen bewirkten. Lechners wissenschaftliche Karriere, seine Lehrtätigkeit an der Universität Wien und seine Aktivitäten als Wissenschaftsorganisator bilden die Überleitung zum zweiten Teil der Arbeit. Dieser stellt zwar nicht den Anspruch, Lechners breites wissenschaftliches Euvre zur Gänze zu analysieren und zu bewerten, dennoch möchte er Impulse dazu liefern. Die historiografische Analyse Lechners als „Begründer der mediävistischen Regionalforschung in Niederösterreich“"versteht sich als ein erster Baustein dafür.

\section{I.2 Herkunft und Ausbildung}

Karl Lechner stammte aus kleinbürgerlichen Verhältnissen. Am 6. Mai I 897 als erster Sohn eines Wagnermeisters in Wien geboren, besuchte er eine fünfklassige Volksschule und wech-

5 Helmuth FeIGL, Die Bedeutung Karl Lechners für die niederösterreichische Landesgeschichtsforschung und die Methodik der historischen Wissenschaften, in: Unsere Heimat. Zs. für Landeskunde von Niederösterreich (= UH) 46 (1975) 213-217, hier 213.

6 Günter Fellner, Die österreichische Geschichtswissenschaft vom „Anschluß“ zum Wiederaufbau, in: Kontinuität und Bruch 1938-1945-1955. Beiträge zur österreichischen Kultur- und Wissenschaftsgeschichte, hg. v. Friedrich Stadler (Wien/München 1988) 135-155, hier 135. 
selte dann an die Schottenfelder Realschule im 7. Wiener Gemeindebezirk. Er maturierte dort am 3. Juli I9I 5 mit Auszeichnung. Im darauffolgenden Herbst begann er - zunächst als außerordentlicher Hörer - das Studium seiner bereits in der Mittelschule bevorzugten Fächer Geschichte und Geografie an der Universität Wien. Die für Realschüler notwendigen Ergänzungsprüfungen aus Latein, philosophische Propädeutik und aus Griechisch absolvierte er im Oktober I9I 6 und im Oktober I9I7 mit sehr gutem Erfolg. ${ }^{7}$ Seine bevorzugten Universitätslehrer im Fach Geschichte waren der Mediävist Oswald Redlich und der Wirtschaftshistoriker Alfons Dopsch. Darüber hinaus belegte Lechner auch Lehrveranstaltungen beim Ordinarius für osteuropäische Geschichte, Hans Uebersberger, sowie beim Leiter des IÖG, Emil von Ottenthal, bei Wilhelm Bauer, August Fournier, Alfred Francis Přibram und Ludwig Bittner. Geografie hörte er insbesondere bei Eugen Oberhummer und Eduard Brückner, doch absolvierte er auch landeskundliche Lehrveranstaltungen bei Hugo Hassinger und Norbert Krebs. Vorlesungen beim Mediävisten und Verfassungshistoriker Theodor Mayer, den Kunsthistorikern Julius von Schlosser, Max Dvořák und Josef Strzygowski, beim Urgeschichtler Oswald Menghin sowie in Altgermanistik und sogar Gesteinskunde zeugen von einem breit gestreuten Interesse Lechners ${ }^{8}$.

Im März I920 promovierte er mit einer Arbeit über „Die Entwicklung des Grundbesitzes der Herren von Maissau - der typische Aufstieg eines österreichischen Ministerialengeschlechtes“, die von Dopsch mit befriedigend bewertet wurde`. Die Rigorosen legte Lechner bei Dopsch, Redlich und Brückner (zweistündig) sowie bei Adolf Stöhr und Robert Reininger (einstündig) mit insgesamt ausgezeichnetem Erfolg ab. Dopsch hatte Lechner allerdings nur mit genügend beurteilt ${ }^{10}$.

Bereits I9I9 war Lechner, der aus gesundheitlichen Gründen keinen Wehrdienst zu leisten hatte, als ordentliches Mitglied in den 32. Ausbildungskurs des IÖG aufgenommen worden ${ }^{11}$. Spätestens hier lernte er mit Ernst Klebel einen seiner zukünftig engsten

7 NÖLA, NL KL, K. I, Mappe I/1, Prüfungszeugnis des IÖG vom 07.07.1921.

8 Richard Pittioni, Karl Lechner, in: Almanach der ÖAW 125 (1975) 584-594, hier 584f. Zu den angeführten Hochschullehrern siehe die entsprechenden Beiträge in: Fellner, Corradini, Geschichtswissenschaft (wie Anm. 2); Österreichische Historiker 1900-1945. Lebensläufe und Karrieren in Österreich, Deutschland und der Tschechoslowakei in wissenschaftsgeschichtlichen Porträts, hg. v. Karel Hruza (Wien/Köln/Weimar 2008). Zum Fach Geschichte an der Universität Wien siehe jetzt: Pavel Kolář, Geschichtswissenschaft in Zentraleuropa. Die Universitäten Prag, Wien und Berlin um 1900 1-2 (Geschichtswissenschaft und Geschichtskultur im 20. Jahrhundert 9, Berlin 2008), hier 2 267-325.

9 UAW, Phil. Fak., Rigorosenakt Nr. 4792, Karl Lechner.

10 Ebd.

11 Zum 32. Kurs siehe Leo Santifaller, Das Institut für österreichische Geschichtsforschung. Festgabe zur Feier des zweihundertjährigen Bestandes des Wien Haus-, Hof- und Staatsarchivs (Veröff. des IÖG 11, Wien 1950) 139-141; Alphons Lнотsку, Geschichte des Instituts für österreichische Geschichtsforschung 1854 1954 (MIÖG Erg.-Bd. 17, Graz/Köln 1954) 365-367. 
Freunde kennen; ein weiterer Kurskollege und Lechner seither gleichfalls freundschaftlich verbunden war Leo Santifaller, später Universitätsprofessor für mittelalterliche Geschichte und Hilfswissenschaften sowie ab I945 Leiter des IÖG und Direktor des ÖStA ${ }^{12}$. I 92 I beendete Lechner diesen Institutskurs mit sehr befriedigendem Erfolg. Seine schriftliche Arbeit „Zur Geschichte der Besiedelung und der Grundbesitzverteilung des niederösterreichischen Waldviertels" wurde von Dopsch und Redlich mit vorzüglich bewertet ${ }^{13}$. Am I6. Mai 1923 trat Lechner in das NÖLA ein. Er sollte dort bis zu seiner Pensionierung Ende I 962 Dienst versehen. Bei seiner Anstellung genoss er die Unterstützung seines Lehrers Redlich, der zum damaligen Archiv- und Bibliotheksdirektor Max Vancsa in freundschaftlichen Beziehungen stand ${ }^{14}$.

\section{I.3 Das Netzwerk des (reform-)katholischen Milieus - der Bund „Neuland“}

Lechners wissenschaftliches Werk wie sein ganzes Leben war eingebettet in den metaphysischen Rahmen seines katholischen Weltbildes. „Niemand glaubt heute ernstlich mehr, daß Wissenschaft und Religion im Widerspruch stehen. Denn ernstes Streben nach Wahrheit muß zum Mittelpunkt und zum Quell der Wahrheit führen, zu Gott!“, postulierte der jugendbewegte Jung-Wissenschaftler 1923 in der Zeitschrift der katholischdeutschen Akademikerschaft Österreichs ${ }^{15}$. Dem katholischen Akademiker wies Lechner gesellschaftliche Aufgaben, ja Verpflichtungen zu. Dessen Mission sah er in der moralischen Vorbildfunktion im Sinne eines „positiven Tatchristentums“, und die vordringlichsten Aufgaben erblickte er in der sozialen wie auch in der „,ölkischen Arbeit“"16.

Lechners Gesellschaftsbild war religiös geprägt und wies „ständische“ Züge auf. Es orientierte sich an seinem Bild von der Kirche. Die Menschen seien allesamt Glieder eines Leibes - und zwar des „corpus Christi mysticum“ - und jedes Glied habe die ihm zugedachte Funktion bestmöglich zu erfüllen ${ }^{17}$. In der „organisch-ganzheitlichen Einheit des Urchristentums“ sah er daher wohl auch sein ideales Gesellschaftsmodell, das im Mittelalter wieder in Erscheinung getreten, danach aber verloren gegangen sei, und nach dem

$12 \mathrm{Zu}$ Klebel siehe den Beitrag von Wolfram Ziegler in diesem Band, zu Santifaller siehe Hannes Oве R мa Ir, Leo Santifaller (1890-1974). Von Archiven, Domkapiteln und Biografien, in: Österreichische Historiker (wie Anm. 8) 597-617.

13 NÖLA, NL KL, K. I, Mappe 1, Prüfungszeugnis des IÖG vom 07.07.1921.

14 Pittioni, Lechner (wie Anm. 8) 584-594, hier 585.

15 Karl Lechner, Die Korporation Arbeits-, Erziehungs- und Lebensgemeinschaft, in: Unser Weg. Blätter für zeitgerechtes Studententum 5 (September/Oktober 1923) 133-138, hier 133.

16 Ebd. $136 f$.

17 Karl Lechner, Pfarre und Heimat, in: Heimat-Jb. Mauer bei Wien 10 (1933) 3-5, hier 3. 
sich seiner Ansicht nach nun wieder „ein so großes Sehnen“ zeige ${ }^{18}$. Die "Zerrissenheit und Trennung unserer Lebensäußerungen“, die „Isolierung und Individualisierung“ sollte nach Lechner wieder „jener mittelalterlichen Einheit des Lebens, der Einheit von Kultur und Religion [...], dem Willen zur Ganzheit, zur Synthese weichen“19. Großen Einfluss auf Lechners Denken übte auch die Gegensatzlehre des in Deutschland wirkenden Jugendseelsorgers und Religionsphilosophen Romano Guardini aus.

Lechner war zwar gegen Ende seines Studiums, I920, einer Verbindung des katholischen Cartellverbandes (= CV) namens „Kürnberg“ beigetreten ${ }^{20}$, doch erschien ihm das katholische Farbstudententum schon bald als „Form ohne Inhalt“21. Ohne mit dem CV je offen zu brechen, zog es ihn schon sehr früh hin zur bündischen Jugend und zur katholischen Laienbewegung. Lechner zählte in der Zwischenkriegszeit zu den führenden Propagandisten einer innerkirchlichen Erneuerungsbewegung, die Teilen der Amtskirche wie auch der Christlichsozialen Partei durchaus kritisch gegenüberstand. Er wurde ein profiliertes Mitglied des Bundes mit dem programmatischen Namen „Neuland“22. In dieser „große[n] Ideen-, Werk- und Gebetsgemeinschaft“ lernte er nicht nur seine zukünftige Ehefrau Helga Kolisko kennen ${ }^{23}$, sondern auch viele künftige Freunde und andere Personen, mit denen er später immer wieder zusammentreffen sollte.

Entstanden im Umfeld der bündischen Jugendbewegung, war der Bund „Neuland“ I92 I aus den älteren Mitgliedern des „Christlich-deutschen Studentenbundes“ hervorgegangen. Er wurde von den charismatischen jungen Priestern Karl Rudolf und Michael Pfliegler geleitet ${ }^{24}$, und Lechner war von Beginn an in dieser Bewegung aktiv. Gemeinsam mit Pfliegler und einem weiteren Laien gab Lechner sogar das tägliche Gebetbuch von „Neuland“ heraus ${ }^{25}$, in den Zeitschriften des Bundes zählte er zu den produktivsten Auto-

18 Karl Lechner, Unsere Stellung zur Liturgie, in: Neuland. Blätter jungkatholischer Erneuerungsbewegung 1 (Allerseelenmond 1923) 32-36, hier 34.

19 Ebd. 35.

20 Amt der niederösterreichischen Landesregierung, LAD2, PA Karl Lechner (= ANÖLR, PA KL), Fragebogen vom 29.09.1938.

21 Karl Lechner, Neuland und Neustudententum. Gedanken dazu von einem CVer, der Neuländer ist, in: Neuland. Blätter jungkatholischer Erneuerungsbewegung 1 (Hornung 1924) 97-101, hier 100.

22 Franz M. Kapfinammer, Neuland. Erlebnis einer Jugendbewegung (Graz/Wien/Köln 1987) $202 f$.

23 Lechner, Neuland (wie Anm. 21) 99.

24 Klaus Breuning, Die Vision des Reiches. Deutscher Katholizismus zwischen Demokratie und Diktatur (1929-1934) (München 1969) 94; detailliert zum Bund Neuland siehe Gerhard SEEWANN, Österreichische Jugendbewegung 1900 bis 1938. Die Entstehung der Deutschen Jugendbewegung in Österreich-Ungarn 1900 bis 1914 und die Fortsetzung in ihrem katholischen Zweig „Bund Neuland“ von 1918 bis 1938 1-2 (Frankfurt/M. 1971); zum Christlich-deutschen Studentenbund siehe neben SEewann 1, 163-194, Otto Krammer, Der Christlich-Deutsche Studentenbund (C.D.S.B.) (Miscellanea aus dem Kirchenhistorischen Institut der Katholisch-theologischen Fakultät 41, Wien 1973).

25 Franz Maria Kapғнамmer, Die katholische Jugendbewegung, in: Kirche in Österreich 1918-1965 2, hg. 
ren. Er wirkte als Vortragender in zahlreichen katholischen Fortbildungsveranstaltungen, fungierte als Obmann der „Akademischen Rompilgerschaft“26, war Mitglied der katholischen Leo-Gesellschaft und engagierte sich in den religiösen Vereinen seines späteren Wohnortes Mauer bei Wien ${ }^{27}$.

\section{I.4 Soziale Arbeit}

Intensiver als die meisten anderen Jugendgemeinschaften befasste sich „Neuland“ mit sozialen und politischen Problemen. Das soziale Engagement wurde insbesondere von Pfliegler forciert ${ }^{28}$, und Lechner wie auch seine zukünftige Gattin zählten zu denjenigen, die diese Bemühungen aktiv unterstützten ${ }^{29}$. Auch die Bekanntschaft Lechners mit dem von ihm sehr geschätzten Historiker Karl Helleiner könnte aus dieser Zeit herrühren. Helleiner, Schwiegersohn des jüdischen sozialdemokratischen Spitzenpolitikers Julius Deutsch, war als Führer junger Sozialisten Anfang der I920er-Jahre mit Pfliegler in Kontakt gekommen und hatte sich mit diesem angefreundet ${ }^{30}$. Lechner setzte sich vor allem in den I920er-Jahren intensiv mit der österreichischen Sozialdemokratie auseinander. Mit kritischer Aufmerksamkeit und viel Verständnis studierte er die „Arbeiter-Zeitung“31, und beim Parteitag der Sozialdemokratischen Arbeiterpartei im Favoritner Arbeiterheim 1925 dürfte sich Lechner sogar unter den Zuhörern befunden haben. Er berichtete davon mit „aufrichtiger Bewunderung“ und fand bei allem Misstrauen „vor allem in Fragen der Religion und der Weltanschauung das Positive unverkennbar“32. Lechner strich die Gemeinsamkeiten der „Neuländer“ mit den Sozialdemokraten heraus; etwa das Streben, einen „neuen Menschen“ zu schaffen, die Kritik an der Korrumpierung des öffentlichen Lebens, und besonders beeindruckt war er von der sachlichen Diskussion am Parteitag. Er kritisierte die Borniert-

v. Ferdinand Klostermann, Hans Kriegl, Otto Mauer, Erika Weinzierl (Wien/München 1967) 23-53, hier 34.

26 Karl Lechner, Akademische Rompilgerschaft, in: Unser Weg. Blätter für zeitgerechtes Studententum 5 (Ostern 1923) 63; Die erste Pilgerfahrt österreichischer Akademiker ins Heilige Land (Wien 1928).

27 ANÖLR, PA KL, Fragebogen der Landeshauptmannschaft Niederösterreich vom 23.01.1946 samt Beilagen.

28 Breuning, Vision (wie Anm. 24) 94.

29 Helga Kolisкo: Helft mit!, in: Neuland 2 (Allerseelenmond 1925) 241.

30 Kapfнамmer, Neuland (wie Anm. 22) 42; zu Helleiner, der seit Ende 1927 als Stadtarchivar von St. Pölten beschäftigt war, 1939 wegen seiner als Jüdin verfolgten Frau emigrieren musste und sich in Toronto (Kanada) eine neue Existenz schuf, siehe Karl Gut kas, Karl Helleiner †, in: MIÖG 92 (1984) 525-527, sowie FellNer, Corradini, Geschichtswissenschaft (wie Anm. 2) 181.

31 Karl Lechner, Sozialistische Kultur?, in: Neuland 3 (Oster 1926) 91-95.

32 Karl Lechner, Gedanken zum sozialdemokratischen Parteitag, in: Neuland 3 (Hartung 1926) 15-19, hier 19. 
heit all jener, die sich Christen nannten, aber vor Not und Elend der Arbeiter und des Landproletariats die Augen verschlossen. Erschüttert berichtete er von den am Parteitag gehörten Schilderungen des „entsetzlichen Elends der landwirtschaftlichen Arbeiter, für das oft kein anderer Ausdruck als Sklaventum, Leibeigenschaft paßt “33. Er schrieb auch von ähnlichen, eigenen Erlebnissen, die er bei „Fahrten“ durch „österreichisches Waldland“ gemacht habe und stellte schließlich „[s]chaudernd“ fest, „daß unsere Bauern tief in den Materialismus hineingekommen sind, weil auch ihnen

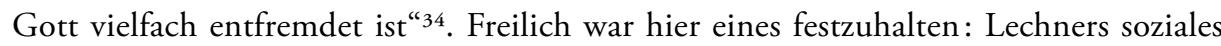
Engagement stand fest in der Tradition christlicher Mission. Die „soziale Frage“ war ihm zuvorderst eine religiöse, die soziale Not eine religiöse Not. Denn ohne „diesen sicheren Halt“, so Lechner, sei für die Helfenden eine Gefahr „ungeheuer: das Versinken in diesem Mystizismus des Proletariats, des Verbrecher- und Dirnentums“35.

Zumindest der Lechner der I920er-Jahre war überzeugt davon, dass der „rein negative und zerstörende Sozialismus beginnt abgelöst zu werden durch den positiven, aufbauenden"36. Er ortete ein wachsendes metaphysisches Bedürfnis im Proletariat und betrachtete es als Aufgabe von „Neuland“, dieses zu fördern, um die Arbeiterschaft „zur wahren Erlösung“ zu führen ${ }^{37}$. Die Ablehnung der „religiösen Sozialisten“ durch die Bischofskonferenz fand bei ihm keine Zustimmung, und der Christlichsozialen Partei sprach er jede religiöse Orientierung ab. Er wetterte gegen den stets negativen, nur abwehrenden „Geist der ,Gegenreformation““, der „in uns immer noch lebt“, und warb für teilweise recht unorthodoxe katholische Maßnahmen in den Städten. So regte er etwa die Schaffung neuer „Gottesdienststätten“ in Form kleiner Lokale in der Nähe von Fabriken an, um den Arbeitern kurze Morgenandachten zu ermöglichen, und für Sonnund Feiertage empfahl er die Abhaltung von Frühmessen an allen Wiener Bahnhöfen für die Ausflügler aufs Land ${ }^{38}$.

\section{I.5 „Völkische“ Arbeit}

In der Publizistik von „Neuland“ überwog in den I920er-Jahren Lechners soziale Arbeit ganz eindeutig die „,ölkische“. Die programmatischen Ausführungen zum deutschen

33 Ebd. 18.

34 Ebd.

35 Karl Lechner, Sozialismus, Kirche, Leben. Eine ernste Aussprache, in: Neuland 2 (Scheiding-Gilbhart 1925) 210-213, hier 212.

36 Lechner, Sozialistische Kultur (wie Anm. 31) 94. Die Sperrung erfolgte im Original.

37 Ebd.

38 Karl Lechner, Volksmission und religiöse Großstadtnot, in: Neuland 6 (Lenz/März 1929) 53-63, hier 5963. 
„Volkstumskampf“ in „Neuland“ stammten unter anderem von seinen Freunden Ernst Klebel, Franz Riedl ${ }^{39}$, Anton Böhm ${ }^{40}$ oder auch von dem Srbik-Assistenten Reinhold Lorenz ${ }^{41}$. Lechner hat sich dazu kaum geäußert. „Unsere Akademikerbewegung wäre wertlos, wenn sie nicht im Volke wurzeln würde“, schrieb er lapidar I923; und der katholische Akademiker könne seine moralische Vorbildwirkung nur dann erzielen, „wenn er sich als Glied des Volkes fühlt“"42.

Lechners damalige ordnungspolitische Vorstellungen für Mitteleuropa zeigten zwar schon deutliche Ansätze einer „gesamtdeutschen“ Ausrichtung. Der christliche Universalismus stand aber noch stark im Vordergrund, ebenso die Betonung der vielfältigen kulturellen Leistungen Österreichs, dessen große Bedeutung für Deutschland und Mitteleuropa er postulierte. Im katholisch-konservativ ausgerichteten Jahrbuch der österreichischen Leo-Gesellschaft präsentierte Lechner 1925 seine Vorstellungen von einer geschichtlichen Sendung Österreichs und damit auch seine Alternative zur ungeliebten Nachkriegsordnung der Pariser Vororteverträge. Gleich zu Beginn erläuterte Lechner das Verhältnis zwischen einem nicht näher definierten „Mitteleuropa“ und dessen österreichischer „Ostmark“ und übertrug das Gliedschafts-Modell auch auf politische Einheiten: „Mark sein heißt zunächst Glied eines Ganzen sein, in enger Verbindung mit diesem Ganzen bleiben, vom selben Kulturleben durchflossen sein wie das Ganze, teilnehmen an seinem Schicksal. [...] Die Mark ist Trägerin eines ganz besonders eigenständigen Lebens, welches auf das Ganze selbst wieder fördernd zurückwirkt. Das Ganze aber, dem diese Ostmark angehört, ist jenes Gebilde, als dessen Mark sie entstanden ist, das fränkische Reich, weiter das Heilige Römische Reich Deutscher Nation, endlich ein kräftiges Mitteleuropa.“43 In der Folge stellte Lechner die jahrhundertealte Bestimmung der Ost-

39 Ein detaillierter, auch die frühe Freundschaft mit Lechner erwähnender, teils apologetischer Lebenslauf des Publizisten und späteren „Volkstumsforschers“ Franz Riedl ist abgedruckt in: Volkstum zwischen Moldau, Etsch und Donau. FS für Franz Hieronymus Riedl. Dargeboten zum 65. Lebensjahr im Auftrag eines Freundeskreises von Theodor Veiter (Wien/Stuttgart 1971) 1-22; zu Riedl, Student bei Hans Hirsch und 1926/27 offenbar auch Teilnehmer der vorbereitenden Lehrveranstaltungen für den 36. IÖG-Kurs, siehe auch Andreas H. ZAJIC, Hans Hirsch (1878-1940). Historiker und Wissenschaftsorganisator zwischen Urkunden- und Volkstumsforschung, in: Österreichische Historiker (wie Anm. 8) 307-417, hier 348-350.

40 Ein Lebenslauf Böhms unter besonderer Berücksichtigung von dessen Tätigkeit in der Zeitschrift „Schönere Zunkunft“ findet sich bei Peter Eppes, Zwischen Kreuz und Hakenkreuz. Die Haltung der Zeitschrift „Schönere Zukunft“ zum Nationalsozialismus in Deutschland 1934-1938 (VKGÖ 69, Wien/Köln/Graz 1980) 44-53.

41 Die Titel dieser volkstumspolitischen Aufsätze sind angeführt bei SE Ewann, Jugendbewegung 2 (wie Anm. 24) $927 \mathrm{f}$.

42 Lechner, Korporation (wie Anm. 15) 136.

43 Karl Lechner, Der Ostmarkberuf Österreichs, in: Jb. der österreichischen Leo-Gesellschaft (1925) 168-191, hier 168 . 
mark als „Schild und Herz des Reiches“, als „Hort der gesamtdeutschen Interessen“ und im Ersten Weltkrieg als „Grenzwächter Deutschlands im Osten gegen Moskowitertum und Panslawismus, als Glied eines großen Mitteleuropa, dem es die Wege nach Osten weist“", heraus ${ }^{44}$. Ähnlich wie Heinrich von Srbik verwies Lechner dabei wiederholt auf die eigenständigen kulturellen Leistungen dieses östlichen Gebietes, die stets auch befruchtend ins Reich zurückgewirkt hätten ${ }^{45}$.

Zentral in Lechners Mitteleuropa-Vision war der Befund, dass seit der Zeit Karls des Großen das Reich, Böhmen und Ungarn „zueinander gravitiert“ hätten ${ }^{46}$. Lechner leugnete zwar nicht, dass es in den beiden letzteren Ländern nationale Gewalten gegeben habe, doch verwies er nachdrücklich darauf, „wie sehr in Böhmen deutsche Kultur herrschend“ gewesen und auch Ungarn diesbezüglich nicht weit zurückgestanden sei ${ }^{47}$. Dezidiert wandte sich Lechner gegen die kleindeutsche Geschichtsauffassung, die übersehen habe, „daß Österreich für das deutsche Geistesleben und für sein Gemeinschaftsbewußtsein

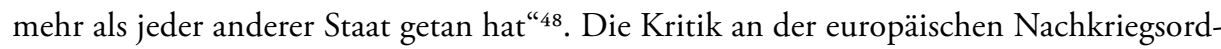
nung fiel bei Lechner im Vergleich etwa zu Klebel oder Lorenz sehr moderat aus. So habe „Großösterreich“ ebenso wie Deutschland „seine Aufgabe im Innern ungenügend erfüllt", und auch „die Mitspielenden auf dem großen Welttheater“ hätten „ihre Rolle schlecht gespielt“ ${ }^{49}$. Österreich stehe nun wieder als kleine Ostmark da, mit Deutschland, „wenn auch nicht politisch, so doch wirtschaftlich und kulturell aufs innigste" verbunden ${ }^{50}$. Ungarn und Böhmen seien nun selbstständig, aber wie schon im Mittelalter wären „auch heute wieder alle drei Länder aufeinander angewiesen, zueinander gravitierend" ${ }^{51}$. Daraus ergebe sich „so wie einst die große Aufgabe: Einigung dieser drei Ländergebiete und ihrer Völker einerseits und Eingliederung in den großen Verband eines christlichen Mitteleuropa andererseits, mit jener negativen Aufgabe, alle Unkultur von Osten abzuwehren, und jener positiven, edles Kulturgut nach Osten zu vermitteln "52. Die Lösung dieses jahrhundertealten Problems würde demnach „von dieser unserer Ostmark aus erfolgen“ ${ }^{53}$.

44 Ebd. 190.

45 Ebd. 185, 188. Zu Srbik siehe den Beitrag von Martina Pesditschek in diesem Band.

46 Ebd. 180.

47 Ebd.

48 Ebd. 189.

49 Ebd. 190.

50 Ebd.

51 Ebd.

52 Ebd. 190f.

53 Ebd. 191. 


\section{I.6 Ein „Programm junger Katholiken“}

Als am Tiefpunkt der Weltwirtschaftskrise die Stimmen nach Überwindung des parlamentarisch-demokratischen Systems lauter und das Vertrauen der katholischen Jugend in die regierende Christlichsoziale Partei zunehmend geringer wurden, konstituierte sich I932 auch eine Gruppe katholischer Intellektueller und trat mit einem „Programm junger Katholiken“ für eine „,ölkisch-staatliche Neugestaltung“ ein ${ }^{54}$. Laut Theodor Veiter, selbst Mitglied dieser Gruppe, gehörte auch Lechner diesem Kreis an ${ }^{55}$. Die Gruppe firmierte später als „Volksdeutscher Arbeitskreis österreichischer Katholiken“, war an der Vorbereitung des „Deutschen Katholikentages“ 1933 in Wien maßgeblich beteiligt und initiierte mehrere geschichtspolitische Publikationsprojekte. Sie setzte sich überwiegend aus Mitgliedern des deutschnationalen rechten Randes im katholischen CV (etwa Wilhelm Wolf, Taras Borodajkewycz, Walter Ternik, Theodor Veiter, Ernst Klebel ${ }^{56}$ ) und „Neuländern“ (neben Lechner etwa auch Karl Rudolf, Anton Böhm, Franz Riedl, Fritz Flor) zusammen; wieder andere, wie etwa Reinhold Lorenz oder der spätere Bundeskanzler Josef Klaus, standen dem Bund „Neuland“ zumindest nahe ${ }^{57}$. Das genannte Programm wurde zwar nie in vollem Wortlaut veröffentlicht ${ }^{58}$, fand aber in der Reichspost in die von Friedrich Funder neu geschaffene Kolumne „Der junge Strom“ in veränderter Form Eingang. Wenn auch nicht mit Sicherheit behauptet werden kann, dass Karl Lechner dieses Programm in allen Einzelheiten mitgetragen und gutgeheißen hat, sei es dennoch in der Fassung, wie es sein Freund Franz Riedl gleich in der ersten Folge des „jungen Stroms“ erläutert hat, vorgestellt.

54 Anton Staudinger, Zu den Bemühungen katholischer Jungakademiker um eine ständisch-antiparlamentarische und deutsch-völkische Orientierung der Christlichsozialen Partei, in: Februar 1934. Ursachen - Fakten - Folgen, hg. v. Erich Fröschl, Helge Zoitl (Thema Zeitgeschichte 2, Wien 1984) 221-231, hier 224f.; Anton Staudinger, Austrofaschistische „Österreich“-Ideologie, in: Austrofaschismus. Politik - Ökonomie - Kultur 1933-1938, hg. v. Emmerich Tálos, Wolfgang Neuge bauer (Politik und Zeitgeschichte 1, Wien $\left.{ }^{5} 2005\right)$ 28-52, hier 31-33.

55 Theodor Veiter, Politik, Gesellschaft, Wissenschaft. Memoiren aus Politik und Zeitgeschichte unter Mitarbeit von Isabella Ackerl und Edith Wimmer (Thaur bei Innsbruck 1993) 104; Institut für Zeitgeschichte Wien, Archiv, K. Do 183, Nl 10, Sammlung Theodor Veiter, Mappe 1; beiliegend auch die Liste der Mitglieder von 1932.

56 Zum rechten Rand des CV samt einigen Kurzbiografien der Genannten siehe Herbert Fritz, Reinhart Hande, Peter Krause, Gerhard Taus, Farben tragen, Farbe bekennen 1938-45. Katholische Korporierte in Widerstand und Verfolgung (Wien 1988) 381-388.

57 Seewann, Jugendbewegung 2 (wie Anm. 24) 771.

58 Das Programm findet sich im Institut für Zeitgeschichte Wien, Archiv, K. Do 183, Nl 10, Sammlung Theodor Veiter, Mappe 1; beiliegend auch die Liste der Mitglieder des „Volksdeutschen Arbeitskreises österreichischer Katholiken"von 1932. 
In dem langen Artikel nahm Riedl für sich in Anspruch, für die ,junge katholische deutsche Generation in Österreich" zu sprechen ${ }^{59}$. Deren Grundhaltung sei „entschieden katholisch, unwandelbar deutsch und eindeutig konservativ“. Die Quellen ihrer Haltung seien Gott, Heimat und Volk. Am Beispiel der beiden Kaiserkronen in der Wiener Schatzkammer - die Kaiserkrone des „Heiligen Römischen Reiches Deutscher Nation “ und die habsburgische Krone der österreichischungarischen Monarchie - erläuterte Riedl die „doppelte [...] und zwiespältige [...] Tradition Oesterreichs“, um dann fortzufahren, dass sich die junge katholische Generation „rückhaltlos zum deutschen Volk und zu einer gesamtdeutschen Gestaltung“ bekenne, in der „Oesterreich, seinen besonderen Aufgaben entsprechend, eine eigenrechtliche autonome Stellung " innehabe. Die besondere Aufgabe Österreichs bestehe in der „Bewahrung und Verwirklichung der elfhundertjährigen österreichi-
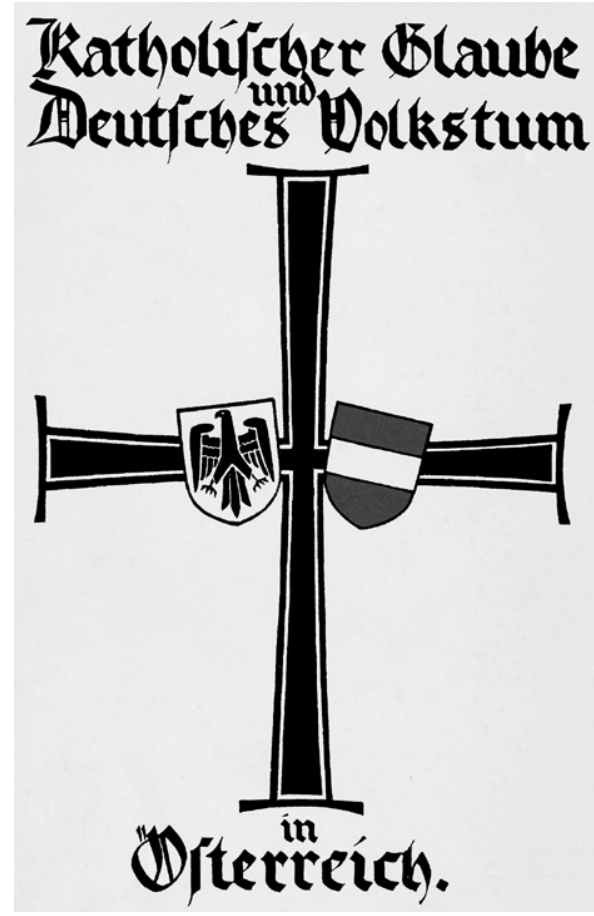

Abb. 34: Titelseite der Publikation „Katholischer Glaube und Deutsches Volkstum in Österreich, hg. v. volksdeutschen Arbeitskreis österreichischer Katholiken (Salzburg I933)“ schen Sendung: der Einigung der Staaten- und Völkerwelt zwischen Nord- und Südmeer in einem föderalen Mitteleuropa unter deutscher Führung“. Die „Pariser Friedensdiktate“ lehne man freilich ab. Unter „Volk“ verstehe man „Gemeinschaft des Geistes und Schicksals, aber auch des Blutes. Freilich, Ableitung des Volkstums aus Blut und Rasse allein erscheint - als Materialismus - der Jugend falsch. Das Judentum ist nach Art und Geist ein Fremdkörper und sein übermäßiger Einfluß ist mit allen Mitteln [!] zu bekämpfen und besonders auf kulturellem Gebiet ganz zu beseitigen“. Im reformbedürftigen Schulwesen hielt man u. a. die „Aktivierung der Kulturarbeit für das Auslanddeutschtum und gegen Südosten“ für besonders erforderlich, und ihr staatliches Ideal erblicke die junge katholische Generation im „wahren“, ständisch gegliederten „Volksstaat, im autoritären Staat, der den göttlichen Ordnungswillen im menschlichen Bereich verwirklicht“. Den „Parteienstaat“ lehne sie ebenso ab wie das „gegenwärtige [...] atomistische [...], demokra-

59 Reichspost (09.06.1932) 13f., dort auch die folgenden Zitate. 
tische [...] System“. Solange aber der Parteienstaat noch existiere, sei zu verhüten, dass Kirche und politisches Parteiwesen verwechselt würden. Ein Bekenntnis zu „grundstürzender, vorbehaltloser sozialer Reform“, ohne die jede Forderung nach „organischer Volksgemeinschaft" sinnlos sei, rundete das Programm ab.

Antiparlamentarismus, Antiliberalismus, Antimarxismus und Antisemitismus, Ständeordnung, soziales Engagement und hegemoniales Gesamtdeutschtum in Mitteleuropa bildeten also den Referenzrahmen dieser katholischen und betont deutschnationalen Gruppe; Ideologeme, die zumindest überwiegend auch in den Schriften Lechners auftauchten, jedenfalls aber sein engeres politisches Umfeld charakterisierten. Nach dem Zeugnis des Srbik-Schülers und „Neuland“ nahestehenden Adam Wandruszka ${ }^{60}$ sei diese Gruppe 1932 auch hinter der Herausgabe des Sammelbandes „Bekenntnis zu Österreich“ gestanden $^{61}$. Der Titel war freilich irreführend, denn das Motto der Bekenner lautete „Deutschland, Deutschland über alles!“. ${ }^{62}$ Der Band war anlässlich der „Sternfahrt deutscher Jugend“ zum Grab des „Schöpfers des Deutschlandliedes“ Josef Haydn erschienen und firmierte laut Wandruszka als „Vorläufer“ der Publikationen „Katholischer Glaube und Deutsches Volkstum in Österreich“ (1933) wie auch des Nadler-Srbik-Werkes „Österreich. Erbe und Sendung im deutschen Raum" (1936) ${ }^{63}$, die gleichfalls von der katholisch-deutschnationalen Gruppe von CVern und „Neuländern“ angeregt worden waren ${ }^{64}$. Anders als Lorenz, der in allen drei Büchern vertreten war, fungierte Lechner nur in den beiden letzteren Werken als Autor.

Der Band mit dem programmatischen Titel „Katholischer Glaube und Deutsches Volkstum in Österreich“ war vom erwähnten „Volksdeutschen Arbeitskreis österreichischer Katholiken" anlässlich des Allgemeinen deutschen Katholikentages in Wien im September

60 Fritz Fellner bezeichnete den Neuland-Führer Michael Pfliegler als Lehrer und Mentor Wandruszkas. Adam Wandruszka wirkte überdies - wie auch Lechner und Böhm - 1961 an der FS für Pfliegler mit. Fritz FeLLNER, Adam Wandruszka - Erlebte Geschichte, in: DERs., Geschichtsschreibung und nationale Identität. Probleme und Leistungen der österreichischen Geschichtswissenschaft (Wien/Köln/Weimar 2002) 375-384, hier 375; Custos quid de nocte? Österreichisches Geistesleben seit der Jahrhundertwende, hg. v. Karl Rudolf, Leopold LentNer (Wien 1961) 1-6.

61 Adam Wandruszka, Österreichs politische Struktur. Die Entwicklung der Parteien und politischen Bewegungen, in: Geschichte der Republik Österreich, hg. v. Heinrich Benedikt (Wien 1954) 289-485, hier 411; Bekenntnis zu Österreich, hg. v. Friedrich Heiss, A. Hillen Ziegfeld (Berlin 1932). Als Autoren fungierten Böhm, Lorenz, Riedl, Veiter, Otto Brunner, Fritz Flor, Emil Mika, Hermann Neubacher und Konrad Pfitzner.

62 Bekenntnis (wie Anm. 61) VIII; vgl. auch FellneR, Geschichtswissenschaft (wie Anm. 6) 144.

63 Wandruszka, Struktur (wie Anm. 61) 411-412.

64 Das bestätigten auch Borodajkewycz, Böhm und Riedl Ende der 1970er-Jahre gegenüber dem Germanisten Sebastian Meissl; siehe dazu Gernot Heiss, Im „Reich der Unbegreiflichkeiten“, in : ÖZG 7 (1996) 455-478, hier 460, 464; vgl. auch Erika Weinzierl, Prüfstand. Österreichs Katholiken und der Nationalsozialismus. Unter Mitwirkung von Ursula Schulmeister (Mödling 1988) 71. 
I933 herausgebracht worden ${ }^{65}$. Kardinal Innitzer „ehrerbietigst“ gewidmet, versammelte er „[f]ührende Persönlichkeiten der jungen katholischen Historikerschule Österreichs, die darlegten, wie das Schicksal Österreichs durch eineinhalb Jahrtausende [...] durch das harmonische Zusammenwirken von Kirche und deutschem Volkstum bestimmt und zu historischer Größe geführt wurde" 66 . Darüber hinaus präsentierte das Buch auch Arbeiten, die innerkirchliche, katholisch-soziale und katholisch-kulturelle Probleme behandelten $^{67}$. Die Hälfte der durchwegs männlichen Autoren waren „Neuländer" ${ }^{68}$. Von den Übrigen standen Klebel, Lorenz, Veiter und Eduard Winter dem Bund „Neuland“ sehr nahe ${ }^{69}$; bei Franz Geßl handelte es sich um den Gemeindeseelsorger von Lechner, mit dem dieser auch befreundet war. Lechners Beitrag befasste sich zwar mit einem religiösen Thema - „Der Laie in der Kirche“ -, gewährte aber auch Einblicke in sein Gesellschaftsbild. Gleich zu Beginn schwärmte er von der „mittelalterliche[n] Gemeinschaft“, in der sich die Frage des Laientums in der Kirche gar nicht erst gestellt habe, weil Geistlichkeit und Weltlichkeit aufs Engste miteinander verknüpft gewesen seien ${ }^{70}$. Lechner übte in dem Text recht unverhohlen Kritik an der Amtskirche, aber auch - und freilich indirekt an der Christlichsozialen Partei und der neu geschaffenen „Vaterländischen Front“ (VF). Die letzteren Passagen fehlten übrigens in den „Ausgewählten Schriften“ Lechners, die ihm I 947 als Festschrift dargebracht wurden. Mit Nachdruck sprach sich Lechner etwa gegen die „Vermengung kirchlichen Lebens mit der Politik“ aus ${ }^{71}$. So wie es als „unbedingt erstrebenswertes Ziel“ gelte, dass kein Angehöriger des Weihepriestertums ein politisches Mandat übernehmen dürfe, so sei es ebenso dringlich, „daß kein aktiver Politiker irgendeine nennenswerte Rolle in der ,Katholischen Aktion" spielt". Auf die neue Einheitspartei der Vaterländischen Front gemünzt war die folgende Passage: „Man beachte nur, wie gerne heute in geistigen Auseinandersetzungen das Wort ,Front verwendet wird. Der Unterton von ,Kampf , ,Ablehnung' und ,Negation', der darin liegt, scheint gar nicht mehr gehört zu werden. Mit Volksgemeinschaft und Dienst am Volk, mit Mission hat das nichts mehr zu tun. All das gilt es zu überwinden!“

\footnotetext{
65 Katholischer Glaube und deutsches Volkstum in Österreich, hg. v. volksdeutschen Arbeitskreis österreichischer Katholiken (Salzburg 1933).

66 Ebd. 5, Klappentext.

67 Ebd. Klappentext.

68 Neben Lechner handelte es sich dabei um Böhm, Riedl, Hans Petermair, Hans Sündermann, Helmut Burgert, Herbert Franz; siehe dazu SeEwan , Jugendbewegung 2 (wie Anm. 24) 772.

69 Ebd. 772; weitere Autoren in dem Band waren Edmund Glaise-Horstenau, Hugo Hantsch, Hieronymus Gaßner und Thomas Michels.

70 Karl Lechner, Der Laie in der Kirche, in: Katholischer Glaube (wie Anm. 65) 224-233, hier 224.

71 Ebd. 232 bzw. 232f. wie auch die folgenden Zitate.
} 
Die Auflösung der gesellschaftlichen Widersprüche und die harmonische Einbindung von politisch links wie rechts Stehenden erblickte Lechner damals weder in der Politik noch primär im Volk, sondern in der Einheit der „volkstumsfreundliche[n], übervölkische[n] Kirche“. Durch die Pfarre sollte „der heimatlose Großstädter, der Proletarier wieder Wurzel fassen“ können, durch sie sollte „vielen Menschen wieder Heimat bereitet“ werden, auf dass sie „wieder eingegliedert werden in das Volk, zur Volksgemeinschaft zurückgeführt werden“. Die Pfarrgemeinschaft werde „sich weiten zur Volksgemeinschaft und umgekehrt wird der national Denkende gerade in der Kirche den Bejaher und Schützer der Nation - als einer Idee Gottes - erblicken können, wird erkennen, wie sehr alle natürlichen Grundlagen des eigenen Volkes verklärt und emporgehoben werden in die volkstumsfreundliche, übervölkische Einheit der Kirche“.

Auch in einer anderen Passage seiner katholischen Publizistik zeigte sich, dass Lechner den Begriff „Volk“ nicht „rassisch“, sondern weltanschaulich-politisch fasste. Zugleich stellte er aber auch klar, dass er sich die angeblich notwendige Neuordnung des mitteleuropäischen Raumes nur unter der Führung des deutschen Volkes vorstellen konnte. „Familie und Heimat, wenn sie ganz tief erlebt werden, müssen zum Letzten führen, zum Volk. Nicht Boden und Landschaft, nicht Sprache und Rasse, nicht die Beziehung zum Staat machen ein Volk zum Volk“, schrieb er 1935, „sondern seine geschichtliche Sendung, seine politische Funktion unter den Völkern."72 Und diese Sendung des deutschen Volkes sei es nun, „Volk der Mitte zu sein [...] und Führer zu sein im mitteleuropäischen Raum"73.

Obwohl sich Lechner hier gegen eine rassische Definition von Volk wandte und obwohl er sein wissenschaftliches Euvre wie auch seinen privaten und amtlichen Schriftverkehr von antisemitischen Tendenzen weitestgehend frei gehalten hatte, war doch auch er von rassistischen Denkmustern geprägt. Ganz selten verlieh er diesen so deutlich Ausdruck wie in einem Aufsatz über eugenische Bestrebungen von 1934. Darin bezeichnete er „das Verlangen, die eigene Rasse hoch und ungeschändet zu erhalten, als ein gesundes und richtiges“74. Denn „[g]roße geistige und körperliche Nachteile seien von Rassenmischungen ausgegangen“, und selbst wenn diese Nachteile nicht sofort erkennbar würden, sei es „ein heiliges Recht, für die Reinerhaltung der eigenen Rasse einzutreten“. Offenbar Bezug nehmend auf die allmählich anlaufenden antisemitischen Maßnahmen in NS-Deutschland fuhr er fort: „Es ist ein entwürdigendes Schauspiel, wie viele Mädchen

72 Karl Lechner, Familienkunde, Heimat- und Volkstumspflege, in: Die Familie 10, Nr. 2 [1935] 13-16, hier 16.

73 Ebd.

74 Karl Lechner, Wie stellt sich der Mann und Vater zu den eugenischen Bestrebungen?, in: Das Familienglück. Blätter für katholische Familiengestaltung 9 (Januar-Februar 1934) 5-9, hier 8 wie auch die folgenden Zitate. 
unseres deutschen Volkes bis vor kurzem noch von Juden umgarnt wurden, oder sich, wie man es zu Zeiten feindlicher Besetzung großer Teile des deutschen Landes sehen konnte, mit Angehörigen der schwarzen Rasse eingelassen haben. So wird man also mit Recht auch nachforschen dürfen, ob sich etwa jüdisches Blut unter den Vorfahren des erwählten Lebensgefährten findet."

Der bekannte, I936 publizierte Sammelband „Österreich. Erbe und Sendung im deutschen Raum“ wurde gleichfalls von der erwähnten katholisch-deutschnationalen Gruppe rechtsgerichteter CVer und „Neuländer“ initiiert und von Nadler und Srbik herausgegeben $^{75}$. In seinem Beitrag sprach Lechner primär als Historiker ${ }^{76}$. Er präsentierte sich - ebenso wie die meisten Autoren des Bandes - als Vertreter der „gesamtdeutschen Geschichtsauffassung" und wurde in den Rezensionsjournalen NS-Deutschlands auch entsprechend gefeiert ${ }^{77}$. Der Band wurde allerdings auch in Österreich ein Bestseller und in regimeloyalen Kreisen lobend besprochen. In einer grundsätzlich sehr positiven Rezension in der Reichspost gab es aber auch Kritik: Sie richtete sich allein gegen den Text Lechners und zielte auf ideologische Gesichtspunkte ab. Der Rezensent billigte Lechner durchaus Kenntnisreichtum zu, monierte aber, dass der Beitrag an Überzeugungskraft nur gewonnen hätte, wenn er auf ,jede Polemik gegen die großösterreichische Betrachtungsweise der Probleme und [gegen; Anm. S.E.] die Resultate der urgeschichtlichen Forschung verzichtet und gewisse allzu deutschtümelnde Phrasen, die überdies in einer streng wissenschaftlichen Abhandlung schlecht am Platze sind, vermieden hätte“78.

Tatsächlich hatte sich Lechner vor allem gegen Ende seines Aufsatzes zu begeisterten Bekenntnissen zum Deutschtum hinreißen lassen, und es waren denn auch diese Wendungen, auf die in den Rezensionen NS-Deutschlands immer wieder hingewiesen wurde: „Aber lebendiges deutsches Volkstum war der Mutterboden, aus dem jene geistigen und kulturellen Schöpfungen flossen, und je mehr politisch die österreichischen Länder vom Reiche abgedrängt wurden und sich nach Osten richteten, desto tiefer wurde jenes erkannt. Denn seinen letzten geschichtlichen Sinn empfängt dieses Land nur als Glied eines größeren Ganzen."79

75 Heiss, Reich (wie Anm. 64) 460, 464.

76 Karl Lechner, Besiedlung und Volkstum der österreichischen Länder, in: Österreich. Erbe und Sendung im deutschen Raum, hg. v. Josef NADLER, Heinrich von SRBiк (Salzburg/Leipzig 1936) 21-42; auch bei den anderen Autoren des Bandes handelte es sich um Wissenschaftler: Bauer, Bittner, Borodajkewycz, Brunner, Glaise-Horstenau, Hirsch, Lorenz, Nadler, Srbik, Karl Braunias, Rudolf Egger, Heinrich Kretschmayr, Paul Müller, Leopold Nowak und Hans Sedlmayr.

77 Karl G. Hugelmann in: ZBLG 10 (1937) 438-439; W[ilhelm] Schüssler in: HZ 157 (1938) 377.

78 Reichspost (28.06.1936) 19f., hier 19. Rezensent war der St. Pöltener Prälat und Religionslehrer Johann Triebl.

79 Lechner, Besiedlung (wie Anm. 76) 42. 
Ganz in der Tradition der gesamtdeutschen Geschichtsauffassung erfüllte sich für Lechner „der Sinn neuerer landesgeschichtlicher Forschung in der Herausstellung der deutschen geschichtlichen Landschaft als Glied am gesamtdeutschen Volks- und Kulturboden" ${ }^{80}$, und „rückschauend auf das Werden des deutschen Volkstums in unseren Landen“ vermeinte er schon im Hochmittelalter ein fertig ausgebildetes deutsches Nationalgefühl in Österreich erkennen zu können: „[...] aus dem altgermanischen Stammesgefühl beginnt sich im ostfränkischen Reich - im Gegensatz zu dem stark romanisierten westfränkischen Reich - und mit Dienstbarmachung keltischer und slawischer Kulturelemente ein neues ,Volks'-Gefühl zu bilden, ein deutsches Nationalgefühl, das zur Zeit des Investiturstreites, um I Ioo, uns fertig entgegentritt." 81

Diesen emphatischen Bekenntnissen zum deutschen Volkstum widersprach allerdings nicht, dass Lechner in dem gleichen Text auch eine „Arteigenheit“ und Besonderheit des „österreichischen Deutschtums“ postulierte. Er verwies sogar auf eine, wenn auch seiner Ansicht nach nicht überzubewertende, „bluts- und rassenmäßige“ Besonderheit des österreichischen Deutschtums: „Dieses Land aber im Südosten ist deutsches Land, es ist altes deutsches Volkstum, das es erfüllt. Freilich, entsprechend der Umwelt (Gebirgsland gegenüber der Hochebene!), der bluts- und rassenmäßigen Zusammensetzung (deren Sonderbedeutung gegenüber dem benachbarten bayrischen Altland aber nicht überschätzt werden darf, wenngleich andererseits neuere anthropologische Forschung bis in die urgeschichtliche Zeit zu schließen versucht), dem geschichtlichen Aufbau und der geschichtlichen Sendung und endlich entsprechend der staatlichen dynastischen Formung ist es von besonderer Stammesprägung. Deutsches Grenzland ist es und darum allen Einflüssen ringsum in verstärktem Maße ausgesetzt und offen; aber nicht nur in der Abwehr, mehr noch in der Vermittlung liegt seine Aufgabe. Dabei aber und gerade deswegen ist es erfüllt von besonders eigenständigem, quellendem Leben." 82

Obwohl als Gegenentwurf zu „vaterländisch-kleinösterreichischen“ Geschichtskonstruktionen á la Ernst Karl Winter und Konrad Josef Heilig gedacht ${ }^{83}$, zeigte der Sammelband und mit ihm Lechners Text doch auch gewisse Ähnlichkeiten zwischen der regimekonformen und der oppositionellen katholisch-deutschnationalen Geschichtsdeutung auf. Die Grenzen erwiesen sich hier mitunter als schwer zu ziehen; der Grat zwischen Loyalität und Dissidenz war schmal. Die „ständestaatliche“ Konzeption des „österreichischen Menschen“ als besseren Deutschen ${ }^{84}$ und Lechners gesamtdeutsch-föderalistisch-,,stammesgeschichtlicher“

\footnotetext{
80 Ebd. 39.

81 Ebd. 41.

82 Ebd.

83 Heiss, Reich (wie Anm. 64) 464. Zu Heilig siehe den Beitrag von Helmut Maurer in diesem Band.

84 Staudinger, „Österreich“-Ideologie (wie Anm. 54) 48.
} 
Entwurf zeugten von dieser Nähe ebenso wie die beiden Konzepten inhärente deutsch-österreichische „Sendung“ als vorgeblich friedenssichernde Ordnungsmacht im multinationalen mitteleuropäischen Raum. Die Unterschiede lagen vor allem in der Bewertung der Rolle Preußens und NS-Deutschlands, die seitens des „Ständestaates“ in eins gesetzt wurden ${ }^{85}$. Während die „vaterländische“ Geschichtskonstruktion die alleinige Führungsrolle eines universalistisch katholisch-deutschen Österreichs betonte, war die gesamtdeutsch-nationalsozialistische Position bestrebt, im Wege eines „innerdeutschen Ausgleichs“ auch dem Preußentum eine gleichermaßen positive Rolle in der deutschen Geschichte zuzugestehen ${ }^{86}$.

\section{I.7 Das wissenschaftliche Netzwerk - der Verein für Landeskunde von Niederösterreich}

Neben dem Bund „Neuland“, der zwar das Wohlwollen Kardinal Innitzers genoss, aber Mitte der I930er-Jahre in den Verdacht nationalsozialistischer Betätigung geraten war ${ }^{87}$, bildete der VfLKNÖ ein weiteres wichtiges Netzwerk für Lechner. Der I 864 gegründete Verein war seit dem Ende des I9. Jahrhunderts mit dem NÖLA und der niederösterreichischen Landesverwaltung eng verwoben. Er bezweckte, das Land Niederösterreich aus der Perspektive möglichst vieler Wissenszweige zu erforschen und diese Ergebnisse

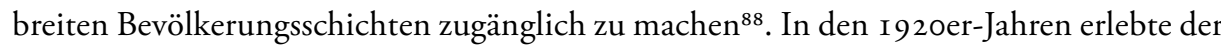
Verein eine neue Hochblüte. Mit etwa 2000 Mitgliedern Ende I927 - traditionellerweise aus dem bildungsbürgerlich-konservativen Spektrum ${ }^{89}$ - bildete er die weitaus größte landeskundliche Vereinigung Österreichs, ja des gesamten deutschen Sprachraums. Unter den Mitgliedern befanden sich seit den I 88 oer Jahren namhafte Wissenschaftler, wie etwa die Historiker Dopsch, Mayer, Oskar von Mitis und Engelbert Mühlbacher; der Geograf Oberhummer und der Historiker Viktor Bibl fungierten sogar als Ausschussmitglieder ${ }^{90}$, und der schon früh an landeskundlichen Fragestellungen interessierte Redlich verlieh dem Verein nicht nur besonderes Prestige, sondern gestaltete ihn als Ausschussmitglied über Jahrzehnte entscheidend mit $^{91}$.

85 Heiss, Reich (wie Anm. 64) 465.

86 Dazu siehe den Beitrag von Martina Pesditschek in diesem Band und Gernot Heiss, Von der gesamtdeutschen zur europäischen Perspektive? Die mittlere, neuere und österreichische Geschichte sowie die Wirtschafts- und Sozialgeschichte an der Universität Wien 1945-1955, in: Zukunft mit Altlasten. Die Universität Wien 1945 bis 1955, hg. v. dems., Margarete Grandner, Oliver Ratн коцв (Querschnitte 19, Innsbruck 2005) 189-210, hier 207.

87 SeEWAnn, Jugendbewegung 2 (wie Anm. 24) 572-580.

88 Karl Lechner, 1864-1964. 100 Jahre „Verein für Landeskunde von Niederösterreich und Wien“ im Rahmen wissenschaftlich-landeskundlicher Bestrebungen seit Ende des 18. Jahrhunderts (Wien 1964) 84.

89 Ebd. 146, Anm. 91.

90 Ebd. 125-127.

91 Max Vancsa, Oswald Redlich zum 70. Geburtstag, in: FS zum Siebzigsten Geburtstage Oswald Redlichs, hg. v. Verein für Landeskunde und Heimatschutz von Niederösterreich und Wien (Wien 1928) 1f. 
Seit 1920 bereits Mitglied, folgte Lechner I 927 Max Vancsa als Generalsekretär des Vereins nach. Dessen Sohn, der erst 23-jährige Kurt Vancsa, avancierte gleichzeitig zum Sekretär und Schriftführer und wirkte fortan als Lechners engster Mitarbeiter ${ }^{92}$. Auch privat verband Lechner mit Kurt Vancsa bald eine lebenslange „wirkliche Seelenfreundschaft“93. Der Amtsantritt des 30-jährigen Karl Lechner bedeutete den Beginn einer neuen, lang andauernden Ära im Verein ${ }^{94}$. Eine neue Generation von zumeist um die Jahrhundertwende geborenen Wissenschaftlern drückte dem Verein als Autoren, Vortragende, Exkursionsleiter und vielfach auch als Funktionäre allmählich ihren Stempel auf ${ }^{95}$. Schon bald entstand rund um Lechner jener Kreis der „jüngeren landesgeschichtlichen Forschung“, der die geschichtliche Landeskunde in Niederösterreich bis in die I970er-Jahre hinein dominieren sollte. Die Mitglieder dieser Gruppe arbeiteten einander zu, schienen einander in ihren Forschungsergebnissen zu bestätigen und befestigten auf diese Weise ihre Deutungshoheit ${ }^{96}$. Zu nennen sind hier etwa der Verfassungs- und Rechtshistoriker Klebel, der Architekt und Siedlungsplanforscher Adalbert Klaar, der Ur- und Frühgeschichtler Herbert Mitscha-Märheim ${ }^{97}$, der Namens- und Wüstungsforscher Heinrich Weigl98, der Pfarrund Patrozinienhistoriker Hans Wolf sowie die Ältereren in dieser Runde ${ }^{99}$, der Verfassungshistoriker und Direktor des Wiener Stadtarchivs Otto Heinrich Stowasser ${ }^{100}$ und der Sprachwissenschaftler Walter Steinhauser ${ }^{101}$. Brunner und dessen Freund, der Mediävist Helleiner ${ }^{102}$, zählten zwar nicht zu dieser Gruppe, gehörten im Umfeld des Vereins aber zu jenen jungen Wissenschaftlern, welche zur Qualität der Vereinspublikationen beitrugen ${ }^{103}$.

92 LeChner, 1864-1964 (wie Anm. 88) 166.

93 Karl Lechner, Oswald Redlich †, in: Jb. für Landeskunde von Niederdonau NF 28 (1939-1943) V-XX; Karl Lechner: Max Vancsa †, in: JbLKNÖ 29 (1944-1948) 1-14; Zitat in: Karl Lechner, Kurt Vancsa - tot, in: UH 40 (1969) 123-127.

94 Lechner, 1864-1964 (wie Anm. 88) 176.

95 Ebd. 178.

96 Max Weltin, Probleme der mittelalterlichen Geschichte Niederösterreichs. Unter besonderer Berücksichtigung des Hollabrunner Bezirkes, in: DE Rs., Das Land und sein Recht. Ausgewählte Beiträge zur Verfassungsgeschichte Österreichs im Mittelalter, hg. v. Folker Reichert, Winfried Stelzer (MIÖG Erg.-Bd. 49, Wien/München 2006) 436-486, hier 436f.

97 Richard Pittioni, Herbert (von) Mitscha-Märheim. Nachruf (mit Schriftenverzeichnis), in: Almanach der ÖAW 127 (1977) 545-562.

98 Silvia Petrin, Dr. Heinrich Weigl †, in: UH 49 (1978) $89 f$.

99 Karl Lechner, Oberstudienrat Dr. Hans Wolf $\dagger$, in: UH 32 (1960) $217 f$.

100 Ders., Otto H. Stowasser $\dagger$, in: UH 7 (1934) 95-97.

101 Weltin, Probleme (wie Anm. 96) 437; zu Walter Steinhauser siehe Herbert Tatzreiter, Walter Steinhauser (1885-1980), in: UH 51 (1980) 307-311.

102 Gutкas, Helleiner (wie Anm. 30) 526. Nach 1945 setzte sich Helleiner übrigens vergeblich dafür ein, dass Brunner die nach der Flucht Klebels vakant gewordene Stelle eines Stadtarchivars von St. Pölten erhielt.

103 Lechner, 1864-1964 (wie Anm. 88) 172, 176. 
In Abgrenzung zur „älteren landesgeschichtlichen Forschung“, die lediglich eine Reichsgeschichte in verkleinerter Ausgabe gewesen war ${ }^{104}$, entwickelte die ,jüngere landesgeschichtliche Forschung“ neue Methoden, erschloss bislang wenig beachtete Quellensorten und erzielte neue Erkenntnisse ${ }^{105}$. Sie berief sich auf die Konzepte Hermann Aubins, Rudolf Kötzschkes und Redlichs und betonte ihre ganzheitliche und „organische“ Ausrichtung ${ }^{106}$. Sie verstand sich - ähnlich der Heimatkunde - als „totalisierende Wissenschaft, erstrebte die Überwindung der Spezialisierung und Atomisierung unseres Wissenschaftsbetriebes “ und plädierte insbesondere für eine enge Zusammenarbeit von Geschichte und Geografie ${ }^{107}$. Darüber hinaus propagierte die „jüngere landesgeschichtliche Forschung“ die „Zusammenschau“ von Methoden und Ergebnissen unterschiedlichster Natur- und Geisteswissenschaften, betonte dabei aber stets den Vorrang der historischen Disziplin ${ }^{108}$. Verfassungs- und Rechtsgeschichte, Siedlungs- und Wirtschaftsgeschichte, Orts- und Flurnamenkunde, Archäologie, Burgen-, Wege- und Patrozinienforschung sollten konsequent aufeinander ausgerichtet werden ${ }^{109}$, und ein Hauptaugenmerk lag auch auf der Wechselwirkung von allgemeiner Geschichte und Landesgeschichte ${ }^{110}$. Das „Land“ als ihren Forschungsgegenstand definierte sie „nicht nur als politische, als verfassungs- und verwaltungsrechtliche Einheit, sondern auch als Boden für siedelndes Volk und kulturellen Aufbau"111. Im Kontext der politischen Neuordnung Mittel- und Osteuropas der Zwischenkriegszeit und in den Worten Kötzschkes bedeutete das, dass „Land“ nicht nur als Staatsboden, sondern über die Staatsgrenzen hinausgehend auch als Kulturboden und Volksboden zu fassen sei $^{112}$. Wie anderen mittel- und osteuropäischen Historikern galt ihr die Landesgeschichte vielfach auch als politisches Instrument im Nationalitätenkonflikt ${ }^{113}$. Kötzschke bezeichnete sie etwa als „Helferin“ einer

104 Theodor Mayer, Hundert Jahre Verein für Landeskunde von Niederösterreich. Gedanken eines Auslandsösterreichers, in: JbLKNÖ NF 36 (1964) 1036-1043, hier 1036.

105 Ders., Probleme der österreichischen Geschichtswissenschaft, in: Alteuropa und die moderne Gesellschaft. FS für Otto Brunner, hg. v. Historischen Seminar der Universität Hamburg (Göttingen 1963) 346-363, hier 357.

106 Karl Lechner, Sinn und Aufgaben geschichtlicher Landeskunde, in: MIÖG 58 (1950) 159-184, hier 163f., 166.

107 Ebd. 166.

108 Ebd.; Hermann Au вın, Aufgaben und Wege der geschichtlichen Landeskunde, in: Rheinische Neujahrsblätter Heft 4 (1925) 28-45, hier 29.

109 Weltin, Probleme (wie Anm. 96) 436f.

110 Lechner, Sinn (wie Anm. 106) 163f.

111 Karl Lechner, Oswald Redlich und die Landeskunde, in: UH 31 (1959) 203-209, hier 207.

112 Rudolf Kӧтzsснке, Nationalgeschichte und Landesgeschichte, in: Thüringisch-Sächsische Zs. für Geschichte und Kunst 13 (1923/1924) 2-22, hier 18-20.

113 Manfred Hett ling, Volk und Volksgeschichten in Europa, in: Volksgeschichten im Europa der Zwischenkriegszeit, hg. v. DEMs. (Göttingen 2003) 7-37, hier 17, 34. 
wiederherzustellenden „Schicksalsgemeinschaft und Willenseinheit“ des deutschen Volkes $;^{114}$ in der Kulturraumforschung Aubins galt sie als Voraussetzung, „hinweg über alle Territorial- und modernen Verwaltungsgrenzen, das Bild der historischen Landschaften als organischen Unterbau einer Geschichte des deutschen Volkes gewinnen“ zu können ${ }^{115}$. Wenn sich auch dieser volksgeschichtliche Zug der Landesgeschichte zumindest unter rassistischen Vorzeichen in den Publikationen des VfLKNÖ selten niederschlug, verstanden auch Lechner und sein Lehrer Redlich die Landeskunde als "nationale Pflicht" ${ }^{116}$. Den Festvortrag anlässlich der Feier des 60-jährigen Bestandes des VfLKNÖ I 924 schloss Redlich denn auch mit den Worten: „Denn die Pflege, die Kunde, die Wissenschaft von Heimat und Volk sind nicht toter Wissenskram, nicht antiquarische Liebhaberei, sondern eine nationale Pflicht, eine Bürgschaft der Liebe und Treue zur Heimat und zu unserem deutschen Volke."117

Unter der Ägide Lechners, der auch als Schriftleiter sämtlicher Vereinspublikationen firmierte, wurden die Kontakte mit landesgeschichtlichen Vereinen in Deutschland intensiviert. Bereits I 903 war der VfLKNÖ Mitglied des „Gesamtvereins der deutschen Geschichts- und Altertumsvereine“ geworden ${ }^{118}$, und seit den I920er-Jahren war es zumeist Lechner, der an den Versammlungen des "Gesamtvereins“ in Deutschland teilnahm ${ }^{119}$. Zum einen zeigte sich hier sein wissenschaftliches Verständnis von Landeskunde, das den Blick auf kleine Regionen nicht als Selbstzweck, sondern stets in Bezug auf die allgemeine Geschichte pflegte und für den überregionalen Vergleich offen war. Zum anderen verwies diese exklusiv mit deutschen landeskundlichen Organisationen betriebene Kontaktpflege auf Lechners „gesamtdeutsche“ Orientierung. In den I930er-Jahren wurden denn auch die Kontakte zum „Gesamtverein“ wie zu den „sudetendeutschen“ landeskundlichen Vereinigungen zunehmend enger ${ }^{120}$. Generell hatte der Ende der I920er-Jahre einsetzende Generationswechsel die deutschnationalen Tendenzen im Verein für Landeskunde befördert. Neben Lechner sind hier die „Alten Kämpfer“ der NSDAP Hans Wolf ${ }^{121}$ und

114 Кӧтzsснке, Nationalgeschichte (wie Anm. 112) 17.

115 Aubin, Aufgaben (wie Anm. 108) 44-45.

116 Zu Redlich als „meinungsbildender Exponent des historiographisch unterstützten ,volksdeutschen` Denkens vor 1918“ siehe Willi Ове к коме, Volksgeschichte. Methodische Innovation und völkische Ideologisierung in der deutschen Geschichtswissenschaft 1918-1945 (Kritische Studien zur Geschichtswissenschaft 101, Göttingen 1993) 49; zur Haltung Lechners siehe Lechner, Redlich (wie Anm. 111) 209.

117 Oswald ReDLICH, Landeskunde und Geschichtswissenschaft, in: JbLKNÖ NF 19 (1924) 1-9, hier 9.

118 Lechner, 1864-1964 (wie Anm. 88) 188.

119 Ebd. 178; Lechner war schon Mitte der 1920er-Jahre ein eifriger Besucher dieser Versammlungen und dort u.a. auch mit Kötzschke enger bekannt geworden; NÖLA, NL KL, K. I, Mappe I/3, Korrespondenz K und L, Schreiben Kötzschke an Lechner vom 28.01.1926 und vom 16.09.1926.

120 Lechner, 1864-1964 (wie Anm. 88) 184.

121 Hans Wolf, Gymnasialprofessor für Geschichte und Geografie, war der NSDAP schon im August 1931 bei- 
Steinhauser ${ }^{122}$ sowie der schon 1934 verstorbene Burschenschafter Stowasser zu nennen und freilich auch Klebel, dem I 934 wegen seiner Nähe zum Nationalsozialismus die Lehrbefugnis entzogen wurde ${ }^{123}$. I93 I avancierte überdies Lechners direkter Vorgesetzter, der Burschenschafter und Naturwissenschaftler Günther Schlesinger, zum zweiten Vizepräsidenten des Vereins ${ }^{124}$, und im gleichen Jahr wurde der nach Wien zurückgekehrte Geograf und Leiter der Südostdeutschen Forschungsgemeinschaft (SODFG) Hassinger in den Ausschuss gewählt ${ }^{125}$.

Wie seine Freunde Klebel und Vancsa ${ }^{126}$ stand Lechner der Regierungsdiktatur von Dollfuß und Schuschnigg kritisch, ja ablehnend gegenüber ${ }^{127}$. In augenfälligem Unterschied zur Begeisterung beim „Anschluss“ I 938 wurde die Etablierung des „christlichen Ständestaates“ I 934 im Monatsblatt des VfLKNÖ weitgehend ignoriert. Noch I 964 beschrieb Lechner die Machtübernahme des Regimes Dollfuß mit düsteren Metaphern - „am Horizont [zeigten sich; Anm. S.E.] dunkle Wolken“ -, während der „Anschluss“ weitgehend wertfrei dargestellt wurde ${ }^{128}$. Als öffentlich Bediensteter vermochte Lechner seine oppositionelle Haltung freilich nur sehr vorsichtig zum Ausdruck zu bringen. Neben seiner verschlüsselten Kritik an Christlichsozialer Partei und VF 1933 kann hier auch sein verhältnismäßig später

getreten und fungierte bis 1934 in Weidling bei Klosterneuburg als Organisationsleiter, dann als Ortsgruppenleiter der NSDAP, später übte er auch in der Phase der Illegalität der NSDAP Parteiämter aus. ÖStA/ AdR, GA, Zl. 28.177, Hans Wolf, Personal-Fragebogen vom 15.05.1938.

122 Walter Steinhauser, 1927 für „Germanische Sprachgeschichte und Altertumskunde“ in Wien habilitiert und seit 1934 Professor in diesem Fach, war der NSDAP im April 1932 beigetreten. Er konnte bei seinem Parteibeitritt auf einen geradezu idealtypischen „deutsch-völkischen“ Lebenslauf verweisen. ÖStA/AdR, GA, Zl. 75.067, Personal-Fragebogen vom 20.05.1938; zu Steinhauser siehe auch Sebastian MeissL, Wiener Ostmark-Germanistik, in: Willfährige Wissenschaft. Die Universität Wien 1938-1945, hg. v. Dems., Gernot Heiss, Siegfried Mattr, Edith Saurer, Karl Stuhlpfarrer (Österreichische Texte zur Gesellschaftskritik 43, Wien 1989) 133-155, hier 140f.

123 ÖStA/AdR, GA, Zl. 239.813, Ernst Klebel, Personal-Fragebogen vom 27.06.1938.

124 Lechner, 1864-1964 (wie Anm. 88) 180.

125 Ebd. 181.

126 Noch am 11.10.1946 bezeichnete sich Vancsa als Gegner der Regierung Schuschnigg. NÖLA, NS-Fragebögen, Konrad [recte: Kurt] Vancsa.

127 Diese Haltung kam noch 1964 in der FS des VfLKNÖ deutlich zum Ausdruck: „Die Hoffnung, daß etwa der seit 1933/34 so stark propagierte Gedanke des Vaterlandes einem Verein, der seit seiner Gründung Heimat und Vaterland, in Kenntnis und Liebe, auf seine Fahnen geschrieben hat, förderlich (auch im Finanziellen) sein könnte, erwies sich als trügerisch! Das militante Moment war stärker als das kulturelle und volksbildnerische. [...] Und das Denken in ,Fronten' war einer gemeinschafts- und ganzheitsverbundenen ,totalisierenden“ (nicht ,totalitären`!) Schau von Land und Leuten nicht günstig! Der Gedanke, ja selbst das Wort ,Heimatschutz', das der Verein in seinem Titel trug, aber war usurpiert von einer quasi-militärischen ,Formation‘. Bestrebungen, hier zu einer einverständlichen ,Sprachregelung zu kommen, mußten fehlschlagen!“'Lechner, 1864-1964 (wie Anm. 88) 182.

128 Ebd. 182, 185. 
Eintritt in diese Einheitspartei des Regimes am I9. Juni I934 - übrigens gleichzeitig mit Vancsa - als Regimekritik interpretiert werden ${ }^{129}$. Nach 1938 behauptete Lechner überdies, er hätte gegenüber einem Vertrauensmann der VF schon am Vortag der Abstimmung Schuschniggs über die Selbstständigkeit Österreichs seine Mitwirkung verweigert ${ }^{130}$, und gleichfalls nach dem „Anschluss“ bezeichnete er in einer Festrede des VfLKNÖ das vergangene Regime als ein aus einer negativen Ideologie lebendes System [, das] vor lauter „Vaterland“Geschrei gar nicht mehr die engere Heimat und ihre Nöte gesehen habe ${ }^{131}$.

Dessen ungeachtet beteiligte sich Lechner vor I 938 an der Volksbildung des ungeliebten Regimes. Die prononciert katholische Ausrichtung der gleichgeschalteten Volksbildung wie auch der hohe Stellenwert, welcher dabei der geschichtlichen Heimatkunde beigemessen wurde $^{132}$, bildeten wohl wesentliche Anknüpfungspunkte für ihn und trafen sich mit seiner auch bei „Neuland“ unter Beweis gestellten pädagogischen Neigung. So referierte Lechner I933 und I934 auf mehreren Fortbildungskursen des Volksbildungsreferates über die Geschichte des österreichischen Bauernstandes ${ }^{133}$, und im November 1935 erläuterte er in dem bisweilen als „Bürgermeisterschule“ bezeichneten bundesstaatlichen Volksbildungsheim Hubertendorf ${ }^{134}$ die Grundzüge der Geschichte Niederösterreichs ${ }^{135}$. Auch in der Lehrerfortbildung des Regimes war Lechner tätig. Im Juni 1937 sprach er etwa im Rahmen eines Fortbildungskurses der christlichen Lehrer Niederösterreichs über die Geschichte dieses Bundeslandes von der deutschen Besiedlung bis zum Aussterben der Babenberger ${ }^{136}$.

\section{I.8 Der „Anschluss"}

Der „Anschluss“ Österreichs an Deutschland schien für Lechner zunächst die Erfüllung seiner gesamtdeutschen Hoffnungen zu bedeuten. Das „Anschluss“-Heft der Vereinszeit-

129 In seinem NS-Erfassungsantrag weist Lechner auf diesen späten Eintritt eigens hin; ÖStA/AdR, GA, Zl. 316.372, Karl Lechner, Personal-Fragebogen vom 19.05.1938; zu Vancsa: NÖLA, NS-Fragebögen, Kurt Vancsa, Fragebogen vom 01.10.1938.

130 Lechner, Personal-Fragebogen 19.05.1938 (wie Anm. 129).

131 NÖLA, NL KL, K. II, Mappe II/7, Redemanuskript für die Feier des 70. Geburtstages von Dr. Anton Becker 1938.

132 Thomas Dostal, Volksbildung - Erwachsenenbildung - Lifelong Learning, in: Niederösterreich im 20. Jahrhundert 3: Kultur, hg. von Oliver Kühschelm, Ernst Langthaler, Stefan Eminger (Wien/Köln/ Weimar 2008) 73-110, hier 80, 100.

133 ANÖLR, PA KL, Fragebogen der Landeshauptmannschaft NÖ vom 23.01.1946, Beilage zu Punkt IV.B.

134 Dostal, Volksbildung (wie Anm. 132) 84; G[ustav] A[dolf] Witt, L[eopold] Teufelsbauer, Das Bäuerliche Volksbildungsheim Hubertendorf und sein Wirken (Stand 1929-1935). Ein Beitrag zur Geschichte österreichischer Volksbildungsarbeit (Schriften für den Volksbildner 32, Wien 1936).

135 ANÖLR, PA KL, Fragebogen der Landeshauptmannschaft NÖ vom 23.01.1946, Beilage zu Punkt IV.B. 136 Ebd. 
schrift „Unsere Heimat“ hatte Lechner ganz der „Geschichte des Waldviertels - der Heimat der Vorfahren Adolf Hitlers“ gewidmet. ${ }^{137}$ Im Eindruck der „atembeklemmende[n] Wucht und Entscheidungskraft dieses weltgeschichtlichen Vorganges“ apostrophierte er Adolf Hitler, der seiner Ansicht nach „auch äußerlich schon einen echten Waldviertler Typus“ darstelle, als den „Schmied des neuen großdeutschen Volksreiches und größten Sprossen“ des Waldviertels ${ }^{138}$. In der Einleitung stellte Lechner die bisherige Tätigkeit des Vereins ganz in den Dienst der deutschen Sache. Seit fast 75 Jahren arbeite man an der Erforschung und Darstellung von Geschichte, Kultur und Volkstum „jenes Landes, das der Markboden des Reiches war, [...] besiedelt von fast allen Stämmen des deutschen Mutterlandes“, deren „Blut- und Kulturgemeinschaft“ durch all die Jahrhunderte lebendig geblieben sei ${ }^{139}$. Er beteuerte, dass der Verein seinen „Dienst[...] an der niederösterreichischen Heimat und damit am deutschen Volke“ auch weiterhin und mit verstärkten Kräften versehen werde, auf dass „die Gliedschaft am gesamtdeutschen Volks- und Kulturboden“ noch bewusster gelebt werde. Er schloss mit dem „Gelöbnis unseres Vereins: Dienst an der engeren Heimat und am deutschen Volk, am Deutschen Reich und seinem Führer Adolf Hitler!“. ${ }^{140}$

Als „Katholisch-Nationaler“ gehörte Lechner auch zu jener kleinen Minderheit im katholischen Milieu, die mit dem „Anschluss“ auch einen „Ausgleich“ zwischen Kirche und Nationalsozialismus erhoffte. Die zustimmende Erklärung der österreichischen Bischöfe zum „Anschluss“ war Lechner daher ein großes Anliegen. Als an dieser Erklärung unter anderem vom Vatikan Kritik geübt wurde, stellte sich Lechner als Mitglied einer „Aktion für den religiösen Frieden“ klar hinter die Erklärung und versuchte Innitzer in dessen anfänglichen „Ausgleichs“-Bemühungen zwischen Kirche und NS-Staat möglichst zu bestärken. Neben seinen Freunden von „Neuland“, Böhm und Riedl, den „Neuland“ nahestehenden Borodajkewycz und Friedrich Schreyvogl sowie dem Philosophieprofessor Hans Eibl und dem Ehepaar Graf Dubsky zählte Lechner zu den Laien in dieser von Geistlichen „niederer und mittlerer hierarchischer Stufen“ dominierten Gruppierung ${ }^{141}$, die als „Arbeitsgemeinschaft für den religiösen Frieden “ noch für einige Monate in Kirchenkreisen von sich reden machen sollte. ${ }^{142}$ Das auch von Lechner unterzeichnete Schreiben der „Aktion“ an Innitzer vom

137 Karl Lechner, Aus der Geschichte des Waldviertels - der Heimat der Vorfahren Adolf Hitlers, in: UH 11 (März/April 1938) 72-78, hier 72.

138 Ebd. 72, 78.

139 An unsere Mitglieder!, in: UH (März/April 1938) 71f., hier 71.

140 Ebd. $71 \mathrm{f}$.

141 Josef Lettr, Arbeitsgemeinschaft für den religiösen Frieden 1938 (Diplomarbeit Linz 1981) 11.

142 Detailliert zu dieser Vereinigung siehe ebd.; vergleiche auch Erika WeInzı ERL-Fischer, Österreichs Katholiken und der Nationalsozialismus. Zweiter Teil : 1933-1945, in: Wort und Wahrheit. Monatsschrift für Religion und Kultur 18 (August/September 1963) 493-526, hier 508-516. 
Karfreitag 1938 dokumentierte die Haltung dieser Gruppe recht deutlich: Abrechnung mit dem vergangenen Regime, Vereinnahmung der österreichischen Bevölkerung für den Nationalsozialismus und Plädoyer für eine „Aussöhnung“ des Katholizismus mit dem Nationalsozialismus als wichtigste Überlebensbedingung der Kirche im neuen Staat. In dem Schreiben hieß es: Die katholische Kirche hat sich in den vergangenen Jahren in Oesterreich weitgehend mit einem politischen Regime identifiziert, das unter der Flagge eines katholischen Regimes namenloses Leid über das Land gebracht hat. Infolge der brutalen Unterdrückung des, wie sich nun zeigt, in seiner erdrückenden Mehrheit nationalsozialistisch eingestellten Volkes ist in diesem eine Erbitterung grossgezogen worden, die sich unter geschilderten Umständen auch gegen die Kirche und die Geistlichen richten musste. Zehntausende und Aberzehntausende haben seinerzeit den Vorsatz gefasst am ersten Tag der Befreiung durch den Austritt aus der Kirche, dieser die Quittung für das erlittene Leid zu erteilen. Diese Vorsätze sind unerfüllt geblieben, weil [...] die Handlungen Euer Eminenz den Zorn der nationalen Massen entwaffneten [...]. In dem Augenblick, da sich die Kirche gegen den neuen Staat stellt, wird in den Augen der Bevölkerung der zum Verräter, der die Partei der Kirche ergreift. [...] Mit mindestens demselben Recht, mit dem die französischen Katholiken sich mit der Regierung des Gottesleugners Leon Blum gut stellen dürfen, können wir österreichischen Katholiken einen tiefgläubigen Adolf Hitler unterstützen, der durch Taten christlicher Barmherzigkeit mehr Menschen mit Gott versöhnt hat, als in Frankreich mit Streik und Klassenhass dem Satan in die Hände getrieben werden !143

Lechner zeigte sich damals vom barmherzigen Wirken eines „tiefgläubigen Adolf Hitler“ überzeugt. Zumindest zu Beginn der NS-Herrschaft in Österreich unterzeichnete er auch private Korrespondenz mit Heil Hitler ${ }^{144}$, und bald nach dem „Anschluss“ stellte er sich auch in den Dienst der nunmehr nationalsozialistisch ausgerichteten Volksbildung. Im WS 1938/1939 wirkte auch er an der Erziehungs- und Bildungsarbeit des Deutschen Volksbildungswerkes Gau Wien mit $^{145}$. Lechner konnte dabei offenbar an seine bereits I 935 publizierten Überlegungen zu Eugenik und Familienkunde anknüpfen, denn sein Kurs in der Wiener Urania wurde im Rahmen des Generalthemas „Gesundes Volk“ angekündigt. Neben Rassekundlern wie Eberhard Geyer ${ }^{146}$ und Karl Tuppa ${ }^{147}$ oder auch dem späteren „Euthanasiearzt“ an der Kindertötungsanstalt „Am Steinhof“, Erwin Je-

143 Dieses Schreiben findet sich als Faksimile in Maximilian Lie bmann, Theodor Innitzer und der Anschluß. Österreichs Kirche 1938 (Graz/Wien/Köln 1988) 140f.

144 NÖLA, NL Ernst Klebel (= NÖLA NL EK), K. III, Mappe III/2, Korrespondenz Lechner.

145 NÖLA, NL KL, K. I, Mappe I/1, Schreiben Deutsches Volksbildungswerk, Gau Wien, Dr. F. Richter an die Mitarbeiter vom 16.09.1938.

$146 \mathrm{Zu}$ ihm ÖBL 1, $433 \mathrm{f}$.

147 Der Anthropologe Tuppa veröffentlichte in der vom Gaupresseamt Niederdonau der NSDAP herausgegebenen Schriftenreihe auch eine rassekundliche Untersuchung über Niederdonau. Karl Tuppa, Rassenkunde von Niederdonau (Niederdonau, Ahnengau des Führers 22, St. Pölten o.J.). 
kelius $^{148}$, vermittelte Lechner unter dem Titel „Wie finde ich meine Ahnen?“ an fünf Abenden die Grundbegriffe der Familien- und Ahnenforschung ${ }^{149}$.

Im Mai 1938 hatte sich Lechner zudem um Aufnahme in die NSDAP sowie um Anerkennung als „Illegaler“ bemüht ${ }^{150}$. Wie es scheint, dürfte er aber als Mitglied des CV und engagierter Katholik den NS-Parteistellen gegenüber doch einigen Erklärungsbedarf gehabt haben. In platzsparender, kleiner Schrift vermerkte er daher in seinem Erfassungsantrag auf einer halben Seite seine angeblichen Verdienste um die Partei, die er vor 1938 an seinem Arbeitsplatz, als Historiker, im VfLKNÖ und in anderen Zusammenhängen erworben habe.

Von seiner Dienststelle - also von Landesbibliothek, Landesmuseum und Landesarchiv - berichtete er, dass diese als braune Zelle bekannt und Treffpunkt von Illegalen und ,Sympathisierenden' gewesen sei. Er selbst habe in der Beamtenschaft aufklärend gewirkt, seit Ende 1935 das VF-Abzeichen nicht mehr getragen und bereits am II. III. 38 vorm. [vormittags; Anm. S. E.] dem Vertrauensmann der VF gegenüber [die] Teilnahme an [der] Schuschnigg-Abstimmung verweigert! Als Generalsekretär und Schriftleiter des VfLKNÖ sei er in Veröffentlichungen und Veranstaltungen für eine gesamtdeutsche Haltung eingetreten, weshalb der Verein bei der Landesregierung als ,Nazi-Verein'bekannt gewesen sei. Als Historiker sei er für die ,gesamtdeutsche Geschichtsauffassung' (gegen ,österr. Geschichtsauffassung' und,österr. Menschen'!) in Vorträgen (auch vor VF-Kreisen) und Büchern eingetreten - konkret verwies er hier auf seinen Beitrag im Nadler-Srbik-Werk 1936 und auf die kritische Rezension in der Reichspost. In seiner CV-Verbindung sei er als ,Nazi abgelehnt worden. Er habe dort die Ehrenmitgliedschaft der „Ständestaat“-Politiker Dollfuß, Schuschnigg, Fey und Starhemberg verhindert, und wegen der Organisierung einer Bildungswoche für CV-Mitglieder, die er mit ausgesprochen, nationalpolitischen 'Inhalten gestaltet habe, sei er angegriffen worden. In seinem Wohnort Mauer sei er besonders von VF-Kreisen als ,Nazi' und ,unverläßlich' bezeichnet worden. Er habe dort nie das VF-Abzeichen getragen, sei deshalb öffentlich kritisiert worden, habe 1938 zum Boykott der Schuschnigg-Abstimmung aufgerufen und schon seit 1933 in Vorträgen und kleinen

148 Zu ihm Herwig Czech, Erfassung, Selektion und „Ausmerze“. Das Wiener Gesundheitsamt und die Umsetzung der nationalsozialistischen „Erbgesundheitspolitik“ 1938 bis 1945 (Forschungen und Beiträge zur Wiener Stadtgeschichte 41, Wien 2003) 35f. Anm. 102.

149 NÖLA, NL KL, K. I, Mappe I/1, Arbeitsplan der Volksbildungsstätte Urania für das Wintersemester 1938/39. Im selben Programm war auch Wandruszka angekündigt. Sein Kurs war unter dem Generalthema „Deutsches Schicksal in Vergangenheit und Gegenwart“ angekündigt und handelte über „Die Gegner unserer Bewegung. Das Ringen der Weltanschauungen in den letzten zwei Jahrhunderten“.

150 Siehe zum Folgenden auch Gernot Heiss, Von Österreichs deutscher Vergangenheit und Aufgabe. Die Wiener Schule der Geschichtswissenschaft und der Nationalsozialismus, in: Willfährige Wissenschaft (wie Anm. 122) 39-76, hier $57 f$. 
Runden für die Grundsätze der NSDAP aufklärend gewirkt. Ferner sei er Mitglied der von staatlichen Stellen berechtigtermaßen als ,naziverdächtig' angesehenen Jugendbewegung „Neuland“ gewesen, habe illegale Presseerzeugnisse gelesen und weitergegeben. ${ }^{151}$

Als Gewährspersonen für seine Angaben bot er seinen Freund vom VfLKNÖ und schon in der Illegalität als NS-Ortsgruppenleiter von Klosterneuburg-Weidling tätigen Pfarrhistoriker Hans Wolf auf ${ }^{152}$, ferner den Wiener Stadthistoriker Gustav Gugitz, Parteimitglied seit 1926 (!) ${ }^{153}$, und den wie Lechner in Mauer bei Wien wohnhaften, bevölkerungswissenschaftlich interessierten Arzt Ernst Sedlacek, nunmehr Kreisamtsleiter für Rassenpolitik und seit 1936 SS-Mitglied ${ }^{154}$. In einem anderen, der politischen „Säuberung" der Beamtenschaft im Sinne des Nationalsozialismus dienenden Fragebogen berief sich Lechner unter anderem auch auf seinen IÖG-Kurs-, ehemaligen Arbeitskollegen und nunmehrigen NS-Staatssekretär DDr. Friedrich Wimmer sowie ${ }^{155}$ - gleichsam als Beweisführer der politischen „Gegenseite“ - auf den sofort nach dem „Anschluss“ des Dienstes enthobenen CVer und vormaligen Landesamtsdirektor Josef Schlüsselberger ${ }^{156}$.

Lechner verband mit dem Regimewechsel offenbar auch Hoffnungen, vermeintliche Benachteiligungen in seiner bisherigen amtlichen Karriere wett zu machen. Im September 1938 suchte er daher um Einreihung in eine ihm angeblich längst zustehende höhere Dienstklasse an. Er wandte sich dafür zwar nicht an das Referat für „politische Schadensgutmachung", sondern an das Präsidium der Landeshauptmannschaft, doch warf auch er die Frage auf, ob die Übergehung seiner Ansprüche etwa wegen seiner als nat.soz.

151 Lechner, Personal-Fragebogen 19.05.1938 (wie Anm. 129).

152 ÖStA/AdR, GA, Zl. 28.177, Hans Wolf, Personal-Fragebogen vom 15.05.1938.

153 ÖStA/AdR, GA, Zl. 170.201, Gustav Gugitz, Personal-Fragebogen vom 26.05.1938.

154 Lechner, Personal-Fragebogen 19.05.1938 (wie Anm. 129). Zu Sedlacek siehe ÖStA/AdR, GA, Zl. 8434, Stammbuch vom 16.07.1938; Ernst SEDLACEK, Die unehelichen Geburten in Niederösterreich in den Jahren 1881 bis 1885, in: UH 10 (1937) 124-126; Ernst SedLACEK, Der Einzugsbereich Wiens 1880 und 1934, in: Archiv für Bevölkerungswissenschaft und Bevölkerungspolitik 6 (1936).

155 Friedrich Wimmer, der übrigens mit Klebel befreundet war, hatte die Abschlussprüfung des IÖG-Kurses nicht abgelegt (Lноткку, Geschichte des Instituts [wie Anm. 11] 367) und war 1927-1935 im niederösterreichischen Landesdienst beschäftigt, wo er zunächst als Kunsthistoriker und Archäologe dem Landesmuseum und als Jurist später dem Rechtsbüro zugeteilt war. Er hatte 1932/33 als Rechtsberater des niederösterreichischen Landesrates der NSDAP Josef Leopold fungiert, war Anfang 1934 der mittlerweile illegalen NSDAP beigetreten und hatte sich nach der Enthaftung Leopolds 1936 in der illegalen NS-Gauleitung in Niederösterreich betätigt. Beim „Anschluss“ war er auch der SS beigetreten. Ein detaillierter Lebenslauf Wimmers findet sich in Nikolaus von Preradovich, Österreichs höhere SS-Führer (Berg am See 1987) 222-227.

156 ANÖLR, PA KL, Fragebogen des Reichsstatthalters, Der Staatskommissar, vom 21.06.1938; zu Schlüsselberger siehe Ernst Bezemeк, Stefan Eminger, Das Land und seine Meister. Verfassung und Verwaltung, in: Niederösterreich im 20. Jahrhundert 1: Politik, hg. von Stefan Eminger, Ernst Langthaler (Wien/Köln/ Weimar 2008) 163-195, hier 183. 
verdächtigten Gesinnung erfolgt sei. Er ließ sie aber offen ${ }^{157}$. Jedenfalls hob er in dem Schreiben neuerlich hervor, dass seine wissenschaftlichen Arbeiten das Land Niederösterreich stets im Rahmen der gesamtdeutschen Geschichte und bedeutsam für sie dargestellt habe. Abermals verwies er auf den als nation.-soz. angesehenen, Verein für Landeskunde von N.Ö.', in dem sich seine völkische Einstellung gezeigt habe und die ihm wiederholt Vorwürfe u. Ermahnungen seitens des Präsidiums und der Amtsdirektion der ehemaligen Landesverwaltung eingebracht hätte. Lechners Ansuchen wurde von seinem Vorgesetzten Günther Schlesinger, bestens und von dem zuständigen Landesrat Leopold Pindur, Partei- und SA-Mitglied seit 1926, wärmstens befürwortet. Schlesinger fügte noch hinzu, dass Dr. Lechner sich mehrmals in den abgelaufenen Jahren durch seine in Vorträgen oft vertretene großdeutsche Einstellung weitgehend exponiert habe, und Pindur wollte seine Befürwortung sowohl vom sachlichen wie auch politischen Standpunkte aus verstanden wissen. Dennoch wurde Lechners Antrag auf Einreihung in eine höhere Dienstklasse abgewiesen ${ }^{158}$.

Trotz aller Belege und Fürsprecher blieben parteiamtliche Stellen Lechner gegenüber misstrauisch. Hauptgrund dafür war zunächst seine Mitgliedschaft beim CV, weswegen im Oktober 1938 auch gegen seine Eintragung in die Berufsliste der Schriftleiter zumindest vorläufig politische Bedenken erhoben wurden ${ }^{159}$. Vor allem seine katholische Einstellung brachte ihn in der Folge zunehmend in Konflikt mit Parteistellen. So handelte er sich Anfang 1939 eine scharfe Rüge seines Ortsgruppenleiters ein, weil er für den in der Bevölkerung weithin beliebten, aber von den Nationalsozialisten mit Schulverbot belegten Kaplan seines Wohnortes Unterschriften gesammelt hatte ${ }^{160}$. Für Unmut in der Ortspartei sorgte auch, dass er zu Fronleichnam 1939 mit dem Parteiabzeichen an der kirchlichen Prozession teilnahm. Als er bald darauf in dem von der NSDAP beschlagnahmten katholischen Jugendheim angetroffen wurde, erstattete der Ortsgruppenleiter Anzeige: gegen Lechner wurde ein Verfahren bei einem Parteigericht eingeleitet. Um einer Entscheidung dieses Gerichts zuvorzukommen und weil er im Frühjahr I940 aus einer verpflichtend zu besuchenden Zellenversammlung ausgewiesen worden war, zog Lechner die Konsequenzen. Er erklärte seinen Aufnahmeantrag für zurückgezogen und schloss diesem Schreiben auch

157 ANÖLR, PA KL, Schreiben Lechner an das Präsidium der Landeshauptmannschaft Niederdonau vom 14.09.1938, wie auch die folgenden Zitate.

158 Ebd. Pro domo Vermerk vom 20.09.1938.

159 ÖStA/AdR, GA, Zl. 316.372, Karl Lechner, Schreiben der NSDAP, Gauleitung Wien, an den Reichsverband der Deutschen Presse vom 19.10.1938.

160 Es handelte sich um Kaplan Eduard Novotny, der seit 1935 in Mauer bei Wien für die Jugendarbeit zuständig war. Für ein Dossier zu Novotny, zusammengestellt von der Maurer Heimatrunde, danke ich Ing. Heinz Böhm; ÖStA/AdR, GA, Zl. 316.372, Karl Lechner, Schreiben NSDAP Wien, Kreisleitung V, an die Gauleitung Wien, Gaupersonalamt, vom 15.04.1940. 
seine provisorische Beitragskarte bei ${ }^{161}$. Das Parteigerichtsverfahren wurde eingestellt, und die bereits auf den Weg gebrachte NS-Mitgliedskarte - mit der ihm aufgrund seiner Verdienste um die Partei vor 1938 tatsächlich der Illegalenstatus zugebilligt worden wäre wurde von der Ortsgruppe Mauer wieder ans Gauschatzamt zurückgeschickt ${ }^{162}$.

Auf seine Karriere im Dienst der Gauverwaltung hatte das - wie auch seine gelegentlichen fachlichen Auseinandersetzungen mit Amtsträgern von NS-Parteistellen ${ }^{163}$ - keine negativen Auswirkungen. Mitte 1940 wurde Lechner zum Direktor des neuen Reichsgauarchivs Niederdonau ernannt, zwei Jahre später wurde er Oberarchivrat ${ }^{164}$. Das Verhältnis zu seinen Vorgesetzten in der Reichsgauverwaltung schien im Großen und Ganzen ungetrübt ${ }^{165}$. Viele Jahre später jedoch äußerte Lechner im Rahmen eines heftigen Streites mit seinem politisch ganz anders denkenden Freund Ernst Karl Winter, dass er, was Winter als Emigrant nicht wissen könne, 1938-45 einen sehr schweren Stand gehabt habe und es nur einem ausgezeichneten Vorgesetzten $z u$ danken hatte, dass ich nicht hinausgeflogen bin ${ }^{166}$. Worin diese Schwierigkeiten bestanden hatten, ist nicht überliefert; auch der Personalakt gibt darüber keine Auskunft. Lechner charakterisierte seinen Vorgesetzten Leopold Pindur - einen „Alten Kämpfer“ der NSDAP und ehemaligen Häftling im Anhaltelager Wöllersdorf - jedenfalls noch I 964 als „ruhige[n] und gerechte[n], kulturerfüllte[n] Menschen" ${ }^{167}$.

Lechners politische und charakterliche Beurteilungen durch NS-Parteistellen blieben widersprüchlich. Vermerkte etwa das Personalamt der Gauleitung Niederdonau I943, dass Lechner während der Systemzeit für den Großdeutschen Gedanken eingetreten sei und als offener, aufrechter Charakter gelten könne, allerdings als jemand, der seiner früheren religiösen Einstellung treu geblieben sei und durchaus kein Konjunkturmensch sein wolle ${ }^{168}$, so

161 ANÖLR, PA KL, Rechtfertigungsschrift Lechners vom 09.06.1945; ÖStA/AdR, GA, Zl. 316.372, Karl Lechner, Schreiben NSDAP Wien, Kreisleitung V, an die Gauleitung Wien, Gaupersonalamt, vom 15.04.1940.

162 ÖStA/AdR, GA, Zl. 316.372, Karl Lechner, Schreiben Gauleitung Wien an die Reichsleitung der NSDAP, Reichsschatzmeister, vom 24.10.1940.

163 NÖLA, Archiv-Akten, Zl. 24/1944, K. 13, Pokorny Wilhelmine, Langenlois, Unter-Schutz-Stellung von 2 Urkunden des 14. Jahrhunderts; NÖLA, Archiv-Akten, Zl. 170/1943, K. 12, Stadtwappen Neunkirchen.

164 ANÖLR, PA KL, Abschrift der Ernennungsurkunde vom 15.05.1942.

165 Das „enge und gute Einvernehmen mit der, Gauselbstverwaltung““ betont Lechner u.a. in : NÖLA, ArchivAkten, Zl. 21/1944, K. 13, Schreiben Lechner an den Generaldirektor der Staatsarchive und Direktor des Reichsarchivs Potsdam, Kommissar für den Archivschutz, vom 28.08.1942.

166 NÖLA, NL KL, K. VII, Mappe VII/4, Severin-Polemik mit E. K. Winter und Klemens Kramert, Schreiben Lechner an Winter vom 28.05.1956.

167 Lechner, 1864-1964 (wie Anm. 88) 187.

168 ÖStA/AdR, GA, Zl. 316.372, Karl Lechner, Schreiben NSDAP, Gauleitung Niederdonau, Personalamt, an die Gauleitung Wien, Personalamt, vom 22.07.1943. 
bezeichnete ihn der Leiter des Kreises V der NSDAP in Wien I 942 als betont klerikale[n] Anhänger und Förderer der katholischen Aktion vor 1938, der gegenwärtig „äusserst zurückhaltend und vorsichtig, echt jesuitisch agiere und eben kein offener Charakter, sondern verschlossen und hinterhältig sei ${ }^{169}$. Lechner dürfte auch in der sogenannten Gegnerkartei der NSDAP belassen worden sein ${ }^{170}$.

\section{I.g Karl Lechner und die Volksgeschichte}

Lechners wissenschaftliches Wirken erfolgte lange Zeit vor dem Hintergrund heftiger nationalistischer Polemiken. Seine Karriere als Historiker begann mitten in der revolutionären Umbruchsphase zu Ende des Ersten Weltkriegs und zu Beginn der von Vielen ungeliebten Ersten Republik. Lechners engeres Forschungsgebiet, die Siedlungsgeschichte, der Kötzschke die „größte nationale Bedeutung“ beimaß, lag mitten im volkstumspolitischen „Kampfgebiet“171. Gerade Lechners frühe Arbeiten verwiesen auch auf diesen Kontext, und wie Ralph Andraschek-Holzer in seinem historiografiegeschichtlichen Beitrag unter anderem zeigt, war Lechners Frühwerk über das Waldviertel von antislawischen Ressentiments nicht frei geblieben.

Als profilierter Vertreter der landesgeschichtlichen Forschung in Österreich war Lechner „gesamtdeutsch“ orientiert, wenn auch seine öffentliche Kritik an der Nachkriegsordnung relativ moderat ausfiel. Mitte der I 93oer-Jahre engagierte er sich als Experte der Geschichte des Waldviertels und der angrenzenden Gebiete auch im Kontext der SODFG. Im Frühjahr I 934 nahm er an der als Studienfahrt deklarierten Tagung der SODFG über das nördliche Niederösterreich und Südmähren teil ${ }^{172}$. Er traf dabei auch mit Vertretern des „Deutschen Vereins für die Geschichte Mährens und Schlesiens“ zusammen und referierte über die Siedlungs- und ältere Herrschaftsgeschichte in diesem Raum ${ }^{173}$; weitere

169 ÖStA/AdR, GA, Zl. 316.372, Karl Lechner, Politisches Gutachten der NSDAP Wien, Kreisleitung V, vom 21.12.1942.

170 NÖLA, NS-Fragebögen, Karl Lechner, Auskunftszettel, Abschrift eines Schreibens der NSDAP, Gau Wien, Kreisleitung V, an die Gauleitung Wien vom 09.12.1941.

171 Кӧтzsснке, Nationalgeschichte (wie Anm. 112) 19, betrachtete die Siedlungsgeschichte durchaus auch als „volkstumspolitisches“ Instrument: „Denn nicht so sehr um die Idee des Nationalstaates an sich, als um die Bodenverteilung Mitteleuropas auf nationale Staaten und ihre gegenseitige Abgrenzung geht der Kampf, und nicht allein mit Machtmitteln wird er geführt, sondern auch mit geschichtlichen Gründen für uraltes Heimatrecht."

172 Michael Faнlвusch, Wissenschaft im Dienst der nationalsozialistischen Politik? Die „Volksdeutschen Forschungsgemeinschaften“"von 1931-1945 (Baden-Baden 1999) 290.

173 Der gleichfalls referierende Hans Reutter vom „Deutschen Verein für die Geschichte Mährens und Schlesiens“ sollte nach der Annexion der „Resttschechei“ im März 1939 bei Lechner wegen einer Eingliederung des Vereins in den VfLKNÖ vorfühlen. Dazu dürfte es aber nicht gekommen sein. NÖLA, NL KL, K. I, Mappe I/5, Korrespondenz mit südmährischen Historikern etc., Schreiben Reutter an Lechner vom 30.03.1939. 
Vortragende dieser Tagung waren Hassinger, Brunner und Karl Giannoni - allesamt Mitglieder des VfLKNÖ - sowie Hirsch, Leiter des IÖG, der Altertumskundler Rudolf Egger und andere ${ }^{174}$. An der Fortsetzung dieser Tagung im Waldviertel und in Südböhmen im Jahr darauf war Lechner gleichfalls und neben Hirsch und Hassinger abermals als Referent beteiligt ${ }^{175}$. 1937 wurde er zum Mitglied der SODFG ernannt, und über Antrag dieser Organisation wurde ihm 1939 auch die Medaille zur Erinnerung an den „Anschluss“ Österreichs an das Deutsche Reich verliehen ${ }^{176}$.

Die von der SODFG mit vorbereitete Einverleibung der südmährischen und südböhmischen Gebiete versetzte Lechner als Archivar in die Lage, nun auch jene Materialien ins Landesarchiv zu bringen, die seiner „gesamtdeutschen “ Auffassung zufolge wohl gar nicht in „tschechischen“ Besitz hätten geraten dürfen. Nur einen Monat nach der Angliederung der sudetendeutschen Gebiete befand sich Lechner mit einem Mitarbeiter in Znaim (Znojmo), um mit dem NS-Beauftragten für Südmähren die Sicherung der Archivalien des südmährischen Gebietes zu organisieren ${ }^{177}$. Auch an der Ausscheidung und Übernahme von Schriftgut aus den Archiven des Protektorates Böhmen und Mähren war Lechner beteiligt. Unter seiner Leitung wurden in den folgenden dreieinhalb Jahren tonnenweise Archivalien aus der ehemaligen Tschechoslowakei ins nunmehrige Reichsgauarchiv Niederdonau verbracht. Diese Materialien mussten nach dem Zusammenbruch der NS-Herrschaft wieder rückgestellt werden ${ }^{178}$.

Zusammenfassend kann festgehalten werden, dass Lechner der Volksgeschichte zwar nahestand, er rassistischen Varianten derselben aber erhebliche Vorbehalte entgegenbrachte $^{179}$. Die Ausrichtung seiner Geschichtsschreibung war zwar ohne Zweifel „gesamtdeutsch“, aber nicht biologistisch. Wenn Lechner auch seine kommentierte „Bibliographie“ von I940 in der volksgeschichtlich orientierten Reihe „Deutsche Schriften zur Landes- und Volksforschung" herausbrachte und darin als Juden geltende Autoren mit „(J.)“ kennzeichnete ${ }^{180}$, verblieb er dennoch in seinen Arbeiten, wie auch oben ge-

174 Fahlbusch, Wissenschaft (wie Anm. 175) 290.

175 Ebd. 291; im Zuge seines Entnazifizierungsverfahrens bezeichnete Lechner diese Veranstaltung als Tagung d. Wiener u. Prager Hochschullehrer, siehe dazu ANÖLR, PA KL, Fragebogen der Landeshauptmannschaft NÖ vom 23.01.1946, Beilage zu Punkt IV.B.

176 Ebd. Grundlagen für den Beförderungsantrag Dr. Karl Lechner zum Oberarchivrat, undatiert (ca. 1940).

177 NÖLA, Archiv-Sonderakten, K. IV, Zl. 133/1943, Bd. 1, Schreiben Archiv für Niederdonau an Archivamt vom 05.12.1938.

178 Ebd.

179 Die folgende Einschätzung bemüht sich, das von Hettuing, Einleitung (wie Anm. 113) 23, postulierte Plädoyer für eine differenzierte Bewertung der verschiedenen volksgeschichtlichen Strömungen umzusetzen. Entscheidend sind dabei die Fragen, „in welchem Maße die jeweiligen Forschungen wissenschaftlichen Kriterien verpflichtet blieben“" (die Biologisierung kultureller Äußerung markiert hier die klare Überschreitung der Grenze zur Ideologie) und ob sie den Anspruch verfolgten, „(rassen-)politisches Handeln anzuleiten.“

180 Karl Lechner, Bibliographie zur Landeskunde der nördlichen Hälfte der Gaue Niederdonau und Wien 
zeigt wurde, weit überwiegend im Rahmen eines politisch und/oder historisch fundierten Volksbegriffes und im Kontext einer dem entsprechenden „Kulturbodenforschung“, wie sie auch in anderen europäischen Staaten betrieben wurde. Die gleichwohl in manchen seiner Arbeiten zu findenden Bezugnahmen auf „Volkskörperforschung“ und Rassenkunde wirken eher schematisch und additiv. $\mathrm{Zu}$ grob dürften ihm die Kategorien der Volksgeschichte, und analytisch wenig weiterführend mochten ihm die rassenkundlichen Typologien erschienen sein. In seinem groß angelegten Literaturbericht zur siedlungskundlichen Forschung in Österreich verwies er unter anderem zwar auf das "große Werk“ Helboks - „Grundlagen der Volksgeschichte Deutschlands und Frankreichs“ - und konzedierte diesem eine „Reihe von wertvollen methodischen Anregungen“181. Gleichzeitig monierte er aber „den Mangel einer intensiven Einzelforschung “182. Gegen Ende dieser Untersuchung widmete Lechner auch der Rassekunde einen kurzen Absatz. Dabei wies er gleich einleitend darauf hin, dass man „ohne genaue siedlungsgeschichtliche Untersuchungen, die sich auch in die Zeit vor der deutschen Landnahme zu erstrecken haben“, $\mathrm{zu}$ „keinem klaren Bild kommen werde“ ${ }^{183}$. Nach der Referierung einiger rassekundlicher Arbeiten kam er zu dem Schluss, „daß mit diesen großen Gruppen der Besiedlungsgeschichte nicht viel gedient ist und forderte von dieser Disziplin weitere Aufgliederungen nach sog. ,Gauschlägen' [...] sowie Untersuchungen über Auslese und ihre Ursachen usw."; auch seien jüngere Zuwanderungen zu untersuchen ${ }^{184}$.

Darüber hinaus wies Lechners wissenschaftliches Werk auch nach der Zäsur I 938 keine signifikanten inhaltlichen oder thematischen Änderungen oder nennenswerte politisch motivierte Anpassungen auf. In seinem Beitrag im „Anschlussband“ des JbLKNÖ von I 938 hielt er gleich eingangs am Vorrang „einer systematisch aufgebauten Siedlungsund Herrschaftsgeschichte“ fest und legte klar: „Auch die Anerkennung der grundlegenden Funktion von Blut und Boden kann praktische Bedeutung für die geschichtliche Forschung nur dann gewinnen, wenn ausgegangen wird von den Gemeinschaften, in denen der Mensch, vor allem der bäuerliche Mensch steht, wieder also von der Herrschaft, als Grund-, bzw. Orts- (Dorf-), Vogtei- und Gerichtsherrschaft, und Pfarre." ${ }^{185}$

(von Nöchling bis Theben) 1920-1938 (Deutsche Schriften zur Landes- und Volksforschung 4, Leipzig 1940).

181 Karl LeChner, Leistungen und Aufgaben siedlungskundlicher Forschung in den österreichischen Ländern mit besonderer Berücksichtigung von Niederdonau, in: DALV 4 (Dezember 1940) 494-546, hier 500.

182 Ebd.

183 Ebd. 543.

184 Ebd.

185 Karl Lechner, Die geschichtliche Landschaft zwischen Donau und Wagram. Ein Beitrag zur Geschichte niederösterreichischer Herrschaften, in: JbLkNÖ NF 27 (1938) 30-70, hier 30. 
Auch in den von Lechner redigierten Publikationen des VfLKNÖ wurde die bislang verfolgte, überwiegend traditionell landeskundlich ausgerichtete Linie über weite Strecken beibehalten. Völlig frei von Rassismen oder NS-volksgeschichtlich orientierten Betrachtungen blieben diese Veröffentlichungen aber dennoch nicht. Gerade Schlesinger, Vizepräsident des VfLKNÖ, äußerte sich im Jahrbuch von 1938 diesbezüglich mit großer Radikalität ${ }^{186}$, und krude rassekundliche Aufsätze - zumeist von Ämilian Kloiber verfasst - fanden sich $\mathrm{ab}$ und an im Monatsblatt des Vereins ${ }^{187}$. Von Klebel wiederum stammte ein programmatischer Beitrag zur Volksgeschichte im „Anschluss“-Heft I938 ${ }^{188}$; als der intendierte Anstoß für entsprechende Arbeiten wirkten sie in diesem Forum aber nicht.

\section{I.Io Entnazifizierung}

Nach dem Zusammenbruch des Nationalsozialismus standen für Lechner - wie er noch in den I960er-Jahren schrieb - die „Feinde“"189, „fremde Völker und fremdrassisches Militär“ im Lande ${ }^{190}$. Darüber hinaus hatte er erneut Erklärungsbedarf - diesmal gegenüber den neuen demokratischen und sich zumindest vorerst noch als dezidiert antifaschistisch verstehenden Behörden. Als ehemaliger Parteianwärter der NSDAP war er zunächst noch registrierungspflichtig; ein Entnazifizierungsverfahren wurde eingeleitet. Im Unterschied zu vielen anderen, die ihr Interesse an der NSDAP mit persönlichen oder politischen Zwangslagen zu rechtfertigen suchten, war Lechner bestrebt, sich von Opportunismus und Materialismus abzugrenzen. So räumte er im Februar I 946 zwar ein, in seinem Fragebogen 1938 eine etwas übersteigerte, aufspreitende [sic] und schmückende Formulierung gewählt zu haben, legte aber Wert auf die Feststellung, dass sein Aufnahmeantrag damals weder aus Zwang und Feigheit noch um materieller Vorteile willen, sondern lediglich aus ideellen Gründen (kirchentreuer Katholik, mittelalterlicher Histo-

186 Günther SCHLESINGER, Landschaftsraum und Landschaftsrhythmus als Planungsgrundlagen, in: JbLKNÖ N.F. 27 (1938) 311-318, hier 311, 318.

187 Ämilian Kloiber, Deutsche und Tschechen aus Südböhmen und Österreich im 19. Jahrhundert, in: UH 11 (September/Oktober/November 1938) 245-256; Ders., Franz Freitag, Rasse und Kultur in Niederdonau, in: UH 13 (Januar-Februar 1940) 3-18; Ämilian Kloiber, Über die Notwendigkeit der rassenkundlichen Bearbeitung von geschichtlich wichtigen Schädeln und Skeletten, in: UH 15 (Oktober-Dezember 1942) 171-174; siehe ferner Anton LANG, Eine bevölkerungsgeographische Studie aus dem Waldviertel, in: UH 12 (1939) 35-44.

188 Ernst Klebel, Reichsgeschichte und Landesgeschichte, in: UH 11 (März/April 1938) 86-93.

189 Lechner, 1864-1964 (wie Anm. 88) 193, 195.

190 Karl Lechner, Niederösterreich und Wien. Landschaft, Geschichte, Kultur. Strukturen und Funktionen, in: Custos quid de nocte? Österreichisches Geistesleben seit der Jahrhundertwende, hg. v. Karl Rudolf, Leopold Lentner (Wien 1961) 7-45, hier 45. 
riker) erfolgt sei ${ }^{191}$. Seine schon 1938 umstrittene Auslegung von Kirchentreue suchte er mit seinem anfänglichen Glauben an einen Ausgleich zwischen katholischer Kirche und NS-Staat zu begründen ${ }^{192}$. Eine Erklärung für den von ihm behaupteten Zusammenhang zwischen mediävistischer Forschung und NS-Parteimitgliedschaft blieb er zwar schuldig; sie dürfte aber in der Neigung „Katholisch-Nationaler“ zu suchen sein, das Heilige Römische Reich Deutscher Nation mit dem Dritten Reich zu analogisieren ${ }^{193}$.

Lechner wurde - wie übrigens auch sein Freund Kurt Vancsa - am 25. Oktober 1946 vom Dienst suspendiert, seine monatlichen Bezüge auf I 50 öS gekürzt. Wie sich bald herausstellte, war die Außerdienststellung aber nicht von Vertretern der sowjetischen Besatzungsmacht ausgegangen. Lechner gelangte bald zu der Auffassung, dass es im Haus Kreise, gebe, die mir übelwollen ${ }^{194}$. Er und Vancsa konnten aber schon Anfang I 947 ihren Dienst wieder antreten ${ }^{195}$. Nur wenige Wochen später erschien aber in dem Wochenblatt „Österreichisches Tagebuch“ ein mit „ein österreichischer Katholik“ gezeichneter Artikel, der sich unter anderem mit der Person Lechners beschäftigte. Lechner wurde darin als „waschechter, fanatischer Pg“ [Parteigenosse; Anm. S. E.] bezeichnet und insbesondere auf die von ihm vertretene „gesamtdeutsche Geschichtsauffassung“ hingewiesen, die er nach wie vor im VfLKNÖ verbreite ${ }^{196}$.

Wie Lechner selbst feststellte, verriet der Artikel viel intime Kenntnis seiner Person. Lechner war empört, antwortete aber nicht öffentlich, sondern übersandte dem Präsidium der Landeshauptmannschaft eine Stellungnahme. Darin wandte er sich gegen die seiner Meinung nach tendenziöse Darstellung und gegen die tatsächlich teilweise unkorrekte Zitierung seines Textes. Der in dem Artikel gleichfalls angegriffene VfLKNÖ mutierte in der Darstellung Lechners nun aber wieder zum alten, wie jeder weiß, konservativen, Verein für Landeskunde ${ }^{197}$. Die „gesamtdeutsche“ Geschichtsauffassung Lechners, welche er

191 ANÖLR, PA KL, Kurze Erklärung und Rechtfertigung zu den vier aus meinem Fragebogen vom 29.09.1938 ableitbaren besonderen Vorwürfen vom 09.02.1946.

192 Ebd.

193 Der führende „Neuländer“ Anton Böhm reflektierte darüber zwanzig Jahre nach dem Zusammenbruch des Dritten Reiches im „Rheinischen Merkur“: „Reich war das Verzauberungswort einer politischen Romantik, die nicht wiederkommen darf, wenn wir nicht von neuem der deutschen Versuchung verfallen sollen, die Wirklichkeit durch Wunschträume zu korrigieren. Dem Staat, indem man ihn Reich tauft, eine Art von übernatürlichem Charakter zu verleihen, als ihm etwas von der Heiligkeit des mittelalterlichen Sacrum Imperium zuzubringen, war ein Irrweg [...]. Eine nationale Mission, die ein Volk über das andere erhebt, kann es nicht mehr geben, sondern nur das Wetteifern im Dienste eines gemeinsamen Ziels“. Zitiert nach EppeL, Kreuz (wie Anm. 40) 53.

194 NÖLA NL EK, K. III, Mappe III/2, Korrespondenz Lechner, Schreiben Lechner an Klebel vom 02.03.1947. 195 ANÖLR, PA KL, Bericht von Dr. Willmitzer an den Herrn Landeshauptmann vom 12.03.1948.

196 Österreichisches Tagebuch. Wochenschrift für Kultur, Politik, Wirtschaft 2 (15.02.1947) 11.

197 ANÖLR, PA KL, Schreiben Lechner an Friedrich Funder vom 06.03.1947. 
I 938 noch als politisches Verdienst im Sinne des Nationalsozialismus verstanden wissen hatte wollen, blieb aber auch in der Folge im Zentrum der Erörterung. Bei der geplanten Veröffentlichung seiner kurzen Geschichte der Babenberger ergaben sich deshalb Schwierigkeiten. ,Reich' und ,Mark' sind gefährliche Begriffe geworden, schrieb er Anfang März I947 an Klebel ${ }^{198}$. Nachdem das Präsidium der niederösterreichischen Landesregierung ein entsprechendes Ersuchen gestellt hatte, erfolgte im Frühjahr I 947 sogar eine politische Begutachtung des literarischen Schaffens Lechners durch das BMU ${ }^{199}$. Der Leiter der Abteilung Schrifttum und Verlagswesen verwies dabei zwar allgemein auf die verhängnisvolle Rolle der „gesamtdeutschen“ Geschichtsauffassung und stellte fest, dass sich Lechner vor allem mit seinem Beitrag im Nadler-Srbik-Werk in ein, grossdeutsches 'Fahrwasser begeben habe ${ }^{200}$. Letztlich gelangte er aber zu der Auffassung, dass Lechner damit nicht auch für den Nationalsozialismus eingetreten sei ${ }^{201}$. Begründet wurde diese Einschätzung insbesondere mit dem Stellenwert, den Lechner in seinen Schriften der Kirche eingeräumt habe, sowie mit Passagen seines 1944 veröffentlichten Nachrufs auf Redlich. Dort hatte er seinen Lehrer Redlich gleich im ersten Absatz als „Symbol einer besseren, lautereren und vornehmeren Zeit" bezeichnet, was als deutliche Polemik gegen den zur Herrschaft gelangten Nationalsozialismus gewertet wurde ${ }^{202}$. Mit geringer Sorgfalt dürfte allerdings die Begutachtung von Lechners katholischer Publizistik durchgeführt worden sein. Auf die oben erwähnten antisemitischen Wendungen in Lechners Beitrag über die eugenischen Bestrebungen, der in dem Gutachten sogar namentlich angeführt wird, wurde nicht eingegangen ${ }^{203}$.

Mit dieser Bewertung und vor dem Hintergrund der Lockerung der Entnazifizierungsmaßnahmen 1947 vermochte Lechner die Probleme, welche sich aus seiner „gesamtdeutschen" Haltung ergeben hatten, weitgehend hinter sich zu lassen. Im Herbst I 947 konnten schließlich auch seine Babenberger erscheinen ${ }^{204}$. Lechner hatte, wie er es nannte, alle gefährlichen Stellen getilgt und den Text vorher auch noch Friedrich Funder, dem Herausgeber der „Furche“, zur Durchsicht gegeben ${ }^{205}$. Dennoch war er, wie er Klebel mitteilte, auf das politische Echo fast neugieriger als auf das wissenschaftliche ${ }^{206}$.

198 NÖLA NL EK, K. III, Mappe 2, Schreiben Lechner an Klebel vom 02.03.1947.

199 NÖLA, NS-Fragebögen, Karl Lechner, Abschrift der Begutachtung der literarischen Tätigkeit des Archivars Dr. Karl Lechner durch Dr. Dolberg o.D. [vermutlich April 1947].

200 Ebd.

201 Ebd.

202 Ebd.; Lechner, Redlich † (wie Anm. 93) V.

203 NÖLA (wie Anm. 202).

204 Karl Lechner, Die Babenberger in Österreich (Der Bindenschild. Darstellungen aus dem Kultur- und Geistesleben Österreichs 6, Wien 1947).

205 NÖLA NL EK, K. III, Mappe III/2, Schreiben Lechner an Klebel vom 25.06.1947.

206 Ebd. Schreiben Lechner an Klebel vom 17.12.1947. 
Politisch recht hilfreich für Lechner war die Herausgabe einer ihm gewidmeten Festschrift anlässlich seines 50. Geburtstages im Mai $1947^{207}$. Sein Freund Kurt Vancsa hatte ihn damit überrascht und ${ }^{208}$ - wohl mit Rücksicht auf ÖVP-Kreise - auch gleich die bereits zitierten regimekritischen Passagen im Beitrag „Der Laie in der Kirche“ von I 933 getilgt. Die Festschrift enthielt sieben ausgewählte historische und religiöse Schriften Lechners, eine Bibliografie sowie eine lange Gratulantenliste; diese Liste vereinte sehr unterschiedliche Kreise von Personen und Institutionen ${ }^{209}$. So war etwa die universitäre Wissenschaft mit dem politisch belasteten Historiker Klebel ebenso vertreten wie mit Santifaller, der neuen Leitfigur der Wiener Geschichtswissenschaft, und dem vordem als „jüdisch versippt" diskriminierten Erich Zöllner ${ }^{210}$. Die Stadt- und Landesgeschichte war durch die politisch „unbelasteten“ Adalbert Klaar und Richard Kurt Donin, den erklärten Gegner der Nationalsozialisten Ferdinand Tremel ${ }^{211}$ und den 1938 aus politischen Gründen entlassenen Richard Pittioni ${ }^{212}$ repräsentiert, wie auch durch die „Alten Kämpfer“ der NSDAP Hans Wolf und Gustav Gugitz. Kirchliche Kreise wie etwa Kardinal Innitzer und die „Neuland“-Führer Karl Rudolf, Michael Pfliegler und Franz Maria Kapfhammer gratulierten ebenso wie die Repräsentanten der neuen österreichischen Volksbildung Adolf Bruck und Franz Hurdes ${ }^{213}$ und die Archivdirektoren Rudolf Geyer und Ignaz Zibermayr. Unter den beglückwünschenden Institutionen fanden sich viele Landesarchive, kirchliche und kommunale Archive, Museen und Bibliotheken sowie Klöster und Stifte. Wissenschaftliche Institute wie etwa das IÖG und das Institut für Geschichte und Landeskunde in Innsbruck waren gleichfalls vertreten, doch auch der in Niederösterreich politisch so einflussreiche Niederösterreichische Bauernbund zählte zu den Gratulanten. Diese vielstimmige Feierrunde diente nicht nur der Mehrung von Lechners symbolischem und sozialem Kapital. Im Kontext des kurz zuvor stattgefundenen radikalen politischen

207 Karl Lechner. Ausgewählte Schriften mit einer Bibliographie. Zu seinem 50. Geburtstag, hg. v. Kurt VAnCSA mit Unterstützung des Vereines für Landeskunde von Niederösterreich und Wien (Wien 1947). Lechner war sich dieser politischen Wirkung durchaus bewusst. An Klebel schrieb er: Ich weißja, daß die Sache unverdient groß aufgezogen wurde, aber, propter forum externum ' freut es mich doch. Ob's etwas nützt. NÖLA NL EK, K. III, Mappe III/2, Schreiben Lechner an Klebel vom 10.09.1947.

208 Ebd. Schreiben Lechner an Klebel vom 25.06.1947.

209 Karl Lechner (wie Anm. 210) 235-238.

210 Zu Zöllner siehe Manfred Stoy, Das Österreichische Institut für Geschichtsforschung 1929-1945 (MIÖG Erg.-Bd. 50, Wien/München 2007) 369f.

211 Heinz Dopsch, Geschichtsvereine in Österreich. Anfänge und Entwicklungen - Leistungen - Aufgaben, in : Blätter für deutsche Landesgeschichte 138 (2002) 85.

212 Heiss, Perspektive (wie Anm. 86) 194-195.

213 Zu Bruck und Hurdes sowie zur neuen österreichischen Volksbildung nach 1945 allgemein siehe auch Stefan Speva , Das Jubiläum „950 Jahre Österreich“. Eine Aktion zur Stärkung eines österreichischen Staats- und Kulturbewußtseins im Jahr 1946 (Veröff. des IÖG 37, Wien/München 2003) 40-43. 
Bruchs und vor dem Hintergrund von Entnazifizierung und Statusunsicherheit kann dieses Neben- und Ineinander von politisch „Belasteten“ und „Unbelasteten“, von „Tätern“ und „Opfern“, von „Deutschnationalen“ und „Österreichern“ sowie die Verquickung der unterschiedlichen Freundeskreise Lechners im Sinne der Stiftung von Kontinuität und Stabilität interpretiert werden, gleichsam als „Versöhnung“ von Vergangenheit und Gegenwart. Eine Folge dieser „Glättung“ von Widersprüchlichem war freilich, dass eine ernsthafte Auseinandersetzung mit Ursachen und Ausmaß der Verstrickung von Wissenschaft und Bürokratie in den Nationalsozialismus nicht stattfand. Von Lechner ist eine Reflexion über derartige Fragen nicht bekannt.

Die Entnazifizierung empfand Lechner als bloße Schikane. Sie führte bei ihm keineswegs zu der politisch intendierten selbstkritischen Analyse des eigenen Verhaltens in einem arbeitsteilig organisierten Terrorregime; im Gegenteil - Lechner sah sich eher selbst als Opfer und wollte darin ausschließlich böswillige und gegen ihn persönlich gerichtete Motive erkennen. Noch viele Jahre später setzte er Maßnahmen der Entnazifizierung kurzerhand mit der menschenverachtenden Politik der Nationalsozialisten gleich ${ }^{214}$. Charakteristisch für seine Haltung in dieser Frage war auch der Rat, den er dem nach Deutschland geflohenen Klebel erteilte. Da Klebel damals Schwierigkeiten hatte, eine adäquate Beschäftigung zu finden, fragte ihn Lechner, ob er nicht mit einem der niederösterreichischen Stiftsäbte bekannt gewesen sei; denn zumindest in Oberösterreich habe fast jedes Kloster seinen ,Hausn..i' als Archivar u. Bibliothekar etz. ${ }^{215}$.

\section{I.II Amtliche und wissenschaftliche Karriere nach I945}

Ende 1947 wurde Lechner aus den NS-Registrierungslisten gestrichen ${ }^{216}$. Die politischen Probleme von NS- und Nachkriegszeit konnte er dadurch endgültig abschütteln; einzig die Spannungen zum gerade im niederösterreichischen Landesdienst nach I945 kräftig aufstrebenden CV blieben bestehen. Ohne je formell ausgeschlossen worden zu sein, wurde Lechner nach 1945 in den Verzeichnissen des CV nicht mehr geführt ${ }^{217}$. Seine Beförderung zum Oberlandesarchivar I948 vermochte er nach eigenen Angaben gegen den Widerstand der (CV-dominierten) ÖVP-Gewerkschaft durchzusetzen; die von ihm angestrebte Betrauung mit einem eigenen Referat habe Letztere aber vorerst blockiert ${ }^{218}$.

214 Lechner, 1864-1964 (wie Anm. 88) 195.

215 NÖLA NL EK, K. III, Mappe III/2, Schreiben Lechner an Klebel vom 25.06.1947; pikanterweise trägt dieses Schreiben auch den Stempel der damals noch üblichen Briefzensur.

216 ANÖLR, PA KL, Bericht von Dr. Willmitzer an den Herrn Landeshauptmann vom 12.03.1948.

217 Otto Krammer, Geschichte der katholisch akademischen Verbindung Bajuvaria 1920-1980 (Wiener Katholische Akademie Miscellanea III,24, Wien 1984) 293.

218 NÖLA NL EK, K. III, Mappe III/2, Schreiben Lechner an Klebel vom 27.08.1949. 
Andererseits verfügte Lechner im Bauernbund über eine politische Stütze. Unmittelbar nach Aufhebung seiner Suspendierung Anfang 1947 trug ihm der Österreichische Bauernbund einen Vortrag im Rahmen eines Schulungskurses für bäuerliche Abgeordnete, Funktionäre und Sekretäre des Bauernbundes und der Kammern $a^{219}$, und kaum ein Jahr nach der öffentlichen Gratulation des Niederösterreichischen Bauernbundes zu Lechners 50. Geburtstag setzte sich dessen Obmann Josef Reither, zudem Präsident des Österreichischen Bauernbundes sowie niederösterreichischer Landeshauptmann, mit Erfolg für Lechners Beförderung ein ${ }^{220}$. 1955 stieg Lechner schließlich doch noch zum Referatsleiter auf $^{221}$, und später nahm er auch unter den österreichischen Archivaren eine führende Stellung ein. Als sich I 967 der „Verband österreichischer Archivare“ konstituierte, wurde der bereits seit fünf Jahren pensionierte Lechner einhellig zum ersten Präsidenten gekürt ${ }^{222}$. Dessen ungeachtet hielt sich das Land Niederösterreich mit Ehrungen lange zurück. War Lechner staatlicherseits bereits I963 mit dem Großen Ehrenzeichen für Verdienste um die Republik Österreich und anlässlich seines 70. Geburtstages I 967 mit dem Ehrenzeichen für Wissenschaft und Kunst I. Klasse ausgezeichnet worden, so wurde er in Niederösterreich erst I975 - also knapp vor seinem Tod - mit dem Großen Ehrenzeichen für Verdienste um das Land Niederösterreich bedacht ${ }^{223}$.

Vergleichsweise reibungslos und jedenfalls erfolgreich verlief Lechners Nachkriegskarriere auf wissenschaftlichem Gebiet; seine zwar leicht adaptierte, aber weiterhin „deutsche“ Interpretation der österreichischen Geschichte war hier kein Hindernis ${ }^{224}$. Der Topos von der Bollwerkfunktion des Landes im Osten war in die geopolitisch neue Situation des Kalten Krieges ebenso gut integrierbar wie Lechners Betonung der kulturellen Leis-

219 NÖLA, NL KL, K. I, Mappe I/5, Verschiedene Korrespondenz nach 1945, Schreiben des Österreichischen Bauernbundes an Lechner vom 08.01.1947; Lechner sagte zu und hielt den Vortrag Aus der Geschichte des österreichischen Bauerntums am 24.01.1947 in Wallsee an der Donau; ebd. K. IX, Mappe IX/2, Schulungskurs des Österreichischen Bauernbundes in Wallsee a. Donau vom 23. bis 29. Januar 1947.

220 ANÖLR, PA KL, Information für Herrn Präsidialvorstand Dr. Willmitzer vom 12.02.1948; die Beförderung erfolgte mit Beschluss der Nö. Landesregierung vom 05.05.1948; ebd, Schreiben ANÖLR, Präsidium, an Lechner vom 01.06.1948.

221 ANÖLR, PA KL, Abschrift eines Schreibens des Amtes der Nö. Landesregierung, Landesamtsdirektion, an Lechner vom 09.06.1956.

222 NÖLA, NL KL, K. II, Mappe II/8, Schreiben Dr. Franz Gall an Lechner vom 26.06.1967.

223 Pittioni, Lechner (wie Anm. 8), 586.

224 Heiss, Reich (wie Anm. 64) 470; wie aus einem Schreiben des Herausgebers des „Territorien-Ploetz“, Georg Wilhelm Sante, an Lechner 1962 geschlossen werden kann, wollte Lechner Österreich offenbar auch nach 1866 im Rahmen der deutschen Geschichte behandelt wissen. Die Antwort Santes lautete: Vor der Hand bin ich der Ansicht, daß Österreich nur bis 1866 zu behandeln ist - wir können die Geschichte nicht ändern. Mancher $N u r$-Österreicher würde es uns verübeln, wenn wir Österreich auch nach 1866 zu Deutschland rechneten. NÖLA, NL KL, K. I, Mappe I/5, Mappe Verschiedene Korrespondenz nach 1945, Schreiben Sante an Lechner vom 06.12.1962. 
tungen des deutschen Österreichertums in die neue Österreich-Ideologie ${ }^{225}$. So beschwor Lechner in einem Beitrag für die Festschrift seines Freundes Pfliegler I96I weiterhin die jahrhundertealte „Ostmarkaufgabe“ Niederösterreichs: In der Monarchie sei sie dem Land „für das ganze Deutsche Reich, für ein deutsches Mitteleuropa, ja ein christliches Abendland“ gestellt gewesen ${ }^{226}$; der Erste Weltkrieg habe dann neuerlich die Aufgabe Österreichs herausgestellt, „Grenzwächter zu sein gegen Moskowitertum und Panslavismus im Osten und nationalchauvinistische Aspirationen im Süden ${ }^{227}$, und nach dem gescheiterten, mit untauglichen Mitteln und unter irrigen historischen Voraussetzungen unternommenen Versuch, dieses Österreich [...] einem größeren Ganzen als Ostmark einzuverleiben“, sei Niederösterreich stärker als je zuvor „wieder Grenz- und Markland gegen Nord und Ost, gegen ,Eiserne Vorhänge“"228. Wie für ganz Österreich bleibe aber die „weitere Aufgabe und Sendung: Abwehr und Wall gegen Ungeist und Unkultur von Ost und Nord zu sein, Brücke und Vermittlung aber für alle kulturellen Werte, nach West und Ost, nach Nord und Süd“229.

Bemerkenswert war, wie Lechner hier das Bekenntnis zu deutscher Kultur und deutschem Volkstum mit Versatzstücken des neuen Österreich-Mythos verknüpfte. Mit der Ausweitung der kulturellen Mission Österreichs vom Osten in nunmehr alle Himmelsrichtungen erklärte er dieses Land nun kurzerhand zum „geistigen Zentrum, das befähigt ist, auf nähere und entferntere Anrainer fruchtbar einzuwirken“230. Denn „als eine besondere Funktion dieses Österreich innerhalb deutscher Kultur und deutschen Volkstums [sei] erkannt worden, daß es allseits mehr oder weniger fremde Einflüsse aufnimmt, das ihm Wesensgemäße daran herausgreift, es mit dem eigenen Bodenständigen verbindet und es weiterbildet, das Vielfache und Mannigfaltige zu einer Einheit zusammenbindet, zu einem harmonischen Ganzen, Eigen-artigen, Eigenständigen, zu einem Österreichischen!“231

Auch Lechners Zuschnitt der Heimatkunde passte gut in das Konzept der katholischkonservativen „Heimat-Macher“ am Beginn der Zweiten Republik. Indem ihm „Heimat“

225 Mit Bezug auf Wilhelm Bauer verwies darauf auch Ernst Han Isch, Der forschende Blick. Österreich im 20. Jahrhundert: Interpretationen und Kontroversen, in: Carinthia I 189 (1999) 567-583, hier 571.

226 Karl Lechner, Niederösterreich und Wien. Landschaft, Geschichte, Kultur. Strukturen und Funktionen, in: Custos quid de nocte? Österreichisches Geistesleben seit der Jahrhundertwende, hg. v. Karl Rudolf, Leopold LentNer (Wien 1961) 7-45, hier 19.

227 Ebd. 44.

228 Ebd. 45.

229 Ebd.

230 Ebd. 19; zu den nach 1945 stark forcierten Topoi von Österreich als „schöpferischer Mitte“ und vom „Kulturland Österreich“ siehe Ernst Brucкмüller, Nation Österreich. Kulturelles Bewußtsein und gesellschaftlich-politische Prozesse (Studien zu Politik und Verwaltung 4, Wien/Köln/Graz ${ }^{2} 1996$ ) 120-123.

231 LeChner, Niederösterreich und Wien (wie Anm. 229) 19. 
mehr war „als Staat oder Land, ja selbst mehr als Volk“232, konnte auch seine prinzipiell "gesamtdeutsche“ Ausrichtung überblendet werden, und Lechner engagierte sich sehr bald in der neuen österreichischen Volksbildung. Von Vorteil war dabei wohl auch seine Bekanntschaft mit dem niederösterreichischen Volksbildungsreferenten Hurdes. Die beiden kannten einander wohl schon seit den I93oer-Jahren, als Hurdes noch in der „vaterländischen“ Volksbildung und in Hubertendorf aktiv gewesen war ${ }^{233}$. Darüber hinaus war Hurdes gleich in der ersten Vollversammlung der Nachkriegszeit in den Ausschuss des VfLKNÖ aufgenommen worden ${ }^{234}$. Bereits auf der ersten niederösterreichischen Volksbildnertagung im Juli I 949 referierte Lechner - unter anderem neben den „Neuland“-Priestern Pfliegler und Kapfhammer - über „Heimatkunde als Grundlage der Volksbildung “235. Er agierte damit im Kontext einer Volksbildung, die unter anderem die Erziehung zur Demokratie und zu einem „österreichischen Staats- und Kulturbewußtsein“ auf ihre Fahnen geschrieben hatte und „an der geistigen Wiedergenesung unseres Volkes“ mitzuhelfen bestrebt war ${ }^{236}$. Lechner nahm darauf zwar nie Bezug, doch fügten sich sein stark religiös durchwirkter Heimatbegriff und sein konservatives Verständnis von Heimatkunde nahtlos ein in die politisch sanktionierten und stark an die I93oerJahre anknüpfenden Heimat-Diskurse der Nachkriegszeit ${ }^{237}$. Selbst an der Initialzündung der neuen österreichischen Volksbildung I946, an der Feier „950 Jahre Österreich“ hatte Lechner Anteil. Stefan Spevak vermutet in ihm sogar einen der möglichen „Erfinder“ von „Ostarrichi“, denn der Babenberger-Spezialist Lechner hatte mit seinem in der ÖVP-nahen Kulturzeitschrift „Neue Ordnung“ erschienen Kommentar zur „Ostarrichi-Urkunde“

232 Karl Lechner, Heimatkunde als Grundlage der Volksbildung, in: Zur Volksbildungsarbeit in Niederösterreich. Eine Zusammenfassung der Referate und Berichte von der ersten niederösterreichischen Volksbildnertagung nebst einem Verzeichnis „Das niederösterreichische Schrifttum“, hg. v. Franz Hurdes (Wien 1950) 46-57, hier 46.

233 Zu Hurdes - übrigens der Bruder des Neuländers und Mitbegründers der ÖVP 1945 Felix Hurdes - kurz Richard Szerelmes, Leopold Teufelsbauer und das Bäuerliche Volksbildungsheim Hubertendorf 1929-38. Eine Dokumentation (St. Pölten/Wien 1982) 36.

234 Lechner, 1864-1964 (wie Anm. 88) 197.

235 NÖLA, NL KL, K. IX, Mappe IX/3, Arbeitsplan der ersten niederösterreichischen Volksbildnertagung vom 11.-15. Juli 1949 im Landesheim Norbertinum, Tullnerbach/Westbahn.

236 Franz Hurdes, Vorwort, in: Zur Volksbildungsarbeit in Niederösterreich. Eine Zusammenfassung der Referate und Berichte von der ersten niederösterreichischen Volksbildnertagung nebst einem Verzeichnis „Das niederösterreichische Schrifttum“, hg. v. Franz Hur des (Wien 1950) 5-9, hier 6f., 9.

237 Lechner, Heimatkunde (wie Anm. 2358) 46-56. 
eine erste Basis gelegt ${ }^{238}$, auf der das ganze Fest aufbauen konnte ${ }^{239}$. Lechner dürfte sich in weiterer Folge aber nicht mehr mit dem Jubiläum befasst haben ${ }^{240}$. Engagiert wirkte er aber an der Förderung des offiziellen niederösterreichischen Landesbewusstseins mit. So verfasste er für die im Sender Wien I seit Ende 1947 vierzehntägig ausgestrahlte Hörfunkreihe „Niederösterreichische Heimatstunde“ wiederholt Beiträge ${ }^{241}$. Am I. Juni 1949 lief seine Sendung „Das ,Poigreich“. Eine geschichtliche Landschaft Alt-Österreichs“, an der auch der Chor des neu geschaffenen Niederösterreichischen Heimatwerkes teilhatte ${ }^{242}$, und am Landesfeiertag am I 5 . November 1950 wurde sein in Dialogform verfasstes Laienspiel „St. Leopold, unser Landespatron“ gesendet ${ }^{243}$. Die „Heimatstunde“ war Teil der offiziellen Volksbildungsarbeit in Niederösterreich. Sie bezweckte, „einen Beitrag zur Stärkung des niederösterreichischen Heimatgedankens und zur Weckung der kulturellen Kräfte im Lande“ zu leisten ${ }^{244}$, wandte sich stark an Jugend und „Dorfgemeinschaften“ und trachtete in ihrem kulturellen Engagement, „die ,Rastenden“, die Arbeitsmüden, die Industriegehetzten, vom Rande aufzuheben, sie mitzunehmen und ihnen zu ihrem Arbeits- und Ruhebedürfnis das Kulturbedürfnis zu wecken“245.

Den weiterhin aktiven und sendungsbewussten „Neuländer“ Lechner sprach diese Programmatik zweifellos an, und darüber hinaus erwies sich der öffentlich Bedienstete Lechner als pflichtbewusster Diener seiner neuen Herren. Als etwa am 26. Oktober I956 zum zweiten Mal der „Tag der Fahne“ gefeiert werden sollte, war es der Wappenspezialist Lechner, der in der amtlichen Wiener Zeitung unter dem (vielleicht nicht selbst gewählten) staatstragenden Titel „Bindenschild und Rot-Weiß-Rot. Aus großer Vergangenheit in eine glückliche Zu-

238 Karl Lechner, Ostarrichi, in: Neue Ordnung. Monatsschrift für Gesellschaftsfragen (April 1946) 17-21; ebd. 22-27 findet sich eine Abrechnung mit der gesamtdeutschen Geschichtsauffassung in Österreich durch den von den Nationalsozialisten als ,jüdisch versippt“ diskriminierten Friedrich Korger: DE Rs., Die gesamtdeutsche Geschichtsauffassung in Oesterreich.

239 Speva , Jubiläum (wie Anm. 216) 49.

240 Ebd.

241 Franz Hurdes, Die Volksbildungsarbeit in Niederösterreich, in: Zur Volksbildungsarbeit in Niederösterreich. Eine Zusammenfassung der Referate und Berichte von der ersten niederösterreichischen Volksbildnertagung nebst einem Verzeichnis „Das niederösterreichische Schrifttum“, hg. v. Franz Hurdes (Wien 1950) 119-127, hier 122.

242 Ders., „Niederösterreichische Heimatstunde“. (Übersicht über die Sendungen seit Beginn der Sendereihe bis 31. Dezember 1949), in: ebd. 134.

243 NÖLA, NL KL, K. IX, Mappe IX/5, Niederösterreichisches Heimatwerk „N.Oe. Heimatstunde“ 15. November 1950 .

244 Hurdes, Volksbildungsarbeit (wie Anm. 244) 122.

245 Franz Thalhammer, Die „Niederösterreichische Heimatstunde“. Eine kritische Stellungnahme, in: Zur Volksbildungsarbeit in Niederösterreich. Eine Zusammenfassung der Referate und Berichte von der ersten niederösterreichischen Volksbildnertagung nebst einem Verzeichnis „Das niederösterreichische Schrifttum“, hg. v. Franz Hurdes (Wien 1950) 128-131, hier 130. 
kunft“ den Werdegang der österreichischen Fahne schilderte ${ }^{246}$. Später hielt er auch Vorträge am Institut für Österreichkunde ${ }^{247}$, das, unterstützt mit öffentlichen Geldern des BMU und primär an Lehrpersonal gerichtet, dezidiert um eine Stärkung des „Österreich-Bewusstseins“ bemüht war ${ }^{248}$.

Lechners religiös-wertkonservatives Engagement erleichterte auch seine rasche Integration in den Lehrbetrieb der Wiener Universität. Dort hatte sich am Beginn der Zweiten Republik ein katholisch-restauratives Klima etabliert ${ }^{249}$, und angeblich auch auf Wunsch der „grauen Eminenz“ und des späteren Rektors Richard Meister, bemühte sich Lechner im Sommer 1948 um seine Habilitation ${ }^{250}$. Unterstützung erfuhr er dabei von seinem Freund und Kurskollegen Leo Santifaller ${ }^{251}$. Als Habilitationsschrift reichte Lechner die anlässlich seines 50. Geburtstages herausgegebenen „Ausgewählten Schriften“ - fünf geschichtswissenschaftliche und zwei religiöse [!] Texte - ein ${ }^{252}$, im Besonderen aber seine aus 1940 datierende Arbeit über "Leistungen und Aufgaben siedlungskundlicher Forschung in Österreich mit besonderer Berücksichtigung von Niederösterreich" ${ }^{253}$. Die neunköpfige Kommission der philosophischen Fakultät - darunter neben Santifaller und Meister auch Lhotsky, Hassinger, Pittioni und Hantsch - plädierte einstimmig für Lechners Zulassung. Unter Verweis auf dessen wissenschaftliche Verdienste und weil Lechners rhetorische und pädagogische Begabung allgemein bekannt sei, empfahl die Kommission

246 Wiener Zeitung (24.10.1956) 3.

247 NÖLA, NL KL, K. I, Mappe I/4, Korrespondenz W und Z, Schreiben des Instituts für Österreichkunde, Landesverband Oberösterreich, an Lechner vom 10.02.1964. Vortrag „Die Geschichte der Bauern in den österreichischen Ländern“.

248 Christian Gerbel, Zur „gesamtdeutschen“ Geschichtsauffassung, der akademischen Vergangenheitspolitik der Zweiten Republik und dem politischen Ethnos der Zeitgeschichte, in: Transformationen gesellschaftlicher Erinnerungen. Studien zur „Gedächtnisgeschichte“ der Zweiten Republik, hg. v. DEms. u.a. (Reihe Kultur.Wissenschaften 9, Wien 2005) 86-130, hier 109.

249 Zu diesem Klima siehe Günter Fellner, Ludo Moritz Hartmann und die österreichische Geschichtswissenschaft. Grundzüge eines paradigmatischen Konfliktes (Veröff. des Ludwig-Boltzmann-Institutes für Geschichte der Gesellschaftswissenschaften 15, Wien/Salzburg 1985) 351-368.

250 NÖLA NL EK, K. III, Mappe III/2, Schreiben Lechner an Klebel vom 27.08.1949.

251 ÖStA/AdR, BMU, Geschäftszeichen 4, Philosophie, PA Karl Lechner, Kommissionsbericht o.D. [Anfang Oktober 1948].

252 Die geschichtswissenschaftlichen Beiträge lauteten: Grafschaft, Mark und Herzogtum (8-44), Studien zur Besitz- und Kirchengeschichte der Karolingischen und Ottonischen Mark an der Donau (45-68), Die Gründung des Klosters Maria-Zell im Wiener Wald und die Besitzgeschichte seiner Stifterfamilie (69-100), Oswald Redlich $\dagger$ (101-118), Leistungen und Aufgaben siedlungskundlicher Forschung in Österreich mit besonderer Berücksichtigung von Niederösterreich (119-210); die religiösen Beiträge waren: Der Laie in der Kirche (211-222), Pfarre und Familie (223-230); sämtliche Beiträge in: Karl Lechner (wie Anm. 210).

253 UAW, PA KL, Schreiben Lechner an das Professoren-Kollegium der Phil. Fak. der Universität Wien vom 29.06.1948. 
auch, Lechner das Kolloquium und die öffentliche Probevorlesung zu erlassen ${ }^{254}$. Das Professorenkollegium der philosophischen Fakultät schloss sich der Empfehlung an und beschloss am I6. Oktober I948 mit 24 Ja-, o Nein-Stimmen und 2 Stimmenthaltungen, Lechner für die Erteilung der Venia legendi für „Landesgeschichte und historisch-geographische Landeskunde von Nieder- und Oberösterreich" vorzuschlagen ${ }^{255}$. I955 wurde Lechner einstimmig der Titel eines außerordentlichen Professors zuerkannt ${ }^{256}$, und 1959 avancierte er auch zum Prüfungskommissär für Deutsches Recht und Österreichische Verfassungs- und Verwaltungsgeschichte an der rechts- und staatswissenschaftlichen Fakultät in Wien sowie zum korrespondierenden Mitglied der ÖAW ${ }^{257}$.

\section{I.I2 Lechner als Leitfigur der Landesgeschichte}

Schon seit den I930er-Jahren galt Lechner als der „anerkannt führende Fachmann“ auf dem Gebiet der geschichtlichen Landeskunde ${ }^{258}$. Sein wissenschaftliches Prestige wurde seit den I950er-Jahren weiter gestärkt, als er etwa zu den Tagungen des „Konstanzer Arbeitskreises für mittelalterliche Geschichte“ eingeladen wurde. Dessen Begründer Theodor Mayer war Lechners ehemaliger Lehrer und hatte um seinen vormaligen Schüler geradezu geworben ${ }^{259}$. Neben Klebel und anderen Österreichern wurde so auch Lechner zu einem häufigen Besucher der Arbeitskreis-Tagungen auf der Insel Reichenau ${ }^{260}$, ohne jedoch Mitglied des Arbeitskreises zu werden.

Lechners dominierende Position in der Landesgeschichte manifestierte sich auch darin, dass er über lange Zeit hinweg auch die methodische und inhaltliche Ausrichtung der Disziplin bestimmte. Sein aus I950 datierender Aufsatz über „Sinn und Aufgaben der geschichtlichen Landeskunde“ setzte hier die Standards ${ }^{261}$. Er wurde noch 1978 unverändert in einem Sammelband abgedruckt, der als Einführung in Problemstellung und Methodologie der Landesgeschichte in Deutschland und Österreich konzipiert war ${ }^{262}$. Lechner vertrat darin die österreichische Landesgeschichte. Hand in Hand mit dieser

254 UAW, PA KL, Schreiben des Dekans der Phil. Fak. an das BMU vom 12.11.1948.

255 Ebd.; wer sich der Stimme enthalten hatte, geht aus den zitierten Akten nicht hervor.

256 Pittioni, Lechner (wie Anm. 8) 586.

257 Zöllner, Lechner (wie Anm. 2) 566, 568.

258 Maximilian Weltin, Der Begriff des Landes bei Otto Brunner und seine Rezeption durch die verfassungsgeschichtliche Forschung, in: DERs., Land (wie Anm. 96) 384-409, hier 391.

259 Stadtarchiv Konstanz, NL Theodor Mayer, Schreiben Mayer an Lechner vom 06.11.1956 und 10.03.1957.

260 Heinz Dopsch, Vergleichende Landesgeschichte in Österreich: Realität, Vision oder Utopie?, in: ZHVSt 91/92 (2000/01) 53-92, hier 67.

261 Lechner, Sinn (wie Anm. 106) 159-184.

262 Karl Lechner, Sinn und Aufgaben geschichtlicher Landeskunde, in: Probleme und Methoden der Landesgeschichte, hg. v. Pankraz Fried (Wege der Forschung 492, Darmstadt 1978) 83-116. 
Abb. 35: Der Vorstand des VfLKNÖ um I965. Von links: Karl Lechner,

Herbert Mitscha-Märheim, Adalbert Klaar (stehend), Rudolf Broinger, Rudolf Steuer.

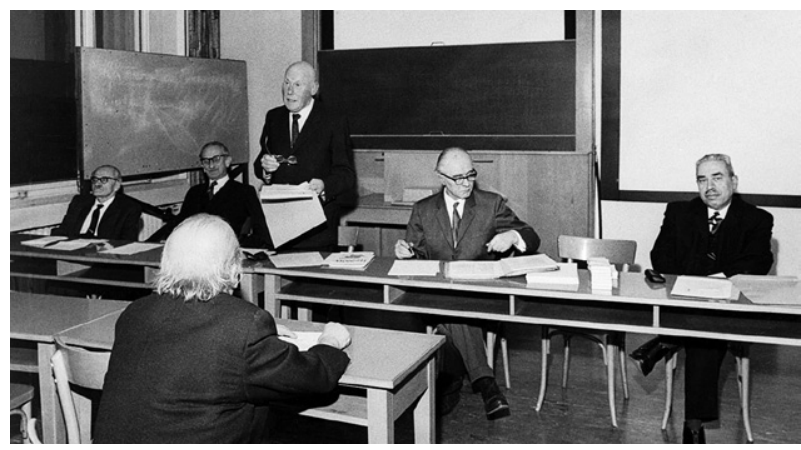

Dominanz ging freilich auch die Langlebigkeit methodisch wie inhaltlich problematischer Versatzstücke der landeskundlichen Forschung. So wurde etwa die „besitzgeschichtlichgenealogische" Methode weiterhin als erfolgversprechendes wissenschaftliches Instrument angepriesen ${ }^{263}$ und auch gesamtdeutsche Deutungen wurden fortgeschrieben. Die Konzepte Aubins, Kötzschkes und Redlichs aus den I920er-Jahren waren auf diese Weise weiterhin verbindlich. Nach wie vor war von einer „allgemeinen Schau über den ganzen deutschen Volks- und Kulturboden hinweg“ die Rede, die zu erforschenden „Landschaften“ galten als „Glieder des österreichischen und deutschen Raumes“264. Fallweise Anpassungen an die neue Strukturgeschichte erfolgten lediglich auf sprachlicher, nicht aber auf konzeptueller Ebene; die wegweisenden landeshistorischen Anregungen Brunners fanden in der Forschung des Lechner'schen Kreises wenig Beachtung ${ }^{265}$. Die in den I920er-Jahren als Innovation geltende „Zusammenschau“ verschiedener Disziplinen mündete bei Lechner bisweilen in eine mystifizierend-agrarromantische Heimattümelei ${ }^{266}$, und das alte Redlich'sche Diktum von der Landeskunde als „nationale[r] Pflicht“ mit dem Aufruf zu „Liebe und Treue zur Heimat und zu unserem deutschen Volk“ hatte für Lechner Ende der I950er-Jahre sogar mehr Gültigkeit als in den I920er-Jahren ${ }^{267}$. Der spätere Ruf der Landeskunde und der landeskundlichen Vereine, veralteten Paradigmen und fragwürdig gewordenen deutschnationalen Einstellungen zu huldigen, rührte unter anderem von diesen Kontinuitäten her. Er war auch deshalb nicht unberechtigt, weil, wie Lechner in Niederösterreich, auch in anderen Bundesländern Protagonisten einer „traditionellen“

263 Ebd. 88, 103.

264 Ebd. 86, 94.

265 Dopsch, Landesgeschichte (wie Anm. 263) 67.

266 Lechner, Sinn, 1978 (wie Anm. 265) 95.

267 Lechner, Redlich (wie Anm. 111) 209. 
Landeskunde über die politischen und methodischen Zäsuren hinweg einflussreich geblieben waren ${ }^{268}$.

Am Höhepunkt seiner Laufbahn wurde Lechner auch die Erarbeitung der großen landesgeschichtlichen Synthesen angetragen. Ob als Autor des Artikels „Österreich“ im verbreiteten Nachschlagewerk „Territorien-Ploetz“269 oder als Herausgeber und Mitautor des ersten Bandes des Handbuchs der historischen Stätten ${ }^{270}$ - stets war es Lechner, der hier verantwortlich zeichnete. Allerdings waren es vor allem gerade diese prestigeträchtigen „Meistererzählungen“, die Lechners Grenzen aufzeigten. Lechner war zweifellos einer der hervorragendsten Kenner der niederösterreichischen Landesgeschichte; wie kaum ein anderer hatte er fast jeden Flecken dieses Bundeslandes bearbeitet; doch außerhalb der Grenzen „seines“ Landes standen seine Darstellungen und Schlussfolgerungen mitunter auf schwachen Beinen, ja erwiesen sich bisweilen als schlichtweg unzutreffend ${ }^{271}$. Ambivalent fiel auch die Bewertung von Lechners letzter großer Monografie, der Geschichte der Babenberger, aus. Postum und gerade noch rechtzeitig zum großen Babenberger-Jubiläum I 976 von Mitarbeitern des IÖG, des NÖLA und des Böhlau-Verlages druckfertig gemacht, stellte diese Publikation die Summe seiner nahezu lebenslangen Beschäftigung mit Problemen des babenbergischen Österreich dar ${ }^{272}$. Noch einmal und in zusammenfassender Form hatte Lechner hier seine zentralen Theorien dargelegt. Aufgrund seiner profunden Quellenkenntnis hatte er eine Vielzahl von Material verarbeitet, was das Buch - wie Leopold Auer in seiner ausführlichen Besprechung resümierend hervorhob - „zweifellos zu einer Grundlage für künftige Forschungen über das babenbergische Österreich machen" werde ${ }^{273}$. Auer verwies aber auch darauf, dass manche von Lechners Theorien keineswegs unanfechtbar wären. Aufgrund des „Forschungsmonopols“, das sich Lechner und sein Kreis vor allem für die Zeit vor dem Privilegium minus erworben hatten, präsentierte Lechner nach wie vor seine mittlerweile dreißig bis vierzig Jahre alten Forschungsergebnisse. Neuere Erkenntnisse hat Lechner zwar gekannt, aber nicht (mehr) eingearbeitet ${ }^{274}$.

268 Dopsch, Geschichtsvereine (wie Anm. 214) $84 f$.

269 Geschichte der deutschen Länder („Territorien-Ploetz“) 1, hg. v. Georg Wilhelm SAnte (Würzburg 1964) 619-753.

270 Handbuch der historischen Stätten - Österreich 1: Donauländer und Burgenland, hg. v. Karl LeCHNER (Stuttgart 1970, ND 1985).

271 Dopsch, Landesgeschichte (wie Anm. 263) 62; siehe dazu auch das nahezu vernichtende, allerdings teilweise auch polemisch formulierte Urteil über Lechners Darstellung der Geschichte Vorarlbergs im „Territorien-Ploetz“ von Benedikt BilgERI, Vorarlberger Geschichte im neuen „Territorien-Ploetz“, in: Montfort. Zs. für Geschichte, Heimat- und Volkskunde Vorarlbergs 17 (1965) 389-397.

272 Leopold Auer, „Die Babenberger. Markgrafen und Herzöge von Österreich 976-1246“. Bemerkungen zu Karl Lechners gleichnamigem Buch, in: UH 48 (1977) 109-114, hier 109.

273 Ebd. 114.

274 Ebd. 109. 


\section{I.I3 Karl Lechner als Lehrer und Wissenschaftsorganisator}

Lechner hatte der Vermittlung landeskundlichen Wissens und landeskundlicher Methoden stets viel Bedeutung beigemessen. Das zeigte sich nicht nur in seinem Engagement im Rahmen des NÖLA und des VfLKNÖ275, sondern auch an der Universität Wien und bei seinem fast lebenslangen Kampf um ein „Institut für Landeskunde“. Lechners erste Lehrveranstaltung fand im WS 1949/1950 statt. Sie handelte über „Sinn, Entwicklung und Aufgaben der Landesgeschichte und geschichtlichen Landeskunde, mit besonderer Berücksichtigung der österreichischen Donauländer “276. Von Beginn an legte Lechner das Hauptgewicht seiner Lehre auf die praktischen Übungen, die er stets in seinem Zimmer im NÖLA in der Herrengasse abhielt. Bis zu seiner letzten Lehrveranstaltung im Sommersemester 1968 hat Lechner im Großen und Ganzen auch seinen bevorzugten Adressatenkreis beibehalten ${ }^{277}$. Seine Lehrveranstaltungen richteten sich in aller Regel an Mitglieder des IÖG und waren in dessen Ausbildungskurs eingebunden ${ }^{278}$. Das Themenspektrum seines Lehrangebots umfasste Landes-, Burgen- und Siedlungskunde, die Dynastie der Babenberger sowie verfassungs- und rechtsgeschichtliche Probleme vorzugsweise des Mittelalters. Lediglich Mitte der 1960er-Jahre setzte Lechner mit der Geschichte des Bauerntums und des ländlichen Siedlungswesens vorübergehend einen sozial- und wirtschaftsgeschichtlichen Schwerpunkt. ${ }^{279}$ Mit der in den 1960er-Jahren rasch aufstrebenden Zeitgeschichte vermochte der mediävistisch orientierte Lechner wenig anzufangen. Wenn er ihr zunächst auch eine gewisse Berechtigung nicht absprach ${ }^{280}$, so polemisierte er doch später gegen dieses Fach, das seiner Ansicht nach „bei vielen Zeitgenossen, und nicht nur bei primitiven und naiven, [...] als das heute allein Wichtige gesehen werde ${ }^{\text {"281 }}$. Mitverantwortlich für diese Haltung könnte auch der von der Zeitgeschichte Ende der I96oer-Jahre vollzogene Bruch mit der am Beginn der Zweiten Republik konzipierten, hegemonialen akademischen Vergangenheitspolitik gewesen $\operatorname{sein}^{282}$. Indem sich die Zeitgeschichte politisch-emanzipatorisch im Sinne einer Stärkung des Demokratiebewusstseins engagierte, unter anderem auch Fragestellungen wie „Widerstand und Verfolgung

275 Pongratz, Erinnerung (wie Anm. 326) 216-224.

276 Vorlesungs-Verzeichnis für das Wintersemester 1949/50, hg. v. Rektorat der Universität Wien (Wien 1949) 40.

277 Vorlesungs-Verzeichnis für das Sommersemester 1968, hg. v. Rektorat der Universität Wien (Wien 1968) 52.

278 UAW, PA KL, Schreiben Lechners an das Professorenkollegium der Phil. Fak. der Universität Wien vom 03.12. 1959.

279 Siehe dazu die Vorlesungs-Verzeichnisse der Jahre 1949 bis 1968.

280 Lechner, 1864-1964 (wie Anm. 88) 195.

281 Karl Lechner, Zum Geleit, in: Scrinium Heft 1 (1969) 3-6, hier 4.

282 Ger bel, Geschichtsauffassung (wie Anm. 251) 87, 115. 
während der NS-Herrschaft" forcierte ${ }^{283}$, wurden die bislang vorherrschende, freilich nur vermeintlich „unpolitische“ Geschichtsschreibung und das restaurativ-konservative Klima in der österreichischen Historikerschaft zunehmend problematisiert ${ }^{284}$. Mit einer Disziplin, die das historische Erkenntnisinteresse im demokratischen Horizont der Gegenwart verankerte ${ }^{285}$, konnte sich Lechner wohl kaum anfreunden.

Lechners Lehrtätigkeit wurde allgemein als sehr erfolgreich bezeichnet ${ }^{286}$. Auch in der Wiener Professorenschaft war bekannt, dass die Studierenden sehr gern Lechners Vorlesungen besuchen, vor allem aber mit Begeisterung an seinen in hohem Grade anregenden und mit viel pädagogischem Geschick durchgeführten Uebungen und Exkursionen teilnehmen ${ }^{287}$. Von seinen Studierenden wurde unter anderem der kollegiale Ton und Umgang, der in Lechners Lehrveranstaltungen herrschte, geschätzt sowie der unorthodoxe Blick, den man auf die Quellen zu richten erlernte. „Lechner lehrte uns, was man aus Urkunden und anderen Quellen an Sachbezügen herauslesen kann, wie das Werden einer Landschaft aus der Kombination aller Quellen, auch der nichtschriftlichen, ersichtlich gemacht werden kann“, erinnerte sich etwa einer seiner Schüler an die charakteristisch interdisziplinäre Quelleninterpretation bei Lechner ${ }^{288}$.

Darüber hinaus waren aus Lechners Übungen nicht wenige Dissertationen hervorgegangen $^{289}$. Wenn auch Lechner als Titular-ao.-Prof. offiziell nicht als Betreuer von Dissertationen und Institutsarbeiten firmieren konnte, so vergab er dennoch schon seit spätestens Ende der I930er-Jahre entsprechende Themen und betreute solche Arbeiten ${ }^{290}$; später

283 Ebd. 113.

284 Günter Fellner, Die Emigration österreichischer Historiker. Ein ungeschriebenes Kapitel in der Zeitgeschichte ihres Faches, in: Vertriebene Vernunft II. Emigration und Exil österreichischer Wissenschaft. Internationales Symposion 19. bis 23. Oktober 1987 in Wien (Wien/München 1988) 474-494, hier 487.

285 Ger bel, Geschichtsauffassung (wie Anm. 251) 115.

286 ÖStA/AdR, BMU, Geschäftszeichen 4, Philosophie, PA Karl Lechner, Schreiben des Vorstandes des IÖG an das Professorenkollegium der Phil. Fak. der Universität Wien vom 12.01.1955.

287 Ebd.

288 Fritz Eнегм, Karl Lechner - 75 Jahre, in: Scrinium Heft 7 (1972) 3-4, hier 4. Das sehr gute Verhältnis Lechners zu seinen Studierenden und die große Beliebtheit seiner Exkursionen zeigten sich u.a. auch nach Lechners Autounfall 1960. In einem Schreiben von Teilnehmern des 49. Kurses des IÖG an Lechner übermittelten ihm sieben Studierende die besten Genesungswünsche und bedauerten, dass der Unfall den uns nun schon gewohnten und vertrauten Weg in die ,Herrengasse' zu Ihren Übungen, in denen Sie uns so viel Interessantes und Nützliches geboten haben, plötzlich überflüssig gemacht habe. Gleichzeitig ersuchten die Studierenden, unsere geplante Exkursion, auf die wir uns schon sehr gefreut hatten und die aber unter diesen widerwärtigen Umständen entfallen muß, im kommenden Herbst nachzuholen. Als Absender des Schreibens wurde das „Seminar ,Verwaiste Landes- und Siedlungsgeschichte 'Wien I, Herrengasse“ angegeben. NÖLA, NL KL, K. I, Mappe Korrespondenz Verschiedenes, Schreiben vom 01.06.1960.

289 ÖStA/AdR (wie Anm. 289).

290 So berichtete etwa Friedrich Hausmann, dass er damals von Hirsch zu Lechner geschickt worden sei, um sich 
verfasste er auch die Gutachten darüber ${ }^{291}$. Vor allem in Niederösterreich ging eine ganze Reihe von Archivaren aus Lechners Lehrveranstaltungen und beeinflusst durch seine Arbeitsweise hervor; so etwa die Landesarchivare Fritz Eheim und Helmuth Feigl, von denen sich Letzterer auch habilitierte, ferner der St. Pöltner Diözesanarchivar Gerhard Winner und der Archivar der Stadt St. Pölten und Titular-ao.-Prof. Karl Gutkas ${ }^{292}$. Auf universitärer Ebene zählten - zu Beginn ihrer Karriere - Heide Dienst ${ }^{293}$, vor allem aber Michael Mitterauer zu Lechners profiliertesten Schülern ${ }^{294}$. Lechners Einfluss wirkte vor allem auch in die Steiermark. So beeinflusste er etwa die Arbeiten des Direktors des steiermärkischen Landesarchivs, Fritz Posch, der dann mit einem Kreis von Mitarbeitern die dortige Landeshistorie nachhaltig dominieren sollte.

Was Posch in der Steiermark werden sollte, war Lechner in Niederösterreich. Nach dem Zweiten Weltkrieg war es Lechner bald gelungen, seine wissenschaftspolitisch starke zu einer hegemonialen Position auszubauen. In seiner Vierfachfunktion als Universitätslehrer, Generalsekretär des VfLKNÖ, Redakteur dreier landeskundlicher Zeitschriften und Direktor des größten österreichischen Landesarchivs kam ihm eine Schlüsselfunktion zu. Im VfLKNÖ war Lechner schon lange Zeit unangefochten. Anfang der I $960 e r-$ Jahre waren zudem sämtliche Spitzenpositionen mit seinen auch wissenschaftlich engsten Mitarbeitern besetzt. Das Präsidentenamt bekleidete der Siedlungsplanforscher Adalbert Klaar; Vizepräsident war der Urgeschichtler Herbert Mitscha-Märheim, und als Schriftführer firmierte der von Lechner zu seinem Nachfolger als Archivdirektor gemachte Ru-

von diesem ein Dissertations-Thema zuweisen zu lassen. Friedrich Hausmann, Friedrich Hausmann, in: Recht und Geschichte. Ein Beitrag zur österreichischen Gesellschafts- und Geistesgeschichte unserer Zeit. Zwanzig Historiker und Juristen berichten aus ihrem Leben, hg. v. Hermann Balt L, Nikolaus Grass, Hans Constantin Faussner (Studien zur Rechts-, Wirtschafts- und Kulturgeschichte 14, Sigmaringen 1990) 115-134, hier 121.

291 NÖLA, NL KL, K. III, Mappe III/1, Gutachten; so stammen etwa auch die Gutachten der Staatsprüfungsarbeiten von Wolfgang Häusler und Heinz Dopsch von Lechner.

292 Lechner, 1864-1964 (wie Anm. 88) 211.

293 Seine überaus positive Besprechung der Dissertation von Heide Dienst (Babenberger-Studien. Niederösterreichische Traditionsnotizen als Quellen für die Zeit Markgraf Leopolds III. [Wien 1966]) beschloss Karl Lechner mit einem „persönlichen Bekenntnis: Es kann einem akademischen Lehrer keine größere Freude und Genugtuung bereitet werden, als wenn ein Schüler, in bestimmten Fragen seine Anregungen aufgreifend, über ihn hinauswächst und neue Gesichtspunkte und bessere Lösungen beibringt“. Karl Lechner (Rez.), in: UH 39 (1968) 34-38, hier 38.

294 Michael Mitter auer, Zollfreiheit und Marktbereich. Studien zur mittelalterlichen Wirtschaftsverfassung am Beispiel einer niederösterreichischen Altsiedellandschaft (Forschungen zur Landeskunde von Niederösterreich 19, Wien 1969) 13, widmete seine Studie Lechner und erwies ihm in der Einleitung seine Reverenz: „Als eine Studie zur Landeskunde von Niederösterreich stützt sich die Arbeit sowohl methodisch als auch sachlich weithin auf die Forschungen des führenden Vertreters dieser Disziplin, Karl Lechner. Ihm weiß sich der Autor in vieler Hinsicht verpflichtet." 
dolf Broinger ${ }^{295}$. Nicht zuletzt Lechners wissenschaftlicher Reputation war es zu danken, dass führende Gelehrte der Universität Wien in den Veröffentlichungen des Vereins publizierten, und auch die wissenschaftlichen Projekte des VfLKNÖ konnten sich sehen lassen. $\mathrm{Zu}$ nennen ist hier etwa der gemeinsam mit der Akademie der Wissenschaften herausgebrachte „Atlas von Niederösterreich“296 und das in jahrzehntelanger Arbeit von Heinrich Weigl erarbeitete „Historische Ortsnamenbuch von Niederösterreich“ in den I96oer- und I970er-Jahren ${ }^{297}$.

Für die Umsetzung derartiger Großprojekte und auch um die Landeskunde im universitären Bereich zu verankern, forcierte Lechner die Schaffung eines „Instituts für geschichtliche Landeskunde von Niederösterreich“. Seine diesbezüglichen Initiativen gehen hier bis in die Zwischenkriegszeit zurück. Bereits in dem repräsentativen Werk „Das Bundesland Niederösterreich I920-1930", herausgegeben von der niederösterreichischen Landesregierung, hatte sich Lechner 1930 öffentlich „für eine von der Landesregierung erhaltene oder unterstützte Lehrkanzel für Landesgeschichte an der Wiener Universität“ starkgemacht ${ }^{298}$. In Verbindung damit forderte er auch die Schaffung einer „kleinere[n] Körperschaft“, die „streng wissenschaftliche Aufgaben“ wie vor allem Akten- und weitere Urkundeneditionen „unbehindert von der Sorge um Absatzmöglichkeit“ zu organisieren hätte. In Fortführung der „alten Traditionen des I9. Jahrhunderts“ wünschte er sich hier ein finanzielles Engagement des Landes Niederösterreich ${ }^{299}$. Nachdem er sich Mitte der I930er-Jahre in einem Vortrag neuerlich öffentlich für die Errichtung eines landesgeschichtlichen Forschungsinstitutes, etwa in Verbindung mit einem Lehrstuhl für Landesgeschichte, eingesetzt, gleichzeitig das Versagen der kompetenten Stellen in der Öffentlichkeit beklagt und während der NS-Zeit an den diversen NS-volksgeschichtlichen Instituts-Projekten des Geografen Fritz Bodo wenig Interesse gezeigt hatte ${ }^{300}$, unternahm er bald nach dem Zusammenbruch der NS-Herrschaft einen weiteren Versuch. Bestärkt durch die Haltung Santifallers, der ihm anlässlich der Feier zum 50. Geburtstag I 947

295 Lechner, 1864-1964 (wie Anm. 88) $251 \mathrm{f}$.

296 Atlas von Niederösterreich, hg. v. Kommission für Raumforschung und Wiederaufbau der ÖAW und VfLKNÖ, redigiert v. Erik Arnberger (Wien 1951-1958).

297 Heinrich Weigl, Historisches Ortsnamenbuch von Niederösterreich 1-8, unter Mitarbeit von Fritz Eheim, Karl Lechner, Roswitha Seidelmann, Maximilian Weltin (Wien 1964-1981).

298 Karl Lechner, Heimatkunde und Landeskunde, in: Das Bundesland Niederösterreich. Seine verfassungsrechtliche, wirtschaftliche, kulturelle und soziale Entwicklung im ersten Jahrzehnt seines Bestandes 1920 1930 (Wien 1930) 443-449, hier 448.

299 Ebd.

300 NÖLA, NL KL, K. VII, Mappe VII/6, Manuskript Aufgaben landeskundlicher Forschung und der Verein für Landeskunde und Heimatschutz von Niederösterreich und Wien o.D. [ca. 1935-1937]; zu den Projekten Bodos siehe Helmuth Feigl, Landeskundliche Bestrebungen im Reichsgau Niederdonau, in: JbLKNÖ NF 63/64 (1998) 258-264. 
öffentlich zu Institutsgründung und Habilitation geraten hatte ${ }^{301}$, verfasste Lechner bald darauf ein entsprechendes, an den Unterrichtsminister gerichtetes Memorandum über die Errichtung eines „Instituts für geschichtliche Landeskunde von NÖ“302. In dem Konzept berief er sich gleich eingangs auf das Vorbild der in Deutschland nach dem Ersten Weltkrieg gegründeten landeskundlichen - und später vielfach volksgeschichtlich engagierten - Institute, insbesondere auf jenes von Aubin in Bonn. Als Hauptargument für die Dringlichkeit eines solchen Instituts für Niederösterreich nannte er zwar nicht die angebliche „Ostmark-Funktion“ dieses Landes, sondern - den staatspolitischen Erfordernissen angemessen - dessen Stellung als Kernland und Keimzelle Österreichs. Freilich fügte er dann hinzu, dass sich hier Probleme der landeskundlichen Forschung stellten, deren Lösung für die österreichische und deutsche Geschichtswissenschaft und Landesforschung von entscheidender Bedeutung seien. Als engere Forschungsaufgaben nannte Lechner vor allem seine eigenen Arbeitsgebiete: Besiedlungs- und Besitzgeschichte des nunmehrigen Landes Niederösterreich für das 6. bis 9. Jahrhundert im Rabmen des fränkisch-karolingischen Reiches, im Io. bis I2. Jahrhundert im Rahmen des deutschen Reiches, die Entstehung des Territorialfürstentums und des Flächenstaates in Österreich sowie Fragen der kirchlichen Verfassungsgeschichte und des religiösen Lebens in Niederösterreich vom späten Mittelalter bis zur Zeit der Gegenreformation. Auch rechts-, sozial- und wirtschaftsgeschichtliche Probleme des Spätmittelalters und der - allerdings nur am Rande erwähnten - neueren Zeit zählten zu Lechners Themenkanon, wie auch die Geschichte des niederösterreichischen Bauernstandes. Als konkrete Projekte führte Lechner vor allem die Veröffentlichung von Quellen an, die erforscht werden sollten, aber auch Haus- und Flurformen, Mundart und Brauchtum, Kunst und Literatur. In organisatorischer Hinsicht sprach sich Lechner wie schon 1930 für einen eigenen Lehrstuhl für Landesgeschichte von Niederösterreich an der Universität Wien aus, ergänzt um mindestens eine Assistenten- sowie eine Bibliothekarsstelle. Die Finanzierung hätte primär das Land Niederösterreich zu tragen, das ohnehin bereits Forschungsmittel (in der Niederösterreichischen Landesbibliothek) und Forschungsmaterial (im NÖLA) zur Verfügung stelle. Bibliothek, Archiv und zu schaffendes Forschungsinstitut sollten in Personalunion von Lechner selbst zu führen sein, als erster Mitarbeiter und Bibliothekar ergebe sich von selbst der Leiter der Niederösterreichischen Landesbibliothek, Kurt Vancsa. Da das Land Niederösterreich alles Interesse daran haben [müsste], hier nicht, Beamte, sondern Wissenschaftler und Gelehrte zur Verfügung zu haben, die den Ruf des Landes und

301 NÖLA NL EK, K. III, Mappe III/2, Schreiben Lechner an Klebel vom 27.08.1949.

302 NÖLA, NL KL, K. III, Mappe III/10, Memorandum über die Errichtung eines „Instituts für geschichtliche Landeskunde von NÖ“ an den Herrn BM f. Unterricht o.D. [vermutlich 1947/1948], wie auch die folgenden Zitate. 


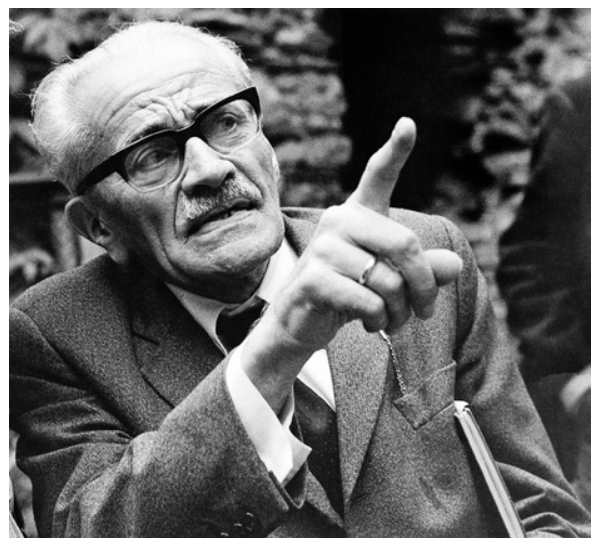

Abb. 36: Karl Lechner um 1970

dessen Interesse für Geschichte und Kunde dieses Landes weit über den engeren Rahmen des Landes hinaustragen, müssten Bibliothek und Archiv aus der Referatseinteilung der Landesverwaltung ausgegliedert und gemeinsam mit dem zu schaffenden Institut - schon aus optischen Gründen direkt dem Landeshauptmann unterstellt werden.

Warum diese Pläne nicht verwirklicht wurden, ist nicht bekannt. Schon 1948 war Vancsa jedenfalls nicht mehr in Wien, sondern als Leiter der "Studienbibliothek“ nach Linz gewechselt ${ }^{303}$. Lechner verfocht dagegen weiter seine Instituts-Pläne. Sowohl in seinem Vortrag auf der ersten Tagung der österreichischen Geschichtsvereine als auch in der kurz darauf gehaltenen Antrittsvorlesung I 949 an der Universität Wien ${ }^{304}$ forderte er die Schaffung eines „Institut[es], das zugleich Forschungs- und Lehrstelle sein muß“305. Diesmal nannte er es - seiner Venia entsprechend - „Institut für geschichtliche Landeskunde der österreichischen Donauländer" und stellte die Zusammenfassung und Vereinheitlichung der landeskundlichen und landesgeschichtlichen Bestrebungen als Hauptaufgabe heraus. Er sprach sich für die Erstellung von einheitlichen Richtlinien für Fragestellung und Methode aus, „so daß nach einem festen Plan an die Erforschung des Landes herangetreten“ werden könne ${ }^{306}$. Doch auch nun ist von einem Echo auf seine Vorschläge nichts bekannt, und anlässlich seiner Ernennung zum Titular-ao.-Prof. I955 deponierte er bei der Unterrichtsverwaltung erneut sein diesbezügliches Anliegen ${ }^{307}$. Im Zusammenhang mit der in den halbamtlichen „Kulturberichten aus Niederösterreich“ Mitte der I 96oer-Jahre geführten Diskussion um die „Zukunft der Landeskunde“ erörterte Lechner abermals die Frage eines „Instituts für Landes- und Volkskunde“308. Er hatte damals die Hoffnung auf Umsetzung seiner Pläne

303 Lechner, Vancsa (wie Anm. 93) 123.

304 Karl Lechner, Sinn und Aufgaben wissenschaftlicher Landeskunde, in: Kulturberichte aus Niederösterreich. Beilage der „Amtlichen Nachrichten der N.Ö. Landesregierung“ Heft 12 (1966) 92-96, hier 96.

305 Lechner, Sinn (wie Anm. 106) 159, 184; dieser Aufsatz, den Lechner übrigens seinem Kurskollegen Santifaller zum 60. Geburtstag gewidmet hat, stellt die bedeutend erweiterte Fassung des auf der Geschichtsvereinstagung gehaltenen Vortrags dar.

306 Ebd. 184.

307 UAW, PA KL, Curriculum vitae vom 17.03.1955.

308 Lechner, Sinn, 1966 (wie Anm. 313) 96. 
wohl schon aufgegeben. Die mangelnde Beachtung dieses Projektes führte er zum einen auf das Desinteresse seitens des Landes Niederösterreich zurück, zum anderen auf den im Vergleich zu Deutschland geringeren Stellenwert der geschichtlichen Landeskunde an der Wiener Universität ${ }^{309}$. Angeblich hat Lechner es nie verstanden, warum an der Universität Wien keine Lehrkanzel für Landesgeschichte und Landeskunde eingerichtet wurde ${ }^{310}$. Die 1978 erfolgte Gründung des Niederösterreichischen Instituts für Landeskunde hat Lechner jedenfalls nicht mehr erlebt. Als reine Forschungs- und nicht auch zugleich Lehrstelle erfüllte dieses Institut wohl auch nur zum Teil seine Vorstellungen, wies mit Helmuth Feigl aber einen seiner Schüler als ersten Leiter auf.

\section{I.I4 Resümee}

Die Biografie Karl Lechners ist die eines Grenzgängers. Als Grenzgänger zwischen verschiedenen politischen und wissenschaftlichen Strömungen, aber auch zwischen Wissenschaft und Politik insgesamt hat er mehrere politische Systeme und Brüche scheinbar unbehelligt und in leitender Funktion überdauert.

Obgleich Mitglied des konservativ-bürgerlichen IÖG, war Karl Lechner zumindest in den I92oer-Jahren weder „bürgerlich“ noch „konservativ“. Geprägt durch sein Engagement in der bündischen Jugendbewegung und als Mitglied des reformorientierten Bundes „Neuland“, war er durchdrungen vom radikalen Idealismus und der Aufbruchsstimmung dieser vorwiegend studentischen Jugendlichen. Politik und Pädagogik, Diskussion und Mission waren allgegenwärtig in diesen Kreisen, Parteipolitik und Kathedergelehrsamkeit hingegen waren verpönt. In den I920er-Jahren schien Lechners Aktivismus mehr dem linken Spektrum von „Neuland“ zuzuneigen. Sein soziales Engagement, seine offene Haltung gegenüber der sozialdemokratischen Arbeiterschaft, seine Kritik an der Amtskirche und seine Bemühungen um eine stärkere Stellung der Laien in der Kirche nahmen wesentliche Impulse für das Zweite Vatikanum um Jahrzehnte vorweg.

Wie „Neuland“ generell, stellte auch Lechner das „Volkliche vor das Staatliche“311. Wie viele „Neuländer“ dachte auch Lechner „gesamtdeutsch“, kreisten auch seine Überlegungen um die Fixpunkte katholischer Glaube und deutsches Volkstum. Seine ordnungspolitischen Vorstellungen teilte er mit dem rechten Rand von „Neuland“ und CV. Dieser Kreis „volksdeutscher Katholiken“ fühlte sich als intellektuelle Elite und umfasste mit Klebel, Borodajkewycz und Lorenz auch mehrere Historiker der „gesamtdeutschen“ Schule der Wiener Universität. Sie träumten wie Lechner vom Universalismus des „Heiligen Römi-

309 Ebd.

310 Pittioni, Lechner (wie Anm. 8) 586.

311 Kapfнammer, Jugendbewegung (wie Anm. 25) 44. 
schen Reichs Deutscher Nation“ und der hegemonialen Kraft des Deutschtums im mittelund osteuropäischen Raum. Ihre Vision handelte vom harmonischen Zusammenklang von katholischer Kirche und deutschem Volkstum, von Agrarromantik und überzeitlicher Reichsidee, aber auch von Antisemitismus, Antiparlamentarismus, Antimarxismus und Großstadtfeindlichkeit. Es blieb nicht beim Träumen. Über die katholische Publizistik, im Rahmen von Vorträgen und Fortbildungen sowie im Wege geschichtswissenschaftlicher Arbeiten versuchten Lechner und andere „Katholisch-Nationale“ ihre Visionen auch praktisch umzusetzen.

Lechners wissenschaftliches Schaffen war mit seinen politischen Entwürfen eng verschränkt. Sozialisiert im Kontext von Weltkrieg und staatlicher Neuordnung, erfasst von der nationalistischen Erregung, die ganz Mittel- und Osteuropa in ihren Bann gezogen hatte, wählte Lechner mit der Siedlungsgeschichte an der Sprachgrenze ein hoch politisches Forschungsthema. Als führender Exponent der „jüngeren landesgeschichtlichen Forschung “ im VfLKNÖ wandte er sich gegen den geschichtswissenschaftlichen Mainstream und konzentrierte sich auf die Untersuchung regionaler Siedlungsräume, die jenseits staatlich-administrativer Grenzen lagen. Mit Kötzschke und Aubin galt sein Interesse weniger der hohen Politik der "großen Männer“, als der Siedlungstätigkeit des breiten „Volkes“, vor allem des deutschen Bauerntums. Daraus ergab sich eine Nähe zur Volksgeschichte, mit der insbesondere nach den Pariser Vororteverträgen „Volk“ gegen „Staat“ und Geschichte gegen Politik gestellt werden konnte ${ }^{312}$. Lechners Beteiligung an Projekten der SODFG und seine immer offensiver vertretene gesamtdeutsche Interpretation der österreichischen Geschichte zeugten von der zunehmend engeren Verquickung von Wissenschaft und Politik. Lechner selbst machte 1938 nicht nur auf die politische Qualität seiner gesamtdeutschen Geschichtsauffassung aufmerksam, sondern wollte sie auch als Unterstützung der NSDAP verstanden wissen.

Lechner gehörte wie etwa auch Borodajkewycz I938 zu der kleinen Minderheit in der katholischen Kirche, die an einen „Ausgleich“ zwischen Kirche und Nationalsozialismus glaubte. Dieser Glaube bewog ihn auch, zum ersten und einzigen Mal in seinem Leben Mitglied einer politischen Partei werden zu wollen. Als seine Versuche, diesen „Ausgleich“ zu leben, scheiterten und als die NSDAP eine Entscheidung erzwang, wählte er die Kirche. Dieser Schritt war für Lechners berufliche Karriere im Nationalsozialismus nicht ohne Risiko. Er schürte damit das Misstrauen, welches der Nationalsozialismus als totalitäres System gegen jedwede Grenzgänger hegte, nur noch weiter. An seiner gesamtdeutschen Grundeinstellung hielt er jedoch fest, und auch andere, nicht unbeträchtliche Überschneidungen von „volksdeutsch-katholischer“ Gesinnung mit der NS-Ideologie dürften davon kaum betroffen gewesen sein.

312 Hettling, Einleitung (wie Anm. 113) 19. 
Trotz dieses Grenzgängertums zwischen Wissenschaft und Politik blieben Lechners wissenschaftliche Texte innerhalb der Grenzen fachgerechter Argumentation und Beweisführung. Lechner kann daher nicht als Exponent einer rassistischen Volksgeschichte à la Helbok gelten. Weder fanden sich in seinen Arbeiten Biologisierungen kultureller Erscheinungen, noch versuchte er darin rassenpolitisches Handeln anzuleiten. Seine metaphysisch überfrachtete Terminologie eröffnete aber einer „politischen Religion“ wie dem Nationalsozialismus mancherlei Anknüpfungspunkte. So war Lechners prinzipiell religiös grundiertes Glied-Körper-Modell offen für biologistische Organ-Volkskörper-Deutungen, und auch seine Interpretation der „deutschen Sendung“ der Ostmark erwies sich für jedwede deutsche - und damit auch eine nationalsozialistische - Großraumorientierung als anschlussfähig. Letzteres wiederum verband ihn mit Repräsentanten der „austrofaschistischen“, gleichfalls deutsch-betonten Österreich-Ideologie etwa eines Hantsch. Was Lechner und andere „Gesamtdeutsche“ auch nach dem Zusammenbruch des Nationalsozialismus nicht sehen wollten, das waren ebendiese Schrittmacherdienste, die dadurch dem Nationalsozialismus geleistet worden waren und die sie 1938 auch so verstanden hatten wissen wollen. Vereinzelt sehr wohl rassenpolitisches Handeln anzuleiten suchte Lechner dagegen in seiner katholischen Publizistik. Dort warnte er eindringlich vor „Rassenmischungen“, wobei ihm die größten Gefahren von der „schwarzen“ und der ,jüdischen Rasse“ ausgingen.

Lechners politische Integration in die Zweite Republik wurde durch sein fortgesetztes kirchliches Engagement und durch seine Stützung im VfLKNÖ erleichtert. Die Einbindung in katholisch-konservativ-männerbündische Netzwerke der frühen Zweiten Republik ebnete ihm neben seiner fachlichen Qualifikation den Weg zum Universitätslehrer. Als verlässlicher „Patron“ erwies sich dabei sein Kurskollege Santifaller ${ }^{313}$; politische Wirkung zeitigte auch die von seinem Freund Vancsa initiierte und teils auch politisch „frisierte" Festschrift. Die gleichfalls katholisch-konservativ ausgerichtete Volksbildung der Nachkriegszeit bildete eine weitere Schiene von Lechners politischer Integration. Indem diese nicht nur personell, sondern auch konzeptuell an die „ständestaatlich-vaterländische“ Periode der I930er-Jahre anknüpfte und der katholisch-konservative Heimatbegriff weiterhin in Gebrauch blieb, war sie für Lechner anschlussfähig. Auch die im Rahmen der gesamtdeutschen Geschichtsauffassung propagierten „österreichischen“ Besonderheiten verschmolzen nun - neu kontextualisiert - mit dem staatlich sanktionierten ÖsterreichMythos. Neben die alte "Ostmarkfunktion“ trat nun auch die Konstruktion der Keimzelle, des kulturellen Zentrums.

313 Zur großen Bedeutung von Förderern und „dauerhaften Schutz- und Abhängigkeitsverhältnissen zwischen Patron und Klient" auch im Hinblick auf institutspolitische Ausrichtungen im universitären Bereich siehe in Anlehnung an Pierre Bourdieus „Homo academicus“ Albert Müller, Alte Herren/Alte Meister. ,Ego-Histoire in der österreichischen Geschichtswissenschaft. Eine Quellenkunde, in: ÖZG 4 (1993) 120-133, hier 130f. 
Die „jüngere landesgeschichtliche Forschung“ erlebte mit ihrer Leitfigur Lechner Gründung, Höhepunkt und Ausklang. Fast fünfzig Jahre lang dominierte sie Methode und Ausrichtung der geschichtlichen Landeskunde in Niederösterreich - mit starker Ausstrahlung vor allem auf die landeshistorische Forschung in der Steiermark. Ihr zeitlicher Rahmen war eng; sie konzentrierte sich fast ausschließlich auf das Mittelalter. Sie war zunächst innovativ, zumeist produktiv, bisweilen spekulativ, und im Laufe der Zeit wurde sie zunehmend selbstreferenziell. Bei ihrer Institutionalisierung scheiterte sie; auch Lechner selbst fand trotz zahlreicher Schülerinnen und Schüler keine Nachfolger.

Als Wissenschaftler hatte der Verfassungs-, Siedlungs- und Herrschaftshistoriker Lechner vor allem mit seiner großen Waldviertel-Studie von 1937 Maßstäbe gesetzt. Sie steht daher auch im Zentrum des folgenden Abschnitts. Die detaillierte und umfassende Darstellung eines relativ eng begrenzten Raumes, geschrieben aus unterschiedlichen, miteinander verknüpften Perspektiven, wies bereits auf die moderne Regionalgeschichte voraus; eine Regionalgeschichte, die sich in Österreich erst Jahrzehnte später bemerkbar zu machen begann. Darüber hinaus erwarb sich Lechner durch die Erschließung einer Vielzahl landeskundlicher Quellen Verdienste, wovon Mediävisten mitunter bis heute profitieren. Weniger glücklich agierte Lechner bei seinen Überblicksdarstellungen; auch seine großen Thesen haben der wissenschaftlichen Überprüfung am Einzelfall nicht immer standgehalten. Neben der zunächst sehr einflussreichen „Grafschaftstheorie“ sei hier insbesondere auf die „besitzgeschichtlich-genealogische“ Methode hingewiesen, die im folgenden Abschnitt von Ralph Andraschek-Holzer behandelt wird.

\section{KARL LECHNER ALS BEGRÜNDER DER MEDI ÄVISTISCHEN REGIONALFORSCHUNG IN NIEDERÖSTERREICH}

An dieser Stelle eine umfassende Beurteilung von Lechners wissenschaftlichem Gesamtwerk bieten zu wollen ist nicht möglich - zu kurz war die für tiefer gehendes Forschen erforderliche Zeitspanne bemessen; zu wenige Vorarbeiten existierten. Daher soll anhand zweier ausgewählter Arbeiten Lechners seine Arbeitsweise, vor allem aber Werden und Wachsen seiner „besitzgeschichtlich-genealogischen“ Methode, dargelegt und ihre Rezeption in jüngerer Zeit skizziert werden ${ }^{314}$. Zugleich wird damit ein Baustein für die dringend erforderliche Gesamtbeurteilung Lechners geliefert.

314 Damit sei jedoch nicht verschwiegen, dass diese nur eine Seite von Lechners Cuvre darstellt und hier auf seine verfassungs- bzw. rechtshistorischen Überlegungen nicht näher eingegangen werden kann. 


\section{I Die ausgewählten Arbeiten}

Die Wahl fiel zunächst auf Lechners Erstlingsarbeit aus I924, „Geschichte der Besiedlung und der ursprünglichen Grundbesitzverteilung des Waldviertels“ (= Lechner I924) ${ }^{315}$. Sie steht nicht nur am Beginn von Lechners Schaffen überhaupt, sondern enthält gleichsam auch die Keimzelle der erwähnten Methode. Deren Anwendung durch ihren Urheber selbst wiederum fand ihren Höhepunkt zweifellos in Lechners groß angelegter Publikation „Besiedlungs- und Herrschaftsgeschichte des Waldviertels“ (= Lechner I937) ${ }^{316}$. Veröffentlicht in Stepans siebenbändigem Werk „Das Waldviertel“, handelt es sich bei dieser Arbeit um die neben der postum erschienenen Babenberger-Monografie umfangreichste Publikation aus Lechners Feder und zugleich um den Höhepunkt seiner um die Erforschung des mittelalterlichen Waldviertels kreisenden Forschungen.

Beide Arbeiten in aller Kürze zu charakterisieren, ist nicht einfach. Zunächst zu Lechner I 924. Nach einem einleitenden Abschnitt, in welchem der Autor die Themenwahl rechtfertigt und seine Vorgehensweise - nicht zuletzt gegen andere Forschungsmeinungen gerichtet - darlegt (IO-I7), zeichnet er den „Gang der Besiedlung“ von der Prähistorie bis ins Spätmittelalter nach (I7-96). Es folgt der zentrale Abschnitt, „Träger der Kolonisation - Geschichte der großgrundbesitzenden Geschlechter" (96-I79), in welchem die einzelnen Herrschaftsgebiete bzw. Adelsfamilien erörtert werden. Das letzte Kapitel lautet „Siedlungsformen - Soziale Stellung - Ortsnamen - Stammeszugehörigkeit“ (I 79-207); es nutzt Erträge benachbarter Disziplinen zwecks Verbreiterung der Quellenbasis und Abrundung des via Urkundenforschung erarbeiteten Befundes; dann folgen Berichtigungen.

Lechner I 937 verrät schon eingangs eine großzügigere Konzeption. Die Trennung von „Vorwort“ (5f.) und einleitendem Kapitel (7-I I ; die einzelnen, auf das Vorwort folgenden Kapitel werden durchnummeriert, doch nicht betitelt) allein spricht für eine „buchmäßige" Konzeption der Arbeit; die in beiden Abschnitten begegnenden Angaben zur Methode (6. bzw. Iof.) lassen schon eingangs eine von Reflexion begleitete Themenbehandlung erahnen. Ein überleitender Abschnitt ( 2 2-3 I) beschäftigt sich mit der Besiedlung (von der Spätantike an) und arbeitet Erträge der Namens- bzw. Siedlungsforschung

315 Karl Lechner, Geschichte der Besiedlung und der ursprünglichen Grundbesitzverteilung des Waldviertels, in: JbLKNÖ NF 19 (1924) = FS zur Sechzigjahrfeier des Vereines 10-210; auch als in Titel und Paginierung identischer Sonderdruck vorliegend.

316 Karl Lechner, Besiedlungs- und Herrschaftsgeschichte des Waldviertels. Mit besonderer Berücksichtigung des Mittelalters und der frühen Neuzeit, in: Das Waldviertel 7: Geschichte, hg. v. Eduard Stepan (Wien o.J. [1937]) 2. Buch, 5-276; auch als in der Paginierung identischer Sonderdruck mit dem Zusatz „Mit zwei Beiträgen von H. Weigl und St. Brunner“ vorliegend (also die Beiträge von H[einrich] WEIgL, Abgekommene Siedlungen [ebd. 277-279], bzw. Stephanie Brunner, Zwei Herrschaftskarten des Waldviertels [ebd. 280-299], umfassend). 
ein. Es folgt der Hauptteil, in welchem anhand der urkundlichen Belege schwerpunktmäßig Herrschaftsgebiete, Herrschaftsträger und Rechtsverhältnisse bis in die Frühe Neuzeit hinein untersucht werden (3I-276).

Da eine ausführlichere Darlegung der jeweiligen Inhalte den Umfang dieser Skizze zu Lasten einer analytischen Betrachtung sprengen würde, eine eingehendere Betrachtung besagter Arbeiten jedoch unumgänglich ist, sei folgender, im Grunde „philologischer" Weg beschritten: Ausgangspunkt für eine Analyse der beiden Texte bildet ein vom Verfasser eigens erarbeiteter Fragenkatalog, welcher sich an den Hauptaspekten Publikationsorte, Publikationsformen, Themenwahl und Themenbehandlung orientiert.

\section{Publikationsorte}

Zunächst ist festzustellen, ob es sich bei den vorliegenden Publikationsorten um „etablierte“ Orte wie eine Reihe oder eine Zeitschrift handelt. Lechner I 924 stellt einen für ein landeskundliches Organ thematisch wie formell (kraft wissenschaftlichen Anspruchs) geeigneten und folglich auch sinnfällig in einem solchen veröffentlichten Aufsatz dar; Lechner 1937 wurde hingegen in einem mehrbändigen, sprich als mehrteilige Aufsatzsammlung konzipierten Werk veröffentlicht. Ferner ist zu fragen, ob es sich um für einen bestimmten Ort vorgesehene Arbeiten handelt oder deren Unterbringung aus anderen nachvollziehbaren Gründen erfolgte. Für Lechner I924 bzw. I 937 trifft wohl Ersteres zu. Auch die Frage, ob die Arbeiten aus einem in einer Lehrveranstaltung gehaltenen Referat, aus einer Hochschulschrift oder aus einem Vortragsmanuskript hervorgingen, ist zu erörtern. Lechner 1924 basierte deklariertermaßen (Io, Anm. I) auf einem Referat ${ }^{317}$; ebenso Lechner $1937^{318}$.

\section{Publikationsformen}

Die Frage, ob für die Veröffentlichung die Form einer Monografie oder eines Aufsatzes gewählt wurde, wäre zudem um die Frage der Größendimension der jeweiligen Konzeption zu ergänzen, soll aber hier nur so beantwortet werden: Lechner 1924 ist ein um-

317 Bei der schriftlichen Ausarbeitung handelt es sich übrigens um die am IÖG approbierte Hausarbeit - vgl. Walter Pongratz, Zur Erinnerung an Karl Lechner, in: Das Waldviertel 34 (1985) 216-224; diese Arbeit trug den Titel „Zur Geschichte der Besiedelung und der Grundbesitzverteilung des niederösterreichischen Waldviertel“ (vgl. das Prüfungszeugnis vom 07.07.1921 im NÖLA, NL KL, K. I, Mappe 1).

318 Gehalten wurde dieses Referat im Rahmen einer SODFG-Tagung, welche im April 1935 als Exkursion ins Waldviertel sowie nach Südböhmen führte und deren Beiträge überwiegend in erwähntem Stepan-Sammelband aus 1937 veröffentlicht wurden. Michael FAнцвизсн, Wissenschaft im Dienst der nationalsozialistischen Politik?: Die „Volksdeutschen Forschungsgemeinschaften“ von 1931-1945 (Baden-Baden 1999), 291 bzw. Anm. 576. (Für diesen Hinweis danke ich Stefan Eminger, St. Pölten, herzlich.) 
fangreicher, zu seiner Zeit in gängiger Länge vorgelegter Aufsatz ${ }^{319}$; Lechner I 937 bildet hingegen ein kleines „Buch im Buch“. Die nächste Formfrage stellt genau genommen eine Frage nach der Gattung dar und zielt darauf ab, ob das Thema im Rahmen einer Untersuchung, einer Edition, eines Forschungsberichts oder einer Rezension behandelt wurde. Lechner 1924 bzw. 1937 stellen jeweils eine Untersuchung dar.

\section{Themenwahl}

Als Erstes ist zu fragen, ob das Thema erstmals aufgegriffen wird oder ob es sich um einen Teil eines konsequent erarbeiteten und planmäßig erweiterten Curriculums handelt. Für Lechner I 924 trifft Ersteres zu; Lechner 1937 bildet Teil eines seit I 924 erarbeiteten Curriculums $^{320}$. Damit in engem Zusammenhang steht die Frage, ob das Thema Hauptarbeitsgebiete oder Vorlieben des Verfassers berührt. Für Lechner 1924 bzw. I 937 trifft Ersteres zu. Ferner muss geklärt werden, ob die Themenwahl aufgrund eines äußeren Anlasses (etwa polemisch replizierend oder generell aufgrund eines bestimmten, die Themenwahl provozierenden Forschungsstandes) erfolgt. Für Lechner I 924 trifft wohl Ersteres zu, da z.T. polemisch repliziert wird, für Lechner 1937 nichts dergleichen.

\section{Themenbehandlung}

Mit der zweiten im Abschnitt „Publikationsformen“ gestellten Frage hängt die folgende in nicht geringem Ausmaß zusammen, ob Erzählung oder Analyse, Referat oder Untersuchung, Replik, Polemik oder Appell vorherrscht. Lechner 1924 bzw. I 937 bieten Analyse, Lechner 1924 auch Polemik. Ein weiterer Aspekt berührt die Gliederung. Diese kann eine an inhaltlichen Kriterien orientierte Kapitelgliederung aufweisen, einen durch LeseAbschnitte gegliederten Aufbau oder gar eine „innere“ Gliederung. Für Lechner I924 trifft Ersteres zu; Lechner 1937 verrät hingegen eher einen durch Lese-Abschnitte gegliederten Aufbau.

Weiters ist zu klären, ob eine allmähliche Entwicklung der angestellten Überlegungen erfolgt oder gleich „in medias res“ gegangen, systematisch oder sprunghaft vorgegangen wird. Lechner 1924 bzw. I 937 zeichnen sich durch allmähliche Entwicklung des Gegen-

319 In landeskundlichen Organen erschienen oftmals tranchenweise veröffentlichte Aufsätze von insgesamt beträchtlichem Umfang. Ein Beispiel - auch für einen von Lechner rezipierten Autor -: Josef LAmpel, Die babenbergische Ostmark und ihre „Tres comitatus“, in: JbLKNÖ NF 2 (1903) 1-76, NF 3 (1904) 1-137, NF 4/5 (1905/06) 225-489. - Sobald derartige groß angelegte Aufsätze als Separata vorlagen, wurden ihnen Besprechungen gewidmet: Vgl. die Rezension Lechner 1924 durch Josef Pfitzner in MIÖG 42 (1927) 121-126, bzw. die Rezension von Lechner 1937 durch K[arl] Wührer in MIÖG 53 (1939) 199-202.

320 Man beachte nur die erste Bilanz von Lechners Lebenswerk, die von Kurt Vancsa zusammengestellte Bibliografie in der ausschließlich Lechner-Arbeiten enthaltenden FS zu dessen 50.Geburtstag: Karl Lechner (wie Anm. 207) 231-233. 
standes sowie durch systematisches Vorgehen aus. Als nächstes folgt die Frage, ob große Linien gezeichnet oder Details abgehandelt werden, ob also eine Überblicksarbeit oder eine Spezialuntersuchung vorliegt. Lechner I 924 bzw. I 937 stellen primär Spezialuntersuchungen dar, wenngleich Lechner 1924 im ersten Abschnitt („Gang der Besiedlung“ I7-96) einen komplexeren, sich länger hinziehenden Vorgang skizziert. Ob ein induktives oder ein deduktives Verfahren angewendet wird, ist in diesem Fall rasch zu klären: Für Lechner 1924 bzw. 1937 trifft Ersteres zu. Besonders erhellend ist wohl die Frage, ob ein Reflektieren der gewählten Methode(n) erfolgt. In den untersuchten Arbeiten geschieht dies jeweils in den einleitenden Abschnitten Lechner I924 I6f. und Lechner I 937 Iof.

Genauere Beschäftigung mit den Texten erweist, inwieweit disziplinübergreifend gearbeitet wird. In beiden ausgewählten Arbeiten ist dies der Fall, vor allem in Bezug auf Orts-/Flurnamen bzw. -formen. Die betreffenden Abschnitte werden jedoch anders platziert: Begegnen sie I 924 fast ausschließlich im Schlusskapitel („Siedlungsformen - Soziale Stellung - Ortsnamen - Stammeszugehörigkeit“ I79-207), finden sie sich 1937 im ersten größeren Kapitel (I 2-3 I), bevor Lechner sein eigentliches Anliegen, die „urkundliche Forschung“(3I), in Angriff nimmt.

Schon in Richtung Kontextualisierung zielt die Frage, in welchem Ausmaß eine wissenschaftiche Arbeit Vorkenntnisse vom Leser verlangt, ob sie fach- oder populärwissenschaftliche Ziele verfolgt. Lechner 1924 bzw. 1937 kombinieren erklärendes Vorgehen und die Verfolgung fachwissenschaftlicher Ziele (1924: 96; I937: 2If., I06). Nicht so einfach zu beantworten ist die Frage, ob sich die Arbeit als Ergänzung bisheriger (eigener oder fremder) Forschungsleistungen versteht oder ihren Innovationscharakter betonen will. Für Lechner I 924 kann Ersteres behauptet werden, während Lechner I 937 ihren Innovationscharakter betont (Vorwort 6). Die nächste Frage befasst sich damit, ob die hier gewonnenen Ergebnisse für Forschungen mit weiterem Interessenhorizont fruchtbar gemacht werden bzw. ob ihre Bedeutung für Folgeforschungen betont wird. Für Lechner 1924 kann dies trotz einer Andeutung (I6) nicht behauptet werden, ebensowenig für Lechner 1937, wo im Gegenteil sogar angekündigt wird, speziellere Untersuchungen könnten auf den hier gewonnenen Ergebnissen aufbauen (Vorwort 6).

Antworten auf die Frage nach dem Umgang mit fremdem geistigem Eigentum - redlich deklarierend oder gar verschweigend, sachlich oder polemisch - fallen wohl ebenso erhellend wie reizvoll aus. In Lechner 1924 bzw. I 937 werden fremde Ergebnisse deklarierend und primär sachlich vorgetragen, in Lechner 1924 allerdings auch polemisch ${ }^{321}$. Wie es um die Belegkultur steht, ist keine Nebensächlichkeit, sondern wirft auch ein Licht auf die Publikationskultur von Person und Epoche. Dazu folgende Teilaspekte:

321 Dazu weiter unten mehr. 
- Belegart: Nutzung von publizierten/unpublizierten Quellen, Fachliteratur oder Sonstigem (Zeitungsartikel etc.): In Lechner I 924 bzw. I 937 werden primär publizierte Quellen und Fachliteratur benutzt.

- Belegdichte: Ob konsequent alles an Belegen am jeweiligen Ort angeführt wird oder ihre Nennung summarisch erfolgt: Für Lechner I 924 bzw. I 937 trifft Ersteres zu.

- Gestaltung von Anmerkungsapparaten: konkret, ob diese auch für Diskussionen/Polemiken/Präzisierungen genutzt oder für Belege im engsten Sinn reserviert bleiben: In Lechner I 924 erfolgt die Nutzung des Apparats auch für Polemiken, in Lechner I 937 fast nur für Belege.

\section{II.2 Kontextualisierung: Voraussetzungen und Entwicklung einer Methode}

Mit der Beantwortung dieser Fragen ist die Überleitung zum nächsten, der Kontextualisierung jener Arbeiten gewidmeten Abschnitt gegeben. Den Beginn macht naturgemäß Lechner 1924, eine Arbeit, die thematisch wie methodisch gleichsam als Exposition für Lechners wissenschaftliches Haupt-, ja Lebenswerk gelten darf.

In ihr legt der Autor einleitend sein methodisches Vorgehen dar (I6): Demnach sei Geschichte des ursprünglichen Grundbesitzes zugleich Geschichte der Besiedlung; diese wiederum gebe Aufschluss über Herkunft und Stammeszugehörigkeit der Siedler. Somit sei ein Schluss vom Verbleib des einzelnen Besitzes auf genealogische Beziehungen zwischen den Adelsfamilien und umgekehrt möglich. Erforderlich sei allerdings die Berücksichtigung und Auswertung aller Forschungszweige: also auch der Ortsnamenforschung, Ortsanlage, Hausform, Flureinteilung und Kirchenpatrozinien.

Bevor diese Vorgehensweise weiter behandelt wird, muss noch ein Wort zu Lechners Intention gesagt werden. Die Geburt dieser Arbeit erfolgte nämlich aus dem Geist der Polemik - einer Polemik, welche nicht nur in die Entwicklung besagter Methode mündete, sondern auch eine andere Komponente umfasste: Auf Seite I 4 wird die deutsche Kolonisation in slawischem Gebiet hervorgehoben, womit ein weiteres Hauptthema von Lechner I 924 genannt wäre. Dieses kann hier nicht weiter verfolgt werden; festzuhalten ist allerdings, dass sich Lechner hier in einer bestimmten Tradition antitschechischen Räsonierens befindet ${ }^{322}$.

322 Vielfach dürften unter dem Vorwand gelehrten Polemisierens antislawische - d.h. antitschechische - Ressentiments in die jeweilige Arbeit eingeflossen sein; so erscheint die in LECHNER 1924 97-101, begegnende Stellungnahme gegen A. P. Šlechta gleichsam als Nachfolgerin von Polemiken wie derjenigen Strnadts gegen

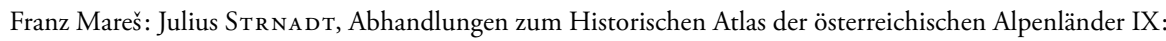
Innviertel und Mondseeland, in: AÖG 99 (1912) 427-1069, hier 655-659 - Die Bedeutung Strnadt'scher Arbeiten für den „frühen“ Lechner zu untersuchen wäre eine eigene, lohnende Aufgabe für historiografiegeschichtliche Forschung. 
Auch die von ihm hier erstmals skizzierte und später so genannte „besitzgeschichtlichgenealogische Methode“ ist nicht zuletzt als Antwort auf eine als unzureichend betrachtende Forschungsposition zu bewerten: Gemeint ist ein thematisch einschlägiger Aufsatz von Franz Heilsberg ${ }^{323}$. Lechner 1924 wartet in den bereits erwähnten Einleitungspassagen (I6) mit einer Anti-Heilsberg-Positionierung als Ouvertüre auf. Eine Einschränkung muss insofern vorgenommen werden, als Heilsberg die Relevanz verwandtschaftlicher Beziehungen für die angemessene Behandlung seines Themas keineswegs leugnet, ihnen allerdings nicht näher nachgeht ${ }^{324}$.

Generell ordnet Heilsberg die Kolonisation des Waldviertels in eine großzügig dimensionierte, überregionale Entwicklung ein. Vergleiche mit anderen Gebieten des Reichs werden gezogen; das Nachzeichnen „großer“ Linien überwiegt gegenüber dem Erfordernis, einmal gewonnene Erkenntnisse auch quellenmäßig genau zu belegen. Oft folgen nach wenigen, faktengesättigten Absätzen längere Passagen ohne genauere Nachweise. Dies alles dürfte Lechners Unwillen erregt haben. Er nämlich geht von Anfang an in die Tiefe, indem er akribisch gesammelte Quellenbelege (vor allem urkundlicher Art) zur Stützung von Behauptungen heranzieht. Induktives Verfahren hat sich hier somit in Reinkultur niedergeschlagen ${ }^{325}$.

Natürlich existierten Vorarbeiten zur Genealogie von Adelsgeschlechtern, die von Lechner verwertet und - verworfen wurden ${ }^{326}$. Auf die Werke Otto von Dungerns und deren Rezeption im frühen 20. Jahrhundert hat schon vor geraumer Zeit Michael Mitterauer hingewiesen $^{327}$; seine Ausführungen suggerieren sogar die Negierung Dungern'scher Forschungen

323 Franz Heilsberg, Geschichte der Kolonisation des Waldviertels, in: JbLKNÖ NF 6 (1907) 1-92.

324 Als Beispiel diene etwa Heilsbergs Aussage über die Nachfolge der Raabser durch die Hirschberger (HeilsBerg, Kolonisation [wie Anm. 323] 67), welche übrigens von Lechner 1924, 157, zugunsten der Beibringung einer Hammerl'schen Meinung aus 1906 ignoriert wird; diese wiederum vermisst man bei Heilsberg. - Mit dem genannten Autor ist übrigens Benedikt Hammerl gemeint, zu welchem eine relativ junge Würdigung vorliegt: Charlotte Ziegle R, P. Benedikt Johann Hammerl (1862-1927). Bibliothekar und Archivar von Stift Zwettl, in: Waldviertler Biographien 1, hg. v. Harald Hiтz [u. a.] (Schriftenreihe des Waldviertler Heimatbundes 42, Horn/Waidhofen an der Thaya 2001) 179-191. - Auch Vancsa ist sich der Relevanz verwandtschaftlicher Beziehungen für einschlägige Forschungen bewusst; in seinem Buch spricht er auch methodische Probleme bezüglich genealogischer Forschungen an: Max VAnCsa, Geschichte Nieder- und Oberösterreich. 1: Bis 1283 (Allgemeine Staatengeschichte 3: Deutsche Landesgeschichten 6,1, Gotha 1905) 253 Anm. 5; ausführlicher übrigens Otto von Dungern, Die Entstehung der Landeshoheit in Oesterreich (Wien/Leipzig 1910) 93-95, und pass.

325 Bereits Feigl, Bedeutung (wie Anm. 5) 216, vermerkte: „Er lehnte deduktive Methoden strikte ab [...]. “

326 Genannt sei nur: Johann Wendrinsky, Die Grafen von Rebgau-Piugen, in: Blätter des Vereines für Landeskunde von Niederösterreich NF 14 (1880) 181-194, welche LECHNER 1924 119, als „freilich ganz verfehlt" bezeichnet.

327 Michael Mitterauer, Formen adeliger Herrschaftsbildung im hochmittelalterlichen Österreich. Zur Frage der „autogenen Hoheitsrechte“, in: MIÖG 80 (1972) 269 Anm. 11. - Ebd. 266 Anm. 4 findet sich auch der 
durch Lechner ${ }^{328}$. Nun, dies stimmt so nicht, zumal dieser schon I 924 die I9Io erschienene Dungern-Monografie über die Entstehung der Landeshoheit rezipiert hat ${ }^{329}$. Somit waren die Voraussetzungen für Lechners Forschungen nicht allzu günstig: Systematisch betriebene, jedoch mangelhafte genealogische Mikrostudien à la Wendrinsky ${ }^{330}$ wurden flankiert von übergreifenden, aus rechtsgeschichtlicher Warte erarbeiteten Büchern eines Dungern; hinzu traten Spezialuntersuchungen wie diejenigen Julius Strnadts ${ }^{331}$ bzw. Franz Heilsbergs ${ }^{332}$, während der Einfluss eines von Lechners akademischen Lehrern, Dopsch, noch genauer nachzuweisen wäre ${ }^{333}$.

Vancsas Landesgeschichte referiert in seiner Einleitung übrigens sehr schön den um I905 gegebenen und weitgehend auch noch für Lechner verbindlichen Forschungsstand $^{334}$. Dieser zeichnete sich durch ein Nebeneinander zahlreicher Quelleneditionen und übergreifender Gesamtdarstellungen, kaum jedoch durch aus den genannten Editionen gespeiste Analysen aus. Dies bedeutete für Lechner, in eine Bresche zu springen, also Vorhandenes zu berichtigen, auf Verlässlichem aufzubauen und somit Neuland zu

Hinweis auf die lesenswerte Würdigung Dungerns durch Theodor Maye R, Die Ausbildung der Grundlagen des modernen deutschen Staates im hohen Mittelalter, in: HZ 159 (1939) 457-487 (hier nach dem fast unveränderten Abdruck in: Herrschaft und Staat im Mittelalter), hg. v. Helmut KäмpF (Wege der Forschung 2, Darmstadt 1974) 287. - Da Mayers Aufsatz 1939 erschien, verwundert das Verschweigen des ebenfalls als Rechtshistoriker hervorgetretenen Sigmund Adler (siehe unten Anm. 328), der jüdischer Abstammung war, nicht.

328 Die bei Mitterauer, Herrschaftsbildung (wie Anm. 327) 269 Anm. 11, angeführte Rezeption Sigmund Adlers lässt sich beispielsweise anhand von Lechner 1937, 160 Anm. 5, nachweisen.

329 Lechner 1924, S. 111 Anm. 1 (Lechner nennt beim Zitieren übrigens irrtümlich S. 163 statt S. 143). Gemeint ist: Dungern, Landeshoheit (wie Anm. 324). - Ferner erfolgte die Rezeption Dungerns durch Lechner etwa in: Karl Lechner, Grafschaft, Mark und Herzogtum. Ein Beitrag zur Territorial- und Verfassungsgeschichte Österreichs, in: Jb. für Landeskunde und Heimatschutz von Niederösterreich und Wien NF 20 (1926/27) 1: FS zum sechzigsten Geburtstage von Max Vancsa, 32-69, hier z.B. 49 Anm. 1; schließlich hat Lechner dem Dungern'schen Buch „Adelsherrschaft im Mittelalter“ eine ausführliche Besprechung im JbLKNÖ NF 22 (1929) 116-121, gewidmet.

$330 \mathrm{Zu}$ diesem siehe oben Anm. 326.

$331 \mathrm{Zu}$ diesem siehe oben Anm. 322.

332 Diese ist laut VAncsa, Geschichte (wie Anm. 324, XI), aus einer Dissertation hervorgegangen (vgl. auch ebd. 223 Anm. 1).

333 Im Zuge einer solchen Untersuchung wäre zu erörtern, ob LECHNE R 1924 gleichsam als Vertiefung etlicher von Dopsch angestellter Überlegungen zum Thema Adel und Grundbesitz betrachtet werden könnte; vgl. etwa Arbeiten wie Alfons Dopsch, Zur Geschichte der patrimonialen Gewalten in Niederösterreich, in : MIÖG 29 (1908) 594-624; hier zitiert nach DERs., Gesammelte Aufsätze 1: Verfassungs- und Wirtschaftsgeschichte des Mittelalters, hg. v. Erna Patzelt (Wien 1928, ND Aalen 1968) 183-216, hier bes. 212-214. - Zu Dopsch vgl. Thomas Buchner, Alfons Dopsch (1868-1953). Die „Mannigfaltigkeit der Verhältnisse“, in: Österreichische Historiker (wie Anm. 8) 155-190, 189 Erwähnung des Dopsch-Dissertanten Lechner. Zu Redlich, einem weiteren Lechner-Lehrer, siehe zuletzt die Beiträge in MIÖG 117 (2009) 399-428.

334 VAnCsA, Geschichte (wie Anm. 324) 1-26. 
betreten. Die wichtigste Voraussetzung dafür war - neben der Nutzung relevanter Erträge anderer Disziplinen - eine genaue Quellenkenntnis, welche für Lechner ein Forscherleben lang das wichtigste Rüstzeug darstellen sollte.

Lechner selbst entwickelte seine auf urkundlichen Belegen zu Genealogie und Grundbesitz aufbauende, Interdisziplinarität stark forcierende Methode weiter. Sein Aufsatz im Horner Heimatbuch aus 1933 erweist sich, wenngleich in der Themenstellung stark eingeschränkt, gewissermaßen als Zwischenstufe auf dem weiteren Weg zur Verfeinerung und weit "großräumigeren“ Anwendung ${ }^{335}$. Auch in ihr wird (246-256) die Bedeutung eines mehrfachen methodischen Zugangs zum Thema vor Augen geführt: ein Vorgehen also unter Berücksichtung von Orts- und Flurnamenforschung, Siedlungsplanforschung und Urkundenforschung zwecks Herausarbeitung der einzelnen Hoheits- und Herrschaftsgebiete.

Einen Namen erhielt Lechners Methode jedoch erst später, nämlich in Lechner I937: Im Vorwort (6) wird die „besitzgeschichtlich-genealogische Methode“ ausdrücklich als solche bezeichnet und als Grundlage der von uns bereits behandelte Aufsatz Lechner I 924 deklariert $(5)^{336}$. Im Zuge dessen wird die stärkere Heranziehung der besitzgeschichtlichen bzw. genealogischen Forschung erwähnt und das weitere Vorgehen programmatisch unterstrichen.

In den Jahren rund um das Erscheinen jenes „Buchs im Buch“ häuften sich derartige Äußerungen in Lechners Werk. In seinem Kleinmariazell-Aufsatz etwa hält der Autor geradezu ein Plädoyer für seine Methode: „Die Urkunde aber, die über die Stiftung erhalten ist, verschweigt oder verschleiert den wahren Sachverhalt. Wir aber sehen, daß es möglich ist, auch in einem solchen Falle zur Aufklärung zu gelangen: durch konsequente Verfolgung nämlich eines bestimmten Gutskomplexes unter verschiedene Teilbesitzer bis in spätere Zeit und durch Vergleich mit anderen Besitzgruppen, dazu mit vorsichtigen genealogischen Schlüssen; außerdem aber mit der umsichtigen Auswertung der Ortsund Flurnamen, der Siedlungsanlagen, der Patrozinien u.a. und selbstverständlich in der sorgfältigeren Interpretation von Urkunden, unter Beachtung der archivgeschichtlichen Momente. Die Fruchtbarkeit der besitzgeschichtlich-genealogischen Methode, die heute für eine kritische Besiedlungs- und Territorialgeschichte als unerläßliche Voraussetzung erkannt wird, hat sich auch für unsere Untersuchung bewährt!“337

335 Karl Lechner, Geschichte der Besiedlung und der ältesten Herrschaftsverteilung, in: Heimatbuch des Bezirkes Horn 1, hg. v. Franz Lukas, Friedrich Moldaschl (Horn 1933) 246-304.

336 Übrigens deutet schon die vorsichtig-abwandelnde Titelwahl auf ein in jeder Hinsicht gegebenes Anknüpfen an jenen älteren Aufsatz hin. Man vergleiche: 1924: „Geschichte der Besiedlung und der ursprünglichen Grundbesitzverteilung des Waldviertels“, 1937: „Besiedlungs- und Herrschaftsgeschichte des Waldviertels [...]“.

337 Karl Lechner, Die Gründung des Klosters Maria-Zell im Wiener Wald und die Besitzgeschichte seiner Stifterfamilie, in: JbLKNÖ NF 26 (1936) 92-118, hier 118 (Schluss), Hervorhebung nach Original. - In einer wenig später publizierten Arbeit führt er einleitend sowie unter Bezugnahme auf seine eben vorgelegte Unter- 
Das Voranschreiten dieser Entwicklung im Methodischen lässt sich vielleicht anhand eines Details veranschaulichen. Vorgeführt wird besagte Methode in Lechner I924 (I 4II 50) am Beispiel der Herren von Pernegg, vor allem der eingangs als Möglichkeit in Aussicht gestellte Schluss von Besitzverhältnissen bestimmter Adelsfamilien auf genealogische Abstammung von Personen, hier konkret auf Beziehungen zwischen den Perneggern und den Peilsteinern. Sätze wie der folgende dürfen für Lechners Vorgehen als charakteristisch erscheinen: Daß eine Familienverbindung zwischen Perneggern und Peilsteinern eingetreten ist, dafür spricht unzweifelhaft, daß der Besitz zwischen Weitenbach und Donau, den wir zu Anfang des I2. Jahrhunderts als alten Besitz der Peilsteiner gefunden haben und von welchem die Schenkungen an Freising und Neustift erfolgten, an die Pernegger übergegangen war, und zwar schon vor II80. (I43) Auch werden die Beziehungen zwischen Perneggern und Babenbergern erörtert und im Zuge dessen die Pernegger direkt auf einen unbekannten Sohn des Markgrafen Ernst (I 4I) zurückgeführt. Diese Behauptung, auch im Horner Heimatbuch vertreten ${ }^{338}$, wird im großen Aufsatz Lechner 1937 (55f.) dahin gehend relativiert, dass für die Pernegger nur noch die Abstammung mütterlicherseits von den Babenbergern konstatiert wird.

Selbst scheinbar nebensächliche Details wie dieses nehmen innerhalb von Lechners methodisch folgerichtigem Argumentationsgang einen festen Platz ein: „Daß die Babenberger in Pernegg Hoheitsrechte ausübten, dafür sprechen auch spätere Zwettler Quellen [...]. Die Hausnamen im Geschlechte der Pernegger Ulrich und Ekbert deuten unzweifelhaft auf die Formbacher [...]; ebenso die Besitzverhältnisse zwischen Traisen und Pielach; endlich aber, daß [...] auch Bischof Ulrich - beachte den Namen! - dem Kloster St. Georgen gerade wieder in Pernegg die Zehente angewiesen hat. Aber die Edlen von Pernegg nennen sich auch nach Deggendorf in Bayern und das ist ein Teil der alten Donaugrafschaft der Babenberger, ein Landgericht der Grafschaft Bogen und Lehe von den Babenbergern. [...] Die Namen Ulrich und Ekbert sind [...] im Hause der Grafen von Formbach heimisch. Doch ist der letztere Name selbst erst wieder von dem Geschlecht der Brunonen [...] an die Formbacher gediehen [...]. Wir halten ferner dazu, daß die Babenberger selbst mit den genannten sächsischen Geschlechtern verbunden waren [...]. So dürfen wir also bezüglich der Herren von Pernegg zusammenfassend wohl an Formbach'schen Beziehungen festhalten, andererseits aber Babenberg'sche Herkunft annehmen. “339

suchung aus 1937 zum Thema „Siedlungs- und Herrschaftsgeschichte“ aus: „Für eine genaue Herausarbeitung der einzelnen Herrschafts- und Hoheitsgebiete in ihrer Bedeutung für das ganze geschichtliche und kulturelle Leben der Siedler bin ich selbst in immer steigendem Maße eingetreten. “- Lechner, Landschaft (wie Anm. 185) 30 Anm. 1.

338 Lukas/Moldaschl, Heimatbuch (wie Anm. 335) 295-297.

339 Lechner 1937, 55f. Hervorhebungen nach Original. 
Dass wir uns gerade bei den Perneggern länger aufhielten, erklärt sich aus der Eignung von deren Beispiel für die Veranschaulichung der Lechner'schen Arbeitsweise ebenso wie seiner Rezeption durch jüngere Forscher. Auf den Problemkreis „Pernegg“ werden wir folglich im nächsten Abschnitt zurückkommen.

\section{II.3 Aspekte der Rezeption}

Im Vorigen wurden die Voraussetzungen für Lechners einschlägiges Schaffen aufgezeigt - ein Schaffen, welches die mediävistische Regionalforschung in Niederösterreich teilweise auf neue Grundlagen gestellt hat. Die logisch nächste Frage zielt auf zeitgenössische Rezeption und „Nachleben“ seiner Ergebnisse. Freilich kann hier nur eine Auswahl des Möglichen geboten werden - eine Auswahl jedoch, welche die Beurteilung des hier untersuchten Lechner-CEuvres erleichtern soll ${ }^{340}$. Einen frühen und handfesten Zeugen für die Rezeption der Lechner'schen Forschungen stellt ein 1937, knapp nach dem Erscheinen der großen Arbeit Lechner I937, erschienener Aufsatz seines Freundes Herbert MitschaMärheim dar ${ }^{341}$. Bereits die Wahl des Titels - „genealogisch-besitzgeschichtliche Untersuchung “ deklariert das Aufgreifen der Lechner'schen Prägung, und der Text selbst verrät das Anwenden von dessen Methode. Dass selbstverständlich auch die relevanten Arbeiten Lechners eifrig benutzt wurden, geht aus dem Anmerkungsapparat hervor.

Auch in der "großen“ Mediävistik wurde man auf Lechner aufmerksam. Mayer - einst wie Lechner im niederösterreichischen Archivwesen tätig ${ }^{342}$ - erwähnt Stepans „Waldviertel-Werk“ aus I 937 und speziell Lechners darin enthaltenen Aufsatz zwar nur in einer Fußnote, hebt ihn aber eigens hervor: „Das beste Beispiel für eine monographische Behandlung einer Landschaft ist das Buch: Das Waldviertel, Wien 1937, das kleinere Beiträge von O. Brunner, Hans Hirsch u.a. und besonders die ausgreifende Besiedlungs- und Herrschaftsgeschichte des Waldviertels von Karl Lechner enthält. "343

340 Die Vernachlässigung gleichfalls früher, doch weniger prominenter Rezeptionszeugen muss in Kauf genommen werden; an dieser Stelle sei - stellvertretend für andere - nur auf folgende Arbeit hingewiesen: Karl BEDNAR, Das Schenkungsgut der ersten Königsschenkung für den Markgrafen Siegfried vom 7. März 1045. (Zur Grundbesitzgeschichte des Neumarkgebietes im 11. Jahrhundert.), in: JbLKNÖ NF 22 (1929) 402-430, hier bes. 406 bzw. 410 .

341 Herbert von Miтsсна-Мӓвнегм, Eine genealogisch-besitzgeschichtliche Untersuchung zur Frühgeschichte Wiens, in: Monatsblatt des Vereines für Geschichte der Stadt Wien 4 (1934-38) 135-140.

342 Zu Mayer vgl. Helmut Maure R, Theodor Mayer (1883-1972). Sein Wirken vornehmlich während der Zeit des Nationalsozialismus, in: Österreichische Historiker (wie Anm. 8) 493-530.

343 Mayer, Ausbildung (wie Anm. 327) 285 Anm. 4. - Mayer äußerte Lechner gegenüber brieflich sogar: „Ein zweites Buch, wie das Waldviertel-Buch gibt es nicht mehr." (StA Konstanz, NL Theodor Mayer, Korr. Lechner, Theodor Mayer an Karl Lechner 1964 Sept. 12 [Kopie im NÖLA, St. Pölten]; für diesen Hinweis danke ich Stefan Eminger, St. Pölten, herzlich.) 
Ein wichtiger Zeuge für die zeitgenössische Rezeption ist Ernst Klebel. In der forschungsgeschichtlichen Einleitung eines Aufsatzes würdigt er Lechner neben anderen Autoren: „Es war für die Landesgeschichtsforschung in Niederösterreich nicht weniger ein Hindernis, daß gerade zwei sehr angesehene, aber auch streitbare Forscher, Heinrich

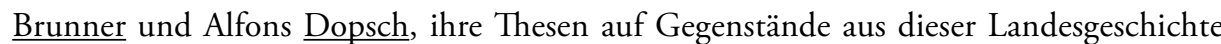
aufgebaut haben. Die Forschung im einzelnen, die Stück für Stück hätte zusammentragen können und sollen, hat es daher jahrelang vermieden, die von diesen beiden berührten

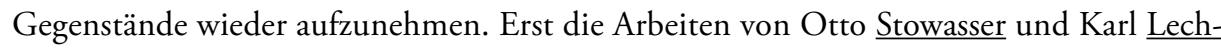
ner haben den Bann gebrochen, der so lange über der Landesgeschichte von Niederösterreich lag. "344

Was die Bewertung Lechner'scher Forschungsergebnisse in jüngerer Zeit betrifft, ist - neben dem genannten Mitscha-Märheim ${ }^{345}$ - etwa Michael Mitterauer zu nennen, der in seinen früheren Arbeiten immer wieder u.a. an Lechner anknüpft. In seinem defensorisch-replizierenden ${ }^{346}$ Aufsatz „Zweierlei Wissenschaft?“ bezeichnet er Lechners „besitzgeschichtlich-genealogische Methode“ „als eine der klassischen Methoden landeskundlicher Forschung“ und meint ferner: „Meine Mitautoren und ich haben aus dem räumlichen Nebeneinander von Reichskirchengut und Adelsherrschaft eines die betreffende Kirche bevogtenden Geschlechtes auf Herrschaftsbildung auf der Basis von Vogteirechten geschlossen, vor allem dann, wenn die Adelsherrschaft unmittelbar im Bereich einer Königsschenkung entstanden ist. Das ist methodisch nichts anderes als der Schluß aus Besitznachbarschaft zweier Adelsgeschlechter auf ursprüngliche Einheit des Besitzes in der Hand eines gemeinsamen Vorfahren, wie er in Lechners besitzgeschichtlich-genealogischer Methode erfolgt. Im einen Fall liegt die vielfach belegbare Besitzsplitterung durch Erbgang der historischen Rekonstruktion zugrunde, im anderen die gewiß ebenso abgesicherte Erkenntnis, daß im Hochmittelalter Adelige unter dem Titel der Vogtei Burgen errichteten und von ihnen aus Herrschaftsrechte ausübten." ${ }^{347}$

344 E[rnst] KLEBEL, Zur Rechts- und Verfassungsgeschichte des alten Niederösterreich, in: Jb. für Landeskunde von Niederdonau NF 28 (1939-43) 11-120, hier 11. Hervorhebung nach Original.

345 Man nehme nur einen seiner letzten Aufsätze zur Hand, etwa Herbert Мiтsсна-Мӓ внегм, Babenberger und Ebersberger und ihre Erben im und um das Poigreich, in: JbLKNÖ NF 42 (1976 = Babenbergerforschungen) 216-234, hier 216: „Karl Lechner [Hervorhebung im Original] hat sich seit über einem Halbjahrhundert wiederholt mit der Geschichte des niederösterreichischen Waldviertels beschäftigt und insbesondere über dessen Grenzgebiete gegen Böhmen: Poigen, Pernegg und Raabs, Bedeutendes und Grundsätzliches ausgesagt. Wir wollen nun versuchen, auf seinen Spuren weiterwandernd, einige neue Aspekte zu setzen [...].“

346 Dieser erschien im Rahmen eines gelehrten Schlagabtauschs zwischen Michael Mitterauer und Othmar Hageneder, der uns hier nicht näher zu beschäftigen braucht. Ausführlich referiert wird er bei Max WeLtin, Die Gedichte des sogenannten „Seifried Helbling“ als Quelle für die Ständebildung in Österreich, in: DERs., Land (wie Anm. 96) 287-295.

347 Michael Mitterauer, Zweierlei Wissenschaft? in: Unsere Heimat 46 (1975) 22. 
Wieder konnte Lechners Methode inspirierend wirken, eine Methode, die Helmuth Feigl in seinem Nachruf so scharfsinnig fast in eine Formel zu pressen versucht hat: „Wenn an einem Ort A und an einem Ort B im I I./ I 2. Jahrhundert Besitz eines Adelsgeschlechtes X und im I 3./I 4. Jahrhundert Besitz des Geschlechtes Y nachweisbar ist, dann kann für einen Ort C, wo im I 3./ I 4. Jahrhundert ebenfalls das Geschlecht Y ansässig ist, für den aus dem I I./I2. Jahrhundert aber keine Urkunden vorliegen, ebenfalls auf das Geschlecht X als Besitzvorgänger geschlossen werden." 348

Selbst nach diesen wenigen Zeugnissen kann man die von Lechner bzw. dessen Methode ausgehende Faszination erahnen. Nicht, dass sich keine Gegenstimmen erhoben hätten, doch ein kritisches Nachprüfen seiner Ergebnisse fand erst relativ spät statt. Speerspitze einer bereits zu Lechners Lebzeiten einsetzenden Kritik war und ist Maximilian Weltin. Dieser vermochte die von Lechner und anderen Autoren vorgetragene „Grafschaftstheorie“ zu erschüttern ${ }^{349}$ : Sie gilt es wenigstens insoweit zu streifen, als sie auch für die bereits erwähnten Herren von Pernegg - und damit auch Lechners zentrale Methode - von Bedeutung ist.

Einen I 995 erschienenen Aufsatz zum Thema „Grafschaft Pernegg-Drosendorf“350 eröffnet Weltin mit einem genauen Referat von Lechners einschlägigen Forschungsmeinungen seit dem erwähnten, im Horner Heimatbuch erschienenen Aufsatz aus I933 351 . Im

348 Feigl, Bedeutung (wie Anm. 5) 216.

349 So etwa Max Weltin, Die „tres comitatus“ Ottos von Freising und die Grafschaften der Mark Österreich, in: DERs., Land (wie Anm. 96) 60-81; ferner DERs., Zur Entstehung der niederösterreichischen Landgerichte, in: ebd. 24-59. - An dieser Stelle wäre auf die Bedeutung der Arbeiten des oben bereits erwähnten Otto Heinrich Stowasser (1887-1934) für Lechners Beschäftigung mit derartigen Fragen hinzuweisen. - Auf weitere, von der Forschung seither erledigte Details wie die Beurteilung von Königsschenkungen durch Lechner (und andere) kann hier nicht eingegangen werden; ich verweise daher auf Erwin Kupfer, Der ältere babenbergische Grundbesitz in Niederösterreich und die Bedeutung der Königsschenkungen für die Entstehung der landesfürstlichen Macht, in: Österreich im Mittelalter. Bausteine zu einer revidierten Gesamtdarstellung. Die Vorträge des 16. Symposions des Niederösterreichischen Instituts für Landeskunde, Puchberg am Schneeberg, 1. bis 4. Juli 1996, hg. v. Willibald Rosner (Studien und Forschungen aus dem Niederösterreichischen Institut für Landeskunde 26; NÖ Schriften 109, Wissenschaft, St. Pölten 1999) 17-65. - Bereits vor Kupfer wurde Kritik an Lechners diesbezüglichen Feststellungen durch Weltin geübt: We ltin, Helbling (wie Anm. 346) 287-322; ferner ist in diesem Zusammenhang hinzuweisen auf: Karl Brunner, Ius, quod veri ministeriales habent, in: MIÖG 100 (1992) 175-180, bzw. DERs., Welche Marken? in: JbLKNÖ NF 62 (1996= Festgabe des Vereins für Landeskunde von Niederösterreich zum Ostarrichi-Millennium), 1. Teil, 159-169, bes. 161. - Aus regionalgeschichtlicher Sicht erfolgte eine sympathisierende Lechner-Rezeption in puncto Königsschenkungen durch den mit Lechner befreundeten Pongratz (vgl. dessen Lechner-Nachruf oben Anm. 317): Walter Pongratz, Königsschenkungen in Niederösterreich unter besonderer Berücksichtigung des Waldviertels (Ein Beitrag zum Werden des Landes Österreich), in: Das Waldviertel 34 (1985) 1-19.

350 Max Weltin, Die Grafschaft Pernegg-Drosendorf, in: Ders., Land (wie Anm. 96) 487-508, bes. 487-489.

351 Lechner, Geschichte der Besiedlung (wie Anm. 335); dessen ältere, im Aufsatz Lechner 1924 vorgestellten Ergebnisse werden von Weltin in diesem Zusammenhang nicht berücksichtigt. 
zentralen Teil seiner Untersuchung geht Weltin sodann auf Lechners „Theorie von den nicht zur Mark gehörenden reichsunmittelbaren Grafschaften“352 ein, um sich sodann den Quellen im einzelnen zu widmen. Im Rahmen der Prüfung einzelner Belege und deren Überlieferung spannt Weltin einen Bogen zurück zu Bernhard Linck, ja Johannes Cuspinianus; auf Lechners eingangs ausführlich referierte Ansichten wird ansonsten jedoch nicht mehr eingegangen. Konsequenterweise, ist man zu sagen versucht, wendet sich Weltin zwar gegen einzelne Schlussfolgerungen Lechners, nicht jedoch gegen die „besitzgeschichtlich-genealogische Methode“ als solche - was er an anderer Stelle jedoch sehr wohl tut ${ }^{353}$. Doch egal, wie es um die Anfechtbarkeit der von Lechner angewendeten Methode steht: Als bedeutender Teil seines Lebenswerks ${ }^{354}$ scheint sie immer noch Strahlkraft auf kommende Forschergenerationen auszuüben.

\section{II.4 Zusammenfassung}

Anhand zweier ausgewählter Arbeiten Karl Lechners wurde der Versuch unternommen, Vorarbeiten für eine tiefer gehende Beschäftigung mit seinem Gesamtwerk zu leisten. Im Zuge einer systematischen Behandlung der Aspekte Publikationsorte, Publikationsformen, Themenwahl und Themenbehandlung konnten Eigentümlichkeiten von Lechners Arbeitsweise und - bei aller Knappheit - die ausgewählten Arbeiten charakterisiert werden. Für diese erscheint ihr landeskundlicher Horizont ebenso bezeichnend wie ihre Funktion im Rahmen eines systematisch erweiterten Curriculums, welches größtenteils um Besiedlungs- und Herrschaftsgeschichte auf urkundlicher Quellenbasis aufgebaut war. Weiters sind das allmähliche Entwickeln der Gedanken, die Klärung von Spezialfragen, ein folgerichtig induktives Vorgehen, interdisziplinäres Arbeiten und eine hoch entwickelte Belegkultur charakteristisch für die sich in den beiden ausgewählten Aufsätzen widerspiegelnde Arbeitsweise Lechners.

Ein Schwerpunkt unserer knappen Analyse lag auf der Herausarbeitung von Genese und Entwicklung der Lechner'schen Methodik. Diese wurde von älteren Forschungen zwar gleichsam provoziert, war jedoch damals etwas völlig Neues. Mit der Kombination aus sorgsamem methodischem Vorgehen und großer Quellenkenntnis avancierte Lech-

352 Weltin, Pernegg-Drosendorf (wie Anm. 350) 490.

353 Weltin, Probleme (wie Anm. 96) 436-486, bes. $451 \mathrm{f}$.

354 Wohlgemerkt: ein Teil, denn folgender Feststellung ist wohl nichts hinzuzufügen: DopscH, Landesgeschichte (wie Anm. 260) 61f.: „So sind die umfangreichen Arbeiten Karl Lechners über das Waldviertel Musterbeispiele für eine ebenso präzise wie umfassende Regionalforschung. In Form von Einzeluntersuchungen hat Lechner fast ganz Niederösterreich bearbeitet und über enorme Detailkenntnisse verfügt. Trotzdem waren seine Interpretationen der Landwerdung Niederösterreichs verfehlt und mußten im letzten Jahrzehnt durch einige bahnbrechende Untersuchungen von Max Weltin berichtigt werden.“ 
ner zum Begründer der mediävistischen Regionalforschung in Niederösterreich. Anhand der hier gewonnenen Einsichten können nun vor allem die Voraussetzungen, unter welchen sein systematisch ausgebautes Euvre entstand, bei klarerem Licht betrachtet werden, als dies anhand bisher vorliegender Nachrufe ${ }^{355}$ möglich war. Da eine erschöpfende Untersuchung aller relevanten Gesichtspunkte hier nicht zu leisten war, wurden auch Ansatzpunkte für eine künftige Lechner-Forschung geboten. Ferner galt es folgerichtig, zeitgenössische Rezeption und späteres „Nachleben“ Lechner'scher Forschungsergebnisse zu beleuchten. Dabei stellte sich heraus, dass zu Lechners Lebzeiten Regionalforschung ebenso wie "große“ Mediävistik von einschlägigen Ergebnissen wohlwollend Kenntnis nahmen, ja diese und die ihnen zugrunde liegende Methodik sogar bis in eine offen imitierende Titelwahl hinein aufgriffen. Die vor etwa dreißig Jahren, also kurz vor Lechners Tod, anhebende Erschütterung vieler Ansichten durch eine kongeniale - wenn auch zuweilen scharfe - Kritik vermochte allerdings nicht nur einzelne von diesem Autor vorgetragene Interpretationen bestimmter Problembereiche zu revidieren, sondern - wenngleich selten explizit - auch die „besitzgeschichtlich-genealogische Methode“ infrage zu stellen. 


\title{
Franz Huter (I899-1997)
}

\author{
„VERFÜGEN SIE ÜBER MICH, WANN IMMER SIE IM KAMPFE UM DIE \\ HEIMAT IM GEDR ÄNGE SIND“1
}

\section{EINLEITUNG}

Bis in die I990er-Jahre hinein galt der aus Bozen stammende Geschichtswissenschaftler und Archivar Franz Huter ${ }^{2}$ als einer der bedeutendsten Historiker nicht nur Tirols, sondern Gesamtösterreichs ${ }^{3}$, als „überragende[r] Wissenschaftler““4, ja - wie der Innsbrucker Geograf Adolf Leidlmair

1 Huter an den Generalvikar der Diözese Brixen, Alois Pompanin, 15.10.1946; zitiert nach: Gerhard OвеR коFler, Franz Huter 1899-1997. Soldat und Historiker Tirols (Innsbruck/ Wien 1999) 113f., hier 114.

2 Zu Huter siehe die quellenreiche, indes stark vom dogmatischen Marxismus-Leninismus determinierte Biografie des mit Huter persönlich bekannten Ове R коғLER, Huter (wie Anm. 1); dazu die Rezension von Othmar Hageneder in: Tiroler Heimat. Jb. für Geschichte und Volkskunde 64 (2000) 302-304. Siehe ferner Adolf Leidlmair, Landeskunde als Verpflichtung: Franz Huter zum 90. Geburtstag,

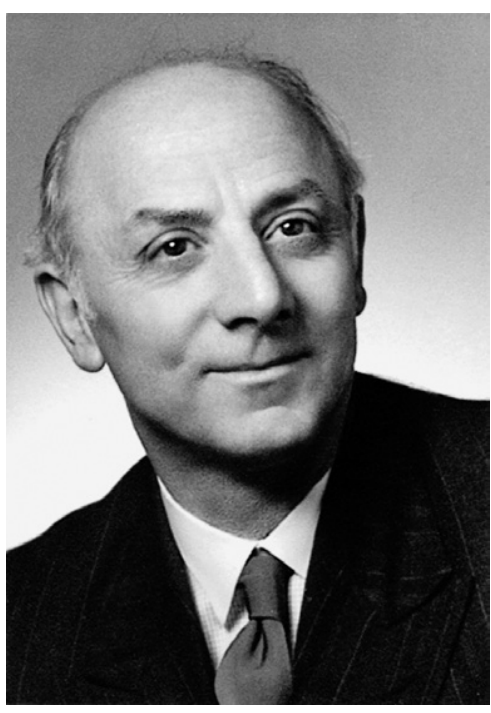

Abb. 37: Franz Huter in: Der Schlern 64 (1990) 5-16; Fritz Fellner, Doris

A. Corradini, Österreichische Geschichtswissenschaft im 20. Jahrhundert. Ein biographisch-bibliographisches Lexikon (VKGÖ 99 Wien 2006) 200; Gustav Pfeifer, Leo Santifaller und Franz Huter im Dienste der Archive: Ein Versuch - Leo Santifaller e Franz Huter al servizio degli archivi: spunti per una ricerca, in: Studi trentini di scienze storiche 86 (2007) 345-367, besonders 355-367; Zu Huters Wirken an der Universität Innsbruck siehe Gerhard Ове в коғ Lе R, Die geschichtlichen Fächer an der Philosophischen Fakultät der Universität Innsbruck 1850-1945 (Forschungen zur Innsbrucker Universitätsgeschichte 6, Innsbruck 1969) passim.

3 Siehe Franz Huter, Aufsätze zur Geschichte Tirols, hg. v. Josef Riedmann, Marjan Cescutti (Innsbruck 1997) Klappentext; Eduard Wallnöfer, Landeshauptmann von Tirol, an Huter, Innsbruck, 12.08.1969, zitiert nach Ове r коf ler, Huter (wie Anm. 1) $227 \mathrm{f}$.

4 Franz Hieronymus Riedl, Em. Univ.-Prof. Dr. Dr. h.c. Franz Huter - 90 Jahre, in: Südostdeutsches Archiv $32 / 33(1989 / 90)$ 250-252, hier 250. 
in einem Nachruf formulierte - als „für uns alle verbindliche[s] Vorbild“. Es war vor allem Huters „kompromisslose[s] Festhalten an seinen Grundsätzen“5, das vielen als Ideal, manchem zudem als spezifisches Erbe seiner Südtiroler Heimat erschien ${ }^{6}$. Auch sein akademischer Lehrer und Mentor, der zeitweise streng nationalsozialistisch orientierte Historiker Harold Steinacker, sah in Huter einen Depositär und Treuhänder kostbarer geistiger Überlieferung, zu der nach ihm niemand mehr vollen Kontakt habe ${ }^{7}$.

In diesen Wertschätzungen schwang indes bereits das Bewusstsein mit, dass eine gesellschaftliche Erosion von Huters Grundsätzen und Werthaltungen, dass ein Bruch mit den von ihm bewahrten weltanschaulich-intellektuellen Kontinuitäten gewissermaßen auch den Sturz seines Denkmals befördern müsse. In der Tat hatte in den letzten Jahren vor dem Tod Huters eine Debatte um die weithin ungebrochenen Traditionslinien, um volkstumswissenschaftlich verpflichtete Methoden und Paradigmen der Tiroler Geschichtswissenschaft angehoben und erstmalig NS-Involvierungen ihrer Vertreter thematisiert ${ }^{8}$. Dem Konformismus zweier Nachkriegsgenerationen Tiroler Historiker - und nicht zuletzt ihren oftmals persistenten ethnozentrischen Orientierungen - war es vor allem geschuldet, dass bis in die I980er-Jahre hinein Huters hoher Ruf, der sich ganz wesentlich auf seine "geschichtswissenschaftliche Verteidigung" Südtirols gründete, nicht infrage gestellt wurde.

5 Adolf Leidlmair, Franz Huter zum Gedenken, in: Innsbrucker Jahresbericht [der Innsbrucker Geographischen Gesellschaft] 14 (1997/98) 150-153, hier 150. - Leidlmair wirkte von 1949-1951 als Huters Assistent am Historischen Seminar der Universität Innsbruck und übernahm von diesem 1969 die Leitung des Instituts für geschichtliche Landeskunde.

6 Ernest Troger, Univ.-Prof. Dr. Franz Huter - 60 Jahre alt, in: Der Schlern 33 (1959) 179-181, hier 180. Troger war seit 1961 als Assistent Huters am Institut für geschichtliche Landeskunde tätig gewesen.

7 Steinacker an Huter, Bad Häring, 14.08.1964, zitiert nach Oве R коғ LeR, Huter (wie Anm. 1) 219-221, hier 219. Zu Steinacker siehe Renate SPR Eitzer, Harold Steinacker (1875-1965). Ein Leben für „Volk und Geschichte“, in: Österreichische Historiker 1900-1945. Lebensläufe und Karrieren in Österreich, Deutschland und der Tschechoslowakei, hg. v. Karel HruZa (Wien/Köln/Weimar 2008) 191-223.

8 Erinnert sei an den Disput zwischen Michael Gehler und Huter um dessen Rolle in den Jahren 1939-1945 sowie an die kritischen Anmerkungen von Brigitte Mazohl-Wallnig und Laurence Cole. Siehe dazu Michael Gehler, Der Hitler-Mythos in den „nationalen“ Eliten Tirols, dargestellt anhand ausgewählter Biographien am Beispiel der Südtirolfrage und Umsiedlung, in: Geschichte und Gegenwart 9,4 (1990) 279-315; Franz Huter, Feststellungen, in: ebd. 10,4 (1991) 319f.; Gehler, Zur Kulturkommission des SS-Ahnenerbes in Südtirol 1940-1943 und Geschichte des „Tolomei-Archivs“ 1943-1945: Entgegnungen zu Franz Huters „Feststellungen“, in: ebd. 11,3 (1992) 208-235; Huter, Neue Feststellungen, in: ebd. 11,3 (1992) 236-238; Brigitte Mazohl-Wallnig, Quousque tandem ...? Das Fach Österreichische Geschichte: eine Herausforderung der männlichen Tradition, in: Geschichte und Region/Storia e regione 4 (1995) 223-243; Laurence Cole, Fern von Europa? Zu den Eigentümlichkeiten Tiroler Geschichtsschreibung, in: ebd. 5 (1996) 191-225; dasselbe auch als DERs., „Fern von Europa?“ The Peculiarities of Tyrolian Historiography, in: Zeitgeschichte 23 (1996) 181-204. 


\section{WEG IN DIE WISSENSCHAFT}

Huters Vita - auch seine frühe Öffnung zum Nationalsozialismus (bereits weit vor I938) ${ }^{9}$ - vermag stellvertretend zu stehen für eine Vielzahl generationell weithin analog verlaufener Biografien von Vertretern des volkstumswissenschaftlichen Milieus der I920er- bis I 940er-Jahre. Huter gehörte einer Alterskohorte an, deren Lebensweg noch in die späten Jahre der Habsburgermonarchie zurückreichte. Sozialisiert im kleinbürgerlichen Milieu Bozens, wo er am I4. August I 899 geboren wurde, noch mit starken Bindungen an die bergbäuerliche Welt seiner Vorfahren am Schlern, erwiesen sich die Koordinaten eines konservativ-katholisch-patriarchalischen, autoritär-streng deutschnationalen Wertesystems für ihn als prägend und über jeden epochalen Wandel hinweg verpflichtend.

Biografisch ebenso wirkmächtig wurde ihm das Weltkriegserleben an der Italien-Front, wo er - nach Kriegsmatura am Franziskaner-Gymnasium in Bozen im Dezember I9I7 und anschließender Absolvierung der Prager Reserveoffiziersschule - zuletzt als Fähnrich des 2. Regiments der Tiroler Kaiserjäger am Monte Pasubio zur Verwendung kam. Geradezu als Trauma erlebte Huter, der mehrfach Kriegsausgezeichnete, dann den Zusammenbruch der Habsburgermonarchie, die Aufrichtung der Nachkriegsordnung und die Teilung des Landes Tirol, über welchem zum Zeitpunkt des italienischen Kriegseintrittes I9I 5 noch der Rauch der vorausgegangenen Nationalitätenkämpfe gehangen hatte. Wie für weite Teile der sich heranbildenden jüngeren Wissenschaftsgeneration, hatte auch für Huter außer Frage gestanden, dass es nun „erst recht zu streiten galt. Zwar nicht mehr auf dem Feld der Ehre, aber dafür auf allen Linien des politischen und kulturellen Lebens"10. Der Kampf gegen die italienische Annexion Südtirols bestimmte maßgeblich seine Stu-

9 Huter hatte von 1934-1938 der Vaterländischen Front angehört. Seinem am 28.06.1938 gestellten NSDAPMitgliedschaftsantrag bei der Ortsgruppe St. Veit an der Wien wurde aufgrund einer allgemeinen Aufnahmesperre und dem Hinweis auf eine notwendige Bewährungsfrist wegen nicht ausreichender Parteitätigkeit erst am 01.07.1940 stattgegeben; siehe BAB, PK (ehem. BDC), Gau Wien/Kreisgericht VI: Beschluss im Ablehnungsverfahren Huter, Wien, 29.11.1938. - Friedrich Wilhelm Antonius, Oberstaatsarchivar am Wiener HHStA, vermerkte im November 1942 in einer Beurteilung Huters, die im Zusammenhang mit dessen Ernennung zum Leiter der Alpenländischen Forschungsgemeinschaft (AFG) in Innsbruck Ende 1942 stehen dürfte: Huter war als Südtiroler, Grenzlanddeutscher, seit jeher streng national eingestellt und war auch, wie ich von ihm selbst weiß und zu beobachten Gelegenheit hatte, schon jahrelang vor dem Umbruch innerlich überzeugter Anhänger der nationalsozialist [ischen] Bewegung. Sofort nach dem Anschluss meldete er sich als Parteianwärter und stellte sich gleichzeitig seiner Ortsgruppe („St. Veit an der Wien“) als Mitarbeiter zur Verfügung. Er war dort bis zu seiner Einberufung zum Militär (1939) mit großem Erfolg tätig. [...] Er ist [...] ein überzeugter, hundertprozentiger Nationalsozialist. Zur Bekleidung eines führenden Postens ist er zweifellos hervorragend geeignet. Siehe StLA, Zeitgeschichtliche Sammlung, K. 213: Friedrich Wilhelm Antonius: [Beurteilung von Huter] Wien, 23.11.1942.

10 Franz Hute R, Laudatio auf Matthias Ladurner-Parthanes, in: Der Schlern 49 (1975) 246-248, hier 246. 
dienwahl, prägte Methoden und Inhalte seiner wissenschaftlichen Arbeit, wurde ihm zur Lebensaufgabe.

Im Februar I919 aus italienischer Kriegsgefangenschaft heimgekehrt, inskribierte $\mathrm{Hu}$ ter im Sommersemester desselben Jahres an der Innsbrucker Leopold-Franzens-Universität für Geschichte, deutsche Philologie und Geografie. Seine nachherige Tiroler Raum- und Volksgeschichte, die sich an der damals noch relativ jungen Volks- und Kulturboden-Theorie des Geografen Albrecht Penck ausrichtete, bezog wesentliche paradigmatisch-methodische Impulse von seinen akademischen Lehrern: Bei Hermann Wopfner, der es gleich I 9 I 8 als „vaterländische und nationale Pflicht“ bezeichnet hatte, „der Annexion DeutschSüdtirols durch Italien mit den Waffen der Wissenschaft entgegenzutreten" ${ }^{11}$, begegnete er dem als innovativ geltenden Ansatz interdisziplinärer landesgeschichtlich-ethnohistorischer Forschung, bei Harold Steinacker einer gesamtdeutschen Geschichtsauffassung. Unter dem Eindruck des Geografen Norbert Krebs und dessen Raumideologie formte sich während eines zweisemestrigen Aufenthaltes I920/2 I an der Universität Freiburg im Breisgau wesentlich Huters Konzeption politischer Raumbildung; der Mediävist Alfons Dopsch, bei dem er im Wintersemester I92I/22 am IÖG in Wien hörte, beeinflusste maßgeblich seine wirtschaftshistorischen und geopolitischen Vorstellungen ${ }^{12}$. Dieses waren Prägungen, die auf Huter nachhaltig und in bruchlosem Strang über das Jahr I945 hinaus wirkten. Hinzu kamen die Erfahrungen einer Vergesellschaftung in Vereinigungen wie dem katholischen und zunehmend deutschvölkischen Akademisch-alpinen Verein Innsbruck, in dem er in engeren Kontakt zu Wopfner treten konnte, oder dem dortigen Akademischen Historikerklub, wo er unter anderem freundschaftliche Beziehungen zu dem nachherigen Innsbrucker Geografen Hans Kinzl, dem Begründer der Innsbrucker Schule der (historischen) Bevölkerungsgeografie der I940er-Jahre, anknüpfte.

Nach der Promotion im Dezember 1923 bei Wopfner in Innsbruck nahm Huter I 924/25 am 34. Ausbildungskurs des IÖG in Wien teil ${ }^{13}$, da ihm die politische Lage in Südtirol den angestrebten Schul- ebenso wie später den Archivdienst verwehrte. Gemeinsam mit Huter absolvierten unter anderem Alphons Lhotsky, mit dem er freundschaftlich verbunden blieb, Ernst Karl Winter, Franz Carl Heimito von Doderer, Karl Helleiner sowie Hugo Hantsch, dem er bereits in Innsbruck begegnet war, den Lehrgang des Wiener Instituts ${ }^{14}$. Nicht zuletzt die spätere Haltung zum Nationalsozialismus hat diese Lebens-

11 Hermann Wopfner, Die Einheit Deutschtirols, in: Denkschrift des akademischen Senats der Universität Innsbruck (Innsbruck 1918) 1-38, hier 4.

12 Huter hörte in Innsbruck ferner u.a. bei Richard Heuberger, Josef Schatz und Johann Sölch, in Wien bei Emil von Ottenthal und Oswald Redlich, mit denen er in späteren Jahren persönliche Kontakte unterhielt, sowie bei Heinrich von Srbik.

13 Siehe IÖG, Archiv, Akten 34. Ausbildungskurs 1923-1925.

14 Siehe Leo Santifaller, Das Institut für österreichische Geschichtsforschung. Festgabe zur Feier des zwei- 
wege teilweise weit und geradezu diametral auseinandergeführt. Huter konnte indes in Wien Netzwerke mit Kurskollegen und Institutsmitgliedern knüpfen, die sich auch bei seinen wissenschaftlichen Rehabilitierungsbemühungen nach dem Zweiten Weltkrieg von Nutzen erweisen sollten.

Im Anschluss an die Ausbildung am Wiener IÖG wandte sich Huter zunächst dem Archivdienst zu. Er volontierte vom Oktober I925 bis März I928 im Archiv der Tiroler Landesregierung in Innsbruck und trat anschließend durch Vermittlung Steinackers und nach Erhalt der österreichischen Staatsbürgerschaft in den Dienst des seinerzeit von Ludwig Bittner geleite-

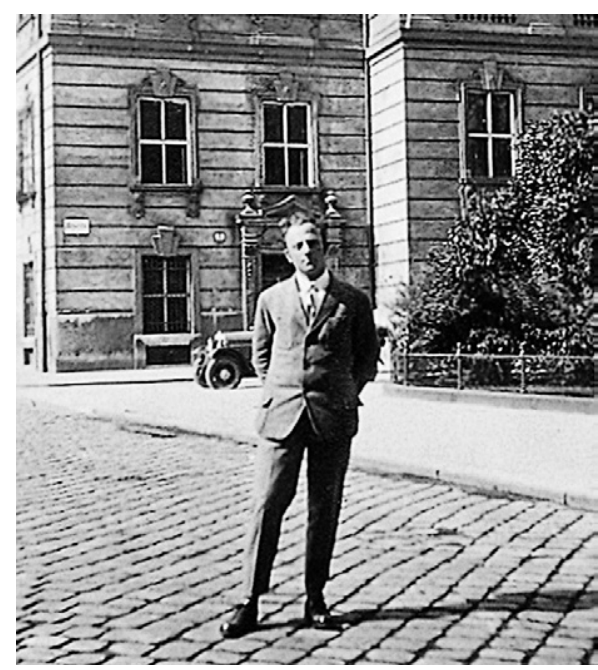

Abb. 38: Franz Huter im Sommer 1928 vor dem Gebäude des HHStA am Wiener Minoritenplatz. ten Wiener HHStA ein. Hier war Huter bis 1934 zunächst als Beamtenanwärter, seither als Staatsarchivar I. Klasse (ab I. Oktober I938 mit der Amtsbezeichnung „Archivrat“) tätig ${ }^{15}$.

Wie schon während seiner akademischen und archivalischen Ausbildung, so blieb in Huters Wiener Jahren sein wissenschaftliches Interesse fast ausschließlich auf Fragen der mittelalterlichen und frühneuzeitlichen Tiroler Landesgeschichte konzentriert, nun mit einem intensiveren Blick auf das Urkundenwesen in Südtirol und jenes der Bischöfe von Trient (Trento). Daneben entstanden 1936 aber auch seine akribisch recherchierten Lebensbilder der Beamten des HHStA ${ }^{16}$. In den Oktober desselben Jahres fiel Huters Eheschließung mit der Südtiroler Lehrerin Marianne Pancheri; aus der Ehe ging eine Tochter, Barbara, hervor.

Ende 1937 habilitierte sich Huter bei dem Wiener Mediävisten Otto Brunner, so dass er im Folgejahr neben dem Archivdienst eine Privatdozentur für Mittlere Geschichte und Hilfswissenschaften an der Universität Wien übernehmen konnte. Nachdem Huter schließlich auf Betreiben Wopfners und Steinackers am I. Oktober I94I auf das Inns-

hundertjährigen Bestandes des Wiener Haus-, Hof- und Staatsarchivs (Veröff. des IÖG 11, Wien 1950) 142f.; Alphons Lнотsку, Geschichte des Instituts für österreichische Geschichtsforschung 1854-1954 (MIÖG Erg.-Bd. 17, Graz/Köln 1954) 370-372; Ове к коғLеR, Huter (wie Anm. 2) $38 f$.

15 Siehe HHStA, Sonderbestand Kurrentakten, Sonderreihe Personalien, 2-1-26 (Franz Huter).

16 Franz Hut er, Biographien der Archivbeamten seit 1749, in: Gesamtinventar des Wiener Haus-, Hof- und Staatsarchivs 1, hg. v. Ludwig Bitt Ner (Inventare österreichischer staatlicher Archive V/4, Wien 1936) $1-166$. 
brucker Extraordinariat für Geschichte des Alpenraumes und Allgemeine Wirtschaftsgeschichte berufen worden war und damit die Nachfolge Wopfners antrat, schied er zum I. Februar 1942 aus dem Wiener Archivdienst aus.

\section{III. „IN VERTEIDIGUNG UND ZUM FROMMEN DER GROSSEN DEUTSCHEN SACHE“17: IM KAMPF UM SÜDTIROL}

Mit Euphorie hatten die volkstumswissenschaftlichen Milieus nicht nur in Österreich den „Anschluss“ des Landes an das Deutsche Reich aufgenommen. Huter bejubelte ihn am I 5. März I938 auf dem Wiener Heldenplatz, nachdem er schon zuvor für sich eine Teilnahme an der von Bundeskanzler Kurt Schuschnigg für den 9. März geplanten Volksabstimmung über die Unabhängigkeit Österreichs ausgeschlossen hatte ${ }^{18}$. In diese Stimmung und in die grundsätzliche Identifizierung mit dem Nationalsozialismus und dessen Expansionsstreben mischten sich indes Irritationen über die offizielle Haltung des NSRegimes in der Südtirol-Frage: Hitlers feierliche Anerkennung der Brenner-Grenze im März I 938 hatte im Juni des Folgejahres zur deutsch-italienischen Vereinbarung über eine radikale und irreversible Lösung des Südtirol-Problems durch Aussiedlung der deutschund ladinischsprachigen Bevölkerung geführt.

Das durch den „Anschluss“ nochmals gestiegene „Führer“-Prestige verhinderte bei Huter indes eine grundsätzliche Distanzierung vom Regime des Nationalsozialismus und führte zu einer Akzeptanz des „Südtirol-Verzichts“, der gewissermaßen als Opfer zu tragen war, in seiner Ernsthaftigkeit und Endgültigkeit zunächst gleichwohl unterschätzt wurde. Wenn der gebürtige Südtiroler Franz Huter schließlich seit April I 940 im Zuge der Umsiedlungsmaßnahmen als Mitarbeiter einer Sonderkommission des Ahnenerbes der SS gewissermaßen an der Abwicklung des Südtiroler Kulturerbes beteiligt war (und hierfür von dem zwischen August 1939 und Juni 1940 in der Etappe - bei Flak-Einheiten zunächst in der slowakischen Zips, dann in Passau - geleisteten Kriegsdienst freigestellt wurde), so mochte er in dieser Aufgabe nicht nur Karriereperspektiven durch exklusiven Zugang zu umfangreichen Quellenmaterialien, sondern zunächst und insbesondere Züge einer tragischen nationalen und auch individuellen Erniedrigung durch das perhorreszierte Italien erblicken. Seine Mitarbeit in der Kulturkommission, die von der Forschungs- und Lehrgemeinschaft Deutsches Ahnenerbe e.V. der SS ${ }^{19}$ eingesetzt und als Dienststelle der

17 BAB, NS 21/93: Huter an den Leiter des SS-Ahnenerbes, Wolfram Sievers, Innsbruck, 30.12.1943.

18 Siehe StLA, Zeitgeschichtliche Sammlung, K. 213: Friedrich Wilhelm Antonius: [Notiz - Beurteilung von Huter] undatiert [ca. 1938]; Ове R коfle R, Huter (wie Anm. 1) 56.

19 Siehe hierzu Michael Wedekind, Kulturkommission des SS-Ahnenerbes in Südtirol, in: Handbuch der 
zentralen Bozner Umsiedlungsbehörde des Reichskommissars für die Festigung deutschen Volkstums, Heinrich Himmler, geführt wurde, war einem Vorstoß des zunächst deutschnationalen, später streng nationalsozialistischen Wiener Archivdirektors Ludwig Bittner beim Reichsminister des Inneren geschuldet ${ }^{20}$. Seit Juli I 940 leitete Huter demnach in der Kulturkommission die Arbeitsgruppe Archive, welche mit Erfassung, Aufnahme, Sicherstellung und Abtransport archivalischer Bestände aus Südtirol beauftragt war.

Huter durfte seinerzeit als einer der besten Kenner der dortigen Archivlandschaft gelten. Dazu hatten zum einen seine Dissertation über „Die Grundherrschaften des Tales Schnals im Untervintschgau“ sowie seine durch Hans von Voltelini angeregte Untersuchung „Über die Quellen des Messgerichtsprivilegs für die Bozner Märkte von I635“ beigetragen, die als Abschlussarbeit bei Dopsch am IÖG 1927 in Druck ging ${ }^{21}$; zum anderen hatte Huter - teilweise im Auftrage des Münchner Instituts für die Erforschung des deutschen Volkstums im Süden und Südosten, dem späteren Südost-Institut ${ }^{22}$ - Ende der I920er- und Anfang der I930er-Jahre verschiedene, bisweilen konspirative Erhebungen in Archiven entlang der Südtiroler Sprachgrenze durchgeführt. Als wissenschaftlicher Mitarbeiter der Historischen Landeskommission für Tirol war er zudem seit 1926 mit der Erstellung des „Tiroler Urkundenbuches“ befasst, mit dessen erstem, dem Vintschgau und dem Südtiroler Etschland gewidmeten Band er sich 1938 habilitiert hatte ${ }^{23}$. Die weit jenseits landesgeschichtlichen Interesses liegende volkstums- und revisionspolitische Relevanz des Werkes, das sich in zeitgenössische raumideologische Konzepte einordnete, hatte dem Vorhaben die finanzielle Unterstützung mehrerer volkswissenschaftlich ausgerichteter Institutionen gesichert ${ }^{24}$.

völkischen Wissenschaften. Personen, Institutionen, Forschungsprogramme, Stiftungen, hg. v. Ingo HaAR, Michael Faнlbusch (München 2008) 356-367; Michael H. Kater, Das „Ahnenerbe“ der SS 1935-1945. Ein Beitrag zur Kulturpolitik des Dritten Reiches (Studien zur Zeitgeschichte 6, München $\left.{ }^{4} 2006\right)$ 159-170.

$20 \mathrm{Zu}$ Bittner siehe Thomas Just, Ludwig Bittner (1877-1945). Ein politischer Archivar, in: Österreichische Historiker 1900-1945 (wie Anm. 7) 283-305.

21 Sie erschien als Franz Huter, Die Quellen des Messgerichts-Privilegs der Erzherzogin Claudia für die Bozner Märkte (1635), in: Bozner Jb. für Geschichte, Kultur und Kunst (= BzJb) 1/2 (1927/28) 5-131.

22 Zum Südost-Institut, das bis 1938 einen wesentlichen Schwerpunkt seiner Tätigkeit auf die Bearbeitung Südtirols legte, siehe Gerhard Se Ewan n, Das Südost-Institut 1930-1960, in: Südostforschung im Schatten des Dritten Reiches. Institutionen - Inhalte - Personen, hg. v. Mathias BeER, Gerhard SeEwann (Südosteuropäische Arbeiten 119, München 2004) 49-92; Südost-Institut München 1930-1990. Mathias Bernath zum siebzigsten Geburtstag, red. v. Karl NeHR ing (München 1990).

23 Tiroler Urkundenbuch. Abteilung I: Die Urkunden zur Geschichte des deutschen Etschlandes und des Vintschgaues 1: Bis zum Jahre 1200, hg. v. Franz Huter (Innsbruck 1937).

24 An der Finanzierung waren die Stiftung für deutsche Volks- und Kulturbodenforschung (Leipzig), das Institut zur Erforschung des deutschen Volkstums im Süden und Südosten (München), die AFG (Innsbruck), die Deutsche Akademie (München) sowie die ÖAW (Wien) beteiligt. 
Etwa zwei Jahrzehnte nach der Annexion durch Italien und fünfzig Jahre nach Emil von Ottenthals und Oswald Redlichs „Archiv-Berichten aus Tirol“ ${ }^{25}$ bemühte sich die von Huter geleitete Arbeitsgruppe der Bozner Kulturkommission durch Anfertigung eines umspannenden Katasters um eine aktuelle Bestandserfassung der Südtiroler Archive ${ }^{26}$. Hiermit sollte vor allem den deutschen Archivgutforderungen gegenüber Italien eine präzise Grundlage verschafft werden. In der Tat hatte Archivdirektor Bittner seinerzeit auf eine Erweiterung der in den deutsch-italienischen Verhandlungen festgelegten Grundlagen für die Überlassung Südtiroler Archivbestände gedrängt und empfohlen, Huter zu den beabsichtigten Nachverhandlungen mit der italienischen Regierung hinzuzuziehen. Obschon die Hauptvertreter der deutschen Umsiedlungsbürokratie vorerst keinen Verhandlungsspielraum bei den italienischen Dienststellen sahen, beabsichtigte Huter angesichts der Einmaligkeit des Umsiedlungsvorganges, die Archivalienauslieferung nun auf gänzlich andere, stark ideologisierte Grundlagen zu stellen: Seiner Ansicht nach war weder das Provenienz- noch das Pertinenzprinzip, sondern ein totaler völkischer Kulturgutanspruch auf ganz Südtirol geltend zu machen und damit die Überlassung des gesamten deutschen Volksgutes zu fordern ${ }^{27}$. Indes fuhren sich die am 3 I. Juli I 940 aufgenommenen Verhandlungen mit der italienischen Seite binnen Kurzem in Auslegungsfragen fest und blieben auch bis zum Ende der Umsiedlungsaktion im Kern ergebnislos.

Huters Arbeitsgruppe ging infolgedessen im Wesentlichen zu einer groß angelegten Reproduktion Südtiroler Archivalien über. Abgesehen von einer Vielzahl von Regesten

25 Emil von Ottenthal, Oswald Redlich, Archiv-Berichte aus Tirol 1-4 (Mittheilungen der dritten [Archiv-]Section der k. k. Central-Commission zur Erforschung und Erhaltung der Kunst- und historischen Denkmale, Wien/Leipzig 1888-1912).

26 In einer Denkschrift Norbert Mumelters, Leiter des Kulturdienstes der Südtiroler Arbeitsgemeinschaft der Optanten, war von Erhebungsarbeiten im Staatsarchiv Bozen, im Bischöflichen Archiv Brixen sowie in 111 Stadt- und Gemeindearchiven, 263 Kirchen- und Klosterarchiven sowie 28 Privatarchiven ausgegangen worden; siehe Karl St uhlpfar re R, Umsiedlung Südtirol 1939-1940 1 (Wien/München 1985) 400.

27 Siehe BAB, DS (ehem. BDC) : Huter, 14.08.1899: [Franz Huter:] Grundsätzliche Bemerkungen zur Frage der Sicherung des Archivguts aus Südtirol, undatiert [etwa Mitte 1940] : Für die Herkunft [der Schriftdenkmäler] ist der heutige Aufbewahrungsort ganz gleichgültig [...]. Darüber hinaus gehören unsere Archivschätze dem ganzen deutschen Volke. Denn die Nation hat ein eminentes Interesse daran, dass ihre Kulturleistung in diesem Lande festgehalten und dargestellt wird. [...] Unser Anspruch auf diese Archivalien ist [...] ideell so fest begründet, dass grundsätzlich von ihm keine Abstriche gemacht werden dürfen. - Zu zwischenstaatlichen archivalischen Restituierungsansprüchen und deren Behandlung siehe allgemein Thomas Fitschen, Das rechtliche Schicksal von staatlichen Akten und Archiven bei einem Wechsel der Herrschaft über Staatsgebiet (Baden-Baden 2004); zum Archivwesen während der Zeit des Nationalsozialismus, zu Archivverwaltung und Archiveinsätzen in deutschen Besatzungsgebieten während des Zweiten Weltkrieges Karl Heinz Rотн, Klios rabiate Hilfstruppen. Archivare und Archivpolitik im deutschen Faschismus, in: Archivmitteilungen 41 (1991) 1-10; Torsten Musial, Staatsarchive im Dritten Reich. Zur Geschichte des staatlichen Archivwesens in Deutschland 1933-1945 (Potsdam 1996); Das deutsche Archivwesen und der Nationalsozialismus, hg. v. Robert Kretzschmar (Essen 2007). 
und etwa I 5.000 Quellenexzerpten fertigte sie über 50.00o Leica-Aufnahmen und über 588.00o Aufnahmen mit den Reproduktionsapparaten des Reichssippenamtes an ${ }^{28}$. Begleitet von Verfahrensdisputen, Behinderungsstrategien der italienischen und Eigenmächtigkeiten der deutschen Seite, persönlichen Zerwürfnissen und Anschuldigungen versuchte die Kulturkommission zugleich - teilweise in Zusammenspiel mit Vertrauensleuten der nationalsozialistischen Südtiroler Arbeitsgemeinschaft der Optanten (AdO) -, sich durch Erschleichung, Diebstahl und Pressionen auf private Eigentümer, durch konspirativen Ankauf sowie durch Unterschlagung umfangreicher nicht-privater Bestände in den Besitz von Archivalien zu bringen. Orientiert an dem Grundsatz, dass alle bedeutenden und für die Wissenschaft wichtigen Archivalien, genealogischen Sammlungen und sonstigen wichtigen Urkunden [...] in deutschen Besitz gelangen ${ }^{29}$ müssen, hat Huter an dieser „höheren Form des Plünderns"30 unmittelbar mitgewirkt. Allein bis August 194I fertigten er und der Reichsgeschäftsführer des Ahnenerbes, Wolfram Sievers, 43 umfangreiche Archivaliensendungen an das Innsbrucker Reichsgauarchiv $a^{31}$. Weitere Sendungen Südtiroler Archivgüter gingen direkt an das Ahnenerbe nach Berlin.

Jenseits jedoch von Archivzensus, Überführung oder Reproduktion archivalischer Bestände verfolgten Huter und das Ahnenerbe klandestin-konspirativ eine politisch-revanchistisch orientierte Forschungsstrategie. Trotz verschiedener Verbote des NS-Regimes, das Thema „Südtirol“ publizistisch aufzugreifen, und ungeachtet des 1939 eingeleiteten ethnischen Umbaues der Provinz wurde hier an dem Axiom einer wissenschaftlichen Wider-

28 BAB, R 153/1556: Huter: Bericht des Leiters der AFG, Bozen/Innsbruck, 25.03.1944.

29 BAB, NS 21/84: Reichsführer-SS/Reichskommissar für die Festigung deutschen Volkstums (gez. SS-Obersturmführer Dr. Walter) an Sievers, Berlin, 20.03.1941.

30 Karl Heinz Rотн, Eine höhere Form des Plünderns. Der Abschlußbericht der „Gruppe Archivwesen“ der deutschen Militärverwaltung in Frankreich 1940-1944, in: 1999. Zs. für Sozialgeschichte des 20. und 21. Jahrhunderts 4,2 (1989) 79-112. - Bereits in seinem ersten Südtiroler Arbeitsbericht notierte Huter: Der Sachbearbeiter hat daher bei den Archivbesichtigungen auf dieses [Privat-]Archivgut, das für die landesgeschichtliche Forschung besonders wichtig ist, sein Augenmerk gerichtet und eine Reihe einschlägiger Stücke sichergestellt. Wo die Archivberichte solche Stücke ausweisen, kann bei einem allfälligen Anspruch der Gegenseite darauf hingewiesen werden, dass während des Weltkrieges manche Privatarchivbesitzer das wertvolle Material nach Österreich gebracht haben. Außerdem kann insbes[ondere] bei Sammlungen auf den Besitzwechsel und die im Zusammenhang damit zu gewärtigenden Abgänge verwiesen werden. BAB (wie Anm. 27) : Arbeitsbericht des Sachbearbeiters für Archivwesen für die Monate Juli und August 1940, Bozen, September 1940.

31 BAB, NS 21/84: Archivdirektor Otto Stolz an Huter, Innsbruck, 18.08.1941. Dieser Vorgang und etwaige Restitutionsforderungen wurden bis in die jüngste Zeit öffentlich nicht thematisiert. Huters Raub von Südtiroler Archivalien und deren Übernahme durch das damalige Reichsgauarchiv Innsbruck finden auch keine Erwähnung bei Wilfried Bегмлонг, Das Reichsgauarchiv Innsbruck, in: Österreichs Archive unter dem Hakenkreuz (MÖSTA 54, 2010) 457-472. Siehe hingegen: Angela MurA, Franz Huter und die Tätigkeit der „Arbeitsgruppe Archive“ der Kulturkommission Südtirol des „SS-Ahnenerbes“, in: Kunsthistoriker im Krieg, hg. v. Christian Fuhrmeister et al. (Wien/Köln/Weimar 2012) 173-186. 
legung des italienischen Herrschaftsanspruches und eines Nachweises der historisch-kulturellen Einheit von Nord- und Südtirol festgehalten. Dabei war die Kulturkommission bestimmt, der deutschen Volkstumswissenschaft entsprechendes Datenmaterial und somit die historiografische Deutungshoheit, dem Ahnenerbe selber schließlich in dieser Weise eine zentrale Stellung in der scientific community des Dritten Reiches zu sichern. Hatte nämlich schon die Annexion Südtirols durch Italien den raumbezogenen Forschungen nach I9I9 einen spezifischen Auftrieb verliehen, so war von der Inventarisierung und Dokumentation Südtiroler Kulturgüter durch das Ahnenerbe - einem in seiner Art einmaligen volkstumswissenschaftlichen Großprojekt - langfristig ein noch wesentlich stärkerer Impuls zu erwarten.

Huters archivalische Erhebungstätigkeit war weithin von deterministischen Erkenntnisinteressen und weltanschaulich bestimmten, selektiven Kriterien geleitet; sie spiegelte damit die methodische Grundproblematik der gesamten Ahnenerbe-Enquête wider: Huter ging es vor allem um bevölkerungsgeschichtlich auswertbare Quellengattungen. Für einen frühen Zeitraum, ab etwa I 400, lagen diese vor allem in Form von Urbaren, Kirchpropstrechnungen, Lehen- und Ehrungsbüchern Südtiroler Stifte und Klöster vor. Für jüngere Epochen richtete sich das Interesse neben den sogenannten Verfachbüchern insbesondere auf Kirchenbücher, die als Grundlage für umfangreiche genealogische und medizinisch-genetische Untersuchungen bis etwa I60o dienen sollten ${ }^{32}$. Mit den städtischen Ratsprotokollen, Stadtrechnungen, Kopial-, Bürger- und Einwohnerbüchern kam eine weitere bevölkerungs-, speziell genealogiegeschichtlich relevante Quellengruppe hinzu, die im Falle Bozens bereits seit den I 920er-Jahren als „Hauptbeweisstück“ sowohl für den ethnisch deutschen Charakter der Stadt als auch für die Herausbildung eines präsumtiven deutschen Volksbewusstseins herangezogen worden $\operatorname{war}^{33}$.

32 Die bis 1945 fortlaufenden Südtiroler Kirchenbuchaufnahmen wurden zunächst einer eigenen Arbeitsgruppe der Kulturkommission unter dem aus Bozen stammenden Franz Sylvester Weber, Leiter des Tiroler Gausippenamtes, übertragen, später indes der Aufsicht Huters unterstellt.

33 Franz Huter, Beiträge zur Bevölkerungsgeschichte Bozens im 16. bis 18. Jahrhundert (BzJb 1948, Bozen 1948) 1. Das Werk lag zumindest in seinem ersten Teil („Die Herkunft der Bevölkerung Bozens in den neueren Jahrhunderten“) bereits 1944 druckfertig vor; dazu gehörte auch die von dem vormaligen Wiener Universitätsassistenten für Geografie Ernst Sturmmair gezeichnete Karte der Herkunftsgebiete zugezogener Bürger. - Siehe ferner Bozner Bürgerbuch 1551-1806 I: Die Bürger- und Inwohneraufnahmen der Handschrift des Bürgerbuches, hg. v. Rudolf Marsoner (BzJb 1929/30, Bozen 1930); Bozner Bürgerbuch 1551-1806 II: Ergänzungen der Bürger- und Inwohneraufnahmen aus den Ratschlag-, Rait- und Kopialbüchern der Jahre 1489-1810, bearb. v. Karl Theodor Hoeniger, Josef Bla As (BzJb 1931/34, Bozen 1933). - Ein Neudruck des „Bozner Urkundenbuches“, versehen mit einem Nachwort Huters, war auf Vorschlag des vormaligen Bozner Museumsdirektors Karl Maria Mayr bereits 1941 durch den NS-Gauverlag Tirol-Vorarlberg in Aussicht genommen; siehe u.a. Stadtarchiv Bozen, Bestand „Arbeitsgemeinschaft der Optanten“ (= SAB, AdO) : Mayr an Sievers, Bozen, 09.10.1942. Ein Neudruck des Werkes erfolgte indes erst 1956 durch den Landesverband für Heimatpflege in Südtirol (Schlern-Schriften 153 und 154). - Siehe ferner M. VöLSE R [i.e. Franz Huter], Zeugnisse deutschen Volksbewusstseins aus dem Bozen des 16. Jahrhunderts, in: Tiroler Heimat. Jb. für Geschichte 
Aufarbeitung und Verwertung dieses als volkstumspolitisch besonders relevant geltenden Materials ${ }^{34}$ erfolgten teilweise noch während der letzten Kriegsjahre, blieben bei grundsätzlich unveränderten Forschungsstrategien und interpretativen Mustern im Wesentlichen aber der Nachkriegszeit vorbehalten. Huter knüpfte an kanonisierte Paradigmen und Thesen der Volkstumswissenschaften $\mathrm{an}^{35}$, die bereits hauptsächlich von Wopfner und Otto Stolz für die Tiroler Historiografie adaptiert worden waren ${ }^{36}$. Im Sinne einer Affirmation der Zugehörigkeit Südtirols zum „deutschen Volks- und Kulturboden“ sollten weiterhin speziell bevölkerungs-, siedlungs- und namengeschichtliche (in Sonderheit mikrotoponomastische) Studien den Nachweis von Ursprünglichkeit und Kontinuität biologischer Grundlagen erbringen, deutsche „Siedlungsleistungen“ sowie Alter und Fortbestand „deutschen Bodenbesitzes“ dokumentieren. „Die Leistung des deutschen Volkes im Alpenraum, sein Anteil an der Urbarmachung früher romanischen und im Osten auch slawischen Volksbodens ist so gewaltig“, so hatte Huter 1939 programmatisch formuliert, „dass die deutsche Forschung an der Erkenntnis dieser Leistung bis ins einzelne das größte Interesse haben muss. Sie tritt an Weite des gewonnenen Gebietes gegenüber den Leistungen im deutschen Nordosten gewiss zurück, dafür ist mit besonderem Nachdruck auf ihren inneren Gehalt hinzuweisen. "37 Wie auch später bei der I94I erfolgten Gründung des mit Huters Innsbrucker Lehrkanzel verbundenen Instituts für Geschichte und Landeskunde des Alpenraumes, wurde hier zwar ein gesamtalpenländischer Analyserahmen angezeigt, doch richtete sich das Hauptinteresse stets nahezu exklusiv auf die revisionspolitisch verpflichtete Beschäftigung mit dem Tiroler (und speziell Südtiroler) Raum ${ }^{38}$.

und Volkskunde 3 (1930) 81-88. - Der Heimatkundler Karl Theodor Hoeniger arbeitete mit Unterbrechungen bereits seit Anfang der 1920er-Jahre an dem erst 1951 veröffentlichten „Häuserverzeichnis der Bozner Altstadt von 1497“ (Schlern-Schriften 92), das ebenfalls den „deutschen Charakter“ Bozens nachweisen sollte. 34 Siehe BAB, NS 21/93: Sievers an Gauleiter Hofer u.a., undatiert [etwa Mai 1943].

35 Hierzu grundsätzlich Willi Овев к воме, Volksgeschichte. Methodische Innovation und völkische Ideologisierung in der deutschen Geschichtswissenschaft 1918-1945 (Kritische Studien zur Geschichtswissenschaft 101, Göttingen 1993); DERs., Aspekte der deutschsprachigen „Volksgeschichte“, in: Zwischen Konfrontation und Kompromiss: Oldenburger Symposium „Interethnische Beziehungen in Ostmitteleuropa als historiographisches Problem der 1930er/1940er-Jahre“, hg. v. Michael Garleff (München 1995) 37-46.

36 Siehe dazu u.a. Cole, Eigentümlichkeiten (wie Anm. 8) 198-204; Michael Wede kind, „Völkische Grenzlandwissenschaft" in Tirol: Vom wissenschaftlichen Abwehrkampf zur Flankierung der NS-Expansionspolitik, in: Geschichte und Region/Storia e regione 5 (1996) 227-265. Zu Wopfner in diesem Zusammenhang auch Reinhard Johle r, Il concetto scientifico di „deutsche Arbeit“ e l'ergologia nell'area alpina, in: Annali di San Michele 8 (1995) 265-286, besonders 278-280. Zu Stolz siehe Gerhard Siegl, Otto Stolz (1881-1957). Trotz Fleiß kein Preis? Der geknickte Marschallstab, in: Österreichische Historiker 1900-1945 (wie Anm. 7) 419-460.

37 Franz Huter, Die Besiedlung des „Landes im Gebirge“. Ein Beispiel alpiner Siedlungsgeschichte, in: Zs. des Deutschen Alpenvereins (Jb.) 70 (1939) 194-198, hier 198.

38 Siehe hierzu allgemein Franz Matris, Die Erforschung des Alpenraumes in der österreichischen Historiographie, in: Histoire des Alpes - Storia delle Alpi - Geschichte der Alpen 1 (1996) 61-67, hier $64 f$. 
Huters Südtirolstudien, in die auch nach 1945 aggressive Ressentiments eingesenkt blieben, kennzeichneten sich durch scharfe ethnische und soziokulturelle Differenzkonstruktionen, in denen sprachliche und soziale Divergenzen eine Übersteigerung zu absoluten Grenzen erfuhren. Demografische, zeitweilig auch rassenideologische Diskurselemente und biologistische Ausdeutungen von Lebensraum-Vorstellungen verbanden sich mit Zuschreibungen zivilisatorischer Inferiorität an benachbarte Ethnien: In Untersuchungen zur frühesten Siedlungsgeschichte und zum Alter von Toponymik und Onomastik stellte er hierarchisierend das Bild schütterer „,vordeutsch“-alpenromanischer Besiedlung der nachfolgenden intensiven „deutschen Durchsiedlung“ und Raumdurchdringung gegenüber. Der hinsichtlich seiner präsumtiven Effizienz und sozioökonomischen Überlegenheit hervorgehobene mittelalterliche Landesausbau, als Ergebnis der „Großtat deutscher Arbeit“39 glorifiziert, wurde lebensraumideologisch und in Anklang an Vorstellungen Friedrich Ratzels als Erwerb eines national gedeuteten, unveräußerlichen Besitzstandes gewertet. Dessen räumlich-zeitliche Kontinuität, welche in Belegen frühester „deutsche[r] Sprachgeltung “40, in bäuerlicher Sippen- und Höfegeschichte, in Familien- und Flurnamen oder der Rechtsform der Hofleihe fassbar schien, galt als Nachweis biologischer Kontinuität und als Widerlegung der siedlungsgeschichtlichen Thesen italienischer Wissenschaftler ${ }^{41}$. In „Siedlungsleistungen“ und „mehrhundertjährige[r] Geschlechterfolge bäuerlicher Sippen“ sah Huter „ein unverjährbares Recht auf die Heimat der Ahnen“42 begründet. Hier ordneten sich seine Studien zur Raumbildung und historischen Inventarisierung des „deutschen Volksbodens“ in Südtirol ebenso ein wie seine retrospektiven Quantifizierungsversuche ethnischer Verhältnisse (speziell im Südtiroler Unterland), seine „volksgenealogischen“ Interessen, seine historisch-genealogischen Forschungen zur Höfegeschichte ${ }^{43}$ und zu

39 M. Völser [i.e. Franz Huter], Südtirols Deutschtum im Angriffs- und Abwehrkampf, in: Tiroler Heimat. Jb. für Geschichte und Volkskunde 3 (1930) 223-230, hier 230. Weiter (227) führte Huter aus: „Die Klause von Salurn, welche heute als Grenze zwischen deutsch und welsch gilt, war es vor 600 Jahren schon nicht mehr. Unaufhaltsam drängten deutsche Arbeit und Volkskraft gegen Süden und schufen in der Verdeutschung des Raumes Salurn-Lavis erst recht die Voraussetzungen, die die völlige Eindeutschung der zweiten Stellung (Raum Bozen-Salurn) ermöglichte.“

40 Franz Huter, Deutsche Sachwörter in Südtiroler Urkunden vor der Mitte des 13. Jahrhunderts, in: FS Moriz Enzinger zum 60. Geburtstag (30. Dezember 1951), hg. v. Herbert SEIDLER (Innsbruck 1953) 63-70, hier 70.

41 Siehe z.B. Franz Huter, Der untere Fennberg. Aus der Geschichte einer Hofgemeinde an der deutsch-romanischen Sprachgrenze, in: Salurner Büchl. Beiträge zur Heimatkunde von Salurn und Umgebung (SchlernSchriften 155, Innsbruck 1956) 29-47; siehe auch DERs., Erbhofbauern - Ritter der Treue zur Heimat, in: Der Schlern 22 (1948) 356f.

42 Franz Huter, Kloster Innichen und die Besiedlung Tirols, in: Stifte und Klöster: Entwicklung und Bedeutung im Kulturleben Südtirols (Jb. des Südtiroler Kulturinstitutes 2, Bozen 1962) 11-32, hier 11.

43 Die später von Huter herausgegebene Höfegeschichte Engelbert Auckenthalers wertete er „als Bekenntnis zur alten und großen Geschichte des Tiroler Bauernstandes“; siehe Franz Huter, Geleitwort zu: Engelbert 
exponierten Mikroisolaten an der Alpenhauptwasserscheide. Darin bemühte er sich keineswegs überzeugend -, einen bis zum Jahre I 920 traditionell „enge[n] Lebenskreis zwischen den Menschen unmittelbar zu beiden Seiten der Jöcher" ${ }^{44}$ aufzuzeigen - ein Untersuchungsansatz, den 1944 ebenfalls der Innsbrucker Historiker und Volkskundler Adolf Helbok mit komplexen, auch „volksgenealogischen“ Forschungen zu den Kulturlandschaften der Pässe und Jöcher zwischen Nord-und Südtirol ${ }^{45}$ ins Auge fasste. Huter folgte in diesen Studien neben siedlungs- und wirtschaftsgeschichtlichen Fragen vor allem dem Ansatz quantitativer Familienforschung. Dabei spürte er hauptsächlich genealogischen Verflechtungen und kleinräumiger Mobilität von geografisch eng umschriebenen Bevölkerungsgruppen nach. Außer Betracht blieben dabei allerdings sowohl die quantitative Marginalität von Exogamie in bergbäuerlichen Gemeinschaften als auch deren diesbezüglichen Vorbehalte und rigiden Mechanismen zur Verhinderung von Fremdzuzug.

Im Zentrum der volksgeschichtlichen Argumentationslinien Huters stand das von Wopfner übernommene Konstrukt der „deutschen Arbeit“. Hiermit verknüpften sich Konzepte diffamatorischer Hierarchisierung, von sozio-ethnischer Differenzierung und dichotomischer Grenzziehung zwischen dem Fremden und dem Eigenen. Das insofern ordnende Element der „deutschen Arbeit“ - im Bild des von exogenen Einflüssen vermeintlich unberührten und wahre „Volkhaftigkeit“ offenbarenden Tiroler Bauern repräsentiert - lieferte jenen identitätsstiftenden Bezug, der „Volk“ und „Raum“, „Blut“ und „Boden“ als festes, historisch gewordenes und irreversibles Gefüge verkittete. Vor dem Hintergrund der forciert nach Südtirol gelenkten italienischen Binnenmigration mar-

Auckenthaler, Geschichte der Höfe und Familien von Ratschings und Jaufental (Oberes Eisacktal, Südtirol), mit besonderer Berücksichtigung des 16. Jahrhunderts (Schlern-Schriften 174, Innsbruck/München 1970) ohne Paginierung. - Im Rahmen der Kulturkommission war auch Karl Maria Mayr mit Höfeforschungen in Südtirol befasst.

44 Franz Hute r, Schnals und Innerötztal. Etwas Geschichte um ein Stück Alpenhauptwasserscheide, in: Jb. des Deutschen Alpenvereins (1951) 25-30, hier 30; ähnlich auch später nochmals DERs., Das Tal Schnals in den Ötztaler Alpen. Geschichte und Gegenwart, in: Südtirol in Wort und Bild 7 (1963) 15-24, besonders 16. Huter hatte spätestens Ende 1944 bereits eine „Geschichtliche Monographie über das Tal Schnals als Beispiel der Besiedlungs- und Wirtschaftsgeschichte eines Hochalpentales in Südtirol“ abgeschlossen; siehe SAB, AdO: Huter an Wolfgang Steinacker, Bozen, 16.11.1944. - Vgl. in diesem Zusammenhang rezente genealogischgenetische Untersuchungen von Isolatpopulationen in Südtirol und historisch-sozialanthropologische Studien ihres demografischen Verhaltens: Gene und Geschichte in Stilfs, Langtaufers und Martell, hg. v. Gerd Klaus Pinggera, Alice Riegler, Umberta Dal Cero, Martin Gögele (o.O. [Bozen] o.J. [2006]); Margareth LANZinger, Das gesicherte Erbe. Heirat in lokalen und familialen Kontexten: Innichen 1700-1900 (Wien/ Köln/Weimar 2003). - Verwiesen sei auch auf die statistisch-bevölkerungsbiologischen Arbeiten, welche die sogenannte Innsbrucker Schule der Bevölkerungsgeografie unter Hans Kinzl während der frühen Nachkriegsjahre in Westösterreich vornahm; siehe dazu Franz Fli RI, Hans Kinzl und die Innsbrucker Schule der Bevölkerungsgeographie, in: Mitteilungen der Österreichischen Geographischen Gesellschaft 138 (1996) 147-181.

45 SAB, AdO: Helbok an Wolfgang Steinacker, Innsbruck, 01.11. und 03.11.1944. 
kierte ein solcher Sinnbezug die Unzugehörigkeit des „Raumfremden“, appellierte an dessen Exklusion und somit an den Umbau ethnischer Strukturen. Dieses Element völkischen Ordnungsdenkens, versetzt mit zivilisationskritischen Vorstellungen, blieb auch nach 1945 zentraler und nicht selten mit Schärfe vorgetragener Bestandteil in Huters volksgeschichtlichem Diskurszusammenhang ${ }^{46}$.

Seine bevölkerungshistorischen Studien kennzeichneten sich indes zugleich durch ein „volksbiologisches“ Interesse. Die Geschichtswissenschaft sah Huter etwa berufen, den Bevölkerungsschwund in alpinen Höhensiedlungslagen (zunächst in Nordtirol) siedlungshistorisch umfassend zu analysieren und sich der Politik mit planerischen Grundlagen als Ressource für agrarökonomische, agrarsoziologische und rassisch-bevölkerungspolitische Interventionen zur Verfügung zu stellen: „Die Wiederbesiedlung dieser Höhen, denen so viel urkräftiges Volkstum entwuchs“, merkte Huter I939 mit Blick auf das „Bergbauerntum“, einem bei ihm durchaus auch rasseideologisch aufgefüllten Topos, an, würde „unserem Volke zweifellos wertvollste Menschen gewinnen“47.

Die von Huter gelieferten historiografischen Ordnungskonzeptionen sozialer und geografischer Räume schienen mit der deutschen Okkupation Italiens und der Einrichtung der annexionsorientierten nationalsozialistischen Sonderverwaltung in der Operationszone Alpenvorland, zu der Südtirol mit den Nachbarprovinzen Trient und Belluno zusammengeschlossen wurde, ihren Realisierungskontext zu finden. An den Sturz des Faschismus und den bündnispolitischen Umbruch in Italien im Sommer 1943 knüpften sich im volkstumswissenschaftlichen und volkstumspolitischen Milieu Tirols durchaus expansions- und aggressive bevölkerungspolitische Konzepte, in deren Dienst sich auch Huter vom Standpunkt „völkischen“ Ordnungsdenkens stellte. Hiermit verbanden sich zudem Vorstellungen von Revanche gegenüber den italienischen Fachkollegen und den Exponenten faschistischer Ethnopolitik. Gleichwohl musste Huter in den folgenden Monaten mit Ungeduld und Enttäuschung gewärtigen, dass die Annexion Südtirols seitens der politischen Führung offiziell nicht vollzogen wurde ${ }^{48}$.

46 Siehe Franz Huter, Geburtstagsansprache, gehalten am 22. Mai 1946 bei der Feier der Schüler [Hermann Wopfners] im Rahmen der Universität, in: Beiträge zur Geschichte und Heimatkunde Tirols. FS zu Ehren Hermann Wopfners 1 (Schlern-Schriften 52, Innsbruck 1947) 7-11, hier 11; siehe in diesem Zusammenhang auch Alexander Pinwin kle R, „Grenze“ als soziales Konzept: Historisch-demographische Konstrukte des „Eigenen“ und des „Fremden“, in: Volks-(An)Ordnung: Einschließen, ausschließen, einteilen, aufteilen!, hg. v. Petra Overath, Daniel Schmidt (Leipzig 2003) 31-48.

47 Huter, Besiedlung (wie Anm. 37) 197.

48 Am 22.03.1944 schrieb Huter aus Bozen an Sievers, es seien ihm jüngst die schlimmen und die schönen Tage des Einsatzes gegen unseren italienischen, Freund' wieder recht zum Bewusstsein gekommen. Hoffen und glauben wir, dass die Drahtzieher der wahnsinnigen Entdeutschungspolitik die endgültige politische Entscheidung über Südtirol im deutschen Sinne bald erleben. BAB (wie Anm. 27). - Drei Tage später merkte Huter an: [...] während auf militärischem Gebiete die durch den Zusammenbruch Italiens geschaffene Lage im Alpengrenzraum rasch und 
Huter hatte seine archivalischen Inventarisierungen und Kopierarbeiten im Dienste des Ahnenerbes über den Sturz des faschistischen Regimes in Italien im Juli I 943 schließlich bis zur deutschen Besetzung des Landes im September in die Länge zu ziehen vermocht ${ }^{49}$. Auch war man im Ahnenerbe der Ansicht, dass sein Abzug aus Südtirol einem Verzicht auf unsere Rechte gleichkäme ${ }^{50}$. Seit Herbst 1943 führte Huter dann das auf dem Bozner Schloss Maretsch untergebrachte Referat Archivwesen innerhalb der NS-Zivilverwaltungsbehörde; zugleich wurde ihm die Leitung der Staatsarchive in Bozen und Trient übertragen. Huter hat in dieser Funktion anerkennenswerte Anstrengungen unternommen, um durch umfangreiche Auslagerungen die wichtigsten staatlichen und kirchlichen Archive der Provinzen Bozen und Trient vor Kriegseinwirkungen zu schützen ${ }^{51}$. Zugleich war er jedoch an der Durchsuchung und Verschleppung des Privatarchivs von Ettore Tolomei, einem der Vordenker der Italianisierung Südtirols, und von dessen Museo della Rivendicazione dell'Alto Adige in Glen bereits wenige Tage nach der deutschen Besetzung des Landes beteiligt ${ }^{52}$. Auch hatte sich das Ahnenerbe schon seit Beginn der

radikal gemeistert wurde, ist es auf politischem Gebiete nur zu einer Zwischenlösung in der Schaffung der Operationszone Adriatisches Küstenland und Alpenvorland gekommen. Es handelt sich um einen deutschen Oberbau auf dem Unterbau der italienischen Verwaltung. Wenn auch Südtirol (Provinz Bozen) enger angeschlossen wurde als die übrigen Provinzen, so bedeutet dies höchstens ein Versprechen für die Zukunft; die politische Entscheidung ist noch nicht gefallen [,] und die Absichten der Reichsführung lassen sich nur vermuten. BAB, R 153/1556: Bericht des Leiters der AFG, Bozen/Innsbruck, 25.03.1944.

49 BAB (wie Anm. 27): Huter an Sievers, Bozen, 05.08.1943: Lieber Standartenführer! Seit meinen letzten Zeilen an Sie hat sich hier Manches ereignet. Nach einigen politisch schwülen Tagen, zu denen die gegenwärtige Bruthitze gut passte, ist eine gewisse Beruhigung eingetreten. Die Anwesenheit unserer prachtvollen Truppen (gestern ist die Division Leibstandarte [SS-Panzer-Grenadier-Division Leibstandarte SS Adolf Hitler] durchgekommen) hat viel dazu beigetragen. Die Aufnahmearbeiten können also weiter gehen. [...] Da die Gegenseite in Voraussicht kommender Ereignisse möglicherweise aus Archiven und Museen Materialien zu verschleppen suchen könnte, bin ich mit $\operatorname{der} A D O$ wegen Überwachung gewisser Objekte in Verbindung getreten. Leider ist eine Überwachung ebensolcher Objekte im Trentino zur Zeit noch kaum möglich.

50 BAB, NS 21/68: Sievers an Stabshauptamt des Reichskommissars für die Festigung deutschen Volkstums, betr.: Tätigkeit der Kulturkommission, Berlin, 30.04.1943.

51 Dieses Verdienst ist bereits verschiedentlich gewürdigt worden. Huter selber hat hierüber nach dem Kriege einen öffentlichen Rechenschaftsbericht vorgelegt; siehe Franz Huter, Die Flüchtung der Archive Südtirols im Zweiten Weltkrieg. Ein Arbeitsbericht, in: Archivalische Zs. 50/51 (1955) 227-233; siehe hierzu auch Pfeifer, Santifaller und Huter (wie Anm. 2) 361-364.

52 Siehe hierzu Gisela Fram ke, Im Kampf um Südtirol. Ettore Tolomei (1865-1952) und das „Archivio per l'Alto Adige“ (Tübingen 1987) 245; Michael WEdE Kind, Nationalsozialistische Besatzungs- und Annexionspolitik in Norditalien 1943 bis 1945: Die Operationszonen „Alpenvorland“ und „Adriatisches Küstenland“ (München 2003) 260; Günther Pallaver, Auf den Spuren des Tolomei-Archivs, in: Das Fenster 63 (1997) 6030-6035; siehe ferner BAB (wie Anm. 27): Huter an Sievers, Bozen, 12.09.1943: Lieber Standartenführer! Die Ereignisse haben sich derart überstürzt, dass ich erst heute dazu komme, Ihnen zu schreiben. Am Abend des 8. September aus dem Pustertal zurückgekehrt, wo ich das Bleiberarchiv auf Schloss Ehrenburg nach Möglichkeit ausgebeutet hatte, kam ich gerade zum Umschmiss zurecht. Peter Hofer bat mich, dass ich mich für die Archiv-und 
deutschen Besatzung des privaten Archivbesitzes ehemaliger Südtiroler Optionsgegner zu bemächtigen bemüht. Huter konnte indes 1955 vor einem Gericht in Trient die erhobene Anklage wegen Kulturgüterraubes entkräften und glaubhaft machen, die Verbringung des Tolomei-Archivs nach Nordtirol auf Befehl seines Dienstvorgesetzten, dem 1948 als Kriegsverbrecher zum Tode verurteilten und hingerichteten Ahnenerbe-Leiter Sievers, veranlasst zu haben.

Durch Mitwirken in der in Innsbruck ansässigen AFG war Huter schon in den I93oerJahren in den Dienst eines volkstumswissenschaftlichen Expertennetzwerkes getreten, das an der Schnittstelle zur Politikberatung nicht nur revisions- und expansionspolitische Konzeptionen für den Ostalpen- und oberen Adriaraum mit legitimatorischen Grundlagen versah, sondern auch ethnopolitisches Wissen und interventionistische Sozialtechniken bereitstellte. Ende 1942 hatte er den Geologen Raimund von Klebelsberg zu Thumburg in der Leitung der AFG abgelöst. Diese stand in enger Verflechtung mit der Tiroler Gauleitung, insbesondere seitdem die Geschäftsführung der Innsbrucker Einrichtung I94I an Wolfgang Steinacker ${ }^{53}$, den Leiter des Tiroler Gaugrenzlandamtes und volkspolitischen Dezernenten des Reichsstatthalters, übertragen worden war. Nach Teilnahme an einer Tagung der Volksdeutschen Forschungsgemeinschaften im März I944 in Prag bot das nunmehr zuständige Reichssicherheitshauptamt Huter im Sommer des Jahres eine weiter gehende, leitende Mitarbeit im Gesamtverbund der Forschungsgemeinschaften an.

[...] Museumsfragen zur Verfügung stelle. Mit Dr. Hoeniger zusammen haben wir zunächst die Lage im Museum Bozen und in Maretsch beschaut und versperrt und versiegelt, was nötig war. Außerdem durchsuchte ich den Fremdenverkehrspalast, in dem ehemals das italienische Hochkommissariat untergebracht war, freilich ohne Erfolg. Gestern war ich mit der Gestapo in Glen bei Tolomei (dieser ist in der Nacht vom 9. auf den 10. verhaftet und dann nach Innsbruck gebracht worden), um eine vorläufige Bestandsaufnahme der Sammlungen (Museum der, Wiedergewinnung Südtirols') und der Korrespondenz des ,Alten'durchzuführen. Nächste Woche will ich nach [Castel] Toblino, um die 80 Kisten [mit Archivalien aus dem Staatsarchiv Bozen] und was sich beim Salonkommunisten sonst noch findet, sicherzustellen. Ich möchte das Material auch nicht dort lassen, sondern wieder heraufbringen [,] und zwar wegen der Luftgefahr nicht nach Bozen, sondern auf Schloss Neumelans in Sand in Taufers (Seitental) [...]. Die Kirchenbuchaufnahmen lasse ich weitergehen im Sinne unserer letzten Besprechung [...].

53 Zu Steinacker, dem ältesten Sohn des Historikers Harold Steinacker, siehe Michael Wede Kind, Wolfgang Steinacker, in: Handbuch der völkischen Wissenschaften (wie Anm. 19) 656-661; Ders., „Wir arbeiten hier an der zukünftigen Gestaltung der Südmark“: Nationalsozialistische Volkstumspolitik in der Operationszone Alpenvorland (1943-1945), in: Die Operationszone Alpenvorland im Zweiten Weltkrieg, hg. v. Andrea Di Michele, Rodolfo Taiani (Veröff. des Südtiroler Landesarchivs 29, Bozen 2009) 59-77; Ders., Grenzlandwissenschaft (wie Anm. 36); Michael Gehler, Versteckter „Grenzlandkampf“ um Südtirol? Die Umsiedlung aus der Sicht des Gaus Tirol-Vorarlberg, in: Die Option. Südtirol zwischen Faschismus und Nationalsozialismus, hg. v. Klaus Eisterer, Rolf Steininger (Innsbrucker Forschungen zur Zeitgeschichte 5, Innsbruck 1989) 315-340; DERs., Wolfgang Steinacker - Obstruktion gegen die „Achse“ Berlin-Rom. Aspekte zur Geschichte der Südtirolfrage und Umsiedlung, in: Das Fenster. Tiroler Kulturzeitschrift 23, 46 (1989) 4548-4554; Ders., Hitler-Mythos (wie Anm. 8). 
Wenn Huter hierauf bereitwillig reagierte, dann war dies keineswegs ein unumgängliches Arrangement mit den Machthabern, sondern seinem aktivistischen Wissenschaftsverständnis geschuldet ${ }^{54}$.

Dieses spiegelte sich auch auf dem Südtiroler Schauplatz wider, wo Huter im Sommer 1944 die Geschäftsführung der Arbeitsgemeinschaft für Landes- und Volksforschung Südtirol übernahm. Deren Errichtung war Ende April des Jahres zwischen Gauleiter Franz Hofer und Ahnenerbe-Leiter Sievers beschlossen worden. Sie ging im Wesentlichen aus der in Abwicklung befindlichen Bozner Dienststelle des Ahnenerbes hervor, dessen Einfluss infolge des volkstumswissenschaftlichen Primatstrebens des Reichssicherheitshauptamtes inzwischen auch in Südtirol stark geschmälert war. Über Steinacker als stellvertretendem Geschäftsführer war die Arbeitsgemeinschaft funktional und personell an dessen volkstumspolitischen Ämter- und Aufgabenkomplex in Innsbruck und Bozen gekoppelt und der Behörde des Obersten Kommissars für die Operationszone Alpenvorland unterstellt. Wie im Falle vergleichbarer volkstumswissenschaftlicher Einrichtungen hatte die Arbeitsgemeinschaft den langfristig geplanten sozioethnischen Umbau des Besatzungsraumes und dessen Eingliederung, Assimilierung und politische Führung durch Bereitstellung von bevölkerungspolitischem Herrschaftswissen zu flankieren und legitimieren.

Neben der „Rückdeutschung“ Südtirols gruppierten sich entsprechende Neuordnungsszenarien zum einen um die Entnationalisierung des Trentino (unter möglichem Ausgriff auf die deutschen Sprachinselrelikte in Venetien), zum anderen um die Assimilierung des ladinischsprachigen Dolomitenraumes, den Huter unter Rekurs auf die expansionspolitisch orientierte Volks- und Kulturbodenthese als Teil der „deutschen Kulturgemeinschaft"55 auswies. Abgesehen von der Fundierung deutscher Herrschaftsansprüche auf Südtirol und dem Entwurf eines ladinischen Raum- und Identitätskonstruktes war es vordringliche Aufgabe der Arbeitsgemeinschaft für Landes- und Volksforschung, die behauptete „germanisch-deutsche“ Durchprägung des Trentino nachzuweisen. Dabei schloss man an eine bereits auf die I 86oer-Jahre zurückgehende Diskursstrategie an, die über den Ausweis einer ehemals intensiven Verbreitung von deutscher Sprache und Kultur im östlichen

54 Sievers vermerkte im Übrigen unter dem 25.08.1944 in seinem Tagebuch, Huter habe nach Ablauf seiner Freistellung vom Wehrdienst um Einsatz für bezw. im Rahmen der SS gebeten; siehe BAB, NS 21/11: Tagebuch Wolfram Sievers' (07.03.-28.09.1944) 231. Eine Übernahme Huters in die Waffen-SS war bereits zuvor durch das SS-Führungshauptamt geprüft und für sehr wahrscheinlich gehalten worden; siehe BAB, NS 21/93: Fernschreiben des Amtes Ahnenerbe an Gauleitung Tirol-Vorarlberg, 18.06.1942 (?).

55 Franz Huter, Stellungnahme zur geschichtlichen Beweisführung der „Documenti“ im Einzelnen, in: „Alto Adige“: Eine offiziöse italienische Tendenzschrift über Südtirol. Kritische Bemerkungen zum italienischen Faksimilewerk „Alto Adige. Alcuni documenti del passato, 3 Bände, Bergamo 1942“ (Innsbruck 1943) (Nur für den Dienstgebrauch) 23-28, hier 25. - Huter funktionalisierte diese These auch im Zusammenhang mit der Auslieferung Südtiroler Archivalien durch Italien; siehe BAB (wie Anm. 27): [Franz Huter:] Grundsätzliche Bemerkungen zur Frage der Sicherung des Archivguts aus Südtirol, undatiert [etwa Mitte 1940]. 
Trentino das Konstrukt einer überwiegend deutschstämmigen, nur sprachlich romanisierten Bevölkerung ableitete.

An der erklärten Absicht der Arbeitsgemeinschaft, die germanischen Grundlagen und die deutschen Kulturkräfte im Raum zwischen Brenner und Belluno aufzuzeigen, das nordsüdliche Kulturgefälle festzustellen und in seinen inneren Triebkräften zu erforschen ${ }^{56}$, hat Huter unmittelbar mitgewirkt: Nachdem schon die Ahnenerbe-Kulturkommission Archivalien mit Bezug auf die Sprachinseldeutschen im Trentino und auf den Sprachgrenzraum besondere Bedeutung beigemessen hatte, begann die Innsbrucker Alpenländische Forschungsgemeinschaft im Frühjahr 1944, durch Zeichnen namenkundlicher Karten und durch die Sammlung von Material aus bisher nicht genutzten Archiven Stoff für den Nachweis deutscher Kulturleistungen über die geschlossene deutsche Sprachgrenze hinaus vorzubereiten ${ }^{57}$. Bereits in den I93oer-Jahren hatte Huter darauf verwiesen, dass infolge eines politisch bedingten Nachlassens des „nötigen Volksnachschubes [...] aus dem unerschöpflich scheinenden Menschenborn Süddeutschlands (einschließlich Tirols)“ seit dem I 5. Jahrhundert „wertvoller deutscher Volks- und Kulturboden“ im östlichen Trentino und im Raum zwischen Bozen und Lavis verloren ging, „auf den die deutsche Arbeit unverjährbaren Anspruch begründet" habe ${ }^{58}$. Im Rahmen der Bozner Arbeitsgemeinschaft für Landesund Volksforschung Südtirol beabsichtigte Huter nun eine breite Bestandsaufnahme der die deutsche Siedlungs- und Kulturleistung in der Provinz Trient beweisenden Quellen sowie Vorarbeiten für ein Urkundenbuch zur Geschichte der deutschen Sprachinseln im Süden der Alpen ${ }^{59}$. In der Tat war bereits eine Arbeitsgruppe des deutschen Zivilverwaltungsapparates mit quantitativen bevölkerungsgeschichtlichen Erhebungen des Trientiner Sprachinsel- und „Streudeutschtums“ befasst ${ }^{60}$.

$56 \mathrm{SAB}$, AdO: Helbok an Wolfgang Steinacker, Innsbruck, 03.11.1944.

57 BAB, R 153/1556: Bericht des Leiters der AFG, Bozen/Innsbruck, 25.03.1944.

58 Völser, Südtirols Deutschtum (wie Anm. 39) 229.

59 SAB, AdO: Huter an Wolfgang Steinacker (Formblatt „Arbeitsbericht etc.“), Bozen, 16.11.1944. - Siehe in diesem Zusammenhang auch Franz Huter, Lusern - das Dorf der Getreuen, in: Bozner Tagblatt 06.05.1944 5. - Freilich hatte Huter (VöLSE R, Südtirols Deutschtum [wie Anm. 39] 228) noch 1930 gewarnt : ,von einer [vormaligen] Verdeutschung Welschtirols bis an den Alpenrand, wie sie manchmal behauptet wird, sollte in der ernsten Forschung nicht gesprochen werden."

60 Siehe hierzu Michael Wede Kind, Volkstumswissenschaft und Volkstumspolitik im Umfeld deutscher Sprachinseln in Oberitalien, in: Ursprünge, Arten und Folgen des Konstrukts „Bevölkerung“ vor, im und nach dem „Dritten Reich“: Zur Geschichte der deutschen Bevölkerungswissenschaft, hg. v. Rainer MaCkEnsen, Jürgen Reulecke, Josef Ehmer (Wiesbaden 2009) 83-105; erweiterte italienische Fassung: Le „sporadi tedesche“: le comunità germanofone dell'Alta Italia come oggetto dell'etno-scienza ed etno-politica tedesca, in : Archivio trentino. Rivista di studi sull'età moderna e contemporanea del Museo storico in Trento 57,2 (2008) 103-138; DE Rs., Gestaltung der Südmark (wie Anm. 53). 
Vor dem Hintergrund der rapiden Machterosion des Dritten Reiches - Huter war seit Januar 1945 noch zeitweilig zum Volkssturm eingezogen worden - ist den expansionspolitisch-legitimatorisch konzipierten Forschungsvorhaben der letzten Kriegsmonate eine eigentümliche Realitätsferne zu attestieren. Wenn das volkstumswissenschaftliche Milieu Tirols - und mit ihm Huter - es mitkonzipierte und sich hierauf mit Verve einließ, so manifestierte sich darin eine ethnozentrische Weltsicht, die - an der ethnischen Peripherie herangebildet und radikalisiert - in ein „anwendungsorientiertes“ Verständnis von Wissenschaft einmündete ${ }^{61}$. Als die staatliche Zugehörigkeit Südtirols nach Kriegsende kurzfristig noch einmal zur Disposition gestellt schien, meinte Huter im Mai 1946 einen Monat bevor Südtirol neuerlich Italien zugesprochen wurde - für sich und seine „völkisch“ orientierte Kollegenschaft deponieren zu können: „Wenn uns dieses Schmerzenskind [Südtirol], das heißgeliebte, jetzt neuerdings geraubt werden sollte, wider alle Versprechungen und wider alles Recht, wider alle Bande des Geistes und des Blutes, dann trifft diesmal die lebende Historikergeneration Tirols kaum eine Schuld daran."62

\section{NETZWERKE DER STAGNATION}

Der NS-Überprüfungsausschuss der Universität Innsbruck vermochte sich Anfang 1946 indes nicht vom politischen Gehalt der bisherigen Arbeiten Huters zu überzeugen und beließ ihm die Venia legendi für Wirtschaftsgeschichte und Historische Hilfswissenschaften. Mit dem Hinweis indes, Huter habe sich in den Kreisen der Beamten des Obersten Kommissars in Bozen ziemlich nationalsozialistisch gegeben ${ }^{63}$, wurde seine Rückversetzung in den Archivdienst verfügt und ihm die Lehrbefugnis für Österreichische Geschichte aberkannt.

61 Auch in Hinblick auf das seit 1941 halbannektierte Oberkrain sekundierte Huter bei der wissenschaftlichen Legitimation nationalsozialistischer Herrschaftsansprüche. Über die maßgebliche Beteiligung der beiden Südtiroler Stifte Brixen und Innichen sowie der Grafen von Ortenburg und Andechs-Meran am mittelalterlichen Siedlungsausbau im obersten Savegebiet sowie über die damit verbundenen bevölkerungsgeschichtlichen Vorgänge im mittelalterlichen Oberkrain leiteten „völkische“ Wissenschaftsmilieus vor allem seit Anfang der 1940er-Jahre die These einer Zugehörigkeit des Landes zum „deutschen Volksraum“ und „Kulturboden“ ab. Huter, der in diesem Zusammenhang unter anderem auf die besondere volkstumswissenschaftliche Relevanz der entsprechenden Archivbestände in Brixen und Innichen verwies, hat das Thema „deutscher Siedlungsleistungen “ in Oberkrain auch in der Nachkriegszeit verschiedentlich wieder aufgegriffen; siehe Hut E R, Kloster Innichen (wie Anm. 42); DERs., Siedlungsleistung und Grundherrschaft von Innichen, in: Der Schlern 45, $1 / 2$ (1971) 475-485.

62 Huter, Geburtstagsansprache (wie Anm. 46) 11.

63 Bescheid des Verwaltungsdirektors der Universität Innsbruck, Richard Pokorny, namens des Überprüfungsausschusses betreffend politische Überprüfung Huters, Innsbruck, 23.02.1946 (UAI, PA Huter), hier zitiert nach Oberkofler, Huter (wie Anm. 1) 190f. 
Dass Huter diese bereits Ende I950 wiedererlangte, dass er I958 zum Ordinarius für Österreichische Geschichte, im Folgejahr auf Betreiben des Mediävisten Leo Santifaller zum wirklichen Mitglied der ÖAW ernannt und für das Studienjahr I 959/60 zum Dekan der Philosophischen Fakultät der Universität Innsbruck gewählt wurde, war vor allem wechselseitigen Rehabilitierungsbemühungen des weiterhin tragfähigen volkstumswissenschaftlichen Personennetzwerkes - darunter insbesondere akademische Gesinnungskreise Innsbrucks um Wopfner, Heuberger, Kinzl und Hans Kramer - zu danken. Der vollen Reetablierung im Wissenschaftsbetrieb folgten bald Auszeichnungen und Ehrungen, auch seitens der Politik ${ }^{64}$, welcher sich Huter als gesuchter Feiergestalter mit geistesverwandten Geschichtsdeutungen zur Tiroler Landesidentität und zur Südtirol-Frage empfahl ${ }^{65}$. Auch konnte er sich alsbald seinerseits für die Rehabilitierung politisch belasteter Kollegen insbesondere für jene seines Mentors Harold Steinacker, dem nationalsozialistischen Rektor der vormaligen „Deutschen Alpenuniversität“ Innsbruck - verwenden: Diesem wurde auf Initiative Huters I 960 die Ehrenmedaille der Universität Innsbruck verliehen und vier Jahre später die Ernennung zum Ehrenmitglied der ÖAW zuteil.

Die Verortung Huters in der historiografischen Denkschule und in Netzwerken der „völkischen“ Wissenschaft hat vor diesem Hintergrund als dringende Positionsbestimmung zu gelten. Seine Forschungen richteten sich weithin auf eine bevölkerungshistorische Wissensproduktion. Der Südtiroler Archiveinsatz zwischen 1940 und I945 erlaubte $\mathrm{ihm}$, diese auf eine breite, indes selektive Datenbasis zu stellen, welche er auch nach dem Kriege ohne Paradigmenbrüche und Hinweis auf den Erhebungskontext nutzte. Diese Wissensproduktion, der Verzerrungen und Unausgewogenheiten anzulasten sind, war geschichtswissenschaftlichen Ordnungsvorstellungen unterworfen, die ethnisch-soziale Grenzen formulierten.

Als Mitglied und Vorsitzender einer volkstumswissenschaftlichen Forschungseinrichtung mit ihrem volkstumspolitischen Beratungs- und Planungsstab hatte Huter bis 1945 an der Spitze eines personellen Ressourcenensembles gestanden, das sich politischer Pla-

641964 verlieh der Tiroler Landeshauptmann Eduard Wallnöfer Huter das Ehrenzeichen des Landes Tirol für Verdienste auf wissenschaftlichem Gebiet. Bereits 1958 war Huter zum korrespondierenden Mitglied der ÖAW ernannt worden. Seitens der Universität Innsbruck folgten 1969 die Goldene Jubiläums-Medaille und 1970 das Ehrendoktorat der Juridischen Fakultät. Im Jahre 1983 wurde Huter das Verdienstkreuz der Stadt Innsbruck verliehen. Erinnert sei auch an die Huter-Festschriften aus den Jahren 1959 (Schlern-Schriften 207) und 1969 (Tiroler Wirtschaftsstudien 26), deren Herausgabe Ernest Troger bzw. der 1964 durch Huter habilitierte Georg Zwanowetz übernommen hatten.

65 Vgl. Leidlmair, Landeskunde (wie Anm. 2), der eine beeindruckende Fülle von Laudationes, Nekrologen und Festschriftbeiträgen für Vertreter des wissenschaftlichen und politischen Lebens Österreichs und Südtirols nachweist. Hinzu treten die Festschriften für Hermann Wopfner und Harold Steinacker, den Juristen und Neuzeithistoriker Oswald Gschließer, den Wirtschaftshistoriker Herbert Hassinger und den Neuzeithistoriker Hans Kramer, welche von Huter eigenständig oder im Verbund mit Kollegen herausgegeben wurden. 


\author{
Abb. 39: Der Tiroler \\ Landeshauptmann Eduard \\ Wallnöfer überreicht Franz Huter \\ I97I das vom österreichischen \\ Bundespräsidenten verliehene \\ Ehrenkreuz für Wissenschaft und
}

Kunst.

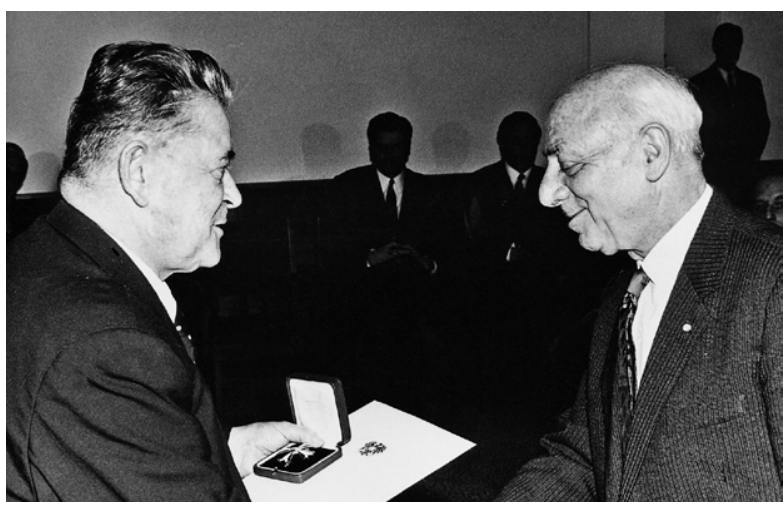

nung verfügbar machte. Dabei sei wissenschaftlich ausgerichtete Politikberatung „nicht als Teil an exekutivem oder administrativem Handeln [verstanden], sondern [als] die geistige Vorarbeit dafür, vorhandene politische und gesellschaftliche Strukturen sichtbar zu machen, alternativ ein Modell für künftige, noch zu schaffende Sozial- und Bevölkerungsordnungen vorzuführen"66 und gar auf mögliche Umstrukturierungsverfahren hinzuweisen. Huter ist insofern, speziell in den Jahren zwischen I943 und I945, auch als Akteur im Kontext nationalsozialistischer Ethnopolitik (zumindest aber ihres Planungsverfahrens) zu historisieren.

Gleichwohl gilt es, Huters unstrittige wissenschaftliche Verdienste nicht unter der Kritik an volkstumspolitischer Instrumentalisierung seiner Forschung zu verschütten. Seine Untersuchungsinhalte dürfen zwar insgesamt als wenig innovativ gelten und sind vielfach in enger Anlehnung an diejenigen seiner Lehrer Wopfner und Stolz zu sehen. Nachdrückliche Würdigung gebührt aber vor allem seinen bedeutenden quelleneditorischen Arbeiten, darunter wegen seiner „methodische[n] Modernität“67 speziell das nach dem Kriege von ihm um zwei Bände vermehrte „Tiroler Urkundenbuch“68 - bis heute ein unentbehrliches Instrument landesgeschichtlicher Forschung -, ferner die aus dem Nachlass Hans von Voltelinis herausgegebenen „Südtiroler Notariats-Imbreviaturen des

66 Ingo HAAR, „Kämpfende Wissenschaft“: Entstehung und Niedergang der völkischen Geschichtswissenschaft im Wechsel der Systeme, in: Deutsche Historiker im Nationalsozialismus, hg. v. Winfried Schulze, Otto Gerhard OExLE (Frankfurt/M. 1999) 215-240, hier 219.

67 Tiroler Urkundenbuch. Abteilung II: Die Urkunden zur Geschichte des Inn-, Eisack- und Pustertals 1: Bis zum Jahr 1140, bearb. v. Martin Bitschnau, Hannes Obermair (Innsbruck 2009) XIII.

68 Urkundenbuch I/1, hg. v. Huter (wie Anm. 23); Tiroler Urkundenbuch. Abteilung I: Die Urkunden zur Geschichte des deutschen Etschlandes und des Vintschgaues 2: 1200-1230, hg. v. DEMs. (Innsbruck 1949); Tiroler Urkundenbuch. Abteilung I: Die Urkunden zur Geschichte des deutschen Etschlandes und des Vintschgaues 3: 1231-1253, hg. v. DEMs. (Innsbruck 1951). 
I3. Jahrhunderts“69, seine „Beiträge zur Bevölkerungsgeschichte Bozens im I6. bis I 8 . Jahrhundert" $" 70$ sowie die von ihm begonnene Edition der Innsbrucker Universitätsmatrikel. Huters wissenschaftliches Euvre deckt in epochaler wie thematischer Hinsicht ein weitgespanntes Spektrum ab, öffnet sich aber nur selten Zusammenhängen, die über die Tiroler Landesgeschichte hinausgehen. Als bedeutende Ausnahme kann sein „Niedergang der Mitte, Aufstieg der Randstaaten Europas im Spätmittelalter"71 als Beitrag zum sechsten Band der von Fritz Valjavec herausgegebenen „Historia mundi“ stehen, in welchem er 1958 zwar kenntnisreich, indes teilweise biologistisch inspiriert den Zerfall der „deutschen Mitte“ beklagte. Zur Kenntnis der Tiroler Landesgeschichte hat Huter, der in den Nachkriegsjahren in Innsbruck vornehmlich über allgemeine Wirtschaftsgeschichte, Urkundenlehre, Paläografie und seit 1958 neuerlich über österreichische Geschichte las, nicht zuletzt auch durch Herausgabe und Redaktion regionalgeschichtlich wichtiger Periodika und Schriftenreihen sowie durch Mitbegründung des am Institut für geschichtliche Landeskunde erarbeiteten „Tirol-Atlasses“ bedeutend beigetragen ${ }^{72}$. $\mathrm{Zu}$ würdigen ist neben seinem Einsatz für das Innsbrucker Universitätsarchiv, dessen Leitung er I950 übernahm, auch seine 1959 beginnende Tätigkeit als Vorsitzender der Kommission der ÖAW für die wichtige Tirolensiensammlung des Südtiroler Politikers, Juristen und Heimatforschers Friedrich Teßmann in Bozen; Huter gelang es, die Grundlagen für deren Ausbau zur zentralen Südtiroler Studienbibliothek (Teßmann-Bibliothek) zu legen.

Huter, der sich dem rassischen Antisemitismus geöffnet und diesen in seinen Lehrveranstaltungen vor 1945 vertreten hatte, hat nach dem Kriege sein Wirken im NS-Regime teils verschwiegen, teils euphemistisch überspielt. Nun zwar opportunistisch, aber keineswegs profund österreichisch-republikanisch gewandelt, hat er sich von antidemokratischen, stark (sozial)konservativen Positionen und der Perhorreszierung von Romania und Slavia ebenso wenig generell zu lösen vermocht wie von einer in Grundzügen „völkisch“mystischen Geschichtsauffassung. Historiografie sah er funktional in der Bewahrung, nicht in der kritischen Analyse des Gewordenen. Wie sein um nur wenige Jahre älterer Südtiroler Historikerkollege Santifaller ${ }^{73}$, so galt auch Huter in einem noch stark positivistischem Sinne Geschichtswissenschaft ganz wesentlich als materialerschließende For-

69 Die Südtiroler Notariats-Imbreviaturen des 13. Jahrhunderts, hg. v. Hans von Voltelini, Franz Huter (Acta Tirolensia 4, Innsbruck 1951).

70 Huter, Beiträge (wie Anm. 33).

71 Franz Huter, Niedergang der Mitte, Aufstieg der Randstaaten Europas im Spätmittelalter, in: Hohes und spätes Mittelalter, hg. von Otto Brunner u.a. (Historia mundi 6, Bern 1958) 190-261.

72 Huter war Herausgeber des Jahrbuches „Tiroler Heimat“, der von ihm begründeten „Tiroler Wirtschaftsstudien“, der „Veröffentlichungen des Museum Ferdinandeum“ sowie der „Schlern-Schriften“.

$73 \mathrm{Zu}$ Santifaller siehe Hannes Ове r мал r, Leo Santifaller (1890-1974). Von Archiven, Domkapiteln und Biografien, in: Österreichische Historiker 1900-1945 (wie Anm. 7). 
schung in Form von Quellenedition und -kommentierung. Anders als Santifaller jedoch, der einer Politisierung der Geschichtsschreibung fernstand, hat Huter diese aktiv mitgetragen. Zur Südtirol-Frage trat er seit 1945 mit zahlreichen populärwissenschaftlichen Schriften (auch in rechtsständigen Organen wie „Die Aula“) an die Öffentlichkeit. Zudem blieb er mit den vormaligen völkischen Aktivisten Südtirols ebenso vernetzt wie mit Exponenten und Institutionen des fortwirkenden volkstumswissenschaftlichen Milieus in Deutschland und Österreich - so beispielsweise mit dem einflussreichen Soziologen und Volkstumstheoretiker Max Hildebert Boehm, nunmehr Vorsitzender des bundesdeutschen Notverbandes amtsverdrängter Hochschullehrer sowie der revisionsorientierten Ostdeutschen Akademie im niedersächsischen Lüneburg. ${ }^{74}$

Huter blieb nach dem Zweiten Weltkrieg bewusstseinsprägender Exponent einer in sich geschlossenen Elite, welche sich die Deutungsmacht über ihre bisherigen Ziele und ihr Tun bewahren konnte ${ }^{75}$. Sie scheute sich nicht, im Moment der tiefen moralischen Niederlage und Widerlegung des Nationalsozialismus erneut öffentlich Zeugnis von beschämender Unduldsamkeit, von kultureller und moralischer Überlegenheit gegenüber dem ethnisch Fremden abzulegen ${ }^{76}$. Der Tiroler Historiografie sicherte Huter methodisch-inhaltliche und wissenschaftsorganisatorisch-gruppensoziologische Kontinuitä$\operatorname{ten}^{77}$. Indem er weithin an tradierten Themata und Methoden, belasteten Terminologien

74 Siehe Südtiroler Landesarchiv, NL Norbert Mumelter, Position 216: Huter an Mumelter, betr. Publikation zur „Deutschen Volkstumsbewegung 1918-1933“ durch das Volkstumsarchiv Lüneburg, Innsbruck, 22.06. und 10.07.1959.

75 Zur österreichischen Historiografie zwischen 1938 und den 1950er-Jahren siehe allgemein Günter FeLLNER, Die österreichische Geschichtswissenschaft vom „Anschluss“ zum Wiederaufbau, in: Kontinuität und Bruch: 1938 - 1945 - 1955. Beiträge zur österreichischen Kultur- und Wissenschaftsgeschichte, hg. v. Friedrich STAdler (Münster 2004) 135-155.

76 So 1946 Huter, Geburtstagsansprache (wie Anm. 46) 11: „Und in dieser Großtat [deutscher Siedlungsarbeit] allein fast liegt unser unzerstörbares und unverjährbares Recht auf dieses Paradies [Südtirol] begründet. [...] Denn hier steht die zeitlose Maschine [italienischer Industrialisierungsmaßnahmen] wider den Pflug, den der Schweiß der Geschlechter geweiht hat, hier steht der Erobererwille des fremden Tyrannen gegen Heimatliebe und Heimattreue, und hier steht der entwurzelte, von der Staatsgewalt herangetriebene Massenmensch gegen das bodenständige Volk mit seinen geschichtlichen Überlieferungen und seiner turmhoch überlegenen Kultur. Die kommenden Entscheidungen werden zeigen, ob [...] die alte Welt der kulturellvolkhaften Werte, die gerade in den Tiroler Bergen noch eine Heimstätte hat, überhaupt weiterleben darf.“

77 Verwiesen sei hier etwa auf das 1954 gegründete und von 1959 bis 1969 von Franz Huter geleitete Innsbrucker Institut für geschichtliche Landeskunde, das die Nachfolge von Huters 1941 errichtetem Institut für Geschichte und Landeskunde des Alpenraumes antrat. - Zur Kontinuität in den geisteswissenschaftlichen Disziplinen an der Universität Innsbruck siehe Peter Golle R, „Natürlich immer auf wissenschaftlicher Ebene!“ - Mystifikationen: Die geisteswissenschaftlichen Fächer an der Universität Innsbruck im Übergang von Nazifaschismus zu demokratischer Republik nach 1945. Dokumentation einer Kontinuität (Innsbruck 1999); Ders., Gerhard Oвеr коғLer, Universität Innsbruck: Entnazifizierung und Rehabilitation von Nazikadern 1945-1950 (Innsbruck 2003). 
und ethnozentrischen Deutungsbildern festhielt, eine auf Neuerung gerichtete Reflexion über die Funktion seiner Disziplin in Österreich zwischen I9I9 und I945 verhindern half, beförderte er in der Tiroler Historiografie langfristige Tendenzen restaurativer Stagnation. 


\title{
Konrad Josef Heilig (1907-1945)
}

\author{
MEDIÄVIST UND POLITISCHER PUBLIZIST
}

I.

„Zu den eindrucksvollsten Leistungen der Generation deutscher Mittelalterhistoriker, die dem Zweiten Weltkrieg zum Opfer fiel, zählt das Werk von Konrad Josef Heilig, Ostrom und das Deutsche Reich um die Mitte des I 2. Jahrhunderts (I944) “. ${ }^{1}$ Der vor allem um die Edition der Urkunden Friedrich Barbarossas verdiente Heinrich Appelt hatte mit dieser seiner Wertung gewiss recht; aber er hatte nur bedingt recht, wenn er Heilig als „deutschen Mittelalterhistoriker" kennzeichnete ${ }^{2}$. Zweifel an einer solchen, auf den ersten Blick eindeutigen Etikettierung werden bereits bei einem Blick in das 2006 erschienene Buch „Österreichische Geschichtswissenschaft im 20. Jahrhundert. Ein biographisch-bibliographische Lexikon“

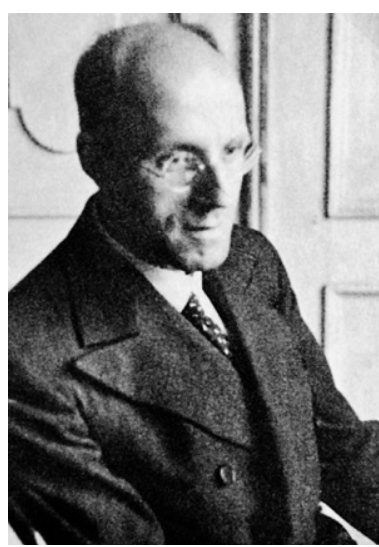

Abb. 40: Konrad Josef Heilig wachgerufen, denn darin findet sich ohne eine einschränkende Bemerkung auch Heilig aufgenommen ${ }^{3}$. Unter den dort aufgeführten Stationen seines 1907 in Erzingen in Baden beginnenden und über Freiburg im Breisgau I 929 nach Wien führenden Lebensweges fällt indessen eine zeitliche Lücke auf: Genannt werden

1 Heinrich Appelt, Privilegium minus. Das staufische Kaisertum und die Babenberger in Österreich (BöhlauQuellenbücher, Wien/Köln/Graz 1973) 17.

2 Zu Heilig grundlegend Hildegard Balcar, Konrad Josef Heilig (1907-1945) als Historiker und Publizist. Teil 1 und 2, Diss. phil. Masch. Wien 1968 (mit den „Biographischen Daten“ in Teil 1, 10-12, und mit dem „Verzeichnis der Publikationen von K. J. H.“ in Teil 2, 15-23). Der Verfasser dieses Beitrags hat sich bemüht, seitdem erschienene Literatur einzubeziehen und darüber hinaus mithilfe archivalischer Quellen, die damals von Balcar noch nicht herangezogen worden waren, das von ihr entworfene Lebensbild noch um einige Züge zu erweitern. - Vgl. außerdem Alphons Lнотsку [1903-1968], Joseph Heilig †, in: HZ 177 (1954) 664f.; Robert Hensle, Dr. phil. Konrad Josef Heilig zum Gedächtnis, in: Badische Heimat 57 (1977) 71-75; Helmut Mau re R, Heilig, Konrad Josef, in: Badische Biographien NF 2 (Stuttgart 1987) 123f.

3 Siehe Fritz Fellner, Doris A. Corradini, Österreichische Geschichtswissenschaft im 20. Jahrhundert. Ein biographisch-bibliographisches Lexikon (VKGÖ 99, Wien 2006) 175. 
unter anderem folgende Tätigkeiten Heiligs: „I932-38 Mitarbeiter Edition mittelalterlicher Bibliothekskataloge Österreichische Akademie der Wissenschaften, I938-40 Archivar Erzbischöfliches Ordinariatsarchiv Freiburg i. Br.“. Die Beendigung seiner Arbeit im Dienste der Wiener Akademie im Jahr 1938 einerseits und sein Überwechseln in die badische Heimat in demselben Jahr andererseits sind angesichts dieses für Österreichs Schicksal entscheidenden Jahres zumindest des Bemerkens wert. Macht man sich im einzigen, von Alphons Lhotsky verfassten Nachruf kundig ${ }^{4}$, dann ist dort zu dieser Übersiedlung lediglich zu lesen: „Im Frühjahr I 938 verließ H. Wien, um eine Archivarstelle beim Erzbischof von Freiburg i. Br. anzunehmen. "Weshalb Heilig Wien gerade im Frühjahr I 938 , also offenbar im zeitlichen Umkreis des „Anschlusses“, der bisherigen österreichischen Hauptstadt, in der er seit 1929 gelebt hatte, den Rücken kehrte, wird von Lhotsky nicht thematisiert. Indessen findet sich einige Zeilen zuvor ein Hinweis auf Heiligs „eigenartige, aber wertvolle Schrift über das Kruckenkreuz (,Österreichs neues Symbol', I934)“. Für den, der weiß, dass der am I. Mai 1934 offiziell proklamierte autoritäre Ständestaat das als Symbol der 1933 gegründeten „Vaterländischen Front“ entworfene Kruckenkreuz auch zu seinem Symbol erhoben hat ${ }^{5}$, der ahnt, dass der Verfasser einer diesem „Zeichen" gewidmeten Schrift sich jenem Österreich verbunden gefühlt hat, das als eigenes Staatsgebilde auszulöschen bzw. an Deutschland anzuschließen erklärtes Ziel der dort seit 1933 die Macht in Händen haltenden Nationalsozialisten gewesen ist. Notwendigerweise konnte für einen dezidierten Anhänger von Österreichs Eigenstaatlichkeit, zumal wenn er deutscher Staatsbürger war, seit dem Frühjahr 1938 kein Verbleiben mehr sein. Dass Heilig aber in ebendieses nationalsozialistische Deutschland zurückkehrte, verwundert denn doch. Schlägt man den Bogen von Heiligs Lebensweg weiter bis hin zum Jahr I944, in dem sein von Heinrich Appelt zu Recht als eindrucksvolle Leistung bezeichnetes Werk über „Ostrom und das Deutsche Reich“ erscheinen konnte, dann lässt ein Blick in eben dieses Werk erneut erstaunen. Dies weniger deswegen, weil es in einen Band der „Schriften des Reichsinstituts für ältere deutsche Geschichtskunde“ (wie die in Berlin angesiedelten Monumenta Germaniae Historica seit 1935 hießen) Aufnahme fand ${ }^{6}$; bemerkenswerter ist vielmehr die Tatsache, dass der Herausgeber des Sammelbandes, der seit

4 Lhотsкy, Heilig (wie Anm. 2).

5 Vgl. Ernst Hanisch, Politische Symbole und Gedächtnisorte, in: Handbuch des politischen Systems Österreichs: Erste Republik 1918-1933, hg. v. DEms., Emmerich TÁlos, Hans Dachs, Anton Staudinge R (Wien 1995) 421-430, hier 427 [Kruckenkreuz gegen Hakenkreuz].

6 Konrad Josef Heilig, Ostrom und das Deutsche Reich um die Mitte des 12. Jahrhunderts. Die Erhebung Österreichs zum Herzogtum 1156 und das Bündnis zwischen Byzanz und dem Westreich, in: DERs., Theodor Mayer, Carl Erdmann, Kaisertum und Herzogsgewalt im Zeitalter Friedrichs I. Studien zur politischen und Verfassungsgeschichte des hohen Mittelalters (Schriften des Reichsinstituts für ältere deutsche Geschichtskunde [Monumenta Germaniae Historica] 9, Stuttgart 1944) 1-271. 
I942 an der Spitze des Reichsinstituts stehende Präsident, Theodor Mayer, ein gebürtiger Österreicher, sich ausdrücklich zu jenen Historikern zählte, die sich dem von Heilig einst vehement bekämpften gesamtdeutschen Gedanken verschrieben hatten ${ }^{7}$.

II.

Der „Anschluss“ Österreichs bedeutete freilich nur einen von vielen Einschnitten in Heiligs Leben, das, als er unmittelbar vor Ende des Krieges, am 6. Mai I 945 in einem Tal der Dolomiten den Tod fand, lediglich 38 Jahre gedauert hatte. Zunächst schien sein Lebensweg ausgesprochen geradlinig zu verlaufen ${ }^{8}$. Geboren wurde er am I4. März I 907 in dem großen, unmittelbar an der Grenze zum schweizerischen Kanton Schaffhausen gelegenen, zum badischen Klettgau zählenden Weinbaudorf Erzingen (Kreis Waldshut)9 ${ }^{9}$ Sein Vater Alois Heilig war Kaufmann und sah sich angesichts dieses Berufes aus der das Dorf prägenden Schicht der Bauern herausgehoben. Hinzu kam, dass er weder aus Erzingen und dem umgebenden Klettgau, ja auch nicht aus einer anderen Landschaft des Alemannisch sprechenden Südbaden, sondern aus dem äußersten Norden Badens stammte, wo man Fränkisch sprach und einer leichteren Lebensart zuneigte. Dagegen entstammte die Mutter, Maria geb. Siebler, einer eingesessenen Erzinger Familie. Wie in anderen, vom Katholizismus geprägten ländlichen Gegenden, wurde für einen aufgeweckten Knaben in erster Linie der Beruf des Pfarrers in Erwägung gezogen. So auch für den jungen Konrad Josef Heilig. Dies umso mehr, als ein Bruder des Vaters, Wendelin Heilig (29. Juli I 88oI9. Mai I93 I), Geistlicher geworden war und seit I9I6 in Müllheim, im evangelischen Markgräflerland, d. h. in der „Diaspora“, als Pfarrer wirkte ${ }^{10}$. Das Vorbild des geistlichen Onkels mag im Übrigen auch dazu beigetragen haben, dass Konrad Josefs älterer Bruder Hermann Josef (1905-1934) Schulbruder in der Privatlehranstalt der „Brüder von der christlichen Lehre“ in dem zwischen Freiburg und Offenburg gelegenen Ettenheimmünster geworden war. So war es geradezu selbstverständlich, dass der dreizehnjährige Konrad Josef in ein auf den Priesterberuf vorbereitendes „Knaben-Konvikt“ geschickt wurde, von dem aus er ein Gymnasium zu besuchen in der Lage war. Für „Knaben“ aus

\footnotetext{
7 Über ihn siehe Helmut Maurer, Theodor Mayer (1883-1972). Sein Wirken vornehmlich während der Zeit des Nationalsozialismus, in: Österreichische Historiker 1900-1945. Lebensläufe und Karrieren in Österreich, Deutschland und der Tschechoslowakei in wissenschaftsgeschichtlichen Porträts, hg. v. Karel Hruza (Wien/ Köln/Weimar 2008) 493-530.

8 Vgl. die Literatur in Anm. 2.

9 Zu Erzingen vgl. Wilhelm Hugo Mayer, Heimatbuch für den Amtsbezirk Waldshut (Waldshut 1926) 194199, und Hans Matт-Willmatt, Erzingen, in: Die Chronik des Kreises Waldshut (Waldshut 1957) 38-39. 10 Nachruf in: „Nekrologium Friburgense“, in: Freiburger Diözesan-Archiv (= FDA) 64 (1936) 13.
} 
dem Kreis Waldshut kam dafür am ehesten das „Konradihaus“ genannte „Erzbischöfliche Gymnasialkonvikt St. Konrad“ in Konstanz infrage ${ }^{11}$. Es lag nahe am See, am Ostrand der Altstadt, gegenüber dem einstigen Dominikanerkloster, das im I 4. Jahrhundert Wirkungsstätte Heinrich Seuses gewesen war. Um vom „Konradihaus“ zum I9I I jenseits des Seerheins neu erbauten Gymnasium zu gelangen ${ }^{12}$, mussten die „Konradihäusler“ an jedem Schultag die Rheinbrücke benützen und konnten sich stets erneut an dem weit über den See bis zum Säntis oder den Vorarlberger Alpen schweifenden Blick erfreuen. Am I 2. September 1920 trat Heilig in die Untertertia des Konstanzer Gymnasiums, des heutigen altsprachlichen „Heinrich Suso-Gymnasiums“ ein ${ }^{13}$. Zwei Jahre später starb sein Vater; das hatte unter anderem zur Folge, dass seine Mutter nach Müllheim zog, wo ihr Schwager als Stadtpfarrer wirkte. Nicht mehr das noch einigermaßen nahe bei Konstanz gelegene Erzingen, sondern Müllheim, jenseits des Schwarzwaldes, südlich von Freiburg gelegen, wurde bis zum Tod seiner Mutter (1934) zur Heimat des insgesamt sechs Jahre in Konstanz zur Schule gehenden Konrad Josef Heilig. Im dortigen „Konradihaus“ begegnete er in dessen Rektor und seinen Präfekten drei bedeutenden Priesterpersönlichkeiten: Rektor war Matthäus Lang, von dem es in einem Nachruf hieß ${ }^{14}$, er sei „einer der verdienstvollsten Erzieher des theologischen Nachwuchses der Erzdiözese Freiburg und eines größeren Kreises der studierenden Jugend überhaupt“ gewesen. „Das Konradihaus war sein Leben und sein Reich."Als Präfekten erlebte Heilig zunächst Hugo Hermann ${ }^{15}$. Hermann wechselte freilich schon 1922 als Kaplan an den „Campo Santo Teutonico“ in Rom und promovierte 1925 in Freiburg zum Dr. theol. Ihm folgte als Präfekt im „Konradihaus“ Emil Rümmele ${ }^{16}$. Ihm, der im Jahr I 938 mit einer Dissertation über das erstaunlich moderne Thema „Der Spielfilm als pastoraltheologisches Problem“ promovierte, wird nicht nur ein „geistreicher Humor“, sondern auch ein „weitgehender Einfluss auf alles, was das Leben im Haus betraf“ nachgerühmt, „wobei es ihm immer gelang, den goldenen Mittelweg zwischen nötiger Strenge und ebenso nötiger Güte und Geduld zu finden“. Am Konstanzer Gymnasium legte der von solchen Priesterpersönlichkeiten Geprägte am 19. März 1926, ausgezeichnet mit dem ersten Klassenpreis, das Abitur ab. Positiv aufgefallen war der Gymnasiast Heilig schon vorher dadurch, dass er sich

11 Über das „Konradihaus“ vgl. „Heimatklänge aus Konradingen. Sondernummer 1866 (1901)-1926“ (Kons$\operatorname{tanz} 1926)$.

12 Vgl. Theodor Humpert, Heinrich-Suso-Gymnasium Konstanz. Jubiläumsschrift zur Feier des 350-jährigen Bestehens (Konstanz 1954) 24-27.

13 Balcar, Heilig (wie Anm. 2) 2, Abschnitt H 2.

14 Nachruf in: „Necrologium Friburgense“, in: FDA 71(1951) 221-223.

15 Nachruf in: „Necrologium Friburgense“, in: FDA 106 (1986) 379.

16 Nachruf aus der Feder von Heiligs einstigem Klassenkameraden Erwin Kelle R in: „Necrologium Friburgense“, in: FDA 106 (1986) 284-287. 
mit Keilschriften und mit ägyptischen und hethitischen Hieroglyphen befasst hatte ${ }^{17}$. Conabiturient in der Parallelklasse war im Übrigen der Kreuzlinger Emil Staiger, der später berühmt gewordene Zürcher Literaturhistoriker ${ }^{18}$. Als das „Konradihaus“ wenige Monate später, am 2. August I 926 das „Silberjubiläum“ seines I 90 I errichteten Neubaus feierte, fand sich in der Liste der „Zöglinge“, die in die zu diesem Anlass erschienene Festschrift Aufnahme gefunden hatte, auch folgender Eintrag: „Nr. I 8 I Heilig, Konrad, Erzingen, I920/26 stud. Theol. Freiburg" ${ }^{19}$. Einige Seiten später war darüber hinaus zu lesen: „Beim Feste waren außer den jetzigen Vorstehern folgende Herren im Hause anwesend: [...] Heilig, Konrad.“20

Heilig hatte also, wie von einem „Zögling“ des Konstanzer „Erzbischöflichen Gymnasialkonvikts" nicht anders zu erwarten war, im Sommer 1926 an der Universität Freiburg das Studium der Theologie aufgenommen ${ }^{21}$. Wiederum bildete seine tägliche „Heimat“ ein Konvikt, das „Erzbischöfliche Theologische Konvikt" „Collegium Borromaeum“ (= CB), von dem aus er in beinahe täglichem Gang durch die Altstadt Freiburgs, vorbei am gotischen Münster, zusammen mit anderen Theologiestudenten, die Lehrveranstaltungen in dem I9I I neu errichteten Kollegiengebäude besuchte, an dessen Giebel die Inschrift „Die Wahrheit wird Euch frei machen“ zu lesen war.

Als Angehöriger seines „Ersten Kurses“ im CB konnte er durchweg gute bis sehr gute Noten vorlegen ${ }^{22}$. Und nicht anders lautete die Bewertung seiner Leistungen in den nächsten Kursen. Nur im „Vortrag“ und in „Moraltheologie“ waren seine Noten etwas schlechter. Zum Sommersemester 1929 berichtete die Direktion des CB an das Erzbischöfliche Ordinariat dies: Von den zur Erweiterung ihrer Studien Beurlaubten hat Konrad Josef Heilig bei Professor Finke mit einer Arbeit über Langenstein "magna cum laude“ promoviert [...] Heilig wird zum Wintersemester in den Dritten Kurs zurückkehren. Im Bericht des CB über das Wintersemester I929/30 steht dann aber zu lesen: Am Ende der Herbstferien reichte K. H. sein Austrittsgesuch ein. Woraufhin das Ordinariat dem CB am 6. November 1929 antwortete: Wir nehmen Kenntnis von dem Austritt des Alumnen [...] K.J.H. [...] Dass die zu profanen Studien beurlaubten Konviktoren H. und [...] nunmehr beide der Theologie den Rücken wenden, ist eine beachtenswerte Tatsache. Der Austritt Heiligs aus dem theologischen Konvikt bedeutete zugleich seinen Verzicht auf die Absicht, Priester zu werden.

17 Balcar, Heilig (wie Anm. 2) 1, 16 Anm. 2.

18 Humpert, Gymnasium (wie Anm. 12) 105f.: „Jahrgang 1925/26“.

19 „Heimatklänge“ (wie Anm. 11) 36.

20 Ebd. $52 \mathrm{f}$.

21 UAF, Matrikel A 66/15. Für die Überlassung von Kopien aus dem UAF danke ich Herrn Archivdirektor Prof. Dr. Dieter Speck herzlich.

22 Für das Folgende stütze ich mich auf die im Erzbischöflichen Archiv Freiburg i. Br. verwahrten Unterlagen des CB, deren Inhalt mir Herr Archivdirektor Dr. Christoph Schmider dankenswerterweise zugänglich machte. 
Diesem Schritt, der einem ersten, tief greifenden Einschnitt in Heiligs Lebensweg gleichkam, war im Sommersemester 1929 eine Änderung seiner Fakultätszugehörigkeit vorausgegangen: Am 24. Juni 1929 war er von der Theologischen zur Philosophischen Fakultät übergewechselt. Das war für ihn deswegen nicht allzu schwierig, weil er bislang nicht nur theologische Fächer, sondern auch philosophische, historische und sprachwissenschaftliche Lehrveranstaltungen besucht hatte ${ }^{23}$, darunter vor allem - seit dem Wintersemester 1927/28 - bei dem bedeutenden Mittelalterhistoriker Heinrich Finke, der von I 899 bis zu seiner Emeritierung im Jahr I 928 den katholischen Konkordatslehrstuhl für Geschichte an der Universität Freiburg innehatte und seit I 924 das einflussreiche Amt eines Präsidenten der Görresgesellschaft bekleidete ${ }^{24}$. Am 26. Juli I 929 legte Heilig vor Finke in Geschichte, sodann vor dem ebenfalls einen katholischen Konkordatslehrstuhl innehabenden Professor der Philosophie Martin Honecker ${ }^{25}$ in „Scholastischer Philosophie" und schließlich vor dem Professor der Orientalistik Josef Schacht ${ }^{26}$, bei dem er Arabisch und Syrisch studiert hatte, in semitischer Sprachwissenschaft sein Rigorosum ab; die Wahl des letzteren Faches entsprach seinen schon als Gymnasiast zum Ausdruck kommenden Interesse für alte Sprachen ${ }^{27}$. Sein die Note „magna cum laude“ tragendes Doktordiplom wurde ihm freilich erst am I8. Januar 1933 ausgefertigt ${ }^{28}$, nachdem er die Pflichtexemplare seiner bei Finke eingereichten, einem geistesgeschichtlichen Thema des I 4. Jahrhunderts gewidmeten Dissertation mit dem Titel: „Kritische Studien zum Schrifttum der beiden Heinriche von Hessen“ abgeliefert hatte ${ }^{29}$. Korreferent der Arbeit war Finkes gerade erst, auf I. April I 929 nach Freiburg berufener Nachfolger auf seinem Lehrstuhl, Philipp Funk ${ }^{30}$. Bereits ein Jahr vor seiner Promotion und im Jahr seiner Pro-

23 Lebenslauf im Sonderdruck der in: Römische Quartalschrift (= RQ) 40 (1932) veröffentlichten Dissertation (vgl. Anm. 29), und Balca r, Heilig (wie Anm. 2) 2, Abschnitt H 2.

24 Zu Finke vgl. Die Freiburger Philosophische Fakultät 1920-1960. Mitglieder - Strukturen - Vernetzungen, hg. v. Eckhard Wirbelauer, Frank-Rutger Hausmann, Sylvia Paletschex (Freiburger Beiträge zur Wissenschafts- und Universitätsgeschichte NF 1, Freiburg i. Br. 2006) 917f., und dazu den Nachruf aus der Feder seines einstigen Freiburger Assistenten (1924-1928) und damit wohl auch mit Heilig bekannten Hermann Heimpes, Heinrich Finke. Ein Nachruf, in: HZ 160 (1939) 534-545, Nachdruck in: Hermann Heim pel, Aspekte (Göttingen 1995) 186-197, hier 187 „als anregender, ja anpeitschender, wohl auch gefürchteter Lehrer“ und 196 „wissenschaftlich“ als „ein großer Finder, Anreger, ja Aufreger“ charakterisiert.

25 Zu Honecker siehe Freiburger Philosophische Fakultät (wie Anm. 24) 941.

26 Zu Schacht siehe Freiburger Philosophische Fakultät (wie Anm. 24) 992.

27 Vgl. Heiligs Lebenslauf im Separatdruck der 1932 erschienenen Dissertation und BALcAR, Heilig (wie Anm. 2) 2, Abschnitt H 2.

28 Das Diplom im UAF, D 29/49/1441.

29 Konrad Josef Heilig, Kritische Studien zum Schriftum der beiden Heinriche von Hessen, in: RQ 40 (1932) 105-176.

30 Zu Funk siehe Freiburger Philosophische Fakultät (wie Anm. 24) 922, und dort noch nicht vermerkt Roland 
motion hatte Heilig erste wissenschaftliche Aufsätze veröffentlicht, die sogleich seine weit gespannten, von der heimatlichen Kirchengeschichte bis zur Theologie- und Philosophiegeschichte reichenden wissenschaftlichen Interessen unter Beweis stellten ${ }^{31}$.

Heilig hatte sich mit seiner Dissertation und seinen ersten wissenschaftlichen Publikationen als Mittelalter-Historiker ausgewiesen. Er war nicht - wie lange Zeit beabsichtigt - Theologe oder gar Priester geworden, wenngleich die Wahl seiner Promotionsfächer letztlich unmittelbar aus dem Studium der Theologie erwachsen war.

III.

Im Oktober 1929 siedelte Heilig nach Wien über. Der Abschied von der vertrauten Heimat im südlichen Baden bedeutete einen neuerlichen und - wie sich bald zeigen sollte - folgenreichen Einschnitt in seine Biografie. Grund gelegt wurde dieser Wechsel letztlich durch seine Beschäftigung mit Heinrich von Langenstein (vor I363-I397), der „zweifellos zu den bedeutendsten Gelehrten seiner Zeit“ gehörte ${ }^{32}$. Er war I 384 von Herzog Albrecht III. von Österreich an die Universität Wien berufen worden, an der er schließlich I 393/34 gar zum Rektor aufgestiegen ist. Heiligs Verdienst war es, in seiner Dissertation „Heinrichs Werke von denen seines hessischen Landsmannes, des Kartäusers Heinrich von Altendorf (gest. I427), präzis zu trennen. Heiligs mustergültige Untersuchung ist auch heute noch Ausgangsbasis für jede Beschäftigung mit Biographie und Werken Heinrichs von Langenstein. “33

Mit Heinrich von Langenstein hatte Heilig zugleich ein Thema österreichischer Geistesgeschichte des I 4. Jahrhunderts angesprochen. Für seinen Doktorvater Finke, der unter anderem der Wiener Akademie der Wissenschaften als korrespondierendes Mitglied angehörte, lag es nahe, seinen Schüler angesichts von dessen Interessen zur Aufnahme in einen Kurs des Österreichischen Instituts für Geschichtsforschung (ÖIG) in Wien zu empfeh$\operatorname{len}^{34}$. Die Aufnahmeprüfung, abgenommen von Oswald Redlich, Alfons Dopsch, Hans

Engelhart, „Wir schlugen unter Kämpfen und Opfern dem Neuen Bresche“. Philipp Funk (1884-1937). Leben und Werk (Europäische Hochschulschriften III, 695, Frankfurt/M. u.a. 1996).

31 Konrad Josef Heilig, Zur Geschichte des Konstanzer Bischofs Gerhard von Bevar, in: ZGORh NF 42 (1928/29) 115-131; Ders., Zum Tode des Johannes Duns Scotus, in: HJb 49 (1929) 641-645.

32 Thomas Нонmann, Georg Kreuzer, Heinrich von Langenstein, in: VL 3 (Berlin/New York 1981) Sp. 763-774, hier Sp. 764.

33 Georg Kreuzer, Heinrich von Langenstein. Studien zur Biographie und zu den Schismatraktaten unter besonderer Berücksichtigung der Epistola pacis und der Epistola concilii pacis (Quellen und Forschungen aus dem Gebiet der Geschichte NF Heft 6, Paderborn/München/Wien/Zürich 1987) 46.

34 Vgl. das Schreiben Heinrich von Srbiks vom 22.01.1940 an das Erzbischöfliche Ordinariat Freiburg i. Br., Erzbischöfliches Archiv Freiburg i. Br., Akte „B 2 - 8/43 Generalia Erzbistum Freiburg. Rubrik: Behörden. 
Hirsch und Julius von Schlosser fand am 5. Juli 1929 und damit noch vor der am 26. Juli in Freiburg abzulegenden mündlichen Doktorprüfung statt ${ }^{35}$. Heilig bestand erfolgreich und sah sich damit als außerordentliches Mitglied in den am 29. Oktober beginnenden 37. Institutskurs aufgenommen, nachdem er sich bereits am I 8. Oktober an der Universität Wien inskribiert hatte. Zu seinen Kurskollegen gehörten unter anderem Anton Julius Walter, Wilhelm Böhm, Taras von Borodajkewycz, Gebhard Rath und - wie Heilig aus Deutschland kommend - Johannes (Pater Ursmar OSB) Engelmann, Hans Götting und Ernst Rieger, die später auf ganz unterschiedliche Weise in Wissenschaft, aber auch in Politik Bekanntheit erlangen sollten.

Aus dem vorausgehenden 36. Institutskurs von I927-1929 lernte er überdies noch einen südbadischen Landsmann kennen, den aus Konstanz gebürtigen Paul Zinsmaier, der im Jahr I930 bei Hirsch über „Die Urkunden Konrads IV.“ promovierte ${ }^{36}$. Zu Hirschs Doktoranden gehörte in etwa derselben Zeit noch ein anderer, aus Heiligs weiterer Heimat, nämlich aus Säckingen stammender junger Historiker, Fridolin Jehle ${ }^{37}$.

Am Wiener Institut nahm Heilig an Lehrveranstaltungen von Hirsch, Dopsch, Otto Brunner, Lothar Groß und Ernst Klebel teil; an der Wiener Universität hörte er darüber hinaus bei Hans Gerstinger (Klassische Philologie, Paläografie und Papyruskunde), Max Jellinek (Deutsche Sprache und Literatur), Alfred Kappelmacher (Klassische Philologie) und Karl Maria Swoboda (Kunstgeschichte) ${ }^{38}$. Nach diesen Studien, die die in Freiburg absolvierten noch um einiges erweiterten, konnte er sich am I4. November I93 I unter Vorlage der schriftlichen Hausarbeit mit dem Titel „Leopold von Wien, der Verfasser der Österreichischen Chronik von den 95 Herrschaften“ zur Institutsprüfung anmelden ${ }^{39}$. Auf

Erzbischöfliche Kanzlei, Betreff: Hilfsarbeiter“, die mir Herr Archivdirektor Dr. Christoph Schmider freundlicherweise zugänglich machte.

35 Das Folgende nach IÖG, Archiv, Akten 37. Ausbildungskurs 1929-1931. Für Kopien danke ich Karel Hruza herzlich. Vgl. auch Balcar, Heilig (wie Anm. 2) 2, Abschnitt H 2; Leo SAntifaller, Das Institut für österreichische Geschichtsforschung. Festgabe zur Feier des zweihundertjährigen Bestandes des Wiener Haus-, Hof- und Staatsarchivs (Veröff. des IÖG 11, Wien 1950) 147; Alphons Lнотsку, Geschichte des Instituts für österreichische Geschichtsforschung 1854-1954 (MIÖG Erg.-Bd. 17, Graz/Köln 1954) 377; Manfred Sтоу, Das Österreichische Institut für Geschichtsforschung 1929-1945 (MIÖG Erg.-Bd. 50, 2007) 316-322 über den 37. Kurs, 320 über das außerordentliche Mitglied Nr. 426 Heilig.

36 Santifaller, Institut (wie Anm. 35) 146; Lнотsкy, Geschichte des Instituts (wie Anm. 35) 375; Stoy, Institut (wie Anm. 35) 50f.; Heinrich Appelt, Paul Zinsmaier †, in: MIÖG 94 (1986) 554-555; Meinrad Scha a , Paul Zinsmaier, in ZGORh 135 (1987) 438-444.

37 Fridolin Jehle promovierte 1931 bei Hirsch mit einer Dissertation über „Die Entwicklung der rechtlichen Beziehungen zwischen Stift und Stadt Säckingen“ (Druck: Säckingen 1933). Über Jehle vgl. Adelheid ENDerle-Jehle, Dr. Fridolin Jehle. Leben und Werk, in: Frühe Kultur in Säckingen, hg. v. Walter Berschin (Sigmaringen 1991) 185-188.

38 Balcar, Heilig (wie Anm. 2) 2, Abschnitt H 2.

39 Siehe den Druck: Konrad Josef Heilig, Leopold Steinreuter von Wien, der Verfasser der sogenannten Öster- 
diesen Autor, der als Augustiner-Eremit an der I 384 errichteten Theologischen Fakultät in Wien lehrte, war Heilig bereits anlässlich seiner Studien über Heinrich von Langenstein aufmerksam geworden, den er in diesem Zusammenhang ausdrücklich als den „größten Gelehrten der habsburgischen Universität im ersten Jahrhundert ihres Bestehens“ bezeichnete $^{40}$. Inzwischen hat die Forschung zwar erwiesen, dass die Identifizierung des Verfassers der Chronik mit dem herzoglichen Hofkaplan Leopold Steinreuter nicht mehr aufrechtzuerhalten ist, dass vielmehr „die von Heilig auf eine einzige Person bezogenen Quellenstellen drei oder doch zwei verschiedenen Personen zuzuweisen " sind ${ }^{41}$. Indessen ändert das nichts an der Bedeutung der grundsätzlichen Ausführungen des „von altphilologischen, theologischen und historischen Studien ausgegangenen Konrad Josef Heilig“42 zu „diese(m) umfangreichste(n) österreichischen Geschichtswerk der 2. Hälfte des I 4. Jahrhunderts“43.

Noch vor dem Ende seiner Ausbildung am Wiener Institut und noch vor der Aushändigung des Freiburger Doktordiploms unternahm Heilig um die Jahreswende I930/3 I den Versuch einer Bewerbung um den Hilfswissenschaftlichen Lehrstuhl an der (katholischen) Universität in Freiburg im Üchtland ${ }^{44}$. Dieser Lehrstuhl war durch den Tod von Franz Steffens (I 853-I930) vakant geworden ${ }^{45}$. Obwohl Heilig den inzwischen in Fribourg lehrenden Professor der Germanistik, den Österreicher Richard Newald, den er vielleicht noch aus dessen Zeit als Privatdozent an der Universität Freiburg im Breisgau (I926-1930) gekannt haben mochte ${ }^{46}$, und dazu noch seinen Erzinger Landsmann, den im Exil auf der Insel Werd im Untersee lebenden einstigen Erzbischof von Bukarest Raymund Netzhammer, als Fürsprecher eingeschaltet hatte ${ }^{47}$ und obgleich auch

reichischen Chronik von den 95 Herrschaften. Ein Beitrag zur österreichischen Historiographie, in: MÖIG 47 (1933) 225-289.

40 Heilig, Leopold (wie Anm. 39) 229, vgl. Kreuzer, Langenstein (wie Anm. 33) 102, Anm. 398.

41 Vgl. Paul Uiblein, Die Universität Wien im Mittelalter (Schriftenreihe des Universitätsarchivs Universität Wien 11, Wien 1999) 338-341, und bereits Ders., Die Quellen des Spätmittelalters, in: Die Quellen der Geschichte Österreichs, hg. v. Erich ZöLlner (Wien 1982) 50-113, hier 102f.

42 Vgl. Alphons Lнотsкy, Quellenkunde zur mittelalterlichen Geschichte Österreichs (MIÖG Erg.-Bd. 19, 1963) 312-314, hier 314 ; DERs., Geschichte (wie Anm. 35) 377, spricht von einer „aufsehenerregenden Studie“.

43 Paul Uiblein in: VL 5 (Berlin/New York 1985) Sp. 716-723, insbes. Sp. 717 und 720, vgl. auch Winfried Stelzer, Landesbewußtsein in den habsburgischen Landen östlich des Arlberg bis zum frühen 15. Jahrhundert, in: Spätmittelalterliches Landesbewußtsein in Deutschland, hg. v. Matthias Werner (VuF 61, Ostfildern 2005) 157-222, hier 218f. mit Anm. 211 und Nachträge 221.

44 Balcar, Heilig (wie Anm. 2) I, 14/15 und 2 Abschnitt H 2.

45 Über ihn Pascal Ladner in: Histoire de l'Université de Fribourg Suisse/Geschichte der Universität Freiburg Schweiz, hg. v. Roland Ruffieux (Fribourg 1991) 689f.

46 Zu ihm siehe Freiburger Philosophische Fakultät (wie Anm. 24) 975.

47 Über ihn Hubert Mатт-Willmatт, Netzhammer, Raymund, in: Badische Biographien 3 (Stuttgart 1990) 194-195. Netzhammer wurde 1931 Ehrenbürger von Erzingen. 
der Ordinarius für mittelalterliche Geschichte Gustav Schnürer sich für ihn eingesetzt hatte $^{48}$, machte im schweizerischen Freiburg doch der Kölner Privatdozent Hans Foerster das Rennen ${ }^{49}$. Die Bewerbung Heiligs legt indessen Zeugnis ab von seiner Selbsteinschätzung. Dass sie nicht unberechtigt war, erwies sich auch daran, dass er - zwischen I930 und 1933 mit dem „Graf Klebelsberg-Kuno-Institut für ungarische Geschichtsforschung" verbunden ${ }^{50}$ - seit I93 I auch Arbeiten zur ungarischen Geistesgeschichte des Spätmittealters publizierte mit der Folge, dass es angesichts dieser seiner Arbeiten um I 933 Bestrebungen gab, ihn für das Fach Mittellatein an die Universität Budapest zu holen ${ }^{51}$, nachdem er schon 1932 an „seinem“ ÖIG mit der Abhaltung eines Kurses für Mittellatein beauftragt worden war $^{52}$.

Zunächst aber hatte er erst einmal seine Abschlussprüfung am Institut abzulegen. Er bestand sie am I7. Dezember I93 I als zweiter von insgesamt I4 Kandidaten mit vorzüglichem Erfolge ${ }^{53}$. Die Prüfungskommission, der er sich gegenübergestellt sah, setzte sich zusammen aus den Herren Hirsch, Redlich, Dopsch, von Schlosser, Groß, Brunner, Ignaz Zibermayr und August von Loehr. Brunner war es auch, der das Gutachten zu Heiligs Hausarbeit über „Leopold von Wien“ verfasste. Sein Gesamturteil lautete so: Die Arbeit, die über das erzielte Ergebnis hinaus unsere Kenntnis der österreichischen Geistesgeschichte des späteren I4. Jahrhunderts erheblich fördert und in methodisch einwandfreier Weise verschiedene Quellenarten heranzieht, ist vorzüglich.

Im Gegensatz zu seinen südbadischen Landsleuten Paul Zinsmaier und Fridolin Jehle, die beide bei Hirsch promoviert hatten ${ }^{54}$, kehrte Heilig, der im Gegensatz zu ihnen seine Dissertation über ein Thema aus der mittelalterlichen Geschichte seines Gastlandes verfasst hatte, nicht in seine Heimat zurück. Möglicherweise fühlte er sich durch seine „österreichischen Arbeiten“ schon zu sehr mit diesem Land verbunden, als dass er an eine Rückkehr nach Deutschland zu denken vermochte. Dies erst recht nicht angesichts dessen, dass er am 25. März 1932 für ein Honorar von monatlich 300 Schilling von der von Redlich präsidierten „Kommission für die mittelalterlichen Bibliothekskataloge Österreichs“ zunächst mit der „Revision und Ergänzung der seinerzeit von [...] Theodor Gottlob gesammelten Materialien für die Länder des heutigen Österreich außer Wien und Niederösterreich“ bzw. „mit der Bearbeitung eines dritten Bandes“ betraut wurde ${ }^{55}$. Bis

48 Über ihn Carl Pfaff in: Ruffieux, Histoire (wie Anm. 45) 686-688.

49 Über ihn Pascal Ladner in: Ruffieux, Histoire (wie Anm. 45) $690 f$.

50 Balcar, Heilig (wie Anm. 2) 1, 25/26 und 50-72.

51 Ebd. 1, 16, Anm. 2.

52 Ebd. 1, 15.

53 Das Folgende nach IÖG, Archiv, Akten 37. Ausbildungskurs 1929-1931.

54 Vgl. oben S. 624.

55 Vgl. Akademie der Wissenschaften in Wien. Almanach für das Jahr 1932. 82. Jg. (1932) 191f. Vgl. Erzbischöf- 
zu seinem „Wegzug“ aus Wien im Frühjahr 1938 bot dieser Arbeitsauftrag die finanzielle Grundlage für Heilig und seine wachsende Familie. Er hatte 1932 geheiratet und bis zu seinem Weggang aus Österreich drei kleine Kinder zu versorgen. Die Arbeiten an der Edition der Bibliothekskataloge brachte es mit sich, dass Heilig eine Vielzahl von Handschriftenbibliotheken aufzusuchen hatte. Neben Graz, Klagenfurt, Innsbruck, Salzburg, Linz, München und mehreren Klosterbibliotheken wie Mondsee und Admont arbeitete er unter anderem auch in Trient und Venedig, so wie er wenige Jahre zuvor auch schon für seine Dissertation in den Bibliotheken und Archiven von Arnheim, Freiburg i. Br., Heidelberg, Karlsruhe, Köln und Mainz ${ }^{56}$ und für seinen „Leopold Steinreuter“ in der Erfurter Amploniana, in der Österreichischen Nationalbibliothek Wien, in der Kölner Stadtbibliothek, in der Universitätsbibliothek Basel und in der Pariser Nationalbibliothek gearbeitet hatte ${ }^{57}$. Bereits im Jahresbericht für I 934 steht zu lesen: „Der Bearbeiter hofft bis Ende des Jahres I934 den 3. Band des Katalogs druckfertig herstellen zu können."58 Für I936 heißt es sodann, dass Heilig „durch länger dauernde Entfernung von Wien am Abschluss der schon weit vorgeschrittenen Arbeiten für den 3. Band etwas gehemmt gewesen sei“59, und für I937: „Da der Bearbeiter Dr. Heilig seit Herbst 1936 wieder dauernd in Wien ist, konnten die Arbeiten [...] reger gefördert werden und gehen ihrem Abschluß entgegen. "60 Für I 938 erschien ein Jahresbericht bemerkenswerterweise nicht ${ }^{61}$. In demjenigen für 1939 ließ Redlich wissen: „Die von dem Bearbeiter Dr. Heilig früher weit geförderten Arbeiten für den 3. Band mußten wegen Verhinderung des Bearbeiters seit längerer Zeit unterbrochen werden"62. Und in seinem Bericht für I 940 klang es nicht viel anders: „Die Arbeiten konnten infolge Behinderung des Bearbeiters nur wenig gefördert werden.“63 Worin diese „Verhinderung“ bzw. „Behinderung“ bestand, wird nicht ausgeführt. Redlich hätte sonst bekennen müssen, dass der Bearbeiter im Frühjahr I 938 Wien und Österreich mehr oder weniger fluchtartig verlassen hatte und in seine südwestdeutsche Heimat zurückgekehrt war. Als dann endlich im Jahr I 96 I der von Gerlinde MöserMersky bearbeitete „III. Band Steiermark“ der „Mittelalterlichen Bibliothekskataloge Österreichs“ erscheinen konnte, wusste Richard Meister als Obmann der dafür zuständigen

\footnotetext{
liches Archiv Freiburg i. Br. „B 2 - 8/43 Generalia Erzbistum Freiburg. Rubrik: Behörden. Erzbischöfliche Kanzlei, Betreff: Hilfsarbeiter“, Schreiben vom 03.04.1940. Siehe auch Anm. 34.

56 Vgl. RQ 40 (1932) 108.

57 Heilig, Leopold (wie Anm. 39) 232 Anm. 13 und 233 Anm. 16.

58 Almanach (wie Anm. 55) 84 (1935) 271.

59 Almanach (wie Anm. 55) 86 (1936) 274.

60 Ebd. 87 (1937) 275.

61 Ebd. 88 (1939) 87.

62 Ebd. 89 (1940) 246.

63 Ebd. 90 (1941) 232.
} 
Akademie-Kommission in seinem Vorwort nur dies zu sagen: „Über die Schicksale des nicht gerade von Glück begünstigten Unternehmens wurde in den Vorbemerkungen zu den beiden ersten Bänden gehandelt. Aber auch in der Folge machte die Arbeit nur sehr langsam Fortschritte. Der Freiburger Diözesanarchivar Konrad Josef Heilig, ein ausgezeichneter Handschriftenkenner, dem die weitere Bearbeitung anvertraut war, kehrte aus dem zweiten Weltkrieg nicht mehr zurück; was er zum Manuskript Gottlobs beigesteuert haben mag, ist verschollen." 64

Im März und April I933, d. h. bald nach der nationalsozialistischen Machtergreifung in Deutschland, hatte Heilig die badische Heimat anlässlich einer im Auftrag der Wiener Akademie unternommenen Bibliotheksreise während etwas mehr als vier Wochen wiedergesehen. Mit dem Direktor der Freiburger Universitätsbibliothek Josef Rest - auch er nebenbei bemerkt ein einer freilich früheren Generation angehörender Schüler Finkes - hatte er noch von Wien aus vereinbart, während dieses Aufenthaltes vom 8. März bis zum I 3. April I 933 gegen Honorar den gesamten lateinischen und deutschen Handschriftenbestand der Freiburger Universitätsbibliothek [...] zu verzeichnen ${ }^{65}$. In seinem aus dem nahen Müllheim, dem Wohnort seiner Mutter, datierten Abschlussbericht an Rest vom I3. April I933 musste er freilich bekennen, daß in solcher Zeit das Material unmöglich zu bewältigen sei; Unterzeichneter konnte nur I20 neue Handschriften beschreiben. Er verpflichtete sich aber, in späterer Zeit, etwa in den Oster-und Großen Ferien 1934 die Arbeit zuende zu fübren und in Wien [...] an der Erweiterung der Kataloge zu arbeiten. Dazu kam es freilich nicht mehr. Aber als Wilfried Hagenmaier I 974 den gedruckten Katalog über „Die Lateinischen mittelalterlichen Handschriften der Universitätsbibliothek Freiburg i. Br. Hs. I-230" herausbrachte, konnte er auch auf die Karteikarten zurückgreifen, die I 933 „durch den Historiker und Publizisten Konrad Josef Heilig“ für insgesamt I 20 Codices angelegt worden waren ${ }^{66}$.

Die Katalogisierung der Freiburger Handschriften führte Heilig nachträglich zu einer vor allem für die Germanistik folgenreichen Entdeckung. Aus Wien konnte er an Direktor Rest in Freiburg am I5. Oktober 1933 Folgendes berichten: Heute habe ich nicht umsonst mal wieder mich hinter die Handschriften Ihrer Bibliothek gemacht und den Haupttreffer aus ihnen gewonnen. Unter den zahlreichen Stücken des Cod. I63 habe ich heute den lateinischen Widmungsbrief des Dichters des Ackermanns aus Böhmen gefunden, worin sich der Verfasser selbst nennt als Johannes de Tepla, wie Bernt, Bartos und Beer gegen Burdach

64 Mittelalterliche Bibliothekskataloge Österreichs 3: Steiermark, bearb. v. Gerlinde MösEr-Mersky (Graz/ Wien/Köln 1961) VII.

65 Das Folgende nach UAF, Bibliotheksakte B 6/585.

66 Wilfried Hagenmaier, Die Lateinischen mittelalterlichen Handschriften der Universitätsbibliothek Freiburg i. Br. (Hs. 1-230) (Wiesbaden 1974) XIII. 
geschlossen haben. Also wieder einmal habe ich, etwas Rares gefunden aus der Bibliothek, wo man so was nicht finden sollte. Noch in demselben Jahrgang der MÖIG 47 von 1933, in dem er bereits seine Institutshausarbeit über „Leopold Steinreuter" veröffentlicht hatte, machte er seine Entdeckung bekannt ${ }^{67}$ : Mit berechtigtem Stolz ließ er die gelehrte Welt wissen, dass er in Codex I63 der Universitätsbibliothek Freiburg, den er sich nach Wien ans ÖIG habe senden lassen, die „bisher für verloren gehaltene Widmung des Werkes in lateinischer Sprache“ gefunden habe: „sie nennt den Autor, [...] es ist Johannes de Tepla. “68 „Durch diese Widmung ist also die Frage nach der Person des Ackermanndichters endgültig entschieden“69. Ja, Heilig behielt sich sogleich „eine auf Grund der vier Saazer Formelbücher anzufertigende Ausgabe aller Briefe aus der Werkstatt des Ackermanns vor [...]; auch die nachfolgende Rhetorik wird von uns ediert werden, die Vorarbeiten, Abschrift der Texte und Versuch einer Ausbesserung der Fehler sind bereits gemacht ${ }^{\text {“70 }}$. Seit diesem Fund Heiligs gilt Johannes von Tepl (Teplá) (ca. I 350-ca. I 4 I 5) unbestritten als Verfasser des Prosastreitgesprächs „Der Ackermann aus Böhmen“71. Heiligs einstiger Freiburger Lehrer Finke war von dessen Fund so sehr beeindruckt, dass er ihm am 23. Januar 1934 schrieb: Sie sind ja ein erstaunlicher Entdecker. Vor Ihnen muß der Finke die Segel streichen ${ }^{72}$. Wie sehr Heilig seinem einstigen Doktorvater in Dankbarkeit verbunden blieb, zeigt sich daran, dass er sich [„Dr. Konrad Josef Heilig, Wien“] in die Tabula Gratulatoria der Finke zu dessen 80. Geburtstag am I3. Juni 1935 von seinen Schülern gewidmeten Festgabe eintragen ließ. Dort ist unter den 1929 von Finke approbierten Dissertationen auch diejenige Heiligs aufgeführt ${ }^{73}$.

IV.

Seit dem Frühjahr 1934 trat neben den kritischen Historiker und Mittellateiner Heilig der politische Publizist, der in Wort und Schrift vehement für den von Engelbert Dollfuß begründeten „christlichen Ständestaat" kämpfte ${ }^{74}$. Welche Gedanken ihn dabei leiteten,

67 Konrad Josef Heılig, Die lateinische Widmung des Ackermanns aus Böhmen, in: MÖIG 47 (1933) 414 426.

68 Ebd. $417 f$.

69 Ebd. 426.

70 Ebd. 418.

71 Vgl. Gerhard Hahn, Johannes von Tepl, in: VL 4 (Berlin/New York 1983) Sp. 763-774.

72 Balcar, Heilig (wie Anm. 2) 2 Abschnitt H 2.

73 Vgl. Heinrich Finke 1855-1935 (Freiburg 1935) 2 und 16.

74 Zum „Ständestaat“ vgl. Ulrich KLuge, Der österreichische Ständestaat 1934-1938. Entstehung und Scheitern (München 1984); zur „Schaffung eines neuen, staatstragenden österreichischen Identitätsprofils“ bzw. einer „neuen Österreich-Ideologie“ im Ständestaat vgl. Gottfried-Karl Kinder m AN N, Österreich gegen Hitler. 
mag seine folgende Aussage vom Juni 1934 zeigen: „Der Kampf gegen die rote Bolschewisierung sowohl wie gegen den Nationalsozialismus ist nichts anderes denn ein Kampf für Christus." ${ }^{75}$

Am I 5. April I 934 veröffentlichte er unter dem Pseudonym Dr. Franz Giehl in der I 933 von deutschen Emigranten begründeten österreichischen Wochenschrift „Der christliche Ständestaat“ (= CS) einen ersten, für ein unabhängiges Österreich eintretenden Artikel mit dem Titel „Hat der österreichische Mensch einen historischen Existenzgrund?"76. Von dieser Wochenschrift ist gesagt worden, dass sich in ihr „die entschiedensten Gegner des Nationalsozialismus und jeden Kompromisses mit ,gesamtdeutschen 'Tendenzen sammelten. Hier waren vor allem Männer führend, die vor Hitler nach Österreich geflohen waren, außer [Dietrich von] Hildebrand selbst Klaus Dohrn, Eugen Kogon, der Historiker Konrad Josef Heilig [...]"77, wobei anzufügen wäre, dass Heilig - im Gegensatz zu den anderen Genannten - nicht aus Deutschland emigriert war. Zur Mitarbeit war er vermutlich durch seinen einstigen Instituts-Kurskollegen Wilhelm Böhm gewonnen worden, der ebenfalls seit I934 im CS veröffentlichte, ja 1936 in dessen Redaktion eintrat $^{78}$. Diesem seinem ersten Artikel im CS ließ Heilig am 6. Mai einen solchen über „Die Zeichen des christlich-deutschen Österreichs“ und am 22. Juli einen weiteren „Zur Frage einer österreichischen Geschichtsauffassung “ folgen. Mit diesen Beiträgen zur Zeitschrift CS, aber auch zur „Reichspost“ oder zu den „Wiener politischen Blättern“ nahm er eine eindeutige Position für ein selbstständiges Österreich ein. Aufsätze mit den Titeln „Um das wahre Deutschtum“79 oder „Einheit und Verschiedenheit im Deutschtum“80 oder „Gesamtdeutsche oder christlich-österreichische Geschichtsauffassung im christlichen

Europas erste Abwehrfront (München 2003) Kap III, 60-101, hier 64 und 87 mit dem Hinweis, „daß deutsche Emigranten vom Range eines Dietrich von Hildebrand und Klaus Dohrn maßgeblich in die ideologische Arbeit des Ständestaates eingebunden waren“. Vgl. auch BALca R, Heilig (wie Anm. 2) 1, 137-146 über die von Heilig bedienten Presseorgane, 180-183 über seine öffentlichen Vorträge und 149-179 sowie 224 über Heiligs politische Ansichten.

75 Balcar, Heilig (wie Anm. 2) 2, 20, Nr. 8: „Gedanken zu einer österreichischen Geschichtsauffassung in katholischem Lichte“.

76 Rudolf Eвnетн, Die österreichische Wochenschrift „Der christliche Ständestaat“. Deutsche Emigration in Österreich 1933-1938 (Mainz 1976), über Heiligs Mitarbeit grundsätzlich 50f. und zu seinen Beiträgen zur Frage einer „österreichischen Geschichtsauffassung“ ebd. 174-179; vgl. auch Martin Kugle R, Die frühe Diagnose des Nationalsozialismus (Europäische Hochschulschriften III 670 (Frankfurt/M. u.a. 1995) Kap. III „Dietrich von Hildebrand und sein Kreis“, hier 123-129 über „Die Gründung der Wochenzeitung ,Der Christliche Ständestaat““. Über Heiligs Mitarbeit vgl. Balca R, Heilig (wie Anm. 2) 1, 143-145.

77 Adam Wandruszka, Österreichs politische Struktur, in: Geschichte der Republik Österreich, hg. v. Heinrich BENEDiKT (München 1977) 289-485, hier 346-348.

78 Eвneth, Wochenschrift (wie Anm. 76) 45.

79 CS vom 02.06.1935.

80 CS vom 09.08.1936. 
und deutschen Österreich? Eine geschichtswissenschaftliche Auseinandersetzung "81 wiesen ihn, den deutschen Staatsanghörigen, als kompromisslosen Kämpfer für Österreichs Unabhängigkeit gegenüber dem nationalsozialistisch gewordenen Deutschland aus. Die ersten Auswirkungen des Nationalsozialismus hatte er bereits während seines Freiburger Aufenthalts im Frühjahr I933 mit eigenen Augen wahrnehmen können. In dem letztgenannten Aufsatz sprach er auch die Gründe an, die ihn zu seinem Eintreten für Österreich geführt hatten: Er wies als „persönliche Bemerkung gegenüber gewißen Einwänden“ darauf hin, „daß es dem Schreiber dieser Zeilen gestattet“ sei, zu bemerken, daß er „im urhabsburgischen und später schwarzenbergischen Klettgau geboren [sei], dessen Geburtsort im berühmten Habsburger Urbar um I 300 verschiedentlich vorkommt ${ }^{82}$, von dessen Ahnen einige sanktblasianische, also vorderösterreichische Dorfvögte waren und im Kampf um die vorderösterreichische Feste Breisach gefallen sind, der in dem seit I 548 vorderösterreichischen Konstanz seine Gymnasialjahre und in dem seit I 368 vorderösterreichischen Freiburg i. Br., an der zweiten österreichischen Universität, und in Wien seine Universitätsjahre verbrachte" ${ }^{83}$. Diese auf seine habsburgisch-vorderösterreichische Herkunft abhebende Aussage ist nicht nur im Blick auf Heiligs Motivation für sein Bekenntnis zu einem eigenständigen Österreich von Interesse; nicht weniger bemerkenswert sind seine landesgeschichtlichen Kenntnisse, die ihn allerdings nicht zu Studien über die mittelalterliche Geschichte seiner heimatlichen Landschaft am Hochrhein veranlasst haben. Der in diesem „Bekenntnis“ enthaltene Hinweis auf seine familiäre Verankerung im „Land zwischen Schwarzwald und Randen" 84 beruhte auf seinen eigenen genealogischen Forschungen zur Herkunft seiner Familie. Die Ergebnisse seiner bis ins I6. Jahrhundert zurückreichenden Nachforschungen hatte er 1933 in Wien aus Anlass der Geburt seines ersten Kindes in Form von Ahnen- bzw. Stammtafeln niedergelegt ${ }^{85}$.

Angesichts dieser seiner historisch begründeten persönlichen Affinität zum Hause Habsburg und zu Österreich sah sich Heilig geradezu „zum Aufbau einer österreichischen Geschichtsauffassung“ gezwungen, die auf der „wissenschaftliche(n) Erkenntnis der Existenz einer österreichischen politischen Gemeinschaft von bald Iooo Jahren und ihre(r) besonderen Bedeutung im Rahmen der abendländischen Christenheit in Vergangenheit

81 CS vom 23.08.1936.

82 Das Habsburgische Urbar 1, hg. v. Rudolf MaAg (Quellen zur Schweizer Geschichte XIV, Basel 1894$) 87$. Das „Amt Krenkingen“, zu dem das Habsburger Urbar Erzingen zählt, war vermutlich erst von König Rudolf von Habsburg angekauft worden.

83 CS vom 23.08.1936 „Gesamtdeutsche oder christlich-österreichische Geschichtsauffassung im christlichen und deutschen Österreich“. Vgl. Balcar, Heilig (wie Anm. 2) 1, 17.

$84 \mathrm{Zu}$ diesem Landschaftsbegriff vgl. Helmut MAUr ER, Das Land zwischen Schwarzwald und Randen im frühen und hohen Mittelalter (Forschungen zur Oberrheinischen Landesgeschichte 16, Freiburg i. Br. 1965) $17 f$.

85 Bei Balcar, Heilig (wie Anm. 2) 2 Abschnitt H 1. 
und Gegenwart“ beruhe. Er wolle „diese österreichische Geschichtsbetrachtung einbauen in die große ewige, katholische Idee“. Die katholische Einheit sei „die vollkommenste“, „vollkommener als jede andere, auch nationale, auch deutsche Einheit“. Eine „starre Bindung an Blut, Boden, Rasse, Volk“ könne nicht infrage kommen ${ }^{86}$. Das war eine eindeutige „Kriegserklärung“ gegen die Ideen des Nationalsozialismus. Die hier von Heilig vertretene „österreichische Geschichtsauffassung“ wandte sich aber auch dezidiert gegen eine "gesamtdeutsche Geschichtsbetrachtung", wie sie etwa Heinrich von Srbik vertrat ${ }^{87}$. Srbik hatte am 9. April I934 an seinen Berner Kollegen Werner Näf geschrieben: Ich kenne nur eine gesamtdeutsche, nicht eine separatistische deutsche Kultur, bin vielleicht mehr Österreicher als die patentierten Wortführer es sind, aber ich bin auch Deutscher durch und durch ${ }^{88}$. Und am I6. März I936 schrieb er an seinen Freiburger Kollegen Gerhard Ritter: Wir beide [...] sind uns der Dienstpflicht gegenüber unserem Volk bewußt. Diese Pflicht besteht für mich in Österreich nicht zuletzt darin, dem Separatismus und der Isolierung eines österreichischen Geschichtsbewußtseins entgegenzutreten $[\ldots]^{89}$.

Einen ersten Höhepunkt von Heiligs gegen ebendiese Sicht gerichteten politischpublizistischen Kampfes für ein eigenständiges Österreich hatte schon im Jahr 1934 die Veröffentlichung der als selbstständige Broschüre erscheinenden Arbeit über „Österreichs neues Symbol. Geschichte und Bedeutung des Kruckenkreuzes“ bedeutet, sie erlebte I 936 noch eine weitere Auflage ${ }^{90}$. Das als Symbol der 1933 gegründeten Vaterländischen Front entworfene „Kruckenkreuz“ war offiziell auch zum Symbol des autoritären österreichischen Ständestaates erhoben worden ${ }^{91}$. Im „Vorwort“ seiner Untersuchung über die Geschichte des „Kruckenkreuzes“ schildert der Verfasser seine Absicht so: „Zwei Zeichen sind heute Symbole der beiden deutschen Staaten, ja zweier gegensätzlicher Welt-

86 CS vom 23.08.1936; Text bei Balcar, Heilig (wie Anm. 2) 1, 17/18; zum folgenden ebd. 149-169.

87 Vgl. zum Folgenden grundsätzlich Eвnетн, Wochenschrift (wie Anm. 76) 176-179; Anton Staudinger, Zur „Österreich“-Ideologie des Ständestaates, in: Das Juliabkommen von 1936. Vorgeschichte, Hintergründe und Folgen. Protokoll des Symposiums in Wien am 10. und 11. Juni 1976 (Wissenschaftliche Kommission des Theodor-Körner-Stiftungsfonds und des Leopold-Kunschak-Preises zur Erforschung der österreichischen Geschichte der Jahre 1927 bis 1938 4, München 1977) 198-240.

88 Vgl. Heinrich von Srbik. Die wissenschaftliche Korrespondenz des Historikers, hg. v. Jürgen KämmERER (Deutsche Geschichtsquellen des 19. und 20. Jahrhunderts 55, Boppard 1988) Brief Nr. 239, 398: zur politischen Lage in Österreich.

89 Ebd. Brief Nr. 274, 440.

90 Dazu auch Balcar, Heilig (wie Anm. 2) 1, 172-179.

91 Zur Bedeutung des Kruckenkreuzes vgl. Christian Böнm-Ermolli, Politische Symbole im Austrofaschismus und Nationalsozialismus. 1934/1938/1945, in: Österreichs politische Symbole, hg. v. Norbert Leser, Manfred Wagner (Wien/Köln/Weimar 1994) 65-80, hier 75; Hanisch, Politische Symbole (wie Anm. 5) 421430, hier 427; DERs., Der politische Katholizismus, in: Austrofaschimus, hg. v. Emmerich TAlos, Wolfgang Neuge bauer ( ${ }^{4} 1988$ ) 53-73, hier 61; Peter Diem, Die Symbole Österreichs (Wien 1995) 273-276: „Das defensive Kruckenkreuz“. 
anschauungen im deutschen Volke geworden, Kruckenkreuz und Hakenkreuz. Diese ,nordische Sonnenrune', die heute über dem Dritten Reiche weht, gilt in weiten Kreisen [...] als Symbol der nordischen, vorzeitlichen und heidnischen Rasse, von der angeblich alle Kultur der ganzen Welt abstammt. [...] Als es seine Herrschaft auch über Österreich auszudehnen drohte, setzte dieses ihm ein anderes, am Kreuze Christi geadeltes Zeichen entgegen, das Kruckenkreuz, das im christlichen Mittelalter höchste Ideale des Abendlandes und des Rittertums verkörperte [...].“

Angesichts dieser pro-österreichischen „Kampfschrift“ verwundert es nicht, dass die „Notgemeinschaft der Deutschen Wissenschaft“ (die heutige „Deutsche Forschungsgemeinschaft"), die im Rahmen der „Deutsch-Österreichischen Wissenschaftshilfe“ auch an die beiden in Österreich lebenden jungen Historiker bzw. Rechtshistoriker Konrad Josef Heilig und Hans Lentze Stipendien verliehen hatte, im selben Jahr 1934 beiden eine weitere Unterstützung versagte. Hirsch, seit dem I. Oktober I 929 als Nachfolger Redlichs wirkender Vorstand des ÖIG ${ }^{92}$, der den ebenfalls I 929 als außerordentliches Mitglied in das Institut eingetretenen und I93 I von ihm mit-geprüften Heilig aufs Beste kannte, setzte sich, nachdem die Angaben, die zur Maßregelung der beiden Herren geführt haben, offenbar aus dem Kreis von Mitgliedern des Instituts stammten, bei Friedrich Schmidt-Ott, dem Präsidenten der „Notgemeinschaft“, mit Schreiben vom I6. Mai 1934 für Heilig ein: Der Fall des Dr. Heilig aber geht mir persönlich nahe, da es sich hier um einen ausserordentlich wertvollen jungen Gelehrten handelt, der bereits grosse Erfolge errungen hat. Eben jetzt im letzten Heft unserer Mitteilungen ist wieder ein kurzer Aufsatz von ihm erschienen, der ihn weit über das deutsche Kulturgebiet hinaus bekannt machen wird, da ihm die endgültige Feststellung des Verfassers der berühmten frühhumanistischen Dichtung,Der Ackermann aus Böhmen' geglückt ist. In Heilig erwächst der deutschen Wissenschaft ein vollwertiger Vertreter der mittellateinischen Philologie, die nach den ersten Erfolgen unter Traube, Winterfeld, Strecker und W. Meyer (Göttingen) nun gänzlich ohne Fortsetzer dazustehen scheint ${ }^{3}$. An Finke schrieb Hirsch zwei Tage später über dessen einstigen Freiburger Doktoranden Heilig nicht weniger lobend: Seine wissenschaftliche Entwicklung verläuft ja wirklich den Erwartungen gemäß, die Sie von allem Anfang im Bezug auf seine Leistungsfähigkeit hegen durften. Für uns hier ist er wertvoll durch seine Arbeiten zur spätmittelalterlichen österreichischen Geschichte. Die Entdeckung in der Universitätsbibliothek Freiburg im Breisgau, durch die die Verfasserfrage für die frühhumanistische Dichtung, Der Ackermann aus Böhmen' endgültig geklärt wird, dürfte seinen Namen über das deutsche Kulturgebiet hinaus schon jetzt bekannt

92 Vgl. Andreas H. ZajIC, Hans Hirsch (1878-1940). Historiker und Wissenschaftsorganisator zwischen Urkunden- und Volkstumsforschung, in: Österreichische Historiker (wie Anm. 7) 307-417, hier 331.

93 Brief in IÖG, Archiv, NL Hans Hirsch; die Kenntnis seines Textes habe ich Karel Hruza zu verdanken. Vgl. auch Stoy, Institut (wie Anm. 35) 102. 
machen. Leider ist es im Zusammenhang mit den politischen Wirren dazu gekommen, daß ihm vor etwa zwei Wochen das Stipendium der Deutsch-Oesterreichischen Wissenschaftshilfe eingestellt wurde ${ }^{94}$.

Beide Schreiben lassen zum einen erkennen, wie sehr die politischen Ereignisse des Frühjahrs I 934 auch die Wiener Historiker berührt hatten, und zum andern, dass ein politisch auf der Gegenseite, der gesamtdeutschen nämlich, stehender Gelehrter wie Hirsch sich so objektiv für den die Österreich-Idee propagierenden Heilig einsetzte. Dies gilt auch im Blick auf Hirschs Fürsprache für den jungen, aus Schlesien stammenden deutschen Rechtshistoriker Hans Lentze, der 1933 zur Unterstützung Hans von Voltelinis bei dessen Ausgabe des Schwabenspiegels nach Wien gekommen war. Von ihm heißt es in einem Nachruf, dass er nach seinem 1934 erfolgten Übertritt zur katholischen Kirche „die Grundlagen für eine lebenslange, existentielle Verbindung mit Österreich, das dem Schlesier nachmals zur Heimat werden sollte", gelegt habe ${ }^{95}$. Wenn man „Schlesien“" durch „Baden“ ersetzen würde, könnte diese Aussage ebenso auch für den gleichfalls wie Lentze im nationalsozialistischen Deutschland missliebig gewordenen und als nicht mehr förderungswürdig betrachteten Heilig Gültigkeit beanspruchen.

Hirsch konnte vermutlich nicht wissen, dass Heilig in ebendiesem Jahr I 934 ein Werk weitgehend vollendet hatte, das den Titel „Das Werden der österreichischen Idee im Mittelalter" sowie die Titelzusätze „Bearbeitet von Dr. Konrad Josef Heilig“ und „Mit einem Exkurs über die Echtheit des Privilegium minus und anderen Anhängen“ tragen sollte96. Dieses bis I 526 reichende Werk, zu dem Heilig zweifellos durch seine Arbeiten zur österreichischen Chronistik angeregt worden war, hätte bereits $1935 \mathrm{im}$ „Reinhold-Verlag, Wien“, dann $1936 \mathrm{im}$ „Verlag Gsúr und Co., Wien“ erscheinen und die Widmung tragen sollen: „Dem Andenken des Erweckers und Blutzeugen der österreichischen Idee, Bundeskanzler Dr. Engelbert Dollfuß, geweiht“. Allerdings war Heilig noch bis März 1937 mit Korrekturen befasst. Gedacht war das Buch als Habilitationsschrift. Dass die Arbeit an diesem Werk auch politisch gewünscht war, vermerkte Heilig selbst mit dem Hinweis, dass er etwas Geld bekomme, das vom Staatssekretär [Hans] Pernter [1887-I95 I] mir persönlich für Studien zu einer österreichischen Geschichtsauffassung, die ich in einer im Druck liegenden Habilitationsschrift mit allem Raffinement modernster Historiker entwickeln will, verliehen wurde ${ }^{97}$. Schon am I 5 . August 1935 hatte Pater Virgil Redlich aus Seckau an ihn geschrieben: ... mit Freude hörte ich, daß Sie sich nun habilitieren werden ${ }^{98}$. Die Habilita-

94 IÖG, Archiv, NL Hans Hirsch.

95 Werner Ogris, Hans Lentze $\dagger$, in: ZRG GA 88 (1971) 508-517, hier 509.

96 Zum Folgenden Balcar, Heilig (wie Anm. 2) 1, 16, Anm. 2 und 127 Anm. 1 sowie vor allem 199 mit Anm. 3.

97 Ebd. 2 Abschnitt H 2 vom 10.07.1935.

98 Ebd. 2 Abschnitt $\mathrm{H} 2$. 
tion zu betreuen hatte sich der Grazer Neuzeithistoriker Hugo Hantsch bereit erklärt ${ }^{99}$. Das verwundert nicht, denn ähnlich wie Heilig vertrat „der Antinazi und Anschluß-Gegner Hugo Hantsch“ eine „großdeutsche Position alten Stils“, sah den „Führungsanspruch allein bei Österreich“ und sprach sich überdies „für das ständestaatliche Österreich“ aus. „Wie Hantsch so schwärmte auch Konrad Josef Heilig mit deutlich katholisch-imperialem Akzent von Österreich als dem wahren Träger der Reichsidee. Seine historiographische Konstruktion richtete sich gegen die völkisch-imperialistische Reichsidee der Nationalsozialisten. Für Heilig war das entscheidende Beiwort ,katholisch` und nicht mehr ,deutsch'; mit der großdeutschen Ideologie hatte aber auch seine Position den Reichsgedanken sowie die Verkündigung einer Führungsaufgabe des deutschsprachigen Österreichs in Mitteleuropa gemein." 100

Hantsch schrieb am 6. März I936 an Heilig: Ich habe immer noch den Wunsch, Sie $z u$ habilitieren ${ }^{101}$, eine Absicht, die noch Jahrzehnte später von Fritz Posch bestätigt wurde $^{102}$. Angesichts der prononciert katholisch-österreichischen Geschichtsauffassung ihres Autors bestand aber offenbar weder in Graz, noch gar in Wien die Möglichkeit, dass das Werk als Habilitationsschrift akzeptiert werden würde. Dies umso weniger, als der Gsúr-Verlag, in dem 1936 auch die zweite, verbesserte, mit „Wien, am 8oo. Todestag St. Leopolds, dem I 5 . November I936" datiertem Vorwort versehene Auflage von Heiligs „Kruckenkreuz“ erschien, jenem Ernst Karl Winter gehörte, der „als interessantester legitimistischer österreichischer Publizist des ständestaatlichen Ära“ bezeichnet wurde ${ }^{103}$. Er sah sein zweibändiges Werk über „Rudolph IV. von Österreich“ bewusst als „ein staatspolitisches Buch“ an, das mithelfen sollte, „dem neuen Österreich aus Wissenschaft und Geschichte eine neue staatspolitische Ideologie zu schaffen“, und zwar ausdrücklich gegen eine Wissenschaftsauffassung, „die bisher in Österreich sich eigentümlicherweise in ganz offizieller Form als ein Glied der imaginären deutschen Kultureinheit gefühlt hat, die aber nunmehr die Universitas Austriaca werden muß, koste es was immer. [...] Dieser Geis-

$99 \mathrm{Zu}$ ihm siehe den Beitrag von Johannes Holeschofsky in diesem Band.

100 Gernot Heiss, Im „Reich der Unbegreiflichkeiten“. Historiker als Konstrukteure Österreichs, in: ÖZG 7/4 (1996) 455-478, hier 464-466. Zu Hantschs und Heiligs politischen Ansichten vgl. auch Fritz FeLLNER, Geschichtsschreibung und nationale Identität (Wien/Köln/Weimar 2002) 74f., 167f., 175-177, 360-371; vgl. auch StAudinger, „Österreich“-Ideologie (wie Anm. 37) 204-206.

101 Balcar, Heilig (wie Anm. 2) 2 Abschnitt H 2.

102 Fritz Posch, in: Recht und Geschichte, hg. v. Hermann Balt L, Nikolaus Grass, Hans Constantin FausSNER (Sigmaringen 1990) 197-219, hier 215: „Hugo Hantsch wollte nur Prof. Konrad Joseph Heilig oder mich habilitieren."

103 staudinger, „Österreich“-Ideologie (wie Anm. 87) 226; über den Politiker Winter vgl. Wolfgang HäUsLER, Der Beitrag der ÖKP und der Legitimisten zum Selbstverständnis Österreichs vor 1938, in: Römische Historische Mitteilungen 30 (1988) 381-411, und die weiterführende Literatur bei Fellner, Cor RADINI, Geschichtswissenschaft (wie Anm. 3) 459. 
teszusammenhang besteht nicht mehr, seit in Deutschland die Wissenschaft zur Magd des Nationalsozialismus, seiner Rassendoktrin und Parteiideologie geworden ist. " ${ }^{104}$ Von Winters enger Zusammenarbeit mit Heilig zeugt auch der im ersten Band seines Werkes „Rudolph IV. von Österreich“ ausgesprochene Dank: „Für freundliche Mitarbeit an dem vorliegenden Werke danke ich Dr. Konrad Josef Heilig, der in Band II dieses Werkes die Epistola ad consules Viennenses Heinrichs von Langenstein herausgibt, [...]."105 Im zweiten Band seines „Rudolph“ dankte Winter Heilig dafür, dass er ihm die Edition der Epistola zur Verfügung gestellt habe. Der Plan, diese Edition in Winters zweitem Band zu veröffentlichen, habe allerdings wegen Raummangels aufgegeben werden müssen. „Die Edition der Epistola und des Tractatus bipartitus de contractibus soll im nächsten Band der ,Wiener Soziologischen Studien` erfolgen und zwar im Rahmen einer Langesteinbiographie, an der Dr. Heilig seit mehreren Jahren arbeitet. "106 Diese von Winter im Vorwort seines zweiten Bandes „im Dezember I935“ wiedergegebene Absicht Heiligs wurde indessen ebenso wenig verwirklicht wie die Veröffentlichung von Heiligs großem Werk über „Das Werden der österreichischen Idee im Mittelalter“ in Winters „Gsúr-Verlag“107. Aufhorchen lässt der dem Titel dieses nie erschienenen Werkes zugefügte Vermerk: „Mit einem Exkurs über die Echtheit des Privilegium minus [...]. “Denn aus dem geplanten und ebenfalls nie erschienen Exkurs sollte sehr viel später dann doch viel mehr als eine solche ergänzende Studie werden ${ }^{108}$. Wie sehr Erforschung und Darstellung der mittelalterlichen Geschichte Österreichs und politische Publizistik im Kampf um ein eigenständiges Österreich für Heilig in jenen Jahren eine Einheit bildeten, zeigte sich in aller Deutlichkeit, als er, Julius Wolf und Hermann M. Görgen auf der ersten, vom 20. bis 25. Juli 1936 in Salzburg im Rahmen der von ihm und Hans-Karl von Zessner-Spitzenberg als Arbeitskreis der „Österreichischen Aktion“ begründeten „Österreichischen Gesellschaft für Kunst und Wissenschaft“ abgehaltenen „Österreichischen Akademie I936“ über das Thema „Österreich und die Reichsidee“" auftraten ${ }^{109}$. Die dort gehaltenen, 1937 in einem Sammelband unter ebendiesem Titel veröffentlichten Vorträge ${ }^{110}$ sollten gewissermaßen eine Antwort darstellen auf jene Beiträge, die der 1936 von Josef Nadler und Srbik besorgte Sammelband „Ös-

104 Ernst Karl Winter, Rudolph IV. von Österreich 2 (Wiener Soziologische Studien 3, Wien 1936) X/XI.

105 Ders., Rudolph IV. von Österreich 1 (Wiener Soziologische Studien 2, Wien 1934) XVI.

106 Ders., Rudolph IV. 2 (wie Anm. 104) XV. Vgl. dazu auch den Hinweis auf den Nachlass in Balcar, Heilig (wie Anm. 2) 1, Abschnitt 9. 1, 190-198, und 2, 28.

107 Vgl. dazu auch den Hinweis auf den Nachlass in Balca R, Heilig (wie Anm. 2) 1, Abschnitt 9. 3, $199-203$.

108 Nämlich die Studie Heilig, Ostrom (wie Anm. 6).

109 Balcar, Heilig (wie Anm. 2) 1, 181f. Vgl. Fellner, Geschichtsschreibung (wie Anm. 100) 167f., 175f.; zur „Österreichischen Aktion“ vgl. HäUsler, Beitrag (wie Anm. 101) 393f.; Kindermann, Österreich (wie Anm. 74) 61f.

110 Julius Wolf, Konrad Josef Heilig, Hermann M. Görgen, Österreich und die Reichsidee (Ideengeschichtliche Reihe 1, Wien 1937). 
terreich. Erbe und Sendung im deutschen Raum“ vereint hatte ${ }^{111}$. Dieser Sammelband, in dem unter anderem Heiligs Instituts-Kurskollege Taras von Borodajkewycz das Thema „Die Kirche in Österreich“ behandelte ${ }^{112}$, war wiederum „als Gegenentwurf zu kleinösterreichischen Geschichtskonstruktionen im Ständestaat gedacht, wie jenen von Ernst Karl Winter und Konrad Josef Heilig [...]"113. Edmund Glaise von Horstenau, der auf der eigentlichen „Salzburger Hochschulwoche“ desselben Jahres I936 über „Altösterreichs Vergangenheit im Spiegel der deutschen Geschichte" sprach ${ }^{114}$, erinnerte sich an das Salzburger Geschehen später so: „Grundsätzlich waren die Katholischen Hochschulwochen in Salzburg so sehr eine ,gesamtdeutsche' Angelegenheit, daß sich die Legitimisten unter Wiesner und Zessner-Spitzenberg schon einige Sommer hindurch veranlaßt sahen, ihnen patentösterreichische Akademien entgegenzustellen, die gleichfalls in Salzburg abgehalten wurden. In diesem Jahre wirkten auf der legitimistischen Akademie: Zessner, Heilig, Görgen, der böse Emigrant Hildebrand." ${ }^{115}$ In der Druckfassung seines Vortrags hatte Heilig unter anderem dies betont: „Österreich war in der Vergangenheit Jahrhunderte lang Führer und Träger des Reichsgedankens. Und weil auch wir diesen Reichsgedanken bejahen, weil wir im derzeitigen Österreich eine Stütze des katholischen Reichsgedankens sehen, [...] deswegen wählen wir unter den vielen Geschichtsauffassungen jene, die dieses Österreich stützt und für dieses Österreich begeistert [...]. Was [...] die österreichische Geschichtsauffassung, zumal sie mit der katholischen Geschichtsauffassung verknüpft ist, der gesamtdeutschen voraus hat, ist die Erziehung zum Staate Österreich, während eine gesamtdeutsche Geschichtsauffassung [...] schließlich zu einem Gesamtdeutschland erzieht und daher den Staat Österreich notwendig schwächt [...]." ${ }^{116}$ Es „[...] muß von uns Österreich in den Mittelpunkt der Betrachtung gerückt werden. Auch hier muß gelten: Österreich über alles! Nicht Deutschland über alles!“117

111 Österreich. Erbe und Sendung im deutschen Raum, hg. v. Josef NADLER, Heinrich von SRBIK (Salzburg/ Leipzig 1936). Dazu Eвneth, Wochenschrift (wie Anm.76) 176-179; Walter Ferber, Geist und Politik in Österreich (Konstanz 1955) 19f. bezeichnet Heilig als „Wortführer“ jener Historikergruppe, die sich gegen Srbiks gesamtdeutsche Geschichtsauffassung wandte.

112 In: Österreich. Erbe und Sendung (wie Anm. 111) 263-314.

113 Heiss, Reich (wie Anm. 100) 464.

114 Vgl. dazu Franz Padinger, Geschichte der Salzburger Hochschulwochen, in: Christliche Weltdeutung. Salzburger Hochschulwochen 1931-1981, hg. v. Paulus Gordan (Kevelaer bzw. Graz/Wien/Köln 1981) 23-58, hier 34-35. Zu Glaise von Horstenau siehe Anm. 115.

115 Vgl. „Ein General im Zwielicht“. Die Erinnerungen Edmund Glaises von Horstenau 2, eingeleitet und hg. v. Peter Brouce к (VKGÖ 70, Wien/Köln/Graz 1983) 108f.

116 Konrad Josef Heilig, Reichsidee und österreichische Idee von den Anfängen bis 1806, in: Ders., Wolf, Görgen, Österreich (wie Anm. 110) 35-170, hier 55f.

117 Ebd. 62; zu Heiligs Auffassung vgl. auch Fer Ber, Geist (wie Anm. 111) 20-22. 
Mit Salzburg selbst war Heilig im Übrigen seit Kurzem durch seine Bekanntschaft mit dem Benediktinerpater Virgil Redlich verbunden ${ }^{118}$. Redlich, der Sohn Oswald Redlichs, hatte sich I93 I an der Theologischen Fakultät Salzburg habilitiert, wirkte seit I932 als Spiritual des Benediktinerkollegs in Salzburg, gründete dort 1935 ein „Forschungsinstitut für deutsche Geistesgeschichte“ und gab - dem ganz entsprechend - von I935 bis I938, bis zu seiner von den politischen Ereignissen erzwungenen Rückkehr in sein Heimatkloster Seckau die „Zeitschrift für deutsche Geistesgeschichte“ heraus. In ihren beiden ersten Jahrgängen veröffentlichte Heilig drei Studien, die offensichtlich mit seinen im Auftrag der Wiener Akademie betriebenen bibliotheksgeschichtlichen und kodikologischen Forschungen zusammenhingen ${ }^{119}$.

Als 1937 der von Heilig mitherausgegebene Sammelband über die Salzburger Tagung erschien, zu dem er selbst einen Beitrag über „Reichsidee und österreichische Idee von den Anfängen bis I 806" beigesteuert hatte ${ }^{120}$, war für die Nationalsozialisten das Maß voll. Heilig, der bereits 1933 als Mitarbeiter des Traditionsreferates der Vaterländischen Front tätig war ${ }^{121}$, stand schon seit Längerem in ihrem Visier. Seine Artikel im CS hatten bereits 1936 zu einem Angriff gegen ihn im „Schwarzen Korps“ geführt. Dort wurde er wegen seines im CS erschienenen Aufsatzes über „Einheit und Verschiedenheit im Deutschtum“122 als deutschfeindlich und „international“ sowie als „Brunnenvergifter" charakterisiert ${ }^{123}$. In seinem am 2 I. Januar 1937 an Bundeskanzler Schuschnigg gerichteten Brief, dem er ein Exemplar der zweiten Auflage seines „Kruckenkreuzes“ beilegte ${ }^{124}$, ließ er diesen wissen, dass er im September 1936 seine Hauslehrerstelle auf dem Land aufgegeben habe, um gleich in Wien zur Verfügung stehen zu können - was immer er damit gemeint haben mochte ${ }^{125}$. Diese Bemerkung war mit dem Hinweis auf seine finanzielle

118 Hierzu und zum folgenden Fellner, Corradini, Geschichtswissenschaft (wie Anm. 3) 337f., und vor allem P. Benno Rотн OSB, Univ.-Prof. Dr. phil. P. Virgil Redlich OSB. 1890-1970. Leben und Werk (Seckau 1970) (für den Hinweis auf diese Schrift und die Übermittlung ihres Textes bin ich Herrn Prof. Dr. Heinz Dopsch/Salzburg dankbar).

119 Konrad Josef Heilig, Mittelalterliche Bibliotheksgeschichte als Geistesgeschichte, in: Zs. für deutsche Geistesgeschichte 1 (1935) 12-23; DERs., Beda in Österreich, ebd 328-330; DERs., Methodisches zu einem Incipitkatalog, in: Zs. für deutsche Geistesgeschichte 2 (1936) 65-77.

120 Wie Anm. 116.

121 Balcar, Heilig (wie Anm. 2) 2, Abschnitt H1, und Irmgard Bärnthaler, Die Vaterländische Front. (Wien/Frankfurt/M./Zürich 1971) $138 f$.

122 CS 3, 32 vom 09.08.1936.

123 Eвneth, Wochenschrift (wie Anm. 76) 222 und 226 Anm. 90, sowie Balcar, Heilig (wie Anm. 2) 1, 145 Anm. 1. Vgl. auch Staudinger, „Österreich-Ideologie“ (wie Anm. 87) 212.

124 Balcar, Heilig (wie Anm. 2) 2, Abschnitt H 1.

125 Ebd. 2, Abschnitt H 2, Brief vom 28.06.1936 aus Schwanegg, Steirisches Salzkammergut, an Redlich wegen der Österreichischen Bibliothekskataloge: muss seine Hauslehrerstelle wegen Schulden seines Dienstherrn aufgeben. 
Lage verbunden, die umso prekärer sei, als er eine Familie mit drei Kindern zu versorgen habe. Und er unterließ nicht, darauf hinzuweisen, daß man zudem in letzter Zeit von gewissen Seiten mich kaufen will, nicht mehr für Österreich zu schreiben. Andererseits gebe es keine Verpflichtung, die ihn an Österreich binde. Angesichts all dessen habe er schwere Gewissenskonflikte. Dieser Brief stand gewiss in engem Zusammenhang mit seinem kurz darauf unternommenen Versuch, die österreichische Staatsbürgerschaft zu erlangen ${ }^{126}$. Sie wurde ihm und seiner Frau Josefine (geb. Habermann) denn auch im März 1937 unter der Bedingung zugesichert, dass er bis zum 24. März I 938 den Nachweis für sein Ausscheiden aus der deutschen Staatsangehörigkeit nachweisen könne. Dementsprechend suchte er am I 5 . Mai 1937 bei der Deutschen Gesandtschaft in Wien „um die Entlassung aus dem deutschen Staatsverband" nach ${ }^{127}$. Die Gesandtschaft aber bat die NSDAP-Kreisleitung Wien um Stellungnahme; sie konnte angesichts von Heiligs politischer Haltung nicht anders als ablehnend ausfallen. Die Kreisleitung wies gleich süffisant auf seinen Namen hin [Nomen est omen], um dann zu betonen, dass Heilig bereits jetzt als hervorragender Interpret der neü̈sterreichischen Reichsidee zu gelten habe, der in übelster Weise gegen das Deutsche Reich und den Nationalsozialismus hetze und - was noch viel belastender sei - sich an der „Österreichischen Akademie“ beteilige und Mitarbeiter am CS sei. Unter Berücksichtigung all dessen sei sein Antrag abzulehnen mit dem Hinweis, dass er bei einem Erwerb der österreichischen Staatsangehörigkeit automatisch die deutsche verliere. Damit sahen sich Heilig und seine Frau gezwungen, deutsche Staatsangehörige zu bleiben.

Am I3. März I938 wurde der „Anschluss“ Österreichs an das nationalsozialistische Deutsche Reich vollzogen. Nicht erst jetzt dürfte Heilig erkannt haben, dass sein Bestreben, „die Österreichische und die Reichsidee durch eine Neuinterpretation des Reichsgedankens in Gegenstellung zur deutschen Geschichte zu bringen“, wirkungslos geblieben war. „[...] viel zu sehr waren Heiligs Bemühungen, aus katholischer Mission eine Alternative zur deutschen Sendung zu formen, im Widerspruch zur akatholischen Realität jener Zeit, um als historiographische Alternative zu einer gesamtdeutschen Geschichtsauffassung wirksam zu werden. " ${ }^{128}$ Auch er musste erkennen, dass der Versuch, den autoritären Ständestaat „nach außen und innen durch eine konservative Österreich-Ideologie abzusichern, die sich gleichwohl für ein besseres Deutschtum hielt, [...] nur von wenigen akzeptiert“ wurde und „auch in österreichischen Historikerkreisen nur in Ausnahmefällen auf eine positive Resonanz"stieß ${ }^{129}$.

126 Balcar, Heilig (wie Anm. 2) 2 Abschnitt H1.

127 Hierzu und zum folgenden Евлетн, Wochenschrift (wie Anm. 76) 50 f.

128 So zumindest Fellner, Geschichtsschreibung (wie Anm. 100) 167f., dazu auch 175f. und 177; vgl. auch StAudinger, „Österreich“-Ideologie (wie Anm. 87) $239 \mathrm{f}$.

129 Günter Fellner, Die Emigration österreichischer Historiker, in: Vertriebene Vernunft 2, hg. v. Friedrich STADLER (Wien/München 1988) 474-494, hier 477. 
Die Ereignisse vom I I. bis I 3 . März I 938 setzten nicht nur Heiligs Rolle als politischer Publizist ein Ende; sie vereitelten auch seine Absicht, sich an der Universität Graz bei Hantsch zu habilitieren. Hantsch war bald nach dem „Anschluss“ verhaftet, ins Gefängnis und schließlich ins KZ Buchenwald gebracht, allerdings zu Beginn des Jahres 1939 wieder entlassen worden ${ }^{130}$. Und Ernst Karl Winter, in dessen Gsúr-Verlag das als Habilitationsschrift einzureichende, bereits in Korrekturfahnen vorliegende Werk über „Das Werden der österreichischen Idee im Mittelalter" erscheinen sollte, hatte sich veranlasst gesehen, zunächst in die Schweiz und danach in die USA zu emigrieren. Aber nicht nur dies. Das Thema des zwar wissenschaftlichen, aber dennoch auch in politischer Absicht geschriebenen Buches musste angesichts der zwangsweisen Eingliederung Österreichs in das "Großdeutsche Reich“ als geradezu subversiv gelten. Für Heilig bedeutete dies, dass sein Werk an keiner deutschen Universität mehr als Habilitationsschrift würde eingereicht werden können. Und doch sollte sich sechs Jahre später zeigen, dass die mit dieser Arbeit verbundenen Mühen nicht umsonst waren, dass vielmehr ein „Unter-Thema“, das nur als Anhang gedacht war, nach seiner weiteren Ausgestaltung die Grundlage einer Veröffentlichung bilden sollte, die das wissenschaftliche Ansehen des Verfassers auf einen Höhepunkt führen würde ${ }^{131}$.

Im Frühjahr 1938 aber hatte Heilig angesichts des „Anschlusses“ andere Sorgen. Denn nicht anders als Hantsch, Winter oder Zessner-Spitzenberg, der 1938 ins Konzentrationslager gebracht wurde ${ }^{132}$, oder der deutsche, 1932 nach Österreich emigrierte, beim CS mitarbeitende katholische Publizist Walter Ferber, der 1938-1942 in den Konzentrationslagern Dachau und Flossenbürg interniert war und nach dem Krieg von Heiligs Einsatz für ein eigenständiges Österreich kündete ${ }^{133}$, oder Dietrich von Hildebrand, der nur durch Flucht seiner Verhaftung in der „Anschlußnacht" entgehen konnte ${ }^{134}$, stand er zumindest seit 1936 bei den Wiener Nationalsozialisten und der dortigen deutschen Gesandtschaft auf der schwarzen Liste.

Mit dem Ende Österreichs, dessen Eigenständigkeit er während der letzten fünf Jahre in Wort und Schrift so vehement verteidigt hatte und dessentwegen er noch 1982 „als

130 Siehe den Beitrag von Johannes Holeschofsky in diesem Band.

131 Heilig, Ostrom (wie Anm. 6).

132 Erika Weinzierl, Prüfstand. Österreichs Katholiken und der Nationalsozialismus (Mödling 1988) 73.

133 Fer ber, Geist und Politik (wie Anm. 111), zu Ferber Jürgen Klöckler, Walter Ferber - der vergessene Föderalist, in: Allmende 46/47, 15. Jg. (1995) 201-216.

134 Евлетн, Ständestaat (wie Anm. 76) 233-236. Zur Emigration österreichischer Geisteswissenschaftler vgl. Erika WeinzierL, Wissenschaft und Nationalsozialismus, in: Vertriebene Vernunft 2 (wie Anm. 129) 5162. 
einer der geistigen Wegbereiter des österreichischen Nationalbewußtseins von heute angesprochen werden muß “135, hatte er zusammen mit seiner Familie, darunter drei kleine Kinder, das Schlimmste zu befürchten. Es ist geradezu als ein Wunder zu bezeichnen, dass er nicht wie viele andere „aus christlichsozial-ständestaatlich orientiertem Milieu“ Stammende verhaftet worden ist ${ }^{136}$, sondern am 22 . April 1938 mit seiner Familie offenbar unbehelligt seine langjährige Wohnung in Weidling bei Wien verlassen konnte, nachdem er seit März für seine Arbeit bei der Wiener Akademie kein Gehalt mehr erhalten hatte ${ }^{137}$. Er „emigrierte“ nicht etwa in das noch freie Ausland, sondern begab sich mit seiner Familie ausgerechnet in die „Höhle des Löwen“, ins „Altreich“. [...] nach kurzem Aufenthalt in München, dann bei Verwandten in Würzburg suchte er ein halbes Jahr bei einem Onkel im badischen Frankenland, d. h. in der Heimat seines Vaters, einer der abgelegensten und damit für einen „politischen Flüchtling“ vielleicht sichersten Gegenden Badens, Unterschlupf. Damit war er zwar aus der Sichtweite der Gestapo, aber ohne laufende Einkünfte. Hier halfen ihm seine alten Konstanzer „Konradihaus“-Verbindungen. Denn ihm war - vielleicht über seinen Klassenkameraden und „Mit-Zögling“ Konrad Welte - bekannt geworden, dass dessen Bruder Bernhard Welte - er war zwei Klassen über beiden am Konstanzer Gymnasium und im Konradihaus gewesen und 1929 zum Priester geweiht worden - seit 1934 als Sekretär des Freiburger Erzbischofs Conrad Gröber, Weltes Meßkircher Landsmanns, fungierte ${ }^{138}$. Bernhard Welte, der viel später als Religionsphilosoph einen bedeutenden Ruf erlangen sollte, stellte in der Tat den Kontakt zu Gröber her ${ }^{139}$ mit der erfreulichen Folge, dass Heilig zur Unterstützung des erkrankten Erzbischöflichen Archivars Josef M. B. Clauss ${ }^{140}$ auf I. Oktober 1938 zum „Hilfsarchivar“ am Erzbischöflichen Archiv in Freiburg im Breisgau ernannt wurde ${ }^{141}$. Er war damit

135 Georg Wagner, Österreich - Profil zweier Jahrtausende, in: Österreich. Von der Staatsidee zum Nationalbewußtsein (Wien 1982) 203-361, hier 268-272 mit Anm. 40.

136 Weinzierl, Prüfstand (wie Anm. 132) 73 und $100 f$.

137 Das Folgende nach der Akte Erzbischöfliches Archiv Freiburg i. Br. „B 2 - 8/43 Generalia Erzbistum Freiburg. Rubrik: Behörden: Erzbischöfliche Kanzlei, Betreff: Hilfsarbeiter“. Vgl. Anm. 34.

138 Zu Gröber vgl. Erwin Keller, Conrad Gröber 1872-1948. Erzbischof in schwerer Zeit (Freiburg/Basel/ Wien 1981), und Hugo Отт, Gröber, Conrad, in: Badische Biographien 1 (Stuttgart 1982) 144-148; zu Welte vgl. Klaus Hemmerle, Welte, Bernhard, in: Baden-Württembergische Biographien 1 (Stuttgart 1994) 378-380.

139 Balcar, Heilig (wie Anm. 2) 2, H 1.

140 Joseph M. B. Clauss, „Andenken an meinen 81. Geburtstag. 20. Mai 1948“ (ohne Erwähnung Heiligs), und „Necrologium Friburgense“, in: FDA 71 (1951) 237-239.

141 Dazu Keller, Gröber (wie Anm. 138) 163: „Ein anderer, Konrad Heilig, überzeugungstreuer Katholik und hochbegabter Historiker, wurde von den Nazis aus seiner Wiener akademischen Stellung fristlos entlassen; der Erzbischof übernahm den aus Erzingen stammenden jungen Gelehrten als Archivar ins erzbischöfliche Archiv.“ Keller war im Übrigen Konstanzer Klassenkamerad und Mit-„Konradihäusler“ Heiligs gewesen. 
nicht nur in die heimische Erzdiözese Freiburg und in kirchliche Dienste zurückgekehrt; sein Dienstsitz, das Erzbischöfliche Ordinariat, lag in unmittelbarer Nachbarschaft jenes Konvikts, das Heilig nach seinem Entschluss, von der Theologischen zur Philosophischen Fakultät überzuwechseln, I 929 verlassen hatte. Angesichts seines neuen archivarischen Aufgabenfeldes und angesichts von Österreichs „Anschluss“ war an eine Wiederaufnahme der ihn noch bis 1937 beschäftigenden Österreich-Thematik nicht mehr zu denken. Stattdessen hatte er in Orten, die nach Kriegsausbruch in den Bereich der Front gegenüber Frankreich zu liegen kamen, Pfarrarchive und vor allem deren Kirchenbücher zu sichern. Darüber hinaus war ihm aufgetragen, für den zweiten Band des „Handbuchs des Erzbistums Freiburg“, dessen erster Band noch 1939 hatte erscheinen können ${ }^{142}$, den historischen Teil und eine als Beilage geplante Karte zu bearbeiten, die „in übersichtlichen Abgrenzungen die Diözesen darstellt, aus deren Teilen im vergangenen Jahrhundert das Erzbistum Freiburg gebildet worden ist" ${ }^{143}$. An die Stelle der mit politischen Implikationen betriebenen Geschichte Österreichs im Mittelalter war notgedrungen, wenn auch gewiss nicht ungern betrieben, die „Kirchliche Landesgeschichte“ getreten. Während der zweite Band des „Handbuchs“, das - nach Heiligs eigenen Worten in der geplanten und begonnenen Ausführung das beste geschichtliche Nachschlagewerk über Baden und Hohenzollern werden soll ${ }^{144}$ - wegen des Krieges nie erscheinen konnte, wurde die von Heilig bearbeitete Karte ausgedruckt. Angesichts dessen war es für ihn nicht schwer, anlässlich einer Zusammenkunft südwestdeutscher Geschichtsvereine Anfang Juni I 939 in Sigmaringen innerhalb einer über die Schaffung eines historischen Atlasses für den deutschen Südwesten geführten Diskussion seine brieflich übermittelte Bereitschaft zur Mitarbeit an einem derartigen Atlaswerk verkünden zu lassen. Der Bericht, der über die Zusammenkunft in den „Blättern für deutsche Landesgeschichte“ erschien ${ }^{145}$, und die darin enthaltene Nennung des „Archivars beim Erzbischöflichen Ordinariat Dr. Heilig - Freiburg" wurde auch in Wien gelesen ${ }^{146}$. Das hatte zur Folge, dass der Präsident der dortigen Akademie der Wissenschaften Srbik am 22. Januar I 940 das Freiburger Erzbischöfliche Ordinariat darum bat, Heilig zu veranlassen, daß er uns alle im Zusammenhang

142 Handbuch des Erzbistums Freiburg 1. Realschematismus (Freiburg 1939).

143 Wie Anm. 142, hier Vorwort 3.

144 Erzbischöfliches Archiv Freiburg i. Br. „B 2 - 8/43 Generalia Erzbistum Freiburg. Rubrik: Behörden. Erzbischöfliche Kanzlei, Betreff: Hilfsarbeiter“. Schreiben vom 04.11.1940.

145 Vgl. Joseph Ludolph Woн Le в, [Protokoll] Zweite Zusammenkunft südwestdeutscher Geschichtsvereine. 3. und 4. Juni 1939 in Sigmaringen, in: Blätter für deutsche Landesgeschichte 85 (1939) 134-156, hier 142 145 Diskussion über Schaffung eines historischen Atlasses für den deutschen Südwesten (Dr. Senn). Dazu Meinrad Sсна в, Der Historische Atlas von Baden-Württemberg, in: Staatliche Förderung und wissenschaftliche Unabhängigkeit der Landesgeschichte (Veröff. der Kommission für geschichtliche Landeskunde in Baden-Württemberg B I 3 I, Stuttgart 1995) 128-172, hier 130f.

146 Zum Folgenden vgl. Anm. 34. 
mit dem ihm erteilten Arbeitsantrag abgefaßten Schriftstücke unserer Akademie ehebaldigst zurückstelle. Der Brief Srbiks, dessen politischer Gegner Heilig noch vor gar nicht so langer Zeit gewesen war, enthält einen Satz, der auf Heiligs überstürzte „Flucht“ aus Wien verweist: Offenbar in Zusammenhange mit dem Umbruch hat er Wien verlassen und auf wiederholte Zuschriften von Altpräsident Hofrat Redlich keine Antwort gegeben. Eine „Gegenrechnung“, die Heilig daraufhin aufmachte, hat die Angelegenheit letztlich im Sande verlaufen lassen.

Dem „Hilfsarchivar“ Heilig hatte das Erzbischöfliche Ordinariat inzwischen noch weitere Arbeiten übertragen. Er sollte - im Anschluss an den I 902 veröffentlichten Registerband ${ }^{147}$ - den Inhalt der seitdem erschienenen rund 40 Bände der vom „Kirchengeschichtlichen Verein“ des Erzbistums Freiburg herausgegebenen Zeitschrift „Freiburger Diözesan-Archiv“ durch in den Druck zu gebende Indices erschließen ${ }^{148}$ und er sollte die Handschriften des Ordinariatsarchivs katalogisieren. Neben diesen kirchenamtlichen Aufträgen arbeitete er sich aber selbst in die Kirchliche Landesgeschichte der Erzdiözese ein. So sprach er am 26. Juli I939 auf der außerordentlichen Jahresversammlung des Kirchengeschichtlichen Vereines im nordbadischen Tauberbischofsheim über „Fragen und Aufgaben der kirchengeschichtlichen Forschung im badischen Frankenland“. „Methodisch und pädagogisch war der Vortrag eine Meisterleistung. "149 Und ein Jahr später konnte ein umfangreicher Aufsatz aus seiner Feder über konfessionelle Wirren, die Gerichtstätten, den Heimatort seines Vaters während des I7. Jahrhunderts heimgesucht hatten, erscheinen ${ }^{150}$. Er hatte die Studie vermutlich während seines Aufenthalts in der väterlichen Heimat zwischen dem Weggang aus Wien im April 1938 und dem Neubeginn in Freiburg im Oktober 1938 erarbeitet. Er plante noch eine Vielzahl weiterer wissenschaftlicher Veröffentlichungen, die der kirchlichen Landesgeschichte dienen sollten. Bei der Befassung mit landesgeschichtlichen Themen aber ließ er es während seiner wenigen Freiburger Jahre keineswegs bewenden. Vielmehr hatte er einen Aufsatz mit dem Titel „Vom Ursprung des Wortes National“ verfasst, der im „Historischen Jahrbuch“ der Görresgesellschaft erscheinen sollte ${ }^{151}$. Dessen Schriftlei-

147 FDA Register zu Band I bis XXVII (Freiburg 1902).

148 Vgl. FDA Registerband zu den Bänden 28-104 (Freiburg 1986).

149 Vgl. den Bericht über das Vereinsjahr 1939, in: FDA 67 (1940) $269 f$.

150 Konrad Josef Heilig, Wie Gerichtstetten wieder katholisch wurden, in: FDA 67 (1940) 1-89.

151 Sollte erscheinen in: HJb 62 (1942) 19-65; vgl. auch BALCAR, Heilig 1 (wie Anm. 2) 23 und 184-189. Über das Schicksal dieses Bandes des HJb vgl. Johannes SPÖRL in seinem Vorwort zu Band 62-69 (1949) und Ursula Wiggershaus-Müller, Nationalsozialismus und Geschichtswissenschaft. Die Geschichte der Historischen Zeitschrift und des Historischen Jahrbuchs 1933-1945 (Studien zur Zeitgeschichte 17, Hamburg 1998) 87. Wiedergabe des bereits gesetzten Textes von Heiligs Aufsatz bei Ba LCA R, Heilig (wie Anm. 2) 2, Abschnitt H 5. 
ter, den Mittelalterhistoriker Johannes Spörl, dürfte Heilig nach seiner Rückkehr in Freiburg kennengelernt haben ${ }^{152}$. Zu diesem Aufsatz, „der bereits im Umbruch für das Historische Jahrbuch [...] gesetzt war, als diese Zeitschrift das Erscheinen einstellte“, meinte er allerdings I944, er sei „[...] durch eigene Forschung [...] inzwischen schon überholt worden"153. Dennoch vermittelt eine Lektüre des Aufsatzes den Eindruck, dass die darin enthaltenen Befunde auch heute noch Aufmerksamkeit verdienen würden.

Dieser „wissenschaftliche Aufbruch“ dauerte freilich nur kurz ${ }^{154}$. Erneut griffen politische Ereignisse in Heiligs Leben ein. Nachdem es seiner Kirchenbehörde zunächst gelungen war, für ihn eine Zurückstellung zu erwirken, musste er dann schließlich doch im Juli I940 Soldat in jener „Wehrmacht“ werden, deren Einmarsch ihn im Frühjahr I 938 aus dem geliebten Österreich vertrieben hatte. Zunächst im Juli bei der Luftnachrichtentruppe, dann seit August bei der Kriegsmarine kam er über die Stationen Wilhelmshaven, Glückstadt und Breda im besetzten Holland im Sommer I94I nach Berlin. Dort arbeitete der „Schreibstuben-Gefreite Dr. Conrad Heilig“ bis Herbst 1942 im Oberkommando der Kriegsmarine in der Bendlerstraße 2 I. Danach wurde er wieder nach Wilhelmshaven versetzt. Der Aufenthalt in Berlin und der gewiss nicht allzu anstrengende Dienst in einer Schreibstube musste den gelehrten Soldaten angesichts der hier vorhandenen Bibliotheken geradewegs dazu verlockt haben, wissenschaftlich weiterzuarbeiten. Er nutzte die Chance, um seine in Wien begonnenen Untersuchungen über das „Privilegium minus“, jenes im Original seit dem I 4. Jahrhundert nicht mehr vorhandene Privileg Kaiser Friedrichs I. vom I7. September I I 56 für Herzog Heinrich (II.) von Österreich und seine Gattin Theodora, eine Nichte des oströmischen Kaisers Manuel (I.), weiterzuführen ${ }^{155}$. Dass sich Heilig bereits seit Langem mit diesem Thema beschäftigt hatte, zeigen entsprechende Artikel, die er seit 1934 in Wochenblättern und Tageszeitungen erscheinen ließ ${ }^{156}$.

152 Spörl wirkte seit 1934 als Privatdozent und seit 1940 als apl. Professor in Freiburg, vgl. Freiburger Philosophische Fakultät (wie Anm. 24) 1005.

153 Heilig, Ostrom (wie Anm. 6) $109 f$.

154 Das Folgende nach der Akte Erzbischöfliches Archiv Freiburg i. Br. „B 2 - 8/43 Generalia Erzbistum Freiburg. Rubrik: Behörden. Erzbischöfliche Kanzlei, Betreff: Hilfsarbeiter“. Vgl. Anm. 34.

155 Vgl. den Druck des „Privilegium minus“ in: MGH Die Urkunden der deutschen Könige und Kaiser X. Die Urkunden Friedrichs I. (1152-1190) 1, bearb. v. Heinrich Appelt (Hannover 1975) Nr. 151, und Urkundenbuch zur Geschichte der Babenberger in Österreich IV/1, ergänzende Quellen 976-1194, bearb. v. Heinrich Fichtenau, Erich Zöllner in Zusammenarbeit mit Heide Dienst (Wien 1968) Nr. 803.

156 So etwa Konrad Josef Heilig, Die Anfänge der Donaupolitik der Babenberger, in: Wiener politische Blätter 1, Nr. 14 (1933/34) 1-5, oder noch eindeutiger DERs., Osteuropäischer Einfluß auf die Gründungsurkunde Österreichs, das sogenannte Privilegium minus, in: Sturm über Österreich 2, Nr. 47 (1934/35) 3; DERs., Byzantinische Einflüsse auf Österreich im 12. und 13. Jahrhundert, in: Reichspost 42, Nr. 311 (1935) 17f.; 
Diese Einzelstudien sollten offenbar dem als Habilitationsschrift geplanten Werk über „Das Werden der österreichischen Idee im Mittelalter“ bzw. genauer einem beigefügten „Exkurs über die Echtheit des Privilegium minus“ zugute kommen. Dieses Werk, dessen Erscheinen für I 935 bzw. 1936 vorgesehen war, ist in Österreich - worauf bereits verwiesen wurde - nie erschienen ${ }^{157}$.

Jetzt aber, nicht mehr in Wien, sondern ausgerechnet im „preussischen“ Berlin erkannte er die erwünschte Gelegenheit, das damalige Vorhaben endlich zu verwirklichen. Seine Arbeitsstätte fand er in freien Stunden vor allem bei den in der Staatsbibliothek Unter den Linden domizilierenden Monumenta Germaniae Historica. Als dort zunächst ab I. April I 942 kommissarisch und danach ab I. Oktober I 942 planmäßig der gebürtige Oberösterreicher Theodor Mayer das Amt des Präsidenten antrat ${ }^{158}$, wurde er auf den sich mit dem „Privilegium minus“ befassenden Historiker aufmerksam. Es wurde Mayer zu einem Anliegen, „daß die Untersuchungen von K. J. Heilig über Ostrom und das deutsche Reich um die Mitte des I 2. Jahrhunderts [...] zum Abschluß gebracht würden“159. Freilich wurde Heilig im Winter 1942 nach Wilhelmshaven versetzt, wo er bis zum Sommer I 943 blieb $^{160}$. Aber auch diese räumliche Entfernung konnte ihn nicht davon abhalten, an seiner Untersuchung weiterzuarbeiten. „Jede freie Stunde und viele Nächte hat er für seine Arbeit benützt, wobei er von sehr verständigen Vorgesetzten manchen kurzen Urlaub erhielt, die er zu Fahrten nach Berlin ausnützte, um dort bis zu I 8 Stunden am Tag zu arbeiten. Dieser fanatischen Hingabe ist es zu verdanken, daß er sein Werk noch zum Abschluß bringen konnte; auch ihn hat das Kriegsende verschlungen, er hat nach dem Waffenstillstand die Heimat nicht mehr erreicht." ${ }^{161}$ Es war das Verdienst Mayers, dass er das Erscheinen von Heiligs insgesamt 27I Seiten umfassender Studie über „Ostrom und das Deutsche Reich um die Mitte des I2. Jahrhunderts“ mit dem Untertitel „Die Erhebung Österreichs zum Herzogtum i 56 und das Bündnis zwischen Byzanz und dem

DE Rs., Ein byzantinisches Hochzeitslied auf das erste österreichische Herzogspaar, in: Sturm über Österreich 4, Nr. 43 (1936) 4.

157 Vgl. Anm. 96.

158 Zu Mayer vgl. zuletzt Maure r, Mayer (wie Anm. 7).

159 Vgl. Theodor Mayer, Ein Rückblick, in: Ders., Mittelalterliche Studien (Konstanz 1959) 463-503, hier 477. Dazu Heilig, Ostrom (wie Anm. 6) 11: Die Arbeit habe erst wieder aufgenommen werden können, „nachdem der Präsident des Reichsinstitutes Herr Prof. Theodor Mayer mit Rat und Tat dazu ermuntert hatte".

160 Ebd. 11: „Der Abschluß und die Ausarbeitung erfolgte, von einem vierzehntägigen Weihnachtsurlaub 1942 nach Freiburg i. Br. und einem dreiwöchigen Arbeitsurlaub nach Berlin im Februar 1943 abgesehen, von November 1942 bis April 1943 im luftgefährdeten Wilhelmshaven auf einer Dienststelle der Kriegsmarine in der Freizeit [...].“

161 Theodor Mayer, Das österreichische Privilegium minus, in: Ders., Studien (wie Anm. 159) 202-246, hier 204. 
Westreich“ zusammen mit einer Arbeit Carl Erdmanns und einer eigenen in einem Sammelband noch 1944 hat bewerkstelligen können ${ }^{162}$. Das ist umso bemerkenswerter, als der in den Nationalsozialismus verstrickte Herausgeber sicherlich um die dem Regime ablehnend gegenüberstehende Haltung sowohl Heiligs als auch Erdmanns gewusst haben dürfte ${ }^{163}$, zumal er in Heiligs Studie lesen konnte, dass dieser zu entscheidenden Fragen unter anderem bereits 1935 sowohl in der von P. Virgil Redlich herausgegebenen „Zeitschrift für Geistesgeschichte" als auch in einer Beilage zu der den Ständestaat politisch unterstützenden Wiener „Reichspost“ Stellung genommen hatte ${ }^{164}$. Für Heilig aber ergab sich die merkwürdige Konstellation, dass er ausgerechnet von einem - nicht anders als Hirsch oder Srbik - prononciert gesamtdeutsch denkenden österreichischen Historiker eine derartige Förderung erfuhr, die mit der Publikation seiner Arbeit über „Ostrom“ keineswegs würde enden sollen ${ }^{165}$.

Heilig hatte die Anmerkungen seiner Untersuchung ganz bewusst teilweise zu Exkursen ausgebaut, „die streng genommen nicht zum Fragenkomplex um das Minus gehören; in dem Heldentode manches Fachkollegen und in der Gefahr, in der Verfasser und Manuskript oft schwebten, wird man eine Erklärung dafür finden, daß hier Ergebnisse eigener Forschung niedergelegt sind, die vielleicht sonst nicht mehr erscheinen würden" ${ }^{166}$. Angesichts seines bald nach der Niederschrift dieser geradezu prophetischen Sätze erfolgten Todes wird man für diese Vorsorge dankbar sein. Denn in der Tat steckt die Studie voller Anregungen, die bis heute noch nicht voll und ganz ausgeschöpft sind.

In seinem Nachruf auf Heilig hat Lhotsky I 954 zu diesem Werk das Folgende bemerkt: „Mag man in Einzelheiten der Deutung und Auffassung auch anderer Meinung sein - Bedenken wurden bereits angemeldet -, so ist doch nicht zu leugnen, daß hier Heiligs reifste und fruchtbarste, auch im Aufbau klarste Leistung vorliegt." ${ }^{167}$ Ähnlich

162 Heilig, Ostrom (wie Anm. 6); Carl Erdmann, Der Prozeß Heinrichs des Löwen, in: Kaisertum und Herzogsgewalt (wie Anm. 6) 273-364; Theodor MAYE R, Friedrich I. und Heinrich der Löwe, in: ebd. $365-444$.

163 Zu Carl Erdmann, dem - vor dessen Einberufung im September 1943 - Heilig bei den MGH in Berlin begegnet sein dürfte und der am 7. März 1945 in einem Lazarett in Agram verstarb, vgl. Friedrich Baethgen, Carl Erdmann, in: Carl Erdmann, Forschungen zur politischen Ideenwelt des Frühmittelalters (Berlin 1951) IX-XXI, und Gerd Tellen Bach, Carl Erdmann, in: Ders., Ausgewählte Abhandlungen und Aufsätze 4 (Stuttgart 1989) 1258-1264.

164 Heilig, Ostrom (wie Anm. 6) 141 Anm. 1.

165 Vgl. Theodor Mayer, Jahresbericht 1942, in: DA 6 (1943) XVI : „Um die griechischen, arabischen usw. Quellen zur deutschen Geschichte des 12. Jahrhunderts für einen breiteren Kreis zugänglich zu machen, wurde beschlossen, eine zweisprachige Ausgabe zu veranstalten. Dr. Konrad Heilig hat diesen Auftrag übernommen und auch schon mit Vorbereitungen begonnen."

166 Heilig, Ostrom (wie Anm. 6) 11.

167 Lнотsкy, Heilig (wie Anm. 2) 665. 
hatte schon Appelt 1949 von „der in jeder Hinsicht außergewöhnlichen Leistung Heiligs“ und von dessen „außerordentlichem Scharfsinn“ und überdies davon gesprochen, dass Heilig „auch die letzten Bedenken gegen die Echtheit [des Privilegium minus] restlos zerstören“ konnte ${ }^{168}$. In dieser Hinsicht hatte bereits Heinrich Mitteis 1947 das „große Verdienst Heiligs“ gewürdigt, „mit staunenswerter Gelehrsamkeit einen Beweis aufgebaut zu haben, der zur vollständigen Rehabilitierung der Urkunde von I I 56 führt"169. Die Einwände, von denen Lhotsky gesprochen hatte, bezogen sich auf die für Heiligs Argumentation zentrale These von einer „unmittelbaren byzantinischen Beeinflussung des Minustextes“170. Für eine solche stützte sich Heilig vor allem auf mittelgriechische Formeln, denen er - ins Lateinische übersetzt - in der im Privilegium minus enthaltenen Wendung affectare aliquid alicui wieder begegnen zu können glaubte. Damit wäre ihm eine Erklärung für den in der Forschung zum Privilegium minus bis dahin umstrittensten Passus geglückt ${ }^{171}$, demgemäß dem Herzogspaar im Falle seiner Kinderlosigkeit die Libertas affectandi, d. h. die Freiheit zustehe, sein Herzogtum wem immer es wollte zu vermachen. Appelt hat indessen mithilfe von „affectare“-Belegen des zu Heiligs Zeiten noch nicht vorliegenden ersten Bandes des „Mittellateinischen Wörterbuchs“ nachweisen können, dass dessen „mit einem Aufwand an staunenswerter Gelehrsamkeit unternommener Versuch, die libertas affectandi auf byzantinischen Einfluß zurückzuführen“, „nicht geglückt“ sei, daß vielmehr „affectare [...] als Synonym von donare, affectatio als Ausdruck für die Schenkung eines Gutes an die Kirche verwendet worden sei“ und „die Beispiele nach Westeuropa“"weisen ${ }^{172}$. Zuvor aber hatte der Byzantinist Franz Dölger der Analyse Heiligs bescheinigt, dass sie „,vor keiner Schwierigkeit zurückschreckt“ und „mittels glücklicher Kombination und scharfsinniger Interpretation eine alte Frage zu ihrer [...] evident richtigen Lösung bringt“ und die Probleme „mit ebensoviel Spürsinn wie Gründlichkeit unter zum großen Teil neuen Gesichtspunkten und mit staunenswerter Quellen- und Literaturkenntnis geprüft“ habe. „Heiligs Buch ist, sowohl was die

168 Heinrich Appelt, Rezension [von Heilig, Ostrom], in: MIÖG 57 (1949) 427-435, und Heinrich Fichtenau, Zur Überlieferung des, Privilegium minus' für Österreich, in: ebd. 73 (1965) 1-16.

169 Heinrich Mitт eis, Zur staufischen Verfassungsgeschichte, in: ZRG GA 65 (1947) 316-337, hier 318.

170 Heilig, Ostrom (wie Anm. 6) 133-146, Abschnitt „IV. 5. Affectare und seine griechische Vorlage“ sowie die Abschnitte IV. 6 und IV. 7; dazu Appelt, Rezension (wie Anm. 168) $432 \mathrm{f}$.

171 MGH DFI (wie Anm. 155) Nr. 151, Absatz 3: Si autem predictus dux Austrie patruus noster et uxor eius absque liberis decesserint, libertatem habeant eundem ducatum affectandi cuicumque voluerint. Dazu APPELT, Rezension (wie Anm. 168) 432f.; DERs., Privilegium minus (wie Anm. 1) 17; DERs., Die libertas affectandi des Privilegium minus, in: MÖSTA 25 (1979) 135-140, hier 137.

172 Appelt, Einleitung zu MGH DFI (wie Anm. 155) Nr. 151, 258. Insgesamt zur Geschichte der Erforschung des Privilegium minus jetzt Werner Maleczeк, Das Privilegium minus. Diplomatische Gesichtspunkte, in: Die Geburt Österreichs. 850 Jahre Privilegium minus, hg. v. Peter Schmid, Heinrich Wanderw itz (Regensburg 2007) 103-141, zu Heilig insbes. 108f. 
methodische Durchführung, die Bewältigung gewaltigen und z. T. ungewohnten Quellenmaterials, die Originalität der Gesichtspunkte und dementsprechend die Vielzahl und die Bedeutung seiner Ergebnisse anlangt, eine außerordentliche Leistung, die um so höher zu bewerten ist, als auch sie unter schwierigsten Verhältnissen während des Krieges entstanden ist." 173

Als Heilig I 944 sein gedrucktes Werk in Händen hielt, konnte er von den gegenüber dessen Ergebnissen anzubringenden Korrekturen noch nichts wissen. Entscheidend dürfte für ihn gewesen sein, dass er im nationalsozialistischen Deutschland und als Soldat der Wehrmacht doch noch ein Vorhaben hatte vollenden können, das er bereits I934/35 im österreichischen Ständestaat begonnen und damals lediglich als Exkurs zu seinem eben diesen Ständestaat wissenschaftlich fundierenden, wegen des „Anschlusses“ allerdings nie erschienenen Buch über „Das Werden der österreichischen Idee im Mittelalter“ hatte veröffentlichen wollen ${ }^{174}$.

Sein Tod ließ all die vielen wissenschaftlichen Vorhaben, denen er sich noch widmen zu können hoffte, unausgeführt: sie reichten von der Geschichte seines Heimatortes Erzingen und der Frühgeschichte der in der badischen Ortenau gelegenen einstigen Abtei Ettenheimmünster sowie einer Untersuchung zu den „Grenzen zwischen den Diözesen Konstanz und Straßburg "175 über eine Edition von Texten Heinrichs von Langenstein, ja über „eine neue große Monographie“ des Gelehrten ${ }^{176}$ und eine Edition aller Briefe aus der Werkstatt des „Ackermann-Dichters“, an der er neben seiner Beschäftigung mit dem Privilegium minus ebenfalls im Sommer 1942 in Berlin arbeitete ${ }^{177}$, bis hin zu einer „auf bisher ungedrucktes Material“ gestützten Studie „über den ältesten Adel Österreichs bis etwa zum Beginn der Habsburgerzeit"178.

Bei dem Versuch, sich nach dem Zusammenbruch der deutschen Front in Oberitalien zu Freunden nach Venedig durchzuschlagen, fand Heilig in der Nähe von Belluno am 6. Mai 1945 den Tod ${ }^{179}$. Damit endete ein Leben, das von zahlreichen Brüchen gekennzeichnet war. Es endete das Leben eines Gelehrten, der sich nach dem Krieg in Freiburg im Breisgau zu habilitieren beabsichtigte ${ }^{180}$ und der neben seinen überlebenden Alters-

173 Franz Dölger, Byzanz und das Westreich, in: DA 8 (1950) 238-249, hier 241f. und 249.

174 Vgl. oben bei Anm. 96.

175 Balcar, Heilig (wie Anm. 2) 1, 33, und über die in Heiligs Nachlass verwahrten Arbeiten ebd. 184-223 und 2, 28-29; Hensle, Heilig (wie Anm. 2) 73-74; Maurer, Heilig (wie Anm. 2) 124.

176 Balcar, Heilig (wie Anm. 2) 1, 74 und 2, 28.

177 Ebd. 134.

178 Heilig, Ostrom (wie Anm. 6) 188, Anm. 4.

179 Beerdigt wurden seine sterblichen Überreste zunächst in Belluno, danach umgebettet auf den deutschen Soldatenfriedhof am Podoi-Joch unmittelbar südlich des Sella-Massivs, siehe BALcar, Heilig (wie Anm. 2) 12, und Hensle, Heilig (wie Anm. 2) 74.

180 Balcar, Heilig (wie Anm. 2) 1, 16 Anm. 2. 
genossen, etwa neben Karl Bosl, Heinrich Büttner, Karl Jordan, Otto Meyer oder Walter Schlesinger, ganz gewiss zu einem der führenden Mediävisten an einer deutschen, vielleicht aber auch an einer österreichischen Universität geworden wäre ${ }^{181}$.

$181 \mathrm{Zu}$ ihren Karrieren siehe Anne Christine Nagel, Im Schatten des Dritten Reichs. Mittelalterforschung in der Bundesrepublik Deutschland 1945-1970 (Formen der Erinnerung 24, Göttingen 2005). 



\section{Abkürzungsverzeichnis}

AAVČR

ABBAW

Abh.

Abh. (und Ortsname)

AMVČR

AÖG

$\mathrm{BAB}$

BDC

BAK

bes.

BMF

BMI

BMU

DA

DALV

DHI

DÖW

DU

FS

FRA

GG

HHStA

$\mathrm{HJb}$

HSK siehe MÚA

Archiv der Berlin-Brandenburgischen Akademie der Wissenschaften (Berlin)

Abhandlungen

Abhandlungen der jeweiligen Akademie der Wissenschaften, philosophisch-historische oder entsprechende Klasse

Archiv für Kulturgeschichte

Archiv ministerstva vnitra České republiky [Archiv des Innenministeriums der Tschechischen Republik] (Praha)

Archiv für österreichische Geschichte

Bundesarchiv Berlin

R Abt. Deutsches Reich

Berlin Document Center

Bundesarchiv Koblenz

besonders

Bundesministerium für Finanzen (Wien)

Bundesministerium für Inneres (Wien)

Bundesministerium für Unterricht (Wien)

Deutsches Archiv für Erforschung (I937-I944: Geschichte) des Mittelalters

Deutsches Archiv für Landes- und Volksforschung

Deutsches Historisches Institut

Dokumentationsarchiv des österreichischen Widerstandes (Wien)

Deutsche Universität (I939-I945: Deutsche Karls-Universität) Prag

Festschrift

Fontes Rerum Austriacarum

Geschichte und Gesellschaft

Haus-, Hof- und Staatsarchiv (Wien), siehe ÖSTA

Historisches Jahrbuch

H-Soz-u-Kult. Kommunikation und Fachinformation für die Geschichtswissenschaften (Website) 
$\mathrm{HZ}$

IÖG

Jb.

JbLKNÖ

K.

Kap.

MGH

MIÖG

MÖIG

MOÖLA

MÖSTA

MÚA

MVGDB

NA

ND

NDB

$\mathrm{NF}$

NL

NÖB

NÖLA

NOFG

OEFG

Ö̈LA

ÖAW
Historische Zeitschrift

Institut für Österreichische Geschichtsforschung (I923-I942:

Österreichisches Institut für Geschichtsforschung; I942-I945:

Institut für Geschichtsforschung und Archivwissenschaft in Wien) (Wien)

Jahrbuch

Jahrbuch für Landeskunde von Niederösterreich

Karton

Kapitel

Monumenta Germaniae Historica (1935-1945: Reichsinstitut für ältere deutsche Geschichtskunde [Monumenta Germaniae Historica])

Mitteilungen des Instituts für Österreichische Geschichtsforschung (I923-I942: MÖIG = Mitteilungen des österreichischen Instituts für Geschichtsforschung; I944: Mitteilungen des Instituts für Geschichtsforschung und Archivwissenschaft) siehe MIÖG

Mitteilungen des Oberösterreichischen Landesarchivs

Mitteilungen des Österreichischen Staatsarchivs Masarykův ústav a Archiv Akademie věd České republiky (AAVČR) [Masaryk-Institut und Archiv der Akademie der Wissenschaften der Tschechischen Republik] (Praha)

Mitteilungen des Vereines für Geschichte der Deutschen in Böhmen

Národní archiv (ehemals SÚA) Praha, oder: Neues Archiv der Gesellschaft für ältere deutsche Geschichtskunde

Neudruck

Neue Deutsche Biographie

Neue Folge

Nachlass

Neue Österreichische Biographie

Niederösterreichisches Landesarchiv (St. Pölten)

Nordostdeutsche Forschungsgemeinschaft

Osteuropäische Forschungsgemeinschaft

Oberösterreichisches Landesarchiv (Linz)

Österreichische Akademie der Wissenschaften (Wien) (I847I92I: Kaiserliche Akademie der Wissenschaften; I92I-I946: Akademie der Wissenschaften in Wien) 
ÖBL

ÖGL

ÖNB

ÖStA

ÖZG

$P A$

REM

RMI

RM

$S$

SB (und Ortsname)

SD

SODFG

SS

StLA

SÚA

TLA

UAB

UAF

UAG

UAI

UAP

UAW

UAWb

UB

Veröff.

Veröff. MPIG

VFG
Österreichisches Biographisches Lexikon

Österreich in Geschichte und Literatur

Österreichische Nationalbibliothek (Wien)

Österreichisches Staatsarchiv (Wien)

AdR Archiv der Republik

AVA Allgemeines Verwaltungsarchiv

HHStA Haus-, Hof- und Staatsarchiv

KA Kriegsarchiv

NPA Neues politisches Archiv

Österreichische Zeitschrift für Geschichtswissenschaften

Personalakt(e)

Reichsministerium für Wissenschaft, Erziehung und Volksbildung (Berlin)

Reichsministerium des Innern

Reichsmark

Schilling

Sitzungsberichte der jeweiligen Akademie der Wissenschaften, philosophisch-historische oder entsprechende Klasse,

oder: Sonderbestände

Sicherheitsdienst der SS

Südostdeutsche Forschungsgemeinschaft

Sommersemester,

oder: Schutzstaffel

Steiermärkisches Landesarchiv (Graz)

Státní ústřední archiv (Praha) (siehe NA)

Tiroler Landesarchiv (Innsbruck)

Humboldt-Universität zu Berlin, Archiv

Albert-Ludwigs-Universität Freiburg im Breisgau, Archiv

Karl-Franzens-Universität Graz, Archiv

Leopold-Franzens-Universität Innsbruck, Archiv

Karlsuniversität Prag, Archiv

Universität Wien, Archiv

Julius-Maximilians-Universität Würzburg, Archiv

Universitätsbibliothek

Veröffentlichungen

Veröffentlichungen des Max-Planck-Instituts für Geschichte

Volksdeutsche Forschungsgemeinschaft 


$\begin{array}{ll}\text { VKGÖ } & \text { Veröffentlichungen der Kommission für Neuere Geschichte Österreichs } \\ \text { VuF } & \text { Vorträge und Forschungen } \\ \text { VSWG } & \text { Vierteljahrsschrift für Sozial- und Wirtschaftsgeschichte } \\ \text { WFG } & \text { Westdeutsche Forschungsgemeinschaft } \\ \text { WS } & \text { Wintersemester } \\ \text { WStLA } & \text { Wiener Stadt- und Landesarchiv } \\ \text { ZBLG } & \text { Zeitschrift für bayerische Landesgeschichte } \\ \text { ZfG } & \text { Zeitschrift für Geschichtswissenschaft } \\ \text { ZfO } & \text { Zeitschrift für Ostmitteleuropa-Forschung } \\ \text { ZGORh } & \text { Zeitschrift für Geschichte des Oberrheins } \\ \text { ZGS } & \text { Zeitschrift für Geschichte der Sudetenländer } \\ \text { ZHF } & \text { Zeitschrift für Historische Forschung } \\ \text { ZHVSt } & \text { Zeitschrift des historischen Vereines für Steiermark } \\ \text { ZRG } & \text { Zeitschrift der Savigny-Stiftung für Rechtsgeschichte } \\ \text { GA } & \text { Germanistische Abteilung } \\ \text { KA } & \text { Kanonistische Abteilung } \\ \text { Zs. } & \text { Zeitschrift } \\ \text { ZSG } & \text { Zeitschrift für sudetendeutsche Geschichte }\end{array}$




\section{Abbildungsnachweis}

Michael Tangl Abb. I: ÖAW; Abb. 2: MGH, Archiv (München).

Anton Chroust Abb. 3: Gesellschaft für fränkische Geschichte (Würzburg).

Arthur Stein und Edmund Groag (1873-I945) Abb. 4: Max Plaček, Double Signature

(Jerusalem 1994); Abb. 5: DVD-Dokumentation „Holocaust. Theresienstadt Camp.

Deception \& Reality I94I-I 945" (Oracle Home Entertainment 2005); Abb. 6 und 7:

Axel Feuß, Das Theresienstadt-Konvolut (Hamburg/Berlin 2002); Abb. 8: Sammlung Hermann, Památník Terezín/Terezín Memorial; Abb: 9: UAP, DU.

Max Dvořák Abb. Io und I4: Institut für Kunstgeschichte der Universität Wien; Abb. I I und I2: Josef Šusta, Mladá léta učňovská a vandrovní. Praha - Vídeň - Řím. Vzpomínky II (Praha 1963); Abb. I3: ÖAW, Archiv; Abb. I5: Ernst Münz, Gustav Künstler, Der Architekt Adolf Loos (Wien 1964).

Martin Wutte Abb. I6 und 17: Kärntner Landesarchiv (Klagenfurt), NL Martin Wutte. Heinrich von Srbik Abb. 18-22: ÖAW, Archiv; Abb. 23: ÖNB, Bildarchiv und Grafiksammlung.

Gustav Pirchan Abb. 24: UAP; Abb. 25: NA, NL Anton Blaschka.

Adolf Grohmann Abb. 26-28: ÖAW, Archiv.

Karl Maria Swoboda Abb. 29: ÖAW, Archiv.

Hugo Hantsch Abb. 30: UAI; Abb. 3 I : ÖAW, Archiv.

Ernst Klebel Abb. 32: Ernst Klebel, Probleme der bayerischen Verfassungsgeschichte (Schriftenreihe zu bayerischen Landesgeschichte 57, München 1957).

Karl Lechner Abb. 33 und 35: NÖLA; Abb. 36: ÖAW, Archiv.

Franz Huter Abb. 37: ÖAW, Archiv; Abb. 38 und 39: UAI.

Konrad Josef Heilig Abb. 40: Hildegard Balcar, Konrad Josef Heilig (1907-1945) als Historiker und Publizist I-2 (Diss. phil. Masch. Wien 1968).

Die Abb. I, I9, 20, 2I und 27 entstammen einem im Archiv der ÖAW aufbewahrten feierlichen Album in Großformat, das dem Historiker Alfons Huber im Jahr I 893 aus Anlass seines 30-jährigen Professorenjubiläums von rund 9o Wissenschaftskollegen dargebracht wurde. Den Hinweis auf das Album gab mir dankenswerterweise Stefan Sienell (ÖAW, Archiv).

Nicht zu allen Fotografien konnten die Inhaber der Rechte ermittelt werden. Der Herausgeber bittet die Inhaber um entsprechende Hinweise. 



\section{Autorinnen und Autoren}

Ralph Andraschek-Holzer, Mag. Dr. phil., geb. 1963 in Horn (A). Studium der Deutschen Philologie und Kunstgeschichte in Wien (1992 Dr. phil.), I995-97 Ausbildungskurs an der Österreichischen Nationalbibliothek. Leiter der Topographischen Sammlung der Niederösterreichischen Landesbibliothek in St. Pölten. ralph.andraschek@noel.gv.at.

Prof. Dr. Hans Aurenhammer, geb. 1958 in Wien (A). Studium der Kunstgeschichte und Geschichte in Wien und Venedig. 1985 Dr. phil. I985-1995 Universitätsassistent, 1996-2004 Assistenzprofessor an der Universität Wien. 2004 Habilitation. 2005-2008 ao. Professor an der Universität Wien. Gastprofessuren in Venedig, Berlin, Dresden und Paris. Seit 2008 Professor für Kunstgeschichte an der Johann Wolfgang Goethe-Universität Frankfurt am Main. Korrespondierendes Mitglied der ÖAW. Aurenhammer@kunst. uni-frankfurt.de.

Mgr. Tomáš Borovský, Ph.D., geb. 1972. Studium der Geschichte und Philosophie in Brünn, 2003 Ph.D., Historiker und Lehrer, Philosophische Fakultät der Masaryk-Universität in Brünn. borovsky@phil.muni.cz

Ass.-Prof. Mag. Dr. Ulfried Burz, geb. 1958 in Radenthein, Kärnten (A). Studium der Geschichte und Germanistik an den Universitäten Klagenfurt und Wien; I987-I99I Stipendiat des Österreichischen Fonds zur Förderung der wissenschaftlichen Forschung (teilbeschäftigt), tw. mehrmalige Forschungsaufenthalte in Bonn, Freiburg i. Br., Koblenz, London, München, Potsdam, Wien; 1991/1992 AHS-Lehrer; 1995 Dr. phil.; 1992 Universitätsassistent; seit 200I Assistenzprofessor am Institut für Geschichte/Abt. Neuere und Österreichische Geschichte an der Alpen-Adria-Universität Klagenfurt. ulfried. burz@uni-klu.ac.at.

Dr. Christoph Egger, geb. 1963 in Wien (A). Studium der Geschichte, Philosophie und katholischen Theologie in Wien. 1996 Dr. phil. 1986-1989 Ausbildungskurs am IÖG in Wien. Universitätsassistent am IÖG und am Institut für Geschichte der Universität Wien. eggerc8@login.univie.ac.at. 
Dr. Stefan Eminger, geb. 1967 in Wien (A). Studium der Geschichte und Deutschen Philologie in Wien. 200 I-2005 Lehrbeauftragter am Institut für Zeitgeschichte der Universität Wien. Wissenschaftlicher Mitarbeiter der Abteilung Niederösterreichisches Landesarchiv und Niederösterreichisches Institut für Landeskunde in St. Pölten. Stefan.Eminger@ noel.gv.at.

Prof. Dr. Peter Herde, geb. 1933 in Ratibor (Racibórz, Pl). 1958 Promotion zum Dr. phil. an der Ludwig-Maximilians-Universität in München, 1965 Habilitation ebendort. I968-1976 Professor für Mittlere und Neuere Geschichte an der Johann Wolfgang von Goethe-Universität in Frankfurt am Main, I976-200 I Professor für Geschichte, insbesondere mittlere Geschichte, Landesgeschichte und Historische Hilfswissenschaften an der Julius-Maximilians-Universität in Würzburg. peter.herde@mail.uni-wuerzburg.de.

Mag. Johannes Holeschofsky, geb. I98 I in Eisenstadt (A). Studium der Geschichte, Österreichischen Geschichte, Neueren Geschichte und Zeitgeschichte (Fächerkombination) in Wien, 2008 Mag. phil. Dissertationsstudium im Fach Geschichte zum Thema Hugo Hantsch. Johannes.Holeschofsky@gmx.at.

Dr. Karel Hruza, MAS, geb. I96I in Aš (CZ). Studium der Geschichte und Politikwissenschaft in Konstanz und Wien. 1994 Dr. phil. I992-I995 Ausbildungskurs am IÖG Wien. Historiker am Institut für Mittelalterforschung der Österreichischen Akademie der Wissenschaften Wien. Lektor an der Masaryk-Universität in Brünn. Karel.Hruza@oeaw.ac.at.

Dr. Alena Janatková, geb. I960 in Prag (CZ). Studium der Kunstgeschichte, Psychologie, Philosphie und Denkmalpflege in Bochum, Bamberg und Berlin. I 996 Dr. tech. (ETH Zürich). Kunsthistorikerin am Institut für Kunst- und Bildgeschichte der HumboldtUniversität zu Berlin. alena.janatkova@culture.hu-berlin.de.

Dr. Stefan Lehr, geb. 1977 in Frankfurt am Main (D). Studium der Geschichte und Internationalen Beziehungen in Düsseldorf, Prag, Krakau und Moskau. 2006 Dr. phil. Wissenschaftlicher Mitarbeiter der Abteilung für Osteuropäische Geschichte des Historischen Seminars der Westfälischen Wilhelms-Universität Münster. stlehr@uni-muenster.de.

Prof. Dr. Helmut Maurer. Stadtarchivdirektor i. R., geb. 1936 in Donaueschingen (D). I963 Dr. phil. Freiburg i. Br. 1963-1964 Stipendiat Deutsches Historisches Institut Rom. I964-I966 Archivschule Marburg an der Lahn. I966-200 I Leiter des Stadtarchivs Konstanz. Seit I98 I Honorarprofessor für mittelalterliche Geschichte an der Universität Konstanz. Prof.Helmut.Maurer@web.de. 
Mag. Dr. Martina Pesditschek, geb. in Graz (A). Studium der Geschichte, Ur- und Frühgeschichte, Kunstgeschichte und Byzantinistik an der Universität Wien. 2005 Dr. phil. Mitarbeiterin am Institut für Alte Geschichte und Altertumskunde, Papyrologie und Epigraphik der Universität Wien. Martina.Pesditschek@univie.ac.at

Dr. Andrea Rzihacek, MAS, geb. 1963 in Laaben (A). Studium der Geschichte und Anglistik in Wien. 1986-1989 Ausbildungskurs am IÖG Wien. 2000 Dr. phil. Mitarbeiterin der Monumenta Germaniae Historica am Institut für Mittelalterforschung der Österreichischen Akademie der Wissenschaften. Andrea.Rzihacek@oeaw.ac.at.

Dr. Klaus Wachtel, geb. 1937 in Döbeln (D). I955-1960 Studium der Klassischen Philologie und Alten Geschichte in Berlin (Humboldt-Universität) und Jena. 1960-2002 Assistent, Oberassistent, wiss. Arbeitsleiter und Arbeitsstellenleiter an der Deutschen Akademie der Wissenschaften zu Berlin, der Akademie der Wissenschaften der DDR und der Berlin-Brandenburgischen Akademie der Wissenschaften. 1965 Dr. phil.; I970 Dr. phil. habil. Ordentliches Mitglied des Deutschen Archäologischen Instituts. Dr.KlausWachtel@t-online.de.

Dr. Michael Wedekind, geb. I960 in Bremen (D). Studium der Geschichte, Romanistik und Erziehungswissenschaften in Münster/Westfalen und Bologna. I 996 Dr. phil. Historiker am Institut für Wirtschafts- und Sozialgeschichte der Universität Wien. michael. wedekind@univie.ac.at.

Dr. Sibylle Wentker, MAS, geb. 1967 in Bonn (D). Studium der Arabistik und Geschichte sowie Turkologie in Wien. 2002 Dr. phil. I992-I995 Ausbildungskurs am IÖG Wien. Wissenschaftliche Mitarbeiterin am Institut für Iranistik der Österreichischen Akademie der Wissenschaften.Sibylle.Wentker@oeaw.ac.at.

Dr. Wolfram Ziegler, geb. I970 in Linz (A). Studium der Geschichte und der Historischen Hilfswissenschaften in Wien. 2004 Dr. phil. 2005-2008 Historiker am WienMuseum, seit 2008 am Institut für Mittelalterforschung der Österreichischen Akademie der Wissenschaften Wien. Wolfram.Ziegler@oeaw.ac.at. 



\section{Personenregister}

Die Sortierung erfolgt nach $\ddot{a}=$ ae; $\check{c}=c$ usw. Bei Personen, deren Vorname nicht bekannt war, wurde „(N.?)“ gesetzt. Fragliche oder unsichere Zuweisungen wurden in runden Klammern mit einem Fragezeichen gesetzt. Abkürzungen: Bf. = Bischof; d. Ä. = der/die Ältere; d. J. = der/die Jüngere; Erzbf. = Erzbischof; Erzhzg. = Erzherzog bzw. Erzherzogin; Hzg. = Herzog bzw. Herzogin; Kg. = König bzw. Königin; Ks. = Kaiser bzw. Kaiserin.

Abert, Joseph Friedrich 108f., 114f., 124

Adler, Viktor 71

Adorno, Theodor W. 310

Albrecht I., röm.-dt. Kg., Hzg. v. Österreich 41

Albrecht II., Hzg. v. Österreich 475

Albrecht III., Hzg. v. Österreich 621

Alföldi, Andreas 151

Alföldy, Géza 164

Althoff, Friedrich 64

Andraschek-Holzer, Ralph 551

Andreas, Willy 281

Angerer, Hans 222, 237

Antal, Frederick 200

Anton, Hermann 92, 124

Antonius, Friedrich Wilhelm 593, 596

Appelt, Heinrich 615f., 645

Aristoteles 468

Arndt, Wilhelm 53, 74

Arneitz, Viktor 231

Arnim, Hans v. 179

Arnold, Robert Franz 136f.

Arnulf, Hzg. v. Bayern 496

Arnulf, Kg. der Franken und Ks. 496

Aschoff, Ludwig 270

Aslan, Raoul 283

Aubin, Hermann 347, 353, 369, 431, 541f., 565,

$$
\text { 571, } 574
$$

Auckenthaler, Engelbert 603

Auer, Leopold 566

Augustinus, Bf. v. Hippo 460

Augustus (Gaius Octavius), römischer Ks. 130, 138

Aurenhammer, Hans H. 417
Ausserer, Karl 136

Bachmann, Adolf 334f., 341

Bachmann, Erich 427, 434, 438

Badeni, Kasimir Felix 267, 364

Baethgen, Friedrich 127

Baeumler, Alfred 318

Balcar, Hildegard 616

Barraclough, Geoffey 49

Bartoš, František M. 626

Bassler, Viktor $146 \mathrm{f}$.

Bauer, Adolf 105, 215

Bauer, Bruno 316

Bauer, Otto 281

Bauer, Wilhelm 10, 12, 14, 268-270, 273, 280, 285, 302, 315, 359f., 466, 505, 515f., 525, 537, 560

Beckenkamp, Jacob 109, $114 \mathrm{f}$.

Becker, Anton 544

Becker, Carl Heinrich $380 f$.

Becking, Gustav 350

Beenken, Hermann Theodor 422

Beer, Adolf 135

Beer, Karl 626

Beetz, Wilhelm 158

Below, Georg v. 62

Bendel, Franz Joseph 121

Benesch, Otto 170, 175, 190

Benn, Gottfried 416

Benndorf, Otto 91, 133, 163

Berchtold, Leopold v. 487

Bergl, Josef 333f., 340-342, 345-348, 353, 356, 358

Bernhard, Abt v. Clairvaux 71 
Bernhard, Thomas 15

Bernhauer, Konrad 151

Bernt, Alois 626

Bethmann-Hollweg, Theobald v. 98

Bibl, Viktor 264f., 313, 321, 539

Bick, Josef 147

Bigelmair, Anton 89, 126

Bilger, Ferdinand 307, 475, 483

Bischoff, Bernhard 87, 97, 518

Bismarck, Otto v. 103, 303, 309, 457

Bittner, Ludwig 257, 271, 497, 525, 537, 595, $597 \mathrm{f}$.

Bittner, Max 384, 390

Blaschka, Anton 334, 336, 341f., 345-348, 353f., 358f., 372

Bloch, Marc 203

Blum, Leon 546

Bock, Friedrich 360, $492 \mathrm{f}$.

Bodo, Fritz 570

Boehm, Max Hildebert 613

Böhm, Alfred 469

Böhm, Anton 532, 534f., 545, 555

Böhm, Wilhelm 622, 628

Bonifatius, Bf. v. Mainz 25, 53f., 56-58, 74

Bonifaz IX., Papst 44, 46

Bonjour, Edgar 293, 295

Borkenau, Franz 14

Bormann, Eugen 133, 137, 139, 144, 163, $166 f$.

Bormann, Martin 313

Borodajkewycz, Taras v. 263, 274, 308, 315, 532, 534, 537, 545, 573f., 622, 635

Borovička, Josef 335

Borovský, Tomáš 14

Borromini, Francesco 181

Bosl, Karl 647

Both, Adolf v. 445-447

Bötticher, (N.?) v. 60

Bourdieu, Pierre 14, 575

Bouterwerk, Karl Wilhelm 458

Brackmann, Albert 34, 36, $516 f$.

Brandenburg, Erich 264, 287, 317

Brandi, Karl 28, 35, 53, 66f., $91 \mathrm{f}$.

Brandl, Alois 72, 87

Brassloff, Stephan 158

Braun v. Braun, Matthias Bernhard 428

Braun, Edmund Wilhelm 420, 438, 447

Braunias, Karl 537

Brehm, Bruno 287, 292
Brenner, Oskar 104-109, 111-113, 115, 121

Bresslau, Harry 28, 30f., 35, 66-69, 88, 96, 98, 494-497

Bretholz, Bertold 24, 69f., 89

Broinger, Rudolf 565, 570

Brokoff, Ferdinand Maximilian 428

Bruck, Adolf 557

Bruckmann, Friedrich 96f., 279, 290

Bruckmann, Hugo 279

Brückner, Alexander 84

Brückner, Eduard 525

Bruegel, Pieter 172, $197 \mathrm{f}$.

Brunner, Heinrich 55, 587

Brunner, Otto 7, 9-11, 14f., 19, 348, 416, 472-475, $482,502,507,515-517,520,534,537,540,552$, 565, 586, 595, 622, 624

Buchheim, David 131

Buchheim, Gerson 131

Buchheim, Karl Adolph 131

Buchner, Max $123 \mathrm{f}$.

Büdinger, Max 51, 133, 163, 166

Bühler, Georg 383

Bujnoch, Herbert 151

Bürckel, Josef 307

Burckhardt, Jacob 269, 279

Burdach, Konrad 96, 626

Burger, Max 230, 237

Burgert, Helmut 535

Burian, Jan 144, 151

Burkhard, Bf. v. Würzburg 86, 88

Butta, Václav 448

Büttner, Heinrich 647

Carpentier, Pierre 26

Cartellieri, Otto 40

Caspar, Erich 29, 38f., 52, 56, 70, 344

Casselmann, Leopold 112-114

Cassiodor(us), Flavius Magnus Aurelius 88

Čejchan, Václav 354

Černý, Jan 339

Cézanne, Paul 189

Chamberlain, Houston Stewart 279, 304

Chlodwig I., Kg. der Franken 481

Chroust, Anton 19, 24, 79, 85, 87-127

Chroust, Anton Hermann Karl 89

Chroust, Johanna (geb. Sander) 90f., 124

Chroust, Karoline 89 
Cibulka, Josef 433, 444f., 448f.

Clauss, Josef M. B. 639

Cohen, (N.?) 447

Cola di Rienzo 171

Conze, Alexander 133

Conze, Werner 18

Corradini, Doris A. 11, 13, 18, 263

Corregio, Antonio da 188

Cosmas v. Prag 175

Crailsheim, Kraft v. 88, 101, 103f., 110f., 116, 120

Crämer, Ulrich 265, $312 \mathrm{f}$.

Curie, Marie 295

Cuspinianus, Johannes 589

Cuthsuuith, Äbtissin v. Inkberrow 86f., 95

Cysarz, Herbert 146, 347, 365

Czermak, Emmerich 484, 507

Daller, Balthasar v. 113

Dante Alighieri 90, 347, 367

Degas, Edgar 188

Deledda, Grazia 90

Dellius (Bürger in Rom) 130

Dengel, Ignaz Philipp 11, 456, 463, 466, 470, 487

Derndarsky, Michael 286, 302, 319

Dessau, Hermann 137, 139f., 156

Deutsch, Julius 281, 528

Diekamp, Wilhelm 42, 46-48

Diels, Hermann 139

Dienst, Heide 569

Dientzenhofer, Christoph 428, 436

Dientzenhofer, Kilian Ignaz 428

Dietrich v. Nieheim 44, 46, 49

Dietrich, Albrecht 409

Dilthey, Wilhelm 195

Dobernig, Johann Wolfgang 221f., 228

Doderer, Franz Carl Heimito v. 277, 310, 594

Dohrn, Klaus 628

Dolberg, (N.?) 556

Dölger, Franz 645

Dollfuß, Engelbert 478f., 484, 507, 627, 632

Domaszewski, Alfred v. 102

Donabaum, Josef 42

Donath, Julius (?) 160

Donin, Richard Kurt 557

Dopsch, Alfons 14, 53, 179, 270-271, 274f., 277, 336, 463, 493, 497, 505-507, 516, 518, 520, 525f., 539, 583, 587, 595, 597, 621f., 624
Dopsch, Heinz 569

Doublier, Othmar 147, 160

Drerup, Engelbert 102

Dressel, Heinrich 139

Dubsky, (N.?) v. 545

Dülfer, Martin 193

Dümmler, Ernst 56f., 60-62, 66

Dungern, Otto v. $582 \mathrm{f}$.

Dunkhase, Jan Eike 21

Dvořák, Gisela (d. J.) 179

Dvořák, Gisela 178

Dvořák, Hermine 184

Dvořák, Josef 172

Dvořák, Marie 178

Dvořák, Max (d. Ä.) 172

Dvořák, Max 19, 169-200, 411-415, 420, 424f., 450, 525

Dvořák, Rosa (geb. Jovanovic-Seatovic) 184

Eberle, Joseph 469

Eck, Werner 164

Egger, Rudolf 298, 537, 552

Eheim, Fritz 569

Ehrenberg, Victor 142-144, 146

Eibl, Hans 545

Einstein, Albert 295

Eiselsberg, Anton 284

Eisenstein, Herbert 382

Eitelberger, Rudolf v. 169

El Greco 183, $197 f$.

Elschner, Curt 122

Emler, Josef 175

Engel, Wilhelm 510

Engel-Janosi, Friedrich 14, $303 f$.

Engelmann, Johannes 622

Engels, Friedrich 461

Epiphanius v. Zypern 403

Epstein, Fritz 289

Erben, Wilhelm 11, 24, 58, 78, 89, 474f., 482, 490, 494f., 510

Erdmann, Carl 89, 127, 644

Erdmann, Karl Dietrich 293, 295

Erler, Georg 44f., 49,

Ernst v. Pardubitz, Erzbf. v. Prag 171

Ernstberger, Anton 369

Eugen Franz, Prinz v. Savoyen 464

Eugen III., Papst 43 
Eugen, Erzhzg. v. Österreich(-Teschen) 311, 323

Evola, Julius 304

Fafl, Zdeněk 401

Fanta, Adolf 41f., 46

Fechter, Paul 195

Fedele, Pietro 71

Feigl, Helmuth 569, 573, 588

Feilitzsch, Max v. 116

Feldner, Josef 238

Fellner, Fritz 13, 17, 263, 320, 534

Ferber, Walter 638

Ferenc, Tone 254

Feuerbach, Anselm 193

Fey, Erich 236, 547

Fichtenau, Heinrich 66, 519, 523

Ficker, Julius v. 79, 472, 510

Filipský, Anton 132

Finke, Heinrich 466, 619-621, 626f., 631

Fischer, Herta 248

Fischhof, Adolf 276

Fitzek, (N.?) 444

Fleischer, Heinrich Leberecht 382

Flor, Fritz 532, 534

Foerster, Hans 624

Förster, Max 87, 100, 104, 107-109, 111f., 114f., 117-121, 126

Fournier, August 275, 277, 525

Frank, Gustav 237

Frank, Karl Hermann 356, 358, 447

Frank, Walter 282f., 288, 293f., 318

Franke, Adolf 507

Frankfurter, Salomon 158

Frankl, Ludwig August v. 276

Franz Ferdinand, Erzhzg. v. Österreich(-Este) 178, 457, $476 f$.

Franz Joseph, Ks. v. Österreich 40, 144f., $302 f$.

Franz, Eugen 125

Franz, Günther 460

Franz, Heinrich Gerhard 419, 438f.

Franz, Herbert 535

Franz, Lothar 462

Frazer, James 416

Freimark, Peter 398, 409

Fresacher, Walter 224

Frey, Dagobert 170, 190

Freytag, Gustav 316
Friedrich I. (Barbarossa), röm.-dt. Kg. und Ks. 79, 90, 473, 615, 642

Friedrich II., Kg. v. Preußen 467

Friedrich II., röm.-dt. Kg. und Ks. 27, 45, 63, 77

Friedrich III., Burggraf v. Nürnberg 271

Friedrich, Gustav 175

Friis, Aage 295

Fritz, Karl 231, 237

Frobenius, Leo 416

Frodl, Walter 240

Frömel, Hermine $159 f$.

Fück, Johann 381

Führer, Erich 503

Funder, Friedrich 532, 555

Funk, Philipp 620

Gall, Franz 559

Gaßner, Hieronymus 535

Gatterer, Matthias (?) 245

Gauguin, Paul 189

Gehler, Michael 592

Gentz, Friedrich v. 478

Geramb, Viktor 292, 420

Gerstenberg, Kurt 422

Gerstenberger, Liborius 113, 126

Gerstinger, Hans 622

Gesemann, Gerhard 347, 422

Geßl, Franz 535

Geyer, Eberhard 546

Geyer, Rudolf 384, 387, 390, 557

Giannoni, Karl 554

Giehl, Franz (Pseudonym Konrad Josef Heiligs) 628

Gierach, Erich 347, 372

Gindely, Anton 269

Ginhart, Karl 518, 520

Gladstein, Tunja 345

Gladt, Karl 137

Glaise-Horstenau, Edmund v. 285, 292, 298, 307f., $535,537,635$

Glantschnig, Josef 237

Glaser, Eduard 386-388, 393f.

Glettler, Monika 7, 13, 396, 408

Glück, Gustav 178

Göbel, Sebastian 89

Gobineau, Joseph Arthur de 304

Gočár, Josef 443

Goebbels, Joseph 258, 311 
Goerdeler, Carl Friedrich 286, 314

Goethe, Johann Wolfgang v. 303, 321

Goetz, Walter 91f., 322

Goldenberger, Franz 123

Goll, Jaroslav 175

Gombrich, Ernst $199 f$.

Gorbach, Alphons 485

Görgen, Hermann M. $634 f$.

Gothein, Eberhard 92

Gotsmich, Alois 143

Götting, Hans 622

Gottschalk, Hans 407, 409

Goya, Francisco de 182

Graber, Georg 81, 234, 254

Graebner, Fritz 416

Grafenauer, Bogo 249-251

Grauert, Hermann v. 64, 95-97, 468

Grauert, Wilhelm Heinrich 266, 277

Gregor VII., Papst 71

Gregor XII., Papst 44

Grill, Heinz 502

Groag, Berthold 131, 166

Groag, Charlotte (geb. Karpeles) 131

Groag, Edmund 129-167

Groag, Pauline (Paula) 131, 157

Gröber, Conrad 639

Grohmann, Adolf 379-410

Grohmann, Erwin 395, 408

Grohmann, Irmelin 395, 401, 407

Grohmann, Maria 407

Groß, Lothar 622

Grün, Anastasius 212

Grundmann, Herbert 502

Grünwald, Alois 419

Gschließer, Oswald 610

Guardini, Romano 527

Gugitz, Gustav 548, 557

Guglia, Eugen 267, 275

Gundlach, Wilhelm 60-65

Günther, Hans F. K. 319

Gutenberg, Johannes 360

Gutkas, Karl 569

Gutschmid, Alfred v. 102

Habsburg, Otto v. 286, 323

Hácha, Emil 446

Hadrian II., Papst 56
Haffner, August $402 \mathrm{f}$.

Hagenmaier, Wilfried 626

Hahn, Eva 331

Hajek, Alois 9

Haller, Johannes 49, 95f.

Hamburger, Käthe 161

Hammer-Purgstall, Joseph v. 382

Hampe, Karl 30f., 37, 96, 500

Hannibal (Barkas) 142, 167

Hanthaler, Chrysostomos (Johannes Adam) 35

Hantsch, Anni 486

Hantsch, Fritz 486

Hantsch, Hugo 11, 19, 451-487, 535, 594, 633

Hantsch, Josef (Pepi) 454, 486

Hantsch, Luis 486

Harmjanz, Heinrich 258

Hartel, Wilhelm v. 174

Hartl, Heinrich 134

Hartmann, Ludo Moritz 69

Hartung, Fritz 264

Hashagen, Justus 282

Hassinger, Herbert 610

Hassinger, Hugo 419f., 507, 543, 552, 563

Haupt, Herman 269

Hauptmann, Gerhard 70

Häusler, Wolfgang 569

Hausmann, Frank-Rutger 15, 20

Hausmann, Friedrich 568

Haußherr, Hans 470

Havelka, (N.?) 422

Heckel, Hans 444, 447

Heckel, Rudolf v. 38, 49, 52, 84

Heeren, Arnold 458

Hegemann, Hans Werner 427, 438

Heidegger, Martin 306, 316, 416

Heigl, Paul 11, 15, 506

Heilig, Alois 617

Heilig, Hermann Josef 617

Heilig, Josefine (geb. Habermann) 637

Heilig, Konrad Josef 19, 21, 474, 538, 615-647

Heilig, Maria (geb. Siebler) 617

Heilig, Wendelin 617

Heilsberg, Franz 582f.

Heimpel, Hermann 348, 502, 516, 622

Hein, Max 38

Heine, Heinrich 302 
Heinrich (der Stolze), Hzg. v. Bayern und v. Sachsen 473

Heinrich II. (Jasomirgott), Hzg. v. Österreich 473, 642

Heinrich II., Kg. v. England 344

Heinrich III., röm.-dt. Kg. und Ks. 71

Heinrich IV., röm.-dt. Kg. und Ks. 65

Heinrich v. Hessen 620

Heinrich v. Langenstein 619, 621, 623, 634, 646

Helbok, Adolf 7, 9, 10, 14, 348., 369, 553, 575, 603, 608

Held, Jutta 427

Helfert, Alexander v. 469

Helfert, Jaroslav 177

Helleiner, Karl 528, 540, 594

Helmolt, Hans Ferdinand 79

Henlein, Konrad 289, 426, 441

Henner, Theodor 101f., 104, 106, $123 f$.

Hergenröther, Joseph 43

Hermann, Hugo 618

Herwegh, Georg 212

Herzog-Hauser, Gertrud 158

Hetsch, Rolf (?) 441

Heuberger, Richard 594, 610

Heuß, Theodor 323

Heydrich, Reinhard 357, 440, 443-446

Heymann, Ernst 149-151

Hieronymus 86

Hildebrandt, Dietrich v. 481, 628, 635, 638

Hilpert, Hans 123

Himmler, Heinrich 597

Hintze, Hedwig 264

Hintze, Otto 38, 73

Hirn, Joseph 483

Hirsch, Hans 10, 21, 141, 269f., 273, 300, 340, 342, 346-348, 360, 366, 409, 420, 435, 466, 472-475, $492,501,505,507,515 f ., 530,537,552,568$, 586, 622, 624, 631f., 644

Hirschfeld, Otto 133, 139, 156, 163

Hitler, Adolf 70, 125, 166, 244f., 247-252, 264 , 279, 289, 294, 297f., 300f., 306-309, 313, 318, $320,350,355,359,368,399,421,434,444,446$, 479, 484, 500f., 504, 513, 542f., 596, 605, 628

Hobsbawm, Eric 3

Hoeniger, Karl Theodor 600, 606

Hoetzsch, Otto 69

Hofer, Franz 601, 607
Hofer, Peter 606

Hofer, Walther 319

Höfler, Constantin 362

Hofmannsthal, Hugo v. 291

Hofmeister, Adolf 38

Hohl, Ernst 142, 153

Holder-Egger, Oswald 25, 29, 57, 60-63, 96

Holinka, Rudolf 358

Holzinger, Carl v. 142

Honecker, Martin 620

Hönigschmid, Rudolf 441

Horaz (Quintus Horatius Flaccus) 129

Horkheimer, Max 310

Horn, Josef 212

Hrdlička, Heinrich 160

Hrozný, Bedřich 392, 397f., 405

Hrubý, Václav 335

Hruza, Karel 17

Huber, Alfons 653

Hugelmann, Karl Gottfried 497, 510

Huizinga, Johan 280, 295, 310, 324

Hülgerth, Ludwig 229, 232, 237, 245f., 491

Hurdes, Felix 561

Hurdes, Franz 557, 561

Huter, Barbara 595

Huter, Franz 316, 458, 591-614

Huter, Marianne (geb. Pancheri) 595

Hutten, Christoph Franz v. 86

Hüttl, Willy Johann $150 f$.

Ignatius v. Loyola 111

Innitzer, Theodor, Erzbf. v. Wien 535, 539, 545, 557

Innocenz III., Papst 32, 50f., 57

Jacobi, Walter 447

Jäger, (N.?) 278

Jahn, Karl 397, 399

Jaksch, August v. 59, 80f., 83

Jambor, Walter 277,310

Janssen, Johannes 461

Jantzen, Hans 432

Jaspers, Karl 416

Jean (Maître Jean) 174

Jedlitschka, Karsten 14

Jehle, Fridolin 622, 624

Jekelius, Erwin 547

Jellinek, Max 622 
Jenšovský, Bedřich 355

Johann (IV.) v. Dražice, Bf. v. Prag 174

Johann v. Neumarkt, Bf. v. Leitomischl und v. Olmütz 173, 177, 197

Johann v. Troppau 177

Johann, Abt v. Viktring 81, 83f.

Johann, Erzhzg. v. Österreich 275

Johannes v. Segovia 135

Johannes v. Tepl 366f., 626f., 631, 646

Johannes VIII., Papst 56

John, Amand 457

Johnson, Alvin S. 161

Jordan, Karl 647

Jordan, Stefan 14

Josef I., röm.-dt. Ks., Kg. v. Böhmen und v. Ungarn $463,465,47$,

Jostmann, Christian 16

Judeich, Walter 102

Junker, Hermann 384, 387

Jusselin, Maurice 26

Kaerst, Julius 102, 121

Kaindl, Raimund Friedrich 264, 287, 470, 482

Kalinka, Ernst 134

Kamil, Murad 404

Kampfhammer, Franz Maria 557, 561

Kandinsky, Wassily 191

Kappelmacher, (N.?) 158

Kappelmacher, Adolf 158

Kappelmacher, Alfred 158

Kappelmann, (N.?) 158

Kappelmann, Adolf 158

Kapras, Jan 364

Karabaček, Josef v. 384f., 387-390, 406, 408

Karda, Josef 448

Karell, Emil 131, 157

Karell, Ludwig 131

Karl der Große, Kg. der Franken, Ks. 54, 473, $499 f$.

Karl I., Ks. v. Österreich 320

Karl IV., röm.-dt. Kg. und Ks., Kg. v. Böhmen 330, 337, 356, 359f., 364, 367, 370, 372f., 375f., 391, 429

Karl V., röm.-dt. Kg. und Ks., Kg. v. Spanien 459, 467

Karl VI., röm.-dt. Ks., Kg. v. Böhmen und v. Ungarn 463, 465

Karlmann, fränkischer Hausmeier 54
Karpeles, Eleazar 131

Karpeles, Elias 131

Karpeles, Gustav 131

Karpeles-Buchheim, Charlotte (= Charlotte

Groag) 131

Kars, Rudolf 131

Kaser, Kurt 273

Kaunitz, Dominik Andreas I. v. 464

Kazbunda, Karel 331, 333, 341, 359

Kehr, Paul Fridolin 25-27, 31f., 34-39, 55, 57, 64, $66,69,78,82,127$

Keil, Josef 151, 160, 166f., 401

Keller, Erwin 639

Kelsen, Hans 481

Kestenberg, Leo 345

Kestenberg-Gladstein, Ruth $344 \mathrm{f}$.

Khoury, Raif 407

Khuen-Belasi, Carl 184

Kienast, Walter 125

Kierkegaard, Sören 416, 418

Kinzl, Hans 594, 603, 610

Kisch, Alexander 138

Kisch, Egon Erwin 138

Klaar, Adalbert 540, 557, 564, 569

Klages, Ludwig 318

Klaus, Josef 532

Klebel, Anna (geb. Erben) 490

Klebel, Ernst 482, 489-522, 525, 530-532, 535, 540, 543, 548, 555-558, 563f., 571, 573, 587, 620

Klebel, Wilhelm 490

Klebelsberg, Raimund v. 240, 606

Klebs, Elimar 137

Klein, Bruno 158-160

Klein, Hedwig 398f., $408 f$.

Klein, Wilhelm 140

Kletzl, Otto 434, 438

Klicman, Ladislav 336, 338-340, 346, $348 f$.

Klimt, Gustav 187

Klinge (Praschek) (?), Silvester 237

Kloiber, Ämilian 554

Knaus, Siegmund 237

Knoll, Fritz Josef 307

Koch, Christoph Wilhelm v. 458

Koebner, Richard 347f.

Kogon, Eugen 628

Kohla, Franz X. 237 
Köhler, Wolfgang 416

Kokoschka, Oskar 185, 191, 199

Koláŕ, Pavel 12, 20, 38, 349

Kolbenheyer, Erwin Guido 311, 428

Kolbes, Walter 140

Kommetter, Viktor 237

König, Friedrich Wilhelm 156

König, Sepp 237

Konrad III., röm.-dt. Kg. 473

Konrad, Cichorius 102

Konrád, Ota 12, 20

Konradin, Kg. v. Sizilien, Hzg. v. Schwaben $76 f$.

Köpl, Karl 333, 336

Korger, Friedrich 562

Körner, Josef 136, 142, $161 \mathrm{f}$.

Koser, Reinhold 29, 64, 98, 98

Koss, Rudolf 333, 341

Kötzschke, Rudolf 369, 541, 551, 565, 574

Krabbo, Hermann 26, 38, 84

Kraigher, Franz 237

Kralik, Dietrich 497

Kralik, Richard 469

Krallert, Wilfried 10f., 15

Kramáŕ, Vincenz 179

Kramer, Hans 316, 610

Kramert, Klemens 550

Krammer, Mario 55

Kraus, (N.?) 446

Kraus, Felix 237

Kraus, Hans-Christof 11, 19-21

Krčmáŕ, Jan 448

Krebs, Norbert 525, 594

Kretschmayr, Heinrich 296, 537

Kretschmer, Ernst 416, 418, 432

Kromayer, Johannes 141

Kronegger, Fritz 231

Krones, Franz v. 215

Kühn, Karl Friedrich 446

Kukula, Wilhelm 344

Külpe, Oswald 120f.

Kümper, Hiram 13

Kunz, Anton 132

Kutnar, František 331

L'Estocq, Hermann 234

Lamprecht, Karl 197, 334

Landau, Horace v. 386
Landmann, Robert v. 88, 100, 103, 105, 109-111, 114-118, 120

Lang, Matthäus 618

Langbehn, Julius 445

Lanske, Eugen 503

Lara y Mendoza, Maria Maximiliana Manrique de 173

Laud, William 86

Lechner, Helga (geb. Kolisko) 527

Lechner, Karl 490, 520, 523-590

Lehmann, Max 64

Lehner, Ferdinand Josef 443

Leibniz, Gottfried Wilhelm 477

Leidlmair, Adolf 591

Lemisch, Arthur 235-237

Lentze, Hans 497, 631f.

Lenz, Max 73

Lenz, Oskar 334

Leo XIII., Papst 49

Leopold I., röm.-dt. Ks., Kg. v. Böhmen und v. Ungarn 172

Leopold Wilhelm, Erzhzg. v. Österreich 172

Leopold, Josef 548

Lesný, Vincenc 401

Leuze, Oskar 140

Lévy-Bruhl, Lucien 416

Lhotsky, Alphons 68, 85, 269, 458, 494, 563f., 616, $644 f$.

Liebermann, Felix 87

Liebermann, Max 72

Liechtenstein, Eduard v. und zu 182

Liechtenstein, Franz v. und zu 185

Linck, Bernhard 589

Lipps, Theodor 193

Lobisser, Suitbert $231 \mathrm{f}$.

Lobkowitz, Polyxena v. 173

Lobkowitz, Wenzel Eusebius v. 172

Lobkowitz, Zdenko Adalbert v. 173

Lodgman v. Auen, Rudolf 338, 349, 362

Loehr, August v. 624

Loesch, Karl v. 236

Loeschke, Georg 139

Loewy, Thedore H. 161

Löffler, Hermann 312

Loos, Adolf $184 f$.

Lorenz, Ottokar 64

Lorenz, Reinhold 309, 316, 483, 530-532, 534f., 537,573 
Loserth, Johann 19, 215

Lothar III., röm.-dt. Kg. und Ks. 473

Lowe, Elias Avery 87, 97

Ludwig I. (der Fromme), Kg. der Franken, Ks. 28, $55,80,228$

Ludwig III., Kg. v. Bayern 99

Ludwig IV. (der Bayer), röm.-dt. Kg. und Ks. 90, 205

Lueger, Karl 71

Luick, Karl 105, 107, 111-113, 115

Luitpold Karl Joseph Wilhelm, Prinzregent v. Bayern 100-102, 115-117, 120

Lukas, Julius 237

Lullus, Erzbf. v. Mainz 54, 56

Luther, Martin 461

Lutz, Johann v. 103

Machatschek, Friedrich 420, 505

Maierhofer, Valentin 237

Maier-Kaibitsch, Alois 237, 241, 243, 247

Malle, Avguštin 222

Manes, Philipp 155f.

Manet, Édouard 187, 189

Manhart, Ilse (geb. Wutte) 208, 218

Mann, Golo 285

Manuel I. Komnenos, Ks. v. Byzanz 642

Marcks, Erich 94, 278, 334

Marcuse, Herbert 310

Marées, Hans v. 193

Mareš, Franz 581

Maria Theresia, Kg. v. Ungarn und v. Böhmen, Erzhzg. v. Österreich 204

Marquard, Odo 280

Masaryk, Tomáš Garrigue 339, 345, 395, 422

Massiczek, Albert 307

Matějček, Antonín 412f., 420-422, 433, 443, $448 f$.

Maximilian I. oder II. (?), röm.-dt. Kg. und Ks. 43

Maximilian I., röm.-dt. Kg. und Ks. 466

Mayer, Franz Martin 215

Mayer, Gustav 73

Mayer, Theodor 14, 345-348, 356, 360, 367, 493f., 497, 501f., 510-512, 516, 520f., 523, 525, 539, $564,583,586,617,643$

Mayr, Karl 51, 91

Mayr, Karl Maria 600, 603

Mayr, Michael 483

Mayrhofer, Manfred 407
McNeill Whistler, James 187

Meier-Graefe, Julius 198

Meinecke, Friedrich 73, 263, 269f., 291-293, 296, 303, 316, $319 \mathrm{f}$

Meinert, (N.?) 357

Meinlschmidt, Karl 344, 368

Meissl, Sebastian 523, 534

Meister, Richard 563, 625

Melcher, Peter 237

Mell, Anton 19, 215, 481f., 507, 510

Mell, Max 292, 310-312

Mendl, Bedřich 333, 340, 354

Menghin, Oswald 292, 298, 506, 525

Menghin, Wilfried 416

Merkle, Sebastian 107, 109, 114f., 126, 468

Merklein, Albert 259

Messel, Alfred 193

Metternich, Clemens Wenzel Lothar v. 263f., 267, 275, 278-281, 283f., 290, 295f., 313, 458f., 477f.

Metz, Friedrich 510

Meunier, Constantin 188

Meurer, Christian 118

Meyer, Christian 50

Meyer, Eduard 73f., 79

Meyer, Otto 517, 647

Meyer, Wilhelm 631

Meyer-Cohn, Alexander 51

Michelangelo (Buonarroti) 188, 192, 194

Michels, Thomas 535

Mika, Emil 534

Milkowicz, Wladimir 24

Miller, Jean François 187

Miltner, Franz 298

Miltschinsky, Viktor 213, 257

Missong, Alfred 469

Mitis, Oskar v. 539

Mitrowitz, Johann Wenzel Wratislaw v. 464

Mitscha-Märheim, Adalbert 540, 565, 569, $586 f$.

Mitterauer, Michael 519, 569, 582, 587

Möhler, Johann Adam 316

Moltke, Helmuth v. 290

Mommsen, Theodor 102, 163

Monet, Claude 199

Moos, Ludwig 265, 296, 307

Moravec, Emanuel 444

Moro, Gotbert 208, 210, 248, 255, 259

Morper, Johann Joseph 438, 442 
Möser-Mersky, Gerlinde 625

Mühlbacher, Engelbert 24f., 27f., 43-47, 49, 52, 54, 65, 68, 78-80, 175, 270f., 539

Mühlfeld, Karl Eugen v. 467

Mühlmann, Kajetan 444

Müller, Alexander v. 278, 293, 322

Müller, David Heinrich 384-388, 394

Müller, Ernst 55

Müller, Friedrich 383

Müller, Karl Valentin 344, 369

Müller, Paul 537

Mumelter, Norbert 598, 613

Münsterberg, Rudolf 136

Müntzer, Thomas 461

Musil, Alois 387, 392, 395

Mussolini, Benito 90, 124, 478

Mzik, Hans v. 158, 160

Nadler, Josef 292, 313, 507, 534, 537, 634

Näf, Werner 282, 293, 297, 301, 630

Napoléon I. Bonaparte, Ks. der Franzosen 309

Neckermann, Josef 122

Netzhammer, Raymund 623

Neubacher, Hermann 534

Neumann, Wilhelm 203, 207f., 216, 240, 247-252

Neurath, Konstantin v. 153, 442-445, 447, 451

Neuwirth, Josef 174, 177, 428, 433

Newald, Richard 623

Nietzsche, Friedrich 176, 270, 416-418

Nikolaus I., Papst 56

Nikolaus III., Papst 48f.

Nipperdey, Thomas 14

Nissl, Anton 273

Norden, Walter 40

Novotny, Eduard 549

Novotný, Kamil 448

Novotný, Václav 360, 364

Nowak, Leopold 537

Oberdorffer, Kurt 331

Oberhummer, Eugen 525, 539

Oberkofler, Gerhard 11,73

Odložilík, Otakar 339, 342, 354, 359

Ogris, Alfred 204, 241

Oliva, Pawel 144

Oncken, Hermann 282f., 288, 293f., 480

Opitz, Gottfried 518
Ortega y Gasset, José 416

Ottenthal, Emil v. 19, 27f., 35, 41-44, 46, 49-51, 65-68, 78f., 96, 98, 178f., 267, 269, 272f., 336, $495,506,525,594$

Palacký, František 362f., 365

Papen, Franz v. 292

Paret, Rudi 381

Parler, Peter 428, 434-436

Pastor, Ludwig v. 456, 468, 483

Patsch, Carl Ludwig 9, 156f., 505

Patzelt, Erna 9

Paul, Gustav 309

Pawlowski, Wladimir 247

Pekař, Josef 177, 358

Pellico, Silvio 59

Penck, Albrecht 133, 594

Perels, Ernst 29, 36, 38-40, 52, 56, 59, 70, 82-84

Perels, Friedrich Justus 70

Perels, Otto 70

Perkonig, Josef Friedrich 206, 229, 232, 237, 243 , 248, 254

Pernerstorfer, Engelbert 71

Pernter, Hans 481, 632

Pertz, Georg Heinrich 29

Perutz, Leo 290

Pesditschek, Martina 19

Pešina, Jaromír 448

Peterka, Otto 354

Petermair, Hans 535

Petersen, Adolf Hermann Eugen 65

Petersen, Leiva 129, 164

Peterson, Erik 416

Petrarca, Francesco 343, 360

Pfitzner, Elisabeth 342

Pfitzner, Josef 142, 342, 346-348, 350, 352, 354, 360, 365, 372f.

Pfitzner, Konrad 534

Pflaum, Hans-Georg 164

Pfliegler, Michael 527f., 534, 557, 560f.

Philipp I., Kg. v. Spanien 173

Philipp II., Kg. v. Spanien 173

Pichler-Mandorf, Franz 237

Pinder, Wilhelm 424, 431-434, 437, 439

Pindur, Leopold 551

Pinwinkler, Alexander 9f.

Pippin (der Jüngere), Kg. der Franken 54 
Pirchan, Adelheid (geb. Hausmann) 332

Pirchan, Elisabeth (Else) (geb. Stradal) 334, 342, 359

Pirchan, Gustav (d. Ä.) 332

Pirchan, Gustav 329-377, 426-428

Pirchegger, Anton 482

Pirchegger, Hans 10, 210, 216, 482

Pitra, Jean-Baptiste-François 48-50

Pittioni, Richard 557, 563

Piur, Paul 360

Pius XII., Papst 502

Plaček, Max 129

Planck, Max 72

Planitz, Hans 497

Platon 468

Platzhoff, Walter 510-513, 521

Plutarch 148

Podewils-Dürnitz, Clemes v. 117f., 120

Pokorny, Richard 609

Pokorny, Wilhelmine 520

Polheim, Karl 259

Pollak, Ludwig 141

Pollak, Robert Adam 157-160

Pompanin, Alois 591

Popelka, Fritz 483

Posch, Andreas 267f.

Posch, Fritz 569, 633

Pozzo, Andrea 171, 184

Präger-Karpeles, Moses 131

Prandtauer, Jacob 462, 466

Praschniker, Camillo 142

Premerstein, Anton v. 138, 140

Přemysl Otakar II., Kg. v. Böhmen 474

Přibram, Alfred Francis 9, 11, 466, 525

Primavesi, Hedda 78

Prokeš, Jaroslav 341, 349, 354

Przibram, Hans 507

Puntschart, Paul 81

Quidde, Ludwig 92

Rachfahl, Felix 101

Radetzky v. Radetz, Josef Wenzel 321

Rainer, Erzhzg. v. Österreich 384f., $394 \mathrm{f}$.

Rainer, Friedrich 206, 248-250, 252-256, $258 f$.

Rainer-Harbach, Victor v. 222

Ranke, Leopold v. 272, 323, 458, 468

Rath, Gebhard 622

Rathjens, Carl 398f.
Ratzel, Friedrich 602

Rauch, Karl 55

Redlich, Oswald 7, 9, 11, 14f., 49, 96, 270f., 277, 336, 360, 415, 506, 525f., 539, 541f., 556, 565. 583, 594, 598, 621, 624f., 641

Redlich, Virgil 632, 636, 644

Regel, Fritz 104, 121

Reimarus, Hermann Samuel 316

Reinalter, Helmut 297

Reinhardt, Max 72

Reinhold, (N.) 440, 449

Reininger, Robert 525

Reinisch, Leo 383, 385

Reinprecht, Franz 237

Reisch, Emil 179

Reither, Josef 559

Rembrandt Harmenszoon van Rijn 186, 188, 445

Renouvin, Pierre 295

Rest, Josef 626

Reutter, Hans 551

Rezek, Antonín 175

Rhodokanakis, Nikolaus 394

Richter, Eduard 103, 212, 215

Rickert, Heinrich 195

Riedel, Emil v. 116

Riedl, Franz 530, 532-535, 545

Riedner, Otto 121, 511

Rieger, Ernst 622

Riegl, Alois 169, 171, 173, 176-179, 185-189, 192-194, 198, 413

Ritter, Gerhard 68, 264, 280, 288f., 301, 314, 324, 487, 630

Ritter, Hellmut 289

Ritter, Moritz 91, 103

Roberg, Francesco 13

Rohan, Karl Anton Prinz 291f.

Rohden, Paul v. 137

Röpke, Wilhelm 280, 324

Roretz, Karl 158, 160

Rosenberg, Alfred 304, 318, 499f., 508

Roth, Gerhard 202

Roth, Joseph 290

Rother, (N.?) 514

Rothfels, Hans 265, 303f.

Roubík, František 358f.

Rudolf I., röm.-dt. Kg. 41, 360, 629

Rudolf IV., Erzhzg. v. Österreich 82, 84, $474 f$. 
Rudolf, Karl 527, 532, 557

Rümmele, Erwin 618

Rumpler, Helmut 204, $229 f$.

Rupnow, Dirk 397

Ruskin, John 188

Rust, Bernhard 125, 311, 515

Rypka, Jan 392, 395

Rzach, Alois 138, $141 \mathrm{f}$.

Said, Edward 380

Salis, Jean Rudolf v. $295 \mathrm{f}$.

Salomon, Richard 34, 39, 70

Sander, Friedrich 90

Sander, Josefine (geb. Erlacher) 90

Sante, Georg Wilhelm 559

Santifaller, Leo 10-12, 14, 449, 490, 502, 526, 557, $563,570,572,575,610,612 \mathrm{f}$.

Saria, Balduin 9

Saßmann, Hanns 283

Sauer, August 142

Saure, Wilhelm 152, 154, 165, 399

Scarrochia, Sandro 181

Schaade, Arthur 398f.

Schachermeyr, Fritz 299, 303

Schacht, Josef 620

Schädler, Franz Xaver (?) 105, 111 f., 114

Schäfer, Dieter 121-123

Schäfer, Dietrich 40, 64, 68f., 73, 103

Schanz, Martin v. $119 f$.

Schaschek, Alberta 148

Schatz, Josef 594

Scheel, Helmuth 149

Scheffer-Boichorst, Paul 62, 68, 72, 74

Scheler, Max 416

Schemann, Ludwig 304

Schiemann, Theodor 69

Schiller, Johann Christoph Friedrich v. 212

Schimmel, Annemarie 407

Schirach, Baldur v. 311

Schlesinger, Günther 543, 549, 554

Schlesinger, Ludwig 362

Schlesinger, Walter 647

Schlick, Kaspar 175

Schlosser, Julius v. 173, 178f., 183, 415, 450, 462, $466,525,622,624$

Schlüsselberger, Josef 548

Schmidt, Erich 78
Schmidt-Ott, Friedrich 631

Schmitt, Alois 90

Schmitz, Bruno 193

Schnaase, Karl 197

Schnabel, Franz 287

Schneider, Erwin 323

Schneider, Fedor 56, 81

Schnerich, Alfred 24

Schnorr v. Carolsfeld, Hans 93

Schnürer, Gustav 621

Schober, Johann $283 \mathrm{f}$.

Schönborn-Buchheim, Friedrich Karl v. 462-464

Schönborn-Wiesentheid, Erwein v. $122 \mathrm{f}$.

Schönerer, Georg v. 71, 103, 221f., 267f., 281, 285

Schönherr, Julius 24

Schottmüller, (N.?, Tochter Conrad Schottmüllers) 65

Schottmüller, Conrad 65

Schreyvogel, Friedrich 292, 545

Schulte, Aloys 282

Schumy, Vinzenz 229f., $236 f$.

Schuschnigg, Kurt v. 296, 482, 506f., 543f., 547 , 596,630

Schüssler, Wilhelm 267, 287, 291, 322

Schwalm, Hans 498

Schwarzenberg, Felix zu 467

Schwarzwald, Eugenie 136

Schweidler, Egon v. 300

Sedlacek, Ernst 548

Sedlmaier, Richard 437

Sedlmayr, Hans 432, 434, 437, 439, 537

Seeliger, Gerhard 94, 334

Seif, Theodor 396

Seifert, Ernst 125

Seipel , Ignaz 281, 291, 469, 479

Sellin, Ernst 387

Senn, (N.?) 640

Seuse, Heinrich 618

Seyß-Inquart, Arthur 297, 310, $508 \mathrm{f}$.

Sicherl, Martin 147

Sickel, Theodor v. 24, 26-28, 37, 40-51, 65-67, 71, 75, 78-80, 89, 169, 176, 272, 506

Sieger, Robert 274, 472

Sievers, Wolfram 596, 599-601, 604-607

Sigismund, röm.-dt. Kg. und Ks., Kg. v. Böhmen und v. Ungarn 175

Simonsfeld, Henry 46f., 79, $95 f$. 
Sinzendorf, Georg Ludwig v. 464

Š́p, (N.?) 445

Šlechta (Schlechta), Anton Peter 581

Sölch, Johann 594

Spahn, Martin 287

Spann, Othmar 469, 481

Späth, Ernst 300

Spengler, Oswald 284, 317, 416, 418

Spevak, Stefan 561

Spiegel, Käthe 142, 152

Spiegel, Ludwig 142

Spindler, Max 517

Sporck, Franz Anton v. 428

Spörl, Johannes 642

Spreitzer, Renate 20

Srbik, Elisabeth 273

Srbik, Franz Joseph 266

Srbik, Franz Joseph v. (d. Ä.) 266

Srbik, Franz Seraphicus v. 266

Srbik, Heinrich v. 7, 10f., 14f., 19, 156f., 263-327, 451f., 457-459, 462f., 465-472, 474f., 477f., 483, 487, 492, 497, 505, 507f., 515f., 530f., 534, 537, 594, 621, 630, 634f., 640f., 644

Srbik, Johanna v. (geb. Nissl) 263, 273

Srbik, Ludmilla v. 266

Srbik, Robert v. 266

Srbik, Sophie v. (geb. Wagner) 269

Srbik, Walpurga 273

Srbik, Walpurga v. (geb. Grauert) 266

Stahl, Friedrich Julius 303

Stählin, Karl 70

Staiger, Emil 619

Starhemberg, Ernst Rüdiger 547

Starzacher, Karl $241 \mathrm{f}$.

Stauffer, Albert 91

Štech, Václav Vilém 429

Steding, Christoph 318

Steffens, Franz 623

Stein, Arthur 129-167, 347, 354, 399

Stein, Flora (geb. Utitz) 137f., 152, 157, 161

Stein, Heinrich Friedrich Karl (Freiherr) vom und zum 29

Stein, Ida (verh. Fischl) 131

Stein, Karoline (geb. Pfau) 130

Stein, Leopold 130

Stein, Olga (verh. Politzer) 131

Steinacher, Hans 229-232, 237, 243
Steinacker, Edmund $456 f$.

Steinacker, Harold 10, 12, 14, 20f., 133f., 152, 165f., 287, 295, 322, 399, 452, 456f., 470, 472, 474f., 487, 592, 594f., 603, 606, 610

Steinacker, Wolfgang 603, 606-608

Steinhauser, Walter 540, 543

Steinherz, Samuel 9, 11, 141, 147, 152, 334, 340, 342,350

Steinlechner, Wolfgang (?) 226

Steinmeyer, Elias v. 98

Steinreuter (auch: Stainreuter), Leopold (auch: v. Wien) 622f., 625, 627

Steinwender, Otto 221, 228

Steklý, Karel 448

Stengel, Edmund Ernst 38, 53, 84, 516

Stepan, Eduard 577f., 586

Stepan, Karl Maria 483f.

Steuer, Rudolf 565

Stieve, Felix 86, 90f.

Stöber, Fritz 24

Stöhr, Adolf 525

Stolz, Otto 14, 599, 601, 611

Stölzle, Remigius 101f., 104, 106

Stourzh, Gerald 269

Stourzh, Herbert v. 269

Stowasser, Otto Heinrich 540, 543, $587 f$.

Strecker, Karl 631

Strnadt, Julius 581, 583

Strobl, Ludwig 506

Stroux, Johannes 140, 151, 162

Strzygowski, Josef 178-180, 305, 317, 414f., 490, 493, 506, 525

Sturmmair, Ernst 600

Suchenwirth, Richard $513 f$.

Sündermann, Hans 535

Šusta, Josef 175-177, 340

Svoboda, Václav 411

Swoboda, Berta (geb. Müller) 411

Swoboda, Heinrich 138, 140f., 333

Swoboda, Hermine (geb. Hein) 411

Swoboda, Kamilla (geb. Rabl) 199, 411, 414, 417

Swoboda, Karl Maria (d. Ä.) 411

Swoboda, Karl Maria 21, 143, 170, 190, 199, 411450

Swoboda, Michael 411

Sybel, Heinrich v. 25, 472

Syme, Ronald 164 
Szanto, Emil 133

Tangl, Claudia 34

Tangl, Eberhard 33f., 39, 59, 81, 83f.

Tangl, Georgine (d. J.) 24, 32-34, 51, 57, 68

Tangl, Georgine (geb. Nüchtern) 33

Tangl, Karlmann 23

Tangl, Michael 19, 23-84, 87, 89, 96, 98

Tardif, Jules 26

Teige, Josef 42

Ternik, Walter 532

Teßmann, Friedrich 612

Thausing, Moritz 169, 179

Theodora (Gattin Hzg. Heinrichs II. v. Österreich) 642

Thode, Henry 189

Tibaldi, Pellegrino 171

Tichý, Josef 358

Tietze, Hans 191

Tietze-Conrat, Erica 191

Till, Walter 396

Tintoretto, Jacobo 183, 188f., 192, 197

Tolomei, Ettore $605 \mathrm{f}$.

Tomaschek, Wilhelm 133

Tosoni, Peter 208, 215, 217, 219

Traube, Ludwig 96f., 631

Treitschke, Heinrich v. 89, 270, 321, 483

Tremel, Ferdinand 557

Troeltsch, Ernst 416

Troger, Ernest 592, 610

Tuppa, Karl 546

Turba, Gustav 466, 505

Twain, Mark 240

Tzöbl, Josef Alois 503

Uberlacker, Johann 211

Uebersberger, Hans 9-11, 81, 465f., 505f., 525

Uhlirz, Karl 67, 78, 494

Uhlirz, Mathilde 274, 476

Unger, Georg Friedrich 101f., 104, 106

Utitz, Emil 137, 154f., 161

Vahlen, Johannes 284

Vahlen, Theodor 284

Valjavec, Fritz 612

Van Eyck, Hubert 185

Van Eyck, Jan $185 f$.
Van Gogh, Vincent 188

Vancsa, Kurt 540, 543f., 555, 557, 571f., 575, 579

Vancsa, Max 498, 526, 540, $582 \mathrm{f}$.

Varga, Lucie 9

Vaugoin, Carl 236

Veiter, Theodor 234f., 532, $534 f$.

Velázquez, Diego Rodríguez de Silva y 188

Viereck, Peter 279

Vierkandt, Alfred 416

Vincke, Georg v. 467

Vodosek, Peter 15

Vojtíšek, Václav 145, 342, 358, 450

Voltelini, Hans v. 497, 507, 511, 521, 597, 612, 632

Volz, Wilhelm 234, 498

Wagner, (N.?) 357

Wagner, Karl Ludwig 162

Wagner, Otto 191

Wagner, Richard 261

Waitz, Georg 71

Waldstein, Albrecht Wenzel Eusebius v. 341, 471

Waldvogel, Prokop 366f.

Wallenstein siehe Waldstein

Wallnöfer, Eduard 591, 610f.

Walter, (N.?) 599

Wandruszka, Adam v. 19, 283, 297f., 322, 534, 547

Wattenbach, Wilhem 25, 62, 71f., 88

Weber, Franz Sylvester 600

Weber, Max 416

Weber, Ottokar $334 f$.

Wegeles, Franz Xaver v. 101

Wehler, Hans Ulrich 21

Wehr, Hans 398f.

Weichselgärtner, Arpad (?) 158,160

Weigl, Heinrich 540, 570, 577

Weinheber, Josef 296, 311

Weiniger, Otto 416

Weizsäcker, Julius 88

Weizsäcker, Wilhelm 354, 365, 426

Welte, Bernhard 639

Welte, Konrad 639

Weltin, Maximilian $588 \mathrm{f}$.

Wendrinsky, Johann 585

Wenskus, Reinhard 521

Werminghoff, Albert 25, 56

Werunsky, Emil 42, 330, 334f., 337, 341f., 346, 357

Wessely, Carl 132, 394 
Westphal, Otto 318

Whitehead, Alfred North 21

Wickhoff, Franz 169, 173, 176-180, 185-187, 189, 194

Wiedenmann, Peter $116 f$.

Wiesner, Friedrich v. 635

Wiessner, Hermann $240 f$.

Wilamowitz-Moellendorff, Ulrich v. 139

Wilcken, Ulrich 102, 104f., 108, 114f., 118-1243, 126, 139f., 149-151

Wilde, Johannes 170, 185, 190, 413f.

Wilde, Oscar 277

Wilhelm II., Deutscher Ks., Kg. v. Preußen 92, 120

Willmitzer, (N.) 555, 558f.

Wilson, Thomas Woodrow 258

Wimmer, Friedrich 509, 548

Windelband, Wilhelm 195

Winner, Gerhard 569

Winter, Eduard 11f., 14, 354, 535

Winter, Ernst Karl 290, 469, 471f., 481, 538, 550, 594, 633f., 638

Winterfeld, Paul v. 631

Wirth, Zdeněk 420-422, 433, 448f.

Wolf, Hans 540, 542, 548, 557

Wolf, Julius 634

Wolf, Karl Hermann 222

Wolf, Wilhelm 532

Wolff, Gustav 314

Wölfflin, Heinrich 178

Wolfram, Herwig 496, 519

Wolsegger, Ferdinand 237
Wopfner, Hermann 7, 9f., 594-596, 601, 603f., $610 f$.

Worringer, Wilhelm 19, 193, 195, $424 \mathrm{f}$.

Wostry, Wilhelm 145, 165, 334f., 340-342, 341, 346-348, 350, 354f., 357, 373f., 421, 427

Wrabetz, Peter 323

Wutte, Anna (geb. Ertl) 211

Wutte, Ernestine (Erna) (geb. Hoffmann) 212

Wutte, Maria (Mitzi) 212

Wutte, Martin (d. Ä.) 211 f.

Wutte, Martin 10, 201-261

Wyclif, John 364

Zajíc, Andreas H. 21

Zankl, Anton 444

Zatschek, Heinz 143, 334, 341f., 344, 346-348, 350, 356f., 359f., 368f., 372f., 409, 426, $515 f$.

Zauner, Adolf $485 \mathrm{f}$.

Zeidler, Jacob 132

Zenegg, Emmerich v. 242

Zessner-Spitzenberg, Hans Karl v. 631f., 638

Zeumer, Karl 25, 31

Zibermayr, Ignaz 491f., 497, 502, 510, 512, 517, 557,624

Ziegler, Matthes 307

Zinsmaier, Paul, 622, 624

Zipfel, Ernst 242, 257, 259, 357, 516

Zöllner, Erich 519, 523, 557

Zwanowetz, Georg 610

Zwiedineck-Südenhorst, Hans v. 215, 272 



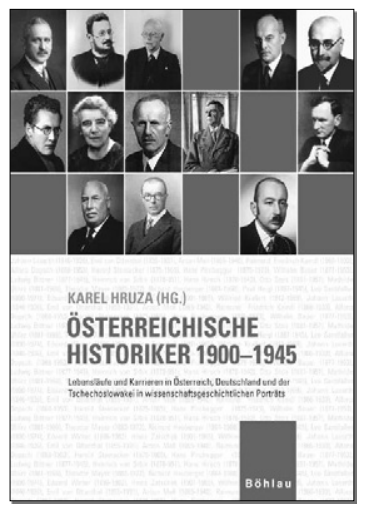

KAREL HRUZA

\section{ÖSTERREICHISCHE HISTORIKER 1900-1945}

LEBENSLÄUFE UND KARRIEREN

IN ÖSTERREICH, DEUTSCHLAND UND

DER TSCHECHOSLOWAKEI IN

WISSENSCHAFTSGESCHICHTLICHEN PORTRÄTS

Zwanzig österreichische Historikerinnen und Historiker in Österreich, Deutschland, der Tschechoslowakei und schließlich im „Großdeutschen Reich“ werden in wissenschaftsgeschichtlichen Porträts vorgestellt. Die Porträtierten erlebten in diesen Jahren die wesentliche Zeitspanne ihres beruflichen Wirkens an Universitäten, Bibliotheken und Archiven. Kritische Fragen nach dem wissenschaftlichen Werk und dessen Zeitgebundenheit sowie nach vollzogenen Perspektiven- oder Paradigmenwechseln werden ebenso gestellt wie nach administrativen und politischen Tätigkeiten in diesen bewegten Jahren.

„Die Beiträge sind aufschlussreich nicht nur deshalb, weil sie deutliche Parallelen zu reichsdeutschen Historiker-Biographien aufzeigen, sondern auch die vielfältigen Vernetzungen in der großdeutschen akademischen Szene bis 1945 erhellen.“

\section{Süddeutsche Zeitung}

BÖHLAU VERLAG, WIESINGERSTRASSE I, A-IOIO WIEN, T: + 43 I 33024 27-O INFO@BOEHLAU-VERLAG.COM, WWW.BOEHLAU-VERLAG.COM | WIEN KÖLN WEIMAR 

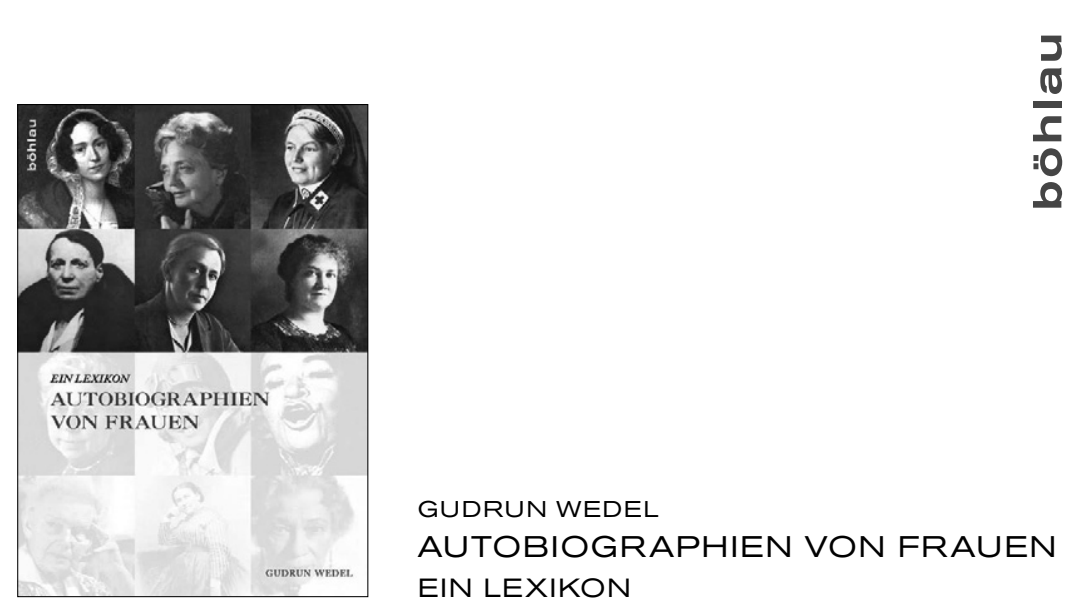

Das Lexikon bietet erstmals und auf breiter Basis Informationen zu mehr als $2.000 \mathrm{im}$ 19. Jahrhundert geborenen Frauen aus dem deutschsprachigen Raum, die sich mit ihren publizierten autobiographischen Schriften der Öffentlichkeit präsentierten. Es gibt Auskunft über das Sozialprofil der Verfasserinnen, die Entstehungskontexte und Themen ihrer Autobiographien, die rezeptionswirksame Ausstattung dieser Texte für die Publikation, deren Publikationsgeschichte sowie ihre mediale Vielfalt und Reichweite.

„Wer dieses umfangreiche Kompendium heranzieht, hat einen Meilenstein der Autobiographie- und Selbstzeugnisforschung in der Hand.“

Sehepunkte

„Wedels Lexikon ist eine Pionierarbeit, die [...] Wissenschaftler/innen, die zu biographischen oder geschlechtergeschichtlichen Themen arbeiten, zur Anschaffung empfohlen sei.“

H-Soz-u-Kult

2010. XIV, 1286 S. GB. $170 \times 240$ MM.

ISBN 978-3-412-20585-O

BÖHLAU VERLAG, URSULAPLATZ I, D-50668 KÖLN, T:+49 22I 9I3 90-O INFO@BOEHLAU-VERLAG.COM, WWW.BOEHLAU-VERLAG.COM | WIEN KÖLN WEIMAR 
Das Buch enthält 15 ausführliche Porträts österreichischer Historiker und setzt sich mit ihren wissenschaftlichen Karrieren und Werken auseinander sowie mit ihrer Einbindung in akademische Netzwerke und politische Tätigkeiten: Porträtiert werden: Michael Tangl (1861-1921), Anton Chroust (1864-1945), Arthur Stein (1871-1950) und Edmund Groag (1873-1945), Max Dvořák (1874-1921), Martin Wutte (1876-1948), Heinrich (Ritter von) Srbik (1878-1951), Gustav Pirchan (1881-1945), Adolf Grohmann (1887-1977), Karl Maria Swoboda (1889-1977), Hugo Hantsch (1895-1972), Ernst Klebel (1896-1961), Karl Lechner (1897-1975), Franz Huter (1899-1997) und Konrad Josef Heilig (1907-1945). 